
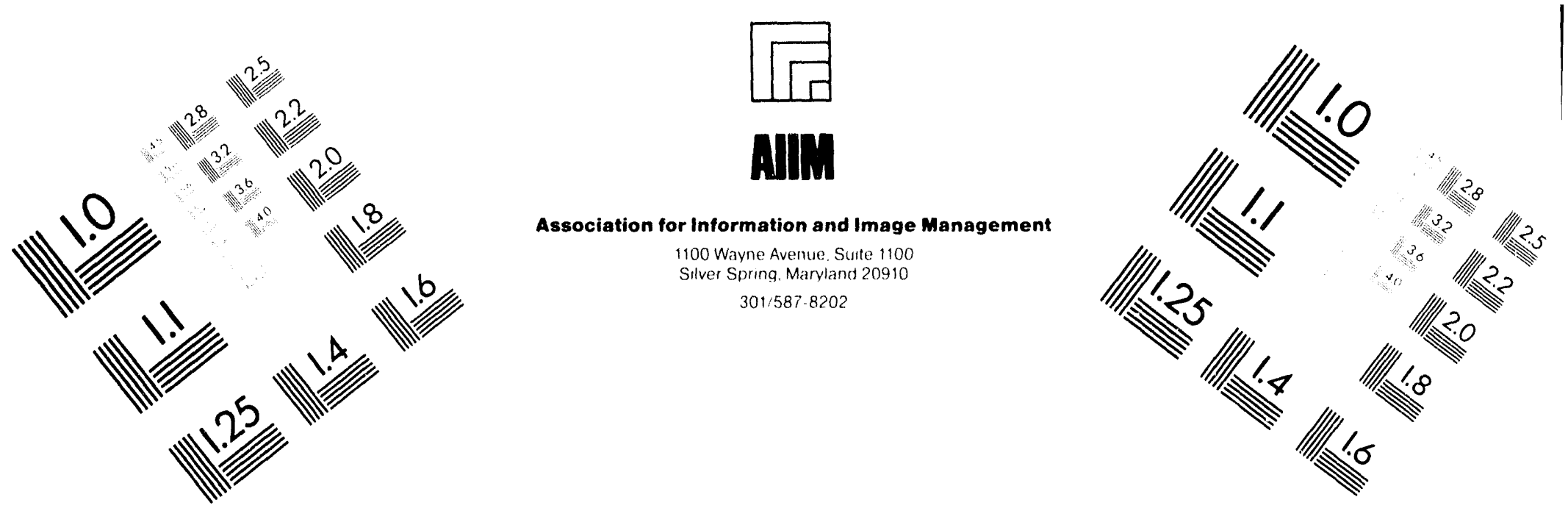

\title{
Centimeter
}

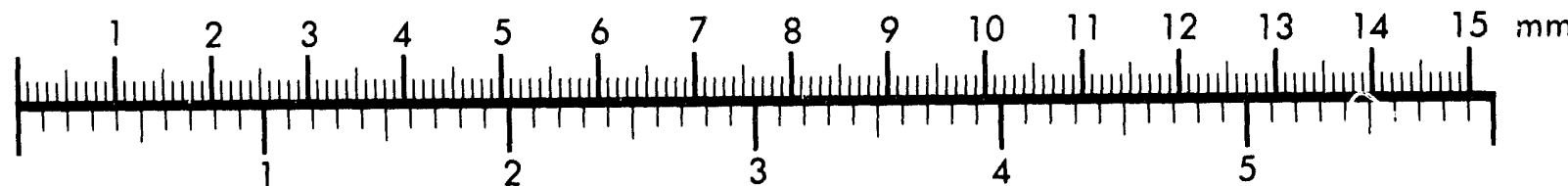

Inches
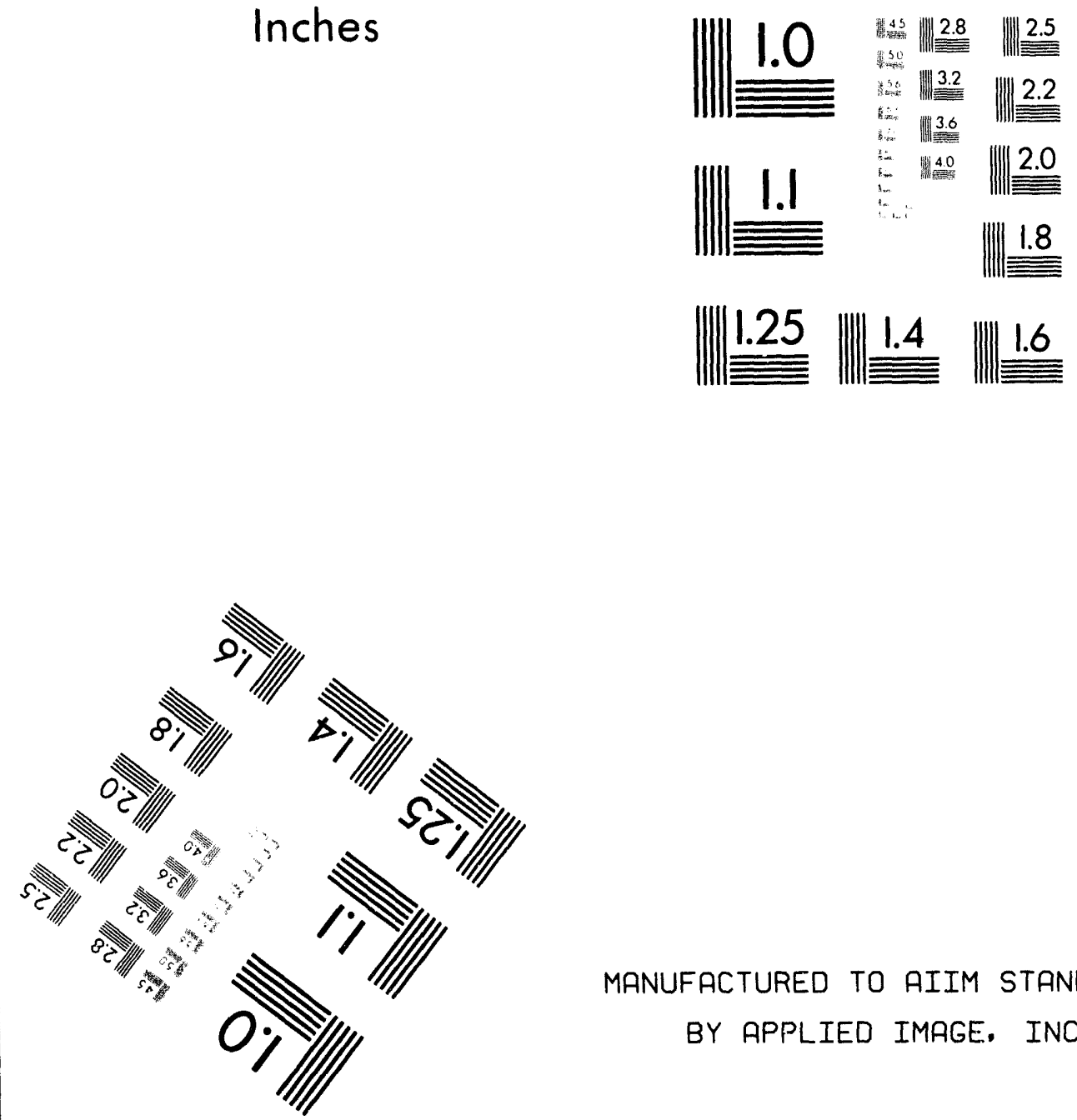

MANUFACTURED TO AIIM STANDARDS

BY APPLIED IMAGE. INC.

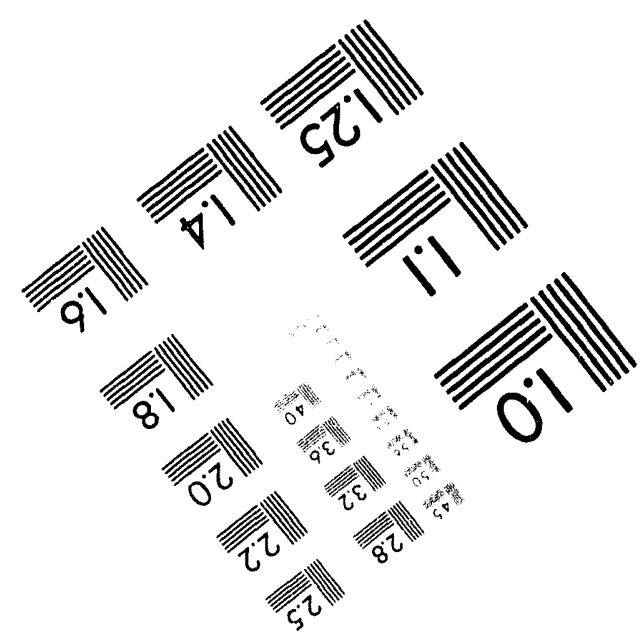



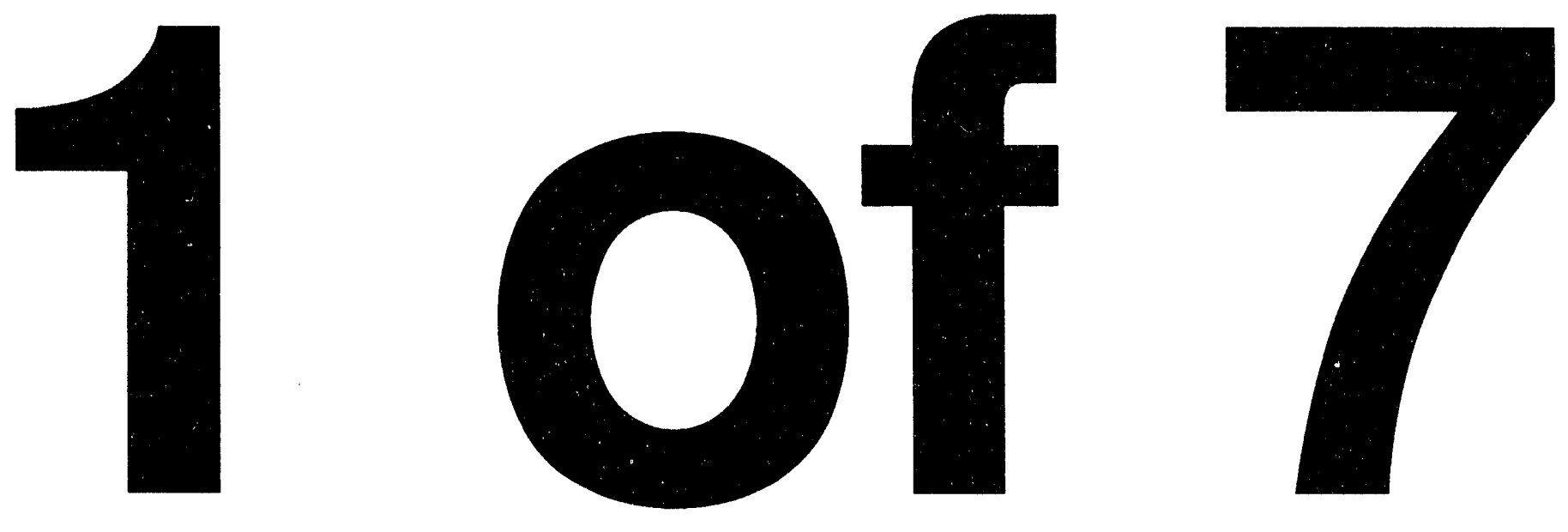
DOE/RL-93-99

Rev. 0

\section{Remedial Investigation and Feasibility Study Report for the Environmental Restoration Disposal Facility}

Date Published

June 1994

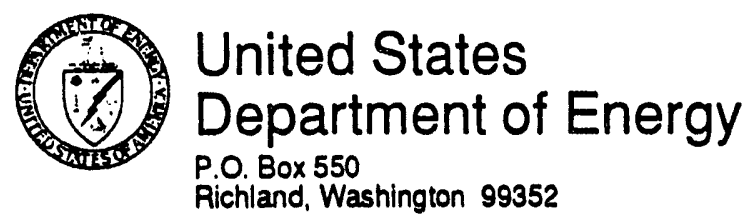




\section{EXECUTIVE SUMMARY}

The U.S. Department of Energy's (DOE) Hanford Facility near Richland, Washington has been operated by the Federal Government since 1943 for plutonium production for military use, and nuclear energy research and development. Past activities released waste to the environment that contaminated soil and groundwater with hazardous/dangerous waste, and radioactive contaminants. The remedy selection process for remediation of operable units located along the Columbia River is scheduled to commence in the fall of 1994 . Based on significant public input to date, it is anticipated that the remedies selected for these operable units may include removal of waste from proximity to the Columbia River and isolation of the waste in a central location. The purpose of this remedial investigation/feasibility study (RI/FS) is to evaluate alternatives to allow the removal of contaminants from portions of the Hanford Site (including near the Columbia River) in a timely manner such that those remediated portions of the Site to be released for other productive uses.

This RI/FS evaluates alternatives for placement of remediation waste generated during remediation of CERCLA and RCRA past practice sites on the Hanford Site. With the exception of the no-action alternative, all of the alternatives evaluated in this RI/FS include a RCRA Corrective Action Management Unit (CAMU) referred to as the Environmental Restoration Disposal Facility (ERDF). The ERDF would serve as the receiving facility for most of the waste excavated during remediation of CERCLA and RCRA past-practice sites. The primary element of the ERDF is a single trench excavated below existing grade that will be filled with remediation waste and closed with a protective surface barrier. Supporting facilities, such as administrative buildings, railroad spurs, waste off-loading and transport equipment, decontamination facilities, etc, will also be included as part of the ERDF. In accordance with the CAMU regulations ( 40 CFR 264.552), only remediation waste that originates within the Hanford Site may be placed in the ERDF. The waste is expected to consist of dangerous/hazardous waste, PCB and asbestos waste, low-level radioactive waste, and low-level mixed waste (containing both dangerous and radioactive waste). The CAMU requirements are specifically addressed in a CAMU application document included as part of the regulatory package.

The Hanford Facility Federal Agreement and Consent Order (Tri-Party Agreement) was signed by the U.S. Environment Protection Agency (EPA), the Washington State Department of Ecology (Ecology), and DOE to provide for cleanup of the Hanford Site. In the most recent Tri-Party Negotiations (Ecology et al. 1994) it was agreed that a pilot project to demonstrate National Environmental Policy Act (NEPA)/CERCLA functional equivalency would be conducted for the ERDF project. Therefore, the scope of this document has been expanded to address NEPA values not normally considered in a CERCLA RI/FS. Many of the NEPA values, such as a description of the affected environment (including meteorology, hydrology, geology, ecological, and land-use), applicable laws and guidelines, short-term and long-term impacts on human health and the environment, emissions to water and air, and cost, are included within a typical CERCLA RI/FS. Other NEPA values not normally addressed in a CERCLA RI/FS, such as socioeconomics, cultural resources, and transportation, have been evaluated in this document. A NEPA roadmap document, which describes where NEPA values are addressed, has been prepared as part of this regulatory package.

ERDF Proposed Site. The proposed site will cover 4.1 square kilometers (1.6 square miles) on the 200 areas plateau at an elevation of 195 to $226 \mathrm{~m}$ (640 to $740 \mathrm{ft}$ ) above mean sea 
level (AMSL), approximately in the center of the Hanford Site, southeast of the 200 West Area and southwest of the 200 East Area. Placement of the ERDF on the 200 Area plateau would facilitate consolidation of waste management activities away from the Columbia River at a relatively high ground surface elevation (with a corresponding greater depth to groundwater).

No waste units are located within the ERDF site. However, contaminated groundwater related to discharge of chemical processing wastewater in the 200 West Area has migrated beneath the ERDF site. Contaminants present in groundwater at the site are: tritium, iodine 129 , technetium 99, gross alpha, gross beta, chloroform, nitrate, chromium and carbon tetrachloride. The highest concentrations of contaminants are generally found at the points nearest the 200 West Area, which is at the west end of the ERDF. Remediation of these plumes will be addressed in the RI/FS process for the 200 Area operable units.

Hydrogeology. The vadose zone beneath the ERDF site is estimated to range from 70 to $90 \mathrm{~m}$ ( 230 to $300 \mathrm{ft}$ ) thick and consist of the following lithologic units: Hanford Formation sediments, Plio-Pleistocene, the upper Ringold unit and Ringold Gravel unit "E". The suprabasalt aquifers beneath the proposed ERDF site consists of the fluvial sands and gravels of the Ringold Formation and the lower Plio-Pleistocene Formation. The silts of the PlioPleistocene unit, the upper Ringold unit and the Ringold lower mud unit may act as aquitards or confining units within the aquifer. The uppermost aquifer beneath the proposed ERDF site is contained primarily within unit $\mathrm{E}$ of the Ringold Formation. The lower mud unit of the Ringold Formation is known to occur beneath this aquifer in the western side of the site but the lateral extent is not known beneath the eastern side of the ERDF. Where the lower mud unit is present, confined aquifer conditions exist in unit A of the Ringold Formation. Units A and E of the Ringold Formation would be combined in a single unconfined aquifer in areas where the lower mud unit is not present. The thickness of the uppermost aquifer beneath the ERDF generally appears to range from 20 io $70 \mathrm{~m}(65-230 \mathrm{ft})$. Groundwater flow beneath the site is generally from west to east. Groundwater discharge is ultimately to the Columbia River.

Cultural Resources. The Hanford Cultural Resources Laboratory (HCRL) conducted a cultural resources survey of the ERDF site and surrounding area during the summer of 1993. The survey identified four archaeological sites, one paleontological site and nine isolated artifacts. One isolated artifact (a cobble tool) was also identified during a previous survey. None of the sites were considered eligible for the National Register. However, HCRL stated that two of the archeological sites may represent part of the greater Euro-American ranching community in Southeast Washington State and may be considered regionally or locally significart viewed in this context. The two sites are located outside of the ERDF boundaries.

Ecological Resources. Ecological surveys of the ERDF site found it to be primarily undisturbed shrub-steppe habitat that had not sustained significant fire damage. The recent surveys identified long-billed curlews, sage sparrows, and loggerhead shrikes as nesting in the area. Grasshopper sparrows were present and possibly nesting at the site. Swainson's hawks were observed hunting in the area. Burrowing owls, while not observed during the surveys, have been seen at the site in the past and are: presumed to currently inhabit the area.

Mature shrub-steppe provides important habitat for a number of plant and animal species of concern that depend on the shrub component, usually sagebrush, for nesting, food and protection. Bitterbrush shrubs provide browse for a resident herd of wild mule deer. Certain passerine birds rely on sagebrush or bitterbrush for nesting (i.e., sage sparrow, sage thrasher, and loggerhead shrike). Loggerhead shrikes are year round residents that are present at low 
densities. Sage sparrows are common summer residents of the Hanford Site that are restricted almost entirely to sagebrush stands. Mature shrub-steppe habitat also provides prime foraging habitat for a variety of raptor species. Shrub-steppe habitat available for species of concern on the Hanford Site may become a more critical issue as agricultural, industrial and urban development decrease the amount of this habitat type in eastern Washington.

The remaining undisturbed shrub-steppe habitat at the Hanford Site is considered priority habitat by the State of Washington due to its relative scarcity in the state and its importance as nesting, breeding and foraging habitat for state- and federal listed or candidate sensitive species.

No plants, birds, or mammals on the federal list of Endangered and Threatened Wildlife and Plants (50 CFR 17.11, 17.12) are known to reside or occur at the ERDF site. There are, however, several species of both plants and animals that are of concern or are under consideration for formal listing by the federal government and Washington State.

Waste Characteristics. It is anticipated that the ERDF will receive waste from the 100,200 , and 300 Areas. The total volume of waste is expected to be less than 21.4 million $\mathrm{m}^{3}$ $\left(28\right.$ million $\left.\mathrm{yd}^{3}\right)$ and is expected to consist of the following: contaminated soil and demolition debris associated with process wastewater disposal units and unplanned releases (approximately 65-75\%); burial ground waste (approximately 15-20\%); and wastewater pipelines, ancillary equipment, and associated soil contamination (approximately 10-15\%). Waste generating activities and waste units for each of the areas are briefly discussed below:

The 100 Area includes nine water-cooled, plutonium production reactors that were built along the shore of the Columbia River upstream from the now-abandoned town of Hanford. Waste units in the 100 Area include cooling water retention basins, pipelines, river outfall structures, subsurface process water disposal units (e.g., french drains), solid waste burial grounds, and unplanned releases (i.e., spills). 100 Area waste includes soil, sediments, sludges, burial ground waste, and demolition debris (e.g., pipe and concrete).

Historically, the 200 Area was used for nuclear fuel reprocessing, plutonium recovery, and waste management and disposal. Although highly radioactive liquid wastes were discharged to numerous subsurface disposal units in the 200 Area, the resulting high-activity contaminated soils are not considered likely waste materials for the ERDF. Waste units where remediation may result in disposal of materials in the ERDF include 24 migration sites (consisting of surface soils contaminated due to spills or wind-blown dispersion of radioactive materials) and an extensive network of pipelines and ancillary equipment with associated soil contamination due to leaks.

Activities in the 300 Area have historically been related primarily to the fabrication of nuclear fuel elements. In addition, many technical support, service support, and research and development activities related to fuel fabrication and reactor testing were carried out. Current R\&D activities focus on peaceful uses of plutonium, liquid metal technology, fast-flux test facility support, gas-cooled reactor development, life science research, and Tri-Party Agreement support. The primary waste units in the 300 Area include unplanned releases, process sewer piping, process sewer ponds and trenches, and burial grounds.

Fate and Transport. Groundwater modeling was based on the following conceptual model: As recharge from the ground surface percolates through the waste it dissolves 
contaminants to form leachate. The contaminant concentration in the leachate is controlled by soil-water partitioning unless the leachate concentration is predicted to exceed the constituent solubility, in which case the concentration is solubility limited. Leachate from the facility migrates through the vadose zone to the groundwater table. The rate of migration is controlled by the rate of infiltration, the moisture content, and retardation. Constituent concentrations may be a function of radioactive decay, volatilization, biodegradation, and dilution. When the leachate reaches the saturated zone, it is subsequently diluted in groundwater. Finally, the leachate migrates towards the ERDF boundary in the direction of groundwater flow. Further retardation and decay can occur in the saturated zone.

A spreadsheet model was developed to simulate the conceptual model described above. Maximum concentrations are identified for all the constituents detected in wastes in the 100 , 200 , and 300 Areas and used as source concentrations in the fate and transport model. Parameters for the fate and transport spreadsheet model were developed to represent the hydrogeological conditions of the ERDF site, the physical and chemical properties of the waste form, and the fate and transport properties of each contaminant constituent. Constituent-specific parameters include soil/water partitioning coefficient $\left(\mathrm{K}_{\mathrm{d}}\right)$, decay or degradation rate, and solubility. The parameter estimation relied first on ERDF-specific information and then on Hanford Site background information when available. Non-Hanford Site information was utilized as a last resort.

Groundwater background screening was conducted to identify the constituents which could occur in concentrations that are elevated over naturally-occurring chemical concentrations. Constituents were evaluated by comparing the predicted groundwater concentrations with the Hanford Site background groundwater concentrations. Those constituents with predicted groundwater concentrations less than background are not considered to represent risk to groundwater and are eliminated from further consideration. Calcium, iron, magnesium, strontium, and sulfate were eliminated from the list of groundwater contaminants.

Groundwater modeling results indicated that certain contaminants will be found in groundwater at extremely low concentrations (e.g., less than one part per trillion). To streamline the risk assessment process, it is helpful to define groundwater concentrations that, for all practical purposes, are indistinguishable from zero. For the purpose of this discussion, these concentrations are called de minimis concentrations. If a modeled groundwater concentration is less than a de minimis concentration, then the contaminant is considered absent in groundwater. The de minimis concentration is $5 \times 10^{-7} \mathrm{mg} / \mathrm{L}$ for non-radioactive contaminants, and $1 \times 10^{-2} \mathrm{pCi} / \mathrm{L}$ for radioactive contaminants. Most of the organic compounds and many of the radionuclides are eliminated in the de minimis screening. Due to their lack of degradation or decay, all of the toxic or carcinogenic metals and anions detected above background are retained.

Constituents of Potential Concern. A risk-based screening process and comparison to ARARs is used to identify contaminants of potential concern. The risk-based screening process involves the calculation of risk-based screening concentrations, which consider both noncarcinogenic and carcinogenic effects. Risk-based screening concentrations are soil or groundwater concentrations that correspond to a hazard quotient (HQ) of 0.1 , or lifetime incremental cancer risk (ICR) of $1 \times 10^{-7}$ using residential scenario exposure parameter values. These screening values are an order of magnitude less than CERCLA risk-based criteria. 
If the maximum concentration detected for a contaminant exceeds a risk-based screening concentration and/or an ARAR for that contaminant, it is retained for evaluation in the risk assessment. Otherwise, the contaminant is eliminated from the risk assessment process. Because the screening criteria for ICR and HQ are an order of magnitude less than CERCLA risk-based criteria, the screening process provides a high degree of confidence that these eliminated contaminants pose only an insignificant risk to human health or the environment. Contaminants of potential concern are identified separately for soil and groundwater.

Base Conditions Risk Assessment. A base conditions risk assessment was conducted to determine the human and ecological impacts associated with placement of Hanford remediation waste in the ERDF with a minimal soil cover, no liner, and no treatment. This scenario was intended to represent the risk associated with a non-engineered ERDF design and does not account for any of the protective features of the design alternatives discussed below.

Furthermore, it was assumed that all the waste in the ERDF was characterized by the maximum concentration detected in 100,200, and 300 Area waste units. For these reasons, the predicted risks provided below for base-conditions are conservatively biased and are not actual risks that any receptor population would experience.

Risks are expressed in terms of incremental cancer risk (ICR) and hazard quotient (HQ). The ICR represents the additional cancer risk to a human receptor due to exposure to a carcinogenic (cancer-causing) contaminant. ICR is generally expressed in terms of the probability of cancer genesis, and is generally expressed in scientific notation. For example, a incremental cancer risk of $1 \times 10^{-6}$ means that on average, 1 in a million receptors will contract cancer. CERCLA has established that incremental cancer risks between $1 \times 10^{-6}$ and $1 \times 10^{-4}$ are acceptable and that risk below $10^{-6}$ are inconsequential. Because the asumption used are only valid for risks less than $1 \times 10^{-2}$, any predicted risks greater than this level are reported as "greater than $1 \times 10^{-2}$." HQ is a measure of non-carcinogenic risk and is expressed as the ratio of contaminant intake to a reference dose. The reference dose is the dose at which adverse health impacts are believed to occur. Therefore, HQs below 1 should not result in any adverse health impacts.

Human health effects associated with soil exposure for the base conditions scenario were predicted to include an total incremental cancer risk (ICR) of greater than $1 \times 10^{-2}$ (1 in a 100) and hazard quotients (HQs) greater than 1 for 11 contaminants. The contaminants with ICRs greater than $1 \times 10^{-4}$ (1 in 10,000$)$ were cesium-137, europium-152, and uranium. The 11 contaminants that exceeded a HQ of 1 were all metals and included aluminum, antimony, arsenic, barium, chromium, copper, mercury, nickel, silver, thallium, and vanadium.

As described above, groundwater fate and transport modeling was conducted to predict concentrations in groundwater downgradient of the ERDF under base conditions. The most mobile contaminants reached groundwater in approximately 500 years. Contaminants that did not reach groundwater within 10,000 years were not included in the risk estimates. Most of the contaminants were predicted to result in extremely low groundwater concentrations (i.e., less than one part per trillion) that present insignificant health risk. The total ICR associated with the groundwater pathways was $>1 \times 10^{-2}$ ( 1 in a 100) and HQs greater than 1 were predicted for six contaminants. The contaminants with ICRs greater than $1 \times 10^{-4}$ were arsenic, carbon-14, and uranium. The six contaminants that exceeded an HQ of 1 were antimony, arsenic, chromium, fluoride, nitrite, and selenium. 
Ecological risk is expressed in terms of an environmental HQ (analogous to the human health HQ) for non-radionuclides and radiological dose for radionuclides. The ecologicai risk assessment predicted environmental HQs greater than 1 for seven contaminants: benzo(a)pyrene, aluminum, barium, copper, manganese, mercury, and zinc. The total radiological dose after 100 years was predicted to equal $0.8 \mathrm{rad} /$ day (primarily due to cesium-137 and uranium). A dose of $1 \mathrm{rad} /$ day is generally considered acceptable for ecological receptors.

Remedial Action Objectives. Remedial action objectives (RAO) were developed to focus the development, screening, and analysis of remedial alternatives to ensure that they are protective of human health and the environment. RAOs are based on a variety of factors, of which the primary driver are applicable or relevant and appropriate requirements (ARARs). A discussion of pertinent chemical, location, and action specific ARARs is provided in the main body of the text. The following remedial action objectives have been identified for the ERDF:

1) Support the removal of contaminants from portions of the Hanford Site (including near the Columbia River) in a timely manner: This is the overall objective of this action and to based on public opinion that contaminants should be removed from near the Columbia Rive: as soon as possible. This opinion is based on concern regarding potential impacts of these contaminants on the Columbia River and the desire to release the remediated areas for other productive uses.

2) Prevent unacceptable direct exposure to waste: Direct exfosure to the types of waste received at the ERDF, via external exposure, dermal contact, or ingestion, could result in unacceptable health risks to humans and biota. Preventing unacceptable exposure to wastes at the ERDF is important during operation of the facility (i.e., during waste transport and filling operations), and following closure. Once the ERDF is closed, direct exposure to waste is only possible if institutional controls fail and the surface barrier is breached.

3) Prevent unacceptable contaminant releases to air: Inhalation exposure to the types of waste received at the ERDF could result in unacceptable health risks. Similar to the direct exposure pathway, inhalation of waste could occur during operation of the ERDF. Once the ERDF is closed, air releases are only possible if institutional controls fail and the surface barrier is breached.

4) Prevent contaminant releases to groundwater above ARARs and healthbased criteria: Migration of contaminants through the unsaturated zone to groundwater could result in unacceptable human exposure to contaminants hundreds to thousands of years in the future. Protecting groundwater beneath the ERDF also results in protecting the Columbia River.

5) Minimize ecological impacts: Construction of the ERDF will result in harmful impacts on the ecology of the ERDF site and the quarry sites providing materials for ERDF construction. Because significant value is attached to the ecology at these sites, ecological impacts will be minimized and/or mitigated to the maximum extent possible.

Screening of Remedial Technologies. The primary technologies evaluated in this report relate to the configuration and design of the waste containment unit, including geometry 
of the trench excavation, liners, and surface barriers. Technologies related to institutional controls, surface water management, dust control, and treatment of waste waters are also addressed. The remediation technologies are screened using the criteria specified in $40 \mathrm{CFR}$ 300.430(e)(7) of the National Contingency Plan (NCP), including effectiveness, implementability, and cost.

Development of Alternatives. The retained technologies were assembled into 9 design alternatives (in addition to the no-action alternative). The nine alternatives represent combinations of three trench liner options with three surface barrier options. The purpose of the liner is to collect leachate generated due to precipitation percolating through the waste before the surface barrier is placed over the waste. The synthetic portions of the liners are not intended to last for more than several decades. The purpose of the surface barrier is to minimize the potential for intrusion into the waste and reduce or eliminate infiltration through the waste after closure.

The three trench liner options include no trench liner, a single composite liner, or a RCRA minimum technology requirements (MTR) double composite liner. The single composite liner consists of the following three primary units:

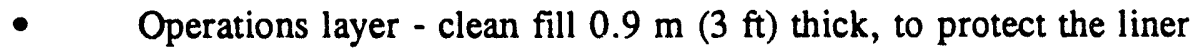
against damage from construction and waste placement equipment, and also against freezing in the exposed portions of the liner.

- Drainage layer - a drainage gravel layer overlain by a geotextile separator to prevent silting of the gravel by the operations layer. The gravel layer directs infiltration percolating through the waste to a collection sump where it is pumped out of the trench. A geocomposite (a geonet sandwiched between layers of geotextile) is used instead of gravel on the side slopes of the trench.

- Low-permeability liner - a synthetic high-density polyethylene (HDPE) geomembrane over $0.3 \mathrm{~m}(1 \mathrm{ft})$ of compacted clay with a permeability no greater than $1 \times 10^{-9} \mathrm{~m} / \mathrm{s}\left(2.8 \times 10^{-4} \mathrm{ft} /\right.$ day $)$. Use of two liners provides redundant low permeability; the synthetic membrane protects the clay against desiccation, and the clay provides a thick liner capable of some self-healing with settling and other geological stresses. A geotextile cushion overlies the HDPE geomembrane to minimize damage during placement of the drainage layer.

The double composite liner is similar to the single liner except that it includes a secondary HDPE liner and leachate collection system directly beneath the primary HDPE liner.

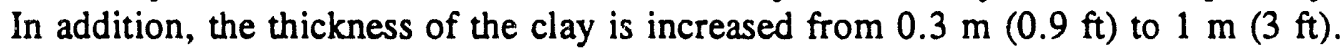

The surface barrier options include a low-infiltration soil barrier, a Hanford barrier, or a

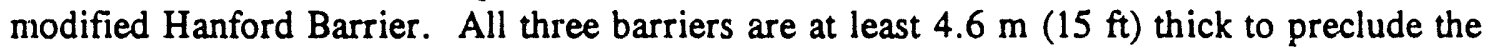
excavation intrusion scenario and include passive controls (such as surface and subsurface markers) to deter intrusion. In addition, all the barriers include vegetated fine-grained soi! layers at the surface to maximize moisture retention and evapotranspiration and thereby reduce the rate of infiltration. The Hanford and modified Hanford barriers also include a low- 
permeability asphalt layer to divert moisture that passes the evapotranspiration layers beyond the horizntal limits of the waste.

The alternatives are listed below:

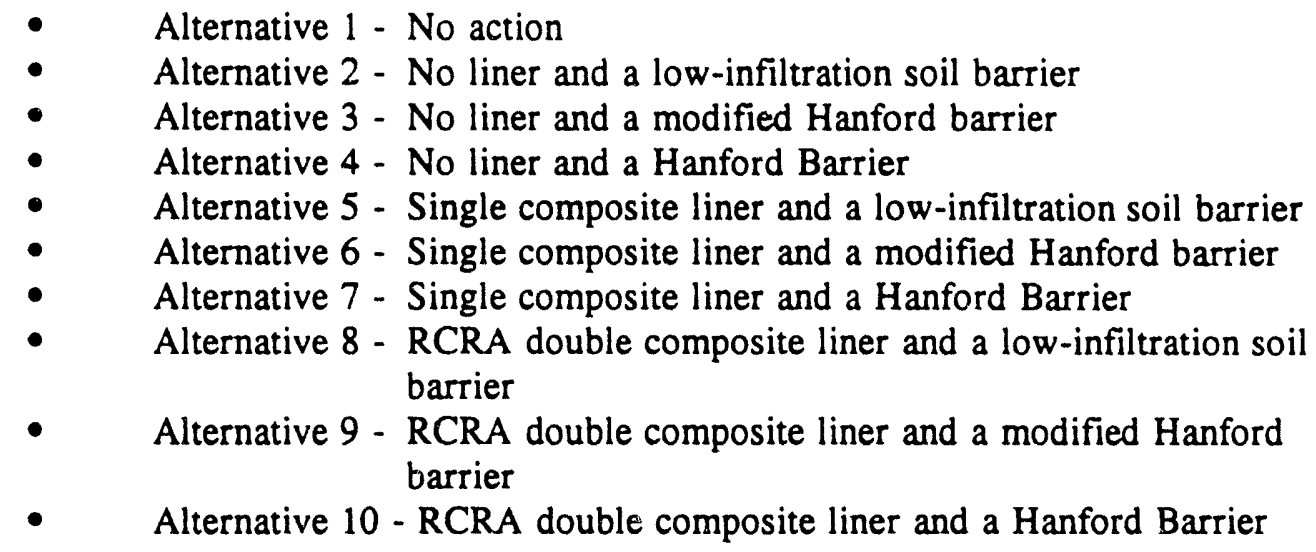

Evaluation of the no-action alternative is required under CERCLA (40 CFR $300.430(e)(6))$. The no-action alternative for this FS consists of not constructing a centralized CAMU on the Hanford Site to accommodate remediation waste from Hanford Site past-practice operable units. Implementation of the no-action alternative would result in the necessity for each operable unit to develop alternatives that include in-situ treatment and/or containment, or disposal facilities at the operable unit.

The remaining alternatives all include institutional controls, dust control, surface water management, wastewat $s_{-i}$ treatment, transportation systems (such as a new rail spur), buildings, a grout batch plant, equipment for internal and external communications, emergency response equipment, and personnel protection. In addition, all of the alternatives (other than no-action) utilize the deep area-fill trench configuration, a single trench design approximately $20 \mathrm{~m}$ (70 ft) deep and $300 \mathrm{~m}(1,000 \mathrm{ft})$ across. This trench configuration minimizes the footprint (areal dimensions) of the facility. The reduced footprint of the deep area-fill design offers the following advantages in comparison to other configurations:

- Less habitat disruption,

- Less leachate generation,

- $\quad$ Reduced material needs (thus, reduced ecological and cultural impact on borrow areas),

- Lower costs for the liner and barrier.

Using the deep area-fill configuration, the disturbed area of the ERDF, including the trench, roads, and supporting facilities, is estimated to be $2.6 \mathrm{~km}^{2}$ (650 acres or $\left.1.0 \mathrm{mi}^{2}\right)$.

Acceptable soil and leachate concentrations. Acceptable soil and leachate concentrations were developed for the contarninants identified in potential waste from the 100 , 200 , and 300 Areas. These concentrations will be included as part of the waste acceptance criteria for ERDF waste to ensure that human and ecological exposures will be less than acceptable standards for the foreseeable future. 
The acceptable soil concentrations were based on exposure to soils due to the 500-year drilling scenario. This scenario was determined to be a reasonable exposure scenario given the protective measures included in the ERDF design such as active institutional controls, passive controls, and a minimum 15-foot thick surface barrier. Based on a comparison with maximum contaminant concentrations in 100,200, and 300 Areas waste units, it appears that most of the waste will meet the acceptable soil concentrations. Waste with soil concentrations that exceed the acceptable levels will require mixing with cleaner soils to reduce concentrations to acceptable levels. For the contaminants that may exceed acceptable levels (metals and radionuclides) no treatment technology exists for reducing concentrations.

Acceptable leachate concentrations were developed to provide protection of groundwater. It is likely that much of the waste received at the ERDF will achieve the leachate criteria without treatment. If this is not the case, however, then the waste will likely require treatment before disposal in the ERDF. For purposes of the detailed evaluation in this report, it was assumed that the wastes would comply with the leachate criteria.

Detailed Evaluation. The NCP provides nine criteria for detailed evaluation of alternatives. Because the no-action alternative does not satisfy the overall objective of this action to "support the removal of contaminants from portions of the Hanford Site (including near the Columbia River) in a timely manner to allow those remediated portions of the Site to be released for other productive uses" it is not evaluated further. Results of the detailed evaluation of alternatives for the remaining alternatives are summarized below:

1) Overall protection of human health and the environment: This criteria draws on the assessments of other evaluation criteria, especially long-term effectiveness and permanence, short-term effectiveness, and compliance with ARARs. As discussed below under these criteria, all the alternatives (except the no-action alternative) fulfill the objectives specified regarding long-term protection of human health and the environment while insuring protection of worker and public health during operations.

2) Compliance with ARARs: The determinations provided in Chapter 7 for action- and location-specific ARARs are valid for all the alternatives except the no-action alternative. In general, all the alternative except the no-action alternative attain ARARs identified in Chapter 7. The only exception is the TSCA requirement that wastes with more than $50 \mathrm{ppm}$ polychlorinated biphenols (PCBs) be disposed in a lined facility. In order to accept wastes with PCB concentrations greater than $50 \mathrm{mg} / \mathrm{kg}$, Alternatives 2 , 3 , and 4 (no liner) would require a waiver under CERCLA. The remaining alternatives include liners and no waiver would be required. The TSCA waiver request could be applied for based on the equivalent standard of performance criteria provided under CERCLA. Demonstration of equivalent standard of performance is justified by the analyses in Appendix A of the RI/FS for an unlined trench, indicating that PCBs would not impact groundwater beneath the ERDF.

The ERDF is being proposed as a Corrective Action Management Unit (CAMU). The CAMU rule provides an option for onsite management of remediation waste previously not available to facilities remediating materials subject to RCRA. The CAMU regulations were promulgated to promote active remediation of contaminated sites, as opposed to merely' capping in place, by allowing more flexibility in management of remediation waste, without compromising human health or the environment. In the preamble to the CAMU Rule, EPA stated its expectation that the substantive CAMU 
Rule requirements will be applicable or relevant and appropriate requirements (ARARs) for the remediation of many CERCLA sites, especially those sites where CERCLA remediation involves the management of RCRA hazardous wastes. An evaluation of the seven decision criteria required under the CAMU regulations determined that the ERDF will meet all CAMU decision criteria and designation of the ERDF as a CAMU is appropriate.

3) Long-term effectiveness and permanence: Long-term effectiveness was measured in terms of future risk to human health and the environment and qualitative assessments of reliability. Future risks are associated with soil exposure resulting from intrusion into the facility or exposure to groundwater impacted by migration of contaminants out of the facility. The risks provided below differ from those presented above for base conditions in that the benefits of protective measures such as passive controls and a barrier that reduces infiltration are accounted for in the analysis. However, it was still assumed that all the waste in the ERDF was characterized by the maximum concentration detected in 100,200, and 300 Area waste units and thus the results are conservatively biased.

All of the alternatives (except the no-action alternative) include active institutional controls (e.g., fences, signs, patrols), passive controls (e.g., markers and off-site records), and a surface barrier that is at least $4.6 \mathrm{~m}$ (15 feet) thick. It is assumed that institutional controls prevent intrusion into the waste for at least 100 years and that passive controls prevent intrusion for 500 years. Furthermore, it is assumed that because the waste is covered with at least $4.6 \mathrm{~m}$ (15 ft) of cover materials, intrusion into the waste due to excavation is precluded. Since none of the evaluated barriers can prevent penetration by a drilling rig, however, it is reasonable to assume that someone might inadvertently drill through the waste sometime after 500 years. Therefore, soil exposures for both human and ecological health are calculated assuming the $500 \mathrm{yr}$ drilling scenario.

Groundwater impacts were calculated assuming that an engineered barrier is constructed over the facility to minimize infiltration through the waste and maximize the travel time to groundwater. In addition, it was assumed that the waste met the maximum leachate concentration criteria (either with or without treatment) before it was placed in the facility. For alternatives with liners, it was further assumed that all leachate was retained by the HDPE liner and removed by the leachate collection system for the first 30 years of operation. In addition, the added travel time associated with migration though the clay layer was accounted for in the analysis.

The human health risks associated with soil exposure resulting from the 500-yr drilling scenario include a total ICR of $4 \times 10^{-5}$ (dominated by uranium) and a maximum HQ of 0.03 (associated with copper). These risks are the same for all the alternatives (except no action). The predicted HQ and ICR associated with the 500-yr drilling scenario are below the goals established in the Tri-Party Agreement of 1 for HQ and $1 \times 10^{-4}$ for ICR.

For all the alternatives except the no-action alternative, none of the contaminants are predicted to reach groundwater within 10,000 years under current climate conditions. Risks after 10,000 years are considered highly uncertain given the potential for climatic changes, geologic events, and human activities, and were not evaluated. Groundwater concentrations and associated risks were also predicted assuming that the rainfall rate 
increased from the current average for Hanford of $18 \mathrm{~cm}(7$ in.) to $40 \mathrm{~cm}(16$ in.) at 100 years. This scenario was intended to represent either a wetter climate or irrigation on top of the ERDF. Although the results of these analyses are intended to demonstrate potential effects associated with climate or land use changes, they should not be considered the most likely scenario. The increased rainfall rate resulted in contaminant travel times from the ERDF to groundwater that were as low as 150 years and the predicted risks ranged from $2 \times 10^{-5}$ to $3 \times 10^{-4}$ for ICR and 0.8 to 7 for HQ. Differences in the results were primarily due to differences in the type of barrier; the shorter travel times and higher risks occurred when the alternative included the low-infiltration soil barrier and the longer travel times and lower risks occurred when the alternative included the Hanford or modified Hanford barriers. Because leachate collection is assumed to last only 30 years and the rainfall rate does not increase for 100 years, only minor differences in risks and travel times can be attributed to the liners.

The maximum ecological health risks associated with soil exposure resulting from the 500 -yr drilling scenario include a total radiological dose of $0.6 \mathrm{rad} /$ day (dominated by uranium) and an environmental HQ of 12 for copper. The remaining environmental HQs were less than 0.05 . It should be noted that the background concentration of copper in soil $(28.2 \mathrm{mg} / \mathrm{kg})$ results in an environmental HQ of 3, which has not resulted in adverse impact to the environment. It is evident that the envirosmpatal exposure analysis results in an overestimate of risk to environmental receptors an it is likely that the intrusion scenario will not result in adverse impacts to the environinen from any potential contaminants disposed in the ERDF. These risks are the same for all the alternatives (except no action).

Reliability in terms of protection against intrusion and erosion will be important if institutional controls were no longer in place. All of the barriers include gravel in the upper soil layer to reduce erosion of the upper silt layers; however, this gravel admix layer is thicker in the Hanford Barrier. To discourage penetration by deep-rooted plants and burrowing animals, the Hanford Barrier employs a crushed basalt layer that provides a hostile environment for plants (little-to-no moisture, no nutrients, large grain size), and a densely compacted asphalt layer. The modified Hanford Barrier employs the asphalt layer and replaces the basalt with a thin layer of coarse-grained materials that is likely to be less effective in preventing root penetration. The low-infiltration soil barrier does not include an layers designed to prevent intrusion by plant roots and animals and relies on thickness alone. Resistance to human intrusion is considered to be primarily a function of barrier thickness, which is similar for all the barriers. In summary, the Hanford Barrier offers the greatest protection against erosion and intrusion in the absence of institutional controls and the modified Hanford barrier is considered to be more effective than the low-infiltration soil barrier in this regard. The barriers are considered to be equal with respect to resisting human intrusion.

Alternatives with trench liners offer several advantages over no-liner alternatives in terms of reliability. The primary advantage is that any leachate generated during the operational period will be retained by the trench liner and pumped out. A secondary advantage of a leachate collection system is that it allows characterization of the leachate generated in the waste. Knowledge of the leachate properties could be used to predict future impacts on groundwater once the leachate collection is terminated or the trench liner fails. The double composite liner offers a redundancy in leachate collection systems not available in the single composite liner. The potential for flaws in the 
primary liner is uncertain, although it is probably low given the high level of construction quality assurance planned for the ERDF. Furthermore, the rate of degradation of a double composite liner will probably be similar to the degradation rate for the single composite liner.

4) Reduction of Toxicity, Mobility, or Volume through Treatment: This criteria was not relevant to the evaluation since none of the alternatives include treatment.

Treatment options will be evaluated in the RI/FSs for the source operable units.

5) Short-Term Effectiveness: Short-term effectiveness includes risks to workers and the public during implementation of an alternative, potential environmental impacts of the alternative, and time until protection is achieved.

Operation of the ERDF will involve potential releases of waste during transport to the ERDF and placement in the ERDF. Health risks for ERDF workers, other Hanford Site workers, and the public due to exposure to waste contaminants were significantly less than generally accepted standards under a variety of conditions, including: normal operating conditions, a 24-hour period of high winds, and rupture of a waste container due to a transportation accident. Since the operation of the ERDF will be the same for all the alternative, these risks would be the same for all the alternatives.

Environmental impacts associated with construction and operation of the ERDF will occur at the ERDF, along the new rail spur, and at any quarry sites for barrier materials. These impacts will include destruction of habitat, displacement of wildlife at these areas, and disturbance of wildlife near these areas and along transport routes due to noise and human activities. The impacted area at the ERDF site is estimated to be $2.6 \mathrm{~km}^{2}$ (650 acres or $1.0 \mathrm{mi}^{2}$ ) although it may be greater depending on the final trench design and waste volume. Ecological impacts at the ERDF will be mitigated to the extent possible by using the deep area-fill trench configuration. Assuming a length of 8 $\mathrm{km}$ (outside the ERDF), and an impacted width of $50 \mathrm{~m}$ (160 ft), the area impacted by the new rail spur will be approximately $0.4 \mathrm{~km}^{2}$. Ecological impacts associated with development of the borrow sites will depend on the type of barrier included in the alternative. The Hanford Barrier is the only barrier that requires basalt and it also requires the most silt. The modified Hanford barrier requires $50 \%$ and the lowinfiltration soil barrier requires $25 \%$ of the silt required by the Hanford Barrier. Since none of the liners included in the alternatives will utilize any on-site materials, the environmental impacts are not impacted by the type of liner. DOE is currently developing a Hanford Site-wide plan in cooperation with the State of Washington Department of Fish and Wildlife and the U.S. Fish and Wildlife Service for mitigating these environmental impacts.

The time until remediation is achieved will depend on the rate that waste is delivered to the ERDF and will be the same for all the alternatives (except the no-action alternative).

6) Implementability: The factors included under this criteria include technical implementability, availability of materials and services, and administrative implementability.

Technical implementability is determined by the complexity of the trench liner and surface barrier designs. The complexity of the barriers decreases in the following 
order: the Hanford Barrier, the modified Hanford barrier, and the low-infiltration barrier. The complexity of the liners decreases in the following order: the double liner, the single liner, and no liner.

All the materials and services for construction of the liners are readily available from off-Hanford Site venders and their availability is not expected to pose any implementability problems. Some of the materials included in the barrier designs (silt and crushed basalt) will come from sources on the Hanford Site and concern has been raised regarding development of potential sources. In particular, cultural resources have been identified at McGee Ranch, the proposed source of silt, that will likely require mitigation before the site may be developed. In addition, basalt outcroppings on the Hanford Site have religious significance to native american tribes and development of a basalt source would require consideration of these cultural values.

None of the alternative require off-site transport, treatment, or disposal of waste. Since CERCLA excludes administrative requirements of ARARs for on-site actions, no permits will be necessary and no administrative difficulties are anticipated.

7) Cost: Common costs included within each of the alternatives (except the no-action alternative) are summarized below:

\section{Common Costs}

\begin{tabular}{|l|c|}
\hline Type & Cost (millions) \\
\hline Support Facilities & $\$ 75$ \\
\hline Permitting and Design & $\$ 22$ \\
\hline Trench Excavation & $\$ 109$ \\
\hline $\begin{array}{l}\text { Operational Cost (over 25 years) } \\
\text { Net Present Value) }\end{array}$ & $\begin{array}{c}\$ 500 \\
\text { present worth) }\end{array}$ \\
\hline $\begin{array}{l}\text { Total Common Costs } \\
\text { (Net Present Value) }\end{array}$ & $\$ 460$ \\
\hline
\end{tabular}

The net present values are calculated assuming a 6 percent discount rate. Total costs for the alternatives can be determined by summing the common costs, the liner costs, and the barrier cost for each of the alternatives in terms of net present worth. The net present worth of the barrier is calculated assuming that the barrier is constructed 20 years in the future. Total costs for each alternative are summarized below: 
Total Costs for Remedial Alternatives.

\begin{tabular}{|l|c|}
\hline Alternative & Total Cost ${ }^{\mathrm{a}}$ (millions) \\
\hline 1. No Action & Not Available \\
\hline 2. No Liner with Low-Infiltration Soil Barrier & $\$ 500$ \\
\hline 3. No Liner with Modified Hanford Barrier & $\$ 600$ \\
\hline 4. No Liner with Hanford Barrier & $\$ 740$ \\
\hline 5. Single Liner with Low-Infiltration Soil Barrier & $\$ 587$ \\
\hline 6. Single Liner with Modified Hanford Barrier & $\$ 690$ \\
\hline 7. Single Liner with Hanford Barrier & $\$ 826$ \\
\hline 8. Double Liner with Low-Infiltration Soil Barrier & $\$ 680$ \\
\hline 9. Double Liner with Modified Hanford Barrier & $\$ 779$ \\
\hline 10. Double Liner with Hanford Barrier & $\$ 920$ \\
\hline a - Measured in terms of net present value assuming a discount rate of 6 percent. \\
\hline
\end{tabular}

8) State acceptance: The Washington Department of Ecology has reviewed the RI/FS and their comments have been resolved and incorporated.

9) Community acceptance: Assessment of this criteria may not be completed until comments on the proposed plan are received. Public comments will be considered in remedy selection for the record of decision.

Comparative Analysis. The results of the detailed evaluation are summarized in the following table: 
Summary Ranking of the Alternatives Against the Criteria.

\begin{tabular}{|c|c|c|c|c|}
\hline Alternative & $\begin{array}{l}\text { Long-Term } \\
\text { Effectiveness }\end{array}$ & $\begin{array}{l}\text { Short-Term } \\
\text { Effectiveness }\end{array}$ & Implementability & Cost \\
\hline 1 & NA & NA & NA & NA \\
\hline 2 & 9 & 1 & 1 & 1 \\
\hline 3 & 6 & 4 & 2 (tie) & 3 \\
\hline 4 & 3 & 7 & 2 (tie) & 6 \\
\hline 5 & 8 & 2 & 2 (tie) & 2 \\
\hline 6 & 5 & 5 & $6(t i e)$ & 5 \\
\hline 7 & 2 & 8 & 6 (tie) & 8 \\
\hline 8 & 7 & 3 & 2(tie) & 4 \\
\hline 9 & 4 & 6 & 6(tie) & 7 \\
\hline 10 & 1 & 9 & 6(tie) & 9 \\
\hline \multicolumn{5}{|c|}{$\begin{array}{l}\text { Notes: } \\
1 \text { - No Action } \\
2 \text { - No Liner with Low-Infiltration Soil Barrier } \\
3 \text { - No Liner with Modified Hanford Barrier } \\
4 \text { - No Liner with Hanford Barrier } \\
5 \text { - Single Liner with Low-Infiltration Soil Barrier } \\
6 \text { - Single Liner with Modified Hanford Barrier } \\
7 \text { - Single Liner with Hanford Barrier } \\
8 \text { - Double Liner with Low-Infiltration Soil Barrier } \\
9 \text { - Double Liner with Modified Hanford Barrier } \\
10 \text { - Double Liner with Hanford Barrier } \\
\text { NA - Not Available.. }\end{array}$} \\
\hline
\end{tabular}

These results suggest the following conclusions regarding the primary components of the alternatives:

- Compared with the other barriers, the Hanford Barrier (Alternatives 4, 7, and 10) provide the best long-term protection of human health and the environment but at the expense of greater impacts on the environment and higher costs.

- $\quad$ Alternatives with the modified Hanford barrier provide similar long-term effectiveness as the Hanford Barrier, but with lower cost and less ecological impact.

- The low-infiltration soil barrier provides the same groundwater protection as the other two barriers under current climatic conditions for significantly less cost and ecological impact. However, under hypothetical wetter climatic conditions, this barrier allows greater infiltration (and thus shorter vadose zone travel times) and less protection against biointrusion than the other two barriers. 
- Because of the low infiltration rates associated with the surface barriers, alternatives with no liner provide similar groundwater protection as alternatives with a liner. Furthermore, the single liner is virtually equivalent to the double liner in telms of groundwater protection.

- One advantage of lined alternatives is that they provide a means to determine the validity of assumptions regarding leachate generation and leachate quality. If these assumptions prove to be non-conservative, and potential groundwater impacts are deemed unacceptable, then it would be possible to initiate corrective action. 


\section{LIST OF ACRONYMS}

\begin{tabular}{|c|c|}
\hline ABS & dermal absorption factor \\
\hline $\mathrm{ACL}$ & alternate concentration limit \\
\hline ALARA & as low as reasonably achievable \\
\hline ALI & annual limit on intake \\
\hline ALE & Arid Land Ecology Reserve \\
\hline amsl & above mean sea level \\
\hline AR & Administrative Record \\
\hline ARAR & applicable or relevant and appropriate requirement \\
\hline ARCL & allowable residual contamination levels \\
\hline ATSDR & Agency for Toxic Substances Disease Registry \\
\hline ASTM & American Society for Testing and Materials \\
\hline AWQC & ambient water quality criteria \\
\hline BEIR & biological effects of ionizing radiation \\
\hline BPA & Bonneville Power Administration \\
\hline CAA & Clean Air Act \\
\hline CAR & corrective action requirement \\
\hline CED & committed effective dose \\
\hline CERCLA & Comprehensive Environmental Kesponse, Compensation, and Liability Act \\
\hline CFR & Code of Federal Regulations \\
\hline $\mathrm{COC}$ & contaminant of concern \\
\hline CRDL & contract required detection limit \\
\hline CRQL & contract required quantitation limit \\
\hline CWA & Clean Water Act \\
\hline $\mathrm{CsOPC}$ & contaminants of potential concern \\
\hline DCG & derived concentration guide \\
\hline DOE & U.S. Department of Energy \\
\hline DOE-RL & U.S. Department of Energy-Richland Field Office \\
\hline Ecology & Washington State Department of Ecology \\
\hline EHQ & environmental hazard quotient \\
\hline EPA & U.S. Environmental Protection Agency \\
\hline ERA & expedited response action \\
\hline ERDA & Energy Research and Development Administration \\
\hline ERDF & Environmental Restoration and Disposal Facility \\
\hline FEMA & Federal Emergency Management Agency \\
\hline FFTF & Fast Flux Test Facility \\
\hline FML & flexible membrane liners \\
\hline FS & feasibility study \\
\hline GI & gastrointestinal \\
\hline HCRL & Hanford Cultural Resources Laboratory \\
\hline HDPE & high density polyethylene \\
\hline HEAST & Health Effects Assessment Summary Tables \\
\hline HI & hazard index \\
\hline HLW & high-level waste \\
\hline HMS & Hanford Meteorological Station \\
\hline HDPE & high-density polyethylene \\
\hline $\mathrm{HQ}$ & hazard quotient \\
\hline HSWA & Hazardous and Solid Waste Amendments (of 1984) \\
\hline
\end{tabular}




\section{LIST OF ACRONYMS (Cont.)}

\begin{tabular}{|c|c|}
\hline HSBRAM & Hanford Site Risk Assessment Methodology \\
\hline IAREC & Irrigated Agriculture Research and Extension Center \\
\hline IARC & International Agency for Research on Cancer \\
\hline ICR & incremental cancer risk \\
\hline ICRP & International Council on Radiation Protection \\
\hline IRIS & Integrated Risk Information System \\
\hline IRM & interim remedial measure \\
\hline LDR & land disposal restrictions \\
\hline LFI & limited field investigation \\
\hline LICR & lifetime incremental cancer risk \\
\hline LLW & lorv-level waste \\
\hline LOAELS & lowest observed adverse effect levels \\
\hline MCL & maximum contaminant level \\
\hline MCLG & maximum contaminant level goals \\
\hline MMI & Modified Mercalli Intensity \\
\hline MTCA & Model Toxics Control Act \\
\hline MTR & minimum technology requirement \\
\hline NAAQS & national ambient air quality standards \\
\hline NCP & National Contingency Plan \\
\hline NEPA & National Environmental Policy Act \\
\hline NERP & National Environmental Research Park \\
\hline NESHAP & National Emission Standards for Hazardous Air Pollutants \\
\hline NFFSC & National Severe Storms Forecast Center \\
\hline NOAEL & no observed adverse effects level \\
\hline NPL & National Priorities List \\
\hline NRC & Nuclear Regulatory Commission \\
\hline OSHA & Occupational Safety and Health Administration \\
\hline PAH & polyaromatic hydrocarbons \\
\hline PCB & polychlorinated biphenyl \\
\hline PMF & probable maximum flood \\
\hline PNL & Pacific Northwest Laboratory \\
\hline PQL & practical quantification limits \\
\hline PSD & Prevention of Significant Deterioration \\
\hline PUREX & plutonium-uranium extraction (Plant) \\
\hline PVC & polyvinylchloride \\
\hline QRA & qualitative risk assessment \\
\hline RAGS & Risk Assessment Guidance for Superfund \\
\hline RAO & remedial action objectives \\
\hline RCRA & Resource Conservation and Recovery Act of 1976 \\
\hline RCW & Revised Code of Washington (State) \\
\hline RfD & reference dose \\
\hline RI/FS & remedial investigation/feasibility study \\
\hline RO & reverse osmosis \\
\hline ROD & record of decision \\
\hline SDWA & Safe Drinking Water Act \\
\hline SEPA & State Environmental Policy Act \\
\hline SER & siting evaluation report \\
\hline
\end{tabular}




\section{LIST OF ACRONYMS (Cont.)}

SF

slope factor

SMCL

SPF

secondary maximum contaminant level

SQL

SSE

TBC

TRU

TSCA

TSD standard project flood

sample quantitation limit

safe-shutdown earthquake

to be considered

transuranic waste

Toxic Substances Control Act

TWRS

treatment, storage, or disposal

UCL

Tank Waste Remediation System

UTL

VF

VOA

VOC

upper confidence limit

upper tolerance limit

volitilization factor

volatile organic analysis

volatile organic compounds

WAC

WHC

WIDS

WIPP

Washington Administrative Code

Westinghouse Hanford Company

Waste Identification Data System

WISHA

WPPSS

Waste Isolation Pilot Plant

Washington Industrial Safety and Health Act

Washington Public Power Supply System 
DOE/RL-93-99, Rev. 0

This page left intentionally blank 


\section{CONTENTS}

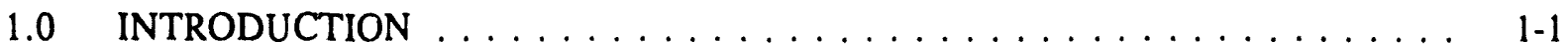

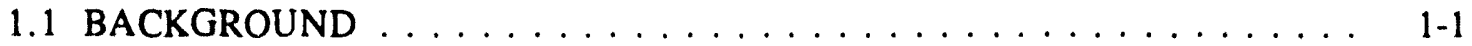

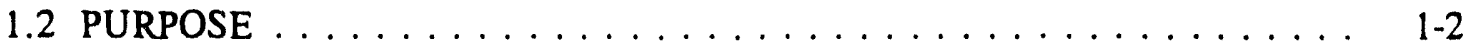

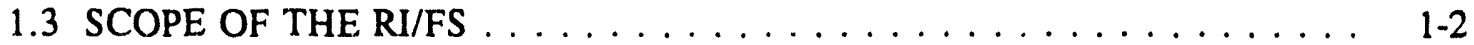

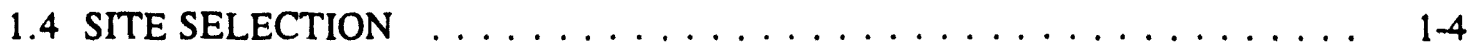

1.5 REPORT ORGANIZATION $\ldots \ldots \ldots \ldots \ldots \ldots \ldots \ldots$

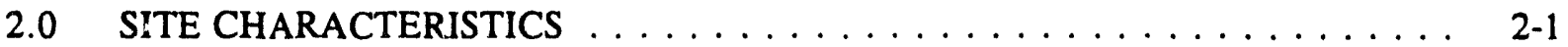

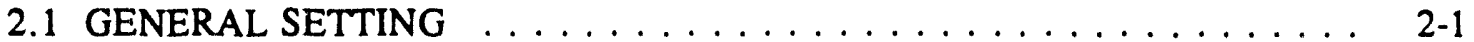

2.1 .1 Regional Setting . . . . . . . . . . . . . . . . . . 2-1

2.1 .2 Local Setting . . . . . . . . . . . . . . . . . . . 2-1

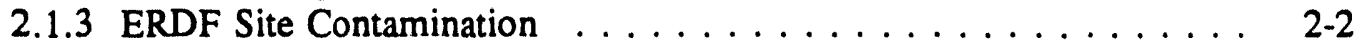

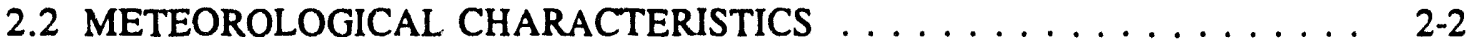

2.2.1 Precipitation . . . . . . . . . . . . . . . . 2-3

2.2.2 Temperature and Humidity . . . . . . . . . . . . . . 2-4

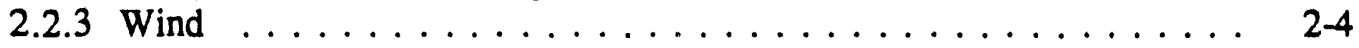

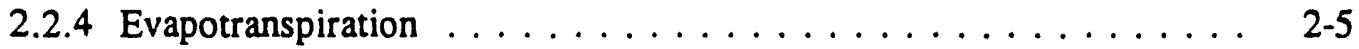

2.2 .5 Severe Weather . . . . . . . . . . . . . . . . . 2-6

2.2.6 Hanford Site Air Quality . . . . . . . . . . . . . . 2-6

2.3 SURFACE HYDROLOGICAL CHARACTERISTICS . . . . . . . . . . . 2-7

2.3.1 Regional Surface Hydrology . . . . . . . . . . . . . 2-7

2.3 .2 Flooding . . . . . . . . . . . . . . . . . . 2 2-9

2.3.3 Local Surface Water Hydrology . . . . . . . . . . . . . . . 2-10

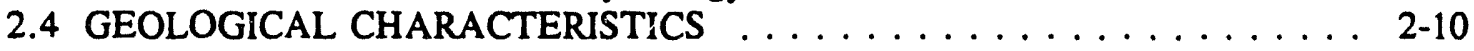

2.4.1 Topography and Physiography ... . . . . . . . . . 2-10

2.4.2 Regional Geologic Structure and Stratigraphy . . . . . . . . . . 2-11

2.4 .3 Local Geology . . . . . . . . . . . . . . . . . . . . . . . 2-14

2.4 .4 Seismicity ...................... 2-15

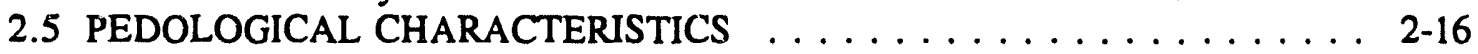

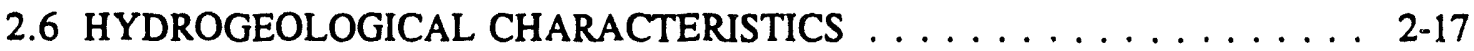

2.6.1 Regional Hydrogeology . . . . . . . . . . . . . . . 2-17

2.6 .2 Local Hydrogeology . . . . . . . . . . . . . . . . . . 2-21

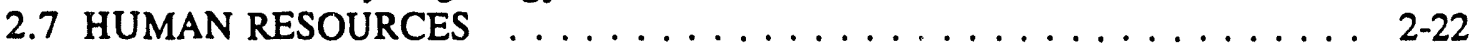

2.7.1 Land Use . . . . . . . . . . . . . . . . . . . 2-22

2.7 .2 Water Use . . . . . . . . . . . . . . . . 2-23

2.7.3 Histcrical, Archaeological, and Cultural Resources . . . . . . . . . 2-24

2.7.4 Socioeconomics . . . . . . . . . . . . . . . . . . . . 2-27

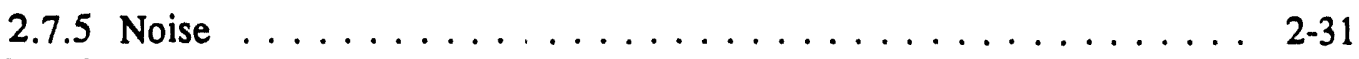

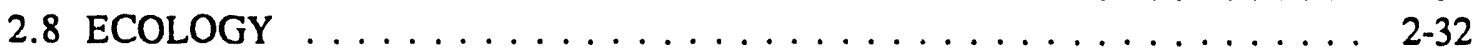

2.8.1 Hanford Site Terrestrial Ecology . . . . . . . . . . . . . . 2-33

2.8.2 Species of Special Concern at the Hanford Site . . . . . . . . . 2-36

2.8.3 Wildlife Refuges . . . . . . . . . . . . . . . . 2-37

2.8.4 ERDF Ecology . . . . . . . . . . . . . . . 2-38 
2.9 CHARACTERISTICS OF FINE-GRAINED SOILS BORROW SITE

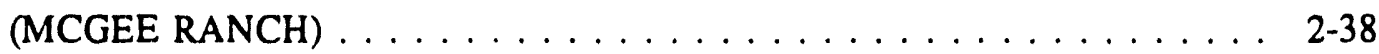

2.9.1 Site Description . . . . . . . . . . . . . . . . . . 2-38

2.9.2 Characteristics of Site Sediments and Fine-Grained

Sediment Volume Estimates . . . . . . . . . . . . . . . . . . . 2-38

2.9.3 Archaeological and Cultural Characteristics . . . . . . . . . . 2-39

2.9.4 Wildlife Ecology . . . . . . . . . . . . . . . . . . . . . 2-40

2.10 CHARACTERISTICS OF BASALT BORROW SITE $\ldots \ldots \ldots \ldots \ldots$. $\ldots$ 2-40

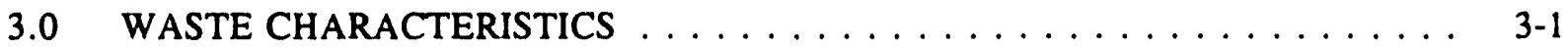

3.1100 AREA WASTE CHARACTERISTICS $\ldots \ldots \ldots \ldots \ldots \ldots \ldots$ 3-3

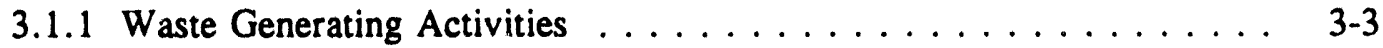

3.1 .2 Waste Units ..................... $3-6$

3.1.3 Physical Characteristics and Components of 100 Area Waste . . . . . 3-11

3.1.4 Chemical Characteristics of 100 Area Waste . . . . . . . . . . 3-13

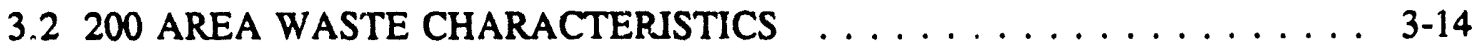

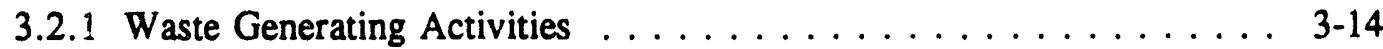

3.2 .2 Waste Units . . . . . . . . . . . . . . . . 3-14

3.2.3 Physical Characteristics and Components of 200 Area Waste . . . . . 3-15

3.2.4 Chemical Characteristics of 200 Area Waste . . . . . . . . . 3-15

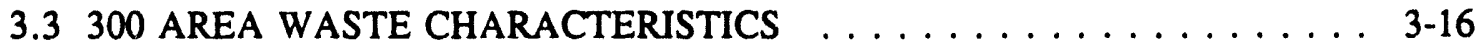

3.3.1 Waste Generating Activities . . . . . . . . . . . . 3-16

3.3 .2 Waste Units . . . . . . . . . . . . . . . 3-17

3.3.3 Physical Characteristics and Components of 300 Area Waste . . . . . 3-20

3.3.4 Chemical Characteristics of 300 Area Waste . . . . . . . . . . 3-21

3.4 MAXIMUM ERDF WASTE CONCENTRATIONS AND BACKGROUND

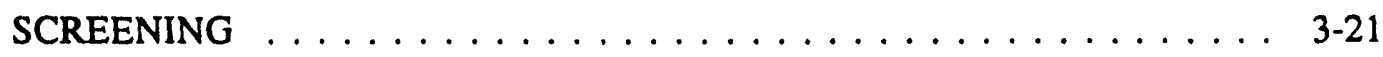

4.0 CONTAMINANT FATE AND TRANSPORT $\ldots \ldots \ldots \ldots \ldots \ldots \ldots$

4.1 MODEL DEVELOPMENT $\ldots \ldots \ldots \ldots \ldots \ldots \ldots \ldots \ldots$ 4-1

4.1.1 Conceptual Model . . . . . . . . . . . . . . . . . . 4-1

4.1.2 Model Parameters . . . . . . . . . . . . . . . 4-2

4.1.3 Fate and Transport Modeling Results . . . . . . . . . . . . 4-6

4.1.4 Sensitivity of Modeling Results to Site Location . . . . . . . . . . . 4-7

4.2 GROUNDWATER BACKGROUND SCREENING $\ldots \ldots \ldots \ldots \ldots \ldots \ldots$. . . . .

4.3 GROUNDWATER DE MINIMIS SCREENING $\ldots \ldots \ldots \ldots \ldots \ldots \ldots$. . . $\ldots$

4.4 TRAVEL TIME CRITERION . . . . . . . . . . . . . . . . . . . . 4-9

4.5 GROUNDWATER CONTAMINANTS . . . . . . . . . . . . . . 4-9

5.0 CONTAMINANTS OF POTENTIAL CONCERN $\ldots \ldots \ldots \ldots \ldots \ldots$

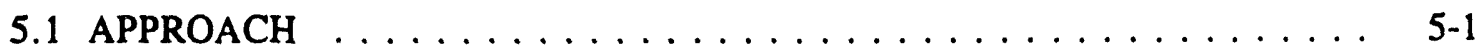

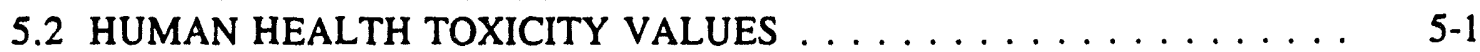

5.3 SOIL RISK-BASED SCREENING $\ldots \ldots \ldots \ldots \ldots \ldots \ldots \ldots \ldots$. $\ldots \ldots \ldots$

5.4 GROUNDWATER RISK-BASED SCREENING $\ldots \ldots \ldots \ldots \ldots \ldots \ldots$

5.5 SUMMARY OF CONTAMINANTS OF POTENTIAL CONCERN $\ldots \ldots \ldots$. $5-4$ 
6.0 RISK ASSESSMENT $\ldots \ldots \ldots \ldots \ldots \ldots \ldots \ldots \ldots \ldots \ldots$ 6-1

6.1 HUMAN HEALTH EVALUATION OF GROUNDWATER EXPOSURE . . . 6-1

6.1.1 Human Exposure Assessment $\ldots \ldots \ldots \ldots \ldots \ldots \ldots$. 6 .2

6.1 .2 Human Health Toxicity Assessment $\ldots \ldots \ldots \ldots \ldots \ldots$ 6 6 .4

6.1.3 Human Health Risk Characterization . . . . . . . . . . . . . 6-8

6.1 .4 Uncertainty Analysis . . . . . . . . . . . . . . . 6 6-11

6.1.5 Human Health Risk Characterization Summary for Groundwater

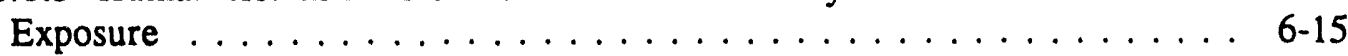

6.2 RISK ASSESSMENT OF EXPOSURE TO CONTAMINATED SOILS . . . . 6-16

6.2.1 Human Health Evaluation $\ldots \ldots \ldots \ldots \ldots \ldots \ldots$. $6-16$

6.2.2 Ecological Risk Assessment . . . . . . . . . . . . . . . 6-25

6.3 RISK ASSESSMENT OF SOILS FOR THE 500-YEAR DRILLING

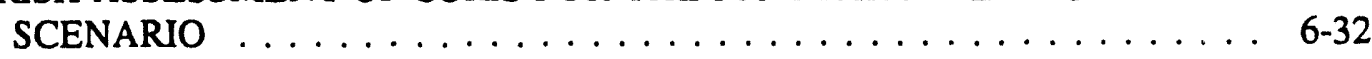

6.3.1 Human Health Evaluation $\ldots \ldots \ldots \ldots \ldots \ldots \ldots .6 \ldots .33$

6.3.2 Ecological Evaluation of the Intruder Scenario . . . . . . . . . 6-33

7.0 DEVELOPMENT OF REMEDIAL ACTION OBJECTIVES $\ldots \ldots \ldots \ldots$. . . . .

7.1 POTENTIAL APPLICABLE OR RELEVANT AND APPROPRIATE

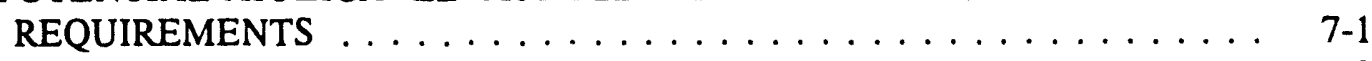

7.1.1 Chemical-Specific ARARs $\ldots \ldots \ldots \ldots \ldots \ldots \ldots \ldots \ldots$ 7-2

7.1 .2 Location-Specific ARARs $\ldots \ldots \ldots \ldots \ldots \ldots \ldots \ldots \ldots$ 7-11

7.1.3 Action Specific ARARs . . . . . . . . . . . . . . 7-13

7.2 REMEDIAL ACTION OBJECTIVES $\ldots \ldots \ldots \ldots \ldots \ldots \ldots \ldots$

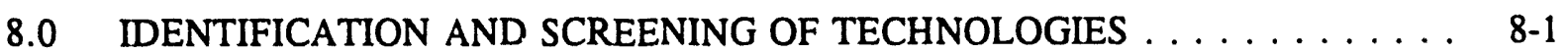

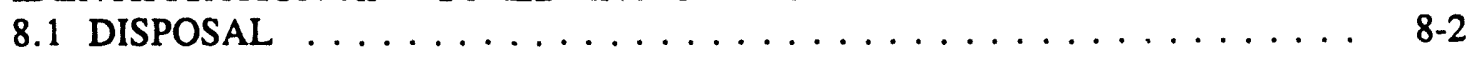

8.1.1 Centralized Engineered Waste Management Facility on the Hanford Site (ERDF) . . . . . . . . . . . . . . $8-2$

8.1.2 Engineered Waste Management Facilities at Individual Source

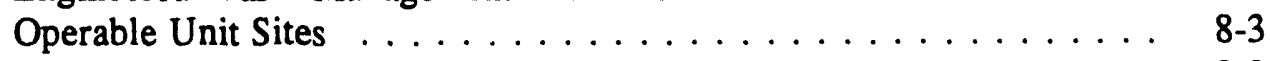

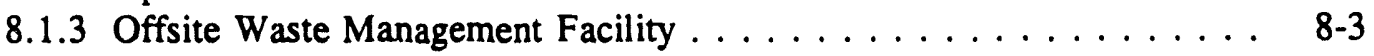

8.1 .4 Geologic Repository . . . . . . . . . . . . . . . . . . . 8-4

8.2 TRENCH CONFIGURATION $\ldots \ldots \ldots \ldots \ldots \ldots \ldots \ldots \ldots$

8.2.1 Shallow Trench Design $\ldots \ldots \ldots \ldots \ldots \ldots \ldots \ldots$ 8-5

8.2 .2 Shallow Area-Fill Design $\ldots \ldots \ldots \ldots \ldots \ldots \ldots \ldots \ldots$. $8-6$

8.2.3 Deep Area-Fill Design $\ldots \ldots \ldots \ldots \ldots \ldots \ldots \ldots \ldots \ldots$. 8 .6

8.3 DUST CONTROL $\ldots \ldots \ldots \ldots \ldots \ldots \ldots \ldots \ldots \ldots \ldots \ldots \ldots$. 8 .7

8.4 SURFACE WATER MANAGEMENT $\ldots \ldots \ldots \ldots \ldots \ldots \ldots$ 8-8

8.5 SURFACE BARRIERS $\ldots \ldots \ldots \ldots \ldots \ldots \ldots \ldots \ldots \ldots \ldots, 8.8$

8.5 .1 Soil Barrier $\ldots \ldots \ldots \ldots \ldots \ldots \ldots \ldots \ldots \ldots \ldots \ldots . \ldots \ldots$

8.5 .2 Asphalt Barrier $\ldots \ldots \ldots \ldots \ldots \ldots \ldots \ldots \ldots \ldots \ldots . \ldots \ldots$

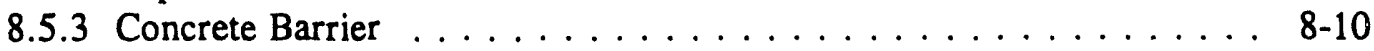

8.5.4 Low-Permeability Clay Barrier $\ldots \ldots \ldots \ldots \ldots \ldots \ldots \ldots$ 8-10

8.5.5 Synthetic Membrane Barrier . . . . . . . . . . . . . . 8-10

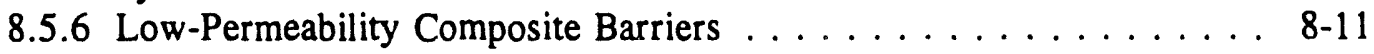




\section{CONTENTS (Cont.)}

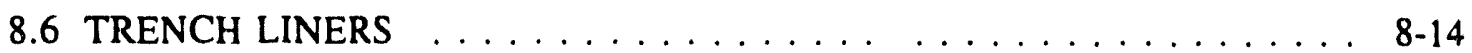

8.6.1 Asphalt Liner . . . . . . . . . . . . . . . . . . . 8-14

8.6.2 Concrete Liner . . . . . . . . . . . . . . . . . . . . 8-14

8.6.3 Low-Permeability Clay Liner . . . . . . . . . . . . . . . . 8 8-15

8.6.4 Composite Liner Designs . . . . . . . . . . . . . . . . . . . 8-15

8.7 INSTITUTIONAL CONTROLS $\ldots \ldots \ldots \ldots \ldots \ldots \ldots \ldots$ 8-16

8.8 WASTEWATER TREATMENT $\ldots \ldots \ldots \ldots \ldots \ldots \ldots \ldots$ 8-17

9.0 ASSEMBLY AND DETAILED EVALUATION OF REMEDIAL ALTERNATIVES 9-1

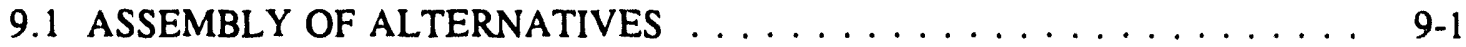

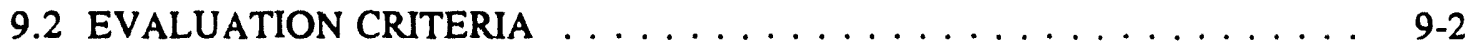

9.3 COMMON ELEMENTS AND IMPACTS $\ldots \ldots \ldots \ldots \ldots \ldots \ldots$

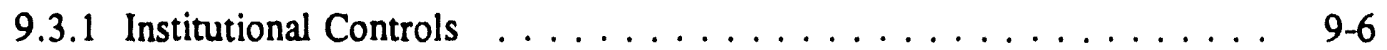

9.3.2 Dust Control . . . . . . . . . . . . . . . . . . . . . . 9-7

9.3.3 Surface Water Managenent . . . . . . . . . . . . . . 9 9-7

9.3.4 Wastewater Treatment . . . . . . . . . . . . . . . . . . 9. 9-8

9.3.5 Transportation Expansion and Impacts . . . . . . . . . . . . . . . 9-8

9.3.6 Other Supporting Facilities and Activities . . . . . . . . . . . . . . . 9-9

9.3.7 Deep Area-Fill Configuration . . . . . . . . . . . . . . . . . . 9-10

9.3.8 Liners . . . . . . . . . . . . . . . . . . . . . 9-11

9.3.9 Surface Barriers . . . . . . . . . . . . . . . . . . . 9-14

9.3 .10 Ecological Impacts . . . . . . . . . . . . . . . . . 9-18

9.3.11 Impacts on Air Quality . . . . . . . . . . . . . . . 9-18

9.3.12 Impacts on Historical and Cultural Resources . . . . . . . . . . . . 9-19

9.3.13 Socioeconomic Impacts . . . . . . . . . . . . . . . . . . . . . 9-19

9.3.14 Impacts on Visual Resources and Noise . . . . . . . . . . . . . . 9 9-19

9.3.15 Common Cost Factors . . . . . . . . . . . . . . . . . . . 9 9-20

9.3.16 Short-Term Worker and Public Risk . . . . . . . . . . . . . . . 9-20

9.3.17 Irreversible and Irretrievable Commitment of Resources . . . . . . . 9-23

9.3.18 Indirect and Cumulative Effects . . . . . . . . . . . . . . . . . 9-24

9.3.19 Mitigation of Impacts from the ERDF . . . . . . . . . . . . . . 9-25

9.3.20 Corrective Action Management Unit (CAMU) Evaluation . . . . . . 9 9-25

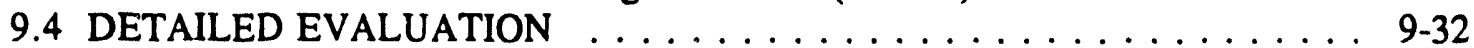

9.4.1 Alternative 1 - No Action . . . . . . . . . . . . . . 9-33

9.4.2 Alternative 2 - No Liner and the Low-Infiltration Soil Barrier . . . . 9-33

9.4.3 Alternative 3 - No Liner and the Modified Hanford Barrier . . . . . . 9. 9-34

9.4.4 Alternative 4 - No Liner and the Hanford Barrier . . . . . . . . . . . 9.35

9.4.5 Alternative 5 - Single Composite Liner and the Low-Infiltration Soil Barrier . . . . . . . . . . . . . . . . . . . 9-35

9.4.6 Alternative 6 - Single Composite Liner and the Modified Hanford Barrier . . . . . . . . . . . . . . . . . . . 9-36

9.4.7 Alternative 7 - Single Composite Liner and the Hanford Barrier . . . 9-37

9.4.8 Alternative 8 - RCRA Double Composite Liner and the LowInfiltration Soi! Barrier . . . . . . . . . . . . . . . . 9-38

9.4.9 Alternative 9-RCRA Double Composite Liner and the Modified Hanford Barrier 


\section{CONTENTS (Cont.)}

9.4.10 Alternative 10 - RCRA Double Composite Liner and the Hanford Barrier ... . . . . . . . . . . . . . . . . . $9-40$

9.5 COMPARATIVE ANALYSIS $\ldots \ldots \ldots \ldots \ldots \ldots \ldots \ldots \ldots$

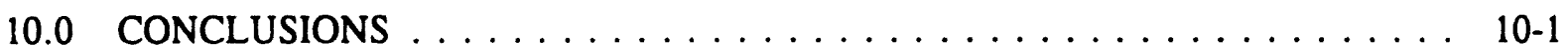

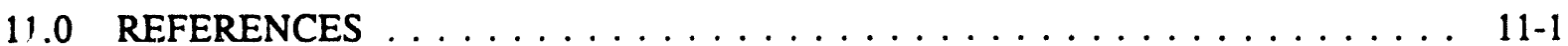

\section{APPENDICES:}

Appendix A Fate and Transport Modeling

Appendix B HELP Modeling Results

Appendix C Acceptable Soil and Leachate Concentration Limits

Appendix D Leachate Generation MEMO

\section{FIGURES:}

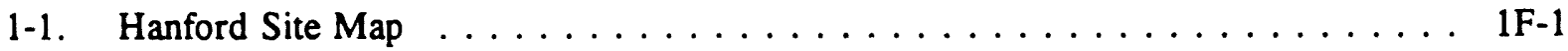

1-2. ERDF Candidate Site Locations . . . . . . . . . . . . . . . . . 1F-2

2-1. Location of the Proposed Environmental Restoration Disposal

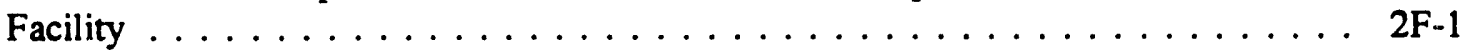

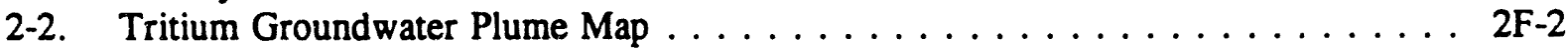

2-3. Iodine-129 Groundwater Plume Map . . . . . . . . . . . . . . 2F-3

2-4. Technetium-99 Groundwater Plume Map . . . . . . . . . . . . 2F-4

2-5. Gross Alpha Groundwater Plume Map $\ldots \ldots \ldots \ldots \ldots \ldots \ldots \ldots \ldots$

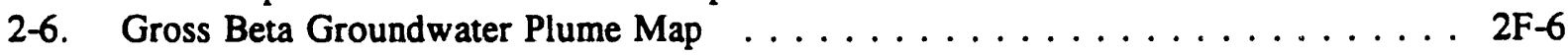

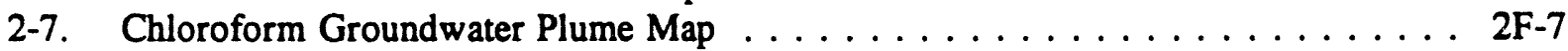

2-8. Nitrate Groundwater Plume Map . . . . . . . . . . . . . . . 2F-8

2-9. Chromium Groundwater Plume Map . . . . . . . . . . . . . . . . . 2F-9

2-10. Carbon Tetrachloride Groundwater Plume Map . . . . . . . . . . . . . 2F-10

2-11. Meteorologic Monitoring Stations at the Hanford Site . . . . . . . . . 2F-11

2-12. Monthly Average Precipitation Amounts, 1912 through $1980 \ldots \ldots \ldots \ldots \ldots$. . . . 2F-12

2-13. Rainfall Intensity Duration and Frequency Based on the Period 1947 to 1969 at Hanford . . . . . . . . . . . . . . . . . . . . . 2F-13

2-14. HMS Monthly Average High and Low Air Temperatures, 1951 through

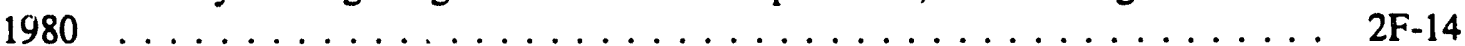

2-15. Average Monthly Temperature and Relative Humidity at the HMS . . . . . . 2F-15

2-16. Monthly Wind Roses for HMS Based on 50 foot Wind Data, 1955 through $1980 \ldots \ldots \ldots \ldots \ldots \ldots \ldots \ldots \ldots \ldots \ldots \ldots \ldots$.F $\ldots \ldots \ldots \ldots$

2-17. Average Monthly Plan Evaporation at Prosser, WA for the

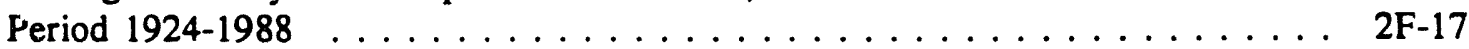

2-18. Total Monthly Evapotranspiration Near the 300 Area $\ldots \ldots \ldots \ldots \ldots$. . . . . . $\ldots$ - .

2-19. Approximate Location of Major Drainage Divides . . . . . . . . . . . 2F-19 


\section{CONTENTS (Cont.)}

FIGURES (cont.):

2-20. Probable Maximum Flood Areas on the Columbia River . . . . . . . . . . . . 2F-20

2-21. Extent of Probable Maximum Flood in Cold Creek Area . . . . . . . . . . . 2F-21

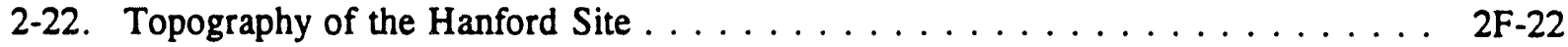

2-23. General Topography and Geomorphic Features in the West-Central

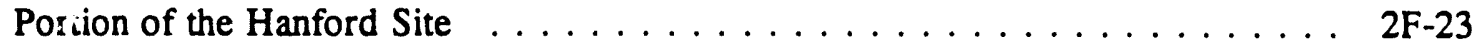

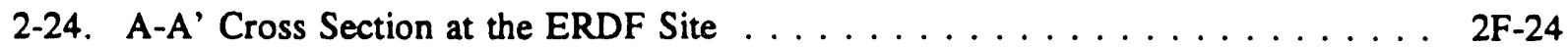

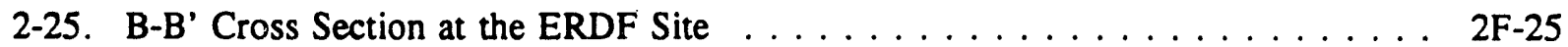

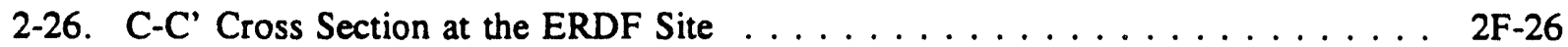

2-27. D-D' Cross Section at the ERDF Site . . . . . . . . . . . . . . . . . . 2F-27

2-28. Historical Seismicity of the Columbia Plateau and Surrounding Areas . . . . . . 2F-28

2-29. Soil Map of the Hanford Site . . . . . . . . . . . . . . . . . . . . . . . 2F-29

2-30. Hanford Site Water Table Map, January $1944 \ldots \ldots \ldots \ldots$. . . . . . . . . . . 2F-30

2-31. Hanford Site Water Table Map, June - Augusta $1990 \ldots \ldots$. . . . . . . . . 2F-31

2-32. Areal Distribution of Hydraulic Conductivity for the Unconfined

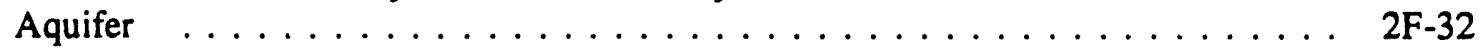

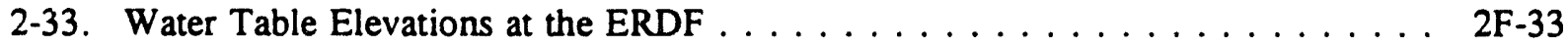

2-34. Approximate Location of the White Bluffs Road on the 200 Area Plateau . . . . 2F-34

2-35. Existing Transportation Network Within the Hanford Site . . . . . . . . . . . 2F-35

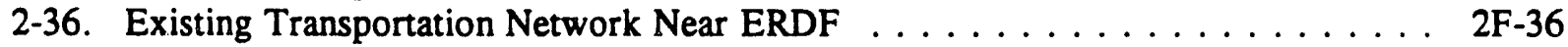

2-37. Distribution of Vegetation Types on the Hanford Site . . . . . . . . . . . . 2F-37

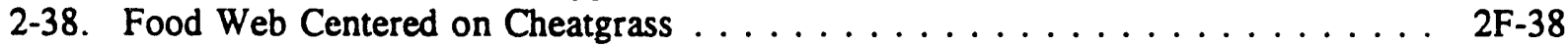

2-39. National and State Wildlife Refuges in the Vicinity of the Hanford Site ........................... 2F-39

2-40. Location Map McGee Ranch Borrow Soil Site . . . . . . . . . . . . . . . . . . 2F-40

2-41. Locational Map of Areas A and B of the McGee Ranch Site . . . . . . . . . 2F-41

4-1. Cross-Sectional Dimensions for ERDF Trench . . . . . . . . . . . . . . 4F-1

4-2. Vadose Zone and Saturated Zone Parameters . . . . . . . . . . . . . . 4F-2

$5-1$. Overview of Contaminant Identification Process $\ldots \ldots \ldots \ldots \ldots \ldots$

6-1. Overview of Risk Assessment of Base Conditions . . . . . . . . . . . . . . 6F-1

6-2. Human Health Conceptual Model for Exposure to Contaminated Soils . . . . . . . . 6F-2

6-3. Conceptual Model for the Ecological Risk Assessment of the Environmental Restoration Disposal Facility . . . . . . . . . . . . . . . . . 6 6F-3

8-1. Cross Sections of Potential ERDF Trench Configurations . . . . . . . . . . . 8F-1

8-2. Cross Section for a Typical Low Infiltration Soil Cover . . . . . . . . . . . . . . 8F-2

8-3. Typical Cross Section of a Standard RCRA Subtitle C Barrier . . . . . . . . . . . 8 8F-3

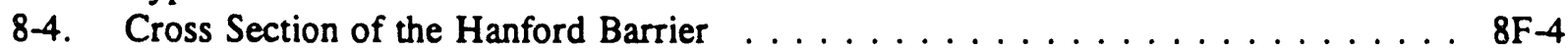

8-5. Cross Section of the Modified Hanford Barrier . . . . . . . . . . . . . . 8F-5

8-6. Cross Section of a Single Liner System . . . . . . . . . . . . . . . . . . . 8F-6

8-7. Cross Section of a Typical RCRA Subtitle C Double Liner System . . . . . . . . 8 8F-7 


\section{CONTENTS (Cont.)}

\section{FIGURES (cont.):}

9-1. Location of Proposed Rail Lines and Roads . . . . . . . . . . . . . . . 9F-1

\section{TABLES:}

2-1. Soil Types on the Hanford Site . . . . . . . . . . . . . . . 2T-1

2-2. Common Vascular Plants on the Hanford Site . . . . . . . . . . . . . . 2T-2

2-3. Partial List and Status of Amphibians and Reptiles Occurring on the Hanford Site . . . . . . . . . . . . . . . . . . . . . . 2T

2-4. Partial List of Status of Birds Found on the Hanford Site . . . . . . . . . . . . 2T-4

2-5. List of Mammals Occurring on the Hanford Site . . . . . . . . . . . . . 2T-5

2-6. Plant Species of Special Concern Occurring on the Hanford Site . . . . . . . . . 2T-6

3-1. Maximum Concentrations for Radionuclides in 100 Area Wastes . . . . . . . . . 3T-1

3-2. Maximum Concentrations for Organic Compounds in 100 Area Wastes . . . . . . 3T-2

3-3. Maximum Concentrations for Inorganic and General Chemistry Constituents in 100 Area Wastes .................... 3T-3

3-4. Maximum Radionuclide Concentrations Detected in Soils in 200 Area Waste Units . . . . . . . . . . . . . . . . . . . . . 3T -4

3-5. Maximum Concentrations for Radionuclides in 300 Area Wastes . . . . . . . . . 3T-5

3-6. Maximum Concentrations for Organic Compounds in 300 Area Wastes . . . . . . . 3T-6

3-7. Maximum Concentrations for Inorganic and General Chemistry Constituents in 300 Area Wastes ... . . . . . . . . . . . . . 3T-7

3-8. Maximum Concentrations for Radionuclides in 100, 200, and 300 Area Wastes .......................... 3T-8

3-9. Maximum Concentrations for Organic Compounds in 100 and 300 Area Wastes . . . . . . . . . . . . . . . . . . . . . . . 3T-9

3-10. Maximum Concentrations and Background Screening for Inorganic and General Chemistry Constituents in 100 and 300 Area Wastes . . . . . . . . 3T-10

4-1. General Parameters Used for the ERDF Modeling . . . . . . . . . . . . . . . . . 4T-1

4-2. Partitioning Coefficients for Organic Compounds . . . . . . . . . . . . . . . 4T-2

4-3. Partitioning Coefficients for Radionuclides . . . . . . . . . . . . . . . . 4T-3

4-4. Partitioning Coefficients for Inorganic Constituents . . . . . . . . . . . . . . . . . 4T-4

4-5. Half-lives for Organic Compounds . . . . . . . . . . . . . . . . . . 4T-5

4-6. Half-lives and Solubilities for Radionuclides . . . . . . . . . . . . . . . . . 4T 4

4-7. Solubilities for Organic Compounds . . . . . . . . . . . . . . . . . 4T-7

4-8. Solubilities for Inorganic Constituents . . . . . . . . . . . . . . . . . 4T-8

4-9. Groundwater Background Screening for Inorganic Constituents . . . . . . . . . . . 4T-9

4-10. De Minimis and Travel Time Groundwater Contaminant Screening . . . . . . . . 4 4T-10

4-11. Potential Groundwater Contaminants at the ERDF . . . . . . . . . . . . . 4T-11

5-1. Contaminant Reference Doses and Slope Factors . . . . . . . . . . . . . . 5T-1

5-2. Summary Screening Factors for Risk-Based Screening . . . . . . . . . . . . . . . . 5T-2

5-3. Risk-Based Screening Concentrations (mg/kg) for Soil Pathways Non-Radioactive Contaminants . . . . . . . . . . . . . . . . . 5T-3

5-4. Risk-Based Screening Concentrations $(\mathrm{pCi} / \mathrm{g})$ for Soil Pathways -
Radioactive Contaminants $\ldots \ldots \ldots \ldots \ldots \ldots \ldots \ldots \ldots \ldots \ldots$ 


\section{CONTENTS (Cont.)}

TABLES (cont.):

5-5. Comparison of Maximum Soil Contaminant Concentrations to

Risk-Based Screening Concentrations and ARARs . . . . . . . . . . . . 5T-5

5-6. Risk-Based Screening Concentrations for Groundwater Pathways . . . . . . . . . 5 ST-6

5-7. Comparison of Predicted Groundwater Contaminant Concentrations

to Risk-Based Screening Concentrations and ARARs . . . . . . . . . . . . . 5T 5 -7

5-8. Contaminants of Potential Concern in Soils . . . . . . . . . . . . . . . . . . 5T

5-9. Contaminarts of Potential Concern in Groundwater . . . . . . . . . . . . . . . . 5T-9

6-1. Residential Scenario Exposure Factors for Noncarcinogenic

Contaminants ......................... 6T -1

6-2. Residential Scenario Exposure Factors for Carcinogenic

(Non-Radioactive) Contaminants . . . . . . . . . . . . . . . . . 6T-2

6-3. Residential Scenario Exposure Factors for Radioactive Contaminants . . . . . . . . 6 6T-3

6-4. Residential Summary Intake Factors . . . . . . . . . . . . . . . . . . 6 6T-4

6-5. Intakes and Risk Values for Groundwater Contaminants via Ingestion . . . . . . . 6 6T-5

6-6. Intakes and Risk Values for Dermal Exposure to Groundwater . . . . . . . . . . . 6T-6

6-7. Summary of Systemic Toxicity Information for Contaminants of

Potential Concern . . . . . . . . . . . . . . . . . . . 6T-7

6-8. Summary of Carcinogenic Toxicity Information for Contaminants of

Potential Concern . . . . . . . . . . . . . . . . . . . 6T-8

6-9. Dermal Toxicity Values for Groundwater Contaminants of

Potential Concern . . . . . . . . . . . . . . . . . . . . . . 6T -9

6-10. Summary of Groundwater Contaminants Risks and Travel Times . . . . . . . . 6 6T-10

6-11. Residential Scenario Exposure Factors for Noncarcinogenic

Contaminants ........................ 6T-11

6-12. Residential Scenario Exposure Factors for Carcinogenic (Non-Radioactive)

Contaminants . . . . . . . . . . . . . . . . . . . . 6T -12

6-13. Residential Scenario Exposure Factors for Radioactive Contaminants . . . . . . . . 6T-13

6-14. Residential Scenario Summary Intake Factors . . . . . . . . . . . . . . . . . . 6 6T-14

6-15. Intakes and Risk Values for Non-Radioactive Soil Contaminants via

Soil Ingestion . . . . . . . . . . . . . . . . . . . . . . . . 6T

6-16. Intake and Risk Values for Non-Radioactive Soil Contaminants via

Dermal Pathway . . . . . . . . . . . . . . . . . . . . . . . 6T-16

6-17. Intake and Risk Values for Non-Radioactive Soil Contaminants via

Fugitive Dust Inhalation . . . . . . . . . . . . . . . . . . . 6T-17

6-18. Intake and Risk Values for Non-Radioactive Contaminants via

Inhalation of Volatiles . . . . . . . . . . . . . . . . . . . . 6 6T-18

6-19. Intake and Risk Values for Radioactive Soil Contaminants

(All Pathways)

6-20. Summary of Systemic Toxicity Information for Soil Contaminants of

Potential Concern (COPC) at the ERDF . . . . . . . . . . . . . . . . . 6T-20

6-21. Summary of Carcinogenic Toxicity Information for Soil Contaminants

of Potential Concern at the ERDF . . . . . . . . . . . . . . . 6T-21

6-22. Dermal Toxicity Values for Soil Contaminants of Potential Concern . . . . . . . 6T-22

6-23. Summary of Current Non-Radioactive Soil Contaminant Risks . . . . . . . . . . 6 6T-23 
DOE/RL-93-99, Rev. 0

\section{CONTENTS (Cont.)}

TABLES (cont.):

6-24. Summary of Current Radioactive Soil Contaminant Risks . . . . . . . . . . . . 6T-24

6-25. Summary of Future Non-Radioactive Soil Contaminants Risks . . . . . . . . . . . 6T-25

6-26. Summary of Future Radioactive Soil Contaminant Risk . . . . . . . . . . . . . 6T-26

6-27. Future Risks Associated with Organic Contaminants in Soil . . . . . . . . . . 6 6T-27

6-28. Future Risks Associated with Radioactive Contaminants in Soil . . . . . . . . . . 6T-28

6-29. Soil-to-Plant Transfer Coefficients Used for Organic Contaminants . . . . . . . . . 6T-29

6-30. Soil-to-Plant Transfer Coefficient for Inorganic Contaminants . . . . . . . . . . . 6T-30

6-31. Soil-to-Plant Factors for Radionuclide Contaminants . . . . . . . . . . . . . . 6 6T-31

6-32. Parameters for Assessing Radiological Exposure to the Great Basin Pocket Mouse . . . . . . . . . . . . . . . . . . . . . . . 6T-32

6-33. Estimated Concentrations of Organic Contaminants in Environmental Media Used to Estimate Intake Rates for the Great Basin Pocket Mouse . . . . . . 6T 6 -33

6-34. Estimated Inorganic Contaminant Concentrations in Environmental Media Used to Estimate Intake Rates for the Great Basin Focket Mouse . . . . . . . . . . 6T-34

6-35. Estimated Activities of Radiological Contaminants in Environmental Media Used to Estimate Intake Rates for the Great Basin Pocket Mouse . . . . . . 6T-35

6-36. Estimated Intakes and Hazards to Great Basin Pocket Mouse Due to Ingestion of Organic Contaminants . . . . . . . . . . . . . . 6T-36

6-37. Estimated Intakes and Hazards to the Great Basin Pocket Mouse from Ingestion of Inorganic Contaminants . . . . . . . . . . . . . . 6T-37

6-38. Estimated Doses and Hazards to the Great Basin Pocket Mouse from Ingestions and Exposure to Radionuclide Contaminants . . . . . . . . . . 6T-38

6-39. Estimated Current and Future Environmental Hazard Quotient for the Great Basin Pocket Mouse from Ingestion of Organic Contaminants . . . . . . 6T-39

6-40. Estimated Current and Future Dose to the Great Basin Pocket Mouse from Ingestion of and External Exposure to Radionuclides . . . . . . . . . . . . 6T -40

6-41. Non-Radioactive Contaminant Human Health Risks for the 500-Year Drilling Scenario . . . . . . . . . . . . . . . . . . . . . . . 6T -41

6-42. Radionuclide Human Health Risks for the 500-Year Drilling Scenario . . . . . . . 6T-42

6-43. Inorganic Contaminant Risks to Environmental Receptors for the 500-Year Drilling Scenario . . . . . . . . . . . . . . . . . . . . 6 6T-43

7-1. Identification of Potential Federal ARARs for the ERDF . . . . . . . . . TT-1

7-2. Identification of Potential State ARARs for the ERDF . . . . . . . . . . . TT-2

7-3. Preliminary Air and Groundwater Chemical-Specific ARARs for the ERDF Contaminants of Potential Concern (Radionuclides) . . . . . . . . . . . 7T-3

7-4. Preliminary Chemical-Specific ARARs for the ERDF Groundwater Contaminants of Potential Concern (Non-Radioactive Contaminants) . . . . . . . TT-4

7-5. Groundwater Standards for Contaminants . . . . . . . . . . . . . . . . . . TT -5

8-1. Summary of Screening Results for Groundwater Remediation

Technologies and Process Options . . . . . . . . . . . . . . . 8T-1

8-2. Unit Costs for a Typical Low-Infiltration Soil Barrier . . . . . . . . . . . . . . . . . 8T-2

8-3. Typical Costs for a Standard RCRA Subtitle C Barrier . . . . . . . . . . . . . . 8 8T-3

8-4. Typical Unit Costs for the Hanford Barrier . . . . . . . . . . . . . . . . . . . 8T-4

8-5. Typical Unit Costs for the Modified Hanford Barrier . . . . . . . . . . . . . . 8T-5

8-6. Typical Unit Costs for a Single Liner System . . . . . . . . . . . . . . . . . . . 8T-6

8-7. Typical Unit Costs for a RCRA Subtitle C Double Liner System . . . . . . . . . . 8T-7 


\section{CONTENTS (Cont.)}

TABLES (cont.):

9-1. Summary of Remedial Action Components for ERDF Alternatives . . . . . . . . 9 9T-1

9-2. Raw Liner Construction Costs . . . . . . . . . . . . . . . . . . . . . 9T-2

9-3. Labor Requirements for Construction of the Liners . . . . . . . . . . . . . . . . 9 9T-3

9-4. Total Material Requirements for the Trench Liners . . . . . . . . . . . . . . . 9T-4

9-5. Labor Requirements for Construction of the Barriers . . . . . . . . . . . . . . 9T-5

9-6. Material Requirements for the Barriers . . . . . . . . . . . . . . 9T-6

9-7. Capital Cost Estimates and Multipliers for ERDF Elements $(\$ \times 1,000) \ldots \ldots$. . . 9T-7

9-8. Predicted Groundwater Human-Health Risks for Remedial Alternatives

under Hypothetical Wetter Climate Conditions . . . . . . . . . . . . . . . . . 9T-8

9-9. Scores for Long-Term Effectiveness . . . . . . . . . . . . . . . . . . . . . . 9T-9

9-10. Scores for Short-Term Effectiveness Sub-Criteria . . . . . . . . . . . . . . 9T-10

9-11. Scores for Implementability Sub-Criteria . . . . . . . . . . . . . . 9T-11

9-12. Costs for Remedial Alternatives . . . . . . . . . . . . . . . . . . . . 9T-12

9-13. Summary Ranking of the Alternatives Against the Criteria . . . . . . . . . 9T-13 


\subsection{INTRODUCTION}

This remedial investigation/feasibility study (RI/FS) document examines construction and operation of the Environmental Restoration Disposal Facility (ERDF) for the U.S. Department of Energy's (DOE's) Hanford Site in Richland, Washington. The ERDF has been proposed to serve as the receiving facility for waste generated due to remediation of Comprehensive Environmental Response, Compensation, and Liability Act of 1980 (CERCLA) past practice units and Resource Conservation and Recovery Act (RCRA) corrective action activities at the Hanford Site. In accordance with the Code of Federal Regulations (40 CFR 264.552) and the Washington Administrative Code (WAC 173-303-646), a separate application for designation of the ERDF as a RCRA Corrective Action Management Unit (CAMU) is being prepared. In accordance with CERCLA RCRA CAMU requirements, only remediation waste that originates within the Hanford Site may be placed in the ERDF. Remediation waste is defined under 40 CFR 260.10 as all solid and hazardous wastes, and all media (including groundwater, surface water, soils, and sediments) and debris, which contain listed or characteristic hazardous wastes, that are managed for the purpose of implementing corrective action requirements. The remediation waste is expected to consist of hazardous/dangerous waste, polychlorinated biphenol (PCB) waste, asbestos waste, radioactive waste, and mixed waste (containing both hazardous/dangerous and radioactive waste).

The ERDF would initially be authorized with a Record of Decision under CERCLA and permitted as a CAMU under RCRA with EPA as the lead agency. Once the State is granted authority for administration of the Hazardous and Solid Waste Amendments of 1984 (HSWA), and the CAMU is included as a modification in the Hanford Facility RCRA permit, the State would be the RCRA Corrective Action lead agency. EPA will retain authority under CERCLA.

\subsection{BACKGROUND}

The Hanford Site is a $1,450 \mathrm{~km}^{2}\left(560 \mathrm{mi}^{2}\right)$ tract of land located along the Columbia River in southeastern Washington and covers portions of Benton, Grant, Franklin and Adams counties (Figure 1-1). Operated by the federal government since 1943, its primary mission has been plutonium production for military use, and nuclear energy research and development. These activities included releases of wastes to the environment that resulted in contamination of soils and groundwater with hazardous/dangerous and radioactive constituents.

The Hanford Site is divided into numerically designated operational areas, including the $100,200,300,400,600$, and 1100 Areas. In November 1989, the U.S. Environmental Protection Agency (EPA) placed the 100, 200, 300, and 1100 Areas on the National Priorities List (NPL) contained within Appendix B of the National Oil and Huzardous Substance Pollution Contingency Plan (NCP, 53 FR 51391 et seq.). The EPA took this action pursuant to their authority under CERCLA (42 USC 9601 et seq.). Restoration of the CERCLA past practice sites at the Hanford Site is expected to result in the generation of wastes requiring further management. RI/FS's will be done for all of the individual operable units. It will be the responsibility of the individual operable units to determine if disposal at the ERDF is the preferred alternative and the need for treatment before disposal.

The Hanford Site is a single RCRA facility with over 60 treatment, storage and disposal (TSD) units conducting dangerous waste management activities. These TSD units are included in the Hanford Facility Dangerous Waste Part A Permit Application (DOE-RL, 1988). The 
Washington State Department of Ecology (Ecology) has authority for RCRA implementation through the State's Dangerous Waste Regulations in the Washington Administrative Code (WAC 173-303). Closure and corrective actions related to TSD facilities on the Hanford Site are expected to result in the generation of wastes requiring further management. The WAC is not applicable to a CAMU at this time because Washington State does not have authority for administration of HSWA. However, the State is expected to have HSWA authority in the next few years.

Agreements between the DOE Richland Operations Office (DOE-RL), the EPA, and Ecology regarding environmental restoration activities and management of wastes at the Hanford Site are documented in the Hanford Federal Facility Agreement and Consent Order (Ecology et al. 1992) also referred to as the Tri-Party Agreemeni. This order was first issued in 1989 and has been renegotiated on several occasions, including the most recent negotiations in 1993 (Ecology et al. 1994).

Milestone M-70-00 of the Tri-Party Agreement calls for the design, approval, construction, and operation of the ERDF by September 1996. It is the stated purpose of the Tri-Party signatories that regulatory approval for the ERDF will be obtained under a CERCLA Record of Decision (ROD) and HSWA using applicable CAMU regulations. This RI/FS will provide the supporting information for a proposed plan that will become the basis for the CERCLA ROD. Preparation of the CAMU application is proceeding concurrently with preparation of this document. Eventually, the RI/FS, proposed plan, anci CAMU application will constitute the regulatory package that provides the basis for regulatory approval as well as the compliance management framework for the ERDF.

\subsection{PURPOSE}

The purpose of the proposed action is to support the removal of contaminants from portions of the Hanford Site (including near the Columbia River) in a timely manner, to allow those remediated portions of the Site to be released for other productive uses. Several Tri-Party Agreement milestones exist for near-term remediation efforts, including issuance of CERCLA operable unit Records of Decision (ROD) in 1995. The remedies to be selected in the operable unit RODs are expected to require excavation and management of large volumes of remediationgenerated waste, which will require disposition.

\subsection{SCOPE OF THE RI/FS}

The primary objectives of the RI/FS are clearly described in the NCP:

The purpose of the remedial investigation $(R I)$ is to collect data necessary to adequately characterize the site for the purpose of developing and evaluating effective remedial alternatives. To characterize the site, the lead agency shall, as appropriate, conduct field investigations, including treatability studies, and conduct a baseline risk assessment. The $R I$ provides information to assess the risks to human health and the environment and to support the development, evaluation, and selection of appropriate response alternatives. (40 CFR 300.400(d)(1)).

The primary objective of the feasibility study (FS) is to ensure that appropriate remedial alternatives are developed and evaluated such that relevant information 
concerning the remedial action options can be presented to a decision-maker and an appropriate remedy selected. The lead agency may develop a feasibility study to address a specific site problem or the entire site. The development and evaluation of alternatives shall reflect the scope and complexity of the remedial action under consideration and the site problems being addressed. Development of alternatives shall be fully integrated with the site characterization activities of the remedial investigation described in paragraph (d) of this section. The lead agency shall include an alternatives screening step, when needed, to select a reasonable number of alternatives for detailed analysis. (40 CFR 300.400(e)(1)).

As stated above, the lead agency may develop an FS to address a specific site problem. Consistent with this objective, the scope of the ERDF RI/FS is focused on the configuration of the waste containment unit (also referred to as the trench), the liner, and the surface barrier. Evaluation of the supporting facilities, including the transportation system, waste handling equipment and procedures, decontamination, and leachate treatment system, are also provided. These supporting facilities are not the focus of this analysis because they do not significantly affect long-term performance of the facility and are considered design details; they will be fully addressed during remedial design.

In addition, treatment of remediation wastes received at the ERDF will not be addressed in this RI/FS. It is not feasible to address treatment in this document because the remediation wastes to be delivered to the ERDF have not yet been sufficiently characterized. Furthermore, performance of different treatment technologies is specific to the characteristics of the waste and generally requires treatability information that is not yet available. Given the variability in waste characteristics for different source operable units and the need for site-specific treatability information, evaluation of treatment technologies will be conducted at the source operable unit level. Acceptable limits on soil and leachate concentrations designed to protect human health and the environment are defined in this document and in a separate document that is currently under preparation. These limits will be used for development of waste acceptance criteria. RI/FS efforts at the source operable units will assess treatment options including whether treatment is required to meet ERDF waste acceptance criteria.

In the most recent Tri-Party Negotiations (Ecology et al. 1994), it was agreed that a pilot project to demonstrate National Environmental Policy Act (NEPA)/CERCLA functional equivalency would be conducted for the ERDF project. Therefore, the scope of this document has been expanded to address NEPA values not normally considered in a CERCLA RI/FS. Many of the NEPA values, such as a description of the affected environment (including meteorology, hydrology, geology, ecological resources, and land-use), applicable laws and guidelines, short-term and long-term impacts on human health and the environment, emissions to water and air, and cost, are included within a typical CERCLA RI/FS. Other NEPA values not normally addressed in a CERCLA RI/FS, such as socioeconomics, cultural resources, and transportation, have been evaluated in this document. Although this document evaluates the implications if the ERDF is not constructed, the broad range of non-ERDF remedial actions for the Hanford Site are not addressed. Remediation of Hanford past-practice waste sites will be addressed in the Hanford Remedial Action Environmental Impact Statement (HRA-EIS), currently under preparation. The HRA-EIS will evaluate the implementation of action alternatives such as in-situ containment/treatment, multiple small waste management facilities on the Hanford Site, and disposal off the Hanford Site. 


\subsection{SITE SELECTION}

Site selection is based on the evaluation in the Siting Evaluation Report for the Environmental Restoration Disposal Facility (WHC 1994a). This siting evaluation report (SER) evaluated three candidate sites that were at least 15 square kilometers (6 square miles) of contiguous land within the boundaries of the 200 Area plateau. This land requirement is based on early design assumptions for the ERDF that resulted in greater land use. By optimizing the trench design, the ERDF will occupy only 4.1 square kilometers (1.6 square miles).

Placement of the ERDF on the 200 Area plateau would facilitate consolidation of waste management activities away from the Columbia River at a relatively high ground surface elevation (with a corresponding greater depth to groundwater). The risk-management benefits of consolidating waste in the 200 Area was supported by the Hanford Future Site Uses Working Group. This group, which consisted of representatives from federal, state, and local governments, native american tribes, labor groups, economic development groups, and public interest groups, was chartered with developing a range of visions concerning future uses of the Hanford Site. A general recommendation by the group was that areas of high future use (e.g., near the Columbia River) be cleaned up and that the interior section of the 200 Area plateau be designated for waste management (Drummond 1992). Use of the 200 Area for waste management is also identified in the Hanford Site Development Plan (DOE-RL 1993d), which is revised on an annual basis to identify land use, infrastructure, and facility requirements to support DOE piograms at the Hanford Site.

The three candidate sites in the SER are shown on Figure 1-2. As discussed in the SER, the primary screening criteria were based on the Washington State Dangerous Waste Regulations Siting Criteria (WAC 173-303-282), DOE Order 6430.1A (General Design Criteria), DOE Order 5820.2A (Radioactive Waste Management), and DOE-RL Order 4320.2C (Site Selection). Using these criteria, Site 3 was selected as the preferred location for the ERDF based on its following factors:

- $\quad$ Compatibility with the Hanford Future Site Uses Working Group recommendations to the degree technically feasible

- Greatest depth to groundwater

- Relatively flat topography

- Lowest cost.

The sites were also evaluated in the SER using the CERCLA criteria and the CAMU criteria. Site 3 was the preferred site for all the applicable CERCLA criteria and the following applicable CAMU criteria:

- Siting will facilitate implementation of reliable, effective, protective, and cost-effective remedies

- Placement will not create unacceptable risks to human health or to the environment resulting from exposure to hazardous wastes or constituents

- The site will not include uncontaminated areas of the facility 
- The selected land area, to the extent practicable, upon which wastes will remain in place after closure of the CAMU will be minimized.

\subsection{REPORT ORGANIZATION}

The ERDF operable unit RI/FS report is organized in a format similar to that recommended by EPA (1988a) with the following 11 chapters and appendices following Chapter 1.0, Introduction:

- Chapter 2, Site Characteristics, provides a description of the relevant meteorologic, surface hydrologic, geologic, pedologic, hydrogeologic, human resources, and ecologic characteristics of the study area. Brief descriptions of the site characteristics for proposed borrow sites for basalt and fine-grained soils are also provided.

- Chapter 3, Waste Characteristics, provides a discussion of the physical and chemical characteristics of the wastes likely to be received at the ERDF.

- Chapter 4, Contaminant Fate and Transport, provides analysis of the environmental fate and transport of likely contaminants in the waste received at the ERDF. Transport modeling is applied in this section to estimate future contaminant concentrations in groundwater.

- Chapter 5, Contaminants of Potential Concern, compares predicted contaminant concentrations in ERDF waste and groundwater with regulatory limits and risk-based limits to identify the potential contaminants of concern.

- Chapter 6, Risk Assessment, estimates the human and environmental health threats posed by likely contaminants in the waste received at the ERDF.

- $\quad$ Chapter 7, Development of Remedial Action Objectives, identifies applicable or relevant and appropriate requirements and remedial action objectives for the ERDF.

- Chapter 8, Identification and Screening of Remedial Technologies, identifies and screens technologics and process options that are potentially applicable to the ERDF.

- Chapter 9, Detailed Evaluation and Comparative Analysis of Remedial Alternatives, assembles the retained technologies into remedial alternatives that are then evaluated against CERCLA criteria. Comparative analysis of the alternatives is also performed in this chapter.

- Chapter 10, Conclusions, summarizes results of the RI/FS.

- Chapter 11, References, provides a list of cited documents within the body of the report. 
DOE/RL-93-99, Rev. 0

- Appendices are used to present technical analyses needed to support the findings of the RI/FS report. 
DOE/RL-93-99, Rev. 0

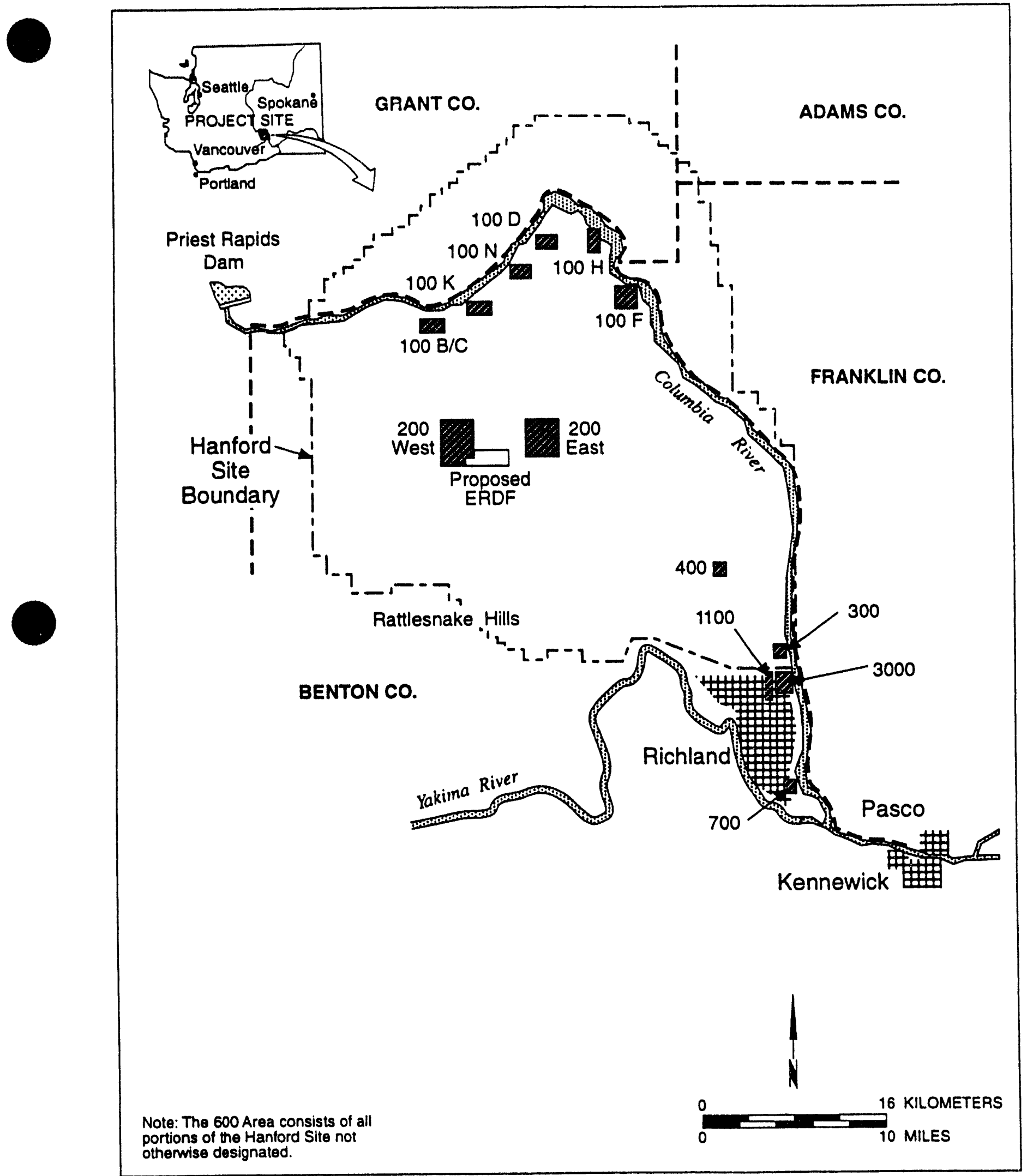

$923 E 412 / 47835 / 6-8-94$

Figure 1-1. Hanford Site Map. 


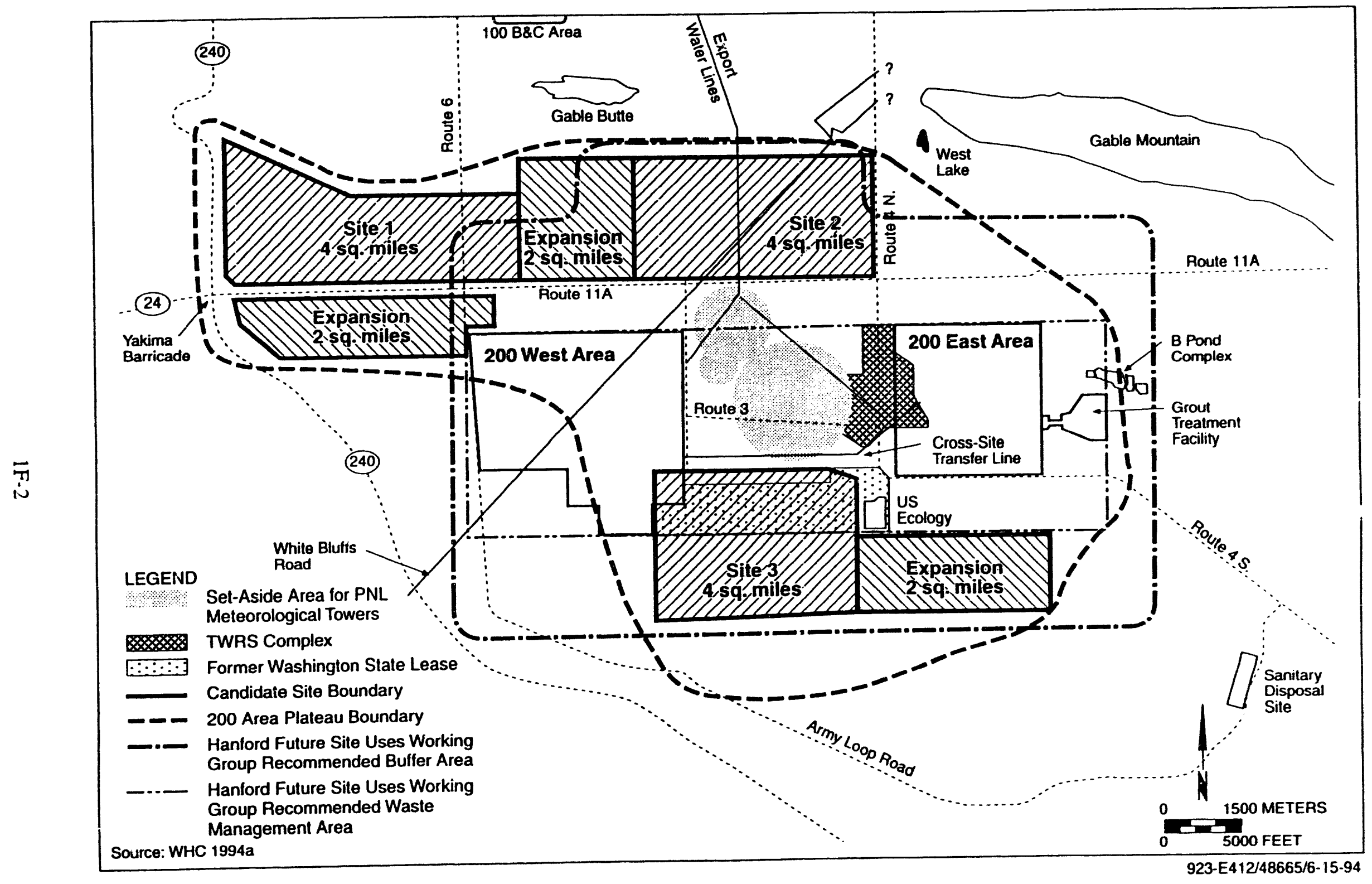

Figure 1-2. ERDF Candidate Site Locations. 


\subsection{SITE CHARACTERISTICS}

This chapter describes the relevant characteristics of the Hanford site as a whole, the proposed ERDF site and likely borrow source areas impacted by construction of the ERDF. Descriptions of the location, meteorology, surface water hydrology, geology, soils, hydrogeology, human resources, and ecology are presented. Much of the regional information presented in this chapter has been adapted from Cushing (1992).

\subsection{GENERAL SETTING}

\subsubsection{Regional Setting}

The U.S. Department of Energy's Hanford Site lies within the semi-arid Pasco Basin of the Columbia Plateau in southeastern Washington State, and covers portions of Benton, Franklin, Grant and Adams counties (Figure 1-1). The Hanford Site occupies an area of about $1,450 \mathrm{~km}^{2}\left(-560 \mathrm{mi}^{2}\right)$ north of the confluence of the Snake and Yakima rivers with the Columbia River. The Hanford Site is about $50 \mathrm{~km}(30 \mathrm{mi})$ north to south and $40 \mathrm{~km}(24 \mathrm{mi})$ east to west. Hanford is located $190 \mathrm{~km}(120 \mathrm{mi})$ southwest of Spokane and $280 \mathrm{~km}(174 \mathrm{mi})$ southeast of Seartle. This land, with restricted public access, provides a buffer for the smaller areas used for storage of nuclear materials and waste management; only about $6 \%$ of the land area has been disturbed and is actively used. The Columbia River flows through the northern part of the Hanford Site, and turning south, it forms part of the Site's eastern boundary. The Yakima River runs along part of the southern boundary and joins the Columbia River south of the city of Richland, which bounds the Hanford Site on the southeast. Rattlesnake Mountain, the Yakima Ridge, and the Umtanum Ridge form the southwestern and western boundary. The Saddle Mountains form the northern boundary of the Hanford Site. Two small east-west ridges, Gable Butte and Gable Mountain, rise above the plateau of the central part of the Hanford Site. Adjoining lands to the west, north, and east are principally range and agricultural land. The cities of Richland, Kennewick, and Pasco (Tri-Cities) constitute the nearest population center and are located southeast of the Hanford Site.

The Hanford Site is divided into numerically designated operational areas, including the $100,200,300,400,600$ and 1100 Areas. Land use in these areas is described in Section 2.7.1. The Hanford Site encompasses more than 1,500 waste management units and numerous groundwater contamination plumes that have been grouped into 73 operable units. Each operable unit has similar characteristics regarding geography, waste characteristics, type of facility, and relationship of contaminant plumes. This grouping into operable units allows for economies of scale to reduce the cost and the number of characterization investigations and remedial actions that will be required for the Hanford Site to complete cleanup efforts (WHC 1989). The 73 operable units have been aggregated into four areas: the 100 Area, the 200 Area, the 300 Area, and the 1100 Area.

\subsubsection{Local Setting}

The proposed ERDF site will cover 4.1 square kilometers (1.6 square miles) on the 200 Area plateau at an elevation of 205 to $230 \mathrm{~m}$ (670 to $750 \mathrm{ft}$ ) above mean sea level (AMSL), approximately in the center of the Hanford Site, southeast of the 200 West Area and southwest 
of the 200 East Area. A map of the ERDF site is shown in Figure 2-1. Topography of the ERDF site is also shown in Figure 2-1.

The proposed ERDF site is located within Sections 7, 8, 9, 14, 15, 16, 17, and 18 of Township $12 \mathrm{~N}$ and Range $26 \mathrm{E}$.

\subsubsection{ERDF Site Contamination}

No solid waste management units are located within the proposed ERDF area; however, solid waste is found in the western and southwestern portions of the land formerly leased to the state. Radiological contamination has been spread by animals to the area east of the ERDF from the nearby BC cribs and trenches. The BC cribs and trenches were used from 1956 to 1967 as a waste disposal site for the 200 and 300 areas. Currently, they contain quantities of plutonium, strontium, cesium, cobalt and uranium.

Animals spread contamination from the BC trenches and cribs from about 1958 to 1964 (O'Farrell et al. 1973). Trench 216-B-28 was burrowed by an animal and used by other animals as a salt lick. Subsequently, radioactivity was spread away from the trench via wind dispersion. The trench burrow was filled and sealed with asphalt in 1964, which effectively stopped further spreading of radioactive contaminants from the trench. The last aerial radiological survey of the Hanford site still showed elevated gross gamma readings south of the BC cribs as well as aroun' the US Ecology Site (Reiman and Dahlstrom 1990).

Contamination may be present at the portion of the ERDF site east of the REDOX plant in the 200 West Area (Figure 2-1). This area was used as a storage area during the construction of the REDOX plant from 1950 to 1952 . The site was used for heavy vehicle parking and maintenance, and as a concrete truck washdown area. Possible soil contaminants include gasoline, oil and other lubricants, and other vehicle-related fluids.

Due to the proximity of the ERDF site to the 200 West Area and its associated groundsurface liquid waste disposal operations, contaminated groundwater has migrated beneath the ERDF site. Contaminants present in the groundwater at the site are: tritium, iodine-129, technetium-99, gross alpha, gross beta, chloroform, nitrate, chromium and carbon tetrachloride. The highest concentrations of contaminants are generally found at the points nearest the 200 West Area, which is at the west end of the ERDF. Figures 2-2 through 2-10 present groundwater contaminant plume maps for the listed constituents.

\subsection{METEOROLOGICAL CHARACTERISTICS}

The Hanford Site is located in a semiarid region of southeastern Washington State. The Cascade Mountains beyond Yakima to the west greatly influence the climate of the Hanford area by means of their rain shadow effect; this range also serves as a source of cold air drainage, which has a considerable effect on the wind regime at the Hanford Site.

This section presents an interpretation of meteorological data for the Hanford Site and the ERDF site. The data have been collected primarily at the Hanford Meteorological Station (HMS), which is located at an elevation of $223 \mathrm{~m}$ ( $733 \mathrm{ft}$ ) AMSL between the 200 East and 200 West Areas of the Hanford Site, approximately $4 \mathrm{~km}(2 \mathrm{mi})$ to the north of the ERDF site. 
Data have been collected at the HMS since 1945. Temperature and precipitation data are also available from nearby locations for the period 1912 through 1943. A summary of these data through 1980 has been published by Stone et al. (1983) which is the primary source of information presented below. Data from the HMS are representative of the general climatic conditions for the region and describe the specific climate of the 200 Area plateau. Local variations in the topography of the Hanford Site may cause some aspects of climate at portions of the Hanford Site to differ significantly from those of the HMS. For example, winds near the Columbia River are different from those at the HMS. Similarly, precipitation along the slopes of the Rattlesnake Mountain differs significantly from that at the HMS. However, due to the close proximity and similar elevations of the HMS and the ERDF, the HMS data should accurately describe conditions at the ERDF.

In addition to the HMS, three $60-\mathrm{m}(200-\mathrm{ft})$ towers and twenty-two $9.1-\mathrm{m}(30-\mathrm{ft})$ towers that provide supplementary weather data are located on and around the Hanford site. These towers are equipped with instruments that measure temperature and wind velocity and direction. Figure 2-11 shows the locations of meteorological monitoring stations on and around the Hanford Site.

\subsubsection{Precipitation}

The Cascade Range is located approximately $130 \mathrm{~km}(80 \mathrm{mi})$ west of the Hanford Site and has an average crest elevation of about $1,800 \mathrm{~m}(6,000 \mathrm{ft}) \mathrm{AMSL}$. This mountain range creates a rain shadow that limits the average total annual precipitation at the HMS to about 16 $\mathrm{cm}$ (6.3 in.). Annual precipitation (98 percentile) ranges from 8 to $27.9 \mathrm{~cm}$ (3.2 to $11 \mathrm{in}$.). The three months from November through January generally contribute approximately $42 \%$ of this total, while the three months from July through September contribute only $12 \%$. January is the wettest month with an average of $2.3 \mathrm{~cm}(0.92 \mathrm{in}$.) while July is the driest month with an average of only $0.38 \mathrm{~cm}(0.15 \mathrm{in}$.). Monthly average precipitation amounts from 1912 through 1980 are shown in Figure 2-12. Precipitation intensity is greatest in the summer months. This seasonal intensity peak coincides with the thunderstorm season.

Days with greater than $1.3 \mathrm{~cm}(0.51$ in.) precipitation occur less than $1 \%$ of the year. Data on the expected frequency of precipitation intensity and short-period duration ( $24 \mathrm{~h}$ or less) are presented in Figure 2-13. Rainfall intensities of $1.3 \mathrm{~cm} / \mathrm{h}(0.51 \mathrm{in} . / \mathrm{h})$ persisting for 1 hour are expected once every 10 years. Rainfall intensities of $2.5 \mathrm{~cm} / \mathrm{h}(0.98 \mathrm{in} . / \mathrm{h})$ for 1 hour are expected only once every 500 years.

Winter monthly average snowfall ranges from $0.8 \mathrm{~cm}(0.31 \mathrm{in}$.) in March to $13.5 \mathrm{~cm}$ (5.3 in.) in January. The unpublished record snowfall of $142 \mathrm{~cm}$ (56 in.) occurred during the winter of 1992 and 1993. The previous record snowfall of $62 \mathrm{~cm}$ (24 in.) occurred in February 1916. About $38 \%$ of annual precipitation occurs as snowfall during the moliths of December through February. However, in only one winter in four does an accumulation in excess of 15.2 $\mathrm{cm}(6$ in.) occur. The average annual snowfall is $33 \mathrm{~cm}$ (13 in.). Complete snowmelt generally occurs within a month of a snow event. 


\subsubsection{Temperature and Humidity}

Diurnal and monthly averages and extremes of temperature, dew point, and humidity are contained in Stone et al. (1983). Average of daily maximum and minimum temperatures vary from $2{ }^{\circ} \mathrm{C}\left(36^{\circ} \mathrm{F}\right)$ in early January to $35^{\circ} \mathrm{C}\left(95^{\circ} \mathrm{F}\right)$ in late July. There are, on the average, 55 days during the summer months with maximum temperatures greater than or equal to $32^{\circ} \mathrm{C}$ $\left(90^{\circ} \mathrm{F}\right)$ and 13 days with maxima greater than or equal to $38^{\circ} \mathrm{C}\left(100^{\circ} \mathrm{F}\right)$. From mid-November through mid-March, minimum temperatures average $0^{\circ} \mathrm{C}\left(32^{\circ} \mathrm{F}\right)$ or less with the minima in early January averaging $-6^{\circ} \mathrm{C}\left(21^{\circ} \mathrm{F}\right)$. During the winter, there are, on average, 4 days with minimum temperatures less than or equal to $-18^{\circ} \mathrm{C}\left(0^{\circ} \mathrm{F}\right)$; however, only about one winter in two experiences such temperatures. The record maximum temperature is $46^{\circ} \mathrm{C}\left(115^{\circ} \mathrm{F}\right)$, and the record minimum temperature is $-32.8^{\circ} \mathrm{C}\left(-27^{\circ} \mathrm{F}\right)$. For the period 1912 through 1980 , the average monthly temperatures ranged from a low of $-1.5^{\circ} \mathrm{C}\left(29.3^{\circ} \mathrm{F}\right)$ in January to a high of $24.7^{\circ} \mathrm{C}\left(76.5^{\circ} \mathrm{F}\right)$ in July. During the winter, the highest monthly average temperature at the HMS was $6.9^{\circ} \mathrm{C}\left(44.4^{\circ} \mathrm{F}\right)$, and the record lowest was $-5.9^{\circ} \mathrm{C}\left(21.4^{\circ} \mathrm{F}\right)$, both having occurred during February. During the summer, the record maximum monthly average temperature was $27.9^{\circ} \mathrm{C}\left(82.2^{\circ} \mathrm{F}\right)$ (in July), and the record lowest was $17.2^{\circ} \mathrm{C}\left(63^{\circ} \mathrm{F}\right)$ (in June).

Relative humidity/dew point temperature measurements are made at the HMS and at the three $60-\mathrm{m}(200-\mathrm{ft})$ tower locations. The annual average relative humidity at the HMS is $54 \%$. It is highest during the winter months, averaging about $75 \%$, and lowest during the summer, averaging about $35 \%$. Wet bulb temperatures greater than $24^{\circ} \mathrm{C}\left(75^{\circ} \mathrm{F}\right)$ had not been observed at the HMS before 1975; however, on July 8, 9, and 10 of that year, there were seven hourly observations with wet bulb temperatures greater than or equal to $24^{\circ} \mathrm{C}\left(75^{\circ} \mathrm{F}\right)$.

Due to low humidity, the diurnal temperature range is substantial. During summer months, when the average relative humidity is 30 to $40 \%$, the diurnal temperature range is greatest, on the order of $15^{\circ} \mathrm{C}\left(27^{\circ} \mathrm{F}\right)$. In winter, with relative humidity ranging from 60 to $80 \%$, the diurnal temperature range is reduced to about $8^{\circ} \mathrm{C}\left(14^{\circ} \mathrm{F}\right)$ (DOE-RL 1990a). Figure 2-14 depicts the monthly average high and low temperatures for the period 1951 to 1980 . Figure 2-15 depicts average monthly temperature and relative humidity at the HMS.

\subsubsection{Wind}

Wind directions at the HMS vary over 360 degrees, with a prevailing wind direction from the northwest for every month of the year (average of $31.6 \%$ of the time). Secondary maxima occur for southwesterly winds. The months of June and July have the highest percentage of winds from the WNW and NW (38 and 37\%, respectively). October has the lowest percentage (25\%) from those directions. Monthly wind roses for the HMS are shown in Figure 2-16.

Monthly and annual joint frequency distributions of wind direction versus wind speed for the HMS are given in Stone et al. (1983). Monthly average wind speeds are lowest during the winter months, averaging 10 to $11 \mathrm{~km} / \mathrm{h}$ (6 to $7 \mathrm{mph}$ ), and highest during the summer, averaging 14 to $16 \mathrm{~km} / \mathrm{h}$ (9 to $10 \mathrm{mph}$ ). Wind speeds that are well above average in winter are usually associated with southwesterly winds. The summertime high winds are generally northwesterly and frequently reach $50 \mathrm{~km} / \mathrm{h}(30 \mathrm{mph})$. These winds are most prevalent over the northern portion of the Hanford Site. 
At the HMS, the strongest winds observed, with speeds up to $130 \mathrm{~km} / \mathrm{h}(80 \mathrm{mph})$, generally are southwesterly. Most hourly wind speeds greater than $52 \mathrm{~km} / \mathrm{h}(32 \mathrm{mph})$ are from the south-southwest to west-southwest and occur at the highest frequency from March through May (Hulstrom 1992).

Wind-blown dust accompanies strong winds on the Hanford Site. Blowing dust originating from the site itself has been observed at wind speeds greater than $32 \mathrm{~km} / \mathrm{h}(20 \mathrm{mph})$. Dust entrained elsewhere and transported to the Hanford Site has been observed for lower wind speeds of $7 \mathrm{~km} / \mathrm{h}$ (4 mph) (DOE-RL 1990a). Observations of blowing dust may occur with any wind direction, however, the strongest winds at the HMS are from the southwest and therefore there are more cases of blowing dust from that direction. Dust transported to the Hanford Site from elsewhere is most often associated with winds from the north and northeast.

\subsubsection{Evapotranspiration}

Pan evaporation data was obtained from the Washington State University Cooperative Extension for Prosser, WA located approximately $37 \mathrm{~km}(23 \mathrm{mi})$ southwest of the ERDF site. Monthly rates of pan evaporation at the Washington State University Irrigated Agriculture Research and Extension Center (IAREC) average from about 8.1 to $25.4 \mathrm{~cm}$ (3.2 to $10 \mathrm{in}$.). These averages are based upon data collected over the period 1924 to 1988 for the months April through October. Total pan evaporation over the April through Octoler period averaged about $126.6 \mathrm{~cm}$ (49.9 in.). This seasonal component represents approximately $80 \%$ of the total annual pan evaporation. Average monthly pan evaporation at Prosser for April through October is depicted in Figure 2-17.

Free surface evaporation (or potential evaporation) is expected to equal approximately $70 \%$ of the pan evaporation for the Hanford Site vicinity, or about $110 \mathrm{~cm}(43 \mathrm{in}$.) (Weather Bureau 1966). Free water surface evaporation is of interest because it closely represents the potential evaporation from adequately watered surfaces, such as vegetation and soil, and the evaporation from a surface body of water.

Beginning in the late 1970s, a monitoring program was conducted to study groundwater recharge and measure parameters that affect recharge rates. Rockhold et al. (1990) reported on water balance data which was collected as part of this program from three sites in 1988 and 1989. The sites included the 300 Area buried waste test facility and grass site, and the 200 East Area closed-bottom lysimeter. While evapotranspiration was not specifically reported for the 200 East Area site, the measured water contents in the soil implied that significant recharge had not occurred within the lysimeter.

For the 300 Area buried waste test facility, evaporation and transpiration were determined to be about $14.3 \mathrm{~cm}(5.6 \mathrm{in}$.) for a bare surface and $19.9 \mathrm{~cm}(7.9 \mathrm{in}$.$) for a$ vegetated surface, using measurements of changes in water storage, drainage, and precipitation. Precipitation during this period was approximately $18 \mathrm{~cm}(7.1$ in.). Drainage was about $4 \mathrm{~cm}$ (1.6 in.) from the bare surface and $1 \mathrm{~cm}(0.4 \mathrm{in}$.) from the vegetated surface. The excess of evapotranspiration and drainage over precipitation was compensated for by a reduction in soil moisture.

Figure 2-18 presents a plot of monthly evapotranspiration totals for the north (bare) and south (vegetated) weighing lysimeters at the buried waste test facility during the period 
December 1987 to August 1990 (Hulstrom 1992). This figure illustrates the large seasonal and annual variations in evapotranspiration and the large differences that can occur as a result of vegetation.

\subsubsection{Severe Weather}

The average occurrence of thunderstorms is 10 per year at the Hanford Site. They are most frequent during the summer; however, they have occurred in every month. The average winds during thunderstorms do not come from any preferred direction. Estimates of the extreme winds, based on peak gusts observed from 1945 through 1980, are given in Stone et al. (1983) and are shown in the following table. Using the National Weather Service criteria for classifying a thunderstorm as "severe" (i.e., hail with a diameter equal to or greater than $20 \mathrm{~mm}$ ( $0.8 \mathrm{in}$.) or wind gusts of $93 \mathrm{~km} / \mathrm{h}(58 \mathrm{mph})$ or greater), only $1.9 \%$ of all thunderstorm events observed at the HMS have been "severe" storms, and all met the criteria based on wind gusts.

\section{Estimates of Extreme Winds at Hanford Site \\ (Cushing 1992)}

\section{Peak Gusts, $\mathrm{km} / \mathrm{h}$}

\begin{tabular}{ccc}
$\begin{array}{l}\text { Return } \\
\text { Period, yr }\end{array}$ & $\begin{array}{c}15.2 \mathrm{~m}(50 \mathrm{ft}) \\
\text { Above Ground }\end{array}$ & $\begin{array}{l}61 \mathrm{~m}(200 \mathrm{ft}) \\
\text { Above Ground }\end{array}$ \\
\cline { 2 - 3 } 2 & 97 & 75 \\
10 & 114 & 109 \\
100 & 137 & 129 \\
1000 & 159 & 151
\end{tabular}

Note: $1 \mathrm{~km}=0.62 \mathrm{mi}$

Tornadoes are infrequent and generally small in the northwest portion of the United States. Grazulis (1984) lists no violent tornadoes for the region surrounding Hanford (DOE 1987). The HMS climatological summary (Stone et al. 1983) and the National Severe Storms Forecast Center (NSSFC) database list 22 separate tornado occurrences within $161 \mathrm{~km}$ $(100 \mathrm{mi})$ of the Hanford Site from 1916 through August 1982. Two additional tornadoes have been reported since August 1982.

\subsubsection{Hanford Site Air Quality}

Air quality in the vicinity of the Hanford Site is considered good since there are only a few industrial sources of air pollutants located in the area. The Benton-Franklin Counties Clean Air Authority routinely compiles emission inventories for permitted major sources of pollutants. In areas where the National Ambient Air Quality Standards (NAAQS) have been achieved, the EPA has established the Prevention of Significant Deterioration (PSD) program to protect existing ambient air quality. The Hanford Site operates under a PSD permit issued by the EPA in 1980. The permit provides specific limits for emissions of oxides of nitrogen from the Plutonium Uranium Extraction (PUREX) and Uranium Oxide $\left(\mathrm{UO}_{3}\right)$ plants (Cushing 1992). 
Limited ambient air quality monitoring has been performed in the vicinity of the Hanford Site for total suspended solids, particulates less than 10 microns in diameter (PM-10) and for nitrogen oxides. Nitrogen oxides were sampled at three locations within the Hanford Site using a bubbler assembly operated to collect 24-hour integrated samples (Woodruff et al. 1991). The highest annual average concentration was $<0.006 \mathrm{ppmv}$, well below the applicable federal and Washington State annual ambient standard of $0.05 \mathrm{ppmv}$. Monitoring for TSP and PM-10 was conducted in two communities surrounding the Hanford Site during 1990. The annual geometric mean of TSP was $71 \mu \mathrm{g} / \mathrm{m}^{3}$ in Sunnyside and $80 \mu \mathrm{g} / \mathrm{m}^{3}$ in Wallula. Both these values exceeded the Washington State annual standard, $60 \mu \mathrm{g} / \mathrm{m}^{3}$. The Washington State 24-hour standard, $150 \mu \mathrm{g} / \mathrm{m}^{3}$, was exceeded six times during the year at Sunnyside and seven times at Wallula. PM-10 was monitored at two locations, at Columbia Center in Kennewick and at Wallula. The 24-hour PM-10 standard established by the state of Washington, $150 \mu \mathrm{g} / \mathrm{m}^{3}$, was exceeded seven times at the Columbia Center monitoring location; the maximum 24-hour concentration at Wallula was $123 \mu \mathrm{g} / \mathrm{m}^{3}$. Neither site exceeded the annual primary standard of $50 \mu \mathrm{g} / \mathrm{m}^{3}$.

Airborne particulate concentrations may reach relatively high levels in eastern Washington due to exceptional natural events such as high winds and brush fires. In addition, elevated particulate levels have been associated with wheat farming. Ambient air quality standards do not consider "rural fugitive dust" from exceptional natural events or agriculture when estimating maximum background concentrations or when considering enforcement of air quality standards and permit applications.

\subsection{SURFACE HYDROLOGICAL CHARACTERISTICS}

This section provides a characterization of surface water hydrology, regionally within the Pasco Basin and locally in the vicinity of the ERDF site. The regional information is presented with attention focused on those aspects which are felt to relate directly to the ERDF site. Additional information on the regional hydrology may be found in DOE (1988), ERDA (1975) and Skaggs and Walters (1981).

\subsubsection{Regional Surface Hydrology}

The Pasco Basin occupies about $4,900 \mathrm{~km}^{2}\left(1,900 \mathrm{mi}^{2}\right)$ and is located centrally within the Columbia Plateau. Elevations within the Pasco Basin are generally lower than other parts of the plateau, and surface drainage enters it from other basins. Within the Pasco Basin, the Columbia River is joined by three major tributaries: the Yakima River, the Snake River, and the Walla Walla River. No perennial streams originate within the Pasco Basin (DOE 1988).

The Hanford Site occupies approximately one-third of the land area within the Pasco Basin. Primary surface-water features associated with the Hanford Site are the Columbia and Yakima rivers. Major watershed divides are shown in Figure 2-19. Several surface ponds and ditches are present, and are generally associated with fuel and waste processing activities.

Total estimated precipitation over the Pasco Basin is about $9 \times 10^{8} \mathrm{~m}^{3}\left(3 \times 10^{10} \mathrm{ft}^{3}\right)$ annually, averaging less than $20 \mathrm{~cm} / \mathrm{yr}(\sim 8 \mathrm{in} . / \mathrm{yr})$. Mean annual runoff from the basin is estimated to be less than $3.1 \times 10^{7} \mathrm{~m}^{3} / \mathrm{yr}\left(1.1 \times 10^{9} \mathrm{ft}^{3} / \mathrm{yr}\right)$, or approximately $3 \%$ of the total precipitation. The basin-wide runoff coefficient is zero for all practical purposes. The 
remaining precipitation is assumed to be lost through evapotranspiration, with a small component (perhaps less than 1\%) recharging the groundwater system (DOE 1988).

2.3.1.1 Major Rivers. The major surface water body in the Pasco Basin is the Columbia River, which flows from the Canadian Rocky Mountains through Washington State, and along the Oregon border, to the Pacific Ocean. Enroute to the Pacific, the Columbia River crosses the northern portion of the Hanford Site (approximately $15 \mathrm{~km}$ [9 mi] to the north of the ERDF site), then turns southward to form the Hanford Site's eastern boundary. About two-thirds of the Hanford Site drains into the Columbia River; the remaining one-third (in the western and southern portions of the Hanford Site) drains into the Yakima River (Figure 2-19). Both the Yakima and the Columbia rivers are important sources of water for domestic, agricultural, industrial, and recreational users in the Pasco Basin (DOE 1987, Jaquish and Bryce 1990). The Hanford Reach of the Columbia River is being considered for designation as a wild and scenic river (NPS 1992).

The Hanford Reach of the Columbia River extends from Priest Rapids Dam, approximately $8.5 \mathrm{~km}(5.3 \mathrm{mi})$ above the Hanford Site boundary, to the head of Lake Wallula approximately at the southeastern Hanford Site boundary. Lake Wallula is created by McNary Dam. The Hanford Reach, which is approximately $100 \mathrm{~km}(60 \mathrm{mi})$ in length, is the last nontidal unimpounded segment of the Columbia River in Washington State and its shoreline remains largely undeveloped (Jaquish and Bryce 1990). Several active drains and intakes are present along this reach, including irrigation outfalls from the Columbia Basin Irrigation Project, the Washington Public Power Supply System (WPPSS) Nuclear Project 2, and the Hanford Site intakes for onsite water use.

Volumetric flow rates in the Columbia River along the Hanford Reach vary widely and erratically due to operations of the Priest Rapids Dam, operated by Public Utility District No. 2 of Grant County, and the operational practices of the nearby upstream dams. A minimum flow rate of $1,000 \mathrm{~m}^{3} / \mathrm{s}\left(36,000 \mathrm{ft}^{3} / \mathrm{s}\right)$ has been established at Priest Rapids (PNL 1988a). The average daily flow varies from a high of approximately $8,000 \mathrm{~m}^{3} / \mathrm{s}\left(283,000 \mathrm{ft}^{3} / \mathrm{s}\right)$ in June to a low of about $2,000 \mathrm{~m}^{3} / \mathrm{s}\left(70,000 \mathrm{ft}^{3} / \mathrm{s}\right)$ in October and November. The average daily flow over the entire period of record is approximately $3,400 \mathrm{~m}^{3} / \mathrm{s}\left(119,000 \mathrm{ft}^{3} / \mathrm{s}\right)$. Monthly average flows have ranged as high as $16,700 \mathrm{~m}^{3} / \mathrm{s}\left(590,000 \mathrm{ft}^{3} / \mathrm{s}\right)$ which occurred in the month of June to about $600 \mathrm{~m}^{3} / \mathrm{s}\left(21,000 \mathrm{ft}^{3} / \mathrm{s}\right)$ for January and February.

The Yakima River, bordering the southern portion of the Hanford Site, has a low annual flow compared to the Columbia River. For 57 years of record, the average annual flow of the Yakima River is about $104 \mathrm{~m}^{3} / \mathrm{s}\left(3,673 \mathrm{ft}^{3} / \mathrm{s}\right)$ with monthly maximum and minimum flows of $490 \mathrm{~m}^{3} / \mathrm{s}\left(17,000 \mathrm{ft}^{3} / \mathrm{s}\right)$ and $4.6 \mathrm{~m}^{3} / \mathrm{s}\left(160 \mathrm{ft}^{3} / \mathrm{s}\right)$, respectively.

2.3.1.2 Other Naturally-Occurring Surface Waters. No perennial streams occur within the central portion of the Hanford Site. Cold Creek and its tributary, Dry Creek, are part of the Yakima River watershed and originate in the synclinal valleys west of the Hanford Site (Figure 2-19). Both streams receive some base flow from springs along portions of their reaches. Other reaches are ephemeral, responding to seasonal runoff from precipitation and snowmelt.

The Cold Creek drainage ultimately connects to the Yakima River about $2 \mathrm{~km}(1 \mathrm{mi})$ upstream from Horn Rapids Dam (Figure 2-19). Actual flow in Cold Creek and Dry Creek, which results from precipitation onto Rattlesnake Mountain, Umtanum Ridge, and Yakima 
Ridge, is not well documented; however, flood magnitudes in Cold Creek, having recurrence intervals of 5 and 10 years, were estimated to be 60 and $125 \mathrm{~m}^{3} / \mathrm{s}\left(2,100\right.$ and $\left.4,400 \mathrm{ft}^{3} / \mathrm{s}\right)$, respectively, in the creek's lower reaches (Skaggs and Walters 1981).

West Lake, located about $6.4 \mathrm{~km} \mathrm{(4} \mathrm{mi)} \mathrm{north-northeast} \mathrm{of} \mathrm{the} \mathrm{ERDF} \mathrm{site} \mathrm{(Figure} \mathrm{2-19),}$ is a shallow pond, with an average depth of about $1 \mathrm{~m}(3 \mathrm{ft})$ and a surface area of approximately 4 ha $(10 \mathrm{ac}$ ) (Fuchs et al. 1985). The pond has previously been described as the "only naturally occurring pond on the Hanford Site" (DOE 1988, DOE-RL 1990b, DOE-RL $1990 \mathrm{c}$ ). This statement is valid in the sense that the pond does not consist of a disposal pond built and constructed specifically as part of the Hanford Site operations. However, the source of recharge to the lake is groundwater which is locally mounded due to infiltration resulting from the 200 Areas operations and groundwater mounding (Graham 1983). It is expected that West Lake will shrink and perhaps disappear as 200 Area operations cease.

2.3.1.3 Man-Made Ditches and Ponds. On the Hanford Site, wastewater discharge into ponds and ditches occurs in the 200,300, and 400 Areas. At these locations, several ponds and ditches exist to hold waste waters, which eventually evaporate or infiltrate. In addition, two new effluent disposal facilities (the Treated Effluent Disposal Facility Pond and the Effluent Treatment Facility Crib) are planned for operation in the 200 Area by 1995.

\subsubsection{Flooding}

Large Columbia River floods have occurred in the past (DOE 1987), but the likelihood of recurrence of large-scale flooding has been reduced by the construction of several flood control/water storage dams upstream of the Site. Major floods on the Columbia River are typically the result of rapid melting of the winter snowpack over a wide area augmented by above-normal precipitation. The maximum historical flood on record occurred June 7, 1894, with a peak discharge at the Hanford Site of $21,000 \mathrm{~m}^{3} / \mathrm{s}\left(742,000 \mathrm{ft}^{3} / \mathrm{s}\right)$. The largest recent flood took place in 1948 with an observed peak discharge of $20,000 \mathrm{~m}^{3} / \mathrm{s}\left(706,000 \mathrm{ft}^{3} / \mathrm{s}\right)$ at the Hanford Site. The probability of flooding at the magnitude of the 1894 and 1948 floods has been greatly reduced because of upstream regulation by dams.

There have been fewer than 20 major floods on the Yakima River since 1862 (DOE 1986). The most severe occurred in November 1906, December 1933, and May 1948; discharge magnitudes at Kiona, Washington, were $1,870,1,900$, and $1,050 \mathrm{~m}^{3} / \mathrm{s}(66,000$, 67,000 , and $37,000 \mathrm{ft}^{3} / \mathrm{s}$ ), respectively. The recurrence intervals for the 1933 and 1948 floods are estimated at 170 and 33 years, respectively. The development of irrigation reservoirs within the Yakima River Basin has considerably reduced the flood potential of the river. Flooded areas could extend into the southern section of the Hanford Site, but the upstream Yakima River is physically separated from the Hanford Site by Rattlesnake Mountain, which would prevent major flooding of the Hanford Site.

Evaluation of flood potential is conducted in part through the concept of the probable maximum flood, which is determined from the upper limit of precipitation falling on a drainage area and other hydrologic factors, such as antecedent moisture conditions, snowmelt, and tributary conditions, that could result in maximum runoff. The probable maximum flood for the Columbia River below Priest Rapids Dam has been calculated to be $40,000 \mathrm{~m}^{3} / \mathrm{s}$ $\left(1.4\right.$ million $\mathrm{ft}^{3} / \mathrm{s}$ ) and is greater than the 500 -year flood. The flood plain associated with the probable maximum flood is shown in Figure 2-20. This flood would inundate parts of the 
100 Areas located adjacent to the Columbia River, but the central portion of the Hanford Site including the ERDF site, would not be flooded (DOE 1986).

A flood risk analysis of Cold Creek was conducted in 1980 as part of the characterization of a basaltic geologic repository for high-level radioactive waste. Such design work is usually done to the Probable Maximum Flood (PMF) rather than the worst case or 100-year flood scenario. Therefore, in lieu of 100- and 500-year floodplain studies, a PMF evaluation was made for a reference repository location directly west of the 200 East area and encompassing the 200 West Area (Skaggs and Walters 1981). Schematic mapping indicates that access to the reference repository would be unimpaired but that Route 240 along the southwestern and western areas would not be usable (see Figure 2-21).

\subsubsection{Local Surface Water Hydrology}

There are no perennial or ephemeral streams at the ERDF site. The ERDF site lies within the Cold Creek watershed, which covers much of the west central and south central portion of the Hanford Site. Cold Creek is located southwest of the ERDF and surface drainage from the site will be to the southwest toward Cold Creek. Surface drainage onto the ERDF site is from the northeast. Surface drainage from the northeast is expected to be limited since the ERDF site is located near the boundary of the Cold Creek watershed and the Columbia River watershed. Surface runoff in the Columbia River watershed runs to the northeast, toward the Columbia River. Figure 2-19 depicts the watersheds at the Hanford Site.

\subsection{GEOLOGICAL CHARACTERISTICS}

This section provides a description of the regional and local geologic characteristics of the ERDF site. The regional information has been largely summarized from a number of technical documents which address the geologic conditions of the Hanford Site, including the nearby 200 East and 200 West Areas. These include DOE (1988), Delaney et al. (1991), and Lindsey et al. (1992). The description of geologic conditions local to the ERDF site is also based upon these sources, as well as recent work undertaken at the ERDF site.

\subsubsection{Topography and Physiography}

The Hanford Site is situated within the Pasco Basin, one of a number of topographic and structural depressions located within the Columbia Plateau physiographic province, a broad basin located between the Cascade Range and the Rocky Mountains (Delaney et al. 1991). The Pasco Basin is bounded on the north by the Saddle Mountains; on the west by Umtanum Ridge, Yakima Ridge, and the Rattlesnake Mountain; and on the east by the Palouse slope. Topography of the Hanford Site is depicted in Figure 2-22.

The Hanford Site includes about $900 \mathrm{~km}^{2}\left(350 \mathrm{mi}^{2}\right)$ of terrace lands located south and west of the Columbia River within the semiarid Pasco Basin of south-central Washington. The terrace plains rise gradually north and west from an altitude of about $104 \mathrm{~m}$ (340 ft) at Richland to 213 to $244 \mathrm{~m}$ ( 700 to $800 \mathrm{ft}$ ) in the northwestern part of the site. From these high terraces the surface descends to $137-\mathrm{m}(450-\mathrm{ft})$ at terraces along the river. Toward the west the terrace lands terminate against the slopes and inter-ridge valleys of low linear mountains known 
collectively as the Yakima Ridges. Rattlesnake Mountain, at the southwest edge of the site, rises to an elevation of $1,067 \mathrm{~m}(3,500 \mathrm{ft})$. A few bedrock outliers, such as Gable Mountain, outcrop above the terraces of the Hanford Site (Newcomb et al. 1972).

The 200 Area and the ERDF site are situated on a broad flat terrace called the 200 Areas plateau located near the center of the Hanford Site at an elevation of approximately 198 to 229 $\mathrm{m}(650$ to $750 \mathrm{ft}) \mathrm{AMSL}$. The plateau decreases in elevation to the north and east toward the Columbia River. The terrace escarpments are steep, with elevation changes between 15 and 30 $\mathrm{m}(50$ and $100 \mathrm{ft})$.

\subsubsection{Regional Geologic Structure and Stratigraphy}

Structurally, the Columbia Plateau is divided into three informal subprovinces: the Palouse, Blue Mountains, and Yakima Fold Belt. These are not physiographic subprovinces, even though some of the names may be the same. All but the easternmost part of the Pasco Basin is within the Yakima Fold Belt structural subprovince (DOE 1988). The Yakima Fold Belt contains four major structural elements: the Yakima Folds, Cle Elum-Wallula disturbed zone, Hog Ranch-Naneum anticline, and northwest-trending wrench faults.

The Yakima Folds are a series of continuous, narrow, asymmetric anticlines that have wavelengths between about 5 and $30 \mathrm{~km}(3$ to $19 \mathrm{mi})$ and amplitudes commonly less than $1 \mathrm{~km}$ (less than $0.6 \mathrm{mi}$ ). The anticlinal ridges are separated by broad synclines or basins. The Yakima Folds are believed to have developed under generally north-south compression, but the origin and timing of the deformation along the fold structures are not well known (DOE 1988).

The Cle Elum-Wallula disturbed zone is the central part of a larger topographic alignment called the Olympic-Wallowa lineament that extends from the northwestern edge of the Olympic Mountains to the northern edge of the Wallowa Mountains in Oregon. The Cle Elum-Wallula disturbed zone is a narrow zone about $10 \mathrm{~km}(6 \mathrm{mi})$ wide that transects the Yakima Fold Belt and has been divided informally into three structural domains: a broad zone of deflected or anomalous fold and fault trends extending south of Cle Elum, Washington, to Rattlesnake Mountain; a narrow belt of aligned domes and doubly plunging anticlines ("The Rattles") extending from Rattlesnake Mountain to Wallula Gap; and the Wallula fault zone, extending from Wallula Gap to the Blue Mountains.

The Hog Ranch-Naneum Ridge anticline is a broad structural arch that extends from southwest of Wenatchee, Washington, to at least the Yakima Ridge. This feature defines part of the northwestern boundary of the Pasco Basin, but little is known about the structural geology of this portion of the feature, nor is the southern extent of the feature known.

Northwest-trending wrench faults have been mapped west of $120^{\circ} \mathrm{W}$ longitude in the Columbia Plateau (DOE 1988). The mean strike direction of the dextral wrench fault is $320^{\circ}$, but there are less numerous northeast-trending sinistral wrench faults that strike $013^{\circ}$. These structures are not known to exist in the central Columbia Plateau.

Most known faults within the Hanford area are associated with anticlinal fold axes, are thrust or reverse faults although normal faults do exist, and were probably formed concurrently with the folding (DOE 1988). Existing known faults within the Hanford area include wrench faults as long as $3 \mathrm{~km}(1.9 \mathrm{mi})$ on Gable Mountain and the Rattlesnake-Wallula alignment, 
which has been interpreted as a right-lateral strike-slip fault. The faults in Central Gable Mountain are considered capable by the U.S. Nuclear Regulatory Commission (NRC) criteria (10 CFR 100) in that they have slightly displaced the Manford formation gravels, but their relatively short lengths give them low seismic potential. Also, there is no observed seismicity on or near Gable Mountain. The Rattlesnake-Wallula alignusent is interpreted as possibly being capable, in part because of lack of any distinct evidence to the contrary and because this structure continues along the northwest trend of faults that appear active at Wallula Gap, some $56 \mathrm{~km}(35 \mathrm{mi})$ southeast of the central part of the Hanford Site (DOE 1988).

The major geologic units of the Hanford Site are, in ascending order: subbasalt rocks (inferred to be sedimentary and volcanoclastic rocks), the Columbia River Basalt Group with intercalated sediments of the Ellensburg Formation, the Ringold Formation, the Plio-Pleistocene unit, and the Hanford formation. Locally, Holocene sand, silt, and loess exist as surficial material.

Knowledge of the sub-basalt rocks is limited to studies of exposures along the margin of the Columbia Plateau and to a few deep boreholes drilled in the interior of the plateau (DOE 1988). No sub-basalt rocks are exposed within the central interior of the Columbia Plateau, including the Pasco Basin. Interpretation of data from wells drilled in the 1980 s by Shell Oil Company in the northwestern Columbia Plateau indicates that, in the central part of the Columbia Plateau, the Columbia River Basalt Group is underlain predominantly by Tertiary continental sediments (Campbell 1989).

The regional and Hanford Site geology is dominated by the thick sequence of Miocene tholeiitic continental flood basalts designated the Columbia River Basalt Group. This layered sequence consists of more than $170,600 \mathrm{~km}^{3}\left(40,800 \mathrm{mi}^{3}\right)$ of basalt covering more than $163,000 \mathrm{~km}^{2}\left(63,000 \mathrm{mi}^{2}\right)$ (Tolan et al. 1987).

Late Neogene (late Miocene to Pliocene) deposits younger than the Columbia River Basalt Group are represented by the Ringold Formation in the Pasco and Quincy basins. The fluvial- lacustrine Ringold Formation was deposited in generally east-west-trending valleys by the ancestral Columbia River and its tributaries in response to the development of the Yakima Fold Belt. The Ringold Formation is classified into three facies associations or stratigraphic section types: deposits of the migrating, thoroughgoing ancestral Columbia and/or Snake River systems; overbank materials beyond the influence of the main river channel(s); and fanglomerate deposits found around the margins of the basin (DOE 1988). Later work by Lindsey (1991) proposed a revised stratigraphy for the Ringold Formation, based on five facies associations: fluvial gravel, fluvial sand, overbank mud, lacustrine mud, and basaltic gravel.

An eolian silt and fine sand (the early "Palouse" soil) overlies the Ringold Formation in the western part of the Hanford Site (Brown 1960). This silty fine sand to sardy silt was deposited when the wind reworked and redeposited Ringold sediments. Relatively high caliche contents are found in much of this unit.

The Hanford formation lies on the eroded surface of the Plio-Pleistocene unit, the Ringold Formation, or locally on the basalt bedrisck. The Hanford formation consists of cataclysmic flood sediments that were deposited when ice dams that formed Lake Missoula in western Montana and northern Idaho were breached and massive volumes of water spilled abruptly across eastern and central Washington. These Missoula floods scoured the land surface, locally eroding the Ringold Formation, the basalts, and sedimentary interbeds, leaving a 
network of buried channels crossing the Pasco Basin (Tallman et al. 1979). Thick sequences of sediments were deposited by several episodes of Pleistocene flooding with the last major flood sequence dated at about 13,000 years before present (Myers et al. 1979). These sediments have locally been divided into two main facies, termed the "Pasco Gravels" facies and the "Touchet Beds" facies (Myers et al. 1979).

Volcanic deposits in the Pasco Basin are limited to occasional, thin layers of airfall tephra from a few millimeters to $10 \mathrm{~cm}(4$ in.) thick. Eolian sediments consisting of loess and sand dunes (both active and inactive) locally veneer the surface of the Hanford Site.

2.4.2.1 Suprabasalt Sediments. The suprabasalt sedimentary sequence at the Hanford Site is up to approximately $230 \mathrm{~m}$ (750 ft) thick in the west-central Cold Creek syncline, while it pinches out against the anticlinal ridges that bound or are present within this Pasco Basin. The suprabasalt sediments are dominated by laterally extensive deposits of the late Miocene to Pliocene-age Ringold Formation and the Pleistocene-age Hanford formation. Locally occurring strata separating the Ringold and Hanford formations are assigned to the informally defined Plio-Pleistocene unit, early "Palouse" soil, and pre-Missoula gravels comprising the remainder of the sequence.

Ringold Formation. Overlying the Columbia River Basalt Group is the late Miocene to Pliocene-age Ringold Formation (Fecht et al. 1987, DOE 1988). The Ringold Formation accumulated to thicknesses of up to $365 \mathrm{~m}(1,200 \mathrm{ft})$ in the Pasco Basin. On the Hanford Site, the Ringold Formation is up to $185 \mathrm{~m} \mathrm{(600} \mathrm{ft)} \mathrm{thick} \mathrm{in} \mathrm{the} \mathrm{deepest} \mathrm{part} \mathrm{of} \mathrm{the} \mathrm{Cold} \mathrm{Creek}$ syncline south of the 200 West Area and $170 \mathrm{~m}$ (560 ft) thick in the western Wahluke syncline near the 100-B Area. The Ringold Formation pinches out against the anticlinal flanks that bound or are present within the Pasco Basin, and is largely absent in the northern and northeastern parts of the 200 East Area and adjacent areas to the north (Delaney et al. 1991, Lindsey et al. 1992).

Post-Ringold Pre-Hanford Sediments. Thin alluvial deposits situated stratigraphically between the Ringold Formation and Hanford formation are found within the Pasco Basin. The three informally defined units include: (1) the Plio-Pleistocene unit; (2) the early "Palouse" soil; and (3) the Pre-Missoula gravels. The Plio-Pleistocene unit and early "Palouse" soil are described in detail in Last et al. (1989) and Lindsey et al. (1991). The pre-Missoula gravels are discussed in PSPL (1982a) and Fecht et al. (1987).

Hanford formation. The informally designated Hanford formation consists of unconsolidated, glaciofluvial sediments that were deposited during several episodes of cataclysmic flooding during the Pleistocene Epoch. The sediments are composed of pebble to boulder gravel, fine- to coarse-grained sand, and silt. These sediments are divided into three facies: (1) gravel dominated, (2) sand-dominated, and (3) silt-dominated (Lindsey et al. 1992). These facies are referred to as coarse-grained deposits, plane-laminated sand facies, and rhythmite facies, respectively (Baker et al. 1991). The silt-dominated deposits are also referred to as "Touchet" beds, and the gravel-dominated facies generally correspond to the Pasco gravels.

The Hanford formation is thickest in the vicinity of the 200 Areas where it is up to 107 $\mathrm{m}$ (350 ft) thick (Lindsey et al. 1992). The formation was deposited by cataclysmic flood waters that flowed out of glacial lake Missoula (Fecht et al. 1987, DOE 1988, and 
Baker et al. 1991). The deposits are absent from ridges above approximately $360 \mathrm{~m}(1,180 \mathrm{ft})$ AMSL, the highest level of cataclysmic flooding in the Pasco Basin (Delaney et al. 1991).

Holocene Surficial Deposits. Holocene surficial deposits consist of silt, sand, and gravel that form a $<4.9 \mathrm{~m}$ ( $<16 \mathrm{ft})$ veneer across much of the Hanford Site. These sediments were deposited by a mix of eolian and alluvial processes.

\subsubsection{Local Geology}

This section focuses on the geologic characteristics of the ERDF site and vicinity. Information presented has been compiled from a variety of sources, including technical reports and documents of the 200 Areas, as well as the results of the recent field investigative work undertaken for the ERDF site.

2.4.3.1 Topography and Geomorphic Setting. The surface topography and geomorphic features in the vicinity of the ERDF site are depicted in Figure 2-23. The topography in the vicinity of the proposed ERDF site was formed primarily by Pleistocene cataclysmic floods beginning at least 750,000 years ago and ending approximately 13,000 year ago (Baker et al. 1991). These floods left behind an array of unique landforms including anastomosing flood channels, giant current ripples, and giant flood bars. As shown in Figure 2-23, the proposed ERDF site is situated at an elevation of approximately $210 \mathrm{~m} \mathrm{(700} \mathrm{ft)} \mathrm{AMSL} \mathrm{on} \mathrm{the} \mathrm{south} \mathrm{slope}$ of one of these landforms, the Cold Creek Bar (Bretz et al. 1956). This flood bar is a compound bar built by multiple floods (DOE 1988). During flooding it prograded southward to its present position. The northern part of the bar has undergone erosion by flood waters receding from the basin, resulting in the creation of at least four major channels, as well as additional minor channels, that have been recognized near the Gable Mountain, Gable Butte area (Fecht 1978).

2.4.3.2 Local Stratigraphy. Figures 2-24, 2-25, 2-26, and 2-27 present geologic cross sections of the proposed ERDF site. The ERDF is in a geologic transitional zone between the 200 East and 200 West Areas where geologic units present in the western portion of the ERDF may not be present in the eastern portions. The proposed ERDF site is underlain by 159 to 177 $\mathrm{m}$ (521 to $580 \mathrm{ft}$ ) of suprabasalt sediments that rest on the Elephant Mountain Member of the Columbia River Basait Group. The ascending geologic sequence from the Elephant Mountain Member basalt starts with the Ringold Formation, comprising gravel unit A, followed by the lower mud sequence, gravel unit E, and the upper unit. Overlying the Ringold Formation in this area is the Plio.Pleistocene unit, early "Palouse" soil, and the Hanford formation. Each geologic unit and its stratigraphic characteristics are discussed in the following sections.

The Elephant Mountain Member is the upper most basalt unit and existing information indicates that it is continuous beneath the proposed ERDF site (Weekes and Borghese, 1993). There is no evidence of significant erosion at the top of the Elephant Mountain Member and no indication of erosional "windows" through the basalt to the underlying Rattlesnake Ridge interbed. The basalt dips to the south into the Cold Creek syncline at about $60 \mathrm{~m} / \mathrm{km}(317$

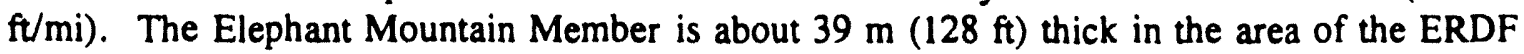
site (Weekes and Borghese 1993).

The Ringold Formation overlies the uppermost basalts beneath the proposed ERDF site. The Ringold Formation generally dips to the south and ranges in thickness from 72 to $111 \mathrm{~m}$ 
(235 to $363 \mathrm{ft}$ ). The Ringold Formation units present (in ascending order) are the fluvial gravels of unit $A$, the lower mud sequence, the gravels of unit $E$, and the sand and lesser muds of the Ringold Formation upper unit. The fluvial gravels of the B, C, and D units are not present beneath the site. The Ringold Formation " $A$ " unit ranges in thickness from 15 to $36 \mathrm{~m}$ ( 50 to $118 \mathrm{ft}$ ), the lower mud unit ranges in thickness from 8 to $29 \mathrm{~m} \mathrm{(27} \mathrm{to} 95 \mathrm{ft}$ ), and the " $\mathrm{E}^{\text {" }}$ unit thickness varies from 19 to $83 \mathrm{~m}(61$ to $273 \mathrm{ft}$ ). The upper Ringold unit is present in the western portion of the site and pinches out to the east. The thickness of the upper unit ranges from 0 to $13 \mathrm{~m}$ ( 0 to $42 \mathrm{ft}$ ).

The Plio-Pleistocene unit overlies the Ringold Formation and ranges in thickness from 0 to $11 \mathrm{~m}(0$ to $35 \mathrm{ft})$. The unit is mostly present in the areas of the site adjacent to the 200 West Area and pinches out to the east within the proposed ERDF site. The unit is composed of laterally discontinuous interbedded carbonate-rich strata and carbonate-poor strata.

Although not shown on any of the cross-sections, the Early "Palouse" soil may be present in the extreme western side of the ERDF site. The Early "Palouse" soil consists of unconsolidated sands and muds. The upper contact of the unit with the Hanford Formation is poorly defined (Weekes and Borghese 1993).

The Hanford formation is present through the ERDF site and ranges in thickness from 41 to $97 \mathrm{~m}$ (135 to $319 \mathrm{ft}$ ). The formation is thickest on the north side of the proposed ERDF site and thins to the south. The Hanford formation is divided into three lithologic facies: graveldominated, sand-dominated, and silty. The sand-dominated facies is considered to be the principal facies under the site and consists of fine- to coarse-grained sand and gravel deposits. Clastic dikes are present within the Hanford formation as vertical to irregularly shaped dipping fissures filled with sand and gravel. Ash deposits are also present within sand-dominated facies of the Hanford formation at the ERDF site.

Sand dunes (Holocene eolian deposits) present above the Hanford formation cover most of the ERDF site and range in thickness from 0 to $3 \mathrm{~m}$ (0 to $10 \mathrm{ft}$ ).

\subsubsection{Seismicity}

A comprehensive network of seismic stations that provides accurate locating information for most earthquakes larger than magnitude 2.5 was installed in eastern Washington in 1969. DOE (1988) provides a summary of the seismicity of the Pacific Northwest, a detailed review of the seismicity in the Columbia Plateau region and the Hanford Site, and a description of the seismic networks used to collect the data. Seismicity of the Columbia Plateau, as determined by the rate of earthquakes per area and the historical magnitude of these events, is relatively low when compared to other regions of the Pacific Northwest, the Puget Sound area and western Montana/eastern Idaho. Figure 2-28 shows the locations of all earthquakes that occurred in the Columbia Plateau before 1969 with MMI of IV or larger and with magnitude of 3 or larger. The largest known earthquake in the Columbia Plateau occurred in 1936 around Milton-Freewater, Oregon. This earthquake had a magnitude of 5.75 and a maximum MMI of VII, and was followed by a number of aftershocks that indicate a northeast-trending fault plane.

In the central portion of the Columbia Plateau, the largest earthquakes near the Hanford Site occurred in 1918 and 1973. These two events had magnitudes of 4.4 and intensity $V$ and were located north of the Hanford Site. Earthquakes often occur in spatial and temporal clusters 
in the central Columbia Plateau, and are termed "earthquake swarms." The region north and east of the Hanford Site is a region of concentrated earthquake swarm activity, but earthquake swarms have also occurred in several locations within the Hanford Site. The magnitude of these swarms is too small to show up on Figure 2-28.

Estimates for the earthquake potential of structures and zones in the central Columbia Plateau have been developed during the licensing of nuclear power plants at the Hanford Site. In reviewing the operating license application for the Washington Public Power Supply System Project WNP-2, the NRC (NRC 1982) concluded that four earthquake sources should be considered for the purpose of seismic design: the Rattlesnake-Wallula alignment, Gable Mountain, a floating earthquake in the tectonic province, and a swarm area.

For the Rattlesnake-Wallula alignment, which passes along the southwest boundary of the Hanford Site, the NRC estimated a maximum magnitude of 6.5, and for Gable Mountain, an east- west structure that passes through the northern portion of the Hanford Site, a maximum magnitude of 5.0. These estimates were based upon the inferred sense of slip, the fault length, and/or the fault area. The floating earthquake for the tectonic province was developed from the largest event located in the Columbia Plateau, the magnitude 5.75 Milton-Freewater earthquake. The maximum swarm earthquake for the purpose of WNP-2 seismic design was a magnitude 4.0 event, based on the maximum swarm earthquake in 1973. (The NRC concluded that the actual magnitude of this event was smaller than estimated previously.)

\subsection{PEDOLOGICAL CHARACTERISTICS}

The term "pedology" is used to refer broadly to the study of the nature, properties, formation, distribution, classification, function and use of soils. The term "soil" is also used broadly as a synonym for regolith, or all unconsolidated materials which overlie bedrock. Pertinent soil characteristics provided in this section include soil classification, and general engineering and physical properties for the regional and local scales.

The earliest study of soils in Benton County, which includes most of the Hanford Site, was performed in 1916 by Kocher et al. (1921). Maps generated from this survey indicate that the soils in the Hanford Site belong within four major groups that can be classified according to their origin. The four groups included:

- Soils derived from loessial or wind-blown material

- Soils derived from eolian or wind-blown material

- Soils derived from old valley-filling material, mainly lake-laid

- Soils derived from stream laid material.

Kocher et al. (1921) mapped 26 classes of soils within these four groups, and three classes of miscellaneous nonagricultural material, including scabland, river wash, and dune sand.

In a later study (Western States Land Grant Universities and Colleges and Soil Conservation Service [SCS] 1960), which consisted of a generalized soil survey of the western United States, the soils of the Hanford Site area were characterized as largely immature soils formed on unconsolidated upland materials and eolian sands with few clearly-defined horizons. 
Few, or no, clearly defined soil horizons are present in regosols, or soils largely dominated by the characteristics of the parent materials. The regosols of the Hanford Site occur on glaciofluvial deposits that have been continually shifted and sorted by wind-erosion and deposition. These soils support a shrub-steppe vegetation community, and are principally used for grazing and limited irrigation crop production (SCS 1960). Hajek (1966) lists and describes 15 different soil types on the Hanford Site. The soil types vary from sand to silty and sandy loam. These are shown in Figure 2-29 and briefly described in Table 2-1. The ERDF is located in an area with Rupert Sand and Burbank Loamy Sand.

\subsection{HYDROGEOLOGICAL CHARACTERISTICS}

This subsection presents the regional and local hydrogeology for the ERDF site. The discussion on regional hydrogeology summarizes groundwater conditions in the Pasco Basin, detailing the primary aquifers and providing the regional context necessary to understand the local hydrogeology.

\subsubsection{Regional Hydrogeology}

The multiaquifer system within the Pasco Basin has been conceptualized as consisting of four geohydrologic units: (1) the Grande Ronde Basalt; (2) Wanapum Basalt; (3) Saddle Mountain Basalt; and (4) suprabasalt Hanford and Ringold Formation sediments.

Geohydrologic units older than the Grande Ronde Basalt are probably of minor importance to the regional hydrologic dynamics and system. Lateral groundwater movement is known to occur within a shallow, unconfined aquifer consisting of fluvial and lacustrine sediments lying on top of the basalts, and within deeper confined to semi-confined aquifers consisting of basalt flow tops, flow bottom zones, and sedimentary interbeds (DOE 1988). These deeper aquifers are intercalated with aquitards consisting of basalt flow interiors. Vertical flow and leakage between geohydrologic units is inferred and estimated from water level or potentiometric surface data but is not quantified, and direct measurements are not available (DOE 1988).

Groundwater at the Hanford Site occurs under unconfined and confined conditions. The unconfined aquifer is contained within the glaciofluvial sands and gravels of the Hanford formation and the Ringold Formation. The bottom of the unconfined aquifer is the basalt surface or, in some areas, the clay zones of the lower member of the Ringold Formation. The confined aquifers consist of sedimentary interbeds and/or interflow zones that occur between dense basalt flows in the Columbia River Basalt Group. The main water-bearing portions of the interflow zones occur within a network of interconnecting vesicles and fractures of the flow tops or flow bottoms.

From the recharge areas to the west, the groundwater flows downgradient to the discharge areas, primarily along the Columbia River. This general west-to-east flow pattern is interrupted locally by the groundwater mounds in the 200 Areas. From the 200 Areas, there is also a component of groundwater flow to the north, between Gable Mountain and Gable Butte. These flow directions represent current conditions; the aquifer is dynamic, and responds to changes in natural and artificial recharge.

The uppermost aquifer is part of a flow system that is local to the Pasco Basin, as are the uppermost basalt interbed aquifers (Gephart et al. 1979, DOE 1980). Groundwater in these 
aquifer systems is probably recharged and discharged locally. Deeper in the basalt, interbed aquifer systems are part of the regional, or interbasin, flow system, which extends outside the margins of the Pasco Basin (DOE 1988). Groundwater in the uppermost aquifer system is regionally unconfined and occurs within the glaciofluvial sands and gravels of the Hanford formation and the fluvial/lacustrine sediments of the Ringold Formation. Confined to semiconfined aquifers of more limited extent also occur in the suprabasalt sediments of the Pasco Basin. These confined zones are generally located within the local flow system, between the unconfined aquifer and the underlying basalt surface. Further discussion of the aquifer system is provided below.

2.6.1.1 Unconfined Aquifer. The unconfined aquifer is laterally extensive, occurring below most of the Hanford Site with saturated thicknesses ranging up to $90 \mathrm{~m}(295 \mathrm{ft})$ under the 200 West Area. The unit thins and is locally absent along the flanks of anticlinal structures (i.e., Gable Mountain/Gable Butte and Yakima Ridge) (Gephart et al. 1979). The base of the unconfined aquifer is generally defined as the top of the uppermost basalt flow. Fine-grained overbank and lacustrine deposits of the Ringold Formation, however, locally form confining or semi-confining layers for underlying Ringold fluvial gravels.

The main body of the unconfined aquifer generally occurs within the sediments of the Ringold Formation. In the southwestern portion of the Pasco Basin, the position of the water table is generally within Ringold fluvial gravels. In the northern and eastern Pasco Basin, the water table generally occurs within the Hanford formation.

2.6.1.1.1 Recharge. Natural recharge to the unconfined aquifer occurs primarily from run-off of precipitation from higher elevation areas including Saddle Mountains, Umtanum and Yakima ridges, and Rattlesnake Mountain (Deju and Fecht 1979, Gephart et al. 1979, DOE 1988), as well as water infiltrating from small ephemeral streams. The Yakima and Columbia rivers also contribute to the natural recharge in places, as may the deep basalt aquifers (DOE 1988).

The movement of precipitation through the unsaturated (vadose) zone has been studied at several locations on the Hanford Site (Isaacson et al. 1974, Jones 1978, Gee and Heller 1985, Gee 1987, Routson and Johnson 1990, Rockhold et al. 1990). Although conclusions from these studies vary the estimates of deep percolation to the uppermost aquifer are consistently low (from 0 to $7.87 \mathrm{~cm} / \mathrm{yr}$ [0 to $3.1 \mathrm{in} / \mathrm{yr}$ ]). Little, if any, recharge to the groundwater occurs from percolating rainfall on the broad areas of the desert terrain because of the high rates of evapotranspiration. Gee (1987) and Routson and Johnson (1990) concluded that no downward percolation of precipitation occurs on the 200 Areas Plateau where the sediments are layered and vary in texture, and that all moisture penetrating the soil is removed by evapotranspiration.

Artificial recharge of the unconfined aquifer system occurs from the disposal of large volumes of wastewater on the Hanford Site and from large irrigation projects surrounding the Hanford Site. Recharge through ponds and cribs in the 200 Areas is the largest single artificial recharge source, beginning in the late 1940s and continuing to the present. Recharge from waste-water disposal was estimated to be about $5.5 \times 10^{7} \mathrm{~L} / \mathrm{d}\left(1.4 \times 10^{7} \mathrm{gal} / \mathrm{d}\right)$ or about 10 times the amount of natural recharge entering the unconfined aquifer system within the Cold Creek Valley (DOE 1988). Other artificial recharge sources include irrigation loss west of the 200 Areas (Graham 1983), infiltration ponds at Advanced Nuclear Fuels Corp (USGS 1978), and infiltration ponds at the City of Richland well field (CWC-HDR, Inc. 1988). 
2.6.1.1.2 Movement. Figures $2-30$ and $2-31$ illustrate the groundwater table for the Hanford Site during January 1944 and June-August 1990, respectively. As seen in the figures, effluent disposal has altered the groundwater flow directions and gradients at the Hanford Site. Before operations at the Hanford Site began in 1944, the hydraulic gradient in all but the southwestern-most portion of the Hanford Site was approximately $0.9 \mathrm{~m} / \mathrm{km}(5 \mathrm{ft} / \mathrm{mi})$. Regional groundwater flow was generally toward the east-northeast. Groundwater flow north of Gable Mountain now trends in a more northeasterly direction as a result of mounding near reactors and flow through Gable Gap. South of Gable Mountain, flow is interrupted locally by the groundwater mounds in the 200 Areas. Under the influence of mounding, groundwater flow in the 200 East Area is radial with portions heading northward, passing between Gable Mountain and Gable Butte (Delaney et al. 1991).

Over the period 1950 to 1980 , water levels in the unconfined aquifer are reported to

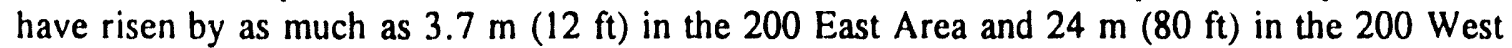
Area (DOE 1988). The rate of increase was most rapid from 1950 to 1960; the rate of increase was slower from 1960 to 1970 . From 1970 to 1980 , only small increases in water table elevation occurred, and the unconfined aquifer appears to have been in approximate steady-state with recharge sources. This rise in water-table elevations increased the potential for downward movement of groundwater from the unconfined to the confined basalt and interbed aquifers. The degree of exchange which occurred between the groundwater systems is not known.

Studies have shown that the existing general flow pattern may reverse and return to the pre-operational pattern if the artificial recharge were discontinued, allowing the groundwater mound to dissipate (DOE-RL 1990c). Data presented in Kasza et al. (1992) indicate that this expected mound dissipation is occurring in the 200 Areas. Water level data from 1988 most nearly corresponds to the highest groundwater levels measured in the recent past. A general lowering of the water table is occurring beneath the 200 Areas in response to the closure of the Gable Mountain pond and the $U$ pond, and the decrease in disposal of process water to $B$ pond. From December 1988 to December 1991, the water table beneath the 200 Areas decreased in elevation by as much as $1 \mathrm{~m}(3.3 \mathrm{ft})$. To the north of the 200 East Area, in the vicinity of West

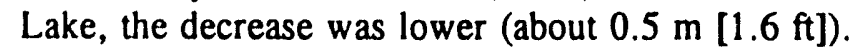

2.6.1.1.3 Discharge. Groundwater discharge from the unconfined aquifer is almost exclusively to the Columbia River along the eastern and northeastern margins of the Pasco Basin (Deju and Fecht 1979, Gephart et al. 1979, DOE 1988). Downward leakage to the lower confined aquifers may be occurring under the eastern groundwater mound beneath B Pond and through features such as erosional windows discussed in Section 2.4.2 (Regional Geology).

West Lake is hydraulically connected to the unconfined aquifer and represents a topographic depression that intersects the water table. Because of high water evaporation rates and low surface overland flow, the lake is expected to result in a net loss of groundwater, and thus constitute a local discharge zone (DOE-RL 1990c).

2.6.1.1.4 Hydraulic Properties. Hydraulic conductivity estimates for the unconfined aquifer have been mapped over the Hanford Site, as shown in Figure 2-32 (DOE 1988). The hydraulic conductivities were obtained from pumping tests (Biershenk 1957, Kipp and Mudd 1973) and are not layer specific, but apply to the combined conductivity of all layers stressed during the test. The hydraulic conductivity range is from approximately $10^{-3}$ to $1 \mathrm{~cm} / \mathrm{s}$ (1 to $10^{3}$ $\mathrm{ft} / \mathrm{d}$ ), reflecting heterogeneity of the soils. Transmissivities vary widely regionally because of the variable saturated thickness of the unconfined aquifer. 
Generally, saturated hydraulic conductivity is greater in the Hanford formation, where values from $10^{-1}$ to $10^{1} \mathrm{~cm} / \mathrm{s}\left(10^{2}\right.$ to $\left.10^{4} \mathrm{ft} / \mathrm{d}\right)$ are typical, than in the Ringold Formation where hydraulic conductivities are generally from about $10^{-5}$ to $10^{-1} \mathrm{~cm} / \mathrm{s}\left(10^{-2}\right.$ to $\left.10^{2} \mathrm{ft} / \mathrm{d}\right)$. The lower hydraulic conductivities are associated with the low-permeability aquitards.

Fewer data are available on specific yield for the unconfined aquifer. Storage coefficients determined in multiple well pumping tests from the unconfined aquifer ranged from 0.0002 to 0.2 (DOE 1988). Values determined at Hanford formation wells ranged from 0.03 to 0.2 , whereas values in Ringold Formation wells were generally less than 0.06 .

2.6.1.2 Confined Aquifers. Confined aquifers occur within the lower portion of the Ringold Formation, but are generally more limited in areal extent than the unconfined aquifer. In the western portion of the Pasco Basin, a confined-to-semi-confined aquifer is present within the basal unit of the Ringold Formation (as defined by DOE 1988). A thick silt deposit (the lower unit of the Ringold Formation as defined in DOE 1988) forms the aquitard between the unconfined and confined zones. Other confined-to-semi-confined zones occur locally within the middle and lower units of the Ringold Formation as a result of interfingering silt aquitards and more permeable lenses of sand and gravel. These zones appear to be laterally discontinuous and likely merge with the unconfined system.

A multiple confined aquifer system occurs within the Columbia River Basalt Group underlying the Pasco Basin (Deju and Fecht 1979, Gephart et al. 1979, DOE 1988). The confined aquifers consist primarily of interbeds within the basalt (DOE 1988). The interbeds occur between basalt flow tops of the older flows and basalt flow bottoms of the younger flows (Graham 1983). Flow interiors, comprised primarily of dense basalts, separate the interbeds forming confining aquitards.

The uppermost interbed aquifers are found in the Saddle Mountains Basalt and include, from youngest to oldest, the Rattlesnake Ridge, Selah, Cold Creek and Mabton interbeds. Interbed aquifers of the Saddle Mountains Basalt range in thickness from 6 to $35 \mathrm{~m} \mathrm{(20} \mathrm{to} 110$ $\mathrm{ft}$ ) and are likely localized to the Pasco Basin by geologic structures along the basin margin (Gephart et al. 1979, DOE 1988). Deeper interbeds which occur in the underlying Wanapum and Grande Ronde Basalt formations, appear to be hydraulically connected with the regional flow system outside the Pasco Basin (DOE 1988).

2.6.1.2.1 Recharge. Recharge to the interbeds of the Saddle Mountains Basalt is obtained directly from precipitation onto the exposed basalt ridges surrounding and within the Pasco Basin (Deju and Fecht 1979, Gephart et al. 1979, DOE 1988). Leakage from the unconfined aquifer also recharges at least the uppermost interbed aquifer (the Rattlesnake Ridge interbed, which underlies the Elephant Mountain basalt member) below the 200 Areas plateau, especially where artificial recharge has caused mounding in the unconfined aquifer (Graham 1983, DOE 1988, Delaney et al. 1991, and Connelly et al. 1992). In this area, erosion of the Elephant Mountain member may have lead to an enhanced hydraulic connection between the Rattlesnake Ridge interbed and the unconfined aquifer (Graham 1983).

The deeper basalt interbed aquifers, between and within the Wanapum and Grande Ronde Basalt Formations, obtain recharge waters in the Pasco Basin from vertical leakage of overlying interbed aquifers within the Saddle Mountains Basalt, and horizontal inflow from the regional flow system to the east and west. 
2.6.1.2.2 Movement. Within the Pasco Basin, groundwater potentials of Saddle Mountains Basalt indicate that groundwater flow is generally from topographically high to topographically low regions, similar to flow in the unconfined aquifer (DOE 1988). Steep groundwater gradients occur on the flanks of the major anticlines, including the Horse Heaven Hills, Frenchman Hills, Rattlesnake Mountain, and Saddle mountains. Lateral groundwater flow in the Saddle Mountains Basalt appears to mirror the surface topography and is generally toward major surface drainage features. The predominant generalized flow direction across the Hanford Site is from west to east (DOE 1988).

Groundwater flow in the Wanapum and Grande Ronde basalts is thought to be controlled less by local surface drainage patterns and more by the major rivers, streams, and coulees. Potentiometric levels in the deeper interbeds of the Wanapum and Grande Ronde basalts are interpreted to have a smoother form as a consequence of being less influenced by smaller surface drainage features (DOE 1988).

2.6.1.2.3 Discharge. Potentiometric and hydrochemical data presented in DOE (1988) portray the Pasco Basin, in relation to the surrounding Columbia Plateau, as an area of regional groundwater flow convergence and probably of groundwater discharge. Regional discharge from basalts appears to take place in the topographically low and well-dissected regions of the plateau where groundwater flows into stream courses (DOE 1988).

Within the Pasco Basin, the Saddle Mountains Basalt apparently discharges along the Columbia River from the confluence of the Columbia River with the Walla Walla northward, except across the northern portion of the Hanford Site. The Saddle Mountains Basalt potentiometric surface indicates that the Columbia River is the ultimate discharge for groundwater from these Basalts in most places where it flows over the unit. The Saddle Mountains Basalt may also discharge into the lower Snake and Yakima rivers. In much of the area of discharge, the Saddle Mountains Basalt discharges to the surface through the suprabasalt sediments (DOE 1988).

2.6.1.2.4 Hydraulic Properties. Hydraulic conductivities within the basalt interbeds are generally orders of magnitude lower than those observed in the unconfined aquifer. Aquifer testing in interbeds of the Saddle Mountains Basalt yielded hydraulic conductivities ranging from $10^{-4}$ to $10^{-3} \mathrm{~cm} / \mathrm{s}\left(10^{-1}\right.$ to $\left.1 \mathrm{ft} / \mathrm{d}\right)$ (DOE 1988). No values of storativity are currently available. Storativity values, however, are anticipated to be within the range commonly reported (i.e., $10^{-5}$ to $10^{-3}$ ) for confined aquifers (DOE 1988).

The flow interiors of the basalt formations have hydraulic conductivities orders of magnitude lower than the interbeds, ranging from $10^{-13}$ to $10^{-7} \mathrm{~cm} / \mathrm{s}\left(10^{-10}\right.$ to $\left.10^{-4} \mathrm{ft} / \mathrm{d}\right)$ (DOE 1988). Storativity estimates for the basalts have not been made, but likely range from $10^{-5}$ to $10^{-3}$ (DOE 1988).

\subsubsection{Local Hydrogeology}

2.6.2.1 Vadose Zone. The vadose zone is the region above the water table in which the fluid pressures of the sediments are negative with respect to local atmospheric pressure. It occurs between the ground surface and the water table and is the zone through which natural and manmade recharge waters may flow to the water table. The vadose zone beneath the ERDF site is estimated to range from 70 to $100 \mathrm{~m}(230$ to $330 \mathrm{ft})$ thick and consist of the following 
lithologic units: Hanford formation sediments, Plio-Pleistocene unit, the upper Ringold unit and Ringold Gravel unit "E". Flow characteristics through the vadose zone depend on a variety of properties, including particle and pore size, interconnectiveness of pores and moisture content.

2.6.2.2 Suprabasalt Aquifers. The suprabasalt aquifers beneath the proposed ERDF site consist of the fluvial sands and gravels of the Ringold Formation and the lower Plio-Pleistocene unit. The silts of the Plio-Pleistocene unit, the upper Ringold unit and the Ringold lower mud unit may act as aquitards or confining units within the aquifer. The uppermost aquifer is contained primarily within unit $E$ of the Ringold Formation. The lower mud unit of the Ringold Formation is known to occur beneath this aquifer in the western side of the site but the lateral extent is not known beneath the eastern side of the ERDF. Where the lower mud unit is present, confined aquifer conditions exist in unit A of the Ringold Formation. Units A and E of the Ringold Formation would be combined in a single unconfined aquifer in areas where the lower mud unit is not present. As shown on the cross-sections (Figures 2-24 to 2-27, locations shown on Figure 2-33) the thickness of the uppermost aquifer beneath the ERDF generally appears to range from 20 to $70 \mathrm{~m}(65-230 \mathrm{ft})$.

Groundwater levels in the area have risen significantly since the 1950's as a result of wastewater disposal activities conducted in the 200 West Area. The groundwater levels stabilized in the late 1960's and started to decline in the mid 1980's. The groundwater level decrease is probably due to reductions in wastewater disposal occurring in the 200 West Area.

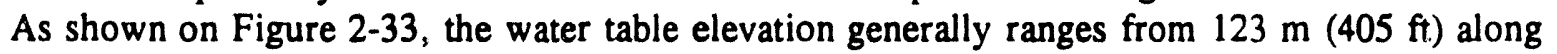
the east side of the proposed site to $139 \mathrm{~m}(455 \mathrm{ft})$ along the west side of the site.

Groundwater flow beneath the proposed ERDF site is predominately from west to east (see Figure 2-33). Saturated hydraulic gradients based on groundwater elevations shown in Figure 2-33 range from 0.0045 along the northern boundary of the site to 0.0025 along the southern boundary. Limited data are available for aquifer properties of transmissivity and hydraulic conductivity in the aquifer beneath the ERDF site. However, two wells near the site completed to the "E" unit of the Ringold Formation were tested in 1958 and 1973. Wells 299W21-1 and 699-33-56 had transmissivity values of $2,700 \mathrm{~m}^{2} /$ day $\left(29,000 \mathrm{ft}^{2} /\right.$ day) and 1,950 $\mathrm{m}^{2} /$ day $\left(21,000 \mathrm{ft}^{2} /\right.$ day), respectively (Connelly et al. 1992) (Weekes and Borghese, 1993). Assuming a saturated thickness of $40 \mathrm{~m}(130 \mathrm{ft})$, the hydraulic conductivities equal $70 \mathrm{~m} /$ day $(220 \mathrm{ft} /$ day) and $50 \mathrm{~m} /$ day (160 ft/day).

\subsection{HUMAN RESOURCES}

\subsubsection{Land Use}

2.7.1.1 Regional Land Use. Land use in the areas surrounding the Hanford Site includes urban and industrial development, irrigated and dry-land farming, and grazing. Industries in the Tri-Cities are mainly those related to agriculture and energy production (DOE 1989). Wheat, corn, alfalfa, hay, barley, and grapes are the major crops in Benton and Franklin counties.

2.7.1.2 Hanford Site Land Use. The Hanford Site encompasses $1,450 \mathrm{~km}^{2}\left(560 \mathrm{mi}^{2}\right)$ and includes several DOE operational areas. The major areas are as follows: 
- The entire Hanford Site has been designated a National Environmental Research Park (NERP).

- The 100 Areas, bordering on the south shore of the Columbia River, are the sites of the eight retired plutonium production reactors and the $\mathrm{N}$ Reactor (also for plutonium production), which was recently shutdown. The 100 Areas occupy about $11 \mathrm{~km}^{2}\left(4 \mathrm{mi}^{2}\right)$.

- The 200 West and 200 East Areas are located on a plateau about 8 and $11 \mathrm{~km} \mathrm{(5}$ and $7 \mathrm{mi}$ ), respectively, from the Columbia River. These areas have been dedicated to waste management and disposal activities. The 200 Areas cover about $16 \mathrm{~km}^{2}\left(6.2 \mathrm{mi}^{2}\right)$.

- The 300 Area, located just north of the City of Richland, is the site of nuclear research and development. This area covers $1.5 \mathrm{~km}^{2}\left(0.6 \mathrm{mi}^{2}\right)$.

- The 400 Area is about $8 \mathrm{~km}(5 \mathrm{mi})$ north of the 300 Area and is the site of the FFTF used in the testing of breeder reactor systems. Also included in this area is the Fuels and Material Examination Facility.

- The 600 Area includes all of the Hanford Site not occupied by the 100, 200, 300, or 400 Areas. Land uses within the 600 Area include the Arid Land Ecology Reserve (ALE), a U.S. Fish and Wildlife Service wildlife refuge, support facilities for controlled access areas, and other lands leased to Washington state and the Washington Public Power Supply System (Cushing 1992).

- The 1100 Area includes the 3000 Area and the Horns Rapids Landfill. It is used for Hanford site support services.

Public Law 100-605 authorized a study of the Hanford Reach of the Columbia River. The purpose of this study was to identify and evaluate the outstanding features of the Hanford Reach of the Columbia River and immediate environment, and to examine alternatives for their preservation. The draft report recommends that Congress designate the Hanford Reach of the Columbia River a wild and scenic river (NPS 1992). The final report is expected for public release in 1994.

2.7.1.3 Land Use at the Proposed ERDF Site. The ERDF site (including the operational facilities and trench) extends east of the existing 200 West Area to near the US Ecology Area, and south of the proposed road from the 200 East Area to the 200 West Area. The area of the site is approximately 4.1 square kilometer (1.6 square miles) with dimensions of $3.2 \mathrm{~km} \mathrm{(2} \mathrm{mi)}$ by $1.3 \mathrm{~km}(0.8 \mathrm{mi})$. The site is not currently used.

\subsubsection{Water Use}

2.7.2.1 Surface Water. Water use in the Pasco Basin is primarily from surface diversion. The Columbia River is the most significant surface-water body in the region. It is used as a source of drinking water, industrial process water, crop irrigation, and for a variety of recreational activities, including fishing, huating, boating, water skiing, and swimming. Industrial and agricultural usage represent about $13 \%$ and $75 \%$, respectively, and municipal use 
about $12 \%$. The Hanford Site uses about $41 \%$ of the water withdrawn for industrial purposes (Cushing 1992).

The Hanford Reach of the Columbia River is a popular recreational sport fishing area. Anadromous salmonids represent the majority of the sport fish harvested. Other significant sport catches include white sturgeon (Acipenser transmontanus), smallmouth bass (Micropterus dolomieui) and walleye (Stizostedion vitreum) (DOE-RL 1990d).

Swimming and water skiing are popular recreational activities as well. The McNary Reservoir is the main location for these activities in the region. A public swimming area has also been established at Leslie R. Groves Park, which is approximately $0.8 \mathrm{~km}(0.5 \mathrm{mi})$ downstream from the city water intake (DOE-RL 1990d).

River water intakes that are downstream from the proposed ERDF location include the Ringold Fish Hatchery intake, the Ringold Flats irrigation intakes, the Taylor Flats irrigation intakes, the WPPSS intake, the 300 Area process and drinking water intake, the Battelle Farm Operations irrigation intake, the Washington State University Center irrigation intake, and the City of Richland drinking water intake (EPA 1987).

The PNL Observatory relies on water from a spring on the side of Rattlesnake Mountain (U.S. Army Corps of Engineers 1994).

2.7.2.2 Groundwater. Groundwater diversions account for less than $10 \%$ of water use in the Pasco Basin. Approximately 50\% of the wells in the Pasco Basin are for domestic use and are generally shallow [less than $150 \mathrm{~m}(500 \mathrm{ft})$ ]. Agricultural wells, used for irrigation and stock supply, make up the second-largest category of well use, about $24 \%$ for the Pasco Basin. Industrial users account for only about $3 \%$ of the wells (DOE 1988).

The principal users of groundwater within the Hanford Site are the FFTF, with a 1988 use of $142,000 \mathrm{~m}^{3}$ ( 37 million gallons) from two wells in the unconfined aquifer.

Groundwater within aquifers in the immediate vicinity and hydraulically downgradient of the proposed ERDF site is not used for either drinking or irrigation. The nearest drinking water supply wells are those that serve the 400 Area. They are located about $15 \mathrm{~km}(9 \mathrm{mi})$ to the southeast of the proposed ERDF site (PNL 1988a). However, these wells are not directly downgradient from the proposed ERDF site.

\subsubsection{Historical, Archaeological, and Cultural Resources}

The Hanford Site contains numerous, well-preserved archaeological sites representing both the prehistoric and historical periods. Management of Hanford's cultural resources follows the Hanford Cultural Resources Management Plan (Chatters 1989) and is conducted by the Hanford Cultural Resources Laboratory (HCRL) of PNL (1988b).

2.7.3.1 Archaeological Resources. More than 10,000 years of prehistoric human activity in the Middle Columbia River region have left extensive archaeological deposits along the river shores (Leonhardy and Rice 1970, Greengo 1982, and Chatters 1989). Well-watered areas inland from the river show evidence of concentrated human activity (Chatters 1982, 1989, Daugherty 1952, Greene 1975, Leonhardy and Rice 1970, and Rice 1980), and recent surveys 
have indicated extensive, although dispersed, use of arid lowlands for hunting. Graves are common in various settings, and spirit quest monuments (rock cairns) may still be found on summits of the mountains and buttes (Rice 1968a). Throughout most of the region, hydroelectric development, agricultural activities, and domestic and industrial construction have destroyed or covered the majority of these deposits. Because of the limited public access to the Hanford Site, some of the archaeological deposits found in the Hanford Reach of the Columbia River and on adjacent plateaus have been preserved.

There are currently 228 prehistoric archaeological sites recorded in the files of the HCRL. Forty-seven of these sites are included on the National Register of Historic Places (National Register), two as single sites (45BN121, Hanford Island Site; 45GR137, Paris Site) and the remainder in seven archaeological districts, listed in the table below. In addition, a nomination has been prepared for one cultural district (Gable Mountain/Gable Butte), and renomination for two additional archaeological districts is pending (Wahluke, Coyote Rapids). Two other sites, 45BN90 and 45BN412, are considered eligible for the National Register. Archaeological sites include remains of numerous pithouse villages, various types of open campsites, and cemeteries along the river banks (Rice 1968a, 1980), spirit quest monuments, hunting camps, game drive complexes and quarries in mountains and rocky bluffs (Rice 1968b), hunting/kill sites in lowland stabilized dunes, and small temporary camps near perennial sources of water located away from the river (Rice 1968b).

Historic Properties on the Hanford Site Listed on the National Register of Historic Places (Cushing 1992):

Property Name

Wooded Island

Archaeological District

Savage Island

Archaeological District

Hanford Island Site

Hanford North

Archaeological District

Locke Island

Archaeological District

Ryegrass Archaeological

District

Paris Site

Rattlesnake Springs

Archaeological District

Snively Canyon

Archaeological District

100-B Reactor
Site(s) Included

45BN107 through 45BN112, 45BN168

45BN116 through 45BN119, 45FR257 through 45FR262

45BN 121

45BN 124 through 45BN133, 45BN134, 45BN 178

45BN137 through 45BN140, 45BN176, 45GR302 through 45GR305

45BN149 through 45BN157

45GR 137

45BN170, 45BN171

45BN172, 45BN173

Not Applicable

2.7.3.2 Native American Cultural Resources. In prehistoric and early historic times, the Hanford Reach of the Columbia River was heavily populated by Native American people of 
various tribal affiliations. The Wanapum and the Chamnapum bands of the Yakama tribe dwelt along the Columbia River from south of Richland upstream to Vantage (Relander 1956, Spier 1936). Some of their descendants still live nearby at Priest Rapids, and others have been incorporated into the Yakama and Umatilla reservations. Palus people, who lived on the lower Snake River, joined the Wanapum and Chamnapum to fish the Hanford Reach and some inhabited the river's east bank (Relander 1956, Trafzer and Scheuerman 1986). Walla Walla and Umatilla people also made periodic visits to the area to fish. These peoples retain traditional secular and religious ties to the region, and many have knowledge of the ceremonies and practices of their aboriginal culture. The Washane, or Seven Drums religion, which has ancient roots and had its start on the Hanford Site, is still practiced by many people on the Yakama, Umatilla, Warm Springs, and Nez Perce reservations. Native plant and animal foods, some of which can be found on the Hanford Site, are used in the ceremonies performed by sect members. Tribal members have expressed an interest in renewing their use of these resources in accordance with the Treaties of 1855 , and the DOE is assisting them in this effort. Certain landmarks, especially Rattlesnake Mountain, Gable Mountain, Gable Butte, Goose Egg Hill, the White Bluffs Road and various sites along the Columbia River, are considered important or sacred to them. The many cemeteries found along the river are also sacred.

The White Bluffs Road is a former Indian trail and freight road between White Bluffs Ferry landing on the Columbia River and Rattlesnake Springs in the western part of the Hanford Site (see Figure 2-34). This road was an important transportation route during the prehistoric era and during settlement, mining, and cattle ranching eras in the Washington Territory (Rice 1984). This history of the White Bluffs Road was reviewed by HCRL staff and was found to meet the criteria for nomination to the National Register of Historic Places. An area is considered eligible if it is "associated with events that have made a significant contribution to the broad patterns of our history" (36 CFR Part 60.4, criterion A).

2.7.3.3 Historic Resources. Sixty-eight historic archaeological sites and 11 other historic localities have been recorded in published literature. Localities include the Allard Pumping Plant at Coyote Rapids, the Hanford Irrigation Ditch, the Hanford townsite, Wahluke Ferry, the White Bluffs townsite, the Richmond Ferry, Arrowsmith townsite, a cabin at East White Bluffs ferry landing, the White Bluffs road, the old Hanford High School, and the Cobblestone Warehouse at Riverland (Rice 1980). Archaeological sites include the East White Bluffs townsite and associated ferry landings, and an assortment of trash scatters and dumps. Thirty-eight additional sites, including homesteads, corrals, and dumps, have been recorded by the HCRL since 1987. ERTEC Northwest was responsible for minor test excavations at some of the historic sites, including the Hanford townsite locality. In addition to the recorded sites, there are numerous areas of gold mine tailings along the river bank, and the remains of homesteads, farm fields, ranches, and abandoned Army installations are scattered over the entire Hanford Site.

More recent sites are the defense reactors and associated materials processing facilities that now dominate the area. The first reactors (100-B, 100-D, and 100-F) were constructed in 1943 as part of the Manhattan Project. Plutonium for the first atomic explosion and the bomb that destroyed Nagasaki at the end of World War II were produced in the 100-B Facility. Additional reactors and processing facilities were constructed after World War II, during the Cold War. All reactor containment buildings still stand, although many ancillary structures have been removed. The 100-B Reactor has been listed on the National Register of Historic Places. Other Manhattan Project facilities remain to be evaluated. 
2.7.3.4 Cultural Resources at the Proposed ERDF Site. The HCRL conducted a cultural resources survey at the ERDF site during the summer of 1993. The survey identified four archaeological sites, one paleontological site and nine isolated artifacts. One isolated artifact (a cobble tool) was also identified during a previous survey. Based on the determination by the State of Washington Office of Archaeology and Historical Preservation in a letter to DOE/RL. dated February 4, 1994, none of the sites were considered eligible for the National Register. However, two of the archeological sites may represent part of the greater Euro-American ranching community in Southeast Washington State and may be considered regionally or locally significant viewed in this context. The two sites are located outside of the ERDF boundaries and will not be impacted by the proposed activities at the ERDF.

\subsubsection{Socioeconomics}

Activity on the Hanford Site plays a dominant role in the socioeconomics of the Tri-Cities (Richland, Pasco, and Kennewick) and other parts of Benton and Franklin counties. The agricultural community also has a significant effect on the local economy. Any major changes in Hanford activity would potentially affect the Tri-Cities and other areas of Benton and Franklin counties. Detailed analyses of the socioeconomics are found in Scott et al. (1987) and Watson et al. (1984).

2.7.4.1 Employment and Income. Two major sectors are currently the principal driving forces of the economy in the Tri-Cities since the early 1970s: (1) the DOE and its contractors, operating the Hanford Site; and (2) the agricultural community, including a substantial food-processing component. Most of the goods and services produced by these sectors are exported outside the Tri-Cities. In addition to the direct employment and payrolls, these major sectors also support a sizable number of jobs in the local economy through their procurement of equipment, supplies, and business services. In addition to these two major employment sectors, three other components are contributors to the economic base of the Tri-Cities economy; other major employers, tourism, and retired persons.

The unemployment rate fluctuates seasonally due to the agricultural sector. The 1992 average unemployment for the Tri-Cities was $8.5 \%$. Average unemployment in Benton and Franklin Counties in 1992 was $7.6 \%$ and $11.9 \%$, respectively. The unemployment rate in Franklin County was higher due to the larger agricultural sector in Franklin County (Washington State Department of Employment Security 1993).

2.7.4.2 Hanford and the Local and State Economy. In 1991, Hanford employment accounted directly for $24 \%$ of total nonagricultural employment in Benton and Franklin counties and slightly more than $0.6 \%$ of all nonagricultural statewide jobs. In 1991, Hanford Site operations directly accounted for an estimated $42 \%$ of the payroll dollars earned in the area (Cushing 1992).

Hanford contractors spent nearly $\$ 154$ million, or $47.5 \%$ of total procurement of $\$ 324$ million, initially through Washington firms in 1986. About $18 \%$ of Hanford orders were filled by Tri-Cities firms. In many cases, these procurement filled by Tri-Cities firms only result in retail and wholesale markups; however, a significant portion of all Hanford orders, $\$ 6.6$ million, are placed directly to Washington manufacturers (Cushing 1992). 
Hanford contractors paid a total of $\$ 10.9$ million in FY 1988 in state taxes on operations and purchases. Estimates show that Hanford employees paid \$27.0 million in state sales tax, use taxes, and other taxes and fees in FY 1988. In addition, Hanford paid \$0.9 million to local government in Benton, Franklin, and Yakima counties in local taxes and fees (Scott et al. 1989).

2.7.4.3 Dernography. Estimates by the U.S. Bureau of the Census for 1990 (U S. Department of Commerce 1991) placed the population totals for Benton and Franklin counties at 112,560 and 37,473 , respectively. When compared to the 1980 census data in which Benton County had 109,444 residents and Franklin County's population totaled 35,025, the 1990 Census figures reflect the current growth occurring in these two counties. Within each county, thie 1990 estimates distribute the Tri-Cities population as follows: Richland, 32,315; Kennewick, 42,159; and Pasco, 20,337. The combined populations of Benton City, Prosser, and West Richland totaled 10,244 in 1990. The unincorporated population of Benton County was 27,842. In Franklin County, incorporated areas other than Pasco have a total population of 2,424. The unincorporated population of Franklin County was 14,712 (Cushing 1992).

2.7.4.4 Housing. In 1990, nearly $92 \%$ of all housing (of 38,781 total units) in the Tri-Cities was occupied. Single-unit housing, which represents nearly $58 \%$ of the total units, has a $96 \%$ occupancy rate throughout the Tri-Cities. Multiple-unit housing, defined as housing with two or more units, has an occupancy rate of nearly $91 \%$, a 10\% increase from 1989 . Pasco has the lowest occupancy rate, $89 \%$, in all categories of housing; followed by Kennewick, $93 \%$, and Richland, $94 \%$. Representing $9 \%$ of the housing unit types, mobile homes have the lowest occupancy rate, $81 \%$. In 1989 , mobile homes had the highest occupancy rate, $93 \%$ (Cushing 1992).

\subsubsection{Transportation.}

2.7.4.5.1 Tri-Cities Area. The Tri-Cities serve as a regional transportation and distribution center with major air, land, and river connections. The Tri-Cities have direct rail service, provided by Burlington Northern and Union Parific, that connects the area to more than 35 states. Docking facilities at the Ports of Benton, Kennewick, and Pasco are important aspects of this region's infrastructure. These facilities are located on the 525-km-long (326-mi-long) commercial waterway, which comprises the Snake and Columbia rivers, that extends from the Ports of Lewiston-Clarkston in Idaho to the deep-water ports of Portland, Oregon, and Vancouver, Washington (Evergreen Com.nunity Development Association 1986). Daily air passenger and freight services connect the area with most major cities through the Tri-Cities Airport, located in Pasco. The airport is currently served by one national and two commuter-regional airlines. The Tri-Cities are linked to the region by five major highways; Route 395, Route 240, Interstate 84, Interstate 82, and Route 14 (Cushing 1992).

2.7.4.5.2 Hanford Site Transportation. The transportation network for the Hanford Site is shown in Figure 2-35. The Hanford Site railroad system extends from the west side of Richland, Washington, throughout the Hanford Site. The DOE controls the rail access into the Hanford Site; the agency trackage ties in with the Union Pacific Railroad tracks southeast of the Richland " $Y$ " area near the U.S. Highway 12 and Route 240 interchange. The Burlington Northern and Union Pacific have trackage rights over the DOE irackage between the Richland "Y" area and the DOE 1100 Area. The DOE tracks serving the Hanford Site are installed parallel to the Route 240 bypass around the Richland, Washington urban area (DOE 1986). The roads and highways on the Hanford Site are also shown in Figure 2-35. Routes 240 and 
24 traverse the Hanford Site and are maintained by Washington State. Other roads within the reservation are maintained by the DOE (Cushing 1992).

2.7.4.5.3 ERDF Transportation. The existing transportation network in the ERDF area is shown in Figure 2-36.

2.7.4.6 Educational Services. Primary and secondary education are served by the Richland, Kennewick, Pasco, and Kiona-Benton school districts. Post-secondary education in the Tri-Cities area is provided by a junior college, Columbia Basin College (CBC), and the Tri-Cities branch campus of Washington State University (WSU-TC). These institutions emphasize technical and vocational programs (Cushing 1992).

2.7.4.7 Health Care and Human Services. The Tri-Cities have three major hospitals and four minor emergency centers. The three hospitals are the Kadlec Medical Center, located in Richland, the Kennewick General Hospital and Our Lady of Lourdes Hospital, located in Pasco. All three hospitals offer general medical services and include a 24-hour emergency room, basic surgical services, intensive care, and neonatal care (Cushing 1992).

The Tri-Cities offer a broad range of social services. State human service offices in the Tri-Cities include the Job Services office of the Employment Security Department; Food Stamp offices; the Division of Developmental Disabilities; Financial and Medical Assistance; the Child Protective Service; emergency medical service; a senior companion program; and vocational rehabilitation (Cushing 1992).

2.7.4.8 Police and Fire Protection. Police protection in Benton and Franklin counties is provided by Benton and Franklin counties' sheriff departments, local municipal police departments, and the Washington State Patrol Division headquartered in Kennewick. The Kennewick, Richland, and Pasco municipal departments maintain the largest staffs of commissioned officers with 53,44 , and 38 , respectively (Cushing 1992).

There were 117 paid fire-fighters in the Tri-Cities in 1992. The Hanford site has its own fire fighters. There are 126 firefighters in the Hanford Fire Patrol, trained to dispose of hazardous/dangerous waste and to fight chemical fires. Each station has access to a Hazardous Material Response Vehicle that is equipped with chemical fire extinguishing equipment, an attack truck that carries foam, halon, and Purple-K dry chemical, a mobile air truck that provides air for gasmasks; and a transport tanker that supplies water to six brush trucks. They have five ambulances and contact with local hospitals (Cushing 1992).

2.7.4.9 Parks and Recreation. The convergence of the Columbia, Snake, and Yakima rivers offers the residents of the Tri-Cities a variety of recreational opportunities. The Lower Snake River Project provides boating, camping, and picnicking facilities in nearly a dozen different areas along the Snake River. In 1986, nearly 385,000 people visited the area and participated in activities along the river. The Columbia River also provides ample water recreational opportunities on the lakes formed by the dams. Lake Wallula, formed by McNary Dam, offers a large variety of parks and activities, which attracted more than 3 million visitors in 1986 . The Columbia River Basin is also a popular area for migratory waterfowl and upland game bird hunting (Cushing 1992). 


\subsubsection{Utilities.}

2.7.4.10.1 Water. The principal source of water in the Tri-Cities and the Hanford Site is the Columbia River from which the water systems of Richland, Pasco, and Kennewick draw a large portion of the average 11.38 billion gallons used in 1991. Each city operates its own supply and treatment system (Cushing 1992). More information on water use is presented in Section 2.7.2.

The major incorporated areas of Benton and Franklin counties are served by municipal wastewater treatment systems, whereas the unincorporated areas are served by onsite septic systems. Richland's wastewater treatment system is designed to treat a total capacity of 27 million $\mathrm{m}^{3} / \mathrm{yr}(7,100 \mathrm{million} \mathrm{gal} / \mathrm{yr})$. Currently, the daily average flow is $34,000 \mathrm{~m}^{3} /$ day ( 8.9 million gal/day) with a peak flow of $170,000 \mathrm{~m}^{3} /$ day (144 million gal/day) (Cushing 1992).

2.7.4.10.2 Electricity. In the Tri-Cities, electricity is provided by the Benton County Public Utility District, Benton Rural Electrical Association, Franklin County Public Utility District, and City of Richland Energy Services Department. All the power that these utilities provide in the local area is purchased from the Bonneville Power Administration (BPA), a federal power marketing agency. Natural gas, provided by the Cascade Natural Gas Corporation, serves a small portion of residents, with 4,800 residential customers in June 1992 (Cushing 1992).

Electrical power for the Hanford Site is purchased wholesale from BPA. Energy requirements for the Site during FY 1988 exceeded 550 average MW (Cushing 1992). The Hanford electrical distribution system is used to distribute power to the bulk of the Hanford Site. The City of Richland distributes power to the 700,1100, and 3000 areas, which constitute approximately $2 \%$ of the total Hanford Site usage (DOE-RL 1993d).

2.7.4.10.3 200 Area Utilities. Sanitary wastes are currently disposed of through septic tanks and drain fields at the 200 Area. The construction of a central collection and treatment evaporation plant is being considered to handle the sanitary sewer (DOE-RL 1993d).

The 200 Areas have two types of water: sanitary (potable) water used for sanitary uses such as drinking water, showers, and laundry; and raw (export) water used for fire protection and other non-potable uses. The sanitary water is pumped and treated. Raw water is drawn from the Columbia River. A looped water system was installed in the 200 areas in 1992. This allows for fire protection and repairs to take place at the same time (DOE-RL 1993d). The communication system is a fiber network system.

2.7.4.11 Visual Resources. The land in the vicinity of the Hanford Site is generally flat with little relief. Rattlesnake Mountain, rising to $1060 \mathrm{~m}$ above mean sea level, forms the western boundary of the site, and Gable Mountain and Gable Butte are the highest land forms within the site. Both the Columbia River, flowing across the northern part of the site and forming the eastern boundary, and the spring-blooming desert flowers provide a visual source of enjoyment to people. The White Bluffs, steep bluffs above the northern boundary of the river in this region, are a striking feature of the landscape (Cushing 1992). 


\subsubsection{Noise}

Studies at Hanford of the propagation of noise have been concerned primarily with occupational noise at work sites. Environmental noise levels have not been extensively evaluated because of the remoteness of most Hanford Site activities and isolation from receptors that are covered by federal or state statutes. The majority of available information consists of model predictions, which in many cases have not been verified because the predictions indicate that the potential to violate state or federal standards is remote or unrealistic (Cushing 1992).

2.7.5.1 Background Noise Levels at the Hanford Site. Environmental noise measurements were made in 1981 during site characterization of the Skagit/Hanford Nuclear Power Plant Site (PSPL 1982b). Fifteen sites were monitored and noise levels ranged from 30 to $60.5 \mathrm{dBA}$ (Leq). The values for isolated areas ranged from 30 to $38.8 \mathrm{dBA}$. Measurements taken around the sites where the Supply System was constructing nuclear power plants (WNP-1, WNP-2, and WNP-4) ranged from 50.6 to $64 \mathrm{dBA}$. Measurements taken along the Columbia River near the intake structures for WNP-2 were 47.7 and $52.1 \mathrm{dBA}$ compared to more remote river noise

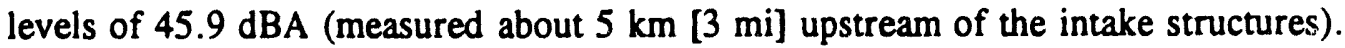

Community noise levels in North Richland (3000 Area at Horn Rapids Road and the By-Pass Highway) were 60.5 BA (Cushing 1992).

In addition, site characterization studies performed in 1987 included measurement of background environmental noise levels at five sites on the Hanford Site. Noise levels are expressed as equivalent sound levels for 24 hours (Leq-24). Wind was identified as the primary contributor to background noise levels with winds exceeding $12 \mathrm{mph}$ significantly affecting noise levels. Coleman concludes that background noise levels in undeveloped areas at Hanford can best be described as a mean Leq-24 of 24 to $36 \mathrm{dBA}$. Periods of high wind, which normally occur in the spring, would elevate background noise levels (Cushing 1992).

2.7.5.2 Hanford Site Sound Levels. Although most industrial facilities on the Hanford Site are located far enough away from the site boundary that noise levels at the boundary are not distinguishable from background noise levels, there is the potential for producing noise from field activities, such as well drilling and sampling (Cushing 1992).

In the interest of protecting Hanford workers and complying with Occupational Safety and Health Administration (OSHA) standards for noise in the workplace, the Hanford Environmental Health Foundation has monitored noise levels resulting from several routine operations performed at Hanford. Occupational sources of noise propagated in the field are summarized in the table below. These levels are reported here because operations such as well sampling are conducted in the field away from established industrial areas and have the potential for disturbing sensitive wildlife (Cushing 1992). 
DOE/RL-93-99, Rev. 0

Monitored Levels of Noise Propagated from Outdoor Activities at the Hanford Site (Cushing 1992)

\begin{tabular}{|c|c|c|c|}
\hline Activity & $\begin{array}{l}\text { Average Noise } \\
\text { Level (Decibels) }\end{array}$ & $\begin{array}{l}\text { Maximum Noise } \\
\text { Level (Decibels) }\end{array}$ & $\begin{array}{c}\text { Year } \\
\text { Measured }\end{array}$ \\
\hline Water wagon operation & 104.5 & 111.9 & 1984 \\
\hline $\begin{array}{l}\text { Well sampling } \\
\text { Truck } \\
\text { Compressor } \\
\text { Generator }\end{array}$ & $\begin{array}{c}74.8-78.2 \\
78-83 \\
88-90 \\
93-95\end{array}$ & & $\begin{array}{l}1987 \\
1989\end{array}$ \\
\hline Well drilling, Well 32-2 & $98-102$ & 102 & 1987 \\
\hline Well drilling, 32-3 & $105-11$ & $120-125$ & 1987 \\
\hline Well drilling, 33-29 & $89-91$ & & 1987 \\
\hline $\begin{array}{l}\text { Pile driver (diesel } 5 \mathrm{ft} \text { from } \\
\text { source) }\end{array}$ & $118-119$ & & 1987 \\
\hline $\begin{array}{l}\text { Tank farm filter building } \\
\text { ( } 30 \mathrm{ft} \text { from source) }\end{array}$ & 86 & & 1976 \\
\hline
\end{tabular}

\subsection{ECOLOGY}

The Hanford Site is a relatively large, undisturbed area $\left[1450 \mathrm{~km}^{2}\left(\sim 560 \mathrm{mi}^{2}\right)\right]$ of shrub-steppe habitat that contains numerous plant and animal species adapted to the region's semiarid environment. The relatively undisturbed native sagebrush-steppe habitat, riparian habitat, sand dunes and unique habitats associated with canyons, basalt outcrops and cliffs, promote biodiversity and support ecologically important species. Important species include plant species of medicinal and dye value, commercial and recreational wildlife including stateand federal-listed and candidate threatened or endangered species, as well as species making up critical habitat used by listed and candidate species. The site consists of mostly undeveloped land with widely spaced clusters of industrial buildings located along the western shoreline of the Columbia River and at several locations in the interior of the site. The industrial buildings are interconnected by roads, railroads, and electrical transmission lines. The major facilities and activities occupy about $6 \%$ of the total available land area, and their impact on the surrounding ecosystems is minimal. Most of the Hanford Site has not experienced tillage or livestock grazing since the early 1940s. Fire can affect the distribution of vegetation. The wildfires that occurred in 1981 and 1984 burned much of the sagebrush from Rattlesnake Mountain. This is discussed further in Section 2.8.1.1.

The Columbia River flows through the Hanford Site, and although the river flow is not directly impeded by artificial dams within the Hanford Site, the historical daily and seasonal water fluctuations have been changed by dams upstream and downstream of the site (Rickard and Watson 1985). The Columbia River and other water bodies on the Hanford Site provide habitat for aquatic organisms. The Columbia River is also accessible for public recreational use and commercial navigation. Other descriptions of the ecology of the Hanford Site can be found 
in ERDA (1975), Rogers and Rickard (1977), Jamison (1982), and Watson et al. (1984), among others. Some of the information presented in this section is adapted from Downs et. al. (1993).

\subsubsection{Hanford Site Terrestrial Ecology}

2.8.1.1 Vegetation. The Hanford Site has been botanically characterized as shrub-steppe habitat (Daubenmire 1970) and is considered to contain one of the largest tracts of undisturbed native sagebrush steppe remaining in the State of Washington. The vegetation mosaic of the Hanford Site currently consists of 10 major kinds of plant communities:

- sagebrush/bluebunch wheatgrass

- sagebrush/cheatgrass or sagebrush/Sandberg's bluegrass

- sagebrush-bitterbrush/cheatgrass

- greasewood/cheatgrass-saltgrass

- winterfat/Sandberg's bluegrass

- thyme buckwheat/Sandberg's bluegrass

- cheatgrass-tumble mustard

- willow or riparian

- spiny hopsage

- sand dunes.

The distribution of the dominant plant communities is shown in Figure 2-37. The sagebrush/cheatgrass (Sandberg's bluegrass) community is perhaps the most common in the 200 Area. In the early 1800 s, the dominant plant in the area was big sagebrush with an understory of perennial bunchgrasses, especially Sandberg's bluegrass and bluebunch wheatgrass.

Livestock grazing and crop raising have altered the natural vegetation mosaic and subjected it to persistent invasion by alien annuals, especially cheatgrass. Today, cheatgrass is the dominant plant on fields that were cultivated 40 years ago and is also well established on rangelands at elevations less than $244 \mathrm{~m}$ (800 ft) (Rickard and Rogers 1983).

The dryland areas of the Hanford Site were treeless in the years before land settlement; however, for several decades before 1943, trees were planted and irrigated on most of the farms to provide windbreaks and shade. When the farms were abandoned in 1943, some of the trees died but others have persisted. Today these trees are ecologically important because they serve as nesting platforms for several species of birds, including hawks and owls, and as night roosts for wintering bald eagles (Rickard and Watson 1985).

The release of water used as industrial process coolant streams at the Hanford Site facilities created several semi-permanent artificial ponds that did not exist before these industrial releases commenced. Over the years, stands of cattails, reeds, and trees, especially willow, cottonwood, and Russian olive, have developed around the ponds. These ponds are ephemeral and will disappear if the industrial release of water is terminated; in fact, many of these have been discontinued and no longer exist. No ponds or ditches are located at the ERDF site.

Almost 600 species of plants have been identified on the Hanford Site (Sackschewsky et al. 1992). More than 100 species of plants have been identified in the 200 Area Plateau (ERDA 1975). The dominant plants on the 200 Area Plateau are big sagebrush, rabbitbrush, cheatgrass, and Sandberg's bluegrass, with cheatgrass providing half of the total plant cover. 
Cheatgrass and Russian thistle, which are annuals introduced to the United States from Eurasia in the late 1800 s, invade areas where the ground surface has been disturbed. A food web centered on cheatgrass is shown in Figure 2-38 (modified from Watson et al. 1984). The main links leading to man would be through mule deer and chukars. Other pathways leading to man through terrestrial food webs could be via upland game birds and elk. Certain desert plants

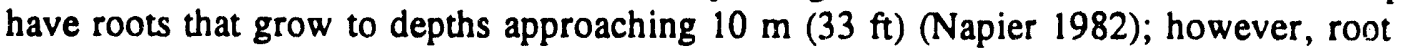
penetration to these depths has not been demonstrated for plants in the 200 Areas. Rabbitbrush

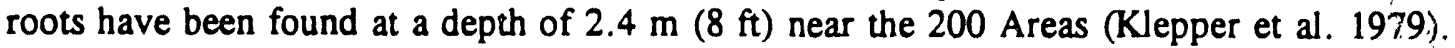
Mosses and lichens appear abundantly on the soil surface; lichens commonly grow on the shrub stems.

The important desert shrubs, big sagebrush and bitterbrush, are widely spaced and : usually provide less than $20 \%$ canopy cover. The important understory plants are grasses, especially cheatgrass, Sandberg's bluegrass, Indian ricegrass, June grass, and needle-and-threxd grass. A list of plants is given in Table 2-2.

Mature shrub-steppe provides important habitat for a number of plant and anim»l species of concern that depend on the shrub component, usually sagebrush, for nesting, food and protection. Bitterbrush shrubs provide browse for a resident herd of wild mule deer. Certain passerine birds rely on sagebrush or bitterbrush for nesting (i.e., sage sparrow, sage thrasher, and loggerhead shrike). Certain species of birds nest only in the mature big sage located south of the 200 Areas. For example, loggerhead shrikes prefer to nest in shrubs with an average height of about 2 meters ( 6 feet). Loggerhead shrikes are year-round residents that are present at low densities. Sage sparrows are common summer residents of the Hanford Site that are restricted almost entirely to sagebrush stands. Mature shrub-steppe habitat also provides prime foraging habitat for a variety of raptor species. Shrub-steppe habitat available for species of concern on the Hanford Site may become a more critical issue as agricultural, industrial and urban development decrease the amount of this habitat type in eastern Washington.

Sagebrush and bitterbrush are easily killed by summer wildfires, but the grasses and other herbs are relatively resistant and usually recover in the first growing season after burning. The most recent and extensive wildfire occurred in the summer of 1984. Fire usually opens the community to wind erosion. The severity of erosion depends on the severity and areal extent of the fire. Hot fires incinerate entire shrubs and damage grasscrowns. Less intensive fires leave dead stems standing, and recovery of herbs is prompt. Bitterbrush shrubs are slow to recolonize burned areas because bitterbrush does not re-sprout even when fire damage is light. Reestablishment of bitterbrush occurs using seeds.

2.8.1.2 Insects. More than 300 species of terrestrial and aquatic insects have been found on the Hanford Site (ERDA 1975). Grasshoppers and darkling beetles are among the more conspicuous groups and, along with other species, are important in the food web of the local birds and mammals. Most species of darkling beetles occur throughout the spring to fall period, although some species are present only during 2 or 3 months in the fall (Rogers and Rickard 1977). Grasshoppers are evident during the late spring to fall. Both groups are subject to wide annual variations in abundance. Grasshoppers are a food source for the Swainson's hawk, which is a federal candidate for threatened and endangered designation.

2.8.1.3 Reptiles and Amphibians. Twelve species (Table 2-3) of amphibians and reptiles are known to occur on the Hanford Site (Fitzner and Gray 1991). The occurrence of these species is infrequent when compared with similar fauna of the southwestern United States. The 
side-blotched lizard is the most abundant reptile and can be found throughout the Hanford Site. Short-horned and sagebrush lizards are also common in selected habitats. The most common snakes are the gopher snake, the yellow-bellied racer, and the Western rattlesnake, which are found throughout the Hanford Site. Striped whipsnakes and desert night snakes are rarely found, but some sightings have been recorded for the site. Toads and frogs are found near the permanent water bodies and along the Columbia River.

2.8.1.4 Birds. Fitzner and Gray (1991) and Landeen et al. (1992) have presented data on birds observed on the Hanford Site. The horned lark and western meadowlark are the most abundant nesting birds in the shrub-steppe. Some of the more common birds present on the Hanford Site are listed in Table 2-4. The game birds inhabiting terrestrial habitats at Hanford are the chukar, gray partridge, and mourning dove. The chukar and grey partridge are yearround residents, but mourning doves are migrants. Although a few doves overwinter in southeastern Washington State, most leave the area by the end of September (Cushing 1992).

Mourning doves nest on the ground and in trees all across the Hanford Site. Chukars are most numerous on Rattlesnake Mountain, Yakima Ridge, Umtanum Ridge, Saddle Mountains, and Gable Mountain areas of the Hanford Site and are somewhat rare on the 200 Area Plateau, but a few birds are known to inhabit the plateau. Gray partridges are not as numerous as chukars, and their numbers also vary greatly from year to year. Sage grouse populations have declined on the Hanford Site since the 1940s, and it is likely that there are no nesting sage grouse on the Site at this time. The nearest viable population is located on the U.S. Army's Yakima Training Center, located to the north and west of the Hanford Site. Other game birds present on the Hanford Site include ring-necked pheasant and California quail.

In recent years, the number of nesting ferruginous hawks has increased, at least in part because the hawks have accepted steel powerline towers as nesting sites. Only about 50 pairs are believed to be nesting in the state of Washington. Other raptors that nest on the Hanford Site are the prairie falcon, northern harrier, red-tailed hawk, Swainson's hawk, and kestrel. Burrowing owls, great horned owls, barn owls, and long-eared owls also nest on the Site but in smaller numbers.

Passerine species inhabiting terrestrial habitats at Hanford include the loggerhead shrike, sage sparrow, and the Western meadowlark. Loggerhead shrikes are year-round residents, although they occur at relatively low densities (Poole 1992). They nest from March through August in undisturbed portions of the big Sagebrush/Sandberg's bluegrass community. The approximate density of the loggerhead shrike is $3.5 \mathrm{pairs} / \mathrm{km}^{2}\left(9.1 \mathrm{pairs} / \mathrm{mi}^{2}\right)$. Sage sparrows are a common summer resident of the Hanford Site (Fitzner and Rickard 1975). These small passerines are restricted in their distribution almost entirely to sagebrush stands (Schuler et.al. 1988). Sage sparrow abundance on the 200 Area Plateau has been shown to be related to sagebrush density (Schuler et. al. 1988). Sage sparrow density is up to $7.5 \mathrm{birds} / \mathrm{km}^{2}$ (19 birds $/ \mathrm{mi}^{2}$ ) in undisturbed areas of the 200 Area Plateau.

2.8.1.5 Mammals. Approximately 39 species of mammals have been identified on the Hanford Site (Fitzner and Gray 1991) (Table 2-5). The largest vertebrate predator inhabiting the Hanford Site is the coyote, which ranges all across the Site. Bobcats and badgers also inhabit the Hanford Site but in low numbers. Black-tailed jackrabbits are common on the Hanford Site, mostly associated with mature stands of sagebrush. Cottontails are also common but appear to be more closely associated with the buildings, debris piles, and equipment laydown areas associated with the onsite laboratory and industrial facilities. 
Townsend's ground squirrels occur in colonies of various sizes scattered across the Hanford Site and marmots are scarce. The most abundant mammal inhabiting the Site is the Great Basin pocket mouse. It occurs all across the Columbia River plain and on the slopes of the surrounding ridges. Other small mammals include the deer mouse, harvest mouse, grasshopper mouse, montane vole, vagrant shrew, and Merriam's shrew.

Seven species of bats inhabit the Hanford Site, occurring mostly as fall or winter migrants. The pallid bat frequents deserted buildings and is thought to be the most abundant of the various species. Other species include the hoary bat, silver-haired bat, California brown bat, little brown bat, Yuma brown bat, and Townsend's big-eared bat.

Mule deer are found throughout the Hanford Site, although areas of highest concentrations are on the ALE Reserve and along the Columbia River. Deer populations on the Hanford Site appear to be relatively stable. The herd is characterized by a large proportion of very old animals (Eberhardt et al. 1982). Islands in the Hanford Reach of the Columbia River are used extensively as fawning sites by the deer (Eberhardt et al. 1979) and thus are a very important habitat for this species. Hanford Site deer frequently move offsite and are killed by hunters on adjacent public and private lands (Eberhardt et al. 1984).

\subsubsection{Species of Special Concern at the Hanford Site}

The remaining undisturbed shrub-steppe habitat at the Hanford Site has been designated priority habitat by the Washington State Department of Wildlife due to its relative scarcity in the state and its importance as nesting, breeding and foraging habitat for state- and federal listed or candidate sensitive species. This designation is a proactive measure to prevent species from becoming threatened or endangered. Threatened and endangered plants and animals identified on the Hanford Site, as listed by the federal government (50 CFR 17) and Washington State (Washington Natural Heritage Program 1994), are shown in Tables 2-3, 2-4, 2-5, and 2-6. No plants or mammals on the federal list of Endangered and Threatened Wildlife and Plants are known to occur on the ERDF Site. There are, however, several species of both plants and animals that are of concern or are under consideration for formal listing by the federal government and Washington State.

2.8.2.1 Plants. The Washington Natural Heritage Progranı, administered by the Department of Natural Resources, is tasked with monitoring the status of vascular plants in the state of Washington. Plant species are designated as endangered, threatened, sensitive, or monitored according to the species' status in Washington state. Columbia milkvetch (Astragalus columbianus) and Hoover's desert parsley (Lomatium tuberosum) are listed as threatened, and persistentsepal yellowcress (Rorippa columbiae) and northern wormwood (Artemisia campestris borealis var. wormskioldii) are designated as endangered. These four plant species are also listed as candidate species by the Federal government. Columbia milkvetch occurs on dry land benches along the Columbia River in the vicinity of Priest Rapids Dam, Midway, and Vernita; it also has been found on top of Umtanum Ridge and in Cold Creek Valley near the present vineyards. Hoover's desert parsley grows on steep talus slopes in the vicinity of Priest Rapids Dam, Midway, and Vernita. Yellowcress occurs in the wetted zone of the water's edge along the Columbia River. Northern wormwood is known to occur near Beverley and could inhabit the northern shoreline of the Columbia River across from the 100 Areas. 
Thompson's sandwort (Arenaria franklinii v. ihompsonii) is listed as a monitored species and is known to occur in stabilized sand dunes in the vicinity of the 200 Area (DOE 1987). Other plant species designated as sensitive by the Washington State National Heritage program and likely to be found in the dryland areas of the Hanford Site are Piper's daisy (Erigeron piperianus), and gray cryptantha (Cryptantha leucophaea) (DOE 1989). False yarrow (Chaenactis douglassii var. glandulosa) is also likely to be found in these areas but it has been re-classified from a sensitive species to a monitor species. A recent survey of the proposed ERDF site identified stalked-pod milkvetch (Astragalus sclerocarpus), a Washington State monitored species, as the only state listed plant present. Table 2-6 lists plant species of special concern and their state and federal status that have been identified at the 200 Area and other locations on the Hanford Site.

2.8.2.2 Animals. Both the Washington Department of Wildlife and U.S. Fish and Wildlife Service are responsible for monitoring the status of animal species (Woodruff and Hanf 1992). The sage sparrow (Amphispiza belli), and sage thrasher (Oreoscoptes montanus) are listed as state candidate species, and depend on sagebrush and bitterbrush for nesting although the sage thrasher is not known to nest near the 200 Area (DOE 1987). The loggerhead shrike (Lanius ludovicianus) is listed as a state and federal candidate species and also inhabits the sagebrushbitterbrush environment. The grasshopper sparrow (Ammodramus savannarum) is a state monitored species found at the Hanford Site. Golden eagles (Aquila chrysaetos) are winter visitors to the Hanford Site and forage in the vicinity of the 200 Area. Burrowing owls (Athene cunicularia) nest on the ground and forage in the vicinity of the 200 Area. Swainson's hawks (Buteo swainsoni) are known to use planted trees in the 200 Area for nesting sites and forage in the area. The golden eagle, burrowing owl, and Swainson's hawk are Washington state candidate species. The long-billed curlew (Numenius americanus) has been proposed for monitor status in Washington state, is a federal candidate species, and is known to nest on the ground in the vicinity of the 200 Area. Table 2-4 lists bird species known to occur at the Hanford Site and their state and federal status.

The pallid bat (Antrozous pallidus), a state monitored species, is likely to inhabit the 200 Area. Merriam's shrew (Sorex merriami), a state candidate species, and Townsend's big-eared bat (Plecotus townsendii), a federal candidate species, are also found at the Hanford Site. The pygmy rabbit (Brachylagus idahoensis), a federal candidate and is a state endangered species, is a potential inhabitant of the Hanford Site, but none have been found at the Site. The striped whipsnake (Masticophis taeniatus) listed by the state as candidate species, and the woodhouse toad (Bufo woodhousei) and the desert night snake (Hypsiglena torquata desertia) are listed as monitored species. Table 2-5 lists mammals known to occur at the Hanford Site and their state and federal status. Table 2-3 lists amphibians and reptiles known to occur at the Hanford Site and their state status (none are listed by the Federal government).

\subsubsection{Wildlife Refuges}

Several national and state wildlife refuges are located on or adjacent to the Hanford Site. These refuges are shown in Figure 2-39. 


\subsubsection{ERDF Ecology}

A recent survey of the planned ERDF site found it to be primarily undisturbed sagebrush habitat that had not sustained significant fire damage. The recent surveys identified long-billed curlews, sage sparrows, and loggerhead shrikes as nesting in the area. Grasshopper sparrows were present and possibly nesting at the site. Swainson's hawks were observed hunting in the area. Burrowing owls, while not observed during the surveys, have been seen at the site in the past and are presumed to currently inhabit the area.

\subsection{CHARACTERISTICS OF FINE-GRAINED SOILS BORROW SITE (MCGEE RANCH)}

\subsubsection{Site Description}

The McGee Ranch area is the proposed borrow site for fine-textured soils, although a complete evaluation of the impacts on cultural, historical, and ecological resources and a mitigation plan remain to be completed before the site can be developed. As shown in Figure $2-40$, McGee Ranch is located approximately $5 \mathrm{~km}(3 \mathrm{mi})$ northwest of the 200 West Area. Figure 2-41 illustrates the general site topography. The ground surface generally slopes to the east or southeast and is dissected by approximately 10 east-trending ephemeral streams. The McGee Ranch has been identified as a potential borrow site for fine-grained sediments that may be used in the construction of closure covers at the ERDF and other locations at the Hanford Site. The fine-grained materials would be used in the closure covers as top-soil material and also as low-permeability barrier material. Use of this site as a source of fine-textured soils is not impacted by inclusion of the McGee Ranch as part of the 100-IU-1 operable unit.

\subsubsection{Characteristics of Site Sediments and Fine-Grained Sediment Volume Estimates}

2.9.2.1 Geological Characteristics. The geological characteristics of the McGee Ranch discussed in this section are based on two characterization efforts conducted within the McGee Ranch. The first characterization effort investigated an area of the site referenced as Area $A$ on Figure 2-41 (Last et al. 1987). The second effort evaluated the area referenced as Area B on Figure 2-41 (Lindberg 1994).

The evaluation of Area A was based on a series of boreholes drilled, sampled and logged to the first significant gravel layer detected. Sediments from each boring were classified based on grain-size into one of 19 sediment classifications. A layer of fine-grained sediments was identified immediately below the surface at Area A and ranges in thickness from 0.5 to $10 \mathrm{~m}$ $(1.6$ to $32.8 \mathrm{ft})$. A layer of silty-sandy gravel was identified directly beneath the surficial layer of fine-grained sediments.

Characterization of Area B of the McGee Ranch is also based on a series of boreholes. In most cases, borehole sampling was discontinued when carbonate-cemented, silty, sandy gravels were intercepted. However, a few boreholes were drilled into the gravels as far as $4 \mathrm{~m}$ $(13 \mathrm{ft})$. The gravel units encountered at the bottom of the boreholes consist of angular basalt gravel weakly cemented with calcium carbonate and lesser amounts of silica. The gravel size distribution was not determined because the drilling technique used did not allow representative 
sampling. Observations of recovered fractured gravels indicated the gravels consist primarily of pebbles with some cobbles. Carbonate concentrations were also estimated to be the strongest in the upper 0.3 to $0.6 \mathrm{~m}$ ( 1 to $2 \mathrm{ft}$ ) of the gravel unit. These gravels are characteristic of the geologic strata referred to as the Plio-Pleistocene Unit found elsewhere on the Hanford Site.

Hanford formation sediments at the site overlay the Plio-Pleistocene unit and range in thickness from $0.15 \mathrm{~m}$ to $12.2 \mathrm{~m}(0.5$ to $40 \mathrm{ft})$. The Hanford formation sediments consisi of a series of graded beds composed of silt to fine sands referred to as the Touchet Beds. The beds of fine sands and silts were occasionally interspersed with small amounts of fine gravels. Clastic dikes also are identified. These dikes consist of sediment layers aligned parallel to the dike walls and composed of sediments similar to the Hanford formation sediments.

Surficial sediments consisting of eolian silt to sandy silt (loess) overlay the Hanford formation and range in thickness up to $1 \mathrm{~m}(3 \mathrm{ft})$. The interface of the upper Hanford formation and the surficial deposits was difficult to determine due to bioturbation and because the local loess has been derived from Touchet Bed sediments. Soils in the area investigated are typical of soils that develop at this altitude under similar conditions. The upper soil layer contains an abundant quantity of roots and the next lower soil level consists of sandy silt graded downward to carbonate-cemented sandy silt. The ground surface at the McGee Ranch is covered with pebbles, some cobble gravels and occasional boulders. The gravels generally occur in low densities, however areas of significantly high density are also present. Gravels are composed of both basalt colluvium and exotic gravels. Exotic gravel deposition is the result of ice rafting during prehistoric glacial flooding.

2.9.2.2 Volume Estimates for Fine-Grained Sediments. The volume of suitable sediments identified at Area A of the McGee Ranch was calculated based on the information collected during borehole sampling and logging. The estimated total volume of fine-grained sediments in Area A suitable for closure cover construction is $3.47 \mathrm{Mm}^{3}$ (4.55 $\mathrm{Myd}^{3}$ ) (Lindberg 1994).

Estimated volumes of fine-grained sediments for Area B were developed using three dimensional modeling. Contour structure maps and isopach maps of intervening intervals were constructed using data collected from borehole sampling. The isopach maps identify an eastsloping wedge of fine-grained sediments (Touchet Beds and eolian sediments) thickening in the direction of the slope. The sediments range in thickness from $3 \mathrm{~m}(10 \mathrm{ft})$ in the western section

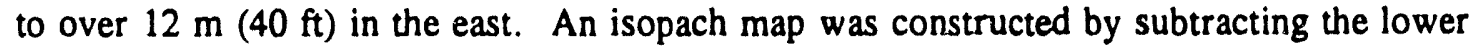
surface of the Touchet Beds from the upper ground surface at each borehole and then contouring the difference. This method considers data between boreholes and adjusts for surficial topographic features between boreholes. The combined volume of suitable Touchet Bed and eolian sediments estimated using this technique was estimated by Lindberg (1994) at $32.7 \mathrm{Mm}^{3}$ $\left(42.8 \mathrm{Myd}^{3}\right)$.

\subsubsection{Archaeological and Cultural Characteristics}

A cultural resources pedestrian survey has identified a number of historic and prehistoric resources at the McGee Ranch Site (Skelly and Wing 1992). Plans are being developed to address mitigation of impacts to cultural resources at the McGee Ranch. 


\subsubsection{Wildife Ecology}

Reconnaissance surveys have been carried out at the proposed borrow site by qualified professionals. No resident species of plants or animals of special concern were identified. However, one or more protected species of birds may use the area during the nesting season, or may exhibit variable patterns of habitation from year to year (Skelly and Wing 1992).

\subsection{CHARACTERISTICS OF BASALT BORROW SITE}

The borrow site for crushed basalt for the Hanford Barrier is currently being evaluated. 


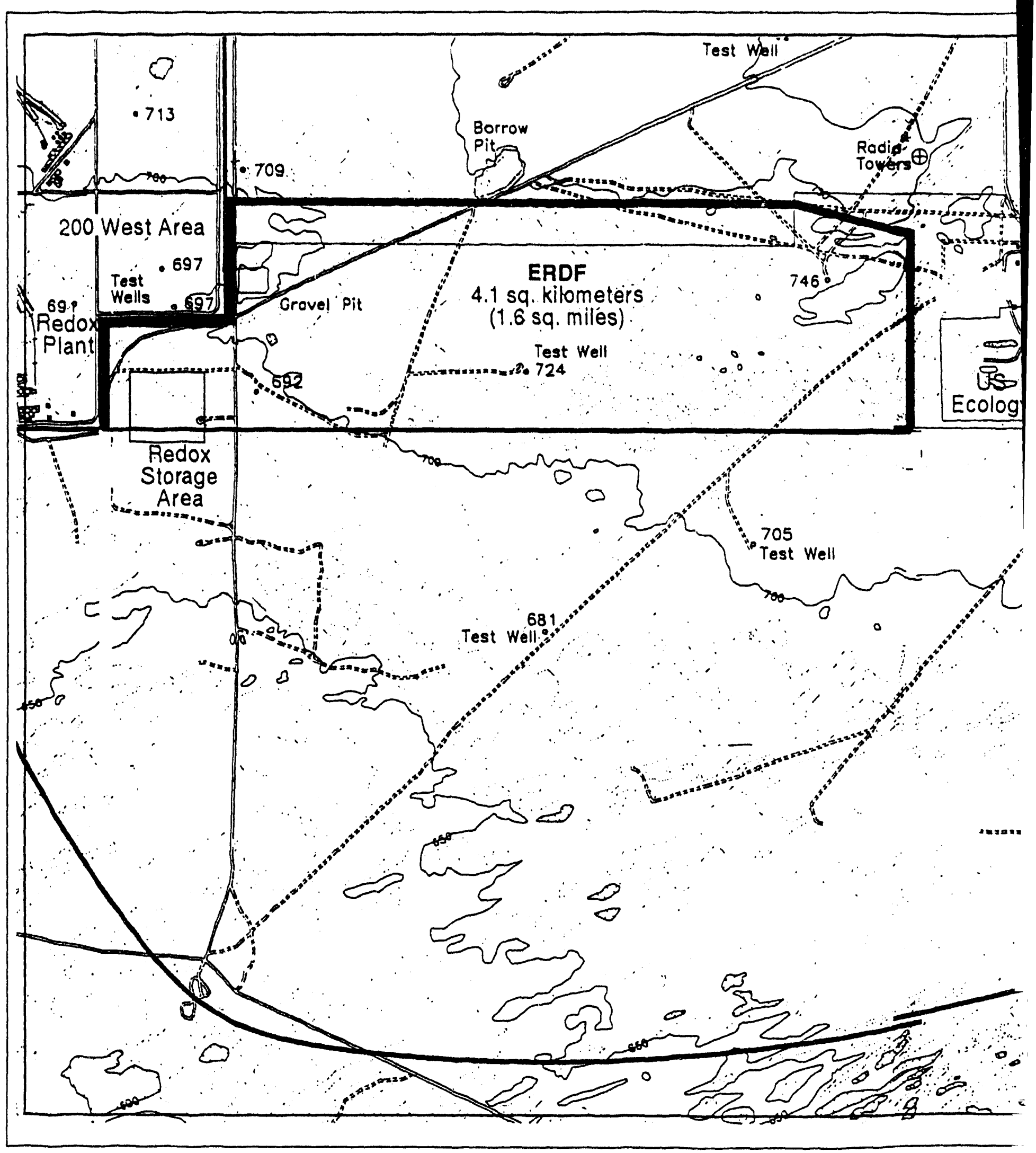




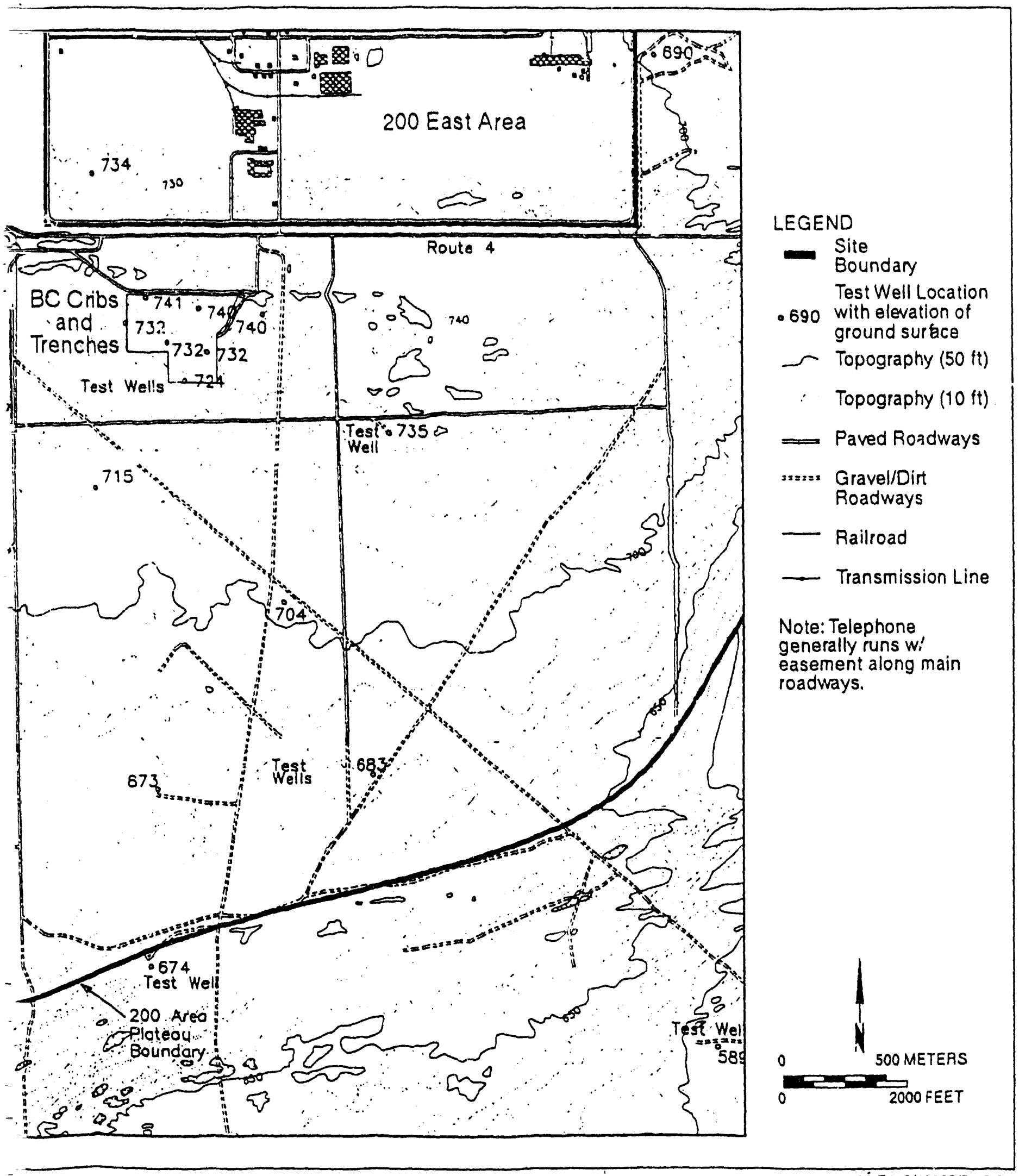

923 E412/48603/5-19.94

Figure 2-1. Location of the Proposed Environmental Restoration Disposal Facility. 


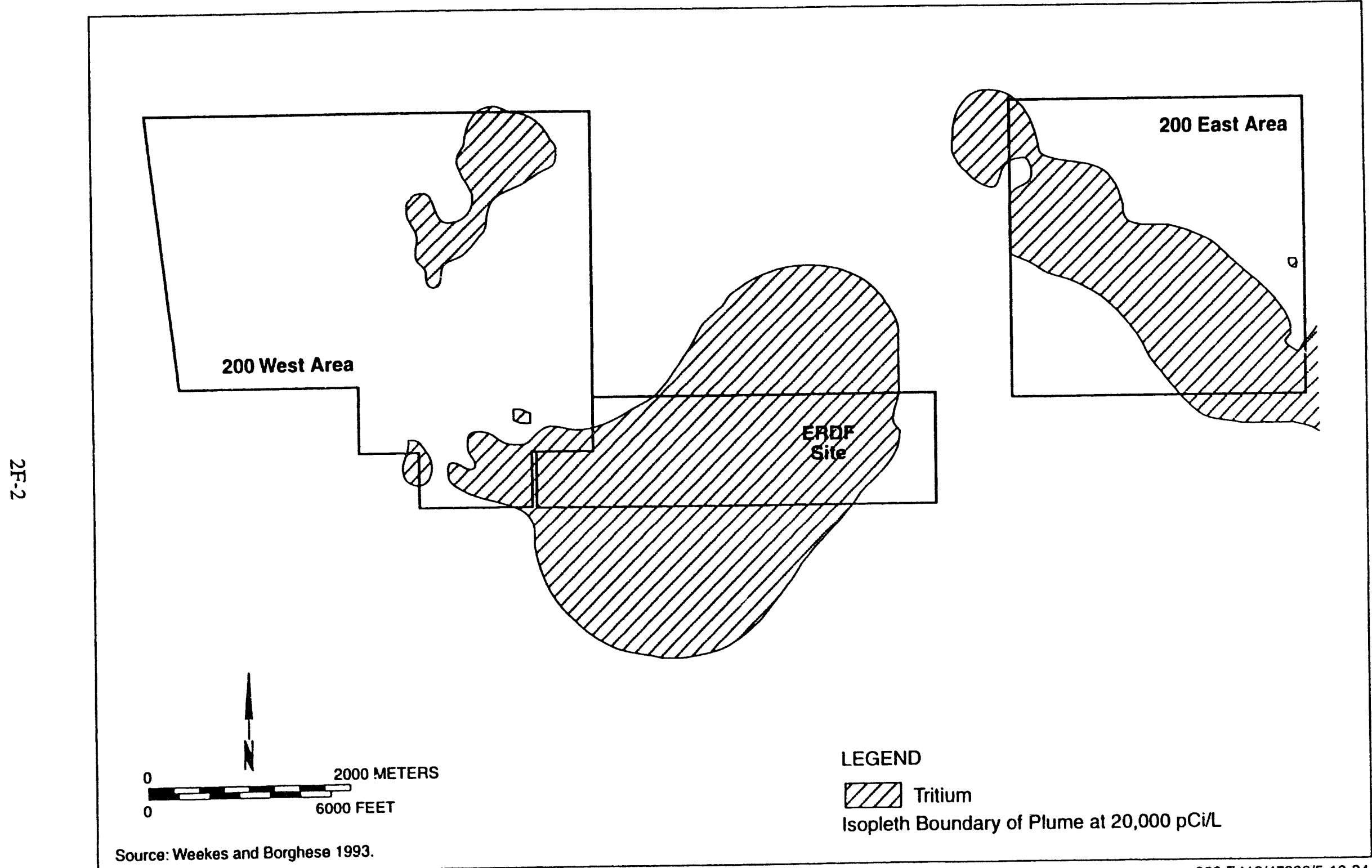

Figure 2-2. Tritium Groundwater Plume Map. 


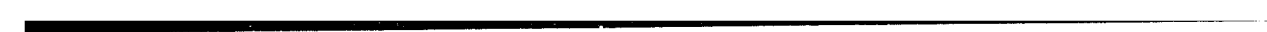

○

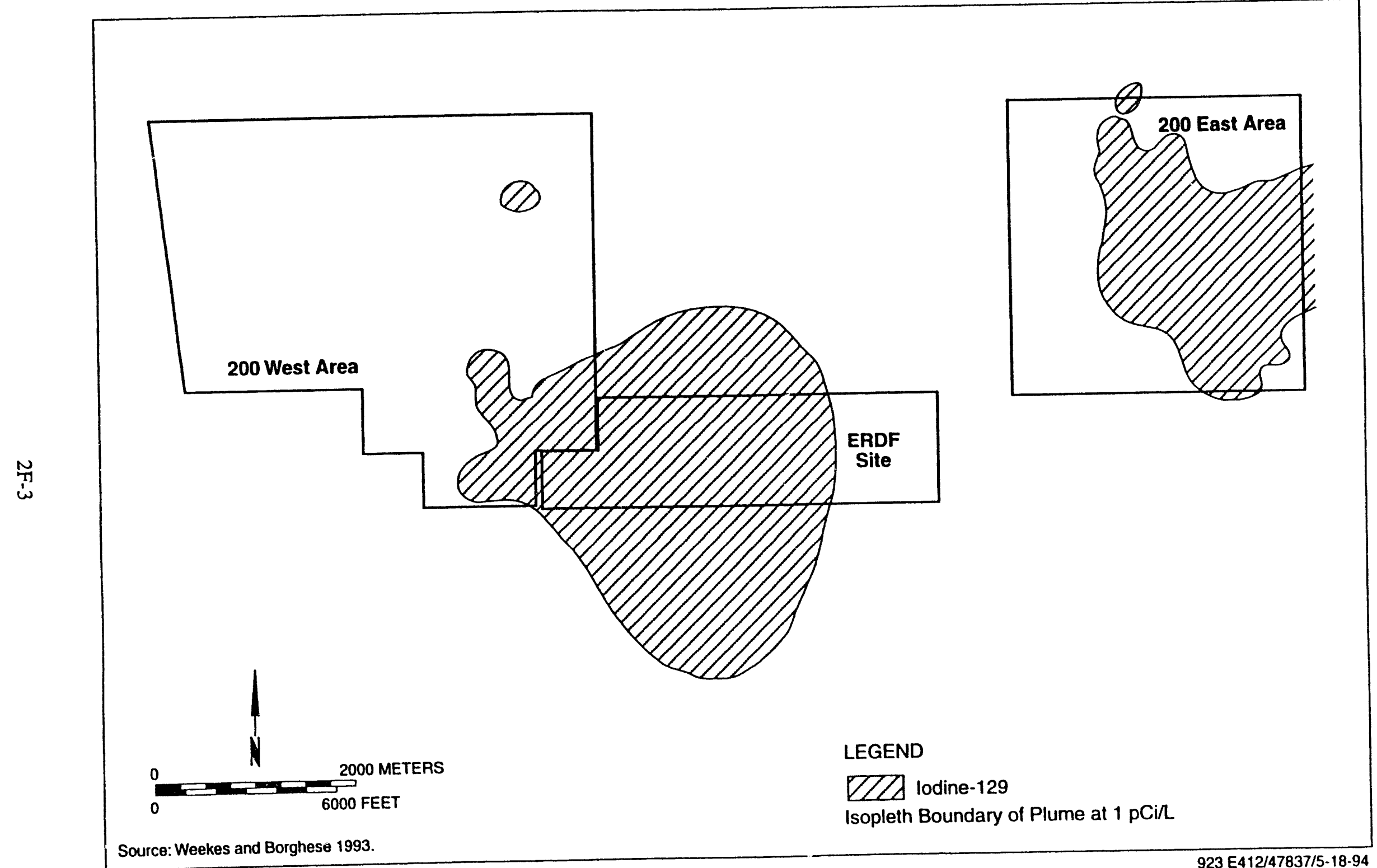

$\square$
0
$\Pi$
0
7
0
0
0
8
0
0
0
0
0

Figure 2-3. Iodine-129 Groundwater Plume Map. 


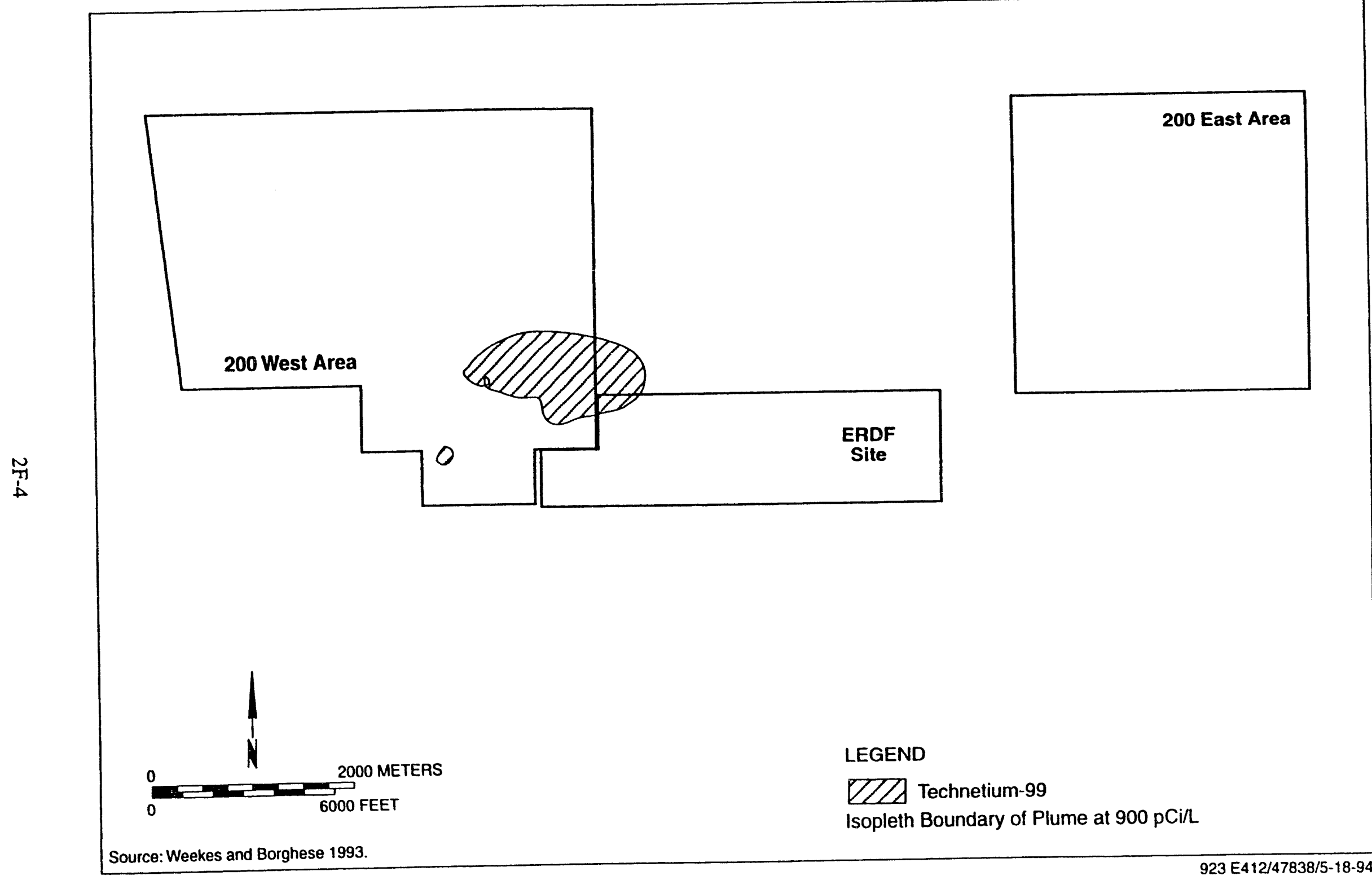

Figure 2-4. Technetium-99 Groundwater Plume Map. 

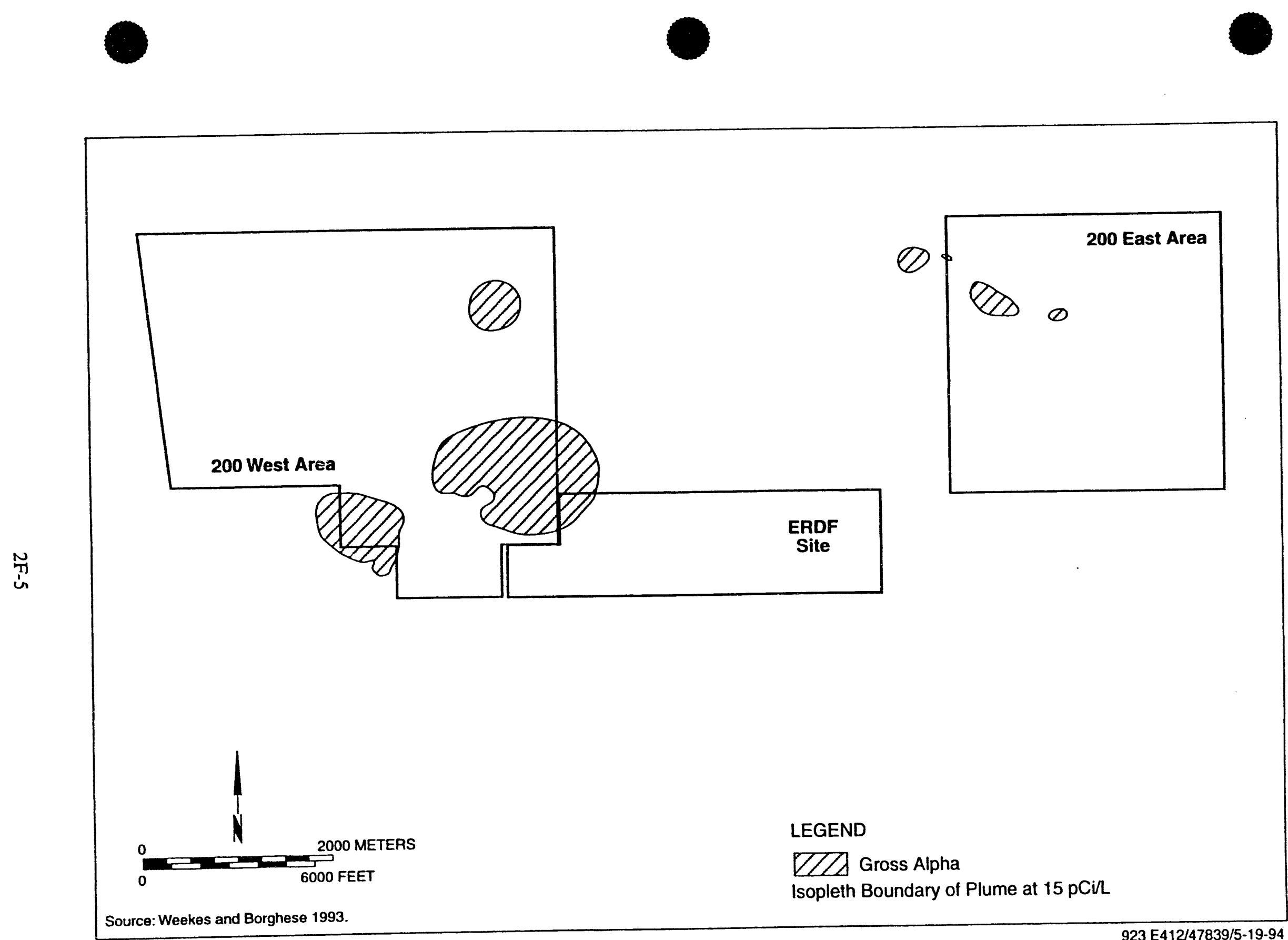

Source: Weekes and Borghese 1993.

$923 E 412 / 47839 / 5-19-94$

Figure 2-5. Gross Alpha Groundwater Plume Map. 


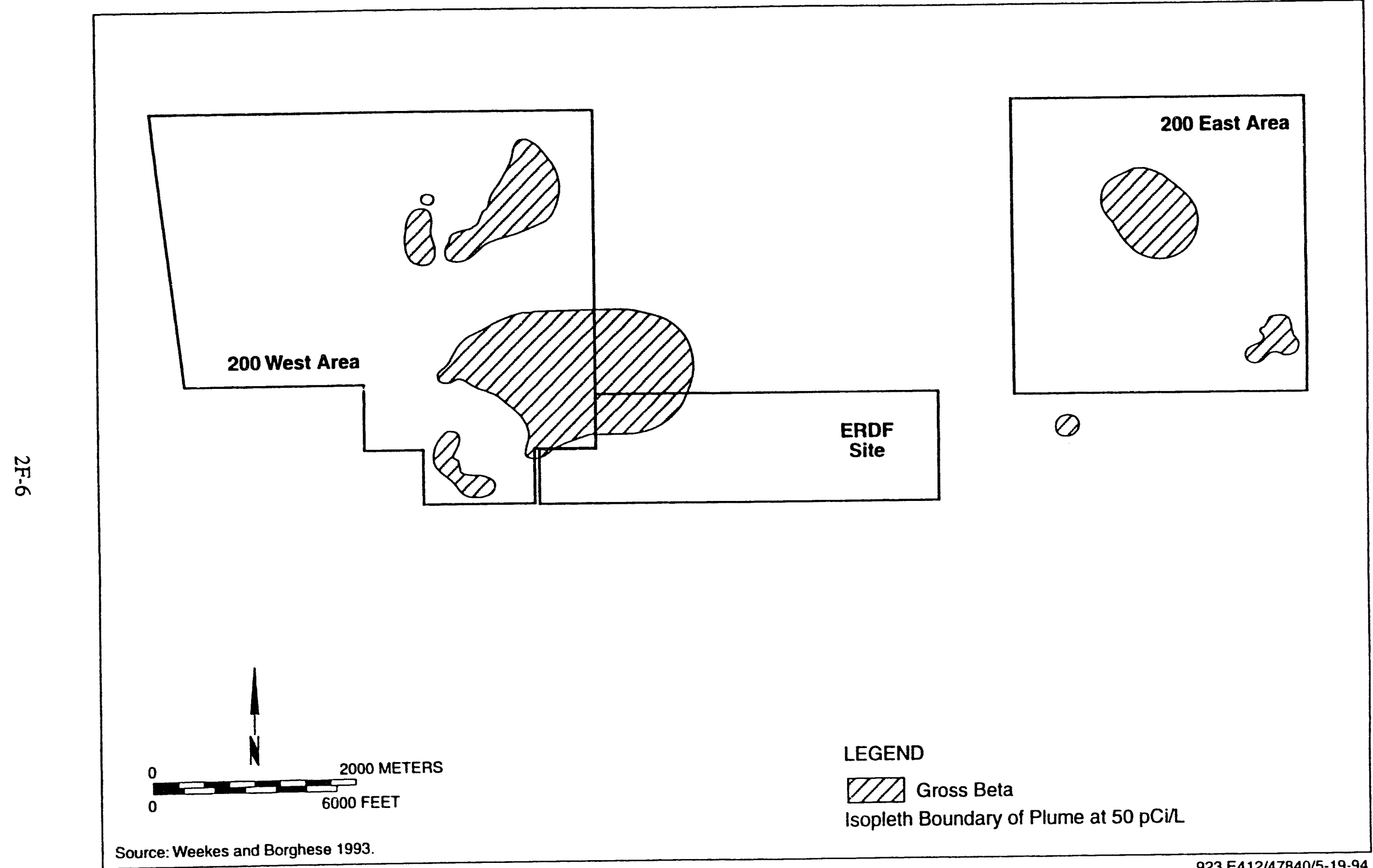

Figure 2-6. Gross Beta Groundwater Plume Map. 


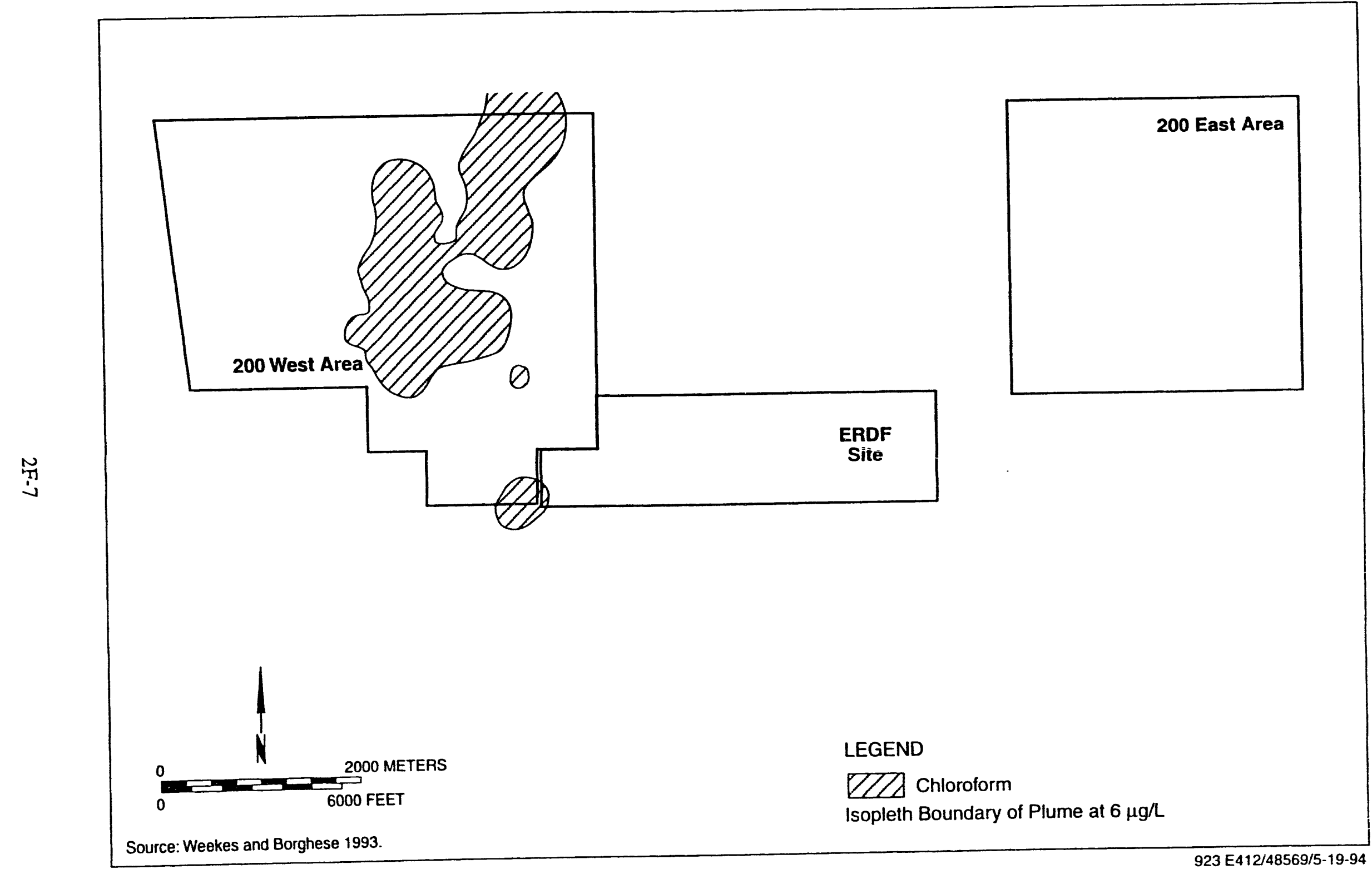

Figure 2-7. Chloroform Groundwater Plume Map. 


\section{0}

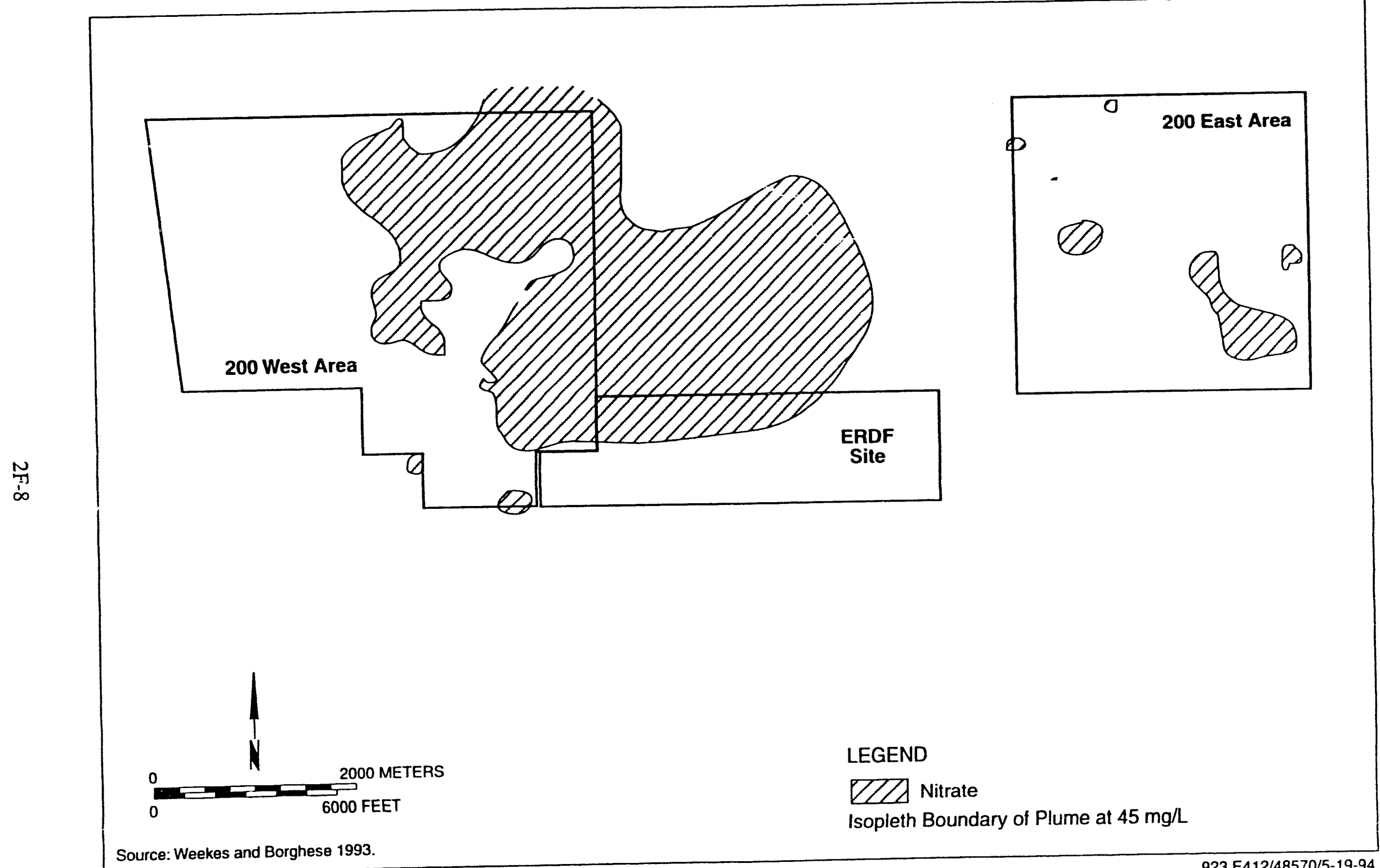

Figure 2-8. Nitrate Groundwater Plume Map. 


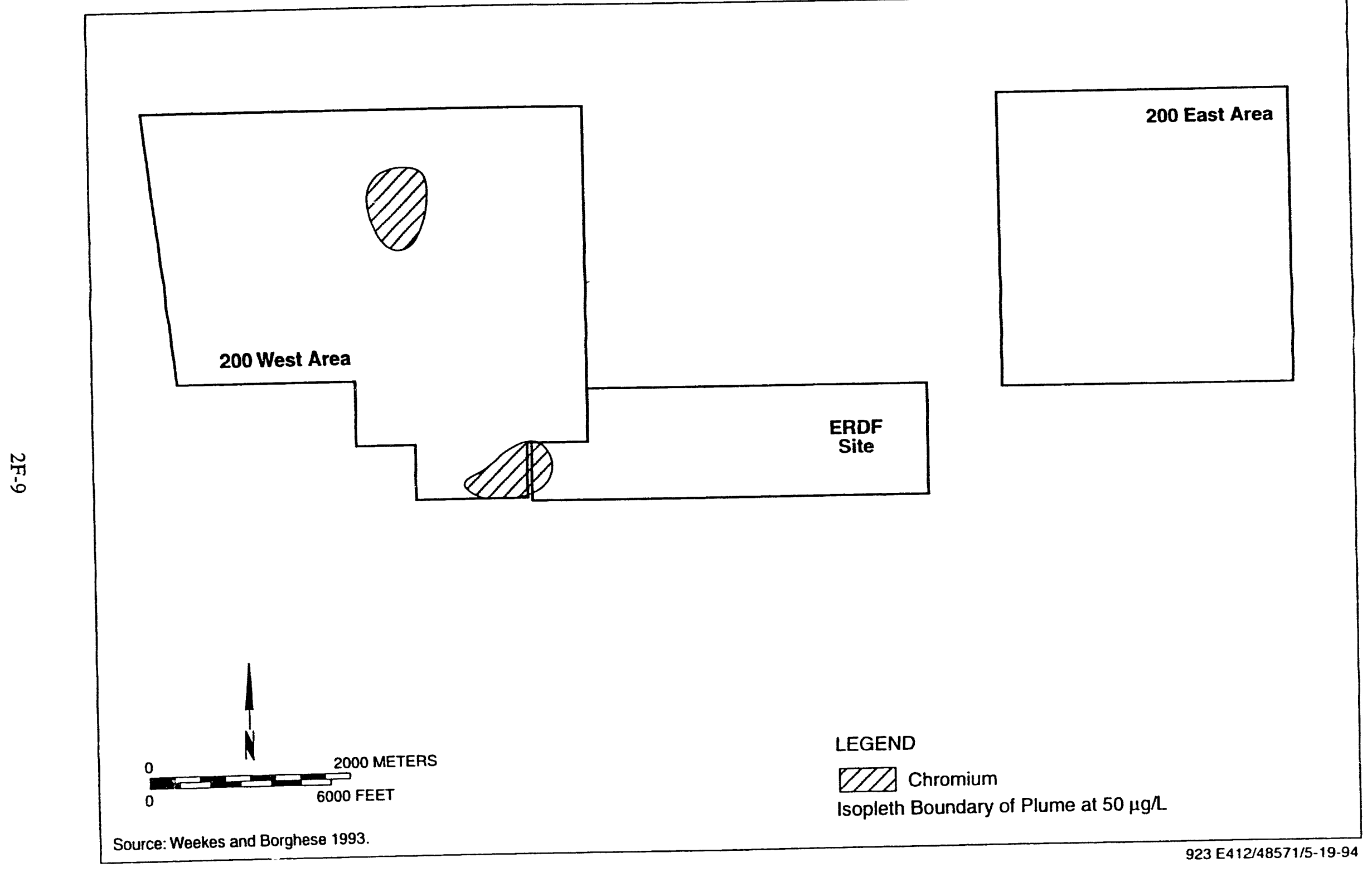

Figure 2-9. Chromium Groundwater Plume Map. 


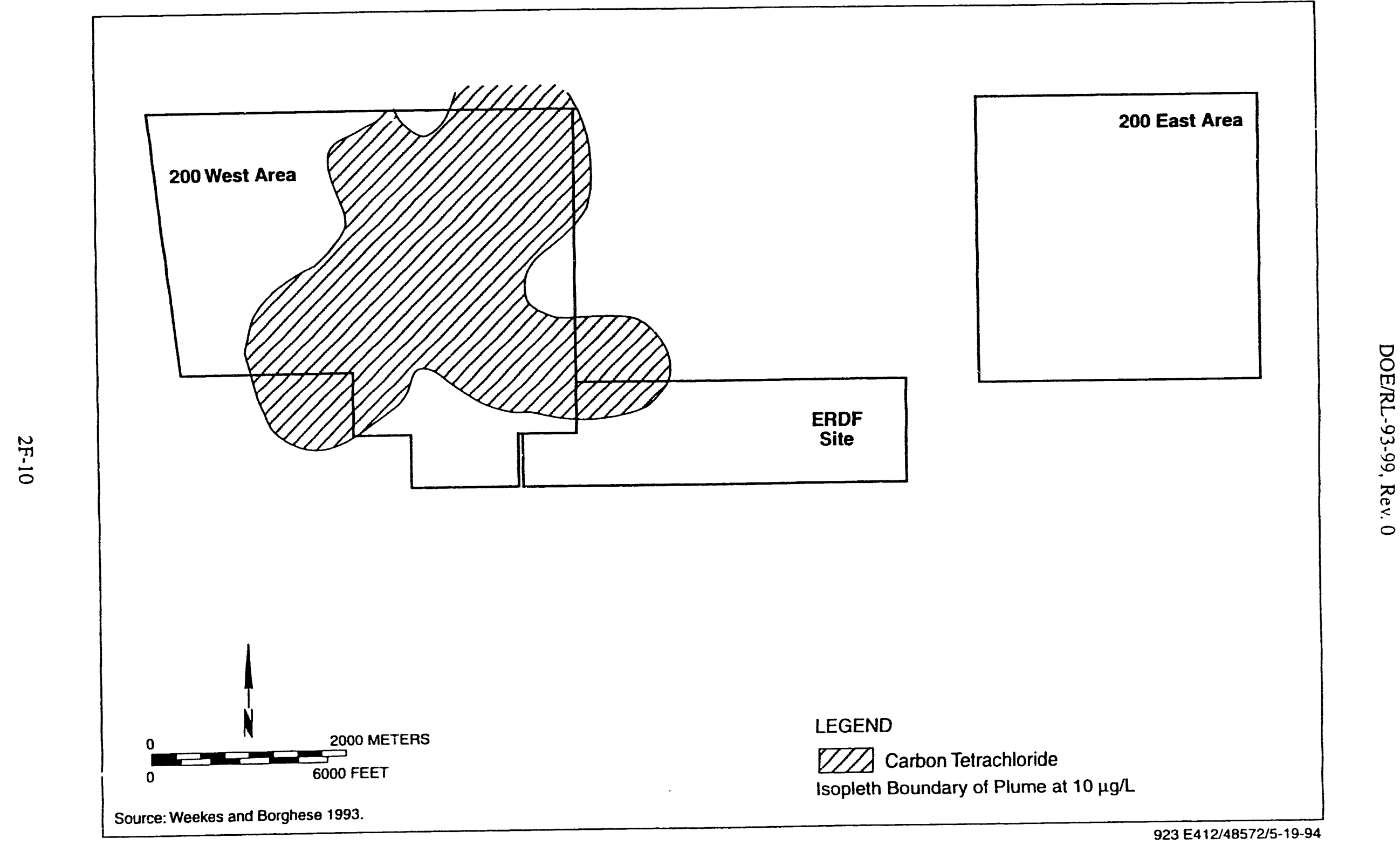

Figure 2-10. Carbon Tetrachloride Groundwater Plume Map. 


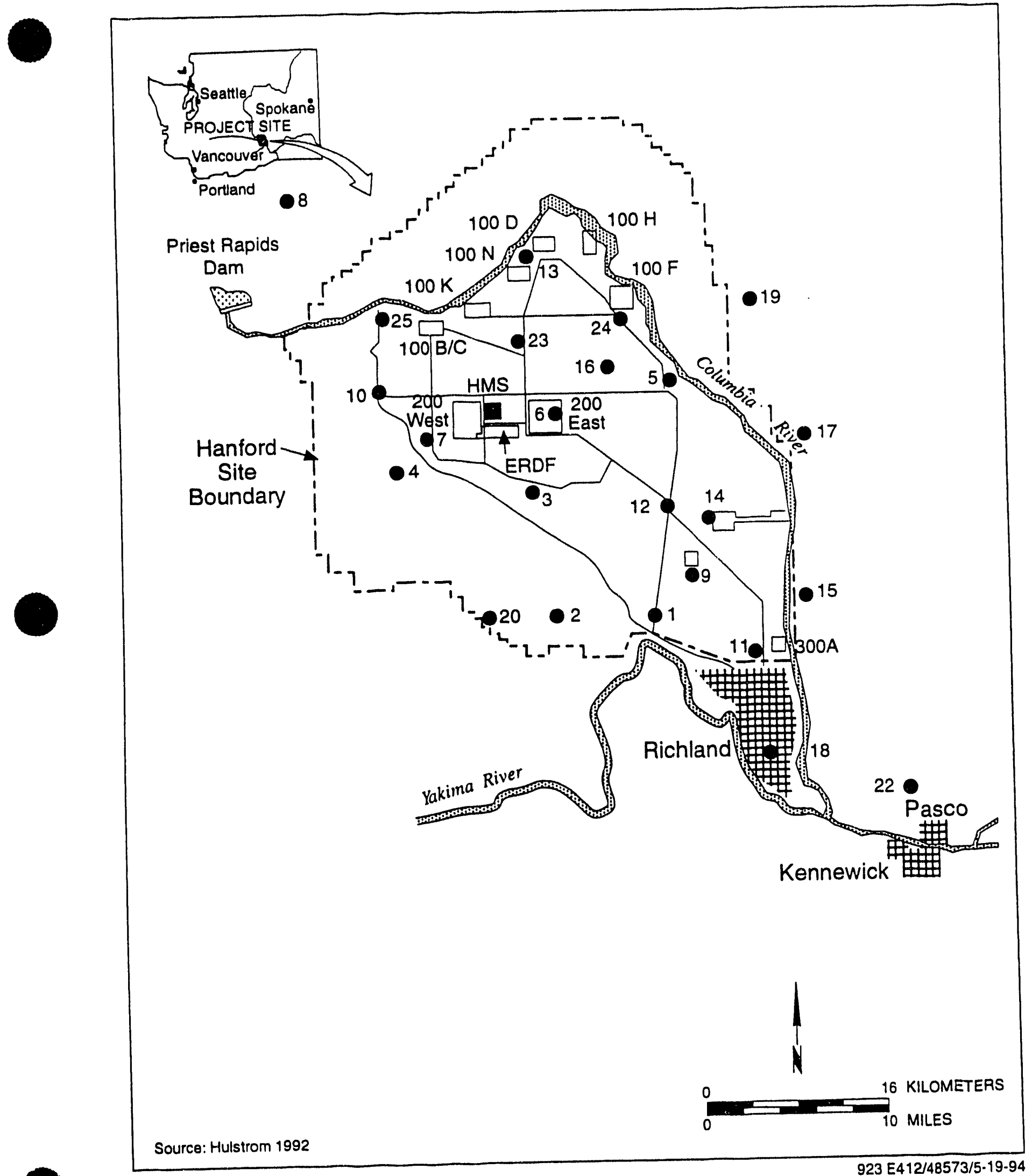

Figure 2-11. Meteorologic Monitoring Stations at the Hanford Site. 


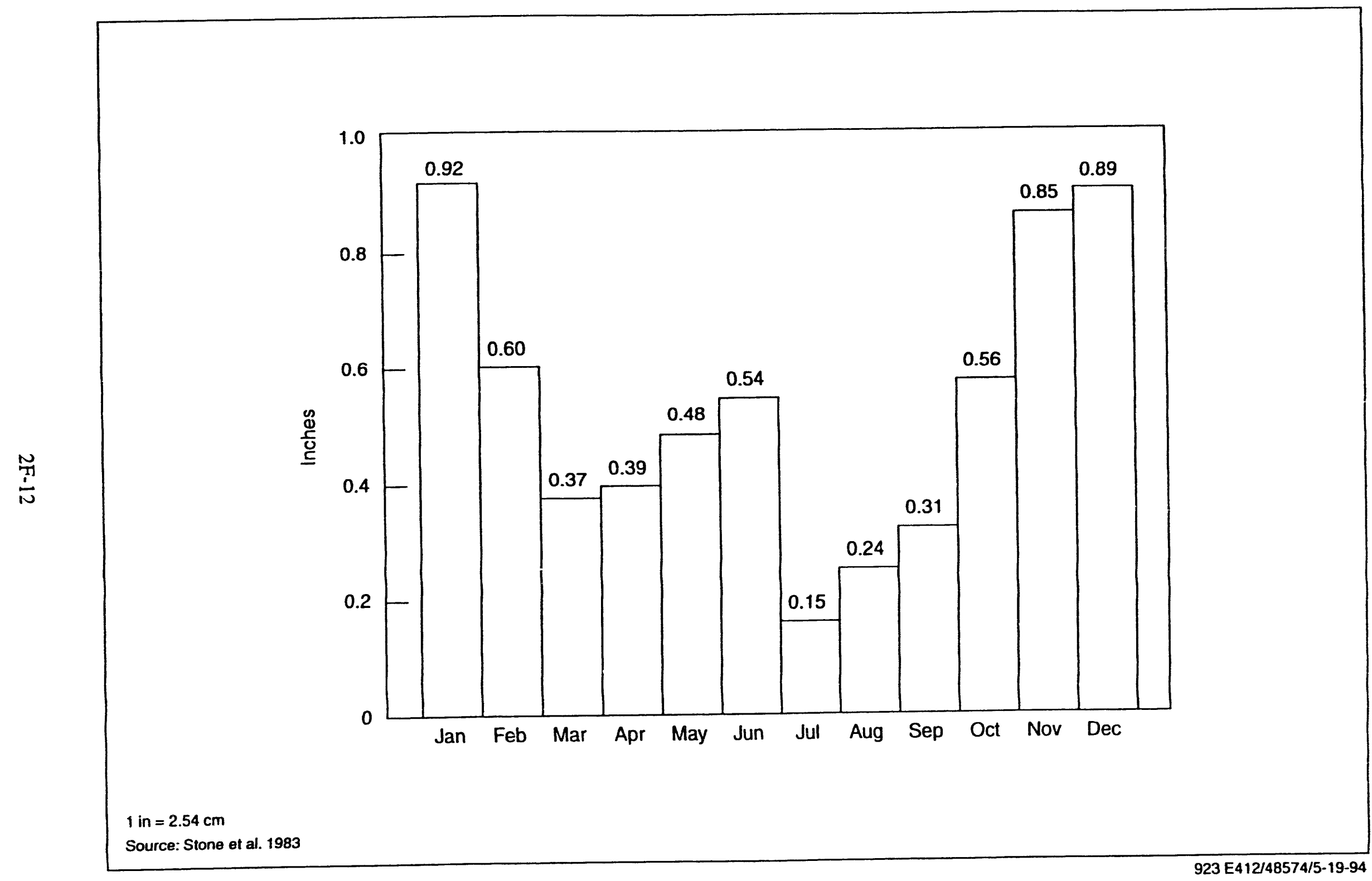

Figure 2-12. Monthly Average Precipitation Amounts, 1912 through 1980. 


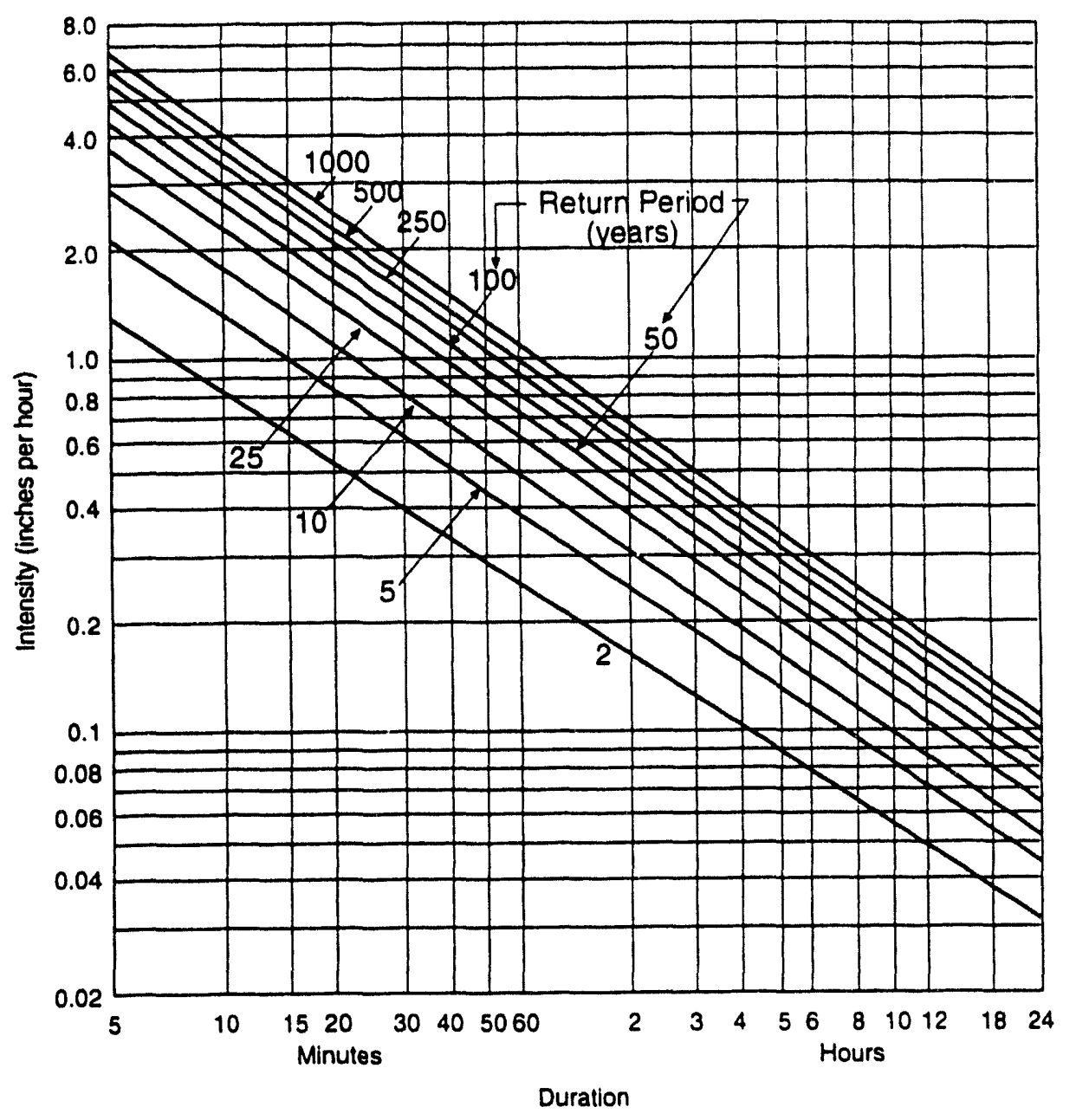

Source: Stone et al. 1983.

Figure 2-13. Rainfall Intensity Duration and Frequency Based on the Period 1947 to 1969 at Hanford. 


\section{-}

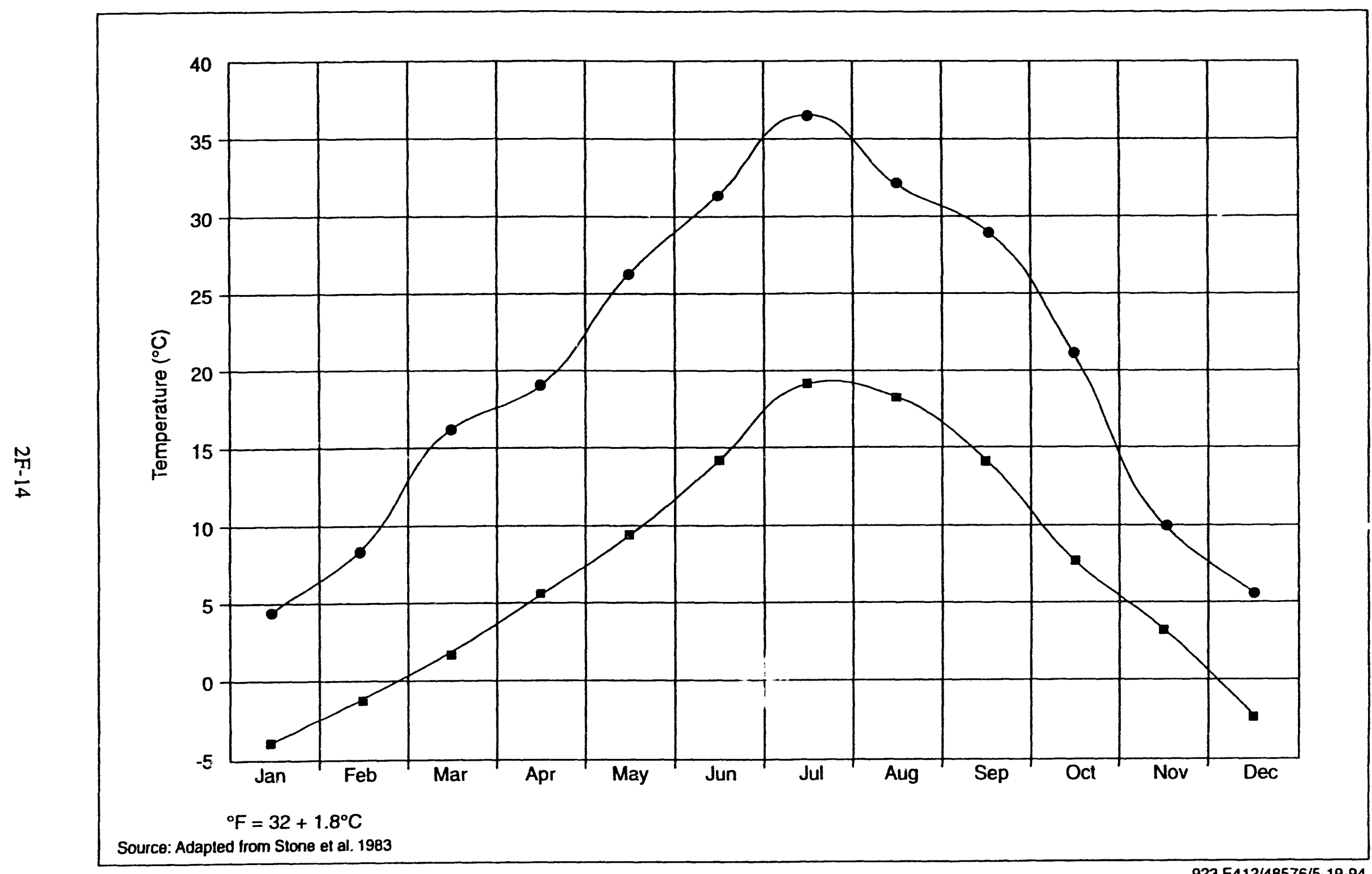

Figure 2-14. HMS Monthly Average High and Low Air Temperatures, 1951 through 1980. 
DOE/RL-93-99, Rev. 0

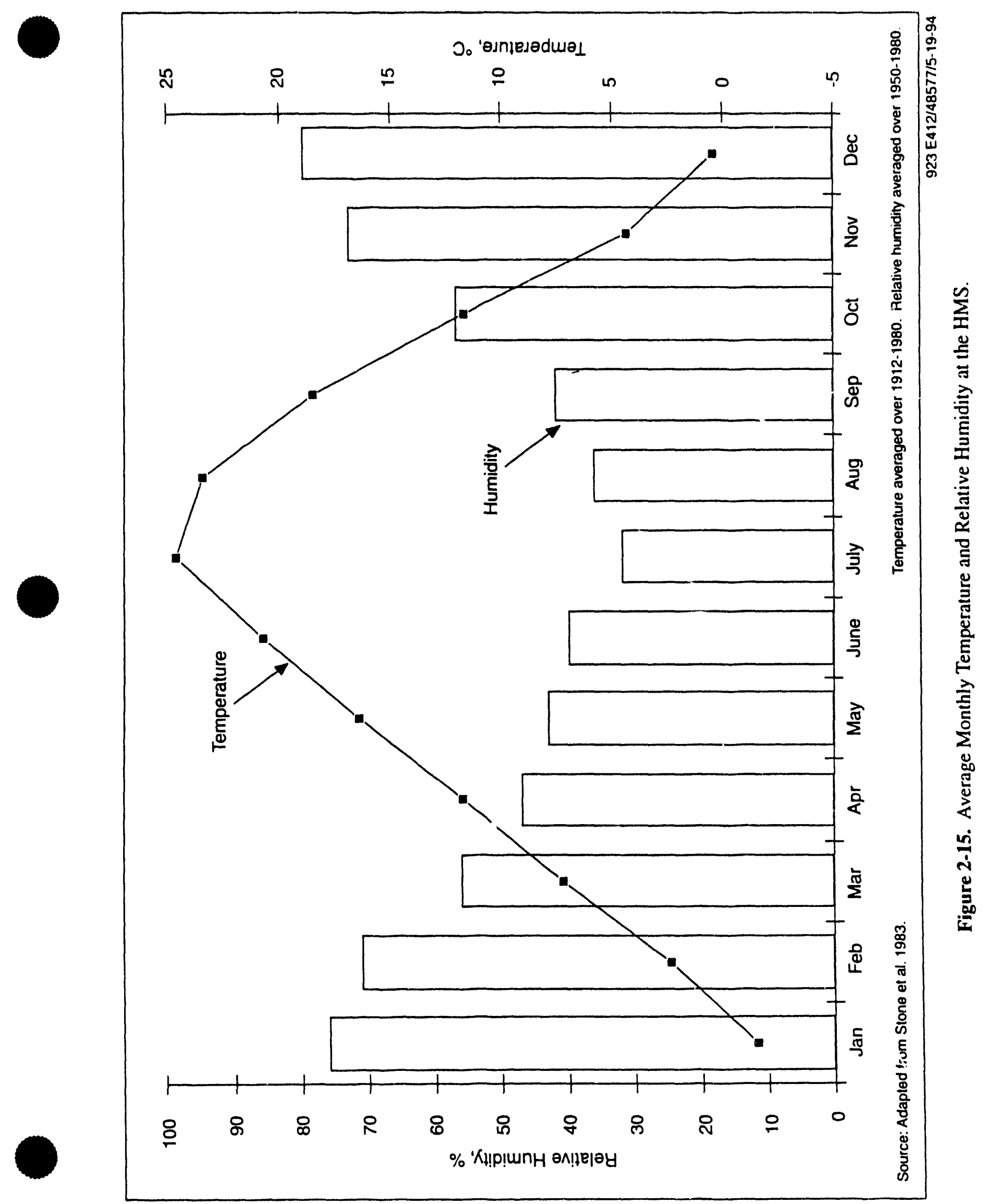



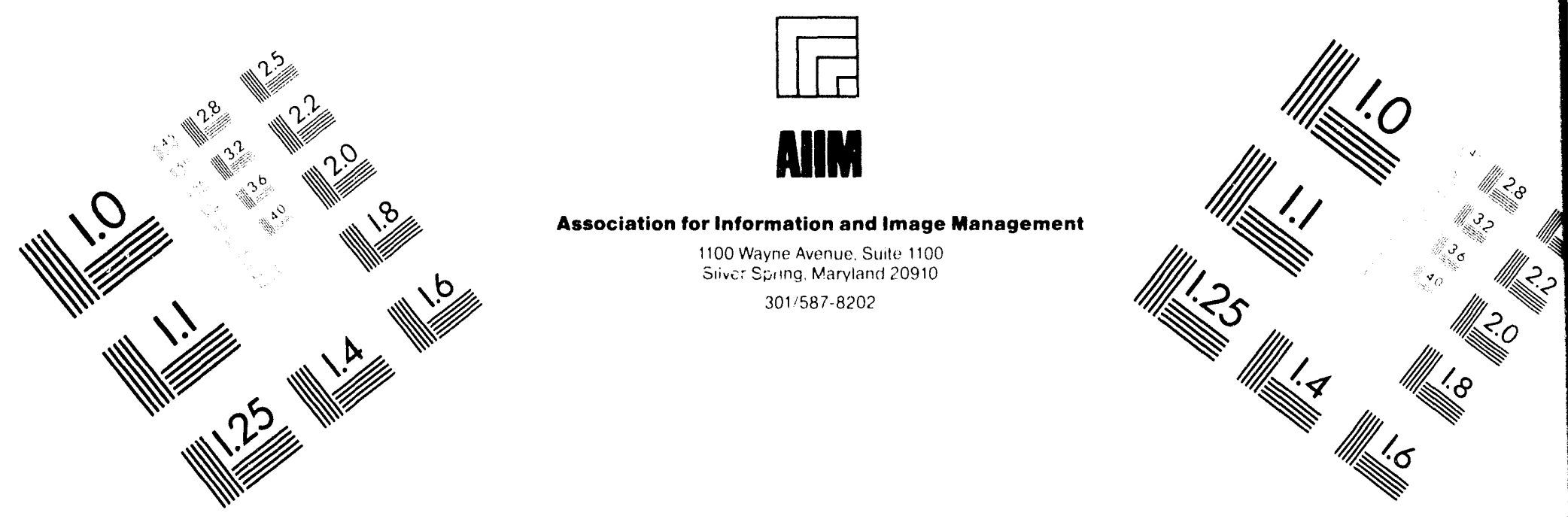

\section{Centimeter}

|

Inches
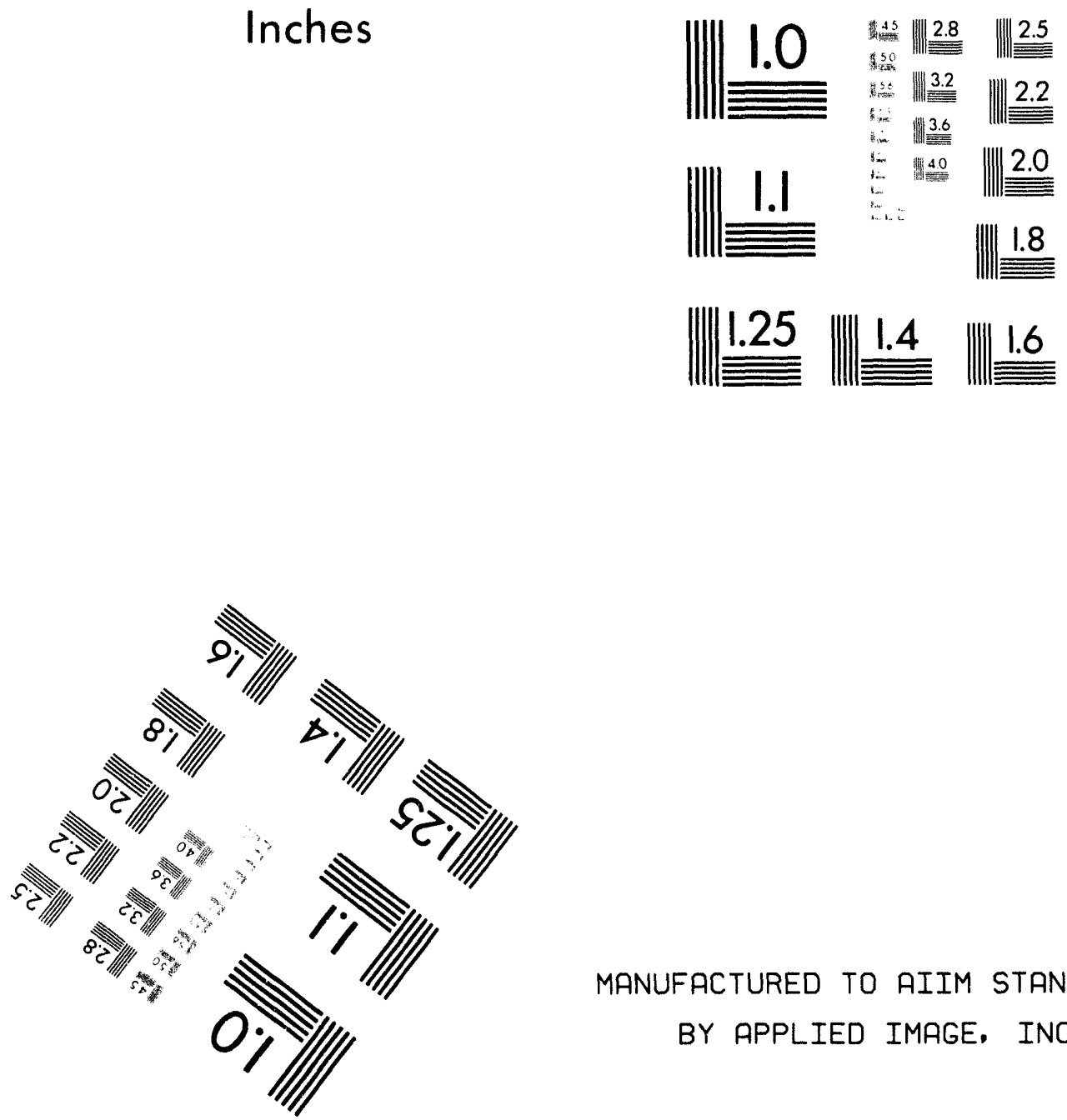

MANUFACTURED TO AIIM STANDARDS

BY APPLIED IMAGE. INC.

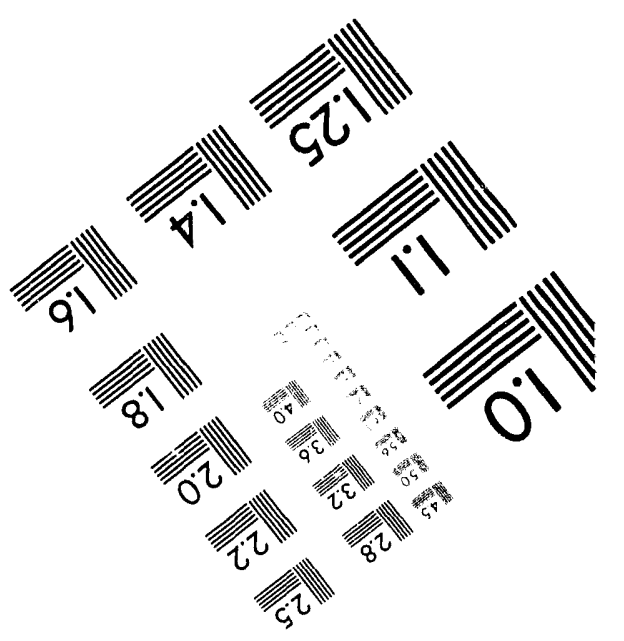



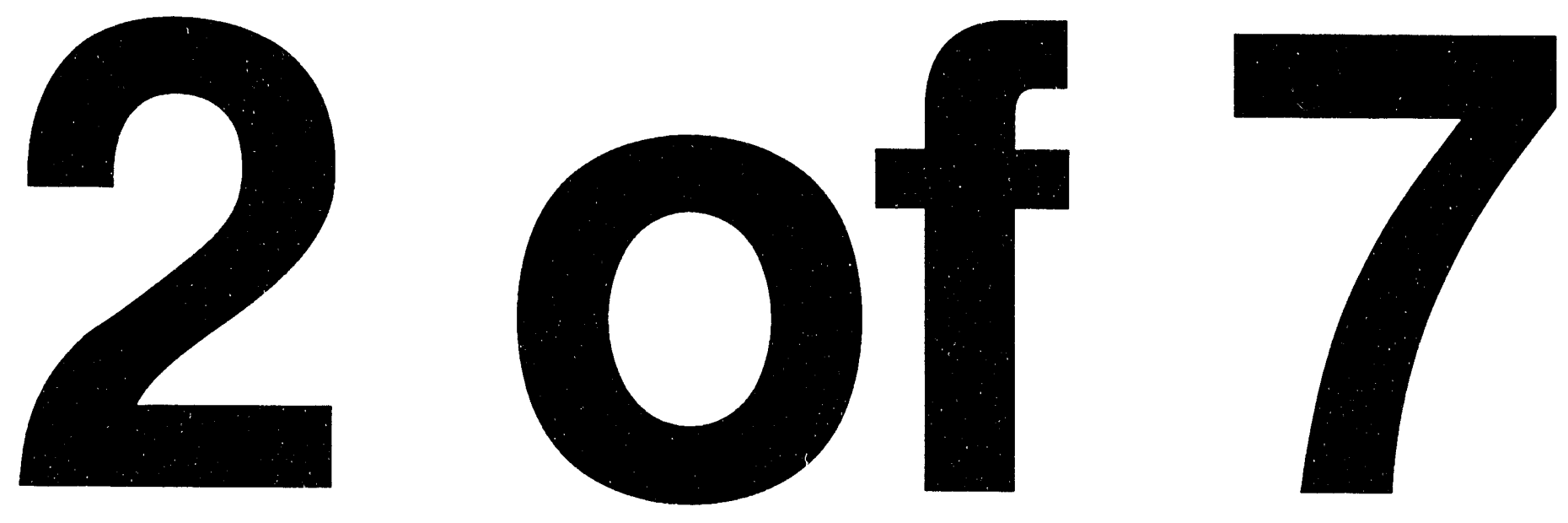


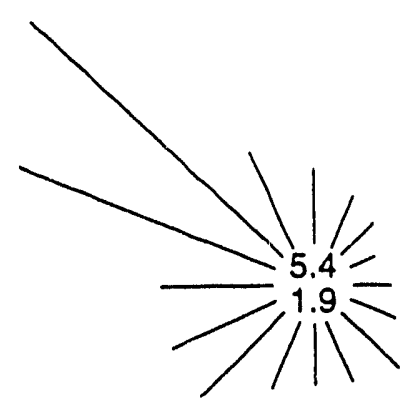

January

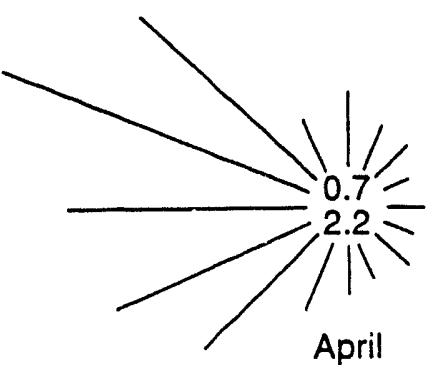

April

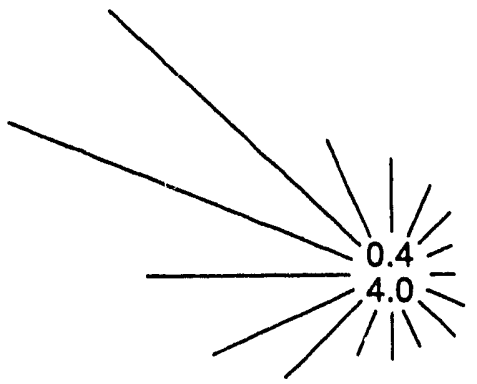

July

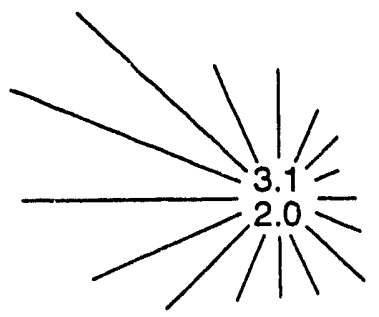

October

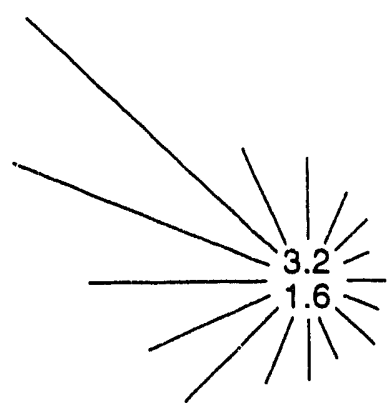

February
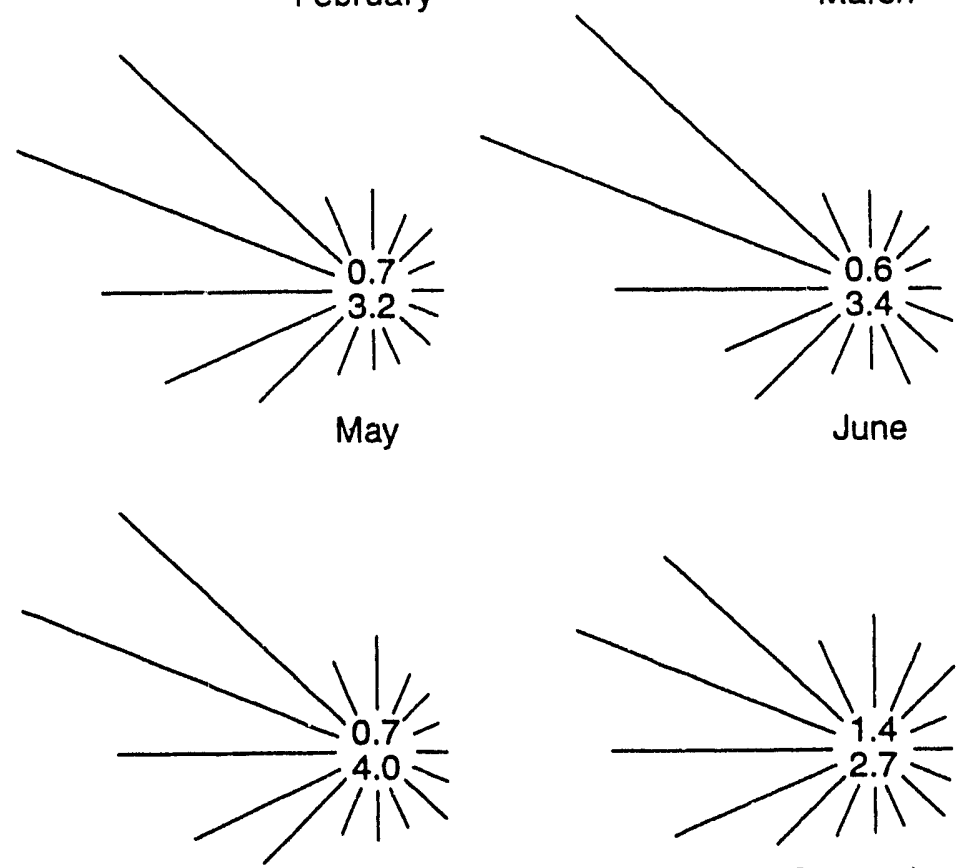

August

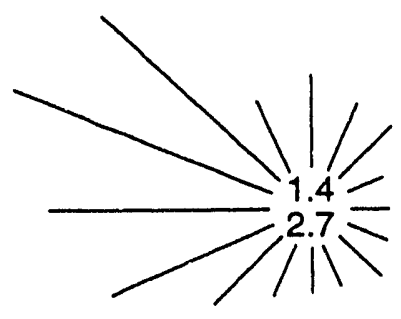

September

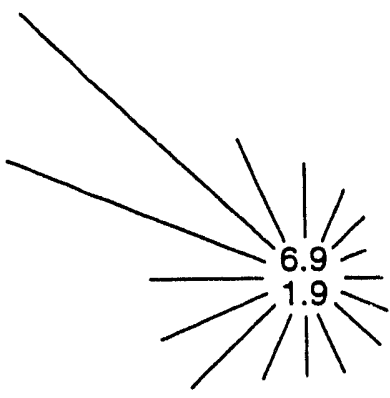

December

The numbers in the centers are the percentages of calm (top numbers) and variable (bottom numbers) winds. The points of the rose represent the directions from which the winds blow.

Source: Stone et al. 1983

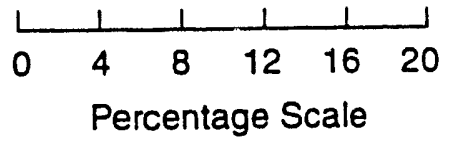

$9231764 / 48578 / 5-19-94$

Figure 2-16. Monthly Wind Roses for HMS Based on 50 foot Wind Data, 1955 through 1980. 


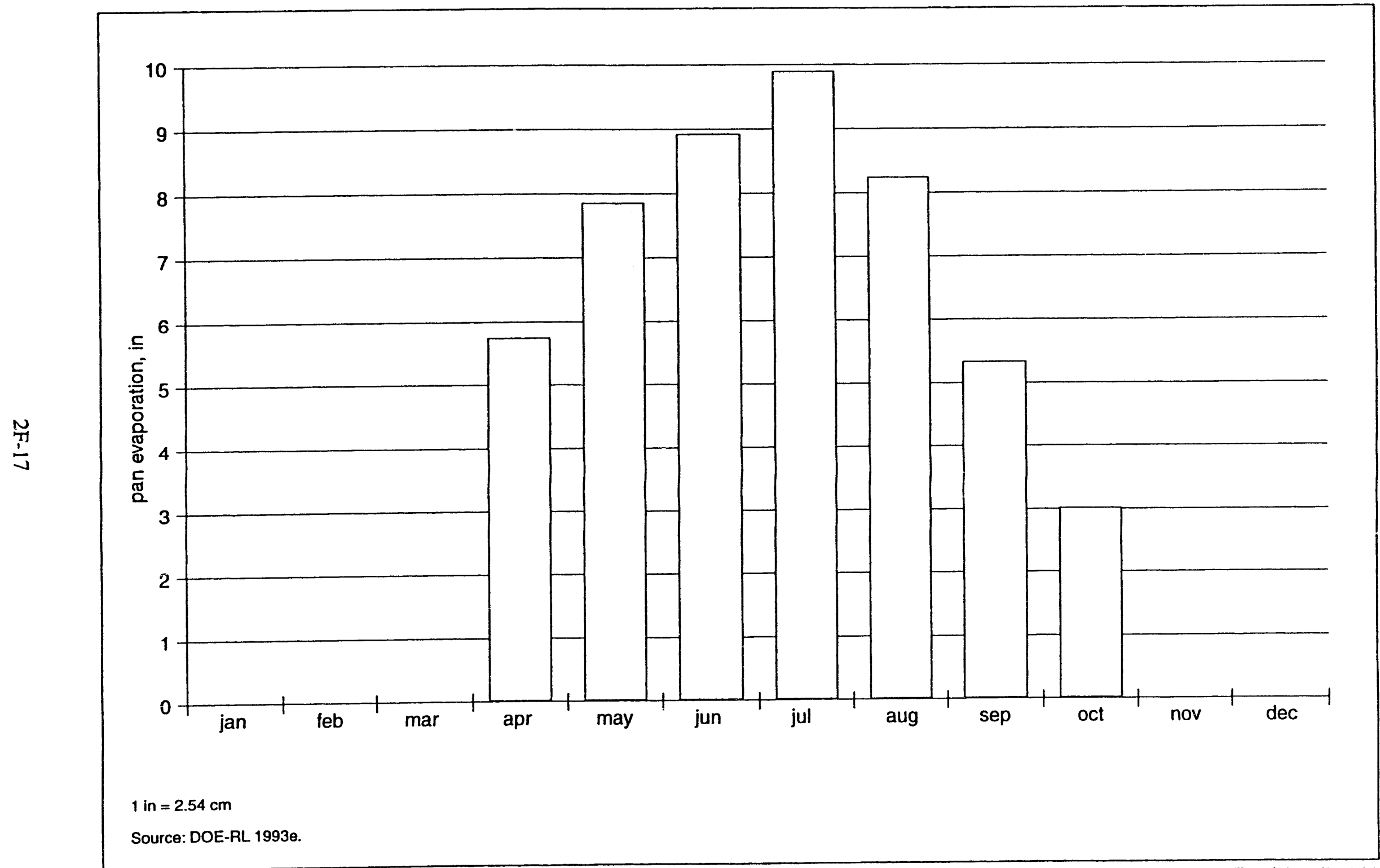

Figure 2-17. Average Monthly Pan Evaporation at Prosser, WA for the

Period 1924-1988. (Measurements not taken for November through March) 
DOE/RL-93-99, Rev. 0

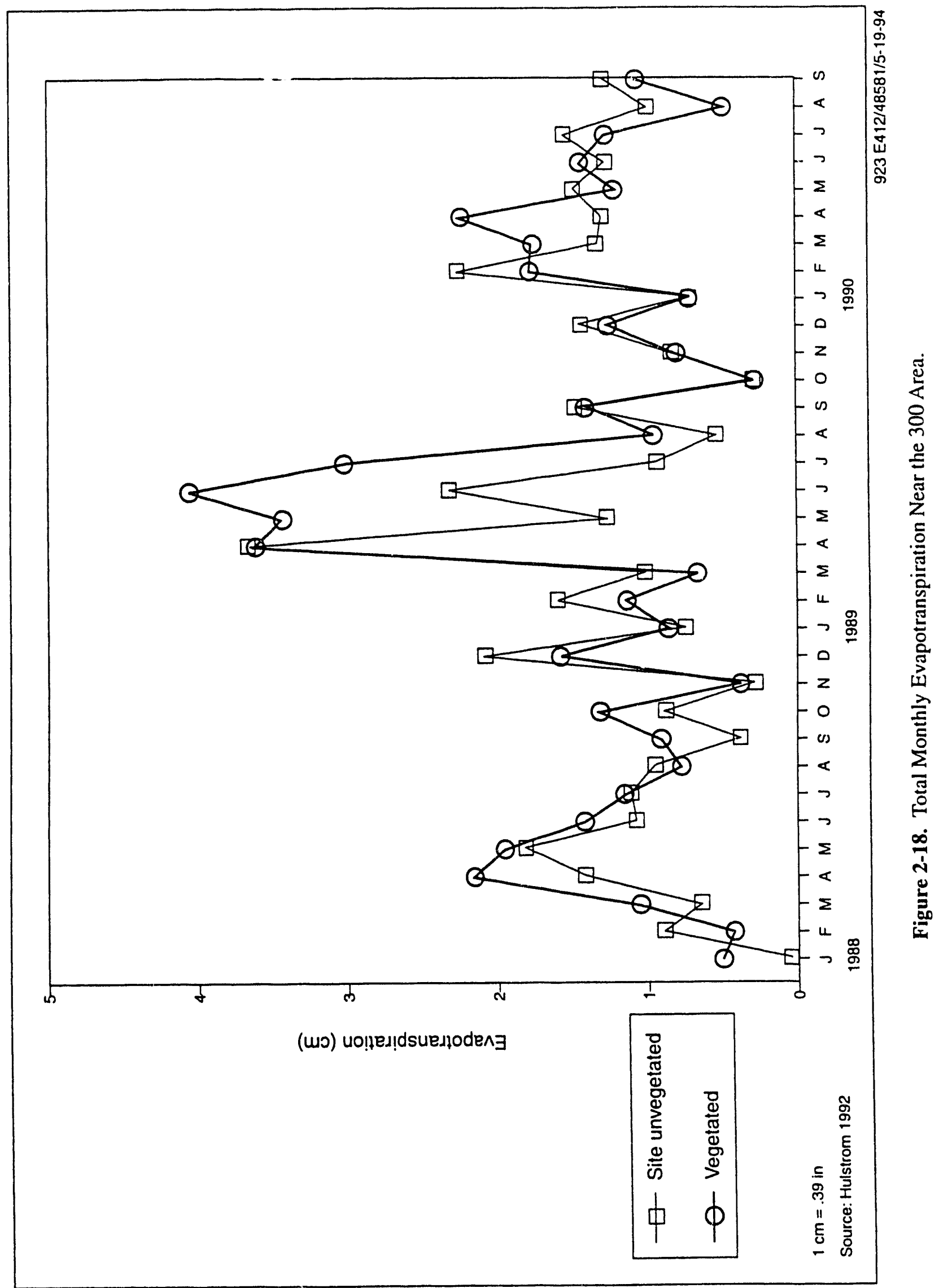




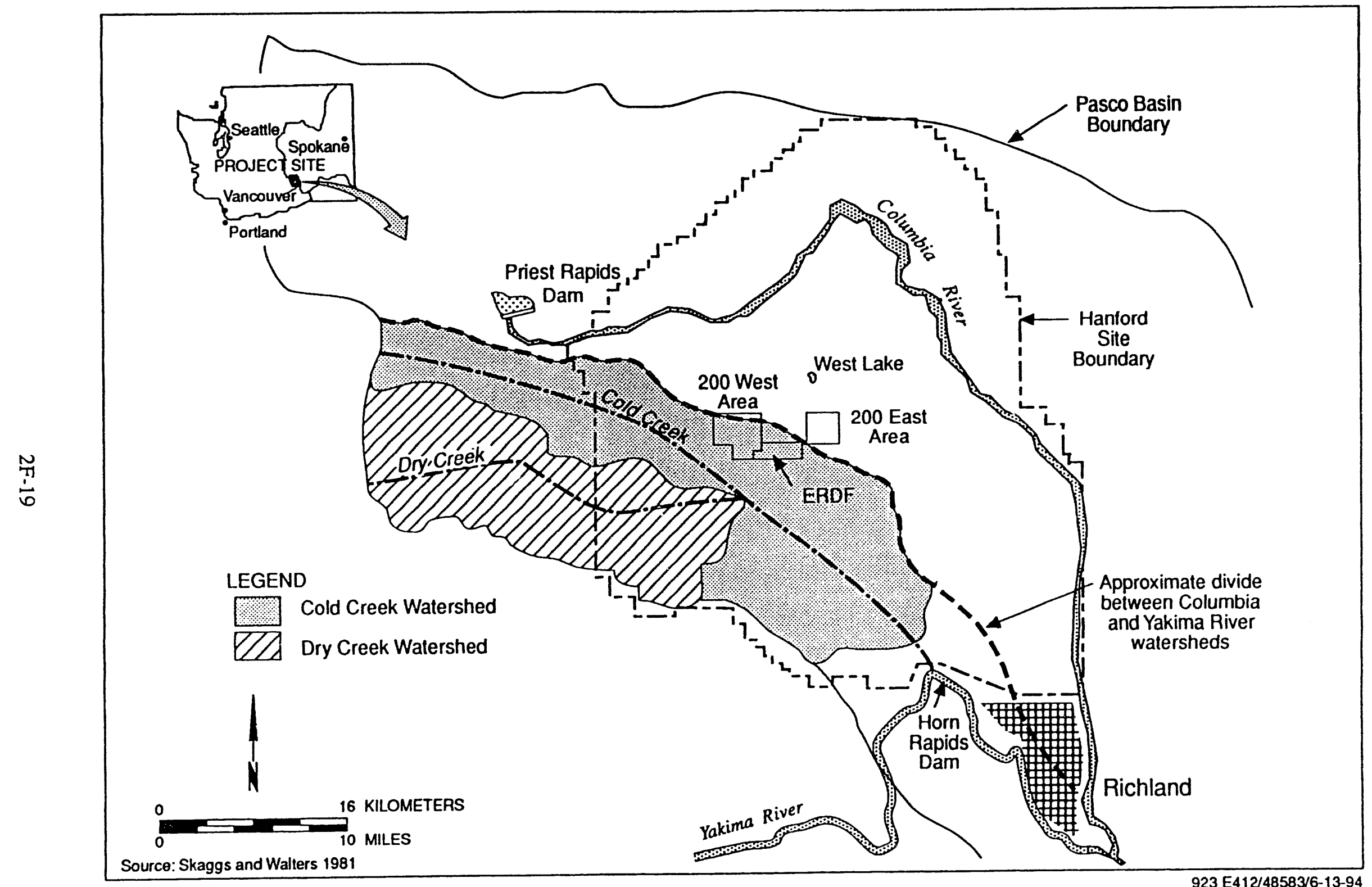

Figure 2-19. Approximate Location of Major Drainage Divides. 


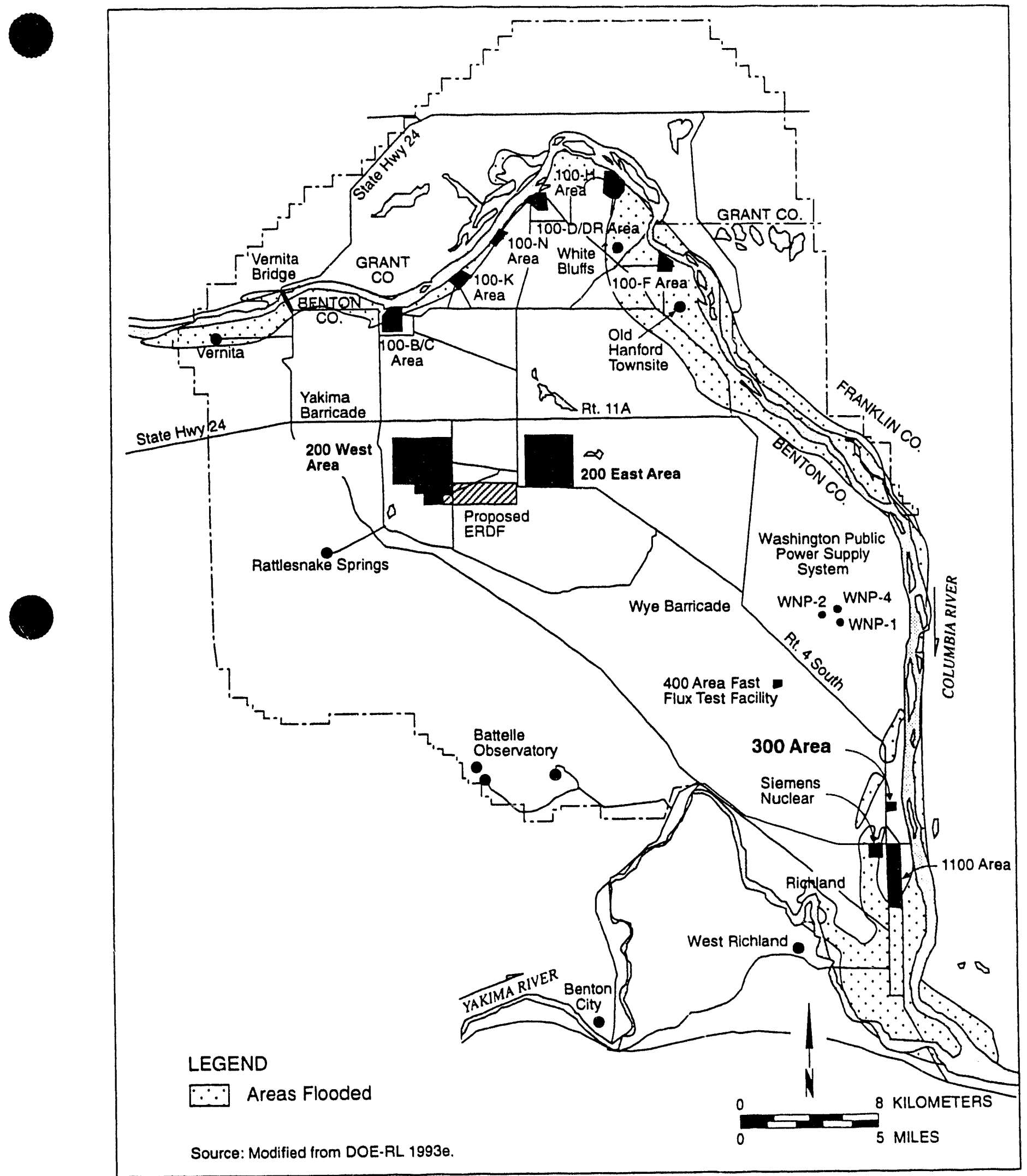

$923 E 412 / 48586 / 6 \cdot 15-94$

Figure 2-20. Probable Maximum Flood Areas on the Columbia River. 


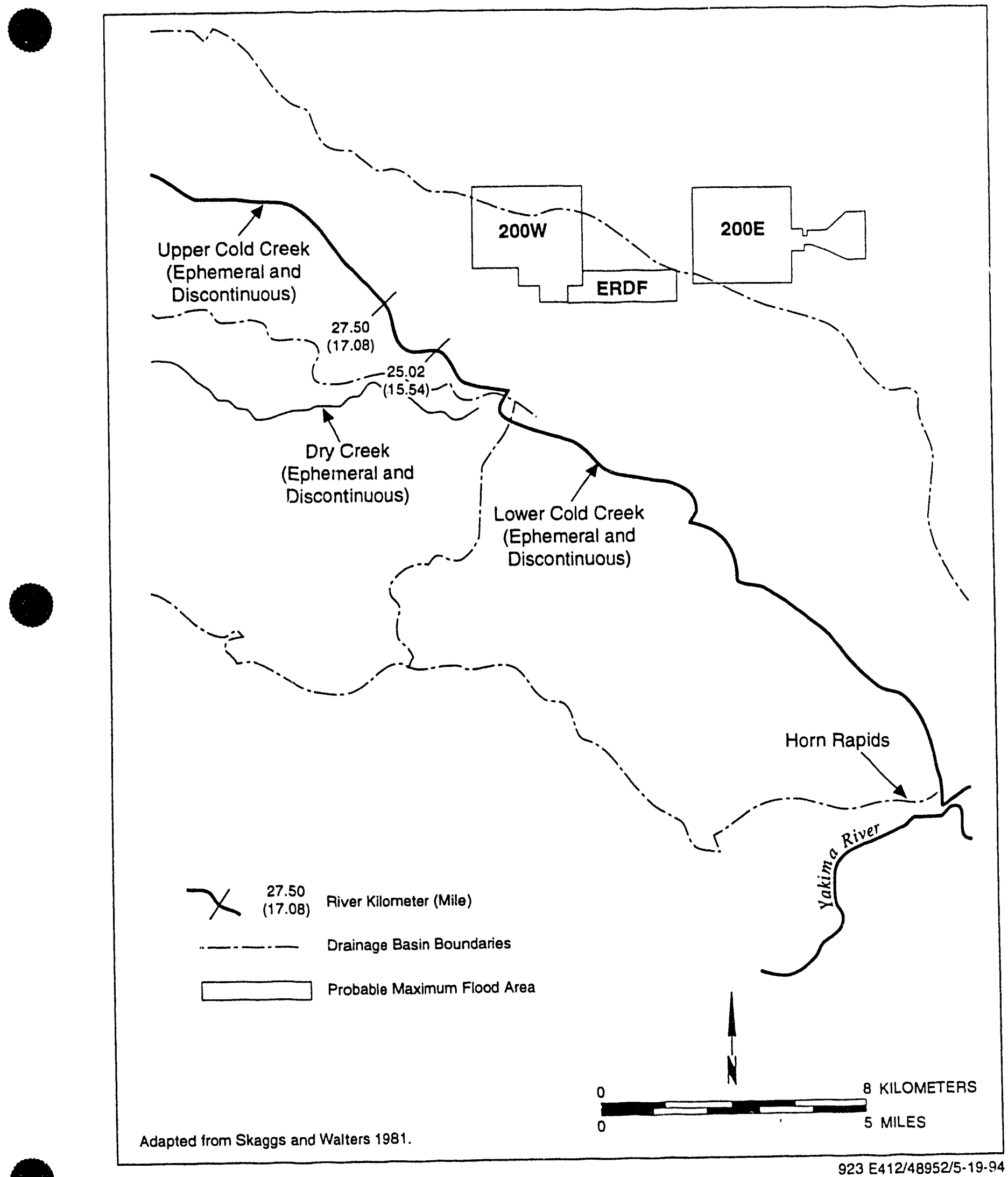

Figure 2-21. Extent of Probable Maximum Flood in Cold Creek Area. 


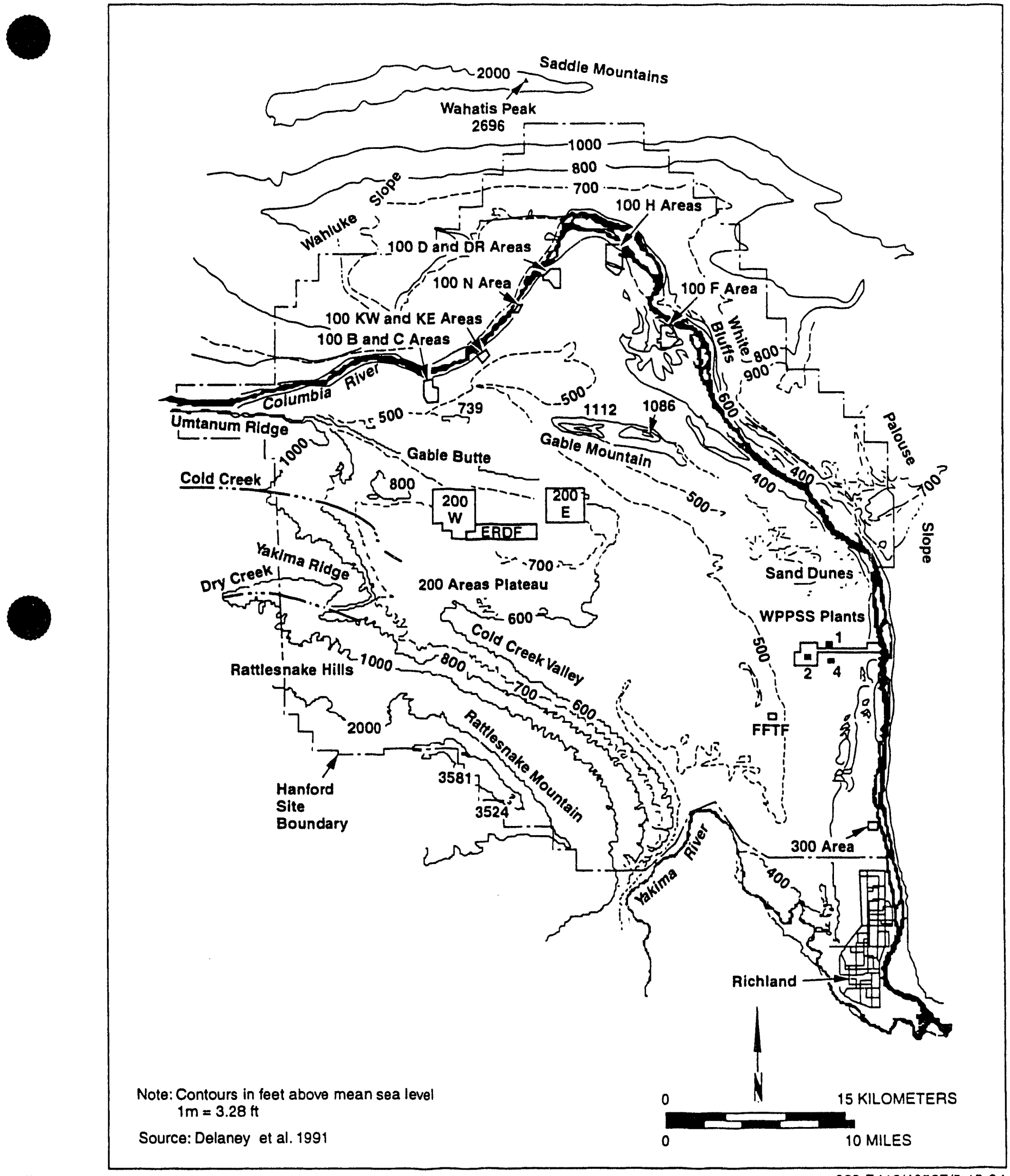

$923 E 412 / 48587 / 5 \cdot 19 \cdot 94$

Figure 2-22. Topography of the Hanford Site. 


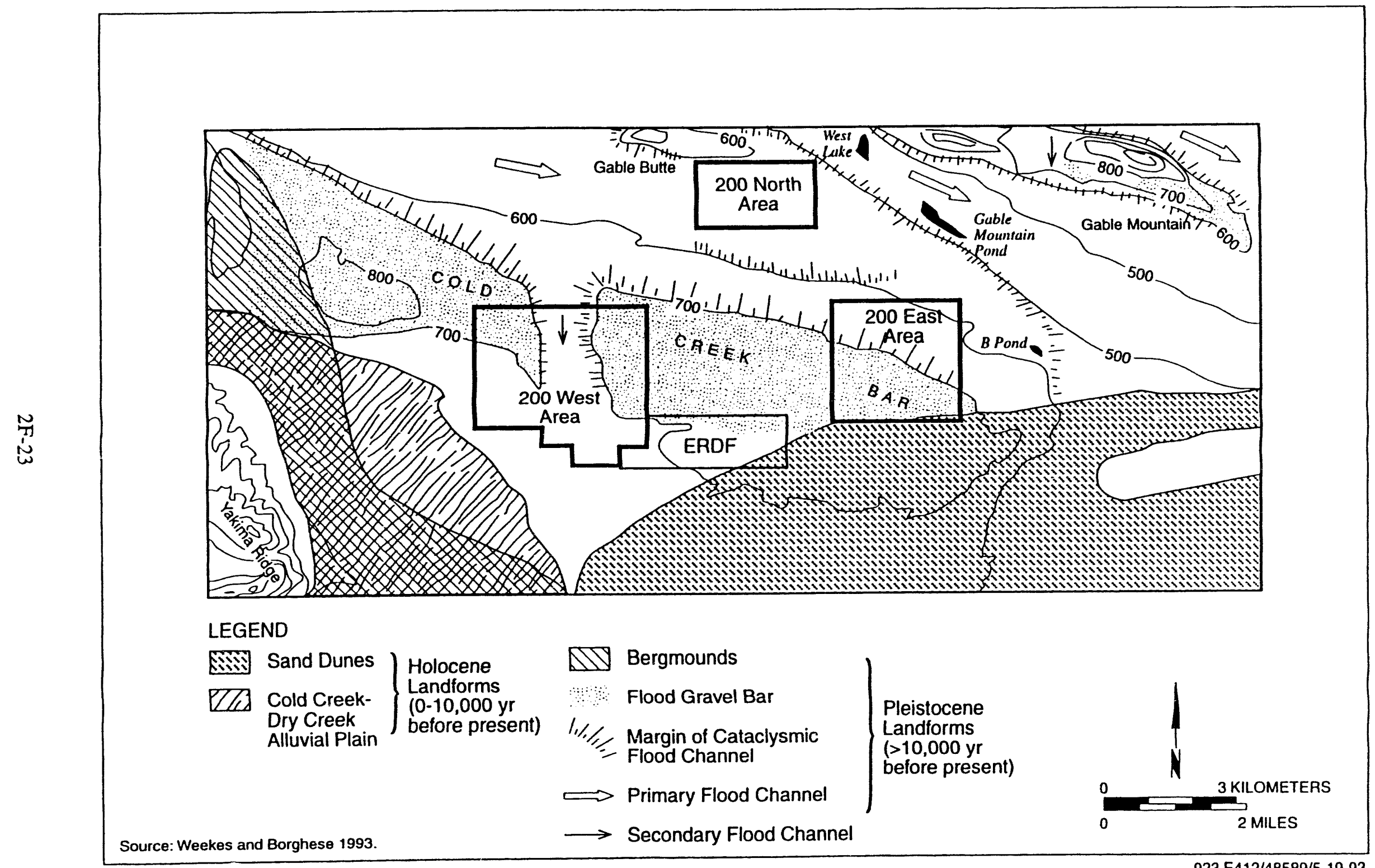

Figure 2-23. General Topography and Geomorphic Features in the West-Central Portion of the Hanford Site. 


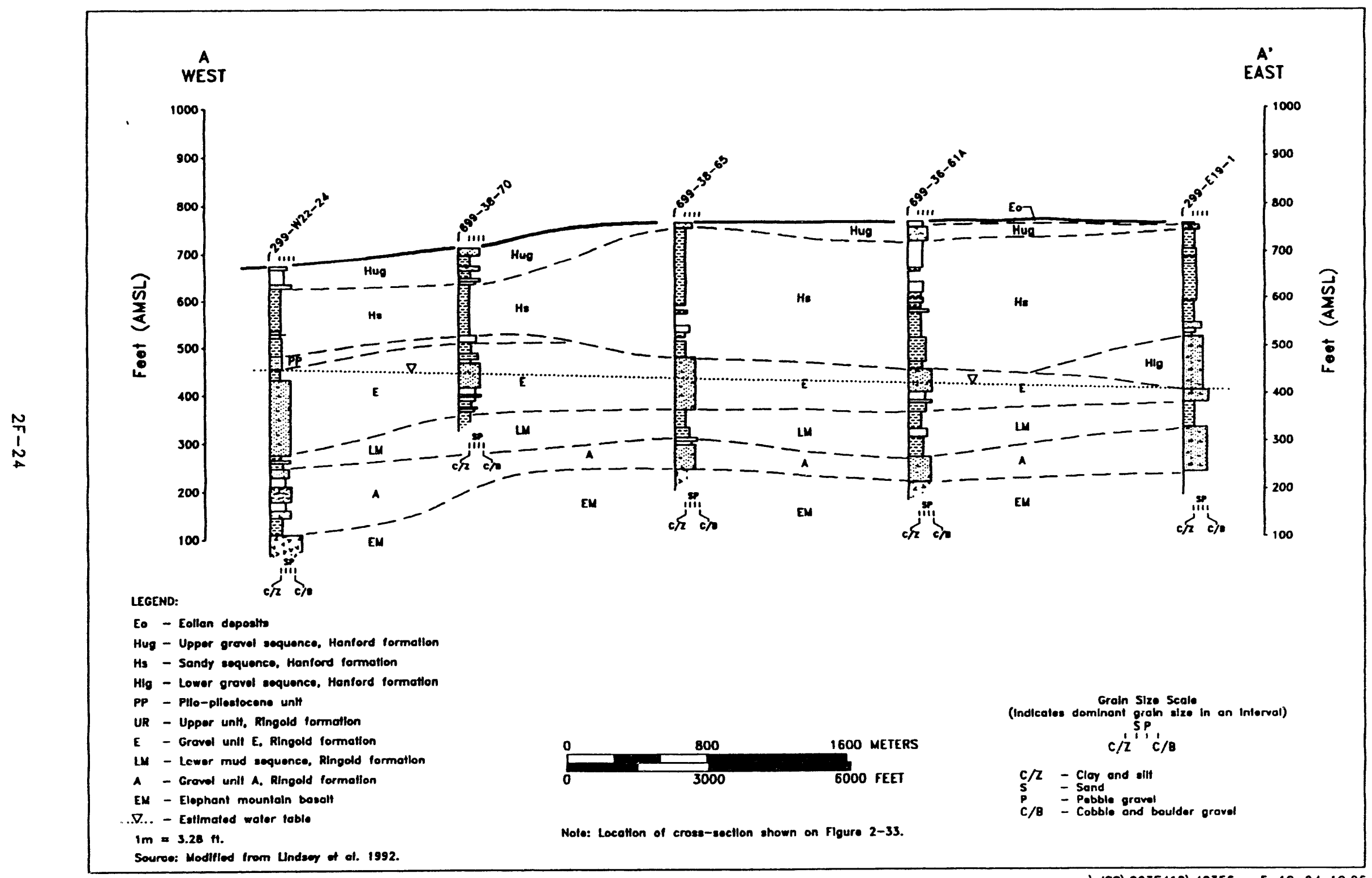

Figure 2-24. A-A' Cross Section at the ERDF Site. 


\section{•}

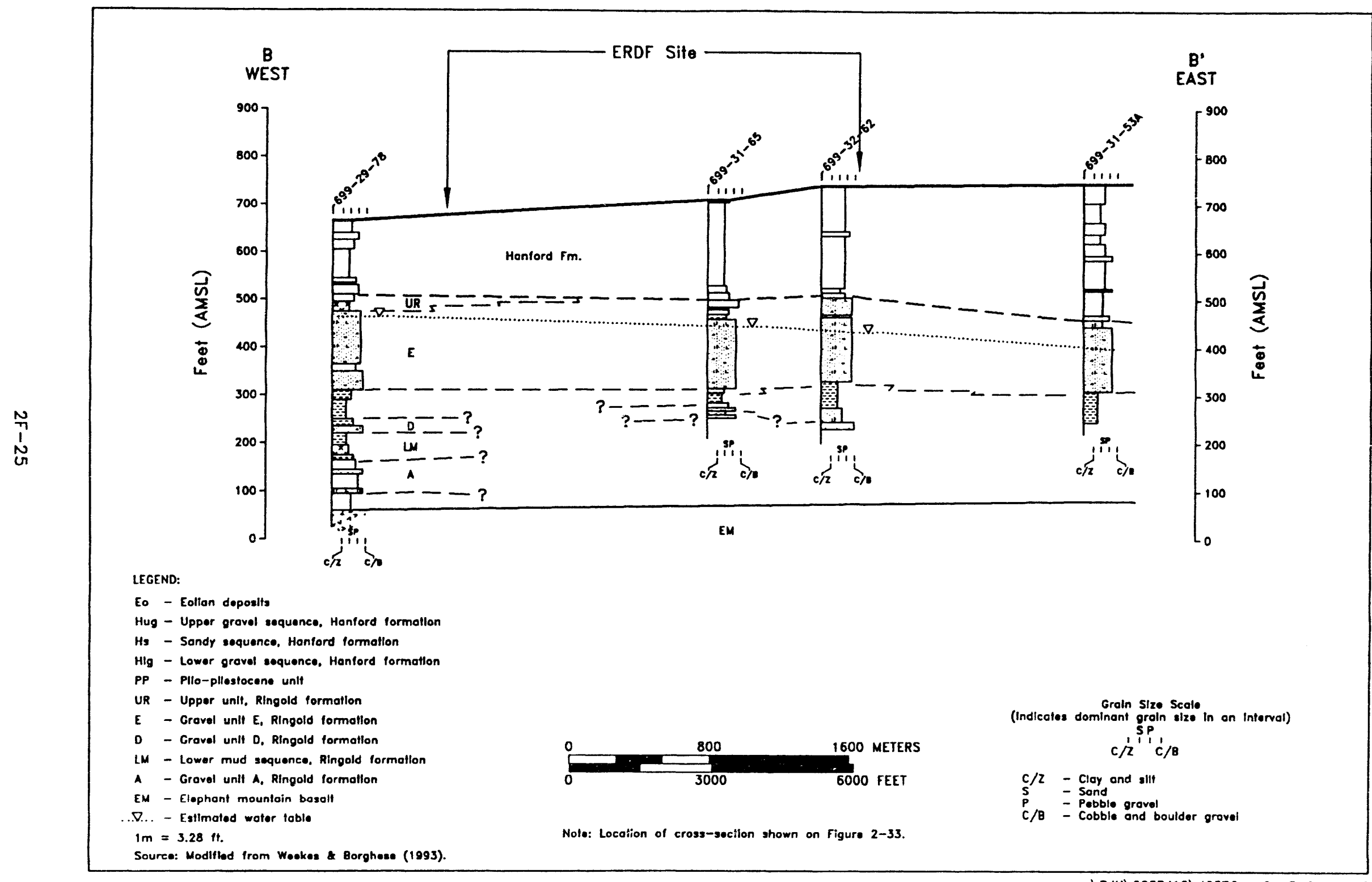

Figure 2-25. B-B' Cross Section at the ERDF Site. 

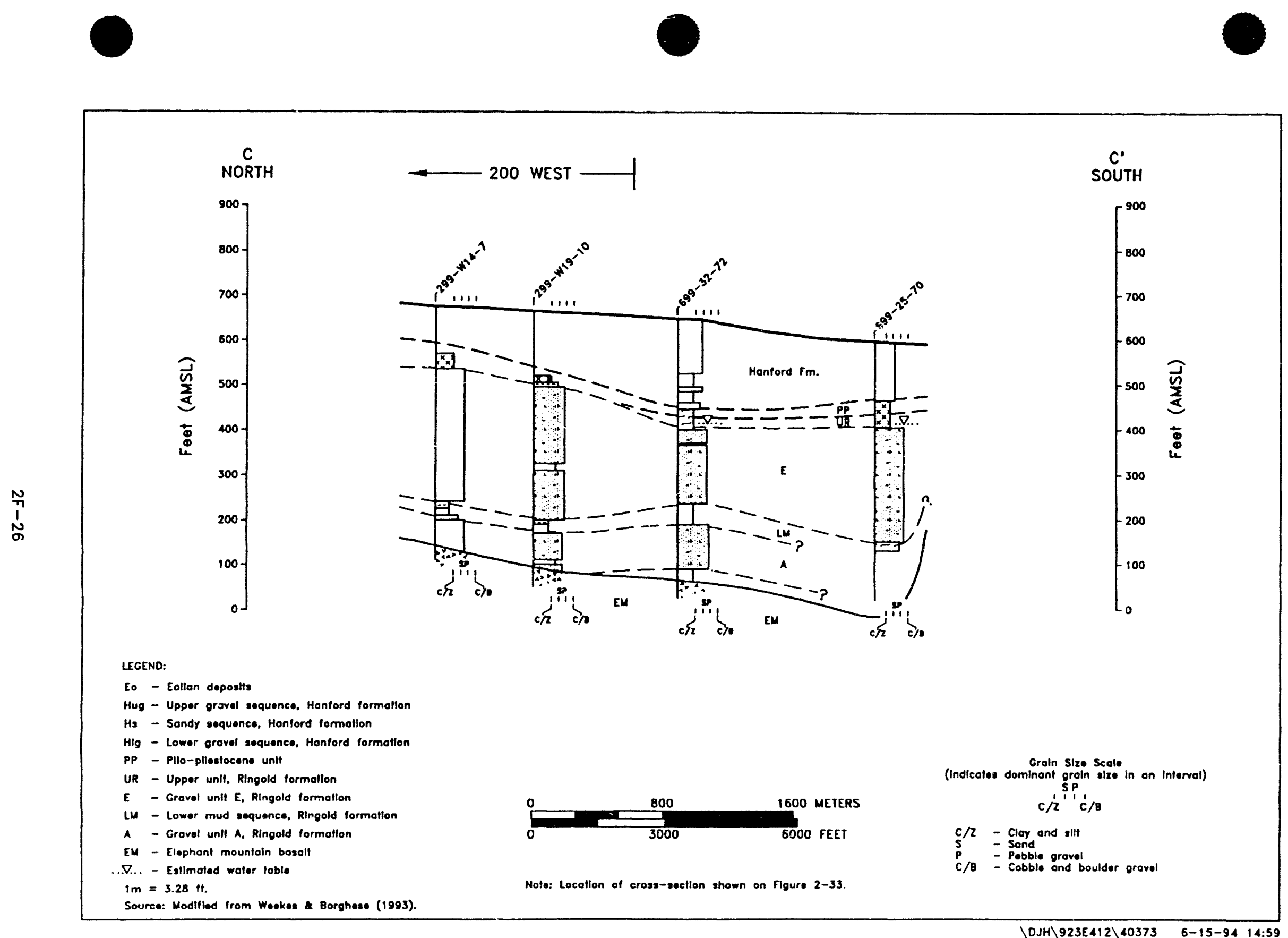

Figure 2-26. C-C' Cross Section at the ERDF Site. 


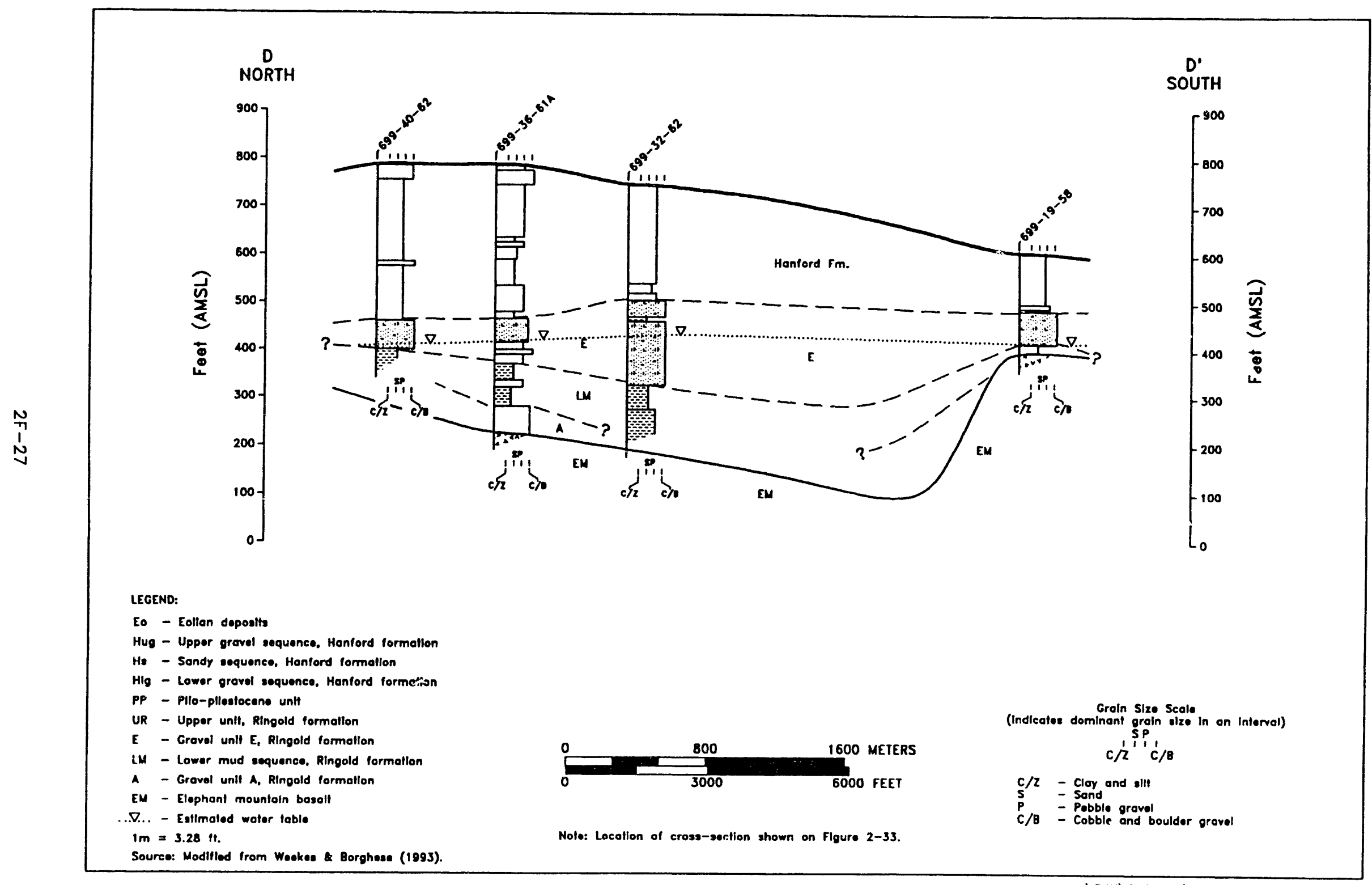

Figure 2-27. D-D' Cross Section at the CRDF Site. 


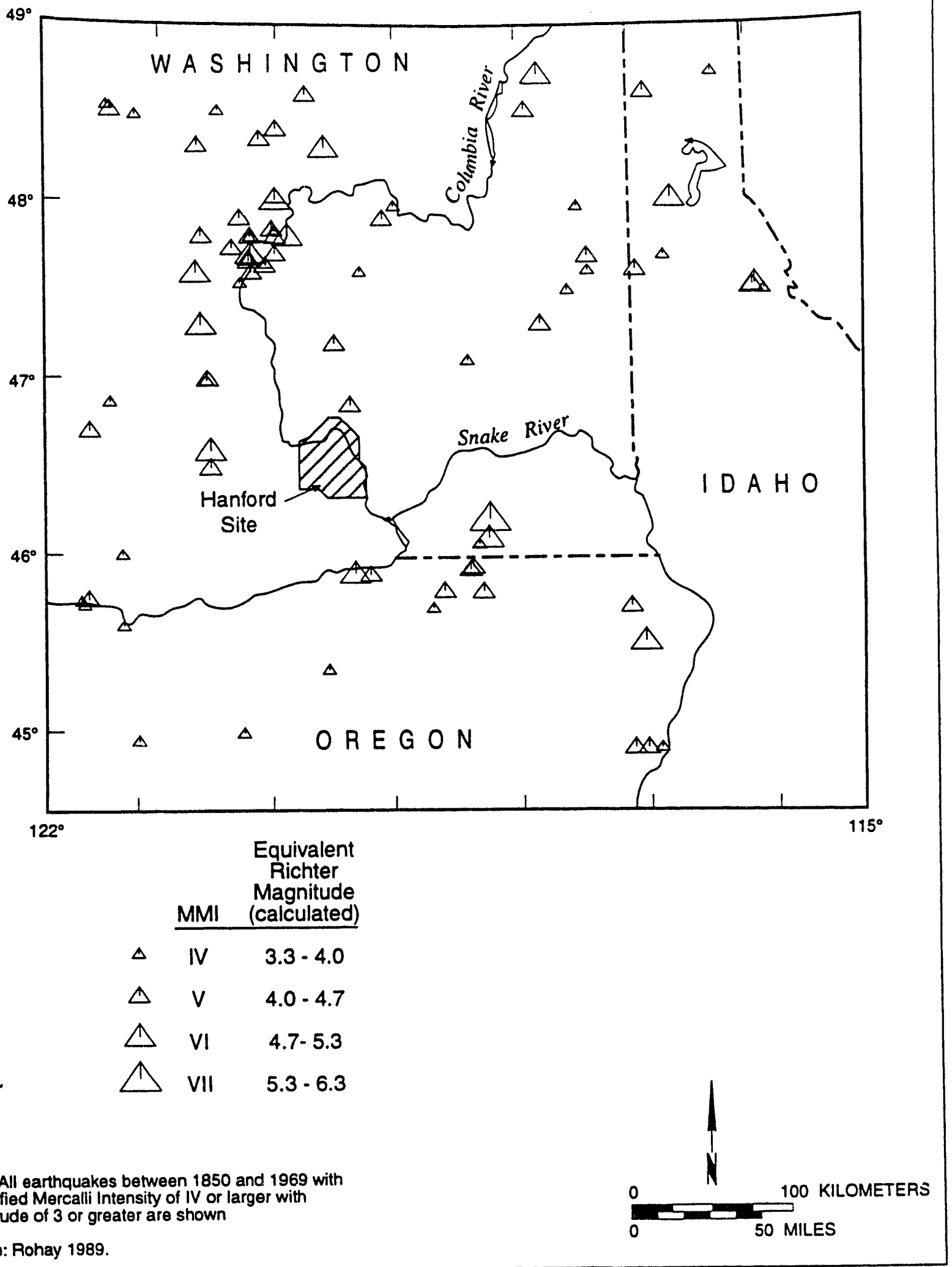

923 E412/48590/5-19-94

Figure 2-28. Historical Seismicity of the Columbia Plateau and Surrounding Areas. 
DOE/RL-93-99, Rev. 0

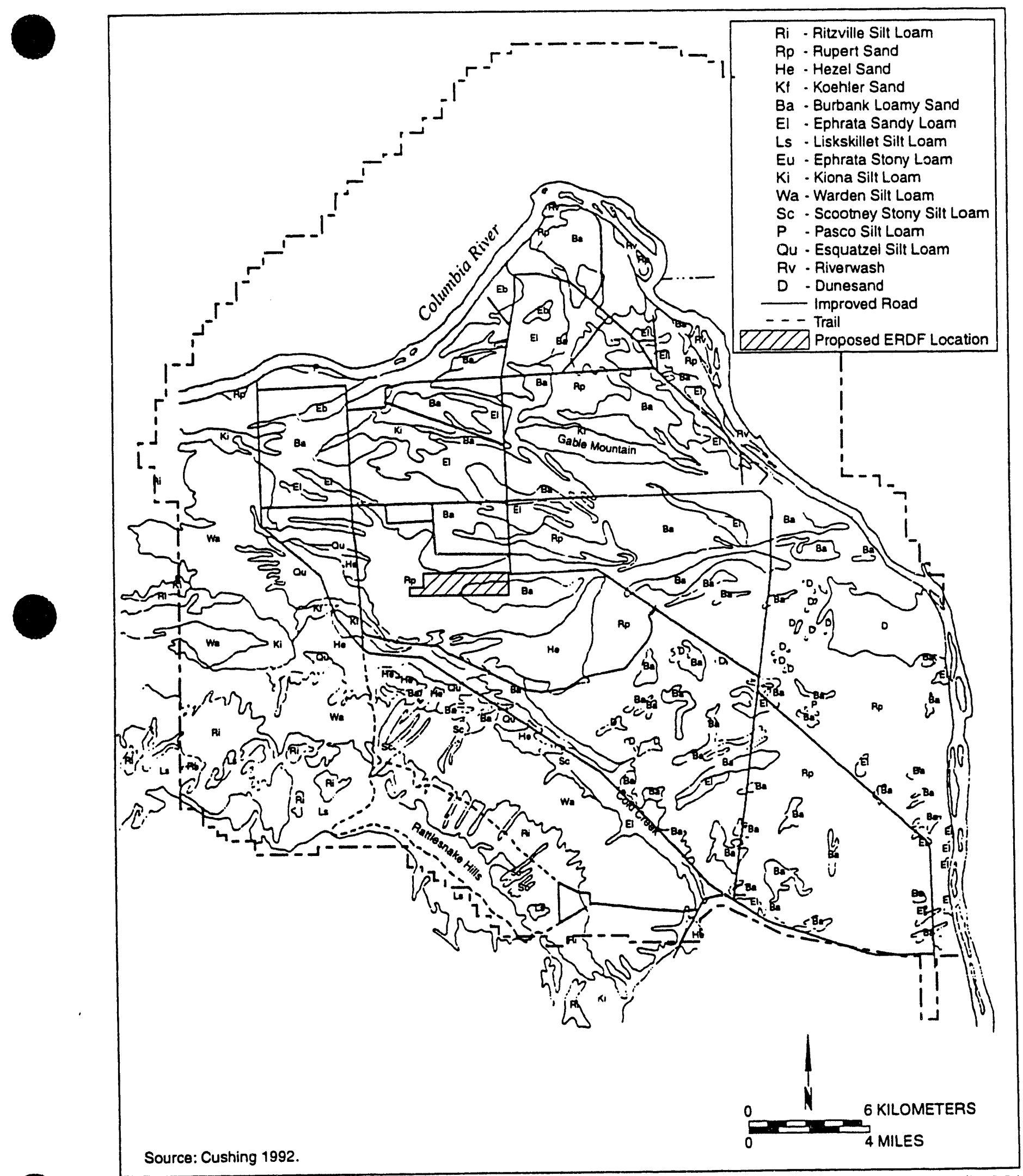

923 E412/48592/5-19-94

Figure 2-29. Soil Map of the Hanford Site. 


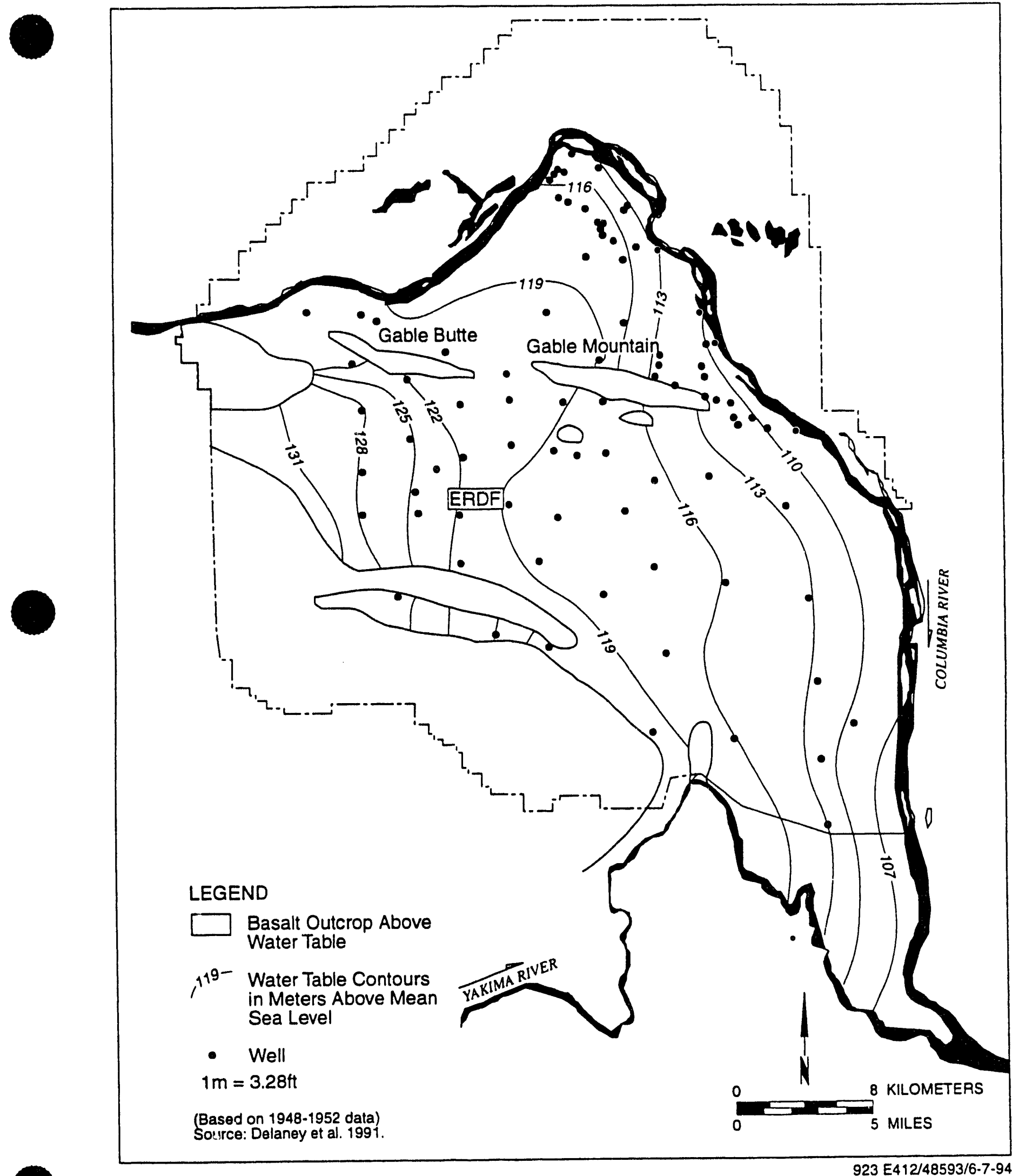

Figure 2-30. Hanford Site Water Table Map, January 1944. 


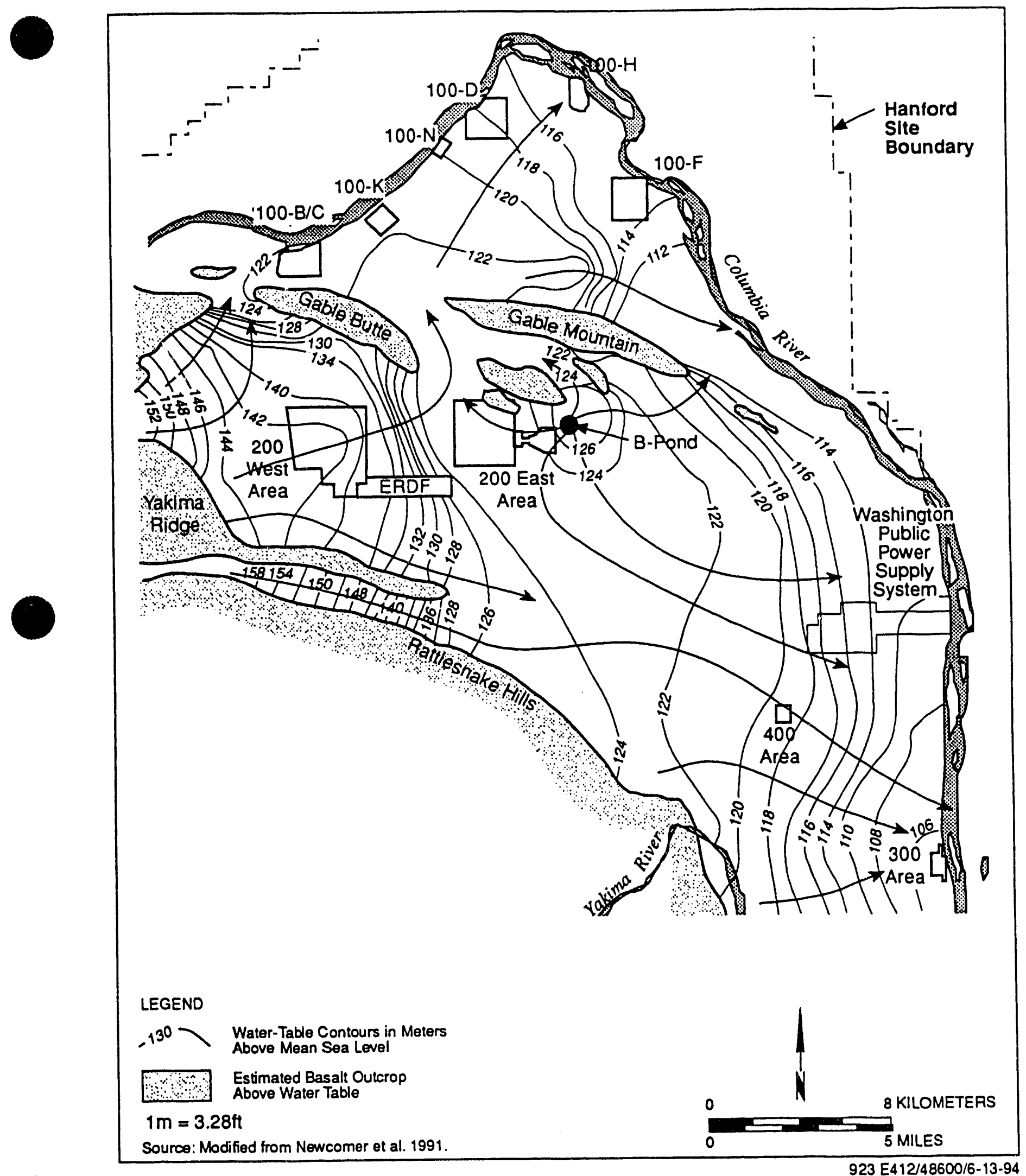

Figure 2-31. Hanford Site Water Table Map, June - August 1990. 


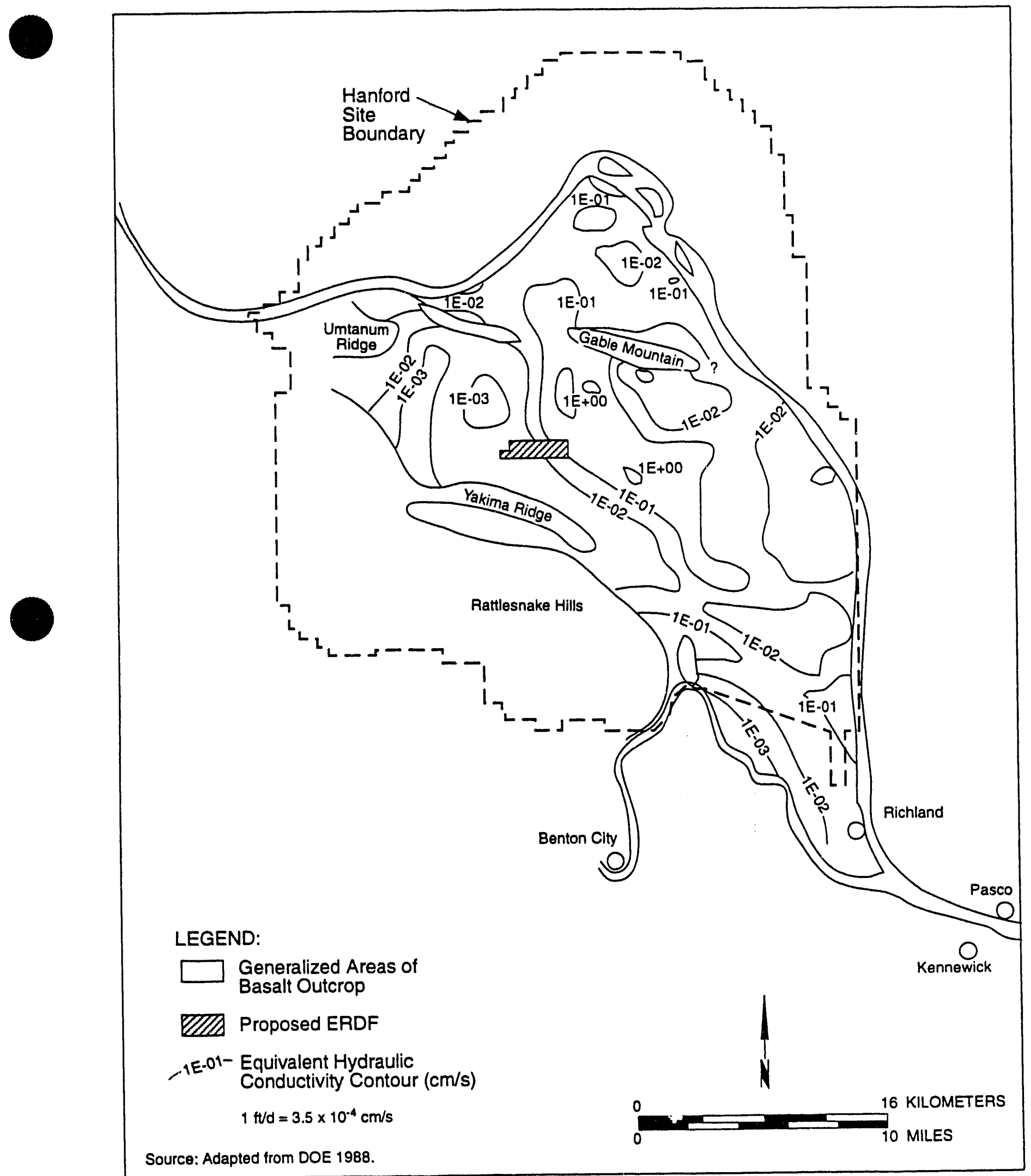

Figure 2-32. Areal Distribution of Hydraulic Conductivity for the Unconfined Aquifer. 


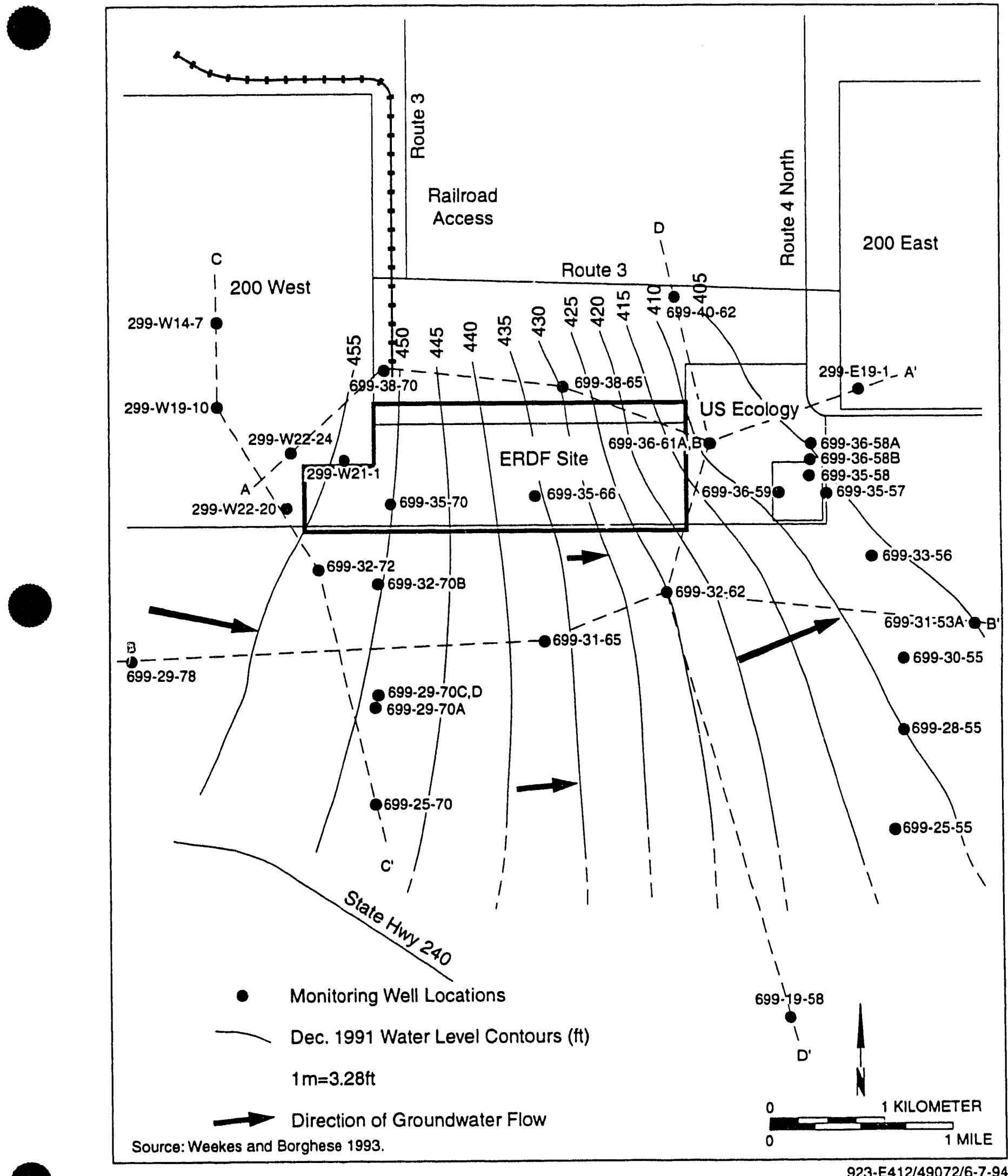

Figure 2-33. Water Table Elevations at the ERDF. 

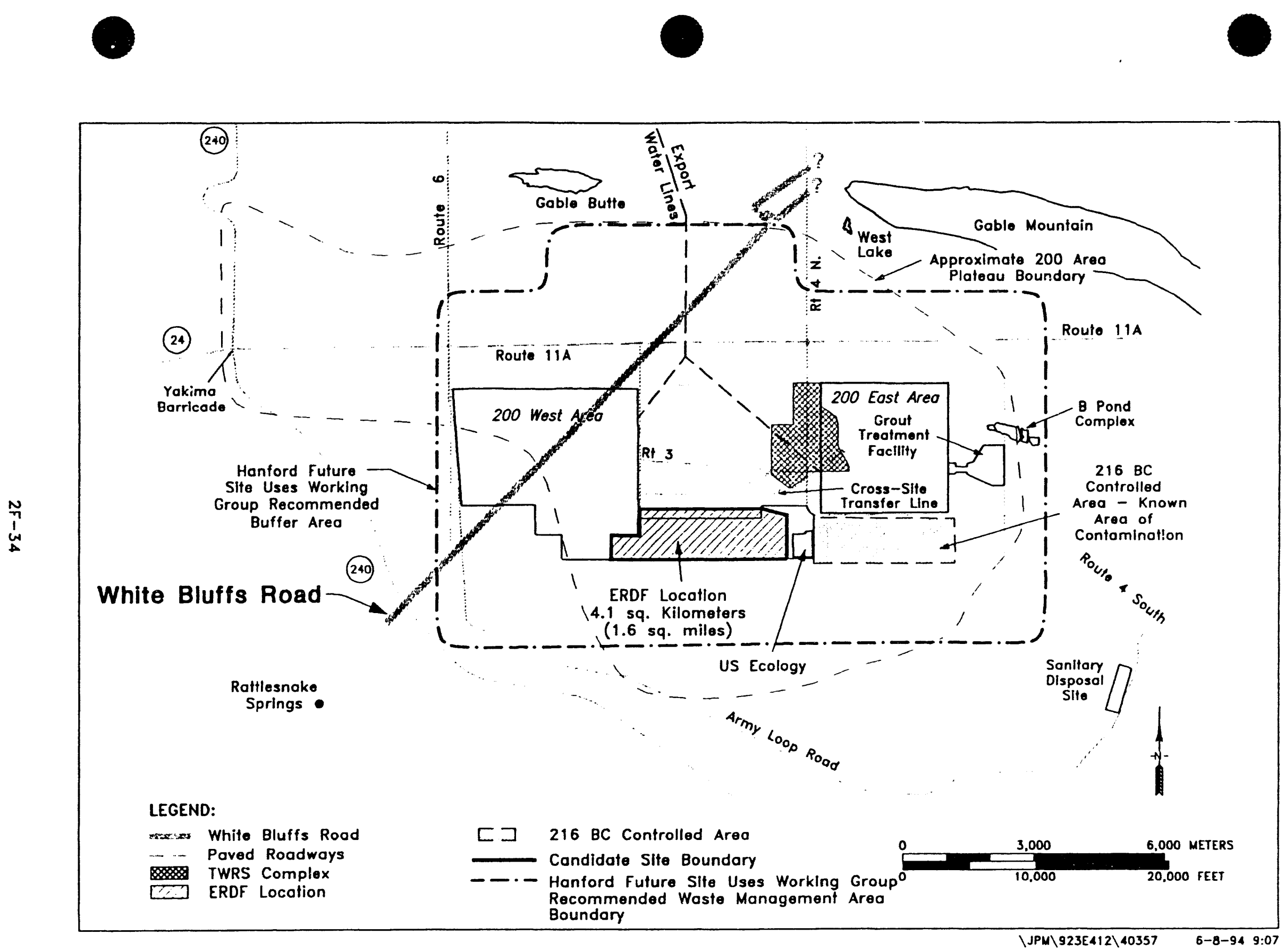

Figure 2-34. Approximate Location of the White Bluffs Road on the 200 Area Plateau 


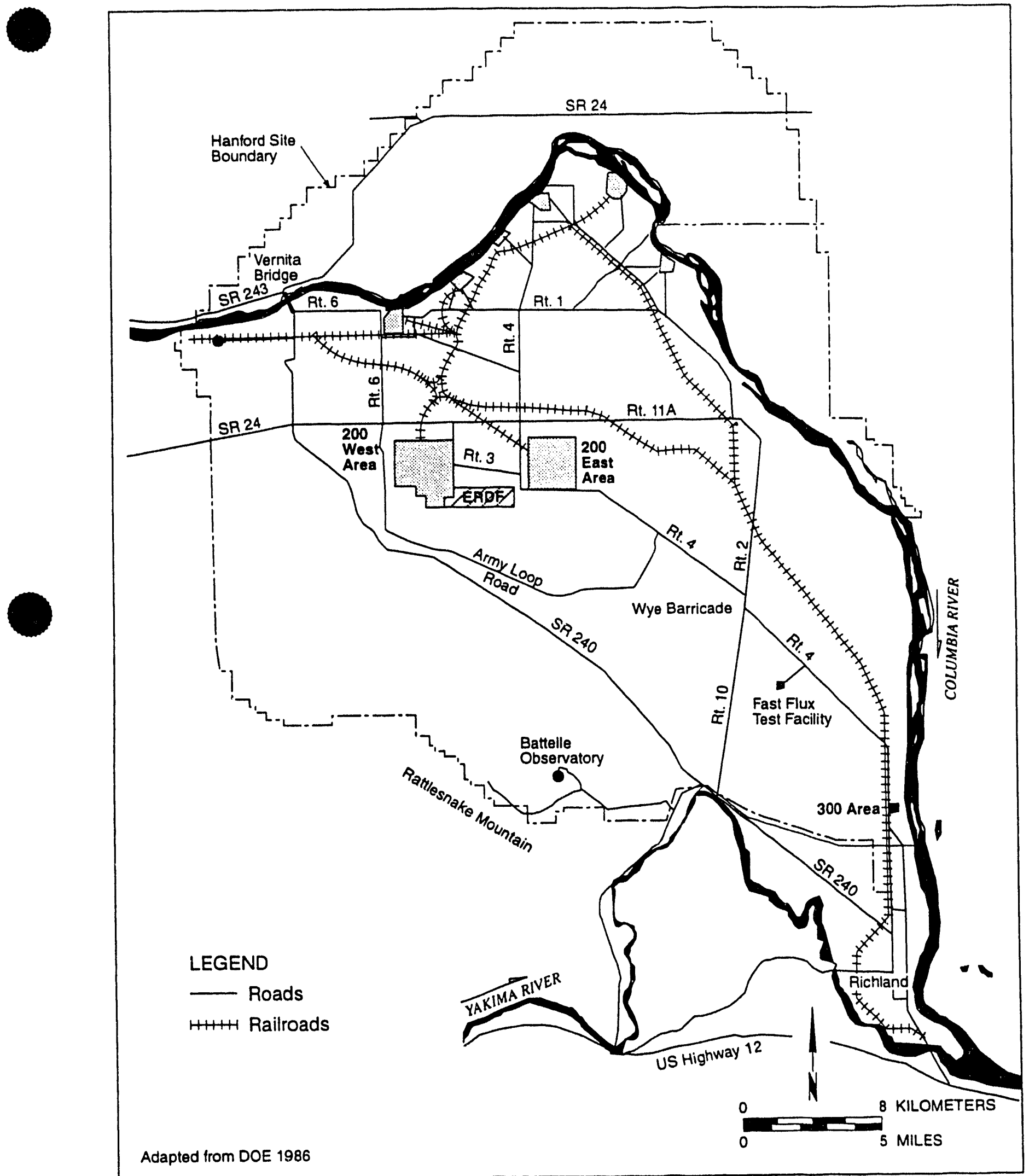

923 E412/48492/5-19-94

Figure 2-35. Existing Transportation Network Within the Hanford Site. 

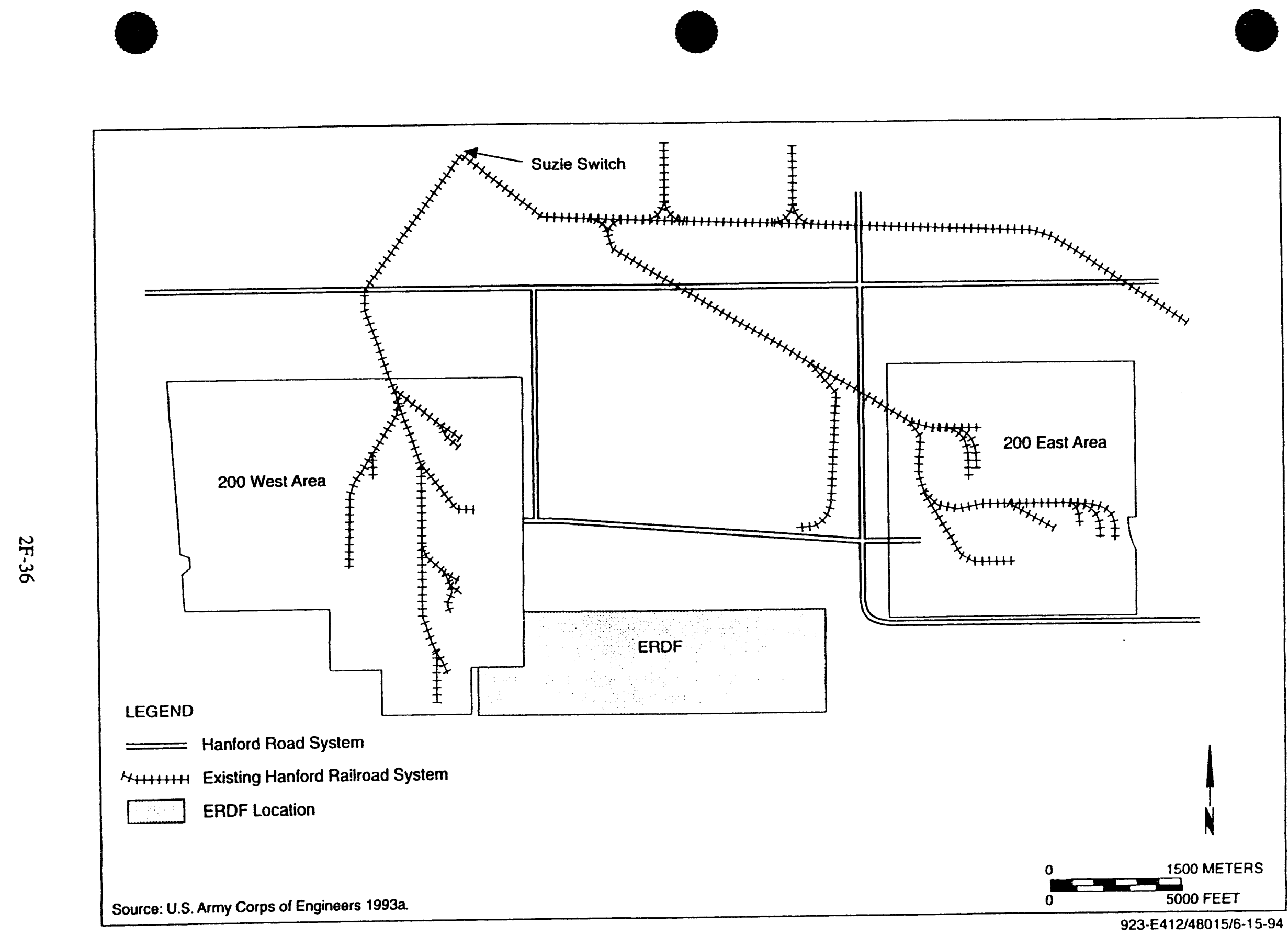

Figure 2-36. Existing Transportation Network Near ERDF. 


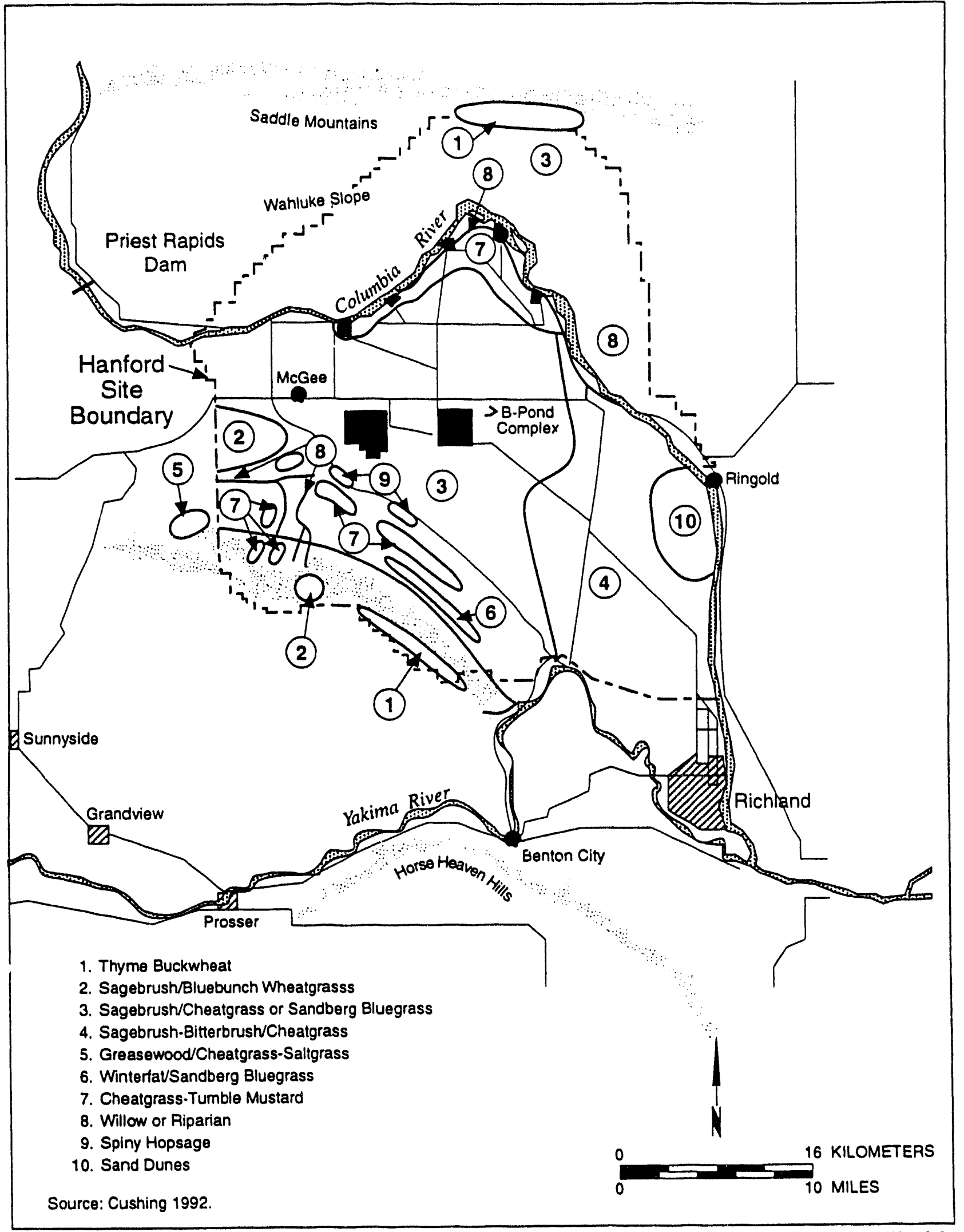

$923 E 412 / 48594 / 5 \cdot 19 \cdot 94$

Figure 2-37. Distribution of Vegetation Types on the Hanford Site. 


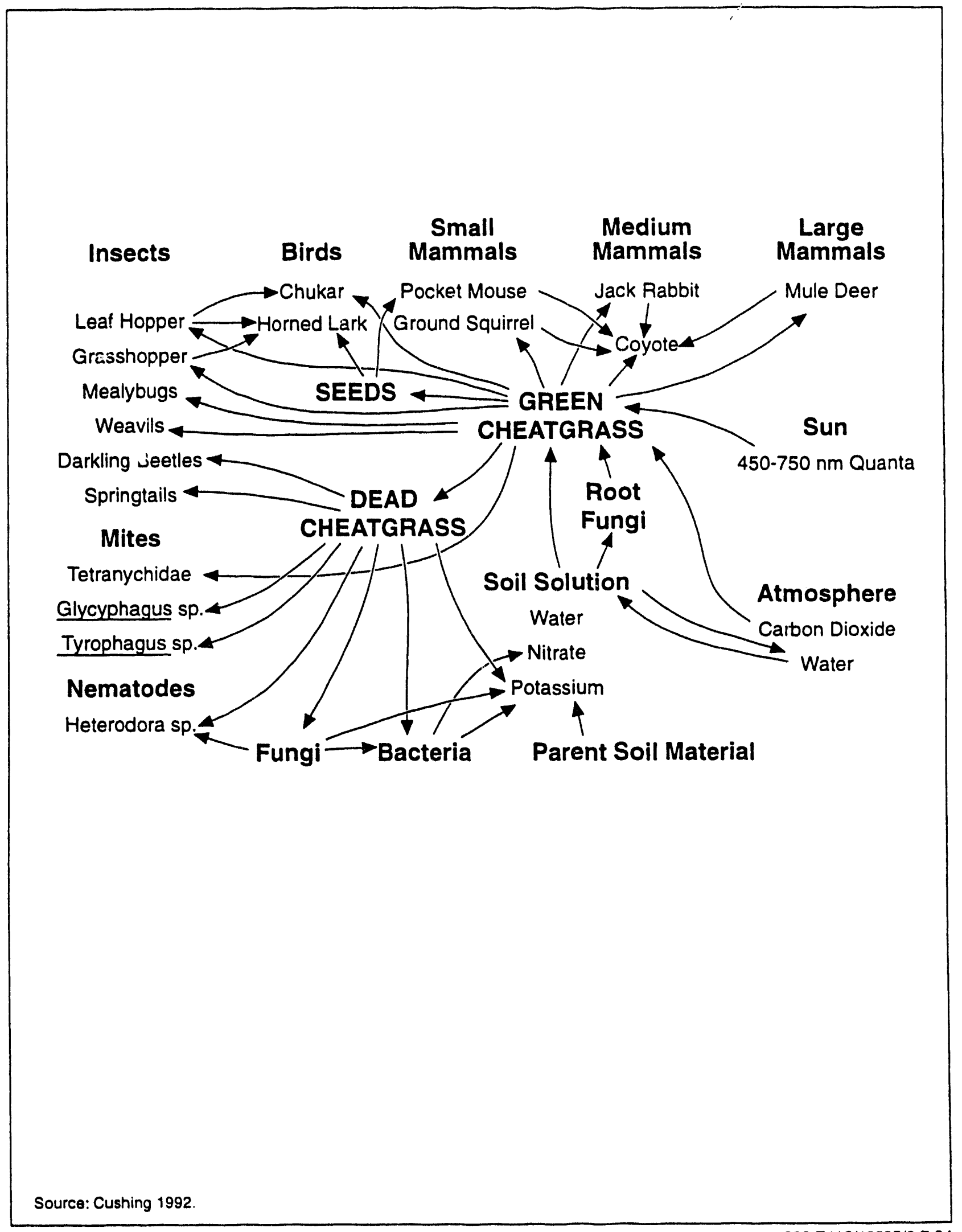

$923 \mathrm{E} 412 / 48595 / 6-7 \cdot 94$

Figure 2-38. Food Web Centered on Cheatgrass (arrows indicate direction of energy and mass transfer). 


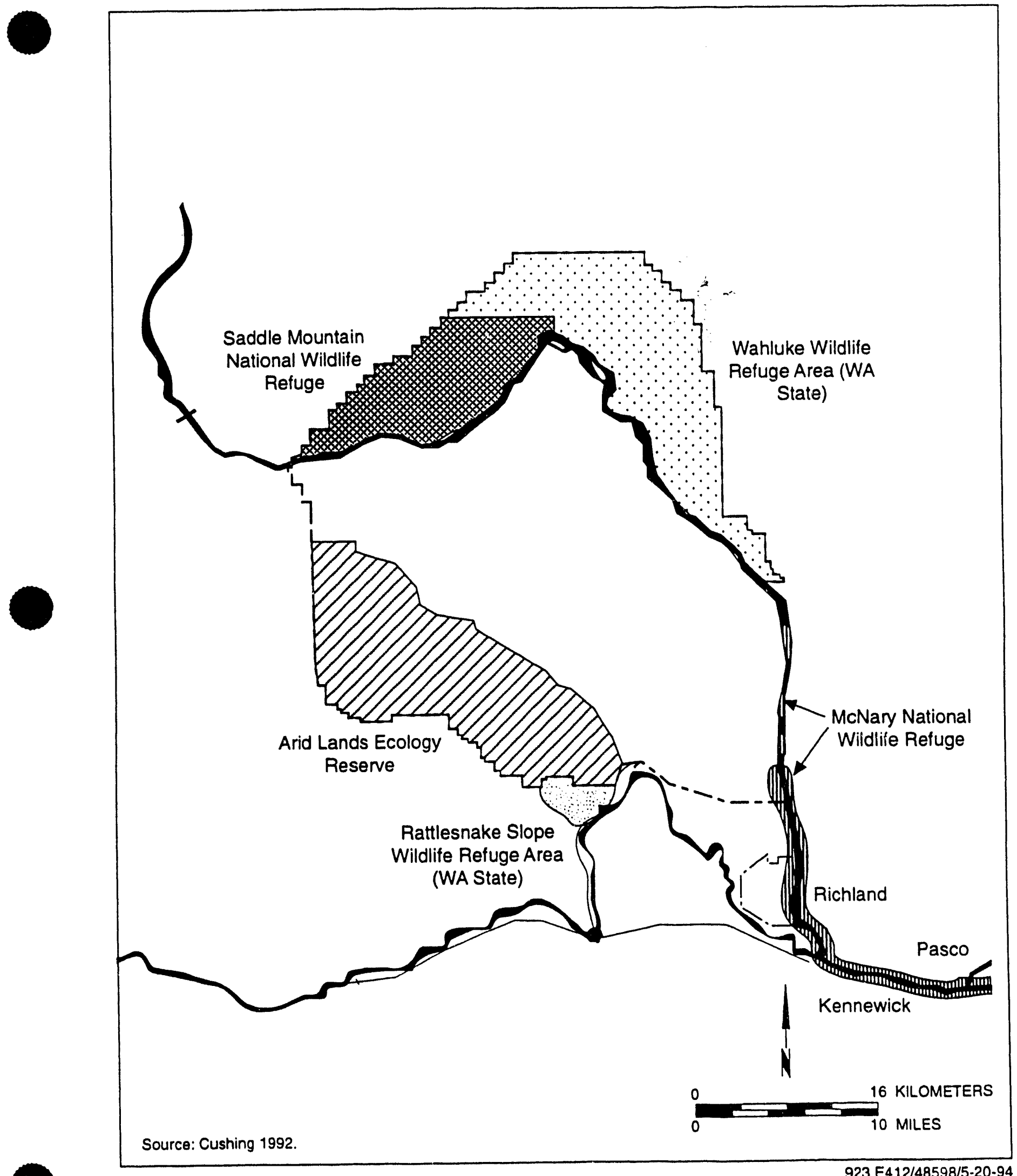

Figure 2-39. National and State Wildlife Refuges in the Vicinity of the Hanford Site. 


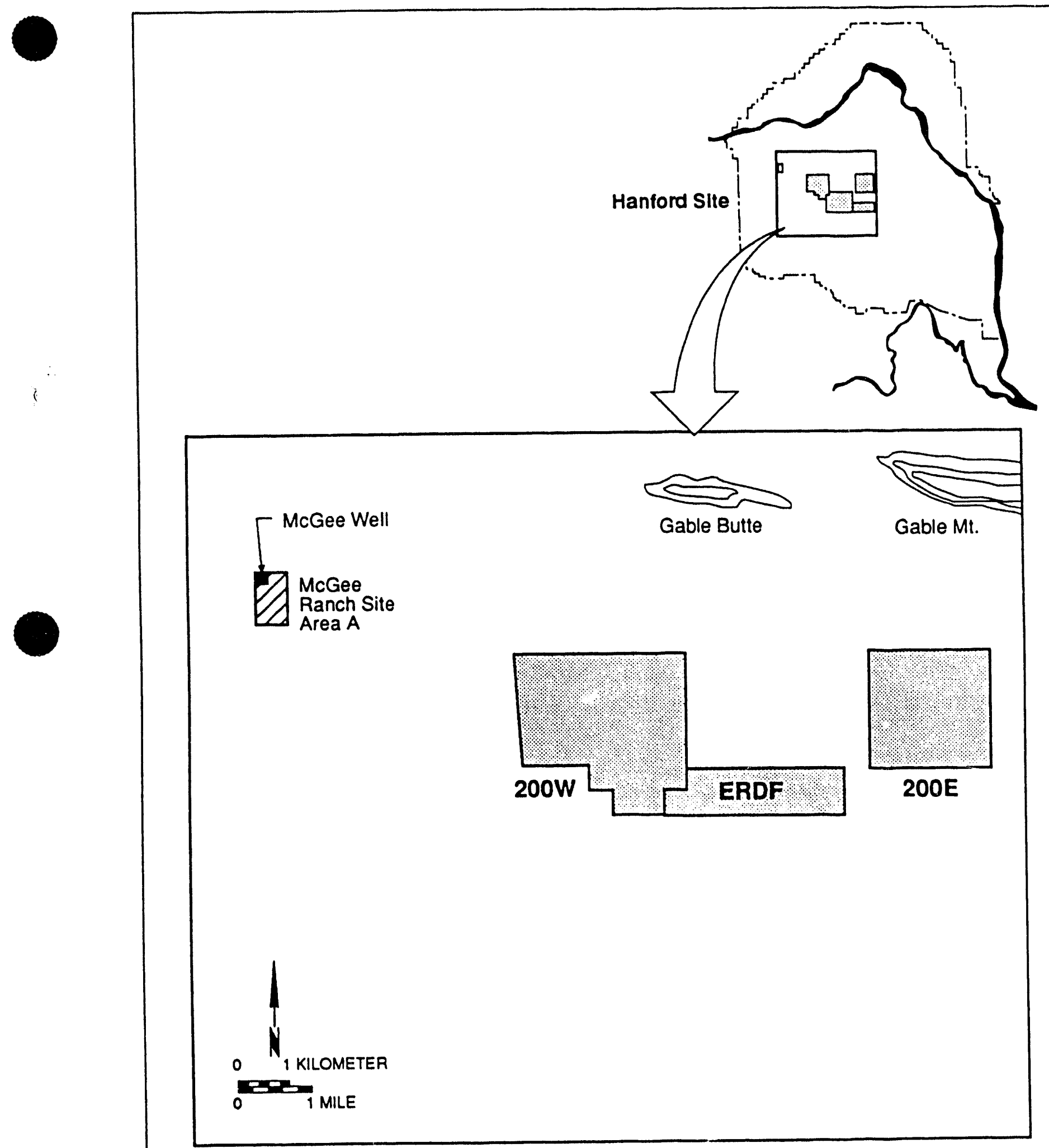

Sourco: Last et al., 1987.

Figure 2-40. Location Map McGee Ranch Borrow Soil Site. 


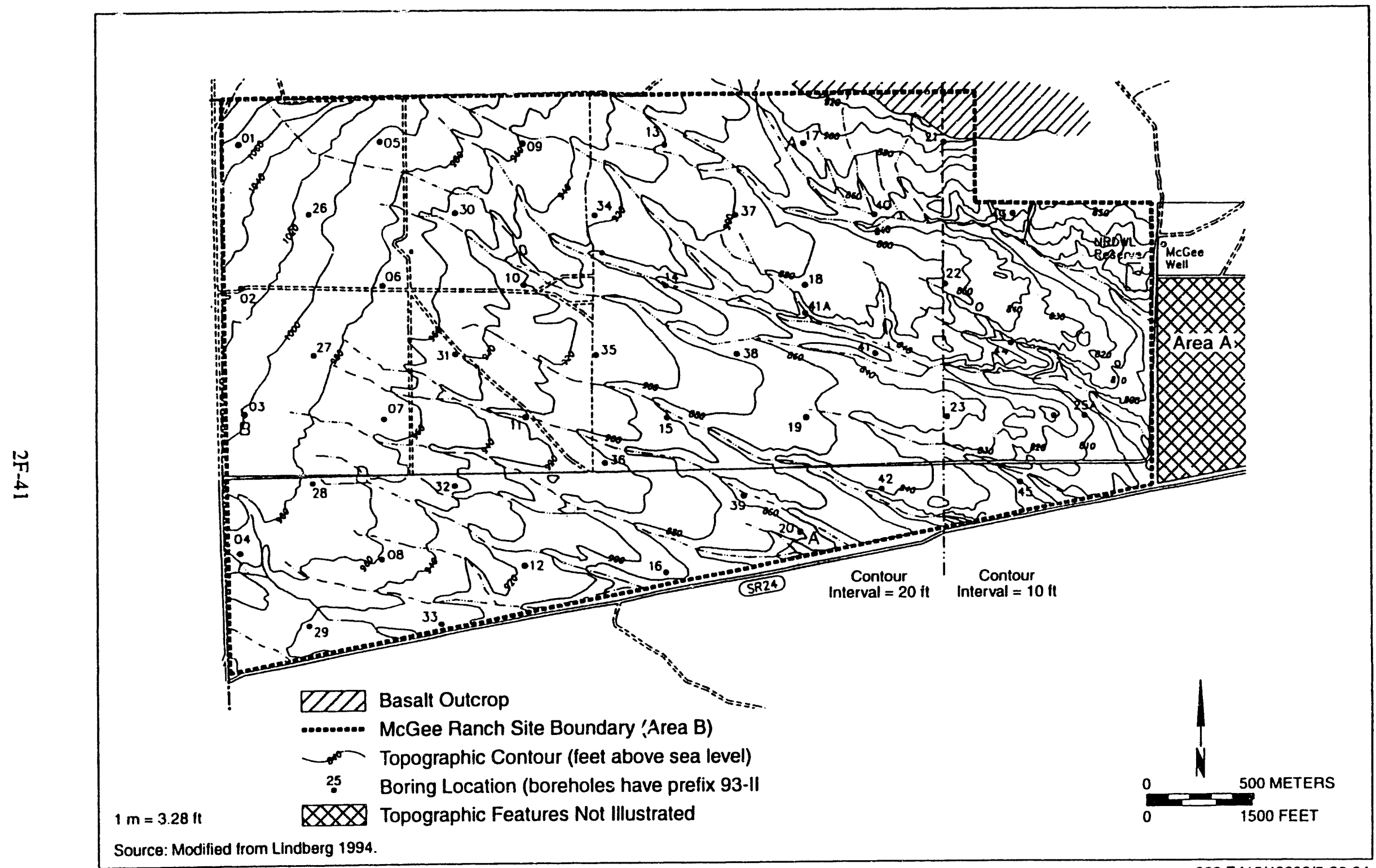

Figure 2-41. Locational Map of Areas A and B of the McGee Ranch Site. 
Table 2-1. Soil Types on the Hanford Site. (Sheet 1 of 2)

\begin{tabular}{|c|c|}
\hline Name (symbol) & Description \\
\hline Ritzville Silt Loam (Ri) & $\begin{array}{l}\text { Dark-colored silt loam soils midway up the slopes of the } \\
\text { Rattlesnake Hills. Developed under bunch grass from silty } \\
\text { wind-laid deposits mixed with small amounts of volcanic ash. } \\
\text { Characteristically }>150 \mathrm{~cm} \text { deep, but bedrock may occur at } \\
<150 \mathrm{~cm} \text { but }>75 \mathrm{~cm} \text {. }\end{array}$ \\
\hline $\begin{array}{l}\text { Rupert (Quincy) Sand } \\
\text { (Rp) }\end{array}$ & $\begin{array}{l}\text { One of the most extensive soils on the Hanford Site. } \\
\text { Brown-to- grayish-brown coarse sand grading to dark } \\
\text { grayish-brown at about } 90 \mathrm{~cm} \text {. Developed under grass, } \\
\text { sagebrush, and hopsage in coarse sandy alluvial deposits that } \\
\text { were mantled by wind-blown sand. Hummocky terraces and } \\
\text { dunelike ridges. }\end{array}$ \\
\hline Hazel Sand (He) & $\begin{array}{l}\text { Similar to Rupert sands; however, a laminated grayish-brown } \\
\text { strongly calcareous silt loam subsoil is usually encountered } \\
\text { within } 100 \mathrm{~cm} \text { of the surface. Surface soil is very dark brown } \\
\text { and was formed in wind-blown sands that mantled lake-laid } \\
\text { sediments. }\end{array}$ \\
\hline Koehler Sand (Kf) & $\begin{array}{l}\text { Similar to other sandy soils on the Hanford Site. Developed in } \\
\text { a wind-blown sand mantle. Differs from other sands in that } \\
\text { the sand mantles a lime-silica cemented layer "Hardpan." Very } \\
\text { dark grayish-brown surface layer is somewhat darker than } \\
\text { Rupert. Calcareous subsoil is usually dark grayish-brown at } \\
\text { about } 45 \mathrm{~cm} \text {. }\end{array}$ \\
\hline $\begin{array}{l}\text { Burbank Loamy Sand } \\
\text { (Ba) }\end{array}$ & $\begin{array}{l}\text { Dark-colored, coarse-textured soil underlain by gravel. Surface } \\
\text { soil is usually about } 40 \mathrm{~cm} \text { thick but can be } 75 \mathrm{~cm} \text { thick. Gravel } \\
\text { content of subsoil ranges from } 20 \% \text { to } 80 \% \text {. }\end{array}$ \\
\hline Kiona Silt Loam (Ki) & $\begin{array}{l}\text { Occupies steep slopes and ridges. Surface soil is very dark } \\
\text { grayish-brown and about } 10 \mathrm{~cm} \text { thick. Dark brown subsoil } \\
\text { contains basalt fragments } 30 \mathrm{~cm} \text { and larger in diameter. Many } \\
\text { basalt fragments found in surface layer. Basalt rock outcrops } \\
\text { present. A shallow stony soil normally occurring in association } \\
\text { with Ritzville and Warden soils. }\end{array}$ \\
\hline Warden Silt Loam (Wa) & $\begin{array}{l}\text { Dark grayish-brown soil with a surface layer usually } 23 \mathrm{~cm} \\
\text { thick. Silt loam subsoil becomes strongly calcareous at about } \\
50 \mathrm{~cm} \text { and becomes lighter colored. Granitic boulders are } \\
\text { found in many areas. Usually }>150 \mathrm{~cm} \text { deep. }\end{array}$ \\
\hline $\begin{array}{l}\text { Ephrata Sandy Loam } \\
\text { (El) }\end{array}$ & $\begin{array}{l}\text { Surface is dark colored and subsoil is dark grayish-brown } \\
\text { medium-textured soil underlain by gravelly material, which } \\
\text { may continue for many feet. Level topography. }\end{array}$ \\
\hline $\begin{array}{l}\text { Ephrata Stony Loam } \\
\text { (Eb) }\end{array}$ & $\begin{array}{l}\text { Similar to Ephrata sandy loam. Differs in that many large } \\
\text { hummocky ridges are presently made up of debris released } \\
\text { from melting glaciers. Areas between hummocks contain many } \\
\text { boulders several feet in diameter. }\end{array}$ \\
\hline
\end{tabular}


Table 2-1. Soil Types on the Hanford Site. (Sheet 2 of 2)

\begin{tabular}{|c|c|}
\hline Name (symbol) & Description \\
\hline Scootney Stony Silt & $\begin{array}{l}\text { Developed along the north slope of Rattlesnake Loam }(\mathrm{Sc}) \\
\text { Hills; usually confined to floors of narrow draws or small fan- } \\
\text { shaped areas where draws open onto plains. Severely eroded } \\
\text { with numerous basaltic boulders and fragments exposed. Sur- } \\
\text { face soil is usually dark grayish-brown grading to } \\
\text { grayish-brown in the subsoil. }\end{array}$ \\
\hline Pasco Silt Loam (P) & $\begin{array}{l}\text { Poorly drained very dark grayish-brown soil formed in recent } \\
\text { alluvial material. Subsoil is variable, consisting of stratified } \\
\text { layers. Only small areas found on Hanford Site, lscated in low } \\
\text { areas adjacent to the Columbia River. }\end{array}$ \\
\hline Esquatzel Silt Loam (Qu) & $\begin{array}{l}\text { Deep dark-brown soil formed in recent alluvium derived from } \\
\text { loess and lake sediments. Subsoil grades to dark } \\
\text { grayish-brown in many areas, but color and texture of the } \\
\text { subsoil are variable because of the stratified nature of the } \\
\text { alluvial deposits. }\end{array}$ \\
\hline Riverwash (Rv) & $\begin{array}{l}\text { Wet, periodically flooded areas of sand, gravel, and boulder } \\
\text { deposits that make up overflowed islands in the Columbia } \\
\text { River and adjacent land. }\end{array}$ \\
\hline Dune Sand (D) & $\begin{array}{l}\text { Miscellaneous land type that consists of hills or ridges of } \\
\text { sand-sized particles drifted and piled up by wind and are } \\
\text { either actively shifting or so recently fixed or stabilized that no } \\
\text { soil horizons have developed. }\end{array}$ \\
\hline Lickskillet Silt Loam (Ls) & $\begin{array}{l}\text { Occupies ridge slopes of Rattlesnake Hills and slopes }>765 \mathrm{~m} \\
\text { elevation. Similar to Kiona series except surface soils are } \\
\text { darker. Shallow over basalt bedrock, with nurnerous basalt } \\
\text { fragments throughout the profile of suggests a location within } \\
\text { a broad region between Lake Chelan, Washington, and the } \\
\text { British Columbia border. }\end{array}$ \\
\hline
\end{tabular}


DOE/RL-93-99, Rev. 0

Table 2-2. Common Vascular Plants on the Hanford Site. (Sheet 1 of 4)

\begin{tabular}{|c|c|}
\hline A. Shrub-Steppe Species & \\
\hline $\begin{array}{l}\qquad \text { Shrubs } \\
\text { Big sagebrush* } \\
\text { Spiny hopsage* } \\
\text { Grey rabbitbrush* } \\
\text { Green rabbitbrush* } \\
\text { Bitterbrush* } \\
\text { Snowy buckwheat } \\
\text { Prickly phlox* }\end{array}$ & $\begin{array}{l}\quad \text { Scientific Name } \\
\text { Artemisia tridentata } \\
\text { Grayia (Atriplex) spinosa } \\
\text { Chrysothamnus nauseous } \\
\text { Chrysothamnus viscidiflorus } \\
\text { Purshia tridentata } \\
\text { Eriogonum niveum } \\
\text { Leptodactylon pungens }\end{array}$ \\
\hline $\begin{array}{l}\quad \text { Perennial Grasses } \\
\text { Bluebunch wheatgrass } \\
\text { Bottlebrush squirreltail* } \\
\text { Sandberg's bluegrass* } \\
\text { Needle and thread grass* } \\
\text { Indian ricegrass* } \\
\text { Crested wheatgrass } \\
\text { Thick-spike wheatgrass* } \\
\text { Sand dropseed } \\
\text { Prairie Junegrass* }\end{array}$ & $\begin{array}{l}\text { Agropyron spicatum } \\
\text { Sitanion hystrix } \\
\text { Poa sandbergii (secunda) } \\
\text { Stipa comata } \\
\text { Oryzopsis hymenoides } \\
\text { Agropyron desertorum (cristatum) } \\
\text { Agropyron dasystachyum } \\
\text { Sporobolus cryptandrus } \\
\text { Koeleria cristata }\end{array}$ \\
\hline $\begin{array}{l}\quad \text { Perennial Forb } \\
\text { False yarrow* } \\
\text { Turpentine spring parsley* } \\
\text { Toad flax* } \\
\text { Scurf pea } \\
\text { Pale evening primrose* } \\
\text { Cluster lily* } \\
\text { Yellow bell* } \\
\text { Franklin's sandwort* } \\
\text { Wallflower } \\
\text { Long-leaved phlox* } \\
\text { Slender hawksbeard* } \\
\text { Carey's balsamroot* } \\
\text { Cusick's sunflower } \\
\text { Desert mallow } \\
\text { Sand beard tongue* } \\
\text { Sandy dock* } \\
\text { Yarrow* }\end{array}$ & $\begin{array}{l}\text { Chaenactis douglasii } \\
\text { Cymopteris terebinthinus } \\
\text { Comandra umbellata } \\
\text { Psoralea lanceolata } \\
\text { Oenothera pallida } \\
\text { Brodiaea douglasii } \\
\text { Frittillaria pudica } \\
\text { Arenaria franklinii } \\
\text { Erysimum asperum } \\
\text { Phlox longifolia } \\
\text { Crepis atrabarba } \\
\text { Balsamorhiza careyana } \\
\text { Helianthus cusickii } \\
\text { Sphaeralcea munroana } \\
\text { Penstemon acuminatus } \\
\text { Rumex venosus } \\
\text { Achillea millefolium }\end{array}$ \\
\hline
\end{tabular}


Table 2-2. Common Vascular Plants on the Hanford Site. (Sheet 2 of 4)

\begin{tabular}{|c|c|}
\hline $\begin{array}{l}\quad \text { Perennial Forb } \\
\text { Stalked-pod milkvetch* } \\
\text { Gray's desert parsley } \\
\text { Threadleaf fleabane* } \\
\text { Buckwheat milkvetch* } \\
\text { Flat topped broomrape } \\
\text { Threadleaf milkbane } \\
\text { Whiteleaf Scorpionweed* } \\
\text { Hoary aster* } \\
\text { Mariposa lily* }\end{array}$ & $\begin{array}{l}\quad \text { Scientific Name } \\
\text { Astragalus sclerocarpus } \\
\text { Lomatium grayi } \\
\text { Erigeron filifolius } \\
\text { Astragalus caricinus } \\
\text { Orobanche corymbosa } \\
\text { Erigeron filifolius } \\
\text { Phacelia hastata } \\
\text { Machaeranthera canescens } \\
\text { Calochortus macrocarpus }\end{array}$ \\
\hline $\begin{array}{l}\quad \text { Biennial Forbs } \\
\text { Cutleaf ladysfoot mustard* } \\
\text { Yellow salsify* }\end{array}$ & $\begin{array}{l}\text { Thelypodium laciniatum } \\
\text { Tragopogon dubius }\end{array}$ \\
\hline $\begin{array}{l}\quad \text { Annual Forbs } \\
\text { Jim Hill (tumble) mustard* } \\
\text { Tansy mustard* } \\
\text { Flixweed } \\
\text { Pink microsteris* } \\
\text { Matted cryptantha* } \\
\text { Broom buckwheat* } \\
\text { Hawk's beard } \\
\text { Low lupine* } \\
\text { Western wall flower } \\
\text { Jagged chickweed* } \\
\text { Annual Jacob's ladder* } \\
\text { Blazing star* } \\
\text { Threadleaf scorpionweed* } \\
\text { Russian thistle (tumbleweed)* } \\
\text { Indian wheat } \\
\text { Spring Whitlowgrass* } \\
\text { Tarweed fiddleneck* } \\
\text { Pepperweed } \\
\text { Purple mustard } \\
\text { Winged cryptantha* } \\
\text { Tall willow-herb } \\
\text { White cupseed* } \\
\text { Bur ragweed* } \\
\text { Prickly lettuce } \\
\text { Tidytips* } \\
\text { Filaree (crane's bill) }\end{array}$ & $\begin{array}{l}\text { Sisymbrium altissimuma } \\
\text { Descurainia pinnata } \\
\text { Descurainia sophia } \\
\text { Microsteris gracilis } \\
\text { Cryptantha circumscissa } \\
\text { Eriogonum vimineum } \\
\text { Crepis atribarba } \\
\text { Lupinus pusillus } \\
\text { Erysimum asperum } \\
\text { Holosteum umbellatum a } \\
\text { Polemonium micranthum } \\
\text { Mentzelia albicaulis } \\
\text { Phacelia linearis } \\
\text { Salsola kali } \\
\text { Plantago patagonica } \\
\text { Draba verna } \\
\text { Amsinckia lycopsoides } \\
\text { Lepidium perfoliatum } \\
\text { Chorispora tenella } \\
\text { Cryptantha pterocarya } \\
\text { Epilobium paniculatum } \\
\text { Plectritis macrocera } \\
\text { Ambrosia acanthicarpa } \\
\text { Lactuca serriola } \\
\text { Layia glandulosa } \\
\text { Erodium cicutarium }\end{array}$ \\
\hline
\end{tabular}


Table 2-2. Common Vascular Plants on the Hanford Site. (Sheet 3 of 4)

\begin{tabular}{|c|c|}
\hline $\begin{array}{l}\quad \text { Annual Grasses } \\
\text { Cheatgrass* } \\
\text { Six-weeks fescue* } \\
\text { Small fescue } \\
\end{array}$ & $\begin{array}{l}\text { Bromus tectorum a } \\
\text { Festuca octoflora } \\
\text { Festuca microstachys }\end{array}$ \\
\hline \multicolumn{2}{|l|}{ B. Riparian Plants } \\
\hline $\begin{array}{l}\quad \text { Trees and Shrubs } \\
\text { Black cottonwood } \\
\text { Black locust } \\
\text { Peach, apricot, cherry } \\
\text { Sand bar willow } \\
\text { Peachleaf willow } \\
\text { Willow } \\
\text { Mulberry } \\
\text { Dogbane }\end{array}$ & $\begin{array}{l}\text { Populus trichocarpa } \\
\text { Robinia pseudo-acacia } \\
\text { Prunus spp. } \\
\text { Salix exigua } \\
\text { Salix amygdaloides } \\
\text { Salix spp. } \\
\text { Morus alba } \\
\text { Apocynum cannabinum }\end{array}$ \\
\hline $\begin{array}{l}\text { Perennial Grasses and Forbs } \\
\text { Reed canary grass } \\
\text { Cattail } \\
\text { Bulrushes } \\
\text { Tickseed } \\
\text { Golden aster } \\
\text { Gumweed } \\
\text { Goldenrod } \\
\text { Prairie sage } \\
\text { Pacific sage } \\
\text { Horsetails } \\
\text { Gaillardia } \\
\text { Lupine } \\
\text { Smartweed } \\
\text { Sedge } \\
\text { Wiregrass } \\
\text { Speedwell } \\
\text { Wild onion } \\
\text { Russian knapweed } \\
\text { Rushes }\end{array}$ & $\begin{array}{l}\text { Phalaris arundinacea } \\
\text { Typha latifolia } \\
\text { Scirpus spp. }{ }^{\mathrm{b}} \\
\text { Coreopsis atkinsoniana } \\
\text { Heterotheca villosa } \\
\text { Grindelia columbiana } \\
\text { Solidago occidentalis } \\
\text { Artemisia ludoviciana } \\
\text { Artemisia campestris } \\
\text { Equisetum spp. } \\
\text { Gaillardia aristata } \\
\text { Lupinus spp. } \\
\text { Polygonum persicaria } \\
\text { Carex spp. } \\
\text { Eleocharis spp. } \\
\text { Veronica anagallis-aquatica } \\
\text { Allium spp. } \\
\text { Centaurea repens } \\
\text { Juncus spp. }\end{array}$ \\
\hline
\end{tabular}


Table 2-2. Common Vascular Plants on the Hanford Site. (Sheet 4 of 4)

\begin{tabular}{|c|c|}
\hline $\begin{array}{l}\quad \text { Aquatic Vascular } \\
\text { Water milfoil } \\
\text { Waterweed } \\
\text { Pondweed } \\
\text { Persistent sepal yellowcress } \\
\text { Watercress } \\
\text { Duckweed }\end{array}$ & $\begin{array}{l}\text { Myriophyllum spicatum } \\
\text { Elodea canadensis } \\
\text { Potamogeton spp. } \\
\text { Rorippa columbiae } \\
\text { Rorippa nasturium-aquaticum } \\
\text { Lemna minor }\end{array}$ \\
\hline $\begin{array}{l}\text { * Plants identified at the ERDF site. } \\
\text { aExotic. } \\
\text { bPerennial grasses and graminoids. } \\
\text { Source: Modified from Cushing } 199\end{array}$ & \\
\hline
\end{tabular}


Table 2-3. Partial List and Status of Amphibians and Reptiles Occurring on the Hanford Site.

\begin{tabular}{|c|c|c|}
\hline Common Name & Scientific Name & State Status \\
\hline $\begin{array}{l}\text { Amphibians } \\
\text { Great Basin spadefoot toad } \\
\text { Woodhouse's toad } \\
\text { Pacific treefrog }\end{array}$ & $\begin{array}{l}\text { Spea intermontanus } \\
\text { Bufo woodhouseii } \\
\text { Hyla regilla }\end{array}$ & M \\
\hline $\begin{array}{l}\text { Reptiles } \\
\text { Sagebrush lizard } \\
\text { Side-blotched lizard* } \\
\text { Short-horned lizard } \\
\text { Striped whipsnake } \\
\text { Western yellow-bellied racer* } \\
\text { Gopher snake* } \\
\text { Desert night snake } \\
\text { Western rattlesnake } \\
\text { Painted turtle }\end{array}$ & $\begin{array}{l}\text { Sceloporus graciosus } \\
\text { Uta stansburiana } \\
\text { Phrynosoma douglassii } \\
\text { Masticophis taeniatus } \\
\text { Coluber constrictor } \\
\text { Pituophis catenifer } \\
\text { Hypsiglena torquata desertia } \\
\text { Crotalus viridis } \\
\text { Chrysemys picta }\end{array}$ & $\mathbf{M}$ \\
\hline \multicolumn{3}{|c|}{$\begin{array}{l}\text { *Identified at the ERDF site. } \\
\text { M, Monitor group. wildlife species that: } \\
\text { 1. were at one time classified as endangered, threatened, or sensitive; } \\
\text { 2. require habitat that has limited availability during some portion of its life cycle; } \\
\text { 3. are indicators of environmental quality; } \\
\text { 4. require further field investigations to determine population status; } \\
\text { 5. have unresolved taxonomy which may bear upon their status classification; } \\
\text { 6. may be competing with and impacting other species of concern; or } \\
\text { 7. have significant popular appeal. } \\
\text { C, state candidate; wildlife species native to the State of Washington that the Department of } \\
\text { Wildlife will review for possible listing as sensitive, threatened or endangered. Candidate } \\
\text { species are desginated in Wildlife Policy } 4802 \text {. }\end{array}$} \\
\hline
\end{tabular}


Table 2-4. Partial List and Status of Birds Found on the Hanford Site.

(Sheet 1 of 2)

\begin{tabular}{|c|c|c|c|}
\hline Common Name & Scientific Name & $\begin{array}{l}\text { State } \\
\text { Status }\end{array}$ & $\begin{array}{c}\text { Federal } \\
\text { Status }\end{array}$ \\
\hline $\begin{array}{l}\text { Aleutian Canada Goose } \\
\text { American coot } \\
\text { American kestrel } \\
\text { American robin } \\
\text { Bald Eagle } \\
\text { Bank swallow* } \\
\text { Barn swallow* } \\
\text { Black-billed magpie } \\
\text { Bufflehead } \\
\text { California gull } \\
\text { California quail } \\
\text { Canada goose } \\
\text { Chukar partridge } \\
\text { Cliff swallow } \\
\text { Common nighthawk* } \\
\text { Common raven* } \\
\text { European starling } \\
\text { Ferruginous hawk } \\
\text { Golden eagle } \\
\text { Grasshopper sparrow* } \\
\text { Gray (Hungarian) partridge } \\
\text { Great blue heron } \\
\text { Horned lark* } \\
\text { House finch } \\
\text { House sparrow } \\
\text { Killdeer } \\
\text { Loggerhead shrike* } \\
\text { Magpie* } \\
\text { Mallard } \\
\text { Mourning dove* } \\
\text { Northern harrier* } \\
\text { Northern shoveler } \\
\text { Peregrine falcon } \\
\text { Pied-billed grebe } \\
\text { Red-tailed hawk* } \\
\text { Red-winged blackbird } \\
\text { Ring-billed gull } \\
\text { Ring-necked pheasant } \\
\text { Rock dove } \\
\text { Rough-legged hawk } \\
\text { (a) }\end{array}$ & $\begin{array}{l}\text { Branta canadensis leucopareia } \\
\text { Fulica americana } \\
\text { Falco sparverius } \\
\text { Turdus migratorius } \\
\text { Haliaeetus leucocephalus } \\
\text { Riparia riparia } \\
\text { Hirundo rustica } \\
\text { Pica pica } \\
\text { Bucephala albeola } \\
\text { Larus californicus } \\
\text { Callipepla californica } \\
\text { Branta canadensis moffitti } \\
\text { Alectoris chukar } \\
\text { Hirundo pyrrhonota } \\
\text { Chordeiles minor } \\
\text { Corvus corax } \\
\text { Sturnus vulgaris } \\
\text { Buteo regalis } \\
\text { Aquila chrysaetos } \\
\text { Ammodramus savannarum } \\
\text { Perdix perdix } \\
\text { Ardea herodias } \\
\text { Eremophila alpestris } \\
\text { Carpodacus mexicanus } \\
\text { Passer domesticus } \\
\text { Charadrius vociferus } \\
\text { Lanius ludovicianus } \\
\text { Pica pica } \\
\text { Anas platyrhynchos } \\
\text { Zenaidura macroura } \\
\text { Circus cyaneus } \\
\text { Anas clypeata } \\
\text { Falco peregrinus } \\
\text { Podilymbus podiceps } \\
\text { Buteo jamaicensis } \\
\text { Agelaius phoeniceus } \\
\text { Larus delawarensis } \\
\text { Phasianus colchicus } \\
\text { Columba livia } \\
\text { Buteo lagopus }\end{array}$ & $\begin{array}{l}\mathrm{T} \\
\mathrm{C} \\
\mathrm{M} \\
\mathrm{M}\end{array}$ & $\mathrm{C} 2$ \\
\hline
\end{tabular}


Table 2-4. Partial List and Status of Birds Found on the Hanford Site.

(Sheet 2 of 2)

\begin{tabular}{|c|c|c|c|}
\hline Common Name & Scientific Name & $\begin{array}{l}\text { State } \\
\text { Status }\end{array}$ & $\begin{array}{c}\text { Federa } \\
\text { Status }\end{array}$ \\
\hline $\begin{array}{l}\text { Sage sparrow* } \\
\text { Sage thrasher } \\
\text { Sandhill crane } \\
\text { Short-eared owl } \\
\text { Swainson's hawk* } \\
\text { Western kingbird } \\
\text { Western meadowlark* } \\
\text { White-crowned sparrow* } \\
\text { White pelican } \\
\text { Ash-throated flycatcher } \\
\text { Black-crowned night heron } \\
\text { Burrowing owl* } \\
\text { Caspian tern } \\
\text { Common loon } \\
\text { Forster's tern } \\
\text { Horned grebe } \\
\text { Long-billed curlew* } \\
\text { Northern goshawk } \\
\text { Osprey } \\
\text { Prairie falcon } \\
\text { Sage grouse } \\
\text { Snowy owl } \\
\text { Western grebe }\end{array}$ & $\begin{array}{l}\text { Amphispiza belli } \\
\text { Oreoscoptes montanus } \\
\text { Grus canadensis } \\
\text { Asio flammeus } \\
\text { Buteo swainsoni } \\
\text { Tyrannus verticalis } \\
\text { Sturnella neglecta } \\
\text { Zonotrichia leucophrys } \\
\text { Pelecanus erythrorhynchos } \\
\text { Myiarchus cinerascens } \\
\text { Nycticorax nycticorax } \\
\text { Athene cunicularia } \\
\text { Sterna caspia } \\
\text { Gavia immer } \\
\text { Sterna forsteri } \\
\text { Podiceps auritus } \\
\text { Numenius americanus } \\
\text { Accipiter gentilis } \\
\text { Pandion haliaetus } \\
\text { Falco mexicanus } \\
\text { Centrocercus urophasianus } \\
\text { Nyctea scandiaca } \\
\text { Aechmophorus occidentalis }\end{array}$ & $\begin{array}{l}\mathrm{E} \\
\mathrm{M} \\
\mathrm{M} \\
\mathrm{C} \\
\mathrm{M} \\
\mathrm{C} \\
\mathrm{M} \\
\mathrm{M} \\
\mathrm{M} \\
\mathrm{C} \\
\mathrm{M} \\
\mathrm{M} \\
\mathrm{C} \\
\mathrm{M} \\
\mathrm{M}\end{array}$ & $\mathrm{C} 2$ \\
\hline \multicolumn{4}{|c|}{ 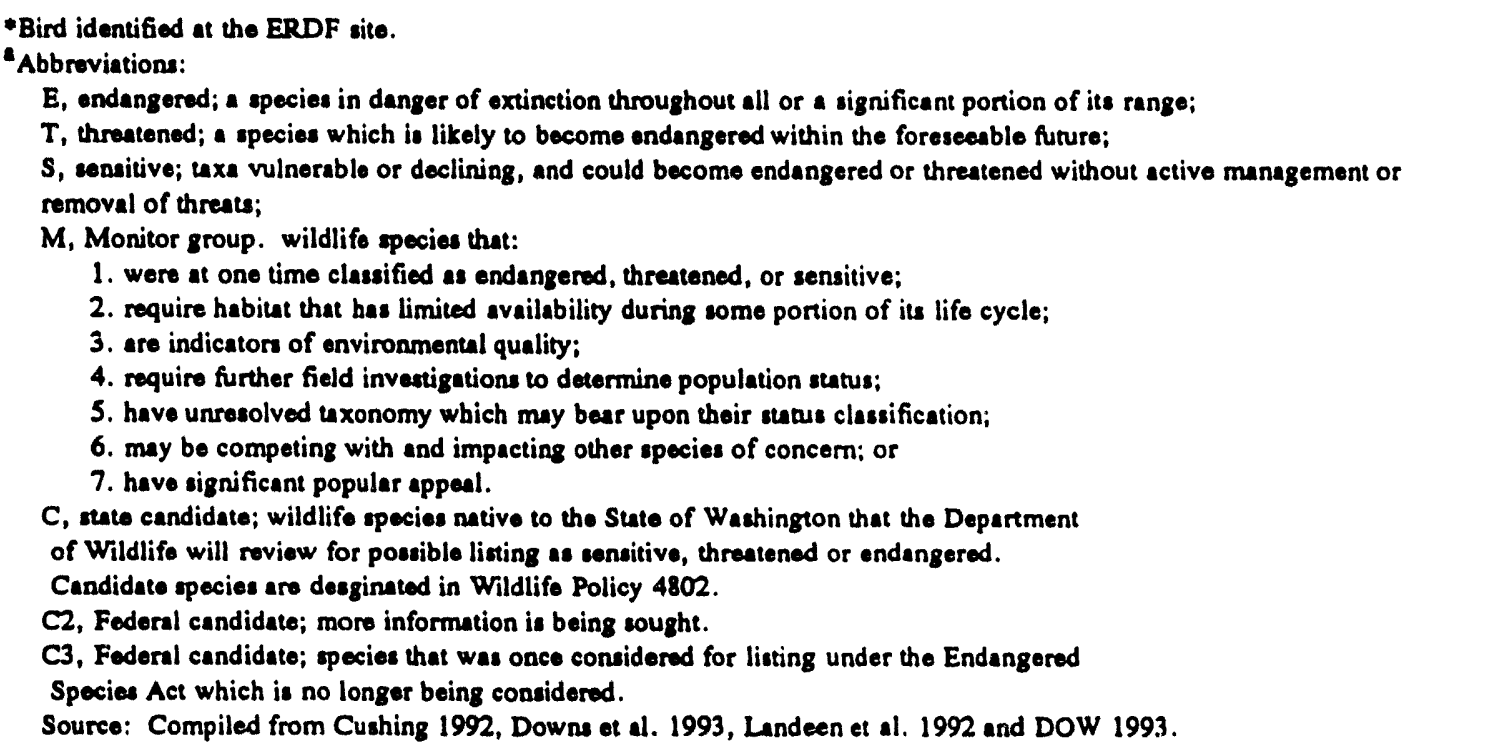 } \\
\hline
\end{tabular}


DOE/RL-93-99, Rev. 0

Table 2-5. List of Mammals Occurring on the Hanford Site. (Sheet 1 of 2)

\begin{tabular}{|l|l|c|c|}
\hline \multicolumn{1}{|c|}{ Common Name } & \multicolumn{1}{|c|}{ Scientific Name } & State & Federal \\
\hline Merriam's shrew & Sorex merriami & $\mathrm{C}$ & \\
Vagrant shrew & Sorex vagrans & $\mathrm{C}$ & $\mathrm{C} 2$ \\
Townsend's big-eared bat & Plecotus townsendii & & \\
Little brown bat & Myotis lucifugus & \\
Silver-haired bat & Lasionycteris noctivagans & \\
California brown bat & Myotis califormicus & \\
Yuma brown bat & Myotis yumanensis & \\
Pallid bat & Antrozous pallidus & \\
Hoary bat & Lasiurus cinereus & \\
Raccoon & Procyon lotor & \\
Mink & Mustela vison & \\
Long-tailed weasel & Mustela frenata & \\
Short-tailed weasel & Mustela erminea & \\
Badger* & Taxidea taxis & \\
Striped skunk & Mephitis mephitis & \\
Coyote* & Canis latrans & \\
Bobcat & Feiis rufus & \\
Least chipmunk & Eutarias minimus & \\
Yellow-bellied marmot & Marmota flaviventris & \\
Townsend's ground squirrel & Spermophilus townsendii & \\
Northern pocket gopher & Thomomys talpoides & \\
Great Basin pocket mouse* & Perognathus parvus & \\
Beaver & Castor canadensis & \\
Western harvest mouse & Reithrodontomys megalotis & \\
Deer mouse & Peromyscus maniculatus & \\
Northern grasshopper mouse & Onychomys leucogaster & \\
Montane meadow mouse & Microtus montanus & \\
Bushy-tailed woodrat & Neotoma cinerea & \\
Sagebrush vole & Lagurus curtatus & \\
Muskrat & Ondatra zibethicus & \\
House mouse & Mus musculus & \\
Norway rat & Rattus norvegicus & \\
Porcupine & Erethizon dorsatum & \\
Black-tailed jackrabbit* & Lepus californicus & \\
White-tailed jackrabbit & Lepus townsendi & \\
Nuttall's cottontail rabbit & Sylvilagus nuttallii & \\
\hline
\end{tabular}


Table 2-5. List of Mammals Occurring on the Hanford Site. (Sheet 2 of 2)

\begin{tabular}{|c|c|c|c|}
\hline Common Name & Scientific Name & State & Federal \\
\hline $\begin{array}{l}\text { Pygmy rabbit } \\
\text { Mule deer* } \\
\text { White-tailed deer } \\
\text { Elk } \\
\text { Otter }\end{array}$ & $\begin{array}{l}\text { Brachylagus idahoensis } \\
\text { Odocoileus hemionus } \\
\text { Odocoileus virginianus } \\
\text { Cervus elaphus } \\
\text { Lutra canadensis }\end{array}$ & $\mathbf{E}$ & $\mathrm{C} 2$ \\
\hline \multicolumn{4}{|c|}{ 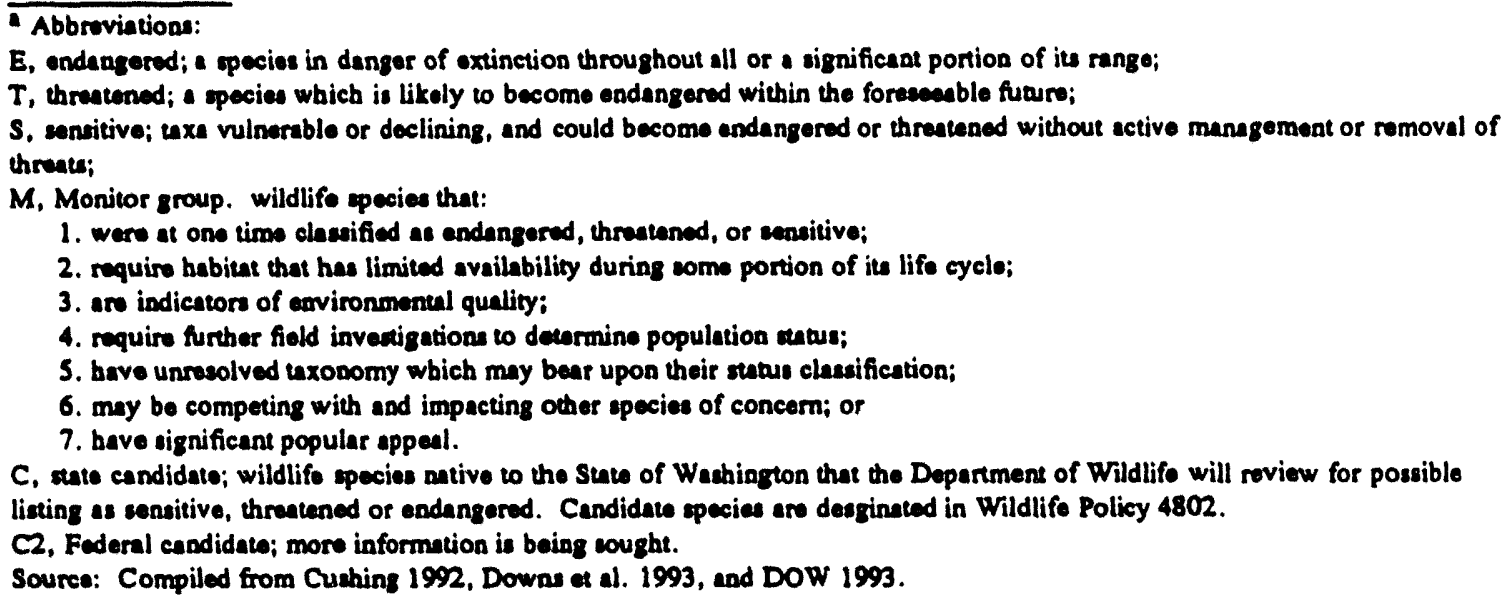 } \\
\hline
\end{tabular}


Table 2-6. Plant Species of Special Concern Occurring on the Hanford Site.

\begin{tabular}{|c|c|c|c|}
\hline Common Name & Scientific Name & Federal & State \\
\hline $\begin{array}{l}\text { Columbia milkvetch } \\
\text { Persistentsepal yellowcress } \\
\text { Hoover's desert parsley } \\
\text { Northern wormwood } \\
\text { Dense sedge } \\
\text { Gray cryptantha } \\
\text { Shining flatsedge } \\
\text { Piper's daisy } \\
\text { Southern mudwort } \\
\text { False-pimpernel } \\
\text { Dwarf evening primrose } \\
\text { Tooth-sepal dodder } \\
\text { Thompson's sandwort } \\
\text { Robinson's onion } \\
\text { Columbia River mugwort } \\
\text { Stalked-pod milkvetch* } \\
\text { Medic milkvetch } \\
\text { Crouching milkvetch } \\
\text { Rosy balsamroot } \\
\text { Palouse thistle } \\
\text { Bristly cyptantha } \\
\text { Smooth cliffbrake } \\
\text { Fuzzy-tongue penstemon } \\
\text { False yarrow }\end{array}$ & $\begin{array}{l}\text { Astragalus columbianus } \\
\text { Rorippa columbiae } \\
\text { Lomatium tuberosum } \\
\text { Artemisia campestris } \\
\text { borealis var. wormskioldii } \\
\text { Carex densa } \\
\text { Cryptantha leucophaea } \\
\text { Cyperus rivularis } \\
\text { Erigeron piperianus } \\
\text { Limosella acaulis } \\
\text { Lindernia anagallidea } \\
\text { Oenothera pygmaea } \\
\text { Cuscuta denticulata } \\
\text { Arenaria franklinii } \\
\text { v. thompsonii } \\
\text { Allium robinsonii } \\
\text { Artemisia lindleyana } \\
\text { Astragalus sclerocarpus } \\
\text { Astragalus speirocarpus } \\
\text { Astragalus succumbens } \\
\text { Balsamorhiza rosea } \\
\text { Cirsium brevifolium } \\
\text { Cryptantha interrupta } \\
\text { Pellaea glabella } \\
\text { Penstemon eriantherus } \\
\text { Chaenactis douglassii var. } \\
\text { glandulosa }\end{array}$ & $\begin{array}{l}\mathrm{C} \\
\mathrm{C} \\
\mathrm{C} \\
\mathrm{C}\end{array}$ & $\begin{array}{l}\mathbf{M} \\
\mathbf{M} \\
\mathbf{M} \\
\mathbf{M} \\
\mathbf{M} \\
\mathbf{M} \\
\mathbf{M} \\
\mathbf{M} \\
\mathbf{M} \\
\mathbf{M} \\
\mathbf{M} \\
\mathbf{M}\end{array}$ \\
\hline \multicolumn{4}{|c|}{$\begin{array}{l}\text { The following species may inhabit the Hanford Site, but have not been recently collected, and the known } \\
\text { collections are questionable in terms of location and/or identification. }\end{array}$} \\
\hline $\begin{array}{l}\text { Palouse milkvetch } \\
\text { Few-flowered blue-eyed Mary } \\
\text { Coyote tobacco }\end{array}$ & $\begin{array}{l}\text { Astragalus arrectus } \\
\text { Collinsia sparsiflora } \\
\text { Nicotiana attenuata }\end{array}$ & & $\begin{array}{l}S \\
S \\
S\end{array}$ \\
\hline \multicolumn{4}{|c|}{ 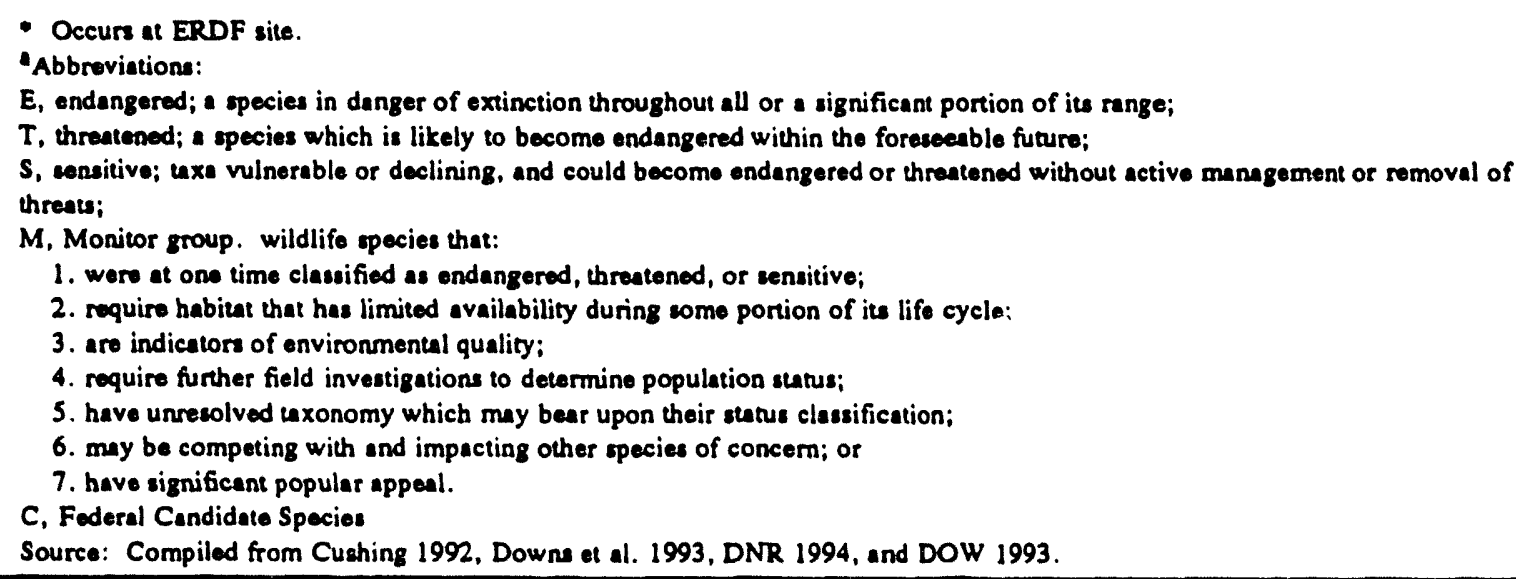 } \\
\hline
\end{tabular}




\subsection{WASTE CHARACTERISTICS}

This chapter describes general characteristics of remediation wastes that $n$ iy be placed in the ERDF. Information provided below includes descriptions of waste generating activities and waste units, physical characteristics of the waste, and chemical characteristics of the waste. The waste characteristics described in this chapter provide the basis for the risk assessment and comparative analysis of alternatives performed in later chapters, as well as the starting point for definition of acceptable waste concentrations and leachate concentrations provided in Appendix C.

Investigations of source operable units that may result in waste suitable for disposal in the ERDF are currently on-going. The status of RI/FS reports for 100 and 300 Area operable units are provided in the table below. Note that a Limited Field Investigation (LFI) is synonymous to a limited $\mathrm{RI}$.

\begin{tabular}{|l|l|l|l|}
\hline \multirow{2}{*}{$\begin{array}{l}\text { Source Operable } \\
\text { Unit }\end{array}$} & RI and LFI/QRA & FS Report \\
\cline { 3 - 4 } & & Phase 1/II & Phase III \\
\hline $100-\mathrm{BC}-1$ & Complete & Complete & In Progress \\
\hline $100-\mathrm{BC}-2$ & & Complete & In Progress \\
\hline $100-\mathrm{DR}-1$ & Complete & Complete & In Progress \\
\hline $100-\mathrm{DR}-2$ & & Complete & \\
\hline $100-\mathrm{FR}-1$ & & Complete & \\
\hline $100-\mathrm{HR}-1$ & Draft & Complete & In Progress \\
\hline $100-\mathrm{HR}-2$ & Complete & Complete & \\
\hline $100-$ KR-1 & & Complete & \\
\hline $300-\mathrm{FF}-1$ & Draft & Complete & In Progress \\
\hline
\end{tabular}

The completed reports identified in the above table are listed below:

- Limited Field Investigation Report for the 100-BC-1 Operable Unit (IT Corp 1993a)

- Limited Field Investigation Report for the 100-DR-1 Operable Unit (DOE-RL 1993k)

- Limited Field Investigation Report for the 100-HR-1 Operable Unit (IT Corp. 1993b)

- Qualitative Risk Assessment for the 100-BC-1 Source Operable Unit (WHC 1994b) 
- Qualitative Risk Assessment for the 100-DR-1 Source Operable Unit (WHC 1994c)

- Qualitative Risk Assessment for the 100-HR-1 Source Operable Unit (WHC 1994d)

- Qualitative Risk Assessment for the 100-KR-1 Source Operable Unit (WHC 1994e)

- 100 Area Feasibility Study Phases 1 and 2 (DOE-RL 1992g)

- Phase I Remedial Investigation Report for the 300- FF-1 Operable Unit (DOE-RL 1993f)

- Phase I and II Feasibility Study Report for the 300-FF-1 Operable Unit (DOE-RL 19931)

The RI and LFI reports include information regarding physical characteristics of the waste, constituent background data, and contaminant concentration data. In addition, they identify the contaminants of concern and the high priority waste sites. Risk assessment information is provided in the QRA and $R I$ reports. The FS reports provided information regarding ARARs, remedial objectives, areas and volumes of affected media, and screening and evaluation of technologies and alternatives. In conjunction with the RI/FS investigations, several treatability tests have been conducted. These include bench, lab, and pilot-scale soil washing in the 300 Area (DOE-RL 1994b); bench and lab-scale soil washing on 100 Area contaminated soils (DOE-RL 1994a); in-situ vitrification testing of 100-BC Area soils (Ludowise 1994); and pilot-scale treatability testing on various methods for excavating soils contaminated with radionuclides (unpublished). Future treatability tests currently scheduled include: pilot-scale test for the exhumation of a burial ground in the 100-BC Area; and ex-situ vitrification in 100 Area soils.

Waste characterization is not yet complete and the information summarized below is considered preliminary. It is anticipated that some of the wastes encountered during remediation will differ from the characterization provided below. In particular, the maximum chemical concentrations reported in this document are based on currently available information. It is possible that higher maximum concentrations will be encountered during future investigations and during remediation. For this reason, the waste acceptance chemical concentration criteria are established as high as possible without resulting in unacceptable risk.

Most of the waste in the ERDF will have chemical concentrations less than the maxima reported in this report. Therefore, the risk estimates provided in Chapters 6 and 9 are conservative and it is likely that actual exposures will be significantly lower. Maximum concentrations are used because of the uncertainty regarding actual waste received at the ERDF and the difficulty in estimating representative "average" exposure concentrations for most of the waste units. The maximum total quantity of waste from the 100,200 , and 300 Areas is estimated to be 21.4 million $\mathrm{m}^{3}\left(28\right.$ million $\left.\mathrm{yd}^{3}\right)$. The percentage breakdown of the types of waste is presented for each area. 
It is anticipated that the ERDF will receive remediation waste from the 100,200 , and 300 Areas. This chapter includes three subsections, one for each of these aggregate areas. This division reflects the difference in waste-generating activities at each of the aggregate areas: the 100 Area waste is primarily associated with operation of plutonium production reactors; the primary waste-generating activities in the 200 Area were fuel reprocessing and plutonium recovery; and the 300 Area waste is primarily associated with nuclear fuel fabrication and research laboratories. A final subsection summarizes maximum waste concentrations and provides screening against background soil concentrations.

\subsection{AREA WASTE CHARACTERISTICS}

Most of the recent investigations of the 100 Area operable units have been conducted as Limited Field Investigations (LFIs). Consistent with the Hanford Site Past-Practice Strategy (DOE-RL 1992f), these investigations have been less extensive than traditional RIs. The objectives of the Hanford Site Past-Practice Strategy are to accelerate decision-making by maximizing the use of existing data and facilitating implementation of expedited response actions (ERAs) and/or interim remedial measures (IRMs) in a timely manner. The information in Section 3.1.1 and 3.1.2 was derived from 100 Area Feasibility Study Phases 1 and 2 (DOE-RL 1992g) unless otherwise referenced.

\subsubsection{Waste Generating Activities}

Between 1943 and 1962, nine water-cooled, graphite-moderated plutonium production reactors were built along the shore of the Columbia River upstream from the now-abandoned town of Hanford. Eight of these reactors (B, C, D, DR, F, H, KE, and KW) have been retired from service and will be decommissioned. The ninth reactor, $N$, was recently shutdown and will also be retired. In some of the reactor areas, after the reactor was retired from plutonium production service, the ancillary facilities were used as laboratories for special studies or for storage/treatment purposes.

3.1.1.1 Reactor Operations (Excluding $\mathbf{N}$ Reactor). The principal components of the original eight reactors consisted of the reactor, the reactor cooling water loop, the reactor gas and ventilation system, and the irradiated fuel handling system.

Reactor. Each reactor was graphite moderated and cooled with water pumped through on a single-pass basis. The reactor moderator stack consisted primarily of graphite blocks, some of which were cored to allow water flow and equipment placement. Aluminum process tubes held aluminum-clad, uranium-metal fuel elements and provided channels for cooling water. Boron was used for control and safety rods. A boron solution was used as a backup safety system requiring the insertion of aluminum thimbles into the channels to protect the graphite. The boron solution system was later replaced with a system utilizing nickel-plated boron balls.

Reactor Cooling Water Loop. Cooling water for the reactor was taken from the Columbia River, alum with excess sulfuric acid was added to aid in the removal of particulates, and then passed through flocculators to settling basins where an organic polyelectrolyte was added as a filter aid. Hydrated calcium oxide, chlorine, and sodium dichromate were also added to the water to control pH, algae, and corrosion, respectively. 
After passage through the reactor, the water was sent to retention basins where it was kept for a period of time to allow for thermal cooling and partial decay of short-lived radionuclides. The water was then released via outfall structures and pipelines to the middle of the river.

Reactor Inert Gas and Ventilation System. Inert gas, composed of helium with carbon dioxide or nitrogen, was used to remove moisture and foreign gases, transfer heat, and detect water leaks within the reactor.

Irradiated Fuel Handling. Refueling occurred on a regular basis and the removed irradiated fuel elements were transferred to the fuel storage basin for radioactive decay. Following the decay period, the fuel elements were transferred to the 200 Areas for reprocessing.

Decontamination Activities. Decontamination activities took place both in the reactor buildings and in nearby facilities. Decontamination solutions consisted of various acids and solvents that were used to remove radionuclides from equipment, tools, reactor hardware, wall surfaces, and other items contaminated during reactor operations (DOE-RL 1992h).

3.1.1.2 Laboratory Operations. Laboratory operations at the 100 Area included a tritium extracting facility at the $100 \mathrm{~B}$ Area, a mechanical development laboratory at the 108-D building, thermal hydraulic laboratories at the 185-D and 189-D buildings, a pharmacology laboratory at the 1705-F building, and biological research laboratories at the $100 \mathrm{~F}$ Area (General Electric 1964). These are described below.

The tritium extracting facility was located at the 132-B-1 building in the $100 \mathrm{~B}$ Area. It was originally designed to be a water treatment facility, but in 1948 it was converted to a laboratory for extracting tritium from lithium-aluminum targets irradiated in the B, C, D, DR, $\mathrm{F}$, and $\mathrm{H}$ reactors. There were two tritium recovery campaigns, one using a stainless steel line and one a glass line. The major contaminants from tritium recovery were tritium and mercury. The mercury was generated as a result of using mercury vapor pumps in the process. In 1954, the process was discontinued and the building used as an aluminum process tube examination facility (DOE-RL 1992h).

The mechanical development laboratory at the 108-D building contained various reactor mock-up facilities such as segments of the C- and K-Reactor lattices, flow mock-ups and simulated elevator and reactor face equipment. The thermal hydraulic laboratories at the 185-D and 189-D buildings were used for boiler burnout, fog cooling, transient heat transfer, and flow instability studies. No information was provided on wastes generated from these laboratory operations (General Electric 1964).

The main biological laboratory (108-F) for studying the effects of radiation on animals and plants operated from 1945 until 1976. The earliest research activities were fish studies conducted in the 146-F laboratory and in adjacent ponds. Effluent water was supplied to the laboratory facilities via the 147-F pump house, and discharged to the PNL outfall via the pump house. Sheep studies began in the late 1940s. Dose studies with sheep used iodine-131, strontium-90, plutonium-239, and cesium-137. Studies were also performed on pigs, goats, milk cows, chickens, and ducks. Animals were housed in buildings 141-F, 141-C, 141-P, and 141-S. The animal monitoring laboratory, which contained a whole body counter, was in building 145-F. Animal research was also conducted on beagle dogs. Approximately 300 to 
400 dogs were housed in the 144-R dog kennel. Plutonium-239 was the main isotope used in the dog studies. Laboratory facilities for the experiments were located in the 132-F-2 inhalation laboratory (DOE-RL 1992i).

In addition to the animal studies, radioecology experiments also took place in the 100-F Area. Greenhouses in the 1705-F building were used for growing potted plants. In addition, the "strontium gardens" plots, located in the southwest corner of the site, were used for growing cereal grains, alfalfa, and other crops in soil containing strontium- 90 and cesium-137

(DOE-RL 1992i).

After the $F$ reactor operations ceased in 1965, the animal research operations took over some of the office buildings and maintenance shops formerly associated with reactor operations (Tipton 1975). Building 1707-F was converted to a dog inhalation laboratory and the 1707-FA building was converted to a rodent inhalation laboratory. Building 1713-F was used for a pathology laboratory, and the 1719-F building was converted to an animal care facility. Small animals were housed in the 1701-FA building. It is not known what radioisotopes or other chemicals were used in these buildings (DOE-RL 1992i).

3.1.1.3 N Reactor Operations. The following information was derived from RCRA Facility Investigation/Corrective Measures Study Work Plan for the 100-NR-2 Operable Unit, Hanford Site, Richland, Washington, Draft C (DOE-RL 1994e).

The $\mathrm{N}$ reactor was the last reactor to be constructed as a major production reactor at the Hanford Site. The $\mathbf{N}$ reactor is a graphite-moderated, light-water cooled, horizontal-pressuretube nuclear reactor. It differs from the other reactors at Hanford in that it was designed as a dual purpose reactor capable of producing special nuclear materials and steam. The steam produced from the $\mathrm{N}$ reactor core cooling systems was piped to the Hanford Generation Plant (HGP) and used for production of electrical power.

Confinement System. The $\mathrm{N}$ reactor used a confinement system based on the concept to release the initial burst of steam resulting from a postulated reactor coolant pipe break. When the confinement pressure subsided, the steam vents were closed and ventilation valves opened. The ventilated steam was filtered through charcoal and high efficiency filters to prevent any release of fission products from fuel failure.

Nuclear Fuel System. The fuel used for operation of the $\mathbf{N}$ reactor was slightly enriched uranium-235 (U-235) (0.94\% to $1.25 \%)$, clad with a zirconium alloy. At shutdown, a concentric tube-in-tube fuel design was in use. In the past, other materials have been used as a target in connection with an enriched uranium driver fuel element to produce useable isotopes such as tritium ( $\mathrm{H}-3)$ and plutonium-238 (Pu-238). The fuel cladding is zircaloy-2 metallurgically bonded to the uranium by a co-extrusion process.

Heat Dissipation System. The secondary steam system for the $\mathrm{N}$ reactor removed the reactor heat from the reactor coolant system by boiling secondary water in the shell side of the steam generator. During operation solely for the production of special nuclear material the major fraction of this steam was routed to 16 dump condensers which were arranged in parallel and cooled by untreated Columbia River water. 
During dual purpose operation, the major fraction of steam generated was routed to the HGP. A portion of the steam generated was used to drive the reactor coolant pumps, the onsite turbine generator and to keep the dump condensers warm so they were ready to accept full steam load in the event of a Hanford Generation Plant turbine generator shutdown.

Water Supply System. Strained untreated water from the Columbia River was supplied as coolant to the dump condensers as well as the reactor coolant pump drive turbine surface condensers and the local turbine generator condensers. This condenser cooling water was then returned to the river. Untreated water was also supplied to the water treatment facility for the filtered water, sanitary water, and demineralized water systems.

Decontamination. Facilities were provided for chemical decontamination of the entire reactor coolant system or for any of several major portions of the system, including the individual heat exchanger cells. The graphite and shield cooling system could also be chemically decontaminated. Included were equipment for storage and preparation of the necessary chemicals and piping for injection at appropriate points. Chemical wastes from decontamination, along with rinse waters, were normally routed to the $116-\mathrm{N}-2$ storage tank, then shipped by tank truck or rail car to the 200 Area of the Hanford Site for disposal.

\subsubsection{Waste Units}

Retention Basins. The 100 Area retention basins were rectangular concrete or circular steel structures used to retain reactor effluent for radioactive decay and thermal cooling before release to the Columbia River. The basins ranged in capacity from 60 to 90 million L (16 to 24 million gal). Initially, effluent to the basins was controlled in a manner that allowed redirection of effluent contaminated by ruptured fuel elements to a crib. This practice was found to cause structural damage to the basins due to differential pressures and stresses on the retention basin walls, and was changed to protect the integrity of the basins. The new procedure precluded redirection of the more highly contaminated effluent to alternate disposal sites, resulting in all effluent being discharged to the river. Some of the retention basins have been partially demolished and buried in place. Some have also been used for disposal of contaminated demolition materials.

Each retention basin contains from $1 / 2 \mathrm{~cm}(1 / 4 \mathrm{in}$.) to $8 \mathrm{~cm}(3 \mathrm{in}$.) of sludge covered by 0.6 to $1.2 \mathrm{~m}$ ( 2 to $4 \mathrm{ft}$ ) of soil fill. Cobalt-60, europium-152, europium-154, and nickel-63 account for approximately $94 \%$ of the radionuclide inventory located within the retention basins. In addition to radionuclide contamination, the basins may be contaminated with chemical constituents used as additives in the cooling water. A major contaminant is chromium which was used extensively in the 100 Area reactor cooling water to minimize corrosion.

Pipelines. Effluent pipelines ran from the reactors to the retention basins, from the retention basins to the outfall structures, and from the outfall structures to the middle of the river. The 100 Area contained approximately $19,000 \mathrm{~m}(62,000 \mathrm{ft})$ of effluent pipeline ranging in size from 31 to $213 \mathrm{~cm}$ (12 to 84 in.) in diameter. The pipelines were constructed of carbon steel, reinforced concrete, or vitreous tile, and included manholes, junction boxes, tie-lines, and valves. Except for a portion of pipeline in the F Area that was removed and placed in its retention basin, the on-land pipelines are still in place underground. The river pipelines are still in place with the exception of approximately $15 \mathrm{~m}(50 \mathrm{ft})$ in the F Area that washed downstream. 
The pipelines contain accumulated sludge. Radionuclide and chemical contamination is expected to be similar to that found in the retention basins.

Outfall Structure. Outfall structures were compartmentalized, reinforced concrete boxes used to direct effluent to the middle of the Columbia River. The spillways associated with them were of concrete or rip-rap construction, and were used only in case of overflow. In the F Area, the PNL outfall structure was used to direct wash water from animal pens to the river.

With the exception of the PNL outfall, radionuclide and chemical contaminants associated with the outfall structures are presumed to be similar to those associated with the retention basins. Contaminants associated with the PNL outfall include strontium-90 and small amounts of cesium-137 and plutonium-239.

Cribs. Cribs received effluent during fuel cladding failures, decontamination activities, and other facilities associated with reactor operations. In general, cribs were buried rock-filled structures with open bottoms of wood construction.

The pluto cribs received effluent from process tubes following fuel cladding failures. Fission products and water additives (such as chromium) are potential contaminants.

The dummy/perf decontamination cribs/drains received radioactive liquid waste from decontamination of dummy fuel element spacers in the F, $\mathrm{H}$, and $\mathrm{B}$ reactors. Acids, including nitric, sulfuric, oxalic, and hydrofluoric, were used extensively in the decontamination process. Therefore, in addition to radionuclides, nitrate and other acid residues are likely contaminants in soils beneath these cribs.

The 108 building cribs/drains at the $100 \mathrm{BC}$ Area received contaminated liquid effluents from the 108 laboratory operations. Tritium has been identified as a waste constituent in the 116-B-5 crib.

The 115 building cribs received condensate and liquid waste from the reactor gas purification systems. Waste passed through a pipe to a $3.2 \mathrm{~m}(10.5 \mathrm{ft})$ long perforated pipe and into the soil column. Tritium and carbon-14 were the principal radionuclides released to these cribs.

The 117 building cribs received drainage from the confinement system seal pits. These cribs generally received only short-lived radionuclides and were released from radiological control prior to 1967.

Special use cribs include the 116-F-5 ball washer crib, the 116-KE-2 crib, and the 116DR-7 inkwell crib. The 116-F-5 crib received liquid wastes from decontamination of boronsteel balls used in the ball $3 X$ system. The principal radionuclides in the $116-F-5$ crib are strontium-90, europium-154, europium-155, and cesium-137. The 116-KE-2 crib received liquid wastes from the 1706-KER loop and was found to contain strontium-90 and cobalt-60, and a maximum concentration of $2.1 \mathrm{pCi} / \mathrm{g}$ of plutonium 239/240. The 116-DR-7 crib received liquid potassium borate solution from the $3 \mathrm{X}$ system prior to the ball $3 \mathrm{X}$ system upgrade.

French Drains. French drains were generally gravel-filled concrete or vitreous pipe. In the $\mathrm{K}$ Area, sulfuric acid sludge was disposed to the drains from the acid storage tanks. The 
120-KE-1 french drain contains approximately $200 \mathrm{~kg}$ of mercury. Drains in the F Area received liquid waste from botany experiments and decontamination processes, while drains in the other areas received liquid waste only from decontamination processes.

Trenches. Trenches were generally open excavations with sloped sides, used as backup for the retention basins when effluent was too contaminated to be released to the river. The 100 Area has five types of trenches that differ in terms of purpose and construction: liquid waste disposal trenches, the $\mathrm{K}$ trench, the 1608 trench, sludge trenches, and the Lewis Canal.

The liquid waste disposal trenches received effluent from retention basins during fuel cladding failures. Fission products and chromium are likely contaminants.

The $\mathrm{K}$ trench regularly received wastes from all contaminated floor drains in the reactor buildings, overflow from the storage basins, and leakage from the effluent basin. Periodic sources of contaminated flow emanated from dummy decontamination, rear face decontamination, storage basin during rod exchange, and retention basins during fuel cladding failures. The trench contained a maximum concentration of $130 \mathrm{pCi} / \mathrm{g}$ of plutonium-239/240. Sodium dichromate, sulfamic acid, sulfuric acid, and copper sulfate were also discharged to the trench.

The 1608 trenches in the $\mathrm{F}$ and $\mathrm{H}$ Areas received effluent during the Ball $3 \mathrm{X}$ Project. (This project involved modification of the emergency reactor control system from a liquid boron system to a solid boron and carbon ball system). Both trenches have overflowed and contaminated adjacent soils. The trenches have since been backfilled. Contaminants include strontium-90, tritium, europium-152, europium-154, cobalt-60, and cesium-137. The maximum plutonium concentration is less than $1 \mathrm{pCi} / \mathrm{g}$. basin.

The sludge trenches in the B Area received sludge removed from the B Area retention

The Lewis Canal in the F Area received miscellaneous waste from the reactor and 190-F buildings in the $\mathrm{F}$ Area as well as decontamination waste from the $189-\mathrm{F}$ building. It also received effluent during the Ball $3 \mathrm{X}$ outage. Occasionally, coolant from the reactor face was discharged to the trench. All but $450 \mathrm{~m}(1500 \mathrm{ft})$ at the inlet has been released from radiological control. The major radionuclides include europium- 152 and -154 , cobalt- 60 , and cesium-137. Sodium dichromate and sulfamic acid are known to have been discharged to the trench.

Solid Waste Disposal Facilities. Solid waste disposal units consisted of burial grounds, landfills, ash/burn pits, and storage caves/vaults. Investigations by Dorian and Richards (1978) found that plutonium-239/240 generally was not detected, that cobalt -60 comprised $90 \%$ of the radionuclide inventory, and other radionuclides included europium-152, $-154,-155$, cesium-134, -137 , strontium-90, and nickel-63.

A total of 28 radioactive burial grounds have been identified in the 100 Area including seven major burial grounds associated with reactor operations, two burial grounds used for biological wastes, and one burial ground used during the tritium separation project at the $100 \mathrm{~B}$ Area. 
Each reactor had an associated burial ground which was used for disposal of high-dose equipment. The total radionuclide inventory for these burial grounds is estimated to be 4,000 $\mathrm{Ci}$, mostly from cobalt -60 and nickel-63. Metallic wastes include lead, cadmium, lead-cadmium alloy, boron, mercury, and graphite. The 118-B-1 burial ground also received waste associated with the tritium separation program, including lithium-aluminum alloy. This waste contained a tritium inventory of about $3,800 \mathrm{Ci}$ and approximately $900 \mathrm{~kg}(2,000 \mathrm{lbs})$ of mercury.

Ball 3X Burial Grounds. The Ball $3 X$ burial grounds were located in the B, D, F, and $\mathrm{H}$ Areas and were used to dispose of highly contaminated waste (containing activation products) removed from the reactor buildings during the Ball $3 \mathrm{X}$ Project. Wastes included thimbles (aluminum components used to provide a sealed access to the reactor for the control and safety rods and for a boron solution used as a shutdown device) and step plugs (an aluminum shielding device used in the reactor tubes). The burial grounds in the $\mathrm{B}, \mathrm{F}$, and $\mathrm{H}$ Areas consisted of a single trench; the D Area burial grounds contained two $12 \times 6 \times 3 \mathrm{~m}(40 \times 20 \times 10 \mathrm{ft})$ trenches. The F Area burial ground was $50 \times 15 \times 5 \mathrm{~m}(175 \times 50 \times 15 \mathrm{ft})$ deep, the B Area burial ground was $15 \times 15 \times 6 \mathrm{~m}(50 \times 50 \times 20 \mathrm{ft})$ deep, and the $\mathrm{H}$ Area burial ground was $46 \times 9 \times 3 \mathrm{~m}(150$ $\times 30 \times 10 \mathrm{ft}$ ) deep.

Tritium Separations Project Burial Ground. Wastes associated with the metal lines used in the tritium separations project were disposed in this burial ground. An estimated 510 metric tons (560 tons) of waste, including 16 metric tons (18 tons) of lead and 23 metric tons (25 tons) of aluminum, were disposed. This included $11,000 \mathrm{Ci}$ of tritium.

Biological Burial Grounds. Two burial grounds in the F Area were used for the disposal of biological wastes. Strontium-90 and plutonium-239/240 are expected contaminants.

Ash Pits. The ash pits received coal ash sluiced with water from the powerhouse. Ash from selected power plants at the Hanford Site has been characterized as nonradioactive and nonhazardous. Common sources of coal were used throughout the site so the ash in the pits will probably be comparable to these analyses. The ash was analyzed using the extraction procedure (EP) toxicity test in accordance with WAC 173-303-090 and no hazardous/dangerous materials were found.

Burn Pits. Burn pits in the 100 Area were used to dispose of nonradioactive combustibles such as paints, solvents, laboratory wastes, and office wastes. Evidence of burning exists at the sites and several of the pits are also believed to have been used to dispose of rubble from demolition projects and debris and soil from retention basin repairs. Other materials which may have been disposed in the burn pits include scrap metal, glass, and asbestos. Sizes of the burn pits range from 890 to $21,000 \mathrm{~m}^{2}\left(9,600\right.$ to $\left.224,000 \mathrm{ft}^{2}\right)$.

Storage Caves/Vaults. The storage caves/vaults were used for temporary storage of horizontal control rods for decay prior to disposal. One vault was used for the storage of miscellaneous reactor hardware and the hardware still remains in the vault. The caves were 12 $\mathrm{m}(40 \mathrm{ft})$ by $8 \mathrm{~m}(25 \mathrm{ft})$ concrete tunnels covered with mounds of dirt. The vault in the F Area was a $5 \times 2.4 \times 2.4 \mathrm{~m}(16 \times 8 \times 8 \mathrm{ft})$ concrete box with a wooden cover. No ir. Cormation is available on specific inventories of radionuclides.

Demolition Sites and Landfills. Demolition sites and landfills in the 100 Area received very low-level construction and demolition wastes. Little or no radiological contamination is expected in these sites. 
Unplanned Releases. Unplanned releases occurred in the 100-F, 100-K, and 100-N Area. The 100-F Area release occurred on March 13, 1971 when the main sewer line between the 141-C and 141-M buildings became plugged. The spill consisted of wash water from the clean out of animal pens and contained strontium-90 and plutonium-239. The area was stabilized with clean gravel.

The unplanned release in the K Area occurred in April 1979 when the 105-KE pickup chute area of the fuel storage basin leaked approximately $1,700 \mathrm{~L} / \mathrm{hr}(450 \mathrm{gal} / \mathrm{hr})$ of fuel storage basin effluent and debris for an unknown period of time. Total activity was estimated at $2,530 \mathrm{Ci}$ including $1.3 \mathrm{Ci}$ of plutonium-239/240.

Documented unplanned releases for the $\mathbf{N}$ Area include:

- two releases associated with the 1314-N Liquid Waste Loadout Station

- two releases at the 119-N Air Sampling and Monitoring Building

- three releases at the $166-\mathrm{N}$ tank farm

- one release at the $116-\mathrm{N}-1$ crib and trench

- two releases at the $1322-\mathrm{N}$ and 1322-NA Sample Buildings

- three releases at the $116-\mathrm{N}-2$ radioactive chemical waste treatment and storage facility

- one release at the 181-N River Pumphouse (that violated NPDES permit conditions)

- $\quad$ six releases at the 1304-N Emergency Dump Tank

- three releases associated with the 118-N-1 Spacer Storage Silos and associated piping

- two releases associated with the $\mathrm{N}$ reactor fuel storage basin and its drainage system

- three significant releases at the 108-N facility associated with unloading and transfer operations (various small spills have occurred over the years; these are the larger ones)

- four significant releases at the 120-N-5 Acid/Caustic Transfer Trench and Neutralization Unit

- two releases associated with the regeneration waste transport system

- three releases associated with the $184-\mathrm{N}$ day tank Area

- five releases from the $166-\mathrm{N}-184-\mathrm{N}$ Pipelines 
- one unplanned release near the 100-N Sewer System.

The RCRA Facility Investigation/Corrective Measures Study Work Plan for the 100NR-1 Operable Unit (DOE-RL 1994f) should be referred to for more detailed information on unplanned releases at the $100-\mathrm{N}$ Area.

Undocumented releases of hydrocarbon products and chemicals may have resulted in contamination of the soils in the 100 Area.

\subsubsection{Physical Characteristics and Components of 100 Area Waste}

Limited characterization of soils has taken place at the 100 Area. Physical properties samples were taken during limited field investigations at 100-BC-1, 100-DR-1, and 100-KR-1. Samples were analyzed for the following parameters using American Society for Testing and Materials (ASTM) methods (where applicable):

- particle size distribution

- $\quad$ specific gravity

- moisture content

- moisture retention

- $\quad$ saturated hydraulic conductivity $\left(\mathrm{K}_{\mathbf{m a d}}\right)$

- porosity.

Samples were taken from 116-DR-1, 116-B-1, and 116-KE-4. The following information on physical properties was taken from Limited Field Investigation Report for the 100-DR-1 Operable Unit (DOE-RL 1993k), Limited Field Investigation Report for the 100-BC-1 Operable Unit (TT Corp. 1993a), and Limited Field Investigation Report for the 100-KR-1 Operable Unit (DOE-RL 1994d). Three split tube samples were collected from vadose borehole 116-DR-1. The samples were dry, slightly gravelly sand, composed of about 5-10\% pebbles and 90-95\% sand. Two split tube samples were collected from vadose borehole 116-B-1. These were dry, dense, sandy gravel composed of about 50\% sand and 50\% gravel. Fcur split spoon samples were collected from vadose borehole 116-KE-4A, at approximately $5 \mathrm{ft}$ intervals. These samples were described in the field as silty sandy gravel with $30 \%$ to $45 \%$ gravel, $45 \%$ to $50 \%$ sand, and $10 \%$ to $25 \%$ silt (fines). Laboratory analysis on particle size showed $49 \%$ to $73 \%$ gravel, $22 \%$ to $42 \%$ sand, and $5 \%$ to $9 \%$ fines.

The specific gravity was determined for both the coarse and fine fraction of the samples. For the 116-DR-1 borehole samples, the average $\mathrm{sG}$ was 2.78 . The average $\mathrm{sG}$ for the 116-B-1 samples was 2.61. Specific gravity was not reported for the $116-\mathrm{KE}-4$ samples.

The moisture contents for the 116-DR-1 borehole samples were $4.05 \%, 3.15 \%$, and $4.01 \%$. For the 116-B-1 borehole, the moisture content of the $22 \mathrm{ft}$ and $27 \mathrm{ft}$ samples were $0.7 \%$ and $1.66 \%$, respectively. The moisture contents for the $116-\mathrm{KE}-4$ borehole samples were $2.46 \%, 3.86 \%$ and $4.49 \%$. These values are consistent with the 116-DR-1 borehole values. 
The hydraulic conductivity ranged from $1.4 \times 10^{-3}$ to $4.9 \times 10^{-3} \mathrm{~cm} / \mathrm{s}$ for the $116-\mathrm{DR}-1$ borehole samples. For the $116-\mathrm{B}-1$ borehole, the hydraulic conductivity ranged from $8.0 \times 10^{-4}$ to $1.6 \times 10^{-3}$. Hydraulic conductivity analysis had not been completed at the publication time of the Limited Fieid Investigation Report for the 100-KR-1 Operable Unit.

The porosity ranged from $35.2 \%$ to $43.2 \%$ for the 116-DR-1 borehole samples. For the 116-B-1 borehole, the porosity ranged from $16.9 \%$ to $25.4 \%$. The porosity ranged from $23.4 \%$ to $27.1 \%$ for the $116-\mathrm{KE}-1$ borehole samples.

100 Area waste includes soil, solid wastes, sediments, and sludges. Solid waste encompasses hard waste, soft waste, demolition waste, and pipes. Soft waste includes collapsed cardboard boxes, paper, rags, clothing, plastic, and miscellaneous trash. Hard waste includes aluminum tubes and spacers, failed steel and stainless steel equipment, timbers, and metal drums. Demolition waste includes concrete with and without rebar, steel plate, and timbers. Pipes range from 1.3 to $61 \mathrm{~cm}(1 / 2$ to 24 in.) in diameter. The estimated percentages of the different types of waste are presented below:

Estimated Distribution of Waste in the 100 Area.

\begin{tabular}{|l|c|}
\hline \multicolumn{1}{|c|}{ Medium } & Percent of Volume \\
\hline Low Activity Soil & $70 \%$ \\
\hline High Activity Soil & $2.2 \%$ \\
\hline Riverbank Sediments, all low activity & $5.3 \%$ \\
\hline $\begin{array}{l}\text { Low Activity Solid Waste } \\
\text { (except pipe >24 inches, diameter) }\end{array}$ & $17 \%$ \\
\hline $\begin{array}{l}\text { High Activity Solid Waste } \\
\text { (except pipe) }\end{array}$ & $1.2 \%$ \\
\hline $\begin{array}{l}\text { Low Activity Pipe } \\
\text { (diameter >24 inches) }\end{array}$ & $5.0 \%$ \\
\hline High Activity Pipe & $0.061 \%$ \\
\hline
\end{tabular}

This breakdown was derived based on the following assumptions:

- $\quad$ All radioactive or radioactive mixed waste removed from contaminated solid media is considered low-level waste. However, in the 100 Area Hanford Past Practice Site Cleanup and Restoration Conceptual Study (WHC 1991b), radioactive waste from the 100 Area is divided into two categories: low activity and high activity wastes. Low activity waste contains less than $100 \mathrm{nCi} / \mathrm{g}$ total transuranium radionuclides and emits beta/gamma radiation at any point resulting in a dose rate less thar. $200 \mathrm{mrem} / \mathrm{hr}$. High activity waste emits beta/gamma radiation at any point resulting in a dose rate greater than $200 \mathrm{mrem} / \mathrm{hr}$, regardless of the activity level of the transuranium radionuclides. 
- Riverbank sediments include all vadose zone soils between the lon and high water elevations of the Columbia River inland to the location where the difference between the high water and low water elevations is minimal. This varies from approximately $15 \mathrm{~m}(48 \mathrm{ft})$ to $55 \mathrm{~m}(180 \mathrm{ft})$ from the river. The riverbank sediments thus represent vadose soils near the river which have been contaminated as a result of fluctuation in the levels of contaminated groundwater which is caused by river stage fluctuations.

The percentages of types of waste are based on the volume estimates from 100 Area Hanford Past Practice Site Cleanup and Restoration Conceptual Study (WHC 1991b) and 100 Area Feasibility Study Phases 1 and 2 (DOE-RL 1992g).

\subsubsection{Chemical Characteristics of 100 Area Waste} evaluation:

The following data sources were used for the 100 Area chemical waste characteristics

- Qualitative Risk Assessment for the 100-BC-1 Source Operable Unit (WHC 1994b)

- Qualitative Risk Assessment for the 100-DR-1 Source Operable Unit (WHC 1994c)

- Qualitative Risk Assessment for the 100-HR-1 Source Operable Unit (WHC 1994d)

- Qualitative Risk Assessment for the 100-KR-1 (WHC 1994e)

- $\quad$ Source Inventory Development Engineering Study for the Environmental Restoration Disposal Facility (U.S. Army Corps of Engineers 1993b).

QRA Data. Analytical data in the Qualitative Risk Assessments (QRAs) were derived from the Limited Field Investigations (LFI) for operable units 100-BC-1, 100-DR-1, 100-HR-1, 100-KR-1 (IT Corp. 1993a, DOE-RL 1993k, IT Corp. 1993b, DOE-RL 1994d) and historical information (Dorian and Richards 1978).

The sampling and analysis conducted for these LFIs were limited in nature, with generally one shallow borehole for each of the high priority waste units. In addition, data from one waste unit were considered representative for analogous waste units at other operable units (for example, all septic tanks were assumed to be analogous to sites 1607-H2 and 1607-H4, pluto cribs or other sites receiving similar liquid waste were considered to be analogous to sites 116-B-3 and 116-D-2A, etc.) and therefore no additional sampling was conducted at these analogous waste units. The analogous site approach is consistent with the Hanford Past Practice Strategy (DOE-RL 1992f). The analogous sites list is presented in Appendix H of the Source Inventory Development Engineering Study for the Environmental Restoration Disposal Facility (U.S. Army Corps of Engineers 1993b). LFIs did not address chemical characteristics of the burial grounds. In general, limited information is available regarding constituents in the burial grounds. 
In the QRAs, the concentration used for risk assessment was the maximum of the LFI and historical data for samples located in the upper $4.6 \mathrm{~m}(15 \mathrm{ft})$ of soil. For the purposes of this evaluation, maximum concentrations were selected from LFI and historical data regardless of sample depth.

Source Inventory Data. Data for the 100-NR-1 operable unit and data for the septic tank waste units were taken from the Source Inventory Development Engineering Study for the Environmental Restoration Disposal Facility (U.S. Army Corps of Engineers 1993b) since these data were not available in the QRAs.

Data Compilation. Tables 3-1, 3-2, and 3-3 contain the 100 Area summaries of the maximum concentrations for radionuclides, organic compounds, and chemistry data, respectively. Summary tables also reference the waste site where the maximum concentration was encountered.

\subsection{AREA WASTE CHARACTERISTICS}

The information in this section was derived from unpublished documents.

\subsubsection{Waste Generating Activities}

Historically, the 200 Areas were used for fuel reprocessing, plutonium recovery, and waste management and disposal. Because of significant human health and environmental risks associated with the excavation of the majority of contaminated sites in the 200 Areas, in-situ remediation methods will probably be used for most sites. For the purposes of this document, it is assumed that only the sites with lower environmental risks will be excavated and placed in the ERDF, as discussed below.

\subsubsection{Waste Units}

There are two primary groupings of waste units: 1) low-activity sites where radioactive contamination produces radiation dose rates below $200 \mathrm{mrem} / \mathrm{hr}$ and 2) high-activity sites where radiation dose rates are above $200 \mathrm{mrem} / \mathrm{hr}$. High-activity sites include a diversity of highly contaminated materials in a variety of underground structures, including cribs, burial grounds, and trenches. For the purpose of this document, it is assumed that higher activity sites will likely be stabilized in place and capped with a protective barrier. The low-activity sites at the 200 Areas resulted from various unplanned releases of radioactive materials and/or from the wind-blown dispersion of radioactive materials. The contaminated media at low-activity sites is almost exclusively soil, with smaller (approximately $10 \%$ of total quantity) quantities of other materials such as pipe Low-activity sites are generally not contaminated below a depth of 15 $\mathrm{cm}$ (6 in). For the purpose of this document, it is assumed that these sites will be excavated and the resulting waste materials will be treated and placed at the ERDF. These sites are grouped into migration sites, and pipelines and ancillary structures, as described below.

Migration Sites. There are 24 migration sites located in and adjacent to the 200-East and 200-West Areas. Many of these migration sites include unplanned release sites which are identified as surface contamination sites, several of which have been partially remediated by 
removal of contaminated soil and the addition of stabilizing backfill. The majority of these migration sites were associated with spills and leaks of radioactive and mixed liquid wastes. The quantities of spills and leaks ranged from a few liters to thousands of liters.

Pipelines. An extensive network of pipelines and ancillary equipment was used to transfer liquid wastes from the generating source to disposal areas, and from one disposal area to another. Pipelines (also referred to as transfer lines, process lines, and process sewer lines) vary in materials of construction (from stainless steel to vitrified clay), size (from $5 \mathrm{~cm}$ (2 in.) to $150 \mathrm{~cm}$ (60 in.) in diameter), and length (from a few meters to several thousand meters).

Ancillary equipment used includes valve pits, pumps, pumphouses, transfer boxes, diversion boxes, instrumentation, localized sumps, pits, and storage pads. The materials of construction, operations and maintenance, and years of service varied.

Pipelines and ancillary equipment are the most frequently referenced source of unplanned releases. Pipeline failures were associated with unplanned releases as a result of corrosion, joint expansion or contraction, rupture from construction activities, thermal expansion and other means of failure. Ancillary equipment was associated with unplanned releases as a result of failed seals, corrosion, material failure, overflow or overtopping, plugging and other similar events. Many of the older pipelines most likely have contaminated soils along some portion of their lengths.

\subsubsection{Physical Characteristics and Components of 200 Area Waste}

A breakdown of the components of 200 Area waste that will likely be disposed in the ERDF is presented below. The percentages are based on relative volume estimates. There is no information available on physical characterization of 200 Area soils likely to be disposed in the ERDF.

\section{Components of 200 Area Waste}

\begin{tabular}{|l|c|}
\hline \multicolumn{1}{|c|}{ Source } & Percentage \\
\hline Migration Sites & $75 \%$ \\
\hline Pipelines & $25 \%$ \\
\hline
\end{tabular}

\subsubsection{Chemical Characteristics of 200 Area Waste}

No analytical data has been located for the pipeline sites and only radionuclide data was found for migration sites. These radionuclide data are summarized in Table 3-4. Only radionuclides with one or more values greater than $1 \mathrm{pCi} / \mathrm{g}$ are reported. 


\subsection{AREA WASTE CHARACTERISTICS}

\subsubsection{Waste Generating Activities}

The information in this section is derived primarily from Phase I Remedial Investigation Report for the 300-FF-1 Operable Unit (DOE-RL 1993f), Phase I Remedial Investigation Report for the 300-FF-5 Operable Unit (DOE-RL 1993g), and Source Inventory Development Engineering Study for the Environmental Restoration Disposal Facility (U.S. Army Corps of Engineers 1993b).

Activities in the 300 Area have historically been related primarily to the fabrication of nuclear fuel elements. In addition, many technical support, service support, and research and development activities related to fuel fabrication were carried out. As fuel fabrication activities have decreased with the shut-down of the Hanford Site production reactors, research and development activities in the 300 Area have increased. The newer buildings in the area house primarily laboratory and large test facilities.

3.3.1.1 Fuel Fabrication. Fuel elements vere fabricated in the 300 Area by a coextrusion process. This process formed the zirconium cladding and the uranium/silicon fuel core from primary material components and bonded the two together in one operation. The fuel elements were protected with a copper jacket for the extrusion process. The jacket also prevented atmospheric contamination of the reactive fuel element, and the copper was easily lubricated for extrusion. Lubricants were removed using organic solvents such as trichloroethylene. After extrusion into billets, the copper was removed by dissolution in nitric acid (Stenner et al. 1988).

The uranium core was recessed by chemical milling so that the billets could receive an end cap. The chemical milling was performed using copper sulfate, nitric acid, and sulfuric acid. A zirconium end cap was then brazed on with beryllium. The fuel elements were tested for cap attachment, cap to core bonding, cladding to core bonding, and cladding to cap bonding before fuel-element supports and locking clips were attached. Next, the tubes were autoclaved in steam to detect any perforations in the cladding or end caps. Finally, the elements were packed for storage and shipment (Stenner et al. 1988).

Prior to the late 1960 's, aluminum-clad fuel was manufactured in the 300 Area as well, and thorium fuel fabrication was initiated in 1969 (Stenner et al. 1988).

Other chemicals routinely used in the fuel fabrication processes included (Douglas United Nuclear 1967; Stenner et. al. 1988):

chromic acid chromium trioxide hydrofluoric acid oxalic acid phosphoric acid potassium nitrite sodium aluminate sodium bisulfate sodium carbonate sodium dichromate sodium fluorosilicate sodium gluconate sodium hydroxide sodium nitrate sodium nitrite sodium pyrophosphate sodium silicate. 
3.3.1.2 Laboratory Operations. Many of the laboratory buildings in the 300 Area provided support for fuel fabrication process development. The wastes generated by these facilities are probably of a nature similar to that of the process wastes.

The research and development activities generated waste radioactive fission products, most of which were discharged to the radioactive liquid waste sewer system. Some of these substances, however, occasionally entered the process sewer. Radioactive isotopes known to be generated in the 300 Area include (Douglas United Nuclear 1967):

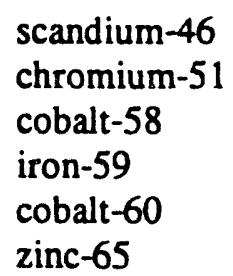

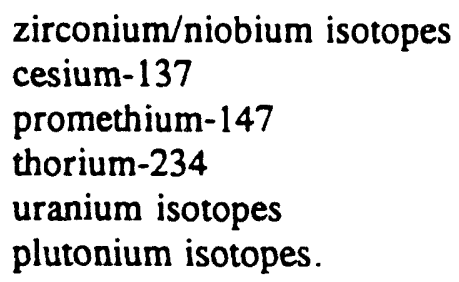

Current research and development activities focus on peaceful uses of plutonium, liquid metal technology, fast-flux test facility support, gas-cooled reactor development, life science research, and Tri-Party Agreement support.

3.3.1.3 Miscellaneous Operations. Other operations at the 300 Area include(d) sign shop operations which discharged photochemicals to the sanitary sewer system, powerhouse generation which generated flyash when coal was burred, and water treatment.

\subsubsection{Waste Units}

The information in this section was primarily derived from Source Inventory Development Engineering Study for the Environmental Restoration Disposal Facility (U.S. Army Corps of Engineers 1993b) and Phase I Remedial Investigation Report for the 300-FF-1 Operable Unit (DOE-RL 1993f).

Process Sewer System. The process sewer system receives or has received pricess water from fuel fabrication operations, cooling water, steam condensate, water treatment processes, and a wide variety of waste liquids from laboratory drains throughout the 300 Area. Due to the number of laboratories in the area, and the diverse nature of the research and development activities over the years, a wide range of chemicals may have been discharged to the system. Numerous chemical spills are known to have entered the process sewer system through the many floor drains in 300 Area buildings.

300 Area Radioactive Liquid Waste Sewer. This sewer has been in use since 1954. It receives radioactive wastes from various 300 Area research and development laboratories. Wastes consist primarily of water with small quantities of various chemicals from the laboratories, decontamination solutions, and acids and bases. Waste is accumulated in stainless steel tanks at the 340 Complex. The waste is stored for less than 90 days and is then transported to the 200 West Area for storage and disposal.

Process Ponds and Trenches. The south process pond received liquid wastes from the process sewer, including cooling water, low-level liquid wastes, and organic wastes. This pond contained large amounts of copper and uranium, but most of these contaminants were removed 
when the bottom of the unit was periodically dredged. The north process pond received liquid waste from the process sewer. Liquid wastes were also trucked to the pond from fuel fabrication operations. The north process pond scraping disposal area was used to dispose of dredged soils from the north process pond as well as flyash (Stenner et al. 1988).

The process trenches constitute the active liquid process waste disposal facility for the 300 Area. They receive condensates, janitorial solutions from cleaning floors, water treatment wastes (mainly salt), laboratory wastes, ethylene glycol, process water from fuel fabrication, and other aqueous solutions. No dangerous wastes have been intentionally discharged to the unit since November 1985. An unplanned release of ethylene glycol occurred in 1994. Sediments in these trenches were removed from contact with infiltrating process water during a 1991 expedited response action (ERA).

The retired 307 disposal trenches were used from 1953 to 1963 . These received wastes from the Hot Semiworks Laboratory area and sludge from 316-1 pond. Wastes went through the 307 retention basin before being released to this unit. The 307 retention basin consisted of four $190,000 \mathrm{~L}(50,000 \mathrm{gal})$ basins.

Sanitary Sewer System. Sewage from the 300 Area is routed through vitreous tile pipes to septic tanks. Overflow from the septic tanks drains into the sanitary trenches. In addition to sanitary wastes from the 300 Area, the sanitary sewer system received an estimated $4 \mathrm{~L} / \mathrm{wk}(1 \mathrm{gal} / \mathrm{wk})$ of miscellaneous photochemicals from sign shop operations. Current sign and paint shop contributions consist of trace, nonhazardous concentrations of carry-over fixers, developers, inks, thinners, solvents, and rinsewaters from the spray booth fume scrubbing system (DOE-RL 1989). The 315, 335, and 336 retired sanitary drain fields received sanitary waste from office buildings.

Ash Pits. Coal flyash generated from the convertible fuel power house for the 300 Area is suspended in a water slurry and transported to the two ash pits within 300-FF-1 operable unit. Once the flyash dries, it is currently hauled for disposal to a pit west of the 300 Area (DOE-RL 1989). In the past, these ashes have been deposited in areas of the north process pond and were used, in part, to backfill the 307 trenches (Dennison et al. 1989; Schalla et al. 1988).

Burial Grounds. Little historical information is available on the burial grounds within the 300-FF-1 operable unit. Burial ground No. 4 is only known to contain miscellaneous materials which are contaminated with uranium (Stenner et al. 1988). It is not known whether liquid wastes were disposed here. Burial ground No. 5 was a trash burning pit from 1945 through 1962. Some of the trash was contaminated with uranium (Stenner et al. 1988). The site was also used as an above-ground storage area for uranium-bearing materials (U.S. Army Corps of Engineers 1993b).

The solid waste burial grounds in the 300-FF-2 operable unit consisted of trenches and/or pits for the disposal of waste products primarily from fuel fabrication with some laboratory waste. Wastes contained plutonium and fission products, uranium-contaminated equipment, and solid metallic uranium oxides. Burial ground No. 1 was primarily used for disposal of plutonium and fission products from the 300 Area laboratories. Burial ground No. 2 was primarily used for disposal of solid metallic uranium oxides in the form of metal cuttings from reactor fuel fabrication facilities in the 300 Area. The solid waste burial ground No. 3 was primarily used for the disposal of uranium waste in the form of contaminated building 
material derived from the 313 buildings. Burial ground No. 6 no longer exists. Solid waste burial ground No. 7 also contains drummed containers of solvent with moderate amounts of uranium. This material was segregated and disposed in this site because of the pyrolytic and explosive hazard of the solvent. Materials buried at this site were derived primarily from the 321 Building. Burial ground No. 8 was used for disposal of uranium-contaminated solid waste derived from reactor fuels manufacturing. Burial ground No. 9 has been excavated but previously contained drums of uranium-contaminated solvent. The 300 North Solid Waste Burial Ground (618-10) and the 300 Wye Burial Ground (618-11) consisted of trenches and vertical pipe storage units. Low-level wastes were buried in the trenches and high-level wastes were stored in the pipe units. Burial ground No. 13 (the 303 Area Contaminated Soil Burial Site) received topsoil containing radioactive contaminants from the 303 Building area (U.S. Army Corps of Engineers 1993b). The 300 West burial ground contained drums of uraniumcontaminated organic solvent from the 321 Building, but the solvent and other debris were removed from the site.

Storage Tanks. Storage tanks were used in the 300 Area for storing the following:

- radioactive wastes from the Plutonium Recycle Test Reactor

- methanol for use as a drying agent for the aluminum cleaning process

- $\quad$ neutralized liquid from the nonrecoverable uranium stream and filtrate from processing of uranium-bearing waste stream from the 313 Building recovery operations

- uranium-contaminated water and acid solutions from reprocessing research and development

- waste acids containing nonrecoverable uranium from the fuel fabrication process

- $\quad$ spent etch acids (nitric and sulfuric acid with uranium in solution)

- materials contaminated with alkali metal wastes.

Tanks were also used for evaporation of radioactive contaminated spent solvents generated in the fuel fabrication process.

Ion Exchange Vaults. These sites consist of underground vaults with ion exchange columns inside. The reactor ion exchange pit and vault were used to remove contaminants from heavy water coolant and shield cooling systems. The rupture loop ion exchange pit was used to remove contaminants and fission fragments from light water coolant.

Hazardous Material and Waste Storage Areas. Hazardous waste and material storage areas were, and are presently, used in the 300 Area for staging and storing the following materials:

- waste oils

- waste oils contaminated with uranium 
- $\quad$ waste oils contaminated with PCBs

- uranium and beryllium/zirconium metal chips and fines

- byproduct waste materials from the fuel fabrication process

- corrosives and ignitables

- $\quad$ solidified waste heat-treat salts from the Fuel Fabrication Facility

- uranium scrap (to be used in recovery)

- $\quad$ solvents and paint shop solids from paint shop operations

- wastes from the alkali metal treatment facility, including sodium, lithium, and sodium-potassium alloys.

300 Area Waste Acid Treatment System. Equipment associated with this treatment system includes the 313 filter press, the 313 waste acid neutralization tank and the 313 centrifuge.

316-4 Crib. This crib was active from 1948 until 1955 or 1956 . It received hexonebearing uranium wastes and limited amounts of other uranium-bearing wastes from the 321 buildings. Liquid containing a total of $560 \mathrm{~kg}(1,230 \mathrm{lb})$ of uranium was discharged to this site.

3718-F Burn Shed. This facility has been inactive since 1968. Wastes consisted of sodium, lithium, and sodium-potassium alloys.

Unplanned Releases. Unplanned releases included releases to the process sewer system (with ultimate disposal in the north process pond, south process pond, or process trenches) a release to burial ground No. 4, and airborne contamination. Releases to the process sewer included waste acids, uranium contaminated acid, degreasing solvent and deoxidation chemicals. The release at burial ground No. 4 constituted the improper disposal of depleted uranium fuel elements.

\subsubsection{Physical Characteristics and Components of 300 Area Waste}

The information in this section was derived from Phase I Remedial Invesigation Report for the 300-FF-1 Operable Unit (DOE-RL 1993f) and 300 Area Cleanup and Restoration Conceptual Study (WHC 1991c) unless otherwise noted.

Limited characterization of soils took place at the 300 Area during the $300-\mathrm{FF}-1$ Operable Unit Remedial Investigation. Based on dry soil sieve analysis, soils in the 300 Area can generally be described as "gravel, some sand with trace fines". More specifically, the soil samples were composed of approximately $1.5 \%$ fines, $29 \%$ sand and $70 \%$ gravel (a small fraction of which may be classified as cobbles) by percent weight. Sieve analysis was not conducted for cobbles. The sand portion of the soil may further be classified as medium sand (67\%) (DOE-RL 1994b). The specific gravity (sG) was determined for both the coarse and fine fraction of the samples. The specific gravity for the fine samples ranged from 2.67 to 2.87 , 
with an average of 2.77. The specific gravity for the coarse samples ranged from 2.61 to 2.75 , with an average of 2.70 . The average overall specific gravity was 2.74 . The dry density ranged from 1.49 to $2.28 \mathrm{~g} / \mathrm{cc}$, with an average of $1.94 \mathrm{~g} / \mathrm{cc}$. The moisture content varied from 1.4 to $35.0 \%$, with an average of $8.1 \%$. The porosity ranged from 19.2 to $44.8 \%$, with an average of $29.1 \%$.

300 Area waste includes soil and solid wastes. Sites have been grouped into four categories based on similarities of cleanup requirements: (1) unplanned releases, (2) process sewer piping, (3) process ponds and trenches, and (4) burial grounds.

The components of 300 Area waste are summarized below:

Components of 300 Area Waste

\begin{tabular}{|l|c|}
\hline \multicolumn{1}{|c|}{ Source } & Percentage \\
\hline Unplanned Releases & $7 \%$ \\
\hline Process Sewer Piping Units & $17 \%$ \\
\hline Process Ponds and Trenches & $40 \%$ \\
\hline Burial Grounds & $36 \%$ \\
\hline
\end{tabular}

\subsubsection{Chemical Characteristics of 300 Area Waste}

Analy'ical data from the field investigations for operable unit 300-FF-1 (DOE-RL 1990a) were used for the 300 Area chemical waste characteristics evaluation. The maximum concentration in the $300-\mathrm{FF} 1$ operable unit for each detected constituent was identified. Tables 3-5, 3-6, and 3-7 contain the 300 Area summaries of the maximum concentrations for radionuclides, organic compounds and chemistry data, respectively. Summary tables also provide the reference information for the waste site where the maximum concentration was encountered.

\subsection{MAXIMUM ERDF WASTE CONCENTRATIONS AND BACKGROUND SCREENING}

Table 3-8 presents the maximum soil concentration in 100, 200, and 300 Area waste for radionuclides. Tables 3-9, and 3-10 present the maximum soil concentrations in 100 and 300 Area wastes for organic compounds and inorganic constituents, respectively. These concentrations are considered representative of the maximum concentration in wastes to be received at the ERDF. The tables also list the waste units where the maximum concentrations occurred. Maximum soil concentrations for organic compounds and inorganic constituents for 200 Area wastes are not included on Tables 3-9 and 3-10 because 200 Area wastes have not been sufficiently characterized.

Table 3-10 also includes Hanford Site background screening for inorganic constituents. Maximum concentrations of constituents detected in soil were compared to Hanford Site background values as a first step in identifying contaminants of potential concern. Background 
concentrations were only available for inorganic constituents. Background levels for organics and radionuclides are not provided because they are generally not naturally occurring or are below detection limits at the Hanford Site. (Note that uranium and some other radionuclides are present at detectable levels in background soils and groundwater). Hanford Site background concentrations were obtained from Table 6-9.b in Hanford Site Background: Part 1, Soil Background for Nonradioactive Analytes (DOE-RL 1993i). The 95/95 upper tolerance limit (UTL) results were used (noted as the "95\% upper confidence limit (UCL)" in Table 6-9.b). The $95 / 95$ UTL is the $95 \%$ UCL on the 95 th percentile. These values are based on lognormal distributions (the title of the table is incorrect; the values are not based on Weibull distributions).

If the ERDF maximum waste concentration exceeded the Hanford soil background concentration, the concentration was considered to be representative of actual contamination and the constituent was retained for further evaluation. Maximum waste concentrations for chloride, nitrate and phosphate were less than background concentrations. Therefore, chloride, nitrate and phosphate were eliminated from further evaluation. The nitrite plus nitrate concentration was compared to the $95 / 95$ UTL for nitrate and this parameter was also eliminated. All other constituents were retained for further evaluation. 
Table 3-1. Maximum Concentrations for Radionuclides in 100 Area Wastes. (Sheet 1 of 2)

\begin{tabular}{|c|c|c|}
\hline Radionuclide & $\begin{array}{l}\text { Maximum } \\
\text { Concentration } \\
(\mathrm{pCi} / \mathrm{g})\end{array}$ & Waste Unit \\
\hline Americium-241 & 34 & 116-C-5 Retention Basin \\
\hline Barium-140 & 400 & 116-D-1A Storage Basin Trench No. 1 \\
\hline Beryllium-7 & 90 & 116-D-1A Storage Basin Trench No. 1 \\
\hline Carbon-14 & 640 & 116-C-5 Retention Basin \\
\hline Cerium-141 & 3 & 116-D-1A Storage Basin Trench No. 1 \\
\hline Cerium-144 & 0.5 & 116-D-1A Storage Basin Trench No. 1 \\
\hline Cesium-134 & 56 & $116-\mathrm{B}-11$ \\
\hline Cesium-137 & 110,000 & Process effluent pipeline (BC1) \\
\hline Cobalt -58 & 14.1 & 116-DR-1 Liquid Waste Disposal Trench No. 1 \\
\hline Cobalt -60 & 11,000 & (HR1) Process effluent pipeline (sludge) \\
\hline Europium-152 & 29,000 & $116-\mathrm{B}-11$ \\
\hline Europium-154 & 9,200 & 116-D-7 \\
\hline Europium-155 & 9,600 & Process effluent pipeline (BC1) \\
\hline Gross Alpha & 78 & 116-K-2 Miscellaneous Trench \\
\hline Gross Beta & 3,700 & 116-C-5 Retention Basin \\
\hline Iron-59 & 1 & 116-D-1A Storage Basin Trench No. 1 \\
\hline Manganese-54 & 0.07 & 116-D-1A Storage Basin Trench No. 1 \\
\hline Nickel-63 & 62,000 & Process effluent pipeline (BC1) \\
\hline Plutonium-238 & 140 & Process effluent pipeline (BC1) \\
\hline Plutonium-239/240 & 2,800 & Process effluent pipeline (BC1) \\
\hline Potassium-40 & 33 & 116-H-7 Retention Basin \\
\hline Radium-226 & 42.8 & 116-D-1A Storage Basin Trench No. 11 \\
\hline Ruthenium-103 & 1 & 116-D-1A Storage Basin Trench No. 1 \\
\hline Ruthenium-106 & 0.8 & 116-D-1A Storage Basin Trench No. 1 \\
\hline Sodium-22 & 9.9 & 116-DR-1 Liquid Waste Disposal Trench No. 1 \\
\hline Strontium-90 & 2,000 & Process effluent pipeline (BC1) \\
\hline Technetium-99 & 1.1 & 116-DR-2 Liquid Waste Disposal Trench No. 2 \\
\hline Thorium-228 & 8.6 & H-2 Septic Tank \\
\hline Thorium-232 & 1.4 & 116-KW-3B Retention Basin \\
\hline Thorium-234 & 1 & 116-D-1A Storage Basin Trench No. 1 \\
\hline
\end{tabular}


DOE/RL-93-99, Rev. 0

Table 3-1. Maximum Concentrations for Radionuclides in 100 Area Wastes. (Sheet 2 of 2)

\begin{tabular}{|l|c|l|}
\hline \multicolumn{1}{|c|}{ Radionuclide } & $\begin{array}{c}\text { Maximum } \\
\text { Concentration } \\
(\mathrm{pCi} / \mathrm{g})\end{array}$ & \multicolumn{1}{|c|}{ Waste Unit } \\
\hline Tritium & 29,000 & $116-\mathrm{B}-5$ \\
\hline Uranium-233/234 & 17 & $116-\mathrm{KW}-3 \mathrm{~B}$ Retention Basin \\
\hline Uranium-235 & 1.7 & $116-\mathrm{KW}-3 \mathrm{~B}$ Retention Basin \\
\hline Uranium-238 & 17 & $116-\mathrm{KW}-3 \mathrm{~B}$ Retention Basin \\
\hline Zinc-65 & 0.3 & 116-D-1A Storage Basin Trench No. 1 \\
\hline Zirconium-95 & 0.56 & $116-\mathrm{H}-7$ Retention Basin \\
\hline
\end{tabular}


Table 3-2. Maximum Concentrations for Organic Compounds in 100 Area Wastes. (Sheet 1 of 3)

\begin{tabular}{|c|c|c|}
\hline Compound & $\begin{array}{c}\text { Maximum } \\
\text { Concentration } \\
(\mu \mathrm{g} / \mathrm{kg})\end{array}$ & Waste Unit \\
\hline \multicolumn{3}{|c|}{ VOLATILE ORGANIC COMPOUNDS } \\
\hline 1,1,1-Trichloroethane & 6 & 100-D-Pond \\
\hline 1,1,2,2-Tetrachloroethane & 3 & 100-D-Pond \\
\hline 2-Butanone & 390 & 100-D-Pond \\
\hline 2-Hexanone & 9 & 100-D-Pond \\
\hline 4-Methyl-2-Pentanone & 11 & 116-B-2 Storage Basin Trench \\
\hline Acetone & 2,800 & $\begin{array}{l}\text { UN-100-N-17 Diesel Oil Supply } \\
\text { Line Leak }\end{array}$ \\
\hline Benzene & 190 & $\begin{array}{l}\text { UN-100-N-17 Diesel Oil Supply } \\
\text { Line Leak }\end{array}$ \\
\hline Carbon Disulfide & 200 & 116-B-5 Crib \\
\hline Carbon Tetrachloride & 8 & $116 \mathrm{~N} 1$ \\
\hline Chloroform & 4 & 130-D-1 Gasoline Storage Tank \\
\hline Ethylbenzene & 330 & $\begin{array}{l}\text { UN-100-N-17 Diesel Oil Supply } \\
\text { Line Leak }\end{array}$ \\
\hline Methylene Chloride & 110 & 100-D-Pond \\
\hline Tetrachloroethene & 4 & 116-K-2 Effluent Trench \\
\hline Toluene & 77 & 116-B-5 Crib \\
\hline Trichloroethene & 6 & $\begin{array}{l}\text { 116-DR-9C Process Effluent } \\
\text { Retention Basin }\end{array}$ \\
\hline Xylenes (Total) & 1,100 & 130-D-1 Gasoline Storage Tank \\
\hline \multicolumn{3}{|c|}{ SEMIVOLATILE ORGANIC COMPOUNDS } \\
\hline 1,3-Dichlorobenzene & 48 & $\begin{array}{l}\text { 116-DR-1 Liquid Waste Disposal } \\
\text { Trench No. } 1\end{array}$ \\
\hline 1,4-Dichlorobenzene & 51 & $\begin{array}{l}\text { 116-N-2 Chemical Waste Storage } \\
\text { Tank }\end{array}$ \\
\hline 2-Methylnaphthalene & 13,000 & UN-100-N-17 \\
\hline 4-Chloro-3-Methylphenol & 38 & $\begin{array}{l}\text { 116-DR-1 Liquid Waste Disposal } \\
\text { Trench No. } 1\end{array}$ \\
\hline Acenaphthene & 210 & $\begin{array}{l}\text { 116-H-1 Liquid Waste Disposal } \\
\text { Trench }\end{array}$ \\
\hline Anthracene & 6,300 & UN-100-N-17 \\
\hline
\end{tabular}


Table 3-2. Maximum Concentrations for Organic Compounds in 100 Area Wastes.

(Sheet 2 of 3)

\begin{tabular}{|c|c|c|}
\hline Compound & $\begin{array}{c}\text { Maximum } \\
\text { Concentration } \\
(\mu \mathrm{g} / \mathrm{kg})\end{array}$ & Waste Unit \\
\hline Benzo(a)anthracene & 1,800 & $\begin{array}{l}\text { 1607-H-4 Septic Tank Discharge } \\
\text { Pipe }\end{array}$ \\
\hline Benzo(a)pyrene & 940 & $\begin{array}{l}\text { 1607-H-4 Septic Tank Discharge } \\
\text { Pipe }\end{array}$ \\
\hline Benzo(b)fluoranthene & 2,400 & $\begin{array}{l}\text { 1607-H-4 Septic Tank Discharge } \\
\text { Pipe }\end{array}$ \\
\hline Benzo(g,h,i)perylene & 460 & $\begin{array}{l}\text { 1607-H-4 Septic Tank Discharge } \\
\text { Pipe }\end{array}$ \\
\hline Benzo(k)fluoranthene & 760 & $\begin{array}{l}\text { 116-H-1 Liquid Waste Disposal } \\
\text { Trench }\end{array}$ \\
\hline Bis(2-ethylhexyl)phthalate & 5,500 & 130-D-1 Gasoline Storage Tank \\
\hline Butylbenzylphthalate & 2,600 & 130-D-1 Gasoline Storage Tank \\
\hline Carbazole & 54 & $\begin{array}{l}\text { 116-D-1B Fuel Storage Basin } \\
\text { Trench No. } 2\end{array}$ \\
\hline Chrysene & 920 & $\begin{array}{l}\text { 116-H-1 Liquid Waste Disposal } \\
\text { Trench }\end{array}$ \\
\hline Di-n-butylphthalate & 1,100 & $120-D-1$ \\
\hline Dibenzofuran & 130 & $\begin{array}{l}\text { 116-H-1 Liquid Waste Disposal } \\
\text { Trench }\end{array}$ \\
\hline Diethylphthalate & 1,000 & 100-D-Pond \\
\hline Fluoranthene & 2,900 & $\begin{array}{l}\text { 1607-H4 Septic Tank Discharge } \\
\text { Pipe }\end{array}$ \\
\hline Fluorene & 1,700 & UN-100-N-17 \\
\hline Indeno(1,2,3-cd)pyrene & 520 & $\begin{array}{l}\text { 116-H-1 Liquid Waste Disposal } \\
\text { Trench }\end{array}$ \\
\hline Naphthalene & 4,100 & UN-100-N-17 \\
\hline N-Nitrosodiphenylamine & 110 & 116-B-2 Storage Basin Trench \\
\hline Pentachlorophenol & 920 & 116-C-5 Retention Basin \\
\hline Phenanthrene & 2,500 & UN-100-N-17 \\
\hline Phenol & 240 & 100-D-Pond \\
\hline Pyrene & 2,700 & $\begin{array}{l}\text { 1607-H4 Septic Tank Discharge } \\
\text { Pipe }\end{array}$ \\
\hline
\end{tabular}


DOE/RL-93-99, Rev. 0

Table 3-2. Maximum Concentrations for Organic Compounds in 100 Area Wastes.

(Sheet 3 of 3)

\begin{tabular}{|l|c|l|}
\hline \multicolumn{1}{|c|}{ Compound } & \multicolumn{1}{|c|}{$\begin{array}{c}\text { Maximum } \\
\text { Concentration } \\
(\mu \mathrm{g} / \mathrm{kg})\end{array}$} & \multicolumn{1}{|c|}{ Waste Unit } \\
\hline PESTICIDES/AROCLORS & 110 & $\begin{array}{l}1607-\text { H4 Septic Tank Discharge } \\
\text { Pipe }\end{array}$ \\
\hline $4,4^{\prime}$-DDD & 170 & $100-$ D-Pond \\
\hline $4,4^{\prime}$-DDE & 6,400 & $190-$ B \\
\hline Aroclor-1254 & 2,300 & $100-$ D-Pond \\
\hline Aroclor-1260 & 7.8 & $\begin{array}{l}116-\text { D-1A Fuel Storage Basin } \\
\text { Trench No. 1 }\end{array}$ \\
\hline Beta-HCH (Beta-BHC) & 18 & $\begin{array}{l}\text { 1607-H4 Septic Tank Discharge } \\
\text { Pipe }\end{array}$ \\
\hline Chlordane, Gamma- & 21 & $\begin{array}{l}\text { 116-D-1A Fuel Storage Basin } \\
\text { Trench No. 1 }\end{array}$ \\
\hline Dieldrin & 83 & \begin{tabular}{l} 
100-D-Pond \\
\hline
\end{tabular} \\
\hline
\end{tabular}


Table 3-3. Maximum Concentrations for Inorganic and General Chemistry Constituents in 100 Area Wastes. (Sheet 1 of 2)

\begin{tabular}{|c|c|c|}
\hline Constituent & $\begin{array}{c}\text { Maximum } \\
\text { Concentration } \\
(\mathrm{mg} / \mathrm{kg})\end{array}$ & Waste Unit \\
\hline \multicolumn{3}{|c|}{ INORGANIC CONSTITUENTS } \\
\hline Aluminum & 78,400 & 100-D Pond - Liquid Waste Disposal \\
\hline Antimony & 18.6 & H-2 Septic Tank \\
\hline Arsenic & 62.2 & 100-D Pond - Liquid Waste Disposal \\
\hline Barium & 4,260 & H-2 Septic Tank \\
\hline Beryllium & 4.7 & 116-H-9 Crib \\
\hline Cadmium & 28.5 & H-2 Septic Tank \\
\hline Calcium & 79,000 & 116-H-9 Crib \\
\hline Cobalt & 90.4 & 116-KW-3B Retention Basin \\
\hline Copper & 627 & H-2 Septic Tank \\
\hline Chromium & 2,510 & H-2 Septic Tank \\
\hline Iron & 184,000 & 116-H-9 Crib \\
\hline Lead & 564 & 116-C-5 Retention Basin \\
\hline Magnesium & 50,000 & 116-H-9 Crib \\
\hline Manganese & 3,050 & 116-H-9 Crib \\
\hline Mercury & 37 & H-2 Septic Tank \\
\hline Nickel & 132 & 116-H-9 Crib \\
\hline Potassium & 13,000 & 116-H-9 Crib \\
\hline Selenium & 11.1 & 100-D Pond - Liquid Waste Disposal \\
\hline Silver & 119 & H-2 Septic Tank \\
\hline Sodium & 2,010 & 116-H-9 Crib \\
\hline Thallium & 5.4 & H-2 Septic Tank \\
\hline Vanadium & 389 & 116-H-9 Crib \\
\hline Zinc & 6,160 & H-2 Septic Tank \\
\hline \multicolumn{3}{|c|}{ GENERAL CHEMISTRY } \\
\hline Chloride & 13.1 & 116-C-5 Retention Basin \\
\hline Chromium VI & 5.03 & 116-C-5 Retention Basin \\
\hline Fluoride & 4.4 & 116-B-3 Pluto Crib \\
\hline Nitrate & 122.3 & 116-B-5 Crib \\
\hline Nitrate/Nitrite & 37 & 116-C-5 Retention Basin \\
\hline
\end{tabular}


DOE/RL-93-99, Rev. 0

Table 3-3. Maximum Concentrations for Inorganic and General Chemistry Constituents in 100 Area Wastes. (Sheet 2 of 2)

\begin{tabular}{|l|r|l|}
\hline \multicolumn{1}{|c|}{ Constituent } & $\begin{array}{c}\text { Maximum } \\
\text { Concentration } \\
(\mathrm{mg} / \mathrm{kg})\end{array}$ & Waste Unit \\
\hline Nitrite & 1.2 & H-2 Septic Tank \\
\hline Phosphate & 15 & $116-\mathrm{KW}-3$ B Retention Basin \\
\hline Sulfate & 7,115 & H-2 Septic Tank \\
\hline
\end{tabular}


Table 3-4. Maximum Radionuclide Concentrations Detected in Soils in 200 Area Waste Units.

\begin{tabular}{|c|c|c|c|c|c|c|c|c|}
\hline Constituent & U Plant ${ }^{a}$ & Z Plant $b$ & $S$ Plant $c^{C}$ & T Plant & PUREXe & B Plant $\mathrm{f}$ & $\begin{array}{c}\text { Semi- } \\
\text { Worksg }\end{array}$ & $\begin{array}{c}\text { Max. } \\
\text { Concentration } \\
(\mathrm{pCi} / \mathrm{g})\end{array}$ \\
\hline Cesium-137 & 256.0 & 6.4 & 24.6 & 47.5 & 36.7 & 157.0 & 3.7 & 256.0 \\
\hline Plutonium-239 & 3.0 & - & - & 1.3 & - & - & - & 3.0 \\
\hline Potassium-40 & 14.5 & 15.9 & 14.7 & 17.1 & 18.0 & 15.8 & 14.8 & 18.0 \\
\hline Strontium-90 & 70.0 & - & 4.7 & 5.3 & 16.8 & 7.6 & - & 70.0 \\
\hline $\begin{array}{l}\text { Notes: Only va } \\
\text { aDOE-RL, } 199 ? \\
\text { bDOE-RL, } 1992 \\
\text { cDOE-RL, } 1992 \\
\text { dDOE-RL, } 1992 \\
\text { eDOE-RL, } 1993 \\
\text { fDOE-RL, } 1993 \\
\text { gDOE-RL, } 1993\end{array}$ & greater th & $\mathrm{pCi} / \mathrm{g}$ are & & & & & & \\
\hline
\end{tabular}


DOE/RL-93-99, Rev. 0

Table 3-5. Maximum Concentrations for Radionuclides in 300 Area Wastes.

\begin{tabular}{|l|r|l|}
\hline \multicolumn{1}{|c|}{ Radionuclide } & $\begin{array}{r}\text { Maximum } \\
\text { Concentration } \\
\text { (in pCi/g) }\end{array}$ & \\
\hline Cerium-141 & 0.28 & $316-1$ South (old) Pond \\
\hline Cesium-134 & 0.45 & Drums \\
\hline Cesium-137 & 50 & Drums \\
\hline Chromium-51 & 3.5 & $618-5$ Burial Ground No. 5 \\
\hline Cobalt-60 & 81 & $316-1$ South (old) Pond \\
\hline Gross Alpha & 4,450 & $316-53904$ Process Waste Trenches \\
\hline Gross Beta & 12,200 & $316-53904$ Process Waste Trenches \\
\hline Potassium-40 & 19.5 & 307 T-1 trench \\
\hline Radium-226 & 2.1 & $316-2$ North (new) Pond \\
\hline Strontium-90 & 18 & $316-53904$ Process Waste Trenches \\
\hline Thorium-228 & 17 & $316-53904$ Process Waste Trenches \\
\hline Thorium-232 & 3.5 & $316-2$ North (new) Pond \\
\hline Total Uranium & 20,000 & $316-53904$ Process Waste Trenches \\
\hline Uranium-234 & 2,100 & $618-4$ Burial Ground No. 4 \\
\hline Uranium-235 & 640 & $316-53904$ Process Waste Trenches \\
\hline Uranium-238 & 9,100 & $316-53904$ Process Waste Trenches \\
\hline Zinc-65 & 0.32 & $316-2$ North (new) Pond \\
\hline & & \\
\hline
\end{tabular}


Table 3-6. Maximum Concentrations for Organic Compounds in 300 Area Wastes. (Sheet 1 of 2)

\begin{tabular}{|c|c|c|}
\hline Compound & $\begin{array}{l}\text { Maximum } \\
\text { Concentration } \\
\text { (in } \mu \mathrm{g} / \mathrm{kg})\end{array}$ & Waste Unit \\
\hline \multicolumn{3}{|c|}{ VOLATILE ORGANIC COMPOUNDS } \\
\hline 1,2-Dichloroethene (Total) & 1,000 & 316-5W 3904 Process Waste Trenches \\
\hline Acetone & 700 & 316-2 North (new) Pond \\
\hline Carbon Disulfide & 100 & 316-5W 3904 Process Waste Trenches \\
\hline Chloroform & 80 & 316-5W 3904 Process Waste Trenches \\
\hline Methylene Chloride & 4,500 & 316-2 North (new) Pond \\
\hline Tetrachloroethene & 1,100 & 316-5W 3904 Process Waste Trenches \\
\hline Toluene & 150 & 316-2 North (new) Pond \\
\hline Trichloroethene & 390 & 618-4 Burial Ground No. 4 \\
\hline Vinyl Chloride & 24 & 316-5W 3904 Process Waste Trenches \\
\hline \multicolumn{3}{|c|}{ SEMTVOLATILE ORGANIC COMPOUNDS } \\
\hline 2-Methylnaphthalene & 8,700 & 316-5E 3904 Process Waste Trenches \\
\hline 4-Chloroaniline & 6,300 & C-Sanitary Tiench \\
\hline 4-Methylphenol & 1,000 & C-Sanitary Trench \\
\hline Acenaphthene & 850 & 316-5W 3904 Process Waste Trenches \\
\hline Anthracene & 1,200 & 316-5W 3904 Process Waste Trenches \\
\hline Benzo(a)anthracene & 1,400 & 316-5E 3904 Process Waste Trenches \\
\hline Benzo(a)pyrene & 27,000 & 316-5E 3904 Process Waste Trenches \\
\hline Benzo(b)fluoranthene & 1,700 & 316-5E 3904 Process Waste Trenches \\
\hline Benzo(g,h,i)perylene & 3,700 & 316-5E 3904 Process Waste Trenches \\
\hline Benzo(k)fluoranthene & 180 & 316-5W 3904 Process Waste Trenches \\
\hline Benzoic Acid & 1,300 & 316-5E 3904 Process Waste Trenches \\
\hline Bis(2-ethylhexyl)phthalate & 33,000 & C-Sanitary Trench \\
\hline Butylbenzylphthalate & 230 & C-Sanitary Trench \\
\hline Chrysene & 43,000 & 316-5E 3904 Process Waste Trenches \\
\hline Di-n-butylphthalate & 5,500 & 316-5E 3904 Process Waste Trenches \\
\hline Dibenz(a,h)anthracene & 1,700 & 316-5E 3904 Process Waste Trenches \\
\hline
\end{tabular}


Table 3-6. Maximum Concentrations for Organic Compounds in 300 Area Wastes.

(Sheet 2 of 2)

\begin{tabular}{|l|r|l|}
\hline \multicolumn{1}{|c|}{ Compound } & $\begin{array}{r}\text { Maximum } \\
\text { Concentration } \\
\text { (in } \mu \mathrm{g} / \mathrm{kg})\end{array}$ & \\
\hline Dibenzofuran & 500 & $316-5 \mathrm{~W} 3904$ Process Waste Trenches \\
\hline Diethylphthalate & 810 & $316-5 \mathrm{E} 3904$ Process Waste Trenches \\
\hline Fluoranthene & 2,800 & $316-5 \mathrm{~W} 3904$ Process Waste Trenches \\
\hline Fluorene & 850 & $316-5 \mathrm{~W} 3904$ Process Waste Trenches \\
\hline Indeno(1,2,3-cd)pyrene & 1,600 & $316-5 \mathrm{E} 3904$ Process Waste Trenches \\
\hline Naphthalene & 190 & $316-5 \mathrm{~W}$ \\
\hline N-Nitrosodiphenylamine & 1,800 & $316-5 \mathrm{E} 3904$ Process Waste Trenches \\
\hline Pentachlorophenol & 1,500 & $316-5 E$ 3904 Process Waste Trenches \\
\hline Phenanthrene & 3,900 & $316-5 \mathrm{~W} 3904$ Process Waste Trenches \\
\hline Pyrene & 12,000 & $316-5 \mathrm{E} 3904$ Process Waste Trenches \\
\hline PESTICIDES/AROCLORS & & \\
\hline 4,4'-DDE & 81 & C-Sanitary Trench \\
\hline PCBs & 19,500 & Process Trenches \\
\hline Aroclor-1248 & 10,000 & $316-2$ North Process Pond \\
\hline
\end{tabular}


Table 3-7. Maximum Concentrations for Inorganic and General Chemistry Constituents in 300 Area Wastes. (Sheet 1 of 2)

\begin{tabular}{|c|c|c|}
\hline Constituent & $\begin{array}{c}\text { Maximum } \\
\text { Concentration } \\
(\mathrm{mg} / \mathrm{kg})\end{array}$ & Waste Unit \\
\hline \multicolumn{3}{|c|}{ INORGANIC CONSTITUENTS } \\
\hline Aluminum & 58,600 & 618-4 Burial Ground No. 4 \\
\hline Antimony & 15.4 & 316-1 South (old) Pond \\
\hline Arsenic & 23.3 & 316-1 South (old) Pond \\
\hline Barium & 3,130 & 618-5 Burial Ground No. 5 \\
\hline Beryllium & 3.3 & 316-2 North (new) Pond \\
\hline Cadmium & 23 & 300 Area Sanitary Sewer system \\
\hline Calcium & 95,300 & 316-1 South (old) Pond \\
\hline Cobalt & 18 & 316-2 North (new) Pond \\
\hline Copper & 95,300 & 316-1 South (old) Pond \\
\hline Chromium & 960 & 618-4 Burial Ground No. 4 \\
\hline Iron & 2,740 & Process trenches (previous sampling) \\
\hline Lead & 747 & 618-4 Burial Ground No. 4 \\
\hline Magnesium & 25,500 & 316-1 South (old) Pond \\
\hline Manganese & 2,480 & 316-5 3904 Process Waste Trenches \\
\hline Mercury & 9.3 & 316-1 South (old) Pond \\
\hline Nickel & 1,750 & 316-1 South (old) Pond \\
\hline Potassium & 4,860 & $307 \mathrm{~T}$ \\
\hline Selenium & 7.7 & 300 Area Sanitary Sewer system \\
\hline Silver & 362 & 316-1 South (old) Pond \\
\hline Sodium & 2,610 & 618-4 Burial Ground No. 4 \\
\hline Strontium & 31 & Process trenches (previous samples) \\
\hline Thallium & 0.8 & 300 Area Sanitary Sewer system \\
\hline Vanadium & 239 & 316-1 South (old) Pond \\
\hline Zinc & 3,830 & 300 Area Sanitary Sewer system \\
\hline \multicolumn{3}{|c|}{ GENERAL CHEMISTRY } \\
\hline Ammonia & 138 & Drums \\
\hline Chloride & 194 & 316-5 3904 Process Waste Trenches \\
\hline Fluoride & 40 & 316-2 North (new) Pond \\
\hline Nitrate & 125 & 316-2 North (new) Pond \\
\hline
\end{tabular}


DOE/RL-93-99, Rev. 0

Table 3-7. Maximum Concentrations for Inorganic and General Chemistry Constituents in 300 Area Wastes. (Sheet 2 of 2)

\begin{tabular}{|l|r|l|}
\hline \multicolumn{1}{|c|}{ Constituent } & \multicolumn{1}{|c|}{$\begin{array}{c}\text { Maximum } \\
\text { Concentration } \\
(\mathrm{mg} / \mathrm{kg})\end{array}$} & \multicolumn{1}{|c|}{ Waste Unit } \\
\hline Nitrite & 2.9 & 300 Area Sanitary Sewer system \\
\hline Phosphate & 14 & 300 Area Sanitary Sewer system \\
\hline Sulfate & 2,636 & $618-5$ Burial Ground No. 5 \\
\hline $\begin{array}{l}\text { Total Organic } \\
\text { Carbon }\end{array}$ & 43.7 & Process trenches \\
\hline $\begin{array}{l}\text { Total Organic } \\
\text { Halogen }\end{array}$ & 7.2 & Process trenches \\
\hline Coliform (MPN) & 110 & Process trenches \\
\hline
\end{tabular}


Table 3-8. Maximum Concentrations for Radionuclides in 100, 200, and 300 Area Wastes. (Sheet 1 of 2)

\begin{tabular}{|c|c|c|}
\hline Radionuclide & $\begin{array}{l}\text { Maximum } \\
\text { Concentration } \\
\text { (in } \mathrm{pCi} / \mathrm{g} \text { ) }\end{array}$ & Waste Unit \\
\hline Americium-241 & 34 & 116-C-5 Retention Basin \\
\hline Barium-140 & 400 & 116-D-1A Storage Basin Trench No. 1 \\
\hline Beryllium-7 & 90 & 116-D-1A Storage Basin Trench No. 1 \\
\hline Carbon-14 & 640 & 116-C-5 Retention Basin \\
\hline Cerium-141 & 3 & 116-D-1A Storage Basin Trench No. 1 \\
\hline Cerium-144 & 0.5 & 116-D-1A Storage Basin Trench No. 1 \\
\hline Cesium-134 & 56 & $116-\mathrm{B}-11$ \\
\hline Cesium-137 & 110,000 & Process effluent pipeline (BC1) \\
\hline Chromium-51 & 3.5 & 618-5 Burial Ground No. 5 \\
\hline Cobalt -58 & 14 & 116-DR-1 Liquid Waste Disposal Trench No. 1 \\
\hline Cobalt -60 & 11,000 & (HR1) Process effluent pipeline (sludge) \\
\hline Europium-152 & 29,000 & $116-B-11$ \\
\hline Europium-154 & 9,200 & $116-\mathrm{D}-7$ \\
\hline Europium-155 & 9,600 & Process effluent pipeline (BC1) \\
\hline Gross Alpha & 4,450 & 316-5 3904 Process Waste Trenches \\
\hline Gross Beta & 12,210 & 316-5 3904 Process Waste Trenches \\
\hline Iron-59 & 1 & 116-D-1A Storage Basin Trench No. 1 \\
\hline Manganese-54 & 0.07 & 116-D-1A Storage Basin Trench No. 1 \\
\hline Nickel-63 & 62,000 & Process effluent pipeline (BC1) \\
\hline Plutonium-238 & 140 & Process effluent pipeline (BC1) \\
\hline Plutonium-239/240 & 2,800 & Process effluent pipeline (BC1) \\
\hline Potassium-40 & 33 & 116-H-7 Retention Basin \\
\hline Radium-226 & 42.8 & 116-D-1A Storage Basin Trench No. 1 \\
\hline Ruthenium-103 & 1 & 116-D-1A Storage Basin Trench No. 1 \\
\hline Ruthenium-106 & 0.8 & 116-D-1A Storage Basin Trench No. 1 \\
\hline Sodium-22 & 9.9 & 116-DR-1 Liquid Waste Disposal Trench No. 1 \\
\hline Strontium-90 & 2,000 & Process effluent pipeline (BC1) \\
\hline Technetium-99 & 1.1 & 116-DR-2 Liquid Waste Disposal Trench No. 2 \\
\hline Thorium-228 & 17 & 316-5 3904 Process Waste Trenches \\
\hline Thorium-232 & 3.5 & 316-2 North (new) Pond \\
\hline
\end{tabular}


Table 3-8. Maximum Concentrations for Radionuclides in 100, 200, and 300 Area Wastes.

(Sheet 2 of 2)

\begin{tabular}{|l|c|l|}
\hline \multicolumn{1}{|c|}{ Radionuclide } & $\begin{array}{c}\text { Maximum } \\
\text { Concentration } \\
\text { (in pCi/g) }\end{array}$ & \multicolumn{1}{|c|}{ Waste Unit } \\
\hline Thorium-234 & 1 & $116-\mathrm{D}-1$ A Storage Basin Trench No. 1 \\
\hline Tritium & 29,000 & $116-\mathrm{B}-5$ \\
\hline Uranium-233/234 & 2,100 & $618-4$ Burial Ground No. 4 \\
\hline Uranium-235 & 640 & $316-5$ 3904 Process Waste Trenches \\
\hline Uranium-238 & 9,100 & $316-5$ 3904 Process Waste Trenches \\
\hline Zinc-65 & 0.3 & $116-\mathrm{D}-1$ A Storage Basin Trench No. 1 \\
\hline Zirconium-95 & 0.56 & $116-\mathrm{H}-7$ Retention Basin \\
\hline Total Uranium & 20,000 & $316-5$ 3904 Process Waste Trenches \\
\hline
\end{tabular}


Table 3-9. Maximum Concentrations for Organic Compounds in 100 and 300 Area Wastes. (Sheet 1 of 3)

\begin{tabular}{|c|c|c|}
\hline Compound & $\begin{array}{c}\text { Maximum } \\
\text { Concentration } \\
(\mu \mathrm{g} / \mathrm{kg})\end{array}$ & Waste Unit \\
\hline \multicolumn{3}{|c|}{ VOLATILE ORGANIC COMPOUNDS } \\
\hline 1,2-Dichloroethene (Total) & 1,000 & $\begin{array}{l}316-5 W 3904 \text { Process Waste } \\
\text { Trenches }\end{array}$ \\
\hline 1,1,1-Trichloroethane & 6 & 100-D-Pond \\
\hline 1,1,2,2-Tetrachloroethane & 3 & 100-D-Pond \\
\hline 2-Butanone & 390 & 100-D-Pond \\
\hline 2-Hexanone & 9 & 100-D-Pond \\
\hline 4-Methyl-2-Pentanone & 11 & 116-B-2 Storage Basin Trench \\
\hline Acetone & 2,800 & $\begin{array}{l}\text { UN-100-N-17 Diesel Oil Supply } \\
\text { Line Leak }\end{array}$ \\
\hline Benzene & 190 & $\begin{array}{l}\text { UN-100-N-17 Diesel Oil Supply } \\
\text { Line Leak }\end{array}$ \\
\hline Carbon Disulfide & 200 & 116-B-5 Crib \\
\hline Carbon Tetrachloride & 8 & $116 \mathrm{~N} 1$ \\
\hline Chloroform & 80 & $\begin{array}{l}316-5 W 3904 \text { Process Waste } \\
\text { Trenches }\end{array}$ \\
\hline Ethylbenzene & 330 & $\begin{array}{l}\text { UN-100-N-17 Diesel Oil Supply } \\
\text { Line Leak }\end{array}$ \\
\hline Methylene Chloride & 4,500 & 316-2 North (new) Pond \\
\hline Tetrachloroethene & 1,100 & $\begin{array}{l}316-5 \text { W } 3904 \text { Process Waste } \\
\text { Trenches }\end{array}$ \\
\hline Toluene & 150 & 316-2 North (new) Pond \\
\hline Trichloroethene & 390 & 618-4 Burial Ground No. 4 \\
\hline Vinyl Chloride & 24 & $\begin{array}{l}\text { 316-5W } 3904 \text { Process Waste } \\
\text { Trenches }\end{array}$ \\
\hline Xylenes (Total) & 1,100 & 130-D-1 Gasoline Storage Tank \\
\hline \multicolumn{3}{|c|}{ SEMI-VOLATILE ORGANIC COMPOUNDS } \\
\hline 4-Chloroaniline & 6,300 & C-sanitary trench (300 Area) \\
\hline 1,3-Dichlorobenzene & 48 & $\begin{array}{l}\text { 116-DR-1 Liquid Waste Disposal } \\
\text { Trench No. } 1\end{array}$ \\
\hline 1,4-Dichlorobenzene & 51 & $\begin{array}{l}\text { 116-N-2 Chemical Waste Storage } \\
\text { Tank }\end{array}$ \\
\hline 2-Methylnaphthalene & 13,000 & $U N-100-N-17$ \\
\hline
\end{tabular}


Table 3-9. Maximum Concentrations for Organic Compounds in 100 and 300 Area Wastes. (Sheet 2 of 3)

\begin{tabular}{|c|c|c|}
\hline Compound & $\begin{array}{c}\text { Maximum } \\
\text { Concentration } \\
(\mu \mathrm{g} / \mathrm{kg})\end{array}$ & Waste Unit \\
\hline 4-Chloro-3-Methylphenol & 38 & $\begin{array}{l}\text { 116-DR-1 Liquid Waste Disposal } \\
\text { Trench No. } 1\end{array}$ \\
\hline 4-Methylphenol & 1,000 & C-sanitary trench (300 Area) \\
\hline Acenaphthene & 850 & 316-5W Process Waste Trenches \\
\hline Anthracene & 6,300 & UN-100-N-17 \\
\hline Benzo(a)anthracene & 1,800 & $\begin{array}{l}\text { 1607-H-4 Septic Tank Discharge } \\
\text { Pipe }\end{array}$ \\
\hline Benzo(a)pyrene & 27,000 & $\begin{array}{l}\text { 316-5E } 3904 \text { Process Waste } \\
\text { Trenches }\end{array}$ \\
\hline Benzo(b)fluoranthene & 2,400 & $\begin{array}{l}\text { 1607-H-4 Septic tank Discharge } \\
\text { Pipe }\end{array}$ \\
\hline Benzo(g,h,i)perylene & 3,700 & $\begin{array}{l}\text { 316-5E } 3904 \text { Process Waste } \\
\text { Trenches }\end{array}$ \\
\hline Benzo(k)fluoranthene & 760 & $\begin{array}{l}\text { 116-H-1 Liquid Waste Disposal } \\
\text { Trench }\end{array}$ \\
\hline Benzoic Acid & 1,300 & $\begin{array}{l}\text { 316-5E } 3904 \text { Process Waste } \\
\text { Trenches }\end{array}$ \\
\hline Bis(2-ethylhexyl)phthalate & 33,000 & C-Sanitary Trench (300 Area) \\
\hline Butylbenzylphthalate & 2,600 & 130-D-1 Gasoline Storage Tank \\
\hline Carbazole & 54 & $\begin{array}{l}\text { 116-D-1B Fuel Storage Basin, } \\
\text { Trench No. } 2\end{array}$ \\
\hline Chrysene & 43,000 & $\begin{array}{l}\text { 316-5E } 3904 \text { Process Waste } \\
\text { Trenches }\end{array}$ \\
\hline Di-n-butylphthalate & 5,500 & $\begin{array}{l}\text { 316-5E } 3904 \text { Process Waste } \\
\text { Trenches }\end{array}$ \\
\hline $\operatorname{Dibenz}(\mathrm{a}, \mathrm{h})$ anthracene & 1,700 & $\begin{array}{l}\text { 316-5E } 3904 \text { Process Waste } \\
\text { Trenches }\end{array}$ \\
\hline Dibenzofuran & 500 & $\begin{array}{l}316-5 \text { W } 3904 \text { Process Waste } \\
\text { Trenches }\end{array}$ \\
\hline Diethylphthalate & 1,000 & 100-D-Pond \\
\hline Fluoranthene & 2,900 & $\begin{array}{l}\text { 1607-H4 Septic Tank Discharge } \\
\text { Pipe }\end{array}$ \\
\hline Fluorene & 1,700 & $U N-100-N-17$ \\
\hline
\end{tabular}


Table 3-9. Maximum Concentrations for Organic Compounds in 100 and 300 Area Wastes. (Sheet 3 of 3)

\begin{tabular}{|c|c|c|}
\hline Compound & $\begin{array}{l}\text { Maximum } \\
\text { Concentration } \\
(\mu \mathrm{g} / \mathrm{kg})\end{array}$ & Waste Unit \\
\hline Indeno $(1,2,3-c d)$ pyrene & 1,600 & $\begin{array}{l}\text { 316-5E } 3904 \text { Process Waste } \\
\text { Trenches }\end{array}$ \\
\hline Naphthalene & 4,100 & UN-100-N-17 \\
\hline N-Nitrosodiphenylamine & 1,800 & $\begin{array}{l}\text { 316-5E } 3904 \text { Process Waste } \\
\text { Trenches }\end{array}$ \\
\hline Pentachlorophenol & 1,500 & $\begin{array}{l}\text { 316-5E } 3904 \text { Process Waste } \\
\text { Trenches }\end{array}$ \\
\hline Phenanthrene & 3,900 & $\begin{array}{l}\text { 316-5W } 3904 \text { Process Waste } \\
\text { Trenches }\end{array}$ \\
\hline Phenol & 240 & 100-D-Pond \\
\hline Pyrene & 12,000 & $\begin{array}{l}\text { 316-5E } 3904 \text { Process Waste } \\
\text { Trenches }\end{array}$ \\
\hline \multicolumn{3}{|c|}{ PESTICIDES/AROCLORS } \\
\hline 4,4'-DDD & 110 & $\begin{array}{l}\text { 1607-H4 Septic Tank Discharge } \\
\text { Pipe }\end{array}$ \\
\hline 4,4'-DDE & 170 & 100-D-Pond \\
\hline Aroclor -1248 & 10,000 & 316-2 North Process Pond \\
\hline Aroclor -1254 & 6,400 & 190-B \\
\hline Aroclor -1260 & 2,300 & 100-D Pond \\
\hline Beta-HCH (Beta-BHC) & 7.8 & $\begin{array}{l}\text { 116-D-1A Fuel Storage Basin, } \\
\text { Trench No. } 1\end{array}$ \\
\hline Chlordane, Gamma- & i8 & $\begin{array}{l}\text { 1607-H4 Septic Tank Discharge } \\
\text { Pipe }\end{array}$ \\
\hline Dieldrin & 21 & $\begin{array}{l}\text { 116-D-1A Fuel Storage Basin, } \\
\text { Trench No. } 1\end{array}$ \\
\hline Methoxychlor & 83 & 100-D-Pond \\
\hline PCBs & 19,500 & Process trenches (300 Area) \\
\hline
\end{tabular}


Table 3-10. Maximum Concentrations and Background Screening for Inorganic and General Chemistry Constituents in 100 and 300 Area Wastes. (Sheet 1 of 2)

\begin{tabular}{|c|c|c|c|}
\hline Constituent & $\begin{array}{c}\text { Maximum } \\
\text { Concentration } \\
(\mathrm{mg} / \mathrm{kg})\end{array}$ & Waste Unit & $\begin{array}{c}\text { Background } \\
(95 / 95 \text { UTL) } \\
(\mathrm{mg} / \mathrm{kg})\end{array}$ \\
\hline \multicolumn{4}{|c|}{ INORGANIC CONSTITUENTS } \\
\hline Aluminum & 78,400 & 100-B Pond & 15,600 \\
\hline Antimony & 18.6 & H-2 Septic Tank & NC \\
\hline Arsenic & 62.2 & 100-D Pond & 8.92 \\
\hline Barium & 4,260 & H-2 Septic Tank & 171 \\
\hline Beryllium & 4.7 & 116-H-9 Crib & 1.77 \\
\hline Cadmium & 28.5 & H-2 Septic Tank & $\mathrm{NC}$ \\
\hline Calcium & 95,300 & 316-1 South (old) Pond & 23,920 \\
\hline Chromium & 2,510 & H-2 Septic Tank & 27.9 \\
\hline Cobalt & 90 & 116-KW-3B Retention Basin & 19.6 \\
\hline Copper & 95,300 & 316-1 South (old) Pond & 28.2 \\
\hline Iron & 184,000 & 116 H-9 Crib & 39,160 \\
\hline Lead & 747 & 618-4 Burial Ground No. 4 & 14.75 \\
\hline Magnesium & 50,000 & 116-H-9 Crib & 8,760 \\
\hline Manganese & 3,050 & 116-H-9 Crib & 612 \\
\hline Mercury & 37 & H-2 Septic Tank & 1.25 \\
\hline Nickel & 1,750 & 316-1 South (old) Pond & 25.3 \\
\hline Potassium & 13,000 & 116-H-9 Crib & 3,120 \\
\hline Selenium & 11 & 100-B Pond & NC \\
\hline Silver & 362 & 316-1 South (old) Pond & 2.7 \\
\hline Sodium & 2,610 & 618-4 Burial Ground No. 4 & 1,290 \\
\hline Strontium & 31 & $\begin{array}{l}\text { Process trenches (previous } \\
\text { sampling) }\end{array}$ & NC \\
\hline Thallium & 5.4 & H-2 Septic Tank & $\mathrm{NC}$ \\
\hline Vanadium & 389 & 116-H-9 Crib & 111 \\
\hline Zinc & 6,160 & H-2 Septic Tank & 79 \\
\hline
\end{tabular}


Table 3-10. Maximum Concentrations and Background Screening for Inorganic and General Chemistry Constituents in 100 and 300 Area Wastes. (Sheet 2 of 2)

\begin{tabular}{|c|c|c|c|}
\hline Constituent & $\begin{array}{c}\text { Maximum } \\
\text { Concentration } \\
(\mathrm{mg} / \mathrm{kg})\end{array}$ & Waste Unit & $\begin{array}{c}\text { Background } \\
\text { (95/95 UTL) }^{a} \\
(\mathrm{mg} / \mathrm{kg})\end{array}$ \\
\hline \multicolumn{4}{|c|}{ GENERAL CHEMISTRY } \\
\hline Ammonia & 138 & Drums & 28.2 \\
\hline Chloride & 194 & $\begin{array}{l}\text { 316-5 } 3904 \text { Process Waste } \\
\text { Trenches }\end{array}$ & 763 \\
\hline Fluoride & 40 & 316-2 North (new) Pond & 12 \\
\hline Nitrate & 125 & 316-2 North (new) Pond & 199 \\
\hline Nitrite & 2.9 & 300 Area Sanitary Sewer system & NC \\
\hline Phosphate & 15 & 116-KW-3B Retention Basin & 16 \\
\hline Sulfate & 7,115 & H-2 Septic Tank & 1,320 \\
\hline $\begin{array}{l}\text { Total Organic } \\
\text { Halogen }\end{array}$ & 7.2 & $\begin{array}{l}\text { Process trenches (previous } \\
\text { sampling) }\end{array}$ & NC \\
\hline Total Organic Carbon & 43.7 & $\begin{array}{l}\text { Process trenches (previous } \\
\text { sampling) }\end{array}$ & $\mathrm{NC}$ \\
\hline Coliform (MPH) & 110 & $\begin{array}{l}\text { Process trenches (previous } \\
\text { sampling) }\end{array}$ & NC \\
\hline Nitrate/Nitrite & 37 & 116-C-5 Retention Basin & $199 \mathrm{~b}$ \\
\hline \multicolumn{4}{|c|}{$\begin{array}{l}\text { Notes: } \\
\text { NC - not calculated } \\
\text { a95/95 UTL is the } 95 \% \text { UCL on the } 95 \text { th percentile; Source: Table } 6-9 \mathrm{~b} \text { in Hanford Site } \\
\text { Background Part 1, Soil Background for Nonradioactive Analytes } \\
\text { (DOE-RL 1993i). } \\
\text { bThe background concentration for nitrate is used. }\end{array}$} \\
\hline
\end{tabular}




\subsection{CONTAMINANT FATE AND TRANSPORT}

The purpose of this chapter is to identify potential groundwater contaminants at the ERDF. A fate and transport model was used to predict groundwater concentrations at the ERDF boundary, based on soil concentrations of constituents presented in Chapter 3. Predicted groundwater concentrations are compared to Hanford Site background groundwater concentrations to identify contaminants that exceed background. Predicted groundwater concentrations are also compared to risk-based de minimis concentrations, as described in Section 4.3. If a predicted groundwater concentration is less than the de minimis concentration, it is excluded from the list of groundwater contaminants. The final list of groundwater contaminants developed in this chapter is carried into Chapter 5 to develop the list of contaminants of potential concern.

\subsection{MODEL DEVELOPMENT}

The fate and transport model was used to identify groundwater contaminants, perform contaminant screening and evaluate alternative ERDF designs. This chapter focuses on the base conditions scenario (no engineered barrier and no liner) used for identification of groundwater contaminants and for the contaminant screening performed in Chapter 5. The base conditions scenario is a worst case analysis that does not correspond to any of the alternatives considered in Chapter 9. The alternatives considered in Chapter 9 all include engineered barriers that are expected to perform better than the assumed performance in the base conditions scenario.

\subsubsection{Conceptual Model}

In general, the mechanisms controlling contaminant fate and transport in the vadose zone are highly coupled, unsteady, and non-linear. Furthermore, the hydrogeologic strata are heterogeneous and anisotropic. Although multi-dimensional numerical models can provide a more accurate representation of these non-linear dynamic processes and complex hydrogeological conditions, they are still limited by uncertainties in many of the controlling factors, such as source term concentrations, soil-water partitioning, and infiltration rate. Since the purpose of this modeling is a screening analysis to identify potential groundwater contaminants at the ERDF and evaluate alternative ERDF designs, a multidimensional numerical model was not considered warranted for this study. Instead, a spreadsheet model was developed based on the conceptual model of the site described below.

The conceptual model assumes the following:

- the media are homogeneous and isotropic

- the flow is plug flow (i.e., no longitudinal dispersion) in both the vadose zone and the saturated zone

- constituent release from ERDF is controlled by either solubility or partitioning between the waste and pore water. 
As recharge from the ground surface percolates through the waste it dissolves contaminants to form leachate. The contaminant concentration in the leachate is controlled by soil-water partitioning unless the leachate concentration is predicted to exceed the constituent solubility, in which case the concentration is solubility limited.

Leachate from the facility migrates through the vadose zone to the groundwater table. The rate of migration is controlled by the rate of infiltration, the moisture content, and retardation. Constituent concentrations may be reduced due to radioactive decay, volatilization, biodegradation, and dilution.

When the leachate reaches the saturated zone, it is subsequently diluted in groundwater. Finally, the leachate migrates towards the ERDF boundary in the direction of groundwater flow. Further retardation and decay can occur in the saturated zone.

The mathematical expressions for the conceptual model described above and the spreadsheet model developed based on the conceptual model are presented in Appendix A.

\subsubsection{Morel Parameters}

Tarameters for the fate and transport spreadsheet model were developed to represent the hydrogeological conditions of the ERDF site, the physical and chemical properties of the waste form, and the fate and transport properties of each contaminant constituent. The parameter estimation relied first on ERDF-specific information and then on Hanford Site background information when available. Non-Hanford Site information was utilized as a last resort.

4.1.2.1 General Parameters. General parameters include the dimensions of the disposal trench, the natural infiltration rate, and the physical and hydrogeological properties of both vadose zone and saturated zone soils. These parameters are summarized in Table 4-1.

ERDF and Trench Dimensions. Cross-sections of the trench dimensions assumed in the base conditions scenario are shown in Figure 4-1. The trench width is $420 \mathrm{~m}(1,300 \mathrm{ft})$ at the ground surface and $300 \mathrm{~m}(1,000 \mathrm{ft})$ at the base of the trench. The trench depth is assumed to equal $20 \mathrm{~m}(70 \mathrm{ft})$. The trench will be approximately $3,000 \mathrm{~m}(9,000 \mathrm{ft})$ long to accommodate the entire design waste capacity (U.S. Army Corps of Engineers, 1994).

Natural Infiltration Rate. To estimate the natural infiltration rate at the ERDF site, information from a variety of lysimeter and modeling studies was evaluated. The longest running lysimeter study was conducted using a pair of lysimeters (one open-bottom, the other closed-bottom) installed in the 200 East Area in 1971. Moisture content data from these lysimeters indicate a relatively constant moisture content of 6 percent below a depth of $5 \mathrm{~m} \mathrm{(17}$ $\mathrm{ft}$ ). An analysis of the unsaturated hydraulic conductivity of the lysimeter soils (which were primarily sands) in the late 1970's suggested an infiltration rate of approximately $0.5 \mathrm{~cm} / \mathrm{yr}(0.2$ in./yr) (Jones 1978). Coring of the closed-bottom lysimeter in 1985 revealed little change in moisture content below a depth of $3 \mathrm{~m}(10 \mathrm{ft})$ and no accumulation of moisture in the bottom of the lysimeter, suggesting that the $0.5 \mathrm{~cm} / \mathrm{yr}(0.2 \mathrm{in} . / \mathrm{yr})$ interpretation was too high. Routson et al. (1988) concluded that the infiltration rate at this location was negligible (less than 0.2 $\mathrm{cm} / \mathrm{year}$ ). Deep-rooted tumbleweeds and other vegetation are believed to have been present on the 200 Area lysimeter for much of the study period. Computer modeling (using UNSAT-H) of the closed-bottom lysimeter indicated that the rate of infiltration was primarily controlled by the 
surface vegetation; infiltration was much higher when transpiration due to vegetation was eliminated from the model. The barrier surface over the ERDF will be vegetated.

Lysimeters have been installed at a variety of other facilities (such as the Buried Waste Test Facility). As summarized in Gee et al. (1992) infiltration rates for these lysimeters range from 0 (for silty loam soils) to $20 \mathrm{~cm} / \mathrm{yr}(8.0 \mathrm{in} . / \mathrm{yr}$ ) (for gravelly soils with no vegetation) and illustrate a strong dependence on soil type and vegetation type. With the exception of one lysimeter which had an infiltration rate of $1.0 \mathrm{~cm} / \mathrm{yr}(0.4 \mathrm{in} . / \mathrm{yr})$, no infiltration occurred in lysimeters with deep-rooted vegetation (Gee et al. 1992). The HELP modeling results presented in Appendix $B$ for the non-engineered soil cover indicate an infiltration rate of $0.035 \mathrm{~cm} / \mathrm{yr}$ ( $0.014 \mathrm{in./yr}$ ). Based on both empirical and modeling results, a natural infiltration rate of 0.5 $\mathrm{cm} / \mathrm{yr}(0.2 \mathrm{in} . / \mathrm{yr})$ was used for the model. This infiltration rate is a reasonably conservative (high) value for vegetated soils. The base conditions scenario modeled in this chapter assumes the infiltration rate through the non-engineered barrier equals the natural infiltration rate of 0.5 $\mathrm{cm} / \mathrm{yr}$.

Vadose Zone Parameters. The range of moisture content in 200 Area soils of the Hanford formation is $2 \%$ to slightly over $6 \%$ (Last et al. 1989). Data from the 200-East Area lysimeters indicate soil moisture values less than $3 \%$ to a depth of $18.3 \mathrm{~m}$ (60 ft) (Gee 1987). The vadose zone moisture content selected for modeling purposes was 4.5 percent.

A geologic cross section of the northern edge of the proposed ERDF site is shown in Figure 2-24. The ground elevation across the proposed ERDF site ranges from approximately $200 \mathrm{~m}(660 \mathrm{ft})$ to $230 \mathrm{~m}(760 \mathrm{ft})$. As shown in Figure 2-25, the water table elevation ranges from approximately $140 \mathrm{~m}(460 \mathrm{ft})$ to $120 \mathrm{~m}(400 \mathrm{ft})$. The vadose zone thickness ranges from

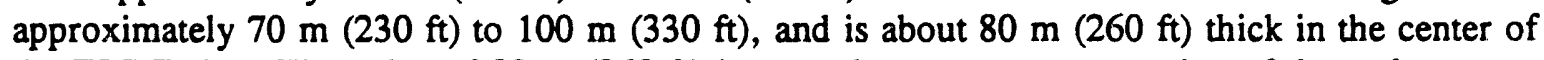
the ERDF site. The value of $80 \mathrm{~m}(260 \mathrm{ft})$ is a good average representation of the vadose zone thickness at this site, and was used in the model.

Vadose zone dilution and travel time are determined in part by the vadose zone mixing width, the vadose zone mixing depth, and the vadose zone mixing factor. As shown on Figure 4-2, the vadose zone mixing width is the width of infiltration on each side of the trench that mixes with the leachate in the vadose zone. The vadose zone mixing depth is the depth at which the leachate mixes with clean vadose zone moisture infiltrating outside the footprint of the ERDF. The amount of dilution is specified by the vadose zone mixing factor. The vadose zone mixing depth used in the base-case scenario is based on the geologic cross section provided in Figure 2-24. The Plio-Pleistocene unit, which has a lower permeability than the rest of the vadose zone materials and may encourage horizontal migration, is found in the western portion of the ERDF site at a depth of approximately $50 \mathrm{~m}(165 \mathrm{ft})$. Therefore, a depth of $50 \mathrm{~m}$ (165 $\mathrm{ft}$ ) was used in the model. The vadose zone mixing factor was assumed to equal 0 , which corresponds to no dilution in the vadose zone. Although mixing with clean infiltration will occur on the edge of the facility, little or no mixing would occur beneath the center of the facility. A mixing factor of 0 reflects a conservative bias. The vadose zone mixing width was assumed to be $100 \mathrm{~m}(330 \mathrm{ft})$. The dry density of soil in the vadose zone was assumed to equal $1.6 \mathrm{~kg} / \mathrm{L}$.

Saturated Zone Parameters. The saturated hydraulic gradient was estimated based on the water table elevation shown on Figure 2-33. The gradients at the ERDF range from 0.0045 along the northern boundary of the site to 0.0025 along the southern boundary. The gradient 
used in the model $(0.0035)$ represents the value of the gradient at a location approximately half of a mile south of the northern boundary of the ERDF.

The saturated hydraulic conductivity of the uppermost aquifer unit was estimated based on pump test results for wells near the ERDF (discussed in Section 2.6.2.) and more general information shown on Figure 2-32. The results from the 2 ERDF wells are within the range indicated on Figure 2-32 for the ERDF $(1-100 \mathrm{~m} / \mathrm{d})$. A value of $30 \mathrm{~m} / \mathrm{d}(100 \mathrm{ft} / \mathrm{d})$ was used in the modeling.

The saturated zone porosity used in the model was assumed to equal 0.3 (Graham et al. 1981). The dry density was assumed to equal $1.6 \mathrm{~kg} / \mathrm{L}$. As shown on Figure 4-2, the saturated

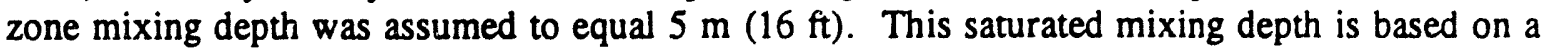
reasonable vertical capture thickness for a water supply well.

4.1.2.2 Constituent-Specific Parameters. Constituent-specific parameters include soil/water partitioning coefficient $\left(\mathrm{K}_{d}\right)$, decay or degradation rate, and solubility. The values of these parameters used in the modeling are summarized in Tables 4-2 through 4-8 and are briefly discussed below. There was no data available for carbazole. Since carbazole is a polynuclear aromatic hydrocarbon (PAH), all parameters for PAH's were compiled and the most conservative values selected as model parameters for carbazole.

Partitioning Coefficient $\left(\mathbf{K}_{d}\right)$. The partitioning coefficient $\left(\mathbf{K}_{d}\right)$ is defined as the ratio of adsorbed chemical concentration in the soil matrix to the aqueous solute concentration. Some literature values for organic constituents are presented in terms of $\mathrm{K}_{\infty}$, the organic carbon partitioning coefficient, or as $\mathbf{K}_{\text {ow, }}$ the octanal-water partitioning coefficient. For the purpose of this report, $\mathrm{K}_{\mathrm{ow}}$ was considered equivalent to $\mathrm{K}_{\mathrm{oc}}$. In general, $\mathrm{K}_{\infty}$ represents partitioning within a 100 percent organic carbon matrix. $K_{\infty}$ can be assumed to relate to $K_{d}$ according to the following relationship:

$$
\mathrm{K}_{\mathrm{d}}=\mathrm{K}_{\mathrm{o}} f_{\alpha}
$$

where:

$\mathrm{K}_{\infty} \quad=\quad$ soil adsorption normalized for soil organic matter content

$f_{\infty}=$ organic content

It should be noted that factors other than $\mathrm{f}_{\mathrm{oc}}$, such as $\mathrm{pH}$, clay content, and salinity, can also influence $K_{d}$, but methods for incorporating these factors are not available. In general, $K_{d}$ 's calculated using the approach described above should be accurate to within a factor of 2 to 10 (Lyman et al. 1982). $K_{d}$ values in Table 4-2 assume that $f_{o c}$ in soil is $0.1 \%$. This value is based on results presented in DOE/RL (1994a) for three soil samples from 100 Area waste sites. The $f_{o c}$ in these samples (reported at total organic carbon) was $0.06 \%, 0.1 \%$ and $0.16 \%$.

There were two sources for $\mathrm{K}_{\infty}$ data: (1) the Hazardous Substance Data Bank (HSDB 1993) and (2) Montgomery and Welkom (1990). If information was not available in the first source, the second source was consulted.

Table 4-2 includes measured $K_{o c}$ data and $K_{o c}$ 's that were estimated based on octanolwater partition coefficients $\left(\mathrm{K}_{o w}\right.$ 's) or solubility information. $\mathrm{K}_{o c}$ 's calculated based on $\mathrm{K}_{\mathrm{ow}}$ 's are 
calculated using empirical equations, and are thus associated with a higher uncertainty than measured $\mathrm{K}_{\mathrm{\alpha}}$ values.

The best estimate for $\mathrm{K}_{\infty}$ was selected in the following manner:

- if measured data were available, these were given preference over estimated values

- if data were available specifically for sand or sandy soils, these were given preference

- $\quad$ soil data were given preference over sediment suspensions

- $\quad$ if no data were available, the $\mathrm{K}_{\mathrm{oc}}$ was assumed to equal zero

- if specific data points were given for measured $\mathrm{K}_{\infty}$, these were averaged to calculate the best estimate

- $\quad$ if average values were given for measured $\mathrm{K}_{\infty}$, the best estimate was calculated from the average of the minimum and maximum data points.

Partitioning coefficients $\left(\mathbf{K}_{\mathbf{d}}\right.$ 's) for radionuclides and inorganic constituents are presented in Tables 4-3 and 4-4, respectively. These values are based on Hanford-specific data in Ames and Serne (1991) and Serne and Wood (1990) for a solution with neutral pH and low organic carbon. The best estimate of $K_{d}$ and the range were given in the references. If more than one estimate was provided, the values were averaged to obtain a best estimate for the $K_{d}$.

Decay (or Degradation) Rate. The degradation half-life for organic constituents is the time needed for half of the concentration to be degraded or volatilized (Dragun 1988). The half-life $\left(T_{1 / 2}\right)$ and its decay or degradation constant $(\lambda)$ are related by the following equation (Faure 1977):

$$
\mathrm{T}_{1 / 2}=0.693 / \lambda
$$

Organic chemicals can be degraded biologically or chemically. Many literature values are based on laboratory experiments designed to optimize biodegradation and may not be representative of natural conditions. Three sources were reviewed for half-life data for organic compounds: the Hazardous Substance Data Bank (HSDB 1993), Handbook of Environmental Degradation Rates (Howard et al. 1991), and The Soil Chemistry of Hazardous Materials (Dragun 1988). Since there is much uncertainty associated with half-lives for organic compounds, the data was reviewed and a range was selected $(<1,1-10,10-100$ years). The results are shown in Table 4-5. The maximum value in the range was used in the model. For compounds with no data, the half-life was set at 10,000 years.

The half-life for an unstable nuclide is the time required for one-half of a given number of atoms to decay. Half-lives for the radionuclides are readily available and are presented in Table 4-6. Metals were assumed not to degrade or volatilize. 
Solubility. Solubilities for organic compounds are relatively insensitive to changes in water chemistry (except when multiple organic compounds are involved and they begin to behave as co-solvents). Solubilities used in the modeling for organic compounds are included in Table 4-7. The primary source for solubility data for organic compounds was Montgomery and Welkom (1990). If no information was available from the primary source, the HSDB (1993 and 1994) was consulted. Solubilities were often available for a range of temperatures. The best estimate for solubility was selected for the temperature closest to 15 degrees Celsius ( 59 degrees Farenheit). Reported solubilities for a few organic constituents (e.g., tetrachloroethene) ranged over an order of magnitude. This variability is likely due to experimental differences. The average of the reported values was used in the simulations. No quantitative data was available for carbazole, however the HSDB (1993) indicated that carbazole is insoluble. A solubility of 1 $\mathrm{mg} / \mathrm{L}$ was chosen as a conservative estimate. No data was available for gamma-chlordane (an isomer of chlordane); therefore the data for chlordane was used.

Solubilities for most inorganic constituents and radionuclides are a function of the controlling solids and are highly dependent upon physio-chemical parameters such as pH, Eh, and the concentrations of other ionic constituents. Consequently, these solubilities are highly variable and are difficult to predict. Solubilities for inorganic constituents and radionuclides are presented in Tables 4-8 and 4-6, respectively. These values are based on Hanford-specific data, for a solution with neutral $\mathrm{pH}$ and low organic carbon. Solubilities are listed as LS (low solubility; <1 mg/L), MS (moderate solubility; $1-25 \mathrm{mg} / \mathrm{L}$ ), and VS (very soluble; $>1000 \mathrm{mg} / \mathrm{L}$ ). These ranges are based on data in the references Ames and Serne (1991) and Serne and Wood (1990).

In the case of elements with multiple isotopes, the isotope-specific solubilities are equal to the element solubility multiplied by the relative mass abundance of the isotope.

Unfortunately, for isotopes associated with nuclear activation and fission products, the relative abundances can be highly variable and difficult to determine. On the other hand, relative abundances for some naturally occurring isotopes, including K-40 and the uranium isotopes, can be predicted. Crustal uranium consists of three isotopes, U-234 (0.0057 percent), U-235 (0.72 percent), and U-238 (99.374 percent) (Faure 1977). Assuming the solubility of total uranium is $25 \mathrm{mg} / \mathrm{L}$, the solubility of U-234 used in the model was:

$$
25 \mathrm{mg} / \mathrm{L} \times 0.000057=0.0014 \mathrm{mg} / \mathrm{L}
$$

An isotope-specific solubility of $0.12 \mathrm{mg} / \mathrm{L}$ was calculated for $\mathrm{K}-40$ assuming a relative abundance of 0.0119 percent (Faure 1977).

\subsubsection{Fate and Transport Modeling Results}

Modeling results are presented as deterministic values, which rely upon the input parameters discussed above. The groundwater screening model provides the following results for each constituent: the initial leachate concentration, the vadose zone travel time, the saturated zone travel time, the vadose and saturated zone dilution factors, the groundwater concentration at the water table, and the groundwater concentration at the ERDF boundary. The results for organic compounds, radionuclides, metals, and anions are presented in Tables A-4 through A-7, respectively. 


\subsubsection{Sensitivity of Modeling Results to Site Location}

The input parameters used in the modeling were based on the proposed location of the ERDF. Alternative locations may or may not result in significantly different risks and travel times to the saturated zone. The parameters that might change for other sites include the following:

- $\quad$ width and length of the trench
- $\quad$ vaickness of the vadose zone
vadose zone mixing depth
- $\quad$ soil density
- $\quad$ saturated zorie purasiture content
- $\quad$ saturated zone hydraulic conductivity

Parameters that are unlikely to change significantly from site to site include vadose zone moisture content, soil density, and saturated zone porosity. These parameters are relatively consistent across the Hanford Site. The remaining parameters are variable across the Hanford Site and the consequences of these variations are discussed below:

- Travel time through the vadose zone is directly proportional to changes in the thickness of the vadose zone. For example, travel time through the vadose zone decreases as thickness of the vadose zone decreases.

- Travel time through the vadose zone is directly proportional to changes in vadose zone mixing depth. For example, if the vadose zone mixing depth decreases, the infiltrating leachate mixes with the clean infiltration higher in the stratigraphic column, resulting in a decreased travel time through the vadose zone.

- Concentration in the saturated zone is inversely proportional to changes in the saturated zone hydraulic conductivity. As the saturated zone hydraulic conductivity increases, the velocity of groundwater in the saturated zone increases, resulting in greater dilution of the vadose zone infiltration and lower constituent concentrations.

- Concentration in the saturated zone is inversely proportional to changes in the saturated zone hydraulic gradient. As the saturated zone hydraulic gradient increases, the velocity of groundwater in the saturated zone increases, resulting in greater dilution of the vadose zone infiltration and lower constituent concentrations.

\subsection{GROUNDWATER BACKGROUND SCREENING}

Groundwater background screening is presented in Table 4-9. It was conducted to identify the constituents which occur in concentrations that are elevated over naturally-occurring chemical concentrations. Constituents were evaluated by comparing the predicted groundwater concentrations with the Hanford Site background groundwater concentrations (DOE-RL 1992e). 
chemical concentrations. Constituents were evaluated by comparing the predicted groundwater concentrations with the Hanford Site background groundwater concentrations (DOE-RL 1992e). Background concentrations used in this screening are the one-sided, 95/95 upper tolerance limits (UTLs) (i.e., the 95 percent upper confidence limit of the 95th percentile for the distribution) of each parameter. The method for calculation of the background UTLs is presented in EPA (1989a). Hanford Site background UTLs are only available for the target analyte list (TAL) metals and inorganic anions. Those constituents with predicted groundwater concentrations less than background are not considered groundwater contaminants and are eliminated from further consideration. Calcium, iron, magnesium, non-radioactive strontium, and sulfate were eliminated from the list of groundwater contaminants based on comparison to background.

\subsection{GROUNDWATER DE MINIMIS SCREENING}

Groundwater modeling results indicate that certain contaminants will be found in groundwater at extremely low concentrations (e.g., less than one part per trillion). To streamline the risk assessment process, it is helpful to define groundwater concentrations that, for all practical purposes, are indistinguishable from zero. For the purpose of this discussion, these concentrations are called de minimis concentrations. If a modeled groundwater concentration is less than a de minimis concentration, then the contaminant is considered absent in groundwater. The de minimis concentration for non-radioactive contaminants is $5 \times 10^{-7} \mathrm{mg} / \mathrm{L}$. This is slightly less than the dieldrin concentration associated with a $1 \times 10^{-7}$ lifetime incremental cancer risk, assuming residential scenario parameters (see section 5.4). This de minimis concentration is based on dieldrin because the dieldrin ingestion slope factor is the largest of any non-radioactive soil contaminant being evaluated in this report (i.e., dieldrin has the greatest carcinogenic potential; see Table 5-1). The de minimis concentration for radioactive contaminants is $1 \times 10^{-2} \mathrm{pCi} / \mathrm{L}$. This is slightly less than the plutonium-239/240 concentration associated with a $1 \times 10^{-7}$ lifetime incremental cancer risk, assuming residential scenario parameters. This de minimis concentration is based on plutonium-239/240 because the plutonium-239/240 ingestion slope factor is the largest of any radioactive soil contaminant being evaluated in this report (Table 5-1).

Although neptunium-237 is not a constituent of potential concern identified in Chapter 3 , it is a daughter product of americium-241. Americiunt-241 decays to neptunium-237 with a half-life of 432 years, and neptunium-237 has a half-life of 2.14 million years. For simulating neptunium-237, it was conservatively assumed that the americium-241 decayed to neptunium237 instantaneously. The concentration of neptunium-237 can be calculated using the following equation:

$$
M_{w}^{N p-237}=\left(\lambda^{N p-237} / \lambda^{A m-241}\right) M_{w}^{A m-241}
$$

where:

$$
\begin{aligned}
& M_{w}{ }^{N-237}=\text { the concentration of neptunium-237 }(\mathrm{pCi} / \mathrm{gm}) \\
& \lambda^{\mathrm{Np}-237}=\text { the decay coefficient of neptunium-237 }\left(3.24 \times 10^{-7} \mathrm{yr}^{-1}\right) \\
& M_{w}^{A m-241}=\text { the concentration of americium-241 (pCi/gm) } \\
& \lambda^{A m-241}=\text { decay coefficient of americium-241 }\left(1.60 \times 10^{-3} \mathrm{yr}^{-1}\right)
\end{aligned}
$$


Assuming the americium-241 concentration is $34 \mathrm{pCi} / \mathrm{gm}$, the maximum neptunium-237 concentration would be $6.86 \times 10^{-3} \mathrm{pCi} / \mathrm{gm}$. This analysis does not account for the decay or leaching of neptunium-237. As shown in Table 4-10, neptunium was eliminated because it reached groundwater after 10,000 years.

Most of the organic compounds and many of the radionuclides are eliminated in the de minimis screening. All of the metals and anions are retained; this is due to their lack of decay.

\subsection{TRAVEL TIME CRITERION}

Based on the Tri-Party Agreement (Ecology et al. 1994), the time of assessment is 10,000 years. The 10,000 year time constraint was used as one criterion to identify groundwater contaminants. If the travel time of a constituent to the ERDF boundary exceeds 10,000 years, the constituent is not considered a groundwater contaminant.

\subsection{GROUNDWATER CONTAMINANTS}

The final list of groundwater contaminants is presented in Table 4-11. Table 4-11 also includes travel times for groundwater contaminants to reach the ERDF boundary. 


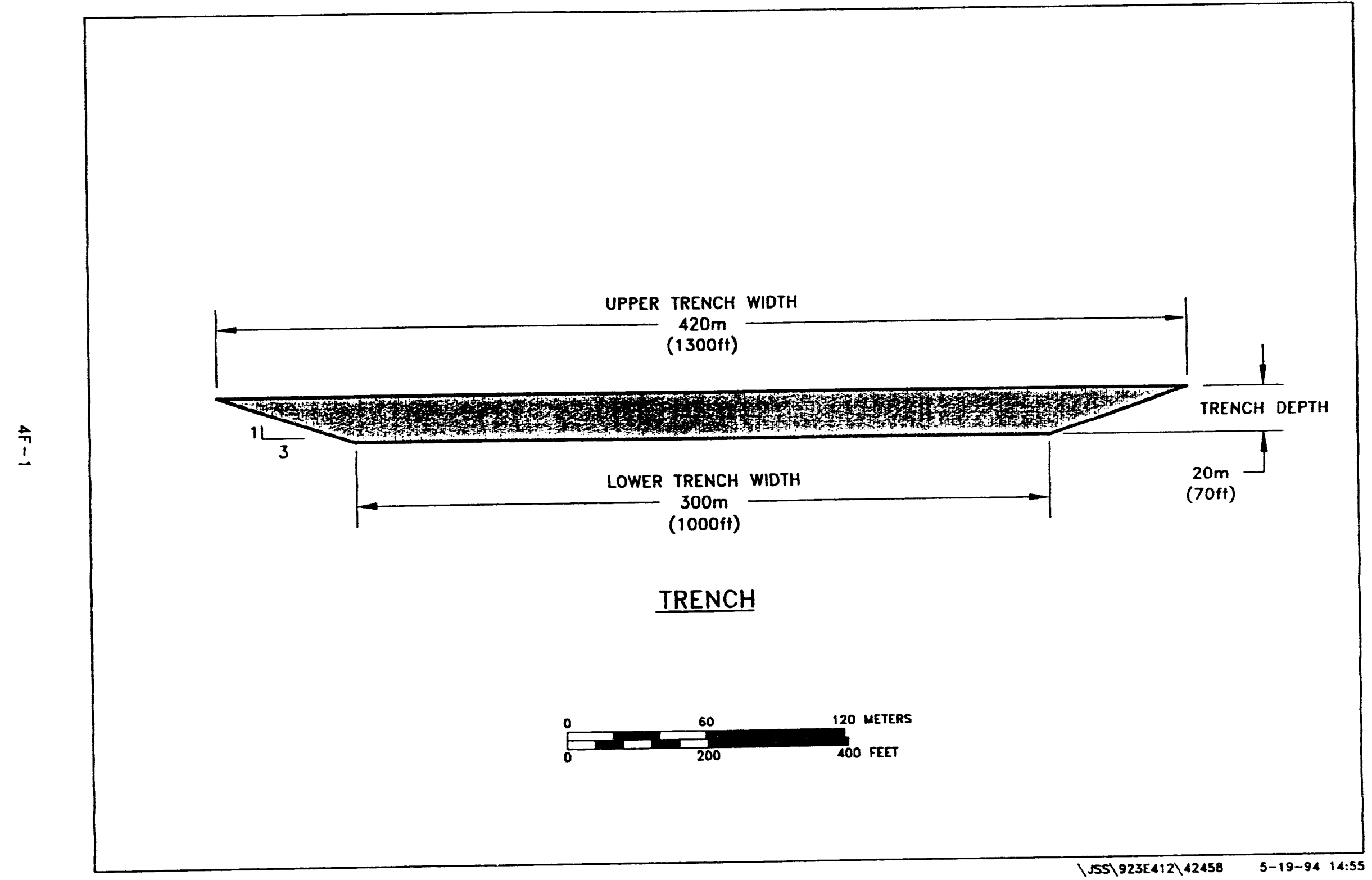

Figure 4-1. Cross-Sectional Dimensions for ERDF Trench. 


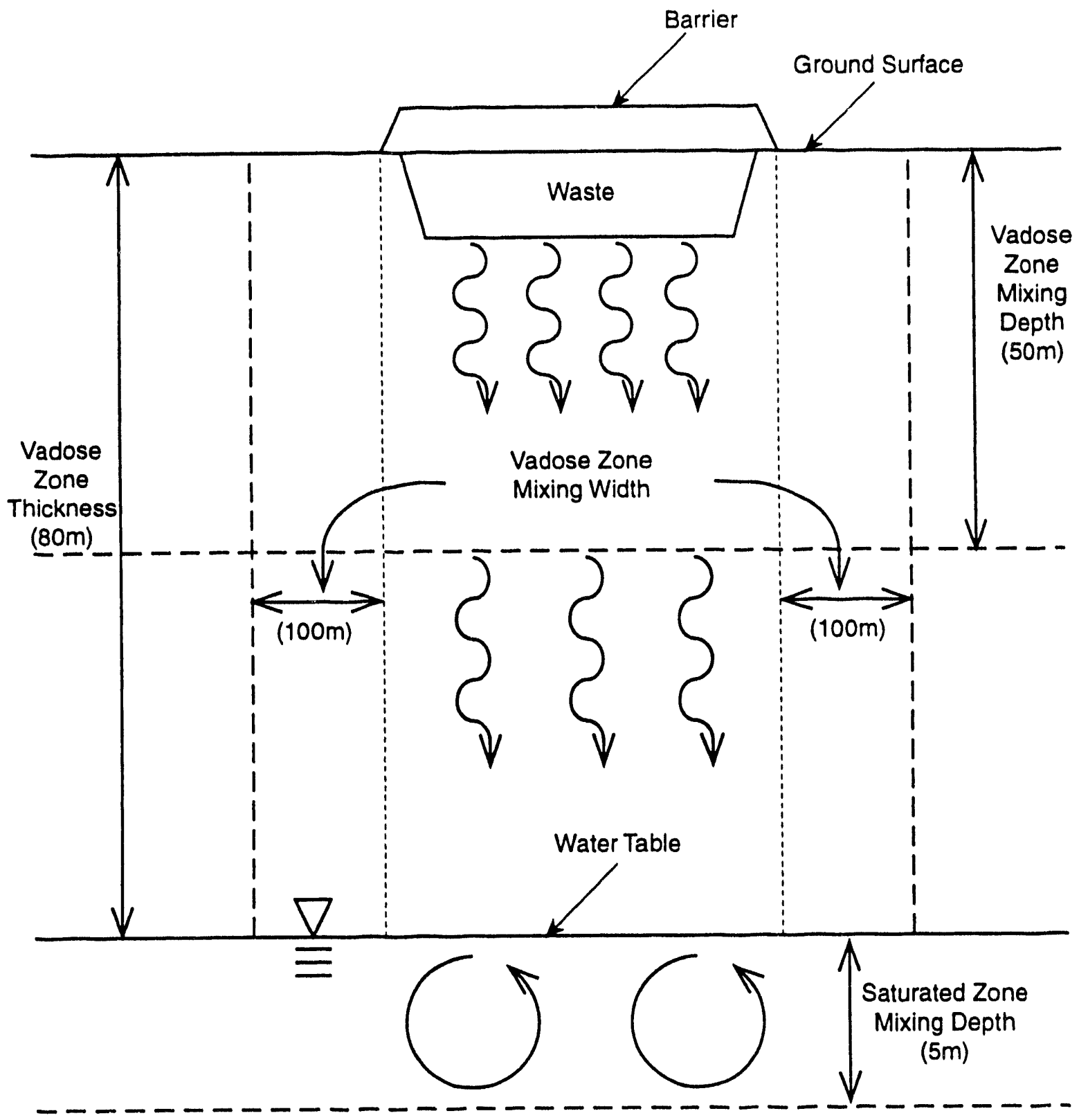

Not to scale

Figure 4-2. Vadose Zone and Saturated Zone Parameters. 
DOE/RL-93-99, Rev. 0

Table 4-1. General Parameters Used for the ERDF Modeling.

\begin{tabular}{|l|c|}
\hline \multicolumn{1}{|c|}{ Parameter } & Most Likely Value \\
\hline Upper Trench Width & $420 \mathrm{~m}$ \\
\hline Lower Trench Width & $300 \mathrm{~m}$ \\
\hline Trench Length & $3000 \mathrm{~m}$ \\
\hline Trench Depth & $20 \mathrm{~m}$ \\
\hline Distance to ERDF Boundary & $100 \mathrm{~m}$ \\
\hline Vadose Zone Water Content & 0.045 \\
\hline Vadose Zone Thickness & $80 \mathrm{~m}$ \\
\hline Vadose Zone Mixing Depth & $50 \mathrm{~m}$ \\
\hline Vadose Zone Mixing Width & $100 \mathrm{~m}$ \\
\hline Vadose Zone Mixing Factor & 0 \\
\hline Saturated Zone Porosity & 0.3 \\
\hline Saturated Zone & $30 \mathrm{~m} / \mathrm{d}$ \\
Hydraulic Conductivity & 0.0035 \\
\hline $\begin{array}{l}\text { Saturated Zone } \\
\text { Hydraulic Gradient }\end{array}$ & $5 \mathrm{~m}$ \\
\hline Saturated Zone Mixing Depth & $1.6 \mathrm{~kg} / \mathrm{L}$ \\
\hline Soil Density (Dry) & $0.5 \mathrm{yr}$ \\
\hline Natural Infiltration Rate & \\
\hline
\end{tabular}


Table 4-2. Partitioning Coefficients for Organic Compounds. (Sheet 1 of 7 )

\begin{tabular}{|c|c|c|c|c|c|c|}
\hline Constituent & : leasured $\mathrm{K}_{\mathrm{oc}}$ & $\begin{array}{l}\text { Estimated } K_{o c} \\
\text { (based on } K_{o w} \text { or } \\
\text { solubility) }\end{array}$ & $\begin{array}{l}\text { Source } \\
\text { of } K_{o c} \\
\text { Data }\end{array}$ & $\begin{array}{c}\text { Best } \\
\text { Estimate } \\
\text { for } K_{o c}\end{array}$ & Comment & $\begin{array}{c}K_{d} \text { Used in } \\
\text { Model } \\
\left(K_{\alpha c} \times 0.001\right. \\
\text { organic content }) \\
\end{array}$ \\
\hline Acenaphthene & ND & $\begin{array}{l}2065-3230(\log \text { Kow }= \\
3.92)\end{array}$ & HSDB & $2.7 \mathrm{E}+03$ & $\begin{array}{l}\text { best estimate is average } \\
\text { of range }\end{array}$ & 2.7 \\
\hline Acetone & no appreciable adsorption & ND & HSDB & 0 & no data & 0 \\
\hline Anthracene & $\begin{array}{l}26,000 \\
1,600 \\
\end{array}$ & ND & HSDB & $1.4 \mathrm{E}+04$ & $\begin{array}{l}\text { best estimate is average } \\
\text { of range }\end{array}$ & 14 \\
\hline Aroclor-1248 & ND & 437,000 & M\&W & $4.4 \mathrm{E}+05$ & $\begin{array}{l}\text { range based on standard } \\
\text { deviation of } 50 \%\end{array}$ & 440 \\
\hline Aroclor- 1254 & $\begin{array}{l}110,000 \text { to } 1,330,000 \\
\text { (review of experimental } \\
\text { data) }\end{array}$ & $\begin{array}{l}42,500 \text { (not clear how } \\
\text { derived) }\end{array}$ & HSDB & $7.2 \mathrm{E}+05$ & $\begin{array}{l}\text { best estimate is average } \\
\text { of measured data only }\end{array}$ & 720 \\
\hline Aroclor- 1260 & $\begin{array}{l}61,000 \text { to } 7,400,000 \\
\text { (review of experimental } \\
\text { data) [for congener hexa] }\end{array}$ & $\begin{array}{l}1 \mathrm{E}+06 \text { (not clear how } \\
\text { derived) [for congener } \\
\text { hepta] }\end{array}$ & HSDB & $2.3 E+06$ & $\begin{array}{l}\text { best estimate is average } \\
\text { of range and other data; } \\
\text { since there are two } \\
\text { congeners }\end{array}$ & 2,300 \\
\hline Benzene & $\begin{array}{l}\text { Woodburn silt loam: } 31 \\
31.7-143 \\
83\end{array}$ & $98\left(K_{o w}=2.13\right)$ & HSDB & $8.7 E+01$ & $\begin{array}{l}\text { best estimate is average } \\
\text { of range }\end{array}$ & 0.087 \\
\hline Benzo(a)anthracene & $\begin{array}{l}5.5 \mathrm{E}+05-1.87 \mathrm{E}+06 \\
\text { (sediments) }\end{array}$ & ND & HSDB & $1.2 \mathrm{E}+06$ & $\begin{array}{l}\text { best estimate is average } \\
\text { of range }\end{array}$ & 1,200 \\
\hline Benzo(a)pyrene & $\begin{array}{l}3.95 \mathrm{E}+06-5.83 \mathrm{E}+06 \\
\text { (experimental) } \\
18,000-52,000 \text { (dissolved } \\
\text { o.c. in natural waters) } \\
890,000 \text { (Aldrich humates) }\end{array}$ & ND & HSDB & $2.9 \mathrm{E}+06$ & $\begin{array}{l}\text { best estimate is average } \\
\text { of range }\end{array}$ & 2,900 \\
\hline Benzo(b)fluoranthene & ND & $\begin{array}{l}7.59 E+05 \text { (solubility- } \\
\text { based) }\end{array}$ & HSDB & $7.6 \mathrm{E}+05$ & $\begin{array}{l}\text { range based on standard } \\
\text { deviation of } 50 \%\end{array}$ & 760 \\
\hline
\end{tabular}


Table 4-2. Partitioning Coefficients for Organic Compounds. (Sheet 2 of 7 )

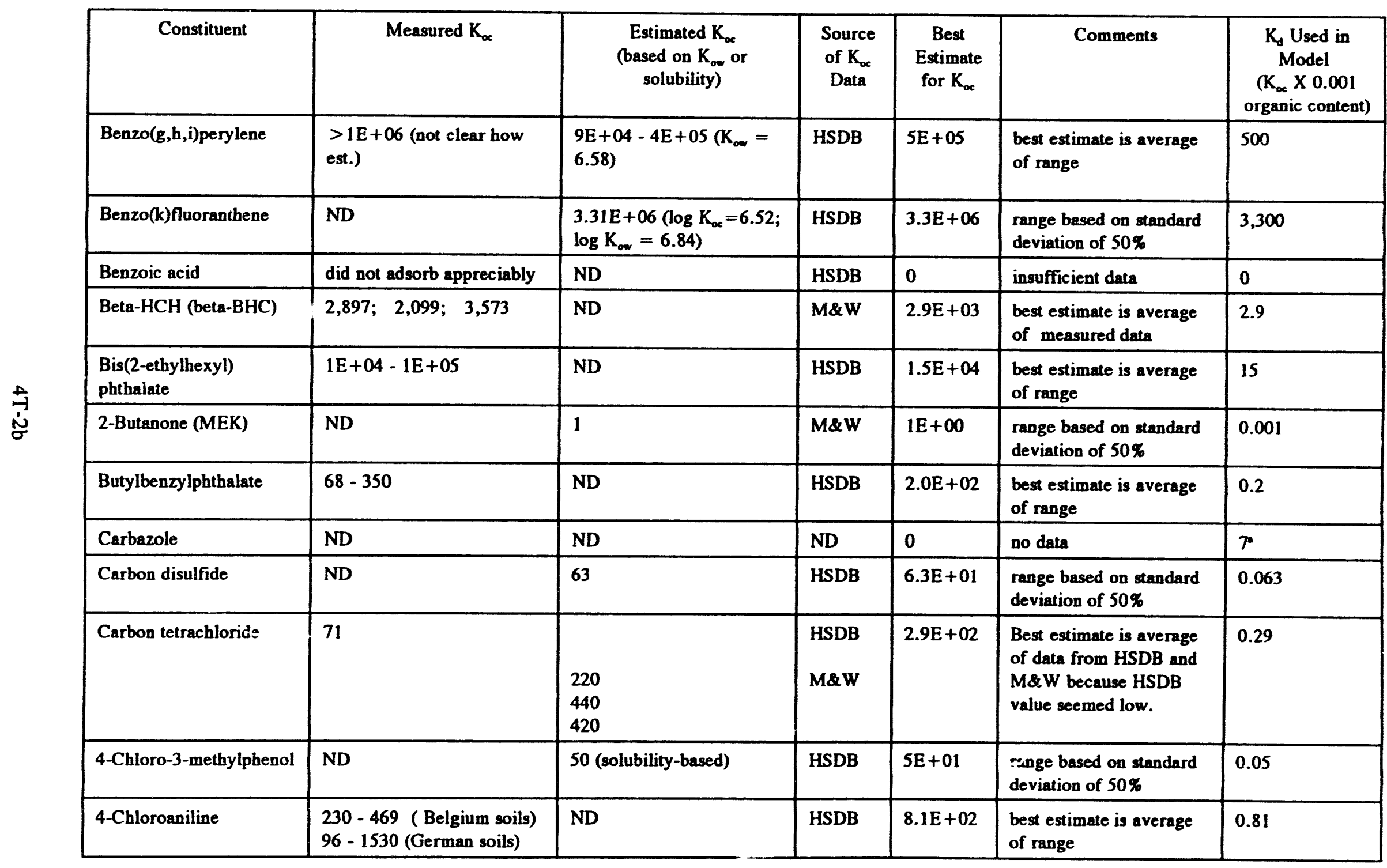


Table 4-2. Partitioning Coefficients for Organic Compounds. (Sheet 3 of 7)

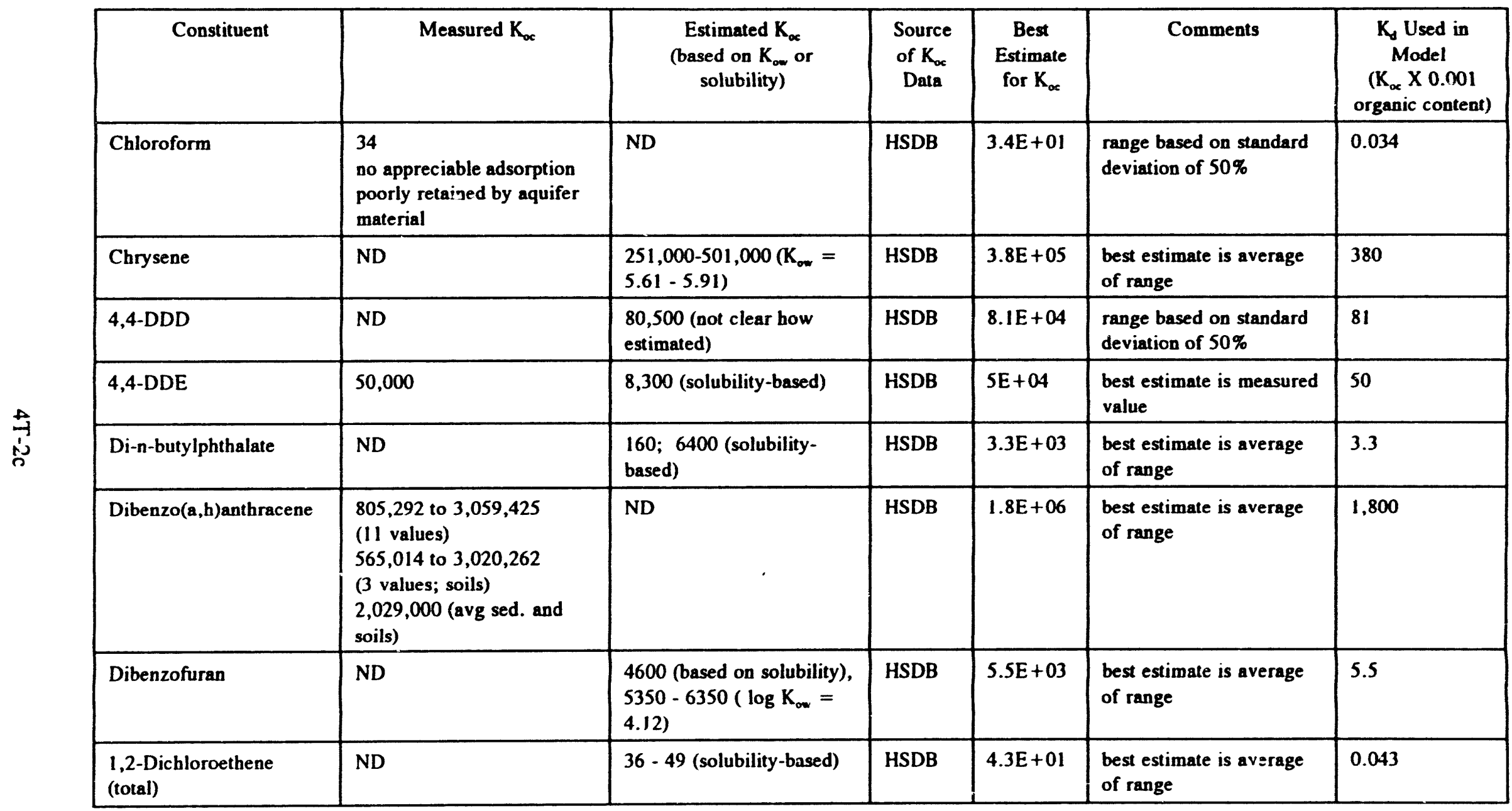



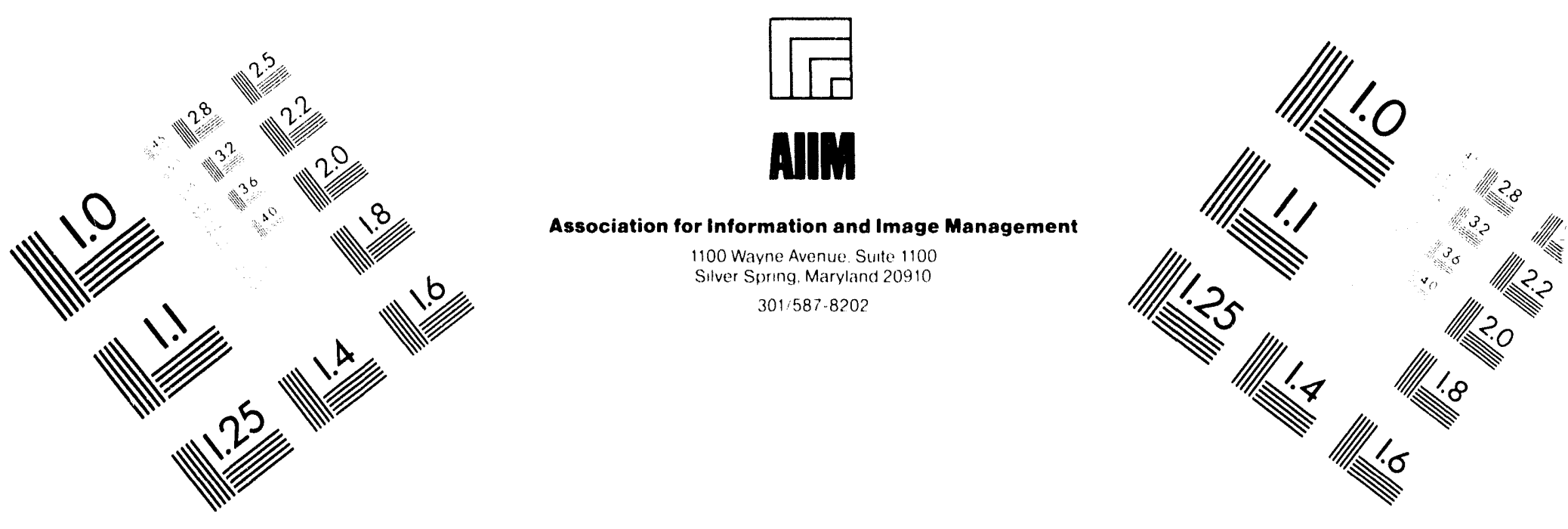

\section{Centimeter}

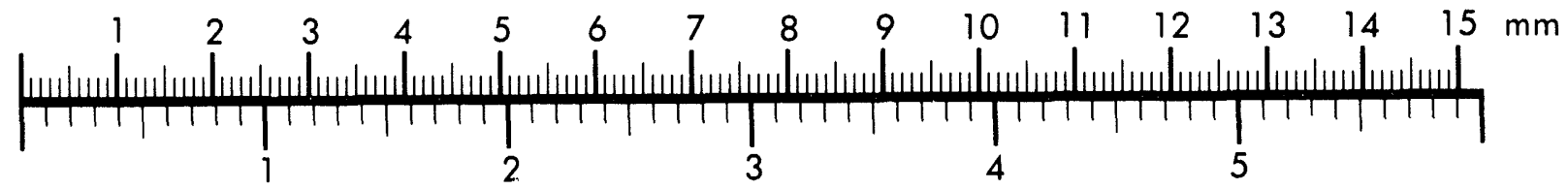
Inches
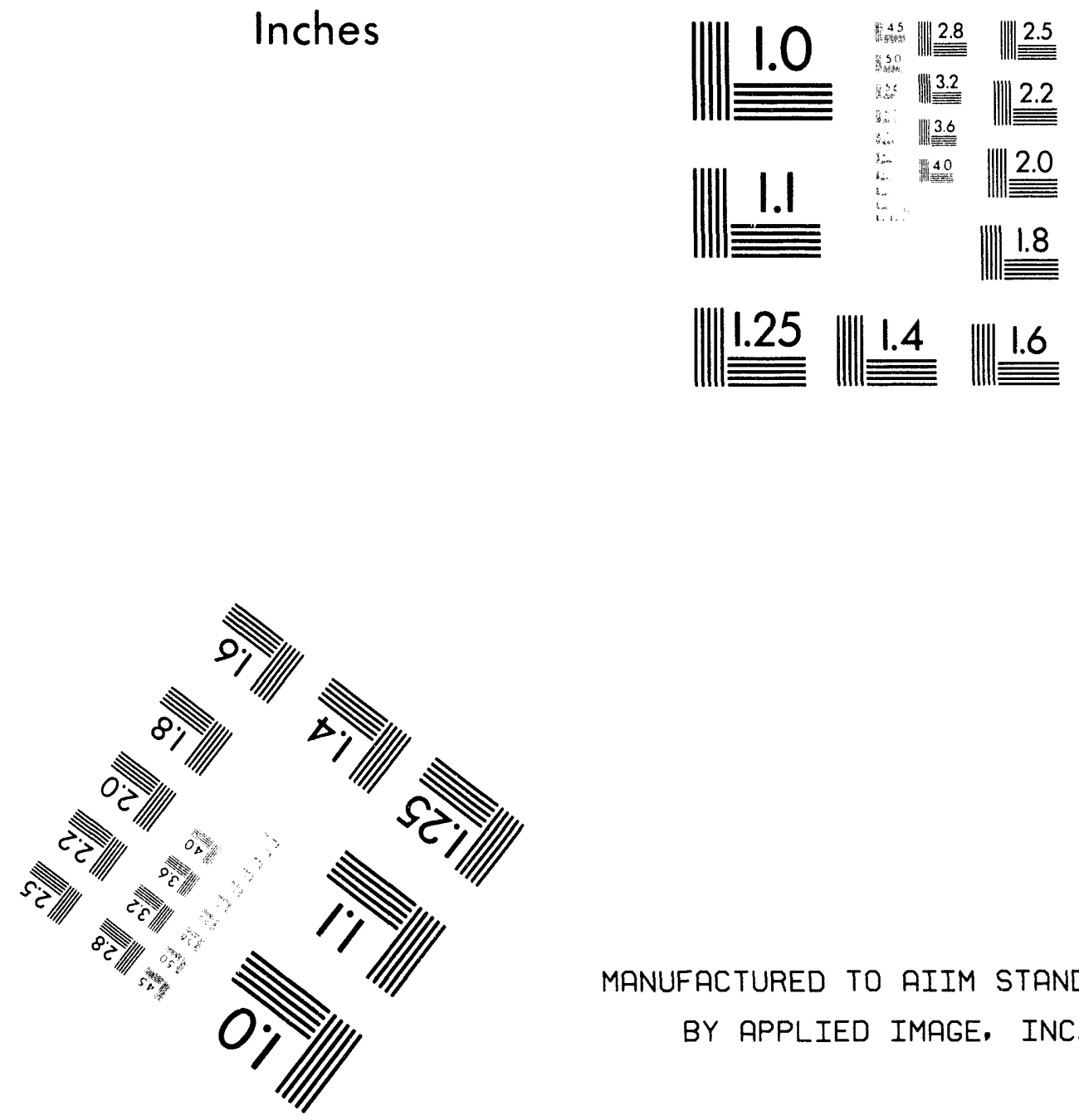

MANUFACTURED TO AIIM STANDARDS

BY APPLIED IMAGE, INC.

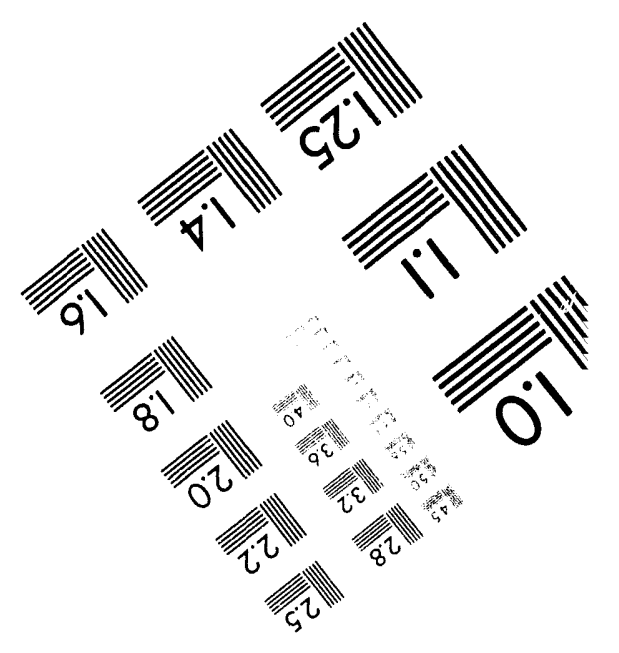



Table 4-2. Partitioning Coefficients for Organic Compounds. (Sheet 4 of 7)

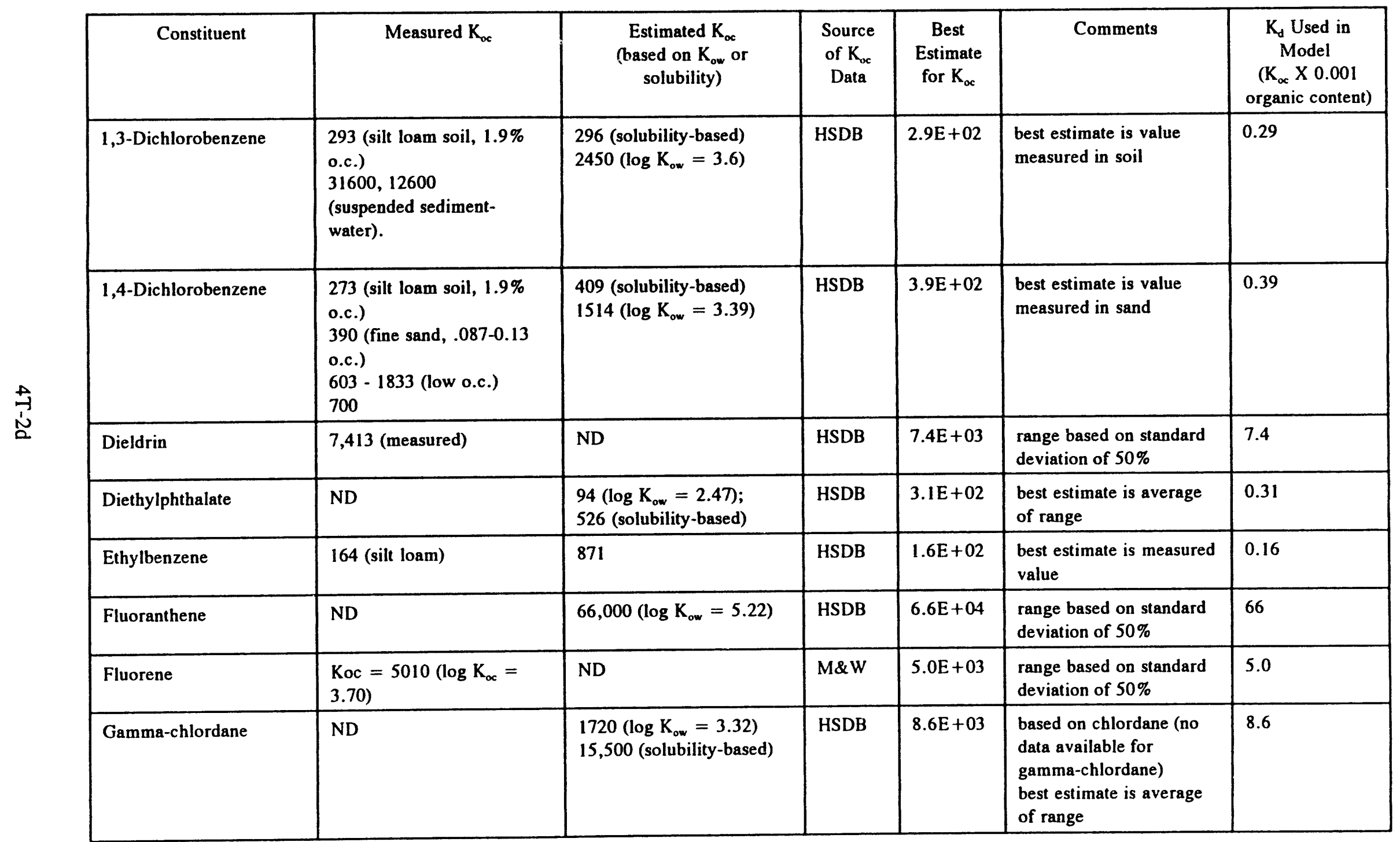


Table 4-2. Partitioning Coefficients for Organic Compounds. (Sheet 5 of 7)

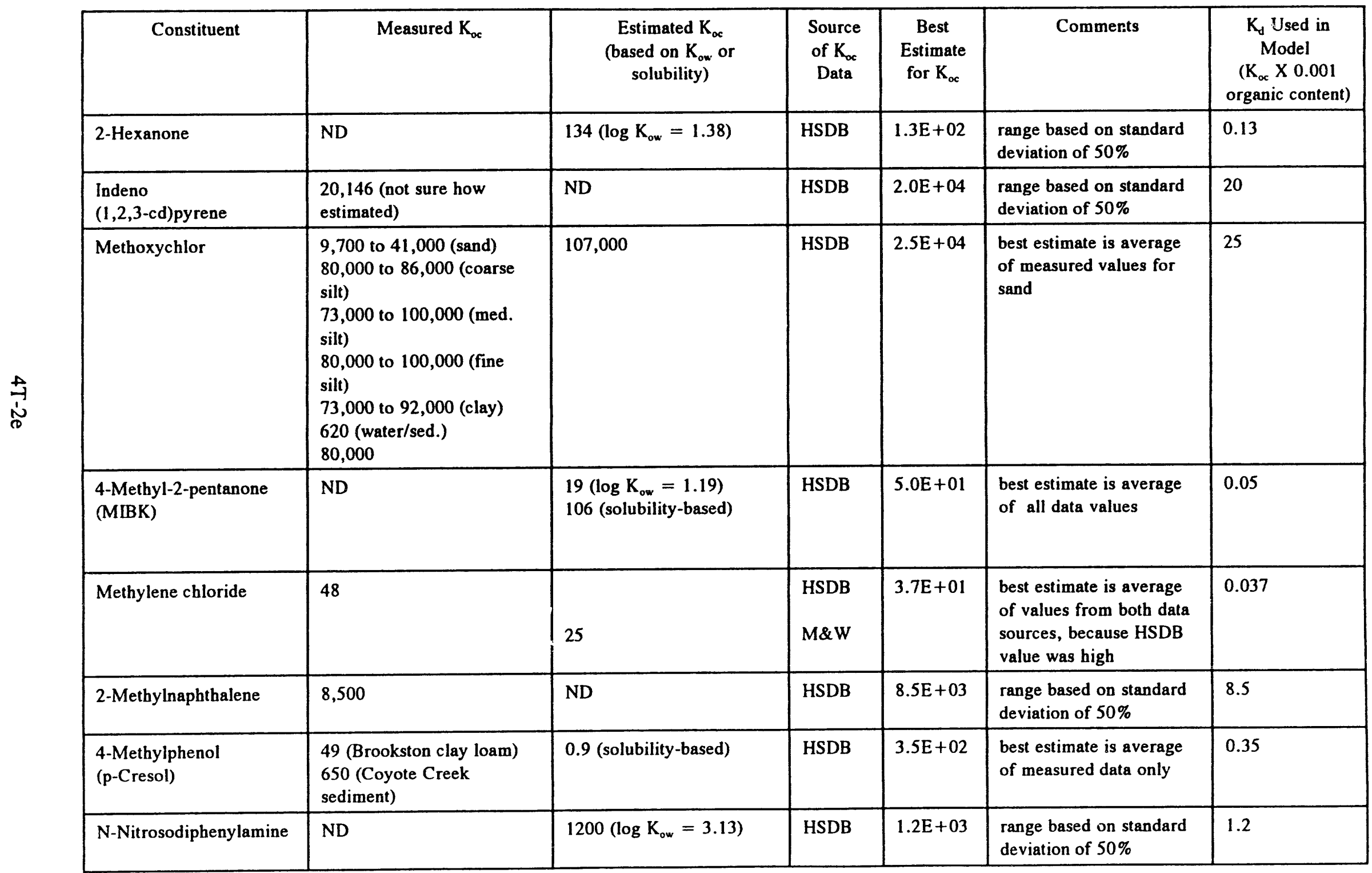


Table 4-2. Partitioning Coefficients for Organic Compounds. (Sheet 6 of 7)

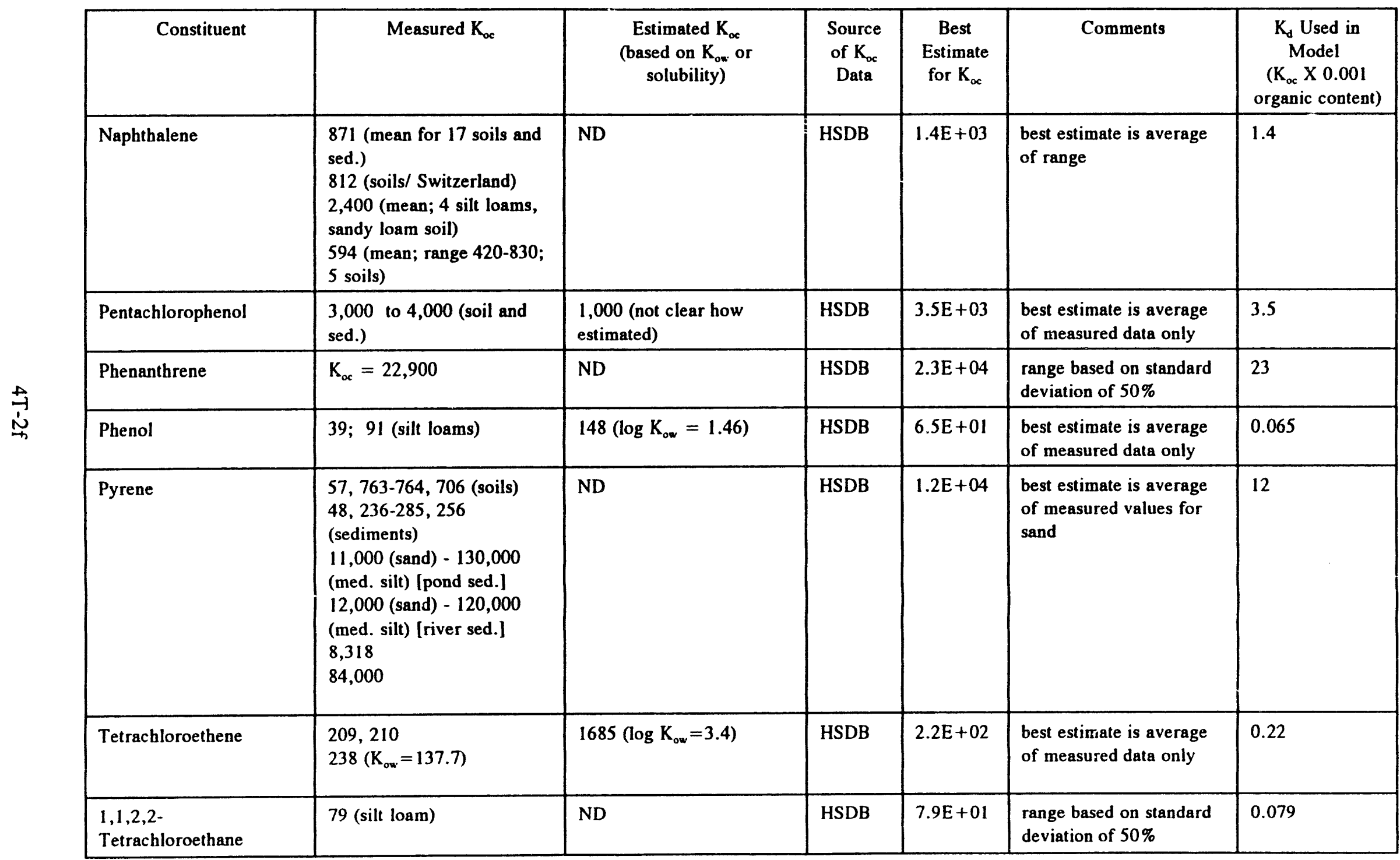


Table 4-2. Partitioning Coefficients for Organic Compounds. (Sheet 7 of 7)

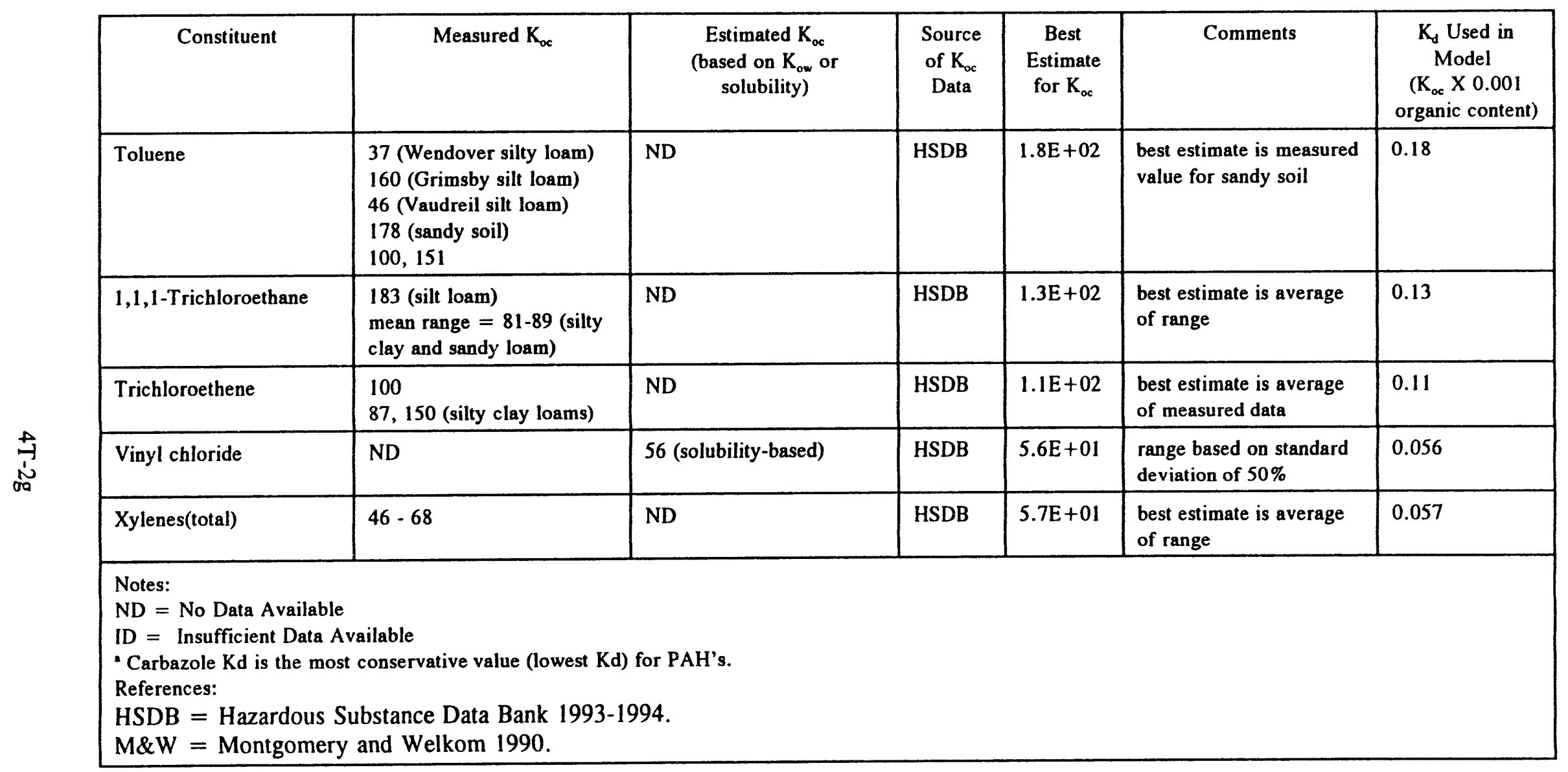


DOE/RL-93-99, Rev. 0

Table 43. Partitioning Coefficients for Radionuclides. (Sheet 1 of 2)

\begin{tabular}{|c|c|c|}
\hline Radionuclide & Hanford-Specific $K_{d}$ Data $^{a}$ & $\begin{array}{c}\text { Best } \\
\text { Estimate } \\
\text { for } \mathrm{K}_{\mathrm{d}}\end{array}$ \\
\hline Amerium-241 & $200(100-500)($ Ames and Serne 1991) & 200 \\
\hline Barium-140 & $25(20-200)$ (Ames and Serne 1991) & 25 \\
\hline Beryllium-7 & $20(15-200)$ (Ames and Serne (1991) & 20 \\
\hline Carbon-14 & $0(0$ to $<5)($ Serne and Wood 1990$)$ & 0 \\
\hline Cerium-141 & $200(100-500)$ (Ames and Serne 1991) & 200 \\
\hline Cerium-144 & $200(100-500)($ Ames and Serne 1991) & 200 \\
\hline Cesium-134 & $50(6->1000)($ Serne and Wood 1990) & 50 \\
\hline Cesium-137 & $50(50-3000)($ Serne and Wood 1990) & 50 \\
\hline Chromium-51 & 0 (Ames and Serne 1991) & 0 \\
\hline Cobalt-58 & $50(10-3000)($ Ames and Serne 1991) & 50 \\
\hline Cobalt -60 & $50(10-3000)$ (Ames and Serne 1991) & 50 \\
\hline Europium-152 & $200(100-500)($ Ames and Serne 1991) & 200 \\
\hline Europium-154 & $200(100-500)($ Ames and Serne 1991) & 200 \\
\hline Europium-155 & $200(100-500)($ Ames and Serne 1991) & 200 \\
\hline Iron-59 & $50(10-3000)($ Ames and Serne 1991) & 50 \\
\hline Manganese-54 & $\begin{array}{l}20 \text { (Serne and Wood 1990) } \\
50(10-3000) \text { (Ames and Serne 1991) }\end{array}$ & 35 \\
\hline Neptunium-237 & $2(2-2,000)($ Ames and Serne 1991) & 2 \\
\hline Nickel-63 & $\begin{array}{l}15 \text { (variable) (Serne and Wood 1990) } \\
30(100-200) \text { (Ames and Serne 1991) }\end{array}$ & 23 \\
\hline Plutonium-238 & $\begin{array}{l}100(80-2000)(\text { Serne and Wood 1990) } \\
25(100-2000)(\text { Ames and Serne 1991) }\end{array}$ & 63 \\
\hline Plutonium-239/240 & $\begin{array}{l}100(80-2000)(\text { Serne and Wood 1990) } \\
25(100-2000)(\text { Ames and Serne 1991) }\end{array}$ & 63 \\
\hline Potassium -40 & $4(1-30)$ (Ames and Serne 1991) & 5 \\
\hline Radium-226 & 20 (Serne and Wood 1990) & 20 \\
\hline Ruthenium-103 & $20(10-1000)($ Ames and Serne 1991) & 20 \\
\hline Ruthenium-106 & $20(10-1000)($ Ames and Serne 1991) & 20 \\
\hline Sodium-22 & $4(1-30)($ Ames and Serne 1991) & 4 \\
\hline Strontium-90 & $\begin{array}{l}25(20-200)(\text { Ames and Serne 1991) } \\
10(5-100)(\text { Serne and Wood 1990) }\end{array}$ & 18 \\
\hline Technetium-99 & $0(0-<1)($ Serne and Wood 1990) & 0 \\
\hline
\end{tabular}


Table 4-3. Partitioning Coefficients for Radionuclides. (Sheet 2 of 2)

\begin{tabular}{|c|c|c|}
\hline Radionuclide & Hanford-Specific $K_{d}$ Data ${ }^{a}$ & $\begin{array}{c}\text { Best } \\
\text { Estimate } \\
\text { for } \mathrm{K}_{\mathrm{d}}\end{array}$ \\
\hline Thorium-228 & 50 (FF-5) (Serne and Wood 1990) & 50 \\
\hline Thorium-232 & 50 (FF-5) (Serne and Wood 1990) & 50 \\
\hline Thorium-234 & 50 (FF-5) (Serne and Wood 1990) & 50 \\
\hline Tritium & 0 (Ames and Serne 1991) & 0 \\
\hline Total Uranium & $\begin{array}{l}2(2-2000)(\text { Ames and Serne 1991) } \\
0(0-<10) \text { (Serne and Wood 1990) }\end{array}$ & 0 \\
\hline Uranium-233/2j4 & $\begin{array}{l}2(2-2000) \text { (Ames and Serne 1991) } \\
0(0-<10) \text { (Serne and Wood 1990) }\end{array}$ & 0 \\
\hline Uranium-235 & $\begin{array}{l}2(2-2000) \text { (Ames and Serne 1991) } \\
0(0-<10)(\text { Serne and Wood 1990) }\end{array}$ & 0 \\
\hline Uranium-238 & $\begin{array}{l}2(2-2000) \text { (Ames and Serne 1991) } \\
0(0-<10)(\text { Serne and Wood 1990) }\end{array}$ & 0 \\
\hline Zinc-65 & $\begin{array}{l}15(\text { Serne and Wood 1990) } \\
30(100-200) \text { (Ames and Serne 1991) }\end{array}$ & 23 \\
\hline Zirconium-95 & $\begin{array}{l}40(10-1000) \text { (Ames and Serne 1991) } \\
30 \text { (Variable) (Serne and Wood 1990) }\end{array}$ & 35 \\
\hline \multicolumn{3}{|c|}{ aRanges are shown in parentheses. } \\
\hline
\end{tabular}


Table 4-4. Partitioning Coefficients for Inorganic Constituents. (Sheet 1 of 2)

\begin{tabular}{|c|c|c|c|}
\hline Constituent & $\begin{array}{c}\text { Hanford-Specific } \\
\text { Partitioning } \\
\text { Coefficient }\left(\mathrm{K}_{\mathrm{d}}\right)(\mathrm{L} / \mathrm{kg})\end{array}$ & Source of $K_{d}$ & $\begin{array}{c}\text { Best } \\
\text { Estimate } \\
\text { for } K_{d}\end{array}$ \\
\hline Aluminum & $20(10-2000)$ & Ames and Serne 1991 & 20 \\
\hline Antimony & $0(0-40)$ & Ames and Serne 1991 & 0 \\
\hline Arsenic & 0 & Serne and Wood 1990 & 0 \\
\hline Barium & $\begin{array}{l}50 \\
25(20-200) \\
\end{array}$ & $\begin{array}{l}\text { Serne and Wood } 1990 \\
\text { Ames and Serne } 1991\end{array}$ & 50 \\
\hline Beryllium & $20(15-200)$ & Serne and Wood 1990 & 20 \\
\hline Cadmium & $\begin{array}{l}15 \text { (variable range) } \\
30(100-200)\end{array}$ & $\begin{array}{l}\text { Serne and Wood } 1990 \\
\text { Ames and Serne } 1991\end{array}$ & 23 \\
\hline Calcium & $\begin{array}{l}10 \text { (Variable) } \\
20(15-200)\end{array}$ & $\begin{array}{l}\text { Serne and Wood } 1990 \\
\text { Ames and Serne } 1991\end{array}$ & 15 \\
\hline Chromium (VI) & 0 (variable) & Serne and Wood 1990 & 0 \\
\hline Cobalt & $\begin{array}{l}10(500-2,000) \\
50(10-3000)\end{array}$ & $\begin{array}{l}\text { Serne and Wood } 1990 \\
\text { Ames and Serne } 1991\end{array}$ & 30 \\
\hline Copper & $\begin{array}{l}15 \text { (variable) } \\
30(100-200)\end{array}$ & $\begin{array}{l}\text { Serne and Wood } 1990 \\
\text { Ames and Serne } 1991\end{array}$ & 23 \\
\hline Iron & $\begin{array}{l}50(10-3000) \\
20\end{array}$ & $\begin{array}{l}\text { Ames and Serne } 1991 \\
\text { Serne and Wood } 1990\end{array}$ & 35 \\
\hline Lead & $\begin{array}{l}30 \\
30(100-200)\end{array}$ & $\begin{array}{l}\text { Serne and Wood } 1990 \\
\text { Ames and Serne } 1991\end{array}$ & 30 \\
\hline Magnesium & $20(15-200)$ & Ames and Serne 1991 & 20 \\
\hline Manganese & $\begin{array}{l}20 \\
50(10-3000)\end{array}$ & $\begin{array}{l}\text { Serne and Wood } 1990 \\
\text { Ames and Serne } 1991\end{array}$ & 35 \\
\hline Mercury & $30(100-200)$ & Ames and Serne 1991 & 30 \\
\hline Nickel & $\begin{array}{l}15 \text { (variable range) } \\
30(100-200)\end{array}$ & $\begin{array}{l}\text { Ames and Serne } 1991 \\
\text { Ames and Serne } 1991\end{array}$ & 23 \\
\hline Potassium & $4(1-30)$ & Ames and Serne 1991 & 4 \\
\hline Selenium & 0 & Serne and Wood 1990 & 0 \\
\hline Silver & $\begin{array}{l}20 \text { (unknown range) } \\
30(100-200)\end{array}$ & $\begin{array}{l}\text { Serne and Wood } 1990 \\
\text { Ames and Serne } 1991\end{array}$ & 25 \\
\hline Sodium & $\begin{array}{l}3 \\
4(1-30) \\
\end{array}$ & $\begin{array}{l}\text { Serne and Wood } 1990 \\
\text { Ames and Serne } 1991\end{array}$ & 3 \\
\hline Strontium & $\begin{array}{l}25(20-200) \\
10(5-100)\end{array}$ & $\begin{array}{l}\text { Serne and Wood } 1990 \\
\text { Ames and Serne } 1991\end{array}$ & 18 \\
\hline
\end{tabular}


Table 4-4. Partitioning Coefficients for Inorganic Constituents. (Sheet 2 of 2)

\begin{tabular}{|l|l|l|c|}
\hline \multicolumn{1}{|c|}{ Constituent } & \multicolumn{1}{|c|}{$\begin{array}{c}\text { Hanford-Specific } \\
\text { Partitioning } \\
\text { Coefficient }\left(\mathrm{K}_{\mathrm{d}}\right)(\mathrm{L} / \mathrm{kg})\end{array}$} & \multicolumn{1}{|c|}{ Source of $\mathrm{K}_{\mathrm{d}}$} & $\begin{array}{c}\text { Best } \\
\text { Estimate } \\
\text { for } \mathrm{K}_{\mathrm{d}}\end{array}$ \\
\hline Thallium & 50 & Serne and Wood 1990 & 50 \\
\hline Vanadium & $50(50-3000)$ & Ames and Serne 1991 & 50 \\
\hline Zinc & $\begin{array}{l}15(\text { variable }) \\
30(100-200)\end{array}$ & $\begin{array}{l}\text { Serne and Wood 1990 } \\
\text { Ames and Serne 1991 }\end{array}$ & 23 \\
\hline $\begin{array}{l}\text { Ammonia } \\
\text { Ammonium }\end{array}$ & $4(1-30)$ & Ames and Serne 1991 & 4 \\
\hline Chloride & $0(0$ to $<1)$ & $\begin{array}{l}\text { Serne and Wood 1990 } \\
\text { Ames and Serne 1991 }\end{array}$ & 0 \\
\hline Fluoride & $\begin{array}{l}0(0 \text { to }<1) \\
0\end{array}$ & $\begin{array}{l}\text { Serne and Wood 1990 } \\
\text { Ames and Serne 1991 }\end{array}$ & 0 \\
\hline Nitrate & $0(0$ to $<1)$ & $\begin{array}{l}\text { Serne and Wood 1990 } \\
\text { Ames and Serne 1991 }\end{array}$ & 0 \\
\hline Nitrite & $0(0$ to $<1)$ & Serne and Wood 1990 & 0 \\
\hline Nitrite+Nitrate & & $\begin{array}{l}\text { use same value as for } \\
\text { nitrate and nitrite }\end{array}$ & 0 \\
\hline Phosphate & $10($ variable $)$ & $\begin{array}{l}\text { Serne and Wood 1990 } \\
\text { Ames and Serne 1991 }\end{array}$ & 30 \\
\hline Sulfate & $0(50-3000)$ & $\begin{array}{l}\text { Serne and Wood 1990 } \\
\text { Ames and Serne 1991 }\end{array}$ & 0 \\
\hline
\end{tabular}


Table 4-5. Half-lives for Organic Compounds. (Sheet 1 of 3)

\begin{tabular}{|c|c|c|c|c|c|}
\hline Constituent & $\begin{array}{l}\text { Half-Life } \\
\text { HSDB } \\
1993\end{array}$ & $\begin{array}{l}\text { Half-life } \\
\text { Howard } \\
\text { et. al } 1991\end{array}$ & $\begin{array}{l}\text { Half-Life } \\
\text { Dragun } \\
1988\end{array}$ & Range & Comments \\
\hline Acenaphthene & $<1$ & $<1$ & $<1$ & 1 & \\
\hline Acetone & $<1$ & $<1$ & ND & 1 & \\
\hline Anthracene & $<1$ & $1 \cdot 10$ & $1 \cdot 10$ & $1 \cdot 10$ & \\
\hline Aroclor-1248 & $<1$ & ND & ID & 1 & \\
\hline Aroclor -1254 & $\underline{\mathrm{D}}$ & ND & ID & ID & use 10,000 years \\
\hline Aroclor -1260 & D & ND & ID & ID & use 10,000 years \\
\hline Benzene & $<1$ & $1-10$ & $<1$ & $1 \cdot 10$ & \\
\hline Benzo(a)anthracene & $\mathrm{ID}$ & $1 \cdot 10$ & $1 \cdot 10$ & $1-10$ & \\
\hline Benzo(a)pyrene & $10-100$ & $1-10$ & $1 \cdot 10$ & $1-100$ & \\
\hline Benzo(b)fluoranthene & $\underline{\mathrm{D}}$ & $1 \cdot 10$ & $1-10$ & $1-10$ & \\
\hline Benzo(g,h,i)perylene & $1-10$ & $1-10$ & $1 \cdot 10$ & $1-10$ & \\
\hline Benzo(k)fluoranthene & $1-10$ & $10-100$ & $1 \cdot 10$ & $1 \cdot 100$ & \\
\hline Benzoic acid & $<1$ & ND & $<1$ & 1 & \\
\hline Beta-HCH (beta-BHC) & ND & ND & ID & ID & use 10,000 years \\
\hline Bis(2-ethylhexyl) phthalate & $<1$ & $1 \cdot 10$ & $\mathbb{D}$ & $1-10$ & \\
\hline 2-Butanone & ID & $<1$ & ND & 1 & \\
\hline Butylbenzylphthalate & $\mathrm{ID}$ & $<1$ & $<1$ & 1 & \\
\hline Carbazole & ND & ND & ND & ND & use 100 years \\
\hline Carbon disulfide & $<1$ & $\mathrm{ND}$ & ND & 1 & \\
\hline Carbon tetrachloride & ID & $1-10$ & $\mathrm{ND}$ & $1 \cdot 10$ & \\
\hline 4-Chloro-3-methylphenol & ID & ND & ND & ID & $\begin{array}{l}\text { "readily biodegradable" } \\
\text { (HSDB); use } 1 \text { year based } \\
\text { on analogy with phenol }\end{array}$ \\
\hline 4-Chloroaniline & $<1$ & ND & ND & 1 & \\
\hline Chloroform & $<1$ & $1 \cdot 10$ & ND & $1 \cdot 10$ & \\
\hline Chrysene & ID & $1-10$ & ND & $1 \cdot 10$ & \\
\hline 4,4-DDD & ID & $10-100$ & ID & $10-100$ & \\
\hline 4,4-DDE & $1 \cdot 10$ & $10 \cdot 100$ & ID & $1 \cdot 100$ & \\
\hline Di-n-butylphthalate & $<1$ & $<1$ & $<1$ & 1 & \\
\hline Dibenzo(a,b)anthracene & $<1$ & $1 \cdot 10$ & $1 \cdot 10$ & $1 \cdot 10$ & \\
\hline Dibenzofuran & $\mathbb{D}$ & $<1$ & $<1$ & 1 & \\
\hline 1,2-Dichloroethene (total) & $<1$ & $1 \cdot 10$ & ND & $1 \cdot 10$ & \\
\hline 1,3-Dichlorobenzene & $<1$ & $<1$ & $<1$ & 1 & \\
\hline 1,4-Dichlorobenzene & $<1$ & $<1$ & $<1$ & 1 & \\
\hline
\end{tabular}


Table 4-5. Half-lives for Organic Compounds. (Sheet 2 of 3)

\begin{tabular}{|c|c|c|c|c|c|}
\hline Constituent & $\begin{array}{l}\text { Half-Life } \\
\text { HSDB } \\
1993\end{array}$ & $\begin{array}{l}\text { Half-life } \\
\text { Howard } \\
\text { et. al } 1991\end{array}$ & $\begin{array}{l}\text { Half-Life } \\
\text { Dragun } \\
1988\end{array}$ & Range & Comments \\
\hline Dieldrin & $1-10$ & $1-10$ & $\mathrm{ID}$ & $1-10$ & \\
\hline Diethylphthalate & $<1$ & $<1$ & $<1$ & 1 & \\
\hline Ethylbenzene & $<1$ & $<1$ & $<1$ & 1 & \\
\hline Fluoranthene & $1 \cdot 10$ & $1-10$ & $1-10$ & $1-10$ & \\
\hline Fluorene & ID & $<1$ & $<1$ & 1 & \\
\hline Gamma-chlordane & ND & $1-10$ & ND & $1-10$ & $\begin{array}{l}\text { based on chlordane (no data } \\
\text { available for gamma- } \\
\text { chlordane) }\end{array}$ \\
\hline 2-Hexanone & $<1$ & ND & ND & 1 & \\
\hline Indeno(1,2,3-cd)pyrene & ND & $1-10$ & $1 \cdot 10$ & $1-10$ & \\
\hline Methoxychlor & $<1$ & $1-10$ & ND & $1-10$ & \\
\hline 4-Metbyl-2-pentanone & ID & $<1$ & ND & 1 & \\
\hline Methylene chloride & $<1$ & $<1$ & $<1$ & 1 & \\
\hline 2-Methylnaphthalene & $<1$ & ND & $<1$ & 1 & \\
\hline 4-Methylphenol & $\mathrm{DD}$ & $<1$ & ND & 1 & \\
\hline N-Nitrosodiphenylamine & $<1$ & $<1$ & $<1$ & 1 & \\
\hline Naphthalene & $<1$ & $<1$ & $<1$ & 1 & \\
\hline Pentachlorophenol & $<1$ & $1-10$ & $<1$ & $1-10$ & \\
\hline Phenanthrene & ID & $1 \cdot 10$ & $<1$ & $1-10$ & \\
\hline Pbenol & $<1$ & $<1$ & $<1$ & 1 & \\
\hline Pyrene & ID & $10-100$ & $1-10$ & $1-100$ & \\
\hline Tetrachloroethene & $<1$ & $1-10$ & $<1$ & $1-10$ & \\
\hline 1,1,2,2-Tetracbloroethane & $<1$ & $<1$ & $<1$ & 1 & \\
\hline Toluene & $<1$ & $<1$ & $<1$ & 1 & \\
\hline 1,1,1-Trichloroethane & $<1$ & $1 \cdot 10$ & $<1$ & $1-10$ & \\
\hline Trichlorsethene & $<1$ & $1 \cdot 10$ & $<1$ & $1-10$ & \\
\hline Vinyl chloride & $<1$ & $1 \cdot 10$ & $<1$ & $1-10$ & \\
\hline
\end{tabular}


DOE/RL-93-99, Rev. 0

Table 4-5. Half-lives for Organic Compounds. (Sheet 3 of 3)

\begin{tabular}{|c|c|c|c|c|c|}
\hline Constituent & $\begin{array}{c}\text { Half-Life } \\
\text { HSDB } \\
1993\end{array}$ & $\begin{array}{l}\text { Half-life } \\
\text { Howard } \\
\text { et. al } 1991\end{array}$ & $\begin{array}{c}\text { Half-Life } \\
\text { Dragun } \\
1988\end{array}$ & Range & Comments \\
\hline Xylenes(total) & $<1$ & $1-10$ & $<1$ & $1 \cdot 10$ & \\
\hline \multicolumn{6}{|c|}{$\begin{array}{l}\text { Notes: } \\
\text { ND = No data. } \\
\text { ID = Insufficient data. } \\
\text { "Half-life for carbazole is based on most conservative value (highest) for all PAH's. } \\
\text { Sources: } \\
\text { Dragun } 1988 . \\
\text { Howard et al. } 1991 . \\
\text { HSDB = Hazardous Substance Data Bank 1993-1994. }\end{array}$} \\
\hline
\end{tabular}


DOE/RL-93-99, Rev. 0

Table 4-6. Half-lives and Solubilities for Radionuclides. (Sheet 1 of 2)

\begin{tabular}{|c|c|c|c|c|}
\hline Radionuclide & $\begin{array}{l}\text { Solubility } \\
\text { (mg/L) }\end{array}$ & Source & $\begin{array}{l}\text { Best Estimate } \\
\text { for Solubility } \\
(\mathrm{mg} / \mathrm{L})\end{array}$ & $\begin{array}{c}\text { Half-Life } \\
(y r)\end{array}$ \\
\hline Amerium-241 & LS $(<1)$ & Ames and Serne 1991 & 1 & 432 \\
\hline Barium-140 & LS $(<1)$ & Ames and Serne 1991 & 1 & 0.0350 \\
\hline Beryllium-7 & Insoluble & Weast 1989 & 1 & 0.146 \\
\hline Carbon-14 & 30 & Wood 1994 & 30 & 5,730 \\
\hline Cerium-141 & ND & & 1,000 & 0.0890 \\
\hline Cerium-144 & ND & & 1,000 & 0.0778 \\
\hline Cesium-134 & ND & & 1,000 & 2.06 \\
\hline Cesium-137 & VS $(>1000)$ & Ames and Serne 1991 & 1,000 & 30.2 \\
\hline Chromium-51 & MS $(>1)$ & Serne and Wood 1990 & 25 & $0.075 n$ \\
\hline Cobalt -58 & $\begin{array}{c}\text { ND } \\
\text { (use } \mathrm{Co}-60 \text { ) }\end{array}$ & & 25 & 0.154 \\
\hline Cobalt -60 & MS (1-25) & Ames and Serne 1991 & 25 & 5.27 \\
\hline Europium-152 & ND & & 1,000 & 13.6 \\
\hline Europium-154 & ND & & 1,000 & 8.80 \\
\hline Europium-155 & ND & & 1,000 & 4.96 \\
\hline Iron-59 & LS $(<1)$ & Ames and Serne 1991 & 1 & 0.122 \\
\hline Manganese-54 & LS $(<1)$ & $\begin{array}{l}\text { Serne and Wood } 1990 \\
\text { Ames and Serne } 1991\end{array}$ & 1 & 0.86 \\
\hline Neptunium-237 & MS $(1-25)$ & Serne and Wood 1990 & 25 & $2.14 E+06$ \\
\hline Nickel-63 & $\mathrm{MS}(>1)$ & Serne and Wood 1990 & 25 & 100 \\
\hline Plutonium-238 & $\begin{array}{c}\text { ND (use Pu- } \\
239 / 240 \text { ) }\end{array}$ & & 1 & 87.8 \\
\hline Plutonium-239/240 & LS $(<1)$ & $\begin{array}{l}\text { Serne and Wood } 1990 \\
\text { Ames and Serne } 1991\end{array}$ & 1 & $24,100^{2}$ \\
\hline Potassium -40 & $\begin{array}{c}\text { VS } \\
(>1000)\end{array}$ & Ames and Serne 1991 & $0.12^{b}$ & $1.28 \mathrm{E}+09$ \\
\hline Radium-226 & ND & & 1,000 & 1,600 \\
\hline Ruthenium-103 & ND & & 1,000 & 0.108 \\
\hline Ruthenium-106 & ND & & 1,000 & 1.01 \\
\hline Sodium-22 & $\begin{array}{c}\text { VS } \\
(>1000)\end{array}$ & Serne and Wood 1990 & 1,000 & 2.60 \\
\hline Strontium-90 & MS (1-25) & Ames and Serne 1991 & 25 & 28.6 \\
\hline
\end{tabular}


Table 4-6. Half-lives and Solubilities for Radionuclides. (Sheet 2 of 2)

\begin{tabular}{|c|c|c|c|c|}
\hline Radionuclide & $\begin{array}{l}\text { Solubility } \\
(\mathrm{mg} / \mathrm{L})\end{array}$ & Source & $\begin{array}{l}\text { Best Estimate } \\
\text { for Solubility } \\
\quad(\mathrm{mg} / \mathrm{L})\end{array}$ & $\begin{array}{l}\text { Half-Life } \\
\quad(y r)\end{array}$ \\
\hline Technetium-99 & VS $(>1000)$ & Ames and Serne 1991 & 1,000 & $2.13 \mathrm{E}+05$ \\
\hline Thorium-228 & LS $(<1)$ & Serne and Wood 1990 & 1 & 1.91 \\
\hline Thorium-232 & LS $(<1)$ & Serne and Wood 1990 & 1 & $1.41 \mathrm{E}+10$ \\
\hline Thorium-234 & LS $(<1)$ & Serne and Wood 1990 & 1 & $\begin{array}{l}0.0660 \\
\text { years }\end{array}$ \\
\hline Tritium & $\begin{array}{c}\text { VS } \\
(>1000)\end{array}$ & Ames and Serne 1991 & $2.7 \mathrm{E}+05^{\mathrm{c}}$ & 12.3 \\
\hline Total Uranium & MS (1-25) & Ames and Serne 1991 & 25 & $4.47 \mathrm{E}+09^{\mathrm{d}}$ \\
\hline Uranium-233/234 & MS (1-25) & Ames and Serne 1991 & $0.0014^{b}$ & $2.45 \mathrm{E}+05^{\circ}$ \\
\hline Uranium-235 & MS (1-25) & Ames and Serne 1991 & $0.18^{b}$ & $7.04 \mathrm{E}+08$ \\
\hline Uranium-238 & MS (1-25) & Ames and Serne 1991 & $24.8^{b}$ & $4.47 \mathrm{E}+09$ \\
\hline Zinc-65 & MS (1-25) & Ames and Serne 1991 & 25 & 0.668 \\
\hline Zirconium-95 & $\begin{array}{l}\text { LS }(<1) \\
\operatorname{LS}(<1)\end{array}$ & $\begin{array}{l}\text { Ames and Serne } 1991 \\
\text { Serne and Wood } 1990\end{array}$ & 1 & 0.175 \\
\hline \multicolumn{5}{|c|}{$\begin{array}{l}\text { LS }=\text { low solubility } \\
\text { MS = moderately soluble } \\
\text { VS = very soluble }\end{array}$} \\
\hline \multicolumn{5}{|c|}{$\begin{array}{l}\text { Using half-life of Pu-239. (Half-life of Pu-240 }=6.57 \mathrm{E}+03 \mathrm{yr} \text { ) } \\
\text { b Accounts for crustal isotopic abundance (Faure, } 1977 \text { ). } \\
\text { c The solubility of tritium was calculated based on the assumption that all hydrogen in water is } \\
\text { tritium. } \\
\text { d Using half-life of U-238. } \\
\text { e Using half-life of U-234. (Half-life of U-233 = } 1.59 \mathrm{E}+05 \mathrm{yr} \text { ) }\end{array}$} \\
\hline \multicolumn{5}{|c|}{$\begin{array}{l}\text { Sources: } \\
\text { 1. Ames and Serne } 1991 . \\
\text { 2. Serne and Wood } 1990 . \\
\text { 3. Weast et al. } 1989 .\end{array}$} \\
\hline
\end{tabular}


DOE/RL-93-99, Rev. 0

Table 4-7. Solubilities for Organic Compounds. (Sheet 1 of 3 )

\begin{tabular}{|c|c|c|c|}
\hline Constituent & $\begin{array}{l}\text { Solubility } \\
(\mathrm{mg} / \mathrm{L})\end{array}$ & Source & Best Estimate \\
\hline Acenaphthene & $\begin{array}{l}3.47 \text { at } 25^{\circ} \mathrm{C} \\
3.93 \text { at } 25^{\circ} \mathrm{C}\end{array}$ & M\&W & 3.7 \\
\hline Acetone & Miscible with water & $\begin{array}{l}\text { M\&W and } \\
\text { HSDB }\end{array}$ & $1 E+99^{a}$ \\
\hline Anthracene & 0.075 at $15^{\circ} \mathrm{C}$ & M\&W & 0.075 \\
\hline Aroclor- 1248 & 0.05 at $20^{\circ} \mathrm{C}$ & $M \& W$ & 0.05 \\
\hline Aroclor- 1254 & 0.05 at $20^{\circ} \mathrm{C}$ & M\&W & 0.05 \\
\hline Aroclor -1260 & 0.08 at $24^{\circ} \mathrm{C}$ & M\&W & 0.08 \\
\hline Benzene & 1,780 at $20^{\circ} \mathrm{C}$ & M\&W & 1,800 \\
\hline Benzo(a)anthracene & 0.0057 at $20^{\circ} \mathrm{C}$ & M\&W & 0.0057 \\
\hline Benzo(i)pyrene & 0.004 at $25^{\circ} \mathrm{C}$ & M\&W & 0.004 \\
\hline Benzo(b)fluoranthene & 0.0012 at $25^{\circ} \mathrm{C}$ & M\&W & 0.0012 \\
\hline Benzo(g,h,i)perylene & 0.00026 at $25^{\circ} \mathrm{C}$ & $M \& W$ & 0.00026 \\
\hline Benzo(k)fluoranthene & 0.00055 at $25^{\circ} \mathrm{C}$ & M\&W & 0.00055 \\
\hline Benzoic acid & $\begin{array}{l}3,000 \text { at } 18^{\circ} \mathrm{C} \\
2,700 \text { at } 18^{\circ} \mathrm{C}\end{array}$ & M\&W & 2,900 \\
\hline Beta-HCH (beta-BHC) & 5 at $20^{\circ} \mathrm{C}$ & M\&W & 5 \\
\hline Bis(2-ethylhexyl) phthalate & 0.041 at $20^{\circ} \mathrm{C}$ & M\&W & 0.041 \\
\hline 2-Butanone & 353,000 at $10^{\circ} \mathrm{C}$ & $M \& W$ & 353,000 \\
\hline Butylbenzylphthalate & 2.9 & HSDB & 2.9 \\
\hline Carbazole & Insoluble & HSDB & $22^{b}$ \\
\hline Carbon disulfide & $\begin{array}{l}2,000 \text { at } 20^{\circ} \mathrm{C} \\
2,940 \text { at } 20^{\circ} \mathrm{C}\end{array}$ & M\&W & 2,500 \\
\hline Carbon tetrachloride & 770 at $15^{\circ} \mathrm{C}$ & $M \& W$ & 770 \\
\hline 4-Chloro-3-methyphenol & 3,850 at $20^{\circ} \mathrm{C}$ & M\&W & 3,900 \\
\hline 4-Chloroaniline & 3,900 at $20-25^{\circ} \mathrm{C}$ & M\&W & 3,900 \\
\hline Chloroform & 8,520 at $15^{\circ} \mathrm{C}$ & M\&W & 8,500 \\
\hline Chrysene & 0.0015 at $15^{\circ} \mathrm{C}$ & M\&W & 0.0015 \\
\hline 4,4-DDD & 0.05 at $15^{\circ} \mathrm{C}$ & M\&W & 0.05 \\
\hline 4,4-DDE & 0.055 at $15^{\circ} \mathrm{C}$ & M\&W & 0.055 \\
\hline Di-n-butylphthalate & 10.1 at $20^{\circ} \mathrm{C}$ & M\&W & 10 \\
\hline Dibenzo(a,h)anthracene & $\begin{array}{l}0.0005 \text { at } 25^{\circ} \mathrm{C} \\
0.0025 \text { at } 25^{\circ} \mathrm{C}\end{array}$ & M\&W & 0.0015 \\
\hline Dibenzofuran & 10 at $25^{\circ} \mathrm{C}$ & M\&W & 10 \\
\hline 1,2-Dichloroethene (total) & 600 at $20^{\circ} \mathrm{C}$ & $M \& W$ & 600 \\
\hline 1,3-Dichlorobenzene & 69 at $22^{\circ} \mathrm{C}$ & M\&W & 69 \\
\hline
\end{tabular}


DOE/RL-93-99, Rev. 0

Table 47. Solubilities for Organic Compounds. (Sheet 2 of 3)

\begin{tabular}{|c|c|c|c|}
\hline Constituent & $\begin{array}{l}\text { Solubility } \\
(\mathrm{mg} / \mathrm{L})\end{array}$ & Source & Best Estimate \\
\hline 1,4-Dichlorobenzene & 49 at $22^{\circ} \mathrm{C}$ & M\&W & 49 \\
\hline Dieldrin & 0.09 at $15^{\circ} \mathrm{C}$ & $M \& W$ & 0.09 \\
\hline Diethylphthalate & $\begin{array}{l}600 \text { at } 20^{\circ} \mathrm{C} \\
928 \text { at } 20^{\circ} \mathrm{C} \\
\end{array}$ & M\&W & 760 \\
\hline Ethylbenzene & 140 at $15^{\circ} \mathrm{C}$ & $M \& W$ & 140 \\
\hline Fluorantbene & 0.275 at $15^{\circ} \mathrm{C}$ & M\&W & 0.275 \\
\hline Fluorene & $\begin{array}{l}1.69,1.98,0.19,1.66 \text { at } \\
25^{\circ} \mathrm{C}\end{array}$ & M\&W & $i .4^{c}$ \\
\hline Gamma-chlordane & $0.009,0.056,1.85$ at $25^{\circ} \mathrm{C}$ & $\mathrm{M} \& W$ & $0.64^{d}$ \\
\hline 2-Hexanone & $3.5 \mathrm{E}+04$ at $25^{\circ} \mathrm{C}$ & M\&W & $3.5 \mathrm{E}+04$ \\
\hline Indeno(1,2,3-cd)pyrene & 0.062 & M\&W & 0.062 \\
\hline Methoxychlor & 0.02 at $15^{\circ} \mathrm{C}$ & M\&W & 0.02 \\
\hline 4-Methyl-2-pentanone (MIBK) & 17,000 at $20^{\circ} \mathrm{C}$ & M\&W & 17,000 \\
\hline Methylene chloride & 20,000 at $20^{\circ} \mathrm{C}$ & M\&W & 20,000 \\
\hline 2-Methylnaphthalene & 24.6 to 25.4 at $25^{\circ} \mathrm{C}$ & M\&W & 25 \\
\hline 4-Methylphenol & 19,400 at $20^{\circ} \mathrm{C}$ & M\&W & 19,000 \\
\hline $\mathrm{N}$-nitrosodiphenylamine & 35.1 at $25^{\circ} \mathrm{C}$ & M\&W & 35 \\
\hline Naphtbalene & 21.64 at $15.4^{\circ} \mathrm{C}$ & M\&W & 22 \\
\hline Pentacblorophenol & $\begin{array}{l}14 \text { at } 20^{\circ} \mathrm{C} \\
20 \text { at } 20^{\circ}\end{array}$ & M\&W & 17 \\
\hline Phenanthrene & $1.6,0.601$ at $15^{\circ} \mathrm{C}$ & M\&W & 1.1 \\
\hline Phenol & 82,000 at $15^{\circ} \mathrm{C}$ & M\&W & 82000 \\
\hline Pyrene & 0.135 at $24^{\circ} \mathrm{C}$ & M\&W & 0.14 \\
\hline Tetrachloroethene & $149,150,2,200$ at $20^{\circ} \mathrm{C}$ & M\&W & 830 \\
\hline 1,1,2,2-Tetrachloroethane & $\begin{array}{l}2,900 \text { at } 20^{\circ} \mathrm{C} \\
3,230 \text { at } 20^{\circ} \mathrm{C} \\
\end{array}$ & M\&W & 3,100 \\
\hline Toluene & 515 at $20^{\circ} \mathrm{C}$ & M\&W & 520 \\
\hline 1,1,1-Trichloroethane & $\begin{array}{l}4,400 ; 480 ; 730 ; 1,550 ; \\
1,360\end{array}$ & M\&W & 1,700 \\
\hline Trichloroethene & 1,$100 ; 1,080$ at $20^{\circ} \mathrm{C}$ & M\&W & 1,100 \\
\hline Vinyl chloride & 1,$100 ; 2,700$ at $25^{\circ} \mathrm{C}$ & M\&W & 1900 \\
\hline
\end{tabular}


DOE/RL-93-99, Rev. 0

Table 4-7. Solubilities for Organic Compounds. (Sheet 3 of 3)

\begin{tabular}{|c|c|c|c|}
\hline Constituent & $\begin{array}{l}\text { Solubility } \\
(\mathbf{m g} / \mathrm{L})\end{array}$ & Source & Best Estimate \\
\hline Xylenes(total) & 152 at $20^{\circ} \mathrm{C}$ & M\&W & 150 \\
\hline \multicolumn{4}{|l|}{ Notes: } \\
\hline \multicolumn{4}{|c|}{$\begin{array}{l}\text { assume infinite solubility. } \\
\text { b } \\
\text { Based on most conservative value for PAH's. } \\
{ }^{c} \text { Average of all values. } \\
{ }^{d} \text { Cblordane values are used for gamma-chlordane. }\end{array}$} \\
\hline \multicolumn{4}{|c|}{$\begin{array}{l}\text { Source: } \\
\text { HSDB = Hazardous Substance Data Bank (1993-1994). } \\
\text { M\&W = Montgomery and Welkom (1990). }\end{array}$} \\
\hline
\end{tabular}


Table 4-8. Solukilities for Inorganic Constituents. (Sheet 1 of 2)

\begin{tabular}{|c|c|c|c|}
\hline Constituent & $\begin{array}{l}\text { Solubility } \\
\text { (mg/L) }\end{array}$ & Source of Solubility Data & Best Estimate of Solubility \\
\hline Aluminum & LS $(<1)$ & Ames and Serne 1991 & 1 \\
\hline Antimony & VS $(>1000)$ & Ames and Serne 1991 & 1,000 \\
\hline Arsenic & $\begin{array}{l}\text { VS }(> \\
1000)\end{array}$ & $\begin{array}{l}\text { Serne and Wood } 1990 \\
\text { Ames and Serne } 1991\end{array}$ & 1,000 \\
\hline Barium & LS $(<1)$ & $\begin{array}{l}\text { Serne and Wood } 1990 \\
\text { Ames and Serne } 1991\end{array}$ & 1 \\
\hline Beryllium & $\begin{array}{l}\text { Unknown } \\
\text { insoluble }\end{array}$ & $\begin{array}{l}\text { Serne and Wood } 1990 \\
\text { Weast } 1989\end{array}$ & 1 \\
\hline Cadmium & $\begin{array}{l}\text { MS }(>1) \\
\text { MS }(1-25)\end{array}$ & $\begin{array}{l}\text { Serne and Wood } 1990 \\
\text { Ames and Serne } 1991\end{array}$ & 25 \\
\hline Calcium & $\begin{array}{l}\operatorname{MS}(>1) \\
\operatorname{MS}(1-25)\end{array}$ & $\begin{array}{l}\text { Serne and Wood } 1990 \\
\text { Ames and Serne } 1991\end{array}$ & 25 \\
\hline Chromium (VI) & $\mathrm{VS}(>1000)$ & Ames and Serne 1991 & 1,000 \\
\hline Cobalt & MS $(1-25)$ & Ames and Serne 1991 & 25 \\
\hline Copper & $\begin{array}{l}\text { MS }(>1) \\
\text { MS }(1-25)\end{array}$ & $\begin{array}{l}\text { Serne and Wood } 1990 \\
\text { Ames and Serne } 1991\end{array}$ & 25 \\
\hline Iron & LS $(<1)$ & $\begin{array}{l}\text { Ames and Serne } 1991 \\
\text { Serne and Wood } 1990\end{array}$ & 1 \\
\hline Lead & $\mathrm{LS}(<1)$ & $\begin{array}{l}\text { Serne and Wood } 1990 \\
\text { Ames and Serne } 1991\end{array}$ & 1 \\
\hline Magnesium & MS (1 - 25$)$ & Ames and Serne 1991 & 25 \\
\hline Manganese & LS $(<1)$ & $\begin{array}{l}\text { Serne and Wood } 1990 \\
\text { Ames and Serne } 1991\end{array}$ & 1 \\
\hline Mercury & $\begin{array}{l}\text { Unknown } \\
\text { Insoluble }\end{array}$ & $\begin{array}{l}\text { Serne and Wood } 1990 \\
\text { Weast } 1989\end{array}$ & 1 \\
\hline Nickel & $\operatorname{MS}(>1)$ & Serne and Wood 1990 & 25 \\
\hline Potassium & VS $(>1000)$ & Ames and Serne 1991 & 1,000 \\
\hline Selenium & VS $(>1000)$ & Serne and Wood 1990 & 1,000 \\
\hline Silver & $\begin{array}{l}\text { MS }(>1) \\
\text { LS }(<1)\end{array}$ & $\begin{array}{l}\text { Serne and Wood } 1990 \\
\text { Ames and Serne } 1991\end{array}$ & 25 \\
\hline Sodium & VS $(>1000)$ & $\begin{array}{l}\text { Serne and Wood } 1990 \\
\text { Ames and Serne } 1991\end{array}$ & 1,000 \\
\hline Strontium & MS (1 - 25) & $\begin{array}{l}\text { Serne and Wood 19:0 } \\
\text { Ames and Serne 1991 }\end{array}$ & 25 \\
\hline Thallium & Insoluble & Weast 1989 & 1 \\
\hline
\end{tabular}


DOE/RL-93-99, Rev. 0

Table 4-8. Solubilities for Inorganic Constituents. (Sheet 2 of 2)

\begin{tabular}{|c|c|c|c|}
\hline Constituent & $\begin{array}{l}\text { Solubility } \\
\text { (mg/L) }\end{array}$ & Source of Solubility Data & Best Estimate of Solubility \\
\hline Vanadium & MS $(1-25)$ & Ames and Serne 1991 & 25 \\
\hline Zinc & $\begin{array}{l}\text { MS }(>1) \\
\text { MS }(1-25)\end{array}$ & $\begin{array}{l}\text { Serne and Wood } 1990 \\
\text { Ames and Serne } 1991\end{array}$ & 25 \\
\hline $\begin{array}{l}\text { Ammonia } \\
\text { (Ammonium) }\end{array}$ & VS $(>1000)$ & Ames and Serne 1991 & 1,000 \\
\hline Chloride & VS $(>1000)$ & Ames and Serne 1991 & 1,000 \\
\hline Fluoride & $\begin{array}{l}\text { VS }(>1000) \\
\text { MS }(1-25)\end{array}$ & $\begin{array}{l}\text { Serne and Wood } 1990 \\
\text { Ames and Serne } 1991\end{array}$ & 1,000 \\
\hline Nitrate & VS $(>1000)$ & Serne and Wood 1990 & 1,000 \\
\hline Nitrite & VS $(>1000)$ & Ames and Serne 1991 & 1,000 \\
\hline Nitrite + Nitrate & & & 1,000 \\
\hline Phosphate & LS $(<1)$ & $\begin{array}{l}\text { Serne and Wood } 1990 \\
\text { Ames and Serne } 1991\end{array}$ & 1 \\
\hline Sulfate & $\begin{array}{l}\text { MS }(>1) \\
\text { MS }(1-25)\end{array}$ & $\begin{array}{l}\text { Serne and Wood } 1990 \\
\text { Ames and Serne } 1991\end{array}$ & 25 \\
\hline \multicolumn{4}{|c|}{$\begin{array}{l}\mathrm{LS}=\text { low solubility } \\
\mathrm{MS}=\text { moderately soluble } \\
\mathrm{VS}=\text { very soluble }\end{array}$} \\
\hline
\end{tabular}


DOE/RL-93-99, Rev. 0

Table 4-9. Groundwater Background Screening for Inorganic Constituents.

(Sheet 1 of 2)

\begin{tabular}{|c|c|c|c|}
\hline Constituent & $\begin{array}{c}\text { Maximum } \\
\text { Detected Soil } \\
\text { Concentration } \\
(\mathrm{mg} / \mathrm{kg})\end{array}$ & $\begin{array}{c}\text { Predicted } \\
\text { Groundwater } \\
\text { Concentration } \\
(\mathrm{mg} / \mathrm{L})^{\mathrm{a}}\end{array}$ & $\begin{array}{c}\text { Hanford Site } \\
\text { Groundwater } \\
\text { Background } \\
(\mathrm{mg} / \mathrm{L})^{\mathrm{b}}\end{array}$ \\
\hline \multicolumn{4}{|l|}{ Metals } \\
\hline Aluminum & 78400 & 0.06 & ND \\
\hline Antimony & 18.6 & 39 & NR \\
\hline Arsenic & 62.2 & 60 & 0.01 \\
\hline Barium & 4260 & 0.06 & 0.0685 \\
\hline Beryllium & 4.7 & 0.014 & ND \\
\hline Cadmium & 28.5 & 0.074 & $\mathrm{ND}$ \\
\hline Calcium & 95300 & 1.5 & 63.6 \\
\hline Chromium-VI & 2510 & 60 & $\mathrm{ND}$ \\
\hline Cobalt & 90,4 & 0.18 & NR \\
\hline Copper & 95300 & 1.5 & $\mathrm{ND}$ \\
\hline Iron & 184000 & 0.06 & 0.086 \\
\hline Lead & 747 & 0.06 & ND \\
\hline Magnesium & 50000 & 1.5 & 16.48 \\
\hline Manganese. & 3050 & 0.06 & 0.0245 \\
\hline Mercury & 37.0 & 0.06 & ND \\
\hline Nickel & 1750 & 1.5 & $\mathrm{ND}$ \\
\hline Potassium $^{c}$ & 13000 & 60 & 7.975 \\
\hline Selenium & 11.1 & 24 & $\mathrm{ND}$ \\
\hline Silver & 362 & 0.86 & $\mathrm{ND}$ \\
\hline Sodium ${ }^{c}$ & 2610 & 51 & 33.5 \\
\hline Strontium & 31 & 0.10 & 0.2641 \\
\hline Thallfum & 5.4 & 0.0064 & NR \\
\hline$V$ anadium & 389 & 0.46 & 0.015 \\
\hline Zinc & 6160 & 1.5 & $\mathrm{ND}$ \\
\hline \multicolumn{4}{|l|}{ Anions } \\
\hline Ammonia & 138.3 & 2.0 & 0.12 \\
\hline Fluoride & 40.3 & 60 & 0.775 \\
\hline Nitrite & 2.9 & 6.1 & NR \\
\hline
\end{tabular}


Table 4-9. Groundwater Background Screening for Inorganic Constituents.

(Sheet 2 of 2)

\begin{tabular}{l|c|c|c|}
\hline Constituent & $\begin{array}{c}\text { Maximum } \\
\text { Detected Soil } \\
\text { Concentration } \\
(\mathrm{mg} / \mathrm{kg})\end{array}$ & $\begin{array}{c}\text { Predicted } \\
\text { Groundwater } \\
\text { Concentration } \\
(\mathrm{mg} / \mathrm{L})^{\mathrm{a}}\end{array}$ & $\begin{array}{c}\text { Hanford Site } \\
\text { Groundwater } \\
\text { Background } \\
(\mathrm{mg} / \mathrm{L})^{\mathrm{b}}\end{array}$ \\
\hline Sulfate & 7115 & 1.5 & 90.5 \\
\hline Notes: & \\
$\mathrm{NR}=$ Not Reported \\
$\mathrm{ND}=$ Not Detected \\
The shaded areas indicate retained groundwater contaminants. \\
a Source: Appendix A, Tables A-3 and A-4. \\
bSource: Hoover and Le Gore (1991). \\
cPotassium and sodium are eliminated because they are not considered toxic to humans under normal \\
circumstances (DOE-RL 1993j). \\
$\mathrm{d}_{\text {Ammonia is eliminated because it converts to nitrate under aerobic conditions (HSDB 1994). }}$ \\
Assuming all ammonia converts to nitrate, the resulting nitrate concentration of \\
2.35 mg/L is below the background concentration of 12.4 mg/L.
\end{tabular}


Table 4-10. De Minimis and Travel Time Groundwater Contaminant Screening. (Sheet 1 of 5)

\begin{tabular}{|c|c|c|c|}
\hline Constituent & $\begin{array}{l}\text { Maximum Detected Soil } \\
\text { Concentration }\end{array}$ & $\begin{array}{l}\text { Predicted } \\
\text { Groundwater } \\
\text { Concentration }\end{array}$ & $\begin{array}{c}\text { Travel Time } \\
\text { to ERDF } \\
\text { Boundary }\end{array}$ \\
\hline Organic Compounds & $(\mu \mathrm{g} / \mathrm{kg})$ & $(\mathrm{mg} / \mathrm{L})$ & (Year) \\
\hline Acenaphthene & 850 & $<5 E-07$ & $>10,000$ \\
\hline Acetone & -800 & $<5 E-07$ & 520 \\
\hline Anthracene & 6300 & $<5 \mathrm{E}-07$ & $>10,000$ \\
\hline Aroclor -1248 & 10000 & $<5 \mathrm{E}-07$ & $>10,000$ \\
\hline Aroclor -1254 & 6400 & $<5 \mathrm{E}-07$ & $>10,000$ \\
\hline Aroclor- 1260 & 2300 & $<5 E-07$ & $>10,000$ \\
\hline Benzo(a)anthracene & 1800 & $<5 \mathrm{E}-07$ & $>10,000$ \\
\hline Benzene & 190 & $<5 E-07$ & 2,200 \\
\hline Benzo(a)pyrene & 27000 & $<5 \mathrm{E}-07$ & $>10,000$ \\
\hline Benzo(b)fluoranthene & 2400 & $<5 \mathrm{E}-07$ & $>10,000$ \\
\hline Benzo(g,h,i)perylene & 3700 & $<5 \mathrm{E}-07$ & $>10,000$ \\
\hline Benzo(k)fluoranthene & 760 & $<5 \mathrm{E}-07$ & $>10,000$ \\
\hline Benzoic acid & 1300 & $<5 E-07$ & 520 \\
\hline Beta-HCH (beta-BHC) & 7.8 & $3.2 \mathrm{E}-06$ & $>10,000$ \\
\hline Bis(2-ethylhexyl) phthalate & 33000 & $<5 \mathrm{E}-07$ & $>10,000$ \\
\hline 2-Butanone (MEK) & 390 & $<5 \mathrm{E}-07$ & 530 \\
\hline Butylbenzylphthalate & 2600 & $<5 \mathrm{E}-07$ & 4,400 \\
\hline Carbazole & 54 & $<5 \mathrm{E}-07$ & $>10,000$ \\
\hline Carbon disulfide & 200 & $<5 \mathrm{E}-07$ & 1,700 \\
\hline Carbon tetrachloride & 8.0 & $<5 \mathrm{E}-07$ & 6,100 \\
\hline Chlordane (gamma) & 18 & $<5 E-07$ & $>10,000$ \\
\hline 4-Chloro-3-methyplhenol & 38 & $<5 E-07$ & 1,500 \\
\hline 4-Chloroaniline & 6300 & $<5 \mathrm{E}-07$ & $>10,000$ \\
\hline Chloroform & 80 & $<5 E-07$ & 1,200 \\
\hline Chrysene & 43000 & $<5 \mathrm{E}-07$ & $>10,000$ \\
\hline 4,4-DDD & 110 & $<5 \mathrm{E}-07$ & $>10,000$ \\
\hline 4,4-DDE & 170 & $<5 \mathrm{E}-07$ & $>10,000$ \\
\hline Di-n-butylphthalate & 5500 & $<5 \mathrm{E}-07$ & $>10,000$ \\
\hline Dibenzo(a,h)anthracene & 1700 & $<5 \mathrm{E}-07$ & $>10,000$ \\
\hline
\end{tabular}


Table 4-10. De Minimis and Travel Time Groundwater Contaminant Screening. (Sheet 2 of 5 )

\begin{tabular}{|c|c|c|c|}
\hline Constituent & $\begin{array}{l}\text { Maximum Detected Soil } \\
\text { Concentration }\end{array}$ & $\begin{array}{c}\text { Predicted } \\
\text { Groundwater } \\
\text { Concentration }\end{array}$ & $\begin{array}{l}\text { Travel Time } \\
\text { to ERDF } \\
\text { Boundary }\end{array}$ \\
\hline Dibenzofuran & 500 & $<5 E-07$ & $>10,000$ \\
\hline 1,3-Dichlorobenzene & 48 & $<5 \mathrm{E}-07$ & 6,100 \\
\hline 1,4-Dichlorobenzene & 51 & $<5 \mathrm{E}-07$ & 8,000 \\
\hline 1,2-Dichloroethene & 1000 & $<5 E-07$ & 1,300 \\
\hline Dieldrin & 21 & $<5 E-07$ & $>10,000$ \\
\hline Diethylphthalate & 1000 & $<5 \mathrm{E}-07$ & 6,500 \\
\hline Ethyl benzene & 330 & $<5 E-07$ & 3,600 \\
\hline Fluoranthene & 2900 & $<5 E-07$ & $>10,000$ \\
\hline Fluorene & 1700 & $<5 \mathrm{E}-07$ & $>10,000$ \\
\hline 2-Hexanone & 9 & $<5 \mathrm{E}-07$ & 3,000 \\
\hline Indeno( $1,2,3-c d)$ pyrene & 1600 & $<5 \mathrm{E}-07$ & $>10,000$ \\
\hline Methoxychlor & 83 & $<5 \mathrm{E}-07$ & $>10,000$ \\
\hline 4-Methyl-2-pentanone & 11 & $<5 E-07$ & 1,500 \\
\hline Methylene chloride & 4500 & $<5 E-07$ & 1,200 \\
\hline 2-Methylnaphthalene & 13000 & $<5 E-07$ & $>10,000$ \\
\hline 4-Methylphenol & 1000 & $<5 \mathrm{E}-07$ & 7,200 \\
\hline Naphthalene & 4100 & $<5 \mathrm{E}-07$ & $>10,000$ \\
\hline $\mathrm{N}$-Nitrosodiphenylamine & 1800 & $<5 \mathrm{E}-07$ & $>10,000$ \\
\hline Pentachlorophenol & 1500 & $<5 E-07$ & $>10,000$ \\
\hline Phenanthrene & 3900 & $<5 \mathrm{E}-07$ & $>10,000$ \\
\hline Phenol & 240 & $<5 \mathrm{E}-07$ & 1,800 \\
\hline Pyrene & 12000 & $<5 \mathrm{E}-07$ & $\geq 10,000$ \\
\hline 1,1,2,2-Tetrachloroethane & 3 & $<5 \mathrm{E}-07$ & 2,000 \\
\hline Tetrachloroethene & 1100 & $<5 E-07$ & 4,700 \\
\hline Toluene & 150 & $<5 E-07$ & 4,000 \\
\hline 1,1,1-Trichloroethane & 6 & $<5 \mathrm{E}-07$ & 3,100 \\
\hline Trichloroethene & 390 & $<5 \mathrm{E}-07$ & 2,600 \\
\hline Vinyl chloride & 24 & $<5 \mathrm{E}-07$ & 1.600 \\
\hline Xylenes(total) & 1100 & $<5 E-07$ & 1,600 \\
\hline
\end{tabular}


DOE/RL-93-99, Rev. 0

Table 4-10. De Minimis and Travel Time Groundwater Contaminant Screening.

(Sheet 3 of 5)

\begin{tabular}{|c|c|c|c|}
\hline Constituent & $\begin{array}{l}\text { Maximum Detected Soil } \\
\text { Concentration }\end{array}$ & $\begin{array}{l}\text { Predicted } \\
\text { Groundwater } \\
\text { Concentration }\end{array}$ & $\begin{array}{c}\text { Travel Time } \\
\text { to ERDF } \\
\text { Boundary }\end{array}$ \\
\hline Radionuclides & $(\mathrm{pCi} / \mathrm{g})$ & $\left(p \mathrm{Ci}^{\prime} \mathrm{L}\right)$ & (Year) \\
\hline Americium-241 & 34 & $<1 \mathrm{E}-06$ & $>10,000$ \\
\hline Barium-140 & 400 & $<1 \mathrm{E}-06$ & $>10,000$ \\
\hline Beryllium-7 & 90 & $<1 \mathrm{E}-06$ & $>10,000$ \\
\hline Carbon-14 & 640 & $1.3 \mathrm{E}+06$ & 520 \\
\hline Cerium-141 & 3 & $<1 \mathrm{E}-06$ & $\geq 10,000$ \\
\hline Cerium-144 & 0.5 & $<1 \mathrm{E}-06$ & $>10,000$ \\
\hline Cesium-134 & 56 & $<1 \mathrm{E}-06$ & $>10,000$ \\
\hline Cesium-137 & 110000 & $<1 \mathrm{E}-06$ & $>10,000$ \\
\hline Chromium-51 & 3.465 & $<1 \mathrm{E}-06$ & 520 \\
\hline Cobalt -58 & 14.1 & $<1 \mathrm{E}-06$ & $>10,000$ \\
\hline Cobalt-60 & 11000 & $<1 \mathrm{E}-06$ & $>10,000$ \\
\hline Europium-152 & 29000 & $<1 \mathrm{E}-06$ & $>10,000$ \\
\hline Europium-154 & 9200 & $<1 \mathrm{E}-06$ & $>10,000$ \\
\hline Europium-155 & 9600 & $<1 \mathrm{E}-06$ & $>10,000$ \\
\hline Iron-59 & 1 & $<1 \mathrm{E}-06$ & $>10,000$ \\
\hline Manganese-54 & 0.07 & $<1 \mathrm{E}-06$ & $>10,000$ \\
\hline Neptunium-237 & 34 & $2.0 \mathrm{E}-01$ & $\geq 10,000$ \\
\hline Nickel-63 & 62500 & $<1$ E-06 & $>10,000$ \\
\hline Plutonium-238 & 140 & $<1 \mathrm{E}-06$ & $>10,000$ \\
\hline Plutonium-239/240 & 2800 & $<1 \mathrm{E}-06$ & $>10,000$ \\
\hline Potassium-40 & 33 & $3.9 \mathrm{E}+02$ & $>10,000$ \\
\hline Radium-226 & 42.8 & $<1 \mathrm{E}-06$ & $>10,000$ \\
\hline Ruthenium-103 & 1 & $<1 \mathrm{E}-06$ & $>10,000$ \\
\hline Ruthenium-106 & 0.8 & $<1 \mathrm{E}-06$ & $>10,000$ \\
\hline Sodium-22 & 9.91 & $<1 \mathrm{E}-06$ & $>10,000$ \\
\hline Strontium-90 & 2000 & $<1 \mathrm{E}-06$ & $>10,000$ \\
\hline Technetium-99 & 1.1 & $2.3 E+03$ & 520 \\
\hline Thorium-228 & 16.79 & $<1 \mathrm{E}-06$ & $>10,000$ \\
\hline Thorium-232 & 3.546 & $4.2 \mathrm{E}+00$ & $>10,000$ \\
\hline Thorium-234 & 1 & $<1 \mathrm{E}-06$ & $>10,000$ \\
\hline
\end{tabular}


Table 4-10. De Minimis and Travel Time Groundwaier Contaminant Screening. (Sheet 4 of 5)

\begin{tabular}{|c|c|c|c|}
\hline Constituent & $\begin{array}{l}\text { Maximum Detected Soil } \\
\text { Concentration }\end{array}$ & $\begin{array}{c}\text { Predicted } \\
\text { Groundwater } \\
\text { Concentration }\end{array}$ & $\begin{array}{c}\text { Travel Time } \\
\text { to ERDF } \\
\text { Boundary }\end{array}$ \\
\hline Tritium & 29000 & $4.2 E-06$ & 520 \\
\hline Total Uranium & 20034 & $1.1 \mathrm{E}+03$ & 520 \\
\hline Granium-233/234 & 2100 & $5.3 E+02$ & 520 \\
\hline Uranium 235 & 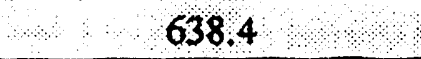 & $2.3 E+01$ & 520 \\
\hline Uranium-238 & 9143 & $4.9 \mathrm{E}+02$ & 520 \\
\hline Zinc -65 & 0.3 & $<1 \mathrm{E}-10$ & $>10,000$ \\
\hline Zirconium-95 & 0.56 & $<1 \mathrm{E}-10$ & $>10,000$ \\
\hline Metals & $(\mathrm{mg} / \mathrm{kg})$ & $(\mathrm{mg} / \mathrm{L})$ & (Year) \\
\hline Aluminum & 78400 & $6.0 \mathrm{E}-02$ & $>10,000$ \\
\hline Antimony & 18.6 & $3.9 E+01$ & 520 \\
\hline Arsenic & 62.2 & $6.0 \mathrm{~F}+01$ & 520 \\
\hline Beryllium & 4.7 & $1.4 \mathrm{E}-02$ & $>10,000$ \\
\hline Cadmium & 28.5 & $7.4 \mathrm{E}-02$ & $>10,000$ \\
\hline Chromium-VI & 2510 & $6.0 \mathrm{E}+01$ & 520 \\
\hline Cobalt & 90.4 & $1.8 \mathrm{E}-01$ & $>10,000$ \\
\hline Copper & 95300 & $1.5 \mathrm{E}+00$ & $>10,000$ \\
\hline Lead & 747 & $6.0 \mathrm{E}-02$ & $>10,000$ \\
\hline Manganese & 3050 & $6.0 \mathrm{E}-02$ & $>10,000$ \\
\hline Mercury & 37.0 & $6.0 \mathrm{E}-02$ & $>10,000$ \\
\hline Nickel & 1750 & $1.5 \mathrm{E}+00$ & $>10,000$ \\
\hline Selenium & 161 & $2.4 \mathrm{E}+01$ & 520 \\
\hline Silver & 362 & $8.6 \mathrm{E}-01$ & $>10,000$ \\
\hline Thallium & 5.4 & $6.4 \mathrm{E}-03$ & $>10,000$ \\
\hline Vanadium & 389 & $4.6 \mathrm{E}-01$ & $>10,000$ \\
\hline Zinc & 6160 & $1.5 E+00$ & $>10,000$ \\
\hline
\end{tabular}


Table 4-10. De Minimis and Travel Time Groundwater Contaminant Screening. (Sheet 5 of 5)

\begin{tabular}{|c|c|c|c|}
\hline Constituent & $\begin{array}{l}\text { Maximum Detected Soil } \\
\text { Concentration }\end{array}$ & $\begin{array}{c}\text { Predicted } \\
\text { Groundwater } \\
\text { Concentration }\end{array}$ & $\begin{array}{l}\text { Travel Time } \\
\text { to ERDF } \\
\text { Boundary }\end{array}$ \\
\hline Anions & $(\mathrm{mg} / \mathrm{kg})$ & $(\mathrm{mg} / \mathrm{L})$ & (Year) \\
\hline Huonde & 40.3 & $6,0 \mathrm{E}+01$ & 520. \\
\hline Wirite. & 29. & $6.1 \mathrm{E}+00$ & 520. \\
\hline \multicolumn{4}{|c|}{$\begin{array}{l}\text { Notes: } \text { N/A }=\text { Not Available } \\
\text { Shaded areas indicate de minimis screening criteria exceeded. } \\
\text { De minimis value for organic compounds is } 5 \mathrm{E}-07 \mathrm{mg} / \mathrm{L} \text {. } \\
\text { De minimis value for radionuclides is } 1 \mathrm{E}-02 \mathrm{pCi} / \mathrm{L} \text {. }\end{array}$} \\
\hline
\end{tabular}


DOE/RL-93-99. Rev. 0

Table 4-11. Potential Groundwater Contaminants at the ERDF.

\begin{tabular}{|l|c|c|c|}
\hline Constituent & $\begin{array}{c}\text { Maximum } \\
\text { Detected Soil } \\
\text { Concentration }\end{array}$ & $\begin{array}{c}\text { Predicted } \\
\text { Groundwater } \\
\text { Concentration }\end{array}$ & $\begin{array}{c}\text { Travel Time to } \\
\text { ERDF Boundary }\end{array}$ \\
\hline Radionuclides & $(\mathrm{pCi} / \mathrm{g})$ & $(\mathrm{pCi} / \mathrm{L})$ & $(\mathrm{yr})$ \\
\hline Carbon-14 & 640 & $1.3 \mathrm{E}+06$ & 520 \\
\hline Technetium-99 & 1.1 & $2.3 \mathrm{E}+03$ & 520 \\
\hline Total Uranium & 20034 & $1.1 \mathrm{E}+03$ & 520 \\
\hline Uranium-233/234 & 2100 & $5.3 \mathrm{E}+02$ & 520 \\
\hline Uranium-235 & 638.4 & $2.3 \mathrm{E}+01$ & 520 \\
\hline Uranium-238 & 9143 & $4.9 \mathrm{E}+02$ & 520 \\
\hline Metals & $(\mathrm{mg} / \mathrm{kg})$ & $(\mathrm{mg} / \mathrm{L})$ & $(\mathrm{yr})$ \\
\hline Antimony & 18.6 & $3.9 \mathrm{E}+01$ & 520 \\
\hline Arsenic & 62.2 & $6.0 \mathrm{E}+01$ & 520 \\
\hline Chromium-VI & 2510 & $6.0 \mathrm{E}+01$ & 520 \\
\hline Selenium & 11.1 & $2.4 \mathrm{E}+01$ & 520 \\
\hline Anions & $(\mathrm{mg} / \mathrm{kg})$ & $(\mathrm{mg} / \mathrm{L})$ & $(\mathrm{yr})$ \\
\hline Fluoride & 40.3 & $6.0 \mathrm{E}+01$ & 520 \\
\hline Nitrite & 2.90 & $6.1 \mathrm{E}+00$ & 520 \\
\hline
\end{tabular}


DOE/RL-93-99, Rev. 0

\subsection{CONTAMINANTS OF POTENTIAL CONCERN}

\subsection{APPROACH}

The purpose of this chapter is to identify chemical and radiological contaminants at the 100,200 , and 300 Areas which may potentially pose risk to human health and the environment once placed in the ERDF. For this purpose, a risk-based screening process and comparison to ARARs is used to identify contaminalts of potential concern (COPC). The risk-based screening process involves the calculation of risk-based screening concentrations, which consider both non-carcinogenic and carcinogenic effects. Risk-based screening concentrations are soil or groundwater concentrations that correspond to a hazard quotient $(\mathrm{HQ})$ of 0.1 , or lifetime incremental cancer risk (ICR) of $1 \times 10^{-7}$ using residential scenario exposure parameter values (see Chapter 6 for a discussion of HQ and ICR). The equations and parameter values used to perform the risk-based screening are provided in Revision 3 of the Hanford Site Risk Assessment Methodology (HSRAM, DOE-RL 1994c).

If the maximum concentration detected for a contaminant exceeds a risk-based screening concentration and/or an ARAR for that contaminant, it is retained for evaluation in the risk assessment as a COPC. Otherwise, the contaminant is eliminated from the risk assessment process. The screening process provides a high degree of confidence that these eliminated contaminants pose only an insignificant risk to human health or the environment. COPC are identified separately for soil and groundwater.

The process for selecting COPC is shown in the flow chart in Figure 5-1. The process begins with the soil contaminants identified in Chapter 3 , and the groundwater contaminants identified in Chapter 4. Concentrations of these contaminants are compared to risk-based screening concentrations and ARARs to determine COPC in soils and groundwater.

The human health screening process is also used to determine COPC for which ecological risks are evaluated. This is justified in part because most of the data used to develop human health toxicity values [i.e., reference doses (RfDs) and slope factors (SFs)] are from animal studies. For this report, the primary indicator species is the Great Basin pocket mouse, for which the animal study data are expected to be generally applicable. The adjustments used in developing RfDs and SFs assumptions (see Section 6.1.2) regarding human exposure patterns (i.e., residential scenario), and restrictive criteria (i.e., target ICR of $1 \times 10^{-7}$ and target HQ of 0.1 ) used in developing human health risk-based screening concentrations ensure that these concentrations will also be protective of most non-human receptors at the ERDF. It is possible that human health screening values for some contaminants are inappropriate for ecological receptors. However, it is expected that the contaminants of greatest concern from an ecological perspective will be identified with a human health risk-based screening process.

\subsection{HUMAN HEALTH TOXICITY VALUES}

Table 5-1 presents RfDs and SFs for soil and groundwater contaminants. The contaminants listed in Table 5-1 are the soil contaminants identified in Tables 3-8, 3-9, and $3-10$, and the groundwater contaminants identified in Table $4-11$. In some cases, toxicity values 
from one contaminant (i.e., a surrogate) are used to permit screening of another contaminant for which toxicity values are not available. The following surrogates are used in this report:

- Aroclor $-1248,-1254$, and -1260 are evaluated separately using toxicity values for PCBs, which are based on a mixture of Aroclors

- benzo(a)pyrene is used as a surrogate for other B2 cancer class polyaromatic hydrocarbons (i.e., benzo(a)anthracene, benzo(b)fluoranthene, benzo(k)fluoranthene, chrysene, $\operatorname{dibenz}(\mathrm{a}, \mathrm{h})$ anthracene, and indeno(1,2,3-cd)pyrene)

- 2-butanone is used as a surrogate for 2-hexanone

- naphthalene is used as a surrogate for 2-methylnaphthalene

- $\quad$ pyrene is used as a surrogate for phenanthrene

- uranium-238+D is used as a surrogate for total uranium.

Radionuclide slope factors presented in Table 5-1 are those that account for the contribution of radioactive daughter products. This is what is meant by the " $D$ " notation.

Although there is an inhalation slope factor for nickel, it is only appropriate for evaluating nickel refinery dust, and is therefore not used to develop a risk-based screening concentration for nickel.

\subsection{SOIL RISK-BASED SCREENING}

Appendix D of HSRAM (DOE-RL 1994c) provides the equations and exposure parameter values used to calculate preliminary risk-based screening concentrations. Appendix D indicates how these parameter values can be combined into summary screening factors. These factors (originally presented in Table D-1 of HSRAM) are provided in Table 5-2. Summary screening factors are combined with toxicity values presented in Table 5-1 to yield risk-based screening concentrations. For carcinogens, a risk-based screening concentration is determined by dividing the summary screening factor by the contaminant-specific SF. For noncarcinogens, a risk-based screening concentration is determined by multiplying the summary screening factor by the contaminant-specific RfD.

For the purpose of screening soil contaminants, risk-based screening concentrations are calculated using residential scenario exposure parameter values and four exposure pathways: soil ingestion, fugitive dust inhalation, inhalation of volatile compounds, and external radiation exposure. Risk-based screening concentrations for soils are provided in Tables 5-3 (nonradioactive contaminants) and Table 5-4 (radioactive contaminants).

Contaminant-specific/site-specific volatilization factors (VFs) are required to determine risk-based screening concentrations for volatile contaminants. The VFs used in this report are taken directly from the original RIs or QRAs identified as the source of the maximum contaminant concentrations. For example, the maximum concentration of trichloroethene $(0.39 \mathrm{mg} / \mathrm{kg})$ is from Burial ground No. 4 of the $300-\mathrm{FF}-1$ operable unit. The $300-\mathrm{FF}-1 \mathrm{RI}$ 
(DOE-RL 1993f; Table 4-14) indicates that the VF for trichloroethene at Burial ground No. 4 is $1.2 \times 10^{3} \mathrm{~m}^{3} / \mathrm{kg}$. VFs are provided in Table $5-3$.

Previous reports provide VFs for only seven of the volatile contaminants being evaluated. Volatile contaminants for which VFs are not available are assigned a VF of $1 \times 10^{3}$ $\mathrm{m}^{3} / \mathrm{kg}$. This value is more conservative than all but one of the VFs from previous reports (vinyl chloride is most conservative with a VF of $6 \times 10^{2} \mathrm{~m}^{3} / \mathrm{kg}$ ). Volatilization factors were determined only for volatile contaminants that have inhalation RfDs or SFs.

The maximum detected concentration in the 100 and 300 Areas and the minimum riskbased screening concentration for each contaminant are provided in Table 5-5. If a maximum detected contaminant concentration exceeds its associated risk-based screening concentration, then it is a contaminant of potential concern. Shading in Table 5-5 indicates that a contaminant is a COPC.

Several contaminants do not have toxicity values (with which to calculate risk-based screening concentrations) or ARARs for comparison with the maximum detected concentration. These contaminants are benze $(\mathrm{g}, \mathrm{h}, \mathrm{i})$ perylene, 4-chloro-3-methylphenol, dibenzofuran, 1,3dichlorobenzene, 4-methylphenol, and sulfate. All except 4-methylphenol are group D carcinogens (not classifiable as to human carcinogenicity); 4-methylphenol is a group C carcinogen (possible human carcinogen). All except sulfate have maximum detected concentrations less than $4 \mathrm{mg} / \mathrm{kg}$. Because of the lack of evidence of carcinogenity and low concentrations, none of these contaminants are considered COPC.

It is unknown whether the maximum concentration for total chromium $\left(2.5 \times 10^{3} \mathrm{mg} / \mathrm{kg}\right)$ represents trivalent or hexavalent chromium. Therefore, the risk-based screening concentrations for both chromium (III) and (VI) are provided in Table 5-5. These values indicate that, if total chromium data represents chromium (III), chromium would not be considered a COPC.

However, all chromium is conservatively assumed to be hexavalent, and chromium is considered a COPC. Because the total chromium concentration of $2.5 \times 10^{3} \mathrm{mg} / \mathrm{kg}$ is assumed to represent chromium (VI), and this value is greater than the maximum detected chromium (VI) concentration of $5.0 \mathrm{mg} / \mathrm{kg}$, only the larger of these two values is carried forward into the risk assessment.

Gross alpha and gross beta activity measurements are general indicators of radioactivity. They are not useful data for quantitative risk assessment because toxicity data for radionuclides is isotope-specific. Because the radionuclide inventory is well characterized with a large number of radioisotopes, gross alpha and gross beta are not carried forward into the risk assessment.

Potassium -40 is also eliminated from further consideration. Potassium-40 is a naturallyoccurring, primordial radionuclide which is present in all soils (Eisenbud 1987). It is not produced in fission reactions, nor is it a daughter product of any radionuclide which is produced in fission reactions. Therefore, any measurements of potassium- 40 in any medium can be attributed to natural potassium, and are not indicative of environmental contamination.

Total uranium as well as the individual isotopes of uranium all exceed their respective risk-based screening concentrations. However, only total uranium is carried forward into the risk assessment. Total uranium is made up of the individual isotopes, such that adding the risk of total uranium to those of individual isotopes essentially means counting the same risk twice. 
It is conservative to evaluate total uranium instead of the individual isotopes because the maximum detected concentration of total uranium is greater than the sum of the isotope concentrations.

\subsection{GROUNDWATER RISK-BASED SCREENING}

Risk-based screening concentrations for groundwater contaminants are calculated using the toxicity factors in Section 5.2 and the same calculation methods as those for soil contaminants (see Section 5.3). Groundwater contaminants are identified in Table 4-11. Toxicity values for these contaminants are provided in Table 5-1, and summary screening factors are provided in Table 5-2. Risk-based screening concentrations are calculated only for the groundwater ingestion pathway. Risk-based screening concentrations for the volatile inhalation are not calculated because none of the volatile soil contaminants are considered groundwater contaminants. Risk-based screening concentrations for groundwater contaminants are provided in Table 5-6.

The predicted groundwater concentration and minimum risk-based screening concentration for each contaminant are provided in Table 5-7. The minimum ARAR concentration (see Chapter 7) for each contaminant is also identified in Table 5-7. If a predicted groundwater concentration exceeds either its associated risk-based screening or ARAR concentration, then it is a contaminant of potential concern. Shading in rable 5-7 indicates that a contaminant is a COPC.

The predicted groundwater concentration of chromium (VI) is based on total chromium data. However, it is conservatively assumed that all chromium is hexavalent.

As with the soil risk-based screening, total uranium is retained for the risk assessment while individual uranium isotopes are not.

\subsection{SUMMARY OF CONTAMINANTS OF POTENTIAL CONCERN}

Contaminants of potential ccrrern for soil and groundwater are provided in Tables 5-8 and 5-9, respectively. Also provided in these tables are the maximum detected soil concentrations and predicted groundwater concentrations. Soil COPC are carried forward into the risk assessment (Chapter 6) to evaluate human health and ecological risks associated with exposure to contaminated soils. Groundwater COPC are used in the risk assessment to evaluate human health risks associated with groundwater exposures. 
DOE/RL-93-99, Rev. 0

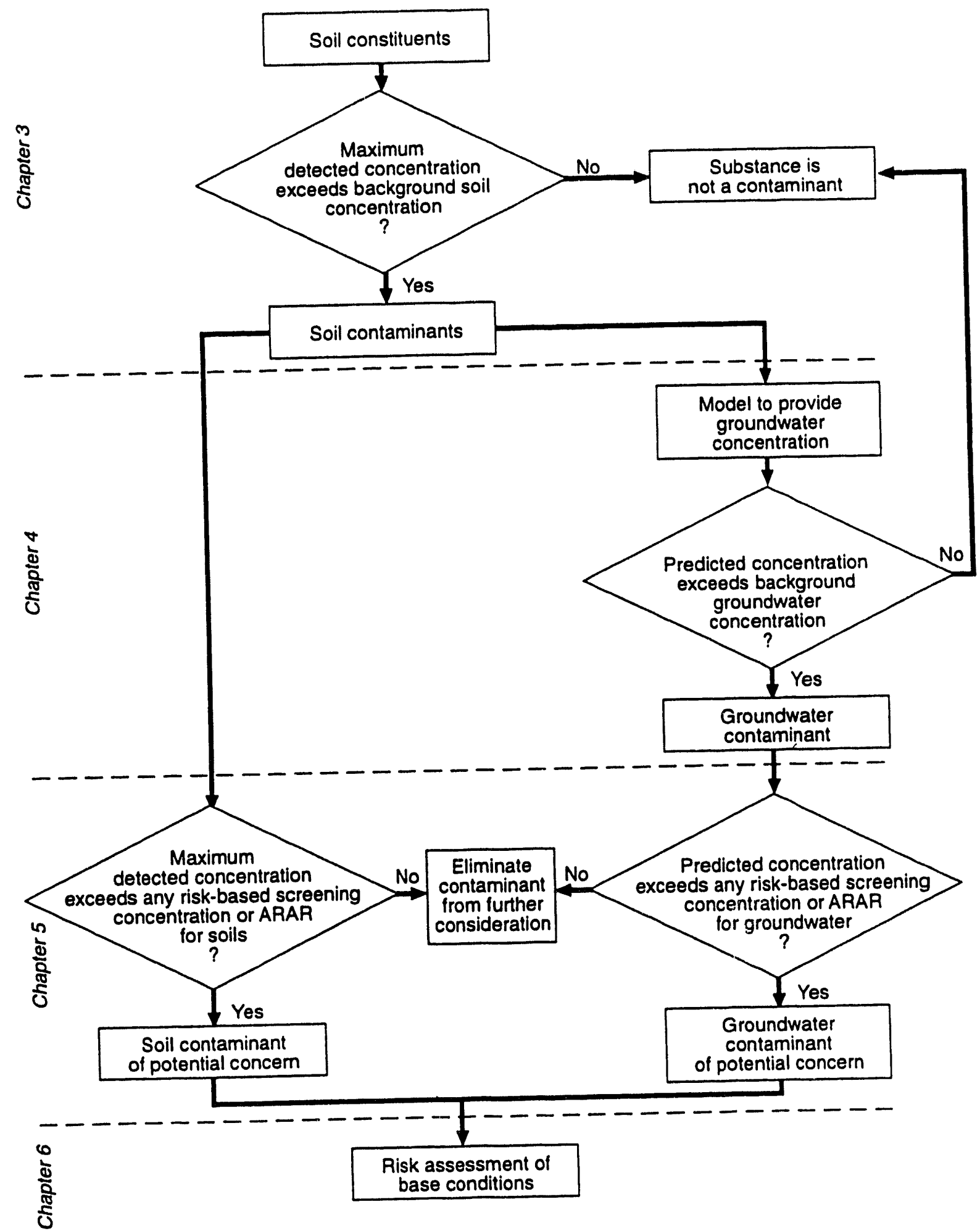

Figure 5-1. Overview of Contaminant Identification Process. 
DOE/RL-93-99, Rev. 0

Table 5-1. Contaminant Reference Doses and Slope Factors. (Sheet 1 of 4)

\begin{tabular}{|c|c|c|c|c|c|}
\hline \multirow[t]{2}{*}{ Contaminant } & \multicolumn{2}{|c|}{ Ingestion } & \multicolumn{2}{|c|}{ Inhalation } & \multirow{2}{*}{$\frac{\text { External }}{\text { SF }}$} \\
\hline & $\mathrm{RfD}$ & SF & $\mathrm{RfD}$ & SF & \\
\hline Organic Compounds & $(\mathrm{mg} / \mathrm{kg}-\mathrm{d})$ & $(\mathrm{mg} / \mathrm{kg}-\mathrm{d})^{-1}$ & $(\mathrm{mg} / \mathrm{kg}-\mathrm{d})$ & $(\mathrm{mg} / \mathrm{kg}-\mathrm{d})^{-1}$ & NA \\
\hline Acenaphthene & $6.0 \mathrm{E}-02^{\mathrm{h}}$ & - & - & - & \\
\hline Acetone & $1.0 \mathrm{E}-01^{\mathrm{h}}$ & - & - & - & \\
\hline Anthracene & $3.0 \mathrm{E}-01^{\mathrm{h}}$ & - & - & - & \\
\hline Aroclor $-1248^{a}$ & - & $7.7 \mathrm{E}+00^{\mathrm{h}}$ & - & - & \\
\hline Aroclor $-1254^{\mathrm{a}}$ & - & $7.7 \mathrm{E}+00^{h}$ & - & - & \\
\hline Aroclor $-1260^{\mathrm{a}}$ & - & $7.7 \mathrm{E}+00^{h}$ & - & - & \\
\hline Benzo(a)anthracene $e^{b}$ & - & $7.3 \mathrm{E}+00^{h}$ & - & - & \\
\hline Benzene & - & $2.9 \mathrm{E}-02^{\mathrm{h}}$ & - & $2.9 \mathrm{E}-02^{\mathrm{h}}$ & \\
\hline Benzo(a)pyrens & - & $7.3 \mathrm{E}+00^{h}$ & - & - & \\
\hline Benzo(b)fluoranthene ${ }^{b}$ & - & $7.3 \mathrm{E}+00^{\mathrm{h}}$ & - & - & \\
\hline Benzo(g,h,i)perylene & - & - & - & - & \\
\hline Benzo(k)fluoranthene $\mathrm{e}^{\mathrm{b}}$ & - & $7.3 \mathrm{E}+00^{\mathrm{h}}$ & - & - & \\
\hline Benzoic acid & $4.0 \mathrm{E}+00^{\mathrm{h}}$ & - & - & - & \\
\hline Bis(2-ethylhexyl)phthalate & $2.0 \mathrm{E}-02^{\mathrm{h}}$ & $1.4 \mathrm{E}-02^{\mathrm{h}}$ & - & - & \\
\hline 2-Butanone & $6.0 \mathrm{E}-01^{\mathrm{h}}$ & - & $2.9 \mathrm{E}-01^{\mathrm{h}}$ & - & \\
\hline Butylbenzylphthalate & $2.0 \mathrm{E}-01^{\mathrm{h}}$ & - & - & - & \\
\hline Carbazole & - & $2.0 \mathrm{E}-02^{\mathrm{h}}$ & - & - & \\
\hline Carbon disulfide & $1.0 \mathrm{E}-01^{\mathrm{h}}$ & - & $3.0 \mathrm{E}-03^{1}$ & - & \\
\hline Carbon tetrachloride & $7.0 \mathrm{E}-04^{\mathrm{h}}$ & $1.3 \mathrm{E}-01^{\mathrm{h}}$ & - & $5.3 \mathrm{E}-02^{\mathrm{h}, \mathrm{i}}$ & \\
\hline Chlordane (gamma) & $6.0 \mathrm{E}-05^{\mathrm{h}}$ & $1.3 \mathrm{E}+00^{\mathrm{h}}$ & - & $1.3 \mathrm{E}+00^{\mathrm{h}, \mathrm{i}}$ & \\
\hline 4-Chloro-3-methyphenol & - & - & - & - & \\
\hline 4-Chloroaniline & $4.0 \mathrm{E}-03^{\mathrm{h}}$ & - & - & - & \\
\hline Chloroform & $1.0 \mathrm{E}-02^{\mathrm{h}}$ & $6.1 \mathrm{E}-03^{\mathrm{h}}$ & - & $8.1 \mathrm{E}-02^{\mathrm{h}, \mathrm{i}}$ & \\
\hline Chrysene ${ }^{b}$ & - & $7.3 \mathrm{E}+00^{\mathrm{h}}$ & - & - & \\
\hline 4,4-DDD & - & $2.4 \mathrm{E}-01^{\mathrm{h}}$ & - & - & \\
\hline 4,4-DDE & - & $3.4 \mathrm{E}-01^{\mathrm{h}}$ & - & - & \\
\hline Di-n-butylphthalate & $1.0 \mathrm{E}-01^{\mathrm{h}}$ & - & - & - & \\
\hline Dibenzo(a,h)anthracene $\mathrm{e}^{\mathrm{b}}$ & - & $7.3 \mathrm{E}+00^{h}$ & - & - & \\
\hline Dibenzofuran & - & - & - & - & \\
\hline 1,3-Dichlorobenzene & - & - & - & - & \\
\hline 1,4-Dichlorobenzene & - & $2.4 \mathrm{E}-02^{\mathrm{i}}$ & $2.0 \mathrm{E}-01^{\mathrm{i}}$ & - & \\
\hline 1,2-Dichloroethene (total) & $9.0 \mathrm{E}-03^{\mathrm{i}}$ & - & - & - & \\
\hline Dieldrin & $5.0 \mathrm{E}-05^{\mathrm{h}}$ & $1.6 \mathrm{E}+01^{\mathrm{i}}$ & - & $1.6 \mathrm{E}+01^{\mathrm{h}}$ & \\
\hline Diethylphthalate & 8.0E- $01^{\mathrm{h}}$ & - & - & - & \\
\hline Ethyl benzene & $1.0 \mathrm{E}-01^{\mathrm{h}}$ & - & $2.9 \mathrm{E}-01^{\mathrm{h}}$ & - & \\
\hline Fluoranthene & $4.0 \mathrm{E}-02^{\mathrm{h}}$ & - & - & - & \\
\hline Fluorene & $4.0 \mathrm{E}-02^{\mathrm{h}}$ & - & - & - & \\
\hline Beta-HCH (Beta-BHC) & - & $1.8 \mathrm{E}+00^{\mathrm{h}}$ & - & $1.8 \mathrm{E}+00^{\mathrm{I}}$ & \\
\hline 2-Hexanone ${ }^{c}$ & $6.0 \mathrm{E}-01^{\mathrm{h}}$ & - & $2.9 \mathrm{E}-01^{\mathrm{h}}$ & - & \\
\hline Indeno(1,2,3-cd)pyrene ${ }^{b}$ & - & $7.3 \mathrm{E}+00^{h}$ & - & - & \\
\hline
\end{tabular}


DOE/RL-93-99, Rev. 0

Table 5-1. Contaminant Reference Doses and Slope Factors. (Sheet 2 of 4)

\begin{tabular}{|c|c|c|c|c|c|}
\hline \multirow[t]{2}{*}{ Contaminant } & \multicolumn{2}{|c|}{ Ingestion } & \multicolumn{2}{|c|}{ Inhalation } & \multirow{2}{*}{$\frac{\text { External }}{\mathrm{SF}}$} \\
\hline & RfD & SF & RfD & SF & \\
\hline Methoxychlor & $5.0 \mathrm{E}-03^{h}$ & - & - & - & \\
\hline 4-Methyl-2-pentanone & $5.0 \mathrm{E}-02^{i}$ & - & $2.0 \mathrm{E}-02^{\mathrm{i}}$ & - & \\
\hline Methylene Chloride & $6.0 \mathrm{E}-02^{\mathrm{h}}$ & $7.5 \mathrm{E}-03^{\mathrm{h}}$ & $9.0 \mathrm{E}-01^{\mathrm{i}}$ & $1.6 \mathrm{E}-03^{\mathrm{h}}$ & \\
\hline 2-Methylnaphthalene ${ }^{d}$ & $4.0 \mathrm{E}-03 \mathrm{~J}$ & - & - & - & \\
\hline 4-Methylphenol & - & - & - & - & \\
\hline Naphthalene & $4.0 \mathrm{E}-03 \mathrm{~J}$ & - & - & - & \\
\hline $\mathrm{N}$-Nitrosodiphenylamine & - & $4.9 \mathrm{E}-03^{\mathrm{h}}$ & - & - & \\
\hline Pentachlorophenol & $3.0 \mathrm{E}-02^{\mathrm{h}}$ & $1.2 \mathrm{E}-01^{\mathrm{h}}$ & - & - & \\
\hline Phenanthrene $\mathrm{e}^{\mathrm{e}}$ & $3.0 \mathrm{E}-02^{\mathrm{h}}$ & - & - & - & \\
\hline Phenol & $6.0 \mathrm{E}-01^{\mathrm{h}}$ & - & - & - & \\
\hline Pyrene & $3.0 \mathrm{E}-02^{\mathrm{h}}$ & - & - & - & \\
\hline 1,1,2,2-Tetrachloroethane & - & $2.0 \mathrm{E}-01^{\mathrm{h}}$ & - & $2.0 \mathrm{E}-01^{\mathrm{h}, 1}$ & \\
\hline Tetrachloroethene & $1.0 \mathrm{E}-02^{\mathrm{h}}$ & $5.2 \mathrm{E}-02^{\mathrm{k}}$ & - & $2.0 \mathrm{E}-03^{\mathrm{k}}$ & \\
\hline Toluene & $2.0 \mathrm{E}-01^{\mathrm{h}}$ & - & $1.0 \mathrm{E}-01^{\mathrm{h}}$ & - & \\
\hline 1,1,1-Trichloroethane & - & - & $3.0 \mathrm{E}-01^{1}$ & - & \\
\hline Trichloroethene & $6.0 \mathrm{E}-03^{\mathrm{m}}$ & $1.1 \mathrm{E}-02^{\mathrm{m}}$ & - & $6.0 \mathrm{E}-03^{\mathrm{m}}$ & \\
\hline Vinyl Chloride & - & $1.9 \mathrm{E}+00^{i}$ & - & $3.0 \mathrm{E}-01^{1}$ & \\
\hline Xylenes (total) & $2.0 \mathrm{E}+00^{\mathrm{h}}$ & - & - & - & \\
\hline Inorganic Constituents & $(\mathrm{mg} / \mathrm{kg}-\mathrm{d})$ & $(\mathrm{mg} / \mathrm{kg}-\mathrm{d})^{-1}$ & $(m g / k g-d)$ & $(\mathrm{mg} / \mathrm{kg}-\mathrm{d})^{-1}$ & NA \\
\hline Aluminum & $1.0 \mathrm{E}+00^{\mathrm{n}}$ & - & - & - & \\
\hline Ammonia & - & - & $2.9 \mathrm{E}-02^{\mathrm{h}}$ & - & \\
\hline Antimony & $4.0 \mathrm{E}-04^{\mathrm{h}}$ & - & - & - & \\
\hline Arsenic & $3.0 \mathrm{E}-04^{\mathrm{h}}$ & $2.0 \mathrm{E}+00^{\mathrm{h}}$ & - & $1.5 \mathrm{E}+01^{\mathrm{h}}$ & \\
\hline Barium & $7.0 \mathrm{E}-02^{\mathrm{h}}$ & - & $1.0 \mathrm{E}-04^{1}$ & - & \\
\hline Beryllium & $5.0 \mathrm{E}-03^{\mathrm{h}}$ & $4.3 \mathrm{E}+00^{h}$ & - & $8.4 \mathrm{E}+00^{\mathrm{h}, 1}$ & \\
\hline Cadmium (food) & $1.0 \mathrm{E}-03^{\mathrm{h}}$ & - & - & $6.3 \mathrm{E}+00^{\mathrm{h}}$ & \\
\hline Chromium (III) & $1.0 \mathrm{E}+00^{\mathrm{h}}$ & - & - & - & \\
\hline Chromium (VI) & $5.0 \mathrm{E}-03^{\mathrm{h}}$ & - & - & $4.2 \mathrm{E}+01^{\mathrm{i}}$ & \\
\hline Cobalt & $6.0 \mathrm{E}-02^{\circ}$ & - & - & - & \\
\hline Copper & $4.0 \mathrm{E}-02 \mathrm{p}$ & - & - & - & \\
\hline Fluoride & $6.0 \mathrm{E}-02^{\mathrm{h}}$ & - & - & - & \\
\hline Lead & - & - & - & - & \\
\hline Manganese (food) & $1.4 \mathrm{E}-01^{\mathrm{h}}$ & - & $1.1 \mathrm{E}-04^{\mathrm{h}}$ & - & \\
\hline Mercury & $3.0 \mathrm{E}-04^{\mathrm{i}}$ & - & $9.0 \mathrm{E}-05^{\mathrm{i}}$ & - & \\
\hline Nickel & $2.0 \mathrm{E}-02^{\mathrm{h}}$ & - & - & $8.4 \mathrm{E}-01^{\mathrm{f}, \mathrm{h}}$ & \\
\hline Nitrite (as N) & $1.0 \mathrm{E}-01^{\mathrm{h}}$ & - & - & - & \\
\hline Selenium & $5.0 \mathrm{E}-03^{\mathrm{h}}$ & - & - & - & \\
\hline Silver & $5.0 \mathrm{E}-03^{\mathrm{h}}$ & - & - & - & \\
\hline Strontium & $6.0 \mathrm{E}-01^{\mathrm{h}}$ & - & - & - & \\
\hline Sulfate & - & - & - & - & \\
\hline
\end{tabular}


DOE/RL-93-99, Rev. 0

Table 5-1. Contaminant Reference Doses and Slope Factors. (Sheet 3 of 4)

\begin{tabular}{|c|c|c|c|c|c|}
\hline \multirow[t]{2}{*}{ Contaminant } & \multicolumn{2}{|c|}{ Ingestion } & \multicolumn{2}{|c|}{ Inhalation } & \multirow{2}{*}{$\frac{\text { External }}{\text { SF }}$} \\
\hline & $\mathrm{RfD}$ & SF & RfD & SF & \\
\hline Thallium (oxide) & $7.0 \mathrm{E}-05^{i}$ & - & - & - & \\
\hline Vanadium & $7.0 \mathrm{E}-03^{\mathrm{i}}$ & - & - & - & \\
\hline Zinc & $3.0 \mathrm{E}-01^{\mathrm{h}}$ & - & - & - & \\
\hline Radionuclides & NA & $(\mathrm{pCi})^{-1}$ & $\mathrm{NA}$ & $(p C i)^{-1}$ & $(\mathrm{pCi}-\mathrm{yr} / \mathrm{g})^{-1}$ \\
\hline Americium-241 & & $2.4 \mathrm{E}-10^{1}$ & & $3.2 \mathrm{E}-08^{1}$ & 4.9E-09i \\
\hline Barium-140 & & $2.7 \mathrm{E}-12^{\mathrm{i}}$ & & $2.0 \mathrm{E}-12^{\mathrm{i}}$ & $5.4 \mathrm{E}-07^{i}$ \\
\hline Beryllium-7 & & $3.0 \mathrm{E}-14^{\mathrm{I}}$ & & $2.7 \mathrm{E}-13^{1}$ & $1.5 \mathrm{E}-07^{1}$ \\
\hline Carbon-14 & & $9.0 \mathrm{E}-13^{\mathrm{i}}$ & & $6.4 \mathrm{E}-15^{i}$ & $0.0 \mathrm{E}+00^{\mathrm{i}}$ \\
\hline Cerium-141 & & $8.3 E-13^{i}$ & & $8.4 \mathrm{E}-12^{i}$ & $1.3 \mathrm{E}-07^{1}$ \\
\hline Cerium-144 & & $6.1 E-12^{i}$ & & $3.4 \mathrm{E}-10^{\mathrm{i}}$ & $2.5 \mathrm{E}-08^{i}$ \\
\hline Cesium-134 & & $4.1 E-11^{i}$ & & $2.8 \mathrm{E}-11^{i}$ & $5.2 \mathrm{E}-06^{1}$ \\
\hline Cesium-137+D & & $2.8 \mathrm{E}-11^{1}$ & & $1.9 \mathrm{E}-11^{1}$ & $2.0 \mathrm{E}-06^{1}$ \\
\hline Chromium-51 & & $4.3 E-14^{1}$ & & $3.0 \mathrm{E}-13^{i}$ & $9.2 \mathrm{E}-08^{\mathrm{i}}$ \\
\hline Cobalt -58 & & $1.6 \mathrm{E}-12^{\mathrm{i}}$ & & $9.8 \mathrm{E}-12^{i}$ & $3.3 \mathrm{E}-06^{\mathrm{i}}$ \\
\hline Cobalt -60 & & $1.5 \mathrm{E}-11^{1}$ & & $1.5 \mathrm{E}-10^{\mathrm{i}}$ & $8.6 \mathrm{E}-06^{i}$ \\
\hline Europium-152 & & $2.1 E-12^{i}$ & & $1.1 \mathrm{E}-10^{\mathrm{i}}$ & $3.6 \mathrm{E}-06^{1}$ \\
\hline Europium-154 & & $3.0 \mathrm{E}-12^{\mathrm{i}}$ & & $1.4 \mathrm{E}-10^{\mathrm{i}}$ & 4.1E-06 \\
\hline Europium-155 & & $4.5 \mathrm{E}-13^{i}$ & & $1.8 \mathrm{E}-11^{\mathrm{i}}$ & $5.9 \mathrm{E}-08^{\mathrm{i}}$ \\
\hline Gross Alpha & & - & & - & - \\
\hline Gross Beta & & - & & - & - \\
\hline Iron-59 & & $2.8 \mathrm{E}-12^{\mathrm{i}}$ & & $9.7 \mathrm{E}-12^{i}$ & $4.1 E-06^{i}$ \\
\hline Manganese-54 & & $1.1 \mathrm{E}-12^{\mathrm{i}}$ & & $5.3 \mathrm{E}-12^{\mathrm{i}}$ & $2.9 \mathrm{E}-06^{\mathrm{i}}$ \\
\hline Nickel-63 & & $2.4 \mathrm{E}-13^{i}$ & & $1.8 \mathrm{E}-12^{\mathrm{i}}$ & $0.0 \mathrm{E}+00^{1}$ \\
\hline Plutonium-238 & & $2.2 \mathrm{E}-10^{1}$ & & $3.9 \mathrm{E}-08^{\mathrm{i}}$ & $2.8 \mathrm{E}-11^{i}$ \\
\hline Plutonium-239/240 & & $2.3 E-10^{1}$ & & $3.8 \mathrm{E}-08^{i}$ & $2.7 \mathrm{E}-11^{i}$ \\
\hline Potassium -40 & & $1.1 \mathrm{E}-11^{\mathrm{i}}$ & & $7.6 \mathrm{E}-12^{\mathrm{i}}$ & $5.4 \mathrm{E}-07^{\mathrm{i}}$ \\
\hline Radium-226+D & & $1.2 \mathrm{E}-10^{i}$ & & $3.0 \mathrm{E}-09 \mathrm{i}$ & $6.0 \mathrm{E}-06^{i}$ \\
\hline Ruthenium-103 & & $9.0 \mathrm{E}-13^{i}$ & & $8.4 E-12^{i}$ & $1.5 \mathrm{E}-06^{\mathrm{i}}$ \\
\hline Ruthenium-106 & & $9.5 \mathrm{E}-12^{i}$ & & $4.4 \mathrm{E}-10^{i}$ & $0.0 \mathrm{E}+00^{i}$ \\
\hline Sodium-22 & & $6.8 \mathrm{E}-12^{\mathrm{i}}$ & & $4.8 \mathrm{E}-12^{\mathrm{i}}$ & $7.2 \mathrm{E}-06^{\mathrm{i}}$ \\
\hline Strontium-90+D & & $3.6 \mathrm{E}-11^{i}$ & & $6.2 \mathrm{E}-11^{i}$ & $0.0 \mathrm{E}+00^{1}$ \\
\hline Technetium-99 & & $1.3 \mathrm{E}-12^{i}$ & & $8.3 E-12^{i}$ & $6.0 \mathrm{E}-13^{i}$ \\
\hline Thorium-228+D & & $5.5 \mathrm{E}-11^{\mathrm{i}}$ & & $7.8 \mathrm{E}-08^{i}$ & $5.6 \mathrm{E}-06^{i}$ \\
\hline Thorium-232 & & $1.2 \mathrm{E}-11^{\mathrm{i}}$ & & $2.8 \mathrm{E}-08^{\mathrm{i}}$ & $2.6 \mathrm{E}-11^{\mathrm{i}}$ \\
\hline Thorium-234 & & $4.0 \mathrm{E}-12^{1}$ & & $3.2 \mathrm{E}-11^{1}$ & $3.5 \mathrm{E}-09 \mathrm{i}$ \\
\hline Tritium (Hydrogen-3) & & $5.4 \mathrm{E}-14^{1}$ & & $7.8 \mathrm{E}-14^{i}$ & $0.0 \mathrm{E}+00^{i}$ \\
\hline Uranium (total)g & & $2.8 \mathrm{E}-11^{1}$ & & $5.2 \mathrm{E}-08^{i}$ & $3.6 \mathrm{E}-08^{i}$ \\
\hline Uranium-233/234 & & $1.6 \mathrm{E}-11^{\mathrm{i}}$ & & $2.7 \mathrm{E}-08^{i}$ & $4.2 \mathrm{E}-11^{\mathrm{i}}$ \\
\hline Uranium-235+D & & $1.6 \mathrm{E}-11^{1}$ & & $2.5 \mathrm{E}-08^{1}$ & $2.4 \mathrm{E}-07^{1}$ \\
\hline Uranium $-238+D$ & & $2.8 \mathrm{E}-11^{i}$ & & $5.2 \mathrm{E}-08^{1}$ & $3.6 \mathrm{E}-08^{\mathrm{i}}$ \\
\hline
\end{tabular}

$5 T-1 \mathrm{c}$ 
Table 5-1. Contaminant Reference Doses and Slope Factors. (Sheet 4 of 4)

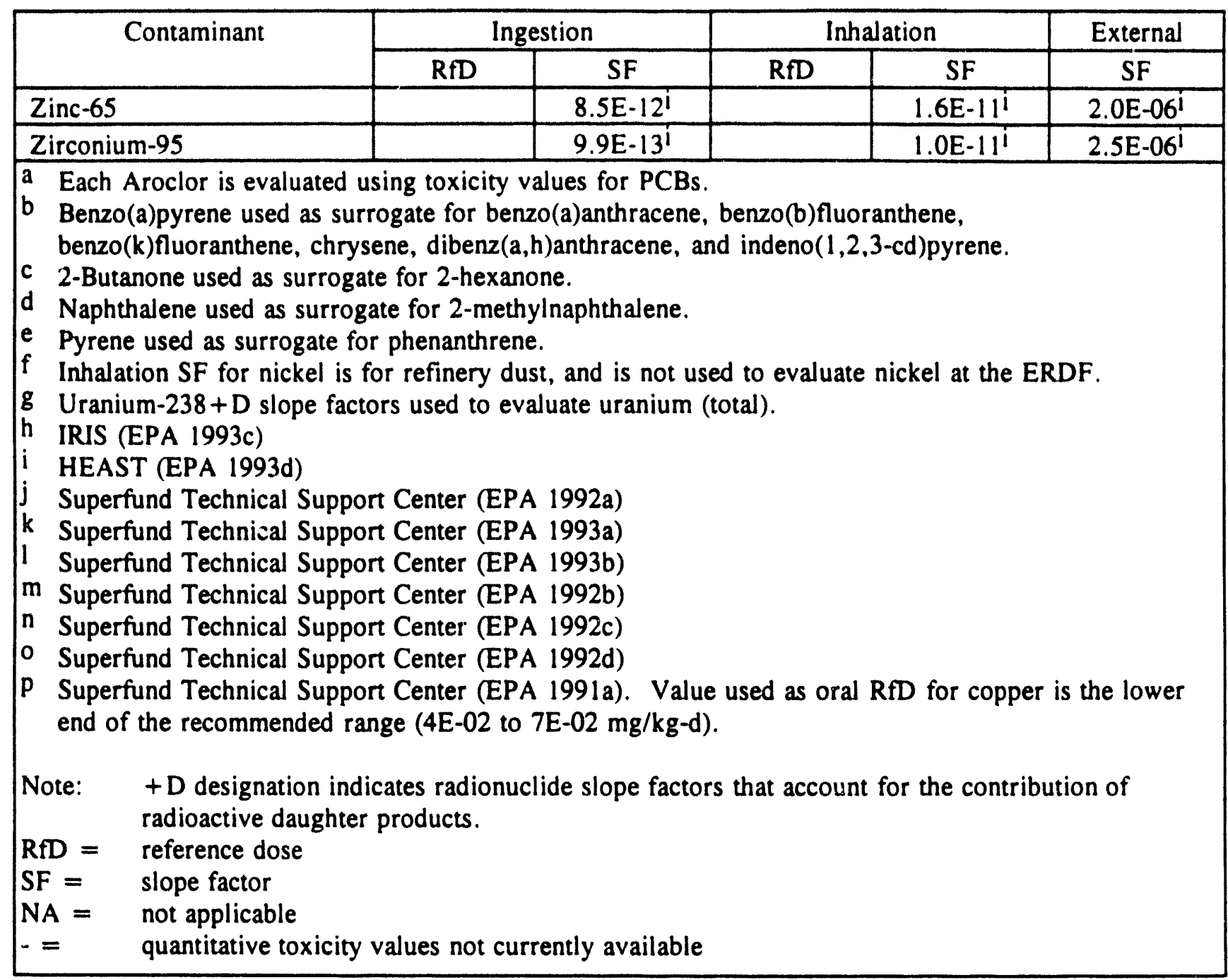


DOE/RL-93-99, Rev. 0

Table 5-2. Summary Screening Factors for Risk-Based Screening.

\begin{tabular}{|c|c|c|c|c|}
\hline \multirow[b]{2}{*}{ Media } & \multirow[b]{2}{*}{$\begin{array}{c}\text { Exposure } \\
\text { Route }\end{array}$} & \multicolumn{3}{|c|}{ Summary Screening Factor } \\
\hline & & Noncarcinogen & $\begin{array}{c}\text { Carcinogen } \\
\text { (Non-radioactive) }\end{array}$ & Radioactive \\
\hline \multirow[t]{4}{*}{ Soil } & Ingestion & $8.0 \mathrm{E}+03$ & $6.4 \mathrm{E}-02$ & $7.6 \mathrm{E}-11$ \\
\hline & Inhalation ${ }^{\mathrm{a}}$ & $3.2 \mathrm{E}+06$ & $1.6 \mathrm{E}+01$ & $9.1 \mathrm{E}-09$ \\
\hline & Inhalation & $1.6 \mathrm{E}-01 \times \mathrm{VF}^{\mathrm{b}}$ & $8.2 E-07 \times V F^{b}$ & NA \\
\hline & External Exposure & NA & NA & $4.2 \mathrm{E}-09$ \\
\hline Groundwater & Ingestion & $1.6 \mathrm{E}+00$ & 8.2E-06 & $4.6 E-12$ \\
\hline \multicolumn{5}{|c|}{$\begin{array}{l}\text { aAssuming a particulate emission factor }=2 \mathrm{E}+07 \mathrm{~m}^{3} / \mathrm{kg} \text {. } \\
\text { bVF = volatilization factor }\left(\mathrm{m}^{3} / \mathrm{kg}\right) \\
\mathrm{NA}=\text { not applicable. }\end{array}$} \\
\hline
\end{tabular}


Table 5-3. Risk-Based Screening Concentrations (mg/kg) for Soil Pathways - Non-Radioactive Contaminants. (Sheet 1 of 4 )

\begin{tabular}{|c|c|c|c|c|c|c|c|c|}
\hline \multirow[b]{2}{*}{ Contaminant } & \multicolumn{2}{|c|}{ Soil Ingestion } & \multicolumn{2}{|c|}{ Fug. Dust Inhalation } & \multicolumn{4}{|c|}{ Inhalation of Volatiles } \\
\hline & Noncarc. RBC & Carc. RBC & Noncarc. RBC & Carc. RBC & volatile? & $\mathrm{VF}(\mathrm{m} 3 / \mathrm{kg})$ & Noncarc. RBC & Carc. RBC \\
\hline Organic Compounds & & & & & & & & \\
\hline Acenaphthene & $4.8 \mathrm{E}+02$ & & & & & & & \\
\hline Acetone & $8.0 \mathrm{E}+02$ & & & & yes & & \multicolumn{2}{|c|}{ no toxicity values } \\
\hline Anthracene & $2.4 \mathrm{E}+03$ & & & & & & & \\
\hline Aroclor- 1248 & & 8.3E-03 & & & & & & \\
\hline Aroclor- 1254 & & $8.3 E-03$ & & & & & & \\
\hline Aroclor -1260 & & 8.3E-03 & & & & & & \\
\hline Benzo(a)anthracene & & $8.8 \mathrm{E}-03$ & & & & & & \\
\hline Benzene & & $2.2 \mathrm{E}+00$ & & $5.5 \mathrm{E}+02$ & yes & $2.6 \mathrm{E}+03$ & & $7.4 \mathrm{E}-02$ \\
\hline Benzo(a)pyrene & & 8.8E-03 & & & & & & \\
\hline Benzo(b)fluoranthene & & $8.8 \mathrm{E}-03$ & & & & & & \\
\hline Benzo $(\mathrm{g}, \mathrm{h}, \mathrm{i})$ perylene & & & & & & & & \\
\hline Benzo(k)fluoranthene & & $8.8 \mathrm{E}-03$ & & & & & & \\
\hline Benzoic acid & $3.2 \mathrm{E}+04$ & & & & & & & \\
\hline Bis(2-ethylhexyl)phthalate & $1.6 \mathrm{E}+02$ & $4.6 \mathrm{E}+00$ & & & & & & \\
\hline 2-Butanone & $4.8 \mathrm{E}+03$ & & $9.3 E+05$ & & yes & $1.0 \mathrm{E}+03$ & $4.6 \mathrm{E}+01$ & \\
\hline Butylbenzylphthalate & $1.6 \mathrm{E}+03$ & & & & & & & \\
\hline Carbazole & & $3.2 \mathrm{E}+00$ & & & & & & \\
\hline Carbon disulfide & $8.0 \mathrm{E}+02$ & & $9.6 \mathrm{E}+03$ & & yes & $1.0 \mathrm{E}+03$ & 4.8E-01 & \\
\hline Carbon tetrachloride & $5.6 \mathrm{E}+00$ & 4.9E-01 & & $3.0 \mathrm{E}+02$ & yes & $3.0 \mathrm{E}+03$ & & $4.6 \mathrm{E}-02$ \\
\hline Chlordane (gamma) & $4.8 \mathrm{E}-01$ & 4.9E-02 & & $1.2 \mathrm{E}+01$ & & & & \\
\hline 4-Chloro-3-methyphenol & & & & & & & & \\
\hline 4-Chloroaniline & $3.2 \mathrm{E}+01$ & & & & & & & \\
\hline Chloroform & $8.0 \mathrm{E}+01$ & $1.0 \mathrm{E}+01$ & & $2.0 \mathrm{E}+02$ & yes & $1.0 \mathrm{E}+03$ & & $1.0 \mathrm{E}-02$ \\
\hline Chrysene & & $8.8 \mathrm{E}-03$ & & & & & & \\
\hline 4,4-DDD & & $2.7 \mathrm{E}-01$ & & & & & & \\
\hline 4,4-DDE & & $1.9 \mathrm{E}-01$ & & & & & & \\
\hline
\end{tabular}


Table 5-3. Risk-Based Screening Concentrations (mg/kg) for Soil Pathways - Non-Radioactive Contaminants. (Sheet 2 of 4)

\begin{tabular}{|c|c|c|c|c|c|c|c|c|}
\hline \multirow[b]{2}{*}{ Contaminant } & \multicolumn{2}{|c|}{\begin{tabular}{|l} 
Soil Ingestion \\
\end{tabular}} & \multicolumn{2}{|c|}{ Fug. Dust Inhalation } & \multicolumn{4}{|c|}{ Inhalation of Volatiles } \\
\hline & Noncarc. RBC & Carc. RBC & Noncarc. RBC & Carc. RBC & volatile? & $\mathrm{VF}(\mathrm{m} 3 / \mathrm{kg})$ & Noncarc. RBC & Carc. RBC \\
\hline Di-N-butylphthalate & $8.0 \mathrm{E}+02$ & & & & & & & \\
\hline Dibenzo(a,h)anthracene & & $8.8 \mathrm{E}-03$ & & & & & & \\
\hline 1,3-Dichlorobenzene & & & & & & & & \\
\hline 1,4-Dichlorobenzene & & $2.7 E+00$ & $6.4 \mathrm{E}+05$ & & & & & \\
\hline Diethylphthalate & $6.4 \mathrm{E}+03$ & & & & & & & \\
\hline Ethyl benzene & $8.0 \mathrm{E}+02$ & & $9.3 E+05$ & & yes & $7.8 \mathrm{E}+03$ & $3.6 \mathrm{E}+02$ & \\
\hline Fluoranthene & $3.2 \mathrm{E}+02$ & & & & & & & \\
\hline Fluorene & $3.2 \mathrm{E}+02$ & & & & & & & \\
\hline Beta-BHC (Beta-BHC) & & $3.6 \mathrm{E}-02$ & & $8.9 E+00$ & & & & \\
\hline Methylene Chloride & $4.8 \mathrm{E}+02$ & $8.5 E+00$ & $2.9 \mathrm{E}+06$ & $1.0 \mathrm{E}+04$ & yes & $1.0 \mathrm{E}+03$ & $1.4 \mathrm{E}+02$ & $5.1 \mathrm{E}-01$ \\
\hline 2-Methylnaphthalene & $3.2 \mathrm{E}+01$ & & & & & & & \\
\hline 4-Methylphenol & & & & & & & & \\
\hline Naphthalene & $3.2 \mathrm{E}+01$ & & & & & & & \\
\hline $\mathrm{N}$-Nitrosodiphenylamine & & $1.3 E+01$ & & & & & & \\
\hline Pentachlorophenol & $2.4 \mathrm{E}+02$ & $5.3 \mathrm{E}-01$ & & & & & & \\
\hline Phenanthrene & $2.4 \mathrm{E}+02$ & & & & & & & \\
\hline Phenol & $4.8 \mathrm{E}+03$ & & & & & & & \\
\hline Pyrene & $2.4 \mathrm{E}+02$ & & & & & & & \\
\hline 1,1,2,2-Tetrachloroethane & & $3.2 \mathrm{E}-01$ & & $8.0 \mathrm{E}+01$ & yes & $1.0 \mathrm{E}+03$ & & 4.1E-03 \\
\hline Tetrachloroethene & $8.0 \mathrm{E}+01$ & $1.2 \mathrm{E}+00$ & & $8.0 \mathrm{E}+03$ & yes & $4.1 E+03$ & & $1.7 \mathrm{E}+00$ \\
\hline
\end{tabular}


Table 5-3. Risk-Based Screening Concentrations (mg/kg) for Soil Pathways - Non-Radioactive Contaminants. (Sheet 3 of 4 )

\begin{tabular}{|c|c|c|c|c|c|c|c|c|}
\hline \multirow[b]{2}{*}{ Contaminant } & \multicolumn{2}{|c|}{ Soil Ingestion } & \multicolumn{2}{|c|}{ Fug. Dust Inhalation } & \multicolumn{4}{|c|}{ Inhalation of Volatiles } \\
\hline & Noncarc. RBC & Carc. RBC & Noncarc. RBC & Carc. RBC & volatile? & $\mathrm{VF}(\mathrm{m} 3 / \mathrm{kg})$ & Noncarc. RBC & Carc. RBC \\
\hline Toluene & $1.6 \mathrm{E}+03$ & & $3.2 \mathrm{E}+05$ & & yes & $2.2 \mathrm{E}+03$ & $3.5 \mathrm{E}+01$ & \\
\hline 1,1,1-Trichloroethane & & & $9.6 \mathrm{E}+05$ & & yes & $1.0 \mathrm{E}+03$ & $4.8 \mathrm{E}+01$ & \\
\hline Trichloroethene & $4.8 \mathrm{E}+01$ & $5.8 \mathrm{E}+00$ & & $2.7 \mathrm{E}+03$ & yes & $1.2 \mathrm{E}+03$ & & $1.6 \mathrm{E}-01$ \\
\hline Vinyl Chloride & & $3.4 \mathrm{E}-02$ & & $5.3 \mathrm{E}+01$ & yes & $6.0 \mathrm{E}+02$ & & $1.6 \mathrm{E}-03$ \\
\hline Xylenes (total) & $1.6 \mathrm{E}+04$ & & & & yes & & \multicolumn{2}{|c|}{ no toxicity values } \\
\hline Inorganic Constituents & & & & & & & & \\
\hline Aluminum & 8.0E+03 & & & & & & & \\
\hline Ammonia & & & $9.3 \mathrm{E}+04$ & & yes & $1.0 \mathrm{E}+03$ & $4.6 \mathrm{E}+00$ & \\
\hline Antimony & $3.2 \mathrm{E}+00$ & & & & & & & \\
\hline Arsenic & $2.4 \mathrm{E}+00$ & $3.2 \mathrm{E}-02$ & & $1.1 \mathrm{E}+00$ & & & & \\
\hline Barium & $5.6 \mathrm{E}+02$ & & $3.2 \mathrm{E}+02$ & & & & & \\
\hline Beryllium & $4.0 \mathrm{E}+01$ & $1.5 \mathrm{E}-02$ & & $1.9 E+00$ & & & & \\
\hline Cadmium & $8.0 \mathrm{E}+00$ & & & $2.5 \mathrm{E}+00$ & & & & \\
\hline Chromium (III) & $8.0 \mathrm{E}+03$ & & & & & & & \\
\hline Chromium (VI) & $4.0 \mathrm{E}+01$ & & & 3.8E-01 & & & & \\
\hline Cobalt & $4.8 \mathrm{E}+02$ & & & & & & & \\
\hline Copper & $3.2 \mathrm{E}+02$ & & & & & & & \\
\hline Fluoride & $4.8 \mathrm{E}+02$ & & & & & & & \\
\hline Lead & & & & & & & & \\
\hline Manganese & $1.1 E+03$ & & $3.5 \mathrm{E}+02$ & & & & & \\
\hline Mercury & $2.4 E+00$ & & $2.9 \mathrm{E}+02$ & & & & & \\
\hline Nickel & $1.6 \mathrm{E}+02$ & & & & & & & \\
\hline Nitrite (as N) & $8.0 \mathrm{E}+02$ & & & & & & & \\
\hline Selenium & $4.0 \mathrm{E}+01$ & & & & & & & \\
\hline Silver & $4.0 \mathrm{E}+01$ & & & & & & & \\
\hline Strontium & $4.8 \mathrm{E}+03$ & & & & & & & \\
\hline Sulfate & & & & & & & & \\
\hline
\end{tabular}


Table 5-3. Risk-Based Screening Concentrations (mg/kg) for Soil Pathways - Non-Radioactive Contaminants. (Sheet 4 of 4 )

\begin{tabular}{|c|c|c|c|c|c|c|c|c|}
\hline \multirow[b]{2}{*}{ Contaminant } & \multicolumn{2}{|c|}{ Soil Ingestion } & \multicolumn{2}{|c|}{ Fug. Dust Inhalation } & \multicolumn{4}{|c|}{ Inhalation of Volatiles } \\
\hline & Noncarc. RBC & Carc. RBC & Noncarc. RBC & Carc. RBC & volatile? & $\mathrm{VF}(\mathrm{m} 3 / \mathrm{kg})$ & Noncarc. RBC & Carc. RBC \\
\hline Thallium & $5.6 \mathrm{E}-01$ & & & & & & & \\
\hline Vanadium & $5.6 \mathrm{E}+01$ & & & & & & & \\
\hline Zinc & $2,4 \mathrm{E}+03$ & & & & & & & \\
\hline \multicolumn{9}{|c|}{$\begin{array}{l}\text { Blank cells indicate that toxicity values are not currently available with which to calculate risk-based screening concentrations. } \\
\text { Toxicity values used to calculate risk-based screening concentrations are provided in Table } 5-1 . \\
\text { RBC = Risk-based screening concentration } \\
\text { VF = volatilization factor } \\
\text { Minimum RBC for each contaminant is shaded. }\end{array}$} \\
\hline
\end{tabular}


DOE/RL-93-99, Rev. 0

Table 5-4. Risk-Based Screening Concentrations (pCi/g) for Soil Pathways - Radioactive Contaminants.

\begin{tabular}{|c|c|c|c|}
\hline Radionuclide & $\begin{array}{l}\text { Soil Ingestion } \\
\text { RBC }\end{array}$ & $\begin{array}{l}\text { Fugitive Dust } \\
\text { Inhalation RBC }\end{array}$ & $\begin{array}{c}\text { External } \\
\text { Exposure RBC }\end{array}$ \\
\hline Americium-241 & $3.2 \mathrm{E}-01$ & $2.8 \mathrm{E}-01$ & $8.6 \mathrm{E}-01$ \\
\hline Barium-140 & $2.8 \mathrm{E}+01$ & $4.6 \mathrm{E}+03$ & $7.8 \mathrm{E}-03$ \\
\hline Beryllium-7 & $2.5 E+03$ & $3.4 \mathrm{E}+04$ & $2.8 \mathrm{E}-02$ \\
\hline Carbon-14 & $8.4 E+01$ & $1.4 \mathrm{E}+06$ & $\mathrm{a}$ \\
\hline Cerium-141 & $9.2 \mathrm{E}+01$ & $1.1 \mathrm{E}+03$ & $3.2 \mathrm{E}-02$ \\
\hline Cerium-144 & $1.2 \mathrm{E}+01$ & $2.7 \mathrm{E}+01$ & 1.7E-01 \\
\hline Cesium-134 & $1.9 E+00$ & $3.3 \mathrm{E}+02$ & 8.1E-04 \\
\hline Cesium-137 & $2.7 \mathrm{E}+00$ & $4.8 E+02$ & $2.1 \mathrm{E}-03$ \\
\hline Chromium-51 & $1.8 \mathrm{E}+03$ & $3.0 \mathrm{E}+04$ & $4.6 \mathrm{E}-02$ \\
\hline Cobalt -58 & $4.8 \mathrm{E}+01$ & $9.3 \mathrm{E}+02$ & $1.3 \mathrm{E}-03$ \\
\hline Cobalt -60 & $5.1 \mathrm{E}+00$ & $6.1 E+01$ & $4.9 \mathrm{E}-04$ \\
\hline Europium-152 & $3.6 \mathrm{E}+01$ & $8.3 E+01$ & $1.2 \mathrm{E}-03$ \\
\hline Europium-154 & $2.5 \mathrm{E}+01$ & $6.5 \mathrm{E}+01$ & $1.0 \mathrm{E}-03$ \\
\hline Europium-155 & $1.7 \mathrm{E}+02$ & $5.1 \mathrm{E}+02$ & 7.1E-02 \\
\hline Iron-59 & $2.7 \mathrm{E}+01$ & $9.4 \mathrm{E}+02$ & $1.0 \mathrm{E}-03$ \\
\hline Manganese-54 & $6.9 \mathrm{E}+01$ & $1.7 \mathrm{E}+03$ & $1.4 \mathrm{E}-03$ \\
\hline Nickel-63 & $3.2 \mathrm{E}+02$ & $5.1 E+03$ & $\mathbf{a}$ \\
\hline Plutonium-238 & $3.5 \mathrm{E}-01$ & 2.3E01 & $1.5 \mathrm{E}+02$ \\
\hline Plutonium-239/240 & $3.3 \mathrm{E}-01$ & 2.4E-01 & $1.6 \mathrm{E}+02$ \\
\hline Potassium-40 & $6.9 E+00$ & $1.2 \mathrm{E}+03$ & $7.8 \mathrm{E}-03$ \\
\hline Radium-226 & $6.3 \mathrm{E}-01$ & $3.0 \mathrm{E}+\infty 0$ & $7.0 \mathrm{E}-04$ \\
\hline Ruthenium-103 & $8.4 \mathrm{E}+01$ & $1.1 \mathrm{E}+03$ & $2.8 \mathrm{E}-03$ \\
\hline Ruthenium-106 & $8.0 E+\infty$ & $2.1 E+01$ & $\mathbf{a}$ \\
\hline Sodium-22 & $1.1 \mathrm{E}+01$ & $1.9 \mathrm{E}+03$ & $5,8 \mathrm{E}-04$ \\
\hline Strontium-90 & $2.1 \mathrm{E}+\infty \mathrm{O}$ & $1.5 E+02$ & a \\
\hline Technetium-99 & $5.8 \mathrm{E}+01$ & $1.1 \mathrm{E}+03$ & $7.0 \mathrm{E}+03$ \\
\hline Thorium-228 & $1.4 \mathrm{E}+00$ & $1.2 \mathrm{E}-01$ & $7.5 \mathrm{E}-04$ \\
\hline Thorium-232 & $6.3 E+00$ & $3.3 \mathrm{E}-01$ & $1.6 \mathrm{E}+02$ \\
\hline Thorium-234 & $1.9 \mathrm{E}+01$ & $2.8 \mathrm{E}+02$ & $1.2 \mathrm{E}+00$ \\
\hline Tritium & $1.4 \mathrm{E}+03$ & $1.2 \mathrm{E}+05$ & $\mathrm{a}$ \\
\hline Uranium (total) & $2.7 \mathrm{E}+00$ & $1.8 \mathrm{E}-01$ & $1.2 \mathrm{E}-01$ \\
\hline Uranium-233/234 & $4.8 \mathrm{E}+00$ & $3.4 \mathrm{E}-01$ & $1.0 \mathrm{E}+02$ \\
\hline Uranium-235 & $4.8 \mathrm{E}+00$ & $3.6 \mathrm{E}-01$ & $1.8 \mathrm{E}-02$ \\
\hline Uranium-238 & $2.7 \bar{E}+00$ & $1.8 \mathrm{E}-01$ & $1.2 \mathrm{E}-01$ \\
\hline Zine-65 & $8.9 E+00$ & $5.7 \mathrm{E}+02$ & 2.1E-03 \\
\hline Zirconium-95 & $7.7 \mathrm{E}+01$ & $9.1 E+02$ & $1.7 \mathrm{E}-03$ \\
\hline
\end{tabular}


DOE/RL-93-99, Rev. 0

Table 5-5. Comparison of Maximum Soil Contaminant Concentrations to Risk-Based Screening Concentrations and ARARs. (Sheet 1 of 5)

\begin{tabular}{|c|c|c|}
\hline Contaminant & $\begin{array}{c}\text { Maximum } \\
\text { Contaminant } \\
\text { Concentration }^{\mathrm{a}}\end{array}$ & $\begin{array}{l}\text { Minimum Risk- } \\
\text { Based } \\
\text { Concentration }\end{array}$ \\
\hline Organic Compounds & $(\mathrm{mg} / \mathrm{kg})$ & $(\mathrm{mg} / \mathrm{kg})$ \\
\hline Acenaphthene & 8.5E-01 & $4.8 E+02$ \\
\hline Acetone & $2.8 E+00$ & $8.0 E+02$ \\
\hline Anthracene & $6.3 E+00$ & $2.4 \mathrm{E}+03$ \\
\hline Aroclor -1248 & $1.0 \mathrm{E}+01$ & $8.3 E-03$ \\
\hline Aroclor 1254 & $6.4 \mathrm{E}+00$ & $8.3 \mathrm{E}-03$ \\
\hline Aroclor -1260 & $2.3 \mathrm{E}+00$ & 8.3E-03 \\
\hline Beazo(a)anthracene & $1.8 \mathrm{E}+00$ & $88 \mathrm{E}-03$ \\
\hline Benzene & $1,9 \mathrm{EO} 01$ & $74 \mathrm{E}-02$ \\
\hline Benzo(a)pyrene & $2.7 \mathrm{E}+01$ & $8.8 \mathrm{E} 03$ \\
\hline Benzo(b)fluoranthene & $2.4 \mathrm{E}+00$ & $8.8 \mathrm{E}-03$ \\
\hline Benzo(g,h,i)perylene & $3.7 \mathrm{E}+00$ & - \\
\hline Benzo(k)fluoranthene & $76 \mathrm{E} 01$ & $8.8 \mathrm{E} 03$ \\
\hline Benzoic acid & $1.3 E+00$ & $3.2 \mathrm{E}+04$ \\
\hline Bis (2-ethylhexyl)phthalate & $3.3 \mathrm{E}+01$ & $4.6 \mathrm{E}+00$ \\
\hline 2-Butanone & $3.9 \mathrm{E}-01$ & $4.6 \mathrm{E}+01$ \\
\hline Butylbenzylphthalate & $2.6 \mathrm{E}+00$ & $1.6 \mathrm{E}+03$ \\
\hline Carbazole & $5.4 \mathrm{E}-02$ & $3.2 E+00$ \\
\hline Carbon disulfide & $2.0 \mathrm{E}-01$ & $4.8 E-01$ \\
\hline Carbon tetrachloride & 8.0E-03 & $4.6 \mathrm{E}-02$ \\
\hline Chlordane (gamma) & $1.8 \mathrm{E}-02$ & $4.9 E-02$ \\
\hline 4-Chloro-3-methyphenol & $3.8 \mathrm{E}-02$ & - \\
\hline 4-Chloroaniline & $6.3 E+00$ & $3.2 \mathrm{E}+01$ \\
\hline Chloroform & $8,0 \mathrm{E}-02$ & $1,0 E-02$ \\
\hline $18 \% 8 \%$ & $4.3 \mathrm{E}+01$ & $8.8 E-03$ \\
\hline 4,4-DDD & $1.1 \mathrm{E}-01$ & 2.7E-01 \\
\hline 4,4-DDE & $1.7 \mathrm{E}-01$ & $1.9 \mathrm{E}-01$ \\
\hline Di-N-butylphthalate & $5.5 \mathrm{E}+00$ & $8.0 E+02$ \\
\hline Dibenzo $(a, h)$ anthracene & $1.7 \mathrm{E}+00$ & $8.8 \mathrm{E}-03$ \\
\hline Dibenzofuran & $5.0 \mathrm{E}-01$ & - \\
\hline 1,3-Dichlorobenzene & $4.8 \mathrm{E}-02$ & - \\
\hline
\end{tabular}


DOE/RL-93-99, Rev. 0

Table 5-5. Comparison of Maximum Soil Contaminant Concentrations to Risk-Based Screening Concentrations and ARARs. (Sheet 2 of 5)

\begin{tabular}{|c|c|c|}
\hline Contaminant & $\begin{array}{c}\text { Maximum } \\
\text { Contaminant } \\
\text { Concentration }\end{array}$ & $\begin{array}{c}\text { Minimum Risk- } \\
\text { Based } \\
\text { Concentration }\end{array}$ \\
\hline 1,4-Dichlorobenzene & $5.1 \mathrm{E}-02$ & $2.7 \mathrm{E}+00$ \\
\hline 1,2-Dichloroethene (total) & $1.0 \mathrm{E}+00$ & $7.2 \mathrm{E}+01$ \\
\hline Dieldrin & 2.1E-02 & 4.0E-03 \\
\hline Diethylphthalate & $1.0 \mathrm{E}+00$ & $6.4 E+03$ \\
\hline Ethyl benzene & $3.3 \mathrm{E}-01$ & $3.6 \mathrm{E}+02$ \\
\hline Fluoranthene & $2.9 \mathrm{E}+00$ & $3.2 \mathrm{E}+02$ \\
\hline Fluorene & $1.7 \mathrm{E}+00$ & $3.2 E+02$ \\
\hline Beta-HCH (Beta-BHC) & $7.8 \mathrm{E}-03$ & $3.6 \mathrm{E}-02$ \\
\hline 2-Hexanone & $9.0 \mathrm{E}-03$ & $4.6 \mathrm{E}+01$ \\
\hline Indeno $(1,2,3$-cd)pyrene & $1.6 \mathrm{~B}+00$ & $8.8 \mathrm{EO} 03$ \\
\hline Methoxychlor & $8.3 E-02$ & $4.0 \mathrm{E}+01$ \\
\hline 4-Methyl-2-pentanone & $1.1 \mathrm{E}-02$ & $3.2 \mathrm{E}+00$ \\
\hline Methylene chloride : & $4.5 \mathrm{E}+00$ & S.1E:01 \\
\hline 2-Methylnaphthalene & $1.3 \mathrm{E}+01$ & $3.2 \mathrm{E}+01$ \\
\hline 4-Methylphenol & $1.0 \mathrm{E}+00$ & - \\
\hline Naphthalene & $4.1 \mathrm{E}+00$ & $3.2 \mathrm{E}+01$ \\
\hline $\mathrm{N}$-Nitrosodiphenylamine & $1.8 \mathrm{E}+00$ & $1.3 \mathrm{E}+01$ \\
\hline Pentachlorophenol & $1.5 \mathrm{E}+00$ & $5.3 \mathrm{E} 01$ \\
\hline Phenanthrene & $3.9 E+00$ & $2.4 \mathrm{E}+02$ \\
\hline Phenol & $2.4 \mathrm{E}-01$ & $4.8 \mathrm{E}+03$ \\
\hline Pyrene & $1.2 \mathrm{E}+01$ & $2.4 \mathrm{E}+02$ \\
\hline 1,1,2,2-Tetrachloroethane & $3.0 \mathrm{E}-03$ & 4.1E-03 \\
\hline Tetrachloroethene & $1.1 \mathrm{E}+00$ & $1.2 \mathrm{E}+00$ \\
\hline Toluene & $1.5 \mathrm{E}-01$ & $3.5 \mathrm{E}+01$ \\
\hline 1,1,1-Trichloroethane & $6.0 \mathrm{E}-03$ & $4.8 E+01$ \\
\hline Trichloroethene & $3.9 \mathrm{E}-01$ & $1.6 \mathrm{E}-01$ \\
\hline Vinyl chloride & $2.4 \mathrm{E}-02$ & $1.6 \mathrm{E}-03$ \\
\hline Xylenes (total) & $1.1 \mathrm{E}+00$ & $1.6 \mathrm{E}+04$ \\
\hline
\end{tabular}


Table 5-5. Comparison of Maximum Soil Contaminant Concentrations to Risk-Based Screening Concentrations and ARARs. (Sheet 3 of 5)

\begin{tabular}{|c|c|c|}
\hline Contaminant & $\begin{array}{c}\text { Maximum } \\
\text { Contaminant } \\
\text { Concentration }\end{array}$ & $\begin{array}{l}\text { Minimum Risk- } \\
\text { Based } \\
\text { Concentration b }\end{array}$ \\
\hline Inorganic Constituents & $(\mathrm{mg} / \mathrm{kg})$ & $(\mathrm{mg} / \mathrm{kg})$ \\
\hline Aluminum & $7.8 \mathrm{E}+04$ & $8.0 \mathrm{E}+03$ \\
\hline Ammonia & $1.4 \mathrm{E}+02$ & $4.6 \mathrm{E}+00$ \\
\hline Antimony & $1.9 \mathrm{E}+01$ & $3.2 \mathrm{E}+00$ \\
\hline Arsente & $6.2 \mathrm{E}+01$ & $3.2 \mathrm{E}-02$ \\
\hline Barium & $4.3 E+03$ & $3.2 \mathrm{E}+02$ \\
\hline Beryilium & $4.7 E+00$ & $1.5 \mathrm{E}-02$ \\
\hline eadmium & $2.9 \mathrm{E}+0 \mathrm{I}$ & $2.5 \mathrm{E}+00$ \\
\hline Qhromium (total) & $2.5 \mathrm{E}+03$ & $8.0 \mathrm{E}+03^{\mathrm{C}} / 3.8 \mathrm{E}-01 \mathrm{~d}$ \\
\hline Qhromium (VI) & $5.0 \mathrm{E}+00$ & $3.8 \mathrm{E}-0 \mathrm{l}$ \\
\hline Cobalt & $9.0 \mathrm{E}+01$ & $4.8 \mathrm{E}+02$ \\
\hline Copper. & $9.5 \mathrm{E}+04$ & $32 \mathrm{E}+02$ \\
\hline Fluoride & $4.0 \mathrm{E}+01$ & $4.8 \mathrm{E}+02$ \\
\hline Eead & $75 \mathrm{E}+02$ & $500-1000^{e}$ \\
\hline Manganese & $3,1 \mathrm{E}+03$ & $3.5 \mathrm{E}+02$ \\
\hline Mercurs: & $37 \mathrm{7E}+01$ & $2.4 \mathrm{E}+00$ \\
\hline Nickel & $1.8 \mathrm{E}+03$ & $1.6 \mathrm{E}+02$ \\
\hline Nitrite (as N) & $2.9 \mathrm{E}+00$ & $8.0 \mathrm{E}+02$ \\
\hline Selenium & $1.1 \mathrm{E}+01$ & $4.0 \mathrm{E}+01$ \\
\hline Silver & $3.6 \mathrm{E}+02$ & $4.0 \mathrm{~B}+01$ \\
\hline Strontium & $3.1 \mathrm{E}+01$ & $4.8 \mathrm{E}+03$ \\
\hline Sulfate & $7.1 \mathrm{E}+03$ & - \\
\hline Thallium & $5.4 \mathrm{E}+00$ & $5.6 \mathrm{E} 01$ \\
\hline Yanadium & $3.9 \mathrm{E}+02$ & $5,6 \mathrm{E}+01$ \\
\hline Zinc & $6.2 \mathrm{E}+03$ & $2.4 \mathrm{E}+03$ \\
\hline Radionuclides & $(\mathrm{pCi} / \mathrm{g})$ & $(\mathrm{pCi} / \mathrm{g})$ \\
\hline Americium-241 & $3.4 \mathrm{E}+01$ & $2.8 \mathrm{E}-01$ \\
\hline Barium-140 & $4.0 \mathrm{E}+02$ & $7.8 \mathrm{E} 03$ \\
\hline Beryllium -7 & $9.0 \mathrm{E}+01$ & $2.8 \mathrm{E}-02$ \\
\hline Carbon-14. & $6,4 \mathrm{E}+02$ & $8.4 E+01$ \\
\hline
\end{tabular}


Table 5-5. Comparison of Maximum Soil Contaminant Concentrations to Risk-Based Screening Concentrations and ARARs. (Sheet 4 of 5)

\begin{tabular}{|c|c|c|}
\hline Contaminant & $\begin{array}{c}\text { Maximum } \\
\text { Contaminant } \\
\text { Concentration }\end{array}$ & $\begin{array}{l}\text { Minimum Risk } \\
\text { Based } \\
\text { Concentration }\end{array}$ \\
\hline Cerium-141 & $3.0 E+00$ & $3.2 E-02$ \\
\hline Cerium-144 & $5.0 \mathrm{~B}-01$ & $1.7 \mathrm{E}-01$ \\
\hline Cesium-134 & $5.6 \mathrm{E}+01$ & 8.1E-04 \\
\hline Cesium-137 & $1,1 E+05$ & 2. $1 \mathrm{E}-03$ \\
\hline Chromium 51 & $3.5 E+00$ & $4.6 \mathrm{E}-02$ \\
\hline cobalt-58 & $1,4 E+01$ & 1.3E-03 \\
\hline Cobalt-60 & $1 / 1 E+04$ & $4.9 \mathrm{E} 04$ \\
\hline Europium 152 & $2.9 \mathrm{E}+04$ & $1.2 \mathrm{E} 003$ \\
\hline Europium-154 & $9.2 \mathrm{E}+03$ & $1.0 \mathrm{E}-03$ \\
\hline Europium-155 & $9.6 \mathrm{E}+03$ & 7.1E-02 \\
\hline Tron -59 & $1.0 \mathrm{E}+\infty$ & $1.0 \mathrm{E}-03$ \\
\hline Manganese-54 & TOE 02 & $1,4 \mathrm{E} 03$ \\
\hline Nickel.63 & $6.2 \mathrm{E}+04$ & $32 \mathrm{E}+02$ \\
\hline Plutonium-238 & $1,4 \mathrm{E}+02$ & $2,3 \mathrm{E} 01$ \\
\hline Plutonium-239/240 & $28 \mathrm{E}+03$ & $2,4 \mathrm{E}-01$ \\
\hline Potassium 40 & $3.3 E+01$ & $7.8 \mathrm{E}-03$ \\
\hline Radium-226 & $4.3 \mathrm{E}+01$ & $70 \mathrm{E}-04$ \\
\hline Rurthenium-103 & $10 \mathrm{OE}+00$ & $2.8 \mathrm{E}-03$ \\
\hline Ruthenium-106 & 8.0E-01 & $8.0 \mathrm{E}+00$ \\
\hline Sodium-22 & $99 \mathrm{E}+00$ & $5.8 \mathrm{E}-04$ \\
\hline Strontium 90 & $2.0 \mathrm{E}+03$ & $2.1 \mathrm{E}+00$ \\
\hline Technetium-99 & $1.1 \mathrm{E}+\infty 0$ & $5.8 \mathrm{E}+01$ \\
\hline Thorium-228 & $1.7 \mathrm{E}+01$ & $7.5 \mathrm{E}-04$ \\
\hline Thorinm-232 & $3.5 \mathrm{E}+\infty$ & $3.3 \mathrm{E}-01$ \\
\hline Thorium-234 & $1.0 \mathrm{E}+00$ & $1.2 \mathrm{E}+00$ \\
\hline Tritium & $2.9 \mathrm{E}+04$ & $1.4 E+03$ \\
\hline Uranium (total) & $2.0 \mathrm{E}+04$ & $1.2 \mathrm{E}-01$ \\
\hline Uranium-233/234 & $2.1 \mathrm{E}+03$ & $3.4 \mathrm{E}-01$ \\
\hline Uranium-235 & $6.4 \mathrm{E}+02$ & $1.8 \mathrm{E}-02$ \\
\hline Uranium-238 & $9.1 \mathrm{E}+03$ & $1.2 \mathrm{E}-01$ \\
\hline
\end{tabular}


Table 5-5. Comparison of Maximum Soil Contaminant Concentrations to Risk-Based Screening Concentrations and ARARs. (Sheet 5 of 5)

\begin{tabular}{|c|c|c|}
\hline Contaminant & $\begin{array}{c}\text { Maximum } \\
\text { Contaminant } \\
\text { Concentration }\end{array}$ & $\begin{array}{c}\text { Minimum Risk- } \\
\text { Based } \\
\text { Concentration }\end{array}$ \\
\hline Zinc-65 & $3.0 \mathrm{E}-01$ & $2.1 \mathrm{E}-03$ \\
\hline Zirconium-95 & $5.6 \mathrm{E}-01$ & $1.7 \mathrm{E}-03$ \\
\hline
\end{tabular}

a From Tables 3-8, 3-9, and 3-10.

b From Tables 5-3 and 5-4.

c Screening value for chromium (III).

d Screening value for chromium (VI).

e No toxicity values are currently available, value shown is based on Interim Guidance on Establishing Soil Lead Cleanup Levels at Superfund Sites, EPA Office of Solid Waste and Emergency Response, Final, September 1989d.

- = quantitative toxicity values not currently available.

NT = contaminant considered non-toxic under typical environmental exposure conditions.

Note: Shading indicates contaminants for which the maximum concentration exceeds a risk-based screening concentration. 
DOE/RL-93-99, Rev. 0

Table 5-6. Risk-Based Screening Concentrations for Groundwater Pathways.

\begin{tabular}{|l|c|c|}
\hline \multirow{2}{*}{ Contaminant } & \multicolumn{2}{c|}{ Groundwater Ingestion } \\
\cline { 2 - 3 } & Noncarcinogen RBC & Carcinogen RBC \\
\hline Inorganic Constituents & $(\mathrm{mg} / \mathrm{L})$ & $(\mathrm{mg} / \mathrm{L})$ \\
\hline Antimony & $6.4 \mathrm{E}-04$ & \\
\hline Arsenic & $4.8 \mathrm{E}-04$ & $4.1 \mathrm{E}-06$ \\
\hline Chromium (VI) & $8.0 \mathrm{E}-03$ & \\
\hline Fluoride & $9.6 \mathrm{E}-02$ & \\
\hline Nitrite (as N) & $1.6 \mathrm{E}-01$ & \\
\hline Selenium & $8.0 \mathrm{E}-03$ & \\
\hline \multicolumn{1}{|c|}{ Radionuclides } & $\mathrm{NA}$ & $(\mathrm{pCi} / \mathrm{L})$ \\
\hline Carbon-14 & & $5.1 \mathrm{E}+00$ \\
\hline Technetium-99 & & $3.5 \mathrm{E}+00$ \\
\hline Uranium (total) & & $1.6 \mathrm{E}-01$ \\
\hline Uranium-233/234 & & $2.9 \mathrm{E}-01$ \\
\hline Uranium-235 & & $2.9 \mathrm{E}-01$ \\
\hline Uranium-238 & & $1.6 \mathrm{E}-01$ \\
\hline $\begin{array}{l}\text { Toxicity values used to calculate RBCs are provided in Table 5-1. } \\
\text { RBC = Risk-based screening concentration } \\
\text { NA = Not applicable } \\
\text { Minimum RBC for each contaminant is shaded. }\end{array}$ \\
\hline
\end{tabular}


DOE/RL-93-99, Rev. 0

Table 5-7. Comparison of Predicted Groundwater Contaminant Concentrations to Risk-Based Screening Concentrations and ARARs.

\begin{tabular}{|c|c|c|c|}
\hline Contaminant & $\begin{array}{c}\text { Predicted } \\
\text { Groundwater } \\
\text { Concentration }\end{array}$ & $\begin{array}{l}\text { Minimum Risk-Based } \\
\text { Concentration } b\end{array}$ & Minimum ARARc \\
\hline Inorganic Constituents & $(\mathrm{mg} / \mathrm{L})$ & $(\mathrm{mg} / \mathrm{L})$ & $(\mathrm{mg} / \mathrm{L})$ \\
\hline Antimony & $1.9 .9 \mathrm{E}+01 \%$ & $.8 .6 \mathrm{E}-04$ & $6.0 \mathrm{E}-03$ \\
\hline Qrosenic $/$, & $6.0 \mathrm{E}+0 \mathrm{t}$ & $1.8 .4 .1 \mathrm{EO} 06$ & $5.2 \mathrm{E}-05$ \\
\hline Carontum (UI) & $6.0 \mathrm{E}+0 \mathrm{l}$ & $8.8 .8 .0 \mathrm{E}-03$ & $1,8 \mathrm{E}-02$ \\
\hline Muoride & $6.0 \mathrm{E}+0 \mathrm{i} / 1 / 1$. & $9.6 \mathrm{E} .02$ & $9.6 \mathrm{E} 01$ \\
\hline Winite (as $\mathrm{N}$ ) & $6.1 \mathrm{~B}+00$ & $1.8 .11 .6 \mathrm{E}-01$. & $1.0 \mathrm{E}+00$ \\
\hline Selentum & $2.4 \mathrm{E}+01$ & $80 \mathrm{D} 03$ & $5.0 \mathrm{E}-02$. \\
\hline Radionuclides & $(\mathrm{pCi} / \mathrm{L})$ & $(\mathrm{pCi} / \mathrm{L})$ & $(\mathrm{pCi} / \mathrm{L})$ \\
\hline Carbon-14 $/ 1 / 1 / 1 / 1 /$. & $13 \mathrm{EE}+06$ & $5.16+00$ & $2.0 \mathrm{E}+03$ \\
\hline Technetium $99:=8$ & $2.3 E+03$ & $3.51+00$ & $9.08+02$ \\
\hline Uraninm (totai) & $11 \mathrm{E}+03$ & $1.6 \mathrm{E} 01 \%$ & $20, g_{11} .:$ \\
\hline Mrantum 2331234 m, & $5,3 \mathrm{E}+02$ & $2.9 \mathrm{E} 01$ & $17.1 .3 .0 \mathrm{E}: 102$ \\
\hline Mranhum 235 / & $23 \mathrm{E}+01$ & $29 \mathrm{E} .01$ & $3.0 \mathrm{E}+02$ \\
\hline Uranium 238 . & $1.1 .49 \mathrm{E}+02$ & $1.6 \mathrm{E} 01 \%$ & $3.02+022 .:$ \\
\hline \multicolumn{4}{|c|}{$\begin{array}{l}\text { aFrom Table 4-11. } \\
\text { bFrom Table 5-6. } \\
\text { cFrom Tables } 7-3 \text { and } 7-4 \text {. } \\
-=\text { quantitative toxicity values not currently available. } \\
\text { Note: Shading indicates contaminants for which the predicted groundwater concentration } \\
\text { exceeds a risk-based screening concentration and/or ARAR. }\end{array}$} \\
\hline
\end{tabular}


DOE/RL-93-99, Rev. 0

Table 5-8. Contaminants of Potential Concern in Soils. (Sheet 1 of 3)

\begin{tabular}{|l|c|}
\hline \multicolumn{1}{|c|}{ Contaminant } & $\begin{array}{c}\text { Maximum Contaminant } \\
\text { Concentration }\end{array}$ \\
\hline Organic Compounds & $(\mathrm{mg} / \mathrm{kg})$ \\
\hline Aroclor-1248 & $1.0 \mathrm{E}+01$ \\
\hline Aroclor-1254 & $6.4 \mathrm{E}+00$ \\
\hline Aroclor-1260 & $2.3 \mathrm{E}+00$ \\
\hline Benzo(a)anthracene & $1.8 \mathrm{E}+00$ \\
\hline Benzene & $1.9 \mathrm{E}-01$ \\
\hline Benzo(a)pyrene & $2.7 \mathrm{E}+01$ \\
\hline Benzo(b)fluoranthene & $2.4 \mathrm{E}+00$ \\
\hline Benzo(k)fluoranthene & $7.6 \mathrm{E}-01$ \\
\hline Bis(2-ethylhexyl)phthalate & $3.3 \mathrm{E}+01$ \\
\hline Chloroform & $8.0 \mathrm{E}-02$ \\
\hline Chrysene & $4.3 \mathrm{E}+01$ \\
\hline Dibenzo(a,h)anthracene & $1.7 \mathrm{E}+00$ \\
\hline Dieldrin & $2.1 \mathrm{E}-02$ \\
\hline Indeno(1,2,3-cd)pyrene & $1.6 \mathrm{E}+00$ \\
\hline Methylene chloride & $4.5 \mathrm{E}+00$ \\
\hline Pentachlorophenol & $1.5 \mathrm{E}+00$ \\
\hline Trichloroethene & $3.9 \mathrm{E}-01$ \\
\hline Vinyl chloride & $2.4 \mathrm{E}-02$ \\
\hline Inorganic Constituents & $(\mathrm{mg} / \mathrm{kg})$ \\
\hline Aluminum & $7.8 \mathrm{E}+04$ \\
\hline Ammonia & $1.4 \mathrm{E}+02$ \\
\hline Antimony & $1.9 \mathrm{E}+01$ \\
\hline Arsenic & $6.2 \mathrm{E}+01$ \\
\hline Barium & $4.3 \mathrm{E}+03$ \\
\hline Beryllium & $4.7 \mathrm{E}+00$ \\
\hline Cadmium & $2.9 \mathrm{E}+01$ \\
\hline Chromium & $2.5 \mathrm{E}+03$ \\
\hline Copper & $9.5 \mathrm{E}+04$ \\
\hline Lead & \\
\hline
\end{tabular}


Table 5-8. Contaminants of Potential Concern in Soils. (Sheet 2 of 3)

\begin{tabular}{|l|c|}
\hline \multicolumn{1}{|c|}{ Contaminant } & $\begin{array}{c}\text { Maximum Contaminant } \\
\text { Concentration }\end{array}$ \\
\hline Manganese & $3.1 \mathrm{E}+03$ \\
\hline Mercury & $3.7 \mathrm{E}+01$ \\
\hline Nickel & $1.8 \mathrm{E}+03$ \\
\hline Silver & $3.6 \mathrm{E}+02$ \\
\hline Thallium & $5.4 \mathrm{E}+00$ \\
\hline Vanadium & $3.9 \mathrm{E}+02$ \\
\hline Zinc & $6.2 \mathrm{E}+03$ \\
\hline \multicolumn{1}{|c|}{ Radionuclides } & $(\mathrm{pCi} / \mathrm{g})$ \\
\hline Americium-241 & $3.4 \mathrm{E}+01$ \\
\hline Barium-140 & $4.0 \mathrm{E}+02$ \\
\hline Beryllium-7 & $9.0 \mathrm{E}+01$ \\
\hline Carbon-14 & $6.4 \mathrm{E}+02$ \\
\hline Cerium-141 & $3.0 \mathrm{E}+00$ \\
\hline Cerium-144 & $5.0 \mathrm{E}-01$ \\
\hline Cesium-134 & $5.6 \mathrm{E}+01$ \\
\hline Cesium-137 & $1.1 \mathrm{E}+05$ \\
\hline Chromium-51 & $3.5 \mathrm{E}+00$ \\
\hline Cobalt-58 & $1.4 \mathrm{E}+01$ \\
\hline Cobalt-60 & $1.1 \mathrm{E}+04$ \\
\hline Europium-152 & $2.9 \mathrm{E}+04$ \\
\hline Europium-154 & $9.2 \mathrm{E}+03$ \\
\hline Europium-155 & $9.6 \mathrm{E}+03$ \\
\hline Iron-59 & $1.0 \mathrm{E}+00$ \\
\hline Manganese-54 & $7.0 \mathrm{E}-02$ \\
\hline Nickel-63 & $6.2 \mathrm{E}+04$ \\
\hline Plutonium-238 & $1.4 \mathrm{E}+02$ \\
\hline Plutonium-239/240 & $2.8 \mathrm{E}+03$ \\
\hline Radium-226 & \\
\hline Ruthenium-103 & \\
\hline
\end{tabular}


DOE/RL-93-99, Rev. 0

Table 5-8. Contaminants of Potential Concern in Soils. (Sheet 3 of 3)

\begin{tabular}{|l|c|}
\hline \multicolumn{1}{|c|}{ Contaminant } & $\begin{array}{c}\text { Maximum Contaminant } \\
\text { Concentration }^{\mathrm{a}}\end{array}$ \\
\hline Sodium-22 & $9.9 \mathrm{E}+00$ \\
\hline Strontium-90 & $2.0 \mathrm{E}+03$ \\
\hline Thorium-228 & $1.7 \mathrm{E}+01$ \\
\hline Thorium-232 & $3.5 \mathrm{E}+00$ \\
\hline Tritium & $2.9 \mathrm{E}+04$ \\
\hline Uranium (total) & $2.0 \mathrm{E}+04$ \\
\hline Zinc-65 & $3.0 \mathrm{E}-01$ \\
\hline Zirconium-95 & $5.6 \mathrm{E}-01$ \\
\hline aFrom Tables 3-8, 3-9, and 3-10. \\
\hline
\end{tabular}


DOE/RL-93-99, Rev. 0

Table 5-9. Contaminants of Potential Concern in Groundwater.

\begin{tabular}{|l|c|}
\hline \multicolumn{1}{|c|}{ Contaminant } & \multicolumn{1}{|c|}{$\begin{array}{c}\text { Predicted } \\
\text { Groundwater } \\
\text { Concentration }\end{array}$} \\
\hline Inorganic Constituents & $(\mathrm{mg} / \mathrm{L})$ \\
\hline Antimony & $3.9 \mathrm{E}+01$ \\
\hline Arsenic & $6.0 \mathrm{E}+01$ \\
\hline Chromium $(\mathrm{VI})$ & $6.0 \mathrm{E}+01$ \\
\hline Fluoride & $6.0 \mathrm{E}+01$ \\
\hline Nitrite (as $\mathrm{N})$ & $6.1 \mathrm{E}+00$ \\
\hline Selenium & $2.4 \mathrm{E}+01$ \\
\hline \multicolumn{1}{|c|}{ Radionuclides } & $(\mathrm{pC} / \mathrm{L})$ \\
\hline Carbon-14 & $1.3 \mathrm{E}+06$ \\
\hline Technetium-99 & $2.3 \mathrm{E}+03$ \\
\hline Uranium (total) & $1.1 \mathrm{E}+03$ \\
\hline aFrom Table 4-11. & \\
\hline
\end{tabular}




\subsection{RISK ASSESSMENT}

The risk assessment presented below evaluates potential adverse effects that could be associated with contaminants that may be disposed of in the ERDF. Only those risks that could potentially occur following completion of the ERDF (i.e., long-term risks) are evaluated in this chapter. Worker and public risk associated with construction and operation of the ERDF is discussed in Chapter 9. The primary focus in this chapter is risk associated with the "base conditions" scenario, that is, a reasonable worst case scenario. The base conditions scenario utilizes the following assumptions:

- The waste is characterized by the maximum concentrations detected in 100,200 , and 300 Area waste units that may generate remediation waste for placement at the ERDF;

- The waste is untreated;

- The ERDF is an unlined trench and the infiltration rate through the waste is a conservatively high $0.5 \mathrm{~cm} / \mathrm{yr}$;

- The cover does not prevent inadvertent exposure to contaminants.

This set of "base conditions" does not incorporate any of the protective features of the design alternatives. Therefore, the risks presented in this chapter are not actual risks that any receptor population would experience. The results of the evaluation presented in this chapter are used to identify adequate design alternatives. In addition, the toxicity and exposure information presented in this chapter is further used to evaluate the remedial alternatives (see Appendix A and Chapter 9) and define acceptable soil and leachate concentration limits for waste placed in the ERDF (See Appendix C).

Figure 6-1 outlines the organization of this chapter. Human exposure to groundwater under base conditions is evaluated in Section 6.1. (Human exposure to groundwater given conditions associated with each of the remedial alternatives is evaluated in Appendix A and summarized in Chapter 9). Inadvertent intrusion and exposure of human and other ecological receptors to contaminated soils under base conditions are evaluated in Section 6.2. The information presented in Section 6.2 is expanded Section 6.3 to provide an evaluation of the inadvertent intrusion scenario for the remedial alternatives. Because all the alternatives (except

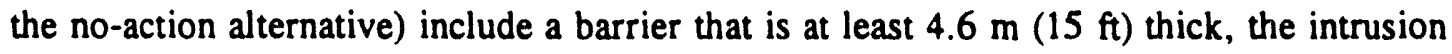
scenario for the remedial alternatives assumes contact with the waste occurs due to drilling through the waste 500 years after closure of the ERDF.

\subsection{HUMAN HEALTH EVALUATION OF GROUNDWATER EXPOSURE}

Infiltration and leaching of contaminants from the ERDF to groundwater would be expected to occur if the ERDF were an unlined trench without a low-infiltration surface barrier. Exposure to groundwater contaminants would occur if a person installed a groundwater well and used groundwater without testing for contamination. For this evaluation, exposure to contaminated groundwater is only evaluated for human receptors; use of contaminated groundwater for crops or livestock is assumed not to occur. 


\subsubsection{Human Exposure Assessment}

6.1.1.1 Conceptual Model. In accordance with the Tri-Party Agreement negotiations (Ecology et al. 1993), this risk assessment evaluates exposure to groundwater via a well installed at the edge of the ERDF. All contaminants are evaluated for 10,000 yr. Groundwater COPC are identified and discussed in Chapter 5.0, and are listed in Table 5-9. Groundwater concentrations used to characterize these contaminants are based on maximum detected soil concentrations.

Human use of groundwater is assumed to be for residential purposes. Exposure pathways are those stipulated in HSBRAM (DOE-RL 1993j) for evaluation of in-home groundwater use. These pathways are groundwater ingestion, and dermal absorption while showering. Dermal absorption is evaluated only for non-radioactive contaminants. Dermal uptake is generally not an important route of uptake for radionuclides, which have small skin permeability coefficients (EPA 1989a). External exposure to radionuclides due to immersion in water is not evaluated because of the short durations of exposure. None of the groundwater COPC are volatile, so a volatile inhalation pathway is not evaluated.

All exposures are evaluated assuming residential exposure parameter values specified in HSBRAM (DOE-RL 1993j). Use of a residential scenario is only appropriate if institutional controls are lost. Institutional controls are assumed to be lost $100 \mathrm{yr}$ after the ERDF begins receiving remediation waste in 1996 (Ecology et al. 1993). The first contaminant is estimated to reach groundwater in 520 years (see Table 4-11). Therefore, institutional controls are assumed not to prevent exposure to groundwater contaminants in the future.

6.1.1.2 Quantification of Human Exposures. The exposure assessment provides quantitative exposure factors for the pathways that have been identified for the receptor population. An exposure point concentration (i.e., a contaminant concentration to which a receptor is subjected over the exposure period) is combined with exposure parameters (e.g., contact rate, body weight, and exposure frequency) to determine intake. Exposure point concentrations are predicted groundwater concentrations based on maximum detected soil concentrations (see Chapter 4). The following sections describe the assumptions and calculations used to quantify exposure intakes for the residential receptor population.

6.1.1.2.1 Intake Equations. Standard EPA equations, as provided in Risk Assessment Guidance for Superfund (RAGS) (EPA 1989a) and HSBRAM (DOE-RL 1993j), are used as the basis for all intake calculations. Intakes of non-radioactive and radioactive contaminants are calculated and presented separately.

Non-Radioactive Contaminants. The basic equation for calculating intakes of non-radioactive contaminants via groundwater ingestion is:

$$
\text { Intake }=\frac{C \times I R \times E F \times E D}{B W \times A T}
$$

where:

Intake $=\quad$ chronic daily intake of the contaminant $(\mathrm{mg} / \mathrm{kg}-\mathrm{d})$

$\mathrm{C}=$ contaminant concentration in the medium $(\mathrm{mg} / \mathrm{L})$ 


$$
\begin{array}{lll}
\mathrm{IR} & =\text { contact rate }(\mathrm{L} / \mathrm{d}) \\
\mathrm{EF} & =\text { exposure frequency }(\mathrm{d} / \mathrm{yr}) \\
\mathrm{ED} & =\text { exposure duration }(\mathrm{yr}) \\
\mathrm{BW} & =\text { body weight }(\mathrm{kg}) \\
\mathrm{AT} & =\text { averaging time }(\mathrm{yr} \times 365 \mathrm{~d} / \mathrm{yr})
\end{array}
$$

Intake equation 6-1 may be used to calculate the absorbed dose resulting from dermal exposure to contaminated groundwater. In this case, the calculated value is an absorbed dose (i.e., the amount entering the bloodstream). Although it uses the same units, this is different from the intake calculated using equation 6-1, which is the amount ingested (i.e., an administered dose). To calculate the absorbed dose resulting from dermal exposure to contaminated groundwater, the contact rate is determined as follows:

$$
I R_{\text {derm }}=S A \times K_{p} \times E T \times C F
$$

where:

$$
\begin{array}{lll}
\mathrm{IR}_{\mathrm{derm}} & = & \text { groundwater/dermal exposure contact rate }(\mathrm{L} / \mathrm{d}) \\
\mathrm{SA} & \text { skin surface area available for contact }\left(\mathrm{cm}^{2}\right) \\
\mathrm{K}_{\mathrm{p}} & = & \text { chemical-specific permeability coefficient }(\mathrm{cm} / \mathrm{hr}) \\
\mathrm{ET} & =\text { event time }(\mathrm{hr} / \mathrm{d}) \\
\mathrm{CF} & =\text { conversion factor }\left(1 \mathrm{~L} / 1000 \mathrm{~cm}^{3}\right)
\end{array}
$$

The dermal exposure contact rate is inserted into Equation 6-1 to yield the intake value for the dermal pathway. See Section 6.1.1.2.2 for a description of the chemical-specific permeability coefficients $\left(\mathrm{K}_{\mathrm{p}}\right)$ used in this evaluation.

Radioactive Contaminants. The quantification of exposures to radioactive contaminants requires a separate treatment. The units used to express environmental concentrations of radioactive and non-radioactive contaminants are different. Unlike non-radioactive contaminants, intake estimates for radionuclides should not be divided by body weight or averaging time. Instead, the calculated intakes represent radionuclide activity ingested over the exposure duration. ingestion is:

The basic equation for calculating intakes of radioactive contaminants via groundwater

$$
\text { Intake }=C \times \text { IR } \times E F \times E D
$$

where:

$$
\begin{array}{lll}
\text { Intake } & = & \text { radionuclide-specific lifetime intake }(\mathrm{pCi}) \\
\mathrm{C} & = & \text { radionuclide concentration in the medium }(\mathrm{pC}: / \mathrm{L}) \\
\mathrm{IR} & = & \text { contact rate }(\mathrm{L} / \mathrm{d}) \\
\mathrm{EF} & = & \text { exposure frequency }(\mathrm{d} / \mathrm{yr}) \\
\mathrm{ED} & = & \text { exposure duration }(\mathrm{yr})
\end{array}
$$


6.1.1.2.2 Calculation of Contaminant Intakes. All exposure parameters (e.g., body weight, averaging time, contact rate, exposure frequency, and exposure duration) presented below are those recommended by HSBRAM (DOE-RL 1993j). These exposure parameters have been specifically developed for a residential population, and are used to evaluate the groundwater ingestion and dermal exposure pathways. Exposure parameters for the noncarcinogenic, carcinogenic (non-radioactive), and radioactive contaminants are summarized in Tables 6-1, 6-2, and 6-3, respectively.

Contaminant intakes are calculated by combining exposure parameters presented in Tables 6-1 through 6-3 and intake Equations 6-1 and 6-3. Example calculations of this process are provided in Appendix D of the Hanford Site Risk Assessment Methodology (HSRAM, Rev. 3) (DOE-RL 1994c).

It is noted that the exposure factors listed in Tables 6-1 through 6-3 can be combined to provide a single numeric value called a summary intake factor. The summary intake factor is specific for each exposure pathway, exposure scenario, and class of contaminant. The only parameter from Equations 6-1 through 6-3 that is not included in the summary intake factor is the contaminant concentration, such that the intake equations can be rewritten as follows:

$$
\text { Intake }=\mathrm{C} \times \text { Summary Intake Factor }
$$

where:

$$
\begin{array}{lll}
\text { Intake }= & \text { contaminant intake }[\mathrm{mg} / \mathrm{kg}-\mathrm{d} \text { (non-radioactive) or } \mathrm{pCi} \text { (radioactive) }] \\
\mathrm{C}= & \text { contaminant groundwater concentration }[\mathrm{mg} / \mathrm{L} \text { (non-radioactive) or } \\
& \mathrm{pCi} / \mathrm{L} \text { (radioactive) }]
\end{array}
$$

Associated summary intake factors have units of $\mathrm{L} / \mathrm{kg}-\mathrm{d}$ (non-radioactive) or $\mathrm{L}$ (radioactive). Summary intake factors for each of the exposure scenarios are provided in Table 6-4. These are multiplied by groundwater concentrations provided in Table 5-9 to provide intake values. Intake values for groundwater ingestion and dermal exposure pathways are provided in Tables 6-5 and 6-6, respectively.

Summary intake factors for dermal exposure require the use of constituent-specific permeability coefficients, $K_{p}$. Permeability coefficients are provided in EPA (1992b). However, $\mathrm{K}_{\mathrm{p}}$ values have not been developed for all constituents. The EPA report indicates that the inorganic contaminants listed in Table $6-6$ can all be characterized by the same $K_{p}\left(1 \times 10^{-3}\right.$ $\mathrm{cm} / \mathrm{hr}$ ).

\subsubsection{Human Health Toxicity Assessment}

The purpose of the toxicity assessment is to identify the potential adverse effects associated with exposure to site-related contaminants and to evaluate, using numerical toxicity values, the likelihood that these adverse effects may occur. The toxicity assessment for this risk assessment is conducted in accordance with RAGS (EPA 1989a) and HSBRAM (DOE-RL 1993j). 
Toxicity information on chemicals and radionuclides is available in the on-line database, Integrated Risk Information System (IRIS, EPA 1993a), Health Effects Assessment Summary Tables (HEAST, EPA 1993b), the Agency for Toxic Substances Disease Registry (ATSDR) Toxicological Profiles, and the scientific literature. Toxicological profiles for the contaminants of potential concern for the ERDF are presented in appendices of operable unit-specific remedial investigation reports (e.g., DOE-RL 1993e,f,g).

6.1.2.1 Toxicity Information for Noncarcinogenic Effects. Systemic toxic effects other than cancer can be associated with exposures to both chemicals and radionuclides. The RfD is the toxicity value which is used to evaluate the noncarcinogenic effects resulting from exposure to toxic chemicals. The $\mathrm{RfD}$ has been developed on the premise that protective mechanisms exist that must be overcome before an appreciable risk of adverse health effects is manifested during a defined exposure period. That is, there is a threshold dose which must be exceeded before adverse effects can occur. The RfD is developed for a specific duration of exposure (e.g., subchronic and chronic exposures), and the route of exposure (i.e., inhalation and ingestion).

Chronic exposure is defined in RAGS (EPA 1989a) as a repeated or prolonged exposure (i.e., from seven years to a lifetime). The chronic RfD is a daily exposure level that is likely to be without an appreciable risk of deleterious effects from lifetime exposure to the general population, including sensitive subpopulations. For purposes of this risk assessment, the chronic RfD is utilized to evaluate noncarcinogenic effects that may be associated with potential exposure to the chemicals of potential concern at this site.

Carcinogens may also have systemic effects other than cancer. Carcinogens are also evaluated for potential noncarcinogenic toxic effects and are included in the determination of chronic toxicity hazard indices which characterize noncancer hazards. Carcinogenic effects, however, are usually manifested at levels that are significantly lower than those associated with systemic toxic effects; thus, cancer is usually the predominant adverse effect for contaminants that elicit carcinogenic as well as noncarcinogenic responses. Exposure to radionuclides need not consider acute toxicity effects because the quantities of radionuclides required to cause adverse effects from acute exposure are extremely large, and such levels will not be encountered via groundwater exposure.

Two chronic toxicity parameters that are used in establishing RfDs are the lowestobserved-adverse-effect levels (LOAELs) and the no-observed-adverse-effect levels (NOAELs). The LOAEL may be defined as the lowest exposure level at which there is a demonstrated statistically and/or biologically significant increase in adverse effects between the exposed animal population and the control group in a toxicological study. The NOAEL is the exposure level at which there are no demonstrated adverse effects in a dose-response toxicity study. Uncertainty factors in multiples of 10 may be further applied to the reported NOAELs or LOAELs in order to adjust for data limitations, and for differences between experimental animal exposure conditions and human exposures (National Academy of Science 1977). These factors are intended to account for inherent variability in human responses to chemical agents, and for general imprecision in extrapolating from laboratory animals to humans.

Table 6-7 summarizes the noncarcinogenic toxicity values (i.e., RfDs) for the groundwater contaminants of potential concern. Also presented in this table are the corresponding critical effects, confidence level in the RfD, and the uncertainty and modifying factors used in the development of each RfD. 
6.1.2.2 Toxicity Information for Carcinogenic Effects. Potential human carcinogenic effects are evaluated using contaminant-specific SFs and the weight-of-evidence classification of the EPA. The weight-of-evidence classification is a qualitative description of the probability of cancer occurrence in humans, based on the strength of human epidemiological and/or animal study data. This system, originally developed by the International Agency for Research on Cancer (IARC), has been slightly modified by the EPA (1986). Carcinogens are classified by the EPA according to the following weight-of-evidence categories:

- Group A - Human Carcinogen

There is sufficient evidence from epidemiological studies that substantiates a causal association between exposure and carcinogenicity in humans.

- Group B1 - Probable Human Carcinogen There is limited evidence of carcinogenicity in humans from available epidemiological data.

- Group B2 - Probable Human Carcinogen

There is sufficient evidence of carcinogenicity in animals, but inadequate or no evidence in humans.

- $\quad$ Group C - Possible Human Carcinogen

There is limited evidence of carcinogenicity in animals.

- Group D - Not Classifiable as to Human Carcinogenicity

The evidence for carcinogenicity in animals and humans is inadequate to support classification.

- Group E - Human Noncarcinogen

There is evidence of noncarcinogenicity in humans.

6.1.2.2.1 Non-Radioactive Substances. The SF is the toxicity value that quantitatively defines the dose-response relationship of a known or suspected carcinogen. The SF is an estimate of an upperbound lifetime probability of an individual developing cancer due to chronic exposure to a potential cancer causing agent. In this evaluation, arsenic is the only nonradioactive COPC, for which EPA assigns a unit risk of $5 \times 10^{-5}(\mu \mathrm{g} / \mathrm{L})^{-1}$. This unit risk can be converted into a slope factor $\left[2(\mathrm{mg} / \mathrm{kg}-\mathrm{d})^{-1}\right]$ by dividing by an ingestion rate of $2 \mathrm{~L} / \mathrm{d}$, and multiplying by a body weight of $70 \mathrm{~kg}$ and the appropriate conversion factor $\left(10^{3} \mu \mathrm{g} / \mathrm{mg}\right)$. The unit risk for arsenic is based on a maximum likelihood estimate (not a $95 \%$ upper confidence limit) and the use of an absolute-risk linear dose extrapolation model. The Carcinogen Assessment Group of the EPA has developed SFs for carcinogens based on the premise that there is no threshold or level of exposure below which carcinogenic effects will not be elicited.

Table 6-8 presents the carcinogenicity weight-of-evidence classifications and the SFs for the ingestion exposure route for non-radioactive contaminants of potential concern. Group D and $\mathrm{E}$ contaminants are not considered carcinogenic, and are not included in this table.

6.1 2.2.2 Radioactive Substances. Cancer induction is the only health effect being evaluated resulting from exposure to environmental radioactive contamination. Systemic toxic effects occur only following relatively high doses of radiation that are not typical of 
environmental exposure. Uranium is known to cause toxic effects that are associated with its chemical (not radiological) characteristics. The proposed MCL for uranium ( $30 \mathrm{pCi} / \mathrm{L}$ ) is based on the chemical effects of uranium. This concentration is noted as an ARAR in Table 7-3. According to EPA (56 FR 33050), this proposed MCL is associated with an ICR of $2 \times 10^{-5}$ (assuming an ingestion rate of $2 \mathrm{~L} / \mathrm{d}$ for $70 \mathrm{yr}$ ). However, while nephrotoxic effects are a threshold response, cancer induction is assumed to have no threshold. For this reason, the potential for cancer induction remains a concern (with a risk greater than $1 \times 10^{-6}$ ) even when the threat of nephrotoxic effects is negligible. Therefore, carcinogenic potential of uranium is considered the primary health effect of concern because carcinogenesis remains a concern at concentrations that are below the threshold for toxic effects of uranium.

Chemical toxicity associated with other radionuclides is not a concern because it is far outweighed by the estimated radiological hazards. The mass of most radionuclides associated with high radiogenic cancer risk levels are so exceedingly small that they are unlikely to pose a chemical hazard. For example, the total activity of strontium- 90 associated with a $1 \times 10^{4}$ cancer risk (from ionizing radiation) via residential scenario soil ingestion is approximately $3 \mu \mathrm{Ci}$. This is the equivalent of $2 \times 10^{-8} \mathrm{~g}$ of strontium-90. In terms of chemical hazard, this mass of strontium is associated with a hazard quotient of $3 \times 10^{-10}$.

Currently, the EPA classifies all radionuclides as Group A (human) carcinogens due to their property of emitting ionizing radiation. Other low dose and low dose rate effects (such as mutagenesis, teratogenesis, and life shortening) have a quantifiable probability of occurrence, but the risk of cancer appears to be the limiting health effect (EPA 1989b). The SFs for radionuclides are individually determined by the EPA, based on the unique chemical, metabolic, and radiological properties of each radionuclide.

Many radionuclides have radioactive daughters that are expected to be in equilibrium with their respective parent. For this risk assessment, the radionuclides evaluated in this report account for the contribution of these daughter products, using the techniques provided in HEAST (EPA 1993b). Daughter products in general have different chemical properties than their parent nuclides, and are not always expected to be in equilibrium as they migrate through environmental media. In this evaluation, the only radioactive contaminants of potential concern with radioactive daughter products are isotopes of uranium. Most of the radioactive daughters accounted for in the " $+D$ " slope factors for uranium have half-lives less than 1 day (maximum half-life is 24 days), such that the assumption of equilibrium does not contribute to an overestimate of risk.

Radionuclide SFs represent best estimates (i.e., median or $50 \%$ confidence limit values) of excess cancer risk in a population per unit intake or exposure during a 70 -year lifetime. As with non-radioactive carcinogens, a non-threshold dose is assumed in the evaluation of carcinogenesis related to potential exposure to radionuclides.

Table 6-8 summarizes the carcinogenicity weight-of-evidence classification and the SFs for the ingestion exposure pathway for radioactive groundwater contaminants of potential concern.

6.1.2.3 Adjustment of Toxicity Factors. There are currently no toxicity values specifically developed for evaluating dermal exposures. As a result, current risk assessment guidance suggests deriving dermal toxicity values from oral toxicity values. This results in significant uncertainty (see Section 6.1.4.4). For the purpose of this risk assessment, oral RfDs and SFs 
are adjusted in accordance with RAGS (EPA 1989a). Oral toxicity values are generally appropriate for evaluating administered doses (i.e., intake-based). However, dermal intake calculations (see Section 6.1.1.2.1) provide absorbed doses. Therefore, oral toxicity values are adjusted (from administration-basis to absorbed-basis) by accounting for the oral absorption fraction of each contaminant. The oral, or gastrointestinal (GI), absorption fraction is the fraction of an orally administered dose that crosses from the GI tract into the bloodstream. This adjustment is made only for non-radioactive contaminants. Dermal exposure to radionuclides is not evaluated due to their small skin permeability coefficients (EPA 1989a).

Toxicokinetic information from the available literature is generally used to determine the extent of GI absorption for non-radioactive contaminants of potential concern. An appropriate GI absorption fraction (expressed as fraction absorbed) is identified, and the factor is applied to the RfD and/or SF to determine the corresponding dermally adjusted toxicity value. Oral RfD values are adjusted by multiplying by the GI absorption fraction, while SF values are adjusted by dividing by the GI absorption fraction.

In the case of inorganic compounds, the available information in the literature suggests that GI absorption efficiencies for these chemicals are typically in the range of $1 \%$ to $10 \%$. Gastrointestinal absorption is likely to be affected by such factors as chemical form, physical state of the compound (e.g., solid or solution), particle size, dosing regimen, age, and diet. In general, the degree of absorption in humans is independent of the exposure level.

Table 6-9 presents the dermally adjusted RfDs and SFs for contaminants of potential concern, including the corresponding GI absorption fractions.

\subsubsection{Human Health Risk Characterization}

The information from the exposure assessment and the toxicity assessment is integrated to form the basis for the characterization of risks and human health hazards. The risk characterization presents quantitative and qualitative descriptions of risk.

6.1.3.1 Quantification of Noncarcinogenic Effects. Potential human health hazards associated with exposure to noncarcinogenic substances, or carcinogenic substances with systemic toxicities, are evaluated separately from carcinogenic risks. The daily intake over a specified time period (e.g., lifetime or some shorter time period) is compared with an RfD for a similar time period (e.g., chronic RfD or subchronic $\mathrm{RfD}$ ) to determine a ratio called the hazard quotient (HQ). Estimates of intakes for this risk assessment are based on chronic exposures. The nature of the contaminant source precludes short-term fluctuations in contaminant concentrations that might produce acute or subchronic effects. The formula used to estimate the $\mathrm{HQ}$ is:

$$
\mathrm{HQ}=\frac{\text { Intake }}{\operatorname{RfD}}
$$


where:

$$
\begin{array}{lll}
\mathrm{HQ} & =\text { hazard quotient } \\
\text { Intake }= & \text { contaminant chronic daily intake }(\mathrm{mg} / \mathrm{kg}-\mathrm{d}) \\
\mathrm{RfD}= & \text { chronic reference dose }(\mathrm{mg} / \mathrm{kg}-\mathrm{d})
\end{array}
$$

If the HQ exceeds unity, the possibility exists for systemic toxic effects and the contaminant is considered a contaminant of concern (COC). The HQ is not a mathematical prediction of the severity or incidence of the effects, but rather is an indication that adverse effects may occur, especially in sensitive subpopulations. It should be noted that due to the conservative bias in the analysis (see Section 6.1.4) a HQ greater than 1 may not result in systemic toxic effects.

Table 6-7 lists the contaminants of potential concern that are evaluated for systemic toxicity. Only ingestion RfDs are presented; an inhalation pathway is not evaluated because none of the COPC are volatile. Dermal RfDs are presented in Table 6-9.

Hazard quotients for the groundwater ingestion and dermal exposure pathways are presented in Tables 6-5 and 6-6, respectively. These tables indicate that the largest HQ is $1 \times 10^{4}$, which is associated with ingestion of arsenic.

The hazard quotients for the ingestion and dermal pathways may be added to provide a total HQ for each inorganic contaminant. These values are presented in Table 6-10. All six inorganic constituents (antimony, arsenic, chromium VI, fluoride, nitrite, and selenium) have hazard quotients greater than 1 . These contaminants are considered contaminants of concern, and are used in the evaluation of ERDF design alternatives.

The HQs may be added together to provide a hazard index (HI) for all of the systemic toxins. However, it is only appropriate to add HQs for contaminants that produce similar adverse effects because the effects associated with such contaminants are assumed to be additive. In contrast, it is not appropriate to add the HQs for contaminants with different effects. For example, the HQs for arsenic and antimony should not be added together because the critical effect for arsenic is hyperpigmentation (i.e., blackfoot disease), while the critical effect for antimony is reduced lifespan and disturbances in glucose and cholesterol metabolism. Based on the critical effects presented in Table 6-7, none of the HQs should be added together. Instead, each HQ (presented in Table 6-10) should be examined separately.

6.1.3.2 Quantification of Carcinogenic Risk. For carcinogens, risks are estimates of the likelihood of an individual developing cancer over a lifetime [i.e., lifetime incremental cancer risk (ICR)] as a result of exposure to a potential carcinogen. The SF converts an intake value, as derived in the exposure assessment, to the estimated lifetime incremental risk of an individual developing cancer. The equation used to estimate cancer risk is:

$$
\mathrm{ICR}=\text { Intake } \times \mathrm{SF}
$$

where:
ICR = lifetime incremental cancer risk
Intake $=$ contaminant intake $[\mathrm{mg} / \mathrm{kg}-\mathrm{d}$ (non-radioactive) or $\mathrm{pCi}$ (radioactive)] 


$$
\left.\mathrm{SF} \quad=\quad \text { slope factor }\left[(\mathrm{mg} / \mathrm{kg}-\mathrm{d})^{-1} \text { (non-radioactive) or }(\mathrm{pCi})^{-1} \text { (radioactive }\right)\right]
$$

For non-radioactive carcinogens, intake values represent a daily intake averaged over a lifetime of exposure. Intake values for radionuclides are defined to represent lifetime (not daily) exposures. ICRs should be expressed using one significant figure only.

Risk estimates made using the above equation become increasingly inaccurate as they approach a value of 1 . This is because the stochastic nature of cancer induction implies that no exposure level is high enough to ensure a carcinogenic response (i.e., ICRs must have values less than 1). It is stated in EPA (1989a) that this linear equation is valid only at low risk levels (i.e., below estimated risks of $1 \times 10^{-2}$ ). For the purposes of this risk assessment, ICR values that exceed $1 \times 10^{-2}$ are reported as " $>1 \times 10^{-2 n}$. The ICR value calculated using the linear equation is provided in parentheses. These values are not intended to represent accurate cancer risk estimates; they are provided as an aid in determining the degree of risk reduction required to reach an ICR level of interest.

The NCP [40 CFR 300.430(e)(2)(i)(A)(2)] states that acceptable exposure levels represent an excess upper bound lifetime cancer risk of between $10^{-4}$ and $10^{-6}$. The $10^{-6}$ risk level is considered a point of departure for determining remediation goals when ARARs are not available or are not considered sufficiently protective. Thus, cancer risks of $10^{-6}$ or less are considered insignificant for regulatory purposes. A contaminant for which the ICR value exceeds $1 \times 10^{-6}$ is considered a contaminant of concern (COC).

'Table 6-8 lists the contaminants of potential concern that are evaluated for carcinogenicity and their associated SFs. Only ingestion SFs are presented; an inhalation pathway is not evaluated because none of the COPC are volatile. Dermal SFs are presented in Table 6-9.

ICRs for the groundwater ingestion and dermal pathways are presented in Tables 6-5 and $6-6$, respectively. ICRs for these pathways may be added to provide a total ICR for each contaminant. These values are presented in Table 6-10, which indicates that the largest ICR $\left(1 \times 10^{\circ}\right)$ is associated with ingestion of arsenic and is greater than $1 \times 10^{-2}$. Four contaminants (arsenic, carbon-14, technetium-99, and total uranium) are considered contaminants of concern because each has a total ICR greater than $1 \times 10^{-6}$. Since it is assumed that cancer risks associated with different contaminants are additive (i.e., ICRs may be added together), the total ICR is greater than $1 \times 10^{-2}$.

ICR values ideally represent risk associated with contamination, excluding background levels of naturally occurring constituents. However, the predicted groundwater concentrations (from which ICR values are calculated) are based on maximum detected soil concentrations which include background concentrations. Hanford Site background soil data are currently available only for non-radioactive, inorganic constituents (see Table 3-10). The average background soil concentration (Table 3-10) represents a significant fraction of the maximum detected soil concentration for arsenic (6\%). Similarly, carbon-14 and uranium in soil represent naturally occurring terrestrial radioactivity as well as contamination. Therefore, a significant fraction of the groundwater risk may be attributed to the naturally occurring fraction of soil constituents. 


\subsubsection{Uncertainty Analysis}

The risks, both noncarcinogenic and carcinogenic, presented in this assessment are not probabilistic estimates, but instead are deterministic estimates given multiple assumptions about exposures, toxicity, and other variables. This discussion focuses on the uncertainty surrounding the projected risks and hazards due to uncertainty in these variables. Current EPA guidance (EPA 1991b, EPA-10 1991) characterizes input parameters with single point values, not probability distributions. As a result, the uncertainty associated with estimated health impacts cannot be quantified; only a qualitative description of uncertainty is presented.

In order to compensate for the uncertainty associated with selecting single point values to characterize input parameters, estimates used to characterize these parameters are often conservatively biased. As a result, the risk estimates provided in this assessment represent a set of assumptions which, as a whole, is extremely unlikely. For this reason, these risk estimates do not represent actual exposure conditions, and may even exceed reasonable bounding estimates. Therefore, HQ values less than 1 and ICR values less than $1 \times 10^{-6}$ are expected to actually be much smaller, and do not require further treatment in the uncertainty analysis. HQ values greater than 1 and ICR values greater than $1 \times 10^{-6}$ warrant further attention, and are examined with respect to the conservative assumptions which inflate these risk estimates.

\subsubsection{Uncertainty Associated with Identification of Contaminants of Potential Concern.} Contaminants are evaluated in the risk assessment if they are associated with an ICR greater than $1 \times 10^{-7}$ or a HQ greater than 0.1 via preliminary screening of a residential scenario groundwater ingestion pathway. Consideration of a volatile inhalation pathway is unnecessary because none of the groundwater contaminants are volatile. This process by which COPC are identified is designed to remove contaminants from consideration only if they pose an insignificant hazard under any potential scenario. Therefore, one can be assured that the contaminants that pose potential adverse health effects have been identified and carried through the risk assessment.

The screening process described in Chapter 5.0 uses maximum detected contaminant soil concentrations and associated predicted groundwater concentrations. Maximum values are used rather than mean values or upper confidence limits to compensate for the lack of knowledge about true contaminant conditions. However, maximum values may not represent bulk soil concentrations. In some cases, maximum detected concentration refers to product inside of drums (e.g., ammonia; Table 3-10), or residue inside of pipelines (e.g., cesium-137;

Table 3-8). Maximum concentrations are also likely to represent outlying data points that would be dismissed as the result of an analysis of the whole data set. Because data sets are not $100 \%$ validated, some maximum detects may represent erroneous data. Therefore, by using maximum detected concentrations, it is likely that more contaminants are labeled COPC than are justified.

6.1.4.2 Uncertainty Associated with Environmental Transport. The most significant conservative bias in fate and transport parameters for metals and radionuclides (no organic compounds are identified as a contaminants of potential concern) is due to the assumed solubilities. Tables 4-6, 4-7, and 4-8 provide contaminant-specific solubility values available in the literature. Very little site-specific information was available regarding solubilities for metals and radionuclides in 100 and 300 Area wastes. Consequently, it was necessary to rely on general information in literature and to assume conservative values. In all likelihood, actual solubilities for the specific chemical forms of the constituents of concern in 100,200, and 300 Area wastes are much lower than the solubilities used in this analysis. 
The other significant sources of uncertainty are associated with $\mathrm{K}_{\mathrm{d}}$ values and the infiltration rate through the barrier. The uncertainty in $K_{d}$ 's are illustrated in Tables 4-2, 4-3, and 4-4. The uncertainty in infiltration rate is discussed in section 4.1.2.1.

6.1.4.3 Uncertainty Associated with the Exposure Assessment. One of the greatest sources of uncertainty associated with the exposure assessment is the choice of exposure point concentrations. For this analysis, contaminants are characterized by the same maximum detected soil concentrations (and associated predicted groundwater concentrations) used in the risk-based screening process (i.e., Chapter 5.0). The conservative biases associated with these concentrations are described in Section 6.1.4.1. Because the maximum detected contaminant concentrations do not reflect realistic estimates of contaminant conditions, the HQs and ICRs provided in this chapter are not realistic estimates of risk.

It is assumed for this assessment that groundwater is used for in-home residential purposes. Other uses of groundwater would be associated with different risk estimates. More important, however, is the likelihood that groundwater would be used at all. Without groundwater use there is no exposure and therefore no risk. For the purpose of this report, it is assumed that groundwater exposure would occur; no evaluation of the likelihood of this event has been accounted for. If the probability of residential use of groundwater were to be quantified (e.g., there may be a $0.1 \%$ chance that a person would install a well close to the ERDF), then the risks could be adjusted to account for this probability (e.g., multiplying all ICRs and HQs by a factor of 0.001 ).

Equally important is the number of potential groundwater users. Exposure parameter values and toxicological data developed for risk assessment purposes are applicable to large populations, not individuals. In addition, the importance of a risk value is different if it applies to one person, several persons, or a large population. This report does not qualify the risks with respect to the number of people that may be impacted; a contaminant is considered to be of concern if the risk to one or more persons exceeds an ICR of $1 \times 10^{-6}$ or HQ of 1 .

Exposure parameter (i.e., body weight, averaging time, contact rate, exposure frequency, and exposure duration) are represented by the estimates of reasonable maximum exposure (RME) values as defined in the HSBRAM (DOE-RL 1993j), but may not reflect actual future exposure conditions. In addition, the combination of RME values does not necessarily result in a RME risk estimate. For example, the ingestion rate (IR) and exposure duration (ED) parameters may be described by lognormal distributions with means of 1.1 and 15 , and standard deviations of 0.7 and 14 , respectively. With these distributions, the 90 th percentiles are $2 \mathrm{~L} / \mathrm{d}$ (IR) and $30 \mathrm{yr}$ (ED). In the risk assessment, IR and ED are multiplied together, such that the point estimate of this product is 60 . However, the value of 60 represents the 97 th percentile of the product distribution. The risk assessment also uses several other biased parameter values, such that the combination of these values yields a risk estimate which is likely to exceed the 99th percentile of the risk distribution.

The use of average (rather than RME) parameter values, as provided by EPA Region 10 (1991), could remove some conservative bias. For the residential groundwater ingestion and dermal pathways, average intake values are approximately an order of magnitude lower than RME values. Therefore, all of the risk estimates for groundwater exposure would be lower by about an order of magnitude if average parameter values were used. 
6.1.4.4 Uncertainty Associated with the Toxicity Assessment. An understanding of the degree of uncertainty associated with toxicity values is an important part of interpreting and using these values. A high degree of uncertainty in the information used to derive a toxicity value contributes to less confidence in the assessment of risk associated with exposure to a contaminant.

The RfDs and SFs have multiple conservatively biased adjustments built into them (i.e., factors of 10 for up to four different levels of uncertainty for RfDs, and the use of an upperbound estimate derived from the linearized multi-stage carcinogenic model for SFs) that can contribute to overestimation of actual risk. For example, Table 6-7 indicates that an uncertainty factor of 1,000 is used to derive the oral $\mathrm{RfD}$ for antimony from a NOAEL. For this reason, EPA qualifies this RfD with a low confidence rating. Therefcre, the HQ associated with antimony $\left(7 \times 10^{3}\right.$, Table 6-10) should also be characterized as having a low confidence level. The only contaminants of concern that have RfDs with a high confidence level are fluoride $(\mathrm{HQ}=60)$ and nitrite $(\mathrm{HQ}=4)$.

One non-radioactive contaminant (arsenic) is evaluated for carcinogenic potential, and is classified as a Group A (human) carcinogen. Arsenic exposure via drinking water is associated with an increased prevalence of skin cancers in humans. However, the IRIS (EPA 1993a) file on arsenic states that "in reaching risk management decisions in a specific situation, risk managers must recognize and consider the qualities and uncertainties of risk estimates. The uncertainties associated with ingested inorganic arsenic are such that estimates could be modified downwards as much as an order of magnitude, relative to risk estimates associated with most other carcinogens." Therefore, the arsenic SF, as well as ICR values, are also conservatively biased. However, even if the arsenic ICR is adjusted downward by an order of magnitude, the ICR value will still be $>1 \times 10^{-2}$.

Although there is substantial evidence to indicate that exposure to ionizing radiation causes cancer in humans, the scenarios upon which this assumption is based are largely acute, external exposures. Sources of uncertainty specific to radionuclide carcinogenicity include the following: the extrapolation of risks observed in populations exposed to relatively high doses, delivered acutely, to populations receiving relatively low dose chronic exposures; estimates of doses delivered to target cells from the inhalation or ingestion of alpha-emitters (e.g., isotopes of uranium and thorium); and statistical variation in the human exposure data.

EPA classifies all radionuclides as Group A (human) carcinogens based on the fact that they emit ionizing radiation. Studies have shown that uranium, like radium, accumulates primarily in bone, and that bone sarcomas may result from radium ingestion (56 FR 33050 , notice of proposed rulemaking, National Primary Drinking Water Regulations for Radionuclides). However, studies using natural uranium do not provide direct evidence of carcinogenic potential, and existing human epidemiology data are inadequate to assess the carcinogenicity of uranium ingested in drinking water. The remaining two radioactive contaminants of concern (carbon-14 and technetium-99) are considered carcinogenic because of their property of emitting ionizing radiation. However, the available information indicates that there is inadequate evidence of carcinogenicity in humans associated with these specific isotopes (56 FR 33050).

Radionuclide slope factors are the median (50th percentile) values of the slopes of their respective dose-response curves. However, more than one dose-response curve can be developed. The EPA (1989b) estimate of average lifetime risk attributable to exposure to 
ionizing radiation incorporates the most conservative model assumptions utilized by the Biological Effects of lonizing Radiation (BEIR) III Committee. Therefore, radionuclide SFs are median values from conservatively biased dose-response curves. In addition, the updated risk estimates provided by BEIR V (NRC 1990) are qualified with the statement that "the possibility that there may be no risks from exposures comparable to external natural background radiation cannot be ruled out. At such low doses and dose rates, it must be acknowledged that the lower limit of the range of uncertainty in the risk estimates extends to zero."

The uncertainty associated with absorption from dermal exposure is another significant source of uncertainty that is reflected in the estimated risks associated with this pathway for some contaminants. The lack of toxicity information to adequately determine RfDs and SFs for dermal exposures forces extrapolation from oral toxicity values, and compounds the uncertainty associated with the calculations. It is a common practice in risk assessment to adopt oral RfDs and SFs as the dermal toxicity values. In this risk assessment, dermal RfDs and SFs were calculated by accounting for the Gl absorption fraction. The uncertainty in this approach should be emphasized. For example, the response to an oral dose may be significantly different from the response to a dermal dose because the risk associated with point-of-entry (skin) effects for locally acting toxicants cannot be estimated from oral toxicity data. Also, dermally applied chemicals would not be subjected to "first-pass" hepatic metabolism prior to systemic circulation, as is the case for or $3 l y$ administered compounds. Consequently, the application of these oral dose-response relationships to dermal exposure doses is a source of a high degree of uncertainty in the estimated potential health risk.

Uncertainty is also present in the overall toxicity assessment because of the route-toroute extrapolation of toxicity values, and potential synergistic or antagonistic interactions of substances. In spite of these uncertainties, it is expected that the contaminants of concern have been adequately identified.

6.1.4.5 Uncertainty Associated with the Risk Characterization. Hazard quotients and risk values provided by risk assessment by themselves do not fully characterize the health impacts associated with environmental contamination. Such a quantitative evaluation must be understood in light of the uncertainties presented above, and interpreted with respect to their significance.

Hazard quotients and cancer risks are calculated by combining multiple factors (e.g., contaminant concentrations, exposure parameters, toxicity values). In an effort to compensate for the uncertainty and/or natural variability in these factors, single point estimates used to characterize these factors are often conservatively biased. However, even if this bias for each factor can be considered reasonable, the product of these factors is likely to far exceed a reasonable maximum exposure. In assessing the effect of bias in the selection of parameter values, the National Council on Radiation Protection and Measurements (NCRP 1985) notes th.e following:

...substantial overestimation is expected when conservatism is applied in the selection of each parameter in a deterministic model. For example, in a model composed of ten or more multiplicative parameters..., the selection of only the 84th percentile for each parameter results in a predicted value that exceeds the 99.9th percentile of the distribution of model output. 
This means that the risk estimates presented in a deterministic risk assessment are representative of a set of assumptions which, as a group, is extremely unlikely. Use of a more realistic set of assumptions is likely to yield significantly lower risk estimates.

The significance of numerical results requires interpretation. Although a $10^{-6}$ cancer risk may be considered insignificant, this does not imply that larger risks are necessarily significant. The NCP [40 CFR $300.430(e)(2)(i)(A)(2)]$ states that acceptable exposure levels represent an excess upper bound lifetime cancer risk of between $10^{-4}$ and $10^{-6}$. In presenting the quantification of carsinogenic risk (Section 6.1.3.2), contaminants and pathways are described if their associated ICRs exceed $10^{-6}$. However, this does not imply that ICRs greater than this value are unacceptable.

\subsubsection{Human Health Risk Characterization Summary for Groundwater Exposure}

This section of the risk assessment evaluates the human health risks associated with exposure to estimates of potential future groundwater contamination caused by disposal of wastes at the ERDF. A number of key assumptions upon which this analysis is based (e.g., conservative exposure point concentrations, residential scenario use of a groundwater well at the edge of the ERDF facility) are not intended to represent actual site or exposure conditions. For this reason, the risk values presented should be used in conjunction with risks associated with ERDF design alternatives as indicators of relative risk, not actual risk.

Pathways used to evaluate exposure are groundwater ingestion and dermal exposure while showering. Non-radioactive contaminants are cvaluated for both noncarcinogenic and carcinogenic effects, as appropriate. Radioactive contaminants are evaluated only for their carcinogenic potential.

The hazard quotients associated with each contaminant of potential concern are presented in Table 6-10. The HQs are not summed to provide a hazard index because the critical health effects are different. Six inorganic contaminants (antimony, arsenic, chromium, fluoride, nitrite, and selenium) have HQs greater than 1, and are considered contaminants of concern.

A summary of ICRs associated with contaminants of potential concern is also presented in Table 6-10. Four contaminants (arsenic, carbon-14, technetium-99, and uranium) have ICRs greater than $1 \times 10^{-6}$ and the total ICR is greater than $1 \times 10^{-2}$.

ICR values are calculated using soil concentrations which include naturally occurring fractions. Average background concentration of arsenic represents a significant fraction of the maximum detected soil concentration $(6 \%)$. Carbon- 14 and uranium are also present in uncontaminated soils.

In order to compensate for uncertainty associated with selecting single point estimates to quantify exposure conditions and toxicity characteristics, input parameters are often conservatively biased. As a result, the risk estimates provided in this assessment do not represent actual exposure conditions, and may even exceed reasonable boundin estimates must be accompanied by a description of the assumptions upon which they are based, the uncertainties inherent in the input parameters, and the conservative biases employed to compensate for these uncertainties. Without an understanding of these issues (see 
Section 6.1.4), the reader is likely to draw erroneous conclusions regarding the impact of ERDF contaminants on groundwater.

Because this is a deterministic risk assessment, the uncertainty associated with these risk estimates cannot be quantified. However, techniques for quantifying uncertainty in risk assessment have been developed, and can be used to remove conservative biases and risk management decisions from the risk assessment. Use of such techniques to evaluate impact of ERDF contaminants on groundwater is likely to indicate that actual risks are much lower than the estimates presented in this report.

\subsection{RISK ASSESSMENT OF EXPOSURE TO CONTAMINATED SOILS}

Section 6.2 provides an evaluation of possible human health and ecological risks resulting from exposure to contaminated soils, assuming that the ERDF cover does not inhibit these exposures. In reality, each ERDF alternative is designed to inhibit inadvertent intrusion by humans, and eliminate exposure to non-human ecological receptors. Therefore, the results of this section are only valid in the case of a design failure scenario in conjunction with a loss of institutional controls. This evaluation does not calculate or incorporate the likelihood of this occurrence.

Institutional controls are assumed to exist at least $100 \mathrm{yr}$ after the ERDF begins receiving remediation wastes in 1996 (Ecology et al. 1993). Therefore, risks associated with exposure to soil contaminants are adjusted for degradation and radioactive decay to indicate potential risk in the year 2096. Risk are also calculated for the years 2496 (500 yr from ERDF operation) and 11996 (10,000 yr from ERDF operation).

The only loss mechanisms accounted for in this analysis are radioactive decay and degradation of organic contaminants. Contaminant loss via transport (e.g., leaching, erosion, and volatilization) are assumed not to occur. Because the analysis of Section 6.1 is based on the assumption that all contaminants eventually migrate to groundwater, the results of the groundwater exposure and soil exposure analyses should not be combined.

This section evaluates only those risks that could occur following completion of the ERDF (i.e., long-term risks). Worker risk associated with construction and operation of the ERDF is discussed in Chapter 9. Short-term ecological effects are also discussed in Chapter 9.

\subsubsection{Human Health Evaluation}

Much of the risk assessment information provided previously in Section 6.1 is applicable to the human health evaluation of exposure to contaminated soils. Such information is not duplicated in this section; only methods and data specific to soil exposures are presented.

\subsubsection{Human Exposure Assessment}

6.2.1.1.1 Conceptual Model. Figure 6-2 illustrates the conceptual model for human exposures to contaminated soils. The exposure pathways evaluated in this human health evaluation are soil ingestion, dermal exposure, fugitive dust inhalation, inhalation of volatiles, and external exposure to radionuclides. An evaluation of these pathways is expected to 
adequately identify risk-driving contaminants. For comparison purposes, risks associated with a produce ingestion pathway are calculated for strontium-90. Strontium-90 was chosen for this analysis because it is a potentially important internal hazard, and the uptake of strontium by plants tends to be relatively high. Dermal absorption is evaluated only for non-radioactive contaminants. Dermal uptake is generally not an important route of uptake for radionuclides, which have small skin permeability coefficients (EPA 1989a).

All exposures are evaluated assuming residential exposure parameter values specified in HSBRAM (DOE-RL 1993j). This scenario is intended to simulate an inadvertent intruder scenario in which a person unknowingly removes the facility cover. Use of this scenario is only appropriate if institutional controls are lost.

6.2.1.1.2 Quantification of Human Exposures. The reader is referred to Section 6.1.1.2 for a description of the general methods associated with quantification of exposures.

Exposure Point Concentrations. An exposure point concentration is the contaminant concentration in each media to which a receptor is assumed to be exposed. For the soil ingestion and dermal exposure pathways, the exposure point concentration is the maximum detected soil concentration for each contaminant (presented in Table 5-8). For the fugitive dust inhalation pathway, contaminant air concentrations are calculated by dividing the maximum detected soil concentration by a particulate emission factor (PEF) as follows:

$$
C_{\text {air }}=\frac{C_{\text {soil }} \times C F}{\text { PEF }}
$$

where:

$$
\begin{aligned}
& \mathrm{C}_{\text {air }}=\text { contaminant concentration in air }\left[\mathrm{mg} / \mathrm{m}^{3} \text { (non-radioactive), } \mathrm{pCi} / \mathrm{m}^{3}\right. \\
& \text { (radioactive)] } \\
& \mathrm{C}_{\text {woil }}=\text { contaminant concentration in soil }[\mathrm{mg} / \mathrm{kg} \text { (non-radioactive), } \mathrm{pCi} / \mathrm{g} \\
& \text { (radioactive)] } \\
& \mathrm{CF}=\text { conversion factor }\left[1 \times 10^{3} \mathrm{~g} / \mathrm{kg} \text { (radionuclides only) }\right] \\
& \mathrm{PEF}=\text { particulate emission factor }\left(\mathrm{m}^{3} / \mathrm{kg}\right)
\end{aligned}
$$

The PEF used in this evaluation $\left(3.0 \times 10^{7} \mathrm{~m}^{3} / \mathrm{kg}\right)$ is based on the annual average for total suspended particulates in the $200-\mathrm{W}$ Area $\left(33 \mu \mathrm{g} / \mathrm{m}^{3}\right.$; Jaquish and Mitchell 1988). An important conservative assumption associated with the use of a PEF is that all of the suspended particulates originate within the ERDF, and are not diluted by dust blowing in from off-site. Another assumption is that the percentage (by weight) of each contaminant in the dust is equal to its percentage in the soil.

In addition to using the PEF approach, air concentrations of volatile contaminants are calculated using a volatilization factor (VF). The air concentration is calculated using Equation B-1, substituting the VF for the PEF. The VFs used in this evaluation are taken directly from the original RIs or QRAs identified as the source of the maximum contaminant concentrations. These VFs were also used in the risk-based screening process for soils (see Section 5.2). The VFs are listed in Table 5-3. 
Intake Equations. Standard EPA equations, as provided in RAGS (EPA 1989a) and HSBRAM (DOE-RL 1993j), are used as the basis for all intake calculations. Intakes of non-radioactive and radioactive contaminants are calculated and presented separately.

Non-Radioactive Contaminants. Equation 6-1 (see Section 6.1.1.2.1) is the basic equation for calculating intakes of non-radioactive contaminants via ingestion (e.g., soil and water) or inhalation. In the case of soil ingestion, the contaminant concentration is in units of $\mathrm{mg} / \mathrm{kg}$, and the contact rate is in units of $\mathrm{mg} / \mathrm{d}$. In the case of inhalation (of either fugitive dust or volatiles), the contaminant concentration is in units of $\mathrm{mg} / \mathrm{m}^{3}$, and the contact rate is in units of $\mathrm{m}^{3} / \mathrm{d}$.

Equation 6-1 may be used to determine the absorbed dose resulting from dermal exposure to contaminated soil by calculating the contact rate as follows:

$$
\mathbb{R}_{\text {derm }}=S A \times A F \times A B S
$$

where:

$$
\begin{array}{lll}
\mathrm{IR}_{\text {derm }}= & \text { dermal exposure contact rate (mg/event) } \\
\mathrm{SA} & = & \text { skin surface area available for contact }\left(\mathrm{m}^{2}\right) \\
\mathrm{AF} & = & \text { soil-to-skin adherence factor }\left(\mathrm{mg} / \mathrm{cm}^{2}\right. \text {-event) } \\
\mathrm{ABS}= & \text { contaminant-specific dermal absorption factor (unitless) }
\end{array}
$$

The dermal exposure contact rate is inserted into Equation 6-1 to yield the intake value for the dermal pathway. For the purpose of this risk assessment, it is conservatively assumed that receptors do not wear protective clothing that would limit dermal exposures. A description of the dermal absorption fraction (ABS) values used in this evaluation is provided in the Calculation of Contaminant Intakes discussion.

Radioactive Contaminants. Equation 6-3 is the basic equation for calculating intakes of radioactive contaminants via ingestion or inhalation. In the case of soil ingestion, the contaminant concentration is in units of $\mathrm{pCi} / \mathrm{g}$, and the contact rate is in units of $\mathrm{mg} / \mathrm{d}$. In the case of inhalation (of fugitive dust), the contaminant concentration is in units of $\mathrm{pCi} / \mathrm{m}^{3}$, and the contact rate is in units of $\mathrm{m}^{3} / \mathrm{d}$. For biota ingestion, the contaminant concentration is in units of $\mathrm{pCi} / \mathrm{g}$ (wet weight), and the contact rate is in units of $\mathrm{g}$ (wet weight)/d.

Equation 6-3 may also be used to evaluate external exposures. In this case, the "intake" has units of $\mathrm{pCi}-\mathrm{yr} / \mathrm{g}$, and represents the time a receptor is in close proximity to a particular radionuclide soil concentration. The "contact rate" is determined as follows:

$$
\mathrm{IR}_{\mathrm{exx}}=\mathrm{ET} \times \mathrm{RF} \times \mathrm{CF}
$$


where:

$$
\begin{array}{lll}
\mathrm{IR}_{e x} & = & \text { external exposure contact rate }(\mathrm{yr} / \mathrm{d}) \\
\mathrm{ET} & = & \text { exposure time }(\mathrm{hr} / \mathrm{d}) \\
\mathrm{RF} & = & \text { dose reduction factor (unitless) } \\
\mathrm{CF} & = & \text { conversion factor }\left(1.14 \times 10^{-4} \mathrm{yr} / \mathrm{hr}\right)
\end{array}
$$

The external exposure contact rate is then inserted into Equation 6-3 to yield the intake value for the external exposure pathway. A dose reduction factor is used to obtain a more realistic estimate of external exposures by taking into account the effects of shielding while indoors and ground roughness.

Calculation of Contaminant Intakes. All exposure parameters (e.g., body weight, averaging time, contact rate, exposure frequency, and exposure duration) presented below are those recommended by HSBRAM (DOE-RL 1993j). These exposure parameters have been specifically developed for a residential population, and are used to evaluate the soil ingestion, dermal exposure, inhalation (fugitive dust and volatiles), external radiation exposure, and biota ingestion pathways. The parameters for the noncarcinogenic, non-radioactive carcinogenic, and radioactive carcinogenic contaminants of potential concern are summarized in Tables 6-11, 6-12, and $6-13$, respectively.

Contaminant intakes are calculated by combining exposure parameters presented in Tables 6-11 through 6-13 and intake Equations 6-1 and 6-3 (as modified by Equations 6-6 and 6-7). Example calculations of this process are provided in Appendix D of the Hanford Site Risk Assessment Methodology (HSRAM, Rev. 3) (DOE-RL 1994c). Summary intake factors (see Section 6.1.1.2.2) are provided in Table 6-14.

Summary intake factors for dermal exposure to soil require the use of contaminant-specific dermal absorption factors (ABS). The ABS is the fraction of the contaminant that crosses the skin and enters the bloodstream. ABS values are either assumed or derived from the literature. Contaminants bound to a soil matrix are less dermally bioavailable than pure or dilute solutions of contaminants applied directly to the skin. Specific information on the dermal absorption of most of the COPC in this risk assessment is limited.

The use of an upper bound estimate of $6 \%$ as an absorption factor for PCBs based on studies of 3,3',4,4'-tetrachlorobiphenyl is recommended in EPA (1992b). For the purposes of this risk assessment, $6 \%$ is used as the ABS for all Aroclors.

Dermal Exposure Assessment (EPA 1992b) does not recommend ABS values for other organic contaminants of potential concern. However, Hawkins et al. (1990) recommend ranges of $\mathrm{ABS}$ values for different classes of constituents. The recommended $\mathrm{ABS}$ range for volatile organics is 10 to $50 \%$. For this risk assessment, all volatile COPC (i.e., benzene, chloroform, methylene chloride, trichloroethene, vinyl chloride, and ammonia) are assumed to have an $A B S$ of $30 \%$, based on the average of the low and high end values of the recommended range.

For semi-volatiles and pesticides, Hawkins et al. (1990) recommend an absorption fraction range of 1 to $10 \%$. For this risk assessment, the remaining organic COPC are assumed to have an ABS of 5\%, based on the average of the low and high end values of the recommended range. 
For metals, Hawkins et al. (1990) recommend an absorption fraction range of 1 to $10 \%$. EPA (1992b) recommends a range of $0.1 \%$ to $1.0 \%$ for cadmium. For this risk assessment, all metals are assumed to have an ABS of $1 \%$.

For the produce ingestion pathway (evaluated for strontium-90), the contaminant concentration in the edible portion of plants needs to be estimated. This is performed by multiplying the strontium- 90 soil concentration $\left(2.0 \times 10^{3} \mathrm{pCi} / \mathrm{g}\right)$ by a plant uptake factor and dry weight/wet weight conversion factor. The uptake factor used for this analysis $(0.25)$ is from Baes et al. (1984), and is intended to represent uptake by fruits, seeds, and tubers. The dry weight/wet weight conversion factor is 0.32 . The result is a strontium- 90 plant concentration of $160 \mathrm{pCi} / \mathrm{g}$ (wet). This concentration is multiplied by the summary intake factor for biota ingestion (Table 6-14) to yield the produce intake value (Table 6-19).

6.2.1.1.3 Summary of Human Exposure Assessment. Intake values are calculated by multiplying exposure point concentrations (see Section 6.2.1.1.2) by summary intake factors (Table 6-14). Intake values for non-radioactive contaminants are provided in Tables 6-15 (soil ingestion), 6-16 (dermal exposure), 6-17 (fugitive dust inhalation), and 6-18 (volatile inhalation). Intake values for radioactive contaminants are provided in Table 6-19 for all three exposure pathways. All intake values represent current exposures. The analysis of future risks is provided in Section 6.2.1.3. Actual future intakes (assuming an intrusion into contaminated soils) would be smaller due to a variety of loss mechanisms (e.g., radioactive decay, volatilization, contaminant degradation).

6.2.1.2 Human Health Toxicity Assessment. The toxicity assessment for this risk assessment is conducted in accordance with RAGS (EPA 1989a) and HSBRAM (DOE-RL 1993j). The reader is referred to Section 6.1.2 for a description of the general characteristics of a human health toxicity assessment. Toxicological profiles for the COPC are presented in appendices of operable unit-specific RI reports (DOE-RL 1993e,f,g).

Table 6-20 summarizes the noncarcinogenic toxicity values (i.e., RfDs) and the corresponding critical effects for the COPC at the site. It is noted that the recommended concentration level for ingestion of ammonia (as published in HEAST, EPA 1993b) is for sensory threshold; it is not intended for use in the characterization of health risk. Table 6-21 presents the carcinogenicity weight-of-evidence classifications and the SFs for the ingestion, inhalation, and external radiation exposure routes for non-radioactive and radioactive contaminants of potential concern.

There are currently no toxicity values specifically developed for evaluating dermal exposures. For the purpose of this risk assessment, oral toxicity values (RfDs and SFs) are adjusted for evaluating dermal intakes. The reader is referred to Section 6.1.2.3 for a complete discussion of the methods used to estimate dermal toxicity values. Table 6-22 presents the dermal RfDs and SFs for COPC, including the corresponding GI absorption factors.

6.2.1.3 Human Health Risk Characterization. The information from the exposure assessment and toxicity assessment is integrated to form the basis for the characterization of human health risks. The risk characterization presents quantitative and qualitative descriptions of risk. The reader is referred to Section 6.1 .3 for a more complete description of the methods used in this risk characterization. 
The HQs and ICRs calculated using the intake values provided in Tables 6-15 through 6-19 represent risks assuming current residential exposure. The HQs and ICRs for each contaminant are summed across pathways to provide contaminant totals. Current non-radioactive contaminant HQ and ICR totals are provided in Table 6-23; current radioactive contaminant ICR totals are provided in Table 6-24.

Table 6-19 indicates that the produce ingestion ICR for strontium-90 is approximately fifty times higher than the soil ingestion ICR $\left(5 \times 10^{-3}\right.$ vs. $\left.9 \times 10^{-5}\right)$. This indicates that a produce ingestion pathway could be the dominant risk pathway for strontium-90. See Section 6.2.1.4.2 for additional discussion on the expected importance of a produce ingestion pathway for other contaminants.

HQ and ICR values are decay-corrected for $103 \mathrm{yr}$ to provide future risk values (assuming residential exposure to maximum concentrations) in the year 2096. The decay correction is calculated for organic compounds, ammonia, and radionuclides. All loss mechanisms are assumed to follow exponential decay, which is characterized by a half-life. Assumed half-lives of organic compounds are presented in Table 6-25. These are the same half-lives used in the groundwater transport model to account for contaminant degradation. Although ammonia is known to degrade to nitrate, a characteristic half-life was not found in the literature. Ammonia was assumed to completely degrade within $100 \mathrm{yr}$. Metals are assumed not to degrade. Radionuclide loss is assumed to be entirely due to radioactive decay. Table 6-25 presents half-lives and decay-corrected HQs and ICRs for non-radioactive contaminants. Table 6-26 presents half-lives and decay-corrected ICRs for radioactive contaminants.

The HQ and ICR values are also decayed for $500 \mathrm{yr}$ and 10,000 $\mathrm{yr}$ and are presented in Table 6-27 for organic compounds, and in Table 6-28 for radioactive contaminants.

6.2.1.3.1 Quantification of Noncarcinogenic Effects. The HQs for future exposure (summed across the soil ingestion, dermal exposure, fugitive dust inhalation, and volatile inhalation pathways for each contaminant) are presented in Table 6-25 (for year 2096). Eleven contaminants have estimated HQs greater than 1 , and are considered contaminants of concern. The COC are aluminum, antimony, arsenic, barium, chromium, copper, mercury, nickel, silver, thallium, and vanadium. The highest $\mathrm{HQ}$ of any single contaminant is for copper $(\mathrm{HQ}=30)$. Assuming no loss mechanisms, the HQs at $500 \mathrm{yr}$ and $10,000 \mathrm{yr}$ are expected to remain the same.

The HQs may be added together to provide a HI for all of the systemic toxins. However, it is only appropriate to add HQs for contaminants that produce similar adverse effects because the effects associated with such contaminants are assumed to be additive. In contrast, it is not appropriate to add the HQs for contaminants with different effects. For example, the HQs for copper and arsenic should not be added together because the critical effect for copper exposure (GI irritation) is different than the critical effect for arsenic (hyperpigmentation). Based on the critical effects presented in Table 6-20, the HQs for antimony and thallium may be added (for a $\mathrm{HI}$ of 2). The HQs from the remaining contaminants of concern should be examined separately.

6.2.1.3.2 Quantification of Carcinogenic Risk. ICRs for future exposure to nonradioactive contaminants (summed across the soil ingestion, dermal exposure, fugitive dust inhalation, and volatile inhalation pathways for each contaminant) are presented in Table 6-25 
(for the year 2096). Seven contaminants (four organics and three inorganics) have ICRs greater than $1 \times 10^{-6}$, and are considered contaminants of concern. These are Aroclor-1254, Aroclor-1260, benzo(a)pyrene, benzo(k)fluoranthene, arsenic, beryllium, and chromium. The largest ICR for a single contaminant is $4 \times 10^{4}$, associated with fugitive dust inhalation of chromium (assumed to be chromium VI). It is assumed that cancer risks associated with different contaminants are additive (i.e., ICRs may be added together). The total ICR for the year 2096 is $1 \times 10^{-3}$.

Table 6-27 indicates that in $500 \mathrm{yr}$ and $10,000 \mathrm{yr}$ only two organic compounds (both PCBs) have ICRs greater than $1 \times 10^{-6}$. Adding the organic risks from Table 6-27 to the inorganic risk from Table 6-25 indicates that the total ICRs in $500 \mathrm{yr}$ and $10,000 \mathrm{yr}$ are both estimated to be $9 \times 10^{-4}$.

ICRs for future exposure to radioactive contaminants via soil ingestion, fugitive dust inhalation, and external exposure are presented in Table 6-26 (for year 2096). An important consideration for repositories of radioactive waste is the ingrowth of radioactive daughter products. Ingrowth is a condition by which the concentration of a radionuclide temporarily increases due to the decay of its parent radionuclide(s). For example, thorium-232 is the head of the thorium series, of which the decay products are relatively short-lived. Assuming no migration of the thorium series members takes place, radioactive equilibrium will be reached in about $60 \mathrm{yr}$. HEAST (EPA 1993b) does not provide a thorium-232+D slope factor to account for this effect. Therefore, as shown in Tables 6-26 and 6-28, ICRs are calculated for the radioactive daughters of thorium-232 (radium-228, thorium-228, and their associated subchains). These radionuclides are expected to be in equilibrium with thorium-232 within $100 \mathrm{yr}$, such that radium-228 and thorium-228 are characterized by the thorium-232 soil concentration and half-life. The slope factors used to calculate ICR values associated with radium-228 and thorium-228 are the radium-228 $+D$ and thorium-228 $+D$ SFs provided in HEAST (EPA 1993b). For the time frame; being evaluated in this appendix, the effect of daughter ingrowth is only important for thorium-232. The " $D$ " slope factor provided in HEAST adequately account for this effect for the uranium and actinium series.

Table 6-26 (radionuclide risk in the year 2096) indicates that thirteen radionuclides have ICR values greater than $1 \times 10^{-6}$, and are considered contaminants of concern. Table 6-28 indicates that following 500 and $10,000 \mathrm{yr}$ of decay, the contaminant of concern list is reduced to eight and five radionuclides, respectively. In all cases, the risk is dominated by uranium (and its associated daughter products). The pathways of concern for uranium are external exposure and inhalation (see Table 6-19). The external exposure hazard is not due to uranium itself, but protactinium-234m (a daughter product of uranium-238).

For the produce ingestion pathway, Table 6-26 indicates that the future (year 2096) strontium-90 ICR is $5 \times 10^{-4}$. Inclusion of a produce ingestion pathway does not change the status of strontium-90 as a contaminant of concern; the risk via other pathways (mostly soil ingestion) is still greater than $1 \times 10^{-6}$ in $100 \mathrm{yr}$. By the year 2496 , the produce ingestion ICR value drops to $3 \times 10^{-8}$, such that strontium-90 is not considered a contaminant of concern after $500 \mathrm{yr}$.

ICR values ideally represent risk associated with contamination, excluding background levels of naturally occurring constituents. However, contaminant soil concentrations (from which ICR values are calculated) are based on maximum detected concentrations, which include background concentrations. Hanford Site background soil data are currently available only for non-radioactive, inorganic constituents (see Table 3-10). The average background soil 
concentration represents a significant fraction of the maximum detected concentration for arsenic $(6 \%)$ and beryllium (23\%). Using the same risk assessment calculations provided in this chapter, the ICR values associated with the background concentrations for arsenic and beryllium are $1 \times 10^{-5}$ and $5 \times 10^{-5}$, respectively. The maximum detected soil concentration $(33 \mathrm{pCi} / \mathrm{g})$ of potassium- 40 , a naturally occurring radionuclide, has an associated ICR of $4 \times 10^{-4}$. Several radioactive contaminants (carbon-14, uranium, thorium) are also naturally occurring; however, Hanford Site background data are currently unavailable.

Naturally occurring terrestrial radionuclides result in a measurable external radiation field. Woodruff and Hanf (1992) provide external radiation dose measurement results for distant communities, which indicate that the average naturally occurring dose rate in 1991 was approximately $87 \mathrm{mrem} / \mathrm{yr}$. Using the current EPA radiation risk factor for cancer incidence $\left(6.2 \times 10^{-7} / \mathrm{mrem}\right.$, EPA $1989 \mathrm{~b}$ ), this dose rate is associated with an ICR of $1 \times 10^{-3}$ (using the exposure parameters provided in Table 6-13. Only five of the thirteen radioactive contaminants of concern (in 2096, Table 6-26) have ICR values greater than the $1 \times 10^{-3}$ ICR associated with naturally occurring terrestrial radiation. In $500 \mathrm{yr}$ (Table 6-28), only three radionuclides (plutonium-238/239, radium-226, and uranium) have associated ICRs greater than background risk. In 10,000 yr, only uranium has an associated ICR greater than background risk.

6.2.1.4 Uncertainty Analysis. The uncertainty analysis for the groundwater risk assessment provided in Section 6.1.4 is largely applicable to this analysis. Only sources of uncertainty specific to the evaluation of soil exposures and risks are presented below.

\subsection{Uncertainty Associated with Environmental Fate and Transport.}

Environmental degradation half-lives are used in this analysis (originally presented in Section 4.1.2) to calculate decay-corrected HQs and ICRs. Since there is much uncertainty associated with half-lives for organic compounds, several sources of data were reviewed, and a range of half-lives was selected for each compound $(<1,1-10,10-100 \mathrm{yr})$. The maximum value in the range is used in this analysis. For compounds with no data, the half-live was arbitrarily set at $10,000 \mathrm{yr}$.

There is a high degree of uncertainty with respect to the choice of half-lives for organic compounds. Much of the current data is not appropriate for conditions expected in the ERDF. Therefore, half-lives presented in Table 6-25 are not precise. The most obvious indication of this is the difference in half-lives for the different Aroclors. Experimental data is available for Aroclor-1248 (indicating a half-life less than $1 \mathrm{yr}$ ), but data are not available for the other two PCBs. It is unlikely the degradation rates for all three PCBs are that different, but it is conservatively assumed that Aroclor- 1254 and Aroclor- 1260 have half-lives of $10,000 \mathrm{yr}$. It is unlikely that these are accurate half-lives for PCBs, and the associated ICRs for these Aroclors are conservatively biased.

Choice of half-life is an important issue because future risk values are very sensitive to this parameter. For example, the maximum detected concentration of Aroclor-1248 is about twice the maximum detected value of Aroclor-1254 (see Table 3-9). However, because of the choice of half-lives, Aroclor-1248 apparently degrades to insignificant levels while Aroclor-1254 remains a contaminant of concern with an ICR of $9 \times 10^{-5}$. Better information on the half-life of Aroclor-1254 and -1260 would probably eliminate these contaminants as a significant risk in the future. 
This analysis conservatively assumed that the repository waste will not migrate away from the ERDF. However, contaminant leaching may be an important loss mechanism. This means that, if the ERDF design allows leaching, then the waste will eventually be depleted of contaminants, starting with the most mobile species. This loss mechanism applies to all contaminants, not just organics and radionuclides. For example, Table 6-10 indicates that (assuming an unlined trench and an infiltration rate of $0.5 \mathrm{~cm} / \mathrm{yr}$ ) arsenic is expected to migrate from the ERDF to groundwater in $540 \mathrm{yr}$. In another $400 \mathrm{yr}$, the groundwater plume is expected to have completely passed beyond the ERDF boundary. This also means that arsenic is no longer present in the ERDF. The risk values in this chapter do not account for this potential loss mechanism; it is conservatively assumed that the waste is stable and will not migrate away from the ERDF.

6.2.1.4.2 Uncertainty Associated with the Exposure Assessment. It is important to note that this chapter provides an evaluation of exposure conditions that the ERDF is expected to prevent. Risk values presented in this chapter do not account for the probability that exposure to repository wastes will occur. However, it is likely that as time following completion of the ERDF increases, the probability of inadvertent intrusion also increases. For this reason, risk values calculated for 500 yr or more in the future are expected to be more representative of potential exposure conditions than risk values calculated for the year 2096.

The produce ingestion pathway appears to be the dominant risk pathway for strontium90. However, there is a high degree of uncertainty associated with this pathway. It is assumed that a person grows enough produce on contaminated soils to support an intake rate of $80 \mathrm{~g} / \mathrm{d}$. The strontium- 90 uptake factor $(0.25)$ is a default value for fruits, seeds, and tubers. Baes et al. (1984) indicates that the range of reference mean values for strontium-90 uptake is 0.077 to 17 .

Strontium-90 was chosen for the evaluation of the produce ingestion pathway because it is a relatively important internal hazard, and has a relatively high uptake value. A produce ingestion pathway may be important for other contaminants as well, but probably only those contaminants that pose a high risk via the soil ingestion pathway. Of the contaminants that are COC in the year 2096 (see Tables 6-25 and 6-26) the soil ingestion pathway is the dominant risk pathway for nearly all non-radioactive contaminants as well as americium-241, nickel-63, and isotopes of plutonium. Of all of these contaminants, current literature (Baes et al. 1984, Travis and Arms 1988) indicates that strontium-90 has the highest uptake factor. In most cases, the strontium-90 uptake factor is higher by more than an order of magnitude. This suggests that, while a produce ingestion pathway may contribute to the overall risk, it is unlikely to be a dominant risk pathway for more than a few contaminants.

6.2.1.4.3 Uncertainty Associated with the Toxicity Assessment. Table 6-20 provides the confidence level assigned by EPA to each RfD. All of the contaminants of concern that exhibit systemic toxic effects (Table 6-25) have confidence levels of medium or low (several contaminants do not have assigned confidence levels). Because of the conservative assumptions inherent in the development of these RfDs, it is unlikely that contaminants of concern represent a significant systemic toxic hazard.

The copper RfD ( $\left.4 \times 10^{-2} \mathrm{mg} / \mathrm{kg}-\mathrm{d}\right)$, which results in the highest HQ (30), may be considered to have high confidence. This RfD is slightly lower than a LOAEL (in humans) of $7 \times 10^{-2} \mathrm{mg} / \mathrm{kg}-\mathrm{d}$ (EPA 1991a). However, the National Academy of Science recommend an intake equal to or greater than the RfD to protect against the adverse health effects associated with copper deficiency. 
The EPA slope factors developed to assess external exposure to radionuclides are likely to be particularly conservative. External exposure SFs are appropriate for a uniform contaminant distribution (i.e., an infinite slab source). Because of the penetrating ability of high-energy photons, this assumption can only be satisfied if the contamination extends to nearly $2 \mathrm{~m}(6.6 \mathrm{ft})$ below ground surface, and over a distance of a few hundred meters or more. Although the ERDF will exceed these dimensions, the soil concentrations used in this evaluation are maximum detects, and are unlikely to represent large volumes of repository waste.

6.2.1.4.4 Uncertainty Associated with the Risk Characterization. The reader is referred to Section 6.2.4.5 for a discussion of risk characterization uncertainty.

\subsubsection{Ecological Risk Assessment}

6.2.2.1 Problem Formulation. The purpose of this ecological risk assessment is to evaluate the likelihood that adverse ecological effects may occur if organisms are exposed to contaminants that may be disposed in the ERDF. The organisms would include all plants and animals, except humans and domestic animals, that could be potentially exposed to site contaminants. This risk assessment is intended to evaluate base conditions at the ERDF. These base conditions are that the ERDF has a soil cover that can be breached by the organisms. This base condition is then used to evaluate alternative designs. To account for temporal changes in contaminant concentrations (e.g., decay), four exposure scenarios are evaluated: current, 103 years in the future, 500 years in the future and 10,000 years in the future.

The ecological evaluation was conducted using biotransfer modeling to account for exposure of ecological receptors to contaminants that might be disposed at the ERDF. Biotransfer modeling is a common method for evaluating ecological risk (Suter 1993). For the ERDF, biotransfer modeling was conducted using available site-specific information, best available information where appropriate, and professional judgment, if necessary. This evaluation calculates risks for a limited set of exposure scenarios. Namely, vegetation uptake of contaminants in soil, ingestion of vegetation (seeds) by the Great Basin pocket mouse (Perognathus parvus), and external exposure of the mouse to radionuclides present in the soil. This evaluation does not consider the potential for bioaccumulation to higher trophic levels because of the high degree of uncertainty associated with biotransfer factors for terrestrial receptors. These scenarios were judged adequate for evaluation of ecological risks at the ERDF because the cover barrier will be at least 15 feet thick, which is sufficient to prevent access to wastes by environmental receptors.

6.2.2.1.1 Stressors. Soil material proposed for disposal at the ERDF will originate from environmental restoration activities at waste management sites in the 100 and 300 Areas. Remedial investigations have been conducted at several of the waste management units. Contaminants recorded at these sites included volatile and semi-volatile organics, pesticides, metals, and radionuclides. Biological monitoring studies have been conducted by PNL (or its predecessors) for much of the time that the Hanford Site has been operating. Although these studies show that biota have been contaminated by contaminants attributable to site activities (especially radionuclides), there has been no report of significant adverse effects to the ecological communities present at the Hanford Site to date.

The contaminants recorded at various waste management units could present a hazard to the environment because of toxicity and persistence in the environment. Soil contaminants of 
potential concern are identified and discussed in Chapter 5.0 and listed in Table 5-8. Soil concentrations used to characterize contaminant conditions are maximum detected concentrations from the 100 and 300 Areas. All organic, inorganic, and radioactive COPC identified in the human risk assessment were considered to be of concern for the ecological risk assessment. The COPC were selected after screening of constituents for human health risk (see Sections 5.2).

6.2.2.1.2 Ecosystem Components. The regional and site-specific ecology of the proposed ERDF site is presented in Section 2.8. Given that the proposed location of the ERDF is on the 200 Area plateau of the Hanford Site, only terrestrial organisms that are resident on the 200 Area plateau are considered for the evaluation of base conditions.

6.2.2.1.3 Endpoint Selection. The risk assessment combined soil data and modeled data with other supportive information to evaluate potential exposure of receptor species to organic, inorganic, and radiological contaminants. The assessment endpoint for study is the health of selected receptor organisms and their populations. The measurement endpoint is the estimated contaminant intake by individuals. Because the ERDF is in planning stages, no mortality studies can be conducted on indicator species.

The focus is on site-wide risks associated with contaminants present in soils that could be disposed of in the ERDF. It is not possible to evaluate all potential effects on all potential receptors. Consequently, this assessment focuses on the potential receptor that is most likely to be exposed to contaminants buried in the ERDF. The organism selected for evaluation is the Great Basin pocket mouse (Perognathus parvus).

6.2.2.1.4 Conceptual Model. Based on the descriptions of ecological resources present at, or near, the proposed ERDF site and assuming a contaminant source limited to the soil, a conceptual ecological model can be derived for the key ecological resources of the area (Figure 6-3). The key receptor evaluated in this risk assessment is the Great Basin pocket mouse which is considered a small herbivorous mammal. In this model, uptake of contaminants from soil by vegetation serves as the basic source of contaminant entry into the food chain. The herbivore component, represented in the model by insects and several herbivorous mammals, acts as the primary conduit between contaminants in vegetation and contaminants in carnivores. Two levels of carnivores are common to the 200 Area plateau. Primary carnivores prey almost entirely on herbivores; therefore, three levels of bioaccumulation are possible (soil to plant, plant to herbivore; herbivore to primary carnivore). Second-order carnivores prey on other carnivores as well as on herbivores. The projected size of the ERDF [ $1.6 \mathrm{sq} \mathrm{mi} \mathrm{(410} \mathrm{ha)]} \mathrm{is}$ extremely large relative to the home range of mice $\left[5,400\right.$ to $43,000 \mathrm{ft}^{2}(0.05$ to $\left.0.4 \mathrm{ha})\right]$. Thus, it is assumed that mice spend their entire lives within the ERDF boundary and ingest only vegetation that grows on the site.

6.2.2.2 Analysis. The analysis phase of the ecological risk assessment is a technical evaluation of the available data to assess the potential effects of exposure to the stressors on the target receptors previously discussed. This analysis is based on the conceptual model and characterizes exposure and ecological effects. The section on exposure characterization focuses on developing the exposure relationship between receptors and site contaminants. Because of the lack of site-specific data for plants and wildlife, this risk analysis can only be considered a screening-level analysis. 
6.2.2.2.1 Characterization of Exposure. For the purpose of the exposure characterization, the maximum detected concentration for any potential contaminant was used to establish the exposure scenario concentration. It was assumed these concentrations were uniformly distributed over the site and were biologically active and available for transport into the biosphere. It was also assumed that the measured activities for the radionuclides were appropriate at the time of the risk assessment.

6.2.2.2.1.1 Exposure Analysis. Because of the need to provide an assessment of base conditions, it was assumed the evaluated receptor spends some fraction of its life in the ERDF, and obtains all its their food from the site when present, and all consumed food is contaminated. There is no source of water within the site, therefore, water ingestion was not considered a route of exposure. Ingestion of vegetation (seeds) is the only food chain exposure pathway presented for the mouse.

The ecological risk assessment focuses on potential effects to vegetation and wildlife potentially exposed to contaminants present in the ERDF. Terrestrial vegetation is represented as a generic plant species for uptake from the soil and as a food source for wildlife. The pocket mouse was selected based upon its presence at the site, trophic position, and habitat requirements.

The major route of contaminant exposure for plants is assumed to be direct uptake of contaminants from soil. Ingestion from food is assumed to be the major route of exposure to wildlife species for both non-radiological and radiological contaminants. For non-radiological contaminants, the receptor exposure to contaminants is based on the intake rate of contaminants within the food source. Uptake factors and transfer coefficients are considered only for determining concentrations in potential food sources. For radiological contaminants, the exposure pathways consider uptake and incorporation of radionuclides from contaminated external food that results in internal exposure and the dose due to direct external exposure. The dose from direct exposure to radionuclides was calculated for the mouse because it spends its life on the ground or in burrows.

6.2.2.2.1.2 Contaminant Intake by Terrestrial Receptors. The intake of contaminants by environmental receptors is estimated from maximum soil concentrations, appropriate transfer coefficients, and species specific intake factors. This section is focused on intake of nonradiological contaminants, but applies to radiological contaminants by the appropriate substitution of radionuclide activity concentration and conversion factors.

Plants

Direct uptake from soil is assumed to be the dominant exposure route for plants. Uptake of contaminants via deposition is not considered. The contaminant concentration within a generic plant was estimated from results of remedial investigation studies at operable units in the 100 and 300 Areas. Soil-to-plant transfer coefficients for organic contaminants (Table 6-29) were derived using the equations of Travis and Arms (1988). Soil-to-plant (seeds) transfer factors for inorganic contaminants (Table 6-30) and radionuclides (Table 6-31) were obtained from available literature (Baes et al. 1984, Coughtrey et al. 1985). Transfer factors to seeds were chosen because seeds represent a significant proportion of the diet of the mouse. The transfer factors do not take into account contaminant bioavailability, biodegradation, or metabolic transformation of compounds. Contaminant concentration (or activity) in plants is calculated by 


$$
C_{i, v}=\left(C_{s, i}\right)(S p)(D w)\left(C f_{1}\right)
$$

where

$$
\begin{aligned}
& C_{i, v}= \begin{array}{l}
\text { concentration (activity) of contaminant } i \text { in vegetation }(\mathrm{mg} / \mathrm{kg} \text { plant or } \mathrm{Ci} / \mathrm{kg} \text { plant, } \\
\text { wet weight) }
\end{array} \\
& \mathrm{C}_{\mathrm{s}, \mathrm{i}}= \begin{array}{l}
\text { concentration (activity) of contaminant } \mathrm{i} \text { in soil }(\mathrm{mg} / \mathrm{kg} \text { soil or } \mathrm{pCi} / \mathrm{g} \text { soil, dry } \\
\text { weight) }
\end{array} \\
& \mathrm{Sp}= \text { soil-to-plant transfer coefficient }(\mathrm{kg} \text { soil } / \mathrm{kg} \text { plant, dry weight) } \\
& \mathrm{Dw}= \text { dry-to-wet weight conversion }(0.32) \\
& \mathrm{Cf}_{1}=\text { conversion factor for radionuclides }(1000 \mathrm{~g} / \mathrm{kg} * 1 \mathrm{E}-12 \mathrm{Ci} / \mathrm{pCi})
\end{aligned}
$$

The transfer factors used in this assessment are for soil to reproductive parts (i.e. seeds).

\section{Wildlife}

The estimated contaminant intake (or activity) by the mouse is estimated using species specific intake parameters. The intake of contaminants is estimated using an equation adapted from the Human Health Evaluation Manual (EPA 1989a) in which

$$
\mathrm{I}_{\mathrm{i}, \mathrm{o}}=\frac{\left(C_{i, \nu}\right)(I R)(F I)(E F)(E D)}{(B W)(A T)}
$$

where

$I_{i, 0}=$ intake rate of contaminant $\mathrm{i}$ by organism $(\mathrm{mg} / \mathrm{kg} /$ day $)$

$C_{i, v}=$ concentration of contaminant $i$ in vegetation $(\mathrm{mg} / \mathrm{kg}$, wet weight)

$\mathrm{IR}=$ ingestion rate $(0.0067 \mathrm{~kg} /$ day $)$

$\mathrm{FI}=$ fraction of food ingested from contaminated area

$E F=$ exposure frequency (days/year)

$\mathrm{ED}=$ exposure duration (years)

$\mathrm{BW}=$ body weight $(0.0235 \mathrm{~kg})$

$\mathrm{AT}=$ averaging time (days)

This equation is used to estimate intake rate of contaminants by herbivores.

The ingestion rate is based on an allometric equation from Calder (1984):

IR $\left(\mathrm{kg} /\right.$ day) $=0.157 \mathrm{BW}{ }^{0.84}$. The mouse body weight is based on Burt and Grossenheider (1976). For this assessment, exposure frequency, exposure duration, and averaging time are assumed to be one year, and can therefore be ignored. The fraction of food ingested from a contaminated area is an estimate based on the home range or species density of the organism. For the mouse whose home range is smaller than the ERDF, it was assumed that $100 \%$ of their diet consisted of contaminated foodstuffs.

6.2.2.2.1.3 Estimation of Radiation Dose to Terrestrial Receptors. Uptake of radionuclides from soils by plants was estimated the same way as uptake for non-radioactive contaminants but substituting appropriate transfer coefficients and conversion factors 
(equation 6-9). The activity of any radionuclide in mice was calculated based on an equation developed by Baker and Soldat (1992) which shows:

$$
\mathrm{A}_{\mathrm{i}, \mathrm{m}}=\left(\frac{\left(A_{\mathrm{i}, \nu}\right)\left(I R_{m}\right)\left(U F_{\mathrm{i}}\right)}{(B W)}\right)\left(\frac{1-e^{-\lambda r}}{\lambda}\right)
$$

where

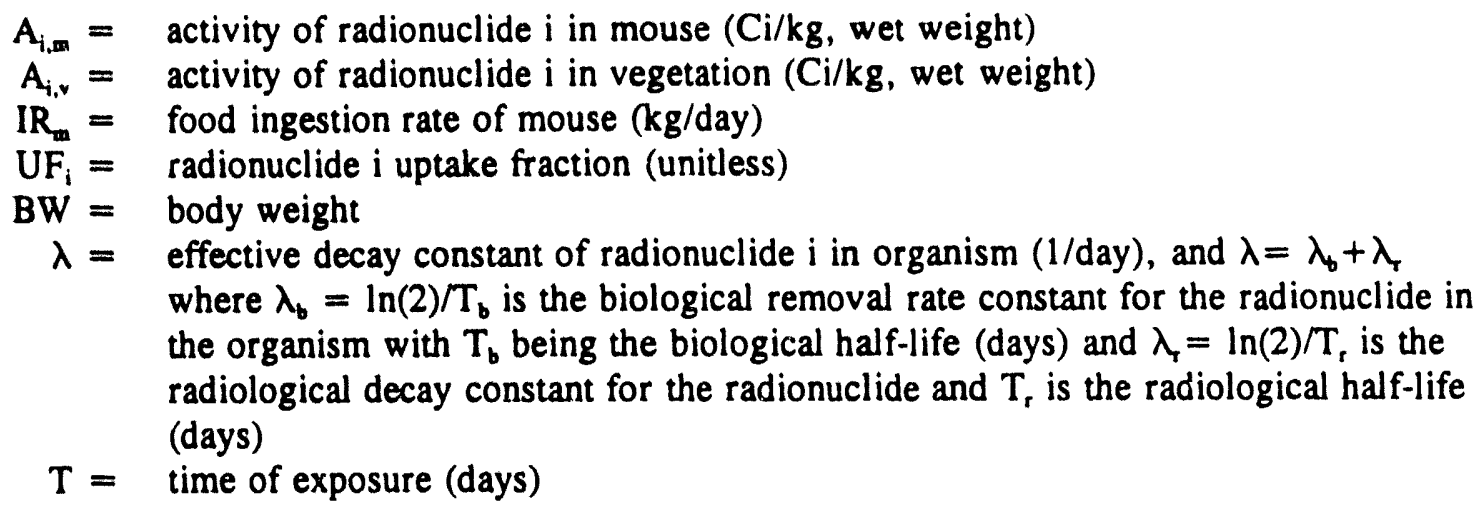

The internal dose rate to an organism by a radionuclide $i$ is then given by

$$
\mathbf{R}_{\mathrm{i}, \mathrm{c}}=\left(\frac{\left(b_{i}\right)\left(I R_{m}\right)\left(U F_{i}\right)}{(B W)}\right)\left(\frac{1-e^{-\lambda T}}{\lambda}\right)\left(E_{i, c}\right)
$$

where

$$
\begin{aligned}
R_{i, c}= & \text { dose rate to total body of organism } c \text { by radionuclide } i\left(\mathrm{rad} d^{-1}\right) \\
b_{i}= & \text { specific body burden of radionuclide } i \text { in food }(\mathrm{Ci} / \mathrm{kg}) \\
E_{i, c}= & \text { effective absorbed energy rate for nuclide } i \text { per unit activity in organism } c(\mathrm{~kg}- \\
& \text { rad/Ci/d), where } E_{i, c}=5.12 E+04 e_{i, c} \text { and } e_{i, c} \text { is the effective absorbed energy } \\
& (\mathrm{MeV} / \text { dis }) \text { for radionuclide } i \text { in organism } c
\end{aligned}
$$

The total dose is determined by summing the dose rate for each radionuclide. A summary of exposure parameters for the mouse is shown in Table 6-32. In the absence of specific data, the removal constants, $\lambda$, and uptake fractions, $U F_{i}$, are taken to be that of standard man (Baker and Soldat 1992, ICRP 1959). For regulatory purposes, the exposure time $(\mathrm{T})$ is assumed to be one year. For a more complete derivation of the dose equations, see Baker and Soldat (1992).

The external dose to wildlife is calculated for the mouse. These organisms spend a significant portion of time either on the ground surface or burrowing into the soil. The external dose due to burrowing beneath the soil surface for any given radionuclide $i$ is estimated by

$$
\mathrm{R}_{\mathrm{b}, \mathrm{c}}=\frac{\left(A_{s, i}\right)\left(D F_{b, i}\right)\left(E F_{b, c}\right)\left(C F_{1}\right)}{(I)\left(C F_{2}\right)}
$$


where

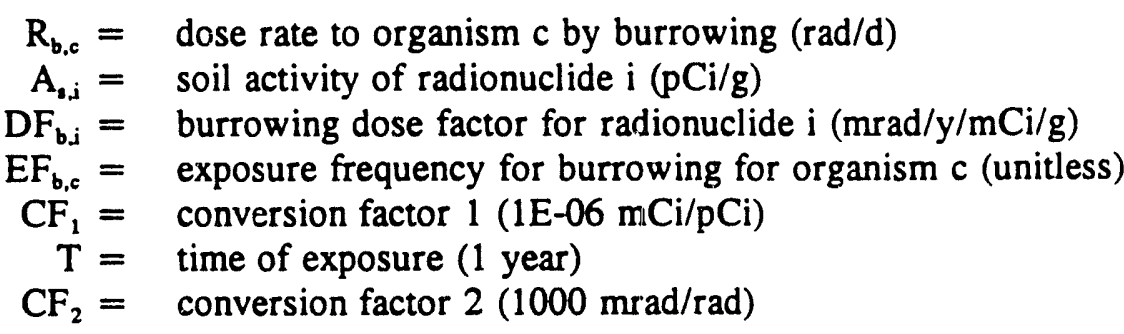

The external dose from exposure at the soil surface is estimated by

$$
\mathrm{R}_{\mathrm{a}, \mathrm{c}}=\frac{\left(A_{s, i}\right)\left(D F_{a, i}\right)\left(E F_{a}\right)(R F)\left(C F_{1}\right)}{(T)\left(C F_{2}\right)}
$$

where

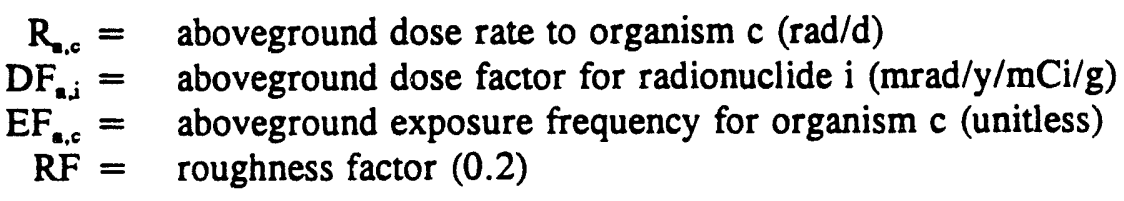

The total dose for external exposure for a radionuclide is the sum of burrowing and aboveground exposure. The exposure frequencies for the mouse are chosen by best professional judgment, and are judged suitable for evaluating base conditions of the ERDF.

6.2.2.1.4 Exposure Profile. The estimated exposure for the mouse for each evaluated pathway are reported below. The risks associated with these exposures are reported in Section 6.2.2.3. The estimated concentrations (or activities) in vegetation of the organic, inorganic, and radiological contaminants are shown in Tables $6-33,-34$, and -35 , respectively. There are no site-specific data to evaluate the estimated concentration. These concentrations were used to estimated the contaminant intake rates for the receptors.

Calculated contaminant intake or dose to wildlife species for organics, inorganics, and radionuclides are given in Tables 6-36, 6-37, and 6-38, respectively. These estimates are based on the exposure pathways chosen for evaluation.

This assessment is only for evaluating the base condition of the ERDF facility and the intakes are not predictive or representative of actual contaminaint concentrations or activities in receptors. These estimates of contaminant concentrations are used together with toxicity information to evaluate potential risk posed by the ERDF under the assumption that there is a loss of institutional control and the cover barrier is breached. There are no representative biota sampling data that can be used for verification or comparison with these estimates.

6.2.2.2.2 Characterization of Ecological Effects. The ecological risk assessment focuses on potential adverse effects to wildlife receptors as a consequence of exposure to contaminants that will be disposed at the ERDF. Ecological effects are characterized by identifying critical intake or exposure values that could result in adverse effects to wildlife 
receptors. The risk to wildlife was assessed by comparisons of predicted intakes to intakes associates with observed (or unobserved) effects.

For organic and inorganic contaminants, the desired toxic endpoint is the NOAEL. The NOAELs used in this assessment were derived using data and methodology cited in Opresko et al. (1993). For several chemicals or analytes, no toxicity information could be identified. These were not evaluated and are so noted in the results.

For radionuclides, Rose (1992) provides an inclusive review on the effects of ionizing radiation on terrestrial organisms that includes the sensitivities of wildlife to ionizing radiation. Rose (1992) reported the lower limits of lethal effects for chronic irradiation was $360 \mathrm{rad} / \mathrm{yr}$ or roughly $1 \mathrm{rad} / \mathrm{d}$ for several American rodents. The lower dose limit for red pine (Pinus resinosa) was reported to be around 0.82 to $1.64 \mathrm{rad} / \mathrm{d}$ for continuous exposure. A dose of $0.008 \mathrm{rad} / \mathrm{d}$ was the lowest dose that produced an effect on the fetuses of laboratory rats irradiated during the third period of intrauterine life. It was found that body mass was reduced and brain mass increased at birth. The increase in brain mass was the result of nerve tissue and not edema. An exposure of $0.49 \mathrm{rad} / \mathrm{d}$ did not effect the growth rate of several American rodents, e.g., Peromyscus leucopus. Pocket mice (Pergnathus formosus) were reported unaffected at a dose of $0.96 \mathrm{rad} / \mathrm{d}$.

In another extensive review of the affects of ionizing radiation on terrestrial organisms, the International Atomic Energy Agency (IAEA 1992) concluded that a "dose rate of approximately $10 \mathrm{mGy} / \mathrm{d}(1 \mathrm{rad} / \mathrm{d})$ represents the threshold at which slight effects of radiation become apparent in those attributes, e.g., reproduction capacity, which are of importance for the maintenance of the population." The IAEA concluded that "reproduction was the population attribute most sensitive to damage from chronic irradiation and also the attribute of greatest significance in the ecological context." On the basis of the studies reported in the scientific literature, a dose rate of $1 \mathrm{rad} / \mathrm{d}$ is the benchmark dose chosen to evaluate potential effects to wildlife receptors from exposure to radionuclides.

\subsubsection{Risk Characterization}

6.2.2.3.1 Risk to Receptors. The likelihood of eliciting an adverse effect to receptor species was estimated through an environmental hazard quotient (EHQ). The EHQ is defined as the ratio of the contaminant dose to some benchmark dose (e.g., NOAEL). The EHQ ratio is used to assess the potential adverse effect to an individual. For example, an EHQ that approaches or exceeds unity would strongly indicate a potential for adverse effects to an individual. Community effects are addressed qualitatively, based on the potential for adverse effects to an individual. The EHQ was only calculated for non-radiological contaminants.

The calculated EHQ for contaminants that will be disposed of at the ERDF are reported in Tables 6-36 and 6-37 for organic and inorganic contaminants, respectively. For radionuclides (Table 6-38), those exposures that exceed the $1 \mathrm{rad} /$ day benchmark are shaded.

The presence of an uncontrolled waste site would pose a significant risk to the environment based primarily on the heavy metal concentrations. The results show that there are organic and inorganic contaminants that represent a potential hazard to the wildlife receptors due to ingestion through the food chain. The total dose (from ingestion and external exposure) to the mouse from radionuclides would exceed $1 \mathrm{rad} / \mathrm{d}$. This assessment shows that the dose from external exposure was more significant than ingestion. Cesium-137, cobalt-60, europium-152, 
strontium-90, and uranium-238 (total) were the principal radionuclides that contribute to the dose received by the receptors.

In addition to evaluating current hazards associated with the ERDF as an uncontrolled waste site, the hazards are evaluated for different times in the future: 103 years, 500 years, and 10,000 years. This analysis accounts for the degradation of organic chemicals and radioactive decay. It was assumed that inorganics do not degrade with time. Tables 6-39 (organics) and 640 (radionuclides) show the estimated current and future hazard to the pocket mouse. After 500 years, the organic chemicals evaluated would degrade to levels that pose minimal risk. After 103 years, radionuclide activity would decay to levels that pose minimal risk.

6.2.2.3.2 Uncertainty. This ecological risk assessment is based only on estimates of an assumed exposure to the maximum concentration of all contaminants that may be disposed of at the ERDF. There is little likelihood that the evaluated scenario would occur. This evaluation does not calculate or incorporate the likelihood of this occurrence. There are no empirical data that can be used to validate the exposure estimates in this risk assessment. Estimating the potential exposure of a receptor to contaminants also required the use of a number of parameters for which there are no data. Many of these parameters are based on professional judgment in the absence of site- or species-specific information. Modeling from soil to potential ecological receptors required a number of assumptions including soil-to-plant, and plant-to-animal transfer factors or coefficients. If the review of the literature produced a range of values, the highest transfer factor was used in an attempt to be protective of the cnvironment. No evaluation or critical review was conducted to determine if these transfer coefficients are relevant to conditions at the proposed ERDF site. The lack of species specific toxicity information and the assumptions and uncertainties incorporated into the estimates of NOAELs is another source of uncertainty.

\subsection{RISK ASSESSMENT OF SOILS FOR THE 500-YEAR DRILLING SCENARIO}

This section extends the risk assessment provided in Section 6.2 (for current exposure to soils) to determine the risks associated with the 500-year drilling scenario. As discussed below, this scenario is considered a reasonable soil exposure scenario for all the remedial alternatives (except no action) evaluated in Chapter 9.

All of the alternatives evaluated in Chapter 9 include active institutional controls (e.g., fences, signs, patrols), passive controls (e.g., markers and off-site records), and a surface barrier that is at least $4.6 \mathrm{~m}$ (15 feet) thick. It is assumed that institutional controls prevent intrusion into the waste for at least 100 years and that passive controls prevent intrusion for 500 years. Furthermore, it is assumed that because the waste is covered with at least $4.6 \mathrm{~m}(15 \mathrm{ft})$ of cover materials, intrusion into the waste due to excavation is precluded. Since none of the evaluated barriers can prevent penetration by a drilling rig, however, it is reasonable to assume that someone might inadvertently drill through the waste sometime after 500 years. The likelihood that someone will drill through the waste is not addressed.

This scenario assumes that 500 years of decay have occurred before the waste is brought to the surface. The decay parameters for organic contaminants and radionuclides are provided in Table 4-5 and 4-6 (inorganics are assumed not to decay). The drilling scenario assumes that waste is brought to the surface in the form of drill cuttings and eventually spread over an area

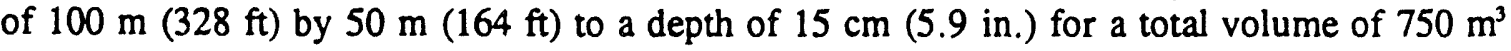


$\left(26,000 \mathrm{ft}^{3}\right)$. Assuming a drill bit diameter of $20 \mathrm{~cm}(7.9 \mathrm{in}$.) and a waste thickness of $20 \mathrm{~m}$ $(66 \mathrm{ft})$ the total volume of waste brought to the surface is $0.63 \mathrm{~m}^{3}\left(22 \mathrm{ft}^{3}\right)$. Dividing the volume of surface soil by the amount of waste results in a dilution factor of 1,190 , which is rounded down to 1,000 .

\subsubsection{Human Health Evaluation}

The human health risks associated with soil exposure to contaminants 500 years after the ERDF is closed are summarized in Table 6-27 for organic contaminants and Table 6-28 for radionuclides. Since metals do not decay, risks associated with metal contaminants 500 years after the ERDF is closed are the same as current risks (presented in Table 6-23). These risks are then diluted by a factor of 1,000 to reflect dilution with clean surface soils and the results are presented in Table 6-41 for non-radionuclides and Table 6-42 for radionuclides. The total hazard quotient is 0.05 and the maximum HQ is associated with copper $(0.03)$. The total ICR is $9 \times 10^{-7}$ for non-radionuclides (dominated by arsenic, beryllium, and chromium) and $3 \times 10^{-5}$ for radionuclides (dominated almost entirely by uranium). Because uptake factors for these contaminants are relatively low, inclusion of a produce ingestion pathway is unlikely to significantly increase these risk values. The predicted HQ and ICR associated with the drilling scenario are below the goals established in the Tri-Party Agreement of 1 for HQ and $1 \times 10^{-4}$ for ICR.

\subsubsection{Ecological Evaluation of the Intruder Scenario}

The intruder scenario results in a release of contaminants buried in the ERDF to the environment. This scenario occurs 500 years in the future and the circumstances of the release (well drilling) results in a thousand-fold dilution of the contaminant concentration. The ecological evaluation of base conditions (Section 6.2.2) showed that after 500 years of decay and degradation, radiological and organic contaminants had EHQs less than one. Therefore, there is little possibility of ecological impacts resulting from an intrusion into the ERDF waste at 500 years in the future. For inorganic contaminants, there is no change in concentration due to decay or degradation. The thousand-fold dilution results, however, in a thousand-fold reduction in the EHQs for inorganic contaminants. These results are shown in Table 6-43. The only contaminant that results in an EHQ that is greater than one is copper with an EHQ of 12 . This indicates that there is a possibility of risk to environmental receptors associated with the intrusion scenario. It should be noted, however, that the background concentration of copper in soil $(28.2 \mathrm{mg} / \mathrm{kg}$; DOE-RL 1993i) results in an EHQ of 3, which has not resulted in an identifiable adverse impact to the environment. It is evident that the environmental exposure analysis results in an overestimate of risk to environmental receptors. The estimate of an EHQ of 12 for the intrusion scenario (due to copper) is within an order of magnitude of the EHQ calculated for background soils, which is typical of the uncertainty associated with risk estimates. Thus, it is likely that the intrusion scenario will not result in adverse impacts to the environment from any potential contaminants disposed in the ERDF. 


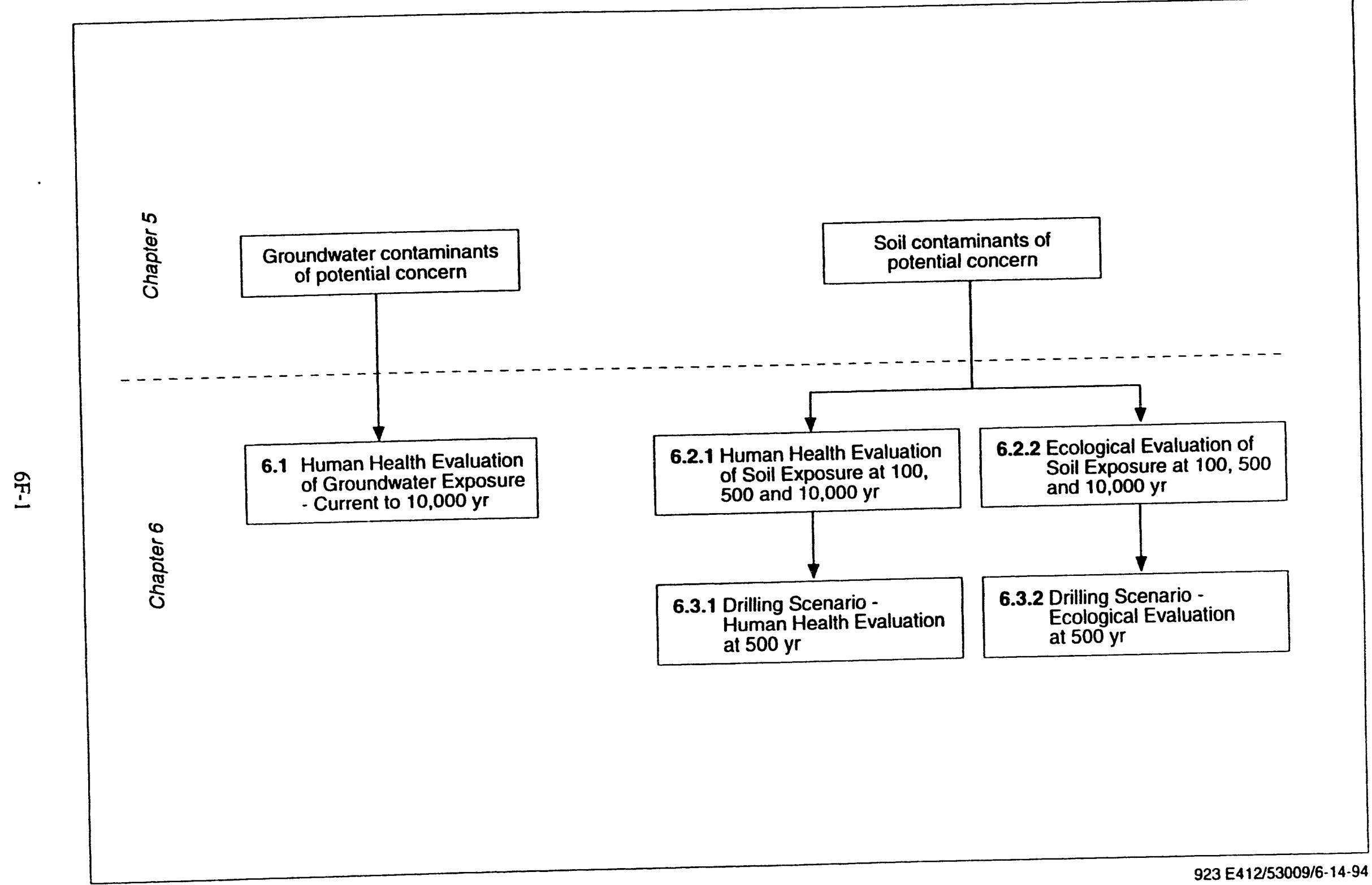

Figure 6-1. Overview of Risk Assessment of Base Conditions. 


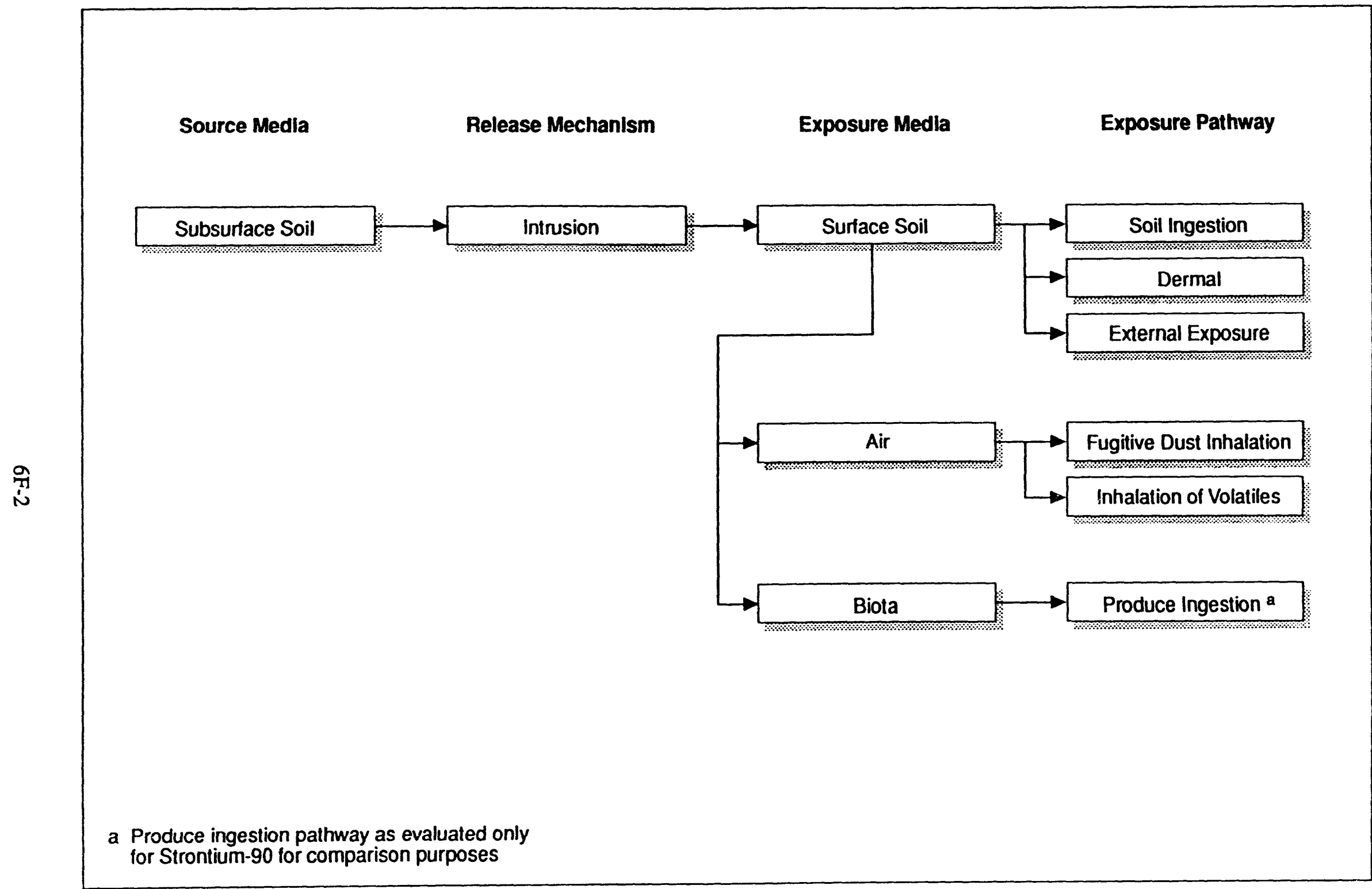

Figure 6-2. Human Health Conceptual Model for Exposure to Contaminated Soils. 


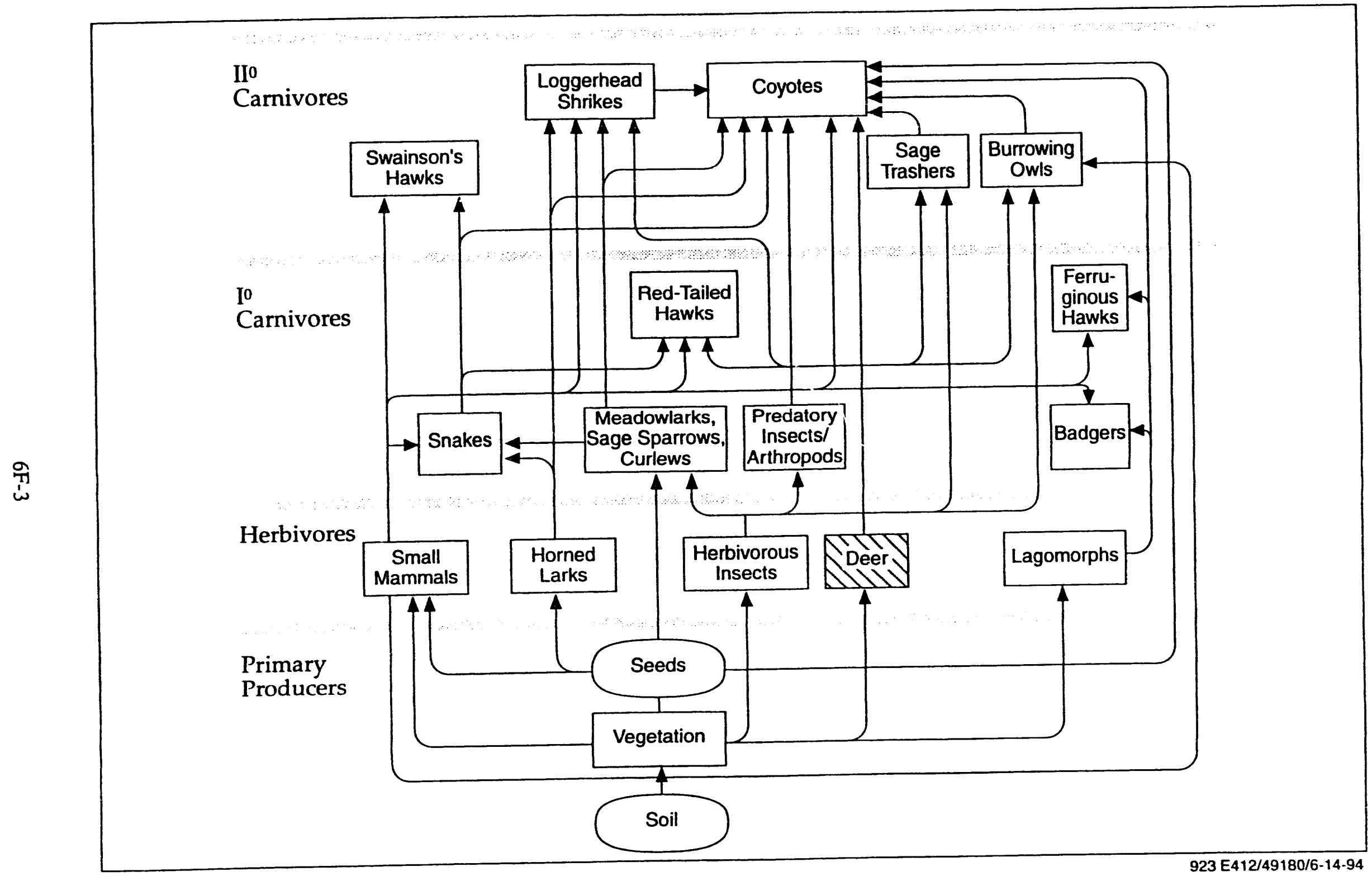

Figure 6-3. Conceptual Model for the Ecological Risk Assessment of the Environmental Restoration Disposal Facility. 
Table 6-1. Residential Scenario Exposure Factors for Noncarcinogenic Contaminants ${ }^{\mathrm{a}}$.

\begin{tabular}{|c|c|c|c|c|c|c|c|c|}
\hline \multicolumn{2}{|c|}{ Exposure Pathway } & \multicolumn{9}{|c|}{ Exposure Parameters } \\
\hline Media & Route & $\begin{array}{c}\text { Daily Intake } \\
\text { Rate }\end{array}$ & $\begin{array}{c}\text { Exposure } \\
\text { Frequency } \\
(\mathrm{d} / \mathrm{yr})\end{array}$ & $\begin{array}{c}\text { Exposure } \\
\text { Duration } \\
(\mathrm{yr})\end{array}$ & $\begin{array}{c}\text { Body Weight } \\
(\mathrm{kg})\end{array}$ & $\begin{array}{c}\text { Averaging } \\
\text { Time } \\
(\mathrm{yr} \times \mathrm{d} / \mathrm{yr})\end{array}$ & $\begin{array}{c}\text { Conversion } \\
\text { Factors }\end{array}$ & $\begin{array}{c}\text { Other } \\
\text { Factors }\end{array}$ \\
\hline \hline Groundwater & Ingestion & $1 \mathrm{~L}$ & 365 & 6 & 16 & $6 \times 365$ & - & - \\
\cline { 2 - 9 } & Dermal & $\mathbf{0 . 1 7} \mathrm{hr}$ & 365 & 30 & 70 & $30 \times 365$ & $1 \mathrm{~L} / 1,000 \mathrm{~cm}^{3}$ & $20,000 \mathrm{~cm}^{2} \mathrm{~K}_{\mathrm{p}}$ \\
\hline aExposure parameters recommended in HSBRAM (DOE-RL 1993j).
\end{tabular}


Table 6-2. Residential Scenario Exposure Factors for Carcinogenic (Non-Radioactive) Contaminants ${ }^{\mathrm{a}}$.

\begin{tabular}{|c|c|c|c|c|c|c|c|c|}
\hline \multicolumn{2}{|c|}{ Exposure Pathway } & \multicolumn{9}{|c|}{ Exposure Parameters } \\
\hline Media & Route & $\begin{array}{c}\text { Daily Intake } \\
\text { Rate }\end{array}$ & $\begin{array}{c}\text { Exposure } \\
\text { Frequency } \\
(\mathrm{d} / \mathrm{yr})\end{array}$ & $\begin{array}{c}\text { Exposure } \\
\text { Duration } \\
(\mathrm{yr})\end{array}$ & $\begin{array}{c}\text { Body } \\
\text { Weight (kg) }\end{array}$ & $\begin{array}{c}\text { Averaging } \\
\text { Time } \\
\text { (yr x d/yr) }\end{array}$ & $\begin{array}{c}\text { Conversion } \\
\text { Factors }\end{array}$ & $\begin{array}{c}\text { Other } \\
\text { Factors }\end{array}$ \\
\hline \hline Groundwater & Ingestion & $2 \mathrm{~L}$ & 365 & 30 & 70 & $70 \times 365$ & -- & -- \\
\cline { 2 - 9 } & Dermal & $0.17 \mathrm{hr}$ & 365 & 30 & 70 & $70 \times 365$ & $1 \mathrm{~L} / 1,000 \mathrm{~cm}^{3}$ & $20,000 \mathrm{~cm}^{2} \mathrm{~K}_{\mathrm{p}}$ \\
\hline
\end{tabular}


Table 6-3. Residential Scenario Exposure Factors for Radioactive Contaminants ${ }^{\mathbf{a}}$.

\begin{tabular}{|c|c|c|c|c|c|c|}
\hline \multicolumn{2}{|c|}{ Exposure Pathway } & \multicolumn{5}{|c|}{ Exposure Parameters } \\
\hline Media & Route & $\begin{array}{c}\text { Daily Intake } \\
\text { Rate }\end{array}$ & $\begin{array}{c}\text { Exposure } \\
\text { Frequency } \\
\text { (d/yr) }\end{array}$ & $\begin{array}{c}\text { Exposure } \\
\text { Duration } \\
\text { (yr) }\end{array}$ & $\begin{array}{c}\text { Conversion } \\
\text { Factors }\end{array}$ & $\begin{array}{c}\text { Other } \\
\text { Factors }\end{array}$ \\
\hline \hline Groundwater & Ingestion & 2L & 365 & 30 & - & - \\
\hline
\end{tabular}


Table 6-4. Residential Summary Intake Factors ${ }^{\mathrm{a}}$.

\begin{tabular}{|c|c|c|c|c|}
\hline \multicolumn{2}{|c|}{ Exposure Pathway } & \multicolumn{3}{|c|}{ Summary Intake Factors } \\
\hline Media & Route & Noncarcinogenic & $\begin{array}{c}\text { Carcinogenic } \\
\text { (Non-Radioactive) }\end{array}$ & Radioactive \\
\hline \multirow[t]{2}{*}{ Groundwater } & Ingestion & $6.3 \mathrm{E}-02$ & $1.2 \mathrm{E}-02$ & $2.2 \mathrm{E}+04$ \\
\hline & Dermal & $4.9 \mathrm{E}-02 \times \mathrm{K}_{\mathrm{p}}^{\mathrm{b}}$ & $2.1 \mathrm{E}-02 \times \mathrm{K}_{\mathrm{p}}^{\mathrm{b}}$ & NA \\
\hline
\end{tabular}


DOE/RL-93-99, Rev. 0

Table 6-5. Intakes and Risk Values for Groundwater Contaminants via Ingestion.

\begin{tabular}{|c|c|c|c|c|}
\hline \multirow[t]{2}{*}{ Contaminant } & \multicolumn{2}{|c|}{ Noncarcinogen } & \multicolumn{2}{|c|}{ Carcinogen } \\
\hline & Intake & HQ & Intake & ICR \\
\hline Inorganic Constituents & $(\mathrm{mg} / \mathrm{kg}-\mathrm{d})$ & & $(\mathrm{mg} / \mathrm{kg}-\mathrm{d})$ & \\
\hline $\begin{array}{l}\text { Antimony } \\
\text { Arsenic } \\
\text { Chromium (VI) } \\
\text { Fluoride } \\
\text { Nitrite (as N) } \\
\text { Selenium }\end{array}$ & $\begin{array}{c}2.4 \mathrm{E}+00 \\
3.8 \mathrm{E}+00 \\
3.8 \mathrm{E}+00 \\
3.8 \mathrm{E}+00 \\
3.8 \mathrm{E}-01 \\
1.5 \mathrm{E}+00\end{array}$ & $\begin{array}{l}6 E+03 \\
1 E+04 \\
8 E+02 \\
6 E+01 \\
4 E+00 \\
3 E+02\end{array}$ & $7.2 E-01$ & $>1 E-02(1 E+00)$ \\
\hline Radionuclides & NA & NA & $(\mathrm{pCi})$ & \\
\hline $\begin{array}{l}\text { Carbon-14 } \\
\text { Technetium-99 } \\
\text { Uranium (total) }\end{array}$ & & & $\begin{array}{l}2.9 E+10 \\
5.1 E+07 \\
2.4 E+07\end{array}$ & $\begin{array}{c}>1 \mathrm{E}-02(3 \mathrm{E}-02) \\
7 \mathrm{E}-05 \\
7 \mathrm{E}-04\end{array}$ \\
\hline \multicolumn{5}{|c|}{$\begin{array}{l}\text { HQ = hazard quotient } \\
\text { ICR = lifetime incremental cancer risk } \\
\text { NA = not applicable } \\
\text { Note: Blank cells indicate that toxicity values are currently unavailable with which to evaluate } \\
\text { groundwater ingestion. } \\
\text { ICR values in parentheses are calculated using a linear cancer risk equation (Equation } \\
\text { 6-5), and are not intended to represent accurate cancer risk estimates. }\end{array}$} \\
\hline
\end{tabular}


Table 6-6. Intakes and Risk Values for Dermal Exposure to Groundwater ${ }^{\mathrm{a}}$.

\begin{tabular}{|l|c|c|c|c|c|}
\hline \multirow{2}{*}{ Contaminant } & Permeability & \multicolumn{2}{c|}{ Noncarcinogen } & \multicolumn{2}{c|}{ Carcinogen } \\
\cline { 3 - 6 } & Factor, $\mathrm{K}_{\mathrm{p}}(\mathrm{cm} / \mathrm{hr})^{\mathrm{b}}$ & Intake & $\mathrm{HQ}$ & Intake & ICR \\
\hline Inorganic Constituents & & $(\mathrm{mg} / \mathrm{L})$ & & $(\mathrm{mg} / \mathrm{L})$ & \\
\hline Antimony & $1.0 \mathrm{E}-03$ & $1.9 \mathrm{E}-03$ & $5 \mathrm{E}+02$ & & \\
Arsenic & $1.0 \mathrm{E}-03$ & $2.9 \mathrm{E}-03$ & $2 \mathrm{E}+01$ & $1.3 \mathrm{E}-03$ & $5 \mathrm{E}-03$ \\
Chromium (VI) & $1.0 \mathrm{E}-03$ & $2.9 \mathrm{E}-03$ & $6 \mathrm{E}+00$ & & \\
Fluoride & $1.0 \mathrm{E}-03$ & $2.9 \mathrm{E}-03$ & $5 \mathrm{E}-02$ & & \\
Nitrite (as N) & $1.0 \mathrm{E}-03$ & $3.0 \mathrm{E}-04$ & $3 \mathrm{E}-03$ & & \\
Selenium & $1.0 \mathrm{E}-03$ & $1.2 \mathrm{E}-03$ & $5 \mathrm{E}+00$ & & \\
& & & & & \\
\hline HQ $=$ hazard quotient & & & & \\
ICR = lifetime incremental cancer risk & & & \\
aRadionuclides are not evaluated for the dermal pathway. \\
bEPA 1992b.
\end{tabular}


Table 6-7. Summary of Systemic Toxicity Information for Contaminants of Potential Concern.

\begin{tabular}{|c|c|c|c|c|c|c|}
\hline Contaminant & $\begin{array}{l}\text { Oral RfD } \\
\mathrm{mg} / \mathrm{kg}-\mathrm{d}\end{array}$ & $\begin{array}{c}\text { Oral RfD } \\
\text { (basis/source) }\end{array}$ & $\begin{array}{c}\text { Confidence } \\
\text { Level }^{\mathrm{a}}\end{array}$ & $\begin{array}{r}\text { Critical } \\
\text { Effect }\end{array}$ & $\begin{array}{l}\text { Uncertainty } \\
\text { Factors }\end{array}$ & $\begin{array}{l}\text { Modifying } \\
\text { Factors }\end{array}$ \\
\hline Antimony & 4.0E-04 & water/IRIS & $\mathbf{L}$ & $\begin{array}{l}\text { longevity, altered blood } \\
\text { chemistry }\end{array}$ & 1,000 & 1 \\
\hline Arsenic & $3.0 \mathrm{E}-04$ & water/IRIS & $\mathbf{M}$ & hyperpigmentation, keratosis & 3 & 1 \\
\hline Chromium (V!) & $5.0 \mathrm{E}-03$ & water/IRIS & L & none observed & 500 & 1 \\
\hline Fluoride & $6.0 \mathrm{E}-02$ & water/IRIS & $\mathbf{H}$ & $\begin{array}{l}\text { cosmetic effect of dental } \\
\text { fluorosis }\end{array}$ & 1 & 1 \\
\hline Nitrite (as N) & $1.0 \mathrm{E}-01$ & water/IRIS & $\mathbf{H}$ & methemoglobinemia & 1 & 10 \\
\hline Selenium & $5.0 \mathrm{E}-03$ & food/IRIS & $\mathbf{M}$ & selenosis & 3 & 1 \\
\hline $\begin{array}{l}a_{L}=\text { low, } M= \\
\text { RfD }= \\
\text { IRIS }=\end{array}$ & $\begin{array}{l}\text { nce dose } \\
\text { rated Risk }\end{array}$ & rmation System & A 1993a) & & & \\
\hline
\end{tabular}



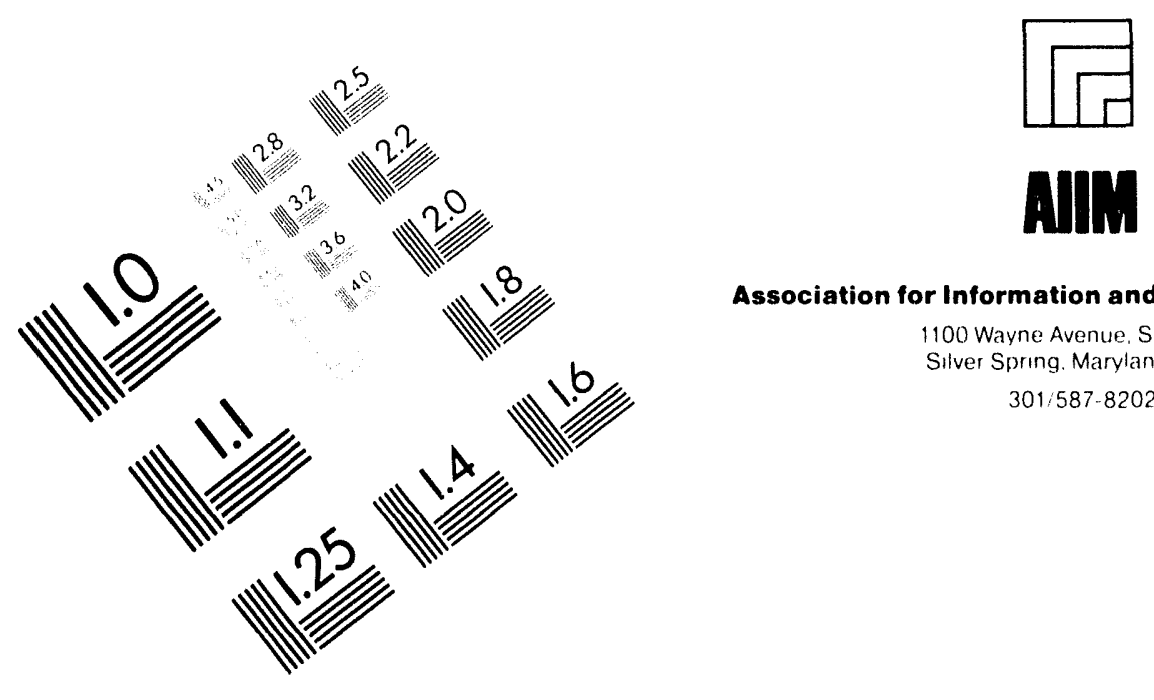

Association for Information and Image Management

1100 Wayne Avenue. Sulte 1100

Silver Spring. Maryland 20910

301/587-8202

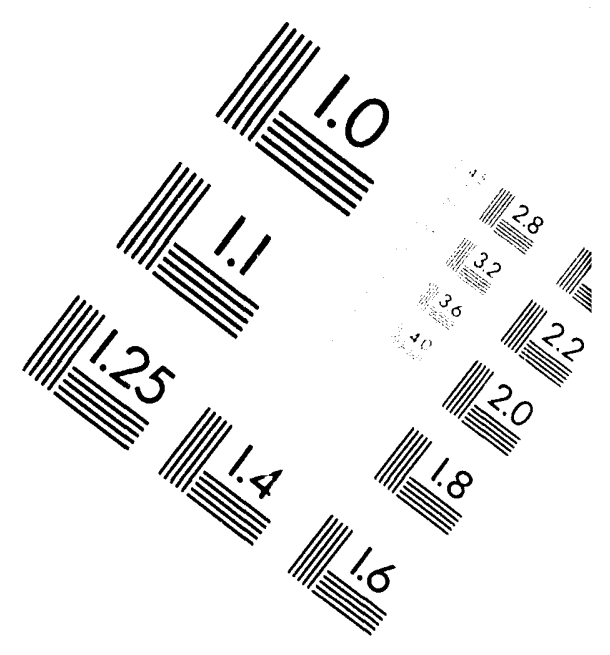

Centimeter

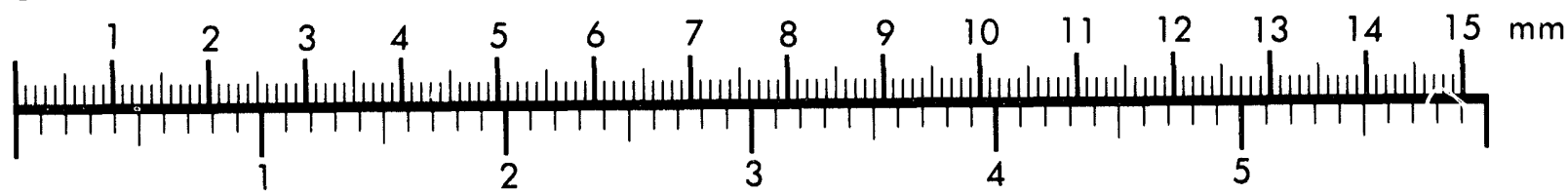

Inches
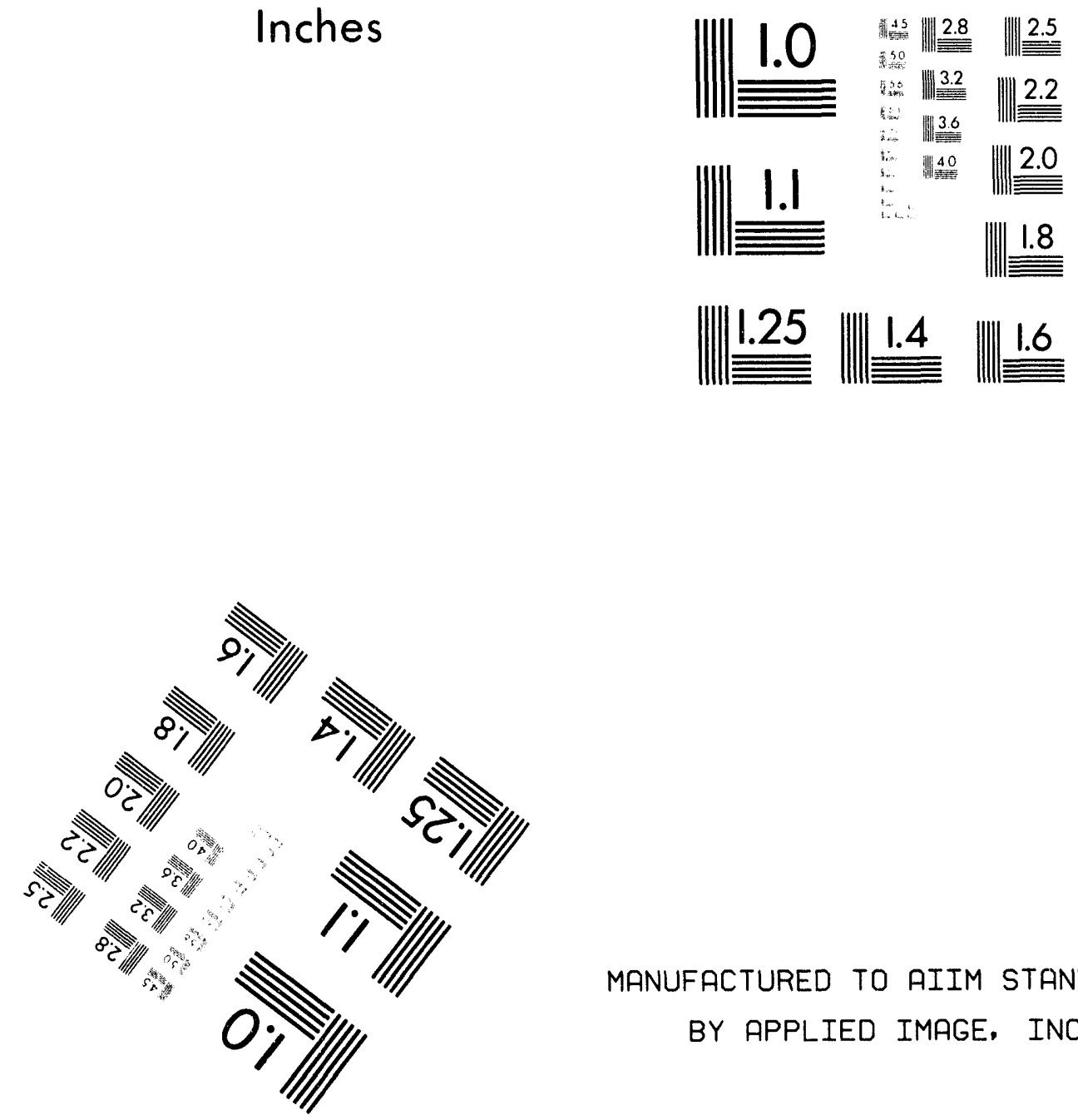

MANUFACTURED TO AIIM STANDARDS

BY APPLIED IMAGE, INC.

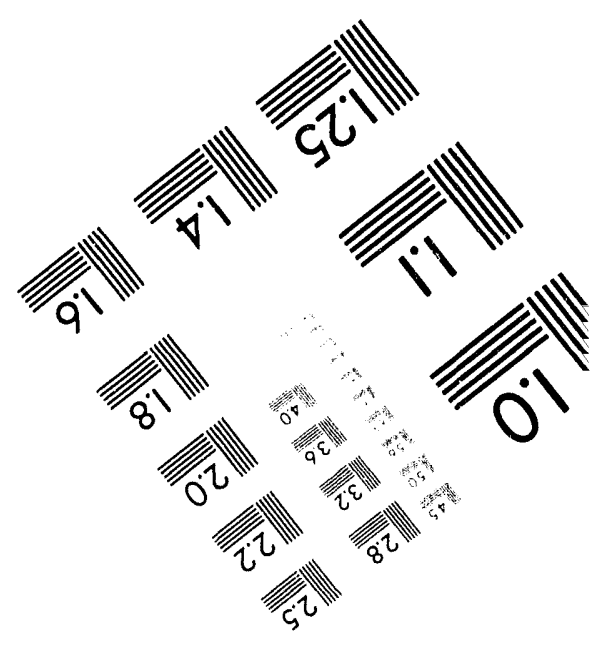



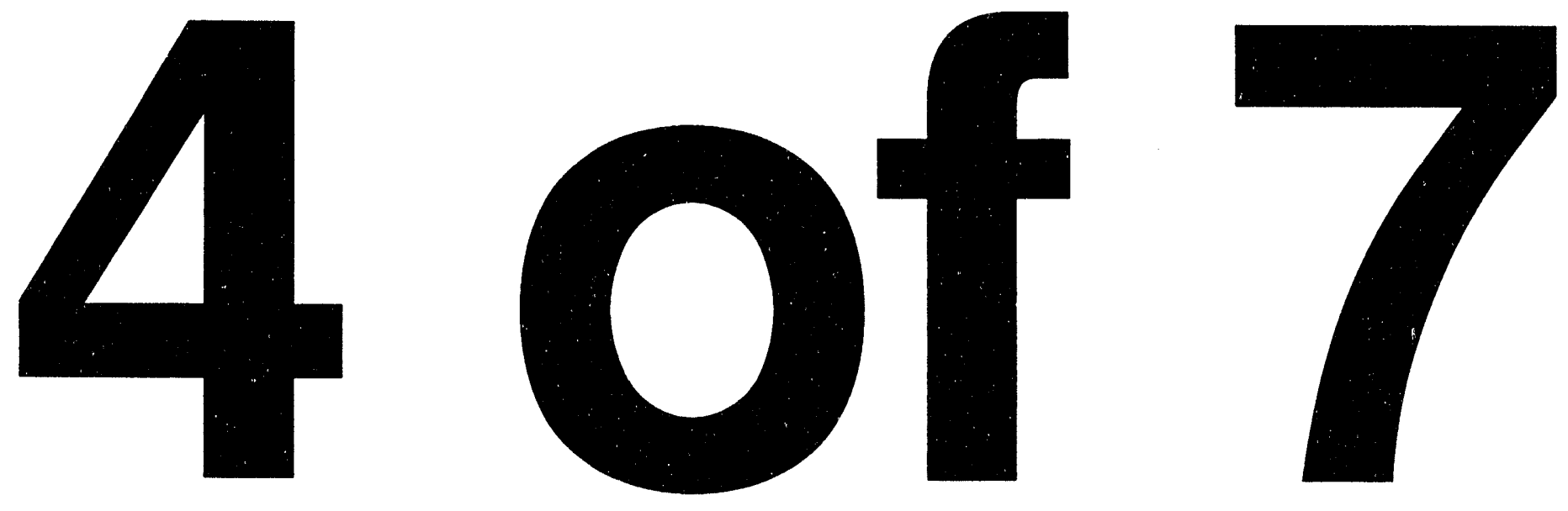
Table 6-8. Summary of Carcinogenic Toxicity Information for Contaminants of Potential Concern.

\begin{tabular}{|l|c|c|c|c|}
\hline \multicolumn{1}{|c|}{ Contaminant } & $\begin{array}{c}\text { Weight of Evidence } \\
\text { Classification }\end{array}$ & Type of Cancer & Oral SF & Source \\
\hline \hline Non-radioactive & & & $(\mathrm{mg} / \mathrm{kg}-\mathrm{d})^{-1}$ & \\
\hline \hline Arsenic & $\mathrm{A}$ & lung, skin & $2 \mathrm{E}+00^{\mathrm{a}}$ & IRIS \\
\hline \hline Radioactive & & & $(\mathrm{pCi})^{-1}$ & \\
\hline \hline Carbon-14 & $\mathrm{A}$ & $\mathrm{ND}^{\mathrm{b}}$ & $9.0 \mathrm{E}-13$ & HEAST \\
Technetium-99 & $\mathrm{A}$ & $\mathrm{ND}^{\mathrm{b}}$ & $1.3 \mathrm{E}-12$ & HEAST \\
Uranium (total) & ND & $2.8 \mathrm{E}-11$ & HEAST \\
\hline aBased on proposed arsenic unit risk of 5E-05 ( $\mu \mathrm{g} / \mathrm{L})^{-1} \cdot$ \\
bCarcinogenic effects of radioactive contaminants are based on effects of ionizing radiation \\
generally. Human epidemiology data provide inadequate evidence of carcinogenicity for \\
these isotopes. \\
cUranium-238+D slope factor is used to evaluate total uranium. \\
SF $=$ slope factor \\
ND $=$ not determined \\
IRIS = Integrated Risk Information System (EPA 1993a) \\
HEAST = Health Effects Assessment Summary Tables (EPA 1993b) \\
\hline
\end{tabular}


DOE/RL-93-99, Rev. 0

Table 6-9. Dermal Toxicity Values for Groundwater Contaminants of Potential Concern. ${ }^{a}$

\begin{tabular}{|c|c|c|c|}
\hline \multirow{3}{*}{ Contaminant } & \multirow{2}{*}{$\begin{array}{l}\text { GI Absorption } \\
\text { Fraction }\end{array}$} & \multicolumn{2}{|c|}{ Dermal } \\
\hline & & RfD & SF \\
\hline & (unitless) & $(\mathrm{mg} / \mathrm{kg}-\mathrm{d})$ & $(\mathrm{mg} / \mathrm{kg}-\mathrm{d})^{-1}$ \\
\hline \multicolumn{4}{|l|}{ Inorganic Constituents } \\
\hline Antimony & $1 E-02^{C}$ & $4.0 \mathrm{E}-06$ & \\
\hline Arsenic & $5 \mathrm{E}-01^{\mathrm{c}}$ & $1.5 \mathrm{E}-04$ & $4.0 \mathrm{E}+00$ \\
\hline Chromium (VI) & $1 \mathrm{E}-01^{\mathrm{c}}$ & $5.0 \mathrm{E}-04$ & \\
\hline Fluoride & $1 \mathrm{E}+00^{\mathrm{b}}$ & $6.0 \mathrm{E}-02$ & \\
\hline Nitrite (as N) & $1 \mathrm{E}+00^{\mathrm{b}}$ & $1.0 \mathrm{E}-01$ & \\
\hline Selenium & $5 \mathrm{E}-02^{\mathrm{C}}$ & $2.5 \mathrm{E}-04$ & \\
\hline \multicolumn{4}{|c|}{ 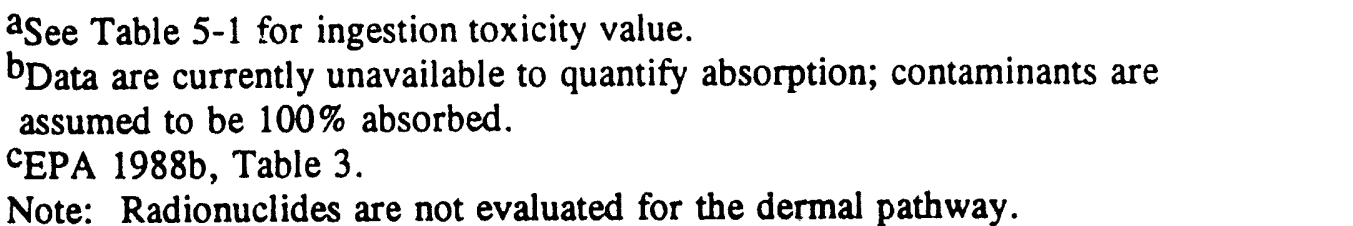 } \\
\hline
\end{tabular}


DOE/RL-93-99, Rev. 0

Table 6-10. Summary of Groundwater Contaminants Risks and Travel Times.

\begin{tabular}{|c|c|c|c|}
\hline Contaminarit & $\begin{array}{c}\text { Contaminant } \\
\text { HQ Total }\end{array}$ & $\begin{array}{l}\text { Contaminant } \\
\text { ICR Total }\end{array}$ & $\begin{array}{c}\text { Travel } \\
\text { Time }^{\mathrm{a}}(\mathrm{yr})\end{array}$ \\
\hline \multicolumn{4}{|l|}{ Inorganic Constituents } \\
\hline Antimony & $7 E+03$ & & $5.2 \mathrm{E}+02$ \\
\hline Arsenic & $1 E+04$ & $>1 E-02(1 E+00)$ & $5.2 E+02$ \\
\hline Chromium (VI) & $8 \mathrm{E}+02$ & & $5.2 \mathrm{E}+02$ \\
\hline Fluoride & $6 \mathrm{E}+01$ & & $5.2 \mathrm{E}+02$ \\
\hline Nitrite (as N) & $4 E+00$ & & $5.2 E+02$ \\
\hline Selenium & $3 E+02$ & & $5.2 \mathrm{E}+02$ \\
\hline \multicolumn{4}{|l|}{ Radionuclides } \\
\hline Carbon-14 & NA & $>1 \mathrm{E}-02(3 \mathrm{E}-02)$ & $5.2 \mathrm{E}+02$ \\
\hline Technetium-99 & NA & $7 \mathrm{E}-05$ & $5.2 \mathrm{E}+02$ \\
\hline Uranium (total) & NA & $7 \mathrm{E}-04$ & $5.2 \mathrm{E}+02$ \\
\hline \multicolumn{4}{|c|}{$\begin{array}{l}\text { aFrom Table 4-11. } \\
\text { HQ = hazard quotient } \\
\text { ICR = lifetime incremental cancer risk } \\
\text { NA = not applicable } \\
\text { Shading indicates contaminants of concern. } \\
\text { Note: ICR values in parentheses are calculated using a linear cancer risk } \\
\quad \text { equation (Equation } 6-5 \text { ), and are not intended to represent accurate } \\
\text { cancer risk estimates. }\end{array}$} \\
\hline
\end{tabular}


Table 6-11. Residential Scenario Exposure Factors for Noncarcinogenic Contaminants ${ }^{\mathrm{a}}$.

\begin{tabular}{|c|c|c|c|c|c|c|c|c|}
\hline \multicolumn{2}{|c|}{ Pathway } & \multicolumn{7}{|c|}{ Exposure Parameters } \\
\hline Media & Route & $\begin{array}{c}\text { Daily Intake } \\
\text { Rate }\end{array}$ & $\begin{array}{l}\text { Exposure } \\
\text { Frequency } \\
(\mathrm{d} / \mathrm{yr})\end{array}$ & $\begin{array}{l}\text { Exposure } \\
\text { Duration } \\
(y r)\end{array}$ & $\begin{array}{c}\text { Body } \\
\text { Weight } \\
\text { (kg) }\end{array}$ & $\begin{array}{c}\text { Averaging } \\
\text { Time } \\
(\mathrm{yr} \times \mathrm{d} / \mathrm{yr})\end{array}$ & Conversion Factors & Other Factors \\
\hline \multirow[t]{2}{*}{ Soil } & Ingestion & $200 \mathrm{mg}$ & 365 & 6 & 16 & $6 \times 365$ & $1 \mathrm{E}-06 \mathrm{~kg} / \mathrm{mg}$ & - \\
\hline & Dermal & $0.2 \mathrm{mg} / \mathrm{cm}^{2}$ & 180 & $\begin{array}{c}6(C) \\
24(A)\end{array}$ & $\begin{array}{l}16(\mathrm{C}) \\
70(\mathrm{~A})\end{array}$ & $30 \times 365$ & $1 \mathrm{E}-06 \mathrm{~kg} / \mathrm{mg}$ & $\begin{array}{l}2,500 \mathrm{~cm}^{2}(\mathrm{C}) \\
5,000 \mathrm{~cm}^{2}(\mathrm{~A}) \\
\text { ABS }\end{array}$ \\
\hline Air & Inhalation & $10 \mathrm{~m}^{3}$ & 365 & 6 & 16 & $6 \times 365$ & - & - \\
\hline \multicolumn{9}{|c|}{$\begin{array}{l}\text { Exposure parameters recommended in HSBRAM (DOE-RL 1993j) } \\
C=\text { child } \\
A=\text { adult } \\
\text { ABS = chemical-specific absorption fraction }\end{array}$} \\
\hline
\end{tabular}


Table 6-12. Residential Scenario Exposure Factors for Carcinogenic (Non-Radioactive) Contaminants ${ }^{\mathrm{a}}$.

\begin{tabular}{|c|c|c|c|c|c|c|c|c|}
\hline \multicolumn{2}{|c|}{ Pathway } & \multicolumn{7}{|c|}{ Exposure Parameters } \\
\hline Media & Route & $\begin{array}{c}\text { Daily Intake } \\
\text { Rate }\end{array}$ & $\begin{array}{c}\text { Exposure } \\
\text { Frequency } \\
(\mathrm{d} / \mathrm{yr})\end{array}$ & $\begin{array}{c}\text { Exposure } \\
\text { Duration } \\
(y r)\end{array}$ & $\begin{array}{l}\text { Body } \\
\text { Weight } \\
\text { (kg) }\end{array}$ & $\begin{array}{c}\text { Averaging } \\
\text { Time } \\
(\mathrm{yr} \times \mathrm{d} / \mathrm{yr})\end{array}$ & Conversion Factors & Other Factors \\
\hline \multirow[t]{2}{*}{ Soil } & Ingestion & $\begin{array}{l}200 \mathrm{mg}(\mathrm{C}) \\
100 \mathrm{mg}(\mathrm{A})\end{array}$ & 365 & $\begin{array}{c}6(C) \\
24(A)\end{array}$ & $\begin{array}{l}16(\mathrm{C}) \\
70(\mathrm{~A})\end{array}$ & $70 \times 365$ & $1 \mathrm{E}-06 \mathrm{~kg} / \mathrm{mg}$ & - \\
\hline & Dermal & $0.2 \mathrm{mg} / \mathrm{cm}^{2}$ & 180 & $\begin{array}{c}6(C) \\
24(A)\end{array}$ & $\begin{array}{l}16(\mathrm{C}) \\
70(\mathrm{~A})\end{array}$ & $70 \times 365$ & $1 \mathrm{E}-06 \mathrm{~kg} / \mathrm{mg}$ & $\begin{array}{c}2,500 \mathrm{~cm}^{2}(\mathrm{C}) \\
5,000 \mathrm{~cm}^{2}(\mathrm{~A}) \\
\text { ABS }\end{array}$ \\
\hline Air & Inhalation & $20 \mathrm{~m}^{3}$ & 365 & 30 & 70 & $70 \times 365$ & - & - \\
\hline \multicolumn{9}{|c|}{$\begin{array}{l}\text { aExposure parameters recommended in HSERAM (DOE-RL 1993j) } \\
\mathrm{C}=\text { child } \\
\mathrm{A}=\text { adult }\end{array}$} \\
\hline
\end{tabular}


Table 6-13. Residential Scenario Exposure Factors for Radioactive Contaminants ${ }^{\mathbf{a}}$.

\begin{tabular}{|c|c|c|c|c|c|c|}
\hline \multicolumn{2}{|c|}{ Pathway } & \multicolumn{5}{|c|}{ Exposure Parameters } \\
\hline Media & Route & $\begin{array}{c}\text { Daily Intake } \\
\text { Rate }\end{array}$ & $\begin{array}{l}\text { Exposure } \\
\text { Frequency } \\
(\mathrm{d} / \mathrm{yr})\end{array}$ & $\begin{array}{l}\text { Exposure } \\
\text { Duration } \\
\text { (yr) }\end{array}$ & Conversion Factors & Other Factors \\
\hline \multirow[t]{2}{*}{ Soil } & Ingestion & $\begin{array}{l}200 \mathrm{mg}(\mathrm{C}) \\
100 \mathrm{mg}(\mathrm{A})\end{array}$ & 365 & $\begin{array}{c}6(\mathrm{C}) \\
24(\mathrm{~A})\end{array}$ & $1 \mathrm{E}-03 \mathrm{~g} / \mathrm{mg}$ & - \\
\hline & External & $24 \mathrm{hr}$ & 365 & 30 & $1.14 \mathrm{E}-04 \mathrm{yr} / \mathrm{hr}$ & 0.8 \\
\hline Air & Inhalation & $20 \mathrm{~m}^{3}$ & 365 & 30 & - & - \\
\hline Biota & Ingestion & $80 \mathrm{~g}$ & 365 & 30 & - & - \\
\hline \multicolumn{7}{|c|}{$\begin{array}{l}\text { a Exposure parameters recommended in HSBRAM (DOE-RL 1993j). } \\
\mathrm{C}=\text { child } \\
\mathrm{A}=\text { adult }\end{array}$} \\
\hline
\end{tabular}




\section{DOE/RL-93-99, Rev. 0}

Table 6-14. Residential Scenario Summary Intake Factors ${ }^{\mathrm{a}}$.

\begin{tabular}{|c|c|c|c|c|}
\hline MEDIA & ROUTE & NONCARCINOGENIC & $\begin{array}{l}\text { CARCINOGENIC } \\
\text { (Non-Radioactive) }\end{array}$ & RADIOACTIVE \\
\hline \multirow[t]{3}{*}{ Soil } & Ingestion & $1.3 \mathrm{E}-05(\mathrm{~d})^{-1}$ & $1.6 \mathrm{E}-06(\mathrm{~d})^{-1}$ & $1.3 \mathrm{E}+03 \mathrm{~g}$ \\
\hline & Dermal & 8.75E-06 $\times$ ABS $^{a}(d)^{-1}$ & 3.75E-06 $\times \mathrm{ABS}^{\wedge}(\mathrm{d})^{-1}$ & NA \\
\hline & External Exposure & NA & NA & $2.4 \mathrm{E}+01 \mathrm{yr}$ \\
\hline Air & Inhalation & $6.3 \mathrm{E}-01 \mathrm{~m}^{3} / \mathrm{kg}-\mathrm{d}$ & $1.2 \mathrm{E}-01 \mathrm{~m}^{3} / \mathrm{kg}-\mathrm{d}$ & $2.2 \mathrm{E}+05 \mathrm{~m}^{3}$ \\
\hline Biota $^{b}$ & Ingestion & - & - & $8.8 E+06 g$ \\
\hline \multicolumn{5}{|c|}{$\begin{array}{l}\text { Exposure parameters recommended in HSBRAM (DOE-RL 1993j). } \\
\text { For this report, the biota pathway is evaluated only for strontium-90. } \\
\text { ABS = Chemical-specific absorption fraction (unitless). } \\
\text { NA = not applicable }\end{array}$} \\
\hline
\end{tabular}


Table 6-15. Intakes and Risk Values for Non-Radioactive Soil Contaminants via Soil Ingestion ${ }^{\mathrm{a}}$. (Sheet 1 of 2)

\begin{tabular}{|c|c|c|c|c|}
\hline \multirow[t]{2}{*}{ Contaminant } & \multicolumn{2}{|c|}{ Noncarcinogen } & \multicolumn{2}{|c|}{ Carcinogen } \\
\hline & $\begin{array}{c}\text { Intake } \\
(\mathrm{mg} / \mathrm{kg}-\mathrm{d})\end{array}$ & HQ & $\begin{array}{c}\text { Intake } \\
\text { (mg/kg-d) }\end{array}$ & ICR \\
\hline \multicolumn{5}{|l|}{ Organic Compounds } \\
\hline Aroclor- 1248 & & & $1.6 \mathrm{E}-05$ & $1 E-04$ \\
\hline Aroclor-1254 & & & $1.0 \mathrm{E}-05$ & $8 E-05$ \\
\hline Aroclor- 1260 & & & $3.6 \mathrm{E}-06$ & $3 E-05$ \\
\hline benz(a)anthracene & & & $2.8 \mathrm{E}-06$ & $2 E-05$ \\
\hline benzene & & & $3.0 \mathrm{E}-07$ & $9 E-09$ \\
\hline benzo(a)pyrene & & & $4.2 \mathrm{E}-05$ & $3 \mathrm{E}-04$ \\
\hline benzo(b)fluoranthene & & & $3.7 \mathrm{E}-06$ & $3 E-05$ \\
\hline benzo(k)fluoranthene & & & $1.2 \mathrm{E}-06$ & $9 \mathrm{E}-06$ \\
\hline bis(2-ethylhexyl)phthalate & 4.1E-04 & $2 \mathrm{E}-02$ & $5.1 \mathrm{E}-05$ & $7 \mathrm{E}-07$ \\
\hline chloroform & $1.0 \mathrm{E}-06$ & $1 \mathrm{E}-04$ & $1.2 \mathrm{E}-07$ & $8 \mathrm{E}-10$ \\
\hline chrysene & & & $6.7 \mathrm{E}-05$ & 5E-04 \\
\hline dibenz(a,h)anthracene & & & $2.7 \mathrm{E}-06$ & 2E-05 \\
\hline dieldrin & $2.6 \mathrm{E}-07$ & $5 \mathrm{E}-03$ & $3.3 \mathrm{E}-08$ & $5 \mathrm{E}-07$ \\
\hline indeno( $1,2,3-c d)$ pyrene & & & $2.5 \mathrm{E}-06$ & $2 E-05$ \\
\hline methylene chloride & $5.6 \mathrm{E}-05$ & 9E-04 & $7.0 \mathrm{E}-06$ & 5E-08 \\
\hline pentachlorophenol & $1.9 \mathrm{E}-05$ & $6 \mathrm{E}-04$ & $2.3 \mathrm{E}-06$ & $3 \mathrm{E}-07$ \\
\hline trichloroethene & $4.9 \mathrm{E}-06$ & $8 E-04$ & $6.1 E-07$ & $7 \mathrm{E}-09$ \\
\hline vinyl chloride & & & 3.7E-08 & $7 \mathrm{E}-08$ \\
\hline \multicolumn{5}{|l|}{ Inorganic Constituents } \\
\hline aluminum & $9.8 \mathrm{E}-01$ & $1 E+00$ & & \\
\hline \multicolumn{5}{|l|}{ ammonia } \\
\hline antimony & $2.3 \mathrm{E}-04$ & $6 \mathrm{E}-01$ & & \\
\hline arsenic & 7.8E-04 & $3 E+00$ & $9.7 \mathrm{E}-05$ & $2 \mathrm{E}-04$ \\
\hline barium & $5.3 \mathrm{E}-02$ & $8 \mathrm{E}-01$ & & \\
\hline beryllium & $5.9 \mathrm{E}-05$ & $1 \mathrm{E}-02$ & $7.3 \mathrm{E}-06$ & $3 E-05$ \\
\hline
\end{tabular}


Table 6-15. Intakes and Risk Values for Non-Radioactive Soil Contaminants via Soil Ingestion. ${ }^{a}$ (Sheet 2 of 2)

\begin{tabular}{|l|c|c|c|c|}
\hline \multirow{2}{*}{ Contaminant } & \multicolumn{2}{c|}{ Noncarcinogen } & \multicolumn{2}{c|}{ Carcinogen } \\
\cline { 2 - 5 } & $\begin{array}{c}\text { Intake } \\
(\mathrm{mg} / \mathrm{kg}-\mathrm{d})\end{array}$ & HQ & $\begin{array}{c}\text { Intake } \\
(\mathrm{mg} / \mathrm{kg}-\mathrm{d})\end{array}$ & ICR \\
\hline cadmium & $3.6 \mathrm{E}-04$ & $4 \mathrm{E}-01$ & & \\
\hline chromium & $3.1 \mathrm{E}-02$ & $6 \mathrm{E}+00$ & & \\
\hline copper & $1.2 \mathrm{E}+00$ & $3 \mathrm{E}+01$ & & \\
\hline lead & & & & \\
\hline manganese & $3.8 \mathrm{E}-02$ & $3 \mathrm{E}-01$ & & \\
\hline mercury & $4.6 \mathrm{E}-04$ & $2 \mathrm{E}+00$ & & \\
\hline nickel & $2.2 \mathrm{E}-02$ & $1 \mathrm{E}+00$ & & \\
\hline silver & $4.5 \mathrm{E}-03$ & $9 \mathrm{E}-01$ & & \\
\hline thallium & $6.8 \mathrm{E}-05$ & $1 \mathrm{E}+00$ & & \\
\hline vanadium & $4.9 \mathrm{E}-03$ & $7 \mathrm{E}-01$ & & \\
\hline zinc & $7.7 \mathrm{E}-02$ & $3 \mathrm{E}-01$ & & \\
\hline
\end{tabular}

${ }^{a}$ Assuming current residential exposure to maximum detected contaminant concentrations.

$\mathrm{HQ}=$ hazard quotient

ICR $=$ lifetime incremental cancer risk

Note: Blank cells indicate that toxicity values are currently unavailable with which to evaluate soil ingestion. 
DOE/RL-93-99, Rev. 0

Table 6-16. Intake and Risk Values for Non-Radioactive Soil Contaminants via Dermal Pathway. ${ }^{a}$ (Sheet 1 of 2)

\begin{tabular}{|c|c|c|c|c|c|}
\hline \multirow[t]{2}{*}{ Contaminant } & \multirow{2}{*}{$\begin{array}{c}\text { ABS } \\
\text { (unitless) }\end{array}$} & \multicolumn{2}{|c|}{ Noncarcinogen } & \multicolumn{2}{|c|}{ Carcinogen } \\
\hline & & $\begin{array}{c}\text { Intake } \\
(\mathrm{mg} / \mathrm{kg}-\mathrm{d})\end{array}$ & HQ & $\begin{array}{c}\text { Intake } \\
(\mathrm{mg} / \mathrm{kg}-\mathrm{d})\end{array}$ & ICR \\
\hline \multicolumn{6}{|l|}{ Organic Compounds } \\
\hline Aroclor -1248 & $6 \mathrm{E}-02^{\mathrm{b}}$ & & & $2.2 \mathrm{E}-06$ & $2 E-05$ \\
\hline Aroclor- 1254 & $6 \mathrm{E}-02^{\mathrm{b}}$ & & & $1.4 \mathrm{E}-06$ & $1 \mathrm{E}-05$ \\
\hline Aroclor -1260 & $6 \mathrm{E}-02^{\mathrm{b}}$ & & & $5.2 \mathrm{E}-07$ & 4E-06 \\
\hline benz(a)anthracere & $5 \mathrm{E}-02^{\mathrm{c}}$ & & & $3.4 \mathrm{E}-07$ & $2 E-06$ \\
\hline benzene & $3 \mathrm{E}-01^{\mathrm{C}}$ & & & 2.1E-07 & $6 \mathrm{E}-09$ \\
\hline benzo(a)pyrene & $5 \mathrm{E}-02^{\mathrm{C}}$ & & & $5.0 \mathrm{E}-06$ & 4E-05 \\
\hline benzo(b)fluoranthene & $5 E-02^{C}$ & & & 4.5E-07 & $3 E-06$ \\
\hline benzo(k)fluoranthene & $5 \mathrm{E}-02^{\mathrm{C}}$ & & & $1.4 \mathrm{E}-07$ & $1 \mathrm{E}-06$ \\
\hline bis(2-ethylhexyl)phthalate & $5 \mathrm{E}-02^{\mathrm{c}}$ & $1.4 \mathrm{E}-05$ & $7 \mathrm{E}-04$ & $6.2 \mathrm{E}-06$ & 9E-08 \\
\hline chloroform & $3 \mathrm{E}-01^{\mathrm{c}}$ & 2.1E-07 & $2 \mathrm{E}-05$ & $9.0 \mathrm{E}-08$ & $5 \mathrm{E}-10$ \\
\hline chrysene & $5 \mathrm{E}-02^{\mathrm{C}}$ & & & $8.0 \mathrm{E}-06$ & $6 \mathrm{E}-05$ \\
\hline $\operatorname{dibenz}(\mathrm{a}, \mathrm{h})$ anthracene & $5 \mathrm{E}-02 \mathrm{C}$ & & & $3.2 \mathrm{E}-07$ & 2E-06 \\
\hline dieldrin & $5 \mathrm{E}-02^{\mathrm{C}}$ & $9.2 \mathrm{E}-09$ & $2 \mathrm{E}-04$ & $3.9 \mathrm{E}-09$ & $6 \mathrm{E}-08$ \\
\hline indeno(1,2,3-cd)pyrene & $5 \mathrm{E}-02^{\mathrm{C}}$ & & & $3.0 \mathrm{E}-07$ & $2 \mathrm{E}-06$ \\
\hline methylene chloride & $3 \mathrm{E}-01^{\mathrm{C}}$ & $1.2 \mathrm{E}-05$ & $2 \mathrm{E}-04$ & $5.0 \mathrm{E}-06$ & 4E-08 \\
\hline pentachlorophenol & $5 E-02^{c}$ & $6.5 \mathrm{E}-07$ & $2 \mathrm{E}-05$ & $2.8 \mathrm{E}-07$ & $3 \mathrm{E}-08$ \\
\hline trichloroethene & $3 \mathrm{E}-01^{\mathrm{C}}$ & $1.0 \mathrm{E}-06$ & 2E-04 & $4.4 \mathrm{E}-07$ & $5 \mathrm{E}-09$ \\
\hline vinyl chloride & $3 \mathrm{E}-01^{\mathrm{C}}$ & & & $2.7 \mathrm{E}-08$ & $5 \mathrm{E}-08$ \\
\hline \multicolumn{6}{|l|}{ Inorganic Constituents } \\
\hline aluminum & $1 \mathrm{E}-02^{\mathrm{b}, \mathrm{c}}$ & $6.8 \mathrm{E}-03$ & $7 \mathrm{E}-01$ & & \\
\hline ammonia & $3 \mathrm{E}-01^{\mathrm{c}}$ & & & & \\
\hline antimony & $1 \mathrm{E}-02^{\mathrm{b}, \mathrm{c}}$ & $1.6 \mathrm{E}-06$ & $4 \mathrm{E}-01$ & & \\
\hline arsenic & $1 \mathrm{E}-02^{\mathrm{b}, \mathrm{c}}$ & $5.4 \mathrm{E}-06$ & $4 \mathrm{E}-02$ & $2.3 \mathrm{E}-06$ & 9E-06 \\
\hline barium & $1 \mathrm{E}-02^{\mathrm{b}, \mathrm{c}}$ & 3.7E-04 & $5 \mathrm{E}-02$ & & \\
\hline beryllium & $1 \mathrm{E}-02^{\mathrm{b}, \mathrm{c}}$ & $4.1 \mathrm{E}-07$ & $2 \mathrm{E}-02$ & $1.8 \mathrm{E}-07$ & $2 \mathrm{E}-04$ \\
\hline
\end{tabular}


Table 6-16. Intake and Risk Values for Non-Radioactive Soil Contaminants via Dermal Pa:hway. ${ }^{\mathrm{a}}$ (Sheet 2 of 2 )

\begin{tabular}{|l|c|c|c|c|c|}
\hline \multirow{2}{*}{ Contaminant } & \multirow{2}{*}{$\begin{array}{c}\text { ABS } \\
\text { (unitless })\end{array}$} & \multicolumn{2}{c|}{ Noncarcinogen } & \multicolumn{2}{c|}{ Carcinogen } \\
\cline { 3 - 7 } & & $\begin{array}{c}\text { Intake } \\
(\mathrm{mg} / \mathrm{kg}-\mathrm{d})\end{array}$ & $\mathrm{HQ}$ & $\begin{array}{c}\text { Intake } \\
(\mathrm{mg} / \mathrm{kg}-\mathrm{d})\end{array}$ & ICR \\
\hline cadmium & $1 \mathrm{E}-02^{\mathrm{b}, \mathrm{c}}$ & $2.5 \mathrm{E}-06$ & $5 \mathrm{E}-02$ & & \\
\hline chromium & $1 \mathrm{E}-02^{\mathrm{b}, \mathrm{c}}$ & $2.2 \mathrm{E}-04$ & $4 \mathrm{E}-01$ & & \\
\hline copper & $1 \mathrm{E}-02^{\mathrm{b}, \mathrm{c}}$ & $8.3 \mathrm{E}-03$ & $4 \mathrm{E}-01$ & & \\
\hline lead & $1 \mathrm{E}-02^{\mathrm{b}, \mathrm{c}}$ & & & & \\
\hline manganese & $1 \mathrm{E}-02^{\mathrm{b}, \mathrm{c}}$ & $2.7 \mathrm{E}-04$ & $2 \mathrm{E}-02$ & & \\
\hline mercury & $1 \mathrm{E}-02^{\mathrm{b}, \mathrm{c}}$ & $3.2 \mathrm{E}-06$ & $5 \mathrm{E}-01$ & & \\
\hline nickel & $1 \mathrm{E}-02^{\mathrm{b}, \mathrm{c}}$ & $1.5 \mathrm{E}-04$ & $2 \mathrm{E}-01$ & & \\
\hline silver & $1 \mathrm{E}-02^{\mathrm{b}, \mathrm{c}}$ & $3.2 \mathrm{E}-05$ & $1 \mathrm{E}-01$ & & \\
\hline thallium & $1 \mathrm{E}-02^{\mathrm{b}, \mathrm{c}}$ & $4.7 \mathrm{E}-07$ & $7 \mathrm{E}-03$ & & \\
\hline vanadium & $1 \mathrm{E}-02^{\mathrm{b}, \mathrm{c}}$ & $3.4 \mathrm{E}-05$ & $5 \mathrm{E}-01$ & & \\
\hline zinc & $1 \mathrm{E}-02^{\mathrm{b}, \mathrm{c}}$ & $5.4 \mathrm{E}-04$ & $4 \mathrm{E}-03$ & & \\
\hline
\end{tabular}

${ }^{a}$ Assuming current residential exposure to maximum detected contaminant concentrations. bEPA $1992 \mathrm{~b}$.

CHawkins, et al. 1990.

ABS $=$ dermal absorption factor

$\mathrm{HQ}=$ hazard quotient

$\mathrm{ICR}=$ lifetime incremental cancer risk

Note: Blank cells indicate that toxicity values are currently unavailable with which to evaluate dermal exposures. Radionuclides are not evaluated for the dermal pathway. 
DOE/RL-93-99, Rev. 0

Table 6-17. Intake and Risk Values for Non-Radioactive Soil Contaminants via Fugitive Dust Inhalation. ${ }^{\mathrm{a}}$ (Sheet 1 of 2)

\begin{tabular}{|c|c|c|c|c|}
\hline \multirow[t]{2}{*}{ Contaminant } & \multicolumn{2}{|c|}{ Noncarcinogen } & \multicolumn{2}{|c|}{ Carcinogen } \\
\hline & $\begin{array}{c}\text { Intaike } \\
\text { (mg/kg-d) }\end{array}$ & HQ & $\begin{array}{c}\text { Intake } \\
\text { (mg/kg-d) }\end{array}$ & ICR \\
\hline \multicolumn{5}{|l|}{ Organic Compounds } \\
\hline \multicolumn{5}{|l|}{ Aroclor -1248} \\
\hline \multicolumn{5}{|l|}{ Aroclor-1254 } \\
\hline \multicolumn{5}{|l|}{ Aroclor- 1260} \\
\hline \multicolumn{5}{|l|}{ benz'(a)anthracene } \\
\hline benzene & & & $7.6 \mathrm{E}-10$ & $2 \mathrm{E}-11$ \\
\hline \multicolumn{5}{|l|}{ benzo(a)pyrene } \\
\hline \multicolumn{5}{|l|}{ benzo(b)fluoranthene } \\
\hline \multicolumn{5}{|l|}{ benzo(k)fluoranthene } \\
\hline \multicolumn{5}{|c|}{ bis(2-ethylhexyl)phthalate } \\
\hline chloroform & & & $3.2 \mathrm{E}-10$ & $3 E-11$ \\
\hline \multicolumn{5}{|l|}{ chrysene } \\
\hline \multicolumn{5}{|l|}{ dibenz $(a, h)$ anthracene } \\
\hline dieldrin & & & $8.5 \mathrm{E}-11$ & $1 \mathrm{E}-09$ \\
\hline \multicolumn{5}{|l|}{ indeno(1,2,3-cd)pyrene } \\
\hline methylene chloride & $9.3 \mathrm{E}-08$ & $1 \mathrm{E}-07$ & $1.8 \mathrm{E}-08$ & $3 \mathrm{E}-11$ \\
\hline \multicolumn{5}{|l|}{ pentachlorophenol } \\
\hline trichloroethene & & & $1.6 \mathrm{E}-09$ & $9 \mathrm{E}-12$ \\
\hline vinyl chloride & & & $9.7 \mathrm{E}-11$ & $3 \mathrm{E}-11$ \\
\hline \multicolumn{5}{|l|}{ Inorganic Constituents } \\
\hline \multicolumn{5}{|l|}{ aluminum } \\
\hline ammonia & $2.8 E-06$ & $1 E-04$ & & \\
\hline \multicolumn{5}{|l|}{ antimony } \\
\hline arsenic & & & $2.5 \mathrm{E}-07$ & $4 \mathrm{E}-06$ \\
\hline barium & $8.8 \mathrm{E}-0.5$ & $9 \mathrm{E}-01$ & & \\
\hline beryllium & & & $1.9 \mathrm{E}-08$ & $2 \mathrm{E}-07$ \\
\hline
\end{tabular}


Table 6-17. Intake and Risk Values for Non-Radioactive Soil Contaminants via Fugitive Dust Inhalation. ${ }^{\mathrm{a}}$ (Sheet 2 of 2)

\begin{tabular}{|c|c|c|c|c|}
\hline \multirow[t]{2}{*}{ Contaminant } & \multicolumn{2}{|c|}{ Noncarcinogen } & \multicolumn{2}{|c|}{ Carcinogen } \\
\hline & $\begin{array}{c}\text { Intake } \\
(\mathrm{mg} / \mathrm{kg}-\mathrm{d})\end{array}$ & HQ & $\begin{array}{c}\text { Intake } \\
(\mathrm{mg} / \mathrm{kg}-\mathrm{d})\end{array}$ & ICR \\
\hline cadmium & & & $1.1 \mathrm{E}-07$ & 7E-07 \\
\hline chromium & & & $1.0 \mathrm{E}-05$ & $4 E-04$ \\
\hline \multicolumn{5}{|l|}{ copper } \\
\hline \multicolumn{5}{|l|}{ lead } \\
\hline manganese & $6.3 \mathrm{E}-05$ & $6 \mathrm{E}-01$ & & \\
\hline mercury & $7.6 \mathrm{E}-07$ & $8 E-03$ & & \\
\hline \multicolumn{5}{|l|}{ nickel } \\
\hline \multicolumn{5}{|l|}{ silver } \\
\hline \multicolumn{5}{|l|}{ thallium } \\
\hline \multicolumn{5}{|l|}{ vanadium } \\
\hline zinc & & & & \\
\hline $\begin{array}{l}{ }^{a} \text { Assuming current resi } \\
\mathrm{HQ}=\text { hazard quotient } \\
\text { ICR = lifetime increme } \\
\text { Note: Blank cell indica } \\
\text { inhalation pathway. In }\end{array}$ & $\begin{array}{l}\text { osure to ma } \\
\text { risk } \\
\text { city values } \\
\text { based on p }\end{array}$ & $\begin{array}{l}\text { detected } \\
\text { rently un }\end{array}$ & $\begin{array}{l}\text { lant concent } \\
\text { with which } \\
\text { of } 3.0 \mathrm{E}+0\end{array}$ & ate an \\
\hline
\end{tabular}


Table 6-18. Intake and Risk Values for Non-Radioactive Soil Contaminants via Inhalation of Volatiles ${ }^{\mathrm{a}}$.

\begin{tabular}{|c|c|c|c|c|c|}
\hline \multirow[t]{2}{*}{ Contaminant } & \multicolumn{3}{|c|}{ Noncarcinogen } & \multicolumn{2}{|c|}{ Carcinogen } \\
\hline & $\begin{array}{c}\text { VF } \\
\left(\mathrm{m}^{3} / \mathrm{kg}\right)\end{array}$ & $\begin{array}{c}\text { Intake } \\
\text { (mg/kg-d) }\end{array}$ & HQ & $\begin{array}{c}\text { Intake } \\
(\mathrm{mg} / \mathrm{kg}-\mathrm{d})\end{array}$ & ICR \\
\hline \multicolumn{6}{|l|}{ Organic Compounds } \\
\hline benzene & $2.6 \mathrm{E}+03$ & & & $8.9 E-06$ & $3 E-07$ \\
\hline chloroform & $1.0 \mathrm{E}+03$ & & & $9.8 E-06$ & $8 E-07$ \\
\hline methylene chloride & $1.0 \mathrm{E}+03$ & $2.8 \mathrm{E}-03$ & $3 E-03$ & $5.5 \mathrm{E}-04$ & $9 \mathrm{E}-07$ \\
\hline trichloroethene & $1.2 \mathrm{E}+03$ & & & $4.0 \mathrm{E}-05$ & $2 \mathrm{E}-07$ \\
\hline vinyl chloride & $6.0 \mathrm{E}+02$ & & & $4.9 \mathrm{E}-06$ & 1E-06 \\
\hline \multicolumn{6}{|l|}{ Inorganic Constituents } \\
\hline ammonia & $1.0 \mathrm{E}+03$ & $8.6 \mathrm{E}-02$ & $3 \mathrm{E}+00$ & & \\
\hline \multicolumn{6}{|c|}{$\begin{array}{l}\text { a Assuming current residential exposure to maximum detected contaminant concentrations. } \\
\text { VF = volatilization factor } \\
\text { HQ = hazard quotient } \\
\text { ICR = lifetime incremental cancer risk } \\
\text { Note: Intakes and risks are calculated only for volatile contaminants. } \\
\text { Blank cells indicate that toxicity values are currently unavailable with which to evaluate volatile inhalation. }\end{array}$} \\
\hline
\end{tabular}


Table 6-19. Intake and Risk Values for Radioactive Soil Contaminants (All Pathways). ${ }^{a}$ (Sheet 1 of 2)

\begin{tabular}{|c|c|c|c|c|c|c|}
\hline \multirow[t]{2}{*}{ Radionuclide } & \multicolumn{2}{|c|}{ Soil Ingestion } & \multicolumn{2}{|c|}{ Fugitive Dust Inhalation } & \multicolumn{2}{|c|}{ External Exposure } \\
\hline & Intake $(\mathrm{pCi})$ & ICR & Intake (pCi) & ICR & Intake (pCi) & ICR \\
\hline americium-241 & $4.5 E+04$ & $1 \mathrm{E}-05$ & $2.5 \mathrm{E}+02$ & $8 \mathrm{E}-06$ & $8.2 E+02$ & $4 E-06$ \\
\hline barium-140 & $5.2 \mathrm{E}+05$ & 1E-06 & $2.9 E+03$ & $6 \mathrm{E}-09$ & $9.6 \mathrm{E}+03$ & 5E-03 \\
\hline beryllium-7 & $1.2 \mathrm{E}+05$ & 4E-09 & $6.5 \mathrm{E}+02$ & $2 \mathrm{E}-10$ & $2.2 E+03$ & 3E-04 \\
\hline carbon-14 & $8.4 E+05$ & $8 \mathrm{E}-07$ & $4.6 \mathrm{E}+03$ & $3 \mathrm{E}-11$ & $1.5 \mathrm{E}+04$ & 0 \\
\hline cerium-141 & $3.9 E+03$ & $3 \mathrm{E}-09$ & $2.2 \mathrm{E}+01$ & $2 \mathrm{E}-10$ & $7.2 \mathrm{E}+01$ & $9 E-06$ \\
\hline cerium-144 & $6.6 \mathrm{E}+02$ & $4 \mathrm{E}-09$ & $3.6 E+00$ & 1E-09 & $1.2 \mathrm{E}+01$ & $3 E-07$ \\
\hline cesium-134 & $7.3 \mathrm{E}+04$ & $3 \mathrm{E}-06$ & $4.0 \mathrm{E}+02$ & 1E-08 & $1.3 E+03$ & 7E-03 \\
\hline cesium-137 & $1.4 E+08$ & 4E-03 & $7.9 E+05$ & $2 \mathrm{E}-05$ & $2.6 \mathrm{E}+06$ & $5 \mathrm{E}+00$ \\
\hline chromium-51 & $4.5 E+03$ & $2 \mathrm{E}-10$ & $2.5 \mathrm{E}+01$ & $8 E-12$ & $8.3 E+01$ & $8 E-06$ \\
\hline cobalt -58 & $1.8 \mathrm{E}+04$ & $3 \mathrm{E}-08$ & $1.0 \mathrm{E}+02$ & 1E-09 & $3.4 \mathrm{E}+02$ & 1E-03 \\
\hline cobalt -60 & $1.4 \mathrm{E}+07$ & $2 \mathrm{E}-04$ & $7.9 \mathrm{E}+04$ & $1 \mathrm{E}-05$ & $2.6 \mathrm{E}+05$ & $2 \mathrm{E}+00$ \\
\hline europium-152 & $3.8 E+07$ & $8 E-05$ & $2.1 \mathrm{E}+05$ & $2 \mathrm{E}-05$ & $7.0 \mathrm{E}+05$ & $3 \mathrm{E}+00$ \\
\hline europium-154 & $1.2 \mathrm{E}+07$ & $4 \mathrm{E}-05$ & $6.6 E+04$ & $9 \mathrm{E}-06$ & $2.2 \mathrm{E}+05$ & $9 E-01$ \\
\hline europium-155 & $1.3 \mathrm{E}+07$ & $6 E-06$ & $6.9 E+04$ & $1 \mathrm{E}-06$ & $2.3 E+05$ & $1 \mathrm{E}-02$ \\
\hline hydrogen-3 & $3.8 \mathrm{E}+07$ & $2 E-06$ & $2.1 \mathrm{E}+05$ & $2 \mathrm{E}-08$ & $7.0 \mathrm{E}+05$ & 0 \\
\hline iron-59 & $1.3 E+03$ & $4 \mathrm{E}-09$ & $7.2 \mathrm{E}+00$ & $7 \mathrm{E}-11$ & $2.4 \mathrm{E}+01$ & $1 E-04$ \\
\hline manganese-54 & $9.2 \mathrm{E}+01$ & $1 E-10$ & $5.1 \mathrm{e}-01$ & $3 E-12$ & $1.7 \mathrm{E}+00$ & $5 E-06$ \\
\hline nickel-63 & $8.1 E+07$ & $2 \mathrm{E}-05$ & $4.5 \mathrm{E}+05$ & $8 \mathrm{E}-07$ & $1.5 E+06$ & 0 \\
\hline
\end{tabular}


Table 6-19. Intake and Risk Values for Radioactive Soil

Contaminants (All Pathways). ${ }^{\mathrm{a}}$ (Sheet 2 of 2)

\begin{tabular}{|c|c|c|c|c|c|c|}
\hline \multirow[t]{2}{*}{ Radionuclide } & \multicolumn{2}{|c|}{ Soil Ingestion } & \multicolumn{2}{|c|}{ Fugitive Dust Inhalation } & \multicolumn{2}{|c|}{ External Exposure } \\
\hline & Intake $(\mathrm{pCi})$ & ICR & Intake (pCi) & ICR & Intake $(\mathrm{pCi})$ & ICR \\
\hline plutonium-238 & $1.8 \mathrm{E}+05$ & $4 \mathrm{E}-05$ & $1.0 \mathrm{E}+03$ & $4 \mathrm{E}-05$ & $3.4 E+03$ & $9 E-08$ \\
\hline plutonium-239/240 & $3.7 E+06$ & 8E-04 & $2.0 \mathrm{E}+04$ & $8 E-04$ & $6.7 E+04$ & $2 E-06$ \\
\hline radium-226 & $5.6 \mathrm{E}+04$ & 7E-06 & $3.1 \mathrm{E}+02$ & $9 \mathrm{E}-07$ & $1.0 \mathrm{E}+03$ & $6 \mathrm{E}-03$ \\
\hline ruthenium-103 & $1.3 E+03$ & $1 \mathrm{E}-09$ & $7.2 \mathrm{E}+00$ & $6 \mathrm{E}-11$ & $2.4 E+01$ & $4 E-05$ \\
\hline sodium-22 & $1.3 \mathrm{E}+04$ & 9E-08 & $7.2 \mathrm{E}+01$ & $3 E-10$ & $2.4 \mathrm{E}+02$ & $2 E-03$ \\
\hline strontium-90 $\mathrm{b}$ & $2.6 \mathrm{E}+06$ & 9E-05 & $1.4 \mathrm{E}+04$ & 9E-07 & $4.8 E+04$ & $\mathbf{0}$ \\
\hline thorium-228 & $2.2 \mathrm{E}+04$ & $1 \mathrm{E}-06$ & $1.2 \mathrm{E}+02$ & $9 \mathrm{E}-06$ & $4.0 \mathrm{E}+02$ & 2E-03 \\
\hline thorium-232 & $4.6 \mathrm{E}+03$ & $6 \mathrm{E}-08$ & $2.6 \mathrm{E}+01$ & 7E-07 & $8.5 \mathrm{E}+01$ & $2 \mathrm{E}-09$ \\
\hline uranium (total) & $2.6 \mathrm{E}+07$ & $7 \mathrm{E}-04$ & $1.4 \mathrm{E}+05$ & $8 E-03$ & $4.8 \mathrm{E}+05$ & $2 \mathrm{E}-02$ \\
\hline zinc-65 & $3.9 E+02$ & $3 \mathrm{E}-09$ & $2.2 \mathrm{E}+00$ & $3 \mathrm{E}-11$ & $7.2 \mathrm{E}+00$ & $1 E-05$ \\
\hline zirconium-95 & $7.3 \mathrm{E}+02$ & $7 \mathrm{E}-10$ & $4.0 \mathrm{E}+00$ & $4 \mathrm{E}-11$ & $1.3 \mathrm{E}+01$ & $3 E-05$ \\
\hline $\begin{array}{l}\text { a Assuming current } r \\
\mathrm{~b} \text { The biota ingestion } \\
\text { ICR = lifetime incre }\end{array}$ & $\begin{array}{l}\text { posure to ma } \\
\text { for strontiur } \\
\text { risk }\end{array}$ & detectec & $\begin{array}{l}\text { inant concer } \\
\text { with an asso }\end{array}$ & $R$ of 5 & & \\
\hline
\end{tabular}

$\mathrm{CR}=$ lifetime incremental cancer risk 
Table 6-20. Summary of Systemic Toxicity Information for Soil Contaminants of Potential Concern (COPC) at the ERDF. (Sheet 1 of 3 )

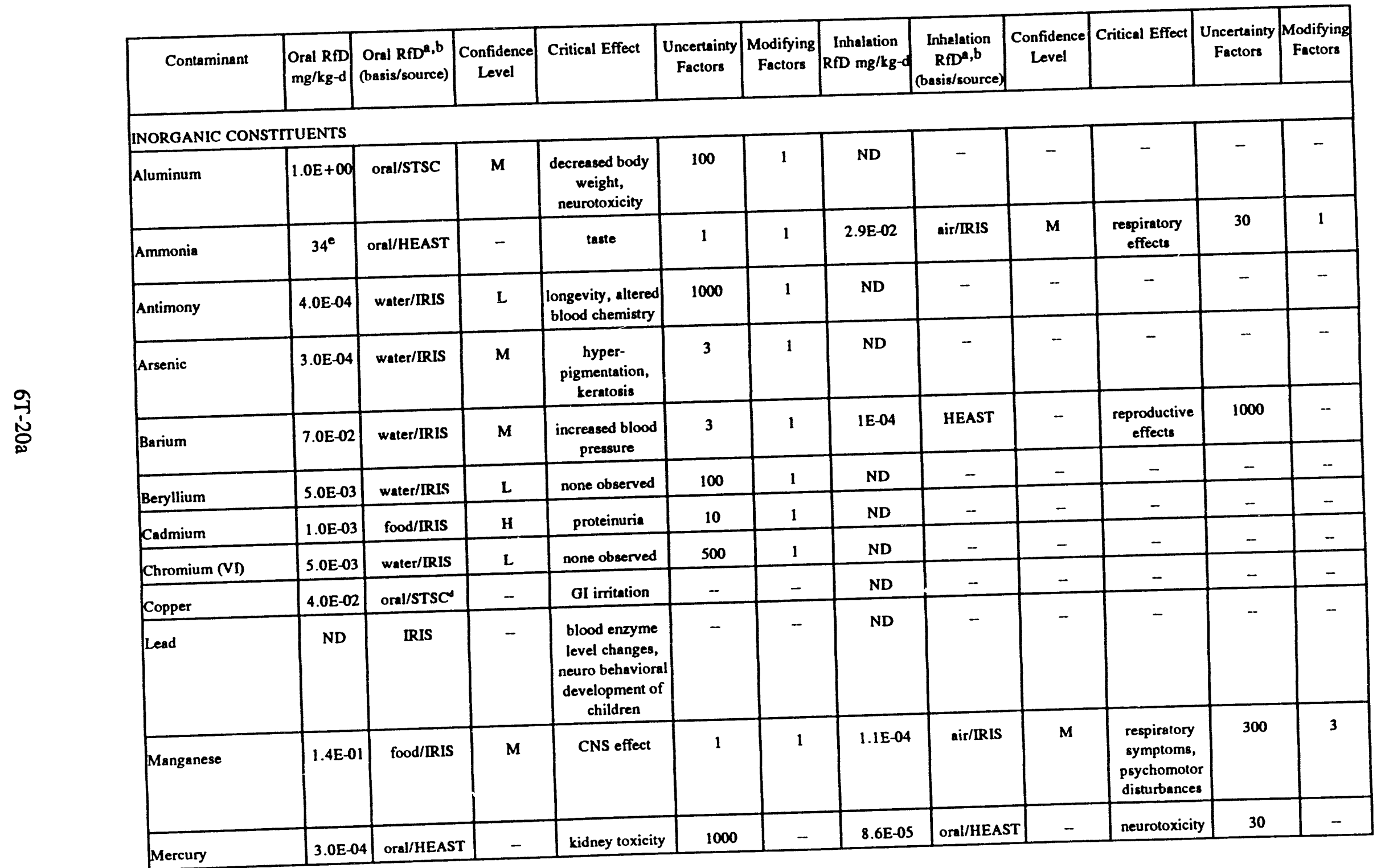


DOE/RL-93-99, Rev. 0

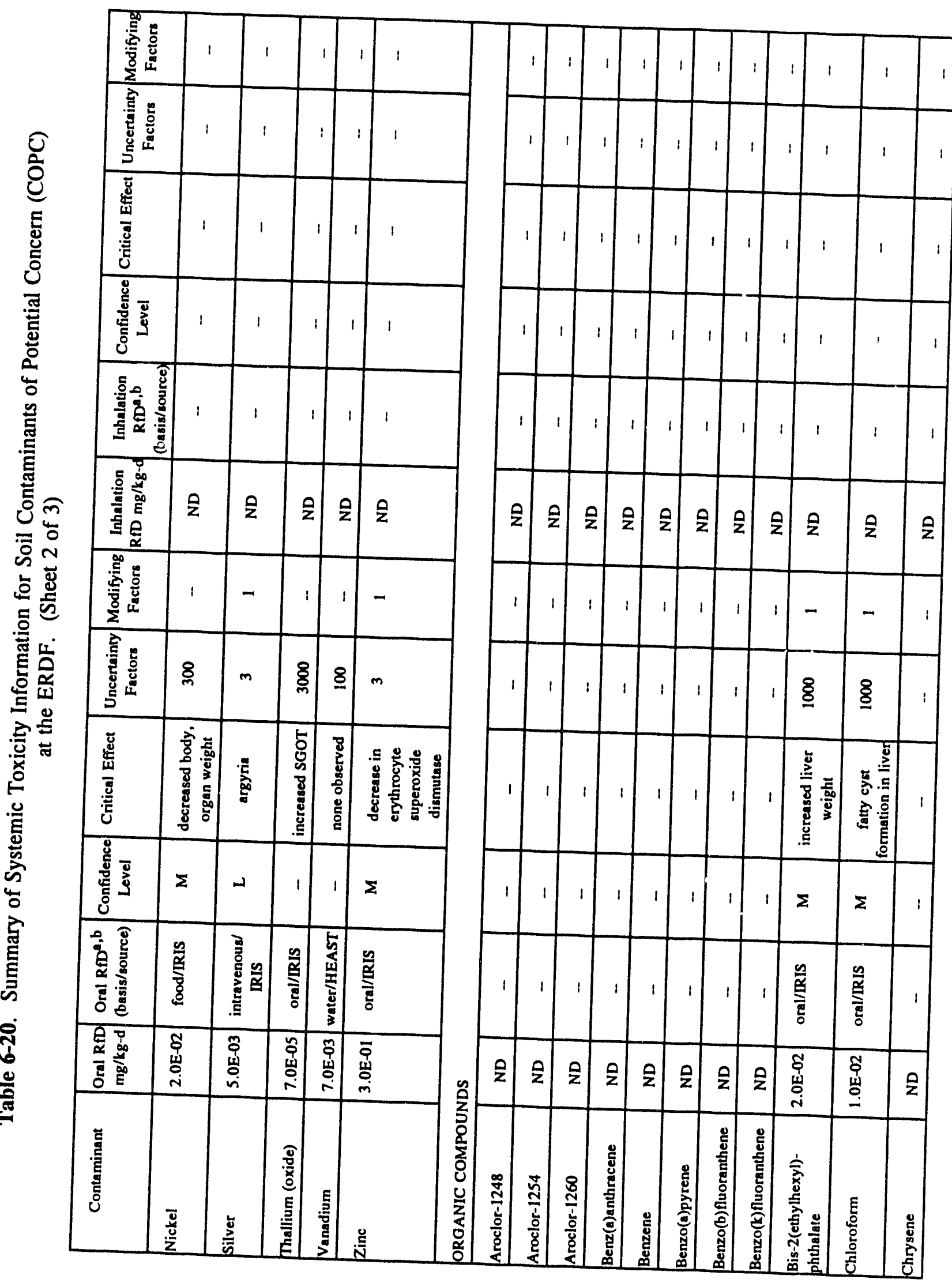


Table 6-20. Summary of Sys $\mathrm{smic}$ Toxicity Information for Soil Contaminants of Potential Concern (COPC) at the ERDF. (Sheet 3 of 3)

\begin{tabular}{|c|c|c|c|c|c|c|c|c|c|c|c|c|}
\hline Conteminant & $\left|\begin{array}{l}\text { Oral RfD } \\
\mathrm{mg} / \mathrm{kg}-\mathrm{d}\end{array}\right|$ & $\begin{array}{c}\text { Oral RfD } \\
\text { (basis/source) }\end{array}$ & $\begin{array}{c}\text { Confidence } \\
\text { Level }\end{array}$ & Critical Effect & $\begin{array}{c}\text { Uncertainty } \\
\text { Factors }\end{array}$ & $\begin{array}{c}\text { Modifying } \\
\text { Factors }\end{array}$ & $\begin{array}{c}\text { Inhalation } \\
\text { RfD mg/kg-d }\end{array}$ & $\begin{array}{c}\text { Inhalation } \\
\text { RfD }, \mathrm{b} \\
\text { (basis/source) }\end{array}$ & $\begin{array}{c}\text { Confidence } \\
\text { Level }\end{array}$ & Critical Effect & $\begin{array}{c}\text { Uncertainty } \\
\text { Factors }\end{array}$ & $\begin{array}{c}\text { Modifying } \\
\text { Factors }\end{array}$ \\
\hline Dibenz $(a, h)$ anthracene & ND & - & - & - & - & - & ND & - & - & - & - & - \\
\hline Dieldrin & $5.0 \mathrm{E}-05$ & oral/IRIS & - & - & - & - & ND & - & - & - & - & - \\
\hline $\begin{array}{l}\text { Indeno(1,2,3-cd) } \\
\text { pyrene }\end{array}$ & ND & - & - & - & - & - & ND & - & - & -- & - & - \\
\hline Methylene Chloride & $6.0 \mathrm{E}-02$ & water/IRIS & $\mathbf{M}$ & liver toxicity & 100 & 1 & $9.0 \mathrm{E}-01$ & air/HEAST & - & liver toxicity & 100 & - \\
\hline Pentachlorophenol & $3.0 \mathrm{E}-02$ & oral/IRIS & $\mathbf{M}$ & $\begin{array}{c}\text { liver \& kidney } \\
\text { pathology }\end{array}$ & 100 & 1 & ND & - & - & - & - & - \\
\hline Trichloroethene & $6.0 \mathrm{E}-03$ & $-/$ STSC & $\mathbf{L}$ & - & 3000 & 1 & ND & - & - & - & - & - \\
\hline Vinyl chloride & ND & - & - & - & - & - & - & - & - & -- & - & - \\
\hline \multicolumn{13}{|c|}{$\begin{array}{l}\text { a Integrated Risk Information System (IRIS, EPA 1993a). } \\
\text { b Health Effects Assessment Summary Tables (HEAST, EPA 1993b). } \\
\text { 2-Butanone is used as a surrogate for 2-Hexanone [HEAST EPA (1993b) indicates that 2-Hexanone data are inadequate for quantitative risk assessment]. } \\
\text { d Superfund Technical Support Center (EPA 1991a). } \\
\text { OValue based on taste threshold, expressed as mg/L. } \\
\text { L = Low } \\
\text { M = Medium } \\
\text { H = High } \\
\text { RfD = Reference Dose } \\
\text { ND = Not determined } \\
\text { STSC = Superfund Technical Support Center } \\
\text { = Not applicable }\end{array}$} \\
\hline
\end{tabular}


Table 6-21. Summary of Carcinogenic Toxicity Information

for Soil Contaminants of Potential Concern at the ERDF. (Sheet 1 of 3)

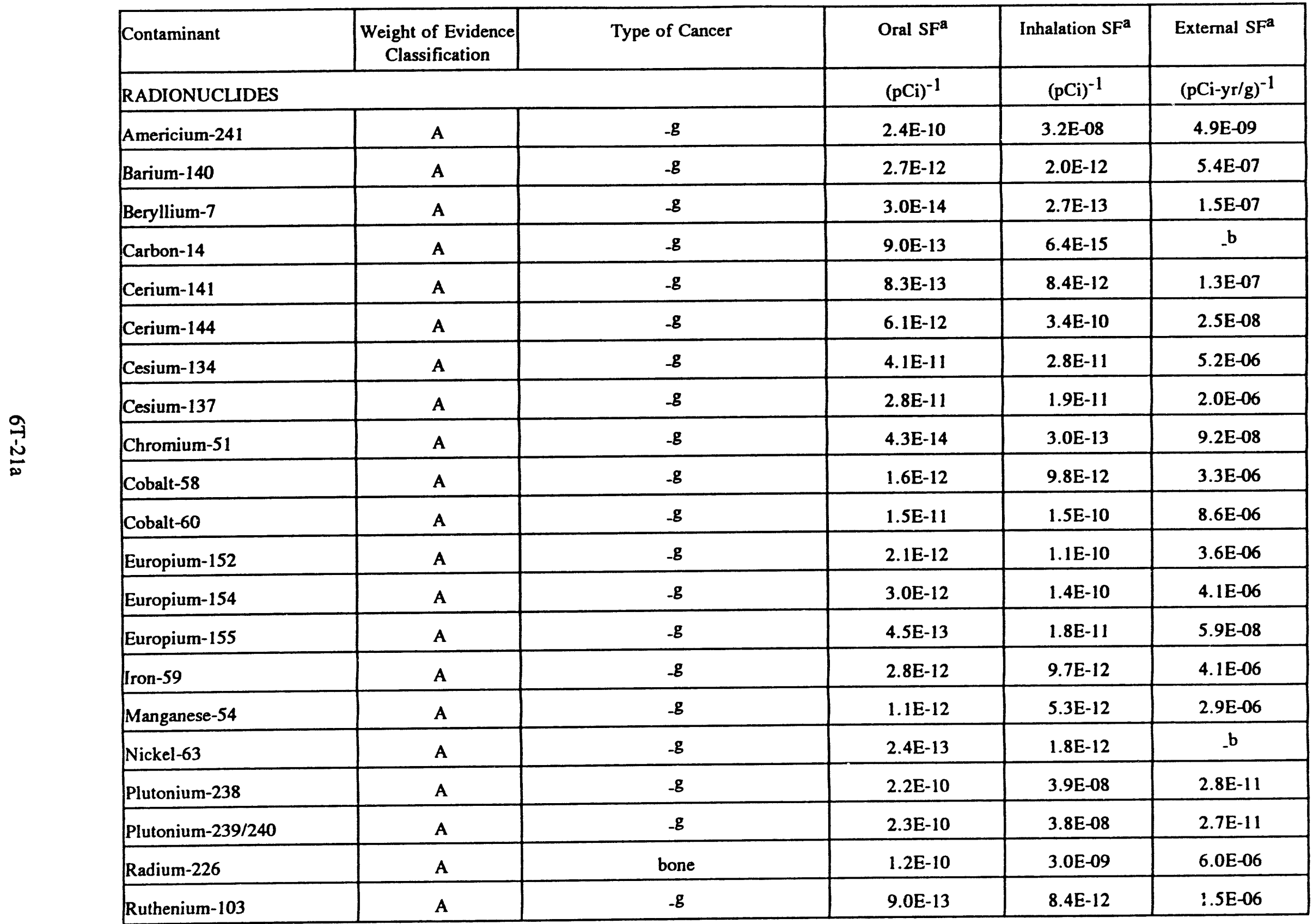


Table 6-21. Summary of Carcinogenic Toxicity Information for Soil Contaminants of Potential Concern at the ERDF. (Sheet 2 of 3)

\begin{tabular}{|c|c|c|c|c|c|c|}
\hline & Contaminant & $\begin{array}{c}\text { Weight of Evidence } \\
\text { Classification }\end{array}$ & Type of Cancer & Oral SFa & Inhalation $S^{a}$ & External SFa \\
\hline \multirow{22}{*}{$\begin{array}{l}\stackrel{\sigma}{\sim} \\
\stackrel{\dot{N}}{\sigma}\end{array}$} & Sodium-22 & $\mathbf{A}$ & $-g$ & $6.8 \mathrm{E}-12$ & $4.8 \mathrm{E}-12$ & $7.2 \mathrm{E}-06$ \\
\hline & Strontium-90 & $\mathbf{A}$ & $-g$ & $3.6 \mathrm{E}-11$ & $6.2 \mathrm{E}-11$ & b \\
\hline & Thorium-228 & A & liver & $5.5 \mathrm{E}-11$ & $7.8 \mathrm{E}-08$ & $5.6 \mathrm{E}-06$ \\
\hline & Thorium-232 & A & liver & $1.2 \mathrm{E}-11$ & $2.8 \mathrm{E}-08$ & $2.6 \mathrm{E}-11$ \\
\hline & Tritium (hydrogen-3) & A & $-g$ & $5.4 \mathrm{E}-14$ & $7.8 \mathrm{E}-14$ & b \\
\hline & Uranium (total) ${ }^{c}$ & $\mathbf{A}$ & $-g$ & $2.8 \mathrm{E}-11$ & $5.2 \mathrm{E}-08$ & $3.6 \mathrm{E}-08$ \\
\hline & Zinc-65 & $\mathbf{A}$ & $-g$ & 8.5E-12 & $1.6 \mathrm{E}-1 !$ & $2.0 \mathrm{E}-06$ \\
\hline & Zirconium-95 & A & $-\mathbf{g}$ & $9.9 \mathrm{E}-13$ & $1.0 \mathrm{E}-11$ & $2.5 \mathrm{E}-06$ \\
\hline & \multicolumn{3}{|c|}{ INORGANIC CONSTITUENTS } & $(\mathrm{mg} / \mathrm{kg}-\mathrm{d})^{-1}$ & $(\mathrm{mg} / \mathrm{kg}-\mathrm{d})^{-1}$ & NA \\
\hline & Arsenic & A & lung, skin & $1.8 \mathrm{E}+00 \mathrm{~d}, \mathrm{c}$ & $1.5 \mathrm{E}+01^{\mathrm{d}, \mathrm{f}}$ & NA \\
\hline & Beryllium & B2 & - & $4.3 E+00^{d}$ & $8.4 \mathrm{E}+00^{\mathrm{d}}$ & NA \\
\hline & Cadmium & B1 & lung & ND & $6.3 \mathrm{E}+00^{\mathrm{d}}$ & NA \\
\hline & Chromium (as VI) & $\mathbf{A}$ & lung & $\mathbf{h}$ & $4.2 \mathrm{E}+01^{\mathrm{d}}$ & NA \\
\hline & Nickel & $\mathbf{A}$ & lung & ND & $8,4 E-01^{a, i}$ & NA \\
\hline & ORGANIC COMPOU & & & $(m g / k g-d)^{-i}$ & $(\mathrm{mg} / \mathrm{kg}-\mathrm{d})^{-1}$ & NA \\
\hline & Aroclor-1248j & B2 & liver & $7.7 \mathrm{E}+00^{\mathrm{d}}$ & ND & NA \\
\hline & Aroclor- $1254 \mathrm{j}$ & B2 & liver & $7.7 \mathrm{E}+00^{\mathrm{d}}$ & ND & NA \\
\hline & Aroclor- 1260 & B2 & liver & $7.7 \mathrm{E}+00^{\mathrm{d}}$ & ND & NA \\
\hline & Benz(a)anthracene & B2 & liver, lung & $7.3 \mathrm{E}+00^{\mathrm{k}}$ & - & NA \\
\hline & Benzene & A & leukemia & $2.9 \mathrm{E}-02^{\mathrm{d}}$ & $2.9 \mathrm{E}-02^{\mathrm{d}}$ & NA \\
\hline & Benzo(a)pyrene & B2 & gross tissue tumors & $7.3 \mathrm{E}+00^{\mathrm{d}}$ & - & NA \\
\hline & Benzo(b)fluoranthene & B2 & liver, lung & $7.3 \mathrm{E}+00^{\mathrm{k}}$ & - & NA \\
\hline
\end{tabular}


Table 6-21. Summary of Carcinogenic Toxicity Information for Soil Contaminants of Potential Concern at the ERDF. (Sheet 3 of 3)

\begin{tabular}{|c|c|c|c|c|c|}
\hline Contaminant & $\begin{array}{c}\text { Weight of Evidence } \\
\text { Classification }\end{array}$ & Type of Cancer & Oral SFa & Inhalation $\mathbf{S F}^{\mathbf{a}}$ & External SFa \\
\hline Benzo(k)fluoranthene & B2 & liver, lung & $7.3 \mathrm{E}+00^{\mathrm{k}}$ & - & NA \\
\hline Bis(2-ethylhexyl)phthalate & B2 & liver & $1.4 \mathrm{E}-02^{\mathrm{d}}$ & ND & NA \\
\hline Chloroform & B2 & hepatocellular carcinomas, kidney & $6.1 E-03^{d}$ & $8.1 E-02^{d}$ & NA \\
\hline Chrysene & B2 & liver, lung, lymph glands & $7.3 \mathrm{E}+\infty 0^{\mathrm{k}}$ & - & NA \\
\hline Dibenz(a,h)anthracene & B2 & lung, mammary & $7.3 \mathrm{E}+00^{\mathrm{k}}$ & - & NA \\
\hline Dieldrin & B2 & liver & $1.6 \mathrm{E}+01^{\mathrm{d}}$ & $1.6 \mathrm{E}+01^{\mathrm{d}}$ & NA \\
\hline Indeno(1,2,3-cd)pyrene & B2 & skin, lung/thorax & $7.3 \mathrm{E}+00^{\mathrm{k}}$ & - & NA \\
\hline Methylene Chloride & B2 & - & $7.5 \mathrm{E}-03^{\mathrm{d}}$ & $1.6 \mathrm{E}-03^{\mathrm{d}}$ & NA \\
\hline Pentachlorophenol & B2 & hepatocellular carcinomas & $1.2 \mathrm{E}-01^{\mathrm{d}}$ & - & NA \\
\hline Trichloroethene & $\mathrm{C}-\mathrm{B} 2^{\mathrm{l}}$ & - & $1.1 \mathrm{E}-02^{1}$ & $6.0 \mathrm{E}-03^{\mathrm{l}}$ & NA \\
\hline
\end{tabular}

All radionuclide slope factors are from Health Effects Summary Tables (HEAST, EPA 1993b). Sources for other SFs are as indicated.

b Not an external exposure hazard.

c As uranium-238+D

d Integrated Risk Information System (IRIS, EPA 1993a).

e Based on the proposed arsenic unit risk of 5E-05 ug/L (IRIS, EPA 1993a).

f This slope factor is used for the amount inhaled, does not account for the 30\% absorption of arsenic.

$g$ Carcinogenic effects of radioactive contaminants are based on effects of ionizing radiation generally. Human epidemiology data provide inadequate evidence of carcinogenicity for these isotopes.

Not consioiered carcinogenic through this exposure pathway.

Nickel as refinery dust is considered carcinogenic.

The potency of PCB cogeners vary greatly, Aroclor 1260 is assumed to he representative of all PCB cogener mixtures.

SF value for benzo(a)pyrene used as a surrogate based on structure-activity relationships.

Superfund Technical Support Center (EPA 1992c).

NA - Not applicable

ND $=$ Not Determined

$\mathrm{SF}=$ Slope factor 
Table 6-22. Dermal Toxicity Values for Soil Contaminants of Potential Concern. ${ }^{\mathrm{a}}$ (Sheet 1 of 2)

\begin{tabular}{|c|c|c|c|}
\hline \multirow[t]{2}{*}{ Contaminant } & \multirow{2}{*}{$\begin{array}{l}\text { Gl Absorption } \\
\text { Fraction } \\
\text { (unitless) }\end{array}$} & \multicolumn{2}{|c|}{ Dermal } \\
\hline & & $\begin{array}{c}\mathrm{RfD} \\
(\mathrm{mg} / \mathrm{kg}-\mathrm{d}) \\
\end{array}$ & $\begin{array}{c}\mathrm{SF} \\
(\mathrm{mg} / \mathrm{kg}-\mathrm{d})^{-1}\end{array}$ \\
\hline \multicolumn{4}{|l|}{ Organic Compounds } \\
\hline Aroclor- 1248 & $9 \mathrm{E}-01^{b}$ & & $8.6 E+00$ \\
\hline Aroclor -1254 & $9 \mathrm{E}-01^{\mathrm{b}}$ & & $8.6 E+00$ \\
\hline Aroclor -1260 & $9 \mathrm{E}-01^{\mathrm{b}}$ & & $8.6 \mathrm{E}+00$ \\
\hline benz(a)anthracene & $1 E+00^{c}$ & & $7.3 E+00$ \\
\hline benzene & $1 E+00^{d}$ & & $2.9 E-02$ \\
\hline benzo(a)pyrene & $1 E+00^{c}$ & & $7.3 E+00$ \\
\hline benzo(b)fluoranthene & $1 E+00^{c}$ & & $7.3 E+00$ \\
\hline benzo(k)fluoranthene & $1 E+00^{c}$ & & $7.3 E+00$ \\
\hline bis(2-ethylhexyl)phthalate & $1 E+00^{c}$ & $2.0 \mathrm{E}-02$ & $1.4 \mathrm{E}-02$ \\
\hline chloroform & $1 E+00^{d}$ & $1.0 \mathrm{E}-02$ & $6.1 \mathrm{E}-03$ \\
\hline chrysene & $1 E+00^{c}$ & & $7.3 \mathrm{E}+00$ \\
\hline dibenz $(\mathrm{a}, \mathrm{h})$ anthracene & $1 E+00^{c}$ & & $7.3 E+00$ \\
\hline dieldrin & $1 \mathrm{E}+00^{\mathrm{C}}$ & $5.0 \mathrm{E}-05$ & $1.6 \mathrm{E}+01$ \\
\hline indeno(1,2,3-cd)pyrene & $1 E+00^{c}$ & & $7.3 E+00$ \\
\hline methylene chloride & $1 \mathrm{E}+00^{\mathrm{d}}$ & $6.0 \mathrm{E}-02$ & $7.5 \mathrm{E}-03$ \\
\hline pentachlorophenol & $1 E+00^{e}$ & $3.0 \mathrm{E}-02$ & 1.2E-01 \\
\hline trichloroethene & $1 \mathrm{E}+\infty 0^{\mathrm{d}}$ & $6.0 \mathrm{E}-03$ & $1.1 \mathrm{E}-02$ \\
\hline vinyl chloride & $1 \mathrm{E}+00^{\mathrm{d}}$ & & $1.9 \mathrm{E}+00$ \\
\hline \multicolumn{4}{|l|}{ Inorganic Constituents } \\
\hline aluminum & $1 E-02^{f}$ & $1.0 \mathrm{E}-02$ & \\
\hline ammonia & - & \multicolumn{2}{|c|}{ no toxicity values } \\
\hline antimony & $1 E-02^{f}$ & $4.0 \mathrm{E}-06$ & \\
\hline arsenic & $5 E-01^{f}$ & $1.5 \mathrm{E}-04$ & $4.0 \mathrm{E}+00$ \\
\hline barium & $1 \mathrm{E}-01^{\mathrm{f}}$ & 7.0E-03 & \\
\hline beryllium & $5 E-03^{f}$ & $2.5 E-05$ & $8.6 E+02$ \\
\hline
\end{tabular}


Table 6-22. Dermal Toxicity Values for Soil Contaminants of Potential Concern. ${ }^{\mathrm{a}}$ (Sheet 2 of 2)

\begin{tabular}{|c|c|c|c|}
\hline \multirow[t]{2}{*}{ Contaminant } & \multirow{2}{*}{$\begin{array}{l}\text { GI Absorption } \\
\text { Fraction } \\
\text { (unitless) }\end{array}$} & \multicolumn{2}{|c|}{ Dermal } \\
\hline & & $\begin{array}{c}\mathrm{RfD} \\
(\mathrm{mg} / \mathrm{kg}-\mathrm{d})\end{array}$ & $\begin{array}{c}\mathrm{SF} \\
(\mathrm{mg} / \mathrm{kg}-\mathrm{d})^{-1}\end{array}$ \\
\hline cadmium (food) & $5 E-02^{f}$ & $5.0 \mathrm{E}-05$ & \\
\hline chromium (VI) & $1 E-01^{f}$ & $5.0 \mathrm{E}-04$ & \\
\hline copper & $5 \mathrm{E}-01^{\mathrm{f}}$ & $2.0 \mathrm{E}-02$ & \\
\hline lead & - & \multicolumn{2}{|c|}{ no toxicity values } \\
\hline manganese (food) & $1 E-01^{f}$ & $1.4 \mathrm{E}-02$ & \\
\hline mercury & $2 E-02^{f}$ & $6.0 \mathrm{E}-06$ & \\
\hline nickel & $5 E-02^{f}$ & $1.0 \mathrm{E}-03$ & \\
\hline silver & $5 E-02^{f}$ & $2.5 E-04$ & \\
\hline thallium (oxide) & $1 E+00^{f}$ & $7.0 \mathrm{E}-05$ & \\
\hline vanadium & $1 E-02^{f}$ & 7.0E-05 & \\
\hline zinc & $5 E-01^{f}$ & $1.5 \mathrm{E}-01$ & \\
\hline \multicolumn{4}{|c|}{$\begin{array}{l}\text { a See Table 5-1 for ingestion toxicity values. } \\
\text { bSRC 1991. } \\
\text { CAssumption. Data are not currently available to quantify absorption. } \\
\text { d Assumption. Volatile contaminants are assumed to be completely absorbed. } \\
\text { eClement Associates } 1989 . \\
\text { fEPA } 1988 \text { b, Table } 3 \text {. } \\
\text { GI = gastrointestial } \\
\text { RfD = reference dose } \\
\text { SF = slope factor } \\
\text { Note: Radionuclides are not evaluated for the dermal pathway. }\end{array}$} \\
\hline
\end{tabular}


Table 6-23. Summary of Current Non-Radioactive Soil Contaminant Risks. ${ }^{\text {a }}$ (Sheet 1 of 2 )

\begin{tabular}{|c|c|c|}
\hline Contaminant & $\begin{array}{c}\text { Contaminant } \\
\text { HQ Total }\end{array}$ & $\begin{array}{c}\text { Contaminant } \\
\text { ICR Total }\end{array}$ \\
\hline \multicolumn{3}{|l|}{ Organic Compounds } \\
\hline Aroclor- 1248 & & $1 E-04$ \\
\hline Aroclor -1254 & & $9 E-05$ \\
\hline Aroclor -1260 & & $3 E-05$ \\
\hline benz(a)anthracene & & $2 \mathrm{E}-05$ \\
\hline benzene & & $3 E-07$ \\
\hline benzo(a)pyrene & & $3 E-04$ \\
\hline benzo(b)fluoranthene & & $3 \mathrm{E}-05$ \\
\hline benzo(k)fluoranthene & & $1 E-05$ \\
\hline bis(2-ethylhexyl)phthalate & $2 \mathrm{E}-02$ & $8 \mathrm{E}-07$ \\
\hline chloroform & $1 E-04$ & $8 \mathrm{E}-07$ \\
\hline chrysene & & 5E-04 \\
\hline $\operatorname{dibenz}(\mathrm{a}, \mathrm{h})$ anthracene & & $2 \mathrm{E}-05$ \\
\hline dieldrin & 5E-03 & $6 E-07$ \\
\hline indeno(1,2,3-cd)pyrene & & $2 \mathrm{E}-05$ \\
\hline methylene chloride & $4 E-03$ & $1 E-06$ \\
\hline pentachlorophenol & $6 E-04$ & $3 E-07$ \\
\hline trichloroethene & $1 E-03$ & $2 \mathrm{E}-0 \%$ \\
\hline vinyl chloride & & $2 E-06$ \\
\hline \multicolumn{3}{|l|}{ Inorganic Constituents } \\
\hline aluminum & $2 \mathrm{E}+00$ & \\
\hline ammonia & $3 E+00$ & \\
\hline antimony & $1 E+00$ & \\
\hline arsenic & $3 E+00$ & $2 \mathrm{E}-04$ \\
\hline barium & $2 E+00$ & \\
\hline beryllium & $3 E-02$ & $2 \mathrm{E}-04$ \\
\hline cadmium & $4 \mathrm{E}-01$ & 7E-07 \\
\hline chromium & $7 E+00$ & 4E-04 \\
\hline
\end{tabular}


Table 6-23. Summary of Current Non-Radioactive Soil Contaminant Risks. ${ }^{\mathrm{a}}$ (Sheet 2 of 2 )

\begin{tabular}{|c|c|c|}
\hline Contaminant & $\begin{array}{c}\text { Contaminant } \\
\text { HQ Total }\end{array}$ & $\begin{array}{l}\text { Contaminant } \\
\text { ICR Total }\end{array}$ \\
\hline copper & $3 E+01$ & \\
\hline \multicolumn{3}{|l|}{ lead } \\
\hline manganese & $9 \mathrm{E}-01$ & \\
\hline mercury & $2 E+00$ & \\
\hline nickel & $1 E+00$ & \\
\hline silver & $1 E+00$ & \\
\hline thallium & $1 E+\infty 0$ & \\
\hline vanadium & $1 E+00$ & \\
\hline zinc & $3 E-01$ & \\
\hline Total & b & $2 E-03$ \\
\hline \multicolumn{3}{|c|}{$\begin{array}{l}\text { Assuming current residential exposure to maximum detected contaminan } \\
\text { concentrations. Exposure pathways include soil ingestion, dermal, } \\
\text { fugitive dust inhalation, and inhalation of volatiles. } \\
\text { bContaminant HQs are not summed because they represent different } \\
\text { critical effects } \\
\text { HQ = hazard quotient } \\
\text { ICR = lifetime incremental cancer risk }\end{array}$} \\
\hline
\end{tabular}


DOE/RL-93-99, Rev. 0

Table 6-24. Summary of Current Radioactive Soil Contaminant Risks. ${ }^{\text {a }}$

\begin{tabular}{|c|c|}
\hline Radionuclide & Radionuclide ICR Total \\
\hline americium-241 & $2 \mathrm{E}-05$ \\
\hline barium-140 & $5 E-03$ \\
\hline beryllium-7 & $3 E-04$ \\
\hline carbon-14 & $8 E-07$ \\
\hline cerium-141 & 9E-06 \\
\hline cerium-144 & $3 E-07$ \\
\hline cesium-134 & 7E-03 \\
\hline cesium-137 & $>1 \mathrm{E}-02(5 \mathrm{E}+00)$ \\
\hline chromium-51 & $8 \mathrm{E}-06$ \\
\hline cobalt -58 & $1 \mathrm{E}-03$ \\
\hline cobalt -60 & $>1 E-02(2 E+\infty)$ \\
\hline europium-152 & $>1 \mathrm{E}-02(3 \mathrm{E}+00)$ \\
\hline europium-154 & $>1 E-02(9 E-01)$ \\
\hline europium-155 & $1 E-02$ \\
\hline bydrogen-3 & 2E-06 \\
\hline iron-59 & $1 \mathrm{E}-04$ \\
\hline manganese-54 & $5 E-06$ \\
\hline nickel-63 & $2 \mathrm{E}-05$ \\
\hline plutonium-238 & $8 \mathrm{E}-05$ \\
\hline plutonium-239/240 & $2 \mathrm{E}-03$ \\
\hline radium-226 & $6 \mathrm{E}-03$ \\
\hline ruthenium-103 & $4 E-05$ \\
\hline sodium-22 & $2 \mathrm{E}-03$ \\
\hline strontium-90 & $9 \mathrm{E}-05$ \\
\hline thorium-228 & $2 \mathrm{E}-03$ \\
\hline thorium-232 & 8E-07 \\
\hline uranium (total) & $>1 E-02(3 E-02)$ \\
\hline zinc-65 & $1 E-05$ \\
\hline zirconium-95 & $3 E-05$ \\
\hline Total & $>1 E-02(1 E+01)$ \\
\hline \multicolumn{2}{|c|}{$\begin{array}{l}\text { Assuming current residential exposure to maximum detected contaminant concentrations. Exposure } \\
\text { pathways include soil ingestion, fugitive dust inhalation, and external exposure. } \\
\text { The produce ingestion ICR is SE-03. } \\
\text { ICR = lifetime incremental cancer risk } \\
\text { Note: ICR values greater than } 1 E-02 \text { are reported as " }>1 E-02 \text { ". ICR values in parentheses are } \\
\text { calculated using a linear cancer risk equation (Equation } 6-5 \text { ), and are not intended to represent } \\
\text { accurate cancer risk estimates. }\end{array}$} \\
\hline
\end{tabular}


Table 6-25. Summary of Future Non-Radioactive Soil Contaminants Risks. ${ }^{\text {a }}$ (Sheet 1 of 2)

\begin{tabular}{|c|c|c|c|}
\hline Contaminant & Half-life ${ }^{b}(y r)$ & $\begin{array}{c}\text { Future HQ } \\
\text { Total (2096) }\end{array}$ & $\begin{array}{c}\text { Future ICR } \\
\text { Total (2096) }\end{array}$ \\
\hline \multicolumn{4}{|l|}{ Organic Compounds } \\
\hline Aroclor- 1248 & 1 & & $1 E-35$ \\
\hline Aroclor 1254 & 10000 & & $9 E-05$ \\
\hline Aroclor 1260 & 10000 & & 3E-05 \\
\hline benz(a)anthracene & 10 & & $2 E-08$ \\
\hline benzene & 10 & & $2 \mathrm{E}-1 \mathrm{~J}$ \\
\hline berzo (a)pyrene. & 100 & & 2504 \\
\hline benzo(b)fluoranthene & 10 & & $2 E-08$ \\
\hline benzo( $\mathbf{k}$ )filoranthene: & 100 & & $5 \mathrm{E}-06$ \\
\hline bis(2-ethylhexyl)phthalate & 10 & $2 \mathrm{E}-05$ & $6 \mathrm{E}-10$ \\
\hline chloroform & 10 & $1 E-07$ & $6 \mathrm{E}-10$ \\
\hline chrysene & 10 & & 4E-07 \\
\hline dibenz $(a, h)$ anthracene & 10 & & $2 \mathrm{E}-08$ \\
\hline dieldrin & 10 & $4 \mathrm{E}-06$ & $5 E-10$ \\
\hline indeno $(1,2,3-c d)$ pyrene & 10 & & $2 \mathrm{E}-08$ \\
\hline methylene chloride & 1 & $4 E-34$ & $1 \mathrm{E}-37$ \\
\hline pentachlorophenol & 10 & $5 E-07$ & $2 E-10$ \\
\hline trichloroethene & 10 & $8 E-07$ & $2 E-10$ \\
\hline vinyl chloride & 10 & & $1 E-09$ \\
\hline \multicolumn{4}{|l|}{ Inorganic Constituents } \\
\hline aluminum & $-c$ & $2 \mathrm{E}+00$ & \\
\hline ammonia & $-d$ & $0 E+00$ & \\
\hline antimony & .c & $1 E+00$ & \\
\hline arsenic & $-c$ & $3 E+00$ & $2 \mathrm{E}-04$ \\
\hline barium & $-c$ & $2 \mathrm{E}+00$ & \\
\hline beryllium & $-c$ & $3 \mathrm{E}-02$ & $2 \mathrm{E}-04$ \\
\hline cadmium & $-c$ & $4 E-01$ & 7E-07 \\
\hline
\end{tabular}


Table 6-25. Summary of Future Non-Radioactive Soil Contaminants Risks. ${ }^{a}$ (Sheet 2 of 2 )

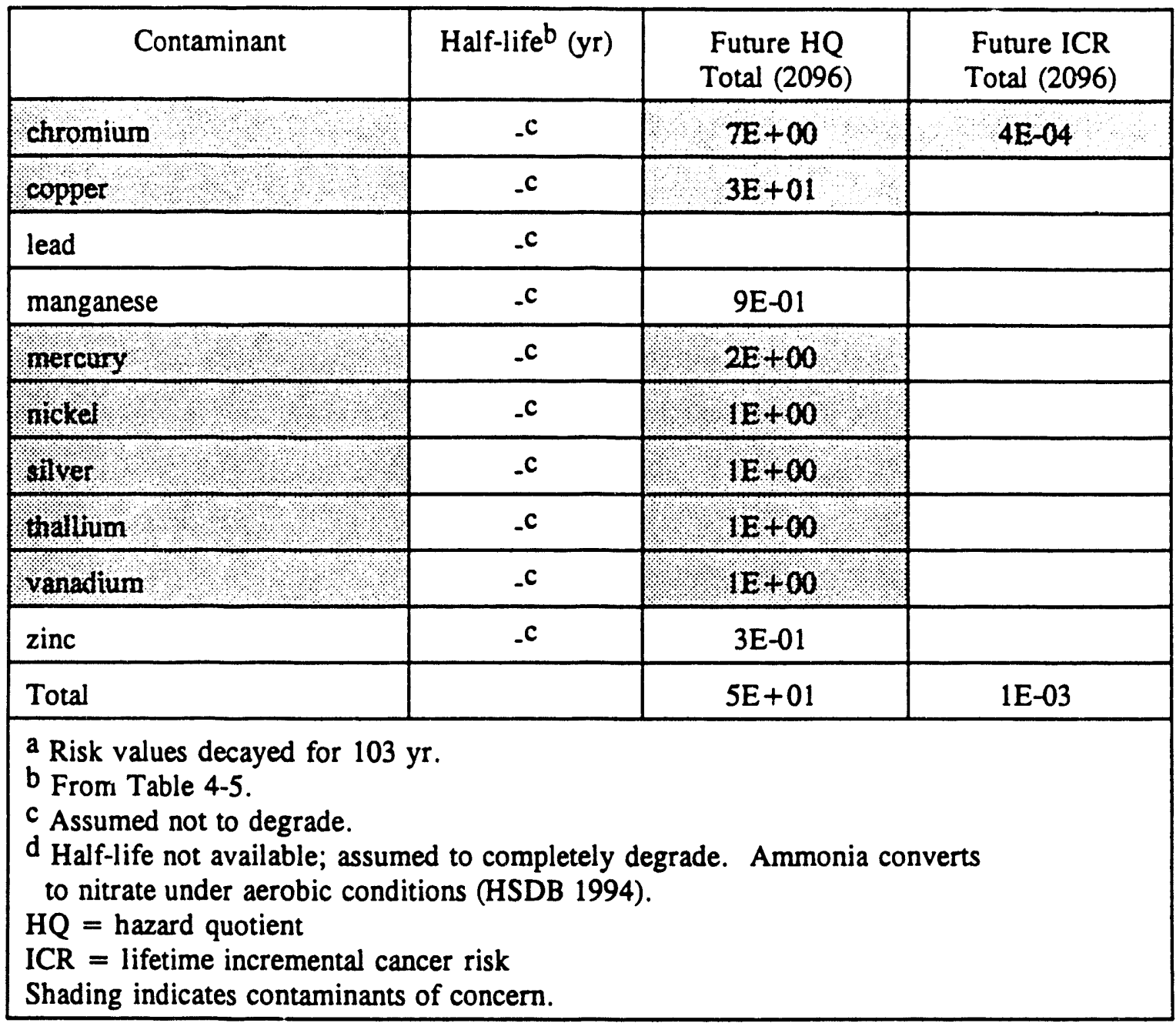


DOE/RL-93-99, Rev. 0

Table 6-26. Summary of Future Radioactive Soil Contaminant Risk. ${ }^{a}$ (Sheet 1 of 2)

\begin{tabular}{|c|c|c|}
\hline Radionuclide & Half-lifeb (yr) & Future ICR Total (2096) \\
\hline americium-241 & $4.32 \mathrm{E}+02$ & $2 \mathrm{E}-05$ \\
\hline barium-140 & $3.50 \mathrm{E}-02$ & 0 \\
\hline beryllium-7 & $1.46 \mathrm{E}-01$ & 0 \\
\hline carbon-14 & $5.73 E+03$ & $7 \mathrm{E}-07$ \\
\hline cerium-141 & $8.90 E-02$ & 0 \\
\hline cerium-144 & $7.78 \mathrm{E}-01$ & 0 \\
\hline cesium-134 & $2.06 \mathrm{E}+00$ & $6 \mathrm{E}-18$ \\
\hline Eesium 137 & $3.02 \mathrm{E}+01$ & $>1 \mathrm{E}-02(5 \mathrm{E}-01)$ \\
\hline chromium-51 & $7.58 \mathrm{E}-02$ & 0 \\
\hline cobalt -58 & $1.94 \mathrm{E}-01$ & 0 \\
\hline cobalt -60 & $5.27 \mathrm{E}+00$ & $3 \mathrm{E}-06$ \\
\hline europium-152 & $1.36 \mathrm{E}+01$ & $1 \mathrm{E}-02$ \\
\hline europium-154 & $8.80 \mathrm{E}+00$ & $3 \mathrm{E}-04$ \\
\hline europium-155 & $4.96 \mathrm{E}+00$ & $8 \mathrm{E}-09$ \\
\hline hydrogen-3 & $1.23 \mathrm{E}+01$ & $6 \mathrm{E}-09$ \\
\hline iron-59 & $1.22 \mathrm{E}-01$ & 0 \\
\hline manganese-54 & 8.57E-01 & 0 \\
\hline nickel.63 & $1.00 \mathrm{E}+02$ & $1 \mathrm{E}-05$ \\
\hline Plutonium-238 & $8.78 \mathrm{E}+01$ & $4 \mathrm{E}-05$ \\
\hline plutonium-239/240 & $2.41 \mathrm{E}+04$ & $2 \mathrm{E} .03$ \\
\hline radium-226 & $1.60 \mathrm{E}+03$ & $6 \mathrm{E}-03$ \\
\hline tadium $-228^{c}$ & $1.41 \mathrm{E}+10^{c}$ & $3 \mathrm{E}-04$ \\
\hline ruthenium-103 & $1.08 \mathrm{E}-01$ & 0 \\
\hline sodium-22 & $2.60 \mathrm{E}+00$ & $2 E-15$ \\
\hline Strontium-90d & $2.86 \mathrm{E}+01$ & $8 \mathrm{E}-06$ \\
\hline horium $-228^{\mathrm{C}}$ & $1.41 \mathrm{E}+10 \mathrm{C}$ & SE-04 \\
\hline thorium-232 & $1.41 E+10$ & $8 \mathrm{E}-07$ \\
\hline Uranium (total) & $4.47 \mathrm{E}+09$ & $>1 \mathrm{E}-02(3 \mathrm{E}-02)$ \\
\hline
\end{tabular}


Table 6-26. Summary of Future Radioactive Soil Contaminant Risk. ${ }^{\mathrm{a}}$ (Sheet 2 of 2)

\begin{tabular}{|l|c|c|}
\hline \multicolumn{1}{|c|}{ Radionuclide } & Half-life $^{\mathrm{b}}(\mathrm{yr})$ & Future ICR Total (2096) \\
\hline zinc-65 & $6.68 \mathrm{E}-01$ & 0 \\
\hline zirconium-95 & $1.75 \mathrm{E}-01$ & 0 \\
\hline Total & & $>1 \mathrm{E}-02(5 \mathrm{E}-01)$ \\
\hline
\end{tabular}

a Risk values decayed for $103 \mathrm{yr}$.

bFrom Table 4-6.

$c_{\text {Assumed to }}$ be in equilibrium with thorium-232. Radium-228 and thorium-228 are evaluated using " $+D$ " slope factors, thorium-232 soil concentration, and thorium-232 half-life.

d The future ICR for strontium-90 via produce ingestion is $5 E-04$.

ICR $=$ lifetime incremental cancer risk

Note: ICR values greater than $1 E-02$ are reported as " $>1 E-02 "$. ICR values in parentheses are calculated using a linear cancer risk equation (Equation 6-5), and are not intended to represent accurate cancer risk estimates.

Shading indicates contaminants of concern. 
DOE/RL-93-99, Rev. 0

Table 6-27. Future Risks Associated with Organic Contaminants in Soil (500 and $10,000 \mathrm{yr}) .^{\mathrm{a}}$

\begin{tabular}{|c|c|c|c|c|}
\hline \multirow[t]{2}{*}{ Contaminant } & \multicolumn{2}{|c|}{ Decay Time $=500 \mathrm{yr}$} & \multicolumn{2}{|c|}{ Decay Time $=10,000 \mathrm{yr}$} \\
\hline & HQ Total & ICR Total & HQ Total & ICR Total \\
\hline \multicolumn{5}{|l|}{ Organic Compounds } \\
\hline Aroclor-1248 & 0 & 0 & 0 & 0 \\
\hline Aroclor 1254 & 0 & $8 \mathrm{E} .05$ & 0 & $4 \mathrm{E}-05$ \\
\hline Aroclor 1260 & 0 & $3 E-05$ & 0 & $2 \mathrm{E}+05$ \\
\hline benz(a)anthracene & 0 & $2 \mathrm{E}-20$ & 0 & 0 \\
\hline benzene & 0 & $2 \mathrm{E}-22$ & 0 & 0 \\
\hline benzo (a)pyrene. & 0 & $1 \mathrm{E} 05$ & 0 & $3 \mathrm{E}-34$ \\
\hline benzo(b)fluoranthene & 0 & $2 \mathrm{E}-20$ & 0 & 0 \\
\hline benzo(k)fluoranthene & 0 & $3 \mathrm{E}-07$ & 0 & $8 \mathrm{E}-36$ \\
\hline bis(2-ethylhexyl)phthalate & $2 \mathrm{E}-17$ & $7 \mathrm{E}-22$ & 0 & 0 \\
\hline chloroform & $1 \mathrm{E}-19$ & $7 \mathrm{E}-22$ & 0 & 0 \\
\hline chrysene & 0 & $5 E-19$ & 0 & 0 \\
\hline dibenz $(\mathrm{a}, \mathrm{h})$ anthracene & 0 & $2 \mathrm{E}-20$ & 0 & 0 \\
\hline dieldrin & $5 \mathrm{E}-18$ & $5 \mathrm{E}-22$ & 0 & 0 \\
\hline indeno(1,2,3-cd)pyrene & 0 & $2 \mathrm{E}-20$ & 0 & 0 \\
\hline methylene chloride & 0 & 0 & 0 & 0 \\
\hline pentachlorophenol & $6 \mathrm{E}-19$ & $3 E-22$ & 0 & 0 \\
\hline trichloroethene & $9 \mathrm{E}-19$ & $2 \mathrm{E}-22$ & 0 & 0 \\
\hline vinyl chloride & 0 & $1 \mathrm{E}-21$ & 0 & 0 \\
\hline Total & $3 E-17$ & $1 \mathrm{E}-04$ & 0 & $6 \mathrm{E}-05$ \\
\hline
\end{tabular}


Table 6-28. Future Risks Associated with Radioactive Contaminants in Soil $(500 \mathrm{yr}$ and $10,000 \mathrm{yr}){ }^{\mathrm{a}}$ (Sheet 1 of 2 )

\begin{tabular}{|c|c|c|}
\hline Radionuclide & $\begin{array}{l}\text { ICR after Decay } \\
\text { Time }=500 \mathrm{yr}\end{array}$ & $\begin{array}{l}\text { ICR after Decay } \\
\text { Time }=10,000 \mathrm{yr}\end{array}$ \\
\hline americium-241 & $1 \mathrm{E}-05$ & $2 \mathrm{E}-12$ \\
\hline barium-140 & 0 & 0 \\
\hline beryllium-7 & 0 & 0 \\
\hline carbon-14 & $7 \mathrm{E}-07$ & $2 \mathrm{E}-07$ \\
\hline cerium-141 & 0 & 0 \\
\hline cerium-144 & 0 & 0 \\
\hline cesium-134 & 0 & 0 \\
\hline cesiun-137? & $5 E-05$ & 0 \\
\hline chromium-51 & 0 & 0 \\
\hline cobalt -58 & 0 & 0 \\
\hline cobalt -60 & $6 \mathrm{E}-29$ & 0 \\
\hline europium-152 & $2 \mathrm{E}-11$ & 0 \\
\hline europium-154 & $7 \mathrm{E}-18$ & 0 \\
\hline europium-155 & $6 \mathrm{E}-33$ & 0 \\
\hline hydrogen-3 & $1 \mathrm{E}-18$ & 0 \\
\hline iron-59 & 0 & 0 \\
\hline manganese-54 & 0 & 0 \\
\hline nickel-63 & $6 E-07$ & $2 \mathrm{E}-35$ \\
\hline plutonium -238 & $2 \mathrm{E}-06$ & $4 E-39$ \\
\hline Butonium-239/240 & $2 \mathrm{E} 03$ & $1 \mathrm{E} 03$ \\
\hline adium-226 & $5 \mathrm{E} 03$ & $8 \mathrm{E}-0.5$ \\
\hline Eadium-228 b & $3 E-04$ & $3 E-04$ \\
\hline ruthenium-103 & 0 & 0 \\
\hline sodium-22 & 0 & 0 \\
\hline strontium-90c & $5 E-10$ & 0 \\
\hline thorium-228b & $5 E-04$ & $5 \mathrm{E}-04$ \\
\hline thorium-232 & $8 E-07$ & $8 E-07$ \\
\hline
\end{tabular}


Table 6-28. Future Radioactive Contaminants in Soil (in $500 \mathrm{yr}$ and $10,000 \mathrm{yr}$ ). ${ }^{\mathrm{a}}$ (Sheet 2 of 2)

\begin{tabular}{|l|c|c|}
\hline \multicolumn{1}{|c|}{ Radionuclide } & $\begin{array}{c}\text { ICR after Decay } \\
\text { Time }=500 \mathrm{yr}\end{array}$ & $\begin{array}{c}\text { ICR after Decay } \\
\text { Time }=10,000 \mathrm{yr}\end{array}$ \\
\hline uranium (total) & $>$ IE-02 (3E-02) & $>1 \mathrm{E}-02(3 \mathrm{E}-02)$ \\
\hline zinc-65 & 0 & 0 \\
\hline zirconium-95 & 0 & 0 \\
\hline Total & $>1 \mathrm{E}-02(3 \mathrm{E}-02)$ & $>1 \mathrm{E}-02(3 \mathrm{E}-02)$ \\
\hline aHalf-lives listed in Table 6-26. \\
bAccounts for ingrowth from Th-232 decay. \\
c-The future ICRs for strontium-90 via produce ingestion are 3E-08 \\
(Time =500 yr) and 0 (Time=10,000 yr). \\
ICR = lifetime incremental cancer risk. \\
Note: ICR values greater than 1E-02 are reported as " > 1E-02". ICR \\
values in parentheses are calculated using a linear cancer risk equation \\
(Equation 6-5), and are not intended to represent accurate cancer risk \\
estimates. Shading indicates contaminants of concern.
\end{tabular}


Table 6-29. Soil-to-Plant Transfer Coefficients Used for Organic Contaminants.

\begin{tabular}{|c|c|c|}
\hline & & Transfer Coefficients \\
\hline & $\log \mathrm{K}_{\mathrm{OW}}$ & $\begin{array}{c}\text { Soil-to-Plant }^{\mathrm{a}} \\
\text { (kg soil/kg plant) }\end{array}$ \\
\hline Aroclor -1248 & 5.6 & 0.022 \\
\hline Aroclor-1254 & 6.47 & $7.1 \mathrm{E}-03$ \\
\hline Aroclor -1260 & 6.11 & 0.011 \\
\hline benzo(a)anthracene & 5.61 & 0.022 \\
\hline benzene & 2.13 & 2.274 \\
\hline benzo(a)pyrene & 6.04 & 0.012 \\
\hline benzo(b)fluoranthene & 6.57 & $6.2 \mathrm{E}-03$ \\
\hline benzo(k)fluoranthene & 6.85 & 4.3E-03 \\
\hline bis(2-ethylhexyl)phthalate & 5.11 & 0.043 \\
\hline chloroform & 1.97 & 2.814 \\
\hline chrysene & 5.61 & 0.022 \\
\hline dibenzo(a,h)anthracene & 5.79 & 0.017 \\
\hline dieldrin & 5.16 & 0.040 \\
\hline indeno(1,2,3-cd)pyrene & 7.66 & $1.4 \mathrm{E}-03$ \\
\hline methylene chloride & 1.25 & 7.337 \\
\hline pentachlorophenol & 5.06 & 0.046 \\
\hline trichloroethene & 2.29 & 1.838 \\
\hline vinyl chloride & 1.38 & 6.171 \\
\hline $\begin{array}{l}\log \mathrm{K}_{\mathrm{ow}}=\log \text { octanol-wat } \\
\text { Source: Travis and Arms } \\
\text { aSoil-to-plant transfer coef } \\
1.588-0.578 \log \mathrm{K}_{\mathrm{ow}} .\end{array}$ & $\begin{array}{l}\text { n coeffi } \\
\text { Cp) esti }\end{array}$ & $\log \mathrm{TC}_{\mathrm{p}}=$ \\
\hline
\end{tabular}


DOE/RL-93-99, Rev. 0

Table 6-30. Soil-to-Plant Transfer Coefficient for Inorganic Contaminants.

\begin{tabular}{|l|c|}
\hline & Transfer Coefficients \\
\cline { 2 - 2 } & Soil-to-Seeds \\
\hline aluminum & $6.5 \mathrm{E}-04$ \\
\hline antimony & $3.0 \mathrm{E}-02$ \\
\hline arsenic & $6.0 \mathrm{E}-03$ \\
\hline barium & $1.5 \mathrm{E}-02$ \\
\hline beryllium & $1.5 \mathrm{E}-03$ \\
\hline cadmium & $1.5 \mathrm{E}-01$ \\
\hline chromium (VI) & $4.5 \mathrm{E}-03$ \\
\hline copper & $2.5 \mathrm{E}-01$ \\
\hline lead & $9.0 \mathrm{E}-03$ \\
\hline manganese & $5.0 \mathrm{E}-02$ \\
\hline mercury & $2.0 \mathrm{E}-01$ \\
\hline nickel & $6.0 \mathrm{E}-02$ \\
\hline silver & $1.0 \mathrm{E}-01$ \\
\hline thallium & $4.0 \mathrm{E}-04$ \\
\hline vanadium & $3.0 \mathrm{E}-03$ \\
\hline zinc & $9.0 \mathrm{E}-01$ \\
\hline Source: Baes et al. 1984 & \\
\hline
\end{tabular}


Table 6-31. Soil-to-Plant Factors for Radionuclide Contaminants.

\begin{tabular}{|c|c|c|}
\hline \multirow[t]{2}{*}{ Radionuclide } & \multicolumn{2}{|c|}{ Transfer Coefficients } \\
\hline & Soil to Plant Seed & Animal uptake \\
\hline americium-241 & $2.5 \mathrm{E}-04$ & 0.001 \\
\hline barium-140 & $1.5 \mathrm{E}-02$ & 0.1 \\
\hline beryllium-7 & $1.5 \mathrm{E}-03$ & 0.005 \\
\hline carbon-14 & $5.5 \mathrm{E}+00$ & 1 \\
\hline cerium-141 & 4.0E-03 & 0.0003 \\
\hline cerium-144 & $4.0 \mathrm{E}-03$ & 0.0003 \\
\hline cesium-134 & $3.0 \mathrm{E}-02$ & 1 \\
\hline cesium-137 + D & $3.0 \mathrm{E}-02$ & 1 \\
\hline chromium-51 & 4.5E-03 & 0.1 \\
\hline cobalt -58 & 7.0E-03 & 0.3 \\
\hline cobalt -60 & 7.0E-03 & 0.3 \\
\hline europium-152 & $4.0 \mathrm{E}-03$ & 0.001 \\
\hline europium-154 & 4.0E-03 & 0.001 \\
\hline europium-155 & $4.0 \mathrm{E}-03$ & 0.001 \\
\hline hydrogen-3 & $4.8 \mathrm{E}+00$ & 1 \\
\hline iron-59 & $1.0 \mathrm{E}-03$ & 0.1 \\
\hline manganese-54 & $5.0 \mathrm{E}-02$ & 0.1 \\
\hline nickel-63 & $6.0 \mathrm{E}-02$ & 0.05 \\
\hline plutonium-238 & $4.5 \mathrm{E}-03$ & 0.001 \\
\hline plutonium-239/240 & $4.5 \mathrm{E}-03$ & 0.001 \\
\hline radium $-226+D$ & $1.5 \mathrm{E}-03$ & 0.2 \\
\hline ruthenium-103 & $2.0 \mathrm{E}-02$ & 0.05 \\
\hline sodium-22 & 5.5E-02 & 1 \\
\hline strontium-90 + D & $2.5 \mathrm{E}-01$ & 0.3 \\
\hline thorium-228 $+D$ & 8.5E-03 & 0.0002 \\
\hline thorium-232 & 8.5E-03 & 0.0002 \\
\hline uranium (total)(U-238+D) & 4.0E-03 & 0.05 \\
\hline zinc-65 & $9.0 \mathrm{E}-01$ & 0.5 \\
\hline zirconium-95 & $5.0 \mathrm{E}-04$ & 0.002 \\
\hline
\end{tabular}


Table 6-32. Parameters for Assessing Radiological Exposure to the Great Basin Pocket Mouse.

\begin{tabular}{|c|c|c|c|c|c|}
\hline \multirow[t]{3}{*}{ Radionuclide } & \multirow{3}{*}{$\begin{array}{c}\text { Radiological } \\
\text { Half-life } \\
\text { (days) }\end{array}$} & \multirow{3}{*}{$\begin{array}{c}\text { Biological } \\
\text { Half-life } \\
\text { (days) }\end{array}$} & \multirow{3}{*}{$\begin{array}{c}\text { Decay } \\
\text { Energy } \\
\text { (mev/dis) }\end{array}$} & \multicolumn{2}{|c|}{ Direct Exposure Dose Factor } \\
\hline & & & & Immersion & External \\
\hline & & & & \multicolumn{2}{|c|}{$(\mathrm{mRad} / \mathrm{y} / \mu \mathrm{Ci} / \mathrm{g})$} \\
\hline americium-241 & 157753 & 20000 & 5.51 & $1.47 \mathrm{E}+05$ & $4.66 E+04$ \\
\hline barium-140 & 12.74 & 65 & 0.32 & $1.45 \mathrm{E}+06$ & $1.10 E+06$ \\
\hline beryllium-7 & 53.3 & 180 & 0.0049 & $4.01 E+05$ & $3.07 E+05$ \\
\hline carbon-14 & 2091450 & 10 & 0.05 & $3.42 \mathrm{E}+01$ & $1.43 E+01$ \\
\hline cerium-141 & 32.501 & 563 & 0.174 & $5.93 E+05$ & $3.39 E+05$ \\
\hline cerium-144 & 284.3 & 563 & 1.32 & $1.49 \mathrm{E}+05$ & $7.65 E+04$ \\
\hline cesium-134 & 752.63 & 115 & 0.259 & $1.28 \mathrm{E}+07$ & $1.01 E+07$ \\
\hline cesium-137+D & 10950 & 115 & 0.267 & $4.87 E+06$ & $3.85 E+06$ \\
\hline chromium-51 & 27.706 & 616 & 0.0028 & $2.57 E+05$ & $1.86 \mathrm{E}+05$ \\
\hline cobalt -58 & 70.8 & 9.5 & 0.0905 & $8.00 E+06$ & $6.36 \mathrm{E}+06$ \\
\hline cobalt -60 & 1923.915 & 9.5 & 0.237 & $2.13 \mathrm{E}+07$ & $1.73 E+07$ \\
\hline europium-152 & 4865.45 & 635 & 0.12 & $9.60 E+06$ & $7.48 \mathrm{E}+06$ \\
\hline europium-154 & 3212 & 635 & 0.311 & $1.03 E+07$ & $8.19 E+06$ \\
\hline europium-155 & 1810.4 & 635 & 0.064 & $4.37 \mathrm{E}+05$ & $1.94 \mathrm{E}+05$ \\
\hline hydrogen-3 & 4507.75 & 10 & 0.0058 & 0.00 & 0.00 \\
\hline iron-59 & 44.529 & 800 & 0.191 & $1.01 \mathrm{E}+07$ & $8.15 E+06$ \\
\hline manganese- 54 & 312.5 & 17 & 0.0514 & $6.93 E+06$ & $5.50 \mathrm{E}+06$ \\
\hline nickel-63 & 35040 & 667 & 0.0176 & 0.00 & 0.00 \\
\hline plutonium-238 & 32025.1 & 65000 & 5.51 & $8.87 E+02$ & $1.61 \mathrm{E}+02$ \\
\hline plutonium-239/240 & 8783725 & 65000 & 5.15 & $8.67 E+02$ & $1.57 \mathrm{E}+02$ \\
\hline radium-226 + D & 584000 & 8100 & 11 & $1.50 \mathrm{E}+07$ & $1.19 \mathrm{E}+07$ \\
\hline ruthenium-103 & 39.28 & 7.3 & 0.125 & $3.81 E+06$ & $2.93 E+06$ \\
\hline sodium-22 & 949.73 & 11 & 0.325 & $1.83 E+07$ & $1.46 \mathrm{E}+07$ \\
\hline strontium-90+D & 10628.8 & 4000 & 1.14 & $2.94 \mathrm{E}+04$ & $2.62 E+04$ \\
\hline thorium-228 + D & 698 & 57000 & 5.6 & $1.36 \mathrm{E}+07$ & $1.09 \mathrm{E}+07$ \\
\hline thorium-232 & $5.1465 E+12$ & 57000 & 4.1 & $1.55 \mathrm{E}+03$ & $5.56 \mathrm{E}+02$ \\
\hline $\begin{array}{l}\text { uranium (total) } \\
(\mathrm{U}-238+\mathrm{D})\end{array}$ & $1.6308 \mathrm{E}+12$ & 100 & 4.3 & $1.59 \mathrm{E}+07$ & $1.24 \mathrm{E}+07$ \\
\hline zinc-65 & 243.9 & 933 & 0.0386 & $4.90 \mathrm{E}+06$ & $3.95 E+06$ \\
\hline zirconium-95 & 63.98 & 450 & 0.254 & $6.09 E+06$ & $4.82 E+06$ \\
\hline
\end{tabular}


DOE/RL-93-99, Rev. 0

Table 6-33. Estimated Concentrations of Organic Cor uminants in Environmental Media Used to Estimate Intake Rates for the Gre $\$$ Basin Pocket Mouse.

\begin{tabular}{|l|c|}
\hline \multicolumn{1}{|c|}{ Contaminant } & $\begin{array}{c}\text { Vegetation } \\
\text { mg/kg (wet) }\end{array}$ \\
\hline Aroclor-1248 & $7.2 \mathrm{E}-02$ \\
\hline Aroclor-1254 & $1.4 \mathrm{E}-02$ \\
\hline Aroclor-1260 & $8.4 \mathrm{E}-03$ \\
\hline benzo(a)anthracene & $1.3 \mathrm{E}-02$ \\
\hline benzene & $1.4 \mathrm{E}-01$ \\
\hline benzo(a)pyrene & $1.1 \mathrm{E}-01$ \\
\hline benzo(b)fluoranthene & $4.7 \mathrm{E}-03$ \\
\hline benzo(k)fluoranthene & $1.0 \mathrm{E}-03$ \\
\hline bis(2-ethylhexyl)phthalate & $4.6 \mathrm{E}-01$ \\
\hline chloroform & $7.2 \mathrm{E}-02$ \\
\hline chrysene & $3.0 \mathrm{E}-01$ \\
\hline dibenzo(a,h)anthracene & $9.5 \mathrm{E}-03$ \\
\hline dieldrin & $2.7 \mathrm{E}-04$ \\
\hline indeno(1,2,3-cd)pyrene & $7.4 \mathrm{E}-04$ \\
\hline methylene chloride & $1.1 \mathrm{E}+01$ \\
\hline pentachlorophenol & $2.2 \mathrm{E}-02$ \\
\hline trichloroethene & $2.3 \mathrm{E}-01$ \\
\hline vinyl chloride & $4.7 \mathrm{E}-02$ \\
\hline
\end{tabular}


DOE/RL-93-99, Rev. 0

Table 6-34. Estimated Inorganic Contaminant Concentrations in Environmental Media Used to Estimate Intake Rates for the Great Basin Pocket Mouse.

\begin{tabular}{|l|c|}
\hline \multicolumn{1}{|c|}{ Contaminant } & $\begin{array}{c}\text { Vegetation (seeds) } \\
\mathrm{mg} / \mathrm{kg} \text { (wet) }\end{array}$ \\
\hline aluminum & 16 \\
\hline antimony & 0.18 \\
\hline arsenic & 0.12 \\
\hline barium & 20 \\
\hline beryllium & 0.0023 \\
\hline cadmium & 1.4 \\
\hline chromium (VI) & 3.6 \\
\hline copper & 7,624 \\
\hline lead & 2.2 \\
\hline manganese & 49 \\
\hline mercury & 2.4 \\
\hline nickel & 34 \\
\hline silver & 12 \\
\hline thallium & 0.0007 \\
\hline vanadium & 0.37 \\
\hline zinc & 1,774 \\
\hline
\end{tabular}


DOE/RL-93-99, Rev. 0

Table 6-35. Estimated Activities of Radiological Contaminants in Environmental Media Used to Estimate Intake Rates for the Great Basin Pocket Mouse.

\begin{tabular}{|l|c|}
\hline \multicolumn{1}{|c|}{ Contaminant } & $\begin{array}{c}\text { Vegetation (seeds) } \\
\text { (Ci/kg) Wet Wt. }\end{array}$ \\
\hline americium-241 & $2.7 \mathrm{E}-12$ \\
\hline barium-140 & $1.9 \mathrm{E}-09$ \\
\hline beryllium-7 & $4.3 \mathrm{E}-11$ \\
\hline carbon-14 & $1.9 \mathrm{E}-06$ \\
\hline cerium-141 & $3.8 \mathrm{E}-12$ \\
\hline cerium-144 & $6.4 \mathrm{E}-13$ \\
\hline cesium-134 & $5.4 \mathrm{E}-10$ \\
\hline cesium-137 + D & $1.1 \mathrm{E}-06$ \\
\hline chromium-51 & $5.0 \mathrm{E}-12$ \\
\hline cobalt-58 & $3.2 \mathrm{E}-11$ \\
\hline cobalt-60 & $2.5 \mathrm{E}-08$ \\
\hline europium-152 & $3.7 \mathrm{E}-08$ \\
\hline europium-154 & $1.2 \mathrm{E}-08$ \\
\hline europium-155 & $1.2 \mathrm{E}-08$ \\
\hline hydrogen-3 & $4.4 \mathrm{E}-05$ \\
\hline iron-59 & $3.2 \mathrm{E}-13$ \\
\hline manganese-54 & $1.1 \mathrm{E}-12$ \\
\hline nickel-63 & $1.2 \mathrm{E}-6$ \\
\hline plutonium-238 & $2.0 \mathrm{E}-10$ \\
\hline plutonium-239/240 & $4.0 \mathrm{E}-09$ \\
\hline radium-226 + D & $2.0 \mathrm{E}-11$ \\
\hline ruthenium-103 & $6.4 \mathrm{E}-12$ \\
\hline sodium-22 & $1.7 \mathrm{E}-10$ \\
\hline strontium-90 + D & $1.6 \mathrm{E}-07$ \\
\hline thorium-228 + D & $4.6 \mathrm{E}-11$ \\
\hline thorium-232 & $9.7 \mathrm{E}-12$ \\
\hline uranium-238+D (total) & $2.7 \mathrm{E}-08$ \\
\hline zinc-65 & $8.6 \mathrm{E}-11$ \\
\hline zirconium-95 & $9.0 \mathrm{E}-14$ \\
\hline
\end{tabular}


Table 6-36. Estimated Intakes and Hazards to Great Basin Pocket Mouse Due to Ingestion of Organic Contaminants.

\begin{tabular}{|c|c|c|c|c|}
\hline & $\begin{array}{l}\text { Intake from } \\
\text { vegetation } \\
(\mathrm{mg} / \mathrm{kg}-\mathrm{d})\end{array}$ & $\begin{array}{c}\text { Adjusted } \\
\text { Wildlife } \\
\text { NOAEL } \\
\text { (mg/kg-day) }\end{array}$ & $\begin{array}{l}\text { Environmental } \\
\text { Hazard } \\
\text { Quotient } \\
\text { (EHQ) }\end{array}$ & $\begin{array}{l}\text { Exceeds } \\
\text { EHQ of } 1\end{array}$ \\
\hline Aroclor -1248 & $2.05 \mathrm{E}-02$ & $1.66 \mathrm{E}-01^{\mathrm{a}}$ & 0.1 & no \\
\hline Aroclor -1254 & 4.12E-03 & $1.66 \mathrm{E}-01^{\mathrm{a}}$ & 0.1 & no \\
\hline Aroclor -1260 & $2.39 \mathrm{E}-03$ & $1.66 \mathrm{E}-01^{\mathrm{a}}$ & 0.0 & no \\
\hline benzo(a)anthracene & $3.64 E-03$ & NA & NA & \\
\hline benzene & $3.94 \mathrm{E}-02$ & $6.26 \mathrm{E}+00^{\mathrm{a}}$ & 0.0 & no \\
\hline benzo(a)pyrene & $3.08 \mathrm{E}-02$ & $1.08 \mathrm{E}-02^{\mathrm{a}}$ & 3 & yes \\
\hline benzo(b)fluoranthene & $1.35 E-03$ & NA & NA & \\
\hline benzo(k)fluoranthene & $2.95 E-04$ & NA & NA & \\
\hline bis(2-ethylhexyl)phthalate & $1.3 \mathrm{E}-01$ & $1.57 \mathrm{E}+00^{\mathrm{a}}$ & 0.1 & no \\
\hline chloroform & $2.05 \mathrm{E}-02$ & $2.25 \mathrm{E}+01^{\mathrm{a}}$ & 0.0 & no \\
\hline chrysene & 8.69E-02 & NA & NA & \\
\hline dibenzo $(a, h)$ anthracene & 2.7E-03 & NA & NA & \\
\hline dieldrin & $7.72 \mathrm{E}-05$ & $5.00 \mathrm{E}-04^{\mathrm{b}}$ & 0.2 & no \\
\hline indeno( $(1,2,3-c d)$ pyrene & $2.11 \mathrm{E}-04$ & NA & NA & \\
\hline methylene chloride & $3.01 E+00$ & $1.47 \mathrm{E}+01^{\mathrm{a}}$ & 0.2 & no \\
\hline pentachlorophenol & $6.30 \mathrm{E}-03$ & $7.38 \mathrm{E}+00^{\mathrm{a}}$ & 0.0 & no \\
\hline trichloroethene & $6.54 \mathrm{E}-02$ & $1.89 \mathrm{E}+02^{\mathrm{a}}$ & 0.0 & no \\
\hline vinyl chloride & $9.22 \mathrm{E}-02$ & NA & NA & \\
\hline \multicolumn{5}{|l|}{$\begin{array}{l}\text { Data Sources for NOAELS: } \\
\text { aOpresko et al. } 1993 \\
\text { bIRIS (EPA 1993a). } \\
\text { NA - Not available }\end{array}$} \\
\hline
\end{tabular}


Table 6-37. Estimated Intakes and Hazards to the Great Basin Pocket Mouse from Ingestion of Inorganic Contaminants.

\begin{tabular}{|c|c|c|c|c|}
\hline & \multicolumn{4}{|c|}{ Mouse (inorganic) } \\
\hline & $\begin{array}{l}\text { Intake from } \\
\text { vegetation } \\
\text { (mg/kg-day) }\end{array}$ & $\begin{array}{c}\text { Wildlife } \\
\text { NOAEL } \\
\text { (mg/kg-day) }\end{array}$ & $\begin{array}{c}\text { Environmental } \\
\text { Hazard } \\
\text { Quotient } \\
\text { (EHQ) }\end{array}$ & $\begin{array}{l}\text { Exceeds } \\
\text { EHQ of } 1\end{array}$ \\
\hline aluminum & $4.65 E+00$ & $1.06 \mathrm{E}-01$ & 4 & yes \\
\hline antimony & $5.09 \mathrm{E}-02$ & 8.61E-02 & 0.6 & no \\
\hline arsenic & $3.4 \mathrm{E}-02$ & $1.08 \mathrm{E}-01$ & 0.3 & no \\
\hline barium & $5.83 E+00$ & $1.28 \mathrm{E}+00$ & 5 & yes \\
\hline beryllium & $6.43 E-04$ & $1.36 \mathrm{E}+00$ & 0.0 & no \\
\hline cadmium & $3.9 \mathrm{E}-01$ & $5.29 \mathrm{E}-01$ & 0.7 & no \\
\hline chromium (VI) & $1.03 \mathrm{E}+00$ & $6.04 \mathrm{E}+00$ & 0.2 & no \\
\hline copper & $2.17 \mathrm{E}+03$ & $1.86 \mathrm{E}-01$ & 11,686 & yes \\
\hline lead & $6.13 E-01$ & $1.97 \mathrm{E}+00$ & 0.3 & no \\
\hline manganese & $1.39 \mathrm{E}+01$ & $2.02 \mathrm{E}+00$ & 7 & yes \\
\hline mercury & $6.75 \mathrm{E}-01$ & $6.07 \mathrm{E}+02$ & 11 & yes \\
\hline nickel & $9.58 \mathrm{E}+00$ & $6.07 \mathrm{E}+01$ & 0.2 & no \\
\hline silver & $3.30 \mathrm{E}+00$ & $2.19 E+01$ & 0.2 & no \\
\hline thallium & $1.97 \mathrm{E}-04$ & NA & NA & \\
\hline vanadium & $1.06 \mathrm{E}+01$ & $4.4 \mathrm{E}-01$ & 0.2 & no \\
\hline zinc & $5.06 \mathrm{E}+02$ & $2.44 \mathrm{E}+01$ & 21 & yes \\
\hline $\begin{array}{l}\text { Data Sources fo } \\
\text { NA - Not availa }\end{array}$ & AELS: Opres & al. 1993 & & \\
\hline
\end{tabular}


Table 6-38. Estimated Doses and Hazards to the Great Basin Pocket Mouse from Ingestions and Exposure to Radionuclide Contaminants.

\begin{tabular}{|c|c|c|c|c|}
\hline \multirow[t]{4}{*}{ Radionuclides } & \multicolumn{4}{|c|}{ Great Basin Pocket Mice } \\
\hline & \multirow{3}{*}{$\begin{array}{l}\text { Ingestion } \\
\text { Dose Rate } \\
\text { (rad/day) }\end{array}$} & \multicolumn{3}{|c|}{ External Exposure } \\
\hline & & Burrowing & Surface & Total \\
\hline & & \multicolumn{3}{|c|}{ (rad/day) } \\
\hline americium-241 & 0.00 & 0.00 & 0.00 & 0.00 \\
\hline barium-140 & 0.00 & 0.00 & 0.00 & 0.00 \\
\hline beryllium-7 & 0.00 & 0.00 & 0.00 & 0.00 \\
\hline carbon-14 & 0.01 & 0.00 & 0.00 & 0.00 \\
\hline cerium-141 & 0.00 & 0.00 & 0.00 & 0.00 \\
\hline cerium-144 & 0.00 & 0.00 & 0.00 & 0.00 \\
\hline cesium-134 & 0.04 & 0.00 & 0.00 & 0.00 \\
\hline cesium-137 + D & 0.60 & 1.03 & 0.07 & 1.10 \\
\hline chromium-51 & 0.00 & 0.00 & 0.00 & 0.00 \\
\hline cobalt-58 & 0.00 & 0.00 & 0.00 & 0.00 \\
\hline cobalt -60 & 0.17 & 0.45 & 0.03 & 0.48 \\
\hline europium-152 & 0.00 & 0.53 & 0.04 & 0.57 \\
\hline europium-154 & 0.00 & 0.18 & 0.01 & 0.19 \\
\hline europium-155 & 0.00 & 0.01 & 0.00 & 0.01 \\
\hline hydrogen-3 & 0.05 & 0.00 & 0.00 & 0.00 \\
\hline iron-59 & 0.00 & 0.00 & 0.00 & 0.00 \\
\hline manganese-54 & 0.00 & 0.00 & 0.00 & 0.00 \\
\hline nickel-63 & 0.05 & 0.00 & 0.00 & 0.00 \\
\hline plutonium-238 & 0.00 & 0.00 & 0.00 & 0.00 \\
\hline plutonium-239/240 & 0.01 & 0.00 & 0.00 & 0.00 \\
\hline radium-226 + D & 0.11 & 0.00 & 0.00 & 0.00 \\
\hline ruthenium-103 & 0.00 & 0.00 & 0.00 & 0.00 \\
\hline sodium-22 & 0.00 & 0.00 & 0.00 & 0.00 \\
\hline strontium-90 + D & 0.28 & 0.00 & 0.00 & 0.00 \\
\hline thorium $-228+D$ & 0.00 & 0.00 & 0.00 & 0.00 \\
\hline thorium-232 & 0.00 & 0.00 & 0.00 & 0.00 \\
\hline uranium-238+D (total) & 0.01 & 0.61 & 0.04 & 0.65 \\
\hline zinc-65 & 0.00 & 0.00 & 0.00 & 0.00 \\
\hline zirconium-95 & 0.00 & 0.00 & 0.00 & 0.00 \\
\hline TOTAL & 0.96 & 2.81 & 0.19 & 3.00 \\
\hline
\end{tabular}


Table 6-39. Estimated Current and Future Environmental Hazard Quotient for the Great Basin Pocket Mouse from Ingestion of Organic Contaminants.

\begin{tabular}{|c|c|c|c|c|c|}
\hline Contaminant & \multirow{2}{*}{$\begin{array}{c}\text { Half-life } \\
(y r)\end{array}$} & \multirow{2}{*}{$\begin{array}{l}\text { Current } \\
\text { EHQ }^{\mathrm{b}}\end{array}$} & \multirow{2}{*}{$\begin{array}{l}\text { Future EHQ at } \\
103 \text { years }\end{array}$} & \multirow{2}{*}{$\begin{array}{l}\text { Future EHQ at } \\
500 \text { years }\end{array}$} & \multirow{2}{*}{$\begin{array}{c}\text { Future EHC } \\
\text { at } 10,000 \\
\text { years } b\end{array}$} \\
\hline Organic & & & & & \\
\hline Aroclor-1248 & 1 & 0.1 & 0.0 & 0.0 & 0.0 \\
\hline Aroclor -1254 & 10,000 & 0.0 & 0.0 & 0.0 & 0.0 \\
\hline Aroclor-1260 & 10,000 & 0.0 & 0.0 & 0.0 & 0.0 \\
\hline benz(a)anthracene & 10 & ND & ND & ND & ND \\
\hline benzene & 10 & 0.0 & 0.0 & 0.0 & 0.0 \\
\hline benzo(a)pyrene & 100 & 2.9 & 1.4 & 0.1 & 0.0 \\
\hline benzo(b)fluoranthene & 10 & ND & ND & ND & ND \\
\hline benzo(k)fluoranthene & 100 & ND & ND & ND & ND \\
\hline bis(2-ethylhexyl)phthalate & 10 & 0.1 & 0.0 & 0.0 & 0.0 \\
\hline chloroform & 10 & 0.0 & 0.0 & 0.0 & 0.0 \\
\hline chrysene & 10 & ND & ND & ND & ND \\
\hline dibenz(a,h)anthracene & 10 & ND & ND & ND & ND \\
\hline dieldrin & 10 & 0.02 & 0.0 & 0.0 & 0.0 \\
\hline indeno(1,2,3-cd)pyrene & 10 & ND & ND & ND & ND \\
\hline methylene chloride & 1 & 0.02 & 0.0 & 0.0 & 0.0 \\
\hline pentachlorophenol & 10 & 0.0 & 0.0 & 0.0 & 0.0 \\
\hline trichloroethene & 10 & 0.0 & 0.0 & 0.0 & 0.0 \\
\hline vinyl chloride & 10 & ND & ND & ND & ND \\
\hline \multicolumn{6}{|c|}{$\begin{array}{l}\text { Notes: } \\
\text { a Half-lives based on values from Table 4-5. } \\
\text { b Based on seed ingestion. } \\
\text { ND = Not determined } \\
\text { EHQ = Environmental Hazard Quotient }\end{array}$} \\
\hline
\end{tabular}


Table 6-40. Estimated Current and Future Dose to the Great Basin Pocket Mouse from Ingestion of and External Exposure to Radionuclides. (Sheet 1 of 2)

\begin{tabular}{|c|c|c|c|c|c|}
\hline Contaminant & $\begin{array}{c}\text { Halflife } \\
(y r)\end{array}$ & $\begin{array}{l}\text { Current } \\
\text { Dose from } \\
\text { Ingestion } \\
\text { (rad/day) }\end{array}$ & $\begin{array}{l}\text { Future } \\
\text { Dose at } \\
103 \text { years } \\
\text { (rad/day) }\end{array}$ & $\begin{array}{c}\text { Future } \\
\text { Dose at } \\
500 \text { years } \\
\text { (rad/day) }\end{array}$ & $\begin{array}{c}\text { Future } \\
\text { Dose at } \\
10,000 \text { years } \\
\text { (rad/day) }\end{array}$ \\
\hline americium-241 & $4.32 \mathrm{E}+02$ & 0.0 & 0.0 & 0.0 & 0.0 \\
\hline barium-140 & $3.50 \mathrm{E}-02$ & 0.0 & 0.0 & 0.0 & 0.0 \\
\hline beryllium-7 & $1.46 \mathrm{E}-01$ & 0.0 & 0.0 & 0.0 & 0.0 \\
\hline carbon-14 & $5.73 E+03$ & 0.0 & 0.0 & 0.0 & 0.0 \\
\hline cerium-141 & 8.90E-02 & 0.0 & 0.0 & 0.0 & 0.0 \\
\hline cerium-144 & $7.78 \mathrm{E}-01$ & 0.0 & 0.0 & 0.0 & 0.0 \\
\hline cesium-134 & $2.06 \mathrm{E}+00$ & 0.0 & 0.0 & 0.0 & 0.0 \\
\hline cesium-137 & $3.02 E+01$ & 0.6 & 0.1 & 0.0 & 0.0 \\
\hline chromium-51 & $7.58 \mathrm{E}-02$ & 0.0 & 0.0 & 0.0 & 0.0 \\
\hline cobalt-58 & $1.94 \mathrm{E}-01$ & 0.0 & 0.0 & 0.0 & 0.0 \\
\hline cobalt -60 & $5.27 E+00$ & 0.0 & 0.0 & 0.0 & 0.0 \\
\hline europium-152 & $1.36 \mathrm{E}+01$ & 0.0 & 0.0 & 0.0 & 0.0 \\
\hline europium-154 & $8.80 E+00$ & 0.0 & 0.0 & 0.0 & 0.0 \\
\hline europium-155 & $4.96 \mathrm{E}+00$ & 0.0 & 0.0 & 0.0 & 0.0 \\
\hline hydrogen-3 & $1.23 \mathrm{E}+01$ & 0.1 & 0.0 & 0.0 & 0.0 \\
\hline iron-59 & $1.22 \mathrm{E}-01$ & 0.0 & 0.0 & 0.0 & 0.0 \\
\hline manganese-54 & 8.57E-01 & 0.0 & 0.0 & 0.0 & 0.0 \\
\hline nickel-63 & $1.00 \mathrm{E}+02$ & 0.0 & 0.0 & 0.0 & 0.0 \\
\hline plutonium-238 & $8.78 \mathrm{E}+01$ & 0.0 & 0.0 & 0.0 & 0.0 \\
\hline plutonium-239/240 & $2.41 \mathrm{E}+04$ & 0.0 & 0.0 & 0.0 & 0.0 \\
\hline radium-226 & $1.60 \mathrm{E}+03$ & 0.0 & 0.0 & 0.0 & 0.0 \\
\hline ruthenium-103 & $1.08 \mathrm{E}-01$ & 0.0 & 0.0 & 0.0 & 0.0 \\
\hline sodium-22 & $2.60 \mathrm{E}+00$ & 0.0 & 0.0 & 0.0 & 0.0 \\
\hline strontium-90 & $2.86 \mathrm{E}+01$ & 0.3 & 0.0 & 0.0 & 0.0 \\
\hline thorium-228 & $1.91 \mathrm{E}+00$ & 0.0 & 0.0 & 0.0 & 0.0 \\
\hline thorium-232 & $1.41 E+10$ & 0.0 & 0.0 & 0.0 & 0.0 \\
\hline uranium (total) & $4.47 \mathrm{E}+09$ & 0.0 & 0.0 & 0.0 & 0.0 \\
\hline zinc-65 & $6.68 \mathrm{E}-01$ & 0.0 & 0.0 & 0.0 & 0.0 \\
\hline zirconium-95 & $1.75 \mathrm{E}-01$ & 0.0 & 0.0 & 0.0 & 0.0 \\
\hline
\end{tabular}


Table 6-40. Estimated Current and Future Dose to the Great Basin Pocket Mouse from Ingestion of and External Exposure to Radionuclides. (Sheet 2 of 2)

\begin{tabular}{|c|c|c|c|c|c|}
\hline Contaminant & $\begin{array}{c}\text { Halflife } \\
\text { (yr) }\end{array}$ & $\begin{array}{l}\text { Current } \\
\text { Dose from } \\
\text { External } \\
\text { Exposure } \\
\text { (rad/day) }\end{array}$ & $\begin{array}{l}\text { Future } \\
\text { Dose at } \\
103 \text { years } \\
\text { (rad/day) }\end{array}$ & $\begin{array}{l}\text { Future } \\
\text { Dose at } \\
500 \text { years } \\
\text { (rad/day) }\end{array}$ & $\begin{array}{c}\text { Future } \\
\text { Dose at } \\
10,000 \text { years } \\
\text { (rad/day) }\end{array}$ \\
\hline americium-241 & $4.32 \mathrm{E}+02$ & 0.0 & 0.0 & 0.0 & 0.0 \\
\hline barium- 140 & $3.50 \mathrm{E}-02$ & 0.0 & 0.0 & 0.0 & 0.0 \\
\hline beryllium-7 & $1.46 \mathrm{E}-01$ & 0.0 & 0.0 & 0.0 & 0.0 \\
\hline carbon-14 & $5.73 E+03$ & 0.0 & 0.0 & 0.0 & 0.0 \\
\hline cerium-141 & $8.90 \mathrm{E}-02$ & 0.0 & 0.0 & 0.0 & 0.0 \\
\hline cerium-144 & $7.78 \mathrm{E}-01$ & 0.0 & 0.0 & 0.0 & 0.0 \\
\hline cesium-134 & $2.06 \mathrm{E}+00$ & 0.0 & 0.0 & 0.0 & 0.0 \\
\hline cesium-137 & $3.02 \mathrm{E}+01$ & 1.1 & 0.1 & 0.0 & 0.0 \\
\hline chromium-51 & $7.58 \mathrm{E}-02$ & 0.0 & 0.0 & 0.0 & 0.0 \\
\hline cobalt -58 & $1.94 \mathrm{E}-01$ & 0.0 & 0.0 & 0.0 & 0.0 \\
\hline cobalt -60 & $5.27 \mathrm{E}+00$ & 0.5 & 0.0 & 0.0 & 0.0 \\
\hline europium-152 & $1.36 \mathrm{E}+01$ & 0.6 & 0.0 & 0.0 & 0.0 \\
\hline europium-154 & $8.80 \mathrm{E}+00$ & 0.2 & 0.0 & 0.0 & 0.0 \\
\hline europium-155 & $4.96 \mathrm{E}+00$ & 0.0 & 0.0 & 0.0 & 0.0 \\
\hline hydrogen-3 & $1.23 E+01$ & 0.0 & 0.0 & 0.0 & 0.0 \\
\hline iron-59 & $1.22 \mathrm{E}-01$ & 0.0 & 0.0 & 0.0 & 0.0 \\
\hline manganese-54 & 8.57E-01 & 0.0 & 0.0 & 0.0 & 0.0 \\
\hline nickel-63 & $1.00 \mathrm{E}+02$ & 0.0 & 0.0 & 0.0 & 0.0 \\
\hline plutonium-238 & $8.78 \mathrm{E}+01$ & 0.0 & 0.0 & 0.0 & 0.0 \\
\hline plutonium-239/240 & $2.41 \mathrm{E}+04$ & 0.0 & 0.0 & 0.0 & 0.0 \\
\hline radium-226 & $1.60 \mathrm{E}+03$ & 0.0 & 0.0 & 0.0 & 0.0 \\
\hline ruthenium-103 & $1.08 \mathrm{E}-01$ & 0.0 & 0.0 & 0.0 & 0.0 \\
\hline sodium-22 & $2.60 \mathrm{E}+00$ & 0.0 & 0.0 & 0.0 & 0.0 \\
\hline strontium-90 & $2.86 \mathrm{E}+01$ & 0.0 & 0.0 & 0.0 & 0.0 \\
\hline thorium-228 & $1.91 \mathrm{E}+00$ & 0.0 & 0.0 & 0.0 & 0.0 \\
\hline thorium-232 & $1.41 E+10$ & 0.0 & 0.0 & 0.0 & 0.0 \\
\hline uranium (total) & $4.47 \mathrm{E}+09$ & 0.6 & 0.6 & 0.6 & 0.6 \\
\hline zinc- 65 & $6.68 \mathrm{E}-01$ & 0.0 & 0.0 & 0.0 & 0.0 \\
\hline zirconium-95 & $1.75 E-01$ & 0.0 & 0.0 & 0.0 & 0.0 \\
\hline
\end{tabular}


DOE/RL-93-99, Rev. 0

Table 6-41. Non-Radioactive Contaminant Human Health Risks for the 500-Year Drilling Scenario

\begin{tabular}{|c|c|c|}
\hline Contaminant & HQ & ICR \\
\hline \multicolumn{3}{|l|}{ Organic } \\
\hline $\begin{array}{l}\text { Aroclor-1248 } \\
\text { Aroclor-1254 } \\
\text { Aroclor-1260 } \\
\text { benz(a)anthracene } \\
\text { benzene } \\
\text { benzo(a)pyrene } \\
\text { benzo(b)fluoranthene } \\
\text { benzo(k)fluoranthene } \\
\text { bis(2-ethylhexyl)phthalate } \\
\text { chloroform } \\
\text { chrysene } \\
\text { dibenz(a,h)anthracene } \\
\text { dieldrin } \\
\text { indeno(1,2,3-cd)pyrene } \\
\text { methylene chloride } \\
\text { pentachlorophenol } \\
\text { trichloroethene } \\
\text { vinyl chloride }\end{array}$ & $\begin{array}{l}0 \mathrm{E}+00 \\
0 \mathrm{E}+00 \\
0 \mathrm{E}+00 \\
0 \mathrm{E}+00 \\
0 \mathrm{E}+00 \\
0 \mathrm{E}+00 \\
0 \mathrm{E}+00 \\
0 \mathrm{E}+00 \\
2 \mathrm{E}-20 \\
1 \mathrm{E}-22 \\
0 \mathrm{E}+00 \\
0 \mathrm{E}+00 \\
5 \mathrm{E}-21 \\
0 \mathrm{E}+00 \\
0 \mathrm{E}+00 \\
6 \mathrm{E}-22 \\
9 \mathrm{E}-22 \\
0 \mathrm{E}+00\end{array}$ & $\begin{array}{l}0 \mathrm{E}+00 \\
9 \mathrm{E}-08 \\
3 \mathrm{E}-08 \\
2 \mathrm{E}-23 \\
2 \mathrm{E}-25 \\
1 \mathrm{E}-08 \\
3 \mathrm{E}-23 \\
3 \mathrm{E}-10 \\
7 \mathrm{E}-25 \\
7 \mathrm{E}-25 \\
5 \mathrm{E}-22 \\
2 \mathrm{E}-23 \\
5 \mathrm{E}-25 \\
2 \mathrm{E}-23 \\
0 \mathrm{E}+00 \\
3 \mathrm{E}-25 \\
2 \mathrm{E}-25 \\
1 \mathrm{E}-24\end{array}$ \\
\hline \multicolumn{3}{|l|}{ Inorganic } \\
\hline $\begin{array}{l}\text { aluminum } \\
\text { ammonia } \\
\text { antimony } \\
\text { arsenic } \\
\text { barium } \\
\text { beryllium } \\
\text { cadmium } \\
\text { chromium } \\
\text { copper } \\
\text { lead } \\
\text { manganese } \\
\text { mercury } \\
\text { nickel } \\
\text { silver } \\
\text { thallium } \\
\text { vanadium } \\
\text { zinc }\end{array}$ & $\begin{array}{c}2 E-03 \\
3 E-03 \\
1 E-03 \\
3 E-03 \\
2 E-03 \\
3 E-05 \\
4 E-04 \\
7 E-03 \\
3 E-02 \\
0 E+00 \\
9 E-04 \\
2 E-03 \\
1 E-03 \\
1 E-03 \\
1 E-03 \\
1 E-03 \\
3 E-04 \\
\end{array}$ & $\begin{array}{c}0 \mathrm{E}+00 \\
0 \mathrm{E}+00 \\
0 \mathrm{E}+00 \\
2 \mathrm{E}-07 \\
0 \mathrm{E}+00 \\
2 \mathrm{E}-07 \\
7 \mathrm{E}-10 \\
4 \mathrm{E}-07 \\
0 \mathrm{E}+00 \\
0 \mathrm{E}+00 \\
0 \mathrm{E}+00 \\
0 \mathrm{E}+00 \\
0 \mathrm{E}+00 \\
0 \mathrm{E}+00 \\
0 \mathrm{E}+00 \\
0 \mathrm{E}+00 \\
0 \mathrm{E}+00\end{array}$ \\
\hline Total & $5 E-02$ & $9 \mathrm{E}-07$ \\
\hline
\end{tabular}


DOE/RL-93-99, Rev. 0

Table 6-42. Radionuclide Human Health Risks for the 500-Year Drilling Scenario.

\begin{tabular}{|c|c|}
\hline RADIONUCLIDES & ICR \\
\hline americium-241 & $1 E-08$ \\
\hline barium-140 & $0 \mathrm{E}+\infty 0$ \\
\hline beryllium-7 & $0 \mathrm{E}+00$ \\
\hline carbon-14 & $7 \mathrm{E}-10$ \\
\hline cerium-141 & $0 \mathrm{E}+00$ \\
\hline cerium-144 & $0 \mathrm{E}+00$ \\
\hline cesium-134 & $0 \mathrm{E}+00$ \\
\hline cesium-137 & $5 E-08$ \\
\hline chromium-51 & $0 \mathrm{E}+00$ \\
\hline cobalt -58 & $0 \mathrm{E}+00$ \\
\hline cobalt -60 & $6 E-32$ \\
\hline europium-152 & $2 E-14$ \\
\hline europium-154 & $7 \mathrm{E}-21$ \\
\hline europium-155 & $6 \mathrm{E}-36$ \\
\hline hydrogen-3 & $1 \mathrm{E}-21$ \\
\hline iron-59 & $0 \mathrm{E}+00$ \\
\hline manganese-54 & $0 \mathrm{E}+00$ \\
\hline nickel-63 & $6 \mathrm{E}-10$ \\
\hline plutonium-238 & 2E-09 \\
\hline plutonium-239/240 & $2 \mathrm{E}-06$ \\
\hline radium-226 & $5 E-06$ \\
\hline radium-228a & $2 \mathrm{E}-07$ \\
\hline ruthenium-103 & $0 \mathrm{E}+00$ \\
\hline sodium-22 & $3 E-64$ \\
\hline strontium-90b & $5 E-13$ \\
\hline thorium-228 ${ }^{\mathrm{a}}$ & $5 E-07$ \\
\hline thorium-232 & $8 E-10$ \\
\hline uranium (total) & $3 E-05$ \\
\hline zinc-65 & $0+00$ \\
\hline zirconium-95 & $0+00$ \\
\hline Total ICR & $3 E-05$ \\
\hline
\end{tabular}


DOE/RL-93-99, Rev. 0

Table 6-43. Inorganic Contaminant Risks to

Environmental Receptors for the 500-Year Drilling Scenario

\begin{tabular}{|l|c|}
\hline \multicolumn{1}{|c|}{ Contaminant } & Environmental Hazard Quotient (EHQ) \\
\hline aluminum & 0.04 \\
\hline antimony & 0.00 \\
\hline arsenic & 0.00 \\
\hline barium & 0.00 \\
\hline beryllium & 0.00 \\
\hline cadmium & 0.00 \\
\hline chromium (VI) & 0.00 \\
\hline copper & 12 \\
\hline lead & 0.00 \\
\hline manganese & 0.01 \\
\hline mercury & 0.01 \\
\hline nickel & 0.00 \\
\hline silver & 0.00 \\
\hline thallium & $\mathrm{NE}$ \\
\hline vanadium & 0.00 \\
\hline zinc & 0.02 \\
\hline Notes: NE $=$ not evaluated & \\
\hline
\end{tabular}


DOE/RL-93-99, Rev. 0

\subsection{DEVELOPMENT OF REMEDIAL ACTION OBJEC IVES}

Development of remedial action objectives (RAOs) is the initial activity of a feasibility study (FS). The primary purpose of RAOs is to focus the development, screening, and analysis of remedial alternatives to ensure that they are protective of human health and the environment. RAOs are based on a variety of factors (described in Section 7.2), of which the primary drivers are applicable or relevant and appropriate requirements (ARARs). Section 7.1 includes a discussion of chemical, location, and action specific ARARs that may be pertinent to the remedial alternatives developed and evaluated in later chapters. The chemical-specific ARARs were also used for constituent-screening performed in Chapter 5.0. Remedial action objectives (RAOs) for the ERDF are developed in Section 7.2.

\subsection{POTENTIAL APPLICABLE OR RELEVANT AND APPROPRIATE REQUIREMENTS}

This section consists of a review of potential federal and state applicable or relevant and appropriate requirements (ARARs) which may be pertinent to the siting, design, operation and closure of the ERDF. The ARARs development process is based on CERCLA guidance (EPA 1988a and EPA 1988c). The review of ARARs included herein is an update of the preliminary ARAR identification presented in the Regulatory Strategy for Macro Engineering Implementation (Lauterbach 1992). Identification of ARARs is directly impacted by characteristics of the site, contaminants present, and remedial alternatives developed, therefore, only specific sections of the regulations may be ARAR. The identification of ARARs will be refined following identification of a preferred alternative.

Section 121 (d) of CERCLA, as amended, establishes cleanup standards for remedial actions. This section requires that any applicable or relevant and appropriate standard, requirement, criteria or limitation under any federal environmental law, or any more stringent state requirement promulgated pursuant to a state environmental statute, be met for any hazardous substance, pollutant, or contaminant remaining on-site. A requirement promulgated under other environmental laws may be either "applicable" or "relevant and appropriate", but not both. Identification of ARARs must be done on a site-specific basis and involves a two-part analysis: first, a determination is made whether a given requirement is applicable; then if it is not applicable, a determination is made whether it is nevertheless both relevant and appropriate. The EPA guidance also includes To-Be-Considered (TBC) materials which are advisories and nonpromulgated guidance issued by federal or state governments that are non-statutory requirements evaluated along with ARARs as part of the risk assessment used to establish protective cleanup limits. These standards will be evaluated for use as performance criteria for siting, design, operation and closure of the ERDF.

The EPA may waive ARARs and select a remedial action that does not attain the same level of cleanup as identified by ARARs. Section 121 (d)(4) of CERCLA identifies six circumstances where EPA may waive ARARs for on-site remedial actions. The six circumstances are:

- The remedial action selected is only a part of a total remedial action (such as an interim action) and the final remedy will attain the ARAR upon its completion. 
- Compliance with the ARAR will result in a greater risk to human health and the environment than alternative options.

- Compliance with the ARAR is technically impracticable from an engineering perspective.

- An alternative remedial action will attain an equivalent standard of performance through the use of another method or approach.

- The ARAR is a state requirement that the state has not consistently applied (or demonstrated the intent to apply consistently) in similar circumstances.

- In the case of Section 104, Superfund-financed remedial actions, compliance with the ARAR will not provide a balance between protecting human health and the environment and the availability of Superfund money for response at other facilities.

The different types of requirements that CERCLA actions may have to comply with are identified as chemical-specific, location-specific and action-specific ARARS. The following definitions are excerpts from EPA guidance in CERCLA Compliance with Other Laws Manual: Interim Final (EPA 1988c). However, some requirements may not fall neatly into the classification system.

Chemical-specific requirements are usually health- or risk-based numerical values or methodologies which, when applied to site-specific conditions, result in the establishment of numerical values. These numbers establish the acceptable amount or concentration of a chemical that can be found in, or discharged to the ambient environment.

Location-specific requirements are restrictions placed on the concentration of hazardous substances or the conduct of activities because they occur in special or sensitive locations or environments.

Action-specific requirements are those that place either technology-based or activity-based requirements on remedial actions at CERCLA sites.

Federal and state regulations along with other guidance were evaluated as potential ARARs and TBC materials. Tables 7-1 and 7-2 present the full list of laws and regulations that were evaluated as potentially applicable or relevant and appropriate requirements for management of Hanford Site remediation waste at the ERDF. The following discussion of ARARs focuses only on the most significant potential ARARs

\subsubsection{Chemical-Specific ARARs}

Chemical-specific ARARs may be federal, state statutory or regulatory requirements and other guidance that identify acceptable health- or risk-based contaminant levels for different media known to be contaminated. Chemical-specific ARARs may be used as criteria during ERDF performance evaluations. The list of contaminants of concern established in Chapter 5 was used to identify potential chemical-specific ARARs. 
7.1.1.1 Federal Chemical-Specific ARARs. Federal chemical-specific requirements, criteria, or guidance for the contaminants of concern identified at the Hanford Site are listed in Table 7-1.

\section{National Primary Drinking Water Regulations - 40 CFR 141}

The National Primary Drinking Water Regulations (40 CFR 141) promulgated under the Safe Drinking Water Act (SDWA) establish maximum contaminant level goals (MCLGs) and maximum contaminant levels (MCLs) for community drinking water systems. MCLs and MCLGs have been established for a large number of both non-radioactive contaminants and radionuclides. The regulations are not applicable to the ERDF because Hanford Site ground and surface waters are not used as public drinking water supplies. However, the regulations may be considered relevant and appropriate to the ERDF as performance criteria for groundwater protection. Section 300.430 (e)(2)(i)(B) of the NCP states that remedial actions for ground or surface water that are current or potential sources of drinking water shall attain standards established under the SDWA, where the MCL or MCLG is relevant and appropriate to the circumstances of the release. Although groundwater affected by the Hanford Site is not currently used for drinking, it could be used in the future if the site is released from institutional controls. If portions of the Hanford Site convert to other land uses, and the ground and/or surface water is considered as a potential source of drinking water, the operation of the ERDF must be protective of ground and surface water. There is also potential for groundwater beneath the ERDF site to discharge to the Columbia River which is used for drinking water. Design, operation and closure of the ERDF needs to prevent migration of contaminants from soils to groundwater at concentrations that cause the groundwater to exceed MCLGs and MCLs. Drinking water MCLGs and MCLs for radionuclide and nonradionuclide contaminants of concern are listed in Tables 7-3 and 7-4.

\section{National Secondary Drinking Water Regulations - 40 CFR 143}

The National Secondary Drinking Water Regulations control contaminants in drinking water that primarily affect aesthetic qualities of the water that relate to public acceptance. These regulations are not applicable to the ERDF because they are not federally enforceable. However, under Washington State regulations (173-340-720(2)(9)(ii)) they are a potential ARAR because the regulation specifies secondary maximum contaminant levels (SMCLs) as cleanup standards.

\section{Resource Conservation and Recovery Act - Title 42 USC 6901 et seq}

The Resource Conservation and Recovery Act (RCRA) regulates the generation, transportation, storage, treatment and disposal of hazardous waste. These regulations also provide authority for the cleanup of spills and environmental releases of hazardous waste to the environment as a result of past practices. Hazardous waste management regulations promulgated pursuant to RCRA are codified at 40 CFR 260 through 270. Washington State Dangerous Waste Regulations implement the federal hazardous waste regulations and are administered by the Washington State Department of Ecology (Ecology).

Regulations established under RCRA are applicable to the ERDF as chemical-specific ARARs because the facility may generate hazardous waste. Operation and design requirements for hazardous waste management facilities in the RCRA regulations are discussed in Section 7.1.3.1, as they are action-specific ARARs. In addition, RCRA regulations for solid waste include groundwater protection standards in 40 CFR 264.92 that establish three remediation levels of groundwater protection: background, MCLs, or alternate concentration levels (ACLs). MCLs are set at the same levels as SDWA MCLs and where no SDWA MCL has been set, health based 
ACLs may be established that are protective of human health and environment. Criteria for Classification of Solid Waste Disposal Facilities and Practices (40 CFR 257) establish groundwater protection requirements for solid waste disposal facilities at the same level as MCLs published under 40 CFR 141.

\section{National Primary and Secondary Ambient Air Quality Standards - 40 CFR 50}

National primary and secondary ambient air quality standards were established pursuant to the Clean Air Act in order to protect air quality and maintain public health. The EPA has promulgated national primary air quality standards for six criteria pollutants; sulfur oxides, particulate matter, carbon monoxide, ozone, nitrogen dioxide, and lead. The requirements of this standard are applicable because potential airborne emission of particulates or lead may result during operation of the facility. Under the Clean Air Act, states are required to develop State Implementation Plans that outline how the state will implement, maintain and enforce the national ambient air quality standards (NAAQS). Upon EPA approval, State plans become enforceable, and state requirements may become federal requirements.

\section{National Emission Standards for Hazardous Air Pollutants - 40 CFR 61}

The Clean Air Act directs the EPA to develop and periodically revise a list of National Emission Standards for Hazardous Air Pollutants (NESHAPs). Hazardous air pollutants are air contaminants that affect human welfare for which no ambient air quality standard exists. The NESHAPs are promulgated for emissions from specific sources, and only the NESHAPs established for radionuclide emissions from DOE facilities are applicable to the ERDF. The remaining NESHAPs may be considered relevant and appropriate to the ERDF if operation of the facility incorporates operations similar to operations associated with the sources identified in the NESHAP.

EPA standards for radionuclide emissions from facilities owned and operated by DOE under 40 CFR 61.90, National Emission Standards for Hazardous Air Pollutants are potentially applicable because radionuclides will be present in wastes managed at the facility and there is potential for airborne release. The regulation establishes general radiation dose limits to members of the public from radionuclides emitted into the air from DOE facilities. The dose equivalent rate to any member of the public shall not exceed $25 \mathrm{mrem} / \mathrm{yr}$ to the whole body or $75 \mathrm{mrem} / \mathrm{yr}$ to any critical organ. Also, no member of the public may receive a continuous exposure, excluding natural background and medical exposure, of more than $100 \mathrm{mrem} / \mathrm{yr}$ effective dose equivalent and a noncontinuous exposure of more than $500 \mathrm{mrem} / \mathrm{yr}$ effective dose equivalent from all sources.

Environmental Radiation Protection Standards for the Management and Disposal of Spent Nuclear Fuel, High-Level and Transuranic Radioactive Waste - 40 CFR 191

The final rule published in the December 20, 1993 Federal Register (58 FR 66398) establishes a 10,000 year performance standard for groundwater protection for radioactive waste disposal facilities regulated under the Environmental Radiation Protection Standards for the Management and Disposal of Spent Nuclear Fuel, High-Level, and Transuranic Radioactive Waste (40 CFR 191). Requirements of the final rule are effective January 20, 1994. The requirements of 40 CFR 191 are not applicable or relevant and appropriate requirements to ERDF because remediation waste to be disposed at the ERDF does not meet the definition of waste subject to the regulation. However, the Tri-Party Agreement between DOE, Ecology and EPA identifies 10,000 yrs as a long-term performance standard for protection to be used as a parameter in the ERDF risk 
assessments. Groundwater protection standards established under the regulation specify that disposal systems shall be designed so that for $10,000 \mathrm{yr}$ after disposal, they shall not cause the levels of radioactivity to exceed the limits specified in 40 CFR 141 (as the limits exist on the date the implementing agency determines compliance). Under the final rule, disposal methods would be required to limit radiation exposure to an individual for an undisturbed performance period of 10,000 years to no more than 15 mrems committed effective dose (CED) per year. The CED is the risk-weighted sum of the doses to the individual organs of the body. If compliance assessments indicate that a disposal system design will fail to meet the 10,000-year individual dose standard, more robust engineered barriers to control releases of radionuclides may be required.

\section{Health and Environmental Protection Standards for Uranium and Thorium Mill Tailings - 40 CFR 192}

Requirements of 40 CFR 192, Health and Environmental Protection Standards for Uranium and Thorium Mill Tailings are potentially relevant and appropriate requirements to the ERDF because they establish performance standards for radioactive waste disposal facilities. The standard requires that waste disposal facilities be designed for an effective life up to 1,000 years, to an extent reasonably achievable, and in any case, no less than 200 years. This is a design standard and monitoring after disposal is not required to demonstrate compliance. These requirements are not applicable to the ERDF because the facility is not associated with uranium or thorium milling.

\section{Standards for Protection Against Radiation - 10 CFR 20}

The NRC Standards for Protection Against Radiation found in 10 CFR 20 are relevant and appropriate to the facility because the regulation establishes standards for protection against radiation hazards that may result from occupational exposure or discharges to air and water. The standard is not applicable because it only applies to operations licensed by the Nuclear Regulatory Commission.

These reguiations establish standards for protection against radiation hazards at facilities licensed by the Nuclear Regulatory Commission (NRC). The regulations were amended on May 21,1991 and are effective as of January 1, 1994. The previous regulation was based upon scientific knowledge from more than 30 years ago. The new regulation modifies the radiation protection standards in order to reflect updated scientific information on radionuclide uptake and metabolism, as well as changes in the basic philosophy of radiation protection. These changes are based upon recommendations of the International Commission on Radiological Protection (ICRP) in ICRP Publication 26 (1977 guidance) and subsequent ICRP publications.

NRC licensed facilities must limit occupational dose to the following:

(1) an annual limit, which is the more limiting of

(i) a total effective dose of 5 rems

(ii) the total dose to any organ or tissue, other than the eye, equal to 50 rems

(2) the annual limits to the lens of the eye, to the skin, and to the extremities, which are:

(i) An eye dose equivalent of 15 rems and

(ii) A shallow-dose equivalent of 50 rems to the skin or to any extremity.

Derived air concentration (DAC) and annual limit on intake (ALI) values, presented in Table 1 of Appendix B of 10 CFR 20, were calculated based upon the occupational dose limits 
described above. The regulation also describes how to add external and internal doses to calculate the total effective dose equivalent. Dose limits for minors are ten percent of the annual dose limits specified for adult workers.

In addition, the licensee must conduct operations so that the total effective dose equivalent to individual members of the public may not exceed $0.1 \mathrm{rem} /$ year. The dose in any unrestricted area from external sources may not exceed $0.002 \mathrm{rem} / \mathrm{hr}$. The licensee must survey radiation levels in unrestricted areas and radioactive materials in effluent released to unrestricted areas in order to demonstrate compliance with the dose limits for individual members of the public. The licensee must show compliance with the annual dose limit by:

(1) Demonstrating by measurement or calculation that the total effective dose equivalent to the individual likely to receive the highest dose from the licensed operation does not exceed the annual dose limit or

(2) Demonstrating that

(i) The annual average concentrations of radioactive material released in gaseous and liquid effluent do not exceed the values specified in Table 2 of Appendix B of 10 CFR 20

(ii) If an individual were continually present in an unrestricted area, the dose from external sources would not exceed $0.002 \mathrm{rem} /$ hour and $0.05 \mathrm{rem} / \mathrm{year}$.

The concentration limits for radionuclides in airborne and liquid effluent discharged to unrestricted areas established under the standard are summarized in Table 7-3.

\section{Radiation Protection of the Public and Environment - DOE Order 5400.5}

Radiation protection and radioactive waste management requirements issued under the Atomic Energy Act are implemented at DOE facilities as DOE orders. Under CERCLA these standards are TBC for activities conducted at the ERDF facility because they are not promulgated regulations. However, compliance with DOE Orders is required at Hanford.

DOE Order 5400.5, Radiation Protection of the Public and Environment, establishes the standards and requirements for radiation protection of the public and the environment at DOE and DOE contractor facilities. This DOE Order defines members of the public as persons not occupationally associated with the DOE facility or operations. However, this DOE Order is discussed because it presents exposure limits for airborne and liquid effluent that may be useful as comparisons to occupational limits. DOE policy is to implement all legally applicable radiation protection standards, and to adopt or consider recommendations from authoritative organizations, such as the Naticnal Council on Radiation Protection and Measurements and the International Commission on Radiological Protection. DOE policy also includes implementation of standards generally consistent with Nuclear Regulatory Commission (NRC) for DOE facilities not subject to NRC regulation.

The DOE Order applies the "As Low As is Reasonably Achievable" (ALARA) process to radiation protection. The ALARA process is not a dose-based limit, but a feasibility limit, in that exposures should be as far below applicable limits as practical. The feasibility limit should account for social, economic, technical, and public policy considerations. As part of the ALARA process DOE operations monitor routine and non-routine exposure and assess the dose to members of the 
public. The ALARA process includes procedures for evaluating alternative operations and other factors to reduce radiation exposures.

This DOE Order adopts radiation protection dose standards consistent with the 1977 ICRP guidance which has been adopted and implemented world wide by countries with nuclear programs. Dose limits presented in this DOE Order are expressed both in terms of effective dose equivalents (ICRP guidance) and dose equivalents to specific organs or whole body in order to be consistent with pre-1977 standards or public dose limits established by EPA for selected exposure pathways or sources.

The DOE primary standard for allowable effective dose equivalent to members of the public in a year is $0.1 \mathrm{rem}$. The DOE Headquarters are to be notified if an annual public exposure in excess of 0.01 rems occurs or is anticipated to occur. This dose considers all exposure modes resulting from DOE activities. "Effective Dose Equivalent", developed by the ICRP is calculated by the weighted summation of doses to various organs of the body. The $0.1 \mathrm{rem}$ effective dose equivalent in a year is the sum of all exposures from external sources plus the committed effective dose equivalent from sources taken into the body during the year. The public dose limit does not include medical exposures, exposure resulting from consumer products, residual fallout from past nuclear accidents and weapons tests or naturally occurring radiation sources.

The DOE Order 5400.5 identifies circumstances where supplemental limits or exceptions to the standards may be implemented. A temporary public dose limit higher than 0.1 rem but not to exceed 0.5 rem for the year may be approved from the DOE Field office in coordination with their Program Office. Situations identified by DOE that may warrant use of a supplemental standard include situations where remedial action would pose a clear and present risk to workers or members of the public using reasonable measures to reduce or avoid the risk.

Exposure to members of the public to airborne emissions released to the atmosphere that result from DOE operations must not cause members of the public to receive in a year, an effective dose equivalent greater than $0.01 \mathrm{rem}$, the same dose limit established by EPA regulation 40 CFR 61, Subpart $\mathrm{H}$ authorized under the Clean Air Act. Compliance may be demonstrated using models specifically approved in accordance with 40 CFR 61 requirements, or may also be demonstrated through environmental measurements using EPA approved methods.

The DOE Order also adopts 40 CFR 191 exposure limits that members of the public may receive as a direct result of DOE management and operation of a disposal facility for spent nuclear fuel, high level or transuranic radioactive wastes that are not regulated by the NRC. The dose resulting from management of these wastes must not cause members of the public to receive, in a year, a dose equivalent greater than $0.025 \mathrm{rem}$ to the whole body, or a committed dose equivalent greater than 0.075 rem to any organ.

Drinking water systems operated by the DOE must meet the level of protection defined in 40 CFR 141, National Interim Primary Drinking Water Standards for community drinking water systems. The standard requires that community drinking water systems must not cause an effective dose equivalent greater than 0.004 rem in a year, the combined activity levels for radium-226 and radium- 228 must not exceed $5 \mathrm{pCi} / \mathrm{L}$ and gross alpha activity must not exceed $15 \mathrm{pCi} / \mathrm{L}$.

The DOE Order presents derived concentration guides (DCGs) for conducting radiological environmental monitoring programs at DOE facilities. The DCGs are presented for three exposure modes; ingestion of water, inhalation of air and immersion in a gaseous cloud. The DCGs are not 
designed as occupational intake limits. The DCGs for internal exposure are based on a committed effective dose equivalent of 0.1 rem per year for radionuclides taken into the body through ingestion or inhalation. The DCGs may be used for evaluating compliance to the drinking water limit of 0.004 rem per year by using $4 \%$ of the DCG for ingestion. The exposure conditions used for development of the ingestion and inhalation DCGs are presented with the DCGs in table format.

Radiological protection requirements are also established for residual radioactive material and cleanup of residual materials. The basic public dose limit is 0.1 rem effective dose equivalent per year in excess of naturally occurring background. Additional guidelines for residual radioactive material in soils for radium and thorium are set at the levels issued under 40 CFR 192.

The proposed DOE rule, Radiation Protection of the Public and the Environment (10 CFR 834) published in the March 23, 1993 Federal Register (58 FR 16268), promulgates the standards presently found in DOE Order 5400.5. The proposed rule retains the substantive portions of the DOE Order and differs from the existing DOE Order in format, enhanced emphasis on the ALARA process, and changes in the usage of DCGs. The proposed rule identifies DCGs not as "acceptable" discharge limits, but to be used as reference values for estimating potential dose and determining compliance with the requirements of the proposed rule. Where residual radioactive materials remain, the proposed rule states that various disposal modes should address impacts beyond the 1,000 year time period identified in the existing DOE Order.

\section{Toxic Substances Control Act 15 USC 2601 et seq.}

TSCA requirements are potentially applicable to the ERDF because PCBs have been identified as potential contaminants of concern and may be disposed of at the ERDF above the regulated concentration of $50 \mathrm{ppm}$. This regulation establishes handling, storage and disposal requirements for wastes with $\mathrm{PCB}$ concentrations greater than $50 \mathrm{ppm}$. In particular, this act requires that wastes greater than $50 \mathrm{ppm} \mathrm{PCB}$ be disposed in a lined facility.

7.1.1.2 State of Washington Chemical-Specific ARARs. CERCLA 121(d) requires that, in addition to satisfying federal ARARs, any state standard, requirement, criterion, or limitation that is more stringent must also be met. State requirements must be legally enforceable regulations or statutes, identified in a timely manner, and be of general applicability to all circumstances covered by the requirement. Table 7-2 identifies preliminary chemical-specific Washington State ARARs for the ERDF facility.

\section{Model Toxics Control Act Cleanup Regulation - WAC 173-340}

Regulations under Chapter 173-340 WAC, which implement requirements of the Model Toxics Control Act (MTCA) establish the administrative processes and standards to identify, investigate and cleanup facilities where hazardous substances have been released. These regulations are not applicable to the ERDF because no contaminant releases have occurred, however, the regulation may be considered relevant and appropriate. These standards may be used in evaluating performance of ERDF design alternatives. The state regulations have the potential to be stricter than federal standards. For example, MTCA specifies secondary drinking water MCLs as applicable requirements. Secondary MCLs are nonenforceable standards under 40 CFR 143 and are based on non-human health-based goals relating to qualities of taste and odor. 
The MTCA regulations under WAC 173-340-700 establish three basic methods for determining cleanup levels. These include Method A - Tables, Method B - standard method, and Method C - Conditional method. Groundwater cleanup standards are presented in WAC 173-340720 and soil cleanup standards are presented in WAC 173-340-740 and WAC 173-340-745. The MTCA regulations specify procedures for establishing levels that are protective of human health and the environment based on reasonable maximum exposure assuming either a residential site use (WAC 173-340-720 for groundwater and WAC 173-340-740 for soil) or industrial site use (WAC 173-340-745 for soil cleanup). Sections 720 and 740 establish standards under all three methods and Section 745 uses only Methods A and C.

By definition (WAC 173-340-200) radionuclides are hazardous substances under MTCA, and are considered Group A (known human) carcinogens by EPA (56FR33050). However, Methods $B$ and $C$ equations are designed to provide cleanup levels for non-radioactive contaminants, not radionuclides.

Method A is generally used for routine cleanups with relatively few contaminants. Method A values come from: tables in the MTCA rule, ARAR values (these do not include values established under WAC $173-360-720,-740$, or -745 unless specifically listed in the tables), practical quantitation limits, and natural background. Standards for Method A cleanups are established based on other federal or state ARARs, including those developed:

- at a $10^{-6}$ risk-level, based on residential site use in WAC $173-340-720,-740$

- at a $10^{-5}$ risk level, based on industrial site use in WAC 173-340-745

- based on natural background concentrations

- based on practical quantification limits (PQLs).

Method B is the standard method for determining cleanup levels and assumes a residential site use. Method B levels are determined using federal or state ARARs or are based on risk equations specified in WAC 173-340-720, and -740. For individual carcinogens, the cleanup levels are based on the upper bound of the excess lifetime cancer risk of one in one million $\left(1 \times 10^{-6}\right)$. Total excess cancer risk under Method $B$ for multiple substances and pathways cannot exceed one in one hundred thousand $\left(1 \times 10^{-5}\right)$. Residential use of the ERDF facility is not a likely scenario either currently or in the future; therefore, Method B is not considered to be an appropriate requirement.

Method C cleanup levels are used where: Method A or B cleanup levels are below area background concentrations; cleanup to Method A or B levels has the potential for creating greater overall threat to human health and the environment than Method C; cleanup to Method A or B is not technically possible; or the site meets the definition of an industrial site. The requirements for qualification as a Method C site are specified in WAC 173-340-720, -740 and -745 . Method C cleanups must comply with other federal or state ARARs, must use all practical levels of treatment and must incorporate institutional controls as specified in WAC 173-340-706(1). Total excess cancer risk for Method $\mathrm{C}$ cannot exceed 1 in one hundred thousand $\left(1 \times 10^{-5}\right)$. Method $\mathrm{C}$ cleanup levels are most appropriate for use at the ERDF facility based on current and projected future land use. 
All three MTCA methods for determining cleanup levels require minimum compliance with other federal or state ARARs, and consideration of cross-media contamination. For example, performance goals for the ERDF may be based on protection of groundwater. Fate and transport modeling has been performed for the ERDF to determine the potential of hazardous substances released from the facility to impact groundwater. The results of the contaminant fate and transport modeling may be compared to the cleanup levels presented in Table 7-3.

The point of compliance based on protection of groundwater and for human exposure via direct contact are defined under MTCA. The point of compliance is defined as the point or points throughout the site where cleanup levels are established in accordance with the cleanup requirements for groundwater and soil specified in Sections 173-340-720 through 750.

\section{Dangerous Waste Regulations - WAC 173-303}

The Washington State Dangerous Waste Regulations implement the federal Hazardous Waste Regulations promulgated pursuant to RCRA. The regulation establishes requirements for generation, storage: treatment and disposal of dangerous waste. General requirements for dangerous waste management facilities are discussed as action-specific ARARs, and requirements for facility siting are presented as location-specific ARARs. However, Section WAC 173-303-070 establishes procedures and methods to determine if solid waste requires management as dangerous waste. These requirements are considered applicable as chemical-specific ARARs to wastes generated at the ERDF. Section WAC 173-303-090 identifies classification of wastes based on specific characteristics such as ignitability, corrosivity, reactivity, and toxicity. Classification of wastes as either dangerous or extremely hazardous is also considered as an applicable chemicalspecific ARAR.

\section{Minimum Functional Standards for Solid Waste Handling - WAC 173-304}

This regulation establishes the standards and requirements for the handling of all solid waste. The requirements of this standard are not applicable to the ERDF because the standard does not address dangerous wastes regulated under WAC 173-303. However, the regulation is considered relevant and appropriate because it establishes groundwater protection requirements for solid waste management facilities.

\section{State Radiation Protection Standards - CH. 70.98 RCW}

Washington State Radiation Standards (Ch. $70.98 \mathrm{RCW}$ ) were developed pursuant to the Atomic Energy Act of 1954 and are implemented in WAC 246-220 through WAC 246-255. Not all the standards in the referenced chapters are specifically applicable to the ERDF and only the following standards are considered as chemical-specific ARARs. The WAC 246-221, Radiation Protection Standards is applicable because it establishes the maximum allowable radiation dose to individuals in restricted areas, exposure to minors and permissible levels of radiation from external sources in unrestricted areas. The occupational dose limit for adults, excluding planned special exposures, shall not exceed an annual limit of a total effective dose equivalent equal to $5 \mathrm{rem}$, or the sum of the deep dose equivalent and the committed dose equivalent to any individual organ or tissue other than the lens of the eye should not exceed $50 \mathrm{rem}$. An eye dose equivalent of $15 \mathrm{rem}$ is set for exposure to the eye. The shallow dose equivalent for the skin or any extremities is 50 rem. Occupational dose limits for minors are set at $10 \%$ of the annual occupational dose limits for adults. 
The standard identifies the methods required to demonstrate compliance and provides derived air concentration (DAC) and annual limit on intake (ALI) values that may be used to determine an individual's occupational dose limits. Dose limits that individual members of public may receive in unrestricted areas or from radioactive effluent are not to cause an individual continually present in an unrestricted area, to receive from external sources, more than 0.002 rem in an hour or 0.50 rem in a year. Chapter 246-221 also establishes concentration limits in effluent released to unrestricted areas. The WAC 246-247, Radiation Protection- Air Emissions, promulgates air emission limits for airborne radionuclide emissions at the same levels as defined in WAC $173-480$ which are consistent with federal NESHAPs. The ambient standard requires that emission of radionuclides to the air must not cause a dose equivalent of 25 mrem per year to the whole body or 75 mrem per year to any critical organ. Radiation protection standards for uranium and thorium milling sites are presented in WAC 246-252 and are not applicable to the ERDF because it was not used for uranium or thorium milling. However, the regulation is considered relevant and appropriate because it presents specific radiation protection standards for groundwater.

\subsubsection{Location-Specific ARARs}

Location-specific ARARs at the ERDF are restrictions placed on the conduct of activities associated with the ERDF based solely on the characteristics of the ERDF location.

7.1.2.1 Federal Location-Specific ARARs. Federal location-specific requirements that were evaluated are summarized in Table 7-1.

\section{The National Historic Preservation Act of 1966 - 16 USC 470 et seq.}

The National Historic Preservation Act requires that historically significant properties be protected. The Act requires that impacts posed by the ERDF to property listed on or eligible for inclusion on the National Register of Historic Places must be evaluated. The National Register of Historic Places is a list of sites, buildings or other resources identified as significant to United States history. Cultural resource surveys have been performed in the area impacted by the ERDF and no facilities identified on the National Register of Historic Places or eligible for inclusion on the list were identified. Based on the survey results, the National Historic Preservation Act is neither applicable nor relevant and appropriate to the ERDF.

\section{The Archeological and Historic Preservation Act - 16 USC 469a}

The Archeological and Historic Preservation Act is not ARAR because no archaeologic or historic sites have been identified at the ERDF location (see Section 2.7). This act is similar to the National Historic Preservation Act but differs in that it mandates only protection of historic or archaeologic data and not the actual archaeologic or historical site. If activities in connection with any federal project or federally approved project may cause irreparable loss to significant scientific, prehistorical, or archeological data, the Act requires that the agency responsible for the project preserve the data.

\section{The Endangered Species Act - 16 USC 1531}

The Endangered Species Act of 1973 is applicable and must be considered during siting, design, operation and closure of the ERDF because the Act establishes requirements to protect species threatened by extinction and habitats important to their survival. The Endangered Species 
Act is designed as a means for the conservation of flora and fauna that are threatened with extinction. Endangered species are identified under the Act as species which are in danger of extinction throughout all or a significant portion of their range. Threatened species are identified as species that are anticipated to ve in danger of extinction within the foreseeable future. The Endangered Species Act provides for the designation of critical habitat, defined as "specific areas within the geographical area occupied by the [endangered or threatened] species ... on which are found those physical or biological features essential to the conservation of the species..." Endangered species and critical habitats have been evaluated throughout the Hanford Site, including the location of the ERDF. No species of flora or fauna listed by the federal or state lists of endangered or threatened species were identified during an ecological survey of the ERDF location. Endangered or threatened species are found elsewhere on the Hanford Site (WHC 1993). However, the survey identified both plant and animal species considered as candidates for inclusion on federal and/or state lists of endangered or threatened species. The survey also noted areas of undisturbed sagebrush habitat considered important to the candidate species identified. The Fish and Wildlife Service will be consulted to determine management policies for the candidate species and evaluate the biological importance of the these species.

\section{Site Selection - DOE-RL Order 4320.2C}

The purpose of this DOE-RL Order is to ensure that Hanford Site facilities meet program requirements and consider economic, engineering and site planning guidelines presented in this Order. Under CERCLA, DOE-RL Orders are TBC because they are not promulgated standards. However, compliance with DOE-RL Orders is required at the Hanford Site. Site selection criteria should address such factors as safety, security, ecological, archeological and cultural resources. Engineering considerations such as proximity to utilities, transportation, adjacent land use and available buffer zones to minimize facility impacts should be evaluated. Area topography, geology, hydrology and meteorology are also siting criteria identified in the DOE-RL Order.

\section{Radioactive Waste Management - DOE Order 5820.2A}

Chapter III of DOE Order 5820.2A specifies the policies, guidelines and minimum requirements for siting DOE LLW management facilities. The disposal site selection criteria are TBC for ERDF and are not applicable because they are non-promulgated standards. The DOE Order requires that disposal site selection evaluate the method of waste confinement proposed, that the location is protective of groundwater resources, and located in areas with low potential for natural disasters. The DOE Order specifies that site selection address impacts to local populations, land use plans, available utilities and transportation routes.

\section{Hanford Future Site Uses Working Group Recommendations}

The Hanford Future Site Uses Working Group was chartered with developing a range of visions concerning future uses of the Hanford Site. The Group considered a range of cleanup scenarios necessary to make the future use visions possible (Drummond 1992). The recommendations of this group are TBC because they are not promulgated standards. The Group was comprised of representatives from federal, state, and local governments, along with interested tribal, labor, economic development and public interest grcups. The Group proposed that areas of the Hanford Site having high future use value be cleaned up and that the interior section of the 200 Area plateau be designated for waste management. The group recommended that wastes from Hanford Site be concentrated in the 200 Area plateau. However, the Group further stated that waste management, storage, and disposal activities should be concentrated within a limited area and 
whenever possible, minimize the amount of land devoted to or impacted. The central portion of the 200 Area plateau was identified as the "squared off" boundaries of the current 200 Areas, expanded east of the 200 East Area in order to incorporate the location of the proposed grout vaults, plus a buffer zone sufficient to minimize risks associated with waste management (Drummond 1992).

\subsubsection{State Location-Specific ARARs.}

\section{Department of Game State Environmental Policy Act Procedures - WAC 232-012}

The regulations include the State of Washington Department of Fish and Wildlife procedures for compliance with the Washington State Environmental Policy Act (SEPA). The act requires that management plans be developed if threatened, endangered, or sensitive wildlife or habitat are affected by remedial actions at the site. Although no endangered or threatened species of flora or fauna have been identified within the area of the ERDF, this regulation should be considered applicable because threatened and endangered species are found elsewhere on the Hanford Site and ecological surveys of the ERDF site identified species considered as candidates for inclusion on state and/or federal lists of endangered or threatened species. The Washington State Department of Fish and Wildlife will be consulted to determine management policies and any mitigation that may be necessary to minimize ecological impacts.

\section{Dangerous Waste Regulations, Siting Criteria - WAC 173-303-282}

The Washington State Dangerous Waste Regulations implement the federal hazardous waste regulations promulgated under RCRA. The siting criteria in WAC 173-303-282 are applicable to the ERDF because the facility will manage hazardous waste. This regulation requires that the proposed location of a hazardous waste facility demonstrate compliance with the location-specific criteria presented in the regulation. The criteria limit waste management facilities to locations that are protective of water resources, ecological resources, human health, and in areas with low potential of natural disasters.

\section{Radioactive Waste, Licensing Land Disposal - WAC 246-250-300}

Requirements established for licensing land disposal facilities for radioactive waste are relevant and appropriate to the ERDF because Section WAC 246-250-300 identifies criteria and considerations used to evaluate site suitability for land disposal of LLW. The requirements of this regulation are not applicable to the ERDF because the regulation only addresses land disposal of radioactive wastes received from others. The ERDF will manage only LLW resulting from Hanford Site remediation. The regulation specifies that $L L W$ land disposal facilities only be sited in areas that are capable of being characterized, have sufficient depth to groundwater, are not subject to natural disasters and are not in areas where natural resources are known to occur.

\subsubsection{Action Specific ARARs}

Action-Specific ARARs are presented in Tables 7-1 and 7-2 and will be refined once general response actions have been formulated and alternative formulation and screening have been completed. 
DOE/RL-93-99, Rev. 0

\subsubsection{Federal Action Specific ARARs}

\section{Resource Conservation and Recovery Act, as amended - Title 42 USC 6901}

The Resources Conservation and Recovery Act (RCRA) regulates the generation, transportation, storage, treatment and disposal of hazardous waste. Federal regulations promulgated under 40 CFR 260 through 268 implement RCRA requirements for disposal facilities including specific financial, siting, design, operation, monitoring, closure and post-closure care requirements. Washington State Dangerous Waste Regulations implement the federal hazardous waste regulations and provide for regulation of state designated dangerous waste. On November 23, 1987, Ecology was given authorization by EPA to regulate mixed waste within the state.

Because the Hanford Facility RCRA permit has not been issued, Hanford Site TSDs currently operate under interim status standards promulgated in 40 CFR 265. Sections of the regulations are applicable to the ERDF if hazardous wastes are generated by the facility. General facility requirements specify waste management practices such as waste analysis, waste segregation, facility inspection, personnel training, emergency preparedness planning and facility siting criteria. Interim status facility requirements for closure and post-closure care are also defined under the regulations. The ERDF will be included in the Hanford wide permit and after permit approval, the ERDF will be required to comply with the standards for owners and operators of Hazardous Waste Treatment, Storage and Disposal Facilities in 40 CFR 264.

The Corrective Action for Solid Waste Management Units regulation (40 CFR 264.552) presents provisions for the use of corrective action management units (CAMUs) and temporary units as remediation waste management units. Previous EPA experience found that implementing RCRA Subtitle $C$ rules to remediation wastes provided disincentives to the implementation of more protective remedies and remediation was negatively impacted by RCRA regulatory controls. Specific areas where increased flexibility in the management of remediation wastes is provided by this regulation include: placement of remediation waste into a CAMU is not considered land disposal of waste and is not subject to LDRs; CAMUs do not have to meet minimum technology requirements for landfills; and finally, CAMUs are only subject to closure requirements as deemed necessary by the EPA Regional Administrator and as appropriate to the waste management unit. The creation of CAMUs allows decision makers and facility operators increased flexibility in order to expedite remediation of environmental releases from operating hazardous waste TSD facilities. The ERDF CAMU would be incorporated in the Hanford Facility RCRA permit as a permit modification.

\section{Radiation Protection for Occupational Workers - DOE Order 5480.11}

DOE Order 5480.11, Radiation Protection for Occupational Workers establishes radiation protection requirements for worker protection from ionizing radiation at DOE and DOE contractor operations. These standards are TBC under CERCLA because they are not promulgated standards. However, compliance with DOE Orders is required at the Hanford Site. DOE policy is to implement all radiation protection requirements that are consistent with EPA guidance or based on the recommendations of authoritative organizations such as the National Council on Radiation Protection and Measurements (NCRP) and the International Commission on Radiological Protection (ICRP). The DOE policy states that DOE operations are to be conducted so that radiation exposures are within the limits established by this Order and as far below the limits set in this Order as reasonably achievable. The DOE adheres to the "As Low As Reasonably Achievable" (ALARA) policy on radiation exposure. The ALARA policy represents a process for monitoring 
and evaluating work practices so that radiation exposure is reduced to levels as far below the acceptable dose as socially, technically and economically feasible.

Radiation protection standards for internal and external exposure for occupational workers are expressed in terms of stochastic and non-stochastic effects. Stochastic effects are effects such as malignancy or hereditary diseases which have a probability of occurring as a function of dose and which have no threshold dose for radiation protection purposes. Non-stochastic effects are effects for which the severity of the effect is related to the dose received and for which a threshold dose may exist. The exposure to workers as a result of DOE operations shall not result in exposure in excess of the limits established under this Order. The exposure limit for stochastic effects resulting from internal and external sources of exposure to any occupational worker must not exceed 5 rem per year. The annual dose equivalent received by an occupational worker for non-stochastic effects to individual organs and tissue is $15 \mathrm{rem}$ to the lens of the eye, and 50 rem to any other organ, tissue (including skin of the whole body), or extremity of the body.

The maximum annual dose equivalent established for the protection of the unborn child (from conception to birth) as a result of occupational exposure is $0.5 \mathrm{rem}$. The employee is responsible for providing written notification of the pregnancy to their employer. Individuals under the age of 18 are not to be employed in or allowed to enter controlled areas if they will exceed an effective dose equivalent of 0.1 rem per year resulting from the sum of the committed effective dose equivalent from internal exposure and the annual effective dose equivalent from external exposure. This same exposure limit also applies to students and is considered as part of the minor's occupational exposure.

The DOE Order establishes annual dose limits for members of the public entering controlled areas at $0.1 \mathrm{rem}$ effective dose equivalent per year. The effective dose equivalent includes the committed internal exposure and the effective dose equivalent external exposure.

Procedural requirements for calculating and evaluating the combined internal and external dose equivalents are provided in the Order. The methodology for calculating dose differentiates external dose to skin and extremities from the dose to external whole body exposures. Methods for calculating non-uniform exposures to skin are based on the surface area of the exposed skin. The Order also presents air and water concentration guides. Derived air concentration (DAC) values for radiation exposure control in the workplace were developed from ICRP publications and converted to units of rem and curie. The DAC are for use in monitoring radiation control and are not to be used in the calculation of internal dose equivalent received by a worker. DOE maintains a policy that drinking water in controlled areas is to meet EPA 40 CFR 141 drinking water standards.

Monitoring of occupational workers is required to demonstrate compliance with the radiation protection standards and under normal circumstances not to calculate the annual effective dose equivalent received from internal and external sources of radiation. Methods used for personnel dosimetry must be effective for monitoring compliance, be performed using equipment that can be periodically calibrated and is maintained by an accredited laboratory. Ambient air monitoring is to be performed in any workplace where the potential to exceed $10 \%$ of the DAC is anticipated. Air samples are to be representative of locations where air borne contaminant concentrations are expected to be elevated. The results of ambient air monitoring are to be used in assessing radiation control practices and are not for use in evaluating the annual effective dose equivalent to workers. 
The DOE Order outlines the requirements for release of equipment and materials from controlled to uncontrolled areas and general practices for facility design. Areas within DOE facilities are to be posted if radioactive materials are present in sufficient quantity to cause a worker to receive a dose equivalent greater than $5 \mathrm{mrem}$ but less than $100 \mathrm{mrem}$ in one hour at 30 $\mathrm{cm}$. Areas are to be posted as "high radiation areas" if the dose equivalent received in $1 \mathrm{hr}$ at 30 $\mathrm{cm}$ exceeds $100 \mathrm{mrem}$ but is less than $5 \mathrm{rem}$, and posted as a "very high radiation area" if the dose received in $1 \mathrm{hr}$ at $30 \mathrm{~cm}$ exceeds $5 \mathrm{rem}$. Access to any area where airborne radioactive material concentration are greater than $10 \%$ of the DAC are to be posted. Entry and exit points from all radiological areas are to be controlled and equipped with visual or audio alarm systems. Records of employee training and exposure are to be maintained. Specific levels of training are required dependent on job function.

\section{Radioactive Waste Management - DOE Order 5820.2A}

This Order specifies the policies, guidelines and minimum requirements for DOE management of radioactive and mixed waste at contaminated facilities. The DOE Order provides management requirements for high-level waste (HLW), transuranic waste (TRU) and low-level waste (LLW). HLW and TRU waste will not be accepted at the ERDF. These standards are TBC under CERCLA because they are not promulgated standards. However, compliance with DOE Orders is required at the Hanford Site. Chapter III of DOE Order 5820.2A requires that LLW management practices limit external exposure to radioactive material released to the environment to levels that will not result in an effective dose equivalent to any member of the public in excess of $25 \mathrm{mrem} / \mathrm{yr}$ and that any air release meet the emission limits specified in 40 CFR 61 . The DOE Order also specifies radiation exposure be limited to as low as reasonably achievable (ALARA). LLW disposal systems must be capable of limiting the effective dose equivalent received by inadvertent intruders into the disposal system after institutional controls cease, to not more than 100 $\mathrm{mrem} / \mathrm{yr}$ or $500 \mathrm{mrem}$ for a single acute exposure.

Guidelines for LLW management require that wastes are to be accurately characterized to allow proper management, and to be tracked using a manifest system. Specific requirements are to be developed for the shipment and receipt of waste between the generator and treatment, storage or disposal facilities. The LLW may require treatment in order that the ERDF meets the established performance objectives. LLW disposal facilities are to be designed and operated according to the performance standards established in Chapter III of DOE Order 5820.2A. Facility operating requirements include specifications for waste placement, protection of public and worker health, and security. Specific closure performance requirements are also specified in Chapter III of DOE Order 5820.2A. Residual radioactivity must meet DOE decommissioning guidelines, and site specific closure plans are required that identify how the facility will meet performance objectives. Environmental monitoring is required to measure release of radioactive contaminants to the air, soil and groundwater, or any other parameter that may affect the long-term performance of the facility.

Chapter II of DOE Order 5820.2A specifies that disposal of TRU waste is to be managed in compliance with the specifications of the Waste Isolation Pilot Plant (WIPP). The DOE Order specifies that material with transuranic waste concentrations greater than $100 \mathrm{nCi} / \mathrm{g}$ shall be managed as TRU waste. Interim storage requirements for TRU waste specified in DOE Order 5820.2A are consistent with RCRA requirements and require that interim storage facilities comply with the permitting requirements from all applicable DOE Orders, federal and state regulations. The implementation plan provides facility closure in compliance with CERCLA and other DOE, EPA, and state requirements. 
Chapter I of DOE Order 5820.2A addresses the management of high-level radioactive waste. Retrievable HLW is to be disposed in a geologic repository according to the requirements of the Nuclear Waste Policy Act of 1982, as amended. This DOE Order notes that HLW which is difficult to retrieve may be disposed of in place. In-situ disposal requires periodic monitoring capable of determining the need for corrective measures. Requirements for existing facilities that manage HLW prior to disposal are also specified in the DOE Order.

Clean Air Act of 1977, as amended - Title 42 USC 4201 et seq.

The Clean Air Act (CAA) regulates emission of hazardous pollutants to the air. Requirements established under this Act are implemented by federal, state and local regulations. Pursuant to the CAA, the EPA has promulgated National Ambient Air Quality Standards (40 CFR 50), National Emission Standards for Hazardous Air Pollutants (40 CFR 61), and New Source Review Standards (NSPS)(40 CFR 60). The National Ambient Air Quality Standards are applicable to airborne releases of radionuclides and criteria pollutants specified under the standard. Specific release limits for particulates are set at $50 \mathrm{ug} / \mathrm{m}^{3}$ annually or $150 \mathrm{ug} / \mathrm{m}^{3}$ per 24 -hour period.

Subpart H of the National Emission Standards for Hazardous Air Pollutants (NESHAP) for emissions of radionuclides other than radon from DOE facilities are applicable to ERDF because the potential to release radionuclides in air emission to unrestricted areas exists. The Subpart $H$ emission limits to ambient air from the entire facility are not to exceed an amount that would cause any member of the public to receive an effective dose equivalent of $10 \mathrm{mrem} / \mathrm{yr}$. The definition of facility includes all buildings, structures and operations on one contiguous site. Radionuclide emissions from operation of the ERDF are required to be monitorcd and an effective dose equivalent value to members of the public calculated.

New Source Performance Standards established under 40 CFR 60 are not applicable to the ERDF because the ERDF is not one of the industrial sources identified in the regulation. However, the CAA also requires that states regulate emissions from existing sources for specific designated contaminants. Therefore, New Source Performance Standards are considered relevant and appropriate because criteria established under this regulation may be used to evaluate ERDF impacts on air quality.

\section{Licensing Requirements for Land Disposal of Radioactive Waste - 10 CFR 61}

The regulations under 10 CFR 61 establish the licensing requirements for land disposal of LLW. These regulations are not applicable to the ERDF because the regulation is not applicable to DOE generated waste at DOE-owned sites. However, the regulation is relevant and appropriate because it establishes performance objectives for land disposal of waste and requirements for siting, design, operation, closure, and long-term control for near-surface land disposal of LLW waste. The regulation specifies that the ALARA be applied to limit releases to the environment and also to workers during operation and includes specific annual release limits of radionuclides. The regulation establishes closure performance objectives for the facility following closure that require the facility to provide long term stability at the site with minimal use of on-going active maintenance, and to provide protection for inadvertent intruders after institutional controls are removed. The regulation identifies a time period of 100 years for institutional control.

Methods for the classification of wastes as to their suitability for near-surface disposal are established under 10 CFR 61.55. Two considerations are involved, the concentration of long-lived 
radionuclides whose potential hazard will persist for extended periods, and the second consideration is given to the concentration of shorter-lived radionuclides for which requirements on institutional control, waste form, and disposal methods are effective. Wastes acceptable for near-surface disposal are grouped into three categories, Class A, B, and C. Class A waste must meet the minimum requirements presented in 10 CFR 61.56; Class B waste must meet the minimum requirements in 10 CFR 61.56 and also the stability requirements in 10 CFR 61.56; Class C must meet the minimum and stability requirements presented in 10 CFR 61.56 and also must meet additional requirements for protection against inadvertent intrusion. Wastes exceeding the Class $\mathrm{C}$ characteristics must be disposed in a deep geologic repository as defined in 10 CFR 60 or as directed by the Nuclear Regulatory Commission.

7.1.3.2 State Action Specific ARARs. The most significant Washington state laws and regulations considered to be potential action-specific ARARs are discussed in the following section. Table 7-2 presents a complete list of potential state action-specific ARARs evaluated for the ERDF.

\section{Dangerous Waste Regulations - WAC 173-303}

The Washington State Dangerous Waste Regulations (WAC 173-303) implement the federal hazardous waste regulations for generation, treatment, storage and disposal of dangerous waste. These regulations are applicable to the ERDF because the facility is designed to be permitted as a corrective action management unit (CAMU) for remediation waste resulting from Hanford Site remediation activities. General requirenents for dangerous waste management facilities specified in WAC 173-303-280 identify acceptable treatment, storage, and disposal practices for designated dangerous waste. Requirements address facility permitting, employee training, emergency preparedness planning, contingency planning, security, waste analysis, and recordkeeping. Additional requirements for landfills and surface impoundments are also specified.

Facilities are to be designed, operated and closed using practices and methods that minimize release of dangerous wastes or constituents to the environment. The regulation identifies maximum contaminant levels allowed in groundwater that insure protection of the resource. Facilities are required to implement monitoring and reporting programs. The regulation presents methods to determine the point where the facility must demonstrate compliance. These requirements may assist in determining if corrective actions are required. Corrective action requirements may be fulfilled through the use of enforcement actions implemented under MTCA, or as established under the Corrective Action requirements of WAC 137-303-646. The Corrective Action program allows increased flexibility for facility operators to address dangerous waste releases from the facility.

\section{Model Toxics Control Act - WAC 173-340}

The Model Toxics Control Act (MTCA) Cleanup Regulations established under WAC 173340 are potentially applicable to the ERDF as operational and performance requirements. This regulation establishes cleanup requirements that are protective of human health and the environment, and the methods necessary to achieve these goals. The MTCA has statutory preference for permanent solutions that minimize the quantity of hazardous contaminants remaining on-site. The hierarchy of preference for remediation favors destruction and treatment over disposal, containment and institutional controls. WAC 173-340-400 outlines specific requirements that insure cleanup actions are designed, constructed, and implemented in a manner consistent with accepted engineering practices. Compliance monitoring requirements are specified in section WAC 173-340-400, and requirements for institutional controls are specified in WAC 173-340-440. 


\section{State Waste Discharge Permit Program - WAC 173-216}

The Washington State Waste Discharge Permit Program implements a permit system applicable to industrial and commercial operations that discharge wastes into ground or surface waters and into municipal sewerage systems. The waste discharge program excludes NPDES waste discharges. Although wastewaters will not be discharged to ground or surface waters, storm water run-off may occur; therefore, this program is ARAR. The permit program prohibits waste discharges that are regulated under the Washington State Dangerous program or exhibit a pH less than 5 or greater than 11. Waste discharges may also be prohibited based on other characteristics which are known to upser municipal sewerage systems, or are likely to pass through the system unaffected by treatment. Under, CERCLA, on-site remedial actions are exempt from administrative requirements, such as permit acquisition. However, CERCLA actions must meet the substantive ARAR renuirements; therefore, this regulation is relevant and appropriate. The ERDF must meet the highest possible standards for waste discharges based on all known available and reasonable methods to prevent and control the discharge of wastes.

\section{Washington Clean Air Act - Ch. 70.94 and Ch. 43.21A RCW}

The Washington Clean Air Act was enacted to comply with the federal Clean Air Act, as amended. The intent of the Clean Air Act is to insure the protection of public health and the air resources of the state. Washington State regulations implemented pursuant to the Clean Air Act considered potential ARARs for the ERDF are presented in the following discussion.

The General Regulations for Air Pollution Sources (WAC 173-400) define the policies and authority of the Department of Ecology to control air pollution from air contaminant sources. The regulation is applicable to the ERDF because it establishes both technical and procedural standards for the control of air contaminant sources. Emission limits are established for visibility, particulates, fugitive odor, and hazardous air emissions. Section WAC 173-400-040 establishes standards for maximum emissions for source units identified under the regulation. The standard is not applicable to the ERDF because the ERDF does not meet any of the source categories identified under the standard. However, the standard is relevant and appropriate because it establishes emission limits and requires that all emission units use reasonably available control technology, which for some source categories may be more stringent than the emission limitations listed.

Emission Standards for Sources Emitting Hazardous Air Pollutants are established in Section WAC 173-400-075. Requirements of this standard are applicable to the ERDF because waste disposal activities could result in the emission of hazardous air pollutants. The regulation requires monitoring, source testing, and the use of specific analytical methods for determining hazardous air pollutant emissions. Section WAC 173-400-115, Standards of Performance for New Sources, adopts and incorporates Title 40 CFR Part 60 as standards of performance for new sources. The standards are not applicable because the ERDF is not considered one of the source categories identified in the regulation. However, the regulation may be considered relevant and appropriate because it establishes review criteria that may be used to evaluate ERDF impacts on air quality.

Requirements of Section WAC 173-480 are applicable to the ERDF. The Ambient Air Quality Standards and Emission Limits for Radionuclides specifies that the maximum allowable level for radionuclides in the ambient air shall not cause a maximum accumulated dose equivalent

of $25 \mathrm{mrems} / \mathrm{yr}$ to the whole body, or $75 \mathrm{mrems} / \mathrm{yr}$ to any critical organ. The standard also states 
that the more stringent of any federal or state standard for the control of radionuclides supersedes the standards of WAC 173-480. The regulation also defines monitoring and compliance procedures, and defines enforcement authority to Ecology and local air pollution control authorities.

\section{Licensing Radioactive Waste Land Disposal Facilities - WAC 246-250}

Section WAC 246-250, establishes the procedures, criteria and conditions for licensing of low-level radioactive waste land disposal for wastes received from others. The requirements of this regulation are not applicable to the ERDF because the ERDF will only manage DOE wastes resulting from Hanford Site remediation. This section may be considered relevant and appropriate because it presents specific levels of radiation protection and technical requirements for land disposal of radioactive waste. The licensing process requires the facility to identify how the following requirements will be achieved: protection of the public from releases of radioactivity, worker protection, facility stability following closure, protection for inadvertent intruders after closure, environmental monitoring and recordkeeping. Requirements for siting a disposal facility are discussed as potential location-specific ARARs.

\subsection{REMEDIAL ACTION OBJECTIVES}

The NCP states that remedial action objectives (RAOs) should include the media and contaminants of concern, the exposure pathways, and the remediation goals

(40 CFR 300.430(e)(2)(i)). Development of RAOs should consider the following factors:

1) ARARs

2) Acceptable exposure levels for systemic toxicants are less than the concentrations that result in adverse effects (i.e., a hazard quotient of 1)

3) Acceptable exposure levels for carcinogens are less than the concentrations that result in an excess upper bound lifetime cancer risk to an individual of between $10^{-4}$ and $10^{-6}$

4) Technical limitations such as detection limits for contaminants

5) Uncertainty

6) Threats to the environment, especially sensitive habitats and critical habitats of protected species.

Development of RAOs for this RI/FS is unusual in that the scope is limited to configuration of a waste management facility and does not address remediation of contaminated sites. Current risks and RAOs for the contaminated sites are evaluated in the operable unit RI/FSs. The following remedial action objectives have been identified for the ERDF:

1) Support the removal of contaminants from portions of the Hanford Site (including near the Columbia River) in a timely manner: This is the overall objective of this action given public opinion that contaminants should be removed from near the Columbia River as soon as possible. This opinion is based on 
concern regarding potential impacts of these contaminants on the Columbia River and the desire to release the remediated areas for other productive uses.

2) Prevent unacceptable direct exposure to waste. As demonstrated in Chapter 6, direct exposure to the types of waste received at the ERDF could result in unacceptable health risks. Direct exposure of workers and biota to waste could occur during operation of the ERDF (i.e., during waste transport and filling operations). Due to access control at the Hanford Site, the direct exposure pathway does not apply to the public during operations. Once the ERDF is closed, direct exposure to waste is only possible if institutional controls fail and the surface barrier is breached.

3) Prevent unacceptable contaminant releases to air. As demonstrated in Chapter 6, inhalation exposure to the types of waste received at the ERDF could result in unacceptable health risks. Similar to the direct exposure pathway, inhalation of waste by workers and biota could occur during operation of the ERDF (i.e., during waste transport and filling operations). Airborne transport of waste off the Hanford Site could result in exposures to the public, but these exposures would be negligible compared with worker risks. Once the ERDF is closed, air releases are only possible if institutional controls fail and the surface barrier is breached.

4) Prevent contaminant releases to groundwater above ARARs and health-based criteria. This RAO addresses the conclusion in Chapter 6 that migration of contaminants through the vadose zone to groundwater could result in unacceptable human exposure to contaminants. This RAO has been acknowledged in the TPA, which states: "the point of [risk] assessment will be the intersection of the groundwater and the vertical line drawn from the edge of the disposal facility". Other agreements contained within the TPA are the time of assessment (10,000 years) and the compliance standard $\left(10^{-5}\right.$ for the first 100 years and $10^{-4}$ thereafter). Since the risk assessment indicates that the risk associated with the groundwater pathway should remain below $10^{-5}$ for the first 100 years, the relevant compliance standard is $10^{-4}$. Maximum acceptable groundwater concentrations for contaminants of potential concern in waste disposed of in the ERDF are provided in Table 7-5. These concentrations summarize the lowest of the ARAR-based concentrations, as well as the concentration equivalent to either a HQ of 1 , or an ICR of $10^{5}$, whichever is lower.

5) Minimize Ecological Impacts. Construction of the ERDF will result in harmful impacts on the ecology of the ERDF site and the borrow sites providing materials for ERDF construction. As discussed in Chapter 2, significant value is attached to the ecology at these sites. As a result, ecological impacts should be minimized and/or mitigated to the maximum extent possible. 
Table 7-1. Identification of Potential Federal ARARs for the ERDF. (Sheet 1 of 13)

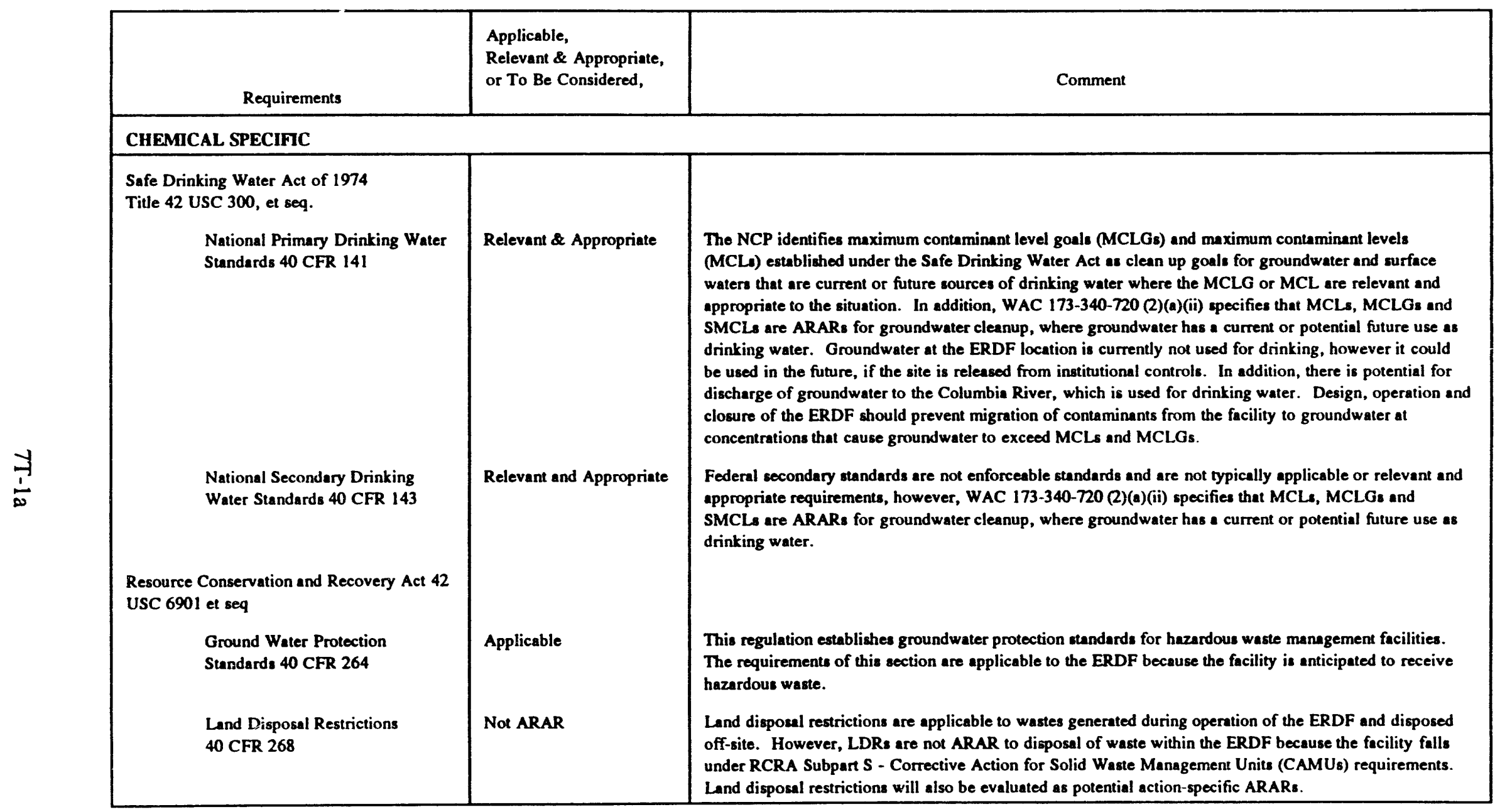


Table 7-1. Identification of Potential Federal ARARs for the ERDF. (Sheet 2 of 13)

\begin{tabular}{|c|c|c|}
\hline Requirements & $\begin{array}{l}\text { Applicable, } \\
\text { Relevant \& Appropriate, } \\
\text { or To Be Considered, }\end{array}$ & Comment \\
\hline \multicolumn{3}{|l|}{$\begin{array}{l}\text { Clean Air Act of } 1977 \text {, as amended } \\
42 \text { USC } 7401 \text { et seq. }\end{array}$} \\
\hline $\begin{array}{l}\text { National Ambient Air Quality } \\
\text { Standards } 40 \text { CFR } 50\end{array}$ & Applicable & $\begin{array}{l}\text { Requirements of these regulations are applicable to airborne releases of radionuclides and criteria } \\
\text { pollutants specified under the statue. Specific release limits for particulates are set at } 50 \mathrm{ugm} / \mathrm{m}^{3} \text { annually } \\
\text { or } 150 \mathrm{ugm} / \mathrm{m}^{3} \text { per } 24 \text {-hour period. Standards for airborne lead measured as elemental lead are set at } 1.5 \\
\text { ugm } / \mathrm{m}^{3} \text {, maximum arithmetic mean averaged over a calendar quarter. }\end{array}$ \\
\hline $\begin{array}{l}\text { National Emission Standard for } \\
\text { Hazardous Air Pollutants } \\
\text { (NESHAPs), Subpart } H \text { - } \\
\text { National Emission Standards for } \\
\text { Emissions of Radionuclides Other } \\
\text { than Radon From Department of } \\
\text { Energy Facilities } 40 \text { CFR } 61\end{array}$ & Applicable & $\begin{array}{l}\text { These requirements are applicable to the ERDF because the potential to release air emissions to } \\
\text { unrestricted areas exists. Subpart } H \text { sets emissions limits from the entire facility to ambient air not exceed } \\
\text { an amount that would cause any member of the public to receive an effective dose equivalent of } 10 \\
\text { mrem/yr. The definition of facility includes all buildings, structures and operations on one contiguous } \\
\text { site. }\end{array}$ \\
\hline \multicolumn{3}{|l|}{$\begin{array}{l}\text { Atomic Energy Act of } 1954 \text {, as amended } \\
\text { Title } 42 \text { USC } 2011 \text { et seq. }\end{array}$} \\
\hline $\begin{array}{l}\text { Environmental Radiation } \\
\text { Protection Standards for Nuclear } \\
\text { Power Operations } \\
40 \text { CFR } 190\end{array}$ & Not ARAR & $\begin{array}{l}\text { The regulation specifies the levels below which normal operations of the uranium fuel cycle are } \\
\text { determined to be environmentally acceptable. These standards are not applicable and not relevant and } \\
\text { appropriate because the standard excludes operations at disposal sites and the definition of the uranium } \\
\text { fuel cycle focuses on those processes that result in generation of electrical power. The standard sets dose } \\
\text { equivalents from the facility which are not to exceed } 25 \mathrm{mrems} / \mathrm{yr} \text { to whole body. } 75 \mathrm{mrems} / \mathrm{yr} \text { to thyroid, } \\
\text { or } 25 \mathrm{mrems} / \mathrm{yr} \text { to any other organ. Release limits at } .5 \mathrm{mCi} \text { for Pu-239 and other alpha emitting } \\
\text { transuranics with half-lives greater than one year. }\end{array}$ \\
\hline
\end{tabular}


Table 7-1. Identification of Potential Federal ARARs for the ERDF. (Sheet 3 of 13)

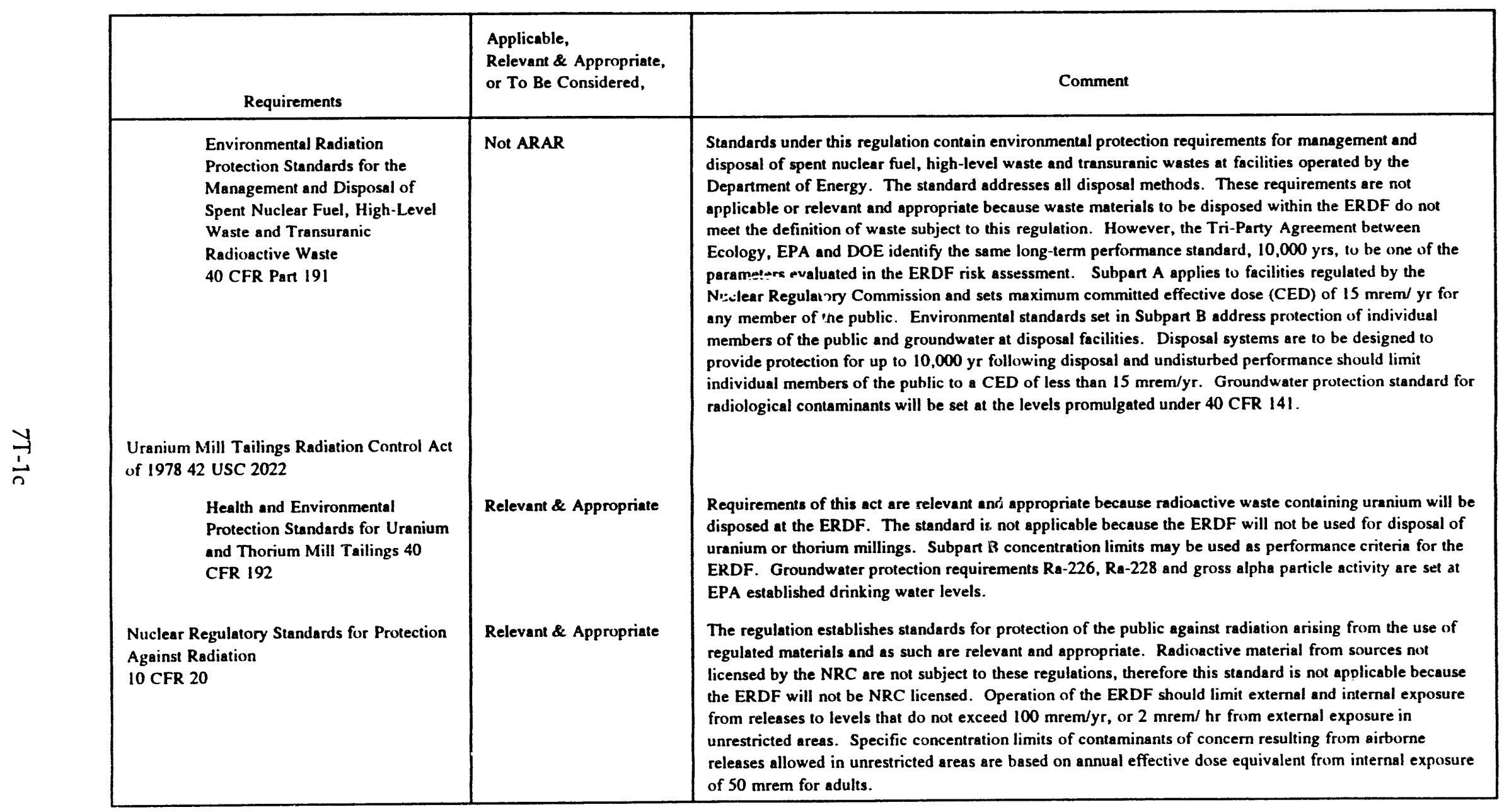


Table 7-1. Identification of Potential Federal ARARs for the ERDF. (Sheet 4 of 13)

\begin{tabular}{|c|c|c|}
\hline Requirements & $\begin{array}{l}\text { Applicable. } \\
\text { Relevant \& Appropriate, } \\
\text { or To Be Considered, }\end{array}$ & Comment \\
\hline $\begin{array}{l}\text { DOE Order } 5400.5 \text { - Radiation Protection of } \\
\text { the Public and the Environment } \\
\text { Toxic Substance Control Act } \\
15 \text { USC } 2601 \text { et seq. } \\
\text { Regulation of PCBs } \\
40 \text { CFR } 761\end{array}$ & Applicable & $\begin{array}{l}\text { This DOE Order sets radiation standards for protection of the public in the vicinity of DOE facilities. } \\
\text { This DOE Order is TBC under CERCLA because DOE Orders are not promulgated standards. However, } \\
\text { compliance with DOE Orders is required at the Hanford Site. The DOE Order sets limits for the annual } \\
\text { effective dose equivalent of } 100 \text { mrem, but allows temporary limits of } 500 \text { mrem if avoidance of higher } \\
\text { exposures is impractical. The standard sets annual dose limits for any organ at } 5 \text { mrem. An annual dose } \\
\text { equivalent from drinking water supplies operated by DOE is set at } 4 \text { mrem and notes that liquid effluent } \\
\text { from DOE activities will not cause public drinking water systems to exceed EPA MCLs. The DOE Order } \\
\text { also establishes design lifetime control and stabilization features as given in } 40 \text { CFR } 192 \text {, including control } \\
\text { and access features to be effective to reasonable extent for } 1000 \text { yrs, and in any case no less than } 200 \text { yrs. } \\
\text { TSCA requirements are potentially applicable to the ERDF becsuse PCBs have been identified as potential } \\
\text { contaminants of concern and may be disposed of at the ERDF above the regulated concentration of } 50 \\
\text { ppm. This regulation establishes handling, storage and disposal requirements for wastes with PCB } \\
\text { concentrations greater than } 50 \text { ppm. }\end{array}$ \\
\hline \multicolumn{3}{|l|}{ LOCATION SPECIFIC } \\
\hline $\begin{array}{l}\text { National Historic Preservation Act of } 1966 \\
\text { USC } 470 \text { et seq. }\end{array}$ & Not ARAR & $\begin{array}{l}\text { Requirements established under this act are not applicable or relevant and appropriate to the ERDF } \\
\text { because no facilities located at site are currently listed on or proposed for inclusion on the National } \\
\text { Register of Historic Places. }\end{array}$ \\
\hline $\begin{array}{l}\text { Archeological and Historic Preservation Act } \\
16 \text { USC 469a-1 }\end{array}$ & Not ARAR & $\begin{array}{l}\text { This act requires that actions conducted at the site must not cause the loss of any archeological and } \\
\text { historic data. This act varies from the National Historic Preservation Act in that it mandates only } \\
\text { preservation of the data and not the actual facility. This Act is not applicable or relevant and appropriate } \\
\text { because no archeological or historic sites have currently been identified within the ERDF area, huwever. } \\
\text { if archeological or historic sites are identified, then these requirements may be applicable. }\end{array}$ \\
\hline $\begin{array}{l}\text { Endangered Species Act of } 1973 \\
16 \text { USC } 1531 \text { et seq. }\end{array}$ & Applicable & $\begin{array}{l}\text { This law is applicable and must be considered during design, operation and closure of the ERDF hecause } \\
\text { it establishes requirements to protect species threatened by extinction and habitats critical to their survival. } \\
\text { No animal or plant species on the federal or state lists of endangered or threatened species where } \\
\text { identified during an ecological survey of the ERDF site. Endangered and threatened species and critical } \\
\text { habitat are found elsewhere on the Hanford Site. However, the survey identified both plant and animal } \\
\text { species considered as candidates for inclusion on federal and/or state lists of threatened or endangered } \\
\text { species. The Washington State Department of Wildlife and the federal Fish and Wildlife Service shuuld } \\
\text { be consulted to determine management policies for candidate species and evaluate the biolugical } \\
\text { importance of these species. }\end{array}$ \\
\hline
\end{tabular}


Table 7-1. Identification of Potential Federal ARARs for the ERDF. (Sheet 5 of 13)

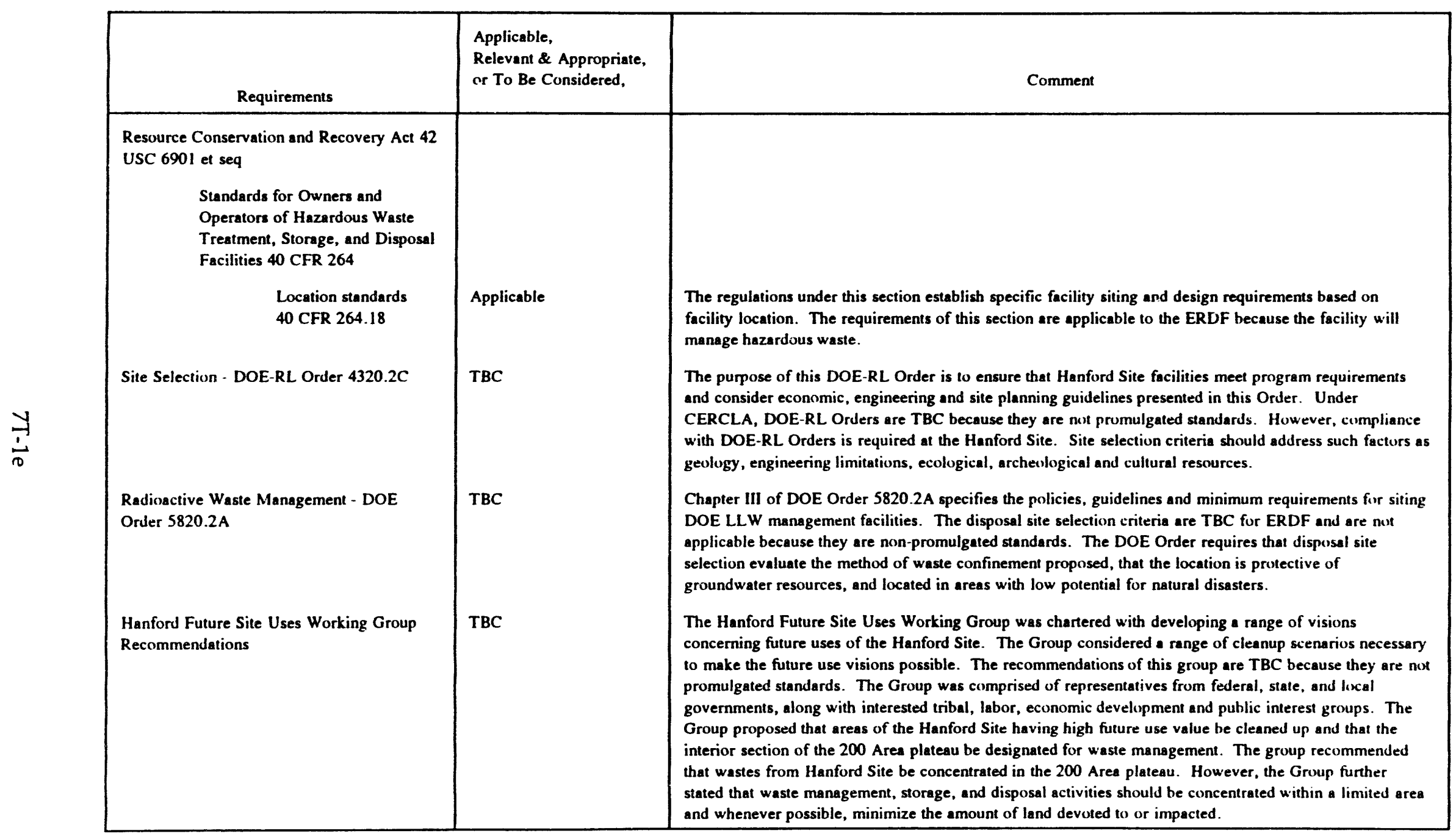


Table 7-1. Identification of Potential Federal ARARs for the ERDF. (Sheet 6 of 13)

\begin{tabular}{|c|c|c|}
\hline Requirements & $\begin{array}{l}\text { Applicable, } \\
\text { Relevant \& Appropriate, } \\
\text { or To Be Considered, }\end{array}$ & Comment \\
\hline $\begin{array}{l}\text { Wild and Scenic Rivers Act } \\
16 \text { USC } 1271 \text { et seq } \\
\text { Comipliance With Floodplain/ Wetlands } \\
\text { Environmental Review Requirements } \\
10 \text { CFR } 1022\end{array}$ & Not ARAR & $\begin{array}{l}\text { Requirements of this act are not applicable or relevant and appropriate because the Columbia River is not } \\
\text { included in the national system of wild and scenic rivers. The Columbia River has been proposed for } \\
\text { inclusion in the system, however, the ERDF is distant from the Columbia River and the facility will be } \\
\text { designed and operated to minimize migration of contaminants from the facility to groundwater and is not } \\
\text { anticipated impact to the Coiumbia River. } \\
\text { This regulation is not ARAR to the ERDF because the facility is not sited within a floodplain and no } \\
\text { wetlands are present at the site. This regulation requires DOE and other federal agencies to comply with } \\
\text { the requirements of Executive Order } 11990 \text { - Protection of Wetlands, and Executive Order } 11988 \text { - } \\
\text { Floodplain Management. Exccutive Order } 11988 \text { requires DOE procedures to insure that any action } \\
\text { conducted in a floodplain consider flood hazards. Executive Order } 11990 \text { requires protection of wetlands } \\
\text { from destruction. This regulation requires federal agencies to implement these considerations through } \\
\text { existies federal standards, such as the National Environmental Policy Act. The U.S. Army Corp of } \\
\text { Engineers has established a nationwide permitting program for actions the impact wetlands. Under } \\
\text { CERCLA, on-site actions are not required to comply with administrative permit requirements of federal, } \\
\text { state and local regulations; however, CERCLA actions, must comply with substantive purtions of the } \\
\text { regulations. }\end{array}$ \\
\hline \multicolumn{3}{|l|}{ ACTION SPECIFIC } \\
\hline \multicolumn{3}{|l|}{$\begin{array}{l}\text { Resource Conservation and Recovery Act, as } \\
\text { amended } 42 \text { USC } 6901\end{array}$} \\
\hline $\begin{array}{l}\text { Criteria for Municipal Solid } \\
\text { Waste Landfills } 40 \text { CFR } 258\end{array}$ & Relevant and Appropriate & $\begin{array}{l}\text { This rule establishes the minimum national criteria for the location, design, operation, cleanup and closure } \\
\text { of municipal solid waste landfills. This rule applies only to municipal solid waste landfills as defined } \\
\text { under the standard that received waste on or after October } 9,1993 \text {. The standard defines a municipal } \\
\text { solid waste landfill as a discrete area of land that receives household waste and is not a land application } \\
\text { unit, surface impoundment or waste pile as defined under } 40 \text { CFR } 257 \text {. This standard is not applicable } \\
\text { because the ERDF does not meet this definition. However, the regulation is relevant and appropriate and } \\
\text { criteria specified in this regulation may be used for ERDF performance evaluations. }\end{array}$ \\
\hline $\begin{array}{l}\text { Identification and Listing of } \\
\text { Wastes } 40 \text { CFR } 261\end{array}$ & Applicable & $\begin{array}{l}\text { These requirements are applicable for all waste generated at or received for disposal in the ERDF. Waste } \\
\text { must be identified and evaluated to determine if it is hazardous waste. }\end{array}$ \\
\hline $\begin{array}{l}\text { Generator Standards } \\
40 \text { CFR } 262\end{array}$ & Applicable & $\begin{array}{l}\text { Regulatory requirements for facilities that generate hazardous waste are applicable if hazardous waste is } \\
\text { generated at the ERDF. }\end{array}$ \\
\hline
\end{tabular}


Table 7-1. Identification of Potential Federal ARARs for the ERDF. (Sheet 7 of 13)

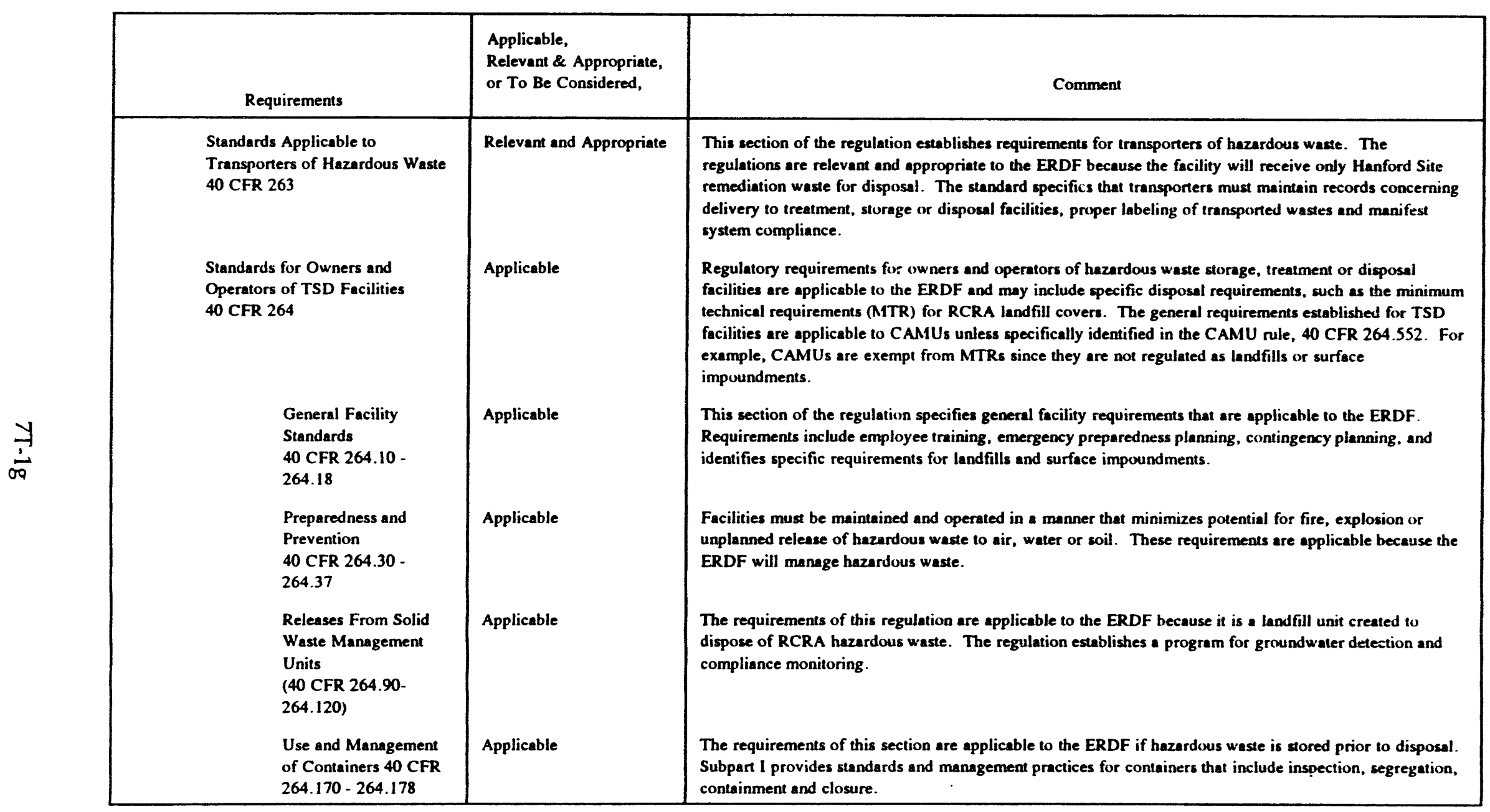


Table 7-1. Identification of Potential Federal ARARs for the ERDF. (Sheet 8 of 13)

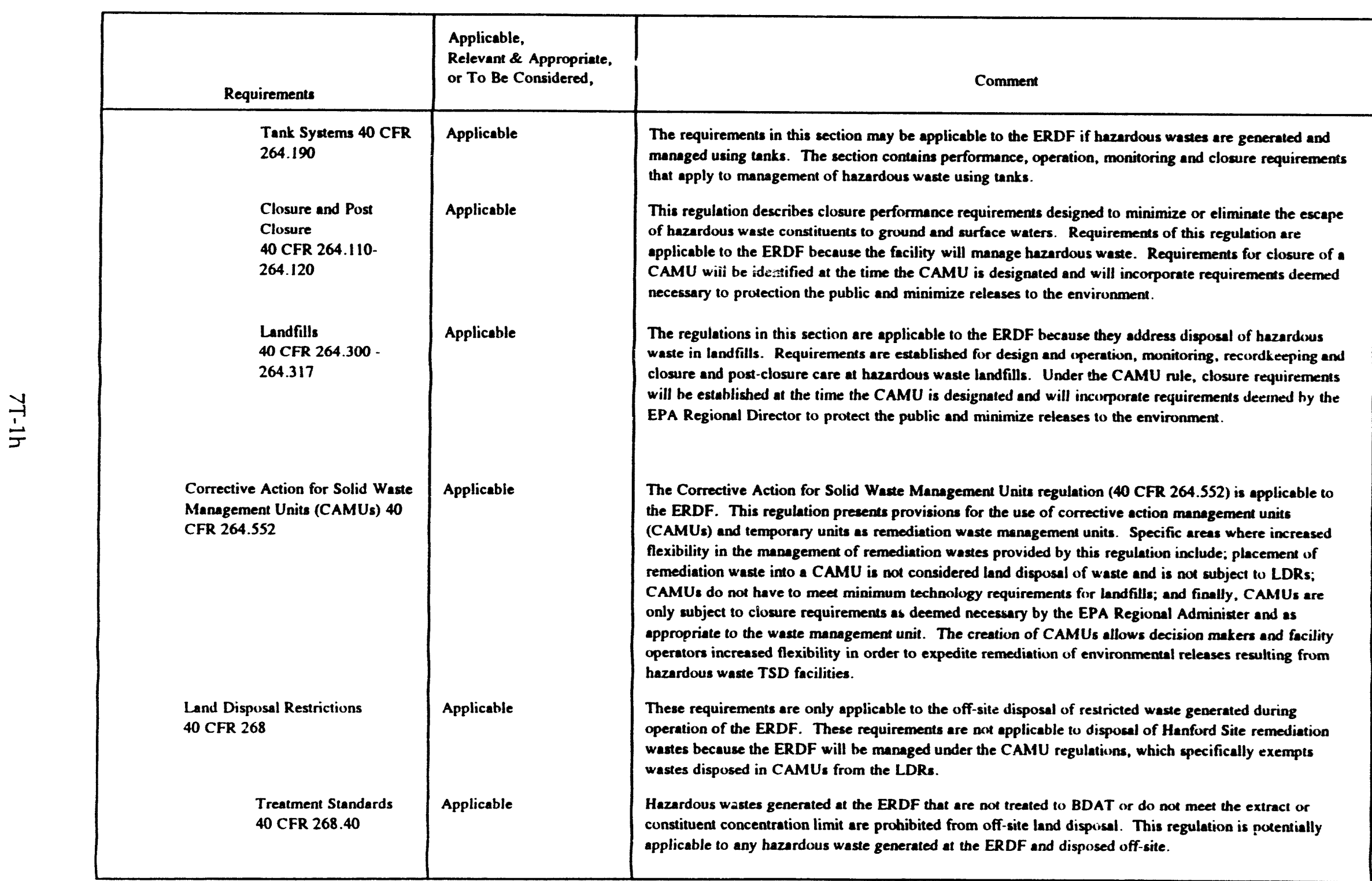


Table 7-1. Identification of Potential Federal ARARs for the ERDF. (Sheet 9 of 13)

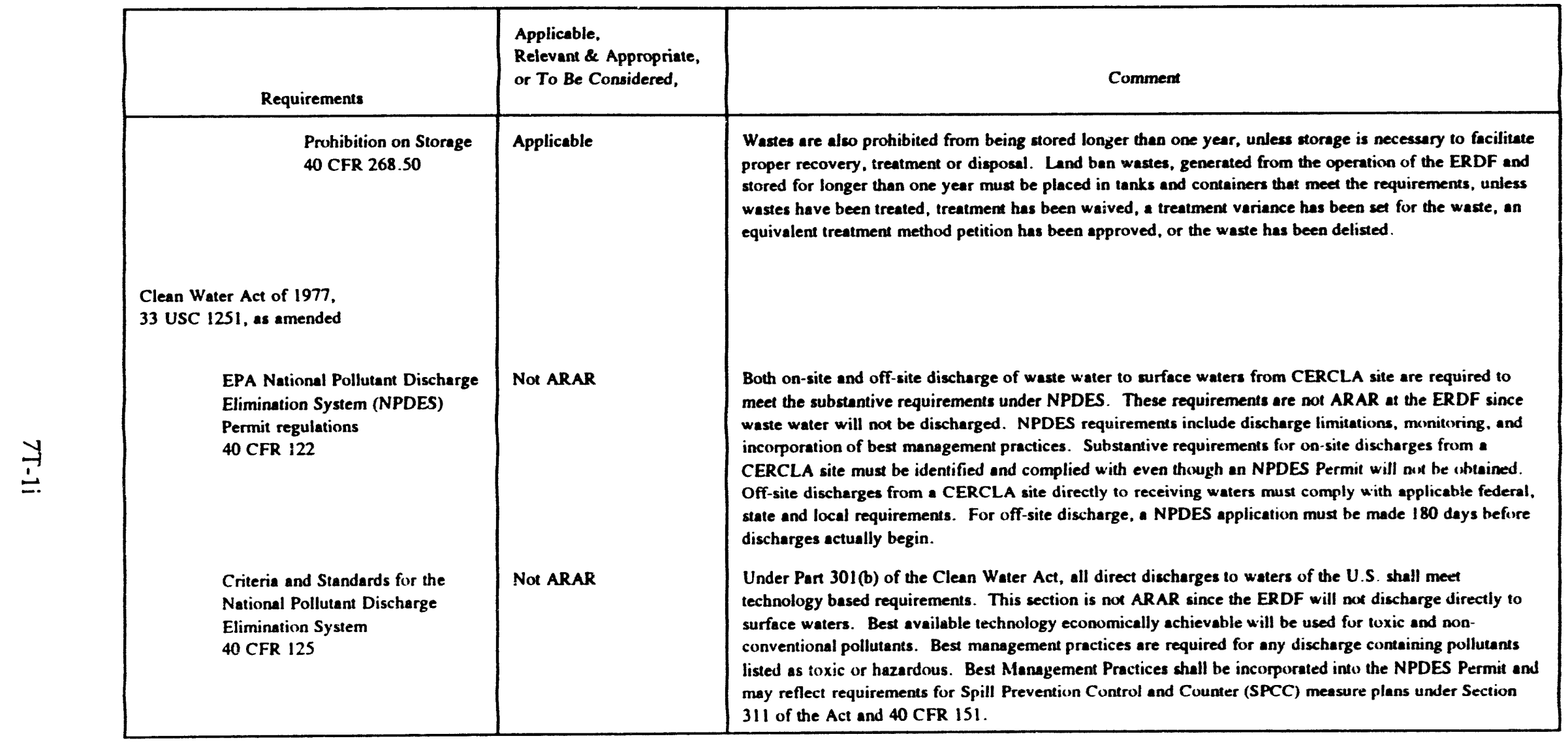


Table 7-1. Identification of Potential Federal ARARs for the ERDF. (Sheet 10 of 13)

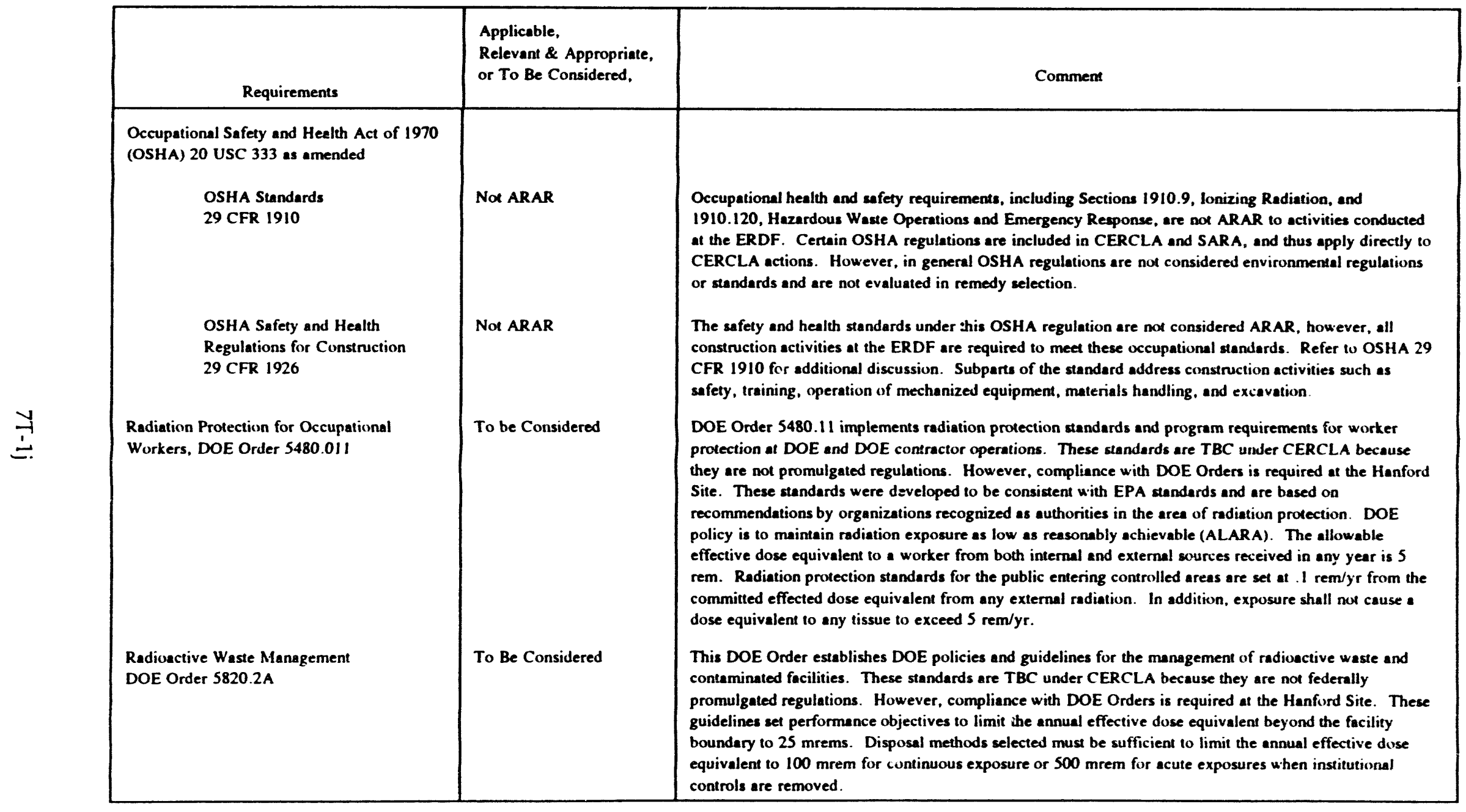


Table 7-1. Identification of Potential Federal ARARs for the ERDF. (Sheet $1 /$ of 13)

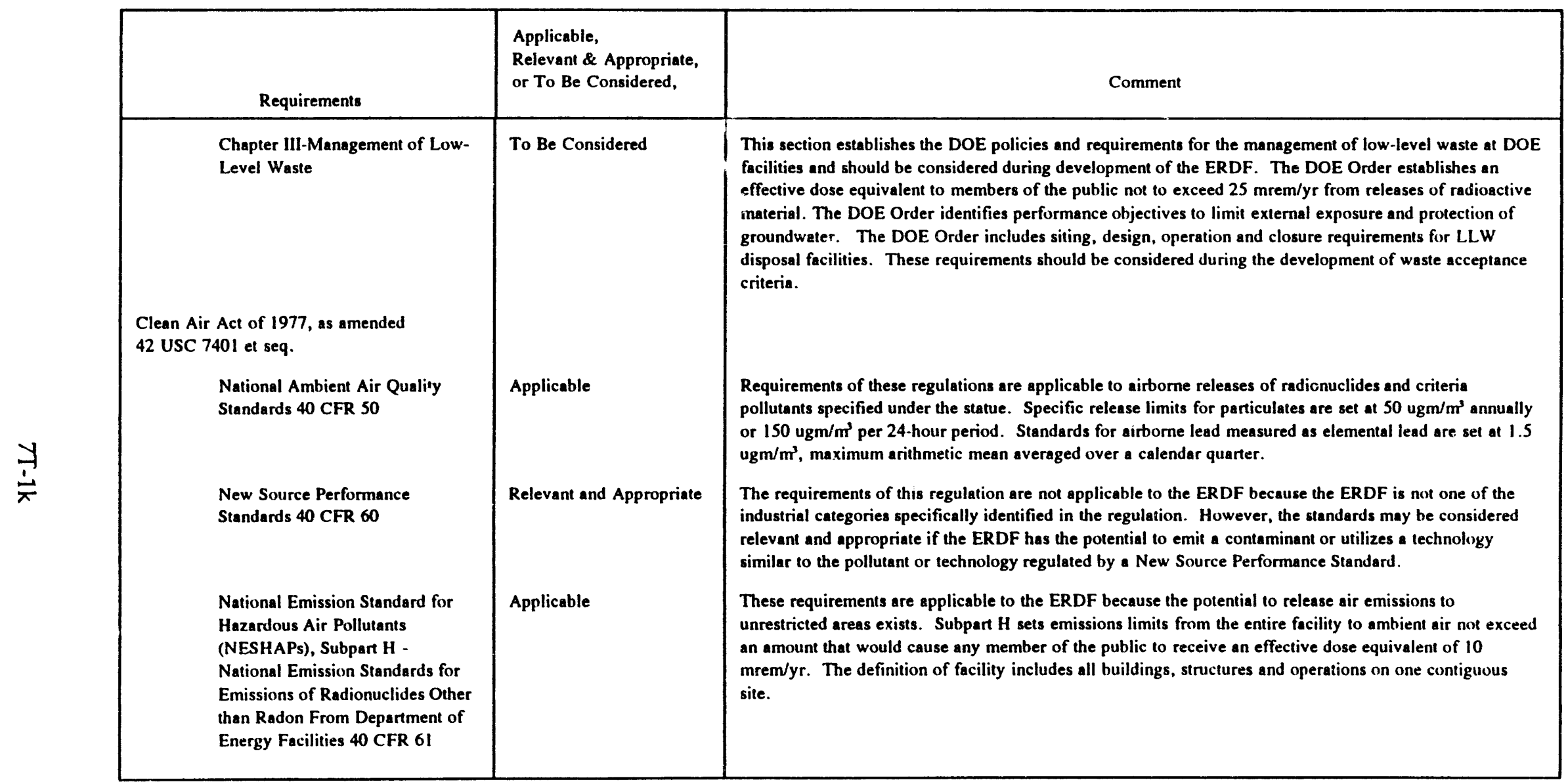


Table 7-1. Identification of Potential Federal ARARs for the ERDF. (Sheet 12 of 13)

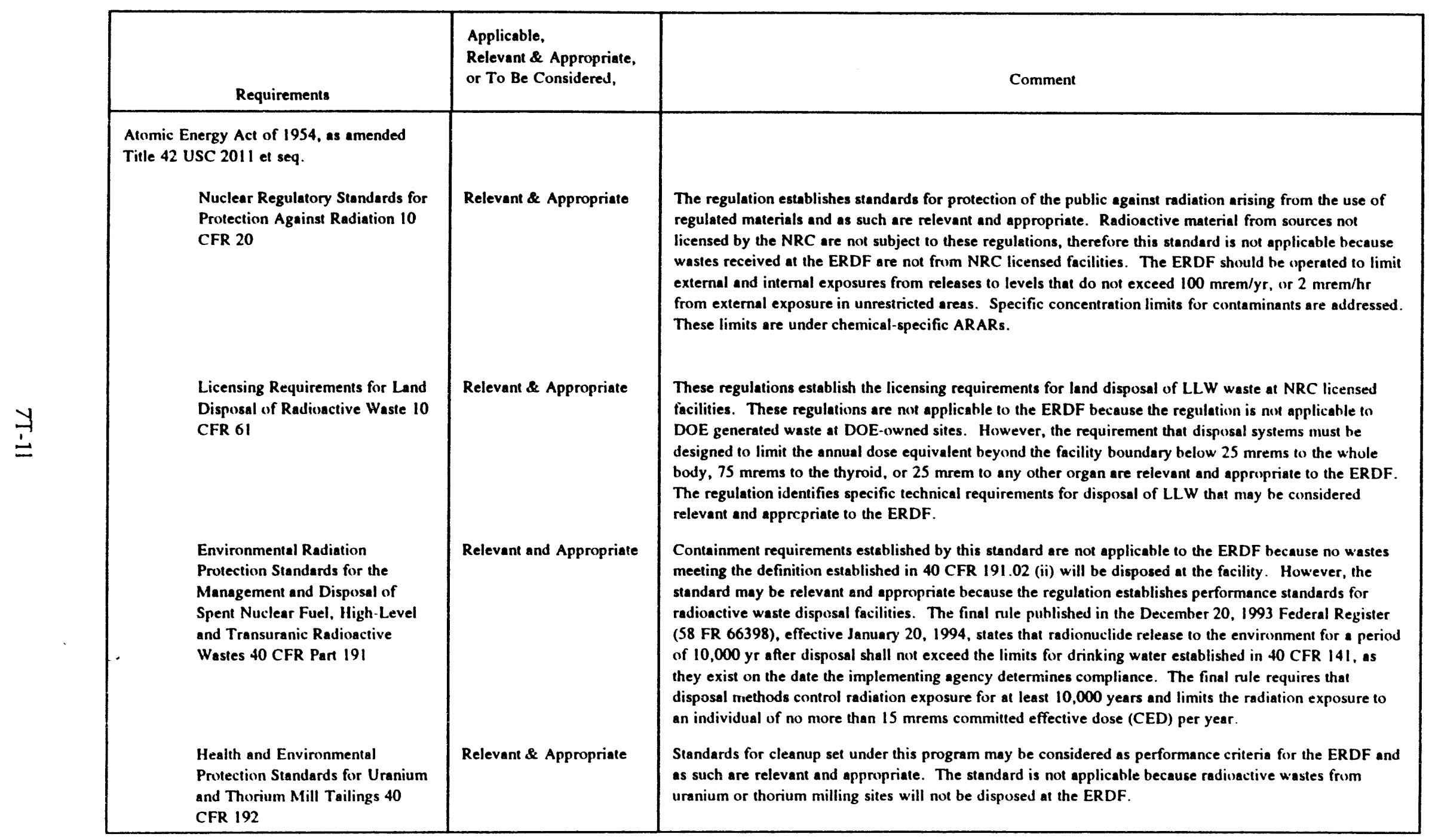


Table 7-1. Identification of Potential Federal ARARs for the ERDF. (Sheet 13 of 13)

\begin{tabular}{|c|c|c|}
\hline Requirements & $\begin{array}{l}\text { Applicable, } \\
\text { Relevant \& Appropriate, } \\
\text { or To Be Considered, }\end{array}$ & Comment \\
\hline $\begin{array}{l}\text { Hazardous Materials Transportation Act } \\
\text { (49 USC 1801, et seq) }\end{array}$ & & \\
\hline $\begin{array}{l}\text { Hazardous Materials Regulation } \\
49 \text { CFR } 171\end{array}$ & Applicable & $\begin{array}{l}\text { The atandards established under this regulation specify that no person may offer or accept hazardous } \\
\text { material for transportation in commerce unless the material is properly classed, described, packsged, } \\
\text { marked, labeled and in condition for ahipment. These requirements are applicable to hazardous material } \\
\text { generated by or ahipped from the ERDF. }\end{array}$ \\
\hline $\begin{array}{l}\text { Hazardous Materials Tables, } \\
\text { Hezardous Materials } \\
\text { Communications Requirements } \\
\text { and Emergency Response } \\
\text { Information Requirements } \\
49 \mathrm{CFR} 172\end{array}$ & Applicable & $\begin{array}{l}\text { This regulation is applicable to hazardous materials generated at or shipped from the ERDF. The class of } \\
\text { each hazardous material is identified in tables with requirements for packaging, labeling and } \\
\text { transportation. Small quantities of radioactive materials are not subject to any other requirements of the } \\
\text { chapter if the activity level does not exceed levels specified under } \$ 8173.421,173.422 \text {, or } 173.424 \text {. } \\
\text { Packages used for shipping hazardous materials shall be designed and constructec, and its contents so } \\
\text { limited, that under conditions normally incident to transportation, there is no significant release of } \\
\text { hazardous materials to the environment. }\end{array}$ \\
\hline
\end{tabular}


Table 7-2. Identification of Potential State ARARs for the ERDF. (Sheet 1 of 10)

\begin{tabular}{|c|c|c|}
\hline REQUIREMENTS & $\begin{array}{l}\text { Applicable, } \\
\text { Relevant \& } \\
\text { Appropriate, To } \\
\text { be Considered }\end{array}$ & COMMENT \\
\hline CHEMICAL SPECIFTC & & \\
\hline $\begin{array}{l}\text { Hazardous Waste Clean Up/ Model Toxics Control Act Ch. } \\
\text { 70.105D RCW } \\
\text { Model Toxics Control Act } \\
\text { WAC 173-340 } \\
\text { Dangerous Waste Regulations } \\
\text { Ch. 70.105 RCW } \\
\text { Dangerous Waste Regulations } \\
\text { WAC 173-303 } \\
\text { Designation of Dangerous Waste } \\
\text { WAC 173-303-070 } \\
\\
\text { Dangerous Waste Characteristics } \\
\text { WAC 173-303-90 }\end{array}$ & $\begin{array}{l}\text { Relevant and } \\
\text { Appropriate }\end{array}$ & $\begin{array}{l}\text { The Washington State Dangerous Wante Regulations implement the federal Hazardous Waste } \\
\text { Regulations promulgated puraunt to RCRA. Requirements found in WAC 173-303-070 } \\
\text { establish the procedures and methods to determine if solid waste requires management as } \\
\text { dangerous waste. These requirements are applicable as chemical-specific ARARS for the } \\
\text { ERDF because the facility may generate dangerous wastes. These requirements are not } \\
\text { applicable to the Hanford Site remediation wastes. } \\
\text { This section sets forth the methods to clessify wastes as dangerous or extremely hazardous } \\
\text { based on characteristics of ignitability, corrosivity, reactivity, and toxicity. Classification of } \\
\text { wastes is only applicable to wastes generated at the ERDF and are not applicable to } \\
\text { remediation wastes disposed of at the ERDF. }\end{array}$ \\
\hline
\end{tabular}


Table 7-2. Identification of Potential State ARARs for the ERDF. (Sheet 2 of 10)

\begin{tabular}{|c|c|c|}
\hline REQUIREMENTS & $\begin{array}{l}\text { Applicable, } \\
\text { Relevant \& } \\
\text { Appropriate, To } \\
\text { be Considered }\end{array}$ & COMMENT \\
\hline \multicolumn{3}{|l|}{$\begin{array}{l}\text { Solid Waste Management, Recovery and Recycling Act Ch. } \\
70.95 \text { RCW }\end{array}$} \\
\hline $\begin{array}{l}\text { Minimum Functional Standards for Solid Waste } \\
\text { Handling WAC 173-304 }\end{array}$ & $\begin{array}{l}\text { Relovant and } \\
\text { Appropriate }\end{array}$ & $\begin{array}{l}\text { The atandard sets the minimum requirements for the handling of all solid waste, including } \\
\text { operation, monitoring and closure requirements. The requirements of this standerd are not } \\
\text { applicable to the ERDF because the standard does not address wastes regulated under WAC } \\
\text { 173-303. However, the standard is relevant and appropriate because it sets maximum } \\
\text { contaminant levels (MCLs) for groundwater at the same levels as the drinking water standards } \\
\text { under } 40 \text { CFK 141. }\end{array}$ \\
\hline \multicolumn{3}{|l|}{$\begin{array}{l}\text { State Radiation Protection Standards } \\
\text { Ch. } 70.98 \text { RCW }\end{array}$} \\
\hline $\begin{array}{l}\text { Radiation Protection Standerds } \\
\text { WAC 246-221 }\end{array}$ & Applicablo & $\begin{array}{l}\text { This regulation is considered applicable because it eatablishes atandards for acceptablo levels, } \\
\text { of expoeure to radiation. The occupational dose limit for adults, excluding planned special } \\
\text { exposures, shall not exceed an annual limit of a total effective dose equivalent equal to } 5 \text { rem, } \\
\text { or the sum of the deep dose equivalent and the committed dose equivalent to any individual } \\
\text { organ or tissue other than the lens of the eye should not exceed } 50 \text { rem. An eye dose } \\
\text { equivalent of } 15 \text { rem is set for exposure to the eye. The shallow dose equivalent for the skin } \\
\text { or any extremities is } 50 \text { rem. Occupational dose limits for minors are set at } 10 \% \text { of the } \\
\text { annual occupational dose limits for adults. }\end{array}$ \\
\hline & & $\begin{array}{l}\text { The andard identifies the methods required to demonstrate compliance and providea derived } \\
\text { air concentration (DAC) and annual limit on uptake (ALD) values that may be used to } \\
\text { determine an individuals occupational dose limits. Dose limits that individual members of } \\
\text { public may receive in unrestricted areas or from radioactive effluent, are not to cause an } \\
\text { individual, if continually present in an unrestricted area, to receive from external sources, not } \\
\text { to exceed } 0.002 \text { rem in an hour or } 0.50 \text { rem in a year. The standard species the requirements } \\
\text { for monitoring personnel exposure from both external and internal exposure. }\end{array}$ \\
\hline & & $\begin{array}{l}\text { Chapter 246-221-290 establishes annual average concentration limits for radionctive releases } \\
\text { in gaseous or liquid effluent released to unrestricted areas. }\end{array}$ \\
\hline $\begin{array}{l}\text { Radiation Protection- Air Emissions } \\
\text { WAC } 246-247\end{array}$ & Applicable & $\begin{array}{l}\text { This regulation promulgates air emission limits for eirborne radionuclide emissions as defined } \\
\text { in WAC } 173-480 \text { and is consistent with federal NESHAPs. The ambient standard requires } \\
\text { that emission of radionuclides to the air must not cause a dose equivalent of } 25 \text { mrem per year } \\
\text { to the whole body or } 75 \text { mrem per year to any critical organ. }\end{array}$ \\
\hline
\end{tabular}


Table 7-2. Identification of Potential State ARARs for the ERDF. (Sheet 3 of 10)

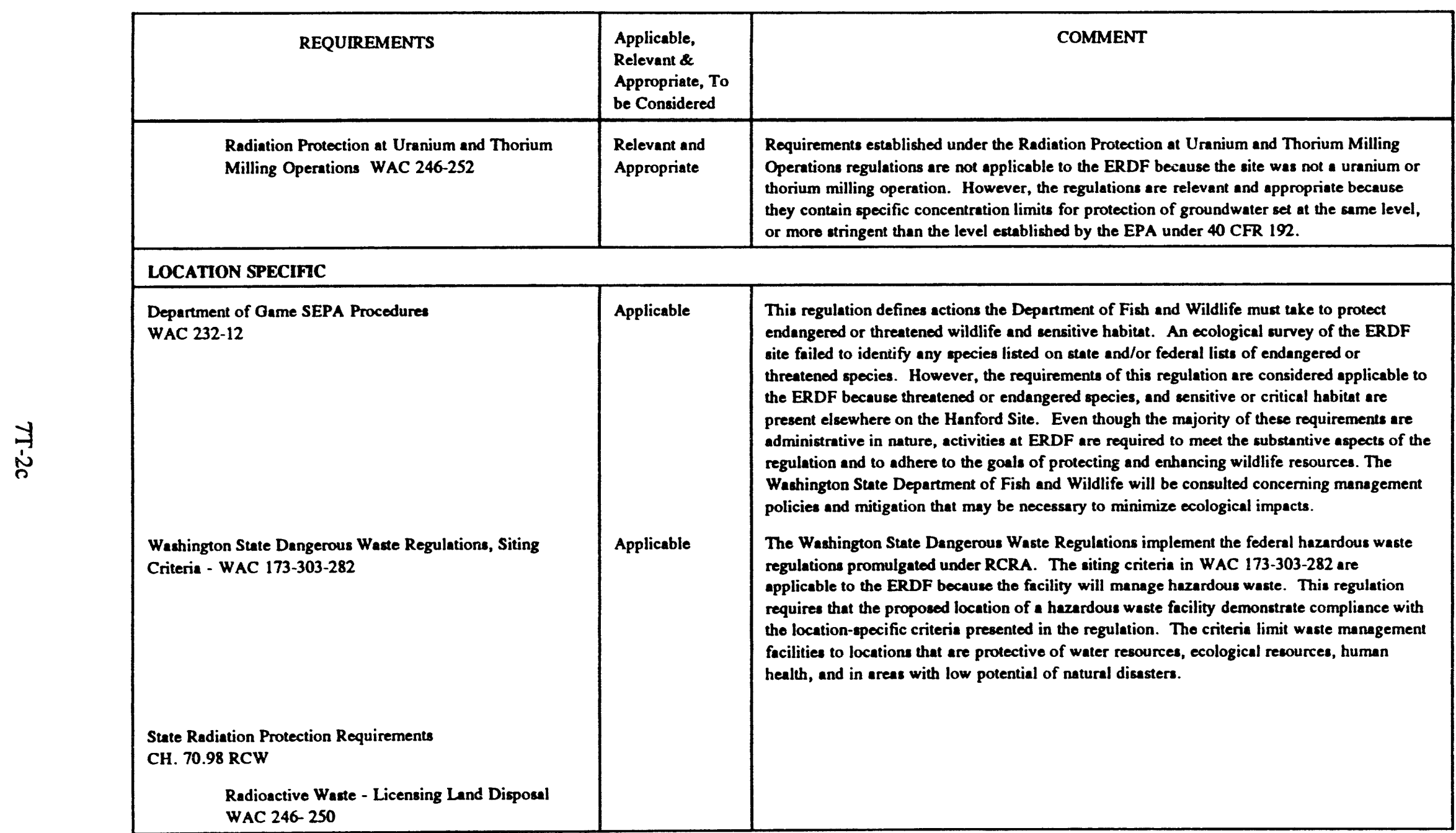


Table 7-2. Identification of Potential State ARARs for the ERDF. (Sheet 4 of 10)

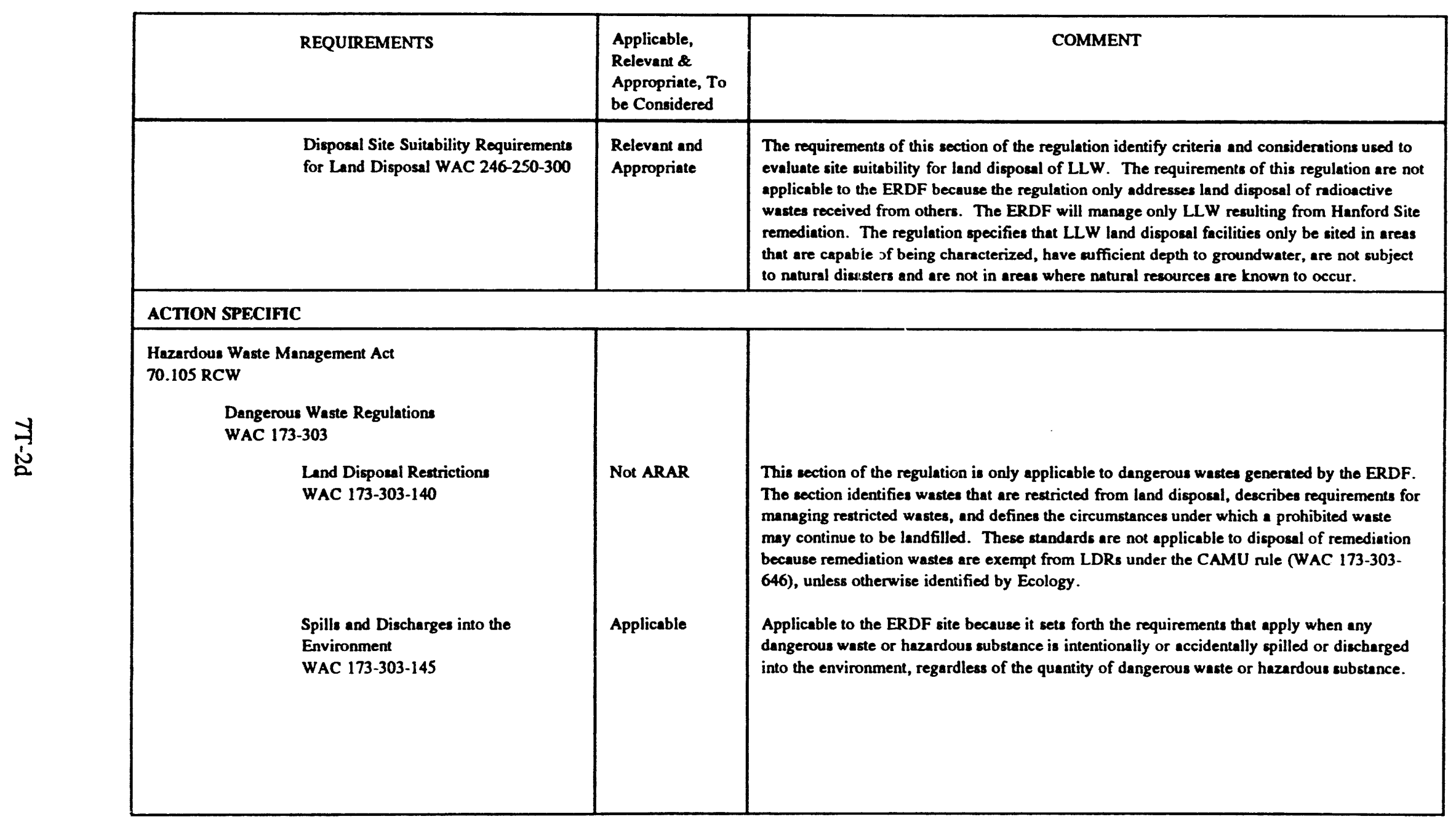


Table 7-2. Identification of Potential State ARARs for the ERDF. (Sheet 5 of 10)

\begin{tabular}{|c|c|c|c|}
\hline & REQUIREMENTS & $\begin{array}{l}\text { Applicable, } \\
\text { Relevant \& } \\
\text { Appropriate, To } \\
\text { be Considered }\end{array}$ & COMMENT \\
\hline & $\begin{array}{l}\text { General Requirements for Dangerous } \\
\text { Waste Management Facilities } \\
\text { 173-303-280 }\end{array}$ & Applicable & $\begin{array}{l}\text { General requirements for dangerous waste management facilities are applicable to the ERDF } \\
\text { and defines requirements that identify acceptable treatment, storage, or disposal practices for } \\
\text { designated dangerous waste. The facility siting standards presented under this section are } \\
\text { discussed as location-specific ARARs. General requirements specified in this section include } \\
\text { procedures for facility permiting, employee training, emergency preparedness, contingency } \\
\text { planning, end management of contuiners. Additional requirements for landfills, and surface } \\
\text { impoundments are also included in the regulation. }\end{array}$ \\
\hline & $\begin{array}{l}\text { General Waste Analysis } \\
\text { WAC 173-303-300 }\end{array}$ & Applicable & $\begin{array}{l}\text { Waste is required to be analyzed to determine the presence of dangerous waste before it is } \\
\text { stored, treated, or disposed. These requirements are applicable to wastes generated by, and } \\
\text { disposed in, the ERDF. }\end{array}$ \\
\hline & $\begin{array}{l}\text { Security } \\
\text { WAC 173-303-310 }\end{array}$ & Applicable & $\begin{array}{l}\text { Security procedures are required so that the ERDF will not cause injuries to personnel at the } \\
\text { site or to the public, and that access to the site is controlled. These requirements are } \\
\text { applicable because dangerous wastes will be managed at the ERDF. }\end{array}$ \\
\hline & $\begin{array}{l}\text { General Inspection } \\
\text { WAC 173-303-320 }\end{array}$ & Applicable & $\begin{array}{l}\text { Requirements to inspect facilities to prevent malfunctions and deterioration, operator errors, } \\
\text { and discharges that may cause or lead to the release of dangerous waste constituents to the } \\
\text { environment, or a threat to human health, are applicable to the ERDFF. }\end{array}$ \\
\hline
\end{tabular}


Table 7-2. Identification of Potential State ARARs for the ERDF. (Sheet 6 of 10)

\begin{tabular}{|c|c|c|c|}
\hline & REQUIREMENTS & $\begin{array}{l}\text { Applicable, } \\
\text { Relevant \& } \\
\text { Appropriate, To } \\
\text { be Considered }\end{array}$ & COMMENT \\
\hline & $\begin{array}{l}\text { Peraonnel Training } \\
\text { WAC 173-303-330 } \\
\text { Preparedness and Provention } \\
\text { WAC 173-303-340 } \\
\text { Contingency Plan and } \\
\text { Emergency Procedures } \\
\text { WAC 173-303-350 } \\
\text { Other General Requirements } \\
\text { WAC 173-303-395 } \\
\text { Use and Management of Containers } \\
\text { WAC 173-303-630 } \\
\text { Releases From Regulated Units } \\
\text { 173-303-645 }\end{array}$ & $\begin{array}{l}\text { Relevant and } \\
\text { Appropriate } \\
\text { Relevant and } \\
\text { Appropriate } \\
\text { Relevant and } \\
\text { Appropriate } \\
\text { Applicable } \\
\text { Applicable } \\
\text { Applicable }\end{array}$ & $\begin{array}{l}\text { This section requires a program of claseroom instruction, or on-the-job training, for facility } \\
\text { personnel and is relevant and appropriate to the ERDF because CERCLA already establishes } \\
\text { apecific personnel training requirements. } \\
\text { This section describes preparations and preventive measures, which help avoid or mitigate } \\
\text { fire, explosion, or unplanned sudden or nonsudden releases of dangerous waste or dangerous } \\
\text { waste conatituents. This section is relevant and appropriate to the ERDF because CERCLA } \\
\text { already requirements preparation of a health and afety plan that includes emergency } \\
\text { preparedness preparations. } \\
\text { Contingency plans are required for dangerous waste management facilities, however, this } \\
\text { requirement is considered relevant and appropriate at the ERDF because CERCLA already } \\
\text { requires development of a contingency plan as part of the site health and safety plan. The } \\
\text { contingency plan describes actions and procedures to be implemented during an emergency } \\
\text { that lessen the potential impact on public health and the environment. } \\
\text { The regulations in this section define apecific precautions for the management of ignitable, } \\
\text { reactive, or incompatible wastes. This section is applicable to the ERDF. } \\
\text { This section discusses procedures for management of containers used to store dangerous waste } \\
\text { and is applicable if a dangerous waste is generated at the ERDF. } \\
\text { The requirements of this section establiah criteria for operation and closure of dangerous } \\
\text { waste management facilities, that are designed to minimize releases into the environment. } \\
\text { The section identifies monitoring requirements, the point where compliance is to be achieved } \\
\text { and the duration for which compliance must be demonstrated. The section also identifies } \\
\text { reporting requirements that assist in determining if corrective action may be necessary. This } \\
\text { section is applicable to the ERDF because dangerous wastes will be disposed at the ERDF. } \\
\text { Allowable contaminant concentrations based on protection of groundwater are discussed as } \\
\text { chemical-specific ARARs. }\end{array}$ \\
\hline
\end{tabular}


Table 7-2. Identification of Potential State ARARs for the ERDF. (Sheet 7 of 10)

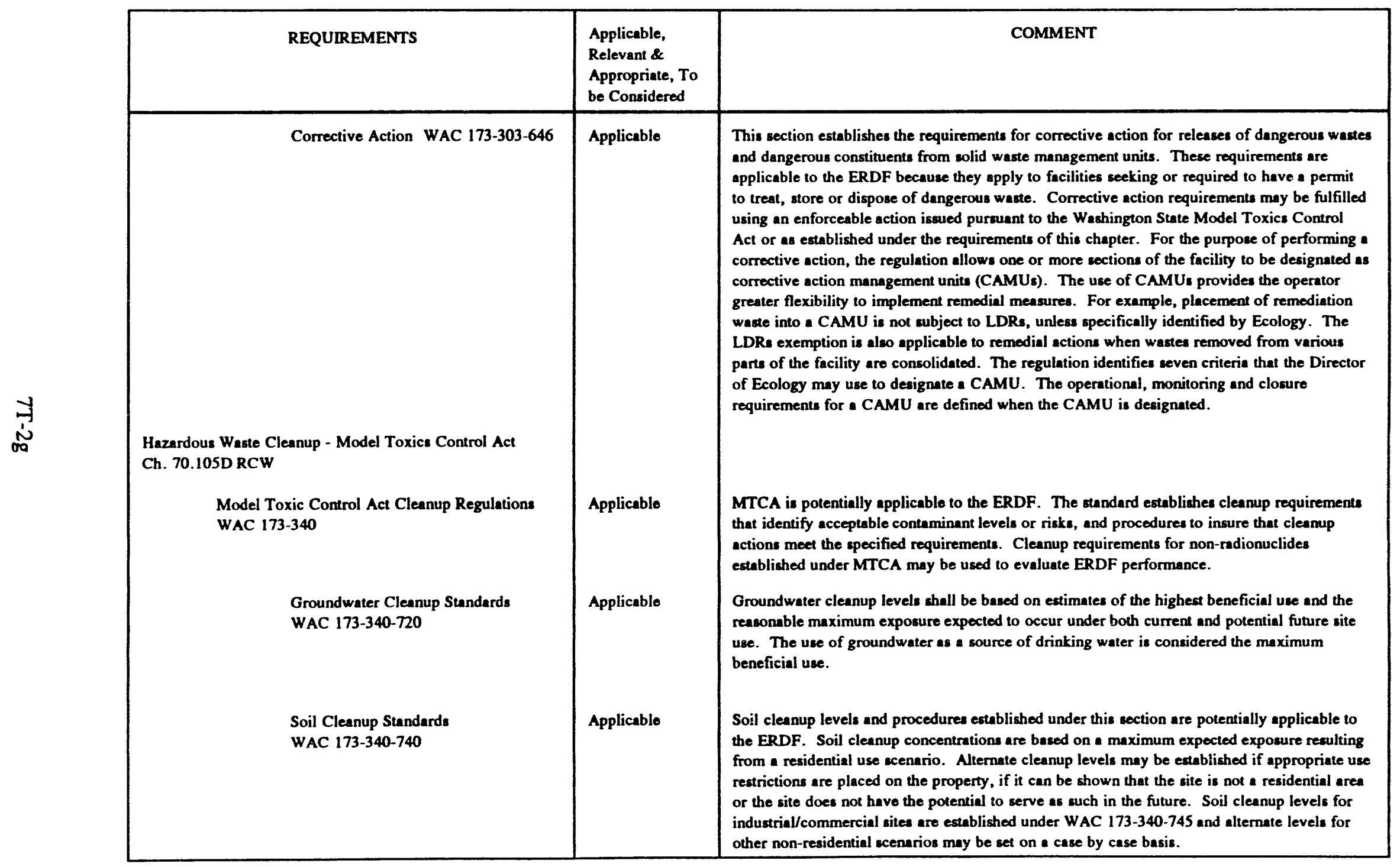


Table 7-2. Identification of Potential State ARARs for the ERDF. (Sheet 8 of 10)

\begin{tabular}{|c|c|c|}
\hline REQUIREMENTS & $\begin{array}{l}\text { Applicable, } \\
\text { Relevant \& } \\
\text { Appropriate, To } \\
\text { be Considered }\end{array}$ & COMMENT \\
\hline $\begin{array}{l}\text { Compliance Monitoring Requirements } \\
\text { WAC 173-340-410 } \\
\text { Solid Wacte Management, Recovery and Recycling Act Ch. } \\
70.95 \text { RCW } \\
\text { Minimum Functional Standards for Solid Waste } \\
\text { Handling WAC 173-304 } \\
\text { Water Pollution Control/ Water Resource Act of } 1971 \\
\text { Ch. } 90.48 \text { RCW/ Ch.90.54 RCW } \\
\text { Protection of Upper Aquifer Zones } \\
\text { WAC 173-154 } \\
\text { Minimum Standards for Construction and } \\
\text { Maintenance of Water Wells WAC } 173-160 \\
\text { Water Quality Standards for Groundwater } \\
\text { WAC 173-200 }\end{array}$ & $\begin{array}{l}\text { Applicable } \\
\text { Not ARAR } \\
\text { Relevant \& } \\
\text { Appropriate } \\
\text { Applicable } \\
\text { Relevant \& } \\
\text { Appropriate }\end{array}$ & $\begin{array}{l}\text { Requirements of this section not considered ARAR to the ERDF because the regulation } \\
\text { apecifies that dangerous wastes identified under WAC } 173-303 \text { are to be managed as } \\
\text { dangerous waste. } \\
\text { This regulation directs Ecology to provide for protection of upper aquifers and upper aquifer } \\
\text { zonea to avoid depletions, exceasive water level declines, or reductions in water quality. This } \\
\text { regulation is not applicable to the ERDF because the regulation only establishes the policy and } \\
\text { program for Ecology. However, the regulation may be considered relevant and applicable } \\
\text { because the ERDF will be designed to protect the upper aquifer zones. } \\
\text { Requirements established under this regulation are applicable to construction of wells used for } \\
\text { monitoring at the ERDF. This regulation establishes standards for the construction, use and } \\
\text { ebandonment of water wells. } \\
\text { This atandard establishes groundwater quality standards. These requirements are relevant and } \\
\text { appropriate to the ERDF becaune the potential for contaminants to migrate from the facility to } \\
\text { groundwater exists. The athndard is not applicable because CERCLA actions are specifically } \\
\text { exemptod by the regulation The standard explicitly notes that groundwater remediation } \\
\text { cleanup levels are to be determined using the standards presented in } 173-340-720 \text {. The ERDF } \\
\text { should be designed and operated in a manner that will protect future beneficial uses of } \\
\text { groundwater. }\end{array}$ \\
\hline
\end{tabular}


Table 7-2. Identification of Potential State ARARs for the ERDF. (Sheet 9 of 10)

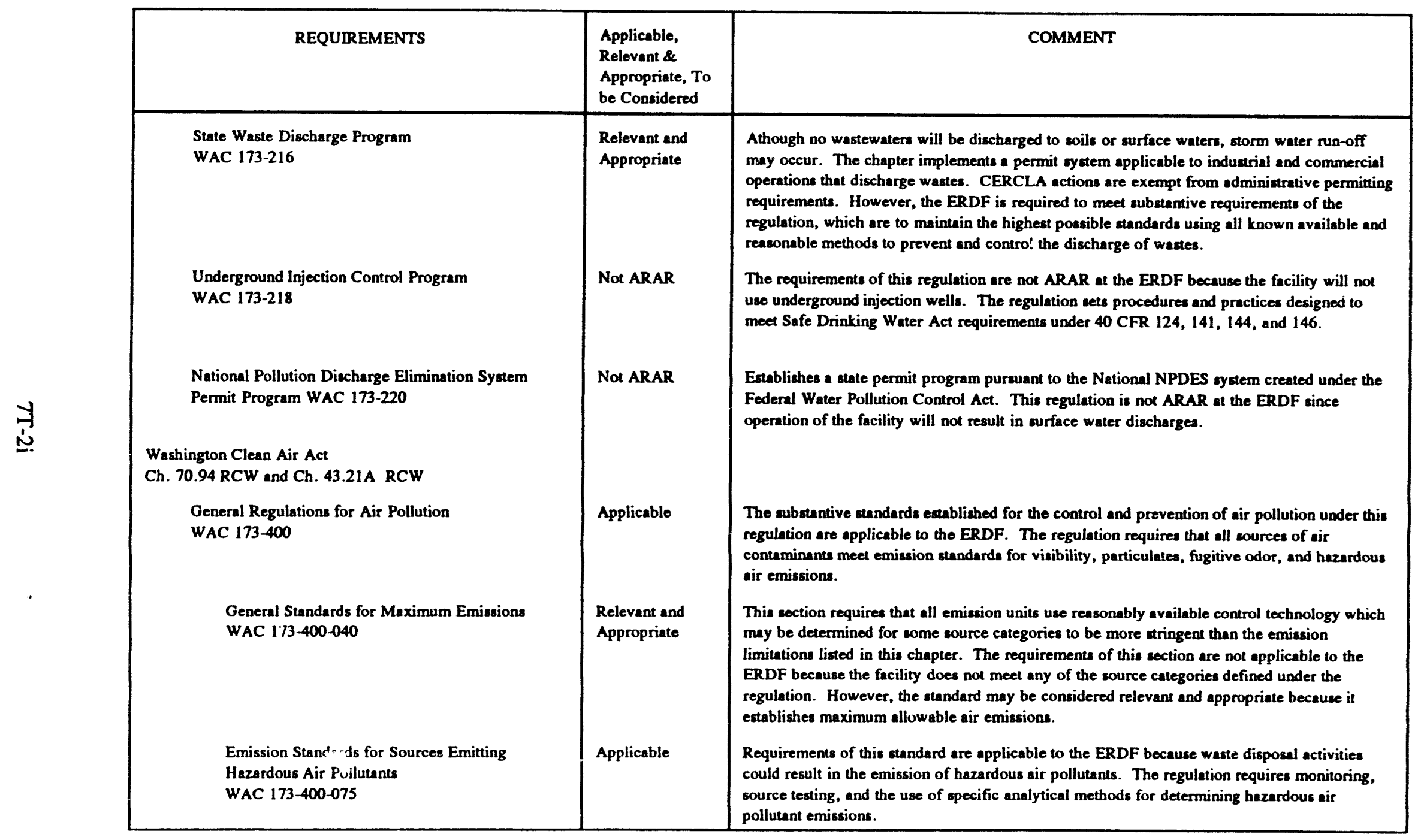


Table 7-2. Identification of Potential State ARARs for the ERDF. (Sheet 10 of 10)

\begin{tabular}{|c|c|c|}
\hline REQUIREMENTS & $\begin{array}{l}\text { Applicable, } \\
\text { Relevant \& } \\
\text { Appropriate, To } \\
\text { be Considered }\end{array}$ & COMMENT \\
\hline $\begin{array}{l}\text { Standards of Performance for New Sources } \\
\text { WAC 173-400-115 } \\
\text { Ambient Air Quality Standards and Emission Limits } \\
\text { for Radionuclides } \\
\text { WAC 173-480 } \\
\text { State Radiation Protection Requirements } \\
\text { CH. 70.98 RCW } \\
\text { Radioactive Waste- Licensing Land Disposal } \\
\text { WAC 246-250 } \\
\text { Washington Industrial Safety and Health Act } \\
\text { Ch. 49.17 RCW } \\
\text { Worker Safety and Health } \\
\text { (WAC 173-340-810) and General Safety and } \\
\text { Health Standards (WAC 296-24) }\end{array}$ & $\begin{array}{l}\text { Relevant and } \\
\text { Approprinte } \\
\text { Not ARAR }\end{array}$ & 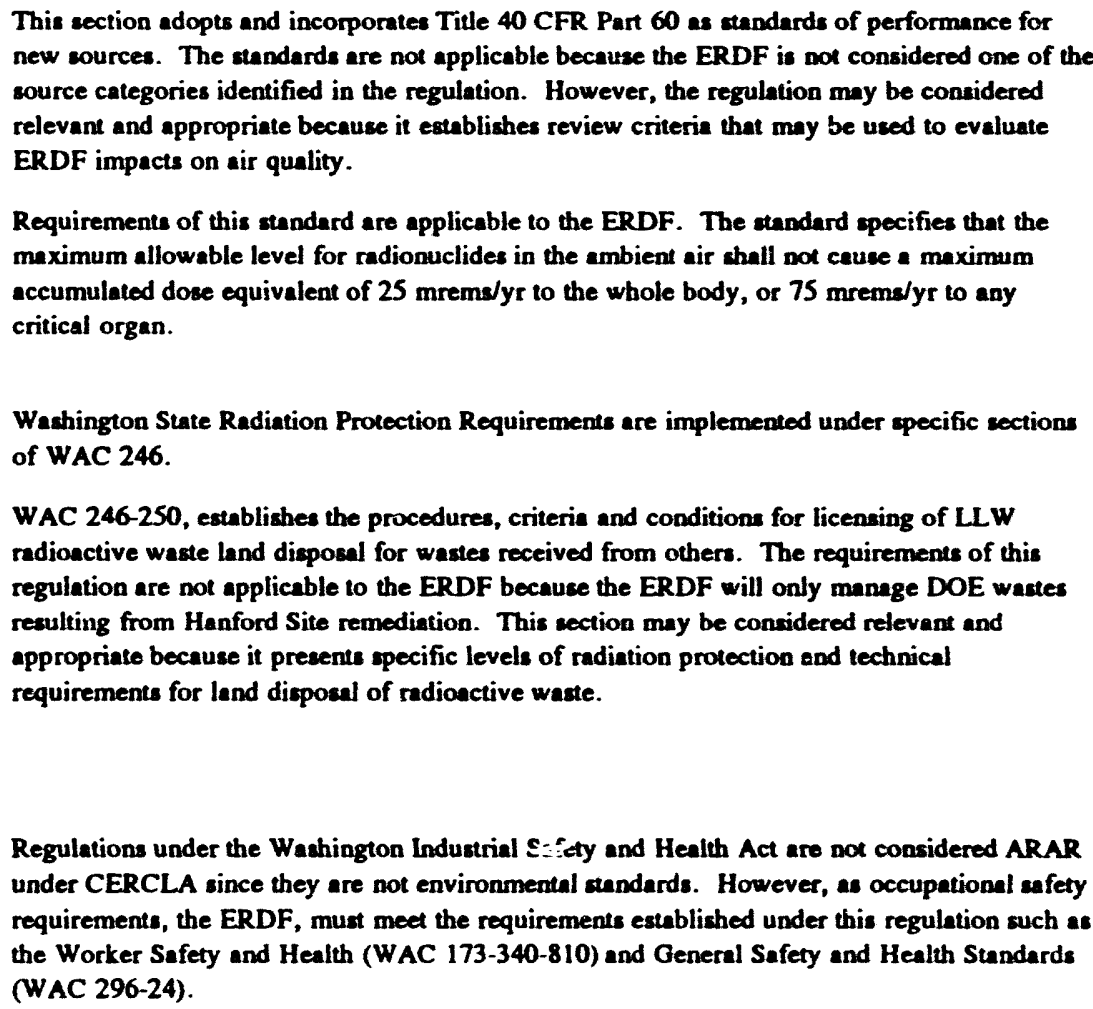 \\
\hline
\end{tabular}


Table 7-3. Preliminary Air and Groundwater Chemical-Specific ARARs for the ERDF Contaminants of Potential Concern (Radionuclides).

\begin{tabular}{|l|l|l|l|l|l|}
\hline Contaminant & $\begin{array}{l}\text { Drinking Water } \\
40 \text { CFR } 141^{\mathrm{a}}\end{array}$ & \multicolumn{2}{|l|}{$\begin{array}{l}\text { NRC Standards } \\
10 \mathrm{CFR} 20^{\mathrm{b}}, \mathrm{c}\end{array}$} & \multicolumn{2}{l|}{$\begin{array}{l}\text { Atomic Energy Act, } \\
\text { Protection of the Public } \\
\text { and Environment, DOE } \\
\text { Order 5400.5 }\end{array}$} \\
\hline & $\begin{array}{l}\text { MCL/Proposed } \\
\text { MCL (pCi/L) }\end{array}$ & Water (pCi/L) & $\begin{array}{l}\text { Air } \\
\left(\mathrm{pCi} / \mathrm{m}^{3}\right)\end{array}$ & $\begin{array}{l}\text { Water } \\
(\mathrm{pCi} / \mathrm{L})\end{array}$ & $\begin{array}{l}\text { Air } \\
\left(\mathrm{pCi} / \mathrm{m}^{3}\right)\end{array}$ \\
\hline Carbon-14 & $2000 /-$ & 30,000 & 3,000 & 70,000 & 6,000 \\
\hline Chromium-51 & $6000 / 38,000^{\mathrm{e}}$ & $5 \mathrm{E}+05$ & 30,000 & $1 \mathrm{E}+06$ & 50,000 \\
\hline Plutonium-238 & $-/ 7.1^{\mathrm{e}}$ & 20 & 0.02 & 40 & 0.03 \\
\hline Plutonium-239 & $-/ 65^{\mathrm{e}}$ & 20 & 0.02 & 30 & 0.02 \\
\hline Potassium-40 & $-/-$ & 4,000 & 600 & 7,000 & 900 \\
\hline Technicium-99 & $900 / 3,790^{\mathrm{e}}$ & $6 \mathrm{E}+04$ & 900 & $1 \mathrm{E}+05$ & 2,000 \\
\hline Thorium-228 + D & $-/ 153^{\mathrm{e}}$ & 200 & 0.02 & 400 & 0.04 \\
\hline Thorium-232 & $-/ 92^{\mathrm{e}}$ & 30 & $4 \mathrm{E}-03$ & 50 & $7 \mathrm{E}-03$ \\
\hline Uranium-233/234 & $-/ \mathrm{f}$ & 300 & $5 \mathrm{E}-03$ & 500 & 0.09 \\
\hline Uranium-235 & $-/ \mathrm{f}$ & 300 & 0.06 & 600 & 0.1 \\
\hline Uranium-238 & $-/ \mathrm{f}$ & 300 & 0.06 & 600 & 0.1 \\
\hline
\end{tabular}

astate Drinking Water Standards, WAC 246-290, are as stringent as current federal MCLs, unless otherwise noted.

b Appendix B, Table II, Column 2, Concentration Limits for Radionuclides in Liquid Effluent Released to

Unrestricted Areas.

${ }^{c}$ Appendix B, Table II, Column 1, Concentration Limits for Radionuclides in Air Effluent Released to Unrestricted Areas.

dDerived concentration guides for air and water.

eproposed MCL as reported in the Advanced Notice of Proposed Rule published in 56 FR 33050, July 18, 1991.

f Proposed MCL for uranium is $20 \mu \mathrm{g} / \mathrm{L}$ (56 FR 33050, July 18, 1991)

- Criteria not listed 

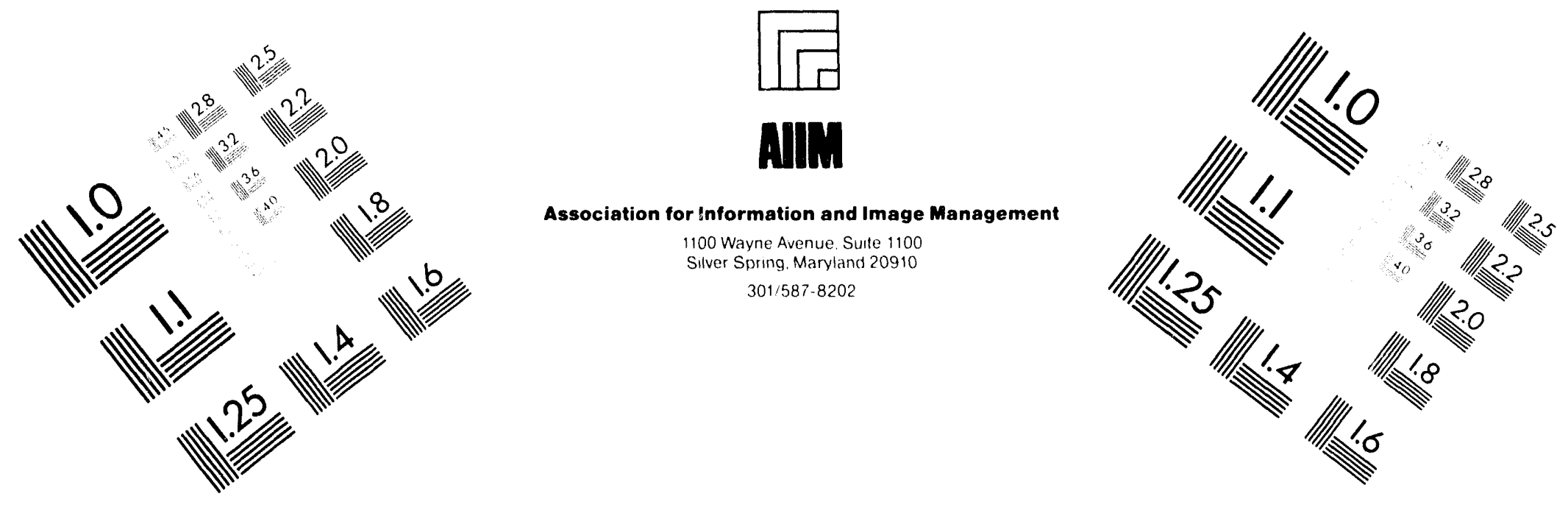

\section{Centimeter}

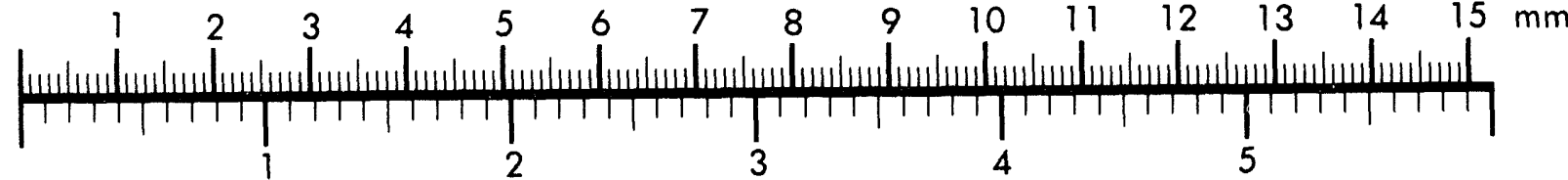

Inches
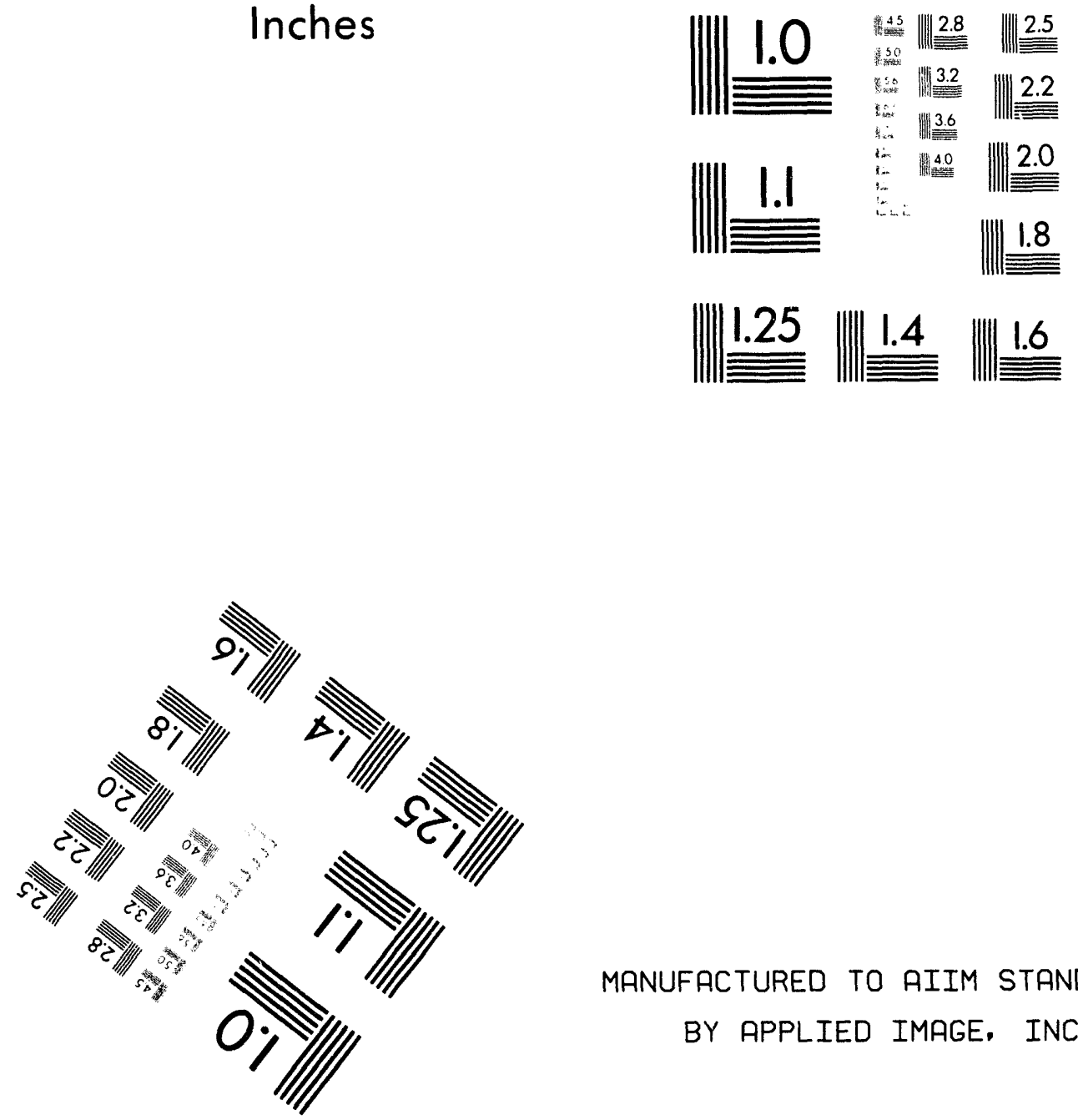

MANUFACTURED TO AIIM STANDARDS

BY APPLIED IMAGE, INC.

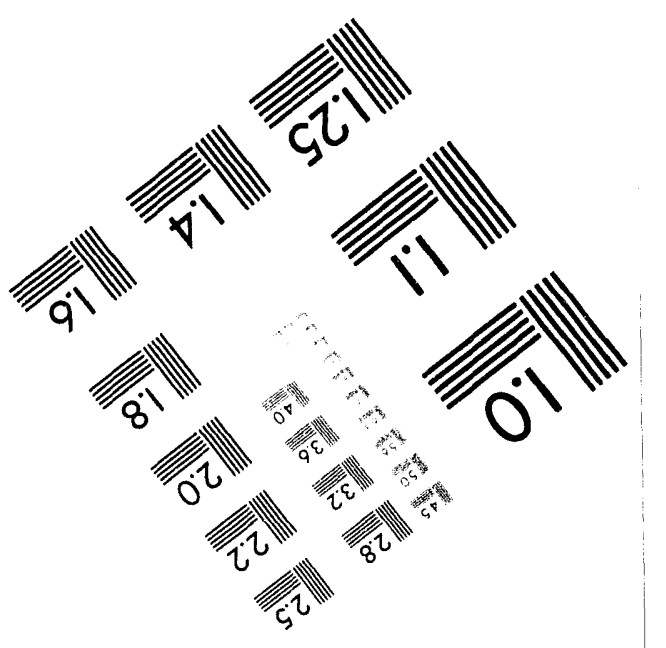



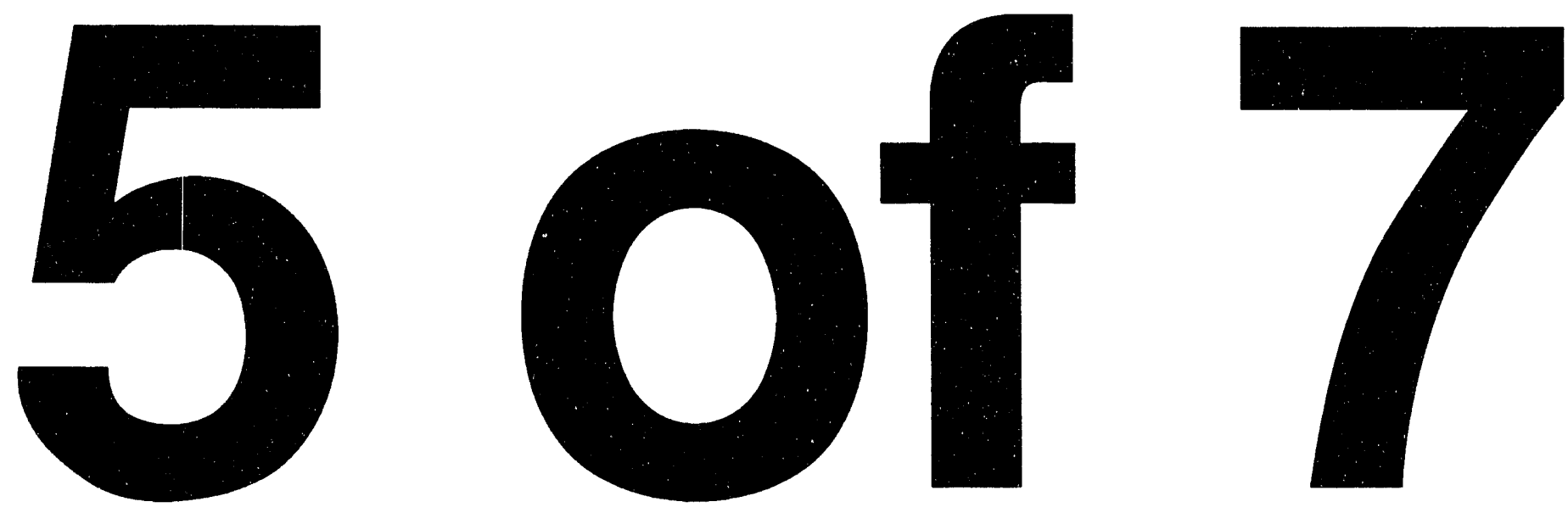
Table 7-4. Preliminary Chemical-Specific ARARs for the ERDF Groundwater Contaminants (Non-Radioactive Contaminants)

(Sheet 1 of 2)

\begin{tabular}{|c|c|c|c|c|}
\hline \multirow[t]{4}{*}{ Contaminant } & \multicolumn{2}{|c|}{$\begin{array}{c}\text { Drinking Water Standards } \\
40 \text { CFR } 141^{\mathrm{a}} \text { and } \\
40 \text { CFR } 143^{\mathrm{b}}\end{array}$} & \multicolumn{2}{|c|}{$\begin{array}{c}\text { Washington State Model Toxics Cleanup } \\
\text { Act WAC 173-340 }\end{array}$} \\
\hline & MCLs & MCLGs & Method B & Method C \\
\hline & & & $\begin{array}{c}\text { Ground Water } \\
173-340-720^{\circ}\end{array}$ & $\begin{array}{c}\text { Ground Water } \\
173-340-720^{c}\end{array}$ \\
\hline & $(\mathrm{mg} / \mathrm{L})$ & $(m g / L)$ & $(\mathrm{mg} / \mathrm{l})$ & $(m g / L)$ \\
\hline Aluminum & $0.05^{\mathrm{b}}$ & - & 16 & 35 \\
\hline Ammonia & - & - & - & - \\
\hline Antimony & 0.006 & 0.006 & .064 & 0.014 \\
\hline Arsenic & 0.05 & $\cdot$ & $5.17 \mathrm{E}-0.5\left(0.005^{\mathrm{e}}\right)$ & 5.17E-04 $\left(0.005^{\mathrm{e}}\right)$ \\
\hline Barium & 2 & 2 & 1.12 & 2.45 \\
\hline Beryllium & 0.004 & 0.004 & $2.5 \mathrm{E}-05^{\mathrm{d}}$ & $2 \mathrm{E}-04$ \\
\hline Cadmium & 0.005 & 0.005 & 0.016 & 0.035 \\
\hline Chromium (VI) & $0.1^{d}$ & $0.1^{d}$ & 0.08 & 0.018 \\
\hline Chloride & $250^{b}$ & - & - & - \\
\hline Cobalt & - & - & - & - \\
\hline Copper & $1.38(1 b)$ & - & $0.64^{f}$ & $1.4^{f}$ \\
\hline Fluoride & $4\left(2^{b}\right)$ & 4 & 0.96 & $2.1^{\mathrm{d}}$ \\
\hline Lead & 0.0158 & 0 & - & - \\
\hline Magnesium & - & - & - & - \\
\hline Manganese & $0.05^{b}$ & - & 0.08 & 0.175 \\
\hline Mercury & 0.002 & 0.002 & 0.0048 & 0.01 \\
\hline Nickel & 0.1 & 0.1 & .32 & 0.7 \\
\hline Nitrate (NO3 as $\mathrm{N}$ ) & 10 & 10 & 26 & 56 \\
\hline Nitrate (NO3 as NO3) & 44 & 44 & - & - \\
\hline Nitrite (NO2 as N) & 1 & 1 & - & - \\
\hline Nitrite (NO2 as NO2) & 3.3 & 3.3 & 1.6 & 3.5 \\
\hline Selenium & 0.05 & 0.05 & 0.08 & 0.175 \\
\hline Silver & $0.1^{\mathrm{b}}$ & - & 0.08 & 0.175 \\
\hline Sulfate & $250^{b}$ & - & $\cdot$ & - \\
\hline Thallium (oxide) & $0.002^{h}$ & $0.0005 g$ & 0.001 & 0.002 \\
\hline Vanadium & - & - & 0.11 & 0.25 \\
\hline
\end{tabular}


Table 7-4. Preliminary Chemical-Specific ARARs for the ERDF Groundwater Contaminants (Non-Radioactive Contaminants)

(Sheet 2 of 2)

\begin{tabular}{|l|c|c|c|c|}
\hline \multirow{3}{*}{ Contaminant } & \multicolumn{2}{|c|}{$\begin{array}{c}\text { Drinking Water Standards } \\
40 \text { CFR } 141^{2} \text { and } \\
40 \text { CFR } 143^{\circ}\end{array}$} & \multicolumn{2}{c|}{$\begin{array}{r}\text { Washington State Model Toxics Cleanup } \\
\text { Act WAC 173-340 }\end{array}$} \\
\cline { 2 - 5 } & MCLs & MCLGs & Method B & Method C \\
\cline { 2 - 5 } & & & $\begin{array}{c}\text { Ground Water } \\
173-340-720^{c}\end{array}$ & $\begin{array}{c}\text { Ground Water } \\
173-340-720^{c}\end{array}$ \\
\cline { 2 - 5 } & (mg/L) & (mg/L) & (mg/L) & (mg/L) \\
\hline Zinc & $5^{\text {b }}$ & - & 4.8 & 10.5 \\
\hline
\end{tabular}

'State MCLs and MCLGs are based on federal standards, as amended.

'Secondary Drinking Water Standards are established under 40 CFR 143. Under CERCLA, Secondary MCLs are not ARAR because they are not federally enforceable standards. However, under Washington State regulation, WAC-173340-720(2)(a)(ii) identifies secondary MCLs as applicable groundwater cleanup levels.

'Reference doses and carcinogenic slope factors taken from IRIS (EPA 1993a), or HEAST (EPA 1993b).

'Valance not specified under 40 CFR 141.

'Cleanup level based on concentration for the State of Washington as noted in Table 1, footnote b, WAC 173-340-720.

HEAST notes that data for copper is insufficient to develop an RfD, however, the Superfund Technical Support Center indicates an interim RfD between 4E-02 and 7E-02 (EPA 1991a).

'Action levels established by the EPA for water systems serving the public. Water systems exceeding these levels are required to implement additional treatment.

"Reported MCL and MCLG are for thallium. 
DOE/RL-93-99, Rev. 0

Table 7-5. Groundwater Standards for Contaminants.

\begin{tabular}{|c|c|c|}
\hline Contaminant & $\begin{array}{l}\text { Risk-Based Groundwater } \\
\text { Standard }\end{array}$ & $\begin{array}{l}\text { Minimum ARAR-Based } \\
\text { Groundwater Standard }\end{array}$ \\
\hline RADIONUCLIDES & $(\mathrm{pCi} / \mathrm{L})$ & $(\mathrm{pCi} / \mathrm{L})$ \\
\hline $\begin{array}{l}\text { Carbon-14 } \\
\text { Chromium-51 } \\
\text { Hydrogen-3 } \\
\text { Plutonium-238 } \\
\text { Plutonium-239 } \\
\text { Potassium-40 } \\
\text { Technicium-99 } \\
\text { Thorium-228 + D } \\
\text { Thorium-232 } \\
\text { Uranium-234 } \\
\text { Uranium-235 } \\
\text { Uranium-238 } \\
\text { Total Uranium }\end{array}$ & $\begin{array}{c}510 \\
11,000 \\
8,500 \\
2.1 \\
2.0 \\
4.2 \\
350 \\
8.4 \\
38 \\
29 \\
29 \\
16 \\
-\end{array}$ & $\begin{array}{c}2,000 \\
6,000 \\
20,000 \\
7.1 \\
20 \\
4,000 \\
900 \\
153 \\
30 \\
300 \\
300 \\
300 \\
20 \mu \mathrm{g} / \mathrm{L}\end{array}$ \\
\hline INORGANICS & $(\mathrm{mg} / \mathrm{L})$ & $(\mathrm{mg} / \mathrm{L})$ \\
\hline $\begin{array}{l}\text { Aluminum } \\
\text { Ammonia } \\
\text { Antimony } \\
\text { Arsenic } \\
\text { Barium } \\
\text { Beryllium } \\
\text { Cadmium } \\
\text { Chromium (VI) } \\
\text { Chloride } \\
\text { Cobalt } \\
\text { Copper } \\
\text { Fluoride } \\
\text { Lead } \\
\text { Magnesium } \\
\text { Manganese } \\
\text { Mercury } \\
\text { Nickel } \\
\text { Nitrite (NO }{ }_{2} \text { and } \mathrm{N} \text { ) } \\
\text { Selenium } \\
\text { Silver } \\
\text { Sulfate } \\
\text { Thallium (oxide) } \\
\text { Vanadium } \\
\text { Zinc }\end{array}$ & $\begin{array}{c}16 \\
0.27 \\
6.4 \mathrm{E}-03 \\
4.1 \mathrm{E}-04 \\
1.1 \\
1.9 \mathrm{E}-03 \\
8.0 \mathrm{E}-03 \\
8.0 \mathrm{E}-02 \\
2.5 \mathrm{E}+04 \\
0.96 \\
0.64 \\
0.96 \\
\text { no tox } \\
\text { no tox } \\
8.0 \mathrm{E}-02 \\
4.8 \mathrm{E}-03 \\
0.32 \\
1.6 \\
8.0 \mathrm{E}-02 \\
8.0 \mathrm{E}-02 \\
\text { no tox } \\
1.1 \mathrm{E}-03 \\
0.11 \\
4.8\end{array}$ & $\begin{array}{c}0.05 \\
- \\
6 \mathrm{E}-03 \\
5.2 \mathrm{E}-05 \\
1.12 \\
2.5 \mathrm{E}-05 \\
5.0 \mathrm{E}-03 \\
0.018 \\
250 \\
- \\
0.64 \\
0.96 \\
0 \\
- \\
0.05 \\
2.0 \mathrm{E}-03 \\
0.1 \\
1 \\
0.05 \\
0.08 \\
250 \\
5.0 \mathrm{E}-04 \\
0.11 \\
4.8\end{array}$ \\
\hline \multicolumn{3}{|c|}{$\begin{array}{l}\text { aBased on an ICR of } 10^{-5} \text { and a HQ of } 1 \text { assuming the groundwater exposure scenarios } \\
\text { described in Chapter } 6 \text {. } \\
\text { b }{ }_{\text {Based on ARARs shown in Table } 7-3 \text { and Table } 7-4 \text {. }}\end{array}$} \\
\hline
\end{tabular}




\subsection{IDENTIFICATION AND SCREENING OF TECHNOLOGIES}

This chapter identifies and screens technologies and process options that are potentially applicable to the ERDF. Chapter 9 assembles the retained technologies into alternatives and provides the detailed evaluation and comparative analysis of the alternatives.

As discussed in Section 1.3, this RI/FS is limited in scope to the technologies and alternatives directly applicable to design of the ERDF facility. To fulfill the CERCLA requirement to address the no-action alternative (i.e., no ERDF), options that do not include the ERDF are also addressed. General response actions other than disposal (such as in-situ containment and treatment) are not addressed in this RI/FS. The 100, 200, and 300 Area source operable unit FSs will address the full range of remedial actions applicable to remediation of the contaminated sites, including institutional controls, in-situ containment, excavation, disposal, ex-situ treatment, and in-situ treatment.

The primary technologies identified in this chapter relate to the configuration of the waste containment unit (also referred to as the trench or trenches). These include geometry of the trench excavation(s), liners, and surface barriers. This FS does not focus on technologies related to institutional controls, surface water management, dust control, and treatment of waste waters, although brief descriptions of such technologies are presented for completeness. These elements are not the focus of this analysis because they do not significantly affect longterm performance of the facility and are considered design details.

The list of identified technologies is screened to develop a refined list of potentially feasible technologies that can be used to develop alternatives for the facility. The remediation technologies are screened using the criteria specified in 40 CFR 300.430 (e)(7) of the NCP for screening of alternatives.

Effectiveness. This criterion focuses on the degree to which a technology reduces toxicity, mobility, or volume through treatment; minimizes residual risks and affords long-term protection; complies with ARARs; minimizes short-term impacts; and how quickly it achieves protection. Technologies providing significantly less effectiveness than other technologies may be eliminated. Technologies that do not provide adequate protection of human health and the environment shall be eliminated from further consideration. It should be noted that treatment technologies are not addressed in this document.

Implementability. This criterion focuses on the technical feasibility and availability of the technology and the administrative feasibility of implementing the technology. Technologies that are not technically or administratively feasible or that would require equipment, specialists, or facilities that are not available within a reasonable period of time may be eliminated from further consideration.

Cost. The costs of construction and any long-term costs to operate and maintain the technology shall be considered. " ists that are grossly excessive compared to the overall effectiveness of the techno, gy may be considered as one of several factors used to eliminate technclogies. Technologies providing effectiveness and implementability similar to that of another technology by employing a similar method of treatment or engineering control, but at greater cost, may be eliminated. 
The technologies and process options were screened against the criteria in the priority order listed above using the "fatal flaw" approach. This approach was adopted for efficiency, and is based on ranking the criteria in order of importance, as listed above. The ranking is based on CERCLA Guidance (EPA 1988a). Once a technology is rejected, based on effectiveness, it is not further evaluated based on implementability or cost. Similarly, if a technology is effective, but not implementable, the technology is rejected; evaluation of cost is not undertaken. This approach streamlined the evaluation of technologies while maintaining the screening methodology required under CERCLA.

Evaluation and screening of technologies are performed in a single step. The key criterion in selecting the screening level (technology class, individual technology, or process option) is whether there is a significant difference between the technologies or process options when evaluated against the screening criteria (effectiveness, implementability, and cost). Technologies and process options that are judged to have significant differences are screened separately, and the retained technologies or process options will be developed into separate remediation alternatives to allow full evaluation and comparison.

Process options retained for any given technology that are screened together (i.e., not evaluated separately) are considered equally suitable (at the screening level of evaluation). Selection of representative process options is performed during the development of alternatives, so that best engineering judgement may be used to select and combine appropriate technologies and process options into cohesive, integrated remediation alternatives.

The potentially applicable technologies considered for the ERDF are presented in Table 8-1. The technology screening is also summarized in this table. Brief descriptions of the listed technologies and discussions of the screening evaluations are provided below. Technologies retained through this screening process are then incorporated into remediation alternatives in Chapter 9.

\subsection{DISPOSAL}

General disposal options considered in this FS include on-Hanford Site near-surface disposal, off-Hanford Site near-surface disposal, or a geologic repository.

\subsubsection{Centralized Engineered Waste Management Facility on the Hanford Site (ERDF)}

A centralized engineered waste management facility (ERDF) has been proposed to serve as the receiving facility for the majority of wastes excavated during remediation of waste management sites in the 100,200, and 300 Areas. This facility would be located on the 200 Area plateau. The primary features of the ERDF include the trench(es), rail and tractor/trailer container handling capability, decontamination and wastewater treatment facilities, railroads, inventory control systems, and operations offices. Conventional, well-developed technologies and methods will be used to construct and operate the facility.

The risks associated with the primary exposure paths (direct exposure, surface water and airborne transport, and transport to groundwater) are minimized for an ERDF located on the 200 Area plateau. Such a location is characterized by an arid climate with low precipitation and low natural infiltration, a thick vadose zone, absence of nearby surface water bodies, and relative isolation from the public. The Hanford Site also provides excellent 
institutional controls to limit public access to the vicinity of the 200 Area plateau. In contrast to offsite disposal facilities, transportation of waste from Hanford Site operable units is not a major concern in terms of public risk and public perception. Hauling distances would be short and contaminated materials would not leave the Hanford Site. Standard Hanford Site safety and environmental controls, including packaging standards and personnel protection, would be used. Additional controls would be used if appropriate.

While waste management facilities could be constructed at individual operable units within the Hanford Site, the ERDF offers economies of scale in construction, monitoring, and administration. A centralized waste management facility provides centralized inventory of wastes disposed and uniform waste screening, handling, and disposal procedures. In addition, removing all waste from the 100 and 300 Areas allows these areas to be released for uses other than waste management. Placemient of Hanford Site derived wastes in an ERDF on the 200 Area plateau is retained for further consideration.

\subsubsection{Engineered Waste Management Facilities at Individual Source Operable Unit Sites}

Landfills similar in design to the ERDF but with smaller capacities could be constructed at source operable unit sites in the 100, 200, and 300 Areas. Waste management facilities located in operable units along the Columbia River would overlie much thinner vadose zones and would be much closer to surface water than a 200 Area ERDF; therefore they would be less protective of human health and the environment. In addition, construction, administration, and monitoring of multiple, smaller waste management facilities is expected to be more difficult to implement and more costly than a single, centralized Hanford Site waste management facility. Furthermore, long-term management of wastes along the Columbia River would conflict with recommendations by the Hanford Future Site Uses Working group (Drummond 1992). Construction of multiple waste management facilities at the source operable units is considered less effective, more difficult to implement, and more expensive than a centralized waste management facility on the 200 Area plateau and is not retained for further evaluation.

\subsubsection{Offsite Waste Management Facility}

Use of an offsite waste management facility for permanent disposal is similar in concept to the other waste management facility options discussed above. The offsite facility would probably be a general low-level waste facility serving a state or regional area, and would most likely offer similar long-term effectiveness as a centralized Hanford Site waste management facility. The disadvantages of using an offsite waste management facility are:

1) There are few existing or planned facilities prepared to accept significant quantities of mixed waste. The nearest existing facility is Envirocare of Utah, Inc., located west of Salt Lake City, Utah, approximately $1,100 \mathrm{~km}(700 \mathrm{mi})$ from the Hanford Site.

2) The potential for accidental contaminant release over long transportation distances outside of Hanford Site controlled areas presents significantly greater short-term public risk than an on-site waste management facility.

3) Public opposition to offsite disposal of Hanford waste is likely to be high, resulting in significant administrative difficulties. 
4) Transportation distances and costs associated with an off-site facility would be significantly greater than for an on-site facility.

Therefore, while an effective off-site waste management facility may be constructed, this technology is not retained based on poor short-term effectiveness, low implementability, and high cost.

\subsubsection{Geologic Repository}

A geologic repository is an underground disposal facility constructed in a stable geologic setting with low rates of groundwater movement. The design goal of a geologic repository is to prevent exposure of biological receptors to radioactive waste or radioactive constituents for at least 10,000 years. A properly located and designed geologic repository would be a very effective disposal technology for Hanford Site remediation wastes.

A geologic repository for high-level nuclear waste (spent nuclear fuel and byproduct wastes) is proposed for construction at Yucca Mountain, Nevada. Another repository for TRU Waste, the Waste Isolation Pilot Plant (WIPP), is presently under construction near Carlsbad, New Mexico and may be operational within a few years. These facilities will not be large enough to accommodate the estimated quantity of Hanford waste. In addition, transportation of radioactive materials presents significant administrative difficulties and has the potential for release of contaminants during transport (see Section 8.1.3 above).

Development of another geologic repository, either on or off the Hanford Site, would be a very expensive undertaking. Several billion dollars have already been spent at Yucca Mountain and WIPP for facilities that are designed for waste volumes several orders of magnitude smaller than expected at the Hanford Site. A new geologic repository of sufficient capacity would cost billions of dollars.

Use of existing or planned geologic repositories is not retained because they do not have the capacity to accept the volume of waste expected from remediation of Hanford Site operable units. A geologic repository constructed on the Hanford Site is not retained based on the very high estimated cost of such a facility relative to other effective and implementable onsite alternatives.

\subsection{TRENCH CONFIGURATION}

The implications associated with different trench configurations for the waste management facility are evaluated as individual technologies. A comparison of three configurations that address different depths and widths is presented in the following subsections. The comparisons are based on information provided in U.S. Army Corp of Engineers (1993c). The following assumptions are common to all the configurations:

- The quantity of excavated soils is assumed to be 23.3 million $\mathrm{m}^{3}(30.5$ million $\left.\mathrm{yd}^{3}\right)$, comprised of 21.8 million $\mathrm{m}^{3}\left(28.5\right.$ million $\left.\mathrm{yd}^{3}\right)$ of waste and an additional 1.5 million $\mathrm{m}^{3}\left(2\right.$ million $\left.\mathrm{yd}^{3}\right)$ for interim soil cover. 
- Unshored excavations may be used providing side slopes are flat enough to be stable. Current conceptual designs include $3 \mathrm{H}: 1 \mathrm{~V}$ (horizontal to vertical) side slopes, which are not expected to require shoring.

- $\quad$ Stockpiled soils are expected to be used for liner construction, clean soil cover during filling operations, cover construction, and as clean backfill for source operable units from which contaminated materials originate.

- $\quad$ Because the soils being excavated are believed to be clean, no excavation health and safety precautions beyond normal construction practices are expected to be required. As part of normal construction practice at the Hanford Site, a radiation survey will be conducted before excavation begins.

Three different cross-section configurations, shown in Figure 8-1, are considered in this analysis: a shallow multiple-trench design, a shallow area-fill design, and a deep area-fill design. There are no implementability problems related to construction or operations identified for any of the trench configurations discussed below. Therefore, the differences between the designs are confined to effectiveness and cost.

\subsubsection{Shallow Trench Design}

The shallow trench design, shown in Figure 8-1, is a trapezoidal trench with a depth of

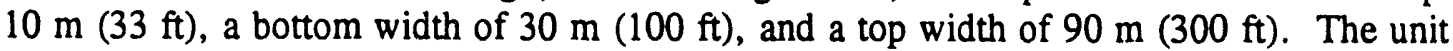
capacity of this design is $650 \mathrm{~m}^{3}$ per linear meter $\left(260 \mathrm{yd}^{3}\right.$ per linear foot) of trench, corresponding to a total trench length of $35,000 \mathrm{~m}(117,000 \mathrm{ft})$. The shallow trench configuration is most similar to existing practice at the Hanford Site low-level burial grounds.

The advantage of the shallow excavation versus the deep excavation is that the waste is $10 \mathrm{~m}$ (33 ft) further from groundwater, resulting in longer migration times to the saturated groundwater system. Assuming that the average thickness of the vadose zone is $80 \mathrm{~m}(260 \mathrm{ft})$, the travel times will be 17 percent longer for the shallow excavation design than for the deep excavation design.

A significant disadvantage of the shallow design compared with the deep excavation design is the greater land usage. As described in U.S. Army Corp of Engineers (1993d), the total area required to accommodate the shallow trench design is $6.5 \mathrm{~km}^{2}(1,600$ acres), compared with $2.6 \mathrm{~km}^{2}$ (645 acres) for the shallow area-fill design and $1.5 \mathrm{~km}^{2}$ (375 acres) for the deep area-fill design. Greater land usage will result in greater impacts to surrounding ecological habitat and cultural resources. Furthermore, given that total infiltration through the trench is proportional to the area of the facility, the shallow trench design results in significantly more leachate generation than the area-fill designs.

The high surface area of the shallow excavation also results in higher liner and surface barrier cost. As described in U.S. Army Corp of Engineers (1993c), the total costs for the liner and cover using the shallow trench design are approximately two to three times greater than the cost using the area-fill designs. 
The shallow trench design is eliminated from further evaluation because it results in greater impacts on ecological and cultural resources and greater leachate generation than the area fill designs, as well as substantially higher costs.

\subsubsection{Shallow Area-Fill Design}

The shallow area-fill design, shown in Figure 8-1, is a trapezoidal trench with a depth of $10 \mathrm{~m}$ (33 ft), a bottom width of $300 \mathrm{~m}(1,000 \mathrm{ft})$, and a top width of $370 \mathrm{~m}(1,200 \mathrm{ft})$. The unit capacity of this design is $4,000 \mathrm{~m}^{3}$ per linear meter $\left(1,600 \mathrm{yd}^{3}\right.$ per linear foot) of trench, corresponding to a total trench length of $5,700 \mathrm{~m}(19,000 \mathrm{ft})$.

This design retains the advantage of the shallow excavation regarding distance above groundwater. Assuming that the average thickness of the vadose zone is $80 \mathrm{~m}(260 \mathrm{ft})$, the travel times will be $17 \%$ longer for the shallow excavation design than the deep excavation design.

The shallow area-fill design represents a compromise between the shallow trench design and the deep area-fill design regarding land usage. As described in U.S. Army Corp of Engineers (1993c) the total area required to accommodate the shallow area fill design is $2.6 \mathrm{~km}^{2}$ (645 acres), approximately $60 \%$ less than the shallow trench design, and $70 \%$ more than the deep area-fill design. The compromise in land usage results in a compromise in terms of impacts to surrounding ecological and cultural resources and the amount of leachate generation. This design results in total liner and cover costs that are approximately twice the costs for the deep area-fill design (U.S. Army Corp of Engineers 1993c).

The shallow area-fill design is eliminated from further evaluation because, in comparison to the deep area-fill design, it results in greater impacts on ecological and cultural resources and greater leachate generation. These effectiveness disadvantages are considered more important than the $17 \%$ advantage in travel time. In addition, costs for this design are significantly greater than the deep area-fill design.

\subsubsection{Deep Area-Fill Design}

The deep area-fill design, shown in Figure 8-1, is a trapezoidal trench with a depth of $20 \mathrm{~m}(70 \mathrm{ft})$, a bottom width of $300 \mathrm{~m}(1,000 \mathrm{ft})$, and a top width of $430 \mathrm{~m}(1,400 \mathrm{ft})$. The unit capacity of this design is $8,800 \mathrm{~m}^{3}$ per linear meter $\left(3,500 \mathrm{yd}^{3}\right.$ per linear foot) of trench, corresponding to a total trench length of $2,600 \mathrm{~m}(8,700 \mathrm{ft})$.

The disadvantage of this design compared with the shallow excavation designs is the smaller distance between the waste and groundwater. Assuming that the average thickness of the vadose zone is $80 \mathrm{~m}$ ( $260 \mathrm{ft}$ ), the travel times will be $17 \%$ longer for the shallow excavation design than for the deep excavation design.

The deep area-fill design results in the smallest land usage requirements for all three of the trench configurations considered in this report. As described in U.S. Army Corp of Engineers (1993c) the total area required to accommodate the deep area-fill design is $1.5 \mathrm{~km}^{2}$ ( 375 acres), approximately $40 \%$ less than the shallow area-fill design. This reduced area will result in the least impact to surrounding ecological and cultural resources and the least amount 
of leachate generation. Furthermore, this design results in significantly lower costs for the liner and cover (U.S. Army Corps of Engineers 1993c).

The deep area-fill design is retained for further evaluation because it results in the least impacts on ecological and cultural resources and the least leachate generation. In addition, costs for this design are significantly less than the other designs.

\subsection{DUST CONTROL}

Dust control includes measures to prevent wind dispersion of contaminated material. Because most types of dust control are surficial treatments, they do not prevent humans or animals from directly contacting contaminated soil at the site and are generally ineffective in preventing offsite migration of contaminants in surface water run-off. Several approaches to dust control are available:

- $\quad$ Adding water to increase the moisture content and reduce dust generation during waste placement.

- Materials such as cement, clay, and organic polymers can be sprayed on or mixed with waste before or during placement to bind the soil matrix or on high traffic areas to minimize dust from equipment. This type of dust control is relatively inexpensive and well-suited for dust control in construction zones over the short term. Because binding additives deteriorate relatively quickly they generally must be re-applied on a regular basis (a few weeks to months) and are not well-suited for longterm stabilization of soil surfaces.

- Vegetation can be planted to hold the soil together, reduce wind velocity at the ground surface, and reduce the velocity of surface water run-off. Vegetation is useful for long-term stabilization of soil surfaces and also increases evapotranspiration, which results in reduced infiltration. Because vegetation requires time to grow and is not resistant to equipment traffic, it is not useful for dust control in construction zones. It should be noted that vegetation could potentially bring contaminants to the surface if roots penetrate into the waste.

- The waste can be contained within containers to prevent dust releases. Although some waste (primarily high activity wastes) will likely be placed in the ERDF within single-use containers, the costs associated with containerizing all the waste would be prohibitive with minimal additional benefit.

- Temporary structures (domes) can be used to cover an excavation. This is the most effective and most expensive dust control measure.

- $\quad$ Terminate construction activities at wind speeds approaching $7 \mathrm{~m} / \mathrm{sec}(15$ $\mathrm{mph}$ ).

In itself, dust control is not considered effective for permanent remediation of soil. It is retained for consideration in combination with other technologies that involve handling of 
contaminated soil and dust generation. In addition, vegetation is retained as an important element of surface barriers.

\subsection{SURFACE WATER MANAGEMENT}

Surface water management involves controlling surface water run-on and run-off at the site. The purpose of these controls is to minimize erosion and run-off of contaminated soil, minimize erosion of cover/barrier materials, and prevent ponding that could increase the amount of water infiltrating through contaminated soils. The controls must eventually be incorporated into the unloading area to prevent run-off of contaminants.

The most common surface water control is grading the ground surface to promote adequate drainage without excessive erosion. In addition, diversion measures, such as berms and ditches, are commonly used to prevent clean surface water from entering a site (run-on) and prevent potentially contaminated surface water from leaving a site (run-off). Potentially contaminated surface water can be collected and treated, if required, prior to discharge. Revegetation can also be used to reduce erosion by stabilizing the soil. Vegetation can be difficult to reestablish in arid climates. However, once established, revegetation requires little or no maintenance.

Surface water controls by themselves are not generally effective as a permanent remedy. These controls may be used as short-term measures, such as during excavation, or as long-term measures as a conponent of a surface barrier, for example. Routine maintenance is required for continuing effectiveness. This technology is therefore retained for use in conjunction with other remediation technologies.

\subsection{SURFACE BARRIERS}

Surface barriers are constructed on the ground surface over contaminated materials and may include a variety of materials such as clay and other types of soils, synthetic membranes, asphalt, and concrete. They may consist of a single layer or be composite barriers with several layers. Barriers provide containment in three primary ways:

- The barrier serves as a physical barrier to prevent humans, other animals, and vegetation from coming in contact with contaminated materials.

- The barrier prevents erosion of contaminated soil by surface water and wind, thereby preventing offsite transport of contaminants via these media.

- The barrier can have low permeability and thus function as a barrier to infiltration of surface water. Less infiltration will reduce the potential for transport of contaminants through the vadose zone to the saturated groundwater zone.

Barriers can be designed to be compatible with many potential future site uses. Institutional controls (deed restrictions) are often used along with barriers to prevent future site 
activities that could violate the integrity of the barrier. For example, foundation pilings would not be allowed to penetrate an impermeable barrier.

All the barriers addressed below are generally readily implemented using standard design and construction techniques. Although the different barriers have different resource requirements that may affect implementability, these factors are not considered significant at the screening stage. Resource requirements will be evaluated in the detailed evaluation of alternatives in Chapter 9. The evaluation provided in this section focuses on differences in effectiveness and cost.

\subsubsection{Soil Barrier}

One or more layers of soil may be used to cover a contaminated site. For discussion purposes, soils barriers can be divided into non-engineered and engineered barriers.

Engineered soil covers include amendments to improve their effectiveness. For example, adding gravel to the top layer may enhance protection against wind erosion, and adding a compacted or fine-grained component to the top layer may reduce surface infiltration.

Non-engineered Soil Cover. The standard practice at the Hanford Site for interim remediation of contaminated waste units and non-RCRA waste management trenches is to use 2.5 to $5 \mathrm{~m}$ ( 8 to $16 \mathrm{ft}$ ) of non-engineered native soil as backfill to provide a thick soil cover. A sufficiently thick soil barrier is effective in providing shielding from radiation, preventing humans, other animals, and shallow-rooting vegetation from contacting contaminants, and preventing offsite migration of contaminated materials via surface water or wind erosion. Generally these barriers do not reduce infiltration compared to native undisturbed surface soils. In fact, the lack of vegetation and topsoil can result in greater infiltration than in undisturbed vegetated areas. Furthermore, unless they are extremely thick, non-engineered barriers do not provide long-term protection against penetration of deep-rooting plants into the waste. Nonengineered soil barriers may be used as interim covers during ERDF operations to control air releases and provide a working surface for equipment. However, due to low effectiveness regarding infiltration, non-engineered soil barriers are not retained for further consideration as the long-term ERDF barrier.

Biological Intrusion Barrier. One type of engineered soil cover utilizes one or more layers of coarse materials at the surface to promote free drainage and minimize establishment of rooting plants. These layers may also be designed to discourage burrowing animals. This type of cover, sometimes referred to as a biointrusion barrier, should only be applied on the Hanford Site in situations where infiltration of precipitation is not a concern. Non-vegetated coarse materials at the surface enhance infiltration, permitting more rapid percolation of water through the waste and into the soil column. Since protection of groundwater is a RAO for the ERDF, biointrusion soil barriers are not considered further in development of alternatives.

Low-Infiltration Soil Barrier. Another type of engineered soil cover includes a surface layer of fine-grained soils and gravel admix to retain moisture and promote growth of vegetation, thereby minimizing infiltration. The surface layer may consist of natural silty soils or bentonite-amended native soils mixed with gravel. The gravel provides protection against erosion. As discussed in Section 4.2.2, fine-grained, vegetated surface soils appear capable of reducing infiltration to zero or close to zero under Hanford Site conditions. Similar to the nonengineered soil barrier, the low-infiltration soil barrier does not provide long-term protection against penetration of deep-rooting plants into the waste (other than protection due to thickness 
of the barrier). If maintenance of the facility included removal of deep-rooting plants before they penetrate the waste, the effectiveness of this type of barrier could be enhanced.

A typical cross-section of a low-infiltration soil barrier is shown in Figure 8-2. The total thickness of this barrier is $4.6 \mathrm{~m}(15 \mathrm{ft})$. Based on the unit costs shown in Table 8-2, this barrier would cost $\$ 21 / \mathrm{m}^{2}\left(\$ 2.0 / \mathrm{ft}^{2}\right)$ to construct. This unit cost is significantly less than composite barriers discussed below. The low-infiltration soil barrier is retained for further consideration.

\subsubsection{Asphalt Barrier}

Asphalt can be used to provide a single-layer, low-permeability barrier (not counting foundation layers, if required). When maintained, asphalt can be an effective barrier against wind erosion, intrusion from burrowing animals and deep rooting plants, and surface water erosion. While effective in the short-term, asphalt requires relatively high maintenance to offset degradation and cracking due to weathering and settlement. Because asphalt barriers are not effective for long-term, reliable protection, they are not retained for further consideration. However, an asphalt layer is used as a component in some of the composite barriers discussed in Section 8.5.6.

\subsubsection{Concrete Barrier}

Concrete can be used to provide a single-layer, low-permeability barrier and has many of the same properties as asphalt. When maintained, concrete can be an effective barrier against wind erosion, intrusion from burrowing animals and deep rooting plants, and surface water erosion. Over the long term, concrete requires relatively high maintenance to offset degradation and cracking due to shrinkage, weathering, and settlement. Because concrete barriers are not effective for long-term, reliable protection, they are not retained for further consideration.

\subsubsection{Low-Permeability Clay Barrier}

A clay barrier is generally constructed with a layer of low-permeability, high plasticity clay covered by clean native soil for vegetative growth and to prevent the clay structure from deteriorating due to freezing. This barrier is similar to the low-infiltration soil barrier described in Section 8.5.1 except the clay barrier is engineered more for low-permeability rather than moisture retention and evapotranspiration. The clay layer may be constructed of native or imported clay, or may use native soils amended with bentonite or other materials. In wet climates, clay barriers are generally considered effective and reliable for reducing infiltration into the waste. However, Hanford's arid climate subjects clay to desiccation, which can result in cracking and increased permeability. For this reason, stand-alone clay barriers are not retained for further evaluation.

\subsubsection{Synthetic Membrane Barrier}

Flexible membrane liners (FMLs) made from synthetic materials such as polyvinylchloride (PVC), high-density polyethylene (HDPE), and neoprene, are commonly 
used in làndfill liners and covers. Their primary purpose is to serve as a barrier to infiltration of precipitation and to promote surface runoff to drainage collection systems. A synthetic membrane can provide lower permeability than clay or other soils so long as the membrane does not puncture, tear or deteriorate. A hydraulic barrier relying primarily on a synthetic membrane would have a bedding layer of soil to provide a foundation and protect the membrane during installation. The membrane is then covered with soil to protect against damage and exposure to ultraviolet components of sunlight, which can weaken or degrade the membrane.

Provided they are constructed with no leaks and are protected by the overlying soil, synthetic membrane barriers can virtually eliminate infiltration. However, synthetic membranes are subject to stresses after installation, such as waste settlement, that can tear the membrane. Aging and deterioration can also be a problem with some types of FMLs. Furthermore, widespread use of synthetic membranes began in the early 1980's; consequently, long-term effectiveness and reliability of synthetic membranes as impermeable barriers is uncertain. Therefore, this barrier type is not retained for further consideration.

\subsubsection{Low'-Permeability Composite Barriers}

Composite (multi-media) barriers are designed using multiple layers of different materials to achieve highly effective and reliable, long-term protection of contaminated sites. The four composite barriers discussed below include the standard RCRA barrier, the Hanford Barrier, the modified Hanford barrier, and the diversion barrier.

Standard RCRA Barrier. The most well-known composite barrier is the standard RCRA Subtitle $C$ barrier, which is designed to meet the minimum technology requirements (MTRs) specified in 40 CFR 264.310 for hazardous waste landfills. EPA has published guidance for complying with MTRs (EPA 1989c). A RCRA barrier design will typically contain the following layers (top to bottom):

- Vegetative layer - vegetated silt and gravel admix, typically 0.6 to $0.9 \mathrm{~m}$ ( 2 to $3 \mathrm{ft}$ ) thick, to protect the barrier against damage (e.g., erosion), and provide moisture retention and evapotranspiration to decrease infiltration.

- Drainage layer - either $0.3 \mathrm{~m}(1 \mathrm{ft})$ of sand or a synthetic geonet to divert infiltration away from the covered area and minimize hydraulic head on the infiltration barrier.

- Low-permeability layer - typically a synthetic membrane over 0.6 to $0.9 \mathrm{~m}$ ( 2 to $3 \mathrm{ft}$ ) of compacted clay with a permeability no greater than $1 \times 10^{-9} \mathrm{~m} / \mathrm{s}\left(2.8 \times 10^{-4} \mathrm{ft} /\right.$ day $)$. Use of both the synthetic membrane and the clay provides redundant low permeability; the synthetic membrane protects the clay against desiccation, and the clay provides a thick barrier capable of some self-healing if settling occurs.

A typical section for a standard RCRA barrier is shown in Figure 8-3. The synthetic materials and clay layer will be subject to the same degradation effects discussed in Section 8.5.4 and 8.5.5, and the ability of these layers to maintain their integrity over hundreds or thousands of years is uncertain. It is likely that over the long-term, the low-infiltration soil 
barrier (Section 8.5.1) would provide an equivalent reduction in long-term infiltration rates.

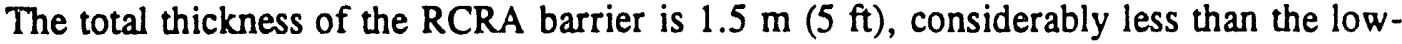
infiltration soil barrier.

The RCRA barrier will be significantly more expensive to construct than the less complex barriers described above. Based on the unit costs shown in Table 8-3, this barrier would cost $\$ 51 / \mathrm{m}^{2}\left(\$ 4.8 / \mathrm{ft}^{2}\right)$ to construct, approximately 250 percent more than the lowinfiltration soil barrier. Since the long-term effectiveness of the standard RCRA barrier is probably similar or less than the low-infiltration soil barrier and the low-infiltration soil barrier is less expensive, this barrier is not retained for further evaluation.

Hanford Barrier. The Hanford Barrier, shown in Figure 8-4, is a composite barrier system specifically designed for the Hanford Site. The Hanford Barrier is comprised of 11 layers in three functional groups:

- A water retention and evapotranspiration zone divided into two layers: an upper layer of silt and gravel, and a lower layer of silt only;

- A biotic intrusion barrier consisting primarily of coarse granular soils and a thick crushed basalt layer; this group also provides a capillary break at the base of the first functional group to increase the water retention capacity;

- A low permeability barrier consisting primarily of asphalt.

This design reflects the current thinking of the Hanford Site Permanent Isolation Surface Barrier Development Program, as discussed in Wing (1993). In order to achieve a design life of at least 1,000 years, natural materials are used to the extent possible. The functions of the Hanford Barrier are based on the following rationale:

- Control of surface water infiltration and percolation is provided primarily by the first functional group. This group retains infiltration near the surface where high evaporation of the arid climate and the high transpiration provided by various species of vegetation can recycle moisture to the atmosphere. The capillary break provided by the second functional group has been demonstrated to double the moisure retention capacity of the first functional group (Wing 1993). Any moisture that does break through the second group layers is finally diverted from the waste by the low permeability barrier provided by the third functional group.

- Biointrusion of plant roots and burrowing animals is prevented primarily by the coarse grained layers of the second functional group. Plant roots do not readily extend into these "hostile" layers due to their very low moisture content, lack of nutrients, and large grain size. Both small and large mammals tend not to burrow more than $1 \mathrm{~m}(3.3 \mathrm{ft})$ into fine grained soils. While some animals are known to burrow deeper than $2 \mathrm{~m}(6.6 \mathrm{ft})$, particularly the Western harvester ant, such animals are expected to be deterred by the highly compacted asphalt layer of the third functional group.

- Wind and water erosion are controlled by a careful mix of gravel into the surface layer of the barrier that is sufficient to limit wind and water erosion but 
that is not excessive to the point of enhancing infiltration or limiting plant growth.

- Human interference, both accidental and intentional, is discouraged by use of offsite markers, surface markers, subsurface markers that will be exposed by even relatively shallow excavation, and by the overall thickness of the barrier design and the coarse basalt layer of the second functional group.

The total thickness of the Hanford Barrier is $4.5 \mathrm{~m}$ (15 ft). This added thickness, combined with the basalt and asphalt layers, provide additional protection against intrusion and erosion compared to the RCRA barrier. Based on the unit costs shown in Table 84 , the Hanford Barrier would cost $\$ 135 / \mathrm{m}^{2}\left(\$ 12.6 / \mathrm{ft}^{2}\right)$ to construct, approximately $260 \%$ more than the RCRA barrier. The Hanford Barrier is retained for further consideration.

Modified Hanford Barrier. The modified Hanford barrier is co:iceptually similar to the Hanford Barrier but has been modified to reduce costs and impacts on borrow sources. The cross-section of the modified Hanford barrier, provided in Figure 8-5, indicates that this barrier includes 10 layers and a total thickness of $4.7 \mathrm{~m}(15.4 \mathrm{ft})$. Modifications from the Hanford Barrier design include:

- The uppermost moisture retention layer has been reduced in thickness from $2 \mathrm{~m}(6.6 \mathrm{ft})$ to $1 \mathrm{~m}(3.3 \mathrm{ft})$.

- The basalt has been eliminated and a general fill layer added to provide at least $4.5 \mathrm{~m}(15 \mathrm{ft})$ thickness. Capillary breaks will be provided at the top and the bottom of the general fill layer.

- Elimination of the geotextile filter.

The protection provided by the modified Hanford barrier is similar to that of the Hanford Barrier. However, the reduction in thickness of the upper silt layers means that the moisture retention capacity is reduced in half. Futhermore, the absence of the crushed basalt layer means that plant roots and burrowing animals can penetrate deeper than permitted by the Hanford Barrier design. Ultimately, the asphalt layer, provides a final deterrant against penetration into the waste.

Based on the unit costs shown in Table 8-5, this barrier would cost $\$ 79 / \mathrm{m}^{2}\left(\$ 7.3 / \mathrm{ft}^{2}\right)$ to construct, approximately $40 \%$ less than the Hanford Barrier. Furthermore, the amount of silt required is significantly reduced and no basalt is required. The modified Hanford Barrier is carried forward for further evaluation.

Diversion Barrier. The diversion barrier is similar to the Hanford Barrier except all the layers above the crushed basalt are eliminated. The total thickness of this barrier is $2 \mathrm{~m}$ $(6.7 \mathrm{ft})$ including two functional groups:

- A biotic intrusion barrier consisting of a crushed basalt layer,

- A low-permeability barrier consisting primarily of asphalt for diversion of infiltration. 
This barrier has been proposed because of concerns that the moisture-retaining silt layers in the Hanford Barrier may actually encourage future generations to plant crops on the barrier. By placing the basalt at the surface, agricultural development is discouraged. The disadvantage of this barrier is that it only provides one line of defense (the asphalt layer) against infiltration, and the amount of water reaching the asphalt will be much greater than for the Hanford Barrier or modified Hanford barrier. Even if the asphalt results in complete diversion of the infiltration, the amount of water that will be diverted to the sides of the barrier will be significantly greater, thereby increasing the amount of infiltration near the outer limits of the waste. For these reasons, this barrier is not retained for further consideration.

\subsection{TRENCH LINERS}

Liners are constructed on excavated surfaces of the waste management trench, and provide the bottom and sides of the containment system for contaminated materials. Liners may be constructed of a variety of materials such as clay, other types of soils, synthetic membranes, asphalt, and concrete. They may consist of a single layer or be composite liners with several layers. Liners provide containment in two primary ways:

- The primary purpose of a liner is to provide a barrier beneath the waste to allow collection of leachate, thereby reduce the migration of contaminants into the vadose and saturated zones beneath the facility. This function is only fulfilled while leachate is removed from the liner. If leachate is allowed to accumulate on the liner it will eventually migrate out of the facility.

- A secondary function of the liner is to serve as a physical barrier to prevent lateral intrusion by burrowing animals, insects, and plant roots.

All the liners addressed below are generally readily implemented using standard design and construction techniques. Therefore, the evaluation provided in this section focuses on differences in effectiveness and cost.

\subsubsection{Asphalt Liner}

Asphalt can be used to provide a single-layer, low-permeability liner (not counting foundation layers, if required). Because of its low strength, however, asphalt may be prone to cracking under the loads from the waste and cover. Once cracked, permeability increases and the effectiveness of the liner is significantly reduced. Asphalt liners are therefore not retained.

\subsubsection{Concrete Liner}

Similar to asphalt, concrete can be used to provide a single-layer low-permeability liner. Although concrete has higher strength than aspha $\uparrow$, it is still prone to cracking due to its brittle nature and tendency to shrink as it cures. Once cracked, concrete becomes more permeable and its effectiveness is significantly reduced. Concrete liners are therefore not retained. 


\subsubsection{Low-Permeability Clay Liner}

Clay liners are generally constructed with a layer of low-permeability, high plasticity clay covered by clean native soil as an operations layer. The clay layer may use native or imported clay, or may use native soils amended with bentonite or other materials that lower its permeability. If not permitted to desiccate, clay liners are self-healing and are plastic in their response to external forces. In wet climates, clay liners are generally considered effective and reliable. However, the arid climate at Hanford increases the likelihood of desiccation, which can crack the clay and significantly raise its permeability. Clay liners are therefore not retained as a stand-alone liner because of their potential for low effectiveness. However, they are included in the composite liner designs in the following sections.

\subsubsection{Composite Liner Designs}

Composite liners are designed using multiple layers of different materials to achieve highly effective and reliable, long-term protection at waste management units. Low-permeability is a key design consideration. Design and installation of composite liner requires specialized expertise, and synthetic liners particularly require specialized installation. However, this expertise and equipment are readily available. Composite liners are generally more expensive than less complex liners. Two types of liners are considered in this RI/FS: a single liner and a standard RCRA Subtitle $\mathrm{C}$ double liner.

Single Composite Liner. The single composite liner system, shown on Figure 8-6, consists of the following layers (from top to bottom):

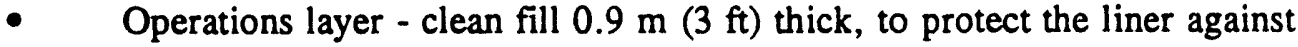
damage from construction and waste placement equipment, and also against freezing in the exposed portions of the liner.

- Drainage layer - a drainage gravel layer overlain by a geotextile separator to prevent silting of the gravel by the operations layer. The gravel layer directs infiltration percolating through the waste to a collection sump where it is pumped out of the trench. A geocomposite (a geonet sandwiched between layers of geotextile) is used instead of gravel on the side slopes of the trench.

- Low-permeability liner - a synthetic high-density polyethylene (HDPE) geomembrane over $0.3 \mathrm{~m}(1 \mathrm{ft})$ of compacted clay with a permeability no greater than $1 \times 10^{-9} \mathrm{~m} / \mathrm{s}\left(2.8 \times 10^{-4} \mathrm{ft} /\right.$ day $)$. Use of two liners provides redundant low permeability; the synthetic membrane protects the clay against desiccation, and the clay provides a thick liner capable of some self-healing with settling and other geological stresses. A geotextile cushion overlies the HDPE geomembrane to minimize damage during placement of the drainage layer.

This liner will be effective in capturing leachate during the operational phase and afterwards, as long as the leachate in the sumps is removed. In contrast with the RCRA double liner, this liner does not provide a secondary leachate collection system. 
Based on the unit costs provided in Table 8-6, the unit costs for the single composite are $\$ 32 / \mathrm{m}^{2}\left(\$ 3.0 / \mathrm{ft}^{2}\right)$ for the bottom and $\$ 29 / \mathrm{m}^{2}\left(\$ 2.7 / \mathrm{ft}^{2}\right)$ for the sideslope. The single composite liner system is retained for further consideration

RCRA Double Liner. The most widely used composite liner type is the RCRA Subtitle C liner, which is designed to meet the MTRs specified in 40 CFR 264.310 for hazardous waste landfills. EPA has published guidance for complying with MTRs (EPA 1989c). An example of a RCRA double liner is provided in Figure 8-7. The RCRA MTR double composite liner system is similar to the single composite, with the following changes and additions:

- The clay adinix layer is increased in thickness from $0.3 \mathrm{~m} \mathrm{(1} \mathrm{ft)} \mathrm{to} 0.9 \mathrm{~m}$ $(3 \mathrm{ft})$

- A second FML and leachate collection system is installed above the lower liner and leachate collection system. The individual components of the upper liner system are the same as those of the lower system.

As with the single composite liner, the gravel drainage layers used on the floor are replaced by drainage geocomposites for both the secondary and primary leachate collection systems on the sideslopes.

The RCRA double liner system provides a redundancy not present in the single liner system, whereby any leachate that leaks through the upper liner is captured in the secondary system. In addition, the RCRA double liner contains a thicker clay layer at the liner base. Based on the unit costs provided in Table 8-7, the unit costs for the double composite liner are $\$ 71 / \mathrm{m}^{2}\left(\$ 6.6 / \mathrm{ft}^{2}\right)$ for the bottom and $\$ 64 / \mathrm{m}^{2}\left(\$ 6.0 / \mathrm{ft}^{2}\right)$ for the sideslope. The RCRA double composite liner system is retained for further consideration

\subsection{INSTITUTIONAL CONTROLS}

Institutional controls, including monitoring, are usually included as a component of any alternative that relies on containment. Institutional controls prevent or minimize direct exposure to contaminated waste, thereby reducing risk. They do not prevent offsite transport of contaminants via air, surface water, or infiltration into groundwater, and are often ineffective in preventing ecological exposures (e.g., to birds). They also require ongoing maintenance, albeit simple and inexpensive, to remain effective. Institutional controls and monitoring are effective within their limitations, are easily implemented, and are low in cost (and thus very cost-effective). Institutional controls are typically included in any remedy where contaminants will remain after completion of remediation. All of the institutional controls discussed below are retained.

Access Restrictions. Access restrictions involve preventing access by unauthorized personnel. Risk is minimized by preventing exposure except in cases of trespass. Fencing the site perimeter is the most common means of restricting site access. Security personnel at entrance gates or patrolling can also be used to restrict site access and prevent or discourage trespass. Security personnel are significantly more expensive than other access restriction measures, and therefore use of security personnel is often limited to the period of active remediation. Long-term use of security would probably be limited to occasional patrols. Security costs could be reduced by use of remote TV cameras for monitoring the facility. 
Warning Markers. Warning markers would be installed to discourage site trespass by warning potential intruders of the hazards of entering the area. Warning markers have been developed for long-term isolation of radioactive waste at the Hanford site. Markers could include large stone pylons with pictorial and verbal warnings that most people could understand. In addition, ceramic disks with similar information would be buried at the site where they would be encountered by anyone digging there.

Land Use Restrictions. Land use restrictions can include zoning and deed restrictions. At present, the Hanford site is not subject to zoning. However, zoning could become relevant under some future uses. Deed restrictions involve specific limitations on future land use that are incorporated in the deed of ownership to the property. Such restrictions would prevent activities that could cause direct exposure or releases of contaminants. Deed restrictions accompany the deed to the property in a manner that is legally binding and must be transferred to all subsequent owners of the property. The restrictions would include a description of the site and reasons for the limits on future activity.

Monitoring. Under CERCLA, site monitoring is a required component of any site remedy (including "no action"). Short-term monitoring is conducted to ensure that potential risks to human health and the environment are controlled while a site remedy is being implemented. Long-term monitoring is conducted to measure the effectiveness of the remedy and thereby ensure that the remedy continues to be protective of human health and the environment. A monitoring plan will be developed for the selected remedial action. The type of monitoring performed will depend on the nature of the remedy. Monitoring would include sampling and analysis of air, surface water run-off, and groundwater as appropriate. Monitoring would also include periodic site inspections to determine maintenance needs.

Air monitoring would be used to detect airborne contamination generated during remedial activities, so that appropriate mitigation measures could be taken. Long-term air monitoring is normally not necessary if no contaminated soil remains exposed on the su face following completion of remediation.

Surface water would be monitored for contamination in waters that contact or might have contacted contaminated materials from the site. As with air monitoring, surface water monitoring is normally a short-term measure conducted during remedial activities. It would not be necessary if no contaminated soil remains exposed on the surface following completion of remediation. There are no surface water bodies near the proposed ERDF location.

Groundwater monitoring would consist of establishing a network of groundwater wells (using existing wells where possible) upgradient and downgradient of contaminated soil, and collecting and analyzing water samples from them on a regular basis. For the ERDF unit, groundwater monitoring would be conducted on a long-term basis to determine if the containment system is functioning adequately.

\subsection{WASTEWATER TREATMENT}

Potential sources of contaminated wastewater at the ERDF include sanitary wastewater, decontamination facility wastewater, and trench leachate. The sanitary wastewater will be treated in a septic system and disposed to an on-site drain field. The decontamination facility wastewater and the trench leachate will be combined and treated in a single treatment facility. Estimated flow rates are as high as 6.3 million L/yr (1.7 million gal/yr) (U.S. Army Corps of 
Engineers 1994). The primary contaminants in the wastewater are likely to be metals and radionuclides, although organic compounds may also occur. Potential treatment technologies are discussed below.

Gravity Separation. Gravity separation is a common, well-established technology for removal of suspended solids from water. It is effective only on larger particle sizes; very small particles must be removed by filtration. Sedimentation or clarification are common gravity separation processes. However, gravity separation would be usable as an ancillary technology. This technology is therefore retained for further consideration.

Filtration. Filtration is a method for removing suspended solids from a liquid using a porous medium. Filtration cannot directly remove chemicals that are dissolved in water. However, filtration is very effective at removing solids created by precipitation technology. Filtration is typically used at the beginning of many treatment systems to remove particulates that may affect later treatment operations. Filtration is retained for further consideration.

Ion Exchange. Ion exchange has been widely applied to the treatment of high flows of wastewaters with dilute concentrations of metals. The contaminant ions are exchanged with ions on the resin (e.g., $\mathrm{Na}^{+}$). When the exchange capacity for a bed is reached, the resin is regenerated with a brine solution. The regenerant exchanges the original resin ion with the contaminant ion, using an acidic, basic, or brine solution (depending on the specific resin). The regenerant stream then contains the contaminants in a more concentrated form. Cation resins can be weak acid, strong acid, and chelating-type resins. Anion resins are weak or strong base types. The resin is chosen to selectively remove the target contaminant. A mixture of resins may be used to remove multiple contaminants.

Ion exchange resins are easily fouled by suspended solids and organic compounds. The ion exchange influent is usually treated to remove high levels of organic compounds (if present) and filtered to remove suspended solids. The regenerant solution is treated to remove the metals for disposal, generally by precipitation. The sludge from precipitation is then dewatered and disposed. Ion exchange is a proven technology and can be applied to a range of contaminants; therefore, it is retained for further consideration.

Reverse Osmosis. Reverse osmosis (RO) can be used to remove the inorganic and some organic compounds from water. RO separates dissolved materials in solution by diffusion through a semi-permeable membrane. Pressure is used to overcome the osmotic pressure caused by the dissolved compounds. Treatment by RO results in a permeate stream with low concentrations of ions and organic compounds, and a low-volume reject stream that contains the concentrated dissolved compounds. RO is effective for a wide range of metals. Removal efficiency is dependent on membrane type, operating pressure, and the specific compounds.

Equipment from a large number of vendors is available commercially. RO has been used to concentrate metals from dilute solutions and also has been used to remove uranium from solution. Membranes are easily fouled by suspended solids and some organic compounds and are expensive to replace. Pre-treatment by filtration is usually required. RO is a proven technology for removal of inorganic contaminants in wastewater, and is retained for further consideration.

Electrodialysis. Electrodialysis uses a direct current electrical field and ion-exchange membranes to separate ionic species from solution. The electrodialysis process consists of an 
electrolytic cell containing an anode and a cathode separated by cation-selective and anionselective membranes. The feed material enters the cell between the two selective membranes. When a direct current charge is applied to the cell, cations are attracted to the cathode and anions to the anode. Ions pass through the appropriate membrane and are concentrated in two brine solutions. The process has limited waste treatment applications because of the sensitivity of the membranes to fouling. Based on its sensitivity to membrane fouling and cost, this technology is not retained.

Evaporation. Evaporation can be used to achieve physical separation of water from a dissolved or suspended solid. Evaporation can be accomplished using boilers to evaporate the water (and possibly condensers to recover the water) or using solar energy to evaporate water from evaporation ponds or tanks. Evaporation is feasible for low flow rates and is retained for further evaluation.

Electrolysis. Electrolysis is a process in which there is electrochemical reduction of metal ions at the cathode. These ions are reduced to elemental metal. Electrolytic recovery is used primarily to remove metal ions from concentrated solutions such as metal plating and etching solutions. Treatment of dilute solutions using conventional electrolysis is not practical because of high power consumption. The process is not feasible for treatment of ERDF wastewaters because of the low concentrations of metals, and the technology is therefore not retained.

Precipitation. Dissolved metals in wastewaters are typically found as metal cations. The addition of specific chemicals to the solution causes the metal cations to react and precipitate out of solution as insoluble compounds. The most common chemical precipitation technology uses lime $\left(\mathrm{Ca}(\mathrm{OH})_{2}\right)$ to produce insoluble hydroxides. Other common precipitation chemicals are caustic soda $(\mathrm{NaOH})$, sulfides, and carbonates. Selection of precipitation chemicals is based on a number of site-specific parameters. Precipitates are then removed from solution by flocculation and sedimentation or filtration. Sludge from precipitation is then dewatered for disposal. Additional treatment (e.g., chemical fixation) may be required or desired.

Precipitation is generally more effective for wastewater with influent metals concentrations in the $\mathrm{mg} / \mathrm{L}$ range rather than the $\mu \mathrm{g} / \mathrm{L}$ range. Low influent concentrations may not provide enough driving force for the precipitation reactions to occur quickly, and overdosing of treatment chemicals would be required. Over-dosing will result in a larger amount of solids for final disposal. Precipitation is better suited to treatment of a concentrated secondary stream (e.g., regenerant from ion exchange). Chemical precipitation is retained for further consideration.

Air Stripping. Air stripping is a process that transfers a contaminant from the liquid phase to the vapor phase. Air stripping is an effective process for removing volatile and slightly soluble organic compounds from water. The effectiveness of air stripping is related to the air/water partitioning of the contaminant determined by Henry's Constant. The stripping takes place in a column where the groundwater flows downward over trays or packing, and air flows upward from the bottom of the column, countercurrent to the water flow. The air stripping process results in an effluent stripped of volatile compounds, and an air stream containing the stripped volatile compounds. Volatile organic compounds are not likely to be significant contaminants in ERDF wastewater and air stripping is therefore not retained for further consideration. 
Carbon Adsorption. The carbon adsorption process utilizes activated carbon to provide a solid surface where organic compounds can be removed by adsorption. Carbon adsorption may used in liquid-phase or vapor-phase media. For treatment, the medium is passed through beds containing activated carbon where the contaminants are adsorbed. When the adsorptive capacity for the contaminants has been exceeded, the activated carbon must be replaced. The adsorptive capacity of activated carbon depends on the target compound and the individual characteristics of the carbon. Performance characteristics of activated carbon vary by source and manufacturing methods. Volatile organic compounds are not likely to be significant contaminants in ERDF wastewater and carbon adsorption is therefore not retained for further consideration.

Enhanced Oxidation. This technology includes processes in which the oxidation state of a substance is increased with subsequent destruction or conversion of undesirable organic chemicals to $\mathrm{CO}_{2}$ and $\mathrm{H}_{2} \mathrm{O}$ or other less harmful materials. This technology is not normally applicable to metals. UV photo-oxidation utilizes strong oxidants, such as hydrogen peroxide or ozone, combined with ultraviolet (UV) radiation to oxidize organic contaminants. Volatile organic compounds are not likely to be significant contaminants in ERDF wastewater and enhanced oxidation is therefore not retained for further consideration.

Chemical Oxidation/Reduction. Chemical oxidation-reduction reactions are used to reduce toxicity or to transform a substance to one more easily handled. For example oxidation-reduction reactions between waste components and added chemicals in which the oxidation state of one reactant is raised while that of another is lowered. An example of chemical reduction is the conversion of hexavalent chromium to trivalent chromium, which is less toxic and more easily removed from solution than hexavalent chromium. Chemical oxidation or reduction generally requires the addition of relatively large quantities of chemical oxidizing or reducing agents and is therefore generally expensive. Other effective and less costly technologies are available for treatment and this technology is therefore not retained. 


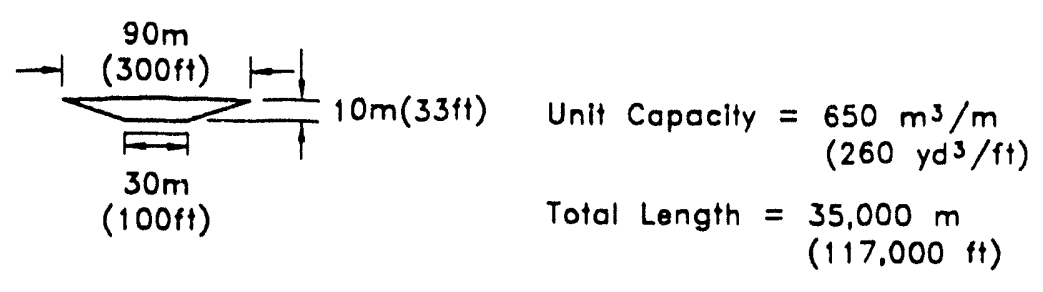

SHALLOW TRENCH DESIGN

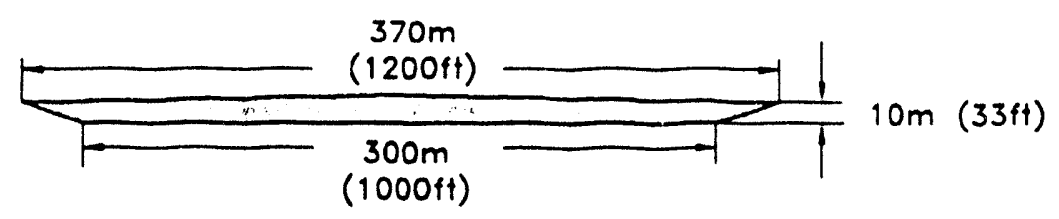

$$
\begin{aligned}
\text { Unit Copacity }= & 4,000 \mathrm{~m}^{3} / \mathrm{m} \\
& \left(1,600 \mathrm{yd}^{3} / \mathrm{ft}\right) \\
\text { Total Length }= & 5,700 \mathrm{~m} \\
& (19,000 \mathrm{ft})
\end{aligned}
$$

\section{SHALLOW AREA FILL DESIGN}

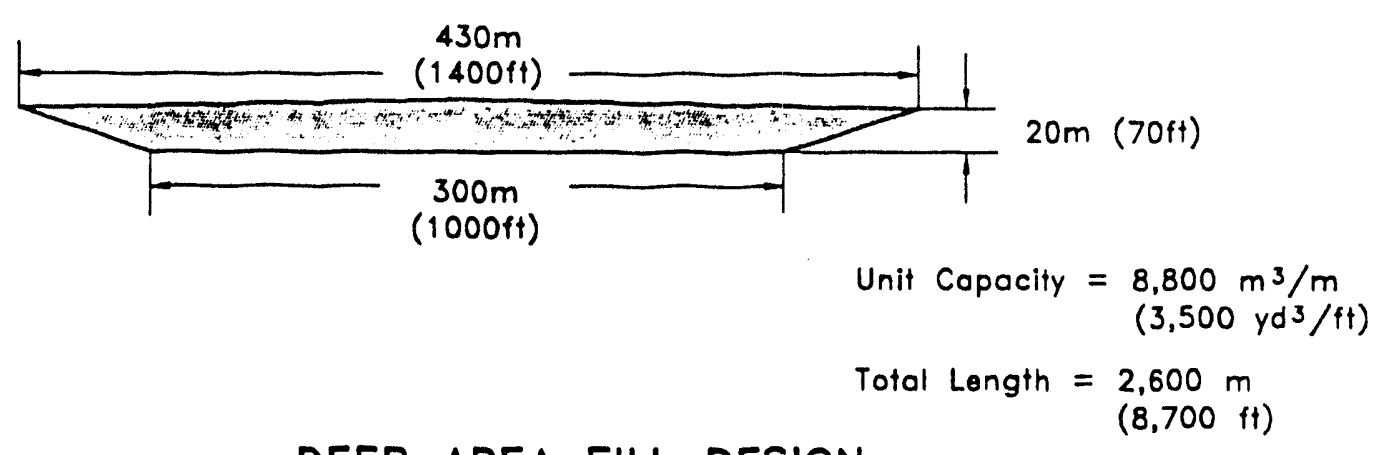

\section{DEEP AREA FILL DESIGN}

NOTES

1. All configurations have $3 \mathrm{H}: 1 \mathrm{~V}$ side slopes.

2. All configurations have $2 \%$ crown on waste surface.

Adopted from: U.S. Army Corps of Engineers (1993c).

Figure 8-1. Cross Sections of Potential ERDF Trench Configurations. 
DOE/RL-93-99, Rev. 0

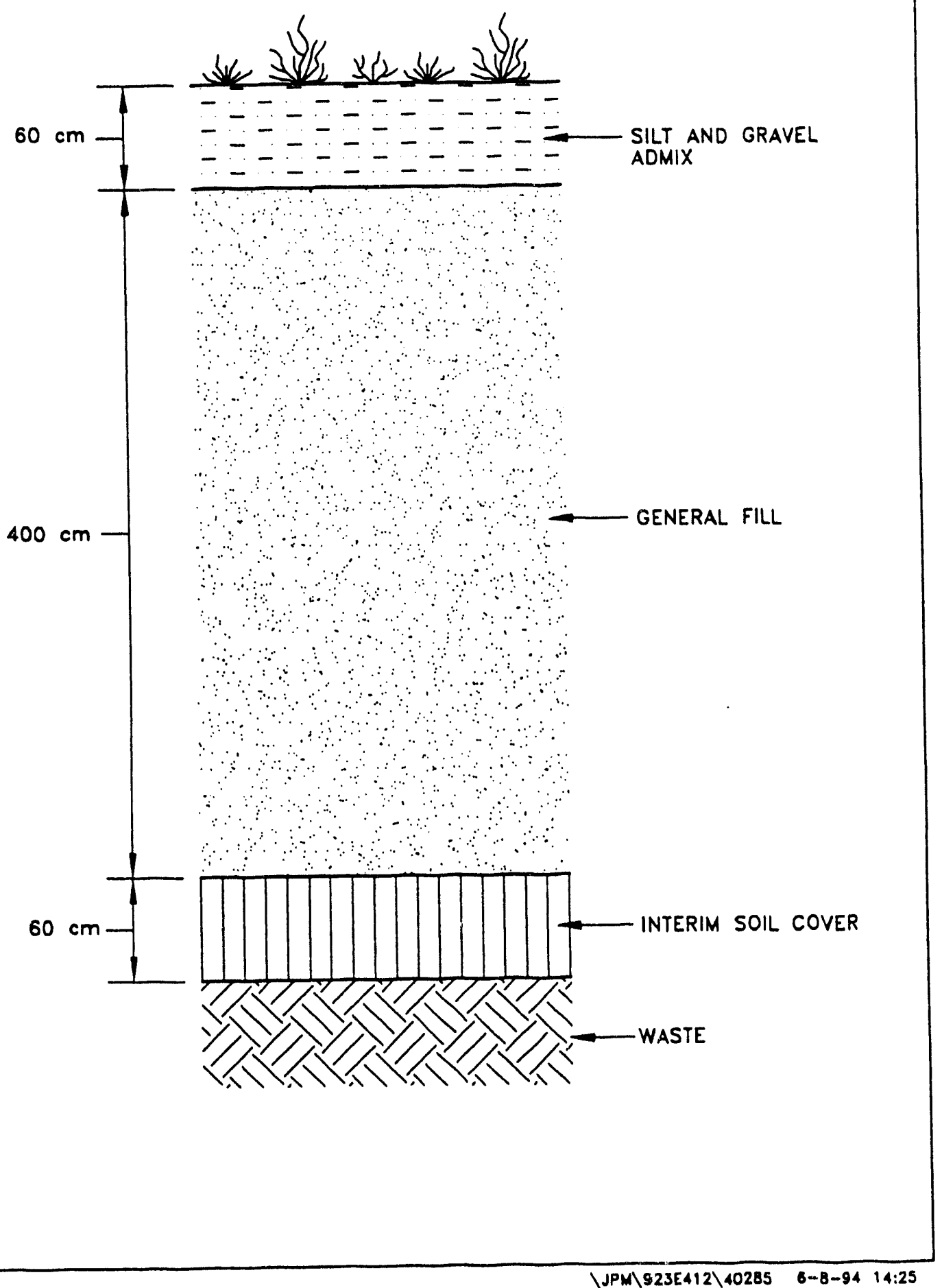

Figure 8-2. Cross Section for a Typical Low Infiltration Soll Cover.

$8 F-2$ 


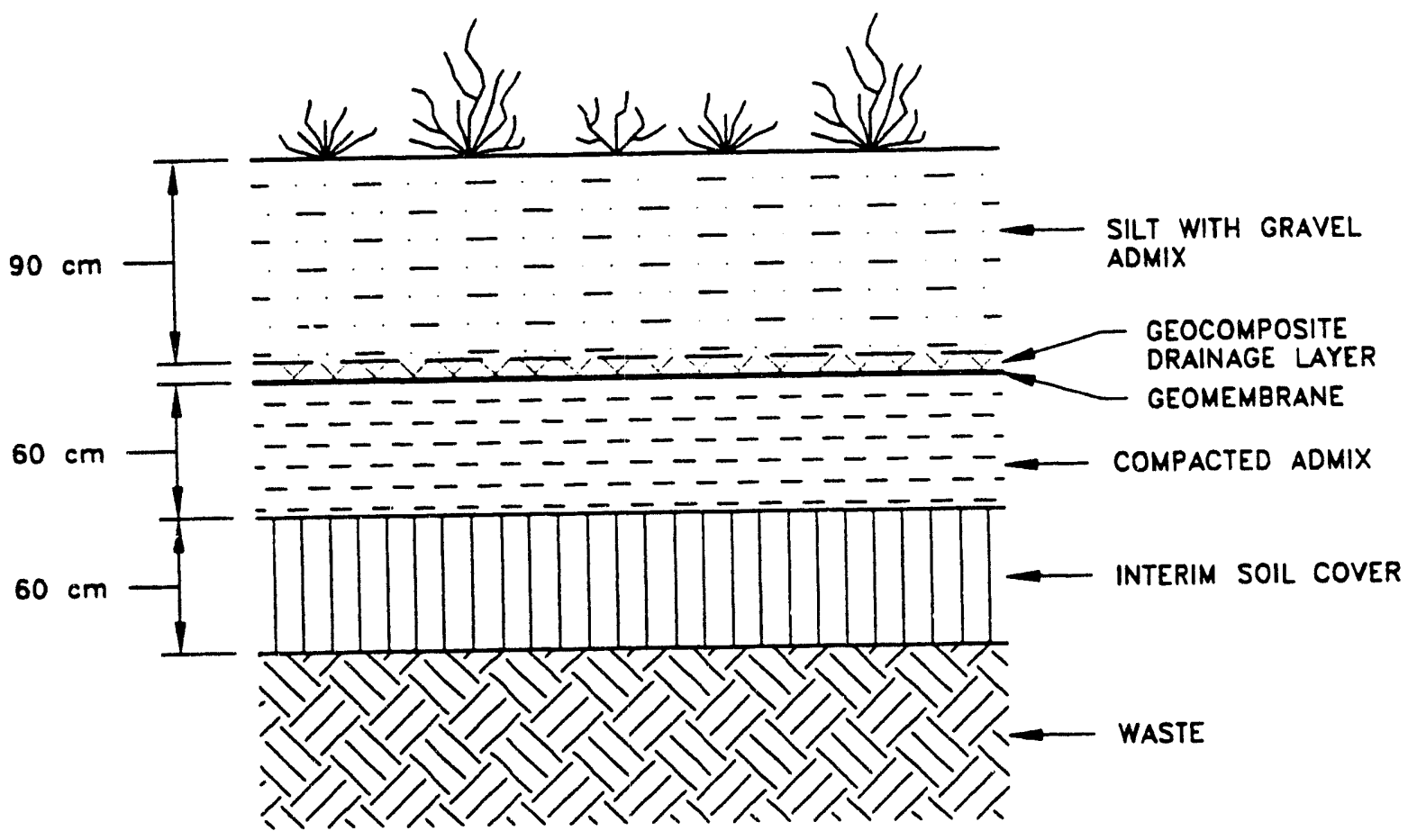

$1 \mathrm{~cm}=0.4$ in

Figure 8-3. Typical Cross Section of a Standard RCRA Subtitle C Barrier. 

DOE/RL-93-99, Rev. 0

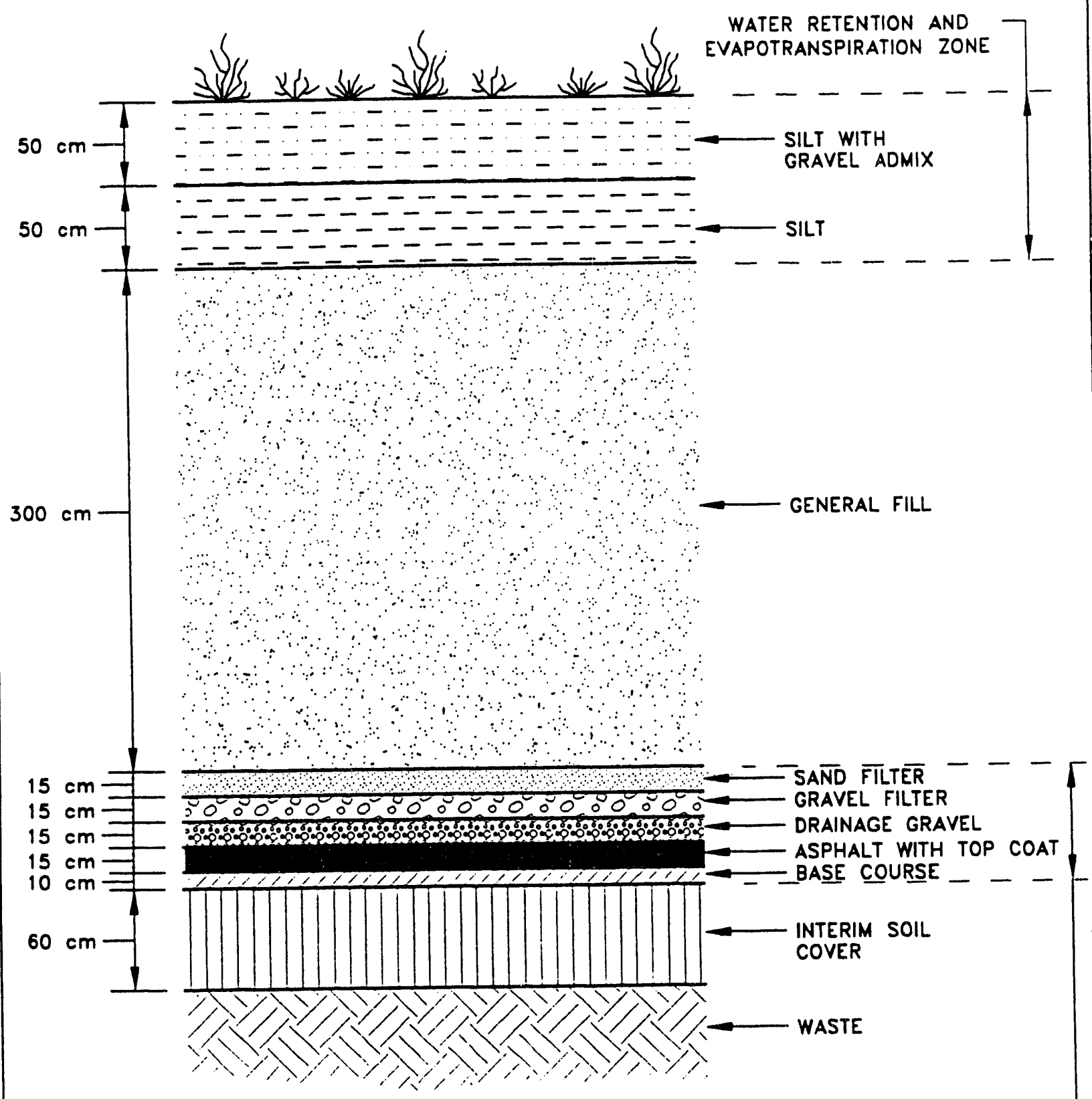

LOW-PERMEABILITY AND BIOTIC INTRUSION BARRIER

$1 \mathrm{~cm}=0.4 \mathrm{in}$

Figure 8-5. Cross Section of the Modified Hanford Barrier. 


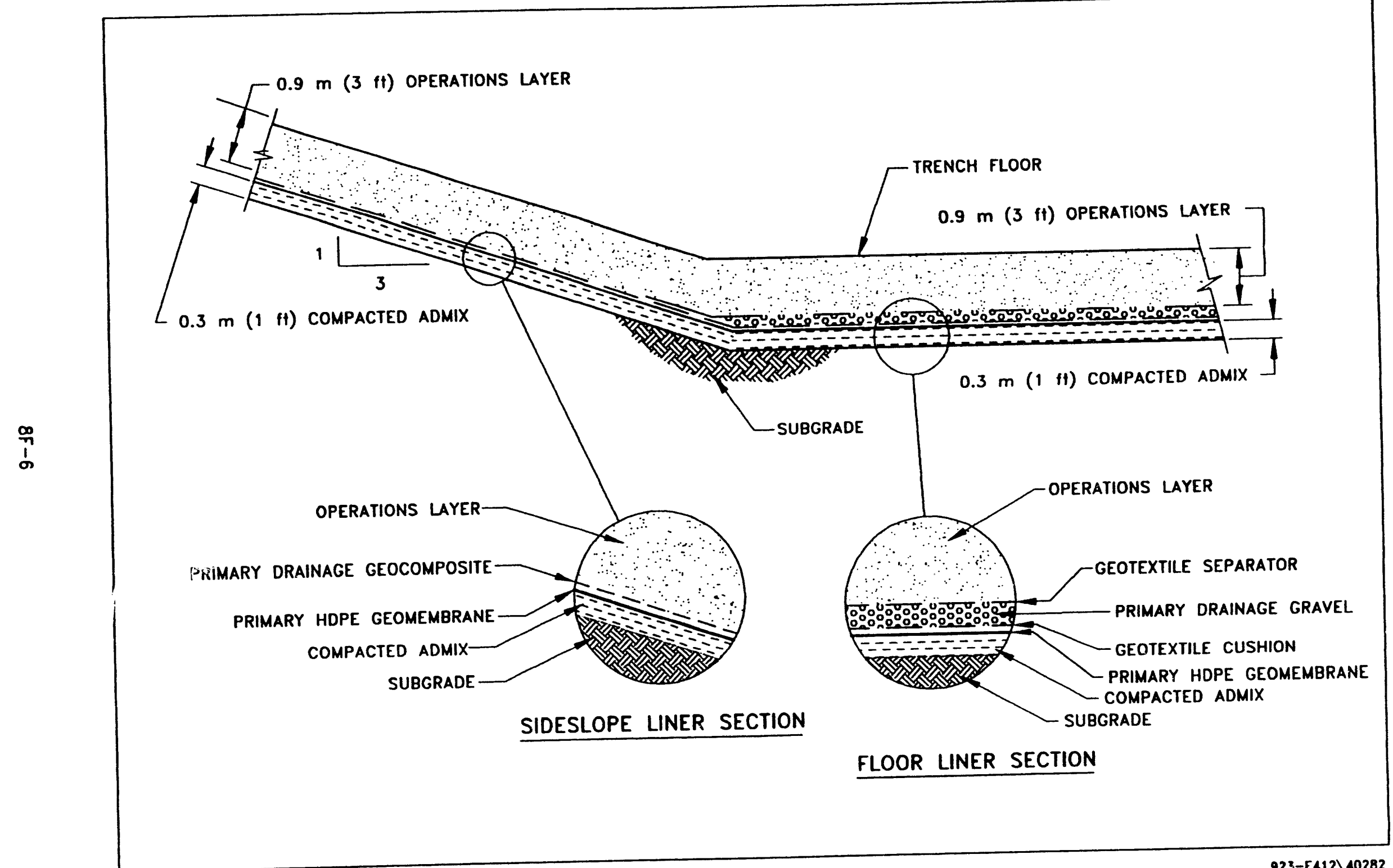

Figure 8-6. Cross Section of a Single Liner System. 


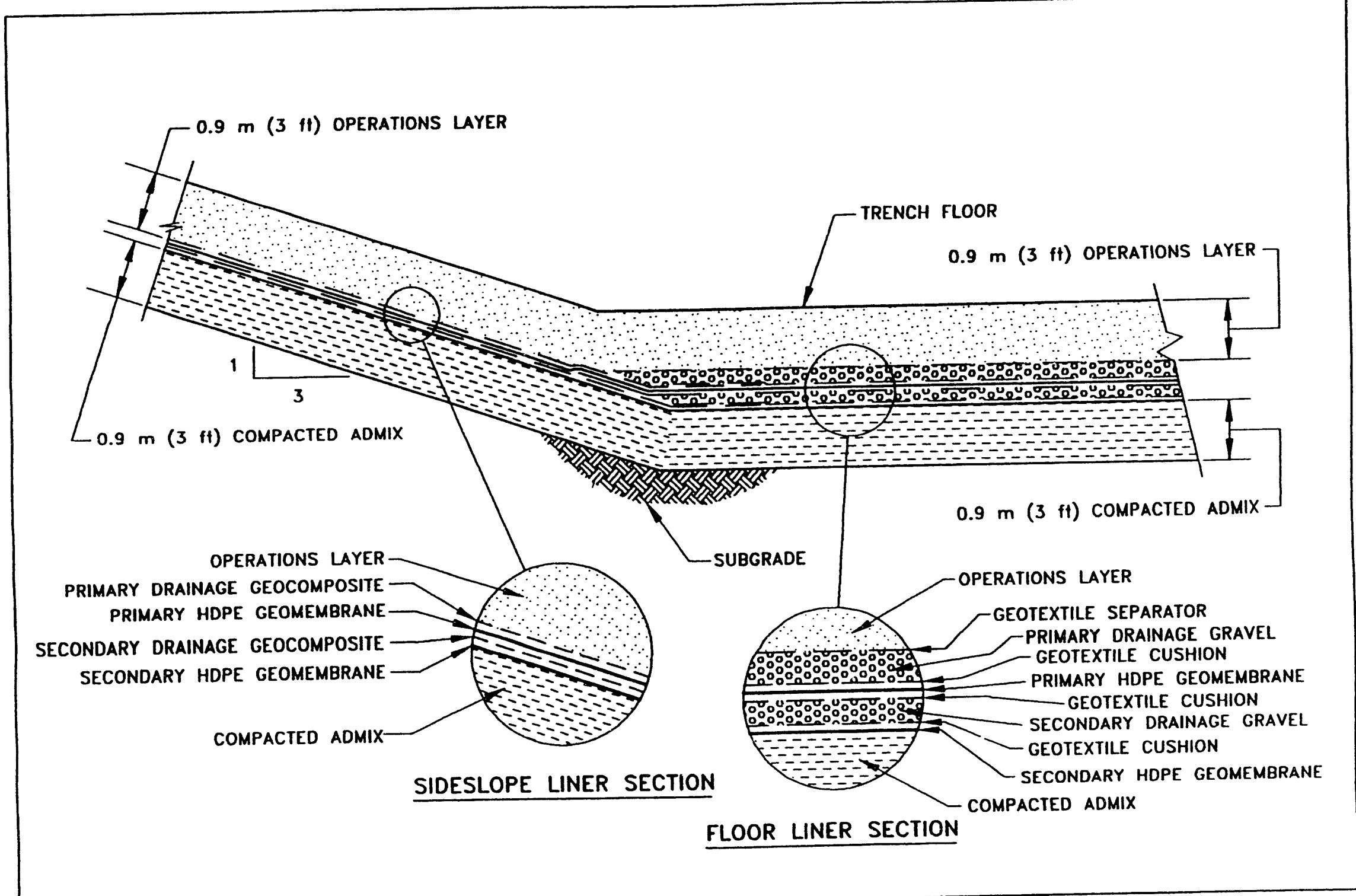

\JS5\923E412\40281 5-19-94 $11: 13$

Figure 8-7. Cross Section of a Typical RCRA Subtitle C Double Liner System. 
Table 8-1. Summary of Screening Results for Groundwater Remediation Technologies and Process Options. (Sheet 1 of 3)

\begin{tabular}{|c|c|c|}
\hline Technology/Process Option & Screening Comments & Retain \\
\hline $\begin{array}{l}\text { Disposal } \\
\text { Centralized Engineered Facility on } \\
\text { the Hanford Site (ERDF) }\end{array}$ & $\begin{array}{l}\text { Effective, relatively easy to implement, low-cost } \\
\text { compared with other options. }\end{array}$ & Yes \\
\hline $\begin{array}{l}\text { Engineered Facilities at Individual } \\
\text { Source Operable Unit Sites }\end{array}$ & $\begin{array}{l}\text { Less effective, more difficult to implement, and } \\
\text { more expensive than a centralized landfill. }\end{array}$ & No \\
\hline Off-site Facility & $\begin{array}{l}\text { Good long-term effectiveness, but poor short-term } \\
\text { effectiveness, low implementability, and high } \\
\text { cost. }\end{array}$ & No \\
\hline Geologic Repository & $\begin{array}{l}\text { Very effective, but low implementability and very } \\
\text { high cost. }\end{array}$ & No \\
\hline $\begin{array}{l}\text { Trench Configuration } \\
\text { Shallow Trench Design }\end{array}$ & $\begin{array}{l}\text { Less effective and more costly compared with the } \\
\text { deep area-fill design. }\end{array}$ & No \\
\hline Shallow Area-Fill Design & $\begin{array}{l}\text { Less effective and more costly compared with the } \\
\text { deep area-fill design. }\end{array}$ & No \\
\hline Deep Area-Fill Design & Effective and relatively cost-effective. & Yes \\
\hline Dust Control & $\begin{array}{l}\text { Not effective in itself, but effective in } \\
\text { combination with other technologies. }\end{array}$ & Yes \\
\hline Surface Water Management & $\begin{array}{l}\text { Not effective in itself, but effective in } \\
\text { combination with other technologies. }\end{array}$ & Yes \\
\hline $\begin{array}{l}\text { Surface Barrier } \\
\text { Soil Barrier } \\
\quad \text { Non-engineered Soil Cover }\end{array}$ & Not effective. & No \\
\hline Biological Intrusion Barrier & Not effective for protection of groundwater. & No \\
\hline Low-Infiltration Soil Barrier & $\begin{array}{l}\text { Effective for protection of groundwater. } \\
\text { Moderately effective against intrusion. }\end{array}$ & Yes \\
\hline
\end{tabular}


Table 8-1. Summary of Screening Results for Groundwater Remediation Technologies and Process Options. (Sheet 2 of 3)

\begin{tabular}{|c|c|c|}
\hline Technology/Process Option & Screening Comments & Retain \\
\hline Asphalt & Not effective for long-term. & No \\
\hline Concrete Barrier & Not effective for long-term. & No \\
\hline Low-Permeability Clay Barrier & Not effective in Hanford's arid climate. & No \\
\hline Synthetic Membrane Barriers & Not certain for long-term. & No \\
\hline $\begin{array}{l}\text { Low-Permeability Composite } \\
\text { Barriers }\end{array}$ & & \\
\hline Standard RCRA Barrier & $\begin{array}{l}\text { Groundwater protection is similar to the low- } \\
\text { permeability soil cover, but the low-permeability } \\
\text { soil cover provides better protection against } \\
\text { intrusion at lower cost. }\end{array}$ & No \\
\hline Modified Hanford Barrier & $\begin{array}{l}\text { More resistant to biointrusion and long-term } \\
\text { degradation than the standard RCRA Subtitle C } \\
\text { design. }\end{array}$ & Yes \\
\hline Hanford Barrier & $\begin{array}{l}\text { About } 90 \text { percent more expensive than the } \\
\text { modified Hanford barrier, but its added thickness } \\
\text { provides additional protection against intrusion. }\end{array}$ & Yes \\
\hline Diversion Barrier & Less redundant than the Hanford Barrier & No \\
\hline Trench Liners & & \\
\hline Asphalt Liner & $\begin{array}{l}\text { Prone to cracking. Once cracked, permeability } \\
\text { increases and the effectiveness of the liner is } \\
\text { significantly reduced. }\end{array}$ & No \\
\hline Concrete Liner & $\begin{array}{l}\text { Prone to cracking. Once cracked, permeability } \\
\text { increases and the effectiveness is significantly } \\
\text { reduced. }\end{array}$ & No \\
\hline Low-Permeability Clay Liner & Not suitable for the arid climate at Hanford. & No \\
\hline $\begin{array}{l}\text { Composite Liner Designs } \\
\text { Single Composite Liner }\end{array}$ & Effective in capturing leachate. & Yes \\
\hline RCRA Double Liner & Most effective in capturing leachate. & Yes \\
\hline Institutional Controls & & \\
\hline Access Restrictions & $\begin{array}{l}\text { Effective and feasible. May be used in } \\
\text { conjunction with other technologies. }\end{array}$ & Yes \\
\hline Warning Markers & $\begin{array}{l}\text { Effective and feasible. May be used in } \\
\text { conjunction with other technologies. }\end{array}$ & Yes \\
\hline
\end{tabular}


Table 8-1. Summary of Screening Results for Groundwater Remediation Technologies and Process Options. (Sheet 3 of 3)

\begin{tabular}{|l|l|c|}
\hline \multicolumn{1}{|c|}{ Technology/Process Option } & \multicolumn{1}{|c|}{ Screening Comments } & Retain \\
\hline Land Use Restrictions & $\begin{array}{l}\text { Effective and feasible. May be used in } \\
\text { conjunction with other technologies. } \\
\text { Gonitoring }\end{array}$ & Yes \\
Groundwater monitoring is a necessary & Yes \\
Gravtewater Treatment & Effective for removal of suspended solids. May & Yes \\
Filtration & be used in conjunction with other technologies. & \\
Ion Exchange & $\begin{array}{l}\text { Effective for removal of suspended solids. May } \\
\text { be used in conjunction with other technologies. }\end{array}$ & Yes \\
Reverse Osmosis & Effective for removal of metals and radionuclides. \\
Electrodialysis & Effective for removal of metals and radionuclides. & Yes \\
Evaporation & $\begin{array}{l}\text { Susceptible to membrane fouling. Eliminated } \\
\text { because of high cost. }\end{array}$ & No \\
Electrolysis & Effective for low flow rates. & Yes \\
Precipitation & Not effective for dilute wastewaters. & No \\
Air Stripping & Effective for treatment of concentrated secondary & Yes \\
Carbon Absorption & stream. & No \\
Enhanced Oxidation & Not effective for metals. & No \\
Chemical oxidation/reduction & Not effective for metals. & No \\
Not effective for metals. & Eliminated because of high cost. \\
\hline
\end{tabular}


DOE/RL-93-99, Rev. 0

Table 8-2. Unit Costs for a Typical Low-Infiltration Soil Barrier.

\begin{tabular}{|l|c|c|c|r|}
\hline & Units & Quantity & $\begin{array}{l}\text { Unit } \\
\text { Cost }\end{array}$ & Total Cost \\
\hline Vegetation & $\mathrm{m}^{2}$ & 1 & $\$ 0.86$ & $\$ 0.86$ \\
\hline Silt and Gravel Admix & $\mathrm{m}^{3}$ & 0.6 & $\$ 15.48$ & $\$ 9.29$ \\
\hline General Fill & $\mathrm{m}^{3}$ & 4.0 & $\$ 2.61$ & $\$ 10.44$ \\
\hline Total Unit Cost $\left(\mathrm{m}^{2}\right)$ & & & $\$ 21.00$ \\
\hline $\begin{array}{l}\text { Notes: } \\
\mathrm{m}^{2}=10.7 \mathrm{ft}^{2} \\
\mathrm{~m}^{3}=35.2 \mathrm{ft}^{3}\end{array}$ & & \\
\hline
\end{tabular}


DOE/RL-93-99, Rev. 0

Table 8-3. Typical Costs for a Standard RCRA Subtitle C Barrier.

\begin{tabular}{|l|c|c|r|r|}
\hline & Units & Quantity & Unit Cost & Total Cost \\
\hline Vegetation & $\mathrm{m}^{2}$ & 1 & $\$ 0.86$ & $\$ 0.86$ \\
\hline $\begin{array}{l}\text { Silt and Gravel } \\
\text { Admix }\end{array}$ & $\mathrm{m}^{3}$ & 0.9 & $\$ 15.49$ & $\$ 13.94$ \\
\hline Geocomposite & $\mathrm{m}^{2}$ & 1 & $\$ 7.49$ & $\$ 7.49$ \\
\hline Geomembrane & $\mathrm{m}^{2}$ & 1 & $\$ 9.10$ & $\$ 9.10$ \\
\hline Compacted Admix & $\mathrm{m}^{3}$ & 0.6 & $\$ 32.59$ & $\$ 19.55$ \\
\hline Total Unit Cost $\left(\mathrm{m}^{2}\right)$ & & & & $\$ 51.00$ \\
\hline $\begin{array}{l}\text { Notes: } \\
\mathrm{m}^{2}=10.7 \mathrm{ft}^{2} \\
\mathrm{~m}^{3}=35.2 \mathrm{ft}^{3}\end{array}$ & & & \\
\hline
\end{tabular}


DOE/RL-93-99, Rev. 0

Table 8-4. Typical Unit Costs for the Hanford Barrier.

\begin{tabular}{|l|c|c|r|r|}
\hline & Units & Quantity & Unit Cost & \multicolumn{1}{|c|}{ Total Cost } \\
\hline Vegetation & $\mathrm{m}^{2}$ & 1 & $\$ 0.86$ & $\$ 0.86$ \\
\hline Silt and Gravel Admix & $\mathrm{m}^{3}$ & 1.0 & $\$ 15.49$ & $\$ 15.49$ \\
\hline Silt & $\mathrm{m}^{3}$ & 1.0 & $\$ 13.02$ & $\$ 13.02$ \\
\hline Geotextile Filter & $\mathrm{m}^{2}$ & 1 & $\$ 3.21$ & $\$ 3.21$ \\
\hline Sand Filter & $\mathrm{m}^{3}$ & 0.15 & $\$ 18.30$ & $\$ 2.75$ \\
\hline Gravel Filter & $\mathrm{m}^{3}$ & 0.3 & $\$ 13.02$ & $\$ 3.91$ \\
\hline Crushed Basalt & $\mathrm{m}^{3}$ & 1.5 & $\$ 27.46$ & $\$ 41.19$ \\
\hline Drainage Rock & $\mathrm{m}^{3}$ & 0.3 & $\$ 13.02$ & $\$ 3.91$ \\
\hline Asphalt Coating & $\mathrm{m}^{2}$ & 1 & $\$ 32.10$ & $\$ 32.10$ \\
\hline Asphaltic Concrete & $\mathrm{m}^{3}$ & 0.15 & $\$ 104.19$ & $\$ 15.63$ \\
\hline Asphalt Base Course & $\mathrm{m}^{3}$ & 0.1 & $\$ 20.77$ & $\$ 2.08$ \\
\hline Total Unit Cost $\left.\mathrm{m}^{2}\right)$ & & & & $\$ 134.00$ \\
\hline $\begin{array}{l}\text { Notes: } \\
\mathrm{m}^{2}=10.7 \mathrm{ft}^{2} \\
\mathrm{~m}^{3}=35.2 \mathrm{ft}^{3}\end{array}$ & & & & \\
\hline
\end{tabular}


DOE/RL-93-99, Rev. 0

Table 8-5. Typical Unit Costs for the Modifled Hanford Barrier.

\begin{tabular}{|l|c|c|c|c|}
\hline & Units & Quantity & $\begin{array}{r}\text { Unit } \\
\text { Cost }\end{array}$ & $\begin{array}{c}\text { Total } \\
\text { Cost }\end{array}$ \\
\hline Vegetation & $\mathrm{m}^{2}$ & 1 & $\$ 0.86$ & $\$ 0.86$ \\
\hline Silt and Gravel Admix & $\mathrm{m}^{3}$ & 0.5 & $\$ 15.49$ & $\$ 7.75$ \\
\hline Silt & $\mathrm{m}^{3}$ & 0.5 & $\$ 13.02$ & $\$ 6.51$ \\
\hline General Fill & $\mathrm{m}^{3}$ & 3.0 & $\$ 2.60$ & $\$ 7.80$ \\
\hline Sand Filter & $\mathrm{m}^{3}$ & 0.15 & $\$ 18.30$ & $\$ 2.75$ \\
\hline Gravel Filter & $\mathrm{m}^{3}$ & 0.15 & $\$ 13.02$ & $\$ 1.95$ \\
\hline Drainage Gravel & $\mathrm{m}^{3}$ & 0.15 & $\$ 13.02$ & $\$ 1.95$ \\
\hline Asphalt Coating & $\mathrm{m}^{2}$ & 1 & $\$ 32.10$ & $\$ 32.10$ \\
\hline Asphaltic Concrete & $\mathrm{m}^{3}$ & 0.15 & $\$ 104.19$ & $\$ 15.63$ \\
\hline Asphalt Base Course & $\mathrm{m}^{3}$ & 0.1 & $\$ 20.77$ & $\$ 2.08$ \\
\hline Total Unit Cost $\left(\mathrm{m}^{2}\right)$ & & & & $\$ 79.00$ \\
\hline $\begin{array}{l}\text { Notes: } \\
\mathrm{m}^{2}=10.7 \mathrm{ft}^{2} \\
\mathrm{~m}^{3}=35.2 \mathrm{ft}^{3}\end{array}$ & & & & \\
\hline
\end{tabular}


DOE/RL-93-99, Rev. 0

Table 8-6. Typical Unit Costs for a Single Liner System.

\begin{tabular}{|l|c|c|c|r|}
\hline Bottom Liner & Units & Quantity & $\begin{array}{c}\text { Unit } \\
\text { Cost }\end{array}$ & $\begin{array}{c}\text { Total } \\
\text { Cost }\end{array}$ \\
\hline Operations Layer & $\mathrm{m}^{3}$ & 0.9 & $\$ 2.61$ & $\$ 2.35$ \\
\hline Geotextile Separator & $\mathrm{m}^{2}$ & 1 & $\$ 3.21$ & $\$ 3.21$ \\
\hline Primary Drainage Gravel & $\mathrm{m}^{3}$ & 0.3 & $\$ 13.02$ & $\$ 3.91$ \\
\hline Geotextile Cushion & $\mathrm{m}^{2}$ & 1 & $\$ 3.21$ & 3.21 \\
\hline Primary HDPE Geomembrane & $\mathrm{m}^{2}$ & 1 & $\$ 9.10$ & $\$ 9.10$ \\
\hline Compacted Admix & $\mathrm{m}^{3}$ & 0.3 & $\$ 32.59$ & $\$ 9.78$ \\
\hline Total Unit Cost (m²) & & & & $\$ 32.00$ \\
\hline Sideslope Liner & $\mathrm{m}^{3}$ & 0.9 & $\$ 2.61$ & $\$ 2.35$ \\
\hline Operations Layer & $\mathrm{m}^{2}$ & 1 & $\$ 7.49$ & $\$ 7.49$ \\
\hline Primary Drainage Geocomposite & $\mathrm{m}^{2}$ & 1 & $\$ 9.10$ & $\$ 9.10$ \\
\hline Primary HDPE Geomembrane & $\mathrm{m}^{3}$ & 0.3 & $\$ 32.59$ & $\$ 9.78$ \\
\hline Compacted Admix & & & $\$ 29.00$ \\
\hline Total Unit Cost (m $\left.{ }^{2}\right)$ & & & \\
\hline $\begin{array}{l}\text { Notes: } \\
\mathrm{m}^{2}=10.7 \mathrm{ft} \\
\mathrm{m}^{3}=35.2 \mathrm{ft}^{3}\end{array}$ & & & \\
\hline
\end{tabular}


DOE/RL-93-99, Rev. 0

Table 8-7. Typical Unit Costs for a RCRA Subtitle ( )ouble Liner System.

\begin{tabular}{|c|c|c|c|c|}
\hline Bottom Liner & Units & Quant $y$ & $\begin{array}{l}\text { Unit } \\
\text { Cost }\end{array}$ & Total Cost \\
\hline Operations Layer & $\mathrm{m}^{3}$ & 0.9 & $\$ 2.61$ & $\$ 2.35$ \\
\hline Geotextile Separator & $\mathrm{m}^{2}$ & 1 & $\$ 3.21$ & $\$ 3.21$ \\
\hline Primary Drainage Gravel & $\mathrm{m}^{3}$ & 0.3 & $\$ 13.02$ & $\$ 3.91$ \\
\hline Geotextile Cushion & $\mathrm{m}^{2}$ & 1 & $\$ 3.21$ & $\$ 3.21$ \\
\hline Primary HDPE Geomembrane & $\mathrm{m}^{2}$ & 1 & $\$ 9.10$ & $\$ 9.10$ \\
\hline Geotextile Cushion & $\mathrm{m}^{2}$ & 1 & $\$ 3.21$ & $\$ 3.21$ \\
\hline Secondary Drainage Gravel & $\mathrm{m}^{3}$ & 0.3 & $\$ 13.02$ & $\$ 3.91$ \\
\hline Geotextile Cushion & $\mathrm{m}^{2}$ & 1 & $\$ 3.21$ & $\$ 3.21$ \\
\hline Secondary HDPE Geomembrane & $\mathrm{m}^{2}$ & 1 & $\$ 9.10$ & $\$ 9.10$ \\
\hline Compacted Admix & $\mathrm{m}^{3}$ & 0.9 & $\$ 32.59$ & $\$ 29.33$ \\
\hline \multicolumn{4}{|l|}{ Total Unit Cost $\left(\mathrm{m}^{2}\right)$} & $\$ 71.00$ \\
\hline \multicolumn{5}{|l|}{ Sideslope Liner } \\
\hline Operations Layer & $\mathrm{m}^{3}$ & 0.9 & $\$ 2.61$ & $\$ 2.35$ \\
\hline Primary Drainage Geocomposite & $\mathrm{m}^{2}$ & 1 & $\$ 6.42$ & $\$ 6.42$ \\
\hline Primary HDPE Geomembrane & $\mathrm{m}^{2}$ & 1 & $\$ 9.10$ & $\$ 9.10$ \\
\hline Secondary Drainage Geocomposite & $\mathrm{m}^{2}$ & 1 & $\$ 7.49$ & $\$ 7.49$ \\
\hline Secondary HDPE Geomembrane & $\mathrm{m}^{2}$ & 1 & $\$ 9.1$ & $\$ 9.10$ \\
\hline Compacted Admix & $\mathrm{m}^{3}$ & 0.9 & $\$ 32.59$ & $\$ 29.33$ \\
\hline \multicolumn{4}{|l|}{ Total Unit Cost $\left(\mathrm{m}^{2}\right)$} & $\$ 64.00$ \\
\hline \multicolumn{5}{|l|}{$\begin{array}{l}\text { Notes: } \\
\mathrm{m}^{2}=10.7 \mathrm{ft}^{2} \\
\mathrm{~m}^{3}=35.2 \mathrm{ft}^{3}\end{array}$} \\
\hline
\end{tabular}




\subsection{ASSEMBLY AND DETAILED EVALUATION OF REMEDIAL ALTERNATIVES}

Technologies retained following the screening process in Chapter 8 are assembled into alternatives and evaluated in this chapter. Screening of alternatives was not considered useful for this RI/FS and all the alternatives are carried into detailed evaluation. In Section 9.1, the technologies are assembled to create a range of alternatives that represent various approaches to achieving remedial action objectives. The criteria used to evaluate the alternatives are discussed in Section 9.2. Elements common to one or more of the alternatives are described and evaluated in Section 9.3. Section 9.4 describes and evaluates the alternatives against the applicable CERCLA criteria. Section 9.5 provides a comparative analysis of the alternatives to assist selection of the preferred alternative.

\subsection{ASSEMBLY OF ALTERNATTVES}

A range of alternatives is formulated frorn the technologies and process options retained in Chapter 8. The key elements of each alternative are described and briefly discussed below. Other than the no-action alternative, all the alternatives rely on a centralized waste management facility at the proposed ERDF location. Treatment of the incoming waste is not included in any of the alternatives; as has been stated previously, treatment is considered in the feasibility studies for the individual operable units. Institutional controls, dust control, surface water management, transportation, and wastewater treatment are components of all of the alternatives (except no action), and are discussed as common elements in Section 9.3. These elements are considered to be necessary for each of these alternatives, but are not expected to affect the relative performance of the alternatives.

In addition to a no-action alternative, nine alternatives were developed by selecting combinations of barrier and liner technologies retained after the screening conducted in Chapter 8. The nine alternatives represent combinations of either no liner, a single composite liner, or a RCRA MTR double composite liner; with either a low-infiltration soil barrier, a modified Hanford barrier, or a Hanford Barrier. As discussed in Chapter 8, the shallow trench and shallow area-fill designs were eliminated due to their high cost and the large area required to provide sufficient waste capacity. Therefore, each of the nine alternatives is based on the deep area-fill design, which minimizes the area impacted by construction of the facility. The alternatives assembled for detailed evaluation include:

- Alternative 1 - No action

- Alternative 2 - No liner and a low-infiltration soil barrier

- Alternative 3 - No liner and a modified Hanford barrier

- Alternative 4 - No liner and a Hanford Barrier

- Alternative 5 - Single c smposite liner and a low-infiltration soil barrier

- Alternative 6 - Single composite liner and a modified Hanford barrier

- Alternative 7 - Single composite liner and a Hanford Barrier

- Alternative 8 - RCRA double composite liner and a low-infiltration soil barrier

- Alternative 9 - RCRA double composite liner and a modified Hanford barrier

- Alternative 10 - RCRA double composite liner and a Hanford Barrier

The components included in each of the alternatives are summarized in Table 9-1. 


\subsection{EVALUATION CRTTERIA}

The NCP provides nine criteria for detailed evaluation of alternatives. These criteria are described below. Application of the criteria to the ERDF RI/FS is developed based on the directive in the NCP that "the analysis of alternatives under review shall reflect the scope and complexity of site problems and alternatives being evaluated and consider the reiative significance of the factors within each criteria" (40 CFR 300.430(e)(9)(iii)). The significance of each criteria and how they will be evaluated for the detailed evaluation is explained below:

1) Overall protection of human health and the environment: Alternatives shall be assessed to determine whether they can adequately protect human health and the environment, in both the short- and long-term, from unacceptable risks posed by hazardous substances, pollutants, or contaminants present at the site by eliminating, reducing, or controlling exposures to levels established during development of remediation goals. Overall protection of human health and the environment draws on the assessments of other evaluation criteria, especially long-term effectiveness and permanence, short-term effectiveness, and compliance with ARARs.

This criteria is considered a threshold criteria that must be attained. Assuming the waste acceptance criteria provided in Appendix $C$ will be implemented, all the retained alternatives will fulfill the RAOs specified in Section 7.2. Assuming appropriate worker safety measures and dust controls, all the alternatives will be sufficiently protective of short-term human and environmental health. Therefore. overall protection of human health and the environment is not further addressed in the detailed evaluation of alternatives.

2) Compliance with ARARs: The alternatives shall be assessed to determine whether they attain applicable or relevant and appropriate requirements under federal environmental laws and state environmental or facility siting laws. This criterion is also considered a threshold criterion that must be attained. Assuming the acceptable soil and leachate concentrations provided in Appendix $C$ will be implemented, all the retained alternatives will comply with chemical-specific ARARs. The determinations provided in Chapter 7 for action- and locationspecific ARARs are valid for all the alternatives except the no-action alternative. Furthermore, all the alternatives satisfy the ARAR requirements with the exception of the TSCA requirement that PCB's greater than $50 \mathrm{mg} / \mathrm{kg}$ must be disposed in a lined facility. In order to accept wastes with PCB concentrations greater than $50 \mathrm{mg} / \mathrm{kg}$, alternatives that do not include a liner (i.e., Alternatives 2, 5, and 8) would require a waiver under CERCLA. The circumstances under which CERCLA waivers may be granted are listed in Section 7.1. The TSCA waiver request would be applied for based on the equivalent standard of performance criteria. Demonstration of equivalent standard of performance is provided by the analyses in Appendix A for an unlined trench, indicating that PCBs would not impact groundwater beneath the ERDF. Since all the alternatives (except the no-action alternative) include a CAMU, evaluation of the CAMU criteria is provided in Section 9.3.

3) Long-term effectiveness and permanence: Alternatives shall be assessed for the long-term effectiveness and permanence they afford, along with the degree of certainty that the alternative will prove successful. Factors that shall be considered, as appropriate, include the following:

- Magnitude of residual risk remaining from untreated waste or treatment residuals remaining at the conclusion of the remedial activities. Residual risk is associated with migration of contaminants to groundwater and will be addressed 
by predicting the risk via the groundwater pathway for each alternative. The risk will be predicted using both current climatic conditions and hypothetical wet climatic conditions. As discussed in Appendix A, none of the alternatives result in contaminants reaching groundwater within 10,000 years under current climate conditions. Therefore, the only difference between the alternatives occur under the hypothetical wetter climate conditions.

- $\quad$ Adequacy and reliability of controls such as containment systems and institutional controls. This factor addresses the uncertainties regarding long-term protection from residuals, the assessment of the potential need to replace technical components of the alternative, and the potential exposure pathways and risks posed should the remedial action need replacement. This factor will be addressed by qualitatively evaluating the durability and redundancy in the liner and barrier provided by each of the alternatives. In addition, to facilitate assessment of the no-action alternative, the reliability of location (near the Columbia River or the 200 Area) will also be assessed.

- Reduction of toxicity, mobility, or volume through treatment. This factor is not relevant to this evaluation since none of the alternatives include treatment.

Long-term effectiveness will be measured in terms of future groundwater risk and qualitative assessments of liner reliability and barrier reliability. For scoring purposes, barrier reliability is weighted 0.5 , groundwater risk is weighted 0.4 , and liner reliability is weighted 0.1 . Liner reliability is considered least important because the liner is expected to fail over the long-term and does not significantly affect risk estimates (see Appendix A). Barrier reliability is weighted slightly more than groundwater risk because barrier reliability impacts intrusion in addition to groundwater impacts.

4) Reduction of toxicity, mobility, or volume through treatment: This criteria is not relevant to this evaluation since none of the alternatives include treatment. Treatment will be addressed in the source operable unit FSs.

5) Short-term effectiveness: The short-term impacts of alternatives shall be assessed considering the following:

- Short-term risks that might be posed to the community during implementation of an alternative. Risks to the community during implementation are associated with potential air releases of waste constituents during waste transport and placement. Since operations would be conducted in the same manner for all the alternatives (except the no-action alternative), this criteria will not differentiate between the alternatives. The dust controls included in all the alternatives will be sufficient to protect worker health. Since the proposed ERDF is isolated from the public, public risk is considered negligible compared with worker risk.

- Potential impacts on workers during remedial action and the effectiveness and reliability of protective measures. Risks to workers include both exposure to hazardous substances in the waste and physical hazards associated with construction activities and equipment operation. Potential worker exposure to waste contaminants during waste transport and placement would be the same for all the alternatives (except the no-action alternative). Since all the alternatives involve similar types of 
construction activities, the magnitude of physical hazard associated with an alternative would be approximately proportional to the amount of labor necessary to construct the facility. Generally the more complex liners and covers require the most labor.

- Potential environmental impacts of the remedial action and the effectiveness and reliability of mitigative measures during implementation. Since all the alternatives (except the no-action alternative) utilize the same trench configuration, environmental impacts at the ERDF are virtually the same. However, since the three barriers require different quantities of silt and crushed basalt, impacts on environmental and cultural resources at the borrow sources will vary.

- Time until protection is achieved. Assuming that all alternatives will result in a facility ready to receive waste by September, 1996, this factor would be the same for all the alternatives. As discussed below under implementability, however, those alternatives that include non-RCRA MTR liners may require greater technical effort to defend and consequently may take longer to permit. Since the final cover will not be constructed until after waste is received, non-RCRA MTR barriers should not impede Hanford's restoration program.

Given these factors, short-term effectiveness will be measured primarily in terms of the expected number of fatalities due to physical accidents and the impacted areas at the borrow sites (a surrogate for environmental and cultural impacts). For scoring purposes, the 2 borrow site impacts subcriteria are weighted 0.4 each, and the worker accidents criterion is weighted 0.2 . Worker accidents is weighted less than the other criteria because the differences between the alternatives are relatively minor for this criterion. The timeliness factor will be evaluated under implementability. Short-term risk to workers and the public due to exposure to wastes is addressed in Section 9.3.16.

O) Implementability: The ease or difficulty of implementing the alternatives shall be assessed by considering the following types of factors as appropriate:

- Technical feasibility including technical difficulties and unknowns associated with the construction and operation of a technology, the reliability of the technology, ease of undertaking additional remedial actions, and the ability to monitor the effectiveness of the remedy. In general, all the alternatives are technically feasible. However, the more complex alternatives that include liners and barriers that require certain weather conditions for construction are more likely to have problems resulting in schedule delays. The number of layers in the liner and barrier will be considered a relative measure of technical complexity.

- Administrative feasibility, including activities needed to coordinate with other offices and agencies and the ability and time required to obtain any necessary approvals and permits from other agencies (for off-site actions). CERCLA waives administrative requirement (such as permitting) for on-site activities. Since none of the alternatives include off-site transport, treatment, or disposal, this factor is not relevant to the detailed evaluation.

- Availability of services and materials, including the availability of adequate off-site treatment. storage capacity, and disposal capacity and services; the availability of necessary equipment and specialists, and provisions to ensure any necessary additional 
resources: the availability of services and materials: and availability of prospective . technologies. The primary differences between the alternatives regarding this factor is related to the types and quantities of materials included in the liners and covers. Off-the-shelf materials or materials that utilize soil excavated at the ERDF are considered easy to obtain. Materials that must be obtained from borrow sources on the Hanford Site (primarily silt and basalt) will be considered the most difficult to obtain because of their potential impact on ecological and cultural resources. Impacts at the borrow sources are addressed under short-term effectiveness and are not further addressed under implementability.

In summary, the only factor included within implementability is technical implementability.

7) Cost: The types of cost factors that shall be assessed include the following:

- Capital costs, including both direct and indirect costs. Construction costs for the different liners and barriers will vary significantly. Therefore, capital costs will be the primary factor for this criteria in evaluation of the alternatives. Costs for excavating the trench and supporting facilities will also be determined to provide a perspective on the relative significance of the liner and barrier costs. Accuracy of the cost estimates is generally in the + or $-25 \%$ range. More than 2 significant figures were retained in the cost estimates to minimize rounding inaccuracies.

- Annual operation and maintenance costs. These are similar for all the alternatives (except the no-action alternative) and therefore will not differentiate between the alternatives. Only costs incurred during operation of the ERDF will be considered. Long-term, post closure monitoring and maintenance costs will be relatively small and are not included.

- Net present value of capital and O\&M costs. The net present value will include capital costs and operation and maintenance costs. Since the barrier will be constructed after the trench is full, net present value of the barrier costs will be calculated assuming the barrier will be built 20 years after the liner and supporting facilities are constructed. A 6 percent discount rate will be assumed.

Comparative performance of the alternatives will be based on the total net present value of capital and $O \& M$ costs.

8) State acceptance: The state concerns that shall be assessed include the following:

- The state's position and key concerns related to the preferred alternative and other alternatives.

- State comments on ARARs or the proposed use of waivers.

The State's concerns have been identified and resolved during the RI/FS review process. This is a modifying criteria that will also be considered in remedy selection for the ROD.

9) Community acceptance: This assessment includes determining which components of the alternatives interested persons in the community support, have reservations about, or 
oppose. This assessment may not be completed until comments on the proposed plan are received; therefore, this criteria is not addressed in the RI/FS. This is a modifying criteria that will also be considered in remedy selection for the ROD.

\subsection{COMMON ELEMENTS AND IMPACTS}

This section describes elements that will be included in one or more of the alternatives and impacts that will generally be common to one or more of the alternatives. Elements in all the alternatives (except the no-action alternative) are institutional controls, dust control, surface water management, wastewater treatment, transportation, supporting facilities, and the deep area-fill trench configuration. Elements included in more than one alternative (but not all) are the different liners and barriers. Common impacts discussed in this section include ecological, air quality, historical resources, socioeconomic, transportation, visual, noise, and worker risk. In addition, cost assumptions and estimates for all common elements are provided.

\subsubsection{Institutional Controls}

Surveillance and access controls are currently maintained for the entire Hanford Site for protection of government property, classified information, and special nuclear materials. Additional institutional controls will be implemented at the ERDF during the operational period and after closure. These include 24-hour surveillance, fencing, entry control, and warning

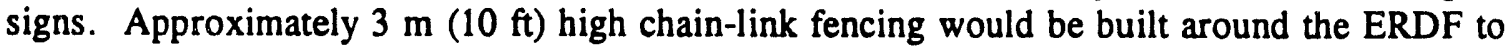
prevent inadvertent entry to the trench and operations areas. Radiation and hazard warning signs would be placed every $30 \mathrm{~m}(100 \mathrm{ft})$ around the fence to discourage trespass.

Groundwater use restrictions would prevent withdrawals of groundwater near the site boundary and would be coordinated with remedial actions undertaken in the neighboring 200 Area.

Institutional controls also include monitoring and maintenance activities. Environmental monitoring stations will be installed at various locations around the facility (some possibly offsite). These stations will monitor some or all of the following parameters:

- Weather - wind direction and speed, temperature (off the proposed ERDF site)

- Radiological air monitoring

- Groundwater well monitoring

- Continuous air quality monitoring system.

Maintenance activities include maintenance of the fence and warning signs, maintenance of the leachate collection/detection and removal system, maintenance and repairs to the cover system, and the monitoring systems described above. Maintenance activities may be required for the tubing, pumps, and piping system of the leachate collection/detection and removal system. Maintenance of the cover system will include controls and repairs of any damage due to wind erosion, water erosion, deep-rooted plants, burrowing animals, subsidence and settlement, seismic events, cover drainage and run-on, and freeze/thaw effects. Periodic inspections will be conducted to prevent malfunctions and deterioration, human errors, and discharges that may cause or lead to the release of radioactive or dangerous waste to the environment or pose a threat to human health.

Preventing site access and maintaining the cover would minimize the potential for direct human and environmental exposure to contaminated soils and wastes associated with the ERDF. 
Therefore, institutional controls address the first RAO: prevent unacceptable direct exposure to waste. Since it is not known how long institutional controls will remain effective, the surface barrier provides additional protection against intrusion into the waste. In addition, the surface barrier provides the primary mechanism for achieving long-term compliance with the third and fourth remedial action objectives (preventing unacceptable contaminant release to air and groundwater, respectively) because it would detect contaminant releases to groundwater and signal the need for corrective actions. In addition, groundwater monitoring will be conducted to provide an additional level of protection against exposure to contaminated groundwater.

\subsubsection{Dust Control}

Dust control will be conducted to minimize contaminant release to air during the ERDF operations. Dust control will be achieved by using dust suppressant sprays and controlling moisture content in the waste. At the end of each shift, the top of the trench fill will be covered with clean (uncontaminated) soil and the working face will be covered with clean soil or sprayed with a dust suppressant. Dust control will help achieve short-term compliance with the third remedial action objective (prevent unacceptable contaminant release to air) as well as comply with any ARARs regarding releases to air.

\subsubsection{Surface Water Management}

A drainage system will be developed to be compatible with runoff volume. Stormwater run-on/runoff systems will be designed to meet the requirements of 40 CFR 264.301. The stormwater runoff from clean areas of the site will be collected and routed through ditches to a detention storage pond. Stormwater entering this pond will be metered and discharged to an existing drainage channel in a controlled manner. Drainage ditches will be vegetation-lined where feasible, and asphalt and/or concrete channels where flows are too great for vegetation channels.

It is anticipated that stormwater runoff in potentially contaminated areas will not require treatment under normal conditions. If spillage of waste material occurs, however, the stormwater runoff may become contaminated and require treatment. Therefore, stormwater runoff from potentially contaminated areas will be collected separately from runoff from clean areas and routed to RCRA-compliant detention tanks. The wastewater contained in these tanks will be sampled and uncontaminated drainage will be released to natural drainage areas near the southwest side of the ERDF trench. If the sampling indicates that treatment is needed, either lime will be added or the water will be pumped to either the wastewater treatment facility, the grout plant, or into tankers for off-site treatment.

Potential sources of radioactive contamination include accidental spillage of small amounts of materials from the tractor/trailer/container or an accident where a tractor/trailer carrying a full container tips. Special precautions and measures will be taken in transportation of the radioactive materials. Therefore, the potential for radioactive materials being in the storm runoff will be minimized. Due to the expectation that only very low amounts of radioactivity will occur in the runoff, the use of a dedicated treatment system is not justified. 


\subsubsection{Wastewater Treatment}

Wastewater at the ERDF includes sanitary wastewater, leachate, and decontamination wastewater. The sanitary wastewater from the operations building and decontamination facility will be collected and treated in septic tanks located near each facility in uncontaminated areas. The liquid from the septic tanks will be diverted to drain field systems.

The decontamination facility wastewater and the trench leachate will be combined and treated in the wastewater treatment system. Off-the-shelf reverse-osmosis (RO) units may be used to treat the wastewater. The concentrate from the RO unit will be stored in tanks and transferred to evaporation basins or used for grout production. The treated (clean) effluent will be recycled for use in the decontamination facility or used in tanker trucks for dust control.

\subsubsection{Transportation Expansion and Impacts}

Hanford Site Transportation. The ERDF is expected to receive 150 rail containers of waste per shift. The location of the existing railroad system is shown on Figure 2-35 and 2-36. In order to accommodate waste transport to the ERDF, a new railroad track will be constructed from the existing Hanford rail system north of the 200 West Area to the proposed ERDF site. The new railroad spur is shown on Figure 9-1. The existing railroad system combined with the new railroad system will provide sufficient capacity for the additional rail traffic associated with the ERDF.

Additional car and truck traffic on Hanford roads due to the ERDF will include primarily truck-hauled waste, truck-hauled clean fill (for filling excavations at the waste units), commuting workers, and transport of materials for construction of the liner and barrier. Primary existing surface roads on the Hanford Site are shown on Figure 2-35. Existing and planned surface roads near the ERDF are shown on Figure 9-1. The ERDF is expected to receive 65 truckloads of waste per shift. Assuming 80 percent of the excavated waste is replaced with clean fill from the ERDF, 52 truckloads of clean fill will be transported to the source operable units each shift. Clean fill will be transported in dedicated "clean" containers; therefore, a total of 107 truckloads will be transported each shift. Commuting traffic is expected to include 167 full-time employees for operations, less than 163 workers for construction of the ERDF, and a negligible number of Hanford site-wide service personnel. Since some employees ride the bus and others carpool, commuting traffic will likely be less than 150 vehicles per day. The amount of traffic associated with liner and barrier construction will depend on the specific liner and barrier design and the rate of construction; estimates are provided in Sections 9.3.8 and 9.3.9. As discussed in these sections, the material hauling traffic ranges from a low of 14 trucks per day for the single liner to a maximum of 41 trucks per day for the double liner.

Adding together the traffic loads associated with waste transport, commuting, and material delivery, a maximum of 310 additional vehicles per day on Hanford roads will be associated with the ERDF.

Transportation Within the ERDF. The transportation network inside the ERDF facility will include the following elements:

- Incoming waste operations, 
- Waste transfer to the internal ERDF transport trucks,

- Transport of waste within the ERDF,

- Decontamination operations,

- Waste grouting,

- Waste cover,

- Construction.

These transportation elements are discussed below.

Waste-receiving facilities will accommodate delivery of waste materials to the proposed ERDF from the source operable units and the return of empty containers after external decontamination. Inbound operations will include waste delivery by tractor/trailer or rail, waste container transfer to tractor/trailers for internal ERDF transport, manifest checking, and tractor/trailers dispatching to the burial trenches. Waste is expected to arrive at the ERDF in both single-use and reusable containers. Containers will be transferred from railcars and tractor/trailers by wheeled container handlers. The tractor/trailers will travel along dedicated paved ERDF haul roads between the railhead and the trench and on gravel roads within the trench.

After the waste is emptied into the ERDF trench, containers will be transported to the decontamination facility where they will pass though the washing system on conveyors to a position for transfer back to railcars. Single-use containers will be placed on the floor of the working area within the ERDF trench by a crane. Backhauled soil will be transported in "clean" containers that are not used for waste transport.

Materials excavated from the ERDF trench will be used for grout aggregate. Cement will be imported from off-site. Grout production will include transport of aggregate materials to the batch plant, mixing of the grout in the batch plant, and transfer to a mixer/transport truck. The grout mixer/transport truck will deliver the grout to the designated grouting area, unload the grout using the mixer drum and unloading chute, and return to the batch plant.

Materials excavated from the ERDF trench will be used for daily cover. Cover material will be spread and compacted by a dozer unit towing a vibratory roller compactor. At the end of each shift, the exposed working face areas will be covered by a dust suppressant material.

Traffic requirements associated with construction of the ERDF include transport of excavated materials from the trench excavation to stockpiles within the ERDF and transport of liner and barrier construction materials within the ERDF. The maximum on-site traffic load would be associated with simultaneous trench excavation and liner construction. Trench excavation is expected to include 33 pieces of equipment (see Section 9.3.7) and liner construction would include a maximum of 41 trucks (see Section 9.3.8) for a total of 74 vehicles.

\subsubsection{Other Supporting Facilities and Activities}

Other supporting facilities and activities include buildings, a grout batch plant, equipment for internal and external communications, emergency response, and personnel protection. 
Three buildings will be included in the ERDF: the operations building, the decontamination facility, and the wastewater treatment facility. The operations building will include personnel decontamination (showers and change rooms), a lunch room, maintenance shops, and offices. The decontamination facility will provide a control room for decontamination operations personnel, a personnel decontamination area, restrooms, and a container decontamination, monitoring, and storage area. The wastewater treatment facility will include treatment equipment.

Although most of the waste to be received at the ERDF is expected to be bulk soils that can be easily compacted and stabilized, some of the waste will be metal and construction debris that may result in voids that could cause settlement of the waste and surface barrier. Therefore, void space will be filled with grout and a portable grout batch plant will be included at the ERDF. The grout plant will mix cement, fly ash, aggregate, water, and pozzolans (as necessary). The batch plant will be placed over a buried leak-collection liner to prevent water releases to the subsurface.

The ERDF will use a combination of telephone communications, radio communications, computer and alarm systems to provide immediate emergency instruction to facility personnel. The external communications will be provided through a telephone system to be installed in the operations buildings at the ERDF site.

Emergency equipment will be available for use at the ERDF site and personnel will be trained in the use of emergency equipment. Facility buildings will have fire sprinklers connected to a raw water supply system. Water for fire control in other areas of the ERDF is supplied by the main raw water line connected to adequately spaced fire hydrants located near the operations and decontamination buildings.

At a minimum, all personnel will be required to wear radiation protection coveralls, cloth shoe covers plus rubber boots or shoe covers, gloves, and a cloth cap when working in the ERDF site. In addition, various types of respiratory devices will be available if required and personnel will be trained in their use.

\subsubsection{Deep Area-Fill Configuration}

The deep area-fill design (described in Section 8.2.3) is used for all the alternatives except no-action. The assumed cross-sectional dimensions of the trench are shown in Figure 4-1. In order to accommodate the estimated final waste volume of 21.9 million $\mathrm{m}^{3}(28.5$ million $\left.\mathrm{yd}^{3}\right)$, the trench would need to be approximately $3,000 \mathrm{~m}(9,800 \mathrm{ft})$ long. Assuming these dimensions, the footprint of such a trench would be $1.26 \mathrm{~km}^{2}$ (315 acres). Because the final waste volume may be significantly different than anticipated, trench construction will proceed in stages such that capacity expands to fit the immediate needs of the Hanford Site restoration program.

As discussed in Section 8.2, the reduced footprint of the deep area-fill design offers the following advantages in comparison to other configurations:

- Less habitat disruption at the ERDF,

- Less leachate generation, 
- Reduced material needs (thus, reduced ecological and cultural impact on borrow areas),

- Lower costs for the liner and barrier.

The proposed site for the ERDF extends east of the 200 West Area to the state leased land (the US Ecology area) and south of the proposed 16th Avenue extension (see Figure 1-2). The area of the ERDF is estimated to be 4.1 square kilometers (1.6 square miles).

Soils removed from the trench excavation will be stockpiled within the ERDF site. Excavation of the trench is anticipated to be accomplished in the following manner:

- The crew will consist of 50 workers who will operate 33 pieces of equipment (primarily scrapers, dozers, graders, loaders, and water trucks),

- The crew will move $10,000 \mathrm{~m}^{3}\left(13,000 \mathrm{yd}^{3}\right)$ per shift,

- A week will include 10 shifts (double shifting),

- One cell of 0.7 million $\mathrm{m}^{3}\left(0.9\right.$ million $\left.\mathrm{yd}^{3}\right)$ will be excavated every 7 weeks.

Labor Requirements. Based on the assumptions listed above, trench excavation of all 32 cells is expected to require 110,000 worker days. Assuming 50 workers per shift, trench excavation will result in 100 jobs over a period of 4.5 years.

\subsubsection{Liners}

Two liner systems are included in the remedial alternatives, the single composite liner and the RCRA Subtitle C double composite liner. Features of these two liner systems that are applicable to multiple alternatives are presented in this section, including implementability, cost, labor requirements for construction, material usage, traffic loading, modeling assumptions, and reliability.

Implementability. Technical implementability is scored qualitatively based on the number of layers in each liner system. As described in Section 8.6.4, the single liner has six layers on the bottom and 4 layers on the sideslope for an average of 5 . The double liner has 10 layers on the bottom and 6 layers on the sideslope for an average of 8 .

Raw Cost. Material unit costs for the liners were presented in Section 8.6.4. The areas for the bottom and sideslope portions of the liners were calculated assuming a top trench width of $420 \mathrm{~m}(1,400 \mathrm{ft})$ a bottom trench width of $300 \mathrm{~m}(980 \mathrm{ft})$, a top length of $3,000 \mathrm{~m}$ $(9,800 \mathrm{ft})$ and a bottom length of $2,880 \mathrm{~m}(9,400 \mathrm{ft})$. The plan area of the sideslope liner was converted to actual surface area by dividing by the cosine of 18.4 degrees $(0.95)$ to account for the $3 \mathrm{H}: 1 \mathrm{~V}$ sideslopes. Total raw costs for the two types of liners are shown in Table 9-2. The cost for the single liner ( $\$ 39$ million) is less than half the total cost for the double liner (\$88 million).

Labor Requirements. Only labor associated with construction and Hanford Site material transport is addressed. Labor for production of materials included in the liners is not addressed in this section. The assumed crew sizes for placement of each type of material are provided in Table 9-3. Labor requirements for material transport are based on traffic loading information provided below. The estimated labor associated with each liner, provided in Table 9-3, ranges from 40,000 worker-days for the single liner to 79,000 worker-days for the double 
liner. Assuming that the liner construction will occur over a 5 year (1.250 working days) period, construction of the liner will result in between 32 and 63 jobs over a five year period.

Material Usage. Thicknesses for each component in the liners are discussed in Section 8.6.4. The assumptions for the area estimates are provided above in the cost discussion. Quantities of material used in each liner are summarized in Table $9-4$ and are based on the following assumptions:

- The operations layer will consist of general fill

- The compacted admix at the base of the liners will consist of 80 percent silty fine sand and 20 percent bentonite (by volume).

The sand, gravel, and general fill will likely be obtained from native soils excavated for the ERDF trench. Therefore, they will have no impact on cultural and ecological resources at borrow sources. If materials excavated for the ERDF are not suitable, these granular materials will likely be obtained from gravel pits located between the 200 East and 200 West Areas. The vegetation seed, bentonite, and geotextiles will likely be obtained from off-Hanford Site suppliers.

Trafric Loads. The only materials included in the liners that must be imported from off the ERDF site are geosynthetics and bentonite. The remaining materials are derived from ERDF trench excavation soils. The assumed truckload size is provided for each material and the daily traffic loads are calculated assuming that the synthetic materials for each layer in each cell (each cell equals approximately 1/32th of the complete facility) arrive over a period of 5 working days and the bentonite arrives over a period of 20 days. The results are summarized below.

\begin{tabular}{|l|c|c|c|}
\hline \multicolumn{4}{|c|}{$\begin{array}{c}\text { Traffic Associated with Liner Construction } \\
\text { (Trucks per day) }\end{array}$} \\
\hline & Daily Quantity Per Truck & Single Liner & Double Liner \\
\hline Geotextile Separator & $20,000 \mathrm{~m}^{2}$ & $<1$ & $<1$ \\
\hline Geotextile Cushion & $20,000 \mathrm{~m}^{2}$ & $<1$ & 1 \\
\hline Drainage Geocomposite & $15,000 \mathrm{~m}^{2}$ & $<1$ & $<1$ \\
\hline HDPE Geomembrane & $10,000 \mathrm{~m}^{2}$ & 1 & 2 \\
\hline Bentonite & $10 \mathrm{~m}^{3}$ & 12.5 & 37.5 \\
\hline Maximum Total & & 14 & 41 \\
\hline
\end{tabular}

The maximum total traffic loads per day range from 14 trucks/day for the single liner to 41 trucks/day for the double liner. These maximums assume that the delivery days for different materials overlap.

Modeling Assumptions. The contaminant transport simulations presented in Appendix A assume that no leakage occurs through the liners during operations (i.e., while leachate is removed). The operational time period is assumed to equal 30 years. At the end of the operational time period, it is assumed that the synthetic membranes have degraded and all leachate migrates through the underlyiing admix layer. As discussed in Appendix A, liner 
parameters used in the equations are thickness, bulk density, moisture content, and liner $\mathrm{K}_{\mathrm{d}}$ 's. The admix thickness of the double liner $(0.9 \mathrm{~m} \mathrm{[3} \mathrm{ft}])$ is three times greater than the admix

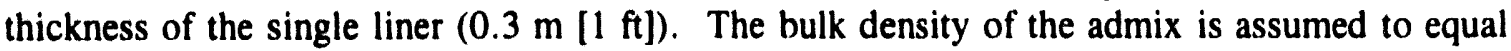
$1.5 \mathrm{gm} / \mathrm{cm}^{3}$, and the moisture content of the admix is assumed to equal 22.5 percent. The liner $K_{d}$ 's are constituent specific and are assumed to be 5 times greater than the $K_{d}$ 's used for the vadose zone (see Section 4.1.2.2).

Reliability. Alternatives that include liners offer several advantages over no-liner alternatives. The primary advantage is that any leachate generated during the operational period will be retained by the liner and pumped out. This means that constituent release to the vadose zone is delayed by the length of the operational period. Conceivably, the operational period could extend for hundreds or thousands of years. However, the effectiveness of the leachate collection system is limited by the lifetime of the synthetic membranes. Once the synthetic membranes degrade and develop leaks, the permeability of the liner is controlled by the permeability of the admix material. Since the infiltration rate is generally less than the design permeability of the admix material $\left(10^{-7} \mathrm{~cm} / \mathrm{sec}\right)$, leachate will migrate through the admix layer and leachate collection will not be possible. This element of reliability is addressed in the risk estimates for the alternatives.

A secondary advantage of a leachate collection system is that it allows characterization of the leachate generated in the waste. Knowledge of constituent concentrations in the leachate, and the $K_{d}$ 's of the leachate constituents, could be used to predict future impacts on groundwater once the leachate collection is terminated or the liner fails. If these future impacts are considered unacceptable, then corrective actions (such as excavation and further treatment of the waste) could be implemented before groundwater is impacted.

The double composite liner offers a redundancy in leachate collection systems not available in the single composite liner. The potential for flaws in the primary liner is uncertain, although it is probably low given the high level of construction quality assurance planned for the ERDF. Furthermore, the rate of degradation of a double composite liner will probably be similar to the degradation rate for the single composite liner. The value of the redundancy in the double composite liner is uncertain.

The advantages discussed above for the lined trench only apply if leachate is generated during the operational period. In other words, an unlined facility performs just as well as a lined facility if no infiltration occurs during the first 30 years (i.e., the operational period). Given the lysimeter results indicating zero infiltration in vegetated soils at the Hanford Site, it may be that a properly constructed barrier will eliminate leachate generation and a liner is superfluous.

Given the advantages of the single and double liners over no liner, alternatives that have no liner will be given a liner reliability score of low. Given the advantages of the double liner over the single liner, alternatives that include the single liner will be given a liner reliability score of medium and alternatives with the double liner will be will be given a liner reliability score of high. 


\subsubsection{Surface Barriers}

Three surface barriers are included in the remedial alternatives, the low-infiltration soil barrier, the modified Hanford barrier, and the Hanford Barrier. Features of these barriers that are applicable to multiple alternatives are presented in this section, including implementability, cost, material usage, impacted areas at the borrow areas, traffic loading, labor requirements for construction, modeling assumptions, and reliability.

Implementability. Technical implementability is semi-qualitatively measured based on the number of layers in each barrier. As described in Section 8.5, the low-infiltration soil barrier has 3 layers, the modified Hanford barrier has 10 layers, and the Hanford Barrier has 11 layers.

Raw Cost. Unit costs for the barriers were presented in Section 8.5. The areas for the barriers are calculated assuming a top trench width of $420 \mathrm{~m}(1,400 \mathrm{ft})$ and a length of $3,000 \mathrm{~m}$ $(9,800 \mathrm{ft})$. In addition, the overhang beyond the edge of the trench is assumed to be $30 \mathrm{~m}(100 \mathrm{ft})$ for the Hanford Barrier and $15 \mathrm{~m}(50 \mathrm{ft})$ for the other two barriers. Total costs for the three barriers are developed below:

\begin{tabular}{|c|c|c|c|}
\hline \multicolumn{4}{|c|}{ Total Barrier Costs } \\
\hline & $\begin{array}{c}\text { Low-Infiltration Soil } \\
\text { Barrier }\end{array}$ & $\begin{array}{c}\text { Modified Hanford } \\
\text { Barrier }\end{array}$ & Hanford Barrier \\
\hline Unit Cost (per $\mathrm{m}^{2}$ ) & $\$ 21$ & $\$ 79$ & $\$ 134$ \\
\hline Total Area $\left(\mathrm{m}^{2}\right)$ & 1.36 million & 1.36 million & 1.47 million \\
\hline Total Barrier Cost & $\$ 29$ million & $\$ 107$ million & $\$ 197$ million \\
\hline
\end{tabular}

As shown in this table, the cost for the low-infiltration soil barrier is approximately $27 \%$ of the cost of the modified Hanford barrier and approximately $15 \%$ of the Hanford Barrier. The modified Hanford barrier costs are approximately $55 \%$ of the Hanford Barrier costs.

Labor Requirements. Only labor associated with construction and Hanford Site material transport is addressed in this section. Labor for production of materials included in the barriers is not addressed. Labor requirements for construction of each barrier are estimated assuming that all granular materials are placed using crews made up of the following personnel:

- 3 Scraper Operators

- 2 Dozer Operators

- 1 Blade Operator

- 1 Water Truck Operator

- 1 Grade Checker

- 1 Foreman

- 1 Supervisor

- 1 Oiler

- 1 Quality Control Technician. 
for a total of 12 workers per crew. Placement of the asphalt is also assumed to require a crew of 12 workers. Material transport labor estimates are based on the number of trucks per day discussed below and a construction duration of 1,000 working days. The estimated labor associated with each barrier, provided in Table 9-5, ranges from 21,000 worker-days for the low-infiltration barrier to 84,000 worker-days for the Hanford Barrier. Assuming that the construction period is 4 years (1,000 working days), multiple crews will be needed and construction of the barriers will result in between 21 and 84 jobs over a four year period.

Material Usage. Thicknesses for each component in the barriers are discussed in Section 8.5. The assumptions for the area estimates are provided above in the cost discussion. Estimated quantities of materials used for each barrier, summarized in Table 9-6, are based on the following assumptions:

- The silt quantities include silt layers and 85 percent of the silt and gravel admix,

- The gravel quantities include gravel filter material, drainage gravel, drainage rock, the asphalt base course, and 15 percent of the silt and gravel admix.

The silt will likely be obtained from the McGee Ranch site. The Hanford Barrier requires twice as much silt as the modified Hanford barrier and four times as much silt as the low-infiltration soil barrier. Furthermore, only the Hanford Barrier uses crushed basalt, which will likely be obtained from a quarry to be developed somewhere on the Hanford Site.

The sand, gravel, and general fill will likely be obtained from native soil excavated for the ERDF trench. Therefore, they will have no impact on cultural and ecological resources at borrow sources. If materials excavated for the ERDF are not suitable, these granular materials will likely be obtained from gravel pits located between the 200 East and 200 West Areas. The vegetation seed, geotextiles, and asphalt materials will likely be obtained from off-Hanford Site suppliers.

Impacted Areas at the Borrow Sources. Assuming the silt and basalt usage estimates provided in Table 9-6, areas impacted at McGee Ranch and at the basalt borrow source can be estimated. The estimated areas provided below assume that the excavation depths will average 5 $\mathrm{m}(16 \mathrm{ft})$ at McGee Ranch and $10 \mathrm{~m}(33 \mathrm{ft})$ at the basalt borrow source.

\begin{tabular}{|l|c|c|c|}
\hline \multicolumn{4}{|c|}{ Impacted Areas at the Borrow Sources } \\
\hline & $\begin{array}{c}\text { Low-Infiltration Soil } \\
\text { Barrier }\left(\mathrm{km}^{2}\right)\end{array}$ & $\begin{array}{c}\text { Modified Hanford } \\
\text { Barrier }\left(\mathrm{km}^{2}\right)\end{array}$ & $\begin{array}{c}\text { Hanford Barrier } \\
\left(\mathrm{km}^{2}\right)\end{array}$ \\
\hline McGee Ranch & 0.14 & 0.26 & 0.54 \\
\hline Basalt Borrow Source & 0 & 0 & 0.22 \\
\hline Note: $1 \mathrm{~km}^{2}=250$ acres $=0.4 \mathrm{mi}^{2}$ & \\
\hline
\end{tabular}

Traffic Loads. Materials included in the barriers that must be imported from off the ERDF site are vegetation (seed), silt, geotextile filter, crushed basalt, asphalt coating, and asphalt. Volumes of seed and asphalt coating are much less that the other materials and will not be evaluated in terms of traffic load. The assumed daily quantity of material transported per truck is provided for each material. The daily traffic loads are calculated assuming that the 
DOE/RL-93-99, Rev. 0

barriers are built over a period of 1,000 working days (approximately 4 years). The results are summarized below:

\begin{tabular}{|l|c|c|c|c|}
\hline \multicolumn{5}{|c|}{$\begin{array}{c}\text { Traffic Associated with Barrier Construction } \\
\text { (Trucks per day) }\end{array}$} \\
\hline & $\begin{array}{c}\text { Daily Quantity Per } \\
\text { Truck }\end{array}$ & $\begin{array}{c}\text { Low-Infiltration } \\
\text { Soil Barrier }\end{array}$ & $\begin{array}{c}\text { Modified } \\
\text { Hanford } \\
\text { Barrier }\end{array}$ & $\begin{array}{c}\text { Hanford } \\
\text { Barrier }\end{array}$ \\
\hline Silt & $150 \mathrm{~m}^{3}$ & 5 & 9 & 18 \\
\hline Geotextile Filter & $20,000 \mathrm{~m}^{2}$ & 0 & 0 & $<1$ \\
\hline Crushed Basalt & $150 \mathrm{~m}^{3}$ & 0 & 0 & 15 \\
\hline Asphalt & $100 \mathrm{~m}^{3}$ & 0 & 2 & 2 \\
\hline Total & & 5 & 11 & 35 \\
\hline
\end{tabular}

Fate and Transport Parameters. The only barrier-specific parameter used in the simulations presented in Appendix $A$ is the infiltration rate. Based on the HELP modeling results presented in Appendix $B$, the infiltration rates through the three barriers are similar for current climatic conditions and are very close to zero. Results are also presented in Appendix B for a hypothetical wetter climate that uses Spokane climatic data. Infiltration increases for all three barriers under these wetter conditions. Under wet conditions, the infiltration rate for the low permeability soil barrier is approximately 15 times greater than for the modified Hanford and Hanford Barriers (which are virtually identical). The infiltration rates assumed for the simulations in Appendix A are summarized below:

\begin{tabular}{|l|c|c|c|}
\hline & $\begin{array}{c}\text { Low-Infiltration Soil } \\
\text { Barrier }\end{array}$ & $\begin{array}{c}\text { Modified Hanford } \\
\text { Barrier }\end{array}$ & Hanford Barrier \\
\hline Current Climate & 0.01 & 0.01 & 0.01 \\
\hline Wet Climate & 5 & 0.4 & 0.4 \\
\hline Notes: $1 \mathrm{~cm}=0.39$ in.
\end{tabular}

Since the waste may be coarse-grained material and will not be vegetated, operational infiltration may be significantly higher than infiltration after placement of the barrier. The analysis in Appendix B suggests that infiltration before the waste is covered could be up to $3 \mathrm{~cm} / \mathrm{yr}(1.2 \mathrm{in} . / \mathrm{yr})$. Therefore, the fate and transport simulations in Appendix A assumed that the initial infiltration rate would be $3 \mathrm{~cm} / \mathrm{yr}$ for the first 5 years. If the trench is lined, then it is assumed that all of this excess infiltration (in addition to the long-term infiltration that occurs during the operational period) is intercepted by the leachate collection system and pumped out.

Reliability. Assuming that the barriers maintain their design capabilities, all three barriers appear to perform similarly under current climatic conditions. Based on HELP analyses, however, the modified Hanford barrier and the Hanford Barrier would provide greater infiltration protection than the low-infiltration soil barrier in a wetter climate. Therefore, the low-infiltration soil barrier should be considered less reliable over the long term with respect to 
groundwater protection. This element of reliability is addressed in the predicted risks for the alternatives assuming a wet climate.

Reliability in terms of protection against intrusion and erosion would be important if institutional controls were no longer in place. Qualitative evaluations are provided below for all three barriers in terms of protection against erosion, plant intrusion, animal and insect intrusion, and human intrusion.

All of the barriers include gravel in the upper soil layer. The gravel-size fraction is sufficient to help to minimize erosion due to surface water and wind processes but not so great as to promote increased infiltration. The gravel admix layer is approximately $0.5 \mathrm{~m}(1.6 \mathrm{ft})$ thick in the low-infiltration soil and modified Hanford barriers, and $1.0 \mathrm{~m}(3.3 \mathrm{ft}$ ) thick in the Hanford Barrier. In addition, the presence of the basalt rip-rap layer in the Hanford Barrier provides additional erosion resistance should the upper layers be completely eroded away.

To discourage penetration by deep-rooted plants, the Hanford Barrier employs a large overall thickness of $4.5 \mathrm{~m}$ (15 ft), a series of layers in the second functional group that provide a hostile environment for plants (little-to-no moisture, no nutrients, large grain size), and a densely compacted asphalt layer. Although the modified Hanford Barrier employs a thin layer of coarse-grained materials, these layers are not expected to be as effective as the basalt layer in preventing root penetration. As a result, plant roots may extend deeper into the barrier, although the asphalt layer should prevent penetration into the waste. The low-infiltration soil barrier employs thickness alone, without a zone that is hostile to plant roots and without a dense asphalt layer. Therefore, the Hanford Barrier appears to provide the best resistance to root penetration, followed by the modified Hanford barrier, with the low-infiltration soil barrier providing the least resistance to root penetration.

Burrowing animals, including large and small mammals, and insects, have the potential to disturb barrier layers and penetrate into buried wastes. Studies at the Hanford Site indicate that animal burrows do not significantly increase the net deep percolation of precipitation into barrier soils (Wing 1993). Mammals appear to have little need to burrow below depths of $1 \mathrm{~m}$ (3.3 ft) on the Hanford Site (Wing 1993). Therefore, each of the barriers should be effective at preventing disturbance of the waste by mammals. As with root penetration resistance, the basalt rip-rap layer and the asphalt layer in the Hanford barrier appear to offer the most resistance to intrusion from burrowing mammals and insects. The modified Hanford barrier is slightly more effective than the low-infiltration soil barrier at preventing intrusion, due to the presence of the asphalt layer.

Resistance to human intrusion is considered to be primarily a function of barrier thickness. None of the barriers will resist drilling or deep excavation, although warning markers should alert humans to the dangers associated with such activities. The basalt rip-rap layer of the Hanford barrier may be more obvious and difficult to penetrate, but will not withstand concerted excavation efforts. Surficial disturbances such as agricultural tilling or

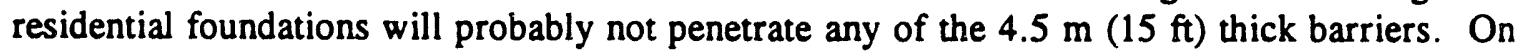
this basis, the barriers are considered to be equal with respect to resisting human intrusion.

In summary, the Hanford Barrier offers the greatest protection against erosion and intrusion in the absence of institutional controls. The modified Hanford barrier is considered to be more effective than the low-infiltration soil barrier in this regard. Alternatives will be scored 
high for long-term reliability if they include the Hanford Barrier, medium if they include the modified Hanford barrier, and low if they include the low-infiltration soil barrier.

\subsubsection{Ecological Impacts}

Ecological impacts will occur at the ERDF site, along the new rail spur, and at any borrow sites for materials in the liner and cover. These impacts will include destruction of habitat, displacement of wildlife at these areas, and disturbance of wildlife near these areas and along transport routes due to noise and human activities. As discussed in Section 2.8, the shrub-steppe habitat at the ERDF site is considered priority habitat by the State of Washington. The DOE recognizes that contiguous blocks of mature shrub-steppe habitat are important for many plant and animal species, and this habitat is rapidly shrinking elsewhere in Eastern Washington. Habitat value will be assessed before start of construction and losses will be mitigated based on the ecological value of the habitat disturbed. However, rather than implementing mitigation measures on a project-by-project basis, DOE is developing a Hanford Site-wide mitigation plan in cooperation with the State of Washington Department of Fish and Wildlife and the U.S. Fish and Wildlife Service. Negotiations with these agencies are in progress.

The impacted area at the ERDF site is estimated to be $2.6 \mathrm{~km}^{2}$ (650 acres or $1.0 \mathrm{mi}^{2}$ ) (U.S. Army Corps of Engineers 1994). Ecological impacts at the ERDF will be mitigated to the extent possible by using the deep area-fill trench configuration.

Ecological impacts will occur during construction of the rail spur. As shown in Figure 9-1, the rail spur passes through a variety of habitats containing sagebrush, Sandburg's bluegrass, cheatgrass, and Russian thistle. Assuming a length of $8 \mathrm{~km}$ (outside the ERDF), and an impacted width of $50 \mathrm{~m}(160 \mathrm{ft})$, the area impacted by the new rail spur will be approximately $0.4 \mathrm{~km}^{2}$.

Ecological impacts associated with development of the borrow sites will depend on the type of barrier included in the alternative. Estimated quantities of silt from McGee Ranch and basalt included in each barrier are provided in Section 9.3.9. The areas impacted are calculated assuming that the excavation depth will average $5 \mathrm{~m}$ (16 ft) at McGee Ranch and $10 \mathrm{~m}(33 \mathrm{ft})$ at the basalt borrow source.

\subsubsection{Impacts on Air Quality}

As discussed in Section 2.2.6, air quality at the Hanford Site is generally good. Construction and operation of the ERDF will result in dust generation and engine fumes (associated with vehicle and equipment operation). These impacts are discussed below.

As discussed in Section 9.3.5, ERDF construction and operation will result in a maximum of 310 vehicles per day on Hanford roads. Operation and construction of the ERDF is expected to result in an additional 50-100 vehicles per day within the ERDF. Air quality impacts associated with these vehicles are considered negligible. Dust generation will be monitored and kept below allowable limits using dust controls discussed in Section 9.3.2. 


\subsubsection{Impacts on Historical and Cultural Resources}

Significant historical or cultural resources have not been identified at the ERDF site or the proposed route of the new rail spur. Historic and prehistoric resources have been identified at McGee Ranch which could be disturbed or destroyed if the site was developed. Mitigation plans are currently being prepared. Development of a basalt borrow source may result in the degradation of basalt outcroppings that have cultural significance to Native Americans. This issue will be resolved with the Native Americans before development of the borrow source begins.

\subsubsection{Socioeconomic Impacts}

Construction of the ERDF will provide jobs and an influx of federal funds to the Tricity area. Although construction of the ERDF will be conducted in phases and the level of employment will fluctuate, it is estimated that construction will employ an average of 45 workers on the Hanford Site. Operation of the ERDF is expected to provide 167 full-time positions. It is expected that construction and operations would be spread over a period of approximately 30 years. The total number of jobs associated with the ERDF, approximately 210 , is a small percentage of the total employment at the Hanford Site.

As discussed in Section 9.4, the estimated total capital costs for the ERDF range from $\$ 246$ million to $\$ 663$ million for the different alternatives. Assuming that the costs are spread over 30 years, plus an annual operating budget of $\$ 20$ million, the total annual costs for the ERDF are estimated to range from $\$ 28$ million to $\$ 42$ million. This is approximately $2 \%$ of Hanford's current annual budget of approximately $\$ 1,600$ million.

Given the relatively small percentage of employment and funding associated with the ERDF compared with the Hanford Site as a whole, socioeconomic impacts due to the ERDF are considered negligible.

\subsubsection{Impacts on Visual Resources and Noise}

The ERDF is a low-lying facility that will result in minimal visual impact from ground level. Although construction and operation of the ERDF will detract from the natural beauty of the sagebrush ecology from elevated locations (such as the top of Rattlesnake Mountain), the barrier will be revegetated and natural vegetation will eventually return to impacted areas. The long-term impacts on visual resources at the Hanford Site are considered negligible.

Noise will be generated due to operation of equipment at the ERDF, the borrow sources, and during transport of waste and construction materials to the ERDF. If OSHA noise standards are exceeded, appropriate measures to protect workers will be employed. The ERDF, the borrow sources, and the transportation routes on the Hanford Site are not located near any residential communities. Consequently, noise impacts on humans are considered negligible. Wildlife will be impacted by noise near the ERDF, borrow sources, and transport routes. 


\subsubsection{Common Cost Factors}

Estimated costs for construction of ERDF facilities, permitting, trench excavation, liners, and barriers are provided in Table 9-7. The cost multipliers, which include overhead, profit, contingency and management, result in final costs that are approximately 90 percent higher than raw construction cost. The multipliers are added to raw construction costs to obtain the total cost for each item. The total cost for each alternative will include the costs for the liner, the barrier, excavation, permitting, and the supporting facilities. Costs for supporting facilities, permitting, and excavation (which will be the same for all the alternatives) are $\$ 75$ million, \$22 million, and \$109 million, respectively. Liner costs range from zero for the noliner alternatives to $\$ 167$ million for the RCRA double composite liner. Costs for the leachate collection system are $\$ 11$ million and are only included in alternatives with liners. Barrier costs range from $\$ 53$ million for the low-infiltration soil barrier to $\$ 373$ million for the Hanford Barrier. Since the barrier will be built after the trench is excavated and lined, a present worth adjustment is applied to the barrier costs. The present worth adjustment assumes that barrier costs will be incurred an average of 20 years after the rest of the cost are incurred and that the discount rate is 6 percent.

Operational costs are estimated to range from $\$ 15$ million to $\$ 25$ million per year over 25 years. The total operational cost is estimated to range from $\$ 375$ million to $\$ 625$ million with a present worth of $\$ 192$ million to $\$ 320$ million.

\subsubsection{Short-Term Worker and Public Risk}

Short-term risks associated with construction and operation of the ERDF are evaluated below for the ERDF workers, non-ERDF workers on the Hanford Site, and the public.

ERDF Worker Risk. This evaluation of ERDF worker risk during operation of the ERDF relies upon the methods and conclusions provided in the Source Inventory Development Engineering Study for the Environmental Restoration Disposal Facility (U.S. Army Corps of Engineers 1993b), also known as the Source Inventory Report (SIR). The SIR develops contaminant-specific soil concentrations associated with occupational regulatory limits. The exposure pathways evaluated are inhalation of fugicive dust, inhalation of volatile organics, and external exposure to radiation. Therefore, the regulatory limits of interest are those related to occupational air exposure and external radiation dose (see Chapter 5 of the SIR for a listing of the occupational criteria considered). Limits for ingestion, dermal absorption and skin and/or eye contact were not determined because they are not probable exposure pathways. Personnel normally occupying the ERDF trench will include heavy equipment operators and truck drivers. These personnel will normally be inside an enclosed cab with filtered air, so there will not be direct contact with constituents under normal operating conditions.

In order to relate occupational air concentration criteria to soil concentrations, the SIR assumes a dust concentration (in air) of $10 \mathrm{mg} / \mathrm{m}^{3}$. Using this factor, the SIR provides constituent soil concentrations associated with occupational limits for exposure to contaminants in air. Soil concentrations of volatile contaminants are also calculated by using contaminantspecific volatilization factors. These "occupational soil concentration limits" are provided in Tables 8, 9, and 10 of the SIR for inorganic constituents, organic compounds, and radionuclides, respectively. In addition, radionuclide soil concentration limits based on external exposure are provided in Appendix J of the SIR. 
The maximum detected soil concentration of each contaminant (presented in Tables 3-8, 3-9, and 3-10 of this report) are compared to its respective occupational soil concentration limit(s) (found in Tables 4, 5, and 6 of the SIR) to determine which contaminants pose potential health hazards to the working population. The results are discussed below:

- For the inorganic contaminants, most maximum detected concentrations are less than the occupational soil concentration limits by more than an order of magnitude. Only copper and iron are roughly equal to or exceed the soil criteria $(95,300 \mathrm{mg} / \mathrm{kg}$ vs. $100,000 \mathrm{mg} / \mathrm{kg}$, and $184,000 \mathrm{mg} / \mathrm{kg}$ vs. 100,000 $\mathrm{mg} / \mathrm{kg}$, respectively).

- All of the organic compound soil concentrations are less than the occupational limits, most by at least three orders of magnitude.

- $\quad$ For the inhalation pathway, plutonium-239/240 (2,800 pCi/g) and uranium-238 $(9,143 \mathrm{pCi} / \mathrm{g})$ are present at concentrations that exceed occupational soil concentration limits $(500 \mathrm{pCi} / \mathrm{g}$ and $3,000 \mathrm{pCi} / \mathrm{g}$, respectively). In addition, plutonium-238 and uranium-234 have maximum detected soil concentrations that are slightly below their occupational soil concentration limits. It is important to note that the maximum plutonium concentrations are associated with a process effluent pipeline, such that these concentrations are not representative of a large volume of a material, and may be in a form that is not readily suspended as dust.

For the external exposure pathway, maximum detected radionuclide concentrations (presented in Table 3-8 of this report) are compared to criteria based on $5 \mathrm{rem} / \mathrm{yr}$ (Appendix $\mathrm{J}$ of SIR). This comparison indicates that cesium-137 $(110,000 \mathrm{pCi} / \mathrm{g}$ vs. $10,000 \mathrm{pCi} / \mathrm{g})$, cobalt-60 (11,000 pCi/g vs. $2,000 \mathrm{pCi} / \mathrm{g})$, europium- $152(29,000 \mathrm{pCi} / \mathrm{g}$ vs. $5,000 \mathrm{pCi} / \mathrm{g})$, and europium-154 $(9,200 \mathrm{pCi} / \mathrm{g}$ vs. $5,000 \mathrm{pCi} / \mathrm{g})$ all exceed their respective criteria.

It is important to note the conservative biases inherent in this analysis. The occupational air concentration limits and radiation dose criteria used in this evaluation assume continuous exposure during a working year. The maximum detected soil concentrations assumed in this analysis are not representative of average contaminant concentrations that would be deposited in the ERDF (see Section 6.1.4 for a more thorough discussion). The period of exposure to the maximum detected concentrations would be small because these concentrations are expected to represent only small volumes of waste. Furthermore, this analysis does not account for institutional controls, field monitoring during ERDF operation, and use of personal protective equipment, each of which will reduce exposure to contaminants.

An additional conservative bias is that the assumed dust concentration of $10 \mathrm{mg} / \mathrm{m}^{3}$ is probably not representative of actual exposure conditions. To put this in perspective, the SIR indicates that the maximum dust concentration observed in the Tri-City area during a dust storm is approximately $1.7 \mathrm{mg} / \mathrm{m}^{3}$. Travis et al. (in press) use a resuspension factor of $0.5 \mathrm{mg} / \mathrm{m}^{3}$ for earth-moving activities. This factor assumes that $10 \%$ of the resuspended dust particles are of respirable size $(<20 \mu \mathrm{m})$ and that dust is suppressed by surface wetting. Therefore, it is reasonable to assume that the dust concentration used in this analysis $\left(10 \mathrm{mg} / \mathrm{m}^{3}\right)$ is potentially an order of magnitude too high. Given the conservative bias of the assumptions, this analysis should be considered a screening of potential hazards associated with worker exposure to contaminants. 
The analysis presented above only considered exposure to soil contaminants. Bulk materials present in burial grounds (containing waste from reactor operations) present an additional potential external exposure hazard. Historical field measurements indicate that dose rates as high as 1 to $5 \mathrm{rem} / \mathrm{hr}$ were common for the 105-B burial ground. However, such data do not differentiate between short-lived radionuclides (many of which will have decayed to negligible levels) and those that may still be a concern. Chapter 6 of the SIR provides an evaluation of burial grounds based on historical field data. With respect to ERDF operations, such materials will require characterization during remediation to determine appropriate handling practices.

This analysis indicates that there are a number of contaminants of potential concern to workers during ERDF operation. These contaminants are alpha-emitting radionuclides (a concern via inhalation) and high-energy gamma emitters (a concern via external exposure).

It is noted that it is not acceptable to expose workers to contaminants at the occupational soil concentration limits without justification. A number of contaminants are known or probable human carcinogens, and it is generally assumed that there is no safe dose which will not elicit a carcinogenic response. Although it is likely that occupational exposure criteria will not be exceeded, the as low as reasonably achievable (ALARA) principle should be practiced.

Physical Hazards to ERDF Workers. Construction and operation of the ERDF will expose workers to physical hazards that can result in accidental injury to workers. The risk associated with these physical hazards can be quantified by multiplying the labor requirements by the injury rate to estimate the expected number of accidents. Injury rates can vary considerably for different activities and a detailed analysis of physical risk would account for these variations. For purposes of this document, however, a more general approach that treats all labor as general construction activity will be utilized.

The number of person days for trench excavation, liner construction, and barrier construction are provided in Sections 9.3.7, 9.3.8, and 9.3.9. Although operation of the ERDF is not truly a construction activity, many of the associated activities are similar to construction. The total number of employees for operation of the ERDF is estimated to be 167 . Approximately 40 of these jobs are administrative or supervisory in nature and would entail relatively little physical risk. Assuming 230 work days in a year, the total number of worker days associated with operation of the ERDF is 29,000 days per year. Assuming the facility operates for 25 years, the total number of worker days is 725,000 .

Based on statistics from the U.S. Department of Labor (1992), construction workers have a fatality rate of $6 \times 10^{-7}$ per person day and a lost-time injury rate of $2 \times 10^{-4}$ per person day. Since fatalities are of most concern, only the fatality rate is used in the evaluations. The expected number of fatalities for each construction activity and ERDF operation are summarized below. 
DOE/RL-93-99, Rev. 0

Expected Number of Worker Fatalities Due to Physical Hazards

\begin{tabular}{|l|c|c|}
\hline Activity & Worker Days & Expected Fatalities \\
\hline Trench Excavation & 110,000 & 0.066 \\
\hline Single Liner & 40,000 & 0.024 \\
\hline Double Liner & 79,000 & 0.047 \\
\hline Low-Infiltration Soil Barrier & 21,000 & 0.013 \\
\hline Modified Hanford Barrier & 27,000 & 0.016 \\
\hline Hanford Barrier & 84,000 & 0.050 \\
\hline ERDF Operation & 725,000 & 0.44 \\
\hline
\end{tabular}

Risks to Non-ERDF Hanford Workers and the Public. The facility hazard classification (Cain 19n4) provides qualitative evaluations of potential radiological impacts of ERDF operations and accident conditions to non-ERDF Hanford Site workers and the public. The impacts were evaluated for three scenarios: normal operations, abnormal occurrence of continuous strong winds $(113 \mathrm{~km} / \mathrm{hr}$ [70 mph]) for 24 hours, and a container breach. In all cases, risks were characterized as low. Impacts from hazardous (non-radioactive) contaminants were not evaluated.

\subsubsection{Irreversible and Irretrievable Commitment of Resources}

The ERDF will require an irreversible and irretrievable commitment of the following resources:

- liner material

- borrow material

- natural resources

- $\quad$ building and facility construction materials

- energy

The liner and borrow materials required are discussed in Sections 9.3.8 and 9.3.9, respectively. The natural resources affected are described in Section 9.3.10. The buildings and support facilities will require standard construction materials that are readily available, and constitute a resource commitment that is relatively minor compared to the materials required for construction of the ERDF trench. The primary energy usage will be for operation of equipment. 


\subsubsection{Indirect and Cumulative Effects}

Indirect effects associated with construction and operation of the ERDF include influencing remedial decisions across the Hanford Site. The existence of a Hanford Site-wide waste management facility for remedial wastes will minimize implementability difficulties associated with alternatives that include excavation of the waste. Without a centralized waste management facility to receive the treated or untreated waste, remedies that include excavation would score lower in terms of implementability. This is because of the potential difficulties associated with permitting and constructing such a facility. As a result, in-situ remedies (e.g., in-situ treatment and in-situ containment) would score higher and would have a higher likelihood of being the preferred remedy. In-situ remedies for operable units in the 100 and 300 Areas would result in more waste being left near the Columbia River.

Cumulative impacts will be associated with other actions on the Hanford Site. Actions that will have similar impacts as the ERDF include primarily construction and remediation activities. These activities will potentially involve destruction of habitat, disturbance of wildlife, utilization of borrow materials, increased traffic, job creation, and releases of waste constituents to air and water.

Current or planned Hanford Site activities not addressed in this analysis that may increase cumulative effects include the following:

- Construction of new double-shelled tanks in the 200 Area;

- Terminal cleanout of chemical processing facilities (such as PUREX, PFP, UO3) in the 200 Area and decontamination and decommissioning of these and other retired Hanford Site surface facilities;

- Potential construction of a waste vitrification facility in the 200 Area;

- Operation of the US Ecology commercial low-level landfill located just east of the ERDF location;

- Operation of the low-level burial grounds in the 200 Area and the NonRadioactive Dangerous Waste Landfill located approximately $8 \mathrm{~km}(5 \mathrm{mi})$ southeast of the ERDF;

- Environmental restoration activities in the 100, 200, and 300 Areas; these activities may involve soil excavation and disposal activities, groundwater extraction, treatment, and disposal, construction and operation of treatment facilities, and construction of containment structures such as slurry walls and barriers;

- Operation of the 200 Area Effluent Treatment Facility Disposal Site. 


\subsubsection{Mitigation of Impacts from the ERDF}

Impacts on resources due to construction and operation of the ERDF will be mitigated to the extent possible. Mitigation considerations that have been incorporated into the facility design include the following:

- Use of the deep area-fill trench configuration (described in Section 9.3.7) to minimize the amount of land disturbed at the ERDF and the quantity of liner and cover materials;

- Rerouting of the rail spur to avoid impacts on undisturbed portions of potentially historic White Bluffs road;

- Limiting consideration of barriers to those that are specifically designed to minimize infiltration through the waste and therefore minimize groundwater impacts and are at least 15 feet thick to eliminate the inadvertent intrusion pathway associated with foundation excavation;

- Implementation of institutional controls (described in Section 9.3.1) to minimize hazards to workers and the public during construction, operation, and postclosure;

- Implementation of dust controls (described in Section 9.3.2) to minimize airborne releases during waste transport and placement;

- Implementation of surface water management (described in Section 9.3.3) controls to minimize the potential for releases due to surface water transport;

- Grouting void space in the waste (described in Section 9.3.6) to minimize the potential for settlement that might reduce the effectiveness of the barrier;

- $\quad$ As described in Section 9.3.6, emergency equipment will be available on site and the workers will receive emergency response training to minimize the impacts of any accidents;

- Any clearing of the site in preparation for construction will not be conducted during nesting season to ensure that wildlife is not destroyed, but only displaced.

In addition, habitat value will be assessed before the start of construction and losses will be mitigated based on the value of the disturbed habitat. DOE is currently developing a Hanford Site-wide mitigation plan in cooperation with the State of Washington Department of Fish and Wildlife and the U.S. Fish and Wildlife Service.

\subsubsection{Corrective Action Management Unit (CAMU) Evaluation}

The ERDF is proposed to accept both CERCLA and RCRA remediation waste as part of the overall remediation strategy at Hanford. As such, evaluation of ERDF suitability is following both RCRA and CERCLA decision processes. Evaluation of the ERDF could have occurred solely as part of the operable units' RODs or permit modifications. However, this 
separate evaluation of ERDF provides several advantages: it allows a more thorough evaluation of the entire proposed facility (as opposed to merely the portion that may be required for any single operable unit), and it expedites remediation by allowing design and construction of the ERDF prior to final RODs/permit modifications for the operable units, thereby allowing movement of waste to occur quickly once the remediation strategy for the operable units is finalized. A separate evaluation of the suitability of ERDF for receipt of specific operable unit waste streams will be included in the remedy selection process for each operatle unit. Each individual operable unit's ROD/permit modification will specify how waste from that operable unit may be managed and will reference, as appropriate, placement of waste in the ERDF.

The ERDF is being proposed as a Corrective Action Management Unit (CAMU). The CAMU rule provides an option for on-site management of remediation waste previously not available to facilities remediating materials subject to RCRA. The CAMU regulations were promulgated to promote active remediation of contaminated sites, as opposed to merely capping in place, by allowing more flexibility in management of remediation waste, without compromising human health or the environment.

In the preamble to the CAMU rule, EPA stated its expectation that the substantive CAMU rule requirements will be applicable or relevant and appropriate requirements (ARARs) for the remediation of many CERCLA sites, especially those sites where CERCLA remediation involves the management of RCRA hazardous wastes. EPA determined that, in the CERCLA context, CAMU requirements that are designated to be ARARs would be incorporated into CERCLA decision documents, rather than RCRA permits or orders. This would allow remediation under CERCLA of RCRA hazardous waste at Federal facilities that are listed on the National Priorities List. For this reason, the seven decision criteria required under the CAMU regulations are evaluated below.

CAMU Criterion No. 1: The CAMU shall facilitate the implementation of reliable, effective, protective, and cost-effective remedies:

As demonstrated by the risk assessment in Appendix A, operation of the ERDF as a CAMU for placement of waste that meets the risk-based ERDF leachate criteria will be protective of human health and the environment for at least 10,000 years. Alternatives considered are both effective and reliable.

Current conditions consist of waste sites immediately adjacent to the Columbia River without significant engineered controls over infiltration or migration of constituents. Among the range of remedial options for these sites available in the absence of a CAMU are capping the waste in place; consolidation of wastes within the areas of contamination along the river; in-situ stabilization or treatment; and excavation, full LDR characterization, and best demonstrated available technology (BDAT) treatment of the waste prior to disposal.

The ERDF site is located in an area remote from the Columbia River and the public

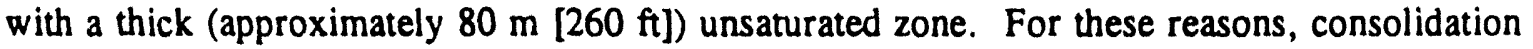
of remediation waste at the ERDF Site will be more reliable, effective, and protective than either current conditions, capping the waste in place or in-situ treatment at the multitude of small sites along the river, or consolidation of the untreated waste within the riverside areas of contamination. 
Based on the demonstration of protectiveness in the risk assessment, waste characterization sufficient to demonstrate achievement of the ERDF waste acceptance criteria standards can be performed consistent with the observational approach and need not meet the restrictive standards that might apply were LDRs fully applicable to the waste. Without a CAMU designation, waste excavated in remediation of the 100 and 300 Areas may require full LDR waste code characterization and BDAT treatment, without providing any significant benefit in risk reduction, at a cost estimated to be approximately five to ten billion dollars. Expenditure of an additional five to ten billion dollars without significant risk reduction is not cost-effective.

Operation of the ERDF as a CAMU therefore will be: protective, effective, and reliable when measured independently against risk standards; significantly more protective, effective, and reliable than remedial options that would leave untreated waste near the river; and equally as protective but significantly less costly than other excavation and disposal waste management options.

ERDF will be protective of human health and the environment and a reliable, effective, protective, and cost-effective remedy because it will:

- Isolate hazardous/dangerous waste and radioactive waste and constituents to a single, manageable facility in a remote, arid, hydrogeologically protected area;

- Remove hazardous/dangerous materials from current locations close to the Columbia River and to sensitive environmental receptors;

- Contain hazardous/dangerous and radioactive material within a unit designed to offer both long-term and short-term protection of the environment;

- Accept only those remediation wastes in a concentration or form that will not allow the contaminants to migrate to groundwater at a concentration in excess of health-based standards at the point of assessment;

- Be much more cost-effective than other active remediation alternatives.

CAMU Criterion No. 2: Waste management activities associoted with the CAMUs shall not create unacceptable risks to humans or to the environment resulting from exposure to hazardous wastes or hazardous constituents:

The risk assessment in Appendix A demonstrates that operation of ERDF as a CAMU will not pose long-term risks to human health or the environment from exposure to hazardous or radioactive wastes or constituents. Furthermore, the evaluation of short-term effectiveness demonstrates that there will be no significant risk to workers or the public due to waste releases during operation of the ERDF.

Although risk due to waste releases during operations will be below acceptable levels, placement of interim cover materials on a daily basis and use of dust suppression technology at the ERDF will mitigate potential airborne contaminant transport to the extent possible. In addition, use of equipment such as dust filters will further protect worker health by decreasing potential for inhalation of dust particles. 
Significant operational constraints and controls shall be in place to minimize both the risk of occurrence of air emissions, and the potential impact if any emissions were to occur. The operations plan will assure waste management activities are properly conducted within the ERDF; the site-specific emergency and training plan will establish procedures to prevent hazards; personnel will be appropriately trained and emergency situations handled appropriately, or avoided altogether.

In summary, the ERDF will not create unacceptable risks to human health or the environment because it: provides long-term protection from unacceptable risks by deterring intrusion and preventing contaminant migration in excess of health-based risk levels; mitigates short-term exposure to contaminants from air transport by use of interim cover, dust suppression, and HEPA filters; and ensures that ERDF personnel are appropriately trained and procedures are in place to avoid, reduce, and mitigate potential hazards.

CAMU Criterion No. 3: The CAMU shall include uncontaminated areas of the facility, only if including such areas for the purpose of managing remediation waste is more protective than management of such waste at contaminated areas of the facility:

Because the contaminants of concern in the 100 and 300 Area waste consist of longlived radionuclides and metals, the main factor that will provide long-term protection to human health and the environment is isolation of the waste from the public, the river and groundwater. Such isolation cannot physically be accomplishe' within the riverside areas of contamination to the degree possible at the ERDF site.

Consolidation of waste within one facility rather than dispersing it mong several locations on the 200 Area plateau will be more protective both in the short term and in the long term. Use of a single ERDF site rather than multiple sites allows for better performance monitoring, is less costly, and offers less opportunity for hazards to arise because there is only one site at which such situations could arise. Prevention of degradation of the cover or inadvertent intrusion would be easier in the long term for a single ERDF site than for multiple dispersed waste locations.

Although the proposed ERDF site does not contain surface soil contamination, preexisting groundwater contamination is present below the ERDF site. The source of this contamination is upgradient of the ERDF. The ERDF site, therefore, is not a pristine location.

Because of the nature of the radioactive contaminants found in the surface-contaminated areas of the Hanford Site, construction of the ERDF in an area of surface contamination would pose greater risk to workers, the public, and the environment than construction at the proposed location. Construction of the ERDF in an area of surface contamination could expose the construction workers to radiation, and would involve a higher short-term risk to the public and the environment because radioactive contaminants could become air borne during facility construction. The proposed ERDF location is completely within the boundaries of the exclusive waste management area selected by the Hanford Future Site Uses Working Group for consolidation of long-term waste management activities. In evaluating the possible locations for ERDF, significant weight was given to the public input represented by the Future Site Uses Group Report. 
Criterion No. 3 is met because the ERDF site will provide a more protective location than management of the wastes within the riverside areas of contamination or at locations on the 200 Area plateau with surface contaminated areas.

CAMU Criterion No. 4: Areas within the CAMU, where wastes remain in place after closure of the CAMU, shall be managed and contained so as to minimize future releases, to the extent practicable:

As described previously, the ERDF is planned to provide protective waste containment. The ERDF will be capped with a protective barrier designed to prevent infiltration, deter intrusion, and minimize releases to the extent practicable. The final barrier will minimize releases of contaminants by controlling dust and limiting infiltration.

The post-closure plan includes inspections and maintenance to ensure that the final barrier integrity is maintained. Groundwater monitoring will be conducted to detect any releases during the operational and post-closure periods. Institutional controls will prevent intrusion and unintentional releases during the post-closure period. Consolidation of waste into a single ERDF unit will facilitate long-term monitoring and maintenance and minimize the risk of inadvertent intrusion and release of contaminants.

The ERDF will therefore meet the requirement to minimize releases to the extent practicable, by means of its single unit design, protective barrier, groundwater protectiveness (as demonstrated in the RI/FS risk assessment) and release prevention procedures.

CAMU Criterion No. 5: The CAMU shall expedite the timing of remedial activity implementation, when appropriate and practicable:

As described previously, placement of waste in the ERDF that meets the ERDF leachate criteria will be protective of human health and the environment for 10,000 years. Performance of this evaluation and authorization of the ERDF as a CAMU will allow remediation to proceed quickly for those operable units that select ERDF as part of their preferred remedial option.

Consolidation of waste into the single ERDF CAMU requires only one analysis to determine whether the site and design will be protective of human health and the environment. If multiple sites or designs were to be used, multiple analyses would be required to demonstrate protectiveness, which would require significantly more time and resources to complete.

Operation of ERDF as a CAMU will allow for flexibility in the time consuming and expensive processes of full LDR characterization and BDAT treatment, while still providing full protectiveness of human health and the environment. The protectiveness sought to be achieved by LDRs can be attained by operating the ERDF in compliance with the ERDF waste acceptance criteria, and operations need not conform to the unnecessarily restrictive LDR requirements. Because operation of the ERDF as a CAMU using the ERDF leachate criteria provides a high level of protectiveness, characterization can be allowed to proceed consistent with the expedited timing that can be achieved under the observational approach. 
CAMU Decision Criteria No. 6: The CAMU shall enable the use, when appropriate, of treatment rechnologies (including innovative technologies) to enhance the long-term effectiveness of remedial actions by reducing the toxicity, mobility, or volume of wastes that will remain in place after closure of the CAMU:

Acceptable soil and leachate concentrations to protect human health and the environment are developed in Appendix $C$. The acceptable soil concentrations are intended to address the risk associated with intrusion into the ERDF wastes and the acceptable leachate concentrations are intended to address impacts on groundwater.

In order to address the potential for intrusion into the waste, acceptable soil concentrations were determined based on the 500-year drilling scenario. Based on this evaluation, approximately 40 constituents are determined to have the potential for causing exposures resulting from intrusion greater than risk-based standards (although only copper has been detected at concentrations that exceed its acceptable soil concentration). These constituents are primarily metals or radionuclides and no treatment is available for reducing the toxicity of these constituents (except reduction of chromium VI to chromium III). Furthermore, treatment to reduce the mobility of the constituents will not reduce the risk associated with the intrusion scenario and treatment to reduce the volume of the wastes will increase contaminant concentrations and thus risk. Therefore, treatment of waste will not enhance long-term effectiveness in terms of the intrusion scenario.

As demonstrated in Appendix C, 10 chemicals have the potential to migrate into groundwater in excess of the health standards within 10,000 years. Of these ten contaminants, only three are subject to LDR treatment standards. The ERDF acceptable leachate concentrations establish standards for these three contaminants that are more stringent than the applicable LDRs. Any prospective ERDF waste found to exceed the ERDF waste acceptance criteria for one or more of these three constituents, therefore, will be treated to a level that would meet the LDR treatment standard, if it were applicable.

The other seven contaminants of concern are not subject to LDRs. For these contaminants, the ERDF leachate criteria establish stringent standards that will be protective of human health and the environment for 10,000 years. Any prospective ERDF waste found to exceed the ERDF leachate criteria for one or more of these constituents will be treated to conform to the ERDF health-based standard.

Treatment of waste will be undertaken based on evaluations and remedial decisions made at the operable units. Feasible treatment that will enhance long-term effectiveness and protectiveness will be undertaken. Treatment that will have no benefit to protectiveness will not be required. In particular, since treating to LDR requirements would not provide any significant benefits in terms of long-term effectiveness, it will not be required.

Because the Hanford Site remediation wastes will consist primarily of soil and debris contaminated with metals and radionuclides, there is no known destruction (toxicity reduction) treatment that can be applied. Significant quantities or concentrations of organics, for which destruction treatment technologies may exist, are not expected to be encountered. If any significant quantities or concentrations of organics are encountered during remediation, an evaluation of potential treatment options by the affected operable unit will be required. 
Immobilization is considered to be the most likely treatment technology to be used if needed to meet the standards set for contaminants of concern in the ERDF waste acceptance criteria.

The feasibility of volume reduction treatment is heavily dependant on specific physical and chemical parameters of the target waste stream. It is believed that volume reduction technology may be a feasible option for some operable unit wastes. Volume reduction treatability tests are currently being conducted at operable units in the 100 and 300 Areas.

It is anticipated that the bulk of the waste to be emplaced at the ERDF will be highvolume, low concentration (e.g., toxicity). The CAMU preamble states that "Given the example, therefore, of a situation involving large volumes of low concentration contaminated soils or other wastes, the Regional Administrator would have the discretion to evaluate containment-based remedial approaches."

Based on the demonstration of protectiveness in the RI/FS, and the CAMU preamble which allows the discretion to consider containment for waste of the type expected to be received at ERDF, it is reasonable to authorize operation of ERDF as a CAMU subject only to the treatment limitations imposed by the ERDF waste acceptance criteria. Such authorization will not preclude use of treatment technologies where such technologies will have a beneficial result in reduction of risk to human health or the environment, but it also will not require the use of treatment when no significant benefit can be gained by such treatment.

CAMU Criterion No. 7: The CAMU shall, to the extent practicable, minimize the land area of the facility upon which wastes will remain in place after closure of the CAMU:

ERDF will consolidate, within a single unit, waste material from around the Hanford Facility, thereby maximizing the area which will be available for future use, and minimizing the land area upon which wastes would remain after closure. Because of the dispersed nature of the waste units and the need for sufficient buffer zones around each of the waste units, it is estimated that remediation wastes within the 100, 200, and 300 Areas cover as much as approximately $28.5 \mathrm{~km}^{2}\left(11 \mathrm{mi}^{2}\right)$. The ERDF trench covers approximately $1.24 \mathrm{~km}^{2}\left(0.48 \mathrm{mi}^{2}\right)$, which represents a reduction in areal extent of up to 95 percent.

Furthermore, the size of ERDF itself has been minimized to the extent practicable by designing it as a single evolving trench. The single trench design minimizes the space needed for waste placement, and the evolving trench concept assures that only the amount of trench actually needed for waste management will be built.

Thus, ERDF will meet the criterion for space minimization both by consolidating waste from multiple waste units and by minimizing the amount of space needed for the ERDF itself.

CAMU Specifications. In addition to the determination that the proposed CAMU will meet all of the substantive requirements of the seven CAMU criteria, the regulatory agency is required to specify certain information in its order, permit or remedy selection document relating to the physical and operational aspects of the CAMU. As described below, information sufficient to make these specifications is contained in the Regulatory Package. 
The areal configuration of the ERDF CAMU will be a single trench built as a series of cells approximately 23,225 square meters $(250,000$ square feet $)$ in area each. The total trench dimensions may be as much as 305 meters (1000 feet) wide, 2740 meters ( 9000 feet) long and 21.3 (70 feet) deep. The final size may be less than the projected maximum because only the amount of trench needed to contain remediation waste generated in Hanford Site cleanup will be built.

ERDF operations will be conducted in a manner that is protective of human health and the environment and consistent with the CAMU designation. Waste proposed for placement at the ERDF CAMU shall be characterized at the operable unit consistent with the observational approach. The operable unit will either determine that the waste will meet ERDF waste acceptance criteria, or determine appropriate treatment or other waste management options. The majority of waste will be sent in bulk containers either by rail or truck and tipped into the ERDF trench. Air emissions will be abated by use of interim cover and dust suppression technology.

ERDF will be closed with the waste in place, covered by a final barrier that will deter intrusion, limit infiltration and minimize the need for long-term maintenance. Equipment, devices and structures used in support operations will be removed and decontaminated, or if decontamination is not possible, placed into the trench prior to installation of the final barrier. The RI/FS modeling has demonstrated that closure of ERDF with the waste in place under a final barrier that limits infiltration will protect human health and the environment, and minimize post-closure escape of hazardous waste, hazardous constituents, leachate, contaminated runoff, or hazardous waste decomposition products to the ground, to surface waters, or to the atmosphere.

The post-closure plan for ERDF shall assure protection of human health and the environment by means of monitoring and maintenance activities performed at a frequency that will ensure the integrity of the final barrier.

Groundwater will continue to be monitored around the ERDF site during operation and the closure/post-closure period by means of the groundwater well monitoring network described in the CAMU Application. The monitoring shall detect and characterize releases from ERDF or from other sources around ERDF.

Summary. As described above, the ERDF will meet all CAMU decision criteria, and operation of the ERDF as a CAMU will be fully protective of human health and the environment. Therefore, designation of the ERDF as a CAMU at this time is appropriate.

\subsection{DETAILED EVALUATION}

This section provides the detailed evaluation of each alternative in terms of the applicable CERCLA criteria described in Section 9.2. Alternative scores for each subcriteria are provided in Tables 9-8 through 9-12. Quantitative scores were utilized when available. For all the qualitative criteria, "high" is considered best and "low" is considered worse. Overall rankings for each primary criteria were determined by normalizing the subcriteria scores on a scale of zero to 1 and weighting the subcriteria. Qualitative scores were normalized by setting "low" equal to 0 , "medium" equal to 0.5 , and "high" equal to 1 . Normalized quantitative scores are provided in the tables. The rationale for the subcriteria weighting is provided in 
Section 9.2. Total scores for each criteria are obtained by summing the products of the weights and the subcriteria scores.

\subsubsection{Alternative 1 - No Action}

Evaluation of the no-action alternative is required under CERCLA (40 CFR 300.430(e)(6)). The no-action alternative for this FS consists of not constructing a centralized waste management unit on the Hanford Site to accommodate remediation waste from Hanford Site past-practice operable units. Implementation of the no-action alternative would likely result in the necessity for each operable unit to develop alternatives that are limited to in-situ remedial actions, or excavation and disposal at the operable unit. These alternatives would result in waste remaining dispersed across the Hanford site, including near the Columbia River. The noaction alternative is not evaluated against the standard CERCLA criteria given the uncertainty in the selected remedies if the ERDF is not constructed. It should be noted, however, that the noaction alternative will not satisfy the purpose stated in section 1.2 to "support the removal of contaminants from portions of the Hanford Site (including near the Columbia River) in a timely manner".

\subsubsection{Alternative 2 - No Liner and the Low-Infiltration Soil Barrier}

This alternative consists of an unlined trench and a low-infiltration engineered soil barrier (as described in Section 8.5.1). The barrier prevents direct exposure to the waste and includes a vegetated surface layer of fine-grained soils to retain moisture and encourage evapotranspiration, thereby minimizing infiltration and vadose zone transport of contaminants to groundwater. The upper $60 \mathrm{~cm}$ of the soil cover system is composed of an admixture of silt and gravels. This layer is intended to both reduce infiltration through the cover and to enhance the resistance of the cover to burrowing animals and long-term wind erosion. Institutional controls and the other common elements described in Section 9.3 are included with this alternative. Evaluations of this alternative against the relevant CERCLA criteria are provided below.

Long-Term Effectiveness and Permanence. Based on the results presented in Appendix A, none of the contaminants reach groundwater within 10,000 years for this scenario under current climate conditions. Under the hypothetical wetter climate, as presented in Table 9-8, this alternative results in a total ICR of $3 \times 10^{-4}$ and a HQ of 7 within 10,000 years. This alternative, along with the other alternatives that utilize the low-infiltration soil barrier, performs slightly poorer than the alternatives with the modified Hanford or Hanford barriers and is scored low in terms of groundwater protection.

Reliability scores are provided in Table 9-9. As discussed in Sections 9.3.8 and 9.3.9, this alternative scores low for both liner and barrier reliability. This aiternative performs worst in term of long-term effectiveness.

Short-Term Effectiveness. Scores for each of the short-term effectiveness sub-criteria are summarized in Table 9-10. The expected number of worker fatalities was determined by summing the expected fatalities for excavation, construction of the low-infiltration soil barrier, and ERDF operations as presented in Section 9.3.16. The expected number of worker fatalities for this alternative $(0.519)$ is the lowest for all the alternatives. The total impacted area at the 
silt borrow source is $0.14 \mathrm{~km}^{2}$, which is tied for the lowest, and no basalt is used. Therefore, this alternative performs best in terms of short-term effectiveness.

Implementability. Implementability scores are summarized in Table 9-11. This alternative has 3 layers in the barrier and no liner, giving it the best technical implementability score.

Cost. As summarized on Table 9-12, the total net present value for this alternative is $\$ 500$ million. This is the lowest cost alternative.

\subsubsection{Alternative 3 - No Liner and the Modified Hanford Barrier}

This alternative consists of an unlined trench and the modified RCRA barrier (as described in Section 8.5.6). The barrier prevents direct exposure to the waste and includes a vegetated surface layer of fine-grained soils to retain moisture and encourage evapotranspiration, thereby minimizing infiltration and vadose zone transport of contaminants to groundwater. The upper $50 \mathrm{~cm}$ ( $20 \mathrm{in}$.) of the soil cover system is composed of an admixture of silt and gravels. This layer is intended to both reduce infiltration through the cover and to enhance the resistance of the cover to burrowing animals and long-term wind erosion. In addition, a 15-cm (6-in.) thick asphalt layer provides secondary protection against both infiltration and intrusion. Institutional controls and the other common elements described in Section 9.3 are included with this alternative. Evaluations of this alternative against the relevant CERCLA criteria are provided below.

Long-Term Effectiveness and Permanence. Based on the results presented in Appendix A, none of the contaminants reach groundwater within 10,000 years for this scenario under current climate conditions. Under the hypothetical wetter climate, this alternative results in a total ICR of $2 \times 10^{-5}$ and a maximum HQ of 0.8 within 10,000 years and this alternative scores high in terms of groundwater protection (Table 9-8).

Reliability scores are summarized in Table 9-9. As discussed in Sections 9.3.8 and 9.3.9, this alternative scores low on liner reliability and medium on barrier reliability.

Short-Term Effectiveness. Scores for each of the short-term effectiveness sub-criteria are summarized in Table 9-10. The expected number of fatalities was determined by summing the expected fatalities for excavation, construction of the modified Hanford barrier, and ERDF operations as presented in Section 9.3.16. The estimated worker fatalities for this alternative ( 0.522$)$ ranks second best. The total impacted area at the silt borrow source is $0.26 \mathrm{~km}^{2}$, which is average, and no basalt is used. This alternative has the 4 th best short-term effectiveness score.

Implementability. Implementability scores are summarized in Table 9-11. This alternative has 9 layers in the barrier and no liner, resulting in a medium score for technical implementability.

Cost. As summarized on Table 9-12, the total net present value for this alternative is $\$ 600$ million. This is the third lowest cost alternative. 


\subsubsection{Alternative 4 - No Liner and the Hanford Barrier}

This alternative consists of an unlined trench and the Hanford Barrier (as described in Section 8.5.6). The barrier prevents direct exposure to the waste and includes a vegetated surface layer of fine-grained soils to retain moisture and encourage evapotranspiration, thereby minimizing infiltration and vaduse zone transport of contaminants to groundwater. The upper 1 $\mathrm{m}$ (3.28 $\mathrm{ft})$ of the soil cover system is composed of an admixture of silt and gravels. This layer is intended to both reduce infiltration through the cover and to enhance the resistance of the cover to burrowing animals and long-term wind erosion. A $1.5-\mathrm{m}(4.9-\mathrm{ft})$ thick crushed basalt layer beneath the evapotranspiration zone provides additional protection against intrusion. In addition, a $15-\mathrm{cm}$ (6-in.) thick asphalt layer provides additional protection against both infiltration and intrusion. Institutional controls and the other common elements described in Section 9.3 are included with this alternative. Evaluations of this alternative against the relevant CERCLA criteria are provided below.

Long-Term Effectiveness and Permanence. Based on the results presented in Appendix A, none of the contaminants reach groundwater within 10,000 years for this scenario under current climate conditions. Under the hypothetical wetter climate, this alternative results in a total ICR of $2 \times 10^{-5}$ and a HQ of 0.8 within 10,000 years (Table 9-8) and is considered high in terms of groundwater protection.

Reliability scores are summarized in Table 9-9. As discussed in Sections 9.3.8 and 9.3.9, this alternative scores low on liner reliability and high on barrier reliability.

Short-Term Effectiveness. Scores for each of the short-term effectiveness sub-criteria are summarized in Table 9-10. The expected number of fatalities was determined by summing the expected fatalities for excavation, construction of the Hanford barrier, and ERDF operations as presented in Section 9.3.16. The estimated worker fatalities for this alternative (0.556) ranks 5th best. The total impacted area at the silt borrow source is $0.54 \mathrm{~km}^{2}$, which is tied for last, and the impacted area at the basalt borrow source is $0.22 \mathrm{~km}^{2}$. Overall, this alternative is ranked 7 th for short-term effectiveness.

Implementability. Implementability scores are summarized in Table 9-11. This alternative has 11 layers in the barrier and no liner, giving it a medium technical implementability score.

Cost. As summarized on Table 9-12, the total net present value for this alternative is $\$ 740$ million. This is the sixth lowest cost alternative.

\subsubsection{Alternative 5 - Single Composite Liner and the Low-Infiltration Soil Barrier}

This alternative consists of a single-composite liner (described in Section 8.6.4) and a low-infiltration engineered soil barrier (as described in Section 8.5.1). The barrier prevents direct exposure to the waste and includes a vegetated surface layer of fine-grained soils to retain moisture and encourage evapotranspiration, thereby minimizing infiltration and vadose zone transport of contaminants to groundwater. The upper $60 \mathrm{~cm}$ of the soil cover system is composed of an admixture of silt and gravels. This layer is intended to both reduce infiltration through the cover and to enhance the resistance of the cover to burrowing animals and longterm wind erosion. The liner retains leachate within the trench which is then pumped out using 
a leachate collection system and treated. Institutional controls and the other common elements described in Section 9.3 are included with this alternative. Evaluations of this alternative against the relevant CERCLA criteria are provided below.

Long-Term Effectiveness and Permanence. Based on the results presented in Appendix A, none of the contaminants reach groundwater within 10,000 years for this scenario under current climate conditions. Under the hypothetical wetter climate, this alternative results in a total ICR of $2 \times 10^{-4}$ and a HQ of 7 within 10,000 years. This alternative, along with the other alternatives that utilize the low-infiltration soil barrier, performs slightly poorer that the alternatives with the modified Hanford or Hanford barriers and is scored low for groundwater protection.

Reliability scores are summarized in Table 9-9. As discussed in Sections 9.3.8 and 9.3.9, this alternative scores medium for liner reliability and low for barrier reliability.

Short-Term Effectiveness. Scores for each of the short-term effectiveness sub-criteria are summarized in Table 9-10. The expected number of fatalities was determined by summing the expected fatalities for excavation, construction of the single composite liner and the lowinfiltration soil barrier, and ERDF operations as presented in Section 9.3.16. The estimated worker fatalities for this alternative $(0.543)$ ranks third best. The total impacted area at the silt borrow source is $0.14 \mathrm{~km}^{2}$, which is tied for first, and no basalt is used. The overall short-term effectiveness score is ranked second.

Implementability. Implementability scores are summarized in Table 9-11. This alternative has a total of 8 layers in the barrier and liner, giving it a medium score for technical implementability.

Cost. As summarized on Table 9-12, the total net present value for this alternative is $\$ 587$ million. This is the second lowest cost alternative.

\subsubsection{Alternative 6 - Single Composite Liner and the Modified Hanford Bai rier}

This alternative consists of a single-composite liner (described in Section 8.6.4) and the modified RCRA barrier (as described in Section 8.5.6). The barrier prevents direct exposure to the waste and includes a vegetated surface layer of fine-grained soils to retain moisture and encourage evapotranspiration, thereby minimizing infiltration and vadose zone transport of contaminants to groundwater. The upper $50 \mathrm{~cm}$ (20 in.) of the soil cover system is composed of an admixture of silt and gravels. This layer is intended to both reduce infiltration through the cover and to enhance the resistance of the cover to burrowing animals and long-term wind erosion. In addition, a $15-\mathrm{cm}$ (6-in.) thick asphalt layer provides secondary protection against both infiltration and intrusion. The liner retains leachate within the trench which is then pumped out using a leachate collection system and treated. Institutional controls and the other common elements described in Section 9.3 are included with this alternative. Evaluations of this alternative against the relevant CERCLA criteria are provided below.

Long-Term Effectiveness and Permanence. Based on the results presented in Appendix A, none of the contaminants reach groundwater within 10,000 years for this scenario under current climate conditions. Under the hypothetical wetter climate, this alternative results 
in a total ICR of $2 \times 10^{-5}$ and a maximum HQ of 0.8 within 10,000 years and is scored high in terms of groundwater protection.

Reliability scores are summarized in Table 9-9. As discussed in Sections 9.3.8 and 9.3.9, this alternative scores medium on both liner and barrier reliability.

Short-Term Effectiveness. Scores for each of the short-term effectiveness sub-criteria are summarized in Table 9-10. The expected number of fatalities was determined by summing the expected fatalities for excavation, construction of the single composite liner and the modified Hanford barrier, and ERDF operations as presented in Section 9.3.16. The estimated worker fatalities for this alternative $(0.546)$ rank 4 th best. The total impacted area at the silt borrow source is $0.26 \mathrm{~km}^{2}$, which is tied for fourth, and no basalt is used. This alternative is fifth in terms of overall short-term effectiveness.

Implementability. Implementability scores are summarized in Table 9-11. This alternative has a total of 14 layers in the barrier and liner, giving it a low score for technical implementability.

Cost. As summarized on Table 9-12, the total net present value for this alternative is $\$ 690$ million. This is the fifth lowest cost alternative.

\subsubsection{Alternative 7 - Single Composite Liner and the Hanford Barrier}

This alternative consists of a single-composite liner (described in Section 8.6.4) and the Hanford Barrier (as described in Section 8.5.6). The barrier prevents direct exposure to the waste and includes a vegetated surface layer of fine-grained soils to retain moisture and encourage evapotranspiration, thereby minimizing infiltration and vadose zone transport of contaminants to groundwater. The upper $1 \mathrm{~m}(3.28 \mathrm{ft})$ of the soil cover system is composed of an admixture of silt and gravels. This layer is intended to both reduce infiltration through the cover and to enhance the resistance of the cover to burrowing animals and long-term wind erosion. A $1.5-\mathrm{m}(4.9-\mathrm{ft})$ thick crushed basalt layer beneath the evapotranspiration zone provides additional protection against intrusion. In addition, a $15-\mathrm{cm}$ (6-in.) thick asphalt layer provides additional protection against both infiltration and intrusion. The liner retains leachate within the trench which is then pumped out using a leachate collection system and treated. Institutional controls and the other common elements described in Section 9.3 are included with this alternative. Evaluations of this alternative against the relevant CERCLA criteria are provided below.

Long-Term Effectiveness and Permanence. Based on the results presented in Appendix A, none of the contaminants reach groundwater within 10,000 years for this scenario under current climate conditions. Under the hypothetical wetter climate, this alternative results in a total ICR of $2 \times 10^{-5}$ and a HQ of 0.8 within 10,000 years and is scored high in terms of groundwater protection.

Reliability scores are summarized in Table 9-9. As discussed in Sections 9.3.8 and 9.3.9, this alternative scores medium on liner reliability and high on barrier reliability.

Short-Term Effectiveness. Scores for each of the short-term effectiveness sub-criteria are summarized in Table 9-10. The expected number of fatalities was determined by summing 
the expected fatalities for excavation, construction of the single composite liner and the Hanford barrier, and ERDF operations as presented in Section 9.3.16. The estimated worker fatalities for this alternative $(0.58)$ is the second worst score. The total impacted area at the silt borrow source is $0.54 \mathrm{~km}^{2}$, which is tied for last, and the impacted area at the basalt borrow source is $0.22 \mathrm{~km}^{2}$. This alternative has the second worst short-term effectiveness score.

Implementability. Implementability scores are summarized in Table 9-11. This alternative has a total of 16 layers in the barrier and liner, giving it a low technical implementability score.

Cost. As summarized on Table 9-12, the total net present value for this alternative is $\$ 826$ million. This is the second most expensive alternative.

\subsubsection{Alternative 8 - RCRA Double Composite Liner and the Low-Infiltration Soil Barrier}

This alternative consists of a RCRA Subtitle C double-composite liner (described in Section 8.6.4) and a low-infiltration engineered soil barrier (as described in Section 8.5.1). The barrier prevents direct exposure to the waste and includes a vegetated surface layer of finegrained soils to retain moisture and encourage evapotranspiration, thereby minimizing infiltration and vadose zone transport of contaminants to groundwater. The upper $60 \mathrm{~cm}$ of the soil cover system is composed of an admixture of silt and gravels. This layer is intended to both reduce infiltration through the cover and to enhance the resistance of the cover to burrowing animals and long-term wind erosion. The liner retains leachate within the trench which is then pumped out using a leachate collection system and treated. A secondary leachate collection system retains any leachate that leaks through the primary leachate collection system. Institutional controls and the other common elements described in Section 9.3 are included with this alternative. Evaluations of this alternative against the relevant CERCLA criteria are provided below.

Long-Term Effectiveness and Permanence. Based on the results presented in Appendix A, none of the contaminants reach groundwater within 10,000 years for this scenario under current climate conditions. Under the hypothetical wetter climate, this alternative results in a total ICR of $2 \times 10^{-4}$ and a maximum HQ of 7 within 10,000 years. This alternative, along with the other alternatives that utilize the low-infiltration soil barrier, performs slightly poorer that the alternatives with the modified Hanford or Hanford barriers and is scored low on groundwater protection.

Reliability scores are summarized in Table 9-9. As discussed in Sections 9.3.8 and 9.3.9, this alternative scores high for liner reliability and low for barricr reliability.

Short-Term Effectiveness. Scores for each of the short-term effectiveness sub-criteria are summarized in Table 9-10. The expected number of fatalities was determined by summing the expected fatalities for excavation, construction of the double composite liner and the lowinfiltration soil barrier, and ERDF operations as presented in Section 9.3.16. The estimated worker fatalities for this alternative $(0.566)$ is the fourth worst. The total impacted area at the silt borrow source is $0.14 \mathrm{~km}^{2}$ and no basalt is used. This alternative has the third best overall short-term effectiveness score. 
Implementability. Implementability scores are summarized in Table 9-11. This alternative has a total of 11 layers in the barrier and liner, giving it a medium technical implementability score.

Cost. As summarized on Table 9-12, the total net present value for this alternative is $\$ 680$ million. This is the fourth cheapest alternative.

\subsubsection{Alternative 9 - RCRA Double Composite Liner and the Modified Hanford Barrier}

This alternative consists of a RCRA Subtitle C double-composite liner (described in Section 8.6.4) and the modified RCRA barrier (as described in Section 8.5.6). The barrier prevents direct exposure to the waste and includes a vegetated surface layer of fine-grained soils to retain moisture and encourage evapotranspiration, thereby minimizing infiltration and vadose zone transport of contaminants to groundwater. The upper $50 \mathrm{~cm}(20 \mathrm{in}$.) of the soil cover system is composed of an admixture of silt and gravels. This layer is intended to both reduce infiltration through the cover and to enhance the resistance of the cover to burrowing animals and long-term wind erosion. In addition, a $15-\mathrm{cm}(6-\mathrm{in}$.) thick asphalt layer provides secondary protection against both infiltration and intrusion. The liner retains leachate within the trench which is then pumped out using a leachate collection system and treated. A secondary leachate collection system retains any leachate that leaks through the primary leachate collection system. Institutional controls and the other common elements described in Section 9.2 are included with this alternative. Evaluations of this alternative against the relevant CERCLA criteria are provided below.

Long-Term Effectiveness and Permanence. Based on the results presented in Appendix A, none of the contaminants reach groundwater within 10,000 years for this scenario under current climate conditions. Under the hypothetical wetter climate, this alternative results in a total ICR of $2 \times 10^{-5}$ and a maximum HQ of 0.8 within 10,000 years and is scored high in terms of groundwater protection.

Reliability scores are summarized in Table 9-9. As discussed in Sections 9.3.8 and 9.3.9, this alternative scores high on liner reliability and medium on barrier reliability.

Short-Term Effectiveness. Scores for each of the short-term effectiveness sub-criteria are summarized in Table 9-10. The expected number of fatalities was determined by summing the expected fatalities for excavation, construction of the double composite liner and the modified Hanford barrier, and ERDF operations as presented in Section 9.3.16. The estimated worker fatalities for this alternative $(0.569)$ is the third worst. The total impacted area at the silt borrow source is $0.26 \mathrm{~km}^{2}$, which is tied for fourth, and no basalt is used, resulting in the sixth best overall short-term effectiveness score.

Implementability. Implementability scores are summarized in Table 9-11. This alternative has a total of 17 layers in the barrier and liner, giving it a low technical implementability score.

Cost. As summarized on Table 9-12, the total net present value for this alternative is $\$ 779$ million. This is the third most expensive alternative. 


\subsubsection{Alternative 10 - RCRA Double Composite Liner and the Hanford Barrier}

This alternative consists of a RCRA Subtitle-C double-composite liner (described in Section 8.6.4) and the Hanford Barrier (as described in Section 8.5.6). The barrier prevents direct exposure to the waste and includes a vegetated surface layer of fine-grained soils to retain moisture and encourage evapotranspiration, thereby minimizing infiltration and vadose zone transport of contaminants to groundwater. The upper $1 \mathrm{~m}(3.28 \mathrm{ft})$ of the soil cover system is composed of an admixture of silt and gravels. This layer is intended to both reduce infiltration through the cover and to enhance the resistance of the cover to burrowing animals and longterm wind erosion. A $1.5-\mathrm{m}(4.9-\mathrm{ft})$ thick crushed basalt layer beneath the evapotranspiration zone provides additional protection against intrusion. In addition, a $15-\mathrm{cm}(6-\mathrm{in}$.$) thick asphalt$ layer provides additional protection against both infiltration and intrusion. The liner retains leachate within the trench which is then pumped out using a leachate collection system and treated. A secondary leachate collection system retains any leachate that leaks through the primary leachate collection system. Institutional controls and the other common elements described in Section 9.2 are included with this alternative. Evaluations of this alternative against the relevant CERCLA criteria are provided below.

Long-Term Effectiveness and Permanence. Based on the results presented in Appendix A, none of the contaminants reach groundwater within 10,000 years for this scenario under current climate conditions. Under the hypothetical wetter climate, this alternative results in a total ICR of $2 \times 10^{-5}$ and a maximum HQ of 0.8 within 10,000 years and is scored high in terms of groundwater protection.

Reliability scores are summarized in Table 9-9. As discussed in Sections 9.3.8 and 9.3.9, this alternative scores high on both liner and barrier reliability.

Short-Term Effectiveness. Scores for each of the short-term effectiveness sub-criteria are summarized in Table 9-10. The expected number of fatalities was determined by summing the expected fatalities for excavation, construction of the double composite liner and the Hanford barrier, and ERDF operations as presented in Section 9.3.16. The estimated worker fatalities for this alternative $(0.603)$ is the worst score for all the alternatives. The total impacted area at the silt borrow source is $0.54 \mathrm{~km}^{2}$, which is tied for last, and the impacted area at the basalt borrow source is $0.22 \mathrm{~km}^{2}$. This alternative has the worst overall short-term effectiveness score.

Implementability. Implementability scores are summarized in Table 9-11. This alternative has a total of 19 layers in the barrier and liner, giving it a low technical implementability score.

Cost. As summarized on Table 9-12, the total net present value for this alternative is $\$ 920$ million. This is the most expensive alternative.

\subsection{COMPARATIVE ANALYSIS}

A summary of the alternative rankings for each of the criteria is provided in Table 9-13. The following conclusions may be drawn from the summary ranking and other information provided in the detailed evaluations: 
- Groundwater protection is primarily a function of the surface barrier. All three barriers provide equivalent groundwater protection under current climate conditions. Under hypothetical wetter climate conditions, however, alternatives with the Hanford Barrier and modified Hanford barrier provide better groundwater protection than alternatives with the low-infiltration soil barrier.

- The Hanford barrier is more reliable than the modified Hanford barrier which is itself more reliable than the low-infiltration soil barrier.

- Given the fate and transport assumptions used in this analysis, alternatives with no liner provide similar groundwater protection as alternatives with a liner. Furthermore, the single liner is virtually equivalent in effectiveness to the double liner.

- The most important advantage of alternatives with a liner is that they provide a means to determine the validity of assumptions regarding leachate generation and leachate quality. If these assumptions prove to be non-conservative, it would be possible to initiate corrective action.

- Alternatives with the Hanford Barrier provide the best long-term effectiveness but at the expense of greater impacts on the environment and higher costs.

- Worker risk is dominated by operations, which is the same for all the alternatives. Consequently, the expected number of worker fatalities ranges from 0.52 to 0.60 over the life of the facility, and is not a useful differentiator between the alternatives. 


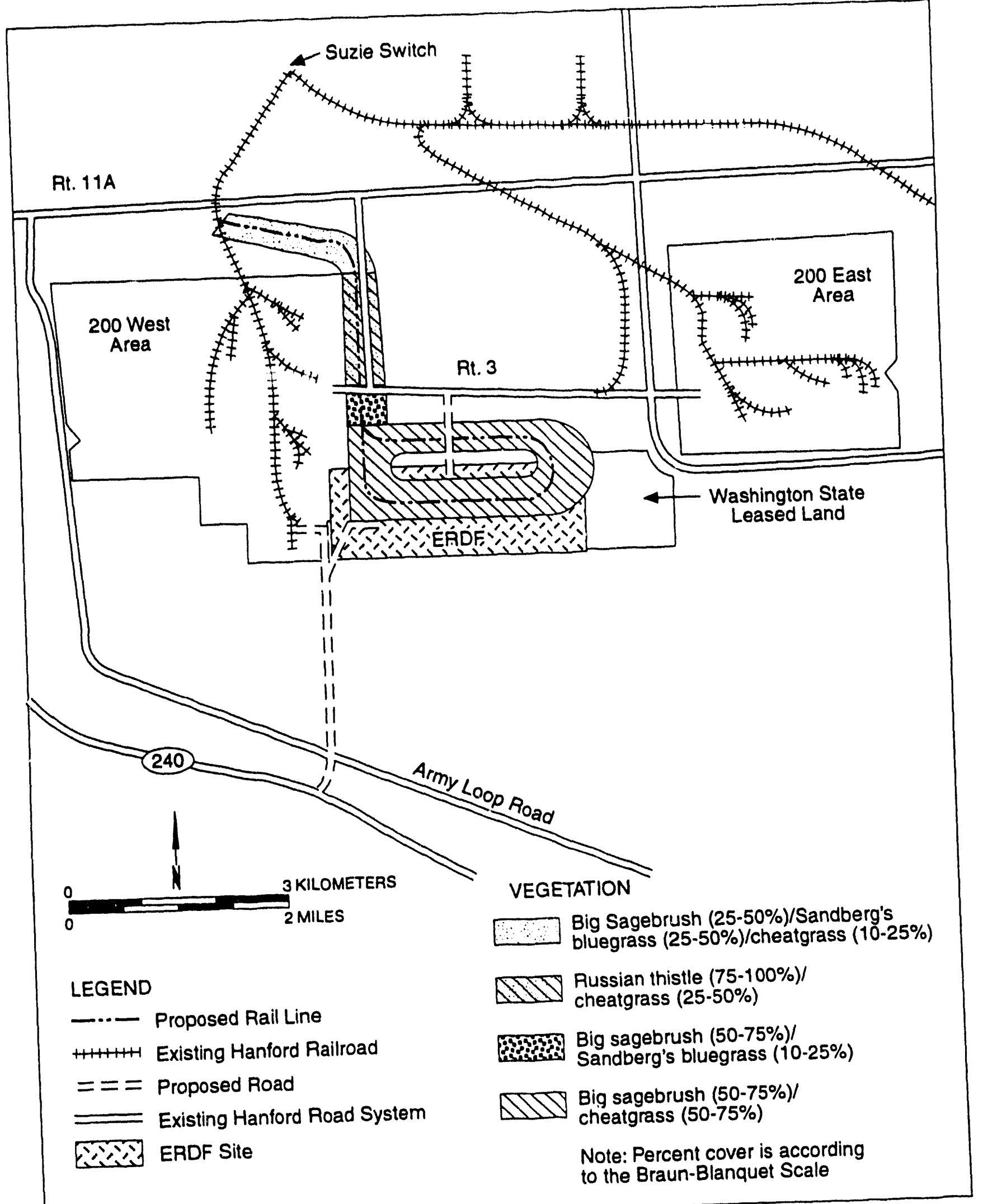

Figure 9.1. Location of Proposed Rail Lines and Roads. 
DOE/RL-93-99, Rev. 0

Table 9-1. Summary of Remedial Action Components for ERDF Alternatives.

\begin{tabular}{|c|c|c|c|c|c|c|}
\hline $\begin{array}{l}\text { Alternative } \\
\text { Number }\end{array}$ & $\begin{array}{l}\text { No } \\
\text { Liner }\end{array}$ & $\begin{array}{l}\text { Single } \\
\text { Liner }\end{array}$ & $\begin{array}{l}\text { Double } \\
\text { Liner }\end{array}$ & $\begin{array}{l}\text { Low } \\
\text { Infiltration } \\
\text { Soil Cover }\end{array}$ & $\begin{array}{c}\text { Modified } \\
\text { Hanford } \\
\text { Barrier }\end{array}$ & $\begin{array}{c}\text { Hanford } \\
\text { Barrier }\end{array}$ \\
\hline \multicolumn{7}{|l|}{1} \\
\hline 2 & $\mathrm{X}$ & & & $X$ & & \\
\hline 3 & $X$ & & & & $X$ & \\
\hline 4 & $X$ & & & & & $X$ \\
\hline 5 & & $\mathbf{X}$ & & $X$ & & \\
\hline 6 & & $X$ & & & $X$ & \\
\hline 7 & & $X$ & & & & $X$ \\
\hline 8 & & & $X$ & $\mathrm{X}$ & & \\
\hline 9 & & & $X$ & & $X$ & \\
\hline 10 & & & $X$ & & & $X$ \\
\hline
\end{tabular}

Note: "X" indicates the technology is included in the alternative.

Blank spaces indicate the technology is not part of the alternative.

\section{ALTERNATIVE NAMES}

1. No Action Alternative

2. No Liner with a Low Infiltration Soil Cover

3. No Liner with a Modified Hanford Barrier

4. No Liner $n$ ith a Hanford Barrier

5. Single Composite Liner with Low Infiltration Soil Cover

6. Single Composite Liner with a Modified Hanford Barrier

7. Single Composite Liner with a Hanford Barrier

8. Double Composite Liner with a Low Infiltration Soil Cover

9. Double Composite Liner with a Modified Hanford Barrier

10. Double Composite Liner with a Hanford Barrier 
DOE/RL-93-99, Rev. 0

Table 9-2. Raw Liner Construction Costs.

\begin{tabular}{|c|c|c|}
\hline & Single Liner & Double Liner \\
\hline \multicolumn{3}{|l|}{ Bottom Liner $\left(864,000 \mathrm{~m}^{2}\right)$} \\
\hline Unit Cost (per $\mathrm{m}^{2}$ ) & $\$ 31.56$ & $\$ 70.54$ \\
\hline Total Cost for Bottom & $\$ 27$ million & $\$ 61$ million \\
\hline \multicolumn{3}{|l|}{ Sideslope Liner $\left(417,000 \mathrm{~m}^{2}\right)$} \\
\hline Unit Cost (per m²) & $\$ 28.72$ & $\$ 63.79$ \\
\hline Total Cost for Sideslope & $\$ 12$ million & $\$ 27$ million \\
\hline Total Liner Cost & $\$ 39$ million & $\$ 88$ million \\
\hline
\end{tabular}


DOE/RL-93-99, Rev. 0

Table 9-3. Labor Requirements for Construction of the Liners.

\begin{tabular}{|c|c|c|c|c|c|c|}
\hline \multirow[b]{2}{*}{ Layer } & \multirow{2}{*}{$\begin{array}{l}\text { Crew } \\
\text { Size }\end{array}$} & \multirow{2}{*}{$\begin{array}{c}\text { Material } \\
\text { Placement } \\
\text { Rate } \\
\text { (per day) }\end{array}$} & \multicolumn{2}{|c|}{ Single Liner } & \multicolumn{2}{|c|}{ Double Liner } \\
\hline & & & $\begin{array}{l}\text { Material } \\
\text { Quantity }\end{array}$ & $\begin{array}{l}\text { Labor } \\
\text { (days) }\end{array}$ & $\begin{array}{l}\text { Material } \\
\text { Quantity }\end{array}$ & $\begin{array}{l}\text { Labor } \\
\text { (days) }\end{array}$ \\
\hline Operations Layer $\left(\mathrm{m}^{3}\right)$ & 11 & 2,000 & $1.20 \mathrm{E}+06$ & 6,600 & $1.20 \mathrm{E}+06$ & 6,600 \\
\hline Geotextile Separator $\left(\mathrm{m}^{2}\right)$ & 24 & 7,500 & $8.60 \mathrm{E}+05$ & 2,752 & $8.60 \mathrm{E}+05$ & 2,752 \\
\hline Drainage Gravel $\left(\mathrm{m}^{3}\right)$ & 9 & 750 & $2.60 \mathrm{E}+05$ & 3,120 & $5.20 \mathrm{E}+05$ & 6,240 \\
\hline $\begin{array}{l}\text { Drainage Geocomposite } \\
\left(\mathbf{m}^{2}\right)\end{array}$ & 24 & 5,000 & $4.20 \mathrm{E}+05$ & 2,016 & $8.30 E+05$ & 3,984 \\
\hline Geotextile Cushion $\left(\mathrm{m}^{2}\right)$ & 24 & 7,500 & $8.60 \mathrm{E}+05$ & 2,752 & $2.60 \mathrm{E}+06$ & 8,320 \\
\hline HDPE $\left(\mathbf{m}^{2}\right)$ & 24 & 2,500 & $1.30 \mathrm{E}+06$ & 12,480 & $2.60 \mathrm{E}+06$ & 24,960 \\
\hline Bentonite Admix $\left(\mathrm{m}^{3}\right)$ & 18 & 1,500 & $3.90 \mathrm{E}+05$ & 4,680 & $1.20 \mathrm{E}+06$ & 14,400 \\
\hline Subgrade $\left(\mathrm{m}^{2}\right)$ & 4 & 5,000 & $1.30 \mathrm{E}+06$ & 1,040 & $1.30 \mathrm{E}+06$ & 1,040 \\
\hline Material Transport & & & & 5,000 & & 11,000 \\
\hline Total & & & & 40,440 & & 79,296 \\
\hline
\end{tabular}


DOE/RL-93-99, Rev. 0

Table 9-4. Total Material Requirements for the Trench Liners.

\begin{tabular}{|c|c|c|c|c|}
\hline & \multicolumn{2}{|c|}{ Single Liner } & \multicolumn{2}{|c|}{ Double Liner } \\
\hline & $\begin{array}{l}\text { Thickness } \\
\text { (m) }\end{array}$ & $\begin{array}{l}\text { Quantity } \\
\text { (million) }\end{array}$ & $\begin{array}{l}\text { Thickness } \\
\text { (m) }\end{array}$ & $\begin{array}{l}\text { Quantity } \\
\text { (million) }\end{array}$ \\
\hline $\begin{array}{l}\text { General Fill } \\
\text { (Bottom and Sideslope) }\end{array}$ & 0.9 & $1.2 \mathrm{~m}^{3}$ & 0.9 & $1.2 \mathrm{~m}^{3}$ \\
\hline $\begin{array}{l}\text { Geotextile Separator } \\
\text { (Bottom only) }\end{array}$ & (area) & $0.86 \mathrm{~m}^{2}$ & (area) & $0.86 \mathrm{~m}^{2}$ \\
\hline $\begin{array}{l}\text { Gravel } \\
\text { (Bottom only) }\end{array}$ & 0.3 & $0.26 \mathrm{~m}^{3}$ & $0.3 \times 2$ & $0.52 \mathrm{~m}^{3}$ \\
\hline $\begin{array}{l}\text { Geotextile Cushion } \\
\text { (Bottom only) }\end{array}$ & (area) & $0.86 \mathrm{~m}^{2}$ & (area)x3 & $2.6 \mathrm{~m}^{2}$ \\
\hline $\begin{array}{l}\text { Drainage Geocomposite } \\
\text { (Sideslope only) }\end{array}$ & (area) & $0.42 \mathrm{~m}^{2}$ & $($ area $) \times 2$ & $0.83 \mathrm{~m}^{2}$ \\
\hline $\begin{array}{l}\text { HDPE Geomembrane } \\
\text { (Bottom and Sideslope) }\end{array}$ & (area) & $1.3 \mathrm{~m}^{2}$ & $($ area $) \times 2$ & $2.6 \mathrm{~m}^{2}$ \\
\hline $\begin{array}{l}\text { Sand } \\
\text { (Bottom and Sideslope) }\end{array}$ & 0.24 & $0.31 \mathrm{~m}^{3}$ & 0.72 & $0.92 \mathrm{~m}^{3}$ \\
\hline $\begin{array}{l}\text { Bentonite } \\
\text { (Bottom and Sideslope) }\end{array}$ & 0.06 & $0.08 \mathrm{~m}^{3}$ & 0.18 & $0.23 \mathrm{~m}^{3}$ \\
\hline \multicolumn{5}{|c|}{$\begin{array}{l}\text { Notes: } \\
\text { (area) - Two-dimensional material that is considered to have a thickness of zero. } \\
\text { Assumes areas of } 864,000 \mathrm{~m}^{2} \text { for the bottom liner and } 417,000 \mathrm{~m}^{2} \text { for the sideslope liner. } \\
1 \mathrm{~m}=3.28 \mathrm{ft}\end{array}$} \\
\hline
\end{tabular}


DOE/RL-93-99, Rev. 0

Table 9-5. Labor Requirements for Construction of the Barriers.

\begin{tabular}{|c|c|c|c|c|c|c|c|}
\hline \multirow[t]{2}{*}{ Layer } & \multirow{2}{*}{$\begin{array}{c}\text { Material } \\
\text { Placement } \\
\text { Rntea } \\
\text { (per day) }\end{array}$} & \multicolumn{2}{|c|}{$\begin{array}{c}\text { Low-Infiltration Soil } \\
\text { Barrier }\end{array}$} & \multicolumn{2}{|c|}{$\begin{array}{c}\text { Modified Hanford } \\
\text { Barrier }\end{array}$} & \multicolumn{2}{|c|}{ Hanford Barrier } \\
\hline & & $\begin{array}{l}\text { Material } \\
\text { Quantity }\end{array}$ & $\begin{array}{l}\text { Labor } \\
\text { (days) }\end{array}$ & $\begin{array}{l}\text { Material } \\
\text { Quantity }\end{array}$ & $\begin{array}{l}\text { Labor } \\
\text { (days) }\end{array}$ & $\begin{array}{l}\text { Material } \\
\text { Quantity }\end{array}$ & $\begin{array}{l}\text { Labor } \\
\text { (days) }\end{array}$ \\
\hline Silt Admix $\left(\mathrm{m}^{3}\right)$ & 3,000 & $8.16 \mathrm{E}+05$ & 3,264 & $6.80 \mathrm{E}+05$ & 2,720 & $1.47 E+06$ & 5,880 \\
\hline Silt $\left(m^{3}\right)$ & 1,500 & & & $6.80 \mathrm{E}+05$ & 5,440 & $1.47 \mathrm{E}+06$ & 11,760 \\
\hline General Fill $\left(\mathrm{m}^{3}\right)$ & 5,000 & $5.44 E+06$ & 13,056 & $4.08 E+06$ & 9,792 & & \\
\hline Geofilter $\left(m^{2}\right)$ & 7,500 & & & & & $1.46 \mathrm{E}+06$ & 2,236 \\
\hline Sand Filter $\left(\mathrm{m}^{3}\right)$ & 1,500 & & & $2.04 \mathrm{E}+05$ & 1,632 & $2.20 \mathrm{E}+05$ & 1,760 \\
\hline Gravel Filter $\left(m^{3}\right)$ & 1,500 & & & $2.04 \mathrm{E}+05$ & 1,632 & $4.41 E+05$ & 3,528 \\
\hline Crushed Basalt $\left(\mathrm{m}^{3}\right)$ & 1,500 & & & & & $2.21 E+06$ & 17.640 \\
\hline Drainage Gravel $\left(\mathrm{m}^{3}\right)$ & 1,500 & & & $2.04 E+05$ & 1,632 & $4.41 E+05$ & 3,528 \\
\hline Asphalt $\left(\mathrm{m}^{3}\right)$ & 2,000 & & & $2.04 \mathrm{E}+05$ & 1,224 & $2.20 E+05$ & 1,320 \\
\hline Base Course $\left(\mathrm{m}^{3}\right)$ & 1,500 & & & $1.36 \mathrm{E}+05$ & 1,088 & $1.47 \mathrm{E}+05$ & 1,176 \\
\hline Material Transport & & & 5,000 & & 11,000 & & 35,000 \\
\hline Tolal & & & 21,320 & & 36,160 & & 83,928 \\
\hline
\end{tabular}


DOE/RL-93-99, Rev. 0

Table 9-6. Material Requirements for the Barriers.

\begin{tabular}{|c|c|c|c|c|c|c|}
\hline & \multicolumn{2}{|c|}{$\begin{array}{c}\text { Low Infiltration Soil } \\
\text { Barrier }\end{array}$} & \multicolumn{2}{|c|}{$\begin{array}{c}\text { Modified Hanford } \\
\text { Barrier }\end{array}$} & \multicolumn{2}{|c|}{ Hanford Barrier } \\
\hline & $\begin{array}{l}\text { Thickness } \\
\text { (m) }\end{array}$ & $\begin{array}{l}\text { Quantity } \\
\text { (million) }\end{array}$ & $\begin{array}{l}\text { Thickness } \\
\text { (m) }\end{array}$ & $\begin{array}{l}\text { Quantity } \\
\text { (million) }\end{array}$ & $\begin{array}{l}\text { Thickness } \\
\text { (m) }\end{array}$ & $\begin{array}{l}\text { Quantity } \\
\text { (million) }\end{array}$ \\
\hline Vegetation & (area) & $1.36 \mathrm{~m}^{2}$ & (area) & $1.36 \mathrm{~m}^{2}$ & (area) & $1.47 \mathrm{~m}^{2}$ \\
\hline Silt & 0.5 & $0.68 \mathrm{~m}^{3}$ & 0.93 & $1.3 \mathrm{~m}^{3}$ & 1.85 & $2.7 \mathrm{~m}^{3}$ \\
\hline Sand & 0 & 0 & 0.15 & $0.20 \mathrm{~m}^{3}$ & 0.15 & $0.22 \mathrm{~m}^{3}$ \\
\hline Gravel & 0.1 & $0.14 \mathrm{~m}^{3}$ & 0.47 & $0.64 \mathrm{~m}^{3}$ & 0.85 & $1.2 \mathrm{~m}^{3}$ \\
\hline General Fill & 4.0 & $5.4 \mathrm{~m}^{3}$ & 3.0 & $4.1 \mathrm{~m}^{3}$ & 0 & 0 \\
\hline Geotextile Filter & 0 & 0 & 0 & 0 & (area) & $1.47 \mathrm{~m}^{2}$ \\
\hline Crushed Basalt & 0 & 0 & 0 & 0 & 1.5 & $2.2 \mathrm{~m}^{3}$ \\
\hline Asphalt Coating & 0 & 0 & (area) & $1.36 \mathrm{~m}^{2}$ & (area) & $1.47 \mathrm{~m}^{2}$ \\
\hline Asphalt & 0 & 0 & 0.15 & $0.20 \mathrm{~m}^{3}$ & 0.15 & $0.22 \mathrm{~m}^{3}$ \\
\hline \multicolumn{7}{|c|}{$\begin{array}{l}\text { Notes: } \\
\text { (area) - Two-dimensional material that is considered to have a thickness of zero. } \\
\text { Assumes areas of } 1.36{\text { million } \mathrm{m}^{2} \text { for the low permeability soil barrier and modified Hanford }} \text { barrier and } 1.47 \text { million } \mathrm{m}^{2} \text { for the Hanford Barrier. } \\
1 \mathrm{~m}=3.28 \mathrm{ft}\end{array}$} \\
\hline
\end{tabular}


Table 9-7. Capital Cost Estimates and Mulipliers for ERDF Elements $(\$ \times 1,000)$.

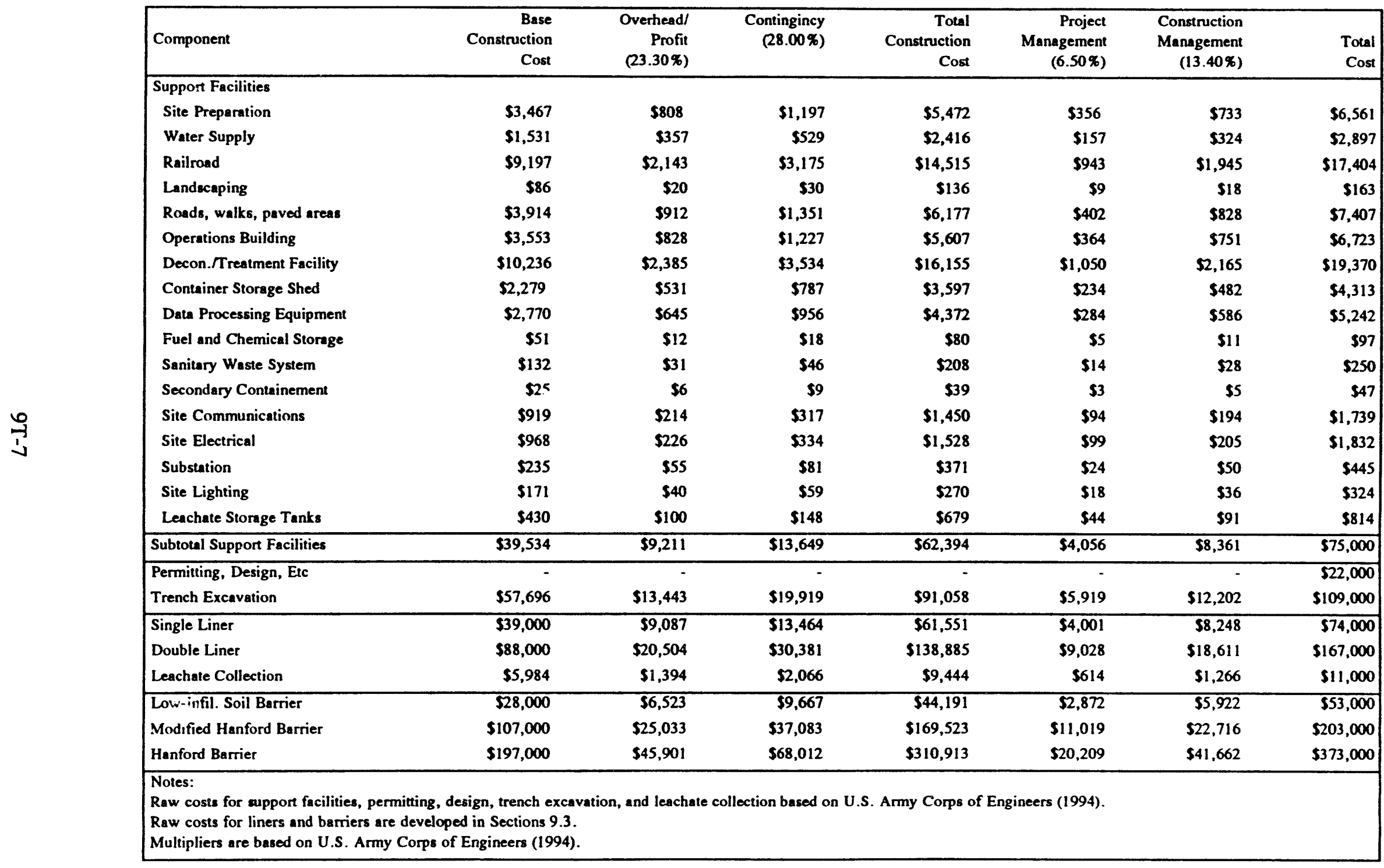


Table 9-8. Predicted Groundwater Human-Health Risks for Remedial Alternatives under Hypothetical Wetter Climate Conditions.

\begin{tabular}{|l|c|c|}
\hline \multicolumn{1}{|c|}{ Alternative } & Total ICR & Maximum HQ \\
\hline 1. No Action & NA & NA \\
\hline 2. No Liner with Low Infiltration Soil Barrier & $3 \mathrm{E}-04$ & 7 \\
\hline 3. No Liner with Modified Hanford Barrier & $2 \mathrm{E}-05$ & 0.8 \\
\hline 4. No Liner with Hanford Barrier & $2 \mathrm{E}-05$ & 0.8 \\
\hline 5. Single Liner with Low Infiltration Soil Barrier & $2 \mathrm{E}-04$ & 7 \\
\hline 6. Single Liner with Modified Hanford Barrier & $2 \mathrm{E}-05$ & 0.8 \\
\hline 7. Single Liner with Hanford Barrier & $2 \mathrm{E}-05$ & 0.8 \\
\hline 8. Double Liner with Low Infiltration Soil Barrier & $2 \mathrm{E}-04$ & 7 \\
\hline 9. Double Liner with Modified Hanford Barrier & $2 \mathrm{E}-05$ & 0.8 \\
\hline 10. Double Liner with Hanford Barrier & $2 \mathrm{E}-05$ & 0.8 \\
\hline NA = Not Available. & & \\
\hline
\end{tabular}


DOE/RL-93-99, Rev. 0

Table 9-9. Scores for Long-Term Effectiveness.

\begin{tabular}{|c|c|c|c|c|c|}
\hline \multicolumn{2}{|c|}{ Alternative } & $\begin{array}{l}\text { Groundwater } \\
\text { Protection }\end{array}$ & $\begin{array}{c}\text { Liner } \\
\text { Reliability }\end{array}$ & $\begin{array}{l}\text { Barrier } \\
\text { Reliability }\end{array}$ & $\begin{array}{l}\text { Score } \\
\text { (Rank) }\end{array}$ \\
\hline \multicolumn{2}{|c|}{ Weighting } & 0.4 & 0.1 & 0.5 & \\
\hline 1. & No Action & NA & NA & NA & NA \\
\hline 2. & $\begin{array}{l}\text { No Liner with Low Infiltration } \\
\text { Soil Barrier }\end{array}$ & Low & Low & Low & $0.00(9)$ \\
\hline 3. & $\begin{array}{l}\text { No Liner with Modified } \\
\text { Hanford Barrier }\end{array}$ & High & Low & Medium & $0.55(6)$ \\
\hline 4. & No Liner with Hanford Barrier & High & Low & High & $0.90(3)$ \\
\hline 5. & $\begin{array}{l}\text { Single Liner with Low } \\
\text { Infiltration Soil Barrier }\end{array}$ & Low & Medium & Low & $0.05(8)$ \\
\hline 6. & $\begin{array}{l}\text { Single Liner with Modified } \\
\text { Hanford Barrier }\end{array}$ & High & Medium & Medium & $0.70(5)$ \\
\hline 7. & $\begin{array}{l}\text { Single Liner with Hanford } \\
\text { Barrier }\end{array}$ & High & Medium & High & $0.95(2)$ \\
\hline 8. & $\begin{array}{l}\text { Double Liner with Low } \\
\text { Infiltration Soil Barrier }\end{array}$ & Low & High & Low & $0.10(7)$ \\
\hline 9. & $\begin{array}{l}\text { Double Liner with Modified } \\
\text { Hanford Barrier }\end{array}$ & High & High & Medium & $0.75(4)$ \\
\hline 10. & $\begin{array}{l}\text { Double Liner with Hanford } \\
\text { Barrier }\end{array}$ & High & High & High & $1.00(1)$ \\
\hline
\end{tabular}


Table 9-10. Scores for Short-Term Effectiveness Sub-Criteria.

\begin{tabular}{|c|c|c|c|c|}
\hline Alternative & $\begin{array}{l}\text { Expected } \\
\text { Worker } \\
\text { Fatalities }^{a}\end{array}$ & $\begin{array}{c}\text { Silt Quarry } \\
\text { Area }^{\mathrm{a}} \\
\left(\mathrm{km}^{2}\right)\end{array}$ & $\begin{array}{c}\text { Basalt } \\
\text { Quarry } \\
\text { Area } \\
\left(\mathrm{km}^{2}\right)\end{array}$ & $\begin{array}{l}\text { Score } \\
\text { (Rank) }\end{array}$ \\
\hline Weighting & 0.2 & 0.4 & 0.4 & \\
\hline 1. No Action & NA & NA & NA & NA \\
\hline $\begin{array}{l}\text { 2. No Liner with Low Infiltration } \\
\text { Soil Barrier }\end{array}$ & $0.519(1)$ & $0.14(1)$ & $0(1)$ & $1.00(1)$ \\
\hline $\begin{array}{l}\text { 3. No Liner with Modified } \\
\text { Hanford Barrier }\end{array}$ & $0.522(0.96)$ & $0.26(0.7)$ & $0(1)$ & $0.87(4)$ \\
\hline 4. No Liner with Hanford Barrier & $0.556(0.56)$ & $0.54(0)$ & $0.22(0)$ & $0.11(7)$ \\
\hline $\begin{array}{l}\text { 5. Single Liner with Low } \\
\text { Infiltration Soil Barrier }\end{array}$ & $0.543(0.71)$ & $0.14(1)$ & $0(1)$ & $0.94(2)$ \\
\hline $\begin{array}{l}\text { 6. Single Liner with Modified } \\
\text { Hanford Barrier }\end{array}$ & $0.546(0.68)$ & $0.26(0.7)$ & $0(1)$ & $0.82(5)$ \\
\hline $\begin{array}{l}\text { 7. Single Liner with Hanford } \\
\text { Barrier }\end{array}$ & $0.580(0.27)$ & $0.54(0)$ & $0.22(0)$ & $0.05(8)$ \\
\hline $\begin{array}{l}\text { 8. Double Liner with Low } \\
\text { Infiltration Soil Barrier }\end{array}$ & $0.566(0.44)$ & $0.14(1)$ & $0(1)$ & $0.89(3)$ \\
\hline $\begin{array}{l}\text { 9. Double Liner with Modified } \\
\text { Hanford Barrier }\end{array}$ & $0.569(0.40)$ & $0.26(0.7)$ & $0(1)$ & $0.76(6)$ \\
\hline $\begin{array}{l}\text { 10. Double Liner with Hanford } \\
\text { Barrier }\end{array}$ & $0.603(0)$ & $0.54(1)$ & $0.22(0)$ & $0.00(9)$ \\
\hline
\end{tabular}


DOE/RL-93-99, Rev. 0

Table 9-11. Scores for Implementability Sub-Criteria.

\begin{tabular}{|c|c|c|}
\hline Alternative & Technicala & Rank \\
\hline 1. No Action & NA & NA \\
\hline $\begin{array}{l}\text { 2. No Liner with Low Infiltration } \\
\text { Soil Barrier }\end{array}$ & High & 1 \\
\hline $\begin{array}{l}\text { 3. No Liner with Modified } \\
\text { Hanford Barrier }\end{array}$ & Medium & 2 (tie) \\
\hline 4. No Liner with Hanford Barrier & Medium & 2(tie) \\
\hline $\begin{array}{l}\text { 5. Single Liner with Low } \\
\text { Infiltration Soil Barrier }\end{array}$ & Medium & 2(tie) \\
\hline $\begin{array}{l}\text { 6. Single Liner with Modified } \\
\text { Hanford Barrier }\end{array}$ & Low & 6(tie) \\
\hline $\begin{array}{l}\text { 7. Single Liner with Hanford } \\
\text { Barrier }\end{array}$ & Low & 6 (tie) \\
\hline $\begin{array}{l}\text { 8. Double Liner with Low } \\
\text { Infiltration Soil Barrier }\end{array}$ & Medium & 2(tie) \\
\hline $\begin{array}{l}\text { 9. Double Liner with Modified } \\
\text { Hanford Barrier }\end{array}$ & Low & 6(tie) \\
\hline $\begin{array}{l}\text { 10. Double Liner with Hanford } \\
\text { Barrier }\end{array}$ & Low & 6(tie) \\
\hline
\end{tabular}


Table 9-12. Costs for Remedial Alternatives.

\begin{tabular}{|c|c|c|c|c|c|c|}
\hline & $\begin{array}{l}\text { General } \\
\text { Costs }^{\mathrm{a}}\end{array}$ & $\begin{array}{l}\text { Liner } \\
\text { Costs }\end{array}$ & $\begin{array}{l}\text { Barrier } \\
\text { Costs }\end{array}$ & $\begin{array}{l}\text { Operations } \\
\text { Cost }^{d}\end{array}$ & $\begin{array}{l}\text { Total } \\
\text { Present } \\
\text { Value }\end{array}$ & Rank \\
\hline 1. No Action & NA & NA & NA & NA & NA & NA \\
\hline $\begin{array}{l}\text { 2. No Liner with Low } \\
\text { Infiltration Soil Barrier }\end{array}$ & $\$ 206$ & 0 & $\$ 40$ & $\$ 256$ & $\$ 502$ & 1 \\
\hline $\begin{array}{l}\text { 3. No Liner with Modified } \\
\text { Hanford Barrier }\end{array}$ & $\$ 206$ & 0 & $\$ 139$ & $\$ 256$ & $\$ 601$ & 3 \\
\hline $\begin{array}{l}\text { 4. No Liner with Hanford } \\
\text { Barrier }\end{array}$ & $\$ 206$ & 0 & $\$ 279$ & $\$ 256$ & $\$ 741$ & 6 \\
\hline $\begin{array}{l}\text { 5. Single Liner with Low } \\
\text { Infiltration Soil Barrier }\end{array}$ & $\$ 206$ & $\$ 85$ & $\$ 40$ & $\$ 256$ & $\$ 587$ & 2 \\
\hline $\begin{array}{l}\text { 6. Single Liner with Modified } \\
\text { Hanford Barrier }\end{array}$ & $\$ 206$ & $\$ 85$ & $\$ 139$ & $\$ 256$ & $\$ 686$ & 5 \\
\hline $\begin{array}{l}\text { 7. Single Liner with Hanford } \\
\text { Barrier }\end{array}$ & $\$ 206$ & $\$ 85$ & $\$ 279$ & $\$ 256$ & $\$ 826$ & 8 \\
\hline $\begin{array}{l}\text { 8. Double Liner with Low } \\
\text { Infiltration Soil Barrier }\end{array}$ & $\$ 206$ & $\$ 178$ & $\$ 40$ & $\$ 256$ & $\$ 680$ & 4 \\
\hline $\begin{array}{l}\text { 9. Double Liner with Modified } \\
\text { Hanford Barrier }\end{array}$ & $\$ 206$ & $\$ 178$ & $\$ 139$ & $\$ 256$ & $\$ 779$ & 7 \\
\hline $\begin{array}{l}\text { 10. Double Liner with Hanford } \\
\text { Barrier }\end{array}$ & $\$ 206$ & $\$ 178$ & $\$ 279$ & $\$ 256$ & $\$ 919$ & 9 \\
\hline \multicolumn{7}{|c|}{$\begin{array}{l}\text { All costs are in millions. } \\
\text { NA - Not available. } \\
\text { a - Includes support facilities, permitting, design, and trench excavation. } \\
\text { b - Includes liner and leachate collection system. } \\
\text { c - Net present value of barrier costs assuming a discount rate of } 6 \text { percent over } 20 \text { years. } \\
\text { d - Net present value of annual operations cost of } \$ 20 \text { million/yr for } 25 \text { years assuming a discount rate } \\
\text { of } 6 \text { percent. }\end{array}$} \\
\hline
\end{tabular}


DOE/RL-93-99, Rev. 0

Table 9-13. Summary Ranking of the Alternatives Against the Criteria.

\begin{tabular}{|c|c|c|c|c|}
\hline Alternative & $\begin{array}{l}\text { Long-Term } \\
\text { Effectiveness }\end{array}$ & $\begin{array}{l}\text { Short-Term } \\
\text { Effectiveness }\end{array}$ & Implementability & Cost \\
\hline 1 & NA & NA & NA & NA \\
\hline 2 & 9 & 1 & 1 & 1 \\
\hline 3 & 6 & 4 & 2(tie) & 3 \\
\hline 4 & 3 & 7 & 2(tie) & 6 \\
\hline 5 & 8 & 2 & 2 (tie) & 2 \\
\hline 6 & 5 & 5 & 6(tie) & 5 \\
\hline 7 & 2 & 8 & $6($ tie $)$ & 8 \\
\hline 8 & 7 & 3 & $2($ tie $)$ & 4 \\
\hline 9 & 4 & 6 & $6($ tie $)$ & 7 \\
\hline 10 & 1 & 9 & 6 (tie) & 9 \\
\hline \multicolumn{5}{|c|}{$\begin{array}{l}\text { Notes: } \\
1 \text { - No Action } \\
2 \text { - No Liner with Low Infiltration Soil Barrier } \\
\text { 3 - No Liner with Modified Hanford Barrier } \\
4 \text { - No Liner with Hanford Barrier } \\
5 \text { - Single Liner with Low Infiltration Soil Barrier } \\
6 \text { - Single Liner with Modified Hanford Barrier } \\
7 \text { - Single Liner with Hanford Barrier } \\
8 \text { - Double Liner with Low Infiltration Soil Barrier } \\
9 \text { - Double Liner with Modified Hanford Barrier } \\
10 \text { - Double Liner with Hanford Barrier } \\
\text { NA - Not Available. }\end{array}$} \\
\hline
\end{tabular}




\subsection{CONCLUSIONS}

The purpose of this RI/FS was to develop and evaluate design alternatives for the ERDF, a proposed CAMU intended to receive excavated soil and other wastes from CERCLA and RCRA operable units on the Hanford Site. The proposed location for the ERDF is on the 200 Area plateau, just south of the 200 West and 200 East Areas.

Development of Alternatives. Various technologies were evaluated and screened, although the primary focus was on surface barrier and trench liner technologies. The retained technologies were assembled into 9 design alternatives (in addition to the no-action alternative). The nine alternatives represent combinations of no liner, a single composite liner, or a RCRA MTR double composite liner, with a low-infiltration soil barrier, a modified Hanford barrier, or a Hanford Barrier. The alternatives are listed below:

- Alternative 1 - No action

- Alternative 2 - No liner and a low-infiltration soil barrier

- Alternative 3 - No liner and a modified Hanford barrier

- Alternative 4 - No liner and a Hanford Barrier

- Alternative 5 - Single composite liner and a low-infiltration soil barrier

- Alternative 6 - Single composite liner and a modified Hanford barrier

- Alternative 7 - Single composite liner and a Hanford Barrier

- Alternative 8 - RCRA double composite liner and a low-infiltration soil barrier

- Alternative 9 - RCRA double composite liner and a modified Hanford barrier

- Alternative 10 - RCRA Double composite liner and a Hanford Barrier

All of the alternatives, except no action, include institutional controls, dust control, surface water management, wastewater treatment, transportation systems, buildings, a grout batch plant, equipment for internal and external communications, emergency response equipment, and personnel protection. In addition, all of the alternatives (other than no-action) utilize the deep area-fill trench configuration, a single trench design approximately $20 \mathrm{~m}(70 \mathrm{ft})$ deep and $300 \mathrm{~m}(1,000 \mathrm{ft})$ across. This trench configuration minimizes the footprint of the facility. The reduced footprint of the deep area-fill design offers the following advantages in comparison to other configurations:

- Less habitat disruption at the ERDF

- Less leachate generation

- Reduced material needs (thus, reduced ecological and cultural impact on borrow areas)

- Lower costs for the liner and barrier.

Using the deep area-fill configuration, the disturbed area of the ERDF, including the trench, stockpiling areas, roads, and supporting facilities, is estimated to be $2.6 \mathrm{~km}^{2}$ (650 acres or $1.0 \mathrm{mi}^{2}$ ).

Acceptable soil and leachate concentrations. Acceptable soil and leachate concentrations were developed for the contaminants identified in potential waste from the 100 , 200 , and 300 Areas. These concentrations will be included as part of the waste acceptance 

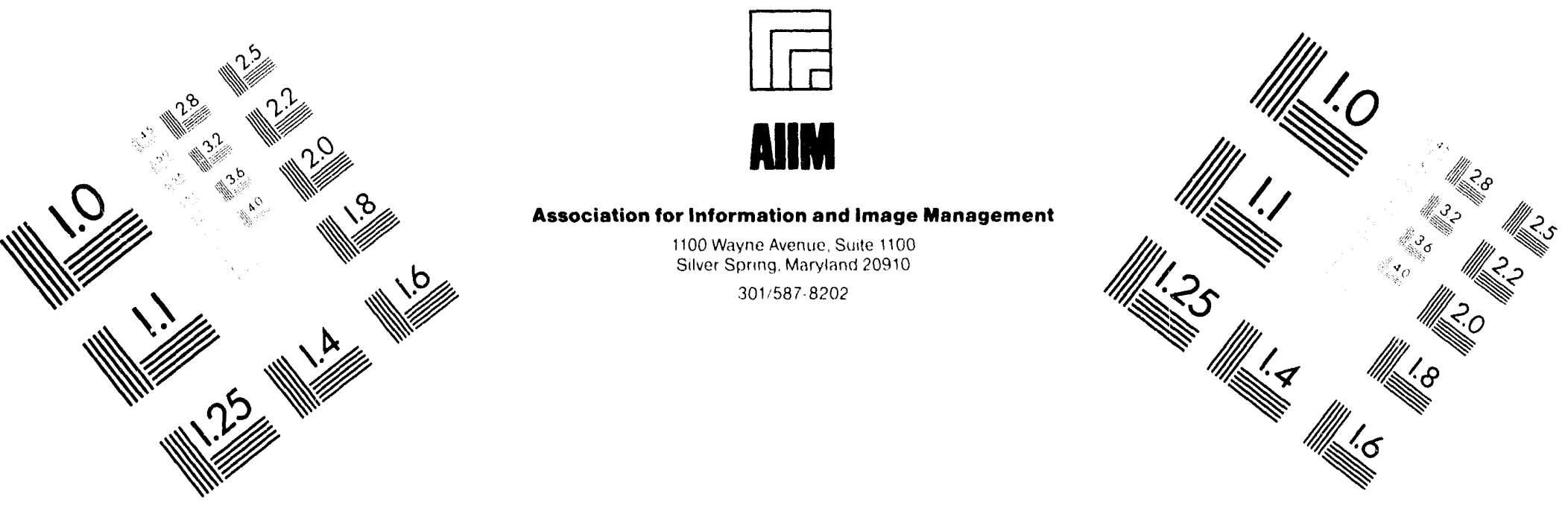

\section{Centimeter}

$\mid$ Inches
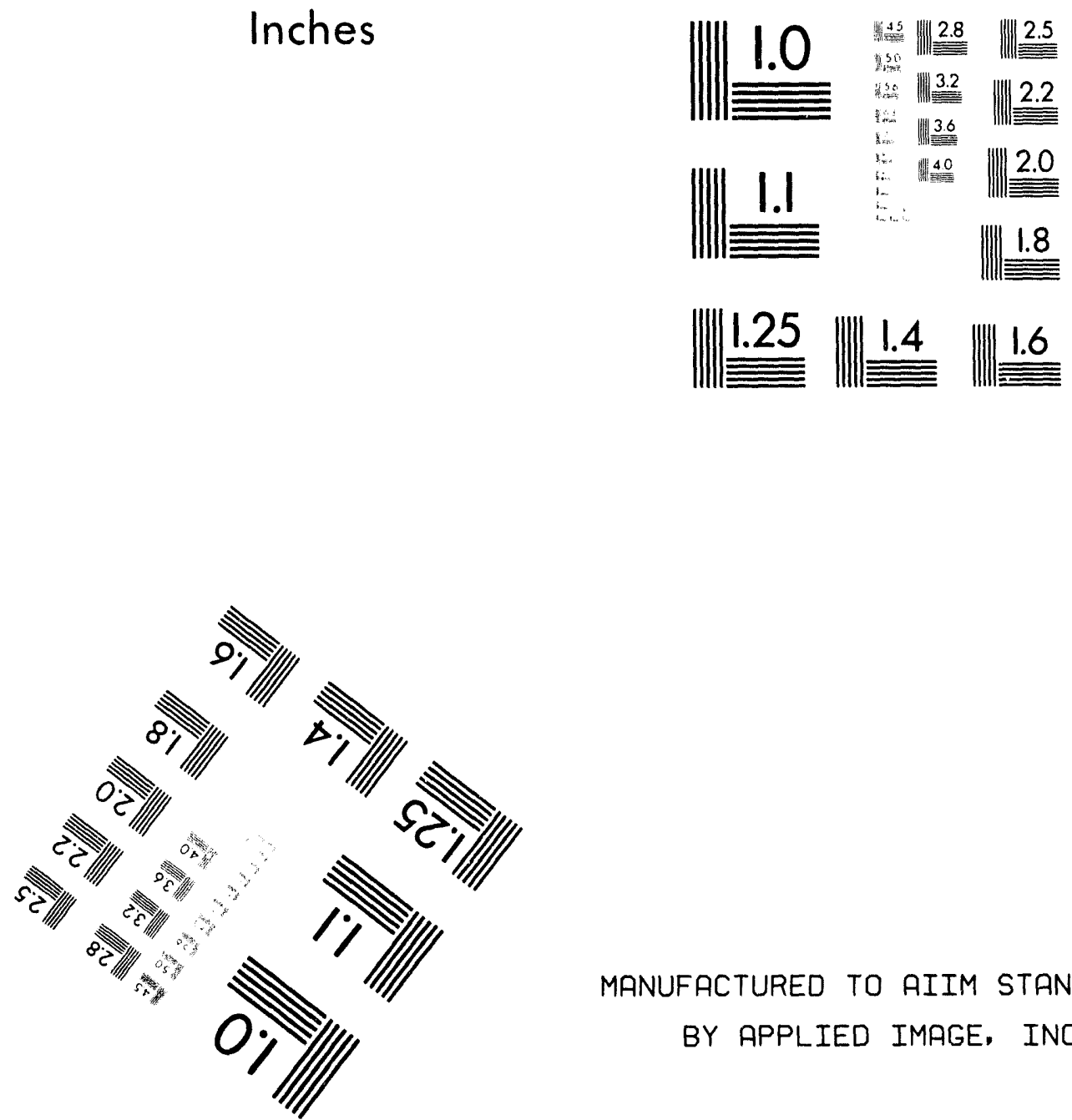

MANUFACTURED TO AIIM STANDARDS BY APPLIED IMAGE, INC.

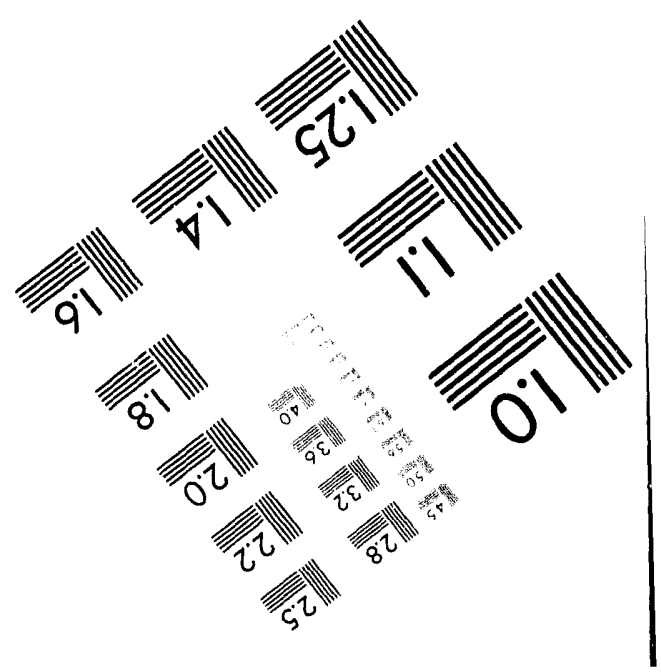



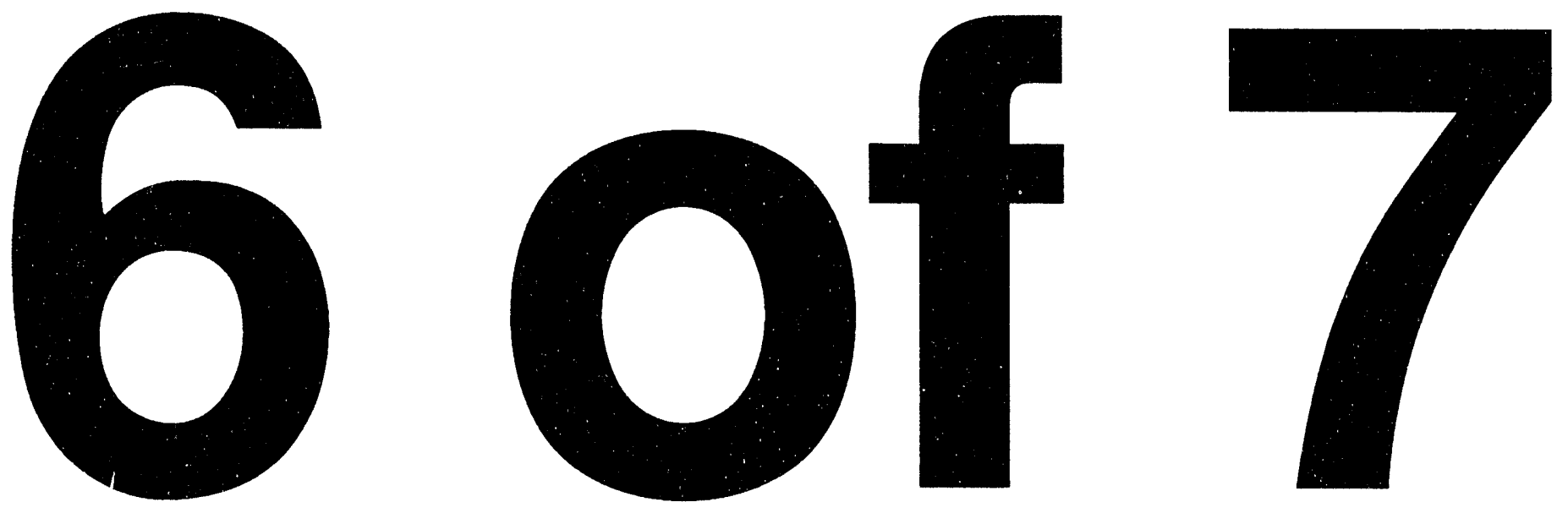
criteria for ERDF waste to ensure that human and ecological exposures will be less than acceptable standards for the foreseeable future.

The acceptable soil concentrations were based on exposure to soils due to the 500 -year drilling scenario. This scenario was determined to be a reasonable exposure scenario given the protective measures included in the ERDF design such as active institutional controls, passive controls, and a minimum 15-foot thick surface barrier. Based on a comparison with maximum contaminant concentrations in 100,200, and 300 Areas waste units, it appears that most of the waste will meet the acceptable soil concentrations. Waste with soil concentrations that exceed the acceptable levels will require mixing with cleaner soils to reduce concuntrations to acceptable levels. For the contaminants that may exceed acceptable levels (metals and radionuclides) no treatment technology exists for reducing concentrations.

Acceptable leachate concentrations were developed to provide protection of groundwater. It is likely that much of the waste received at the ERDF will achieve the leachate criteria without treatment. If this is not the case, however, then the waste will likely require treatment before disposal in the ERDF. For purposes of the detailed evaluation in this report, it was assumed that the wastes would comply with the leachate criteria.

Detailed Evaluation. With the exception of no action, all of the alternatives satisfy the two threshold CERCLA criteria: 1) overall protection of human health and the environment, and 2) compliance with ARARs. The ten alternatives were therefore evaluated against the following CERCLA criteria for detailed evaluation:

- Long-term effectiveness and permanence

- Short-term effectiveness

- Implementability

- Cost.

The criterion that includes reduction of toxicity, mobility, or volume through treatment was not evaluated because it is not within the scope of this RI/FS. Treatment will be evaluated in the source operable units FS reports. The two modifying criteria, state acceptance and community acceptance, will be evaluated following comments on the RI/FS and Proposed Plan and incorporated into the record of decision (ROD).

Comparative Analysis. The results of the detailed evaluation resulted in the following conclusions regarding the primary components of the alternatives:

- Compared with the other barriers, the Hanford Barrier (Alternative 4, 7, and 10) provides the best long-term protection of human health, but at the expense of greater impacts on the environment (due to impacts at borrow sites for construction materials) and higher costs.

- The modified Hanford barrier provides the same groundwater protection as the Hanford Barrier, but with lower cost and less ecological impact. However, because the modified Hanford barrier does not include the crushed basalt layer it is less resistant to intrusion than the Hanford Barrier.

- The low-infiltration soil barrier provides the same groundwater protection as the other two barriers under current climatic conditions for significantly less cost 
and ecological impact. However, under hypothetical wetter climatic conditions, this barrier allows greater infiltration (and thus shorter vadose zone travel times) than the other two barriers.

- Because of the low infiltration rates associated with the surface barriers, alternatives with no liner provide similar groundwater protection as alternatives with a liner. Furthermore, the single liner is virtually equivalent to the double liner in terms of groundwater protection.

- One advantage of lined alternatives is that they provide a means to determine the validity of assumptions regarding leachate generation and leachate quality. If these assumptions prove to be non-conservative, and potential groundwater impacts are deemed unacceptable, then it would be possible to initiate corrective action.

Given the Tri-Party Agreement objective to have the ERDF ready to receive remediation waste by September of 1996, selection of the liner is a time-critical decision. Although the results provided above indicate that a liner may not provide significant benefits (given an effective surface barrier to prevent infiltration), it will provide some measure of redundancy and facilitate confirmation of leachate generation rates and quality.

Selection of the barrier hinges to some extent on the long-term objectives of the ERDF. If the objective is to construct a final remedy that will protect human health and the environment for thousands of years with or without institutional controls, then the extra expense and environmental impacts associated with the Hanford Barrier may be warranted. If the ERDF is expected to be an interim solution, or an evolving facility, that will remain under institutional controls as long as necessary, then a less expensive barrier may be more appropriate. For example, as long as institutional controls are maintained over the ERDF and long-term average precipitation does not increase significantly, the low-infiltration soil and modified Hanford barriers should be just as protective as the Hanford Barrier. Since construction of the barrier will not begin for many years (at least 10 years) selection of the barrier may be postponed until more information is available. 


\subsection{REFERENCES}

Ames, L.L., and R.J. Serne, 1991, Compilation of Data to Estimate Groundwater Migration Potential for Constituents in Active Liquid Discharges at the Hanford Site, PNL-7660, Pacific Northwest Laboratory, Richland, Washington.

Baes, C.F., R.D. Sharp, A.L. Sjoreen, and R.W. Shor, 1984, Review and Analysis of Parameters for Assessing Transport of Environmentally Released Radionuclides through Agriculture, ORNL-5786, Oak Ridge National Laboratory, Oak Ridge, Tennessee.

Baker, V.R., B.N. Bjornstad, A.J. Busacca, K.R. Fecht, E.P. Kiver, U.L. Moddy, J.G. Rigby, D.F. Stradling, and A.M. Tallman, 1991, "Quaternary Geology of the Columbia Plateau", in Quaternary Nonglacial Geology; Conterminus U.S., R.B. Morrison, Editor, Geology of North America, Geological Society of America, Vol. K-2, Boulder, Colorado.

Baker, D.A., and J. K. Soldat, 1992, Methods for Estimating Doses to Organisms from Radioactive Materials Released into the Aquatic Environment, PNL-8150, Pacific Northwest Laboratory, Richland, Washington.

Bierschenk, W.H., 1957, Hydraulic Characteristics of Hanford Aquifers, HW-48916, General Electric Hanford Atomic Products Operation, Richland, Washington.

Bretz, J.H., H.T.U. Smith, and G.E. Neff, 1956, "Channel Scabland of Washington: New Data and Interpretation", Geological Society of America Bulletin, Vol. 67, pp. 957-1049.

Brown, D.J., 1960, Eolian Deposit Beneath 200-West Area, HW-67549, General Electric Company, Richland, Washington.

Burt, W.H., and R.P. Grossenheider, 1976, Field Guide to the Mammals, Houghton Mifflin Company, Boston, Massachusetts.

Cain, F.G., 1994, Environmental Restoration Disposal Facilities (Project W-296) Preliminary Safety Evaluation, WHC-SD-W296-PSE- 001, Rev. 0, Westinghouse Hanford Company, Richland, Washington.

Calder, W., 1984, Size, Function, and Life History, President and Fellows of Harvard College, Cambridge, Massachusetts.

Campbell, N.P., 1989, Structural and Stratigraphic Interpretation of Rocks under the Yakima Fold Belt, Columbia Basin, Based on Recent Surface Mapping and Well Data, Special Paper 239, Geological Society of America, Boulder, Colorado.

Chatters, J.C., 1989, Hanford Cultural Resources Management Plan, PNL-6942, Pacific Northwest Laboratory, Richland, Washington.

Chatters, J.C., 1982, "Prehistoric Settlement and Land Use in the Dry Columbia Basin", in Northwest Anthropological Research Notes, 16, pp. 125-147. 
Clement Associates, 1989, Toxicological Profile for Pentachlorophenol, Syracuse Research Corporation for the Agency for Toxic Substances and Disease Registry, Atlanta, Georgia.

Connelly, M.P., J. V. Borghese, C. D. Delaney, B. H. Ford, J. W. Lindberg, and S.J. Trent, 1992, Hydrogeologic Model for the 200 East Groundwater Aggregate Area, WHC-SD-EN-TI-019, Westinghouse Hanford Company, Richland, Washington.

Coughtrey, P.J., D. Jackson, and M.C. Thorne, 1985, Radionuclide Distribution and Transport in Terrestrial and Aquatic Ecosystems: A Compendium of Data, A.A. Balkema, Boston, Massachusetts.

Cushing, C.E., editor, 1992, Hanford Site National Environmental Policy Act (NEPA) Characterization, PNL-6415, Rev. 5, Pacific Northwest Laboratory, Richland, Washington.

CWC-HDR, Inc., 1988, Water Filtration Plant and North Richland Well Field Evaluation: City of Richland Water and Waste Utilities, City of Richland, Richland, Washington.

Daubenmire, R.A., 1970, Steppe Vegetation of Washington, Washington Agricultural Experiment Station, Technical Bulletin 62, Washington State University, Pullman, Washington.

Daugherty, R.D., 1952, "Archaeological Investigations of O'Sullivan Reservoir, Grant County, Washington", in American Antiquity, 17, pp. 274-278.

Deju, R.A., and K.R. Fecht, 1979, Preliminary Description of Hydrologic Characteristics and Contaminant Transport Potential of Rocks in the Pasco Basin, South-Central Washington, RHO-BWI-LD-20, Rockwell Hanford Operations, Richland, Washington.

Delaney, C.D., K.A. Lindsey, and S.P. Reidel, 1991, Geology and Hydrology of the Hanford Site: A Standardized Text for Use in Westinghouse Hanford Company Documents and Reports, WHC-SD-ER-TI-003, Westinghouse Hanford Company, Richland, Washington.

Dennison, D.I., D.R. Sherwood, and J.S. Young, 1989, Status Report on Remedial Investigation of the 300 Area Process Ponds, PNL-6442, Pacific Northwest Laboratory, Rich'and, Washington.

DNR, 1994, Endangered, Threatened and Sensitive Vascular Plants of Washington, Washington State Department of Natural Resources, Washington Natural Heritage Program, Olympia, Washington.

DOE, 1986, Environmental Assessment - Reference Repository Location, Hanford Site, Washington, Volume 1, DOE/RW-0070, U.S. Department of Energy, Office of Civilian Radioactive Waste Management, Washington, D.C.

DOE, 1987, Final Environmental Impact Statement - Disposal of Hanford Defense High-Level, Transuranic, and Tank Wastes: Hanford Site, Richland, Washington, DOE/EIS-0113, Vols. 1 through 5, U.S. Department of Energy, Washington, D.C. 
DOE, 1988, Site Characterization Plan, Reference Repository Location, Hanford Site, Washington; Consultation Draft, DOE/RW-0164, U.S. Department of Energy, Office of Civilian Radioactive Waste Management, Washington, D.C.

DOE, 1989, Decommissioning of Eight Surplus Production Reactors at the Hanford Site, Richland, Washington; Draft Environmental Statement, DOE/EIS-0119D, U.S. Department of Energy, Washington, D.C.

DOE-RL, 1988, Hanford Facility Dangerous Waste Part A Permit Application, DOE/RL 88-21, Vols. 1-3, U.S. Department of Energy, Richland Operations Office, Richland, Washington.

DOE-RL, 1989, Hanford Site Waste Management Units Report, DOE/RL 88-30, U.S. Department of Energy, Richland Operations Office, Richland, Washington.

DOE-RL, 1990a, Remedial Investigation/Feasibility Study Work Plan for the 300-FF-1 Operable Unit, Hanford Site, Richland, Washington, DOE-RL 88-31, Draft D, U.S. Department of Energy, Richland, Washington.

DOE-RL, 1990b, Phase I Remedial Investigation Report for the Hanford Site 1100-EM-I Operable Unit, DOE-RL-90-18, U.S. Department of Energy, Richland, Washington.

DOE-RL, 1990c, Remedial Investigation/Feasibility Study Work Plan for the 200-BP-1 Operable Unit Hanford Site, Richland, Washington, DOE/RL 88-32, U.S. Department of Energy, Richland, Washington.

DOE-RL, 1990d, Hanford Site Development Plan, DOE/RL 89-15, U.S. Department of Energy, Richland Operations Office, Richland, Washington.

DOE-RL, 1992a, S Plant Aggregate Area Management Study Report, DOE/RL-91-60 Rev. 0, U.S. Department of Energy, Richland Office Operations, Richland, Washington.

DOE-RL, 1992b, T Plant Source Aggregate Area Management Study Report, DOE/RL-91-61 Rev. 0, U.S. Department of Energy, Richland Office Operations, Richland, Washington.

DOE-RL, 1992c, U Plant Source Aggregate Area Management Study Report, DOE/RL-91-52 Rev. 0, U.S. Department of Energy, Richland Office Operations, Richland, Washington.

DOE-RL, 1992d, Z Plant Source Aggregate Area Management Study Report, DOE/RL-91-58 Rev. 0, U.S. Department of Energy, Richland Office Operations, Richland, Washington.

DOE-RL, 1992e, Hanford Site Groundwater Background, DOE/RL-92-23, U.S. Department of Energy, Richland Operations Office, Richland, Washington.

DOE-RL, 1992f, Hanford Site Past-Practice Strategy, DOE/RL-91-40, U.S. Department of Energy, Richland Operations Office, Richland, Washington. 
DOE-RL, 1992g, 100 Area Feasibility Study Phases 1 and 2, DOE/RL-92-11, Draft A, U.S. Department of Energy, Richland Operations Office, Richland, Washington.

DOE-RL, 1992h, Remedial Investigation/Feasibility Study Work Plan for the 100-BC-5 Operable Unit, Hanford Site, Richland, Washington, Rev. 0, DOE/RL 90-08, U.S. Department of Energy, Richland Operations Office, Richland, Washington.

DOE-RL, 1992i, Remedial Investigation/Feasibility Study Work Plan for the 100-FR-1 Operable Unit, Hanford Site, Richland, Washington, DOE/RL 90-33, Rev. 0, U.S. Department of Energy, Richland Operations Office, Richland, Washington.

DOE-RL, 1992j, Remedial Investigation/Feasibility Study Work Plan for the 100-BC-1 Operable Unit, Hanford Site, Richland Washington, Rev. 0, DOE/RL 90-07, U.S. Department of Energy, Richland Operations Office, Richland, Washington.

DOE-RL, 1992k, Remedial Investigation/Feasibility Study Work Plan for the 100-DR-1 Operable Unit, Hanford Site, Richland Washington, DOE/RL 89-09, Rev. 0, U.S. Department of Energy, Richland Operations Office, Richland, Washington.

DOE-RL, 19921, RCRA Facility Investigation/Corrective Measures Study Work Plan for the 100-HR-1 Operable Unit, Hanford Site, Richland, Washington, DOE/RL-88-35, Rev. 0, U.S. Department of Energy, Richland Operations Office, Richland, Washington.

DOE-RL, 1992m, Remedial Investigation/Feasibility Study Work Plan for the 100-KR-1 Operable Unit, Hanford Site, Richland, Washington, DOE/RL-90-20 Rev. 0, U.S. Department of Energy, Richland Operations Office, Richland, Washington.

DOE-RL, 1993a, B Plant Source Aggregate Area Management Study Report, DOE/RL-92-05 Rev. 0, U.S. Department of Energy, Richland Office Operations, Richland, Washington.

DOE-RL, 1993b, PUREX Source Aggregate Area Management Study Report, DOE/RL-92-04 Rev. 0, U.S. Department of Energy, Richland Office Operations, Richland, Washington.

DOE-RL, 1993c, Semiworks Source Aggregate Area Management Study Report, DOE/RL-92-18 Rev. 0, U.S. Department of Energy, Richland Office Operations, Richland, Washington.

DOE-RL, 1993d, Hanford Site Development Plan, DOE/RL-93-19, U.S. Department of Energy, Richland Operations Office, Richland, Washington.

DOE-RL, 1993e, Phase 1 Remedial Investigation Report for the 200-BP-1 Operable Unit, DOE/RL-92-76 Rev. 0, U.S. Department of Energy, Richland, Washington.

DOE-RL, 1993f, Phase I Remedial Investigation Report for the 300-FF-1 Operable Unit, DOE/RL-92-43 Rev. 0, U.S. Department of Energy, Richland Operations Office, Richland, Washington. 
DOE-RL, 1993g, Phase I Remedial Investigation Report for the 300-FF-5 Operable Unit, DOE/RL-93-21, Rev. 0, Vol. 1, U.S. Department of Energy, Richland Operations Office, Richland, Washington.

DOE-RL, 1993h, 300-FF-1 Operable Unit Remedial Investigation Phase II Report: Physical Separation of Soils Treatability Study, DOE/RL-93-96, Draft A, U.S. Department of Energy, Richland Operations Office, Richland, Washington.

DOE-RL, 1993i, Hanford Site Background: Part 1, Soil Background for Nonradioactive Analytes, DOE/RL-92-24, Rev. 1, U.S. Department of Energy, Richland Operations Office, Richland, Washington.

DOE-RL, 1993j, Hanford Site Baseline Risk Assessment Methodology, DOE/RL 91-45, Rev. 2, U.S. Department of Energy, Richland Operations Office, Richland, Washington.

DOE-RL, 1993k, Limited Field Investigation Report for the 100-DR- 1 Operable Unit, DOE/RL-93-29 Draft A, U.S. Department of Energy, Richland Operations Office, Richland, Washington.

DOE-RL, 19931, Phase I and II Feasibility Study Report for the 300-FF-1 Operable Unit, U.S. Department of Energy, Richland Operations Office, Richland, Washington.

DOE-RL, 1994a, 100 Area Soil Washing Bench-Scale Tests, Draft A, DOE/RL-93-107, U.S. Department of Energy, Richland, Washington.

DOE-RL, 1994b, 300-FF-1 Operable Unit Remedial Investigation Phase II Report: Physical Separation of Soils Treatability Study, DOE/RL-93-96, Rev. 0, U.S. Department of Energy, Richland Operations Office, Richland, Washington.

DOE-RL, 1994c, Hanford Site Risk Assessment Methodology, DOE/RL 91-45, Rev. 3, U.S. Department of Energy, Richland Operations Office, Richland, Washington.

DOE-RL, 1994d, Limited Field Investigation Report for the 100-KR- 1 Operable Unit, DOE/RL-93-78, Draft A, U.S. Department of Energy, Richland Operations Office, Richland, Washington.

DOE-RL, 1994e, RCRA Facility Investigation/Corrective Measures Study Work Plan for the 100-NR-2 Operable Unit, Hanford Site, Richland, Washington; Draft C, DOE/RL

91-46, U.S. Department of Energy, Richland Operations Office, Richland, Washington.

DOE-RL, 1994f, RCRA Facility Investigation/Corrective Measures Study Work Plan for the 100-NR-1 Operable Unit, Hanford Site, Richland, Washington; Draft D, DOE/RL

90-22, U.S. Department of Energy, Richland Operations Office, Richland, Washington.

Dorian, J.J., and V.R. Richards, 1978, Radiological Characterization of the Retired 100 Areas, UNI-946, United Nuclear Industries, Richland, Washington.

Douglas United Nuclear, 1967, Investigation of Effluent Control Standards and Practices, DUN-3155, Douglas United Nuclear, Richland, Washington. 
DOW, 1993, Washington Department of Wildlife Species of Special Concern in WashingtonState and Federal Status, Washington State Department of Wildlife. Olympia, Washington.

Downs, J.L., W.H. Rickard, C.A. Brandt, L.L. Cadwell, C.E. Cushing, D.R. Geist, R.M. Mazaika, D.A. Neitzel, L.E. Rogers, M.R. Sackschewsky, and J.J. Nugent, 1993, Habitat Types on the Hanford Site: Wildlife and Plant Species of Concern, PNL-8942, Pacific Northwest Laboratory, Richland, Washington.

Dragun, J., 1988, Soil Chemistry of Hazardous Materials, Hazardous Materials Control Research Institute, Silver Spring, Maryland.

Drummond, M.E., 1992, Future for Hanford: Uses and Cleanup, A Final Report of the Hanford Future Site Uses Working Group, Hanford Future Site Uses Working Group.

Eberhardt, L.E., E.E. Hanson, and L.L. Cadwell, 1982, Analysis of Radionuclide Concentrations and Movement Patterns of Hanford Site Mule Deer, PNL-4420, Pacific Northwest Laboratory, Richland, Washington.

Eberhardt, L.E., E.E.Hanson, and L.L.Cadwell, 1984, "Movement and Activity Patterns of Mule Deer in the Sagebrush-Steppe", Journal of Mammalogy, Vol. 65, pp. 404-409.

Eberhardt, L.E., J.E. Hedland, and W.H. Rickard, 1979, Tagging Studies of Mule Deer Fawns on the Hanford Site, PNL-3147, Pacific Northwest Laboratory, Richland, Washington.

Ecology, EPA, and DOE-RL, 1992, Hanford Federal Facility Agreement and Consent Order, 89-10 Rev. 2, Washington State Department of Ecology, Olympia, Washington, U.S. Environmental Protection Agency, Region X, Seattle, Washington, and U.S. Department of Energy, Richland Operations Office, Richland, Washington.

Ecology, EPA, and DOE-RL, 1993, Tentative Agreement of Tri-Party Agreement Negotiations, Washington State Department of Ecology, Olympia, Washington; U.S. Environmental Protection Agency, Region X, Seattle, Washington, and U.S. Department of Energy, Richland Operations Office, Richland, Washington.

Ecology, EPA, and DOE-RL, 1994, Hanford Federal Facility Agreement and Consent Order, Fourth Amendment, Washington State Department of Ecology, Olympia, Washington, U.S. Environmental Protection Agency, Region X, Seattle, Washington, and U.S. Department of Energy, Richland Operations Office, Richland, Washington.

Eisenbud, M., 1987, Environmental Radioactivity, Academic Press, Inc., San Diego, California.

EPA, 1986, "Guidelines for Carcinogenic Risk Assessment", Federal Register, Vol. 51, pp. 33992-34002.

EPA, 1987, Documentation Records for Hazard Ranking System; NPL Candidate: U.S. DOE Hanford 200 Area, U.S. Environmental Protection Agency, Region X, Seattle, Washington. 
EPA, 1988a, Guidance for Conducting Remedial Investigations and Feasibility Studies Under CERCLA; Interim Final, EPA/540/G-89/004, U.S. Environmental Protection Agency, Office of Emergency and Remedial Response, Washington, D.C.

EPA, 1988b, Limiting Values of Radionuclide Intakes and Air Concentration and Dose Conversion Factors for Inhalation, Submersion, and Ingestion, EPA/520/1-88/020, U.S. Environmental Protection Agency, Office of Radiation Programs, Washington, D.C.

EPA, 1988c, CERCLA Compliance with Other Laws Manual; Interim Final, EPA/540/G-89/006, U.S. Environmental Protection Agency, Office of Emergency and Remedial Response, Washington, D.C.

EPA, 1989a, Risk Assessment Guidance for Superfund: Volume 1, Human Health Evaluation Manual, Part A; Interim Final, EPA/540/1-89/002, U.S. Environmental Protection Agency, Washington, D.C.

EPA, 1989b, Risk Assessment Methodology: Environmental Impact Statement for NESHAPS Radionuclides. Volume I: Background Information Document, EPA/520/1-89/005, U.S. Environmental Protection Agency, Office of Radiation Programs, Washington, D.C.

EPA, 1989c, Technical Guidance Document: Final Covers on Hazardous Waste Landfills and Surface Impoundments, EPA/530/SW-89/047, U.S. Environmental Protection Agency, Office of Solid Waste and Emergency Response, Washington, D.C.

EPA, 1989d, Interim Guidance on Establishing Soil Lead Cleanup Levels at Superfund Sites, U.S. Environmental Protection Agency.

EPA, 1991a, Interim Oral RfD for Copper, U.S. Environmental Protection Agency, Superfund Health Risk Technical Support Center, Cincinnati, Ohio.

EPA, 1991b, Standard Default Exposure Factors, OSWER Directive 9285.6-03, U.S. Environmental Protection Agency, Washington, D. C.

EPA, 1992a, Risk Assessment for Polyaromatic Hydrocarbons, U.S. Environmental Protection Agency, Superfund Health Risk Technical Support Center, Chemical Mixtures and Assessment Branch, Cincinnati, Ohio.

EPA, 1992b, Dermal Exposure Assessment: Principles and Applications, EPA/600/8-91/011B, U.S. Environmental Protection Agency, Exposure Assessment Group, Washington, D.C.

EPA, 1992c, Provisional Oral RfD for Trichloroethylene, U.S. Environmental Protection Agency, Superfund Health Risk Technical Support Center, Chemical Mixtures Assessment Branch, Cincinnati, Ohio.

EPA, 1993a, Integrated Risk Information System (IRIS), data file, U.S. Department of Health and Human Services, National Library of Medicine Toxicology Data Network (TOXNET), Bethesda, Maryland. 
EPA, 1993b, Health Effects Assessment Summary Tables: Annual FY- 1993, EPA/540/R-93/058, U.S. Environmental Protection Agency, Office of Emergency and Remedial Response, Washington, D.C.

EPA-10, 1991, Supplemental Risk Assessment Guidance for Superfund, U.S. Environmental Protection Agency, Region X, Seattle, Washington.

ERDA, 1975, Waste Management Operations: Hanford Reservations, Richland, Washington, Final Environmental Statement, ERDA-1538, Energy Research and Development Administration, Richland, Washington.

Evergreen Community Development Association, 1986, Tri-Cities Enterprise Center Business Development Plan, Evergreen Community Development Association, Richland, Washington.

Faure, G., 1977, Principles of Isotope Geology, John Wiley \& Sons, New York, New York.

Fecht, K.R., 1978, Geology of Gable Mountain -- Gable Burte Area, RHO-BWI-LD-5, Rockwell Hanford Operations, Richland, Washington.

Fecht, K.R., S.P. Reidel, and A.M. Tallman, 1987, Paleodrainage of the Columbia River System on the Columbia Plateau of Washington: A Summary, RHO-BW-SA-318P, Rockwell Hanford Operations, Richland, Washington.

Fitzner, R.E., and W.H. Rickard, 1975, Avifauna of Waste Ponds, ERDA Hanford Reservation, Benton County, Washington, BNWL-1885, Battelle Northwest Laboratory, Richland, Washington.

Fitzner, R.E., and R.H. Gray, 1991, "The Status, Distribution and Ecology of Wildlife on the U.S. DOE Hanford Site: A Historical Overview of Research Activities", Environmental Monitoring and Assessment, Vol. 18, pp. 173-202.

Fuchs, M.R., W.H. Chapman-Riggsbee, K.L. Dillon, R.C. Routson, and M.G. Snow, 1985, Request for Waiver from WAC Requirement for Ground-Water Monitoring at the Non-Radioactive Dangerous Waste Landfill, Hanford Site, Washington State, Rockwell International, Richland, Washington.

Gee, G.W., 1987, Recharge at the Hanford Site: Status Report, PNL-6403, Pacific Northwest Laboratory, Richland, Washington.

Gee, G.W., M.J. Fayer, M.L. Rockhold, and M.D. Campell, 1992, "Variations in Recharge at the Hanford Site", Northwest Science, Vol. 66, pp. 237-250.

Gee, G.W., and P.R. Heller, 1985, Unsaturated Water Flow at the Hanford Site: A Review of Literature and Annotated Bibliography, PNL-5428, Pacific Northwest Laboratory, Richland, Washington.

General Electric, 1964, Catalog of Hanford Buildings and Facilities, General Electric, Hanford Atomic Products Operation, Richland, Washington. 
Gephart, R.E., R.C. Arnett, R.G. Baca, L.S. Leonhart, and F.A. Spane Jr., 1979, Hydrologic Studies Within the Columbia Plateau, Washington: An Integration of Current Knowledge, RHO-BWI-ST-5, Rockwell Hanford Operations, Richland, Washington.

Graham, J.J., 1983, Hydrogeochemical and Mathematical Analysis of Aquifer Intercommunication, Hanford Site, Washington State. Indiana University, Bloomington, Indiana.

Graham, M.J., M.D. Hall, S.R. Strait, and W.R. Brown, 1981, Hydrology of the Separations Area, RHO-ST-42, Rockwell Hanford Operations, Richland, Washington.

Grazulis, T.P., 1984, Violent Tornado Climatology, 1880-1982, NUREG/CR-3670, U.S. Nuclear Regulatory Conmission, Washington, D.C.

Greene, G.S., 1975, "Prehistoric Utilization of the Channeled Scablands of Eastern Washington", Ph.D. Dissertation, Washington State University, Department of Anthropology, Pullman, Washington.

Greengo, R.E., 1982, Studies in Prehistory: Priest Rapids and Wanapum Reservoir Areas, Columbia River, Washington, University of Washington, Department of Anthropology, Pullman, Washington.

Hajek, B.F., 1966, Soil Survey: Hanford Project in Benton County, Washington, BNWL-243, Battelle Northwest Laboratories, Richland, Washington.

Hawkins, E.T., E.A. Ryan, and S.L. Santos, 1990, "Assessing Risk from Dermal Exposure at Hazardous Waste Sites", in New Risks, Cox, L.A.Jr., and P.F. Ricci, editors, Plenum Press, New York, New York.

Hoover, J.D., and T. LeGore, 1991, Characterization and Use of Soil and Groundwter Background for the Hanford Site, WHC-MR-0246, Westinghouse Hanford Company, Richland, Washington.

Howard, P.H., R.S. Boethling, W.F. Jarvis, W.M. Meylan, and E.M. Michalenko, 1991, Handbook of Environmental Degradation Rates, Lewis Publishers, Inc., Chelsea, Michigan.

HSDB Scientific Review Panel, 1993-1994, Hazardous Substance Data Bank, National Library of Medicine Toxicological Data Network (TOXNET), Bethesda, Maryland.

Hulstrom, L.C., 1992, Climatological Summary of the 300 Area for the 300-FF-1 Operable Unit Remedial Investigation, WHC-SD-EN-TI-005, Westinghouse Hanford Company, Richland, Washington.

IAEA, 1992, Effects on lonizing Radiation on Plants and Animals at Levels Implied by Current Radiation Protection Standards, STI/DOC/10/332, Technical Report Series 332, International Atomic Energy Agency, Vienna, Austria. 
ICRP, 1959, "Report of ICRP Committee II on Radiological Protection", in ICRP Publication 2, International Commission on Radiological Protection, Pergamon Press, New York, New York.

Isaacson, R.E., L. E. Brownell, and J. C. Hanson, 1974, Soil Moisture Transport in Arid Site Vadose Zones, ARH-2983, Atlantic Richfield Hanford, Richland, Washington.

IT Corporation, 1993a, Limited Field Investigation Report for the 100-BC-1 Operable Unit, DOE/RL-93-06, U.S. Department of Energy, Richland Operations Office, Richland, Washington.

IT Corporation, 1993b, Limited Field Investigation Report for the 100-HR-1 Operable Unit, DOE/RL-93-51, U.S. Department of Energy, Richland Operations Office, Richland, Washington.

Jamison, J.D., 1982, Standardized Input for Hanford Environmental Impact Statements Part II: Site Descriptions, PNL-3509, Pt 2, Pacific Northwest Laboratory, Richland, Washington.

Jaquish, R.E., and P.J. Mitchell, editors, 1988, Environmental Monitoring at Hanford for 198\%, PNL-6464, Pacific Northwest Laboratory, Richland, Washington.

Jaquish, R.E., and R.W. Bryce, editors, 1990, Hanford Site Environmental Report for Calendar Year 1989, PNL-7346, Pacific Northwest Laboratory, Richland, Washington.

Jones, T.L., 1978, Sediment Moisture Relations Lysimeter Project 1976-1977 Water Year, RHO-ST-15, Rockwell Hanford Operations, Richland, Washington.

Kasza, G.L., M.J. Hartman, F.N. Hodges, and D.C. Weekes, 1992, Ground Water Maps of the Hanford Site, December 1991, WHC-EP-0394-4, Westinghouse Hanford Company, Richland, Washington.

Kipp, K.L., and R.D. Mudd, 1973, Collection and Analysis of Pump Test Data for Transmissivity Values, BNWL-1709, Pacific Northwest Laboratory, Richland, Washington.

Klepper, E.L., L.E. Rogers, J.D. Hedland, and R.G. Schreckhise, 1979, Radioactivity Associated with Biota and Soils of the 216-A- 24 Crib, PNL-1948, Pacific Northwest Laboratory, Richland, Washington.

Kocher, A.E., A.T. Strahorn, and M.H. Lapham, 1921, Soil Survey of Benton County, Washingtor, U.S. Department of Agriculture, Bureau of Soils, Washington, D.C.

Landeen, D.S., A.R. Johnson, and R.M. Mitchell, 1992, Status of Birds at the Hanford Site in Southeastern Washington, WHC-EP-0402, Rev. 1, Westinghouse Hanford Company, Richland, Washington. 
Last, G.V., B.N. Bjornstad, M.P. Bergeron, D.W. Wallace, D.R. Newcomer, J.A. Schramke, M.A. Chamness, C.S. Cline, S.P. Airhart, and J.S. Wilbur, 1989, Hydrogeology of the 200 Areas Low-Level Burial Grounds - An Interim Report, PNL-6820, Pacific Northwest Laboratory, Richland, Washington.

Last, G.V., M.A. Glennon, M.A. Young, and G.W. Gee, 1987, Protective Barrier Materials Analysis: Fine Soil Site Characterization, PNL-6314, Pacific Northwest Laboratory, Richland, Washington.

Lauterbach, M.J., 1992, Westinghouse Hanford Company Regulatory Strategy for Macroengineering Implementation, WHC-SD-EN-EE-008, Rev. 0, Westinghouse Hanford Company, Richland, Washington.

Ledgerwood, R.K., C.W. Myers, and R.W. Cross, 1978, Pasco Basin Stratigraphic Nomenclature, RHO-BWI-LD-1, Rockwell Hanford Operations, Richland, Washington.

Leonhardy, F.C., and D.G. Rice, 1970, "Proposed Culture Typology for the Lower Snake River Region, Southeastern Washington", in Northwest Anthropological Resource Notes, 4, pp. 1-29.

Lindberg, J.W., 1994, Geology of the McGee Ranch Site, Area B: Phase II Characterization, WHC-SD-EN-TI-206, Westinghouse Hanford Company, Richland, Washington.

Lindsey, K.A., 1991, Revised Stratigraphy for the Ringold Formation, Hanford Site, South Central Washington, WHC-SD-EN-EE-004, Westinghouse Hanford Company, Richland, Washington.

Lindsey, K.A., B.N. Bjornstad, J. W. Lindberg, and K. M. Hoffman, 1992, Geologic Setting of the 200 East Area: An Update, WHC-SD-EN-TI-012, Rev. 0, Westinghouse Hanford Company, Richland, Washington.

Ludowise, J.D., 1994, Vitrification Testing of Soil Fines from Contaminated Hanford 100 Area and 300 Area Soils, WHC-SD-EN-TI- 240, Westinghouse Hanford Company, Richland, Washington.

Lyman, W.J., W.F. Reehl, and D.H. Rosenblatt, 1990, Handbook of Chemical Property Estimation Methods - Environmental Behavior of Organic Compounds, American Chemical Society, Washington, D.C.

Montgomery, J.H., and L.M. Welkom, 1990, Groundwater Chemicals Desk Reference, Lewis Publishers, Chelsea, Michigan.

Myers, C.W., S.M. Price, J.A. Caggiano, M.P. Cochran, W.H. Czimer, N.J. Davidson, R.C. Edwards, K.R. Fecht, G.E. Holmes, M.G. Jones, J.R. Kunk, R.D. Landon, R.K. Legerwood, J.T. Lillie, P.E. Long, T.H. Mitchell, E.H. Price, S.P. Reidel, and A.M. Tallman, 1979, Geologic Studies of the Columbia Plateau: A Status Report, RHO-BWI-ST-4, Rockwell Hanford Operations, Richland, Washington. 
Napier, B.A., 1982, Method for Determining "Allowable Residual Contamination Levels" of Radionuclide Mixtures in Soils, PNL-3852, Pacific Northwest Laboratory, Richland, Washington.

National Academy of Science (NAS), 1977, "Drinking Water and Health", National Research Council, Washington, D.C., pp. 22-55.

NCRP, 1985, Radiological Assessment: Predicting the Transport, Bioaccumulation, and Uptake by Man of Radionuclides Released to the Environment, National Council on Radiation Protection and Measurements NCRP Report No. 76, National Council on Radiation Protection and Measurements, Bethesda, Maryland.

Newcomb, R.C., J.R. Strand, and F.J. Frank, 1972, Geology and Ground-Water Characteristics of the Hanford Reservation of the U.S. Atomic Energy Commission, Washington, Professional Paper 717, U.S. Geological Survey, Denver, Colorado.

Newcomer, D.R., K.D. Pohlod, and J.P. McDonald, 1991, Water-Table Elevations on the Harford Site, 1990, PNL-7693, Pacific Northwest Laboratory, Richland, Washington.

NPS, 1992, Draft, Hanford Reach of the Columbia River, Comprehensive River Conservation Study and Environmental Impact Statement, Draft, U.S. National Park Service, Seattle, Washington.

NRC, 1982, Draft Environmental Statement Related to the Construction of Skagit/Hanford Nuclear Projects, Units 1 and 2, NUREG-0894, U.S. Nuclear Regulatory Commission, Washington, D.C.

NRC, 1990, Health Effects of Exposure to Low Levels of lonizing Radiation (BEIR V), National Research Council, National Academy Press, Washington, D. C.

O'Farrell, T.P., R.E. Fitzner, and R.O. Gilbert, 1973, Distribution of Radioactive Jackrabbit Pellets in the Vicinity of the B-C Cribs, 200 East Area, U. S. A. E. C. Hanford Reservation, BNWL-1794, Pacific Northwest Laboratory, Richland, Washington.

Opresko, D.M., B.E. Sample, and G.W. Suter, 1993, Toxicological Benchmarks for Wildlife, ES/ER/TM-86, Oak Ridge National Laboratory, Oak Ridge, Tennessee.

PNL, 1988a, Environmental Monitoring at Hanford for 1987, PNL-6464, Pacific Northwest Laboratory, Richland, Washington.

PNL, 1988b, Hanford Site Groundwater Monitoring for April through June 1987, PNL-6315-1, Pacific Northwest Laboratory, Richland, Washington.

Poole, L.D., 1992, Reproductive Success and Nesting Habitat of Loggerhead Shrikes in Shrubsteppe Communities, Master's Thesis, Oregon State University, Corvallis, Oregon.

PSPL, 1982a, Skagit/Hanford Nuclear Project, Preliminary Safety Analysis Report, Vol. 4, App. 20, Amendment 23, Puget Sound Power and Light Company, Bellevue, Washington. 
PSPL, 1982b, Draft Environmental Statement Related to the Construction of Skagit/Hanford Nuclear Project, Unit 1 and 2, Puget Sound Power \& Light Company, Pacific Power and Light Company, Washington Water Power Company, and Portland General Electric Company, NUREG-0894, Nuclear Regulatory Commission, Washington, D.C.

Reiman, R.T., and T.S. Dahlstrom, 1990, An Aerial Radiological Survey of the Hanford Site and Surrounding Area, Richland, Washington, EGG-10617-1062, EG\&G Energy Measurements, Inc., Richland, Washington.

Relander, C., 1956, Drummers and Dreamers, Pacific Northwest National Parks and Forests Association, Seattle, Washington.

Rice, D.G., 1968a, Archaeological Reconnaissance: Ben Franklin Reservoir Area, 1968, Washington State University, Laboratory of Anthropology, Pullman, Washington.

Rice, D.G., 1968b, Archaeological Reconnaissance: Hanford Atomic Works, U.S. Atomic Energy Commission, National Park Service, Washington State University, Pullman, Washington.

Rice, D.G., 1980, Overview of Cultural Resources on the Hanford Reservation in South Central Washington State, U.S. Department of Energy, Richland, Washington.

Rice, D.G., 1984, Archaeological Inventory of the Basalt Waste Isolation Project, Hanford Reservation, Washington, SD-BWI-TA- 007, Rockwell Hanford Operations, Richland, Washington.

Richard, W.H., and D.G. Watson, 1985, "Four Decades of Environmental Change and Their Influence Upon Native Wildlife and Fish Along the Mid-Columbia River, Washington", Environmental Conservation, Vol. 12, pp. 241-248.

Rickard, W.H., and L.E. Rogers, 1983, "Industrial Land Use and the Conservation of Native Biota in the Shrub-Steppe Region of Western North America", Environmental Conservation, Vol. 10, pp. 205-211.

Rickard, W.H., R.E. Fitzner, and C.E.Cushing, 1981, "Biological Colonization of an Industrial Pond", Environmental Conservation, Vol. 8, pp. 241-247.

Rockhold, M.L., M.J. Fayer, G.W. Gee, and M.J. Kanyid, 1990, Natural Groundwater Recharge and Water Balance at the Hanford Site, PNL-7215, Pacific Northwest Laboratory, Richland, Washington.

Rogers, L.E., and W.H. Rickard, 1977, Ecology of the 200 Area Plateau Waste Management Environs: A Status Report, PNL-2253, Pacific Northwest Laboratory, Richland, Washington.

Rohay, A.C., 1989, "Earthquake Recurrence Rate Estimates for Eastern Washington and the Hanford Site", in Proceedings, Second DOE Natural Phenomena Hazards Mitigation Conference, CONF-8910192, U.S. Department of Energy, Office of Nuclear Safety. 
Rose, K.S.B., 1992, "Lower Limits of Radiosensitivity in Organisms, Excluding Man", Journal of Environmental Radioactivity, Vol. 15, pp. 113-133.

Routson, R.C., M.R. Fuchs, and W.A. Jordan, 1988, Recharge Estimates for the Hanford Sites 200 Areas Plateau, WHC-EP-0046, Westinghouse Hanford Company, Richland, Washington.

Routson, R.C., and V.G. Johnson, 1990, "Recharge Estimates for the Hanford Site 200 Areas Plateau", Northwest Science, Vol. 64,

Sackschewsky, M.R., D.S. Landeen, G.I. Baird, W.H. Rickard, and J.L. Downs, 1992, Vascular Plants of the Hanford Site, WHC-EP-0554, Westinghouse Hanford Company, Richland, Washir:gton.

Schalla, R., R.W. Wallace, R.L. Aaberg, S.P. Airhart, D.J. Bates, J.V.M. Carlile, C.S. Cline, D.I. Dennison, M.D. Freshley, P.R. Heller, E.J. Jensen, K.B. Olsen, R.G. Parkhurst, J.T. Rieger, and E.J. Westergard, 1988, Interim Characterization Report for the 300 Area Process Trenches, PNL-6716, Pacific Northwest Laboratory, Richland, Washington.

Schuler, C.A., W.H. Rickard, and G.A. Sargeant, 1988, Bird Associations with Shrubsteppe Plant Communities at the Proposed Repository Location in Southeastern Washington, PNL-6493, Pacific Northwest Laboratory, Richland, Washington.

Scott, M.J., D.B. Belzer, R.J. Nesse, R.J. Schultz, P.A. Stokowski, and D.C. Clark, 1987, Economic and Community Impacts of Closing Hanford's $N$ Reactor and Nuclear Materials Production Facilities, PNL-6295, Pacific Northwest Laboratory, Richland, Washington.

Scott, M.J., D.B. Belzer, S.J. Marsh, D.M. Beck, R.W. Schultz, and S.A. Harkreader, 1989, Hanford and the Tri-Cities Economy: Review and Outlook, March 1989, PNL-6813, Pacific Northwest Laboratory, Richland, Washington.

SCS, 1960, Soil Classification: A Comprehensive System, 7th Approximation, U.S. Soil Conservation Service, Washington, D.C.

Serne, R.J., and M.I. Wood, 1990, Hanford Waste-Form Release and Sediment Interaction: A Status Report with Rationale and Recommendations for Additional Studies, PNL-7297, Pacific Northwest Laboratory, Richland, Washington.

Skaggs, E., and W.H. Walters, 1981, Flood Risk Analysis of Cold Creek Near the Hanford Site, RHO-BWI-C-120, PNL-4219, Rockwell Hanford Operations, Richland, Washington.

Skelly, W.A., and N.R. Wing, 1992, Site Evaluation Report for a Borrow Site Fine-Textured Soils, WHC-SD-EN-SE-002, Rev. 0, Westinghouse Hanford Company, Richland, Washington.

Spier, L., 1936, Tribal Distribution in Washington, General Services in Anthropology No. 3, George Banta Publishing Co., Menasha, Wisconsin. 
SRC, 1991, Toxicological Profile for Polychlorinated Biphenyls, Syracuse Research Corporation for the Agency for Toxic Substances and Disease Registry, Atlanta, Georgia.

Stenner, R.D., K.H. Cramer, K.A. Higley, S.J. Jette, D.A. Lamar, T.J. McLaughlin, D.R. Sherwood, and N.E. Van Houten, 1988, Hazard Ranking System Evaluation of CERCLA Inactive Waste Sites at Hanford, PNL-6456, Pacific Northwest Laboratory, Richland, Washington.

Stone, W.A., J.M. Thorpe, O.P. Gifford, and D.J. Hoitink, 1983, Climatological Summary for the Hanford Area, PNL-4622, Pacific Northwest Laboratory, Richland, Washington.

Suter II, G.W., 1993, Ecological Risk Assessment, Lewis Publishers, Chelsea, Michigan.

Tallman, A.M., K.R. Fecht, M.C. Marratt, and G.V. Last, 1979, Geology of the Separation Areas, Hanford Site, South-Central Washington, RHO-ST -23, Rockwell Hanford Operations, Richland, Washington.

Terres, J.K., 1980, Audubon Society Encyclopedia of North American Birds, Alfred A. Knopf, New York, New York.

Tipton, W.J., 1975, An Aerial Radiological Survey of the U.S. Energy Research and Development Administration Hanford Reservation, EGG-1183-1661, Energy Research and Development Administration, Washington, D.C.

Tolan, T.L., S.P. Reidel, M.H. Beeson, J.L. Anderson, K.R. Fecht, and D.A. Swanson, 1987, "Revisions to the Areal Extent and Volume of the Columbia River Basalt Group", Geological Society of America Abstracts with Programs, Vol. 19, pp. 458.

Trafzer, C.E., and R.D. Scheuerman, 1986, Renegade Tribe: The Palouse Indians and the Invasion of the Inland Pacific Northwest, Washington State University Press, Pullman, Washington.

Travis, C.C., and A.D. Arms, 1988, "Bioconcentration of Organics in Beef, Milk, and Vegetation", Environmental Science \& Technology, Vol. 22, pp. 271-274.

U.S. Army Corps of Engineers, Walla Walla District, 1993a, On-Site Transportation Network Engineering Study for the Environmental Restoration Storage and Disposal Facility, DOE/RL/12074-12 Rev. 0, U.S. Department of Energy, Richland Operations Office, Richland, Washington.

U.S. Army Corps of Engineers, Walla Walla District, 1993b, Source Inventory Development Engineering Study for the Environmental Restoration Disposal Facility, DOE/RL/12074-29 Rev. 0, U.S. Department of Energy, Richland Operations Office, Richland, Washington.

U.S. Army Corps of Engineers, Walla Walla District, !393c, Engineering Study for the Conveyor and Area Fill Systems for the Environmental Restoration Disposal Facility, DOE/RL/12074-15, Rev. 0, U.S. Department of Energy, Richland Operations Office, Richland, Washington. 
U.S. Army Corps of Enginers, Walla Walla District, 1994, Conceptual Design Report for the Environmental Restoration Storage and Disposal Facility, DOE/RL/12074-28, Rev. 0, U.S. Department of Energy, Richland Operations Office, Richland, Washington.

U.S. Department of Commerce, 1991, 1990 U.S. Census of Population and Housing, State and County Profiles, Washington, U.S. Department of Commerce, Office of Financial Management, Washington, D.C.

U.S. Department of Labor, 1992, Occupational Injuries and Illnesses in the United States by Industry, 1990, Bulletin 2399, U.S. Department of Labor, Bureau of Labor Statistics, Washington, D.C.

USGS, 1978, Richland, Washington, 7.5 Minute Topographic Quadrangle, Scalc : :24,000, U.S. Geological Survey, Denver, Colorado.

Washington National Heritage Program, 1994, Endangered, Threatened and Sensitive Vascular Plants of Washington, Washington State Department of Natural Resources, Olympia, Washington.

Washington State Department of Employment Security, 1993, Labor Force and Employment in Washington State, Washington State Department of Employment Security, Labor Market and Economic Analysis Branch, Olympia, Washington.

Watson, E.C., C.D. Becker, R.E. Fitzner, K.A. Gano, K.L. Imhoff, R.F. McCallum, D.A. Myers, T.L. Page, K.R. Price, J.V. Ramsdell, D.G. Rice, D.L. Schreiber, L.A. Skumatz, D.J. Sommer, J.J. Tawil, R.W. Wallace, and D.G. Watson, 1984, Environmental Characterization of Two Potential Locations at Hanford for a New Production Reactor, PNL-5275, Pacific Northwest Laboratory, Richland, Washington.

Weather Bureau, 1966, Pan and Lake Evaporation, from Weather Bureau Technical Paper No. 37, Weather Bureau.

Weekes, D.C., and J.V. Borghese, 1993, Site Characterization Plan for the Environmental Restoration Disposal Facility, WHC-SD-EN-AP-128, Rev. 0, Westinghouse Hanford Company, Richland, Washington.

Western States Land-Grant Universities and Colleges and SCS, 1964, Soils of the Western United States, Washington State University, Pullman, Washington.

WHC, 1989, Preliminary Operable Units Designation Project, WHC-EP-0216, Westinghouse Hanford Company, Richland, Washington.

WHC, 1991a, Annual Report for RCRA Groundwater Monitoring Projects at Hanford Site Facilities for 1990, DOE-RL-91-03, U.S. Department of Energy, Richland, Washington.

WHC, 1991b, 100 Area Hanford Past Practice Site Cleanup and Restoration Conceptual Study, [Macroengineering study report], Predecisional draft, WHC-EP-0457.

WHC, 1991c, 300 Area Cleanup and Restoration Conceptual Study, WHC-EP-0459, Draft, Westinghouse Hanford Company, Richland, Washington. 
WHC, 1993, Environmental Technology Assessment [Internal Memo to F.V. Roeck, WHC] August 2, 1993

WHC, 1994a, Siting Evaluation Report for the Environmental Restoration Disposal Facility, WHC-SD-EN-EV-009, Rev. 1, Westinghouse Hanford Company, Richland, Washington.

WHC, 1994b, Qualitative Risk Assessment for the 100-BC-1 Source Operable Unit, WHC-SD-EN-RA-003, Rev. 0, Westinghouse Hanford Company, Richland, Washington.

WHC, 1994c, Qualitative Risk Assessment for the 100-DR-1 Source Operable Unit, WHC-SD-EN-RA-005, Rev. 0, Westinghouse Hanford Company, Richland, Washington.

WHC, 1994d, Qualitative Risk Assessment for the 100-HR-1 Source Operable Unit, WHC-SD-EN-RA-004, Rev. 0, Westinghouse Hanford Company, Richland, Washington.

WHC, 1994e, Qualitative Risk Assessment for the 100-KR-1 Source Operable Unit, WHC-SD-EN-RA-009, Rev. 0, Westinghouse Hanford Company, Richland, Washington.

Wing, 1993, Permanent Isolation Surface Barrier: Functional Performance, WHC-EP-0650, Westinghouse Hanford Company, Richland, Washington.

Woodruff, R.K., and R.W. Hanf, 1992, Hanford Site Environmental Report for Calendar Year 1991, PNL-8148, Pacific Northwest Laboratory, Richland, Washington.

Woodruff, R.K., R.W. Hanf, M.G. Hefty, and R.E. Lundgren, 1991 Dec., Hanford Site Environmental Report for Calendar Year 1990, PNL-7930, Pacific Northwest Laboratory, Richland, Washington. 
DOE/RL-93-99, Rev. 0

\section{APPENDIX A}

\section{FATE AND TRANSPORT MODELING}

\section{REFERENCE}

DOE-RL, 1993, Hanford Site Baseline Risk Assessment Methodology, DOE/RL 91-45, Rev. 2, U.S. Department of Energy, Richland Operations Office, Richland, Washington.

WHC, 1993, Screening Performance Assessment/Risk Assessment for the Proposed Environmental Restoration Disposal Facility (ERDF), WHC-SD-EN-TI-201, Rev. 0, Westinghouse Hanford Company, Richland, Washington. 


\section{CONTENTS}

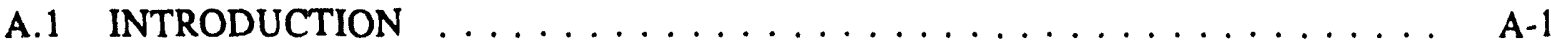

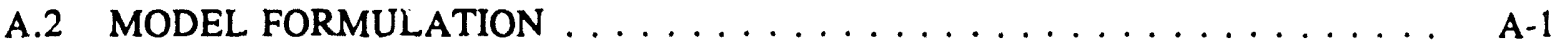

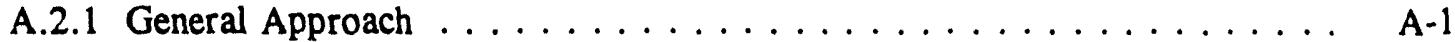

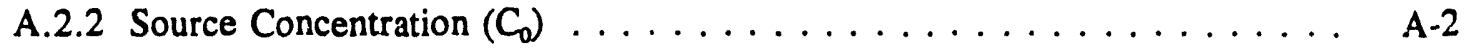

A.2.3 Concentration Directly Beneath the Facility $\left(C_{1}\right) \ldots \ldots \ldots \ldots A$

A.2.4 Concentration at the Water Table Directly Beneath the Facility $\left(C_{2}\right) \ldots \ldots$ A-5

A.2.5 Concentration in Groundwater at the ERDF Boundary $\left(C_{3}\right) \ldots \ldots \ldots \ldots$ A-7

A.2.6 Source Depletion Time . . . . . . . . . . . . . . . . . . . . A-8

A.2.7 Exposure Assessment and Risk Characterization . . . . . . . . . . A A

A.3 SIMULATION FOR BASE CONDITIONS SCENARIO $\ldots \ldots \ldots \ldots \ldots \ldots \ldots$ A-9

A.4 SIMULATIONS FOR REMEDIAL ALTERNATIVES $\ldots \ldots \ldots \ldots \ldots \ldots \ldots$ A . . . . . .

A.4.1 Results for Current Climate Conditions . . . . . . . . . . . . . A-10

A.4.2 Results for Hypothetical Wetter Climate Conditions . . . . . . . . . A-11

FIGURES:

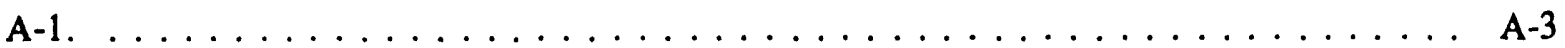

TABLES:

A-1. General Paraneters Used for the ERDF Modeling . . . . . . . . . . . . A-15

A-2. Barrier Parameters Used in the Simulations . . . . . . . . . . . . . . A A-16

A-3. Liner Parameters Used in the Simulations . . . . . . . . . . . . . . . . . . A A-17

A-4. Organic Compound Screening Modeling Results for the Base Conditions Scenario . . . . . . . . . . . . . . . . . . . . . . A-18

A-5. Radionuclide Screening Modeling Results for the Base Conditions Scenario . . . . . . . . . . . . . . . . . . . . . . A-26

A-6. Metal Screening Modeling Results for the Base Conditions Scenario . . . . . . . . A-33

A-7. General Chemistry Screening Modeling Results for the Base Conditions Scenario . . . . . . . . . . . . . . . . . . . . A-36

A-8. Results for Base Conditions Scenario under Current Climate Condition (Accounting for Leachate Limits) . . . . . . . . . . . . . . . . A-37

A-9. Results for Alternatives 2, 3, and 4 under Current Climate Condition

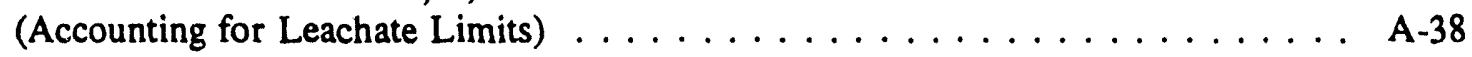

A-10. Results for Alternatives 5, 6, and 7 under Current Climate Condition (Accounting for Leachate Limits) . . . . . . . . . . . . . . . . A-39

A-11. Results for Alternatives 8, 9, and 10 under Current Climate Condition (Accounting for Leachate Limits) . . . . . . . . . . . . . . . . . . . . . . . A-40

A-12. Results for Base Conditions Scenario under Hypothetical Wetter Climate Condition (Accounting for Leachate Limits) . . . . . . . . . . . . . . . A A 
DOE/RL-93-99, Rev. 0

\section{CONTENTS (Cont.)}

TABLES (cont.):

A-13. Results for Alternative 2 under Hypothetical Wetter Climate Condition (Accounting for Leachate Limits) . . . . . . . . . . . . . . . . . . . . . A-43

A-14. Results for Alternatives 3 and 4 under Hypothetical Wetter Climate Condition (Accounting for Leachate Limits) . . . . . . . . . . . . . . . . . A 4 -45

A-15. Results for Alternative 5 under Hypothetical Wetter Climate Condition (Accounting for Leachate Limits) . . . . . . . . . . . . . . . . . . . A A 47

A-16. Results for Alternatives 6 and 7 under Hypothetical Wetter Climate Condition (Accounting for Leachate Limits) . . . . . . . . . . . . . . . . . . . A-49

A-17. Results for Alternative 8 under Hypothetical Wetter Climate Condition (Accounting for Leachate Limits) . . . . . . . . . . . . . . . . . . A A1

A-18. Results for Alternatives 9 and 10 under Hypothetical Climate Condition (Accounting for Leachate Limits) 


\section{A.1 INTRODUCTION}

This appendix describes the modeling conducted to identify the contaminants of potential concern (COPC) and predict the performance of the alternatives regarding future impacts on groundwater. An analytical model is developed to predict the groundwater concentration of each compound detected above soil background at the 100 and 300 Areas operable units. The predicted groundwater concentration of the compound is evaluated against Hanford Site groundwater background concentration and risk-based screening concentration. If the predicted groundwater concentration exceeds both the Hanford Site groundwater background concentration and the risk-based screening concentration, the compound is identified as a COPC. Those identified COPC are further evaluated in the risk assessment to identify contaminants of concern (COC). Groundwater concentrations for the COC are modeled for each of the disposal design alternatives for the proposed ERDF facility. As discussed in Chapter 9, design alternatives differ by barrier type and liner type. Performance is measured in terms of maximum risk and travel time at the facility boundary. This appendix describes the analytical approach for calculation of maximum constituent concentrations in groundwater and travel times to the compliance points. Results of the simulations are also provided.

\section{A.2 MODEL FORMULATION}

\section{A.2.1 General Approach}

Analytical approximations previously described in WHC (1993) are used to approximate maximum concentrations in groundwater at the ERDF boundary for each constituent of interest. This approximate approach attempts to consider all major controlling processes, while still remaining analytically tractable. The equations described in the following sections are implemented in a spreadsheet model. In order to evaluate system performance using the analytical approximations described below, the following major assumptions have been made:

- The media are homogenous and isotropic with no layering.

- All input parameters are time invariant (although decay is accounted for).

- Discrete disruptive events (such as earthquakes, volcanic activity, or human intrusion) or gradual deterioration (such as erosion) which may affect the facility are not considered.

- All travel time calculations assume plug flow (i.e., no longitudinal dispersion).

- No leachate leaks through the liner as long as leachate is pumped from the trench. This period of leachate pumping is referred to as the operational period.

- The synthetic materials in the liners are expected to deteriorate or breach relatively rapidly and are not included in the simulated liners beyond the operational period. 
- Climatic conditions are assumed to remain the same over the duration of the simulations.

Additional assumptions are discussed in subsequent sections.

The model is based on travel time and it accounts for horizontal dilution in the vadose zone and vertical dilution in the saturated zone. The algorithm presented below relies on a stepwise approach to simulate migration from the waste to groundwater at the ERDF boundary. The four points at which concentrations are computed are shown in Figure A-1. $C_{0}$ is the initial leachate concentration at the bottom of the waste. $C_{1}$ is the maximum leachate concentration at the base of the trench (below the liner, if present); $C_{2}$ is the maximum groundwater concentration at the water table (before mixing in the saturated zone); and $\mathrm{C}_{3}$ is the maximum groundwater concentration in the saturated zone at the facility boundary. $\mathrm{C}_{0}$ is calculated based on the waste release mechanisms discussed below. $C_{1}$ is then computed as a function of $C_{0}$ and transport through the liner. $C_{2}$ is computed as a function of $C_{1}$ and transport through the vadose zone. $C_{3}$ is computed as a function of $C_{2}$ and transport in the saturated zone.

\section{A.2.2 Source Concentration $\left(C_{0}\right)$}

Previous modeling using this screening approach for comparing alternative ERDF designs incorporated waste release mechanisms appropriate for grouted and vitrified waste (WHC 1993). These mechanisms, which include waste dissolution and diffusional release, are not addressed in this discussion since only untreated waste is simulated.

For untreated waste, it is assumed that $\mathrm{C}_{0}$ is controlled by the solubility of the contaminant, the amount of contamination in the waste soil, and the partition coefficient between water and soil for the contaminant. Assuming that the contaminant has reached equilibrium between the soil and pore water, $C_{0}$ can be computed as follows:

$$
C_{0}=\operatorname{MIN}\left[\frac{M_{w}}{\left(K_{d, w}+\frac{\theta_{w}}{\rho_{w}}\right)}, C_{s o 1}\right]
$$

where:

$M_{w}=$ concentration of contaminant in the waste $(\mathrm{mg} / \mathrm{kg})$;

$\mathrm{K}_{\mathrm{d}, w}=$ partition coefficient between the waste and infiltrating water $(\mathrm{L} / \mathrm{kg})$;

$\theta_{w} \quad=$ volumetric moisture content of the waste (unitless);

$\rho_{\mathrm{w}}=$ dry density of the waste $(\mathrm{kg} / \mathrm{L}) ;$ and

$\mathrm{C}_{\text {sol }}=$ solubility of contaminant in water $(\mathrm{mg} / \mathrm{L})$. 
This equation indicates that the concentration is controlled by the sorption equilibrium, with the constraint that the concentration can never exceed the solubility.

Given these assumptions, $C_{0}$ should decrease with time if the constituent degrades or decays. This is a reasonable approach given the large uncertainty associated with the radionuclide solubilities. For simplicity, the algorithm relies on the conservative assumption that the leachate is released at time zero with no decay. Furthermore, changes in solubility due to interactions with other waste constituents are not considered.

\section{A.2.3 Concentration Directly Beneath the Facility $\left(C_{1}\right)$}

$\mathrm{C}_{1}$ is computed directly as a function of $\mathrm{C}_{0}$. Assuming plug-flow movement of mass through the liner material (i.e., no longitudinal dispersion), the following equation car be used:

$$
C_{1}=C_{0} e^{-\lambda t_{1}}
$$

where:

$\lambda=$ decay coefficient $\left(\mathrm{yr}^{-1}\right)$, and

$\mathrm{t}_{1} \quad=$ travel time through liner $(\mathrm{yr})$.

This equation assumes no dilution; therefore, if the contaminant does not decay, $C_{1}=C_{0}$. The travel time through the liner, $t_{1}$, is computed by dividing the liner thickness by the advective transport velocity, and multiplying by the retardation factor:

$$
t_{1}=\frac{L_{1}\left(1+\frac{\rho_{1}}{\theta_{1}} K_{d, 1}\right)}{\left(\frac{I_{F C}}{\theta_{1}}\right)}+t_{o p}
$$

where:

$\mathrm{L}_{1} \quad=$ liner thickness $(\mathrm{m})$

$\mathrm{K}_{\mathrm{d}, 1}=$ partition coefficient between liner material and water for contaminant $(\mathrm{L} / \mathrm{kg})$;

$\rho_{1} \quad=$ bulk density of liner material $(\mathrm{kg} / \mathrm{L})$;

$\mathrm{I}_{\mathrm{FC}}=$ infiltration rate through final $\operatorname{cover}(\mathrm{m} / \mathrm{yr})$;

$\theta_{1}=$ moisture content of liner material (unitless);

$t_{\text {op }}=$ duration of the operational period (yr). 
This equation is based on the assumption that leachate is removed during the operational period and that no leakage occurs through the liner during this time. After the operational period, migration through the liner is determined by the advective transport velocity. The advective transport velocity is the rate of migration of a contaminant front assuming plug flow (no diffusion) and is calculated by dividing the rate of infiltration through the final cover by the moisture content.

Previous versions of this model (WHC 1993) also accounted for diffusion through the liner. Including diffusion through the liner could reduce the predicted constituent travel times for liners. Therefore, excluding diffusion means that the model results may over-estimate the benefits of liners. At the proposed ERDF site, travel time through a $1.0 \mathrm{~m}$ thick liner (assuming advective transport) is approximately 8 percent of the vadose zone travel time. Given the greater importance of vadose zone travel time, the advantage of accounting fur diffusion through the liner is not warranted. Additional reasons to ignore this mechanism include the computational difficulties in simulating diffusion as a plug flow process and the lack of information regarding constituent-specific diffusion coefficients.

\section{A.2.4 Concentration at the Water Table Directly Beneath the Facility $\left(C_{2}\right)$}

$\mathrm{C}_{2}$ is computed directly as a function of $\mathrm{C}_{1}$. Assuming plug-flow movement of mass through the unsaturated zone (i.e., no longitudinal dispersion), the following equation can be used:

$$
C_{2}=D \Pi_{2} C_{1} e^{-\lambda t_{2}}
$$

where:

$\mathrm{DIL}_{2}=$ dilution factor for unsaturated zone; and

$t_{2}=$ travel time through unsaturated zone $(\mathrm{yr})$.

As illustrated in this equation, the contaminant concentration is affected by both decay and dilution.

The dilution factor and travel time depend on the hydrogeological behavior of the unsaturated zone. These factors are affected by the degree to which clean water infiltration beyond the horizontal limits of the trench (and the waste) mixes with the contaminated water infiltrating through the trench (and the waste). If we assume that there is no mixing, then the dilution factor, $\mathrm{DIL}_{2}$, is equal to one and the travel time, $t_{2}$, is computed as follows:

$$
t_{2}=\frac{L_{u} \theta_{u}\left(1+\frac{\rho_{v}}{\theta_{u}} K_{d, u}\right)}{I_{F C}}-\frac{t_{\mathrm{IC}}\left(I_{I C}-I_{F C}\right)}{I_{F C}}
$$


where:

$\mathrm{L}_{u} \quad=$ unsaturated zone thickness beneath the trench $(\mathrm{m}) ;$

$\mathrm{K}_{\mathrm{d}, \mathrm{u}}=$ partition coefficient between unsaturated zone soils and water $(\mathrm{L} / \mathrm{kg})$;

$\rho_{\mathrm{u}} \quad=$ bulk density of unsaturated zone material $(\mathrm{kg} / \mathrm{L}) ;$ and

$\theta_{\mathrm{v}}=$ average moisture content of the unsaturated zone (unitless).

$\mathrm{t}_{\mathrm{lc}}=$ length of time until long-term infiltration rate is achieved $(\mathrm{yr}) ;$ and

$I_{\mathrm{IC}}=$ infiltration rate before final cover is completed $(\mathrm{m} / \mathrm{yr})$.

The first term of Equation A-5 is the travel time if the long-term infiltration rate through the final cover controls migration for the entire simulation. The second term of this equation accounts for infiltration that occurs before the final cover is completed. If the interim cover will perform similar to the final cover, this second term can be used to account for infiltration before the interim cover is installed.

The second term of Equation A-5 is normally only relevant for unlined facilities. For lined facilities, the infiltration before installation of the final cover will presumably be retained by the liner (and pumped out) and will not affect vadose zone migration. Elimination of the second term can be accomplished by setting either $t_{\mathrm{lc}}$ or $\mathrm{I}_{\mathrm{IC}}$ to zero.

Assuming some mixing between the contaminated infiltration and clean water infiltrating through the unsaturated zone, the dilution factor and travel time are computed as follows:

$$
\mathrm{DI}_{2}=\frac{I_{\mathrm{FC}} \mathrm{w}_{\mathrm{b}}}{\mathrm{I}_{\mathrm{FC}} \mathrm{w}_{\mathrm{b}}+\mathrm{I}_{\mathrm{z}} \mathrm{w}_{\mathrm{s}} \mathrm{f}_{\text {mix }}}
$$

and

$$
\zeta=\left[\frac{\theta_{v}\left(d_{m}-d_{f}\right)}{I_{F C}}+\frac{\theta_{v}\left(d_{u}-d_{m}\right)}{I_{\text {zve }}}\right]\left[1+\frac{\rho_{v}}{\theta_{v}} K_{d u}\right]-\frac{t_{\mathrm{IC}}\left(I_{\mathrm{TC}}-I_{F C}\right)}{I_{F C}}
$$

where:

$$
I_{\text {ave }}=\frac{I_{F C} W_{b}+I_{s} W_{s}}{W_{b}+w_{s}}
$$

and

$\mathrm{I}_{\mathrm{ave}}=$ average infiltration rate through unsaturated zone $(\mathrm{m} / \mathrm{yr})$;

$\mathrm{I}_{\mathrm{s}}=$ average infiltration rate outside the areal extent of the waste $(\mathrm{m} / \mathrm{yr})$;

$\mathrm{w}_{\mathrm{b}} \quad=$ upper trench width $(\mathrm{m})$; 


$$
\begin{aligned}
& d_{t} \quad=\text { depth of trench }(m) ; \\
& d_{m} \quad=\text { mixing depth }(m) ; \\
& d_{v} \quad=\text { depth to water table (m); } \\
& w_{1} \quad=\text { width of neighboring clean infiltration zone (m); and } \\
& \left.f_{\operatorname{mix}} \quad=\text { mixing factor (unitless fraction between } 0 \text { and } 1\right) .
\end{aligned}
$$

The mixing factor, $f_{\operatorname{mix}}$, quantifies the degree of mixing in the vadose zone between contaminated leachate and uncontaminated water that infiltrates outside the areal extent of the waste. If $\mathrm{f}_{\operatorname{mix}}=0$, there is no mixing; if $\mathrm{f}_{\operatorname{mix}}=1$, there is complete mixing. The mixing depth represents the point in the vadose zone where mixing occurs between contaminated infiltration and clean infiltration. Conceptually, this depth corresponds to a lithologic contrast where horizontal migration would likely occur. The travel time calculation assumes that the migration rate is determined by the barrier infiltration rate above the mixing depth and by the weighted average of the barrier and natural infiltration rates below the mixing depth. As a result, the travel time is reduced as the mixing depth moves closer to the bottom of the trench. In contrast, the dilution due to mixing is the same no matter what the mixing depth. In reality, any dilution and increased migration rates due to infiltration outside the foot print of the barrier will likely occur in multiple increments at distinct lithologic changes. The simplified approach utilized in this exercise is sufficient considering that the compliance point is in the saturated zone.

\section{A.2.5 Concentration in Groundwater at the ERDF Boundary $\left(C_{3}\right)$}

$\mathrm{C}_{3}$ is computed directly as a function of $\mathrm{C}_{2}$. Assuming plug-flow movement of mass through the saturated zone (i.e., no longitudinal dispersion), the following equation can be used:

$$
C_{3}=\mathrm{DI}_{3} \mathrm{C}_{2} \mathrm{e}^{-\lambda_{3}}
$$

where:

$$
\begin{aligned}
& \mathrm{DIL}_{3}=\text { dilution factor for saturated zone; and } \\
& t_{3}=\text { travel time through saturated zone }(\mathrm{yr}) .
\end{aligned}
$$

As illustrated in this equation, the contaminant concentration is affected by both decay and dilution.

The dilution factor and travel time depend on the hydrogeological behavior of the saturated zone. In particular, the dilution factor is determined by the extent that contaminated water at the surface of the aquifer is mixed with deeper clean water. This is, to a large extent, dependent on the assumptions made regarding the depth and pumping rate of the well through which individuals are exposed to concentration $C_{3}$. In this exercise, we assume DIL $_{3}$ is computed as follows: 


$$
D_{3}=\frac{L_{b}\left(I_{F C} w_{b}+I_{g} w_{g} f_{\text {mix }}\right)}{\left(w_{b}+w_{g}\right) K i d_{\text {mix }}+L_{b}\left(I_{P C} w_{b}+I_{s}, f_{\text {mix }}\right)}
$$

where:

$\mathrm{L}_{\mathrm{b}} \quad=$ trench length $(\mathrm{m})$;

$\mathrm{K}=$ hydraulic conductivity of saturated zone $(\mathrm{m} / \mathrm{yr})$;

$\mathrm{i} \quad=$ hydraulic gradient of saturated zone (unitless); and

$\mathrm{d}_{\operatorname{mix}}=$ mixing depth in saturated zone $(\mathrm{m})$, generally assumed to be a minimum well screen length.

The travel time through the saturated zone is computed as follows:

$$
t_{3}=\frac{L_{s} n_{s}\left(1+\frac{\rho_{s}}{n_{s}} K_{d s}\right)}{K i}
$$

where:

$\mathrm{L}_{\mathbf{3}} \quad=$ travel distance in the saturated zone $(\mathrm{m})$;

$\mathrm{K}_{d, 0} \quad=$ partition coefficient between saturated zone material and water $(\mathrm{L} / \mathrm{kg})$;

$\rho_{\mathrm{s}} \quad=$ bulk density of saturated zone material $(\mathrm{kg} / \mathrm{L})$;

$\mathrm{n}_{\mathbf{1}} \quad$ = effective porosity of saturated zone (unitless);

$\mathrm{K}=$ effective hydraulic conductivity of saturated zone $(\mathrm{m} / \mathrm{yr})$; and

i = hydraulic gradient in saturated zone (unitless).

\section{A.2.6 Source Depletion Time}

Source depletion time is defined as the period of time necessary to completely leach a constituent out of the waste. Assuming plug-flow migration of contaminant mass through the soil, the source depletion time, $t_{b}$, can be computed as follows:

$$
t_{b}=\frac{\rho_{w} d M_{w}}{I_{F C} C_{0}}
$$




\section{A.2.7 Exposure Assessment and Risk Characterization}

Lifetime incremental cancer risk (ICR) and hazard quotient (HQ, an indicator of noncarcinogenic toxic effects) are calculated based on concentrations of the contaminants at the compliance point. Expressing performance in terms of risk allows combining the effects of multiple contaminants into two parameters (ICR and HQ) and also illustrates the general magnitude of potential health effects due to the ERDF. Risk calculations were performed using the approach described in the Hanford Site Baseline Risk Assessment Methodology (DOE-RL 1993) and presented in Chapter 5 of this report.

\section{A.3 SIMULATION FOR BASE CONDITIONS SCENARIO}

The base conditions scenario, described in Chapter 4, predicts groundwater concentrations resulting from an ERDF facility with no liner and a non-engineered barrier. Chemical specific parameters (initial concentrations, solubilities and $K_{d}$ 's) are provided in Chapter 4 . Physical parameters used in this scenario are provided in Tables A-1, A-2, and A-3. HELP modeling results presented in Appendix $B$ indicate that infiltration through a non-engineered soil barrier would be $0.035 \mathrm{~cm} / \mathrm{yr}(0.014 \mathrm{in}$./yr) under current climate conditions (rainfall of $18 \mathrm{~cm} / \mathrm{yr}$ [7.1 in./yr]), and $8.6 \mathrm{~cm} / \mathrm{yr}$ (3.4 in./yr) under wetter climate conditions (rainfall of $40 \mathrm{~cm} / \mathrm{yr}$ [16 in./yr]). Since future climate conditions are unknown, a conservative (compared to current conditions) barrier infiltration of $0.5 \mathrm{~cm} / \mathrm{yr}(0.2 \mathrm{in} . / \mathrm{yr})$ was used for this base conditions scenario. Additional infiltration associated with the operational period is not included in the base conditions scenario. The effects associated with the operational period would be minimal considering that the operational infiltration rate of $3 \mathrm{~cm} / \mathrm{yr}(1.2 \mathrm{in} . / \mathrm{yr})$ for five years would only shorten vadose zone travel times by 25 years (compared with a minimum vadose zone travel time of 520 years).

The predicted concentrations are compared to background groundwater concentrations and risk-based de minimis concentrations in Chapter 4 to reduce the list of potential contaminants carried into Chapter 5. The predicted concentrations are then compared to risk-based and ARAR-based screening concentrations in Chapter 5 to identify potential contaminants of concern. Finally, the predicted concentrations are used again in Chapter 6 to conduct the base conditions risk assessment.

Results for the base conditions scenario are presented in Tables $A-4$ for organic compounds, A-5 for radionuclides, A-6 for metal constituents, and A-7 for general chemistry constituents (primarily anions). The conservative biases in the analysis are discussed in Chapter 6.

\section{A.4 SIMULATIONS FOR REMEDIAL ALTERNATIVES}

This section provides predicted groundwater concentrations and associated risk estimates for each of the remedial alternatives (except no-action) and the base conditions scenario described in the previous section. In contrast to the simulation in Section A.3, which included all the identified soil contaminants, simulations in this section only include the constituents of potential concern (identified in Chapter 5). The simulated remedial alternatives, as well as the liner and surface barrier parameters, are described in Chapter 9. General parameters are 
provided in Table A-1, and the constituent-specific parameters are provided in Tables 4-2 through 4-8. Barrier and liner parameters used in the simulations are presented in Tables A-2 and $A-3$, respectively. Note that increased infiltration during the operational time period is included.

For the purposes of the simulations presented in this section, it was assumed that the waste would not generate leachate concentrations that exceeded the acceptable leachate limits described in Appendix C for a HQ of 1 and an ICR of $1 \times 10^{-5}$. This was accomplished by ensuring that the input solubility did not exceed the leachate limits. Note that the leachate limits were calculated assuming the base conditions scenario. In addition, the risk-based criteria were determined using the minimum risk-based concentration for the ingestion and inhalation pathways. The combined effects from both pathways were not included in the waste acceptance criteria. Because the arsenic concentration that corresponds to an ICR of $10^{-5}\left(4.1 \times 10^{-4} \mathrm{mg} / \mathrm{L}\right)$ is less than Hanford Site background $(0.01 \mathrm{mg} / \mathrm{L} 95 / 95 \mathrm{UTL})$, the leachate limit for arsenic is equal to the background concentration. Since this criterion represents background conditions, arsenic is not included in the simulations.

Similar to the results presented in Section A.3 for the baseline scenario, these simulations result in predicted groundwater concentrations. In addition, the hazard quotients (HQ) and incremental cancer risks (ICR) associated with these concentrations are determined. The methodologies for calculating HQs and ICRs, as well as the conversion factors, are discussed in Chapter 6. These conversion factors account for both exposure pathways, ingestion and inhalation; this contrasts with the methodology used to determine the acceptable leachate limits which only includes the dominant pathway. The results presented below, which include both current climate conditions and hypothetical wetter climate conditions, are used in Chapter 9 to assist the detailed evaluation of long-term effectiveness for each of the alternatives.

\section{A.4.1 Results for Current Climate Conditions}

Infiltration rates through the barriers are based on HELP modeling results provided in Appendix B and are summarized in Chapter 9. In general, the HELP results indicate that infiltration through all three engineered barriers is very close to zero. Given uncertainties in the results, however, a conservatively high infiltration rate of $0.01 \mathrm{~cm} / \mathrm{yr}(0.004 \mathrm{in} . / \mathrm{yr})$ was used for the low-infiltration soil barrier, the modified Hanford barrier, and the Hanford Barrier. Results for the base conditions scenario (assuming an infiltration rate of $0.5 \mathrm{~cm} / \mathrm{yr}$ [0.2 in./yr]) as well as the nine alternatives are discussed below.

Base Conditions Scenario. The base conditions scenario presented in this section is the same as in Section A.3 except only constituents of potential concern are simulated, the input solubilities are limited by the acceptable leachate limits, and the effects of increased infiltration during the operational time period are included. The results for the base conditions scenario (non-engineered barrier and no liner) are provided in Table A-8. As discussed above, acceptable leachate limits were determined using only the dominant exposure pathway (ingestion in all cases), while these results account for both pathways. As a result, some of the calculated HQ's and ICR's for individual contaminants are slightly greater than the risk-based criteria of 1 for HQ and $1 \times 10^{-5}$ for ICR. The most significant deviation is the ICR of $1.03 \times 10^{-5}$ for uranium.

The risk drivers under this scenario are carbon-14, technetium-99, and uranium for the ICR and all the metals for the HQ. Summing the results for each constituent results in a total 
ICR of $3 \times 10^{-5}$. The maximum HQ is 1 for antimony. The travel time to the ERDF boundary for all the constituents is 520 years.

No-Liner Alternatives. Because infiltration rates for the low-infiltration soil barrier, the modified Hanford barrier, and the Hanford Barrier are predicted to be the same, the results for Alternatives 2, 3, and 4 (provided in Table A-9) are identical. When an engineered barrier is included in the remedial alternative, the ICRs and HQs drop by approximately two orders of magnitude for each constituent compared to the base conditions scenario except that the ICR of Carbon-14 drops by about three orders of magnitude. The risk drivers under this scenario are technetium-99 and uranium for the ICR (the ICR for carbon-14 is reduced due to decay) and all the metals except chromium (VI) for the HQ. Summing the results for each constituent results in a total ICR of $5 \times 10^{-7}$. The maximum HQ is 0.02 for antimony and fluoride. The travel time to the ERDF boundary is 13,000 years. Therefore, the HQs and ICRs are zero for the 10,000 year time period.

Single-Liner Alternatives. Because infiltration rates for the low-infiltration soil barrier, the modified Hanford barrier, and the Hanford Barrier are the same, the results for Alternatives 5,6 , and 7 (provided in Table A-10) are identical. In comparison with the no-liner alternatives, the single liner increases travel time to the ERDF boundary in two ways:

- The increased infiltration during the operational time period is assumed to be retained by the single liner and pumped out. This adds approximately 2,200 years to the vadose zone travel time.

- The additional travel time through the liner is 710 years (these travel times include the 30 years of leachate removal).

The travel time to the ERDF boundary increases to 16,000 years. Although this additional travel time reduces the risk for decaying contaminants, the constituents that remain have such long half-lives that the effect is negligible. In comparison with the no-liner alternatives, the ICRs and HQs for the single-liner alternatives are essentially the same.

Double-Liner Alternatives. Because infiltration rates for the low-infiltration soil barrier, the modified Hanford barrier, and the Hanford Barrier are the same, the results for Alternatives 8,9 , and 10 (provided in Table A-11) are identical. Due to its greater thickness, the double liner results in a greater liner travel time compared with the single-liner alternatives. The travel time to the ERDF boundary increases to 17,000 years (these travel times include the 30 years of leachate removal). Although this additional travel time reduces the risk for decaying contaminants, the constituents that remain have such long half-lives that the effect is negligible. In comparison with the no-liner alternatives, the ICRs and maximum HQs for the double-liner alternatives are essentially the same.

\section{A.4.2 Results for Hypothetical Wetter Climate Conditions}

These simulations provide information regarding risk and travel time if the rate of infiltration increases due to a climate change or irrigation. Infiltration rates through the barriers under wetter climate conditions are based on HELP modeling results for Spokane climate ( $40 \mathrm{~cm} / \mathrm{yr}$ [16 in/yr] of precipitation) provided in Appendix B and summarized in Chapter 9 . In general, the HELP results indicate that the wetter climate increases infiltration rates through all 
four barriers, and the non-engineered soil cover and the low-infiltration soil barrier allow more infiltration than the modified Hanford barrier or the Hanford Barrier. These simulations use an infiltration rate of $9 \mathrm{~cm} / \mathrm{yr}(3.7 \mathrm{in} / \mathrm{yr})$ for the non-engineered soil cover, $5 \mathrm{~cm} / \mathrm{yr}(2 \mathrm{in} . / \mathrm{yr}) \mathrm{for}$ the low-infiltration soil barrier, and $0.4 \mathrm{~cm} / \mathrm{yr}(0.16 \mathrm{in} . / \mathrm{yr})$ for the modified Hanford and Hanford barriers.

Although this rate of water application is less than that associated with a typical irrigation rate, it turns out that the infiltration rate through the Hanford and mocified Hanford barriers does not increase as the precipitation rate increases. This is because the rate of infiltration is limited by the permeability of the asphalt $\left(1 \times 10^{-8} \mathrm{~cm} / \mathrm{sec}\right)$. Because the low-infiltration soil barrier has no asphalt, the rate of infiltration does increase as precipitation increases. Since risk levels are already above CERCLA standards (see results below) the final conclusions are not significantly affected.

It is unreasonable to assume climate changes or irrigation would occur at time zero (when the facility is closed). Therefore, it was assumed that the infiltration rate for the first 100 years would be the same as the current climate assumptions $(0.5 \mathrm{~cm} / \mathrm{yr}[0.2 \mathrm{in} . / \mathrm{yr}]$ for the base conditions scenario and $0.01 \mathrm{~cm} / \mathrm{yr}$ [0.004 in./yr] for the engineered barrier alternatives). The wet climate infiltration rates were assumed to begin at a time of 100 years. Due to limitations of the spreadsheet model, infiltration before installation of the cover was not included in the wet climate scenarios.

For the base conditions scenario and alternatives that include the low-infiltration soil barrier, the travel times are less than the travel times calculated in the simulations used to screen constituents (see Section A.3). As a result, it was necessary to simulate the full un-screened list of constituents. Although the full list of constituents was simulated, only those constituents with predicted groundwater concentrations above the di-minimis values discussed in Section 4.3 and travel times less than 10,000 years are reported belo'w. The additional constituents include neptunium-237, tritium (H-3), beta-BHC, chloroform, 1,2-dichloroethane, and xylenes.

Base Conditions Scenario. Results for the base conditions Scenario (no liner and a nonengineered soil cover) under wetter conditions are provided in Table A-12. Compared with results for the base conditions scenario under current conditions (Table A-8), the greater infiltration rate under wetter conditions reduces the travel time to the ERDF boundary and the amount of dilution in the saturated zone. The minimum travel time to the ERDF boundary is reduced from 520 years to 130 years. The risk drivers for this scenario are carbon-14, technetium-99, tritium, uranium, and beta-BHC for ICR, and all metals and anions for HQ. Summing the results for each constituent results in a total ICR of $9 \times 10^{-4}$. The maximum HQ is 9 for antimony.

Alternative 2. Results for Alternative 2 (no liner and the low-infiltration soil barrier) under wetter conditions are provided in Table A-13. Compared with results for Alternative 2 under current conditions (Table A-9), the greater infiltration rate under wetter conditions reduces the travel time to the ERDF boundary and reduces the amount of dilution in the saturated zone. The travel time to the ERDF boundary ranges from 150 (e.g., for carbon-14) to 5,400 years (e.g., for beta-BHC).

The risk drivers for this alternative are carbon-14, technetium-99, tritium, uranium, and beta-BHC for ICR, and all the metals and anions for HQ. Summing the results for each constituent results in a total ICR of $3 \times 10^{-4}$. The maximum HQ is 7 for antimony. 
Alternatives 3 and 4. Alternatives 3 (no liner and the modified Hanford barrier) and 4 (no liner and the Hanford Barrier) have exactly the same results for wetter conditions (shown in Table A-14) since the modified Hanford and Hanford barriers have the same infiltration rates. Compared with results for these alternatives under current conditions (Table A-9), the greater infiltration rate under wetter conditions reduces the travel time to the ERDF boundary and reduces the amount of dilution in the saturated zone. The travel time to the ERDF boundary ranges from $500 \mathrm{yr}$ (e.g., for carbon-14) to $42,000 \mathrm{yr}$ (e.g., for beta-BHC).

The risk drivers for these alternatives are carbon-14, technetium-99, and uranium for ICR, and all the metals and anions for HQ. Summing the results for each constituent results in a total ICR of $2 \times 10^{-5}$ within 10,000 years. The maximum HQ is 0.8 for antimony.

Alternative 5. Results for Alternative 5 (single liner and the low-infiltration soil barrier) under wetter conditions are provided in Table A-15. Compared with results for Alternative 5 under current conditions (Table A-10), the greater infiltration rate under wetter conditions reduces the travel time to the ERDF boundary and reduces the amount of dilution in the saturated zone. The travel time to the ERDF boundary is from $150 \mathrm{yr}$ (e.g., for carbon-14) to 5,500 yr (e.g., for beta-BHC).

The risk drivers for this scenario are carbon-14, technetium-99, uranium, and beta-BHC for ICR, and all the metals and anions for HQ. Summing the results for each constituent results in a total ICR of $2 \times 10^{-4}$. The maximum HQ is 7 for antimony. Due to the short source depletion time of tritium ( $18 \mathrm{yr}$ ), the tritium was completely pumped out by the leachate collection system in the liner before it leached out of trench.

Alternatives 6 and 7. Results for Alternatives 6 (single liner and the modified Hanford barrier) and 7 (single liner and the Hanford Barrier) are shown in Table A-16. These alternatives have exactly the same results because the modified Hanford and Hanford barriers have the same infiltration rates. Compared with results for these alternatives under current conditions (Table A-10), the greater infiltration rate under wetter conditions reduces the travel time to the ERDF boundary and reduces the amount of dilution in the saturated zone.

Compared with the results for comparable no-liner alternatives (Alternatives 3 and 4) under wetter conditions, the travel times for these alternatives are increased slightly by the presence of the liner. The minimum travel time to the ERDF boundary for these alternatives is $520 \mathrm{yr}$. Although this additional travel time reduces the risk for decaying contaminants, the constituents that remain have such long half-lives that the effect is negligible. In comparison with the noliner alternatives, the total ICRs and HQs for the single-liner alternatives are essentially the same.

The risk drivers for these alternatives are carbon-14, technetium-99, and uranium for $I C R$, and all the metals and anions for HQ. Summing the results for each constituent results in a total ICR of $2 \times 10^{-5}$ within 10,000 years. The maximum HQ is 0.8 for antimony.

Alternative 8. Results for Alternatives 8 (double liner and the low infiltration soil barrier) under wetter conditions are provided in Table A-17. These results are essentially the same as for Alternative 5 except the travel time through the double liner is longer than the travel time through the single liner. 
The risk drivers for this scenario are carbon-14, technetium-99, uranium, and beta-BHC for ICR, and all the metals and anions for HQ. Summing the results for each constituent results in a total ICR of $2 \times 10^{-4}$. The maximum HQ is 7 for antimony.

Alternatives 9 and 10. The results for Alternatives 9 and 10 are provided in Table A-18. These alternatives have exactly the same results because the modified Hanford and Hanford barriers have the same infiltration rates. The results are essentially the same as for Alternatives 6 and 7 except the travel time through the double liner is longer than the travel time through the single liner.

The risk drivers for these alternatives are carbon-14, technetium-99, and uranium for ICR, and all the metals and anions for HQ. Summing the results for each constituent results in a total ICR of $2 \times 10^{-5}$ within 10,000 years. The maximum HQ is 0.8 for antimony. 
DOE/RL-93-99, Rev. 0

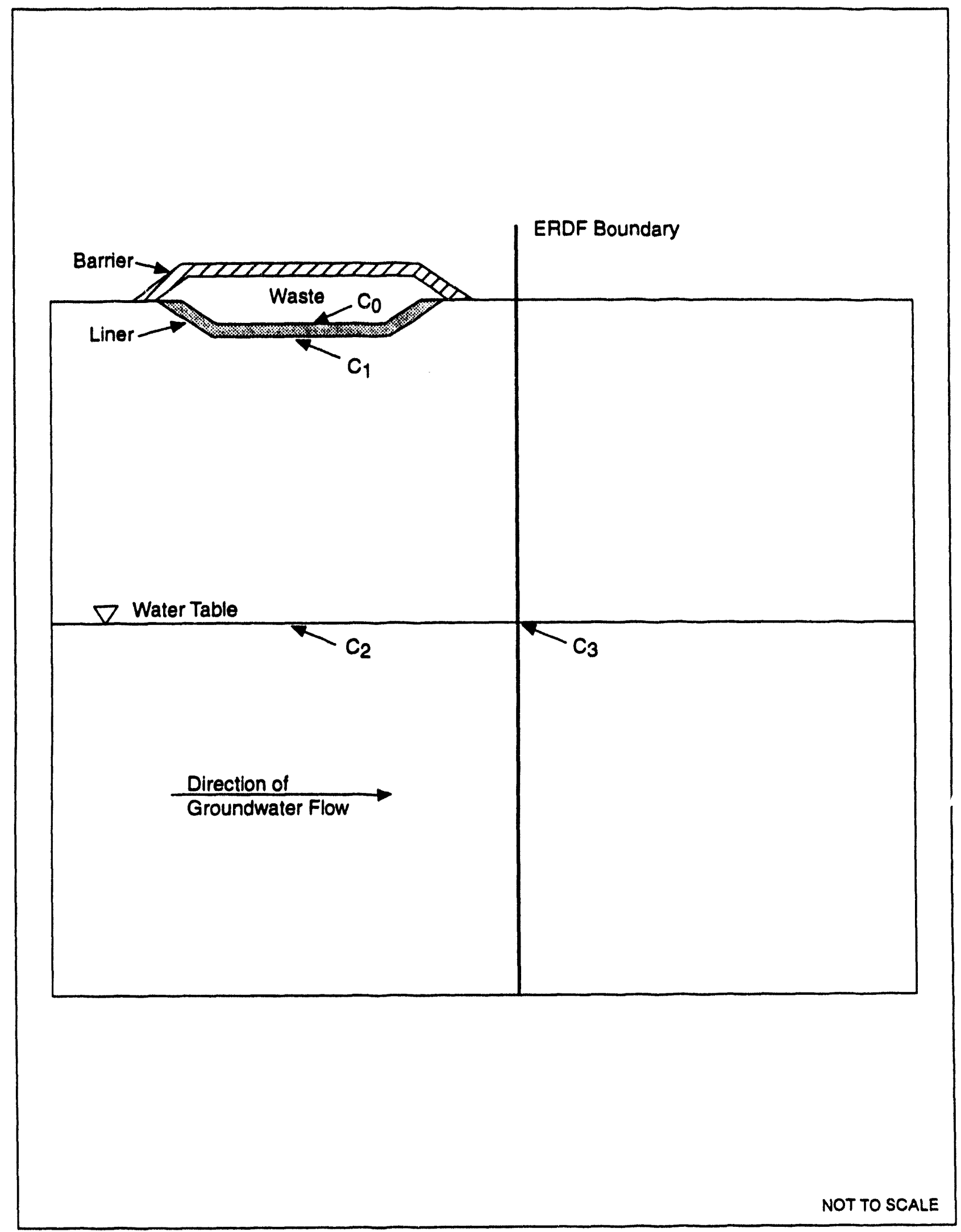

923 E412/49261/3-20-94

Figure A-1. Locations of Compliance Points. 
Table A-1. General Parameters Used for the ERDF Modeling.

\begin{tabular}{|c|c|}
\hline Parameter & Value \\
\hline Upper trench width, $w_{b}(m)$ & 420 \\
\hline Lower trench width, $w_{L}(m)$ & 300 \\
\hline Trench length, $L_{0}(m)$ & 3000 \\
\hline Trench depth, $d_{1}(m)$ & 20 \\
\hline $\begin{array}{l}\text { Distance from edge of facility to nearest trench perpendicular to } \\
\text { direction of groundwater flow, } L_{\mathbf{c}}(\mathrm{m})\end{array}$ & 100 \\
\hline Average moisture content of the unsaturated zone, $\theta_{u}$ (unitless) & 0.045 \\
\hline Depth to water table from ground surface, $d_{\mathrm{a}}(\mathrm{m})$ & 80 \\
\hline Vadose zone mixing depth, $d_{m}(m)$ & 50 \\
\hline Width of neighboring clean infiltration zone, $w,(m)$ & 100 \\
\hline Vadose zone mixing factor, $\mathrm{f}_{\text {mix }}$ & 0 \\
\hline Effective porosity of saturated zone, $n$, (unitless) & 0.3 \\
\hline Effective hydraulic conductivity of saturated zone, $K(\mathrm{~m} / \mathrm{d})$ & 30 \\
\hline Hydraulic gradient in saturated zone, i (unitless) & 0.0035 \\
\hline Mixing depth in saturated zone, $d_{\operatorname{mix}}(m)$ & 5 \\
\hline Soil or waste dry density, $\rho_{1}, \rho_{w}(\mathrm{~kg} / \mathrm{L})$ & 1.6 \\
\hline $\begin{array}{l}\text { Average infiltration rate outside the boundaries of the facility } \\
\text { (natural infiltration rate), } \mathrm{l}(\mathrm{cm} / \mathrm{yr})\end{array}$ & $\begin{array}{l}0.5 \text { (under current climate) } \\
9 \text { (under wet climate) }\end{array}$ \\
\hline
\end{tabular}


Table A-2. Barrier Parameters Used in the Simulations.

\begin{tabular}{|l|c|c|}
\hline & Current Climate & Wet Climate \\
\hline Infiltration rate for base condition, $I_{\mathrm{Fc}}(\mathrm{m} / \mathrm{yr})$ & $5 \mathrm{E}-3$ & $9 \mathrm{E}-2$ \\
\hline Infiltration rate for low infil. soil barrier, $\mathrm{I}_{\mathrm{Fc}}(\mathrm{m} / \mathrm{yr})$ & $1 \mathrm{E}-4$ & $5 \mathrm{E}-2$ \\
\hline Infiltration rate for modified Hanford barrier, $\mathrm{I}_{\mathrm{FC}}(\mathrm{m} / \mathrm{yr})$ & $1 \mathrm{E}-4$ & $4 \mathrm{E}-3$ \\
\hline Infiltration rate for Hanford barrier, $\mathrm{I}_{\mathrm{FC}}(\mathrm{m} / \mathrm{yr})$ & $1 \mathrm{E}-4$ & $4 \mathrm{E}-3$ \\
\hline Initial infiltration rate, $\mathrm{I}_{\mathrm{IC}}(\mathrm{m} / \mathrm{yr})$ & $3 \mathrm{E}-2$ & $\begin{array}{l}5 \mathrm{E}-3 \\
1 \mathrm{E}-4\end{array}$ \\
& & 5 with barrier $)$ \\
\hline $\begin{array}{l}\text { Length of time until long-term infiltration rate is } \\
\text { achieved, } \mathrm{t}_{\mathrm{lc}}(\mathrm{yr})\end{array}$ & 5 & 100 \\
\hline
\end{tabular}


DOE/RL-93-99, Rev. 0

Table A-3. Liner Parameters Used in the Simulations.

\begin{tabular}{|l|c|c|}
\hline & Single Liner & Double Liner \\
\hline Liner thickness, $\mathrm{L}_{1}(\mathrm{~m})$ & 0.3 & 0.9 \\
\hline Bulk density of liner material, $\rho_{1}(\mathrm{~kg} / \mathrm{L})$ & \multicolumn{2}{|c|}{1.5} \\
\hline Moisture content of liner material, $\theta_{1}(\%)$ & 22.5 \\
\hline Duration of operation period, $\mathrm{t}_{\mathrm{p}}(\mathrm{yr})$ & 30 \\
\hline $\mathrm{K}_{\mathrm{d}}$ adjustment factor of liner material & 5 \\
\hline
\end{tabular}


Table A-4. Organic Compound Screening Modeling Results for the Base Conditions Scenario.

\begin{tabular}{|c|c|c|c|c|c|c|c|}
\hline $\begin{array}{c}\text { Orgonic } \\
\text { Compounds }\end{array}$ & Acenephthene & Acetono & Anthrecene & Aroctor-1248 & Aroctor-1254 & Aroclor-1260 & Benzene \\
\hline Bulk Soil Conc. $=(\mathrm{mg} / \mathbf{k g})$ & 8.50E-01 & $2.80 E+\infty$ & $6.30 E+\infty 0$ & $1.00 E+01$ & $6.40 E+\infty$ & $2.30 E+\infty$ & $1.90 E-01$ \\
\hline Partitioning Coof. = & $2.70 E+00$ & $0.00 E+\infty$ & $1.40 E+01$ & $4.40 E+02$ & $7.20 E+02$ & $2.30 E+03$ & $8.70 E-02$ \\
\hline Vedose Zone R = & $9.70 E+01$ & $1.00 E+00$ & $4.99 E+02$ & $1.56 E+04$ & $2.56 E+04$ & $8.18 E+04$ & $4.09 E+\infty$ \\
\hline Saturatod Zone $\mathrm{R}=$ & $1.54 E+01$ & $1.00 E+\infty$ & $7.57 E+01$ & $2.35 E+03$ & $3.84 E+03$ & $1.23 E+04$ & $1.46 E+\infty$ \\
\hline Helf-life & $1.00 E+00$ & $1.00 E+\infty 0$ & $1.00 E+01$ & $1.00 E+\infty$ & $1.00 E+04$ & $1.00 E+04$ & $1.00 E+01$ \\
\hline Decay Rate $=$ & 6.93E-01 & $6.93 E-01$ & 6.93E-02 & 6.93E-01 & $6.93 E-05$ & $6.93 \mathrm{E}-05$ & $6.93 E-02$ \\
\hline Solubility $=$ & $3.70 E+\infty 0$ & $1.00 E+99$ & $7.50 E-02$ & $5.00 E-02$ & $5.00 E-02$ & $8.00 E-02$ & $1.80 E+03$ \\
\hline Soil/Water Partition $\mathrm{CO}=$ & $3.12 E-01$ & $9.96 E+01$ & $4.49 E-01$ & $2.27 E-02$ & $8.89 E-03$ & $1.00 E-03$ & $1.65 E+\infty$ \\
\hline Loochate Conc. $(\mathrm{CO})$ & 3.12E-01 & $9.96 E+01$ & $7.50 E-02$ & 2.27E-02 & 8.89E-03 & $1.00 E-03$ & $1.65 E+\infty$ \\
\hline Vadose Travel Time(T2) = & $5.24 E+04$ & $5.15 E+02$ & $2.69 E+05$ & $8.45 E+08$ & $1.38 E+07$ & $4.42 E+07$ & $2.19 E+03$ \\
\hline Vadose Zone Dilution = & $1.00 E+\infty$ & $1.00 E+00$ & $1.00 E+\infty$ & $1.00 E+\infty$ & $1.00 E+\infty$ & $1.00 E+\infty$ & $1.00 E+\infty$ \\
\hline Wator Table(C2) = & $0.00 E+\infty 0$ & $9.28 \mathrm{E}-154$ & $0.00 E+\infty 0$ & $0.00 E+\infty$ & $0.00 E+\infty$ & $0.00 E+\infty$ & $2.69 \mathrm{E}-66$ \\
\hline Set. Travel Time(T3) $=($ Year) & $1.21 E+01$ & $7.83 E-01$ & $5.92 E+01$ & $1.84 E+03$ & $3.01 E+03$ & $9.60 E+03$ & $1.15 E+\infty$ \\
\hline Set. Zorve Dilution = & 5.95E-02 & $5.95 \mathrm{E}-02$ & $5.95 E-02$ & $5.95 \mathrm{E}-02$ & $5.95 \mathrm{E}-02$ & 5.95E-02 & 5.95E-02 \\
\hline ERDF Boundary $(C 3)=(\mathrm{mg} / \mathrm{L})$ & $0.00 E+00$ & $3.21 E-155$ & $0.00 E+00$ & $0.00 E+\infty$ & $0.00 E+00$ & $0.00 E+\infty$ & $1.48 E-67$ \\
\hline
\end{tabular}


Table A-4. Organic Compound Screening Modeling Results for the Base Conditions Scenario.

\begin{tabular}{|c|c|c|c|c|c|c|c|}
\hline $\begin{array}{c}\text { Organic } \\
\text { Compounds }\end{array}$ & $\begin{array}{c}\text { Benzo(a)- } \\
\text { enthracene }\end{array}$ & $\begin{array}{c}\text { Benzolal- } \\
\text { pyrene }\end{array}$ & $\begin{array}{c}\text { Benzo(b)- } \\
\text { fluoranthene }\end{array}$ & $\begin{array}{c}\text { Benzolo,h,i)- } \\
\text { perylene }\end{array}$ & $\begin{array}{c}\text { Benzo(k)- } \\
\text { fluoranthene }\end{array}$ & $\begin{array}{c}\text { Benzoic } \\
\text { Acid }\end{array}$ & Bote-BHC \\
\hline Bulk Soil Conc. $=(m g / k g)$ & $1.80 E+00$ & $2.70 E+01$ & $2.40 E+00$ & $3.70 E+00$ & 7.60E-01 & $1.30 E+00$ & $7.80 E-03$ \\
\hline Partitioning Coof. = & $1.20 E+03$ & $2.90 E+03$ & $7.60 E+02$ & $5.00 E+02$ & $3.30 E+03$ & $0.00 E+00$ & $2.90 E+00$ \\
\hline Vedose Zone $R=$ & $4.27 E+04$ & $1.03 E+05$ & $2.70 E+04$ & $1.78 E+04$ & $1.17 E+05$ & $1.00 E+\infty 0$ & $1.04 E+02$ \\
\hline Saturated Zone $R=$ & $6.40 E+03$ & $1.55 E+04$ & $4.05 E+03$ & $2.67 E+03$ & $1.76 E+04$ & $1.00 E+\infty 0$ & $1.65 E+01$ \\
\hline Half-life & $1.00 E+01$ & $1.00 E+02$ & $1.00 E+01$ & $1.00 E+01$ & $1.00 E+02$ & $1.00 E+\infty 0$ & $1.00 E+04$ \\
\hline Decay Rate = & $6.93 E-02$ & 8.93E-03 & $6.93 E-02$ & $6.93 \mathrm{E}-02$ & 6.93E-03 & $0.93 E-01$ & 6.93E-05 \\
\hline Solubility $=$ & 5.70E-03 & $4.00 E-03$ & $1.20 E-03$ & 2.60E-04 & 5.50E-04 & $2.90 E+03$ & $5.00 E+00$ \\
\hline & & & & & & & \\
\hline SoilMoter Partition $\mathrm{CO}=$ & $1.50 E-03$ & $9.31 E-03$ & $3.16 E-03$ & $7.40 E-03$ & $2.30 E-04$ & $4.62 E+01$ & $2.66 E-03$ \\
\hline Leachate Conc. (CO) & $1.50 E-03$ & $4.00 E-03$ & $1.20 E-03$ & $2.60 E-04$ & $2.30 E-04$ & $4.62 E+01$ & $2.66 \mathrm{E}-03$ \\
\hline Vedose Travel Time(T2) $=$ & $2.30 E+07$ & $5.57 E+07$ & $1.46 E+07$ & $9.60 E+06$ & $6.34 E+07$ & $5.15 E+02$ & $5.62 E+04$ \\
\hline Vadose Zone Dilution = & $1.00 E+\infty 0$ & $1.00 E+\infty 0$ & $1.00 E+\infty 0$ & $1.00 E+00$ & $1.00 E+\infty 0$ & $1.00 E+00$ & $1.00 E+\infty$ \\
\hline Water Tablo(C2) = & $0.00 E+00$ & $0.00 E+\infty 0$ & $0.00 E+\infty 0$ & $0.00 E+00$ & $0.00 E+00$ & $4.31 E-154$ & 5.42E-05 \\
\hline Set. Travel Timo(T3) $=($ Year $)$ & $5.01 E+03$ & $1.21 E+04$ & $3.17 E+03$ & $2.0 . \mathrm{JE}+03$ & $1.38 E+04$ & $7.83 E-01$ & $1.29 E+01$ \\
\hline Sat. Zone Dilution = & 5.95E-02 & 5.95E-02 & $5.95 E-02$ & $5.95 \mathrm{E}-02$ & 5.95E-02 & 5.95E-02 & 5.95E-02 \\
\hline ERDF Boundary $(\mathrm{C} 3)=(\mathrm{mg} \Omega)$ & $0.00 E+00$ & $0.00 E+\infty$ & $0.00 E+\infty$ & $0.00 E+\infty 0$ & $0.00 E+00$ & $1.49 E-155$ & $3.22 E-06$ \\
\hline
\end{tabular}


Table A-4. Organic Compound Screening Modeling Results for the Base Conditions Scenario.

\begin{tabular}{|c|c|c|c|c|c|c|c|}
\hline \begin{tabular}{|c|}
$\begin{array}{c}\text { Organic } \\
\text { Compounds }\end{array}$ \\
\end{tabular} & $\begin{array}{c}\text { Bia(2-Ethylhexy) } \\
\text { Phthalato }\end{array}$ & Butenone-2 & $\begin{array}{l}\text { Butybenzy- } \\
\text { phtheltate }\end{array}$ & Carbazole & $\begin{array}{c}\text { Cerbon } \\
\text { Diseulfide }\end{array}$ & $\begin{array}{c}\text { Carbon } \\
\text { Totrechloride } \\
\end{array}$ & $\begin{array}{l}\text { Chlordane, } \\
\text { Gernme- }\end{array}$ \\
\hline Bulk Soil Conc. $=(\mathrm{mg} / \mathrm{kg})$ & $3.30 E+01$ & $3.90 E-01$ & $2.60 E+\infty 0$ & 5.40E-02 & $2.00 E-01$ & $8.00 E-03$ & $1.80 E-02$ \\
\hline Partitioning Coof. = & $1.50 E+01$ & $1.00 E-03$ & $2.00 E-01$ & $7.00 E+00$ & $6.30 \mathrm{E}-02$ & 2.90E-01 & $8.60 E+00$ \\
\hline Vedose Zone $\mathrm{R}=$ & $5.34 E+02$ & $1.04 E+\infty 0$ & $8.11 E+\infty$ & $2.50 E+02$ & $3.24 E+00$ & $1.13 E+01$ & $3.07 E+02$ \\
\hline Seturated Zone R = & $8.10 E+01$ & $1.01 E+\infty$ & $2.07 E+\infty 0$ & $3.83 E+01$ & $1.34 E+00$ & $2.55 E+\infty$ & $4.69 E+01$ \\
\hline Half-life & $1.00 E+01$ & $1.00 E+00$ & $1.00 E+00$ & $1.00 E+02$ & $1.00 E+00$ & $1.00 E+01$ & $1.00 E+01$ \\
\hline Decey Rate $=$ & 6.93E-02 & $6.93 E-01$ & $6.93 E-01$ & $6.93 E-03$ & 6.93E-01 & 6.93E-02 & $6.93 E-02$ \\
\hline Solubility $=$ & $4.10 E-02$ & $3.53 E+05$ & $2.90 E+\infty 0$ & $2.20 E+01$ & $2.50 E+03$ & $7.70 E+02$ & 6.40E-01 \\
\hline SoilMater Partition $\mathrm{CO}=$ & $2.20 E+\infty 0$ & $1.34 E+01$ & $1.14 E+01$ & $7.68 E-03$ & $2.19 E+\infty 0$ & $2.51 E-02$ & $2.09 E-03$ \\
\hline Leachato Cone. (CO) & $4.10 E-02$ & $1.34 E+01$ & $2.90 E+\infty 0$ & $7.68 E-03$ & $2.19 E+00$ & $2.51 E-02$ & $2.09 E-03$ \\
\hline Vodose Travel Time(T2) = & $2.89 E+05$ & $5.34 E+02$ & $4.36 E+03$ & $1.35 E+05$ & $1.72 E+03$ & $6.08 E+03$ & $1.66 E+05$ \\
\hline Vedose Zone Dilution = & $1.00 E+\infty 0$ & $1.00 E+\infty 0$ & $1.00 E+\infty 0$ & $1.00 E+\infty$ & $1.00 E+\infty 0$ & $1.00 E+\infty$ & $1.00 E+00$ \\
\hline Woter Table $\left(C_{2}\right)=$ & $0.00 E+\infty 0$ & $2.07 E-160$ & $0.00 E+\infty 0$ & $0.00 E+00$ & $0.00 E+\infty 0$ & $1.92 E-185$ & $0.00 E+\infty$ \\
\hline Sat. Travel Timo(T3) $=($ Yoar $)$ & $6.34 E+01$ & 7.87E-01 & $1.62 E+\infty$ & $3.00 E+01$ & $1.05 E+\infty$ & $1.99 E+\infty$ & $3.67 E+01$ \\
\hline Sot. Zono Dilution = & $5.95 E-02$ & 5.95E-02 & 5.95E-02 & $5.95 E-02$ & 5.95E-02 & $5.95 E-02$ & 5.95E-02 \\
\hline ERDF Boundery $(\mathrm{C} 3)=(\mathrm{mg} / \mathrm{l})$ & $0.00 E+\infty 0$ & $7.14 E-162$ & $0.00 E+\infty$ & $0.00 E+\infty$ & $0.00 E+00$ & $9.96 E-187$ & $0.00 E+\infty$ \\
\hline
\end{tabular}


Table A-4. Organic Compound Screening Modeling Results for the Base Conditions Scenario.

\begin{tabular}{|c|c|c|c|c|c|c|c|}
\hline $\begin{array}{c}\text { Organic } \\
\text { Compounds }\end{array}$ & $\begin{array}{c}\text { Chloro-3- } \\
\text { Mothyiphenol, } 4\end{array}$ & Chloroaniline, 4 & Chloroform & Chrysene & DDD-4,4 & DDE-4.4 & $\begin{array}{c}\text { Di - N - } \\
\text { Butyphthelate }\end{array}$ \\
\hline Bulk Soil Conc. $=(\mathrm{mg} / \mathrm{kg})$ & $3.80 E-02$ & $6.30 E+\infty 0$ & 8.00E-02 & $4.30 \mathrm{E}+01$ & $1.10 E-01$ & $1.70 E-01$ & $5.50 E+\infty 0$ \\
\hline Partitioning Coof. = & $5.00 E-02$ & $8.10 E-01$ & $3.40 E-02$ & $3.80 E+02$ & $8.10 E+01$ & $5.00 E+01$ & $3.30 E+\infty 0$ \\
\hline Vedose Zone $R=$ & $2.78 E+\infty 0$ & $2.98 E+01$ & $2.21 E+\infty 0$ & $1.35 E+04$ & $2.88 E+03$ & $1.78 E+03$ & $1.18 E+02$ \\
\hline Saturated Zone R = & $1.27 E+\infty 0$ & $5.32 E+\infty 0$ & $1.18 E+\infty$ & $2.03 E+03$ & $4.33 E+02$ & $2.68 E+02$ & $1.86 E+01$ \\
\hline Helf-life & $1.00 E+00$ & $1.00 E+00$ & $1.00 E+01$ & $1.00 E+01$ & $1.00 E+02$ & $1.00 E+02$ & $1.00 E+\infty 0$ \\
\hline Decay Rate = & $6.93 \mathrm{E}-01$ & $6.93 \mathrm{E}-01$ & 6.93E-02 & $6.93 \mathrm{E}-02$ & $6.93 \mathrm{E}-03$ & 6.93E-03 & 6.93E-01 \\
\hline Solubility $=$ & $3.90 E+03$ & $3.90 E+03$ & $8.50 E+03$ & $1.50 E-03$ & 5.00E-02 & 5.50E-02 & $1.00 E+01$ \\
\hline SoilMater Partition $\mathrm{CO}=$ & $4.86 E-01$ & $7.52 E+\infty 0$ & $1.29 E+\infty 0$ & $1.13 E-01$ & $1.38 E-03$ & $3.40 E-03$ & $1.65 E+\infty$ \\
\hline Leachate Conc. (CO) & $4.86 E-01$ & $7.52 E+\infty 0$ & $1.29 E+00$ & $1.50 E-03$ & $1.36 \mathrm{E}-03$ & $3.40 E-03$ & $1.65 E+\infty 0$ \\
\hline Vedose Travel Timo(T2) = & $1.48 E+03$ & $1.61 E+04$ & $1.17 E+03$ & $7.30 E+06$ & $1.56 E+06$ & $9.61 E+05$ & $6.39 E+04$ \\
\hline Vedose Zone Dilution = & $1.00 E+\infty 0$ & $1.00 E+00$ & $1.00 E+00$ & $1.00 E+00$ & $1.00 E+\infty$ & $1.00 E+\infty 0$ & $1.00 E+\infty 0$ \\
\hline Woter Tablo $\left(C_{2}\right)=$ & $0.00 E+00$ & $0.00 E+00$ & $9.03 E-36$ & $0.00 E+\infty 0$ & $0.00 E+00$ & $0.00 E+00$ & $0.00 E+00$ \\
\hline Set. Travol Timo(T3) $=$ (Yoar) & 9.92E-01 & $4.16 E+00$ & $9.25 E-01$ & $1.59 E+03$ & $3.39 E+02$ & $2.10 E+02$ & $1.46 E+01$ \\
\hline Sot. Zone Dilution = & $5.95 E-02$ & 5.95E-02 & $5.95 E-02$ & $5.95 E-02$ & 5.95E-02 & $5.95 E-02$ & $5.95 E-02$ \\
\hline ERDF Boundary $(\mathrm{C} 3)=(\mathrm{mg} / \mathrm{L})$ & $0.00 E+00$ & $0.00 E+\infty 0$ & 5.03E-37 & $0.00 E+00$ & $0.00 E+00$ & $0.00 E+00$ & $0.00 E+\infty 0$ \\
\hline
\end{tabular}


Table A-4. Organic Compound Screening Modeling Results for the Base Conditions Scenario.

\begin{tabular}{|c|c|c|c|c|c|c|c|}
\hline $\begin{array}{c}\text { Organic } \\
\text { Compounds }\end{array}$ & $\begin{array}{l}\text { Dibenzo }(a, h) \\
\text { onthrecene }\end{array}$ & Dibenzofuran & $\begin{array}{c}\text { Dichloro- } \\
\text { ethene-1,2 }\end{array}$ & $\begin{array}{c}\text { Dichloro- } \\
\text { benzene-1.3 }\end{array}$ & $\begin{array}{c}\text { Dichloro- } \\
\text { benzeno-1.4 }\end{array}$ & Dioldrin & $\begin{array}{c}\text { Diothy } \\
\text { Phthalate }\end{array}$ \\
\hline Bulk Soil Conc. $=(\mathrm{mg} / \mathrm{kg})$ & $1.70 E+00$ & 5.00E-01 & $1.00 E+00$ & $4.80 \mathrm{E}-02$ & $5.10 E-02$ & $2.10 E-02$ & $1.00 E+00$ \\
\hline Partitioning Coof. $=$ & $1.80 E+03$ & $5.50 E+00$ & $4.30 E-02$ & $2.90 E-01$ & $3.90 E-01$ & $7.40 E+00$ & $3.10 E-01$ \\
\hline Vadose Zone $R=$ & $6.40 E+04$ & $1.97 E+02$ & $2.53 E+\infty 0$ & $1.13 E+01$ & $1.49 E+01$ & $2.64 E+02$ & $1.20 E+01$ \\
\hline Soturated Zone R = & $9.60 E+03$ & $3.03 E+01$ & $1.23 E+00$ & $2.55 E+00$ & $3.08 E+00$ & $4.05 E+01$ & $2.65 E+00$ \\
\hline Half-life & $1.00 E+01$ & $1.00 E+00$ & $1.00 E+01$ & $1.00 E+00$ & $1.00 E+00$ & $1.00 E+01$ & $1.00 E+00$ \\
\hline Decay Rate = & 6.93E-02 & 6.93E-01 & $6.93 E-02$ & 6.93E-01 & $6.93 \mathrm{E}-01$ & 6.93E-02 & $6.93 E-01$ \\
\hline Solubility $=$ & $1.50 E-03$ & $1.00 E+01$ & $6.00 E+02$ & $6.90 E+01$ & $4.90 E+01$ & $9.00 E-02$ & $7.60 E+02$ \\
\hline SoilMater Partition $\mathrm{CO}=$ & $9.44 E-04$ & $9.04 E-02$ & $1.41 E+01$ & $1.51 E-01$ & $1.22 E-01$ & $2.83 E-03$ & $2.96 E+00$ \\
\hline Leachate Conc. (CO) & $9.44 E-04$ & 9.04E-02 & $1.41 E+01$ & $1.51 E-01$ & $1.22 \mathrm{E}-01$ & $2.83 E-03$ & $2.96 E+00$ \\
\hline Vadose Travel Time(T2) = & $3.46 E+07$ & $1.06 E+05$ & $1.34 E+03$ & $6.08 E+03$ & $8.00 E+03$ & $1.43 E+05$ & $6.47 E+03$ \\
\hline Vedose Zone Dilution = & $1.00 E+00$ & $1.00 E+00$ & $1.00 E+00$ & $1.00 E+00$ & $1.00 E+00$ & $1.00 E+00$ & $1.00 E+00$ \\
\hline Water Tablo(C2) $=$ & $0.00 E+00$ & $0.00 E+00$ & $6.19 E-40$ & $0.00 E+00$ & $0.00 E+00$ & $0.00 E+00$ & $0.00 E+00$ \\
\hline Sat. Travel Timo(T3) $=($ Year $)$ & $7.52 E+03$ & $2.37 E+01$ & $9.62 \mathrm{E}-01$ & $1.99 E+00$ & $2.41 E+\infty 0$ & $3.17 E+01$ & $2.08 E+00$ \\
\hline Set. Zone Dilution = & 5.95E-02 & $5.95 \mathrm{E}-02$ & 5.95E-02 & 5.95E-02 & $5.95 \mathrm{E}-02$ & 5.95E-02 & 5.95E-02 \\
\hline ERDF Boundary $(\mathrm{C} 3)=(\mathrm{mg} / \mathrm{L})$ & $0.00 E+\infty$ & $0.00 E+00$ & $3.44 E-41$ & $0.00 E+00$ & $0.00 E+00$ & $0.00 E+00$ & $0.00 E+\infty 0$ \\
\hline
\end{tabular}


Table A-4. Organic Compound Screening Modeling Results for the Base Conditions Scenario.

\begin{tabular}{|c|c|c|c|c|c|c|c|}
\hline $\begin{array}{c}\text { Organic } \\
\text { Compounds }\end{array}$ & Ethylbenzene & Fluorenthene & Fluorene & Hexenone-2 & $\begin{array}{c}\text { Indenol1,2,3- } \\
\text { cd) pyrene }\end{array}$ & $\begin{array}{c}\text { Mothyl } \\
\text { nephtholono-2 }\end{array}$ & $\begin{array}{c}\text { Mothylene } \\
\text { Chloride }\end{array}$ \\
\hline Bulk Soil Conc. $=(\mathrm{mg} / \mathrm{kg})$ & $3.30 E-01$ & $2.90 E+\infty 0$ & $1.70 E+00$ & $9.00 E-03$ & $1.60 E+\infty 0$ & $1.30 E+01$ & $4.50 E+00$ \\
\hline Partitioning Coof. = & $1.60 \mathrm{E}-01$ & $6.60 E+01$ & $5.00 E+00$ & $1.30 \mathrm{E}-01$ & $2.00 E+01$ & $8.50 E+\infty 0$ & $3.70 E-02$ \\
\hline Vedose Zono $R=$ & $6.69 E+00$ & $2.35 E+03$ & $1.79 E+02$ & $5.62 E+00$ & $7.12 E+02$ & $3.03 E+02$ & $2.32 E+00$ \\
\hline Saturated Zono R $=$ & $1.85 E+\infty 0$ & $3.53 E+02$ & $2.77 E+01$ & $1.69 E+\infty 0$ & $1.08 E+02$ & $4.63 E+01$ & $1.20 E+\infty 0$ \\
\hline Helf-life & $1.00 E+\infty 0$ & $1.00 E+01$ & $1.00 E+00$ & $1.00 E+00$ & $1.00 E+01$ & $1.00 E+00$ & $1.00 E+00$ \\
\hline Decay Rate $=$ & $6.93 E-01$ & $6.93 E-02$ & $6.93 \mathrm{E}-01$ & $6.93 E-01$ & $6.93 E-02$ & $6.93 \mathrm{E}-01$ & $6.93 \mathrm{E}-01$ \\
\hline Solubility $=$ & $1.40 E+02$ & $2.75 E-01$ & $1.40 E+\infty 0$ & $3.50 E+04$ & $6.20 E-02$ & $2.50 E+01$ & $2.00 E+04$ \\
\hline Soil/Water Partition $\mathrm{CO}=$ & $1.75 E+\infty$ & 4.39E-02 & 3.38E-01 & $5.69 \mathrm{E}-02$ & $7.99 E-02$ & $1.52 E+\infty$ & $6.91 E+01$ \\
\hline Loechate Conc.(ICO) & $1.75 E+\infty 0$ & 4.39E-02 & 3.38E-01 & $5.69 E-02$ & $6.20 E-02$ & $1.52 E+\infty$ & $6.91 E+01$ \\
\hline Vadose Travel Timo(T2) $=$ & $3.59 E+03$ & $1.27 E+06$ & $9.65 E+04$ & $3.01 E+03$ & $3.85 E+05$ & $1.64 E+05$ & $1.23 E+03$ \\
\hline Vadose Zone Dilution = & $1.00 E+\infty 0$ & $1.00 E+\infty 0$ & $1.00 E+00$ & $1.00 E+00$ & $1.00 E+00$ & $1.00 E+\infty$ & $1.00 E+00$ \\
\hline Water Tablo(C2) $=$ & $0.00 E+\infty$ & $0.00 E+00$ & $0.00 E+\infty$ & $0.00 E+00$ & $0.00 E+00$ & $0.00 E+00$ & $0.00 E+\infty 0$ \\
\hline Sat. Travel Time $(T 3)=$ (Yoar) & $1.45 E+00$ & $2.76 E+02$ & $2.17 E+01$ & $1.33 E+00$ & $8.43 E+01$ & $3.63 E+01$ & $9.37 \mathrm{E}-01$ \\
\hline Sat. Zone Dilution = & 5.95E-02 & $5.95 \mathrm{E}-02$ & $5.95 E-02$ & $5.95 E-02$ & 5.95E-02 & $5.95 E-02$ & 5.95E-02 \\
\hline ERDF Boundary $(\mathrm{C} 3)=(\mathrm{mg} \Omega)$ & $0.00 E+00$ & $0.00 E+00$ & $0.00 E+\infty 0$ & $0.00 E+00$ & $0.00 E+00$ & $0.00 E+\infty$ & $0.00 E+00$ \\
\hline
\end{tabular}


Table A-4. Organic Compound Screening Modeling Results for the Base Conditions Scenario.

\begin{tabular}{|c|c|c|c|c|c|c|c|}
\hline $\begin{array}{c}\text { Organic } \\
\text { Compounds } \\
\end{array}$ & Mothoxychlor & $\begin{array}{c}\text { Mothy } \\
\text { 2-Pentenono. } 4 \\
\end{array}$ & Mothylphenol-4 & $\begin{array}{c}\text { N-Nitroso- } \\
\text { diphonylamine }\end{array}$ & Naphthalone & $\begin{array}{c}\text { Pontectloro- } \\
\text { phenol }\end{array}$ & Phonanthrone \\
\hline Bulk Soil Conc. $=(m g / k g)$ & 8.30E-02 & $1.10 E-02$ & $1.00 E+\infty 0$ & $1.80 E+00$ & $4.10 E+\infty 0$ & $1.50 E+\infty 0$ & $3.90 E+\infty 0$ \\
\hline Partitioning Coof. = & $2.50 E+01$ & 5.00E-02 & $3.50 E-01$ & $1.20 E+\infty 0$ & $1.40 E+00$ & $3.50 E+\infty 0$ & $2.30 E+01$ \\
\hline Vadose Zone R = & $8.90 E+02$ & $2.78 E+00$ & $1.34 E+01$ & 4.37E +01 & $5.08 E+01$ & $1.25 E+02$ & $8.19 E+02$ \\
\hline Soturated Zone R = & $1.34 E+02$ & $1.27 E+\infty 0$ & $2.87 E+\infty$ & $7.40 E+00$ & $8.47 E+\infty 0$ & $1.97 E+01$ & $1.24 E+02$ \\
\hline Helf-lifo & $1.00 E+01$ & $1.00 E+\infty 0$ & $1.00 E+\infty 0$ & $1.00 E+\infty$ & $1.00 E+\infty 0$ & $1.00 E+01$ & $1.00 E+01$ \\
\hline Decay Rate = & $6.93 E-02$ & $6.93 E-01$ & $6.93 E-01$ & $6.93 E-01$ & 6.93E-01 & $6.93 E-02$ & $6.93 E-02$ \\
\hline Solubility = & $2.00 E-02$ & $1.70 E+04$ & $1.90 E+04$ & $3.50 E+01$ & $2.20 E+01$ & $1.70 E+01$ & $1.10 E+\infty$ \\
\hline Soil/Water Partition $\mathrm{CO}=$ & $3.32 E-03$ & $1.41 E-01$ & $2.64 E+\infty$ & $1.47 E+\infty$ & $2.87 E+\infty 0$ & $4.25 E-01$ & $1.69 E-01$ \\
\hline Leachate Conc. $(\mathrm{CO})$ & $3.32 \mathrm{E}-03$ & 1.41E-01 & $2.64 E+\infty 0$ & $1.47 E+00$ & $2.87 E+\infty 0$ & 4.25E-01 & $1.69 E-01$ \\
\hline Vedose Travel Time(T2) $=$ & $4.81 E+05$ & $1.48 E+03$ & $7.24 E+03$ & $2.36 E+04$ & $2.74 E+04$ & $6.77 E+04$ & $4.42 E+05$ \\
\hline Vodose Zone Dilution = & $1.00 E+\infty 0$ & $1.00 E+\infty 0$ & $1.00 E+00$ & $1.00 E+\infty 0$ & $1.00 E+00$ & $1.00 \varepsilon+\infty$ & $1.00 E+\infty 0$ \\
\hline Water Table(C2) = & $0.00 E+\infty 0$ & $0.00 E+\infty$ & $0.00 E+00$ & $0.00 E+00$ & $0.00 E+\infty 0$ & $0.00 E+\infty 0$ & $0.00 E+00$ \\
\hline Sot. Travel Timo(T3) = (Noar) & $1.05 E+02$ & 9.92E-01 & $2.24 E+\infty 0$ & $5.79 E+00$ & $6.63 E+00$ & $1.54 E+01$ & $9.68 E+01$ \\
\hline Set. Zone Dilution = & $5.95 E-02$ & 5.95E-02 & $5.95 E-02$ & 5.95E-02 & 5.95E-02 & 5.95E-02 & $5.95 E-02$ \\
\hline ERDF Boundary $(\mathrm{C} 3)=(\mathrm{mg} /)$ & $0.00 E+\infty$ & $0.00 E+\infty$ & $0.00 E+\infty$ & $0.00 E+\infty$ & $0.00 E+\infty 0$ & $0.00 E+\infty$ & $0.00 E+00$ \\
\hline
\end{tabular}


Table A-4. Organic Compound Screening Modeling Results for the Base Conditions Scenario.

\begin{tabular}{|c|c|c|c|c|c|c|c|}
\hline $\begin{array}{c}\text { Orgenic } \\
\text { Compounds }\end{array}$ & Phenol & Pyreno & $\begin{array}{c}\text { Totro- } \\
\text { chlopoothene }\end{array}$ & $\begin{array}{l}\text { Tetrechloro- } \\
\text { otheno-1,1,2,2 }\end{array}$ & Toluene & $\begin{array}{c}\text { Trichloro- } \\
\text { othene }\end{array}$ & $\begin{array}{c}\text { Trichoro- } \\
\text { othene-1,1,1 }\end{array}$ \\
\hline Bulk Soil Conc. $=(\mathbf{m g} / \mathbf{k g})$ & $2.40 E-01$ & $1.20 E+01$ & $1.10 E+\infty$ & $3.00 E-03$ & $1.50 \mathrm{E}-01$ & $3.90 E-01$ & $6.00 E-03$ \\
\hline Partitioning Coof. $=$ & $6.50 E-02$ & $1.20 E+01$ & $2.20 E-01$ & $7.90 E-02$ & $1.80 E-01$ & $1.10 E-01$ & $1.30 E-01$ \\
\hline Vedose Zono $R=$ & $3.31 E+00$ & $4.28 E+02$ & $8.82 E+00$ & $3.81 E+00$ & $7.40 E+00$ & $4.91 E+\infty$ & $5.62 E+\infty 0$ \\
\hline Saturated Zono $\mathrm{R}=$ & $1.35 E+00$ & $6.50 E+01$ & $2.17 E+00$ & $1.42 E+00$ & $1.96 E+00$ & $1.59 E+00$ & $1.69 E+\infty$ \\
\hline Half-life & $1.00 E+00$ & $1.00 E+02$ & $1.00 E+01$ & $1.00 E+00$ & $1.00 E+00$ & $1.00 E+01$ & $1.00 E+01$ \\
\hline Decay Rate $=$ & $6.93 E-01$ & $6.93 \mathrm{E}-03$ & $6.93 \mathrm{E}-02$ & $6.93 E-01$ & $6.93 \mathrm{E}-01$ & $6.93 E-02$ & $6.93 E-02$ \\
\hline Solubility $=$ & $8.20 E+04$ & $1.40 E-01$ & $8.30 E+02$ & $3.10 E+03$ & $5.20 E+02$ & $1.10 E+03$ & $1.70 E+03$ \\
\hline Soil/Water Partition $\mathrm{CO}=$ & $2.58 E+00$ & $9.98 \mathrm{E}-01$ & $4.43 E+\infty$ & $2.80 E-02$ & 7.21E-01 & $2.82 E+00$ & 3.79E-02 \\
\hline Leachate Conc. (CO) & $2.58 E+00$ & $1.40 E-01$ & $4.43 E+00$ & $2.80 E-02$ & $7.21 \mathrm{E}-01$ & $2.82 E+\infty 0$ & $3.79 E-02$ \\
\hline Vodose Travel Time(T2) $=$ & $1.76 E+03$ & $2.31 E+05$ & $4.74 E+03$ & $2.03 E+03$ & $3.97 E+03$ & $2.63 E+03$ & $3.01 E+03$ \\
\hline Vedose Zone Dilution = & $1.00 E+00$ & $1.00 E+00$ & $1.00 E+00$ & $1.00 E+00$ & $1.00 E+00$ & $1.00 E+\infty$ & $1.00 E+00$ \\
\hline Water Tablo(C2) $=$ & $0.00 E+00$ & $0.00 E+00$ & $9.74 E-143$ & $0.00 E+00$ & $0.00 E+00$ & $2.35 E-79$ & $8.69 E-93$ \\
\hline Sat. Travel Time(T3) $=($ Year) & $1.05 E+00$ & $5.09 E+01$ & $1.70 E+\infty 0$ & $1.11 E+00$ & $1.53 E+00$ & $1.24 E+00$ & $1.33 E+00$ \\
\hline Sat. Zone Dilution $=$ & $5.95 E-02$ & 5.95E-02 & 5.95E-02 & 5.95E-02 & $5.95 E-02$ & $5.95 \mathrm{E}-02$ & $5.95 \mathrm{E}-02$ \\
\hline ERDF Boundery $(\mathrm{C} 3)=(\mathrm{mg} / \mathrm{L})$ & $0.00 E+00$ & $0.00 E+00$ & $5.15 E-144$ & $0.00 E+00$ & $0.00 E+00$ & $1.28 E-80$ & 4.71E-94 \\
\hline
\end{tabular}


Table A-4. Organic Compound Screening Modeling Results for the Base Conditions Scenario.

\begin{tabular}{|c|c|c|}
\hline $\begin{array}{c}\begin{array}{c}\text { Organic } \\
\text { Compounds }\end{array} \\
\end{array}$ & $\begin{array}{c}\text { Vinyt } \\
\text { Chloride }\end{array}$ & $\begin{array}{l}\text { Xylones } \\
\text { (total) }\end{array}$ \\
\hline Bulk Soil Conc. $=(\mathbf{m g} / \mathbf{k g})$ & $2.40 E-02$ & $1.10 E+00$ \\
\hline Partitioning Coof. = & $5.60 E-02$ & $5.70 E-02$ \\
\hline Vodose Zone R $=$ & $2.99 E+00$ & $3.03 E+00$ \\
\hline Seturated Zone R = & $1.30 E+\infty 0$ & $1.30 E+\infty$ \\
\hline Helf-life & $1.00 E+01$ & $1.00 E+01$ \\
\hline Decay Rate $=$ & $6.93 E-02$ & $6.93 \mathrm{E}-02$ \\
\hline Solubility $=$ & $1.90 E+03$ & $1.50 E+02$ \\
\hline Soil/Water Partition $\mathrm{CO}=$ & $2.85 E-01$ & $1.29 E+01$ \\
\hline Leschate Conc. (CO) & $2.85 E-01$ & $1.29 E+01$ \\
\hline Vedoso Travol Timo(T2) = & $1.59 E+03$ & $1.61 E+03$ \\
\hline Vedose Zone Dilution = & $1.00 E+00$ & $1.00 E+00$ \\
\hline Wator Tablo(C2) = & $3.85 E-49$ & $4.61 E-48$ \\
\hline Sot. Travel Time(T3) $=($ Yoar $)$ & $1.02 E+\infty 0$ & $1.02 E+00$ \\
\hline Set. Zone Dilution = & $5.95 E-02$ & $5.95 E-02$ \\
\hline ERDF Boundery $\left(\mathrm{C}^{2}\right)=(\mathrm{mg} \Omega)$ & $2.13 E-50$ & $2.55 E-49$ \\
\hline
\end{tabular}


Table A-5. Radionuclide Screening Modeling Results for the Base Conditions Scenario.

\begin{tabular}{|c|c|c|c|c|c|c|c|}
\hline Redionuclides & Amoricium-241 & Berium-140 & Beryllium-7 & Cerbon-14 & Corium-141 & Corium-144 & Cesium-134 \\
\hline Bulk Soil Conc. $=(p \mathrm{Ci} / \mathrm{g})$ & $3.40 E+01$ & $4.00 E+02$ & $9.00 E+01$ & $6.40 E+02$ & $3.00 E+00$ & $5.00 E-01$ & $5.60 E+01$ \\
\hline Bulk Soil Conc. $=(\mathrm{pCi} / \mathrm{kg})$ & $3.40 E+04$ & $4.00 E+05$ & $9.00 E+04$ & $6.40 E+05$ & $3.00 E+03$ & $5.00 E+02$ & $5.60 E+04$ \\
\hline Partitioning Coof. = & $2.00 E+02$ & $2.50 E+01$ & $2.00 E+01$ & $0.00 E+00$ & $2.00 E+02$ & $2.00 E+02$ & $5.00 E+01$ \\
\hline Vadose Zone $\mathrm{R}=$ & $7.11 E+03$ & $8.90 E+02$ & $7.12 E+02$ & $1.00 E+00$ & $7.11 E+03$ & $7.11 E+03$ & $1.78 E+03$ \\
\hline Seturated Zone R = & $1.07 E+03$ & $1.34 E+02$ & $1.08 E+02$ & $1.00 E+00$ & $1.07 E+03$ & $1.07 E+03$ & $2.68 E+02$ \\
\hline Helf-life (yoars) & $4.32 E+02$ & $3.50 E-02$ & $1.46 \mathrm{E}-01$ & $5.73 E+03$ & $8.90 E-02$ & $7.78 E-01$ & $2.06 E+00$ \\
\hline Decay Rate $=$ & $1.60 E-03$ & $1.98 E+01$ & $4.74 E+00$ & $1.21 E-04$ & $7.78 E+00$ & 8.91E-01 & $3.36 E-01$ \\
\hline Solubility $=(\mathrm{mg} / \mathrm{L})$ & $1.00 E+00$ & $1.00 E+\infty 0$ & $1.00 E+00$ & $3.00 E+01$ & $1.00 E+03$ & $1.00 E+03$ & $1.00 E+03$ \\
\hline Specific Activity $=(\mathrm{TBq} / \mathrm{g})$ & $1.27 E-01$ & $2.71 E+03$ & $1.29 E+04$ & $1.65 E-01$ & $1.05 E+03$ & $1.18 E+02$ & $4.79 E+01$ \\
\hline Solubility $=(p \mathrm{Ci} /)$ & $3.43 E+09$ & $7.32 E+13$ & $3.48 E+14$ & $1.34 E+11$ & $2.84 E+16$ & $3.19 E+15$ & $1.29 E+15$ \\
\hline Soil/Water Pertition $\mathrm{CO}=$ & $1.70 E+02$ & $1.60 E+04$ & $4.49 E+03$ & $2.28 E+07$ & $1.50 E+01$ & $2.50 E+00$ & $1.12 E+03$ \\
\hline Leachate Conc. $(\mathrm{CO})=$ & $1.70 E+02$ & $1.60 E+04$ & $4.49 E+03$ & $2.28 E+07$ & $1.50 E+01$ & $2.50 E+00$ & $1.12 E+03$ \\
\hline Vedose Travel Time(T2) $=$ & $3.84 E+06$ & $4.81 E+05$ & $3.85 E+05$ & $5.15 E+02$ & $3.84 E+06$ & $3.84 E+06$ & $9.61 E+05$ \\
\hline Vadose Zone Dilution = & $1.00 E+00$ & $1.00 E+00$ & $1.00 E+00$ & $1.00 E+\infty 0$ & $1.00 E+\infty 0$ & $1.00 E+\infty 0$ & $1.00 E+\infty 0$ \\
\hline Water Table $\left(C_{2}\right)=$ & $0.00 E+\infty$ & $0.00 E+00$ & $0.00 E+\infty 0$ & $2.14 E+07$ & $0.00 E+\infty 0$ & $0.00 E+00$ & $0.00 E+\infty$ \\
\hline Sot. Travel Time(T3) $=($ Year $)$ & $8.36 E+02$ & $1.05 E+02$ & $8.43 E+01$ & 7.83E-01 & $8.36 E+02$ & $8.36 E+02$ & $2.10 E+02$ \\
\hline Set. Zone Dilution = & 5.95E-02 & $5.95 E-02$ & $5.95 E-02$ & 5.95E-02 & 5.95E-02 & $5.95 E-02$ & 5.95E-02 \\
\hline ERDF Boundary $(C 3)=(p C i / L)$ & $0.00 E+00$ & $0.00 E+00$ & $0.00 E+00$ & $1.27 E+06$ & $0.00 E+00$ & $0.00 E+00$ & $0.00 E+\infty 0$ \\
\hline
\end{tabular}


Table A-5. Radionuclide Screening Modeling Results for the Base Conditions Scenario.

\begin{tabular}{|c|c|c|c|c|c|c|c|}
\hline Rediomuclides & Cosium-137 & Chromium-51 & Cobdit-58 & Cobdit-60 & Europium-152 & Europhum-154 & Europiem-155 \\
\hline Bulk Soil Conc. $=(p \mathrm{Ci} / \mathrm{g})$ & $1.10 E+05$ & $3.47 E+\infty$ & $1.41 E+01$ & $1.10 E+04$ & $2.90 E+04$ & $9.20 E+03$ & $9.60 E+03$ \\
\hline Bulk Soil Conc. $=(p$ Cikg) & $1.10 E+08$ & $3.47 E+03$ & $1.41 E+04$ & $1.10 E+07$ & $2.90 E+07$ & $9.20 E+06$ & $9.60 E+06$ \\
\hline Pertitioning Coof. - & $5.00 E+01$ & $0.00 E+\infty$ & $5.00 E+01$ & $5.00 E+01$ & $2.00 E+02$ & $2.00 E+02$ & $2.00 E+02$ \\
\hline Vodose Zono R = & $1.78 E+03$ & $1.00 E+00$ & $1.78 E+03$ & $1.78 E+03$ & $7.11 E+03$ & $7.11 E+03$ & $7.11 E+03$ \\
\hline Saturated Zone $R=$ & $2.68 E+02$ & $1.00 E+\infty$ & $2.68 E+02$ & $2.68 E+02$ & $1.07 E+03$ & $1.07 E+03$ & $1.07 E+03$ \\
\hline Half-life (yoars) & $3.02 E+01$ & 7.59E-02 & $1.94 E-01$ & $5.27 E+\infty$ & $1.36 E+01$ & $8.80 E+\infty$ & $4.96 E+\infty$ \\
\hline Decoy Rate $=$ & $2.30 E-02$ & $9.13 E+\infty$ & $3.57 E+\infty$ & $1.32 E-01$ & $5.10 E-02$ & $7.88 E-02$ & $1.40 E-01$ \\
\hline Solubility $=(\mathrm{mg} / \mathrm{L})$ & $1.00 E+03$ & $2.50 E+01$ & $2.50 E+01$ & $2.50 E+01$ & $1.00 E+03$ & $1.00 E+03$ & $1.00 E+03$ \\
\hline Specific Activity = (TBq/g) & $3.22 E+\infty$ & $3.42 E+03$ & $3.20 E+04$ & $4.18 E+01$ & $1.70 E+02$ & $2.60 E+02$ & $4.60 E+02$ \\
\hline Solubility = (pCi $/$ ) & $8.69 E+13$ & $2.31 E+15$ & $2.16 E+16$ & $2.82 E+13$ & $4.59 E+15$ & $7.02 E+15$ & $1.24 E+16$ \\
\hline Soil $/$ Wotor Partition $\mathrm{CO}=$ & $2.20 E+06$ & $1.23 E+05$ & $2.82 E+02$ & $2.20 E+05$ & $1.45 E+05$ & $4.60 E+04$ & $4.80 E+04$ \\
\hline Leachote Conc. $(\mathrm{CO})=$ & $2.20 E+06$ & $1.23 E+05$ & $2.82 E+02$ & $2.20 E+05$ & $1.45 E+05$ & $4.60 E+04$ & $4.80 E+04$ \\
\hline Vedose Travel Time(T2) = & $9.61 E+05$ & $5.15 E+02$ & $9.61 E+05$ & $9.61 E+05$ & $3.84 E+06$ & $3.84 E+06$ & $3.84 E+06$ \\
\hline Vodose Zone Dilution = & $1.00 E+\infty$ & $1.00 E+\infty$ & $1.00 E+\infty$ & $1.00 E+\infty$ & $1.00 E+\infty$ & $1.00 E+\infty$ & $1.00 E+\infty$ \\
\hline Water Tablo(C2) = & $0.00 E+\infty$ & $0.00 E+\infty$ & $0.00 E+\infty$ & $0.00 E+\infty$ & $0.00 E+\infty$ & $0.00 E+\infty$ & $0.00 E+\infty$ \\
\hline Sat. Travel Time $(T 3)=($ Yoar $)$ & $2.10 E+02$ & $7.83 E-01$ & $2.10 E+02$ & $2.10 E+02$ & $8.36 E+02$ & $8.36 E+02$ & $8.36 E+02$ \\
\hline Set. Zono Dilution = & $5.95 E-02$ & 5.95E-02 & $5.95 E-02$ & 5.95E-02 & 5.95E-02 & $5.95 E-02$ & $5.95 E-02$ \\
\hline ERDF Boundary $(C 3)=(p C i n)$ & $0.00 E+\infty$ & $0.00 E+00$ & $0.00 E+00$ & $0.00 E+\infty$ & $0.00 E+\infty$ & $0.00 E+\infty$ & $0.00 E+\infty$ \\
\hline
\end{tabular}


Table A-5. Radionuclide Screening Modeling Results for the Base Conditions Scenario.

\begin{tabular}{|c|c|c|c|c|c|c|c|}
\hline Redionuclides & Iron-59 & Manganeso-54 & Neptunium-237 & Nickot-63 & Plutonium-238 & Plutonium-239/240 & Poteadum-40 \\
\hline Bulk Soll Conc. $=(\mathrm{pC} 1 / \mathrm{g})$ & $1.00 E+\infty$ & 7.00E-02 & $6.86 E-03$ & $6.20 E+04$ & $1.40 E+02$ & $2.80 E+03$ & $3.30 E+01$ \\
\hline Bulk Soil Conc. $=\left(p C_{i} / k g\right)$ & $1.00 E+03$ & $7.00 E+01$ & $6.86 E+\infty$ & $6.20 E+07$ & $1.40 E+05$ & $2.80 E+08$ & $3.30 E+04$ \\
\hline Portitioning Coof. = & $5.00 E+01$ & $5.00 E+01$ & $2.00 E+\infty$ & $2.30 E+01$ & $6.30 E+01$ & $6.30 E+01$ & $5.00 E+\infty 0$ \\
\hline Vodose Zone R = & $1.78 E+03$ & $1.78 E+03$ & $7.21 E+01$ & $8.19 E+02$ & $2.24 E+03$ & $2.24 E+03$ & $1.79 E+02$ \\
\hline Saturated Zone R = & $2.68 E+02$ & $2.68 E+02$ & $1.17 E+01$ & $1.24 E+02$ & $3.37 E+02$ & $3.37 E+02$ & $2.77 E+01$ \\
\hline Helf-lifo (yoars) & $1.22 E-01$ & 8.60E-01 & $2.14 E+08$ & $1.00 E+02$ & $8.78 E+01$ & $2.41 E+04$ & $1.28 E+09$ \\
\hline Docay Rato $=$ & $5.67 E+\infty$ & 8.06E-01 & 3.24E-07 & $6.93 E-03$ & 7.89E-03 & $2.88 E-05$ & $5.42 E-10$ \\
\hline Solubility $=(\mathrm{mg} \Omega)$ & $1.00 E+\infty 0$ & $1.00 E+\infty$ & $2.50 E+01$ & $2.50 E+01$ & $1.00 E+\infty$ & $1.00 E+\infty$ & $1.20 E-01$ \\
\hline Specific Activity $=(T B q / g)$ & $1.84 E+03$ & $2.86 E+02$ & 2.61E-05 & $2.19 E+\infty$ & 6.34E-01 & $2.30 E-03$ & $7.00 E-06$ \\
\hline Solubility $=(p$ Cin $)$ & $4.97 E+13$ & $7.72 E+12$ & $1.76 E+07$ & $1.48 E+12$ & $1.71 E+10$ & $6.21 E+07$ & $2.27 E+04$ \\
\hline SollMater Partition $\mathrm{CO}=$ & $2.00 E+01$ & $1.40 E+\infty$ & $3.38 E+\infty$ & $2.69 E+06$ & $2.22 E+03$ & $4.44 E+04$ & $6.56 E+03$ \\
\hline Leachato Conc. $(C O)=$ & $2.00 E+01$ & $1.40 E+\infty$ & $3.38 E+\infty$ & $2.69 E+06$ & $2.22 E+03$ & $4.44 E+04$ & $6.56 E+03$ \\
\hline Vodose Trovel Timo(T2) = & $9.61 E+05$ & $9.61 E+05$ & $3.89 E+04$ & $4.42 E+05$ & $1.21 E+06$ & $1.21 E+06$ & $9.65 E+04$ \\
\hline Vedose Zone Dilution = & $1.00 E+\infty 0$ & $1.00 E+\infty$ & $1.00 E+\infty 0$ & $1.00 E+\infty$ & $1.00 E+\infty 0$ & $1.00 E+\infty$ & $1.00 E+\infty 0$ \\
\hline Water Tablo(C2) = & $0.00 E+\infty$ & $0.00 E+\infty$ & $3.34 E+\infty$ & $0.00 E+\infty$ & $0.00 E+\infty$ & $3.41 \mathrm{E}-11$ & $6.56 E+03$ \\
\hline Set. Travel Time(T3) $=($ Year $)$ & $2.10 E+02$ & $2.10 E+02$ & $9.13 E+\infty$ & $9.68 E+01$ & $2.64 E+02$ & $2.64 E+02$ & $2.17 E+01$ \\
\hline Set. Zone Dilution = & $5.95 E-02$ & 5.95E-02 & 5.95E-02 & 5.95E-02 & 5.95E-02 & 5.95E-02 & $5.95 E-02$ \\
\hline ERDF Boundary $(\mathrm{C} 3)=(\mathrm{pCi}$ & $0.00 E+00$ & $0.00 E+\infty 0$ & $1.99 E-01$ & $0.00 E+\infty$ & $0.00 E+\infty$ & $2.01 E-12$ & $3.90 E+02$ \\
\hline
\end{tabular}


Table A-5. Radionuclide Screening Modeling Results for the Base Conditions Scenario.

\begin{tabular}{|c|c|c|c|c|c|c|c|}
\hline Redionuclides & Redium-226 & Ruthonium-103 & Ruthenium-106 & Sodium-22 & Strontium-90 & Technotium-99 & Thorium-228 \\
\hline Bulk Soil Conc. $=(p \mathrm{C} / \mathrm{g})$ & $4.28 E+01$ & $1.00 E+00$ & $8.00 E-01$ & $9.91 E+00$ & $2.00 E+03$ & $1.10 E+\infty 0$ & $1.68 E+01$ \\
\hline Bulk Soil Conc. $=(p C i / k g)$ & $4.28 E+04$ & $1.00 E+03$ & $8.00 E+02$ & $9.91 E+03$ & $2.00 E+06$ & $1.10 E+03$ & $1.68 E+04$ \\
\hline Partitioning Coof. = & $2.00 E+01$ & $2.00 E+01$ & $2.00 E+01$ & $4.00 E+00$ & $1.80 E+01$ & $0.00 E+\infty 0$ & $5.00 E+01$ \\
\hline Vadose Zone R = & $7.12 E+02$ & $7.12 E+02$ & $7.12 E+02$ & $1.43 E+02$ & $6.41 E+02$ & $1.00 E+00$ & $1.78 E+03$ \\
\hline Satureted Zono R = & $1.08 E+02$ & $1.08 E+02$ & $1.08 E+02$ & $2.23 E+01$ & $9.70 E+01$ & $1.00 E+\infty 0$ & $2.68 E+02$ \\
\hline Helf-lifo (vears) & $1.60 E+03$ & $1.08 E-01$ & $1.01 E+\infty 0$ & $2.60 E+\infty 0$ & $2.86 E+01$ & $2.13 E+05$ & $1.91 E+\infty$ \\
\hline Decay Rate $=$ & 4.33E-04 & $6.42 E+00$ & 6.87E-01 & 2.67E-01 & $2.42 E-02$ & $3.25 E-06$ & 3.63E-01 \\
\hline Solubility $=(\mathrm{mg} \Omega)$ & $1.00 E+03$ & $1.00 E+03$ & $1.00 E+03$ & $1.00 E+03$ & $2.50 E+01$ & $1.00 E+03$ & $1.00 E+\infty 0$ \\
\hline Specific Activity $=(T B q / g)$ & $3.66 E-02$ & $1.19 E+03$ & $1.24 E+02$ & $2.31 E+02$ & $5.05 E+\infty 0$ & $6.30 E-04$ & $3.03 E+01$ \\
\hline Solubility $=(p \mathrm{Cin})$ & $9.88 E+11$ & $3.21 E+16$ & $3.35 E+15$ & $6.24 E+15$ & $3.41 E+12$ & $1.70 E+10$ & $8.18 E+11$ \\
\hline Soil/Wator Partition $\mathrm{CO}=$ & $2.14 E+03$ & $4.99 E+01$ & $3.99 E+01$ & $2.46 E+03$ & $1.11 E+05$ & $3.91 E+04$ & $3.36 E+02$ \\
\hline Loechate Conc. $(C O)=$ & $2.14 E+03$ & $4.99 E+01$ & $3.99 E+01$ & $2.46 E+03$ & $1.11 E+05$ & $3.91 E+04$ & $3.36 E+02$ \\
\hline Vodose Travel Time(T2) = & $3.85 E+05$ & $3.85 E+05$ & $3.85 E+05$ & $7.73 E+04$ & $3.46 E+05$ & $5.15 E+02$ & $9.61 E+05$ \\
\hline Vedose Zone Dilution = & $1.00 E+00$ & $1.00 E+00$ & $1.00 E+00$ & $1.00 E+00$ & $1.00 E+\infty 0$ & $1.00 E+\infty 0$ & $1.00 E+00$ \\
\hline Water Table $\left(C_{2}\right)=$ & $9.68 E-70$ & $0.00 E+\infty 0$ & $0.00 E+\infty 0$ & $0.00 E+\infty 0$ & $0.00 E+\infty 0$ & $3.90 E+04$ & $0.00 E+\infty$ \\
\hline Sat. Travel Timo(T3) $=($ Year $)$ & $8.43 E+01$ & $8.43 E+01$ & $8.43 E+01$ & $1.75 E+01$ & $7.59 E+01$ & $7.83 E-01$ & $2.10 E+02$ \\
\hline Sat. Zone Dilution = & $5.95 E-02$ & $5.95 E-02$ & 5.95E-02 & 5.95E-02 & 5.95E-02 & 5.95E-02 & 5.95E-02 \\
\hline ERDF Boundery $(C 3)=(p C i n)$ & $5.55 E-71$ & $0.00 E+\infty 0$ & $0.00 E+00$ & $0.00 E+00$ & $0.00 E+\infty 0$ & $2.32 E+03$ & $0.00 E+\infty 0$ \\
\hline
\end{tabular}


Table A-5. Radionuclide Screening Modeling Results for the Base Conditions Scenario.

\begin{tabular}{|c|c|c|c|c|c|c|c|}
\hline Redionuclides & Thorium-232 & Thorium-234 & Tritium & Totel Uranlum & U-233/234 & Uronium-235 & Uranium-238 \\
\hline Bulk Soil Conc. $=(p \mathrm{p} / \mathrm{g})$ & $3.55 E+\infty$ & $1.00 E+00$ & $2.90 E+04$ & $2.00 E+04$ & $2.10 E+03$ & $6.38 E+02$ & $9.14 E+03$ \\
\hline Bulk Soil Conc. $=(p C i k g)$ & $3.55 E+03$ & $1.00 E+03$ & $2.90 E+07$ & $2.00 E+07$ & $2.10 E+06$ & $6.38 E+05$ & $9.14 E+06$ \\
\hline Pertitioning Coof. = & $5.00 E+01$ & $5.00 E+01$ & $0.00 E+\infty$ & $0.00 E+\infty$ & $0.00 E+00$ & $0.00 E+\infty$ & $0.00 E+00$ \\
\hline Vadose Zono R = & $1.78 E+03$ & $1.78 E+03$ & $1.00 E+\infty 0$ & $1.00 E+\infty 0$ & $1.00 E+\infty$ & $1.00 E+\infty$ & $1.00 E+00$ \\
\hline Saturated Zone R = & $2.68 E+02$ & $2.68 E+02$ & $1.00 E+\infty$ & $1.00 E+\infty$ & $1.00 E+\infty$ & $1.00 E+\infty$ & $1.00 E+\infty 0$ \\
\hline Holf-life (vears) & $1.41 E+10$ & 6.60E-02 & $1.23 E+01$ & $4.47 E+09$ & $2.45 E+05$ & $7.04 E+08$ & $4.47 E+09$ \\
\hline Decoy Rate = & $4.92 \mathrm{E}-11$ & $1.05 E+01$ & $5.64 E-02$ & $1.55 E-10$ & $2.83 E-06$ & $9.85 E-10$ & $1.55 E-10$ \\
\hline Solubility $=(\mathrm{mg} / \mathrm{L})$ & $1.00 E+00$ & $1.00 E+00$ & $2.70 E+05$ & $2.50 E+01$ & $1.43 E-03$ & $1.80 E-01$ & $2.48 E+01$ \\
\hline Specific Activity $=(T B q / g)$ & $4.05 E-09$ & $8.56 E+02$ & $3.57 E+02$ & $2.63 E-08$ & $2.31 E-04$ & $8.00 E-08$ & $1.24 E-08$ \\
\hline Solubility $=(p C i n)$ & $1.09 E+02$ & $2.31 E+13$ & $2.60 E+18$ & $1.78 E+04$ & $8.89 E+03$ & $3.89 E+02$ & $8.31 E+03$ \\
\hline SollMater Portition $\mathrm{CO}=$ & $7.09 E+01$ & $2.00 E+01$ & $1.03 E+09$ & $7.12 E+08$ & $7.47 E+07$ & $2.27 E+07$ & $3.25 E+08$ \\
\hline Leachate Conc. $(\mathrm{CO})=$ & $7.09 E+01$ & $2.00 E+01$ & $1.03 E+09$ & $1.78 E+04$ & $8.89 E+03$ & $3.89 E+02$ & $8.31 E+03$ \\
\hline Vedose Trovel Timo(T2) = & $9.61 E+05$ & $9.61 E+05$ & $5.15 E+02$ & $5.15 E+02$ & $5.15 E+02$ & $5.15 E+02$ & $5.15 E+02$ \\
\hline Vedose Zone Dilution = & $1.00 E+\infty 0$ & $1.00 E+00$ & $1.00 E+\infty 0$ & $1.00 E+\infty 0$ & $1.00 E+\infty 0$ & $1.00 E+\infty 0$ & $1.00 E+\infty$ \\
\hline Water Table(C2) = & $7.09 E+01$ & $0.00 E+\infty$ & 2.57E-04 & $1.77 E+04$ & $8.87 E+03$ & $3.89 E+02$ & $8.31 E+03$ \\
\hline Set. Trevel Timo(T3) = (Yoar) & $2.10 E+02$ & $2.10 E+02$ & 7.83E-01 & 7.83E-01 & $7.83 E-01$ & $7.83 E-01$ & $7.83 E-01$ \\
\hline Sat. Zone Dilution = & $5.95 E-02$ & $5.95 E-02$ & 5.95E-02 & 5.95E-02 & $5.95 E-02$ & $5.95 E-02$ & $5.95 E-02$ \\
\hline ERDF Boundery $(C 3)=(p C i \Omega)$ & $4.21 E+\infty$ & $0.00 E+\infty$ & $1.46 E-05$ & $1.06 E+03$ & $5.28 E+02$ & $2.31 E+01$ & $4.94 E+02$ \\
\hline
\end{tabular}


Table A-5. Radionuclide Screening Modeling Results for the Base Conditions Scenario.

\begin{tabular}{|c|c|c|}
\hline Redionuclides & Zine-65 & Zirconium-95 \\
\hline Bulk Soil Conc. $=(p \mathrm{pl} / \mathrm{q})$ & $3.00 \mathrm{E}-01$ & 5.60E-01 \\
\hline Bulk Soil Conc. $=\left(p C\left(k_{k g}\right)\right.$ & $3.00 E+02$ & $5.60 E+02$ \\
\hline Portitioning Coof. = & $2.30 E+01$ & $3.50 E+01$ \\
\hline Vodose Zone $R=$ & $8.19 E+02$ & $1.25 E+03$ \\
\hline Saturated Zone $R=$ & $1.24 E+02$ & $1.88 E+02$ \\
\hline Helf-life (yoars) & $6.68 \mathrm{E}-01$ & $1.75 E-01$ \\
\hline Decay Rate $=$ & $1.04 E+00$ & $3.95 E+\infty 0$ \\
\hline Solubility $=(m g \Omega)$ & $2.50 E+01$ & $1.00 E+00$ \\
\hline Specific Activity $=(T B q / g)$ & $3.05 E+02$ & $7.95 E+02$ \\
\hline Solubility $=(p C i n)$ & $2.06 E+14$ & $2.15 E+13$ \\
\hline SoilMoter Partition CO = & $1.30 E+01$ & $1.60 E+01$ \\
\hline Leachate Conc. $(\mathrm{CO})=$ & $1.30 E+01$ & $1.60 E+01$ \\
\hline Vedose Traval Time(T2) = & $4.42 E+05$ & $6.73 E+05$ \\
\hline Vodose Zono Dilution = & $1.00 E+00$ & $1.00 E+00$ \\
\hline Wator Table(C2) $=$ & $0.00 E+\infty$ & $0.00 E+\infty$ \\
\hline Sat. Travel Timo(T3) $=$ (Yoor) & $9.68 E+01$ & $1.47 E+02$ \\
\hline Sat. Zone Dilution = & $5.95 \mathrm{E}-02$ & $5.95 E-02$ \\
\hline ERDF Boundery $(C 3)=(p C i \Omega)$ & $0.00 E+00$ & $0.00 E+00$ \\
\hline
\end{tabular}


Table A-6. Metal Screening Modeling Results for the Base Conditions Scenario.

\begin{tabular}{|c|c|c|c|c|c|c|c|c|c|}
\hline Motals & Aluminum & Antimony & Arsenic & Barium & Beryllium & Codmium & Celcium & Chromium-VI & Cobalt \\
\hline Bulk Soil Conc. $=(m g / k g)$ & $7.84 E+04$ & $1.86 E+01$ & $6.22 E+01$ & $4.26 E+03$ & $4.70 E+00$ & $2.85 E+01$ & $9.53 E+04$ & $2.51 E+03$ & $9.04 E+01$ \\
\hline Partitioning Coof. $=$ & $2.00 E+01$ & $0.00 E+00$ & $0.00 E+00$ & $5.00 E+01$ & $2.00 E+01$ & $2.30 E+01$ & $1.50 E+01$ & $0.00 E+00$ & $3.00 E+01$ \\
\hline Vodose Zone $R=$ & $7.12 E+02$ & $1.00 E+00$ & $1.00 E+00$ & $1.78 E+03$ & $7.12 E+02$ & $8.19 E+02$ & $5.34 E+02$ & $1.00 E+00$ & $1.07 E+03$ \\
\hline Saturated Zone $R=$ & $1.08 E+02$ & $1.00 E+00$ & $1.00 E+00$ & $2.68 E+02$ & $1.08 E+02$ & $1.24 E+02$ & $8.10 E+01$ & $1.00 E+00$ & $1.61 E+02$ \\
\hline Docay Rate $=$ & $0.00 E+00$ & $0.00 E+00$ & $0.00 E+00$ & $0.00 E+\infty 0$ & $0.00 E+\infty 0$ & $0.00 E+00$ & $0.00 E+00$ & $0.00 E+00$ & $0.00 E+00$ \\
\hline Solubility $=(\mathrm{mg} \Omega)$ & $1.00 E+00$ & $1.00 E+03$ & $1.00 E+03$ & $1.00 E+00$ & $1.00 E+00$ & $2.50 E+01$ & $2.50 E+01$ & $1.00 E+03$ & $2.50 E+01$ \\
\hline SoilMater Partition $\mathrm{CO}=$ & $3.91 E+03$ & $6.61 E+02$ & $2.21 E+03$ & $8.52 E+01$ & 2.35E-01 & $1.24 E+00$ & $6.34 E+03$ & $8.92 E+04$ & $3.01 E+00$ \\
\hline Leachate Conc. $(\mathrm{CO})=$ & $1.00 E+\infty 0$ & $6.61 E+02$ & $1.00 E+03$ & $1.00 E+00$ & $2.35 E-01$ & $1.24 E+00$ & $2.50 E+01$ & $1.00 E+03$ & $3.01 E+00$ \\
\hline Vodose Trovel Time(T2) = & $3.85 E+05$ & $5.15 E+02$ & $5.15 E+02$ & $9.61 E+05$ & $3.85 E+05$ & $4.42 E+05$ & $2.89 E+05$ & $5.15 E+02$ & 5.77E + 05 \\
\hline Vodose Zono Dilution = & $1.00 E+\infty$ & $1.00 E+00$ & $1.00 E+00$ & $1.00 E+00$ & $1.00 E+00$ & $1.00 E+00$ & $1.00 E+00$ & $1.00 E+00$ & $1.00 E+00$ \\
\hline Water Table $\left(C_{2}\right)=$ & $1.00 E+\infty 0$ & $6.61 E+02$ & $1.00 E+03$ & $1.00 E+00$ & $2.35 \mathrm{E}-01$ & $1.24 E+00$ & $2.50 E+01$ & $1.00 E+03$ & $3.01 E+00$ \\
\hline Sat. Travel Timo(T3) $=($ Yoar $)$ & $8.43 E+01$ & 7.83E.01 & 7.83E-01 & $2.10 E+02$ & $8.43 E+01$ & $9.68 E+01$ & $6.34 E+01$ & 7.83E-01 & $1.26 E+02$ \\
\hline Sat. Zone Dilution = & 5.95E-02 & 5.95E-02 & 5.95E-02 & 5.95E-02 & $5.95 E-02$ & 5.95E-02 & $5.95 E-02$ & 5.95E-02 & $5.95 E-02$ \\
\hline ERDF Boundory $(\mathrm{C} 3)=(\mathrm{mg} \Omega)$ & 5.95E-02 & $3.93 E+01$ & $5.95 E+01$ & 5.95E-02 & $1.40 E-02$ & $7.36 E-02$ & $1.49 E+00$ & $5.95 E+01$ & $1.79 E-01$ \\
\hline
\end{tabular}


Table A-6. Metal Screening Modeling Results for the Base Conditions Scenario.

\begin{tabular}{|c|c|c|c|c|c|c|c|c|c|}
\hline Motals & Copper & Iron & Lead & Mogneaium & Mangenese & Morcury & Nickel & Potessium & Solenium \\
\hline Bulk Soil Conc. $=(\mathrm{mg} / \mathrm{kg})$ & $9.53 E+04$ & $1.84 E+05$ & $7.47 E+02$ & $5.00 E+04$ & $3.05 E+03$ & $3.70 E+01$ & $1.75 E+03$ & $1.30 E+04$ & $1.11 E+01$ \\
\hline Portitioning Coof. = & $2.30 E+01$ & $3.50 E+01$ & $3.00 E+01$ & $2.00 E+01$ & $3.50 E+01$ & $3.00 E+01$ & $2.30 E+01$ & $4.00 E+\infty 0$ & $0.00 E+00$ \\
\hline Vedose Zone $R=$ & $8.19 E+02$ & $1.25 E+03$ & $1.07 E+03$ & $7.12 E+02$ & $1.25 E+03$ & $1.07 E+03$ & $8.19 E+02$ & $1.43 E+02$ & $1.00 E+00$ \\
\hline Saturated Zono R = & $1.24 E+02$ & $1.88 E+02$ & $1.61 E+02$ & $1.08 E+02$ & $1.88 E+02$ & $1.61 E+02$ & $1.24 E+02$ & $2.23 E+01$ & $1.00 E+00$ \\
\hline Decey Rate $=$ & $0.00 E+00$ & $0.00 E+\infty 0$ & $0.00 E+00$ & $0.00 E+00$ & $0.00 E+\infty 0$ & $0.00 E+00$ & $0.00 E+\infty 0$ & $0.00 E+\infty$ & $0.00 E+00$ \\
\hline Solubility = $(\mathrm{mg} \Lambda)$ & $2.50 E+01$ & $1.00 E+\infty 0$ & $1.00 E+00$ & $2.50 E+01$ & $1.00 E+00$ & $1.00 E+00$ & $2.50 E+01$ & $1.00 E+03$ & $1.00 E+03$ \\
\hline SoilMator Partition $\mathrm{CO}=$ & $4.14 E+03$ & $5.25 E+03$ & $2.49 E+01$ & $2.50 E+03$ & $8.71 E+01$ & $1.23 E+\infty 0$ & $7.60 E+01$ & $3.23 E+03$ & $3.95 E+02$ \\
\hline Leachate Conc. $(\mathrm{CO})=$ & $2.50 E+01$ & $1.00 E+\infty 0$ & $1.00 E+00$ & $2.50 E+01$ & $1.00 E+00$ & $1.00 E+00$ & $2.50 E+01$ & $1.00 E+03$ & $3.95 E+02$ \\
\hline Vedose Travel Time(T2) = & $4.42 E+05$ & $6.73 E+05$ & 5.77E+05 & $3.85 E+05$ & $6.73 E+05$ & $5.77 E+05$ & $4.42 E+05$ & $7.73 E+04$ & $5.15 E+02$ \\
\hline Vedose Zone Dilution $=$ & $1.00 E+00$ & $1.00 E+00$ & $1.00 E+00$ & $1.00 E+00$ & $1.00 E+00$ & $1.00 E+\infty 0$ & $1.00 E+00$ & $1.00 E+00$ & $1.00 E+00$ \\
\hline Water Tabla $\left(C_{2}\right)=$ & $2.50 E+01$ & $1.00 E+00$ & $1.00 E+00$ & $2.50 E+01$ & $1.00 E+00$ & $1.00 E+00$ & $2.50 E+01$ & $1.00 E+03$ & $3.95 E+02$ \\
\hline Sot. Travel Time(T3) $=$ (Yoor) & $9.68 \mathrm{E}+01$ & $1.47 E+02$ & $1.26 E+02$ & $8.43 E+01$ & $1.47 E+02$ & $1.26 E+02$ & $9.68 E+01$ & $1.75 E+01$ & 7.83E-01 \\
\hline Sat. Zone Dilution $=$ & $5.95 E-02$ & 5.95E-02 & 5.95E-02 & 5.95E-02 & 5.95E-02 & 5.95E-02 & 5.95E-02 & 5.95E-02 & 5.95E-02 \\
\hline ERDF Boundery $(C 3)=(\mathrm{mg} / \mathrm{L})$ & $1.49 E+00$ & $5.95 E-02$ & 5.95E-02 & $1.49 E+00$ & 5.95E-02 & 5.95E-02 & $1.49 E+\infty 0$ & $5.95 E+01$ & $2.35 E+01$ \\
\hline
\end{tabular}


Table A-6. Metal Screening Modeling Results for the Base Conditions Scenario.

\begin{tabular}{|c|c|c|c|c|c|c|}
\hline Motals & Silvor & Sodium & Strontium & Thallium & Vanodium & Zine \\
\hline Bulk Soil Conc. $=(\mathbf{m g} / \mathbf{k g})$ & $3.62 E+02$ & $2.61 E+03$ & $3.10 E+01$ & $5.40 E+\infty 0$ & $3.89 E+02$ & $6.16 E+03$ \\
\hline Portitioning Coof. $=$ & $2.50 E+01$ & $3.00 E+00$ & $1.80 E+01$ & $5.00 E+01$ & $5.00 E+01$ & $2.30 E+01$ \\
\hline Vedose Zone R $=$ & $8.90 E+02$ & $1.08 E+02$ & $6.41 E+02$ & $1.78 E+03$ & $1.78 E+03$ & $8.19 E+02$ \\
\hline Saturated Zone $R=$ & $1.34 E+02$ & $1.70 E+01$ & $9.70 E+01$ & $2.68 E+02$ & $2.68 E+02$ & $1.24 E+02$ \\
\hline Decay Rate $=$ & $0.00 E+00$ & $0.00 E+00$ & $0.00 E+00$ & $0.00 E+\infty$ & $0.00 E+00$ & $0.00 E+00$ \\
\hline Solubility $=(\mathrm{mg} / \mathrm{L})$ & $2.50 E+01$ & $1.00 E+03$ & $2.50 E+01$ & $1.00 E+\infty 0$ & $2.50 E+01$ & $2.50 E+01$ \\
\hline SoilMater Partition $\mathrm{CO}=$ & $1.45 E+01$ & $8.62 E+02$ & $1.72 E+00$ & $1.08 E-01$ & $7.78 E+00$ & $1.34 E+02$ \\
\hline Loochate Conc. $(\mathrm{CO})=$ & $1.45 E+01$ & $8.62 E+02$ & $1.72 E+00$ & $1.08 \mathrm{E}-01$ & $7.78 E+\infty 0$ & $2.50 E+01$ \\
\hline Vodose Trovel Time(T2) $=$ & $4.81 E+05$ & $5.81 E+04$ & $3.46 E+05$ & $9.61 E+05$ & $9.61 E+05$ & $4.42 E+05$ \\
\hline Vedose Zone Dilution = & $1.00 E+00$ & $1.00 E+00$ & $1.00 E+00$ & $1.00 E+00$ & $1.00 E+00$ & $1.00 E+00$ \\
\hline Weter Tablo(C2) $=$ & $1.45 E+01$ & $8.62 E+02$ & $1.72 E+\infty$ & $1.08 E-01$ & $7.78 E+\infty$ & $2.50 E+01$ \\
\hline Sat. Travol Time(T3) $=($ Year $)$ & $1.05 E+02$ & $1.33 E+01$ & $7.59 E+01$ & $2.10 E+02$ & $2.10 E+02$ & $9.68 E+01$ \\
\hline Set. Zone Dilution = & $5.95 \mathrm{E}-02$ & $5.95 E-02$ & $5.95 E-02$ & $5.95 E-02$ & $5.95 E-02$ & $5.95 E-02$ \\
\hline ERDF Boundary $(\mathrm{C} 3)=(\mathrm{mg} \Omega)$ & $8.60 \mathrm{E}-01$ & $5.13 E+01$ & $1.02 E-01$ & $6.42 E-03$ & $4.62 E-01$ & $1.49 E+00$ \\
\hline
\end{tabular}


Table A-7. General Chemistry Screening Modeling Results for the Base Conditions Scenario.

\begin{tabular}{|c|c|c|c|c|}
\hline Genoral Chemistry Paremoters & Ammonia & Fluoride & Nitrite & Sulfate \\
\hline Bulk Soil Conc. $=(\mathrm{mg} / \mathrm{kg})$ & $1.38 E+02$ & $4.03 E+01$ & $2.90 E+\infty$ & $7.12 E+03$ \\
\hline Partitioning Coof. $=$ & $4.00 E+00$ & $0.00 E+00$ & $0.00 E+00$ & $0.00 E+00$ \\
\hline Vedose Zone R = & $1.43 E+02$ & $1.00 E+\infty 0$ & $1.00 E+00$ & $1.00 E+00$ \\
\hline Saturated Zone R = & $2.23 E+01$ & $1.00 E+00$ & $1.00 E+\infty 0$ & $1.00 E+\infty 0$ \\
\hline Decay Rate $=$ & $0.00 E+00$ & $0.00 E+\infty 0$ & $0.00 E+\infty 0$ & $0.00 E+00$ \\
\hline Solubility $=$ & $1.00 E+03$ & $1.00 E+03$ & $1.00 E+03$ & $2.50 E+01$ \\
\hline Soil/Water Partition $\mathrm{CO}=$ & $3.43 E+01$ & $1.43 E+03$ & $1.03 E+02$ & $2.53 E+05$ \\
\hline Loechate Conc. $(C O)=$ & $3.43 E+01$ & $1.00 E+03$ & $1.03 E+02$ & $2.50 E+01$ \\
\hline Vedose Travel Timo(T2) $=$ & $7.73 E+04$ & $5.15 E+02$ & $5.15 E+02$ & $5.15 E+02$ \\
\hline Vedose Zone Dilution $=$ & $1.00 E+00$ & $1.00 E+00$ & $1.00 E+00$ & $1.00 E+\infty 0$ \\
\hline Water Toblo(C2) $=$ & $3.43 E+01$ & $1.00 E+03$ & $1.03 E+02$ & $2.50 E+01$ \\
\hline Sat. Travel Time $(T 3)=($ Yoar $)$ & $1.75 E+01$ & 7.83E-01 & $7.83 E-01$ & 7.83E-01 \\
\hline Sat. Zone Dilution $=$ & 5.95E-02 & 5.95E-02 & 5.95E-02 & 5.95E-02 \\
\hline ERDF Boundary $(\mathrm{C} 3)=(\mathrm{mg} \Omega)$ & $2.04 E+\infty 0$ & $5.95 E+01$ & $6.13 E+\infty 0$ & $1.49 E+\infty$ \\
\hline
\end{tabular}


Table A-8. Results for Base Conditions Scenario under Current Climate Condition (Accounting for Leachate Limits).

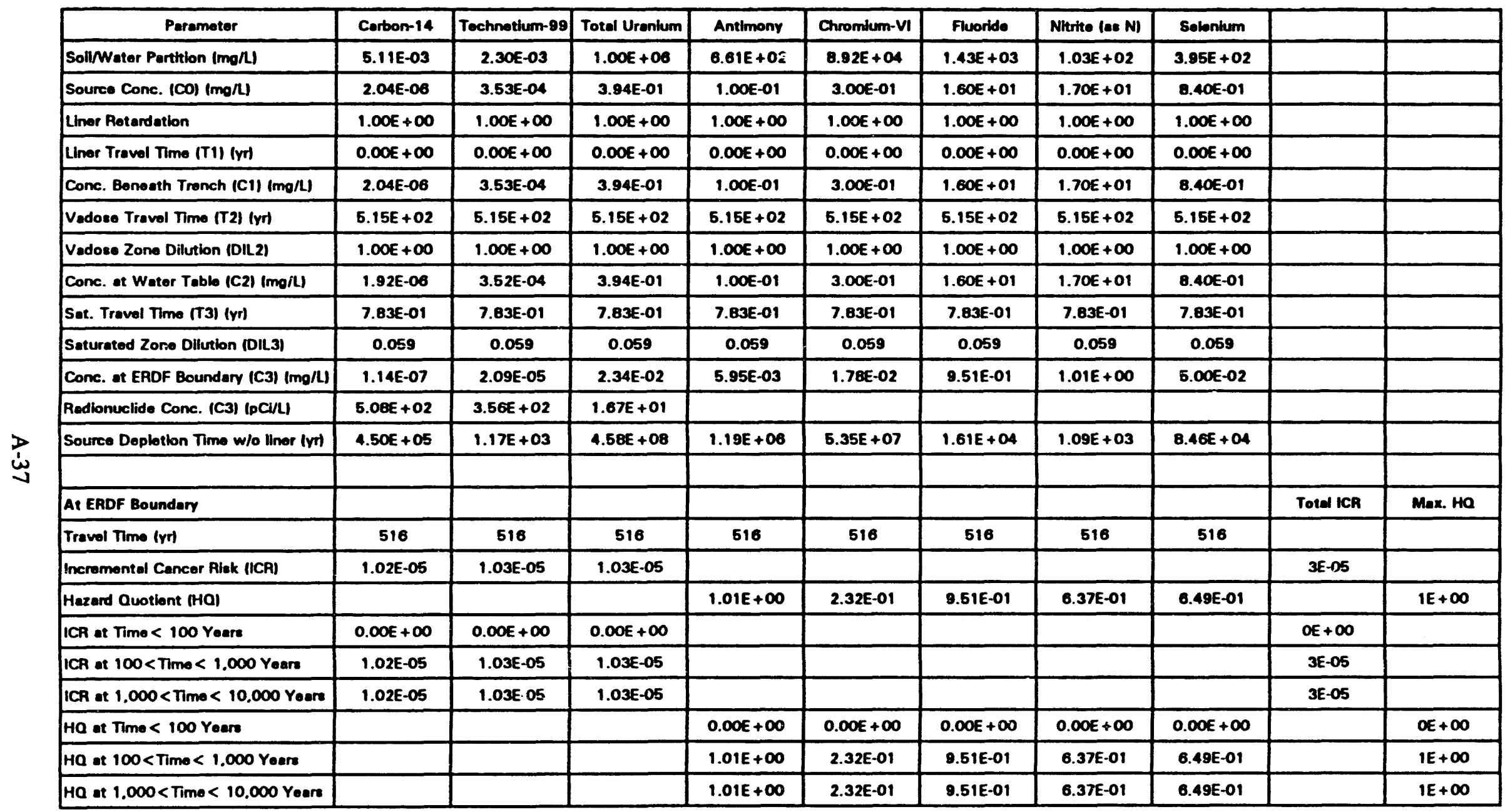


Table A-9. Results for Alternatives 2, 3, and 4 under Current Climate Condition (Accounting for Leachate Limits).

\begin{tabular}{|c|c|c|c|c|c|c|c|c|c|c|}
\hline Poramoter & Carbon-14 & Technotiun-99 & Total Uranium & Antimony & Chromlum-VI & Fluoride & Niturte les N) & Selontersn & & \\
\hline Sollnwater Partition $(\mathrm{ma} / \mathrm{L})$ & 5.11E-03 & $2.30 E-03$ & $1.00 E+06$ & $6.61 E+02$ & $8.92 E+04$ & $1.43 E+03$ & $1.03 E+02$ & $3.95 E+02$ & & \\
\hline Source Conc. (CO) (mg/h) & $2.04 E-06$ & $3.53 E-04$ & $3.84 E-01$ & $1.00 E-01$ & $3.00 E-01$ & $1.60 E+01$ & $1.70 E+01$ & 8.40E-01 & & \\
\hline Liner Retardation & $1.00 E+\infty 0$ & $1.00 E+\infty$ & $1.00 E+\infty$ & $1.00 E+\infty$ & $1.00 E+\infty$ & $1.00 E+\infty$ & $1.00 E+\infty$ & $1.00 E+\infty$ & & \\
\hline Liner Traval Timo (T1) (yr) & $0.00 E+\infty$ & $0.00 E+\infty$ & $0.00 E+\infty$ & $0.00 E+\infty$ & $0.00 E+\infty$ & $0.00 E+\infty$ & $0.00 E+\infty 0$ & $0.00 E+\infty$ & & \\
\hline Conc. Bonouth Trench $(\mathrm{C} 1)(\mathrm{mo} / \mathrm{L})$ & 2.04E-06 & 3.53E-04 & 3.94E-01 & $1.00 E-01$ & $3.00 E-01$ & $1.60 E+01$ & $1.70 E+01$ & 8.40E-01 & & \\
\hline Vadose Travel Time (T2) (Yr) & $1.33 E+04$ & $1.33 E+04$ & $1.33 E+04$ & $1.33 E+04$ & $1.33 E+04$ & $1.33 E+04$ & $1.33 E+04$ & $1.33 E+04$ & & \\
\hline Vedoes Zono Dilution (DIL2) & $1.00 E+\infty$ & $1.00 E+\infty$ & $1.00 E+\infty 0$ & $1.00 E+\infty$ & $1.00 E+\infty$ & $1.00 E+\infty 0$ & $1.00 E+\infty$ & $1.00 E+\infty 0$ & & \\
\hline Conc. at Water Tablo (C2) (mo/L) & 4.09E-07 & $3.38 E-04$ & $3.94 E-01$ & $1.00 E-01$ & $3.00 E-01$ & $1.60 E+01$ & $1.70 E+01$ & 8.40E-01 & & \\
\hline Sat. Trevol Time (T3) (Yr) & 7.83E-01 & 7.83E-01 & 7.83E-01 & 7.83E-01 & 7.83E-01 & 7.83E-01 & 7.83E-01 & 7.83E-01 & & \\
\hline Saturated Zone Dilution (DIL3) & 0.001 & 0.001 & 0.001 & 0.001 & 0.001 & 0.001 & 0.001 & 0.001 & & \\
\hline Conc. at ERDF Boundary (C3) (ma/L) & $5.16 E-10$ & 4.27E-07 & 4.98E-04 & $1.26 E-04$ & 3.79E-04 & $2.02 E-02$ & $2.16 E-02$ & $1.06 E-03$ & & \\
\hline Redionuclide Conc. (C3) (pCV/L) & $2.30 E+\infty$ & $7.26 E+\infty 0$ & $3.54 E-01$ & & & & & & & \\
\hline Source Depletion Time w/o liner (vr) & $2.25 E+07$ & $5.87 E+04$ & $2.29 E+10$ & $5.95 E+07$ & $2.68 E+09$ & $8.06 E+05$ & $5.46 E+04$ & $4.23 E+06$ & & \\
\hline & & & & & & & & & & \\
\hline At ERDF Boundary & & & & & & & & & Totel ICA & Max. HO \\
\hline Traval Time (yr) & 13.301 & 13,301 & 13,301 & 13.301 & 13,301 & 13,301 & 13.301 & 13.301 & & \\
\hline Incromental Cencer Risk (ICA) & $4.60 E-08$ & $2.10 E-07$ & $2.19 E-07$ & & & & & & 5E-07 & \\
\hline Hezard Quotiont (Ha) & & & & 2.15E-02 & 4.93E-03 & $2.02 E-02$ & $1.35 E-02$ & $1.38 E-02$ & & 2E-02 \\
\hline ICR at Time $<100$ Yeare & $0.00 E+\infty$ & $0.00 E+\infty 0$ & $0.00 E+\infty 0$ & & & & & & $O E+\infty$ & \\
\hline ICR at $100<\operatorname{Timo}<1.000$ Yeare & $0.00 E+\infty$ & $0.00 E+\infty$ & $0.00 E+\infty$ & & & & & & $O E+\infty$ & \\
\hline ICR at $1.000<$ Timo $<10,000$ Yoare & $0.00 E+\infty 0$ & $0.00 E+\infty$ & $0.00 E+\infty$ & & & & & & $O E+\infty$ & \\
\hline HO at Timo < 100 Yeare & & & & $0.00 E+\infty$ & $0.00 E+\infty 0$ & $0.00 E+\infty$ & $0.00 E+\infty 0$ & $0.00 E+\infty$ & & $O E+\infty$ \\
\hline HQ at $100<$ Time $<1.000$ Yeare & & & & $0.00 E+\infty$ & $0.00 E+\infty$ & $0.00 E+\infty$ & $0.00 E+\infty$ & $0.00 E+\infty$ & & $0 E+\infty$ \\
\hline HO at $1.000<$ Time $<10,000$ Yoare & & & & $0.00 E+\infty$ & $0.00 E+\infty$ & $0.00 E+\infty$ & $0.00 E+\infty$ & $0.00 E+\infty$ & & $O E+\infty$ \\
\hline
\end{tabular}


Table A-10. Results for Alternatives 5, 6, and 7 under Current Climate Condition (Accounting for Leachate Limits).

\begin{tabular}{|c|c|c|c|c|c|c|c|c|c|c|}
\hline Parramater & Carbon-14 & Tochnotium-99 & Total Uranium & Anthrony & Chromlum-VI & Fluoride & Nitrte (es N) & Solontum & & \\
\hline Soll/Water Partition (mo/L) & $6.11 E-03$ & $2.30 E-03$ & $1.00 E+08$ & $0.61 E+02$ & $8.92 E+04$ & $1.43 E+03$ & $1.03 E+02$ & $3.95 E+02$ & & \\
\hline Source Conc. $(\mathrm{CO})(\mathrm{mg} / \mathrm{L})$ & $2.04 E-08$ & $3.53 E-04$ & $3.94 E-01$ & $1.00 E-01$ & $3.00 E-01$ & $1.60 E+01$ & $1.70 E+01$ & 8.40E-01 & & \\
\hline Liner Rotardation & $1.00 E+\infty$ & $1.00 E+\infty$ & $1.00 E+\infty$ & $1.00 E+\infty$ & $1.00 E+\infty$ & $1.00 E+\infty$ & $1.00 E+\infty$ & $1.00 E+\infty$ & & \\
\hline Conc. Boneath Trench (C1) (mo/L) & $1.88 E-06$ & $3.52 E-04$ & $3.94 E-01$ & $1.00 E-01$ & $3.00 E-01$ & $1.60 E+01$ & $1.70 E+01$ & 8.40E-01 & & \\
\hline Vadose Traval Time (T2) (VrI & $1.48 E+04$ & $1.48 E+04$ & $1.48 E+04$ & $1.48 E+04$ & $1.48 E+04$ & $1.48 E+04$ & $1.48 E+04$ & $1.48 E+04$ & & \\
\hline Vedoso Zone Dilution (DIL2) & $1.00 E+\infty$ & $1.00 E+\infty$ & $1.00 E+\infty$ & $1.00 E+\infty$ & $1.00 E+\infty$ & $1.00 E+\infty$ & $1.00 E+\infty$ & $1.00 E+\infty$ & & \\
\hline Saturetod Zone Dillution (DIL3) & 0.001 & 0.001 & 0.001 & 0.001 & 0.001 & 0.001 & 0.001 & 0.001 & & \\
\hline Conc. at ERDF Boundary (C3) (mo/L) & $3.96 E-10$ & $4.24 E-07$ & $4.98 E-04$ & $1.26 E-04$ & $3.79 E-04$ & 2.02E-02 & $2.15 E-02$ & $1.06 E-03$ & & \\
\hline Redionuclide Cone. (C3) (pCi/2) & $1.76 E+\infty$ & $7.20 E+\infty 0$ & $3.54 E-01$ & & & & & & & \\
\hline Source Deplotion Time w/o liner (yr) & $2.25 E+07$ & 5.87E+04 & $2.29 E+10$ & $5.95 E+07$ & $2.68 E+09$ & $8.06 E+05$ & $5.46 E+04$ & $4.23 E+08$ & & \\
\hline Source Doplotion Time-tlop) (yr) & $2.25 E+07$ & $5.86 E+04$ & $2.29 E+10$ & $5.95 E+07$ & $2.68 E+09$ & $8.06 E+05$ & $5.46 E+04$ & $4.23 E+06$ & & \\
\hline Incremental Cancer Risek (ICA) & $3.52 E-08$ & $2.09 E-07$ & $2.19 E-07$ & & & & & & 5E-07 & \\
\hline Hezand Quotiont (MO) & & & & $2.15 E-02$ & $4.93 E-03$ & $2.02 E-02$ & $1.35 E-02$ & $1.38 E-02$ & & $2 E-02$ \\
\hline ICR at Timo $<100$ Yoars & $0.00 E+\infty$ & $0.00 E+\infty$ & $0.00 E+\infty$ & & & & & & $O E+\infty$ & \\
\hline ICR at $100<$ Thme $<1.000$ Youre & $0.00 E+\infty$ & $0.00 E+\infty 0$ & $0.00 E+\infty$ & & & & & & $O E+\infty$ & \\
\hline ICR at $1.000<\pi$ Timo $<10.000$ Yeare & $0.00 E+\infty$ & $0.00 E+\infty$ & $0.00 E+\infty$ & & & & & & $O E+\infty$ & \\
\hline HO at Time $<100$ Yoars & & & & $0.00 E+\infty$ & $0.00 E+\infty$ & $0.00 E+\infty$ & $0.00 E+\infty$ & $0.00 E+\infty$ & & $O E+\infty$ \\
\hline HO at $100<\pi$ me $<1.000$ Yoare & & & & $0.00 E+\infty$ & $0.00 E+\infty 0$ & $0.00 E+\infty$ & $0.00 E+\infty 0$ & $0.00 E+\infty$ & & $O E+\infty$ \\
\hline Ho at $1.000<$ Time $<10.000$ Years & & & & $0.00 E+\infty$ & $0.00 E+\infty 0$ & $0.00 E+\infty$ & $0.00 E+\infty$ & $0.00 E+\infty$ & & OE $+\infty$ \\
\hline
\end{tabular}


Table A-11. Results for Alternatives 8, 9, and 10 under Current Climate Condition (Accounting for Leachate Limits).

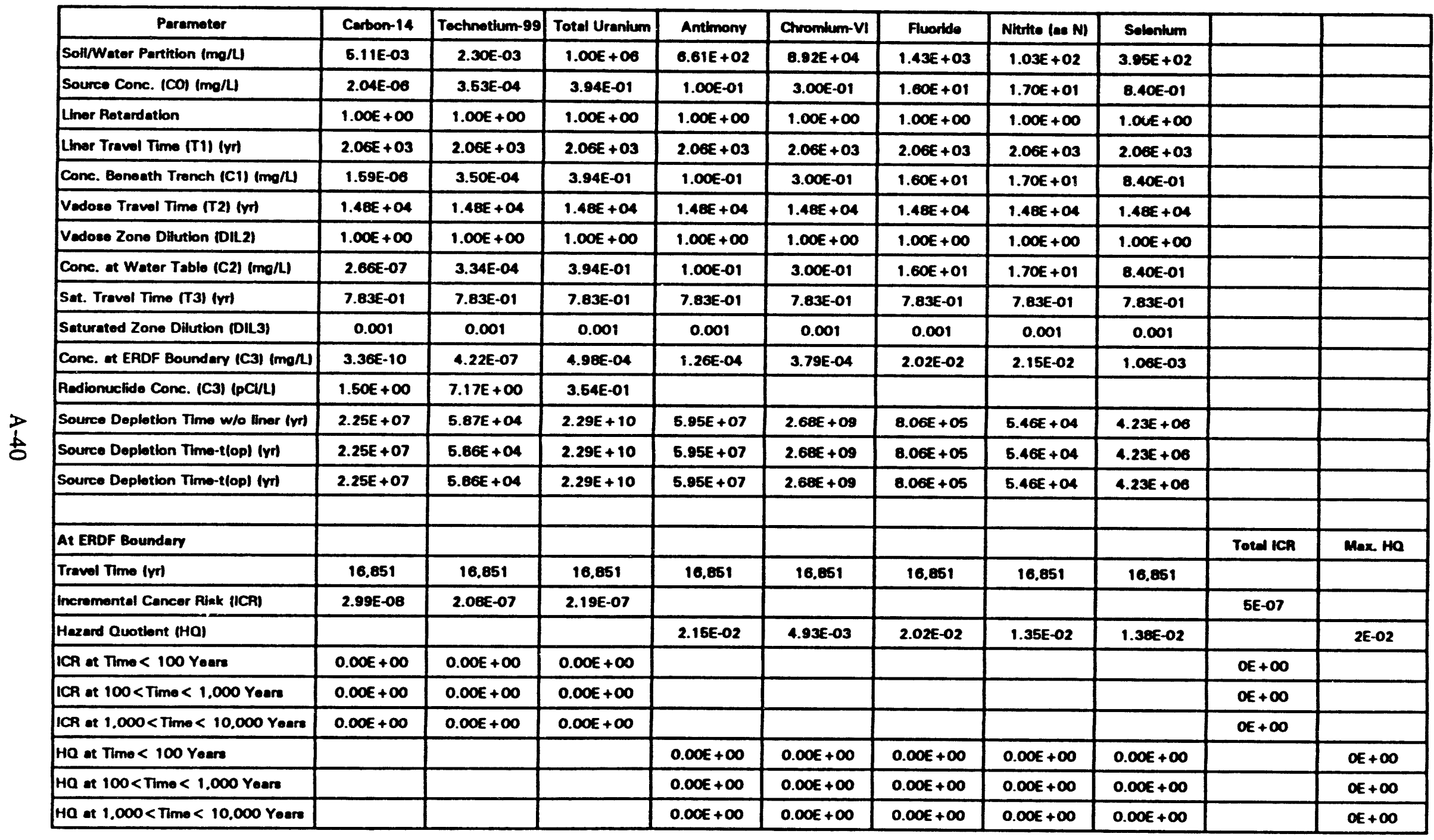


Table A-12. Results for Base Conditions Scenario under Hypothetical Wetter Climate Condition (Accounting for Leachate Limits).

\begin{tabular}{|c|c|c|c|c|c|c|c|c|c|}
\hline Paremetor & Carbon-14 & Noptunilum-237 & Tochnotivm-98 & Totel Urenkum & Trethm & Amtimony & Chromberm-VI & Fheoride & Nhates (ea N) \\
\hline Soll/Water Partition (mo/n) & 6.11E-03 & $4.80 E-08$ & $2.30 E-03$ & $1.00 E+08$ & $1.07 E-04$ & $0.61 E+02$ & $8.92 E+04$ & $1.43 E+03$ & $1.03 E+02$ \\
\hline Source Conc. $(00)(\mathrm{mo} / \mathrm{L})$ & $2.04 E-08$ & $4.80 E-08$ & 3.53E-04 & 3.94E-01 & $1.07 E-04$ & $1.00 E-01$ & $3.00 E-01$ & $1.60 E+01$ & $1.70 E+01$ \\
\hline Liner Roterdation & $1.00 E+\infty$ & $1.30 E+01$ & $1.00 E+\infty$ & $1.00 E+\infty 0$ & $1.00 E+\infty$ & $1.00 E+\infty$ & $1.00 E+\infty$ & $1.00 E+\infty 0$ & $1.00 E+\infty$ \\
\hline Liner Travel Thre (TI) (vr) & $0.00 E+\infty$ & $0.00 E+\infty$ & $0.00 E+\infty$ & $0.00 E+\infty$ & $0.00 E+\infty$ & $0.00 E+\infty$ & $0.00 E+\infty$ & $0.00 E+\infty$ & $0.00 E+\infty$ \\
\hline Conc. Boneath Tronch (C1) $(\mathrm{mon})$ & $2.04 E-06$ & $4.80 E-06$ & 3.53E-04 & 3.94E-01 & $1.07 E-04$ & $1.00 E-01$ & $3.00 E-01$ & $1.60 E+01$ & $1.70 E+01$ \\
\hline Vadoese Travel Time (T2) (yr) & $1.24 E+02$ & $2.26 E+03$ & $1.24 E+02$ & $1.24 E+02$ & $1.24 E+02$ & $1.24 E+02$ & $1.24 E+02$ & $1.24 E+02$ & $1.24 E+02$ \\
\hline Vadoes Zone Dilurtion (DILZ) & $1.00 E+\infty$ & $1.00 E+\infty$ & $1.00 E+\infty$ & $1.00 E+\infty$ & $1.00 E+\infty$ & $1.00 E+\infty$ & $1.00 E+\infty$ & $1.00 E+\infty$ & $1.00 E+\infty 0$ \\
\hline Conc. at Wetor Teblo (C2) (mo/L) & 2.01E-06 & $4.80 E-06$ & $3.53 E-04$ & 3.94E-01 & $9.63 E-08$ & $1.00 E-01$ & $3.00 E-01$ & $1.60 E+01$ & $1.70 E+01$ \\
\hline Sat. Traval Thmo (T3) (Yr) & 7.83E-01 & $9.13 E+\infty$ & $7.83 E-01$ & 7.83E-01 & $7.83 E-01$ & 7.83E-01 & 7.63E-01 & 7.83E-01 & $7.83 E-01$ \\
\hline Saturated Zome Dilution (DLL3) & 0.532 & 0.532 & 0.532 & 0.532 & 0.532 & 0.532 & 0.532 & 0.532 & 0.532 \\
\hline Conc. at ERDF Boundary (C3) $(\mathrm{mg} / \mathrm{ll})$ & $1.07 E-06$ & $2.55 E-08$ & $1.88 E-04$ & 2.10E-01 & $4.906-08$ & 5.32E-02 & $1.60 E-01$ & $8.52 E+\infty$ & $9.05 E+\infty$ \\
\hline Redtomuclide Conc. (C3) (PCIL) & $4.77 E+03$ & $1.80 E+\infty 0$ & $3.19 E+03$ & $1.49 E+02$ & $4.73 E+05$ & & & & \\
\hline Source Deplotion Time w/o liner (yr) & $2.50 E+04$ & $7.21 E+02$ & $6.52 E+01$ & $2.54 E+07$ & $1.006+01$ & $6.61 E+04$ & $2.97 E+\infty 6$ & $8.96 E+02$ & $6.07 E+01$ \\
\hline Ai ERDF Boundery & & & & & & & & & \\
\hline Trevel Time (vr) & 125 & 2.267 & 125 & 125 & 125 & 125 & 125 & 125 & 125 \\
\hline Incremental Cancer Risk (ICP) & 9.54E-05 & $8.64 E-06$ & $9.26 E-05$ & $9.24 E-05$ & 5.67E-04 & & & & \\
\hline Hazerd Qwotiont (HO) & & & & & & $9.05 E+\infty$ & $2.08 E+\infty$ & $8.62 E+\infty$ & $6.70 E+\infty$ \\
\hline ICR at $\pi_{\mathrm{mm}}<100$ Yoars & $0.00 E+\infty 0$ & $0.00 E+\infty$ & $0.00 E+\infty$ & $0.00 E+\infty$ & $0.00 E+\infty$ & & & & \\
\hline ICR at $100<$ Time $<1.000$ Yoars & $9.54 E-05$ & $0.00 E+\infty$ & $9.26 E-05$ & $9.24 E-05$ & 5.67E-04 & & & & \\
\hline ICR at $1.000<\pi m b<10.000$ Yeare & 9.54E-05 & 8.64E-06 & $0.00 E+\infty$ & $0.24 E-05$ & $0.00 E+\infty$ & & & & \\
\hline HO at Timo < 100 Yoere & & & & & & $0.00 E+\infty 0$ & $0.00 E+\infty$ & $0.00 E+\infty$ & $0.00 E+\infty$ \\
\hline HO at $100<\pi m e<1.000$ Yeerse & & & & & & $9.05 E+\infty$ & $2.08 E+\infty$ & $8.62 E+\infty$ & $5.70 E+\infty$ \\
\hline HQ at $1.000<\pi$ me $<10.000$ Yaers & & & & & & $9.05 E+\infty$ & $2.08 E+\infty$ & $8.52 E+\infty$ & $0.00 E+\infty$ \\
\hline
\end{tabular}


Table A-12. Results for Base Conditions Scenario under Hypothetical Wetter Climate Condition (Accounting for Leachate Limits).

\begin{tabular}{|c|c|c|c|c|c|c|c|}
\hline Paremoter & Solonitum & Bota-BHC & Chborotom & 1.2-Dichlorosthene & Xylonee & & \\
\hline Soll/Water Partition $(\mathrm{ma} / \mathrm{l})$ & $3.95 E+02$ & $2.66 E-03$ & $1.29 \varepsilon+\infty$ & $1.41 E+01$ & $1.29 E+01$ & & \\
\hline Source Conc. (CO) $(\mathrm{mg} / \mathrm{n})$ & 8.40E-01 & $2.66 \in-03$ & $1.29 E+\infty$ & $1.41 E+01$ & $1.29 E+01$ & & \\
\hline Linor Potordation & $1.00 E+\infty 0$ & $1.84 E+01$ & $1.20 E+\infty 0$ & $1.26 E+\infty$ & $1.34 E+\infty$ & & \\
\hline Liner Trovel Thro (TII) Iyr) & $0.00 E+\infty$ & $0.00 E+\infty$ & $0.00 E+\infty$ & $0.00 E+\infty 0$ & $0.00 E+\infty$ & & \\
\hline Conc. Bonenth Tronch (C1) (mo/L) & 8.40E-01 & $2.66 E-03$ & $1.29 E+\infty$ & $1.41 E+01$ & $1.29 E+01$ & & \\
\hline Vedoes Travel Thme (T2) Im) & $1.24 E+02$ & $3.22 E+03$ & $1.61 E+02$ & $1.70 E+02$ & $1.65 E+02$ & & \\
\hline Vedoes Zono Dilution (DIL2) & $1.00 E+\infty$ & $1.00 E+\infty$ & $1.00 E+\infty$ & $1.00 E+\infty$ & $1.00 E+\infty$ & & \\
\hline Conc. at Water Table (C2) (ma/l) & 8.40E-01 & $2.13 E-03$ & $1.87 E-05$ & $1.05 E-04$ & $3.43 E-05$ & & \\
\hline Sot. Travel Time (T) I ( $\mathrm{r})$ & 7.83E-01 & $1.29 E+01$ & $9.25 E-01$ & $9.62 E-01$ & $1.02 E+\infty$ & & \\
\hline Seturated Zone Dilution (DIL3) & 0.532 & 0.532 & 0.632 & 0.532 & 0.532 & & \\
\hline Conc. at ERDF Boundary $(\mathrm{C} 3)(\mathrm{ma} / \mathrm{l})$ & 4.47E-0! & $1.13 E-03$ & 9.34E-06 & 6.23E-05 & $1.70 E-05$ & & \\
\hline Redionuclide Conc. (CS) (pCAL) & & & & & & & \\
\hline Source Depiotion Time w/o llher (yr) & $4.70 E+03$ & $1.04 E+03$ & $2.21 E+01$ & $2.53 E+01$ & $3.03 E+01$ & & \\
\hline At ERDF Boundery & & & & & & Totel ICA & Max. Ho \\
\hline Travel Thros (vr) & 125 & 3.231 & 162 & 171 & 188 & & \\
\hline Incromentel Canser Risk (ICR) & & 2.49E-05 & $3.45 E-09$ & & & 9E-04 & \\
\hline Hezend Quotiont (MO) & $6.81 E+\infty$ & & $1.68 E-04$ & $3.66 E-04$ & $5.61 E-07$ & & $9 E+\infty$ \\
\hline ICR ot Timo < 100 Yoers & & $0.00 E+\infty$ & $0.00 E+\infty 0$ & & & $\alpha E+\infty$ & \\
\hline ICA at $100<$ Time $<1.000$ Yeare & & $0.00 E+\infty$ & $3.45 E-\infty 9$ & & & 8E-04 & \\
\hline ICR at $1,000<$ Time $<10,000$ Yeare & & 2.49E-05 & $0.00 E+\infty$ & & & $2 E-04$ & \\
\hline HO et $\mathrm{Tm} 0<100$ Yeers & $0.00 E+\infty$ & & $0.00 E+\infty$ & $0.00 E+\infty$ & $0.00 E+\infty$ & & $\alpha E+\infty$ \\
\hline HO et $100<\pi m e<1.000$ Yoere & $5.81 E+\infty$ & & $1.68 E-04$ & $3.66 E-04$ & 6.61E-07 & & $9 E+\infty$ \\
\hline HO of $1.000<T h n<<10,000$ Yoare & $5.81 E+\infty 0$ & & $0.00 E+\infty$ & $0.00 E+\infty$ & $0.00 E+\infty$ & & $9 E+\infty$ \\
\hline
\end{tabular}


Table A-13. Results for Alternative 2 under Hypothetical Wetter Climate Condition (Accounting for Leachate Limits).

\begin{tabular}{|c|c|c|c|c|c|c|c|c|c|}
\hline Percmoter & Carbon-14 & Neptunhum-237 & Technothum-es & Totel Urenkm & Trithem & Antimony & Chromium $-V$ & Finoulde & Nerites (ea M) \\
\hline SollWwator Partition (mo/L) & $5.11 E-03$ & $4.80 E-00$ & $2.30 E-03$ & $1.00 E+\infty$ & $1.07 E-04$ & $6.61 E+02$ & B. $22 E+04$ & $1.43 E+03$ & $1.03 E+02$ \\
\hline Source Conc. $(\mathrm{CO})(\mathrm{mg} / \mathrm{L})$ & 2.04E-06 & $4.80 E-00$ & $3.63 E-04$ & 3.94E-01 & $1.07 E-04$ & $1.00 E-01$ & $3.00 E-01$ & $1.00 E+01$ & $1.70 E+01$ \\
\hline Linor Rotardation & $1.00 E+\infty$ & $1.30 E+01$ & $1.00 E+\infty$ & $1.00 E+\infty$ & $1.00 E+\infty$ & $1.00 E+\infty$ & $1.00 E+\infty$ & $1.00 E+\infty$ & $1.00 E+\infty$ \\
\hline Liner Travel Trme (TII) (vr) & $0.00 E+\infty$ & $0.00 E+\infty$ & $0.00 E+\infty$ & $0.00 E+\infty$ & $0.00 E+\infty$ & $0.00 E+\infty$ & $0.00 E+\infty$ & $0.00 E+\infty$ & $0.00 E+\infty$ \\
\hline Conc. Bonesth Trench (C1) (mo/L) & $2.04 E-06$ & $4.00 E-08$ & $3.53 E-04$ & 3. 84E-01 & $1.07 E-04$ & $1.00 E-01$ & $3.00 E-01$ & $1.00 E+01$ & $1.70 E+01$ \\
\hline Vedose Traval Time (T2) (vit & $1.50 E+02$ & $3.73 E+03$ & $1.50 E+02$ & $1.50 E+02$ & $1.50 €+02$ & $1.50 E+02$ & $1.50 E+02$ & $1.50 E+02$ & $1.60 E+02$ \\
\hline Vedose Zone Dilution (DIL2) & $1.00 E+\infty$ & $1.00 E+\infty$ & $1.00 E+\infty$ & $1.00 E+\infty$ & $1.00 E+\infty$ & $1.00 E+\infty$ & $1.00 E+\infty$ & $1.00 E+\infty$ & $1.00 E+\infty$ \\
\hline Conc. at Water Tablo (C2) (mo/l) & $2.01 E-06$ & $4.79 E-08$ & $3.53 E-04$ & $3.94 E-01$ & $2.26 E-00$ & $1.00 E-01$ & $3.00<-01$ & $1.60 E+01$ & $1.70 E+01$ \\
\hline Set. Travel Tmo (T3) (yr) & $7.83 E-01$ & $9.13 E+\infty$ & $7.63 E-01$ & 7.83E-01 & $7.83 E-01$ & $7.83 E-01$ & $7.83 E-01$ & 7.83E-01 & 7.63E-01 \\
\hline Seturated Zomo Dilhution (DIL3) & 0.387 & 0.387 & 0.387 & 0.387 & 0.387 & 0.387 & 0.387 & 0.387 & 0.387 \\
\hline Conc. at EROF Boundary (C3) (mo/lu) & 7.77E-07 & $1.86 E-08$ & $1.37 E-04$ & $1.53 E-01$ & 8.36E-09 & 3.87E-02 & $1.16 E-01$ & $6.20 E+\infty$ & $6.58 E+\infty$ \\
\hline Rodionuclide Conc. (C3) (pC)/L) & $3.46 E+03$ & $1.31 E+\infty$ & $2.32 E+03$ & $1.06 E+02$ & 8.06E + 04 & & & & \\
\hline Source Doplotion Time w/o Hrer (ivi) & $4.60 E+04$ & $1.30 E+03$ & $1.17 E+02$ & $4.68 E+07$ & $1.80 E+01$ & $1.19 E+05$ & $6.35 E+06$ & $1.61 E+0.3$ & $1.09 E+02$ \\
\hline & & & & & & & & & \\
\hline At ERDF Boundery & & & & & & & & & \\
\hline Travel Time (y) & 151 & 3.743 & 151 & 151 & 151 & 151 & 151 & 151 & 151 \\
\hline Incromontel Cancer Rlak (ICA) & $6.92 E-05$ & $6.28 E-00$ & $6.74 E-05$ & $6.72 E-05$ & 9.67E-05 & & & & \\
\hline Hezend Quotiont (HO) & & & & & & $6.58 E+\infty$ & $1.51 E+\infty$ & $6.20 E+\infty$ & $4.15 E+\infty$ \\
\hline ICR \& Thmo $<100$ Yeers & $0.00 E+\infty$ & $0.00 E+\infty$ & $0.00 E+\infty$ & $0.00 E+\infty 0$ & $0.00 E+\infty$ & & & & \\
\hline ICA at $100<T m e<1.000$ Years & $6.92 E-05$ & $0.00 E+\infty$ & 6.74E-05 & $6.72 E-05$ & 9.67E-05 & & & & \\
\hline ICA at $1,000<\operatorname{Tm}$ e $<10,000$ Yeare & 6.92E-05 & $6.28 E-08$ & $0.00 E+\infty$ & $6.72 E-05$ & $0.00 E+\infty$ & & & & \\
\hline HO at Time < 100 Years & & & & & & $0.00 E+\infty$ & $0.00 E+\infty$ & $0.00 E+\infty$ & $0.00 E+\infty$ \\
\hline HO et $100<\pi m 0<1.000$ Yeare & & & & & & $6.58 E+\infty$ & $1.61 E+\infty$ & $6.20 E+\infty$ & $4.15 E+\infty$ \\
\hline HQ at $1.000<$ Trme $<10.000$ Years & & & & & & $6.58 E+\infty$ & $1.61 E+\infty$ & $6.20 E+\infty$ & $0.00 E+\infty$ \\
\hline
\end{tabular}


Table A-13. Resulks for Alternative 2 under Hypothetical Wetter Climate Condition (Accounting for Leachate Limits).

\begin{tabular}{|c|c|c|c|c|c|c|c|}
\hline Peramoter & Seloniven & Boto-BhC & Chibrotom & 1.2-Dichloriocthane & Xylonos: & & \\
\hline SollWhater Parthion (ma/L) & $3.95 E+02$ & 2.66E-03 & $1.29 E+\infty 0$ & $1.41 E+01$ & $1.20 E+01$ & & \\
\hline Source Conc. $(\mathrm{co})(\mathrm{ma} / \mathrm{h})$ & 8.40E-01 & $2.68 E-03$ & $1.28 E+\infty$ & $1.41 E+01$ & $1.29 E+01$ & & \\
\hline Linor Roterdation & $1.00 E+\infty$ & $1.84 E+01$ & $1.20 E+\infty$ & $1.26 E+\infty$ & $1.34 E+\infty$ & & \\
\hline Liner Travel Tlmo ITII (yr) & $0.00 E+\infty$ & $0.00 E+\infty$ & $0.00 E+\infty$ & $0.00 E+\infty$ & $0.00 E+\infty$ & & \\
\hline Conc. Bonouth Tronch $(\mathrm{C} 1)(\mathrm{mo} / \mathrm{L})$ & 8.40E-01 & $2.66 E-03$ & $1.29 E+\infty$ & $1.41 E+01$ & $1.29 E+01$ & & \\
\hline Vedose Travel Thmo (T2) (yr) & $1.60 E+02$ & $5.35 E+03$ & $2.11 E+02$ & $2.27 E+02$ & $2.52 E+02$ & & \\
\hline Vedose Zone Dilution (DIL2) & $1.00 E+\infty$ & $1.00 E+\infty$ & $1.00 E+\infty$ & $1.00 E+\infty$ & $1.00 E+\infty$ & & \\
\hline Conc. at Water Tablo (C2) (mo/L) & 8.40E-01 & 1.84E-03 & $5.68 E-07$ & $2.03 E-06$ & $3.27 E-07$ & & \\
\hline Sat. Travel Time (T3) (y) & 7.83E-01 & $1.29 E+01$ & $9.25 E-01$ & $9.62 E-01$ & $1.02 E+\infty$ & & \\
\hline Saturated Zone Dthution IDIL3) & 0.387 & 0.387 & 0.387 & 0.387 & 0.387 & & \\
\hline Conc. at ERDF Boundery (C3) (man) & $3.25 E-01$ & $7.12 E-04$ & $2.06 E-07$ & 7.35E-07 & $1.18 E-07$ & & \\
\hline Aedionuclide Conc. (CS) (pCIn) & & & & & & & \\
\hline Source Depletion Timo w/o liner (vi) & $8.46 E+03$ & $1.87 E+03$ & $3.98 E+01$ & $4.55 E+01$ & $5.45 E+01$ & & \\
\hline & & & & & & & \\
\hline AI ERDF Boundary & & & & & & Total ICA & Max. Ha \\
\hline Trevel Time Irit & 161 & 5.360 & 212 & 228 & 253 & & \\
\hline Incromental Concer Plisk (ICA) & & $1.57 E-05$ & $7.63 E-11$ & & & $3 \in-04$ & \\
\hline Hezend Qwotions OHOS & $4.23 E+\infty$ & & 3.71E-06 & 5.14E-00 & $3.80 E-00$ & & $T E+\infty$ \\
\hline ICR at Timo $<100$ Yoars & & $0.00 E+\infty$ & $0.00 E+\infty 0$ & & & $\alpha E+\infty$ & \\
\hline ICA at $100<T$ Trmo $<1.000$ Yeare & & $0.00 E+\infty$ & 7.63E-11 & & & 3E-04 & \\
\hline ICR at $1,000<T h m e<10.000$ Yoere & & 1.67E-05 & $0.00 E+\infty$ & & & $2 E-04$ & \\
\hline HO at Time < 100 Yeare & $0.00 E+\infty$ & & $0.00 E+\infty$ & $0.00 E+\infty$ & $0.00 E+\infty$ & & $\infty \in+\infty$ \\
\hline $\mathrm{HQ}$ at $100<\pi m e<1.000$ Years & $4.23 E+\infty$ & & 3.71E-08 & 5.14E-06 & 3.90E-09 & & $T E+\infty$ \\
\hline HQ at $1.000<$ Time $<10.000$ Yeare & $4.23 E+\infty$ & & $0.00 E+\infty$ & $0.00 E+\infty$ & $0.00 E+\infty$ & & $7 E+\infty$ \\
\hline
\end{tabular}


Table A-14. Results for Alternatives 3 and 4 under Hypothetical Wetter Climate Condition (Accounting for Leachate Limits).

\begin{tabular}{|c|c|c|c|c|c|c|c|c|c|}
\hline Paramoter & Cerbon-14 & Neptunitum-237| & Technothum-es & Totel Uranium & Tittlum & Antimony & Chrombum-VI & Fhoortes & Murtice $(a m)$ \\
\hline SolllWater Partition $(m a / n)$ & 6.11E-03 & 4.80E-08 & $2.30 E-03$ & $1.00 E+06$ & $1.07 E-04$ & $6.61 E+02$ & $8.92 E+04$ & $1.43 E+03$ & $1.03 E+02$ \\
\hline Source Conc. $1 \mathrm{CO} / \mathrm{mo} / \mathrm{L})$ & $2.04 E-08$ & $4.80 E-08$ & $3.53 E-04$ & 3.94E-01 & $1.07 E-04$ & $1.00 E-01$ & $3.00 E-01$ & $1.00 E+01$ & $1.70 E+01$ \\
\hline Liner Roterdetion & $1.00 E+\infty$ & $1.30 E+01$ & $1.00 E+\infty$ & $1.00 E+\infty 0$ & $1.00 E+\infty$ & $1.00 E+\infty$ & $1.00 E+\infty 0$ & $1.00 E+\infty$ & $1.00 E+\infty$ \\
\hline Liner Traval Trme ITII IyrI & $0.00 E+\infty 0$ & $0.00 E+\infty$ & $0.00 E+\infty$ & $0.00 E+\infty$ & $0.00 E+\infty$ & $0.00 E+\infty$ & $0.00 E+\infty$ & $0.00 E+\infty 0$ & $0.00 E+\infty$ \\
\hline Conc. Bonesth Tronch (C1) (mo/L) & 2.04E-06 & $4.80 E-08$ & $3.63 E-04$ & 3.94E-01 & $1.07 E-04$ & $1.00 E-01$ & $3.00 E-01$ & $1.60 E+0 t$ & $1.70 E+01$ \\
\hline Vedoee Traval Then (T2) (yr) & $5.01 E+02$ & $2.92 E+04$ & $5.01 E+02$ & $6.01 E+02$ & $5.01 E+02$ & $5.01 E+02$ & $5.01 E+02$ & $5.01 E+02$ & $5.01 E+02$ \\
\hline Vedose Zone Dllution (DIL2) & $1.00 E+\infty$ & $1.00 E+\infty$ & $1.00 \varepsilon+\infty$ & $1.00 E+\infty 0$ & $1.00 E+\infty$ & $1.00 E+\infty$ & $1.00 E+\infty$ & $1.00 E+\infty 0$ & $1.00 E+\infty$ \\
\hline Conc. at Water Table (C2) (mo/L) & $1.92 E-06$ & $4.75 E-08$ & $3.52 E-04$ & 3.94E-01 & 5.95E-17 & $1.00 E-01$ & $3.00 E-01$ & $1.60 E+01$ & $1.70 E+01$ \\
\hline Sat. Traval Thme (T3) (yr) & 7.83E-01 & $9.13 E+\infty$ & 7.83E-01 & 7.83E-01 & 7.63E-01 & 7.83E-01 & 7.83E-01 & $7.83 E-01$ & $7.83 E-01$ \\
\hline Saturated Zone Dihution (DIL3) & 0.048 & 0.048 & 0.048 & 0.048 & 0.048 & 0.048 & 0.048 & 0.048 & 0.048 \\
\hline Conc. at EADF Boundory (C3) (moll) & $9.26 E-08$ & $2.29 E-07$ & $1.70 E-05$ & $1.80 E-02$ & $2.74 E-18$ & 4.81E-03 & $1.44 E-02$ & $7.70 E-01$ & $0.18<-01$ \\
\hline Redionuclide Conc. (C3) (pC) & $4.12 E+02$ & $1.61 E-01$ & $2.88 E+02$ & $1.36 E+01$ & 2.64E-05 & & & & \\
\hline Source Depletbn Thme w/o liner (yr) & $6.63 E+05$ & $1.62 E+04$ & $1.47 E+03$ & $6.72 E+08$ & $2.25 E+02$ & $1.49 E+00$ & $6.69 E+07$ & $2.02 E+04$ & $1.36 E+03$ \\
\hline At ERDF Boundery & & & & & & & & & \\
\hline Trevel Timo (vr) & 502 & 29.184 & 502 & 502 & 502 & 502 & 502 & 602 & 502 \\
\hline Incromontal Cencer Riak (ICA) & $8.26 E-08$ & 7.74E-07 & 8.36E-06 & $8.36 E-06$ & $3.17 E-14$ & & & & \\
\hline Hazend Quotiont (HO) & & & & & & 8.18E-01 & $1.68 c-01$ & $7.70 E-01$ & $6.1 \times E-01$ \\
\hline ICA at Timo $<100$ Yeare & $0.00 E+\infty$ & $0.00 E+\infty$ & $0.00 E+\infty$ & $0.00 E+\infty$ & $0.00 E+\infty$ & & & & \\
\hline ICA at $100<\pi$ me $<1.000$ Yeare & $0.25 E-08$ & $0.00 E+\infty 0$ & 8.36E-08 & $8.36 E-06$ & $3.17 E-14$ & & & & \\
\hline ICR of $1.000<T \mathrm{~mm}<10.000$ Yaene & $8.25 E-06$ & $0.00 E+\infty$ & $0.36 E-06$ & 0.30E-00 & $0.00 E+\infty 0$ & & & & \\
\hline HO at Time $<100$ Yeare & & & & & & $0.00 E+\infty$ & $0.00 E+\infty$ & $0.00 E+\infty$ & $0.00 E+\infty$ \\
\hline HO at $100<\pi m e<1.000$ Years & & & & & & 8.18E-01 & 1. BeE-01 & $7.70 E-01$ & 5.16e-01 \\
\hline HO at $1.000<\pi m e<10.000$ Yeare & & & & & & 8.18E-01 & $1.806-01$ & $7.70 E-01$ & 6.16E-01 \\
\hline
\end{tabular}


Table A-14. Results for Alternatives 3 and 4 under Hypothetical Wetter Climate Condition (Accounting for Leachate Limits).

\begin{tabular}{|c|c|c|c|c|c|c|c|}
\hline Parameter & Selenlum & Bate-BHC & Chlorotorm & 1.2-Dichloroethene & Xylones & & \\
\hline Solliwater Partition (mo/L) & $3.95 E+02$ & $2.66 E-03$ & $1.29 E+\infty 0$ & $1.41 E+01$ & $1.29 E+01$ & & \\
\hline Source Conc. (CO) (mg/L) & B.40E-01 & $2.66 E-03$ & $1.29 E+\infty 0$ & $1.41 E+01$ & $1.29 \varepsilon+01$ & & \\
\hline Liner Potardation & $1.00 E+\infty$ & $1.84 E+01$ & - $1.20 E+\infty 0$ & $1.26 E+\infty 0$ & $1.34 E+\infty$ & & \\
\hline Liner Trevel Timo (TI) (yr) & $0.00 E+\infty$ & $0.00 E+\infty$ & $0.00 E+\infty 0$ & $0.00 E+\infty$ & $0.00 E+\infty$ & & \\
\hline Conc. Boneeth Tronch $(C 1)(\mathrm{mo} / \mathrm{L})$ & 8.40E-01 & $2.66 E-03$ & $1.29 E+\infty 0$ & $1.41 E+01$ & $1.29 E+01$ & & \\
\hline Vedose Treval Time (T2) (yr) & $6.01 E+02$ & $4.21 E+04$ & $8.88 E+02$ & $1.12 E+03$ & $1.32 E+03$ & & \\
\hline Vedose Zone Dilution (DIL2) & $1.00 E+\infty$ & $1.00 E+\infty$ & $1.00 E+\infty$ & $1.00 E+\infty$ & $1.00 E+\infty$ & & \\
\hline Conc. et Water Tablo (C2) (mo/l) & 8.40E-01 & $1.44 E-04$ & $2.30 E-30$ & $3.28 E-33$ & 2.74E-38 & & \\
\hline Sat. Travel Time (T3) (yr) & $7.83 E-01$ & $1.29 E+01$ & 9.25E-01 & 9.62E-01 & $1.02 E+\infty$ & & \\
\hline Saturated Zone Dilution (DIL3) & 0.048 & 0.048 & 0.048 & 0.048 & 0.048 & & \\
\hline Conc. at ERDF Boundary (C3) (mo/L) & 4.04E-02 & 6.93E-06 & $1.04 E-31$ & $1.48 E-34$ & $1.23 E-40$ & & \\
\hline Radlonuclide Conc. (C3) (pCl/L) & & & & & & & \\
\hline Source Depletion Time w/o liner (vr) & $1.06 E+05$ & $2.34 E+04$ & $4.87 E+02$ & $6.69 E+02$ & $6.81 E+02$ & & \\
\hline & & & & & & & \\
\hline At ERDF Boundary & & & & & & Total ICA & Max. HQ \\
\hline Travel Time (yr) & 502 & 42.091 & 889 & 1.118 & 1.319 & & \\
\hline Incremental Cancer Risk (ICR) & & $1.53 E-07$ & $3.86 E-35$ & & & 3E-05 & \\
\hline Hezard Quotiont (HO) & $6.26 E-01$ & & $1.87 E-30$ & $1.03 E-33$ & $4.05 E-42$ & & 8E-01 \\
\hline ICA at $\pi m e<100$ Yeare & & $0.00 E+\infty$ & $0.00 E+\infty$ & & & $O E+\infty$ & \\
\hline ICR at $100<\pi \mathrm{me}<1.000$ Yeare & & $0.00 E+\infty$ & $3.66 E-35$ & & & 2E-05 & \\
\hline ICR at $1,000<\pi$ me $<10,000$ Yeare & & $0.00 E+\infty 0$ & $3.85 E-35$ & & & 2E-06 & \\
\hline HO of $\mathrm{Time}<100$ Years & $0.00 E+\infty$ & & $0.00 E+\infty$ & $0.00 E+\infty 0$ & $0.00 E+\infty$ & & $O E+\infty$ \\
\hline HO at $100<\pi m e<1,000$ Yeare & $5.26 E-01$ & & $1.87 E-30$ & $0.00 E+\infty 0$ & $0.00 E+\infty$ & & 8E-01 \\
\hline HO at $1.000<\pi m 0<10.000$ Years & 6.26E-01 & & $1.87 E-30$ & $1.03 E-33$ & $4.05 E-42$ & & BE-01 \\
\hline
\end{tabular}


Table A-15. Results for Alternative 5 under Hypothetical Wetter Climate Condition (Accounting for Leachate Limits).

\begin{tabular}{|c|c|c|c|c|c|c|c|c|c|}
\hline Paramoter & Carton-14 & Neptunium-237 & Technethum-99 & Totel Uranium & Trtitum & Antimony & Chromium-VI & Fivorlde & Nitite (ee N) \\
\hline Soill Water Partition (mo/L) & 6.11E-03 & $4.80 E-06$ & $2.30 E-03$ & $1.00 E+08$ & $1.07 E-04$ & $6.61 E+02$ & $8.92 E+04$ & $1.43 E+03$ & $1.03 E+02$ \\
\hline Soures Cone. $(\mathrm{CO})(\mathrm{mo} / \mathrm{L})$ & 2.04E-06 & 4.80E-06 & 3.53E-04 & $3.84 E-01$ & $1.07 E-04$ & $1.00 E-01$ & 3.00E-01 & $1.60 E+01$ & $1.70 E+01$ \\
\hline Liner Roterdation & $1.00 E+\infty 0$ & 6.77E + 01 & $1.00 E+\infty$ & $1.00 E+\infty$ & $1.00 E+\infty 0$ & $1.00 E+\infty$ & $1.00 E+\infty 0$ & $1.00 E+\infty$ & $1.00 E+\infty 0$ \\
\hline Liner Travel Time (TII (yr) & $3.14 E+01$ & $1.21 E+02$ & $3.14 E+01$ & $3.14 E+01$ & $3.14 E+01$ & $3.14 E+01$ & $3.14 E+01$ & $3.14 E+01$ & $3.14 E+01$ \\
\hline Conc. Benenth Trench $(\mathrm{C} 1)(\mathrm{mg} / \mathrm{L})$ & 2.03E-06 & $4.80 E-06$ & 3.53E-04 & $3.84 E-01$ & $0.00 E+\infty$ & $1.00 E-01$ & $3.00 E-01$ & $1.60 E+01$ & $1.70 E+01$ \\
\hline Vadose Travel Time (T2) IVr) & $1.20 E+02$ & $3.70 E+03$ & $1.20 E+02$ & $1.20 E+02$ & $1.20 E+02$ & $1.20 E+02$ & $1.20 E+02$ & $1.20 E+02$ & $1.20 E+02$ \\
\hline Vedose Zane Dilution (DIL2) & $1.00 E+\infty$ & $1.00 E+\infty$ & $1.00 E+\infty$ & $1.00 E+00$ & $1.005+\infty$ & $1.00 E+\infty$ & $1.00 E+\infty 0$ & $1.00 E+\infty 0$ & $1.00 E+\infty 0$ \\
\hline Conc. at Woter Table (C2) (mo/n) & 2.01E-06 & $4.79 E-06$ & 3.63E-04 & 3.94E-01 & $0.00 E+\infty$ & $1.00 E-01$ & 3.00E-01 & $1.60 E+01$ & $1.70 E+01$ \\
\hline Sat. Travol Time (T3) (yr) & 7.83E-01 & $9.13 E+\infty$ & 7.83E-01 & 7.83E-01 & 7.83E-01 & $7.83 E-01$ & 7.83E-01 & 7.83E-01 & 7.83E-01 \\
\hline Saturated Zone Dilurtion (DIL3) & 0.387 & 0.387 & 0.387 & 0.387 & 0.387 & 0.387 & 0.387 & 0.387 & 0.387 \\
\hline Conc. at ERDF Boundery $(\mathrm{C} 3)(\mathrm{mg} / \mathrm{L})$ & 7.77E-07 & $1.86 E-06$ & $1.37 \mathrm{E}-04$ & 1.53E-01 & $0.00 E+\infty 0$ & $3.87 E-02$ & $1.16 E-01$ & $6.20 E+\infty 0$ & $6.58 E+\infty$ \\
\hline Radionuclide Conc. (C3) (pCl/L) & $3.46 E+03$ & $1.31 E+\infty 0$ & $2.32 E+03$ & $1.06 E+02$ & $0.00 E+\infty$ & & & & \\
\hline Source Depletion Time w/o liner (yr) & $4.50 E+04$ & $1.30 E+03$ & $1.17 E+02$ & $4.58 E+07$ & $1.80 E+01$ & $1.19 E+06$ & $6.35 E+06$ & $1.61 E+03$ & $1.09 E+02$ \\
\hline Source Deplotion Time-tlop) (yr) & $4.50 E+04$ & $1.27 E+03$ & $8.73 E+01$ & $4.68 E+07$ & $-1.20 E+01$ & $1.19 E+06$ & $6.35 E+06$ & $1.58 E+03$ & $7.92 E+01$ \\
\hline Source Deplotion Thme-tlop) (yr) & $4.60 E+04$ & $1.27 E+03$ & $8.73 E+01$ & $4.58 E+07$ & $-1.20 E+01$ & $1.19 E+05$ & $5.35 E+06$ & $1.58 E+03$ & $7.92 E+01$ \\
\hline AP ERDF Boundary & & & & & & & & & \\
\hline Travol Time (yr) & 152 & $\mathbf{3 . 8 3 5}$ & 152 & 162 & 152 & 152 & 162 & 152 & 152 \\
\hline Incromentel Cancer Risk (ICR) & $6.92 E-05$ & $6.28 E-06$ & $6.74 E-05$ & 6.72E-05 & $0.00 E+\infty 0$ & & & & \\
\hline Hazard Quotiont (Ma) & & & & & & $6.68 E+\infty 0$ & $1.51 E+\infty$ & $6.20 E+\infty 0$ & $4.86 E+\infty 0$ \\
\hline ICA at Time $<100$ Yeare & $0.00 E+00$ & $0.00 E+\infty$ & $0.00 E+\infty 0$ & $0.00 E+\infty$ & $0.00 E+\infty$ & & & & \\
\hline ICR at $100<\pi m 0<1.000$ Years & $6.92 E-05$ & $0.00 E+\infty$ & 6.74E-05 & $6.72 E-05$ & $0.00 E+\infty 0$ & & & & \\
\hline ICR at $1.000<$ Thme $<10,000$ Yeare & $6.92 E-05$ & $6.28 E-06$ & $0.00 E+\infty$ & $6.72 E-05$ & $0.00 E+\infty 0$ & & & & \\
\hline HO at $\pi m e<100$ Yoere & & & & & & $0.00 E+\infty$ & $0.00 E+\infty 0$ & $0.00 E+\infty$ & $0.00 E+\infty$ \\
\hline HO at $100<\pi i m e<1.000$ Yeare & & & & & & $6.58 E+\infty 0$ & $1.61 E+\infty 0$ & $6.20 E+\infty 0$ & $4.15 E+\infty 0$ \\
\hline Ha at $1.000<\pi$ mo $<10.000$ Yeare & & & & & & $6.6 B E+\infty$ & $1.61 E+\infty$ & $6.20 E+\infty$ & $0.00 E+\infty$ \\
\hline
\end{tabular}


Table A-15. Results for Alternative 5 under Hypothetical Wetter Climate Condition (Accounting for Leachate Limits).

\begin{tabular}{|c|c|c|c|c|c|c|c|}
\hline Peramoter & Solonilum & Bota-BHC & Chioroform & 1,2. Dichlorosthene & Xylonos & & \\
\hline Sollnwator Partikion (mo/n) & $3.95 E+02$ & 2.66E-03 & $1.29 E+\infty 0$ & $1.41 E+01$ & $1.29 E+01$ & & \\
\hline Source Conc. $(\mathrm{CO})(\mathrm{mg} / \mathrm{L})$ & 8.40E-01 & 2.66E-03 & $1.29 E+\infty 0$ & $1.41 E+01$ & $1.28 E+01$ & & \\
\hline Liner Rotardation & $1.00 E+\infty 0$ & 9.77E + 01 & $2.13 E+\infty 0$ & $2.43 E+\infty 0$ & $2.80 E+\infty$ & & \\
\hline Liner Travel Hime (TII) (yr) & $3.14 E+01$ & $1.62 E+02$ & $3.29 E+01$ & $3.33 E+01$ & $3.39 E+01$ & & \\
\hline Conc. Boneath Tronch $(\mathrm{C} 1)$ (mo/h) & 8.40E-01 & $2.63 E-03$ & $1.32 E-01$ & $1.40 E+\infty 0$ & $1.23 E+\infty 0$ & & \\
\hline Vedoes Travel Thro (T2) (Yr) & $1.20 E+02$ & $5.32 E+03$ & $1.81 E+02$ & $1.87 E+02$ & $2.22 E+02$ & & \\
\hline Vedose Zone Dillution (DIL2) & $1.00 E+\infty$ & $1.00 E+\infty$ & $1.00 E+\infty 0$ & $1.00 E+\infty$ & $1.00 E+\infty 0$ & & \\
\hline Conc. at Water Tublo $(\mathrm{C} 2)(\mathrm{mo} / \mathrm{L})$ & 8.40E-01 & $1.82 E-03$ & 4.63E-07 & $1.61 E-06$ & $2.49 E-07$ & & \\
\hline Set. Travel Time (T3) Iyr) & 7.83E-01 & $1.29 E+01$ & $9.25 E-01$ & $9.62 E-O 1$ & $1.02 E+\infty$ & & \\
\hline Saturated Zono Ditution (DIL3) & 0.387 & 0.387 & 0.387 & 0.387 & 0.387 & & \\
\hline Conc. at ERDF Boundary (C3) $(\mathrm{mo} / \mathrm{L})$ & $3.25 E-01$ & $7.05 E-04$ & $1.68 E-07$ & 6.63E-07 & 8.97E-08 & & \\
\hline Radionuclide Conc. (C3) (pCh) & & & & & & & \\
\hline Source Depletion Time w/o Ilner (vr) & $8.46 E+03$ & $1.87 E+03$ & $3.98 E+01$ & $4.65 E+01$ & $6.46 E+01$ & & \\
\hline Source Deplotion Thre-t(op) (yr) & $8.43 E+03$ & $1.84 E+03$ & $9.76 E+\infty$ & $1.55 E+01$ & $2.45 E+01$ & & \\
\hline Source Dopletion Trme-t(op) (vr) & $8.43 E+03$ & $1.84 E+03$ & $9.76 E+\infty$ & $1.55 E+01$ & $2.45 E+01$ & & \\
\hline A: ERDF Boundary & & & & & & Toted ICA & Max. Ha \\
\hline Trevel Time |rr| & 152 & 5.492 & 215 & 232 & 257 & & \\
\hline Inerementel Cancer Alak (ICR) & & $1.55 E-05$ & $6.23 E-11$ & & & $2 E-04$ & \\
\hline Hazard Quotiont (MO) & $4.23 E+\infty 0$ & & $3.03 E-08$ & 4.08E-06 & 2.96E-09 & & $7 E+\infty$ \\
\hline ICR at Timo $<100$ Yeare & & $0.00 E+\infty$ & $0.00 E+\infty$ & & & $\alpha E+\infty$ & \\
\hline ICA at $100<\pi m$ r $<1.000$ Yoare & & $0.00 E+\infty$ & $6.23 E-11$ & & & $2 E-04$ & \\
\hline ICA at $1.000<\pi$ Time $<10.000$ Yoare & & $1.55 E-05$ & $0.00 E+\infty$ & & & $2 E-04$ & \\
\hline HO at Time $<100$ Yeare & $0.00 E+\infty 0$ & & $0.00 E+\infty$ & $0.00 E+\infty$ & $0.00 E+\infty$ & & $O E+\infty$ \\
\hline HO at $100<\operatorname{Time}<1.000$ Yeare & $4.23 E+\infty 0$ & & $3.03 E-06$ & $4.08 E-06$ & $2.96 E-09$ & & $7 E+\infty$ \\
\hline HO at $1.000<\pi m e<10.000$ Yeare & $4.23 E+\infty$ & & $0.00 E+\infty$ & $0.00 E+\infty$ & $0.00 E+\infty$ & & $T E+\infty$ \\
\hline
\end{tabular}


Table A-16. Results for Alternatives 6 and 7 under Hypothetical Wetter Climate Condition (Accounting for Leachate Limits).

\begin{tabular}{|c|c|c|c|c|c|c|c|c|c|}
\hline Paramotor & Carbon-14 & Neptunlum-237 & Technotium-98 & Total Uranlum & Trthum & Antimony & Chromlum-VI & Fluoride & Nitrite (as N) \\
\hline SolilWater Partition $(\mathrm{mo} / \mathrm{L})$ & 5.11E-03 & $4.80 E-08$ & 2.30E-03 & $1.00 E+08$ & $1.07 E-04$ & $6.61 E+02$ & $8.82 E+04$ & $1.43 E+03$ & $1.03 E+02$ \\
\hline Source Conc. $(\mathrm{CO})(\mathrm{mg} / \mathrm{L})$ & $2.04 E-08$ & $4.80 E-06$ & 3.63E-04 & 3.94E-01 & $1.07 E-04$ & $1.00 E-01$ & 3.00E-01 & $1.60 E+01$ & $1.70 E+01$ \\
\hline Liner Roterdation & $1.00 E+\infty$ & $6.77 E+01$ & $1.00 E+\infty$ & $1.00 E+\infty 0$ & $1.00 E+\infty$ & $1.00 E+\infty$ & $1.00 E+\infty$ & $1.00 E+\infty$ & $1.00 E+\infty$ \\
\hline Linor Travel Time (TII) (yr) & $4.69 E+01$ & $1.17 E+03$ & $4.69 E+01$ & $4.69 E+01$ & $4.69 E+01$ & $4.69 E+01$ & $4.69 E+01$ & $4.69 E+01$ & $4.69 E+01$ \\
\hline Conc. Bonoath Tronch (CII) (moll) & 2.03E-06 & 4.80E-06 & $3.53 E-04$ & 3.94E-01 & $7.62 E-06$ & $1.00 E-01$ & $3.00 E-01$ & $1.60 E+01$ & $1.70 E+01$ \\
\hline Vedose Trevel Time (T2) (Yr) & $4.71 E+02$ & $2.91 E+04$ & $4.71 E+02$ & $4.71 E+02$ & $4.71 E+02$ & $4.71 E+02$ & $4.71 E+02$ & $4.71 E+02$ & $4.71 E+02$ \\
\hline Vedoes Zone Dilution (DIL2) & $1.00 E+\infty$ & $1.00 E+\infty 0$ & $1.00 E+\infty$ & $1.00 E+\infty 0$ & $1.00 E+\infty$ & $1.00 E+\infty$ & $1.00 E+\infty$ & $1.00 E+\infty 0$ & $1.00 E+\infty 0$ \\
\hline Conc. at Water Table (C2) (mo/L) & $1.92 E-06$ & $4.75 E-06$ & $3.52 E-04$ & 3.94E-01 & $2.20 E-17$ & $1.00 E-01$ & $3.00 E-01$ & $1.60 E+01$ & $1.70 E+01$ \\
\hline Sat. Travel Time (T3) (Yr) & 7.83E-01 & $9.13 E+\infty$ & 7.83E-01 & 7.83E-01 & 7.83E-01 & 7.83E-01 & 7.83E-01 & 7.83E-01 & $7.83 E-01$ \\
\hline Saturated Zone Dilution (DIL3) & 0.048 & 0.048 & 0.048 & 0.048 & 0.048 & 0.048 & 0.048 & 0.048 & 0.048 \\
\hline Conc. at ERDF Boundary IC3) (ma/n) & $9.24 E-08$ & 2.29E-07 & $1.70 E-05$ & $1.90 E-02$ & $1.01 E-18$ & $4.81 E-03$ & 1.44E-02 & $7.70 E-01$ & 8.18E-01 \\
\hline Redionuclide Conc. (C3) (pCin) & $4.11 E+02$ & $1.61 E-01$ & $2.88 E+02$ & $1.35 E+01$ & $9.78 E-06$ & & & & \\
\hline Source Deplotion Time w/o liner (yr) & $5.63 E+05$ & $1.62 E+04$ & $1.47 E+03$ & $5.72 E+08$ & $2.25 E+02$ & $1.49 E+08$ & $6.69 E+07$ & $2.02 E+04$ & $1.36 E+03$ \\
\hline Source Deplotion Time-slop) (rr) & $5.63 E+05$ & $1.62 E+04$ & $1.44 E+03$ & $6.72 E+08$ & $1.95 E+02$ & $1.49 E+06$ & $6.69 E+07$ & $2.01 E+04$ & $1.33 E+03$ \\
\hline Source Depletion Time-t(op) (yr) & $5.63 E+05$ & $1.62 E+04$ & $1.44 E+03$ & $5.72 E+08$ & $1.95 E+02$ & $1.49 E+06$ & $6.69 E+07$ & $2.01 E+04$ & $1.33 E+03$ \\
\hline At ERDF Boundary & & & & & & & & & \\
\hline Trevel Time (yr) & 519 & 30.327 & 519 & 519 & 519 & 519 & 619 & 519 & 518 \\
\hline Ineremental Concer Risk (ICA) & 8.23E-08 & 7.74E-07 & 8.36E-06 & 8.36E-08 & $1.17 E-14$ & & & & \\
\hline Hazard Quotiont (HQ) & & & & & & 8.18E-01 & $1.88 E-01$ & 7.70E-01 & 5.16E-01 \\
\hline ICR at Time $<100$ Years & $0.00 E+\infty 0$ & $0.00 E+\infty 0$ & $0.00 E+\infty$ & $0.00 E+\infty 0$ & $0.00 E+\infty 0$ & & & & \\
\hline ICR at $100<$ Time $<1.000$ Yeare & $8.23 E-06$ & $0.00 E+\infty$ & $8.36 E-08$ & 8.36E-06 & $1.17 E-14$ & & & & \\
\hline ICR at $1.000<$ Time $<10.000$ Years & $8.23 E-06$ & $0.00 E+\infty$ & $8.36 E-06$ & 8.36E-06 & $0.00 E+\infty 0$ & & & & \\
\hline HO at Time $<100$ Yeare & & & & & & $0.00 E+\infty$ & $0.00 E+\infty$ & $0.00 E+\infty$ & $0.00 E+\infty 0$ \\
\hline HO at $100<\pi m 0<1.000$ Yoere & & & & & & B.18E-01 & $1.88 E-01$ & $7.70 E-01$ & 5.16E-01 \\
\hline HQ at $1.000<\pi m e<10.000$ Yeare & & & & & & $8.18 E-01$ & $1.88 E-01$ & 7.70E-01 & $5.16 E-01$ \\
\hline
\end{tabular}


Table A-16. Results for Alternatives 6 and 7 under Hypothetical Wetter Climate Condition (Accounting for Leachate Limits).

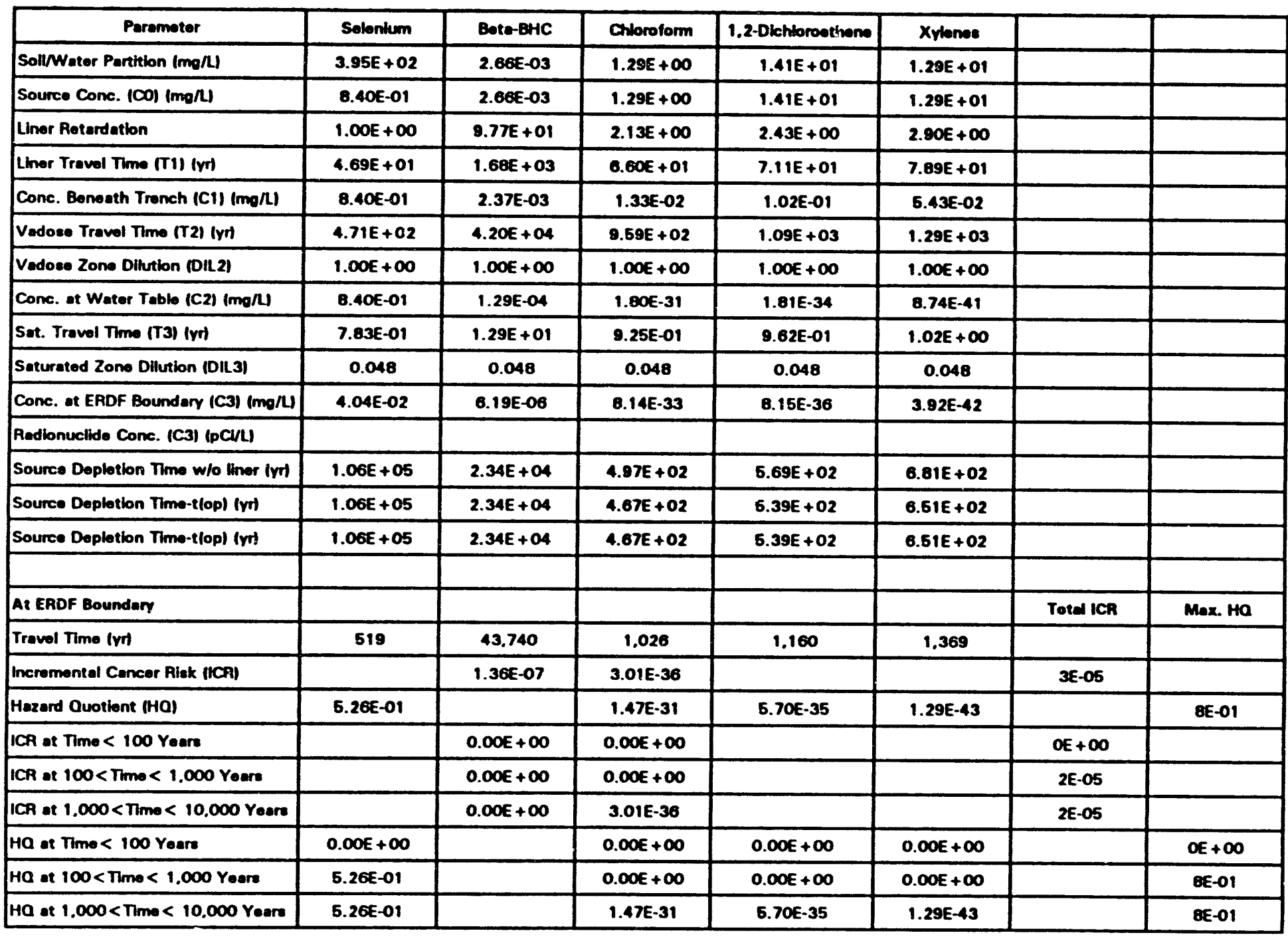


Table A-17. Resulis for Alternative 8 under Hypothetical Wetter Climate Condition (Accounting for Leachate Limits).

\begin{tabular}{|c|c|c|c|c|c|c|c|c|c|}
\hline Paramotor & Contion-14 & Noptunlum-237| & Tochnothum-99 & Total Urantum & Tritium & Antimony & Chrombum-VI & Fluoride & Nitrite (as N) \\
\hline Soll/Water Partition (mo/L) & 6.11E-03 & $4.80 E-06$ & $2.30 E-03$ & $1.00 E+\infty 8$ & $1.07 E-04$ & $6.61 E+02$ & $8.92 E+04$ & $1.43 E+03$ & $1.03 E+02$ \\
\hline Source Conc. $(\mathrm{CO})(\mathrm{mg} / \mathrm{L})$ & 2.04E-06 & $4.80 E-08$ & 3.53E-04 & 3.94E-01 & $1.07 E-04$ & $1.00 E-01$ & $3.00 E-01$ & $1.60 E+01$ & $1.70 E+01$ \\
\hline Liner Rotardation & $1.00 E+\infty$ & $6.77 E+01$ & $1.00 E+\infty$ & $1.00 E+\infty$ & $1.00 E+\infty 0$ & $1.00 E+\infty 0$ & $1.00 E+\infty 0$ & $1.00 E+\infty$ & $1.00 E+\infty$ \\
\hline Liner Travel Time (TI) (yr) & $3.41 E+01$ & $3.04 E+02$ & $3.41 E+01$ & $3.41 E+01$ & $3.41 E+01$ & $3.41 E+01$ & $3.41 E+01$ & $3.41 E+01$ & $3.41 E+01$ \\
\hline Conc. Benoath Tronch $(\mathrm{C} 1)(\mathrm{mo} / \mathrm{L})$ & 2.03E-06 & 4.80E-08 & 3.53E-04 & 3.94E-01 & $0.00 E+\infty$ & $1.00 E-01$ & 3.00E-01 & $1.60 E+01$ & $1.70 E+01$ \\
\hline Vadose Traval Thro (T2) (rr) & $1.20 E+02$ & $3.70 E+03$ & $1.20 E+02$ & $1.20 E+02$ & $1.20 E+02$ & $1.20 E+02$ & $1.20 E+02$ & $1.20 E+02$ & $1.20 E+02$ \\
\hline Vadose Zone Dilution (DIL2) & $1.00 E+\infty$ & $1.00 E+\infty$ & $1.00 E+\infty$ & $1.00 E+\infty$ & $1.00 E+\infty$ & $1.00 E+\infty$ & $1.00 E+\infty$ & $1.00 E+\infty 0$ & $1.00 E+\infty 0$ \\
\hline Conc. at Water Table (C2) (mo/l) & $2.00 E-06$ & $4.79 E-08$ & $3.53 E-04$ & 3.24E-01 & $0.00 E+\infty$ & $1.00 E-01$ & $3.00 E-01$ & $1.60 E+01$ & $1.70 E+01$ \\
\hline Sat. Travol Timo (T3) (yr) & 7.83E-01 & $9.13 E+\infty$ & $7.83 E-01$ & 7.83E-01 & 7.83E-01 & 7.83E-01 & 7.83E-01 & 7.83E-01 & 7.83E-01 \\
\hline Saturated Zone Dilution (DIL3) & 0.387 & 0.387 & 0.387 & 0.387 & 0.387 & 0.387 & 0.387 & 0.387 & 0.387 \\
\hline Conc. at ERDF Boundary (C3) $(\mathrm{mo} / \mathrm{L})$ & $7.77 E-07$ & $1.86 E-06$ & $1.37 E-04$ & $1.63 E-01$ & $0.00 E+\infty$ & 3.87E-02 & $1.16 E-01$ & $6.20 E+\infty$ & $6.58 E+\infty$ \\
\hline Radionuclide Conc. (C3) (pCI/L) & $3.46 E+03$ & $1.31 E+\infty$ & $2.32 E+03$ & $1.08 E+02$ & $0.00 E+\infty$ & & & & \\
\hline Source Depletion Thmo w/o liner (yr) & $4.50 E+04$ & $1.30 E+03$ & $1.17 E+02$ & $4.58 E+07$ & $1.80 E+01$ & $1.19 E+05$ & $5.35 E+06$ & $1.61 E+03$ & $1.09 E+02$ \\
\hline Source Deplotion Timo-tlop) (yrt & $4.50 E+04$ & $1.27 E+03$ & $8.73 E+01$ & $4.58 E+07$ & $-1.20 E+01$ & $1.19 E+05$ & $5.35 E+06$ & $1.58 E+03$ & $7.92 E+01$ \\
\hline Source Dopletion Thmo-t(op) (vr) & $4.50 E+04$ & $1.27 E+03$ & $8.73 E+01$ & $4.68 E+07$ & $-1.20 E+01$ & $1.19 E+05$ & $5.35 E+06$ & $1.68 E+03$ & $7.92 E+01$ \\
\hline At ERDF Boundary & & & & & & & & & \\
\hline Travol Mimo IVrt & 155 & 4.017 & 165 & 155 & 155 & 155 & 155 & 165 & 155 \\
\hline Incromental Cancer Rlak (ICR) & $6.82 E-05$ & $6.28 E-06$ & $6.74 E-05$ & $6.72 E-05$ & $0.00 E+\infty$ & & & & \\
\hline Hazard Quotiont (HO) & & & & & & $6.58 E+\infty$ & $1.61 E+\infty$ & $6.20 E+\infty 0$ & $4.16 E+\infty$ \\
\hline ICR at Time $<100$ Yeare & $0.00 E+\infty$ & $0.00 E+\infty$ & $0.00 E+\infty$ & $0.00 E+\infty$ & $0.00 E+\infty$ & & & & \\
\hline ICR at $100<\pi m e<1.000$ Yeere & 6.92E-05 & $0.00 E+\infty$ & 6.74E-05 & 6.72E-05 & $0.00 E+\infty$ & & & & \\
\hline ICR at $1.000<\pi$ me $<10.000$ Yeare & $6.92 E-05$ & $6.28 E-06$ & $0.00 E+\infty$ & 6.72E-05 & $0.00 E+\infty$ & & & & \\
\hline HO at Timo $<100$ Yoare & & & & & & $0.00 E+\infty$ & $0.00 E+\infty$ & $0.00 E+\infty$ & $0.00 E+\infty$ \\
\hline HO at $100<\pi m e<1.000$ Yeare & & & & & & $6.58 E+\infty$ & $1.61 E+\infty$ & $6.20 E+\infty$ & $4.15 E+\infty 0$ \\
\hline HO at $1.000<$ Time $<10.000$ Yeare & & & & & & $6.58 E+\infty$ & $1.51 E+\infty$ & $6.20 E+\infty 0$ & $0.00 E+\infty 0$ \\
\hline
\end{tabular}


Table A-17. Results for Alternative 8 under Hypothetical Wetter Climate Conditlon (Accounting for Leachate Limits).

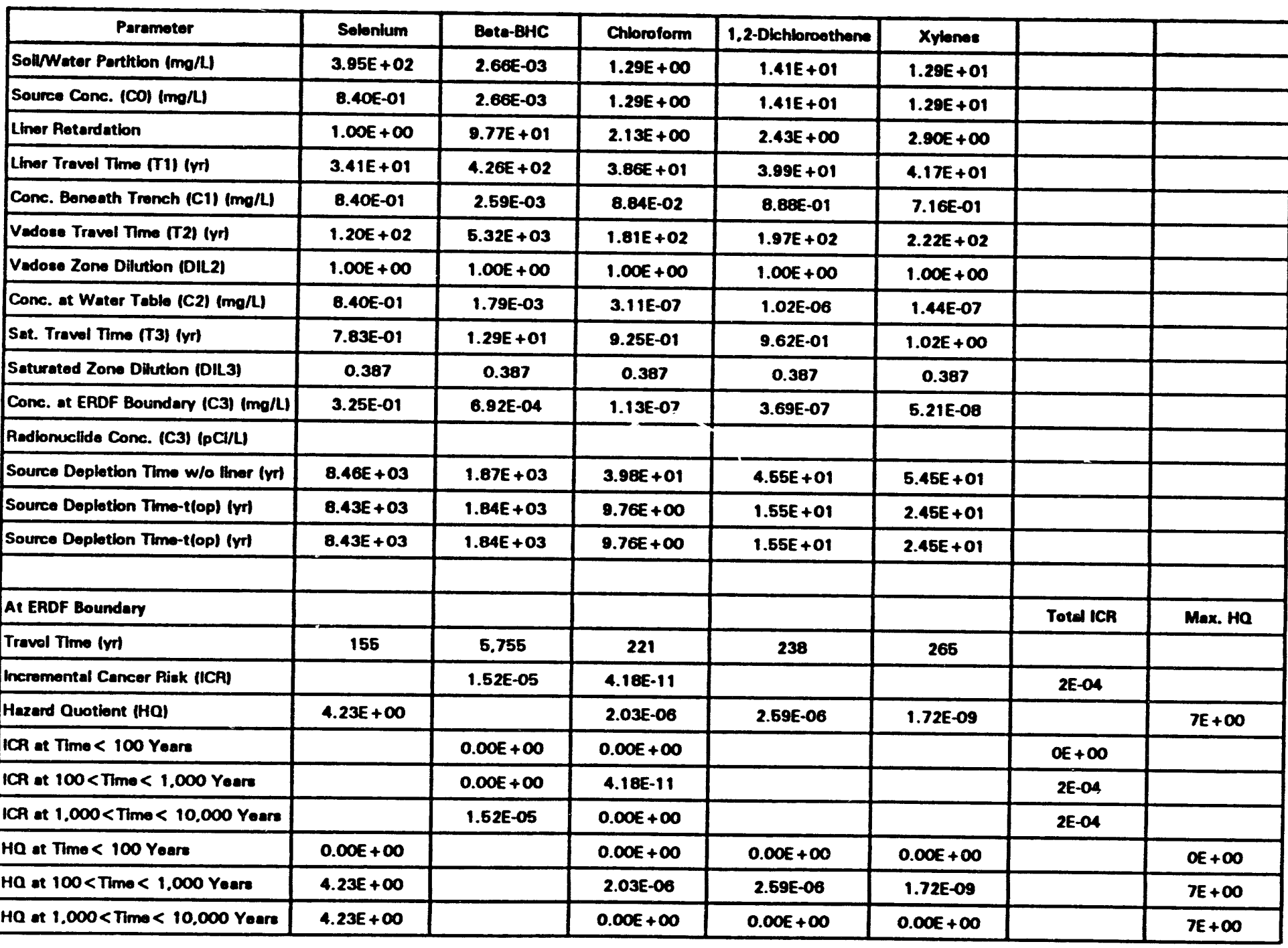


Table A-18. Results for Alternatives 9 and 10 under Hypothetical Wetter Climate Condition (Accounting for Leachate Limits).

\begin{tabular}{|c|c|c|c|c|c|c|c|c|c|}
\hline Parameter & Carbon-14 & Neptunhum-237 & Technetlum-99 & Total Urankum & Trttium & Antimony & Chromtum-VI & Fleortde & Nherte (as N) \\
\hline SolinWater Partition (mo/L) & $5.11 E-03$ & $4.80 E-08$ & $2.30 E-03$ & $1.00 E+08$ & $1.07 E-04$ & $6.61 E+02$ & $8.92 E+04$ & $1.43 E+03$ & $1.03 E+02$ \\
\hline Source Conc. $(\mathrm{CO})(\mathrm{mg} / \mathrm{l})$ & $2.04 E-06$ & $4.80 E-08$ & 3.53E-04 & 3.94E-01 & 1.07E-04 & $1.00 E-01$ & $3.00 E-01$ & $1.60 E+01$ & $1.70 E+01$ \\
\hline Linor Roterdation & $1.00 E+\infty$ & $6.77 E+01$ & $1.00 E+\infty 0$ & $1.00 E+\infty$ & $1.00 E+\infty$ & $1.00 E+\infty$ & $1.00 E+\infty$ & $1.00 E+\infty$ & $1.00 E+\infty$ \\
\hline Liner Travel Time (TI) (Yr) & $8.06 E+01$ & $3.46 E+03$ & $8.06 E+01$ & $8.06 E+01$ & $8.06 E+01$ & $8.06 E+01$ & $8.06 E+01$ & $8.06 E+01$ & $8.06 E+01$ \\
\hline Conc. Beneuth Trench (C1) $(\mathrm{mo} / \mathrm{L})$ & $2.02 E-08$ & $4.79 E-08$ & 3.53E-04 & 3.94E-01 & $1.14 E-06$ & $1.00 E-01$ & $3.00 E-01$ & $1.60 E+01$ & $1.70 E+01$ \\
\hline Vadose Traval Time (T2) (VI) & $4.71 E+02$ & $2.91 E+04$ & $4.71 E+02$ & $4.71 E+02$ & $4.71 E+02$ & $4.71 E+02$ & 4.71E + 02 & 4.71E + 02 & $4.71 E+02$ \\
\hline Vedose Zone Dllution (DIL2) & $1.00 E+\infty$ & $1.00 E+\infty 0$ & $1.00 E+\infty$ & $1.00 E+\infty$ & $1.00 E+\infty$ & $1.00 E+\infty$ & $1.00 E+\infty$ & $1.00 E+\infty$ & $1.00 E+\infty$ \\
\hline Conc. at Water Tablo (C2) (mo/L) & 1.91E-08 & $4.75 E-06$ & $3.52 E-04$ & $3.94 E-01$ & $3.29 E-18$ & $1.00 E-01$ & $3.00 E-01$ & $1.60 E+01$ & $1.70 E+01$ \\
\hline Sat. Traval Thmo (T3) (yr) & 7.83E-01 & $9.13 E+\infty 0$ & 7.83E-01 & 7.83E-01 & 7.83E-01 & 7.83E-01 & 7.83E-01 & 7.83E-01 & 7.83E-01 \\
\hline Saturated Zono Dilution (DIL3) & 0.048 & 0.048 & 0.048 & 0.048 & 0.048 & 0.048 & 0.048 & 0.048 & 0.048 \\
\hline Conc. at ERDF Boundary $(C 3)(\mathrm{mg} / \mathrm{L})$ & 9.20E-08 & 2.29E-07 & $1.70 E-05$ & $1.90 E-02$ & $1.52 E-18$ & 4.81E-03 & $1.44 E-02$ & 7.70E-01 & $0.18 E-01$ \\
\hline Radionuclide Conc. (C3) (pCin) & $4.10 E+02$ & $1.61 E-01$ & $2.88 E+02$ & $1.35 E+01$ & $1.46 E-06$ & & & & \\
\hline Source Depletion Time w/o liner (yr) & $5.63 E+05$ & $1.62 E+04$ & $1.47 E+03$ & $5.72 E+08$ & $2.25 E+02$ & $1.49 E+08$ & $6.69 E+07$ & $2.02 E+04$ & $1.36 E+03$ \\
\hline Source Deplotion Time-t(op) (yr) & $5.63 E+05$ & $1.62 E+04$ & $1.44 E+03$ & $5.72 E+08$ & $1.95 E+02$ & $1.49 E+06$ & $6.69 E+07$ & $2.01 E+04$ & $1.33 E+03$ \\
\hline Source Deplotion Timo-tlop) (vr) & $6.63 E+05$ & $1.62 E+04$ & $1.44 E+03$ & $6.72 E+08$ & $1.95 E+02$ & $1.49 E+06$ & $6.69 E+07$ & $2.01 E+04$ & $1.33 E+03$ \\
\hline At ERDF Boundary & & & & & & & & & \\
\hline Travel Time (vr) & 653 & 32.610 & 653 & 553 & 653 & 653 & 553 & 553 & 563 \\
\hline incrementel Cancer Rlak (ICR) & 8.20E-08 & $7.73 E-07$ & $8.36 E-00$ & $8.36 E-06$ & $1.75 E-16$ & & & & \\
\hline Hazard Quotiont (HO) & & & & & & $8.18 E-01$ & $1.88 E-01$ & $7.70 E-01$ & $6.16 E-01$ \\
\hline ICA at Timo $<100$ Yeare & $0.00 E+\infty$ & $0.00 E+\infty$ & $0.00 E+\infty$ & $0.00 E+\infty 0$ & $0.00 E+\infty$ & & & & \\
\hline ICA at $100<\pi m 0<1.000$ Yeare & 8.20E-08 & $0.00 E+\infty 0$ & 8.36E-06 & $8.36 E-06$ & $1.75 E-15$ & & & & \\
\hline ICR at $1.000<\pi m e<10.000$ Yeare & 8.20E-06 & $0.00 E+\infty$ & 8.36E-06 & 8.36E-06 & $0.00 E+\infty$ & & & & \\
\hline HO at $\pi m e<100$ Yeare & & & & & & $0.00 E+\infty 0$ & $0.00 E+\infty$ & $0.00 E+\infty$ & $0.00 E+\infty$ \\
\hline HQ at $100<\pi m e<1.000$ Yeare & & & & & & 8.18E-01 & $1.88 E-01$ & $7.70 E-01$ & 6.16E-01 \\
\hline HO at $1.000<\pi m o<10.000$ Yeare & & & & & & 8.19E-01 & $1.88 E-01$ & 3.70E-01 & 5.16E-01 \\
\hline
\end{tabular}


Table A-18. Results for Altematives 9 and 10 under Hypothetical Wetter Climate Condition (Accounting for Leachate Limits).

\begin{tabular}{|c|c|c|c|c|c|c|c|}
\hline Paremator & Solentum & Bata-BHC & Chlorotorm & 1.2-Dichlorosthono & Xylonee & & \\
\hline Sollnwater Partition (ma/L) & $3.95 E+02$ & $2.66 E-03$ & $1.29 E+\infty$ & $1.41 E+01$ & $1.29 E+01$ & & \\
\hline Source Conc. $(\mathrm{CO})(\mathrm{mo} / \mathrm{h})$ & 8.40E-01 & $2.66 E-03$ & $1.29 E+\infty 0$ & $1.41 E+01$ & $1.29 E+01$ & & \\
\hline Lher Roterdation & $1.00 E+\infty$ & 9.77E + 01 & $2.13 E+\infty$ & $2.43 E+\infty$ & $2.90 E+\infty 0$ & & \\
\hline Liner Traval Thmo (TI) ivt & $8.06 E+01$ & $4.97 E+03$ & $1.38 \varepsilon+02$ & $1.53 E+02$ & $1.77 E+02$ & & \\
\hline Conc. Bonosth Tronch $(\mathrm{C} 1)(\mathrm{mg} / \mathrm{L})$ & 8.40E-01 & $1.89 E-03$ & $9.03 E-05$ & 3.44E-04 & $6.15 E-0.5$ & & \\
\hline Vadoes Travel Threa (T2) (vr) & $4.71 E+02$ & $4.20 E+04$ & $9.59 E+02$ & $1.09 E+03$ & $1.29 E+03$ & & \\
\hline Vedose Zono Difution (DIL2) & $1.00 E+\infty$ & $1.00 E+\infty$ & $1.00 E+\infty$ & $1.00 E+\infty$ & $1.00 E+\infty$ & & \\
\hline Conc. at Water Table (C2) Imans) & 8.4OE-OR & $1.02 E-04$ & $1.23 E-33$ & $6.10<-37$ & $8.89 E-44$ & & \\
\hline Set. Trevel Timo (T3) (vr) & $7.83 E-01$ & $1.29 E+01$ & $9.25 E-01$ & $9.62 E-01$ & $1.02 E+\infty$ & & \\
\hline Soturnted Zone Diution (DIL3) & 0.048 & 0.048 & 0.048 & 0.048 & 0.048 & & \\
\hline Conc. at ERDF Boundary (C3) (mo/c) & 4.04E-02 & $4.92 E-06$ & $5.54 E-35$ & $2.75 E-38$ & $4.44 E-45$ & & \\
\hline Radionuclide Conc. (C3) (pCVI) & & & & & & & \\
\hline Source Depletion Thme w/o flner (vil & $1.06 E+05$ & $2.34 E+04$ & $4.87 E+02$ & $6.69 E+02$ & $6.81 E+02$ & & \\
\hline Source Doplotion Timo-tlop) (vil & $1.06 E+05$ & $2.34 E+04$ & $4.67 E+02$ & $5.39 E+02$ & $6.61 E+02$ & & \\
\hline Source Depletion Time-t(op) (vr) & $1.06 E+05$ & $2.34 E+04$ & $4.67 E+02$ & $6.39 E+02$ & $6.61 E+02$ & & \\
\hline At ERDF Boundary & & & & & & & \\
\hline Travel Timo Irr) & 553 & 47036 & 1008 & & & Totel KCA & Max. Ha \\
\hline & & & & 1.242 & 1.467 & & \\
\hline Incromentel Concer Plak (ICP) & & $1.08 E-07$ & $2.05 E-38$ & & & $3 E-05$ & \\
\hline Hezard Quotiont (MO) & $5.26 E-01$ & & 9.87E-34 & $1.92 E-37$ & $1.46 E-48$ & & BE-01 \\
\hline ICR at Time < 100 Yesm & & $0.00 E+\infty$ & $0.00 E+\infty$ & & & $O E+\infty$ & \\
\hline ICR at $100<\pi m e<1,000$ Yeare & & $0.00 E+\infty$ & $0.00 E+\infty$ & & & 2E-0S & \\
\hline ICR at $1.000<$ Time $<10.000$ Years & & $0.00 E+\infty$ & $2.05 E-38$ & & & 2E-05 & \\
\hline HO at Thme $<100$ Yeare & $0.00 E+\infty$ & & $0.00 E+\infty$ & $0.00 E+\infty$ & $0.00 E+\infty$ & & $O E+\infty$ \\
\hline Ha at $100<\pi m e<1.000$ Yeare & $5.26 E-01$ & & $0.00 E+\infty$ & $0.00 E+\infty$ & $0.00 E+\infty$ & & 8E-01 \\
\hline HO at $1.000<\pi m e<10.000$ Yeare & $5.26 E-01$ & & $9.97 E-34$ & $1.92 E-37$ & $1.46 E-46$ & & 8E-01 \\
\hline
\end{tabular}


DOE/RL-93-99, Rev. 0

\section{APPENDIX B}

\section{HELP MODELING RESULTS}

\section{REFERENCE}

Skelly, W.A., 1990, Hanford Site-Specific Climate Data Input Files for Use with the Help Model Software, WHC-SD-EN-CSWD-028, Westinghouse Hanford Company, Richland, Washington. 
DOE/RL-93-99, Rev. 0

CONTENTS

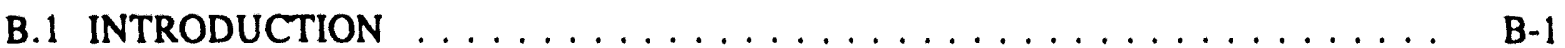

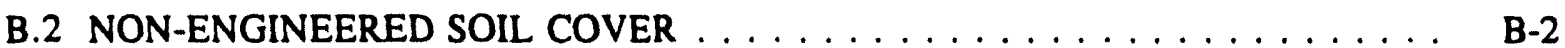

B.3 LOW-INFILTRATION SOIL BARRIER $\ldots \ldots \ldots \ldots \ldots \ldots \ldots \ldots$

B.4 MODIFIED HANFORD BARRIER $\ldots \ldots \ldots \ldots \ldots \ldots \ldots \ldots$

B.5 HANFORD BARRIER $\ldots \ldots \ldots \ldots \ldots \ldots \ldots \ldots \ldots \ldots \ldots$

B.6 SINGLE COMPOSITE LINER $\ldots \ldots \ldots \ldots \ldots \ldots \ldots \ldots \ldots \ldots$

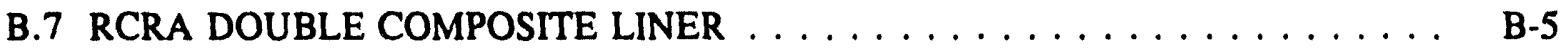

B.8 SUMMARY AND CONCLUSIONS $\ldots \ldots \ldots \ldots \ldots \ldots \ldots \ldots \ldots$

TABLES:

B-1. Parameters for Low-Infiltration Soil Barrier . . . . . . . . . . . . . . . . . . B B-8

B-2. Parameters for Modified Hanford Barrier . . . . . . . . . . . . . . . . . . B-9

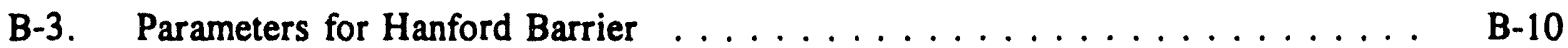

B-4. Parameters for Single Composite Liner . . . . . . . . . . . . . . . . B-11

B-5. Parameters for RCRA Subtitle-C Double Composite Liner . . . . . . . . . . . B-12 


\section{B.1 INTRODUCTION}

Hydrologic modeling was conducted to predict the performance of the barriers and liners considered for use at the ERDF. Four barriers, including the non-engineered soil cover, the low-infiltration soil barrier, the modified Hanford barrier, and the Hanford Barrier, were simulated to determine representative infiltration rates to use in the fate and transport modeling (Appendix A). Two liners, the single composite liner and the RCRA double composite liner, were simulated to determine the rate of leakage through the liners.

HELP Model. The Hydrologic Evaluation of Landfill Performance (HELP) computer model was developed by the U.S. Army Corps of Engineers, Hydraulic Engineering Center, under contract to the U.S. Environmental Protection Agency. The model was originally developed to provide an easy-to-use tool for the comparison of alternative landfill designs in meeting the requirements of RCRA compliance standards for the disposal of hazardous waste. Use of the model has grown considerably in recent years, and it provides a convenient comparative evaluation of the hydraulic performance of barrier and liner technologies for the ERDF.

The HELP model is a sophisticated, daily average water talance that considers a wide variety of meteorological, soils, and geometric parameters, and simulates the hydraulic performance of landfill liners, waste layers, and cover systems under a variety of hydrologic conditions. The HELP model was developed to be a comparative tool for the selection of design approaches that meet RCRA regulatory criteria.

The model was designed to support rapid, detailed, and accurate comparison of landfill designs. To accomplish this goal, the model contains a series of 5-year default data sets for climatic conditions across the United States, and default soils and synthetic component parameters. In additicn, the model allows use of site-specific climate, soils and design data, and supports stochastic generation of climatic parameters. Several sub-models simulate the following processes: 1) the growth of grass vegetation on the surface of landfill covers, 2) the change in the form of precipitation from rain to snow, and the melting of snow, and 3) the unsaturated routing of infiltration through the layers of the surface barrier or the liner system.

Approach. Version 2.05 of the HELP model is used to simulate the performance of four barrier and two liner technologies for the ERDF. Each of the systems is initially simulated using the existing 10-year Hanford Site-specific climatic data set. This data set is used in consecutive 10-year simulations until the system equilibrated or until 120 years of performance were simulated. At the end of each 10-year period, the ending moisture content for each layer is used as the initial moisture content of that layer for the next 10-year simulation. Equilibrium conditions are assumed when the moisture contents of the layers stabilized or when the percolation through the system approached a constant value.

The existing 10-year Hanford Site-specific climate data set was developed for the HELP model by Westinghouse Hanford Company (WHC) from Hanford Meteorological Station (HMS) data, collected between January 1, 1979 and December 31, 1988 (Skelly 1990). This 10-year record provides a reasonable yet conservative representation of historical precipitation for the site. A statistical analysis of the precipitation data, and presentation of all other meteorological and climatic data for use in supporting HELP modeling on the Hanford Site is contained in Skelly (1990). 
The HELP model soil parameters for each of the barrier and cover systems (except the non-engineered soil cover) are summarized in Tables B-1 through B-5. The non-engineered soil cover is discussed in section B.2. The HELP model output files for the final simulation of each system using Hanford, Washington climatic data are presented in Attachments B-1 through B-6. Climatic data for Hanford, Washington used in the simulations were provided by Skelly (1990).

Sensitivity of the barrier and liner technologies being considered for the ERDF to changes in climatic conditions is simulated by using a wetter climatic data set. This second scenario assumes a change in climate over time, and uses the 5-year default HELP climatic data for Spokane, Washington. The Spokane climate is significantly wetter than the current Hanford climate, averaging $39.73 \mathrm{~cm}$ (15.64 in.) of rainfall, compared with $17.98 \mathrm{~cm}$ (7.08 in.) for the Hanford Site. In addition, average monthly temperatures are milder in Spokane.

For all of the scenarios of barrier systems, an evaporative zone depth of $91.5 \mathrm{~cm} \mathrm{(36}$ in.) is used, with a maximum leaf area index of 1.6 , representing a poor grass cover. These values are considered typical for grass existing without maintenance under current Hanford climate conditions, and are not modified under future climate scenarios, although a fair grass cover would likely exist under wetter, milder conditions.

The parameters describing the layers of the barrier and liner systems are developed to provide comparable results using site and layer-component specific data that are discussed in detail in the sections below. However, several generalizations can be made regarding the relative importance of parameters with respect to model performance. Based on sensitivity analyses conducted by the model's authors during development, and on experience using the model in arid climates, the most important parameters affecting model results are the saturated hydraulic conductivity of each layer, the depth of the rooting zone, and the maximum leaf area index of the vegetation growing on the surface of the barriers. The vegetation can be very effective at enhancing evapotranspiration, and limiting the amount of water available for deep infiltration. The hydraulic conductivity of the soils layers limits the rate at which infiltration migrates through the landfill components. Finally, the initial moisture content, the porosity, and the field capacity of each layer determine how much storage and free drainage may occur from each layer. The best estimates available for each of these parameters were used in simulating the barrier and liner technologies for the ERDF. The predicted hydraulic performance of each of the barrier and liner systems is discussed in the sections below. HELP model input files and output summaries of the parameters for each barrier and liner system are attached at the end of this appendix.

\section{B.2 NON-ENGINEERED SOIL COVER}

The non-engineered soil cover is simulated as a single vertical drainage layer. The barrier is composed of native soil, $460 \mathrm{~cm}(15 \mathrm{ft})$ thick, placed as an uncontrolled (uncompacted) fill, with a resulting hydraulic conductivity of $1 \times 10^{-3} \mathrm{~cm} / \mathrm{sec}$. The initial moisture content of the fill was selected as $.062(6.2 \%)$, equal to the field capacity of the soil.

Under current Hanford Site climatic conditions, the moisture content of the single barrier layer stabilized at 0.0635 or $6.4 \%$ moisture within 80 years, and the average annual percolation through the layer stabilized at $0.035 \mathrm{~cm} / \mathrm{yr}(0.014 \mathrm{in} . / \mathrm{yr})$. 
The non-engineered soil cover is also simulated using the present Spokane climate data, representing a future change in climate to wetter conditions. This scenario is simulated for only a 20 year period, at which time the moisture content approaches equilibrium. Percolation through the cover at the end of 20 years exceeded $8.6 \mathrm{~cm} / \mathrm{yr}(3.4 \mathrm{in} . / \mathrm{yr})$.

\section{B.3 LOW-INFILTRATION SOIL BARRIER}

The low-infiltration soil barrier is simulated as a three layer, vertical drainage system, with a total thickness of $460 \mathrm{~cm}$ ( $15 \mathrm{ft}$ ) from the surface to the top of the interim soil cover. The top layer is defined as a $30-\mathrm{cm}$ thick uncompacted silt and gravel admixture with a hydraulic conductivity of $1 \times 10^{-3} \mathrm{~cm} / \mathrm{sec}$. The second layer was defined as a $30-\mathrm{cm}$ thick compacted silt with a hydraulic conductivity of $1.6 \times 10^{-6} \mathrm{~cm} / \mathrm{sec}$. The bottom layer was defined as a $400-\mathrm{cm}$ (13-ft) thick uncontrolled (uncompacted) fill using native soil. Initial moisture contents were set at field capacity for each layer. Layer parameters are summarized in Table B-1.

The low-infiltration soil barrier is simulated under current Hanford Site climatic conditions for a 110 year period. The percolation from the lowest layer was $0.00025 \mathrm{~cm} / \mathrm{yr}$ $(0.0001 \mathrm{in} . / \mathrm{yr})$ at 100 years. The moisture content of this layer was continuing to decrease as the barrier system dewatered, and at 100 years was mid-way between the field capacity and the wilting point defined for this soil type.

Under present day Spokane climatic conditions, percolation from the low-infiltration soil barrier after a 20 year simulation was $4.75 \mathrm{~cm} / \mathrm{yr}(1.87 \mathrm{in} . / \mathrm{yr})$. The moisture content of the upper layer decreased while the moisture content of the lower layers increased from initial conditions during the simulation. Stable results were observed after 20 years.

\section{B.4 MODIFIED HANFORD BARRIER}

The modified Hanford barrier is a multi-layered barrier system with a total thickness of $470 \mathrm{~cm}(15.4 \mathrm{ft})$ from the surface to the top of interim soil cover. A brief summary of the layers is as follows:

- $\quad$ Surface layer - uncompacted 50-cm (20-in.) thick silt and gravel admix

- $\quad$ Second layer - compacted 50-cm (20-in.) thick silt

- Third layer - 300-cm (118-in.) thick uncontrolled (uncompacted) fill

- Fourth layer - $15-\mathrm{cm}(6-$-in.) thick sand filter

- $\quad$ Fifth layer $-15-\mathrm{cm}(6-$ in.) thick gravel filter

- $\quad$ Sixth layer - 15-cm (6-in.) thick gravel drainage layer

- Seventh layer - $15-\mathrm{cm}(6-i n$.$) thick asphalt with spray-applied top coat$ 
- Eighth layer - 10-cm (4-in.) thick base course

The defining layer parameters are summarized in Table B-2.

Under the current Hanford Site climate, the estimated average annual percolation through the modified Hanford barrier is $0.0017 \mathrm{~cm}(0.0007$ in.), and approaches a stable value at 120 years of simulation.

The estimated average annual percolation through the modified Hanford barrier under the present Spokane climate is $0.31 \mathrm{~cm}(0.12 \mathrm{in}$.) and has reached a stable value at the end of 20 years.

\section{B.5 HANFORD BARRIER}

The Hanford Barrier is a multi-layered barrier system with a total thickness of $450 \mathrm{~cm}$ $(14.75 \mathrm{ft}$ ) from the surface to the top of interim soil cover. A brief summary of the layers is as follows:

$$
\begin{aligned}
& \text { - } \quad \text { Surface layer - } 100-\mathrm{cm} \text { (39-in.) thick silt and gravel admix } \\
& \text { - top 50-cm (19-in.) uncompacted; bottom 50-cm (19- } \\
& \text { in.) compacted. } \\
& \text { - Second layer - compacted, 100-cm (39-in.) thick silt } \\
& \text { - Third layer }-15-\mathrm{cm}(6-\text { in.) thick sand filter } \\
& \text { - Fourth layer - 30-cm (12-in.) thick gravel filter } \\
& \text { - Fifth layer - } 150-\mathrm{cm}(60 \text {-in.) thick crushed basalt } \\
& \text { - Sixth layer - 30-cm (12-in.) thick drainage rock layer } \\
& \text { - Seventh layer - } 15-\mathrm{cm}(6-\text {-in.) thick asphalt with spray applied top coat } \\
& \text { - } \quad \text { Eighth layer }-10-\mathrm{cm}(4-\text { in.) thick base course }
\end{aligned}
$$

The defining layer parameters are summarized in Table B-3. To accurately reflect the hydraulic properties of the top layer, the lower half of this layer was compacted and assigned the same properties as layer 2. Therefore, the thicknesses of the first two layers shown in attachment B-4 are 50-cm (19-in.) and 150-cm (59-in.), respectively.

Under the current Hanford Site climate, the estimated average annual percolation through the Hanford Barrier is zero; at no time during the 110 year simulation period did any infiltration percolate through the Hanford Barrier system. Under arid climatic conditions, the HELP Model does not adequately model the capillary break effect of the crushed basalt layer of the Hanford Barrier system. Water slowly accumulates (at a decreasing rate) in the crushed basalt layer as the layers above dewater, rather than remaining in the overlying silt layer. However, the water accumulating in the basalt does not migrate downward, and the results are 
unaffected. No water drains into the lateral drainage layers during the 110 year simulation. The water content in the crushed basalt rises at a decreasing rate from just over 2 percent at the beginning of the simulation to just under 7 percent at 110 years.

The behavior of the same layer under the Spokane climatic conditions is normal. Water accumulates more rapidly in the basalt layer and flows into the lateral drainage layer below, where it migrates laterally to the collection system and downward into the barrier layer. The similarity in behavior between the Hanford Barrier and the modified Hanford barrier under Spokane climatic conditions suggests that percolation through the Hanford Barrier is expected to be similar to percolation through the modified Hanford barrier.

The estimated average annual percolation through the Hanford Barrier under the present Spokane climate is $0.32 \mathrm{~cm}(0.12 \mathrm{in}$.$) , and is approaching a stable value at the end of 20$ years.

\section{B.6 SINGLE COMPOSITE LINER}

The single composite liner is a multi-media, multi-component system designed to limit infiltration and collect any leachate generated during the construction and filling phases of facility operation. The total thickness of the liner system is $120 \mathrm{~cm} \mathrm{(4} \mathrm{ft)} \mathrm{and} \mathrm{is} \mathrm{comprised} \mathrm{of} \mathrm{a}$ $30-\mathrm{cm}(12$-in.) thick compacted clay admix, overlain by a geocomposite liner system and a $90-\mathrm{cm}$ (36-in.) thick operations layer. The geocomposite is made up of a primary 60-mil high density polyethylene (HDPE) geomembrane liner, overlain by a primary drainage gravel sandwiched between layers of geotextile, which function as a bottom cushion and a top separator from the operations layer.

The HELP model formulation uses three layers to simulate the performance of this liner system: a vertical drainage layer represents the operations layer, a lateral drainage layer represents the geotextile/drainage gravel component, and a geomembrane/clay liner represents the barrier. Specific soil properties are summarized in Table B-4. The hydraulic conductivity of the barrier layer is $1 \times 10^{-7} \mathrm{~cm} / \mathrm{sec}$; the leakance factor for the HDPE liner is $1 \times 10^{-4}$. The HELP model simulations assumed that precipitation falls directly onto the operations layer of the liner system, and do not attempt to simulate the properties of waste or interim cover layers.

The results indicate that no infiltration passes through the single composite liner system during a 50 year simulation period. During the simulation period, all lateral drainage flow in the second layer is assumed to flow to a collection sump where it is removed by submersible pumps.

\section{B.7 RCRA DOUBLE COMPOSITE LINER}

The RCRA Subtitle-C double composite liner system is a more complex, redundant version of the single composite liner system described in the previous section, with a total thickness of $240 \mathrm{~cm}(8 \mathrm{ft})$. This liner system has a base compacted clay admix layer $90 \mathrm{~cm}$ (36 in.) thick that is overlain by a secondary geocomposite liner system. This geocomposite is identical to the geocomposite described in the pervious section; the secondary drainage gravel component is $30 \mathrm{~cm}$ (12 in.) thick. Over the secondary geocomposite is a primary 
geocomposite liner system. Its components are identical to the secondary geocomposite system. The primary HDPE liner is placed directly over the secondary geotextile separator layer. The primary drainage gravel layer is also $30 \mathrm{~cm}$ (12 in.) in thickness. The $90 \mathrm{~cm}(36 \mathrm{in}$.) operations layer is placed directly on the primary separator geotextile.

The HELP model formulation uses five layers to simulate the performance of this liner system: a vertical drainage layer represents the operations layer, a lateral drainage layer represents the primary geotextile/drainage gravel component, a geomembrane/clay liner represents the primary barrier, a lateral drainage layer represents the secondary geotextile/drainage gravel component, and a geomembrane/clay liner represents the secondary barrier. Specific soil properties are summarized in Table B-5.

The hydraulic conductivity of the secondary barrier layer is assumed to be $1 \times 10^{-7}$ $\mathrm{cm} / \mathrm{sec}$. However, to simulate the performance of the secondary liner system requires modification of the parameters of the primary liner system. (The performance of the primary barrier layer alone is simulated in the previous section.) Therefore, the hydraulic conductivity of the primary barrier layer is assumed to be $1 \times 10^{-2} \mathrm{~cm} / \mathrm{sec}$, an artificially high value. The leakance factor for the primary HDPE liner is assumed to be $1 \times 10^{-4}$. This combination of parameters provides an estimate of a leaky primary liner, allowing evaluation of the performance of the secondary liner system. The HELP model simulations assumed that precipitation falls directly onto the operations layer of the liner system, and do not attempt to simulate the properties of waste or interim cover layers.

The results indicate that no infiltration passes through the double composite liner system during a 50 year simulation period. During the simulation period, all lateral drainage flow in the second layer is assumed to flow to a collection sump where it is removed by submersible pumps.

\section{B.8 SUMMARY AND CONCLUSIONS}

\section{following: \\ Examination of the HELP model output for the ERDF barrier systems indicates the}

- Under current Hanford Site climate conditions, the average percolation rate for the non-engineered soil cover was $0.035 \mathrm{~cm} / \mathrm{yr}(.014 \mathrm{in} . / \mathrm{yr})$. The percolation rates for the remaining cover systems was below 0.002 $\mathrm{cm} / \mathrm{yr}(.0008 \mathrm{in} . / \mathrm{yr})$ at the end of 110 years.

- Under wetter climatic conditions, using present day Spokane climate data, the non-engineered soil cover and the low-infiltration soil barrier systems allowed significantly more infiltration (between 5 and $8 \mathrm{~cm} / \mathrm{yr}$ [ 2 to 3 in./yr]) than the modified Hanford and Hanford Barrier systems. The modified Hanford and Hanford Barriers perform better because lateral drainage occurs above the asphalt layers, thereby reducing the amount of water infiltrating through the bottom of the barriers.

- Under wetter climatic conditions, the Modified Hanford and Hanford Barriers systems have similar annual average infiltration rates on the 
order of $0.32 \mathrm{~cm} / \mathrm{yr}(0.12 \mathrm{in} . / \mathrm{yr})$, which is equivalent to the saturated hydraulic conductivity of the barrier layer of $1 \times 10^{-8} \mathrm{~cm} / \mathrm{sec}$.

- Under the arid conditions of the Hanford Site, the HELP model does not adequately model the performance of the crushed basalt layer (layer 5) of the Hanford Barrier. Under the conditions provided by the wetter Spokane climate data, the model appears to have adequately simulated the performance of the crushed basalt.

Examination of the HELP model output for the liner systems indicates the following:

- The two composite liner systems exhibit essentially identical performance. As long as the geomembrane/clay liner components remain intact, no percolation flows through the liner system. 
DOE/RL-93-99, Rev. 0

Table B-1. HELP Parameters for Low-Infiltration Soil Barrier.

\begin{tabular}{|c|c|c|c|c|c|c|c|c|}
\hline \multirow{2}{*}{ Layer } & \multirow{2}{*}{$\begin{array}{c}\text { Hydraulic } \\
\text { Conductivity } \\
\text { (cm/sec) }\end{array}$} & \multirow{2}{*}{$\begin{array}{l}\text { Effective } \\
\text { Porosity } \\
\end{array}$} & \multirow{2}{*}{$\begin{array}{c}\text { Field } \\
\text { Capacity } \\
\end{array}$} & \multirow{2}{*}{$\begin{array}{l}\text { Wilting } \\
\text { Point }\end{array}$} & \multicolumn{2}{|c|}{ Moisture Content } & \multicolumn{2}{|c|}{ Percolation $(\mathrm{cm} / \mathrm{yr}$ ) } \\
\hline & & & & & Initial & Final & Initial & Final \\
\hline 1 & $1 \times 10^{3}$ & .4603 & .2272 & .0632 & .2272 & .1173 & NA & $\mathrm{NA}$ \\
\hline$\because$ & $1.6 \times 10^{6}$ & .3702 & .2109 & .0500 & .2109 & .0500 & NA & NA \\
\hline 3 & $1 \times 10^{3}$ & .4370 & .0620 & .0240 & .0620 & .0394 & .0200 & .00025 \\
\hline
\end{tabular}


DOE/RL-93-99, Rev. 0

Table B-2. HELP Parameters for Modified Hanford Barrier.

\begin{tabular}{|c|c|c|c|c|c|c|c|c|}
\hline \multirow{2}{*}{ Leyer } & \multirow{2}{*}{$\begin{array}{c}\text { Hydraulic } \\
\text { Conductivity } \\
(\mathrm{cm} / \mathrm{sec})\end{array}$} & \multirow{2}{*}{$\begin{array}{l}\text { Effective } \\
\text { Porosity }\end{array}$} & \multirow{2}{*}{$\begin{array}{c}\text { Field } \\
\text { Capacity } \\
\end{array}$} & \multirow{2}{*}{$\begin{array}{c}\text { Wilting } \\
\text { Point }\end{array}$} & \multicolumn{2}{|c|}{ Moisture Content } & \multicolumn{2}{|c|}{ Percolation $(\mathrm{cm} / \mathrm{yr})$} \\
\hline & & & & & Initial & Final & Initial & Final \\
\hline 1 & $1 \times 10^{3}$ & .4603 & .2272 & .0632 & .2272 & .0944 & NA & NA \\
\hline 2 & $1.6 \times 10^{\circ}$ & .3720 & .2109 & .0500 & .2109 & .0510 & NA & NA \\
\hline 3 & $1.0 \times 10^{3}$ & .4370 & .0620 & .0240 & .0400 & .0528 & NA & NA \\
\hline 4 & $1.6 \times 10^{4}$ & .3509 & .0705 & .0326 & .0705 & .0694 & NA & NA \\
\hline 5 & $5 \times 10^{4}$ & .3178 & .0391 & .0200 & .0391 & .0347 & NA & NA \\
\hline 6 & $1 \times 10^{\circ}$ & .4170 & .0454 & .0200 & .0454 & .0454 & NA & NA \\
\hline 7 & $1 \times 10^{0}$ & .0220 & .0210 & .0200 & .0220 & .0220 & .1400 & .0015 \\
\hline 8 & $1 \times 10^{2}$ & .4370 & .0620 & .0240 & .0620 & .0300 & NA & NA \\
\hline
\end{tabular}


DOE/RL-93-99, Rev. 0

Table B-3. HELP Parameters for Hanford Barrier.

\begin{tabular}{|c|c|c|c|c|c|c|c|c|}
\hline \multirow{2}{*}{ Layer } & \multirow{2}{*}{$\begin{array}{c}\text { Hydraulic } \\
\text { Conductivity } \\
(\mathrm{cm} / \mathrm{sec})\end{array}$} & \multirow{2}{*}{$\begin{array}{l}\text { Effective } \\
\text { Porosity }\end{array}$} & \multirow{2}{*}{$\begin{array}{c}\text { Field } \\
\text { Capacity } \\
\end{array}$} & \multirow{2}{*}{$\begin{array}{c}\text { Wilting } \\
\text { Point }\end{array}$} & \multicolumn{2}{|c|}{ Moisture Content } & \multicolumn{2}{|c|}{ Percolation $(\mathrm{cm} / \mathrm{yr})$} \\
\hline & & & & & Initial & Final & Initial & Final \\
\hline 1 & $1 \times 10^{3}$ & .4603 & .2272 & .0632 & .2272 & .0954 & NA & NA \\
\hline 2 & $1.6 \times 10^{6}$ & .3702 & .2109 & .0500 & .2109 & .0543 & NA & NA \\
\hline 3 & $1.6 \times 10^{-4}$ & .3509 & .0705 & .0326 & .0705 & .0706 & NA & NA \\
\hline 4 & $5 \times 10^{4}$ & .3178 & .0391 & .0200 & .0391 & .0362 & NA & NA \\
\hline 5 & $1 \times 10^{-1}$ & .4170 & .0210 & .0200 & .0210 & .0699 & NA & $\mathrm{NA}$ \\
\hline 6 & $1 \times 10^{\circ}$ & .4170 & .0454 & .0200 & .0454 & .0454 & $\mathrm{NA}$ & $\mathrm{NA}$ \\
\hline 7 & $1 \times 10^{4}$ & .0220 & .0210 & .0200 & .0210 & .0210 & 0 & 0 \\
\hline 8 & $1 \times 10^{2}$ & .4170 & .0450 & .0200 & .0450 & .0259 & NA & NA \\
\hline
\end{tabular}


DOE/RL-93-99, Rev. 0

Table B-4. HELP Parameters for Single Composite Liner.

\begin{tabular}{|c|c|c|c|c|c|c|c|c|}
\hline \multirow{2}{*}{ Layer } & $\begin{array}{c}\text { Hydraulic } \\
\text { Conductivity } \\
(\mathrm{cm} / \mathrm{sec})\end{array}$ & $\begin{array}{c}\text { Effective } \\
\text { Porosity }\end{array}$ & $\begin{array}{c}\text { Field } \\
\text { Capacity }\end{array}$ & $\begin{array}{c}\text { Wilting } \\
\text { Point }\end{array}$ & \multicolumn{2}{|c|}{ Moisture Content } & \multicolumn{2}{|c|}{ Percolation (cm/yr) } \\
\hline \hline 1 & $1 \times 10^{-4}$ & .4370 & .0622 & .0240 & .0622 & .0454 & NA & NA \\
\hline 2 & $1 \times 10^{\circ}$ & .4170 & .0454 & .0200 & .0454 & .0454 & NA & NA \\
\hline 3 & $1 \times 10^{\prime}$ & .4300 & .3660 & .2800 & .3660 & .3660 & 0 & 0 \\
\hline NA - Not applicable
\end{tabular}


DOE/RL-93-99, Rev. 0

Table B-5. HELP Parameters for RCRA Subtitle-C Double Composite Liner.

\begin{tabular}{|c|c|c|c|c|c|c|c|c|}
\hline \multirow{2}{*}{ Layer } & $\begin{array}{c}\text { Hydraulic } \\
\text { Conductivity } \\
(\mathrm{cm} / \mathrm{sec})\end{array}$ & $\begin{array}{c}\text { Effective } \\
\text { Porosity }\end{array}$ & $\begin{array}{c}\text { Field } \\
\text { Capacity }\end{array}$ & $\begin{array}{c}\text { Wilting } \\
\text { Point }\end{array}$ & \multicolumn{2}{|c|}{ Moisture Content } & \multicolumn{2}{|c|}{ Percolation (cm/yr) } \\
\hline \hline 1 & $1 \times 10^{4}$ & .4370 & .0622 & .0240 & .0622 & .0454 & NA & NA \\
\hline 2 & $1 \times 10^{2}$ & .4170 & .0454 & .0200 & .0454 & .0454 & NA & NA \\
\hline 3 & $1 \times 10^{2}$ & .4300 & .3660 & .2800 & .3660 & .3660 & NA & NA \\
\hline 4 & $1 \times 10^{2}$ & .4170 & .0454 & .0200 & .0454 & .0454 & NA & NA \\
\hline 5 & $1 \times 10^{7}$ & .4300 & .3660 & .2800 & .3660 & .3660 & 0 & 0 \\
\hline NA - Not applicable. & & & & & & & Initial & Final \\
\hline
\end{tabular}


Attachment B-1. HELP Output File for the Non-engineered Soil Cover.

SAIC/ERDF, EIS/FS/ WA 923-E412

CASE 1 - NO ENGINEERED COVER

3/10/94 YEARS 70-80 CASE1JV5.OUT

Soils Data

LAYER 1

$\begin{array}{lcc}\text { LAYER I } & \\ \text { VERTICAL PERCOLATION LAYER } \\ \text { THICKNESS } & = & 181.00 \text { INCHES } \\ \text { POROSITY } & =0.4370 \mathrm{VOL} / \mathrm{VOL} \\ \text { FIELD CAPACITY } & 0.0620 \mathrm{VOL} / \mathrm{VOL} \\ \text { WILTING POINT } & 0.0240 \mathrm{VOL} / \mathrm{VOL} \\ \text { INITIAL SOIL WATER CONTENT } & = & 0.0635 \mathrm{VOL} / \mathrm{VOL} \\ \text { SATURATED HYDRAULIC CONDUCTIVITY } & =0.001000000047 \mathrm{CM} / \mathrm{SEC}\end{array}$

GENERAL SIMULATION DATA

SCS RUNOFF CURVE NUMBER

TOTAL AREA OF COVER

$=77.00$

EVAPORATIVE ZONE DEPTH

UPPER LIMIT VEG. STORAGE

INITIAL VEG. STORAGE

$=43560$. SQ FT

$=\quad 36.00 \mathrm{INCHES}$

$=\quad 15.7320 \mathrm{INCHES}$

INITIAL SNOW WATER CONTENT $=0.0000$ INCHES

INITIAL TOTAL WATER STORAGE IN

SOIL AND WASTE LAYERS

$=\quad 11.4935 \mathrm{INCHES}$

SOIL WATER CONTENT INITIALIZED BY USER.

\section{CLIMATOLOGICAL DATA}

USER SPECIFIED RAINFALL WITH SYNTHETIC DAILY TEMPERATURES AND SOLAR RADIATION FOR YAKIMA, WASHINGTON

MAXIMUM LEAF AREA INDEX $\quad=1.60$

START OF GROWING SEASON (JULIAN DATE) $=124$

END OF GROWING SEASON (JULIAN DATE) $=276$

NORMAL MEAN MONTHLY TEMPERATURES, DEGREES FAHRENHEIT

JAN/JUL FEB/AUG MAR/SEP APR/OCT MAY/NOV JUN/DEC

$\begin{array}{llllll}28.20 & 36.10 & 41.90 & 49.20 & 57.30 & 64.50\end{array}$

$\begin{array}{llllll}70.40 & 68.60 & 60.90 & 49.90 & 38.20 & 31.50\end{array}$ 
Results

AVERAGE MONTHLY VALUES IN INCHES FOR YEARS 79 THROUGH 88 JAN/JUL FEB/AUG MAR/SEP APR/OCT MAY/NOV JUN/DEC PRECIPITATION

TOTALS

$\begin{array}{llllll}0.78 & 0.75 & 0.66 & 0.44 & 0.50 & 0.42\end{array}$

$\begin{array}{llllll}0.18 & 0.09 & 0.51 & 0.41 & 1.09 & 1.25\end{array}$

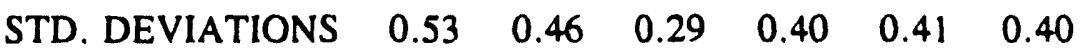

$\begin{array}{llllll}0.14 & 0.12 & 0.28 & 0.40 & 0.57 & 0.60\end{array}$

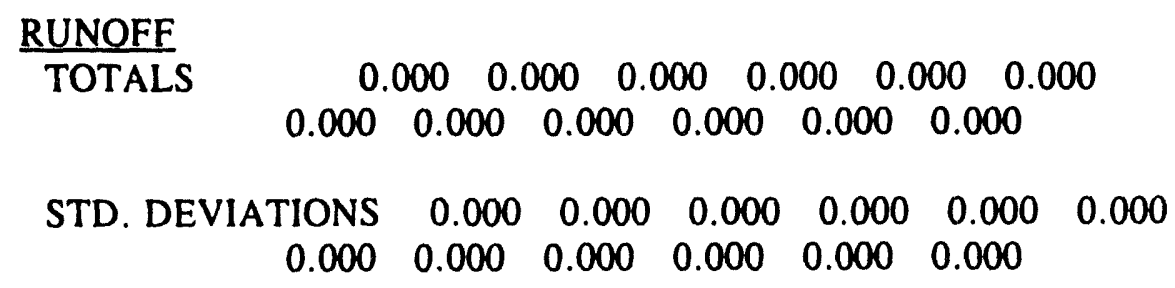

EVAPOTRANSPIRATION

$\begin{array}{lllllll}\text { TOTALS } & 0.630 & 1.060 & 0.818 & 0.487 & 0.730 & 1.257\end{array}$

$\begin{array}{llllll}0.516 & 0.084 & 0.245 & 0.249 & 0.505 & 0.489\end{array}$

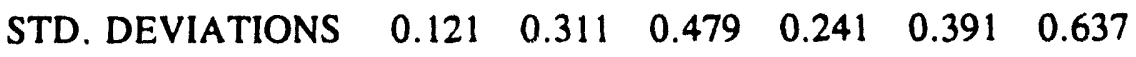

$\begin{array}{llllll}0.436 & 0.092 & 0.132 & 0.120 & 0.268 & 0.137\end{array}$

PERCOLATION FROM LAYER 1

$\begin{array}{lllllll}\text { TOTALS } & 0.0011 & 0.0010 & 0.0011 & 0.0011 & 0.0012 & 0.0012\end{array}$

$\begin{array}{lllllll}0.0012 & 0.0012 & 0.0012 & 0.0012 & 0.0012 & 0.0012\end{array}$

$\begin{array}{lllllll}\text { STD. DEVIATIONS } & 0.0004 & 0.0003 & 0.0004 & 0.0003 & 0.0004 & 0.0003\end{array}$

$\begin{array}{llllll}0.0004 & 0.0004 & 0.0003 & 0.0004 & 0.0003 & 0.0004\end{array}$

AVERAGE ANNUAL TOTALS \& (STD. DEVIATIONS) FOR YEARS 79 THROUGH 88 (INCHES) (CU.FT) PERCENT

\begin{tabular}{|c|c|}
\hline PRECIPITATION & $7.08 \quad(2.085)$ \\
\hline
\end{tabular}

$\begin{array}{llll}\text { RUNOFF } & 0.000(0.000) & 0 . & 0.00\end{array}$

$\begin{array}{llll}\text { EVAPOTRANSPIRATION } & 7.069(1.762) & 25662 . & 99.79\end{array}$

$\begin{array}{llll}\text { PERCOLATION FROM LAYER } 1 & 0.0139(0.0042) & 51 . & 0.20\end{array}$

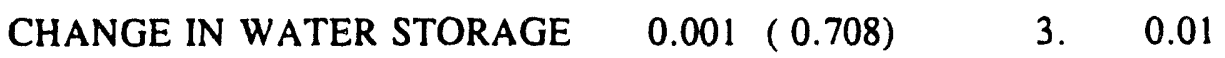


DOE/RL-93-99, Rev. 0

PEAK DAILY VALUES FOR YEARS 79 THROUGH 88

(INCHES) (CU.FT.)

$\begin{array}{lccr}\text { PRECIPITATION } & 0.93 & 3375.9 \\ \text { RUNOFF } & 0.000 & 0.0 & \\ \text { PERCOLATION FROM LAYER } & 1 & 0.0001 & 0.2 \\ \text { PER } & 0.75 & 2734.6 & \\ \text { SNOW WATER } & 0.1214 \\ \text { MAXIMUM VEG. SOIL WATER (VOL/VOL) } & 0.0238\end{array}$

FINAL WATER STORAGE AT END OF YEAR 88 LAYER (INCHES) (VOL/VOL)

$$
1 \quad 11.50 \quad 0.0635
$$

SNOW WATER $\quad 0.00$ 
Attachment B-2. HELP Output File for the Low-Infiltration Soil Barrier.

SAIC/ERDF-EIS,FS/ WA 923-E412

CASE 2B - THICK SOIL COVER, ANALYSIS "B"

3/10/94 YEARS 100-110 CAS2BJV6.OUT

Soils Data

LAYER 1

VERTICAL PERCOLATION LAYER

$\begin{array}{lcc}\text { THICKNESS } & = & 12.00 \mathrm{INCHES} \\ \text { POROSITY } & = & 0.4603 \mathrm{VOL} / \mathrm{VOL} \\ \text { FIELD CAPACITY } & = & 0.2272 \mathrm{VOL} / \mathrm{VOL} \\ \text { WILTING POINT } & = & 0.0632 \mathrm{VOL} / \mathrm{VOL}\end{array}$

INITIAL SOIL WATER CONTENT $=0.1173 \mathrm{VOL} / \mathrm{VOL}$

SATURATED HYDRAULIC CONDUCTIVITY $=0.000989999971 \mathrm{CM} / \mathrm{SEC}$

LAYER 2

THICKNESS

POROSITY

FIELD CAPACITY

WILTING POINT

INITIAL SOIL WATER CONTENT $=0.0500 \mathrm{VOL} / \mathrm{VOL}$

SATURATED HYDRAULIC CONDUCTIVITY $=0.000001600000 \mathrm{CM} / \mathrm{SEC}$
- 12 OO INCHES

$=0.3702 \mathrm{VOL} / \mathrm{VOL}$

$=0.2109 \mathrm{VOL} / \mathrm{VOL}$

$=0.0500 \mathrm{VOL} / \mathrm{VOL}$

LAYER 3

\section{THICKNESS}

POROSITY

FIELD CAPACITY

WILTING POINT

INITIAL SOIL WATER CONTENT $=0.0407 \mathrm{VOL} / \mathrm{VOL}$ SATURATED HYDRAULIC CONDUCTIVITY $=0.001000000047 \mathrm{CM} / \mathrm{SEC}$ $=\quad 157.50$ INCHES

$=0.4370 \mathrm{VOL} / \mathrm{VOL}$ $=0.0620 \mathrm{VOL} / \mathrm{VOL}$ $=0.0240 \mathrm{VOL} / \mathrm{VOL}$

\section{GENERAL SLMULATION DATA}

SCS RUNOFF CURVE NUMBER

TOTAL AREA OF COVER

EVAPORATIVE ZONE DEPTH

UPPER LIMIT VEG. STORAGE

INITIAL VEG. STORAGE

INITIAL SNOW WATER CONTENT

INITIAL TOTAL WATER STORAGE IN

$$
\begin{array}{cc}
= & 77.00 \\
= & 43560 . \text { SQ FT } \\
= & 36.00 \text { INCHES } \\
= & 15.2100 \text { INCHES } \\
= & 2.4960 \text { INCHES } \\
& =\quad 0.0000 \text { INCHES } \\
\text { IN } & \\
= & 8.4178 \text { INCHES }
\end{array}
$$


DOE/RL-93-99, Rev. 0

SOIL WATER CONTENT INITIALIZED BY USER.

\section{CLIMATOLOGICAL DATA}

USER SPECIFIED RAINFALL WITH SYNTHETIC DAILY TEMPERATURES AND SOLAR RADIATION FOR YAKIMA, WASHINGTON

MAXIMUM LEAF AREA INDEX $=1.60$
START OF GROWING SEASON (JULIAN DATE) $=124$
END OF GROWING SEASON (JULIAN DATE) $=276$

NORMAL MEAN MONTHLY TEMPERATURES, DEGREES FAHRENHEIT JAN/JUL FEB/AUG MAR/SEP APR/OCT MAY/NOV JUN/DEC

$\begin{array}{llllll}28.20 & 36.10 & 41.90 & 49.20 & 57.30 & 64.50\end{array}$

$\begin{array}{llllll}70.40 & 68.60 & 60.90 & 49.90 & 38.20 & 31.50\end{array}$

Results

AVERAGE MONTHLY VALUES IN INCHES FOR YEARS 79 THROUGH 88 JAN/JUL FEB/AUG MAR/SEP APR/OCT MAY/NOV JUN/DEC

\section{PRECIPITATION}

TOTALS

$\begin{array}{llllll}0.78 & 0.75 & 0.66 & 0.44 & 0.50 & 0.42\end{array}$

$\begin{array}{llllll}0.18 & 0.09 & 0.51 & 0.41 & 1.09 & 1.25\end{array}$

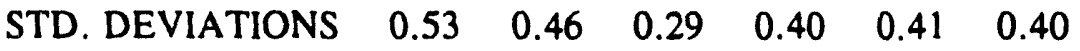
0.14
0.120 .28
$\begin{array}{lll}0.40 & 0.57 & 0.60\end{array}$

RUNOFF

$\begin{array}{llllll}0.000 & 0.000 & 0.000 & 0.000 & 0.000 & 0.000\end{array}$

$\begin{array}{llllll}0.000 & 0.000 & 0.000 & 0.000 & 0.000 & 0.000\end{array}$

$\begin{array}{lllllll}\text { STD. DEVIATIONS } & 0.000 & 0.000 & 0.000 & 0.000 & 0.000 & 0.000\end{array}$

$\begin{array}{llllll}0.000 & 0.000 & 0.000 & 0.000 & 0.000 & 0.000\end{array}$

EVAPOTRANSPIRATION

$\begin{array}{lllllll}\text { TOTALS } & 0.535 & 1.015 & 1.289 & 0.565 & 0.649 & 1.166\end{array}$

$\begin{array}{llllll}0.467 & 0.080 & 0.267 & 0.237 & 0.440 & 0.393\end{array}$

$\begin{array}{lllllll}\text { STD. DEVIATIONS } & 0.148 & 0.392 & 0.631 & 0.268 & 0.400 & 0.672\end{array}$

$\begin{array}{llllll}0.412 & 0.089 & 0.140 & 0.117 & 0.254 & 0.125\end{array}$

PERCOLATION FROM LAYER 3

$\begin{array}{llllllllllll}\text { TOTALS } & 0.0000 & 0.0000 & 0.0000 & 0.0000 & 0.0000 & 0.0000\end{array}$

$\begin{array}{lllllll}0.0000 & 0.0000 & 0.0000 & 0.0000 & 0.0000 & 0.0000\end{array}$ 

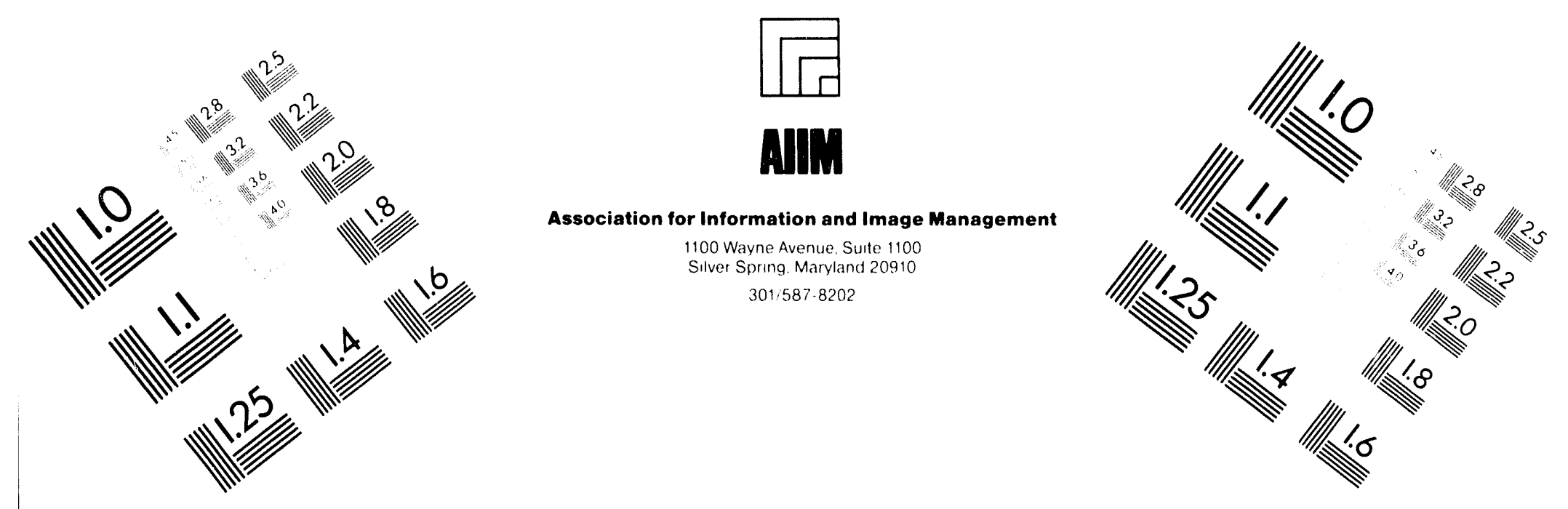

\section{Centimeter}

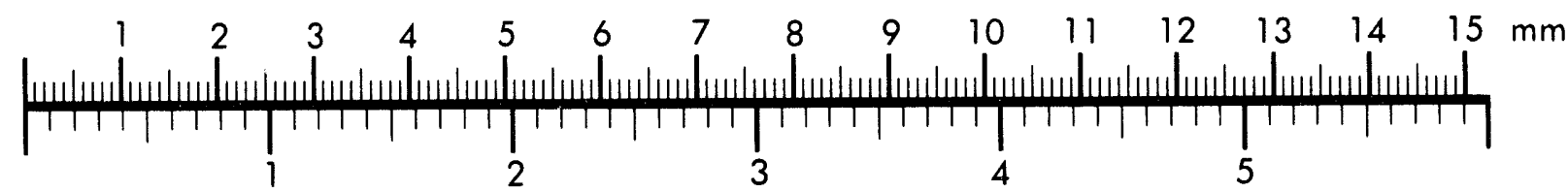
Inches
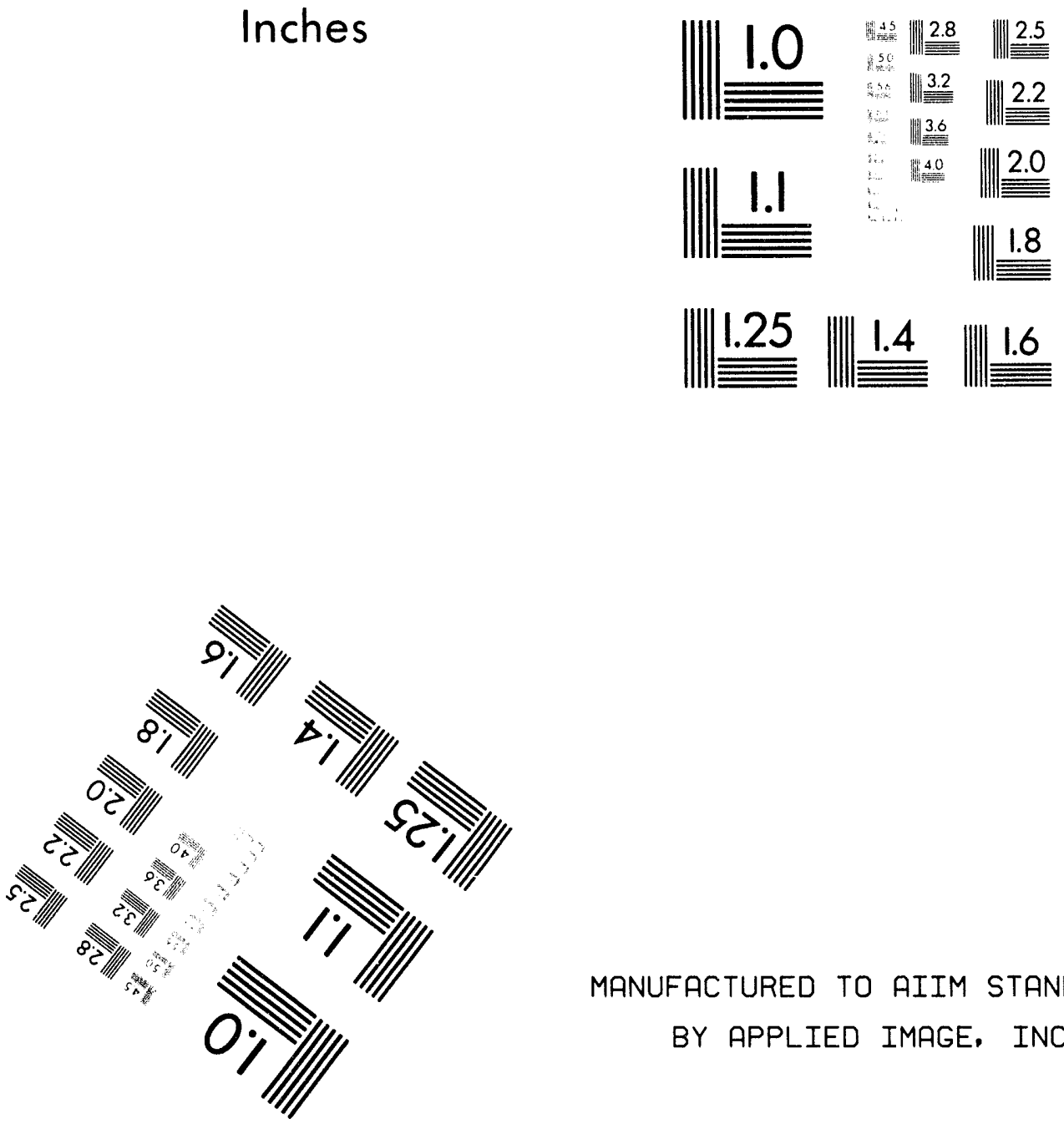

MANUFACTURED TO AIIM STANDARDS BY APPLIED IMAGE, INC.

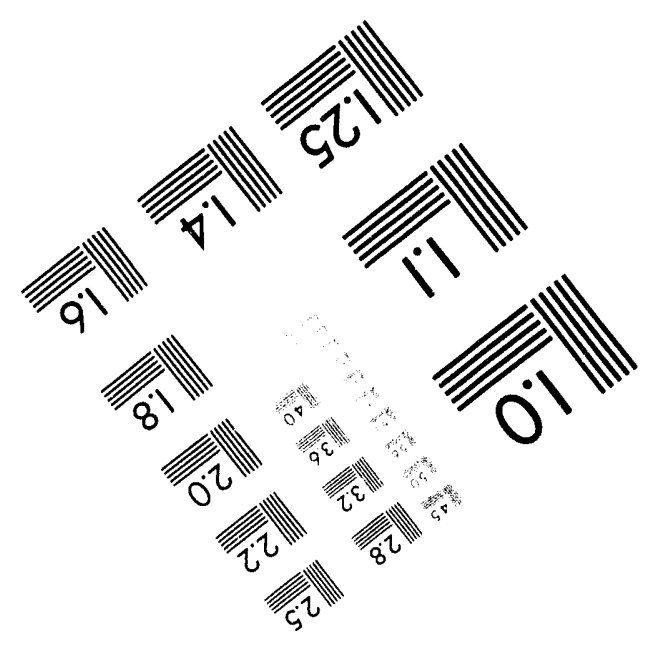



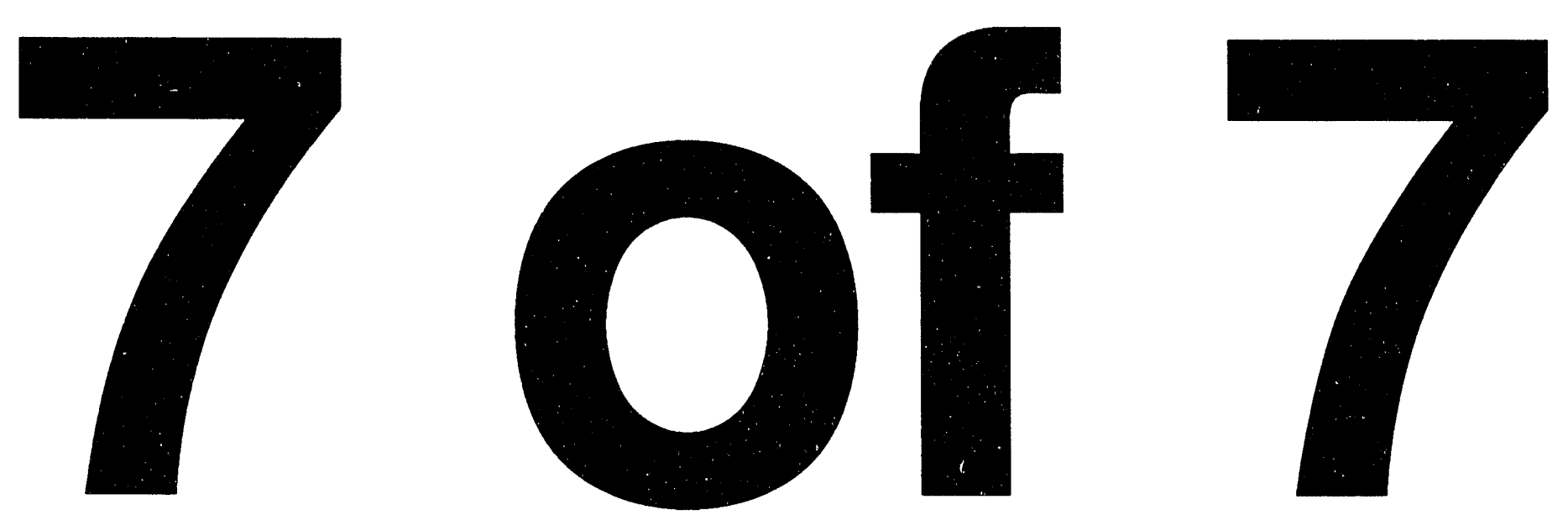
STD. DEVIATIONS $0.0000 \quad 0.0000 \quad 0.0000 \quad 0.0000 \quad 0.0000 \quad 0.0000$

$$
\begin{array}{llllllll}
0.0000 & 0.0000 & 0.0000 & 0.0000 & 0.0000 & 0.0000
\end{array}
$$

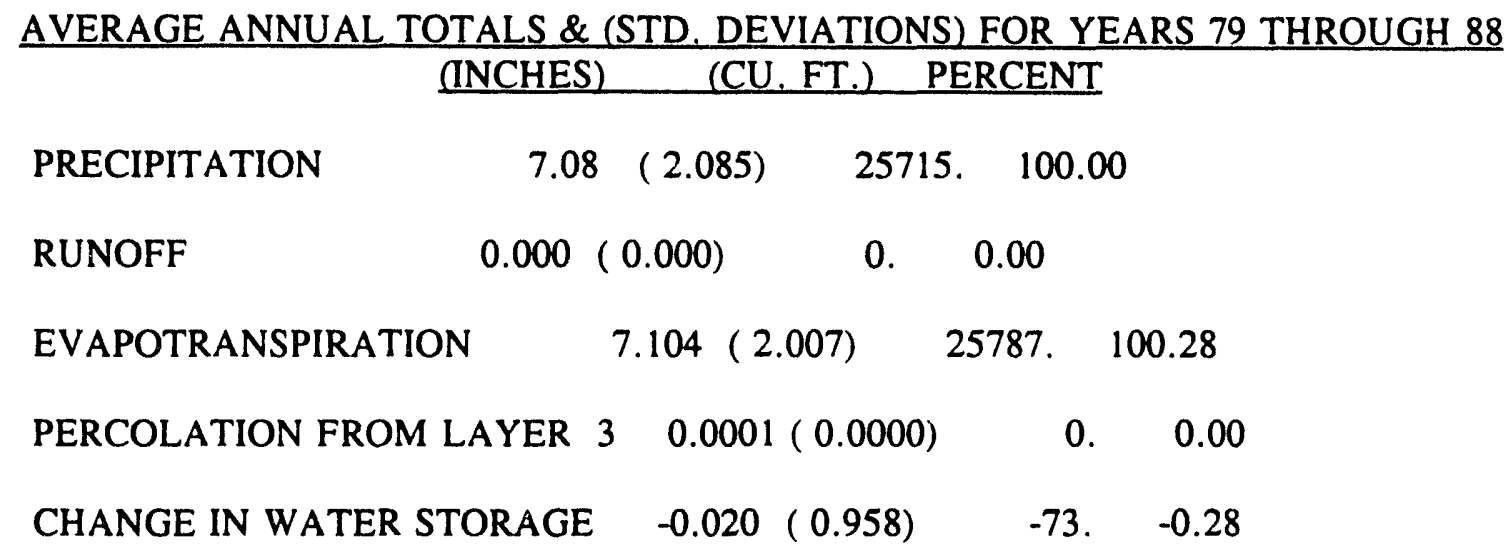

PEAK DAILY VALUES FOR YEARS 79 THROUGH 88 (INCHES) (CU. FT.)

$\begin{array}{lccc}\text { PRECIPITATION } & 0.93 & 3375.9 & \\ \text { RUNOFF } & 0.000 & 0.0 & \\ \text { PERCOLATION FROM LAYER } & 3 & 0.0000 & 0.0 \\ \text { SNOW WATER } & 0.75 & 2734.6 & \end{array}$

MAXIMUM VEG. SOIL WATER (VOL/VOL) $\quad 0.1464$

MINIMUM VEG. SOIL WATER (VOL/VOL) $\quad 0.0457$

FINAL WATER STORAGE AT END OF YEAR 88

\begin{tabular}{|c|c|c|}
\hline LAYER & \multicolumn{2}{|c|}{ (INCHES) } \\
\hline 1 & 1.41 & 0.1173 \\
\hline 2 & 0.60 & 0.0500 \\
\hline 3 & 6.21 & 0.0394 \\
\hline
\end{tabular}

SNOW WATER $\quad 0.00$ 
Attachment B-3. HELP Output for the Modified Hanford Barrier.

SAIC/ ERDF - EIS,FS/ WA 923.E412

CASE 7 - MODIFIED HANFORD BARRIER, FSS \& JSV ANALYSIS

5/23/94 Years 100-110 Cas7JV11.out

$\underline{\text { Soils Data }}$

LAYER 1

VERTICAL PERCOLATION LAYER

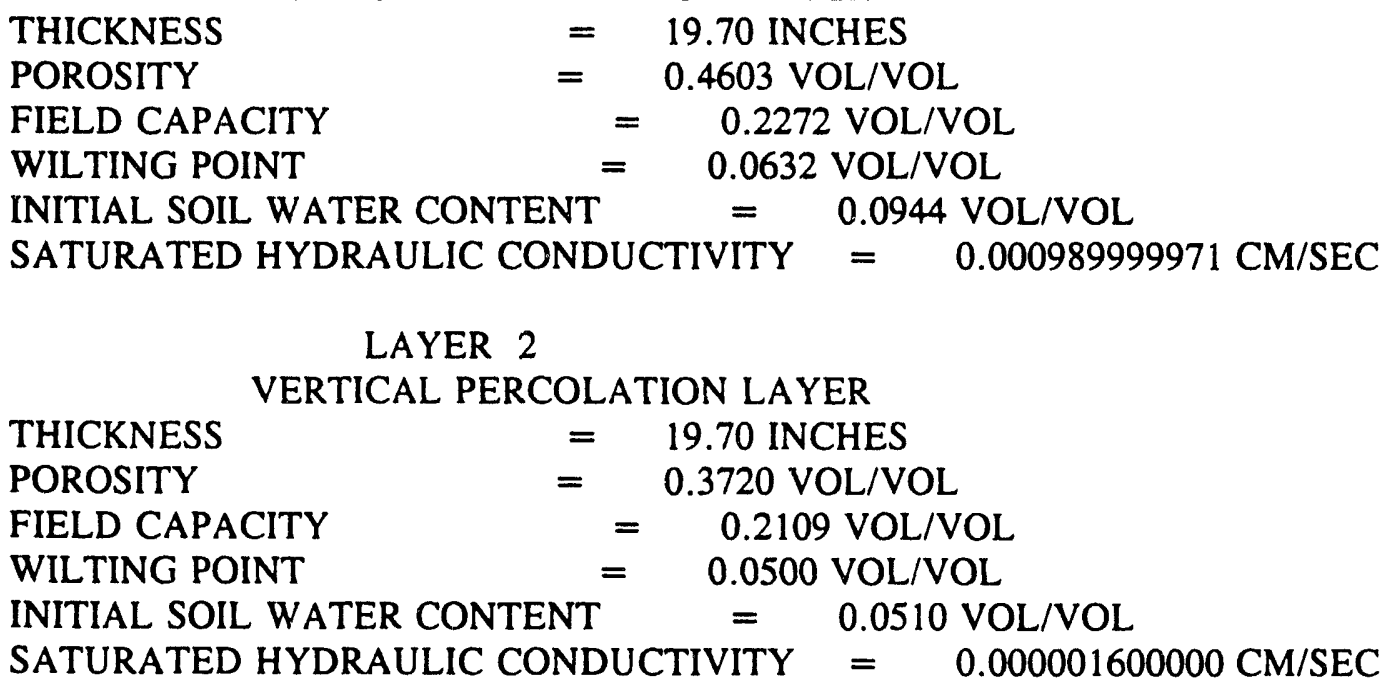

LAYER 3

VERTICAL PERCOLATION LAYER

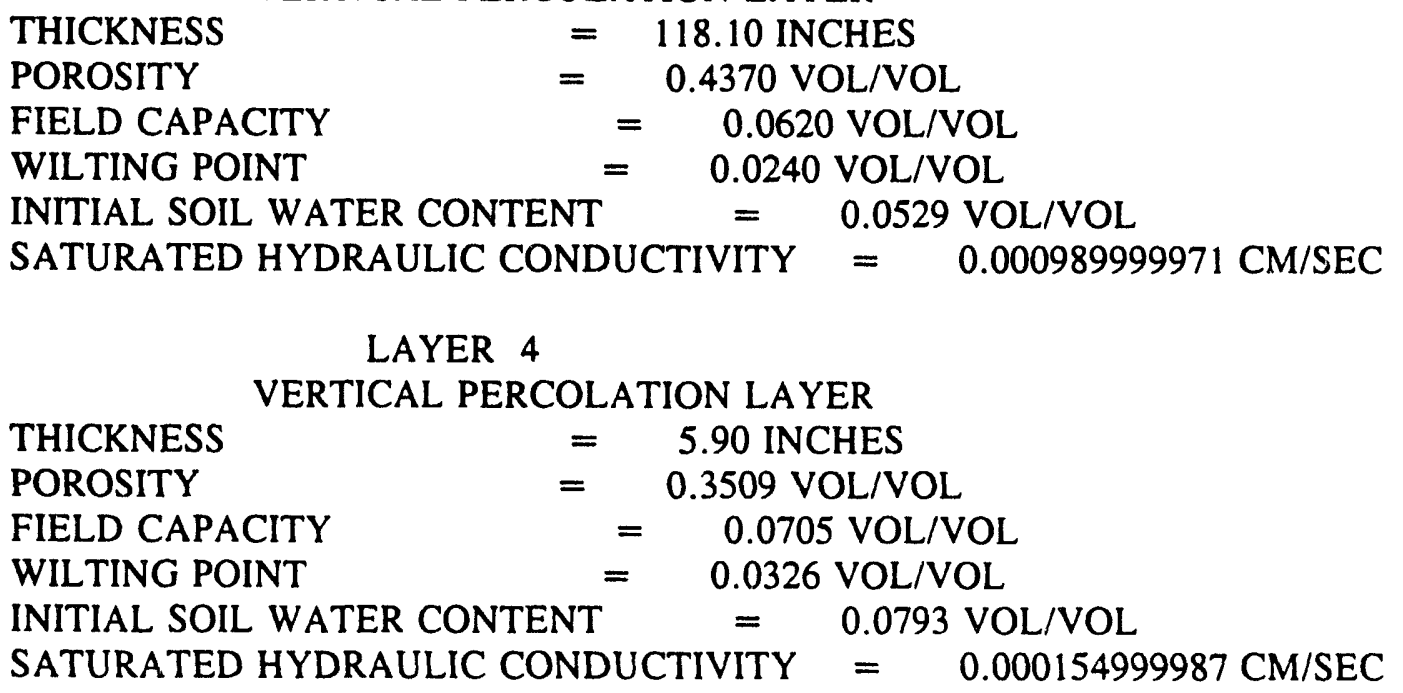


LAYER 5

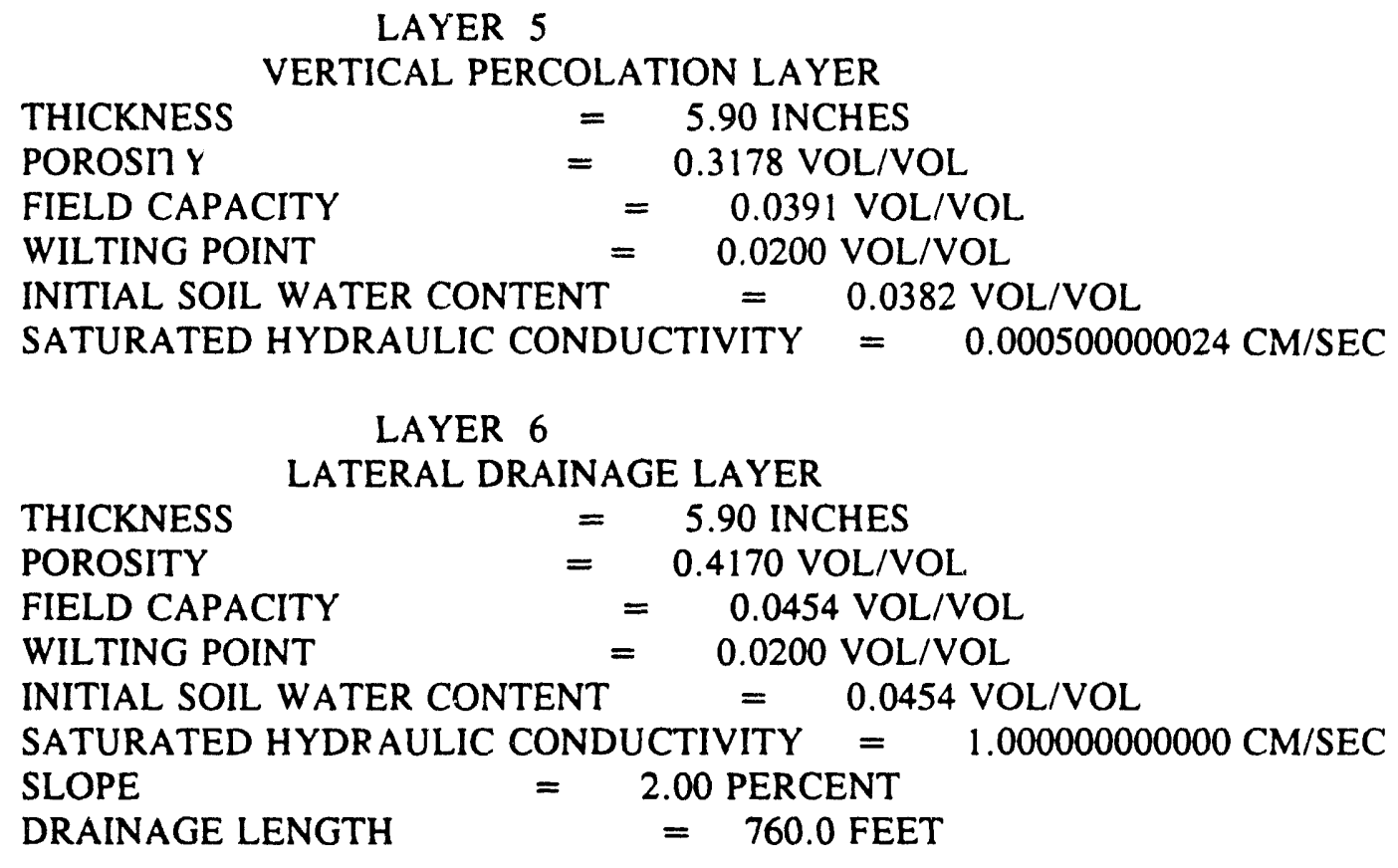

LAYER 7

THICKNESS

BARRIER SOIL LINER

POROSITY

FIELD CAPACITY

WILTING POINT

$=\quad 5.91$ INCHES

$=0.0220 \mathrm{VOL} / \mathrm{VOL}$ $=0.0210 \mathrm{VOL} / \mathrm{VOL}$

INITIAL SOIL WATER CONTENT $=0.0220 \mathrm{VOL} / \mathrm{VOL}$

SATURATED HYDRAULIC CONDUCTIVITY $=0.000000010000 \mathrm{CM} / \mathrm{SEC}$

LAYER 8

$\begin{array}{lcc}\text { VERTICAL PERCOLATION LAYER } \\ \text { THICKNESS } & =3.90 \mathrm{INCHES} \\ \text { POROSITY } & 0.4170 \mathrm{VOL} / \mathrm{VOL} \\ \text { FIELD CAPACITY } & 0.0450 \mathrm{VOL} / \mathrm{VOL} \\ \text { WILTING POINT } & 0.0200 \mathrm{VOL} / \mathrm{VOL} \\ \text { INITIAL SOIL WATER CONTENT } & = & 0.0321 \mathrm{VOL} / \mathrm{VOL} \\ \text { SATURATED HYDRAULIC CONDUCTIVITY } & =0.009999999776 \mathrm{CM} / \mathrm{SEC}\end{array}$

\section{GENERAL SIMULATION DATA}

\begin{tabular}{|c|c|c|}
\hline SCS RUNOFF CURVE NUMBER & & 77.00 \\
\hline TOTAL AREA OF COVER & $=$ & 43560. SQ FT \\
\hline EVAPORATIVE ZONE DEPTH & $=$ & 36.00 INCHES \\
\hline UPPER LIMIT VEG. STORAGE & $=$ & 15.1315 INCHES \\
\hline INITIAL VEG. STORAGE & $=$ & 2.6910 INCHES \\
\hline $\begin{array}{l}\text { INITIAL SNOW WATER CONTENT } \\
\text { INITIAL TOTAL WATER STORAGE }\end{array}$ & & $=\quad 0.0000 \mathrm{INCHES}$ \\
\hline SOIL AND WASTE LAYERS & $=$ & 10.3282 INCHES \\
\hline
\end{tabular}


SOIL WATER CONTENT INITIALIZED BY USER.

CLIMATOLOGICAL DATA

USER SPECIFIED RAINFALL WITH SYNTHETIC DAILY TEMPERATURES AND SOLAR RADIATION FOR YAKIMA WASHINGTON

MAXIMUM LEAF AREA INDEX $\quad=1.60$

START OF GROWING SEASON (JULIAN DATE) $=124$

END OF GROWING SEASON (JULIAN DATE) $=276$

NORMAL MEAN MONTHLY TEMPERATURES, DEGREES FAHRENHEIT

JAN/JUL FEB/AUG MAR/SEP APR/OCT MAY/NOV JUN/DEC

$\begin{array}{llllll}28.20 & 36.10 & 41.90 & 49.20 & 57.30 & 64.50\end{array}$

$\begin{array}{llllll}70.40 & 68.60 & 60.90 & 49.90 & 38.20 & 31.50\end{array}$

\section{RESULTS}

AVERAGE MONTHLY VALUES IN INCHES FOR YEARS 79 THROUGH 88 JAN/JUL FEB/AUG MAR/SEP APR/OCT MAY/NOV JUN/DEC

\section{PRECIPITATION}

$\begin{array}{lllllll}\text { TOTALS } & 0.78 & 0.75 & 0.66 & 0.44 & 0.50 & 0.42\end{array}$

$$
\begin{array}{llllll}
0.18 & 0.09 & 0.51 & 0.41 & 1.09 & 1.25
\end{array}
$$

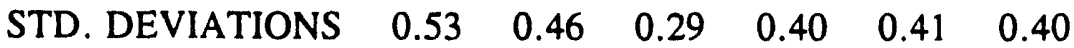

$\begin{array}{llllll}0.14 & 0.12 & 0.28 & 0.40 & 0.57 & 0.60\end{array}$

\section{RUNOFF}

$\begin{array}{lllllll}\text { TOTALS } & 0.000 & 0.000 & 0.000 & 0.000 & 0.000 & 0.000\end{array}$

$$
\begin{array}{llllll}
0.000 & 0.000 & 0.000 & 0.000 & 0.000 & 0.000
\end{array}
$$

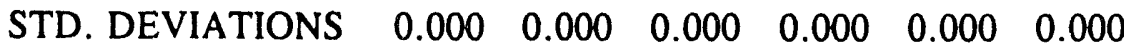

$$
\begin{array}{llllll}
0.000 & 0.000 & 0.000 & 0.000 & 0.000 & 0.000
\end{array}
$$

\section{EVAPOTRANSPIRATION}

$$
\begin{aligned}
& \begin{array}{lllllll}
\text { TOTALS } & 0.524 & 1.057 & 1.258 & 0.529 & 0.647 & 0.984
\end{array} \\
& \begin{array}{llllll}
0.644 & 0.083 & 0.249 & 0.237 & 0.435 & 0.438
\end{array} \\
& \text { STD. DEVIATIONS } \quad 0.166 \quad 0.416 \quad 0.678 \quad 0.278 \quad 0.442 \quad 0.667 \\
& \begin{array}{llllll}
0.506 & 0.091 & 0.123 & 0.106 & 0.247 & 0.150
\end{array}
\end{aligned}
$$




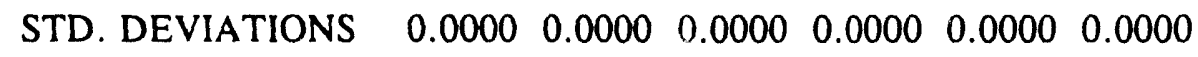
$\begin{array}{llllllll}0.0000 & 0.0000 & 0.0000 & 0.0000 & 0.0000 & 0.0000\end{array}$

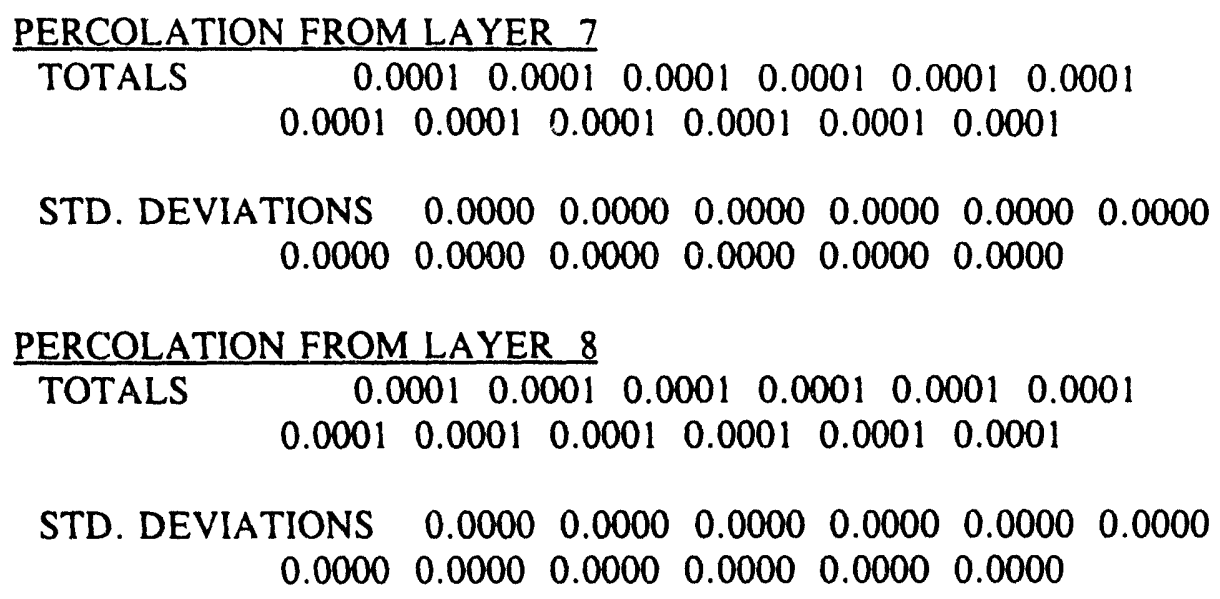

AVERAGE ANNUAL TOTALS \& (STD. DEVIATIONS) FOR YEARS 79 THROUGH 88 (INCHES) (CU.FT.) PERCENT

$\begin{array}{lllll}\text { PRECIPITATION } & 7.08 & (2.085) & 25715.100 .00\end{array}$

$\begin{array}{llll}\text { RUNOFF } & 0.000(0.000) & 0.00\end{array}$

$\begin{array}{llll}\text { EVAPOTRANSPIRATION } & 7.084(2.070) & 25715 . & 100.00\end{array}$
LATERAL DRAINAGE FROM

$$
0.0000(0.0000) \quad 0 . \quad 0.00
$$
LAYER 6

$\begin{array}{llll}\text { PERCOLATION FROM LAYER } 7 & 0.0017(0.0000) & 6 . & 0.02\end{array}$

$\begin{array}{lllll}\text { PERCOLATION FROM LAYER } 8 & 0.0017(0.0000) & 6 . & 0.02\end{array}$

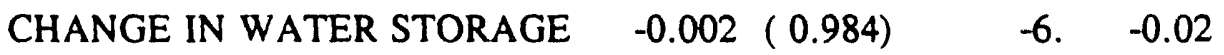

PEAK DAILY VALUES FOR YEARS 79 THROUGH 88

$$
\text { (INCHES) (CU. FT.) }
$$

$\begin{array}{lccc}\text { PRECIPITATION } & 0.93 & 3375.9 & \\ \text { RUNOFF } & 0.000 & 0.0 & \\ & & & \\ \text { LATERAL DRAINAGE FROM LAYER } & 6 & 0.0000 & 0.0 \\ \text { PERCOLATION FROM LAYER } & 7 & 0.0000 & 0.0 \\ \text { HEAD ON LAYER 7 } & 0.0 & & \\ \text { PERCOLATION FROM LAYER } 8 & & 0.0000 & 0.0\end{array}$


DOE/RL-93-99, Rev. 0

$\begin{array}{lll}\text { SNOW WATER } & 0.75 & 2734.6\end{array}$

MAXIMUM VEG. SOIL WATER (VOL/VOL) 0.1594

MINIMUM VEG. SOIL WATER (VOL/VOL) $\quad 0.0570$

\begin{tabular}{ccc}
\multicolumn{4}{c}{ FINAL WATER STORAGE AT END OF YEAR } & 88 \\
\hline \multicolumn{2}{l}{ LAYER } & \multicolumn{2}{c}{ (INCHES) } & (VOL/VOL) \\
1 & 1.86 & 0.0944 \\
2 & 1.00 & 0.0510 \\
3 & 6.23 & 0.0528 \\
4 & 0.47 & 0.0792 \\
5 & 0.23 & 0.0382 \\
6 & 0.27 & 0.0454 \\
7 & 0.13 & 0.0220 \\
8 & 0.13 & 0.0321 \\
SNOW WATER & 0.00
\end{tabular}


Attachment B-4. HELP Output File for the Hanford Barrier.

SAIC/ ERDF EIS/RC/FS/ WA. 923-E412

CASE 4 - HANFORD BARRIER

3/10/94 YEARS 100-110 CAS4JV11.OUT

\section{Soils Data}

LAYER 1

VERTICAL PERCOLATION LAYER

$\begin{array}{lcc}\text { THICKNESS } & = & 19.37 \mathrm{INCHES} \\ \text { POROSITY } & & 0.4603 \mathrm{VOL} / \mathrm{VOL} \\ \text { FIELD CAPACITY } & = & 0.2272 \mathrm{VOL} / \mathrm{VOL} \\ \text { WILTING POINT } & 0.0632 \mathrm{VOL} / \mathrm{VOL} \\ \text { INITIAL SOIL WATER CONTENT } & = & 0.0954 \mathrm{VOL} / \mathrm{VOL}\end{array}$

SATURATED HYDRAULIC CONDUCTIVITY $=0.000992999994 \mathrm{CM} / \mathrm{SEC}$

LAYER 2

THICKNESS

POROSITY

FIELD CAPACITY

WILTING POINT

INITIAL SOIL WATER CONTENT $=0.0556 \mathrm{VOL} / \mathrm{VOL}$

SATURATED HYDRAULIC CONDUCTIVITY $=0.000001600000 \mathrm{CM} / \mathrm{SEC}$

$=\quad 59.37$ INCHES

$=0.3702 \mathrm{VOL} / \mathrm{VOL}$

$=0.2109 \mathrm{VOL} / \mathrm{VOL}$

$=0.0500 \mathrm{VOL} / \mathrm{VOL}$

LAYER 3

VERTICAL PERCOLATION LAYER

THICKNESS

POROSITY

FIELD CAPACITY

WILTING POINT

INITIAL SOIL WATER CONTENT $=0.0714 \mathrm{VOL} / \mathrm{VOL}$

SATURATED HYDRAULIC CONDUCTIVITY $=0.000154999987 \mathrm{CM} / \mathrm{SEC}$

$=\quad 5.91 \mathrm{INCHES}$

$=0.3509 \mathrm{VOL} / \mathrm{VOL}$

$=0.0705 \mathrm{VOL} / \mathrm{VOL}$

$0.0326 \mathrm{VOL} / \mathrm{VOL}$

LAYER 4

VERTICAL PERCOLATION LAYER

\section{THICKNESS}

POROSITY

FIELD CAPACITY

WILTING POINT

INITIAL SOIL WATER CONTENT $=0.0367 \mathrm{VOL} / \mathrm{VOL}$

SATURATED HYDRAULIC CONDUCTIVITY $=0.000500000024 \mathrm{CM} / \mathrm{SEC}$ 
LAYER 5

VERTICAL PERCOLATION LAYER

\begin{tabular}{|c|c|c|}
\hline \multicolumn{3}{|c|}{ THICKNESS $\quad=\quad 59.00$ INCHES } \\
\hline \\
\hline \multicolumn{3}{|l|}{$\begin{array}{l}\text { POROSITY } \\
\text { FIELD CAPACITY }\end{array}$} \\
\hline \multicolumn{3}{|l|}{ WILTING POINT = } \\
\hline \multirow{2}{*}{\multicolumn{3}{|c|}{ SATURATED HYDRAULIC CONDUCTIVITY $=0.100000001490 \mathrm{CM} / \mathrm{SEC}$}} \\
\hline & & \\
\hline \multicolumn{3}{|c|}{$\begin{array}{l}\text { LAYER } 6 \\
\text { LATERAL DRAINAGE LAYER }\end{array}$} \\
\hline \multicolumn{3}{|c|}{$=11.80 \mathrm{INCHES}$} \\
\hline POROSITY & \multicolumn{2}{|c|}{$=\quad 0.4170 \mathrm{VOL} / \mathrm{VOL}$} \\
\hline FIELD CAPACITY & \multicolumn{2}{|c|}{$0.0454 \mathrm{VOL} / \mathrm{VOL}$} \\
\hline WILTING POINT & \multicolumn{2}{|c|}{$0.0200 \mathrm{VOL} / \mathrm{VOL}$} \\
\hline INITIAL SOIL WATER CONTENT & $=$ & $0.0454 \mathrm{VOL} / \mathrm{VOL}$ \\
\hline \multicolumn{3}{|c|}{ SATURATED HYDRAULIC CONDUCTIVITY $=1.000000000000$} \\
\hline SLOPE $\quad=2$ & \multicolumn{2}{|c|}{ 2.00 PERCENT } \\
\hline \multicolumn{3}{|c|}{ DRAINAGE LENGTH $\quad=760.0$ FEET } \\
\hline \multicolumn{3}{|c|}{$\begin{array}{l}\text { LAYER } 7 \\
\text { BARRIER SOIL LINER }\end{array}$} \\
\hline \multicolumn{3}{|c|}{$=\quad 5.91 \mathrm{INCHES}$} \\
\hline POROSITY & \multicolumn{2}{|c|}{$=\quad 0.0220 \mathrm{VOL} / \mathrm{VOL}$} \\
\hline FIELD CAPACITY & \multicolumn{2}{|c|}{$0.0210 \mathrm{VOL} / \mathrm{VOL}$} \\
\hline WILTING POINT = & \multicolumn{2}{|c|}{$0.0200 \mathrm{VOL} / \mathrm{VOL}$} \\
\hline \multirow{2}{*}{\multicolumn{3}{|c|}{$\begin{array}{l}\text { INITIAL SOIL WATER CONTENT }= \\
\text { SATURATED HYDRAULIC CONDUCTIVITY }\end{array}$}} \\
\hline & & \\
\hline \multicolumn{3}{|c|}{$\begin{array}{l}\text { LAYER } 8 \\
\text { VERTICAL PERCOLATION LAYER }\end{array}$} \\
\hline THICKNESS & $3.95 \mathrm{INC}$ & HES \\
\hline POROSITY & $0.4170 \mathrm{~V}$ & OL/VOL \\
\hline FIELD CAPACITY & 0.045 & VOL/VOL \\
\hline WILTING POINT & 0.0200 & VOL/VOL \\
\hline INITIAL SOIL WATER CONTENT & $=$ & $0.0261 \mathrm{VOL} / \mathrm{VOL}$ \\
\hline SATURATED HYDRAULIC CONDU & CTIVITY & $=\quad 0.009999999776 \mathrm{CM}$ \\
\hline
\end{tabular}

\section{GENERAL SIMULATION DATA}

SCS RUNOFF CURVE NUMBER TOTAL AREA OF COVER EVAPORATIVE ZONE DEPTH UPPER LIMIT VEG. STORAGE INITIAL VEG. STORAGE INITIAL SNOW WATER CONTENT INITIAL TOTAL WATER STORAGE IN SOIL AND WASTE LAYERS

$$
\begin{array}{cc}
= & 77.00 \\
= & 43560 . \text { SQ FT } \\
= & 36.00 \text { INCHES } \\
= & 15.0724 \text { INCHES } \\
= & 2.7725 \text { INCHES } \\
& =\quad 0.0000 \text { INCHES } \\
\text { IN } & \\
= & 10.8795 \text { INCHES }
\end{array}
$$


SOIL WATER CONTENT INITIALIZED BY USER.

\section{CLIMATOLOGICAL DATA}

USER SPECIFIED RAINFALL WITH SYNTHETIC DAILY TEMPERATURES AND SOLAR RADIATION FOR YAKIMA, WASHINGTON

MAXIMUM LEAF AREA INDEX $\quad=1.60$

START OF GROWING SEASON (JULIAN DATE) $=124$

END OF GROWING SEASON (JULIAN DATE) $=276$

NORMAL MEAN MONTHLY TEMPERATURES, DEGREES FAHRENHEIT

\begin{tabular}{cccccll} 
JAN/JUL & \multicolumn{2}{c}{ FEB/AUG } & MAR/SEP & APR/OCT & MAY/NOV & JUN/DEC \\
28.20 & 36.10 & 41.90 & 49.20 & 57.30 & 64.50 & \\
70.40 & 68.60 & 60.90 & 49.90 & 38.20 & 31.50 &
\end{tabular}

AVERAGE MONTHLY VALUES IN INCHES FOR YEARS 79 THROUGH 88 JAN/JUL FEB/AUG MAR/SEP APR/OCT MAY/NOV JUN/DEC

\section{PRECIPITATION}

$\begin{array}{lllllll}\text { TOTALS } & 0.78 & 0.75 & 0.66 & 0.44 & 0.50 & 0.42\end{array}$

$$
\begin{array}{llllll}
0.18 & 0.09 & 0.51 & 0.41 & 1.09 & 1.25
\end{array}
$$

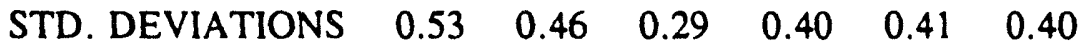

$\begin{array}{llllll}0.14 & 0.12 & 0.28 & 0.40 & 0.57 & 0.60\end{array}$

\section{RUNOFF}

$$
\begin{array}{lllllll}
\text { TOTALS } & 0.000 & 0.000 & 0.000 & 0.000 & 0.000 & 0.000
\end{array}
$$

$$
\begin{array}{llllll}
0.000 & 0.000 & 0.000 & 0.000 & 0.000 & 0.000
\end{array}
$$

STD. DEVIATIONS $\quad 0.000 \quad 0.000 \quad 0.000 \quad 0.000 \quad 0.000 \quad 0.000$

$$
\begin{array}{llllll}
0.000 & 0.000 & 0.000 & 0.000 & 0.000 & 0.000
\end{array}
$$

\section{EVAPOTRANSPIRATION \\ $\begin{array}{lllllll}\text { TOTALS } & 0.526 & 1.065 & 1.254 & 0.546 & 0.591 & 1.024\end{array}$

$$
\begin{array}{lllllll}
0.658 & 0.083 & 0.248 & 0.234 & 0.424 & 0.439
\end{array}
$$

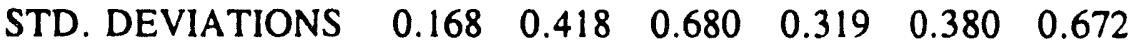

$$
\begin{array}{llllll}
0.515 & 0.091 & 0.123 & 0.106 & 0.241 & 0.152
\end{array}
$$

LATERAL DRAINAGE FROM LAYER 6

$\begin{array}{lllllllllll}\text { TOTALS } & 0.0000 & 0.0000 & 0.0000 & 0.0000 & 0.0000 & 0.0000\end{array}$ $\begin{array}{llllll}0.0000 & 0.0000 & 0.0000 & 0.0000 & 0.0000 & 0.0000\end{array}$

STD. DEVIATIONS $\quad \begin{array}{llllll}0.0000 & 0.0000 & 0.0000 & 0.0000 & 0.0000 & 0.0000\end{array}$ $\begin{array}{llllllllll}0.0000 & 0.0000 & 0.0000 & 0.0000 & 0.0000 & 0.0000\end{array}$

PERCOLATION FROM LAYER 7 


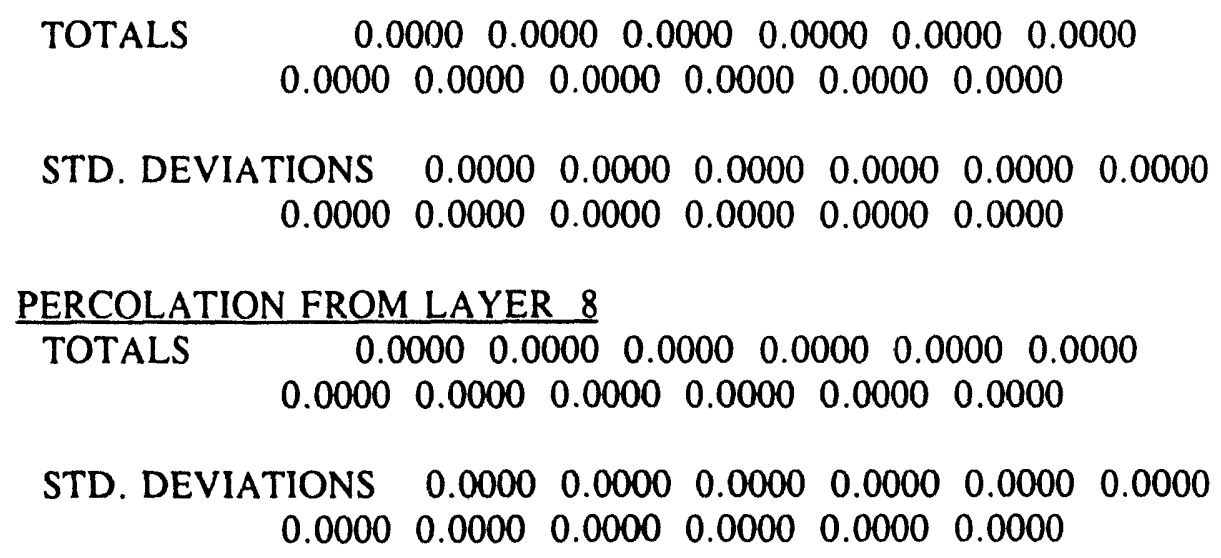


DOE/RL-93-99, Rev. 0

\begin{tabular}{|c|c|c|c|}
\hline \multirow{2}{*}{\multicolumn{3}{|c|}{$\begin{array}{l}\text { MAXIMUM VEG. SOIL WATER (VOL/VOL) } \\
\text { MINIMUM VEG. SOIL WATER (VOL/VOL) }\end{array}$}} & 0.1587 \\
\hline & & & 0.0509 \\
\hline \multicolumn{4}{|c|}{ FINAL WATER STORAGE AT END OF YEAR 88} \\
\hline LAYER & (INCHES) & VOL/VOL & \\
\hline 1 & 1.85 & 0.0954 & \\
\hline 2 & 3.22 & 0.0543 & \\
\hline 3 & 0.42 & 0.0706 & \\
\hline 4 & 0.43 & 0.0362 & \\
\hline 5 & 4.12 & 0.0699 & \\
\hline 6 & 0.54 & 0.0454 & \\
\hline 7 & 0.12 & 0.0210 & \\
\hline 8 & 0.10 & 0.0259 & \\
\hline SNOW W & 0.00 & & \\
\hline
\end{tabular}


Attachment B-5. HELP Output File for the Single Composite Liner System.

SAIC/ ERDF EIS-RI-FS /WA

923-E412

CASE 5 - SINGLE COMPOSITE LINER

3/7/94 YEARS $0-10$ CASESFS1.W51

\section{Soils Data}

LAYER 1

VERTICAL PERCOLATION LAYER

THICKNESS

POROSITY

FIELD CAPACITY

WILTING POINT

INITIAL SOIL WATER CONTENT $=0.0622 \mathrm{VOL} / \mathrm{VOL}$

SATURATED HYDRAULIC CONDUCTIVITY $=0.000099999968 \mathrm{CM} / \mathrm{SEC}$.

LAYER 2

VERTICAL PERCOLATION LAYER

\section{THICKNESS \\ POROSITY \\ FIELD CAPACITY \\ WILTING POINT}

INITIAL SOIL WATER CONTENT $=0.0454 \mathrm{VOL} / \mathrm{VOL}$

SATURATED HYDRAULIC CONDUCTIVITY $=1.00000000000 \mathrm{CM} / \mathrm{SEC}$

LAYER 3

BARRIER SOIL LINER

THICKNESS

POROSITY

FIELD CAPACITY

WILTING POINT

INITIAL SOIL WAT

SATURATED HYDRAULIC CONDUCTIVITY $=0.000000100000 \mathrm{CM} / \mathrm{SEC}$

\section{GENERAL SIMULATION DATA}

SCS RUNOFF CURVE NUMBER

TOTAL AREA OF COVER EVAPORATIVE ZONE DEPTH

UPPER L.IMIT VEG. STORAGE

INITIAL VEG. STORAGE

INITIAL SNOW WATER CONTENT

INITIAL TOTAL WATER STORAGE IN

SOIL AND WASTE LAYERS
$=12.00 \mathrm{INCHES}$

$=\quad 0.4300 \mathrm{VOL} / \mathrm{VOL}$

$=0.3660 \mathrm{VOL} / \mathrm{VOL}$

$=\quad 0.2800 \mathrm{VOL} / \mathrm{VOL}$

$=\quad 0.3660 \mathrm{VOL} / \mathrm{VOL}$

$$
\begin{aligned}
& =\quad 77.00 \\
& =43560 \text {. SQ FT } \\
& =\quad 36.00 \text { INCHES } \\
& =\quad 15.7320 \text { INCHES } \\
& =\quad 2.2392 \text { INCHES } \\
& =0.0000 \text { INCHES } \\
& =\quad 7.1760 \mathrm{INCHES}
\end{aligned}
$$


SOIL WATER CONTENT INITIALIZED BY USER.

\section{CLIMATOLOGICAL DATA}

USER SPECIFIED RAINFALL WITH SYNTHETIC DAILY TEMPERATURES AND SOLAR RADIATION FOR YAKIMA, WASHINGTON

MAXIMUM LEAF AREA INDEX $=1.60$
START OF GROWING SEASON (JULIAN DATE) $=124$
END OF GROWING SEASON (JULIAN DATE) $=276$

NORMAL MEAN MONTHLY TEMPERATURES, DEGREES FAHRENHEIT

JAN/JUL FEB/AUG MAR/SEP APR/OCT MAY/NOV JUN/DEC

$\begin{array}{llllll}28.20 & 36.10 & 41.90 & 49.20 & 57.30 & 64.50 \\ 70.40 & 68.60 & 60.90 & 49.90 & 38.20 & 31.50\end{array}$

$\underline{\text { Results }}$

AVERAGE MONTHLY VALUES IN INCHES FOR YEARS 79 THROUGH 88 JAN/JUL FEB/AUG MAR/SEP APR/OCT MAY/NOV JUN/DEC

\section{PRECIPITATION}

TOTALS

$\begin{array}{llllll}0.78 & 0.75 & 0.66 & 0.44 & 0.50 & 0.42\end{array}$

$\begin{array}{llllll}0.18 & 0.09 & 0.51 & 0.41 & 1.09 & 1.25\end{array}$

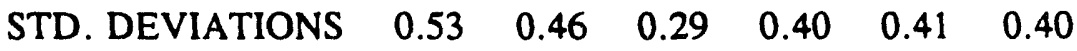

$\begin{array}{llllll}0.14 & 0.12 & 0.28 & 0.40 & 0.57 & 0.60\end{array}$

RUNOFF

$\begin{array}{lllllll}\text { TOTALS } & 0.000 & 0.000 & 0.000 & 0.000 & 0.000 & 0.000\end{array}$

$\begin{array}{lllllll}0.000 & 0.000 & 0.000 & 0.000 & 0.000 & 0.000\end{array}$

$\begin{array}{lllllll}\text { STD. DEVIATIONS } & 0.000 & 0.000 & 0.000 & 0.000 & 0.000 & 0.000\end{array}$

$\begin{array}{llllll}0.000 & 0.000 & 0.000 & 0.000 & 0.000 & 0.000\end{array}$

EVAPORATION

$\begin{array}{lllllll}\text { TOTALS } & 0.565 & 1.020 & 0.919 & 0.513 & 0.713 & 1.232\end{array}$

$\begin{array}{llllll}0.646 & 0.084 & 0.262 & 0.264 & 0.485 & 0.441\end{array}$

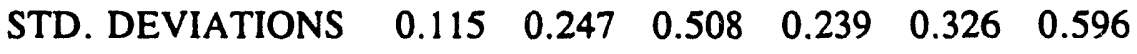

$\begin{array}{llllll}0.603 & 0.089 & 0.138 & 0.140 & 0.267 & 0.112\end{array}$

PERCOLATION FROM LAYER 3

$\begin{array}{llllllllll}\text { TOTALS } & 0.0000 & 0.0000 & 0.0000 & 0.0000 & 0.0000 & 0.0000\end{array}$

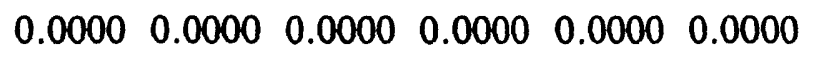

STD. DEVIATIONS $\quad \begin{array}{llllll}0.0000 & 0.0000 & 0.0000 & 0.0000 & 0.0000 & 0.0000\end{array}$

$\begin{array}{llllllll}0.0000 & 0.0000 & 0.0000 & 0.0000 & 0.0000 & 0.0000\end{array}$ 
DOE/RL-93-99, Rev. 0

AVERAGE ANNUAL TOTALS \& (STD. DEVIATIONS) FOR YEARS 79 THROUGH 88 (INCHES) (CU. FT.) PERCENT

PRECIPITATION

$7.08(2.085)$

25715. 100.00

RUNOFF

$0.000(0.000)$

0. $\quad 0.00$

EVAPOTRANSPIRATION

$7.145(1.842)$

25935. 100.85

PERCOLATION FROM LAYER $3 \quad 0.0000(0.0000)$

0. $\quad 0.00$

CHANGE IN WATER STORAGE $\quad-0.061 \quad(0.762)$

$-220 . \quad-0.85$

PEAK DAILY VALUES FOR YEARS 79 THP.OUGH 88 (INCHES) (CU. FT.)

\begin{tabular}{|c|c|c|}
\hline PRECIPITATION & 0.93 & 3375.9 \\
\hline RUNOFF & 0.000 & 0.0 \\
\hline PERCOLATION FROM LAYER & 3 & 0.0000 \\
\hline HEAD ON LAYER 3 & 0.0 & \\
\hline SNOW WATER & 0.75 & 2734.6 \\
\hline
\end{tabular}

MAXIMUM VEG. SOIL WATER (VOL/VOL) 0.1232

MINIMUM VEG. SOIL WATER (VOL/VOL) $\quad 0.0239$

FINAL WATER STORAGE AT END OF YEAR 88

LAYER (INCHES) (VOL/VOL)

$1 \quad 1.63 \quad 0.0454$

$\begin{array}{lll}2 & 0.55 & 0.0454\end{array}$

$\begin{array}{lll}3 & 4.39 & 0.3660\end{array}$

SNOW WATER $\quad 0.00$ 
Attachment B-6. HELP Output File for the RCRA Subtitle-C Double Composite Liner System.

SAIC /ERDF EIS-RI-FS/ WA 923-E412

CASE 6 - DOUBLE COMPOSITE LINER

3/7/94 Years 0 - 10 CASE6FS1.W51

\section{Soils Data}

LAYER 1

VERTICAL PERCOLATION LAYER

$\begin{array}{lcc}\text { THICKNESS } & = & 36.00 \mathrm{INCHES} \\ \text { POROSITY } & & 0.4370 \mathrm{VOL} / \mathrm{VOL} \\ \text { FIELD CAPACITY } & =0.0622 \mathrm{VOL} / \mathrm{VOL} \\ \text { WILTING POINT } & =0.0240 \mathrm{VOL} / \mathrm{VOL} \\ \text { INITIAL SOIL WATER CONTENT } & = & 0.0622 \mathrm{VOL} / \mathrm{VOL} \\ \text { SATURATED HYDRAULIC CONDUCTIVITY } & =0.000099999968 \mathrm{CM} / \mathrm{SEC}\end{array}$

LAYER 2

$\begin{array}{lrrr}\text { VERTICAL PERCOLATION LAYER } \\ \text { THICKNESS } & =12.00 \text { INCHES } \\ \text { POROSITY } & 0.4170 \mathrm{VOL} / \mathrm{VOL} \\ \text { FIELD CAPACITY } & 0.0454 \mathrm{VOL} / \mathrm{VOL} \\ \text { WILTING POINT } & 0.0200 \mathrm{VOL} / \mathrm{VOL} \\ \text { INITIAL SOIL WATER CONTENT } & = & 0.0454 \mathrm{VOL} / \mathrm{VOL} \\ \text { SATURATED HYDRAULIC CONDUCTIVITY } & =0.009999999776 \mathrm{CM} / \mathrm{SEC}\end{array}$

LAYER 3

THICKNESS

POROSITY

FIELD CAPACITY

WILTING POINT

INITIAL SOIL WATER CONTENT $=0.3660 \mathrm{VOL} / \mathrm{VOL}$

SATURATED HYDRAULIC CONDUCTIVITY $=0.009999999776 \mathrm{CM} / \mathrm{SEC}$.

LAYER 4

VERTICAL PERCOLATION LAYER

THICKNESS

POROSITY

FIELD CAPACITY

WILTING POINT

INITIAL SOIL WATER CONTENT $=0.0454 \mathrm{VOL} / \mathrm{VOL}$

SATURATED HYDRAULIC CONDUCTIVITY $=0.009999999776 \mathrm{CM} / \mathrm{SEC}$

\author{
$=\quad 12.00$ INCHES \\ $=\quad 0.4170 \mathrm{VOL} / \mathrm{VOL}$ \\ $=\quad 0.0454 \mathrm{VOL} / \mathrm{VOL}$ \\ $=0.0200 \mathrm{VOL} / \mathrm{VOL}$
}

$=\quad 0.10 \mathrm{INCHES}$

$=0.4300 \mathrm{VOL} / \mathrm{VOL}$

$=\quad 0.3660 \mathrm{VOL} / \mathrm{VOL}$

$=0.2800 \mathrm{VOL} / \mathrm{VOL}$ 


\section{LAYER 5}

THICKNESS

POROSITY

FIELD CAPACITY

WILTING POINT

INITIAL SOIL WATER CONTENT $=0.3660 \mathrm{VOL} / \mathrm{VOL}$

SATURATED HYDRAULIC CONDUCTIVITY $=0.000000100000 \mathrm{CM} / \mathrm{SEC}$

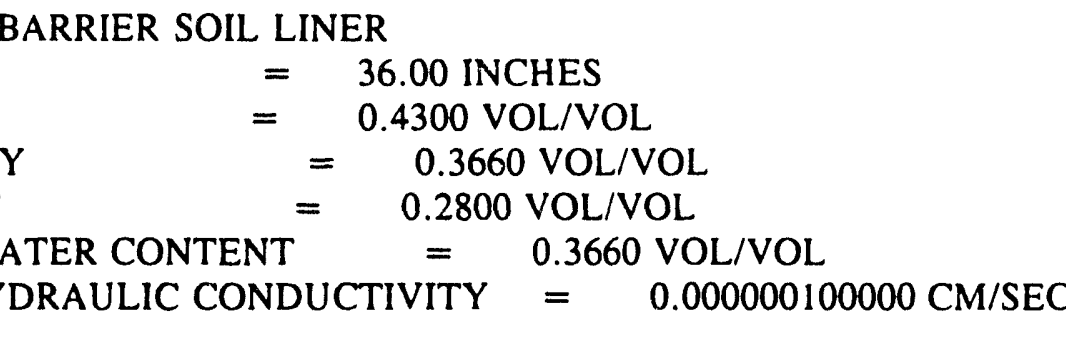

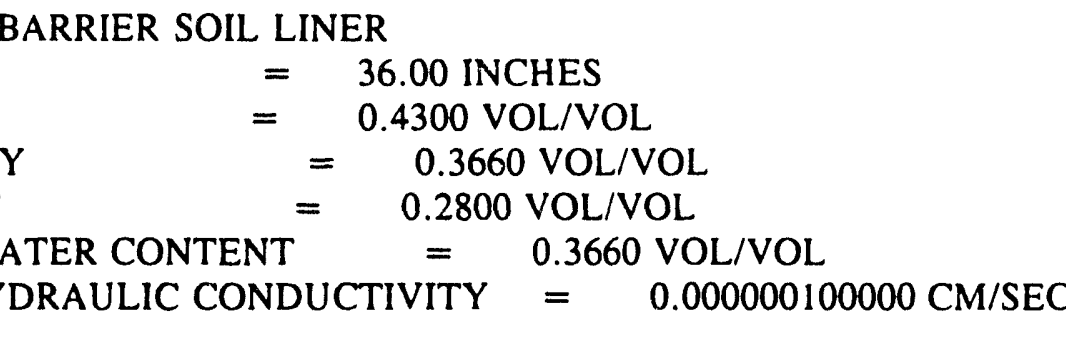

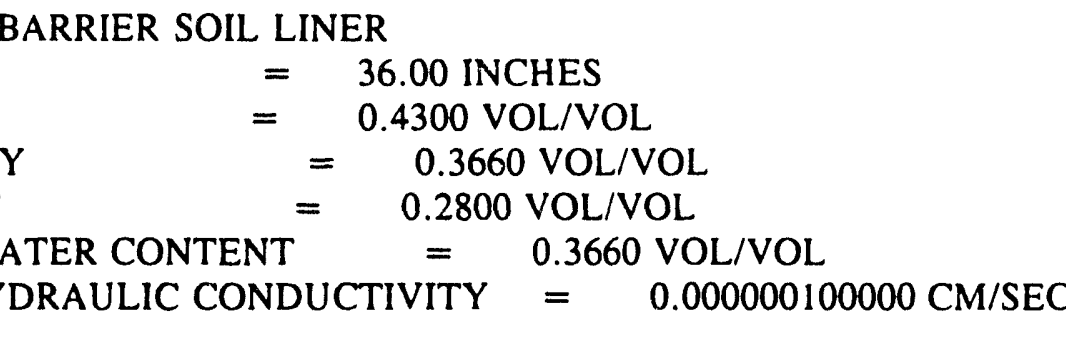

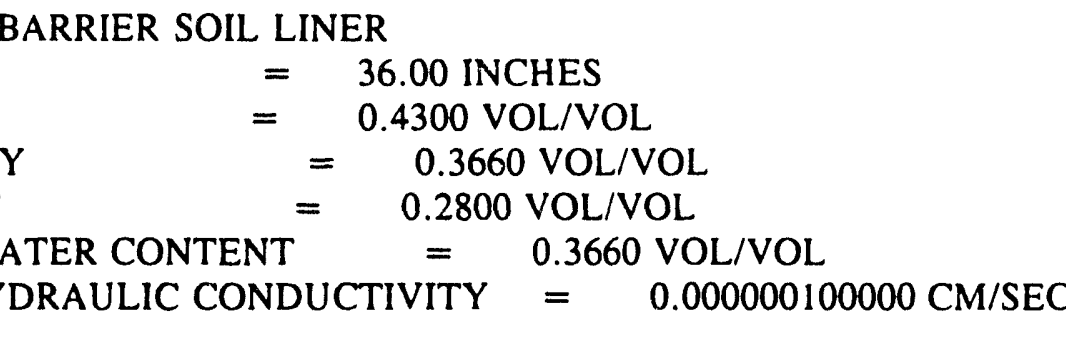

\section{GENERAL SIMULATION DATA}

SCS RUNOFF CURVE NUMBER

TOTAL AREA OF COVER

EVAPORATIVE ZONE DEPTH

UPPER LIMIT VEG. STORAGE

INITIAL VEG. STORAGE

INITIAL SNOW WATER CONTENT

INITIAL TOTAL WATER STORAGE IN

SOIL AND WASTE LAYERS

$$
\begin{array}{cc}
= & 77.00 \\
= & 43560 . \mathrm{SQ} \mathrm{FT} \\
= & 36.00 \mathrm{INCHES} \\
= & 15.7320 \mathrm{INCHES} \\
= & 2.2392 \text { INCHES } \\
= & 0.0000 \text { INCHES }
\end{array}
$$

$=\quad 16.5414 \mathrm{INCHES}$

SOIL WATER CONTENT INITIALIZED BY USER.

\section{CLIMATOLOGICAL DATA}

USER SPECIFIED RAINFALL WITH SYNTHETIC DAILY TEMPERATURES AND SOLAR RADIATION FOR YAKIMA, WASHINGTON

MAXIMUM LEAF AREA INDEX $\quad=1.60$

START OF GROWING SEASON (JULIAN DATE) $=124$

END OF GROWING SEASON (JULIAN DATE) $=276$

NORMAL MEAN MONTHLY TEMPERATURES, DEGREES FAHRENHEIT

\begin{tabular}{cccccll} 
JAN/JUL & \multicolumn{2}{c}{ FEB/AUG } & MAR/SEP & APR/OCT & MAY/NOV & JUN/DEC \\
28.20 & 36.10 & 41.90 & 49.20 & 57.30 & 64.50 & \\
70.40 & 68.60 & 60.90 & 49.90 & 38.20 & 31.50 &
\end{tabular}

Results

AVERAGE MONTHLY VALUES IN INCHES FOR YEARS 79 THROUGH 88 JAN/JUL FEB/AUG MAR/SEP APR/OCT MAY/NOV JUN/DEC

PRECIPITATION

$\begin{array}{lllllll}\text { TOTALS } & 0.78 & 0.75 & 0.66 & 0.44 & 0.50 & 0.42\end{array}$

$\begin{array}{llllll}0.18 & 0.09 & 0.51 & 0.41 & 1.09 & 1.25\end{array}$ 


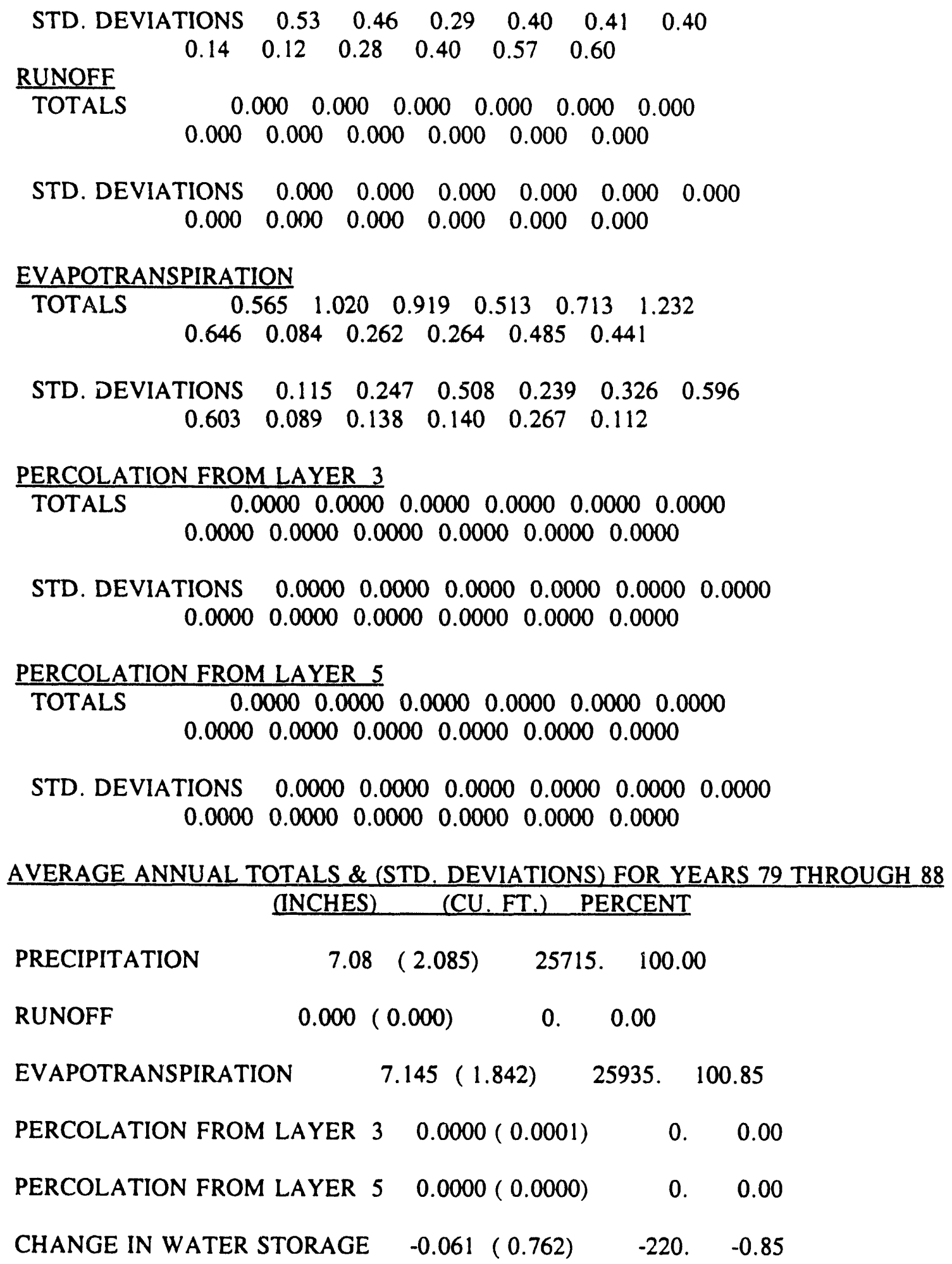


DOE/RL-93-99, Rev. 0

PEAK DAILY VALUES FOR YEARS 79 THROUGH 88 (INCHES) (CU.FT.)

PRECIPITATION

$0.93 \quad 3375.9$

RUNOFF

0.000

0.0

PERCOLATION FROM LAYER 3

0.0000

0.0

HEAD ON LAYER 3

0.0

PERCOLATION FROM LAYER 5

0.0000

0.0

HEAD ON LAYER 5

0.0

SNOW WATER

0.75

2734.6

MAXIMUM VEG. SOIL WATER (VOL/VOL) 0.1232

MINIMUM VEG. SOIL WATER (VOL/VOL) $\quad 0.0239$

FINAL WATER STORAGE AT END OF YEAR 88

\begin{tabular}{|c|c|c|}
\hline LAYER & \multicolumn{2}{|c|}{ (INCHES) } \\
\hline 1 & 1.63 & 0.0454 \\
\hline 2 & 0.54 & 0.0454 \\
\hline 3 & 0.04 & 0.3660 \\
\hline 4 & 0.55 & 0.0454 \\
\hline 5 & 13.18 & 0.3660 \\
\hline
\end{tabular}

SNOW WATER $\quad 0.00$ 
Attachment B-7. HELP Model Data File: DATA4 - Precipitation Data for Hanford, Washington.

$\begin{array}{llllllllllllll}79 & 0 . & 0.0 & 0 . & 0 . & 0 . & 0 . & 0 . & 0.0 & 0.0 & 0.2 & 1\end{array}$

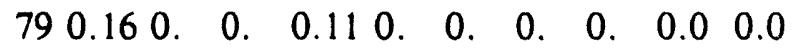

$\begin{array}{llllllllllllll}79 & 0.0 & 0 . & 0.02 & 0.04 & 0 . & 0.0 & 0.0 & 0 . & 0.0 & 0.01\end{array}$

$\begin{array}{lllllllllll}79 & 0.0 & 0.0 & 0.0 & 0 . & 0 . & 0 . & 0.0 & 0 . & 0.0 & 0 .\end{array}$

$\begin{array}{lllllllllllll}79 & 0.0 & 0.01 & 0.08 & 0 . & 0 . & 0.0 & 0.03 & 0.0 & 0 . & 0.0\end{array}$

$\begin{array}{lllllllllll}79 & 0.03 & 0.01 & 0 . & 0.0 & 0.0 & 0.01 & 0.0 & 0 . & 0 . & 0 .\end{array}$

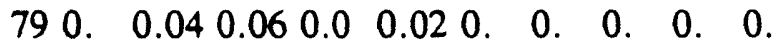

$\begin{array}{llllllllllll}79 & 0 . & 0 . & 0 . & 0.0 & 0.0 & 0 . & 0 . & 0 . & 0 . & 0 .\end{array}$

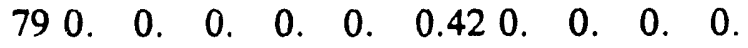

$\begin{array}{lllllllllll}79 & 0.0 & 0.1 & 0 . & 0 . & 0 . & 0.0 & 0 . & 0.01 & 0.0 & 0 .\end{array}$

$\begin{array}{llllllllllllllll}79 & 0.03 & 0.01 & 0 . & 0 . & 0.0 & 0.08 & 0.17 & 0.0 & 0 . & 0 .\end{array}$

$\begin{array}{lllllllllll}79 & 0 . & 0.0 & 0.0 & 0.04 & 0 . & 0 . & 0 . & 0 . & 0 . & 0.08\end{array}$

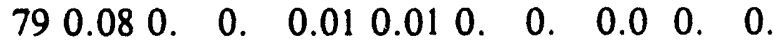

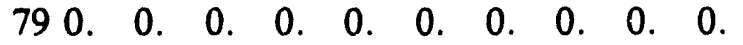

$\begin{array}{lllllllllll}79 & 0 . & 0.0 & 0.0 & 0 . & 0 . & 0 . & 0 . & 0.0 & 0 . & 0 .\end{array}$

$790.0 . \quad 0 . \quad 0 . \quad 0 . \quad 0 . \quad 0 . \quad 0 . \quad 0 . \quad 0$.

$\begin{array}{lllllllllll}79 & 0.0 & 0 . & 0 . & 0 . & 0 . & 0 . & 0.0 & 0.0 & 0.0 & 0 .\end{array}$

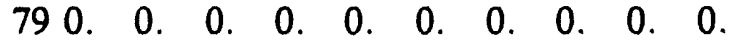

$\begin{array}{lllllllllllllllllll}79 & 0 . & 0.0 & 0 . & 0 . & 0 . & 0 . & 0.02 & 0.0 & 0.01 & 0.0\end{array}$

$790.020 .040 . \quad 0 . \quad 0 . \quad 0 . \quad 0 . \quad 0 . \quad 0 . \quad 0$.

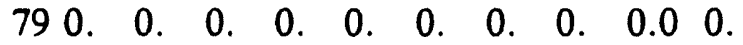

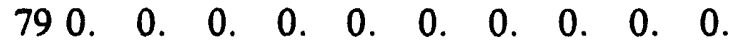

$\begin{array}{llllllllllll}79 & 0 . & 0 . & 0 . & 0 . & 0.040 .09 & 0 . & 0 . & 0 . & 0 .\end{array}$

790.050 .020 .060 . 0.0 . 0.0 .0 .0 .0$.

$\begin{array}{lllllllllll}79 & 0.010 .110 . & 0.06 & 0.01 & 0.130 . & 0 . & 0 . & 0 .\end{array}$

$\begin{array}{lllllllllll}79 & 0 . & 0.0 & 0 . & 0 . & 0 . & 0 . & 0 . & 0 . & 0 . & 0 .\end{array}$

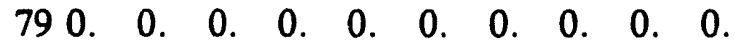

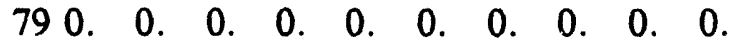

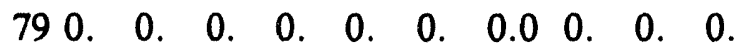

1

3

4

5

6

8

9

10

15

16

17

18

21

22

23

27

28

29

$\begin{array}{llllllllllll}79 & 0.28 & 0.12 & 0.06 & 0 . & 0.0 & 0 . & 0.11 & 0.07 & 0 . & 0.03\end{array}$

$\begin{array}{lllllllllll}79 & 0.0 & 0 . & 0 . & 0 . & 0 . & 0.06 & 0.0 & 0.09 & 0.07 & 0.06\end{array}$

$\begin{array}{lllllllllll}79 & 0 . & 0.0 & 0.0 & 0 . & 0 . & 0 . & 0 . & 0.0 & 0.0 & 0.42\end{array}$

$\begin{array}{lllllllllll}79 & 0.0 & 0 . & 0 . & 0 . & 0 . & 0.37 & 0 . & 0.31 & 0 . & 0.05\end{array}$

$\begin{array}{lllllllllll}79 & 0 . & 0 . & 0 . & 0.0 & 0.07 & 0.02 & 0.03 & 0 . & 0.04 & 0 .\end{array}$

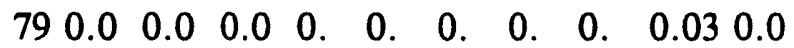

$\begin{array}{llllllllllll}79 & 0.04 & 0.05 & 0.0 & 0.0 & 0.0 & 0 . & 0.27 & 0.05 & 0.03 & 0 .\end{array}$

$790.0 \quad 0.020 .070 .150 .120 .0 . \quad 0 . \quad 0.0$.

$\begin{array}{llllllllllll}80 & 0.110 .0 & 0 . & 0.09 & 0 . & 0 . & 0.05 & 0.22 & 0.200 .0\end{array}$

$800.170 .010 .330 .060 . \quad 0.050 .0 . \quad 0.0$.

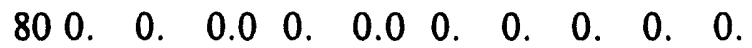

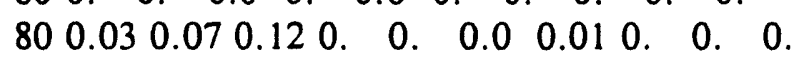

800 . $0 . \quad 0 . \quad 0.170 .030 .020 .010 .280 .010 .07$

800.010 . $\quad 0.0 . \quad 0 . \quad 0 . \quad 0.020 .200 .240 .040$.

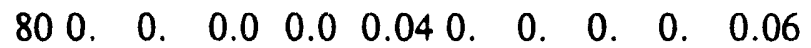

$\begin{array}{llllllllllll}80 & 0 . & 0.0 & 0.05 & 0.06 & 0 . & 0 . & 0.02 & 0 . & 0 . & 0.06\end{array}$

800 . $0 . \quad 0.0 .0 .0 .00 .0 .0 .010$.
30

31

32

33

34

35

36

37

38

39

40

41

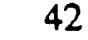

43

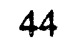

45

46 
$\begin{array}{lllllllllll}80 & 0 . & 0 . & 0.0 & 0.0 & 0.05 & 0.02 & 0.04 & 0 . & 0.0 & 0.12\end{array}$

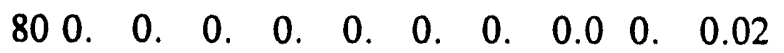

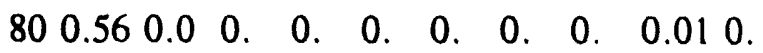

$48^{47}$

$800.040 . \quad 0 . \quad 0 . \quad 0 . \quad 0.020 .100 .0 .00 .08$

$\begin{array}{lllllllllll}80 & 0.150 . & 0.050 . & 0.03 & 0.0 & 0 . & 0 . & 0 . & 0 .\end{array}$

$\begin{array}{llllllllllllll}80 & 0 . & 0.02 & 0.07 & 0 . & 0 . & 0.11 & 0.79 & 0.01 & 0.0 & 0 .\end{array}$

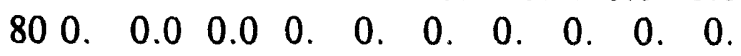

800.00 . $0.0 .220 .350 .0 .0 .140 . \quad 0$.

$\begin{array}{llllllllllllll}80 & 0 . & 0.19 & 0.0 & 0.01 & 0 . & 0.02 & 0.02 & 0.01 & 0 . & 0 .\end{array}$

80 0. $\begin{array}{lllllllllllll} & 0 . & 0 . & 0.0 & 0 . & 0 . & 0 . & 0 . & 0 . & 0 . & 56\end{array}$

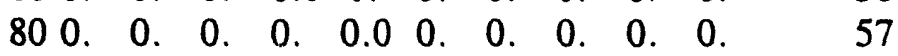

800 . $\begin{array}{llllllllllll} & 0 . & 0 . & 0 . & 0 . & 0 . & 0 . & 0 . & 0 . & 58\end{array}$

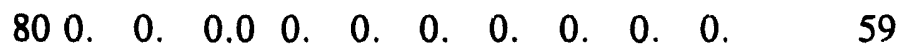

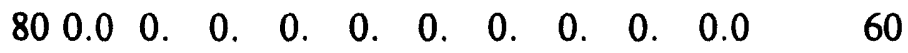

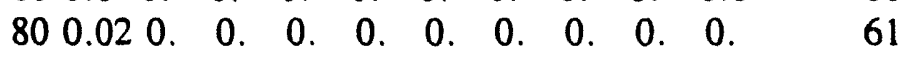

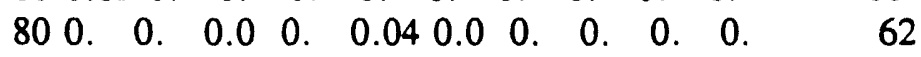

800 . $\begin{array}{lllllllllll}8 . & 0 . & 0 . & 0 . & 0.0 & 0.79 & 0.01 & 0 . & 0 . & 63\end{array}$

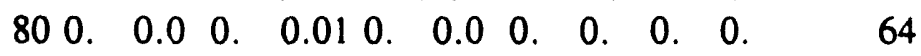

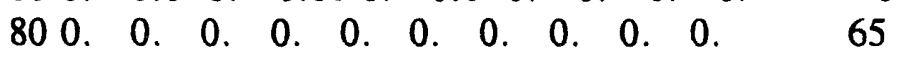

80 0. $0.0 .0 .0 .0 .050 .040 .050 .010 . \quad 0.66$

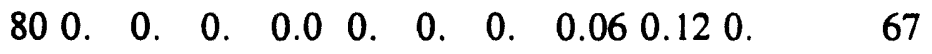

$\begin{array}{llllllllllll}80 & 0 . & 0 . & 0 . & 0 . & 0.0 & 0.02 & 0 . & 0.02 & 0 . & 0.0 & 68\end{array}$

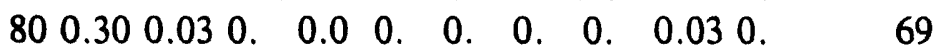

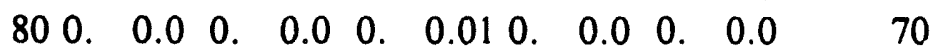

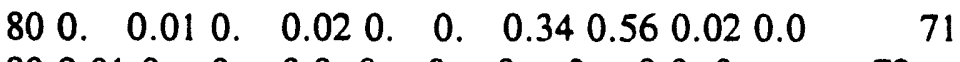

$\begin{array}{llllllllllll}80 & 0.01 & 0 . & 0 . & 0.0 & 0 . & 0 . & 0 . & 0 . & 0.0 & 0 . & 72\end{array}$

$\begin{array}{llllllllllll}80 & 0.0 & 0.0 & 0.0 & 0 . & 0.15 & 0.30 & 0 . & 0 . & 0.15 & 0.26 & 73\end{array}$

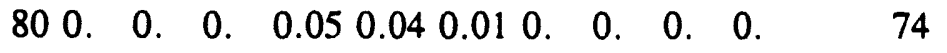

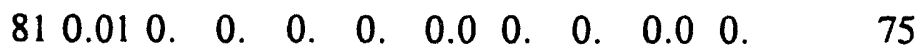

$\begin{array}{lllllllllllll}81 & 0.0 & 0.0 & 0.0 & 0.0 & 0.0 & 0 . & 0.02 & 0.0 & 0.02 & 0 . & & 76\end{array}$

$\begin{array}{llllllllllll}81 & 0.11 & 0.02 & 0.0 & 0 . & 0 . & 0.02 & 0.20 & 0.14 & 0.02 & 0.0 & 77\end{array}$

$\begin{array}{llllllllllll}81 & 0 . & 0 . & 0 . & 0 . & 0 . & 0 . & 0.0 & 0 . & 0 . & 0.0 & 78\end{array}$

$\begin{array}{llllllllllll}81 & 0 . & 0 . & 0.0 & 0.21 & 0.0 & 0.02 & 0.0 & 0 . & 0.19 & 0.07 & 79\end{array}$

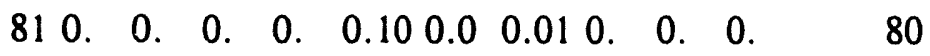

$\begin{array}{llllllllllll}81 & 0 . & 0.0 & 0.14 & 0 . & 0 . & 0.0 & 0 . & 0 . & 0 . & 0 . & 81\end{array}$

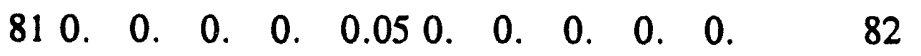

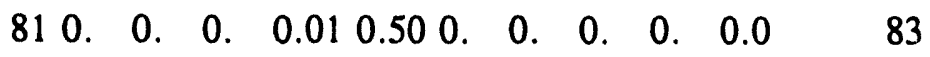

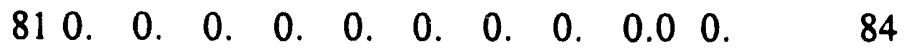

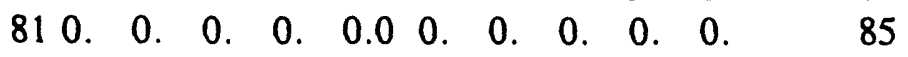

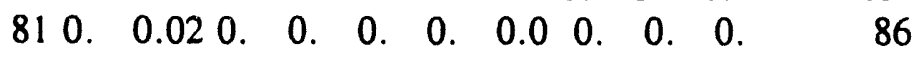

810 . $0 . \quad \begin{array}{lllllllll}8 . & 0 . & 0 . & 0 . & 0 . & 0 . & 0 . & 0 . & 87\end{array}$

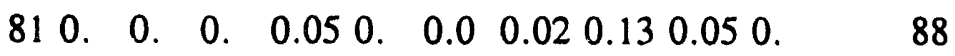

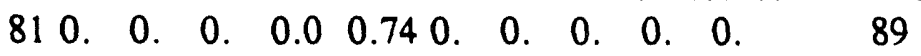

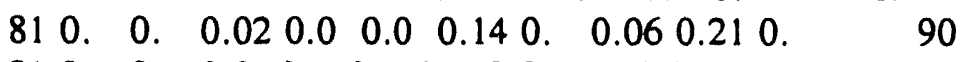

$\begin{array}{lllllllllllll}81 & 0 . & 0 . & 0.0 & 0 . & 0 . & 0 . & 0.0 & 0 . & 0.0 & 0 . & 91\end{array}$

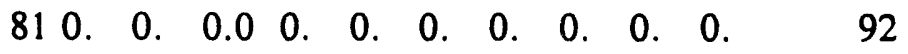

$\begin{array}{llllllllllll}810 . & 0 . & 0 . & 0 . & 0 . & 0.190 . & 0 . & 0 . & 0 . & 93\end{array}$

$\begin{array}{llllllllllll}81 & 0 . & 0 . & 0.0 & 0.0 & 0 . & 0 . & 0 . & 0 . & 0 . & 0 . & 94\end{array}$

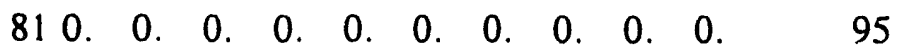

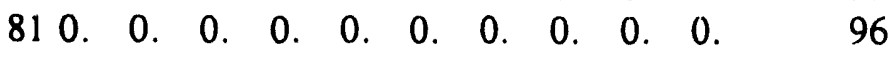




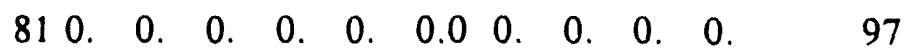

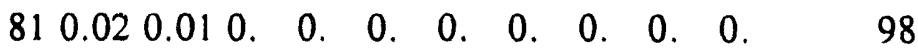

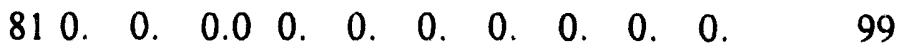

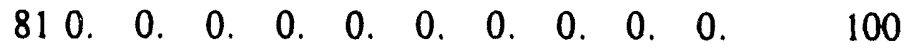
$\begin{array}{llllllllllll}81 & 0.0 & 0.0 & 0.0 & 0 . & 0 . & 0 . & 0 . & 0.0 & 0.22 & 0.38 & 101\end{array}$

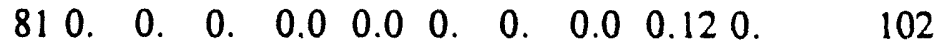

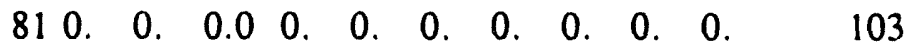

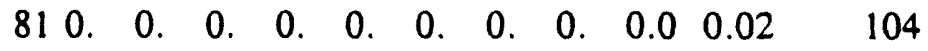

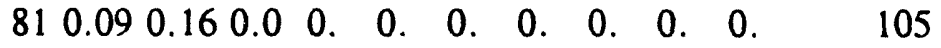
$\begin{array}{lllllllllllllll}81 & 0 . & 0 . & 0 . & 0 . & 0.01 & 0.0 & 0.47 & 0.10 & 0.13 & 0.31 & 106\end{array}$

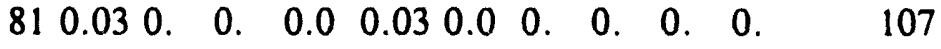
$\begin{array}{llllllllllll}81 & 0 . & 0 . & 0 . & 0.0 & 0 . & 0 . & 0.0 & 0 . & 0.02 & 0.08 & 108\end{array}$ $\begin{array}{llllllllll}810 . & 0 . & 0.040 . & 0 . & 0 . & 0.17 & 0.23 & 0.220 .0 & 109\end{array}$

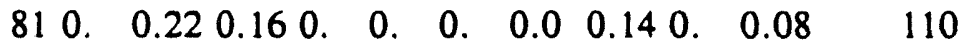

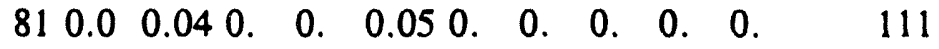

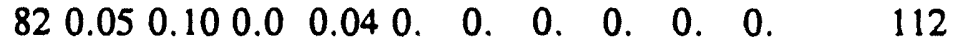
$\begin{array}{llllllllllll}82 & 0 . & 0 . & 0.0 & 0.0 & 0.0 & 0.05 & 0 . & 0 . & 0 . & 0 . & 113\end{array}$

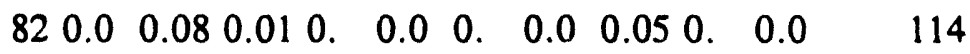

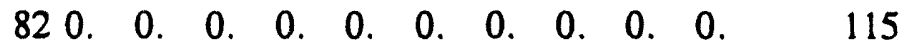
$820.0 .0 \quad 0.0 .080 . \quad 0.200 .0 .010 .040 .09$ 820.050 .0 .0 .0 .0 .0 .0 .010 .0 .090 .09

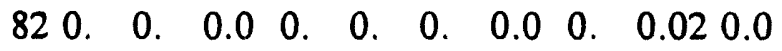

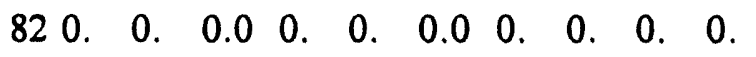
820.0 .0 .0 .0 .0 .0 .130 .010 .020 .03 820.010 .060 . 0.0 .0 .030 .360 .020 . 0.0 .0 .0

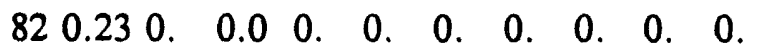

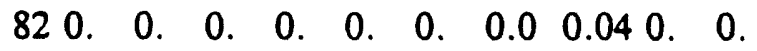

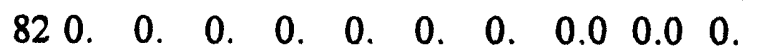

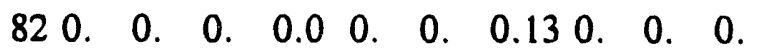

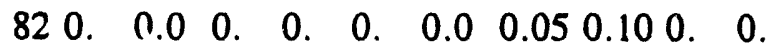

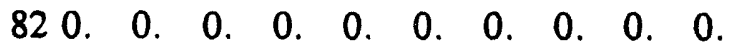

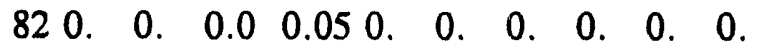
82 0. 0 . $\quad 0.0 .0 .0 .0 .010 .270 .310 .090 .02$

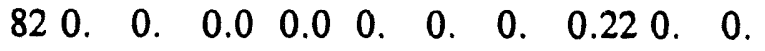

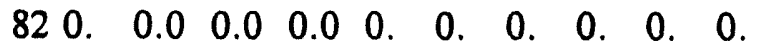

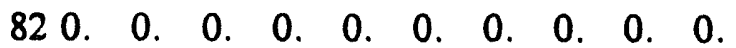

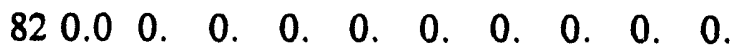

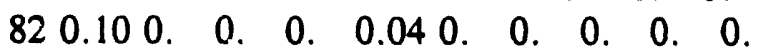

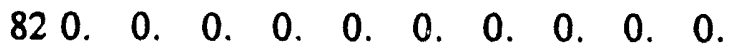

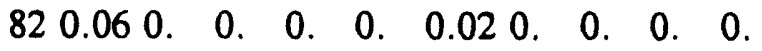

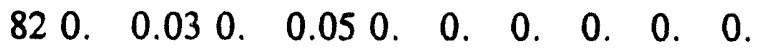
$820 . \quad 0.170 .00 .0 .0 .0 .0 .010 .250 . \quad 0$. 820.020 . 0.0 .0 .0 .030 . 0.0 .0 .0 .00$. 820.0 0. $0.0 .0 .0 . \quad 0 . \quad 0 . \quad 0 . \quad 0 . \quad 0$. 820 . 0. 0.0 .160 .150 . 0.0 .010 .010 .

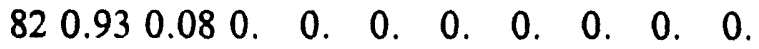
$\begin{array}{lllllllllll}82 & 0 . & 0 . & 0 . & 0 . & 0 . & 0.0 & 0 . & 0 . & 0.02 & 0.02\end{array}$ $820.110 .460 .0 \quad 0 . \quad 0 . \quad 0 . \quad 0 . \quad 0.0 .0 .04$ 820.050 .070 .140 . 0.0 .180 . 0.0 .0 .210 .10 $\begin{array}{lllllllllllllll}82 & 0 . & 0.0 & 0 . & 0 . & 0 . & 0.29 & 0.0 & 0.17 & 0.11 & 0.09\end{array}$ 
$820 . \quad 0.0 \quad 0.040 .330 .270 . \quad 0 . \quad 0 . \quad 0 . \quad 0$. $820 . \quad 0.0 \quad 0.0 .0 .0 .0 . \quad 0 . \quad 0 . \quad 0 . \quad 0$. 147

$830 . \quad 0.170 .080 .0 \quad 0 . \quad 0.500 . \quad 0.0 \quad 0 . \quad 0$. 148

830 . $0.0 \begin{array}{lllllllll}8 . & 0 . & 0 . & 0.05 & 0.0 & 0.11 & 0.12 & 0 .\end{array}$

$\begin{array}{lllllllllllllll}83 & 0 . & 0.0 & 0 . & 0.13 & 0.02 & 0.20 & 0.06 & 0.0 & 0.0 & 0 .\end{array}$

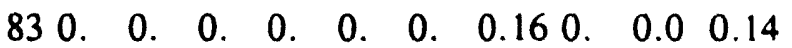
830.090 .010 .010 .020 .070 .110 .0 .070 .340 . $\begin{array}{lllllllllllllllll}83 & 0 . & 0.07 & 0 . & 0.01 & 0.01 & 0.22 & 0.0 .03 & 0 . & 0.0\end{array}$

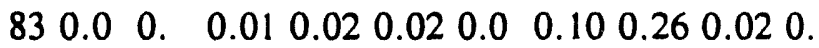
830.020 .350 . $0 . \quad 0 . \quad 0 . \quad 0 . \quad 0 . \quad 0 . \quad 0$.

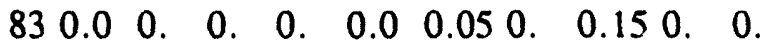

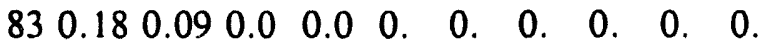

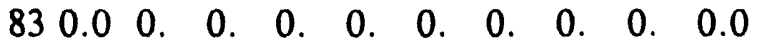

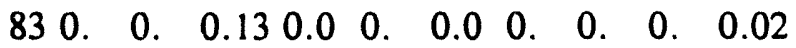
$\begin{array}{lllllllllllll}83 & 0.0 & 0 . & 0 . & 0 . & 0.03 & 0.0 & 0.39 & 0.10 & 0 . & 0 .\end{array}$

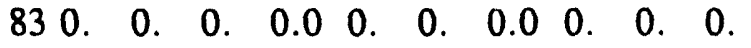

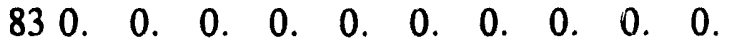

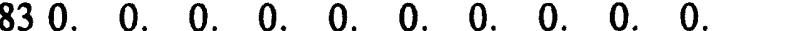
$830.080 .0 .0 .0 .040 .0 .0 .0 .070 .01 \quad 0165$ $\begin{array}{llllllllllllll}83 & 0 . & 0 . & 0.02 & 0.01 & 0 . & 0 . & 0.0 & 0.37 & 0.0 & 0.08\end{array}$ $\begin{array}{lllllllllll}83 & 0.0 & 0.03 & 0.0 & 0 . & 0 . & 0 . & 0.0 & 0 . & 0.0 & 0 .\end{array}$

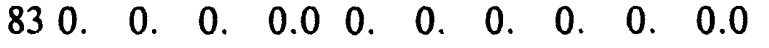
$830.0 \quad 0 . \quad 0 . \quad 0.020 .010 .230 . \quad 0.020 .0$.

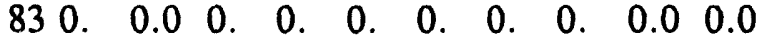

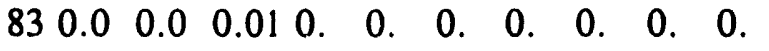
83 0. 0.0 .0 .0 .0 .0 .0 .0 .020 .020 .03

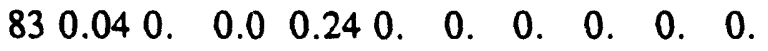

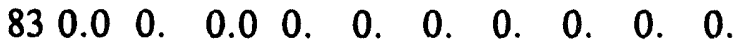

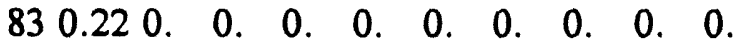
830.0 .0 .0 .0 .0 .0 .0 .0 .0 .0 .176 $\begin{array}{llllllllllll}83 & 0 . & 0 . & 0 . & 0 . & 0 . & 0 . & 0 . & 0 . & 0 . & 0.08 & 177\end{array}$

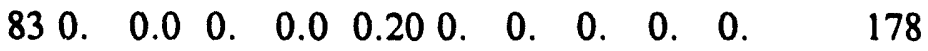
830 . $0 . \quad 0.230 .010 .150 .050 .040 .0 .040 .01$ $\begin{array}{llllllllllllllllll}83 & 0 . & 0 . & 0.07 & 0.66 & 0 . & 0.01 & 0.02 & 0.08 & 0.01 & 0.08\end{array}$ $\begin{array}{lllllllllll}83 & 0.09 & 0 . & 0.08 & 0 . & 0.05 & 0.0 & 0.42 & 0.200 & 0.0 & 0.0\end{array}$ $\begin{array}{lllllllllll}83 & 0 . & 0.060 . & 0 . & 0 . & 0.03 & 0 . & 0.05 & 0.32 & 0.0\end{array}$

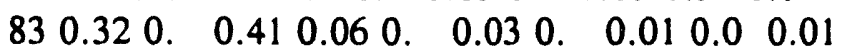
$830 . \quad 0.020 .040 .00 . \quad 0 . \quad 0 . \quad 0.060 .120 .0$ $830.090 .0 \quad 0.550$. $0.0 .0 .0 . \quad 0 . \quad 0.0$. $\begin{array}{lllllllllll}84 & 0.0 & 0.02 & 0.04 & 0 . & 0.0 & 0 . & 0.0 & 0 . & 0 . & 0.02\end{array}$ $840 . \quad 0.0$ 0. $\begin{array}{llllllllllll} & 0 . & 0 . & 0 . & 0 . & 0 . & 0 .\end{array}$

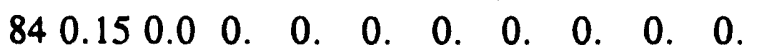

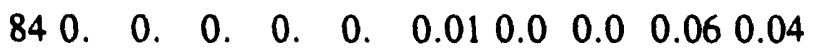
$\begin{array}{lllllllllll}84 & 0 . & 0.01 & 0.03 & 0.18 & 0 . & 0.13 & 0 . & 0 . & 0 . & 0.02\end{array}$

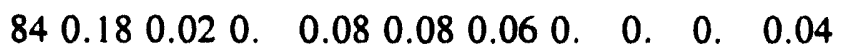

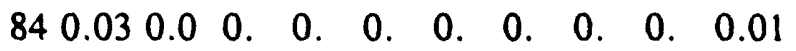
$\begin{array}{llllllllllllllllll}84 & 0 . & 0 . & 0.14 & 0.0 & 0.03 & 0.03 & 0 . & 0.02 & 0.11 & 0.43\end{array}$ $\begin{array}{llllllllllll}84 & 0.10 & 0 . & 0.0 & 0 . & 0.03 & 0.01 & 0 . & 0.07 & 0 . & 0 .\end{array}$ $\begin{array}{lllllllllll}84 & 0 . & 0 . & 0 . & 0.0 & 0.13 & 0 . & 0 . & 0.22 & 0 . & 0.0\end{array}$ 167 168 170 171 172 173 174 175 76 


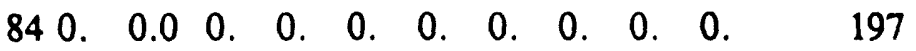

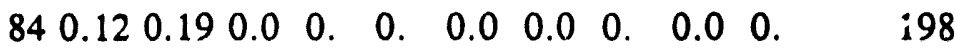

$840.00 .040 .0 .050 .070 . \quad 0.0 .0 .0 .03 \quad 199$

840 . $0 . \quad 0.120 .00 . \quad 0.050 .0 .0 . \quad 0.200$

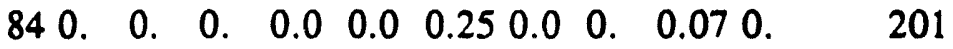

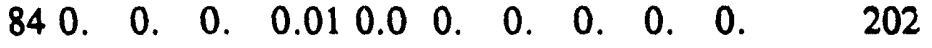

$840 . \quad 0.240 .030 .0 .0 .0 .0 .0 .00 .0 .23 \quad 203$

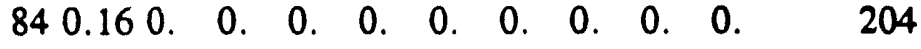

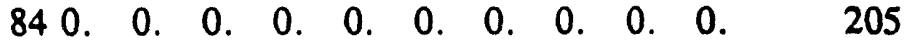

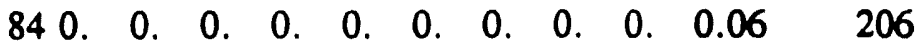

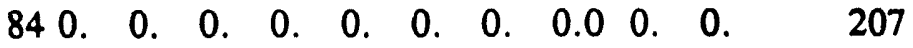

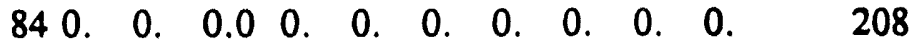

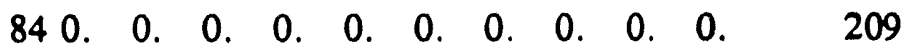

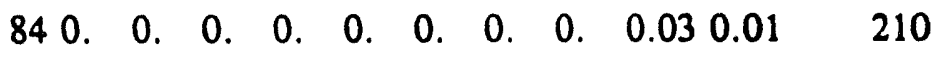

840 . $0 . \begin{array}{llllllllll}0 . & 0 . & 0 . & 0 . & 0 . & 0 . & 0 . & 0 . & 211\end{array}$

840 . $0.0 .00 .110 . \quad 0.200 .070 .0 . \quad 0 . \quad 212$

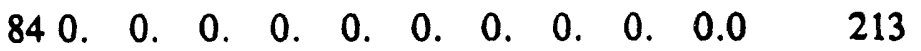

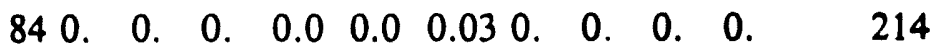

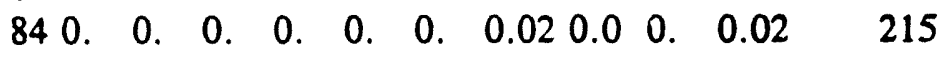

840 . $0.0 . \quad 0 . \quad 0 . \quad 0.030 .250 .010 .0 . \quad 0.216$

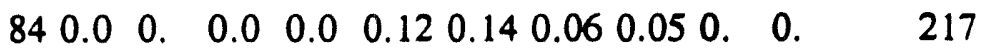

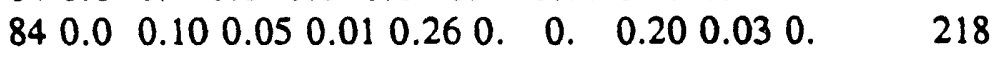

$840.0 .490 .010 .020 .0 . \quad 0.0 .0 .0 . \quad 0.219$

840 . 0 0. $0.0 .140 .0 .050 .050 .00 .0 . \quad 220$

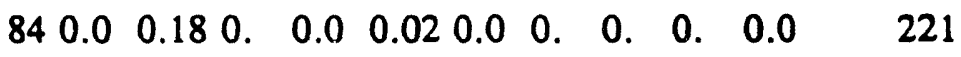

$\begin{array}{llllllllllll}84 & 0 . & 0.0 & 0.0 & 0.13 & 0 . & 0.0 & 0 . & 0 . & 0 . & 0 . & 222\end{array}$

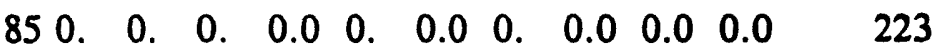

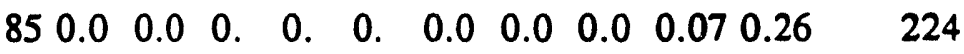

$\begin{array}{lllllllllllll}85 & 0 . & 0.01 & 0.0 & 0.0 & 0.0 & 0.0 & 0.0 & 0 . & 0 . & 0 . & 225\end{array}$

$\begin{array}{llllllllllllllll}85 & 0.0 & 0.26 & 0 . & 0 . & 0.0 & 0.01 & 0.03 & 0.27 & 0.12 & 0.07 & 226\end{array}$

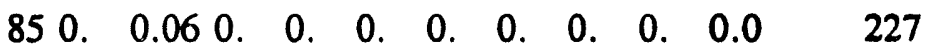

850 . $0 . \begin{array}{llllllllll} & 0 . & 0 . & 0 . & 0 . & 0 . & 0 . & 0 . & 0 . & 228\end{array}$

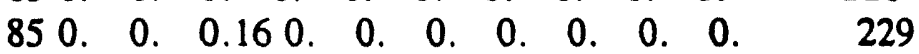

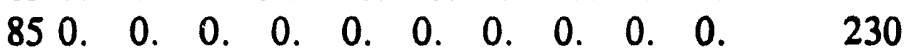

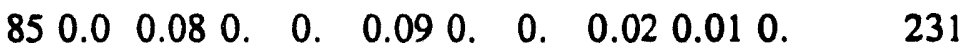

850 . $0 . \begin{array}{lllllllllll} & 0 . & 0 . & 0 . & 0 . & 0 . & 0 . & 0 . & 0 . & 232\end{array}$

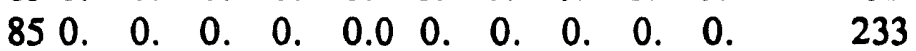

850.0 .010 .0 .00 .0 .0 .0 .0 .0 .234

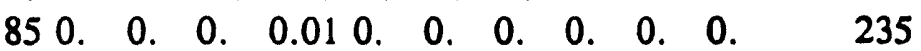

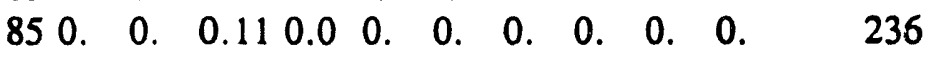

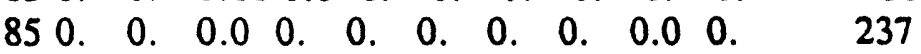

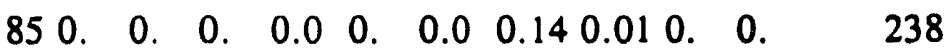

850 . $0 . \begin{array}{llllllllll}8 & 0.0 & 0 . & 0 . & 0 . & 0 . & 0 . & 0 . & 239\end{array}$

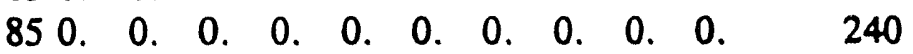

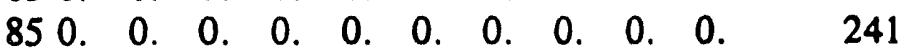

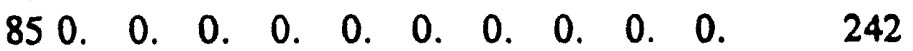

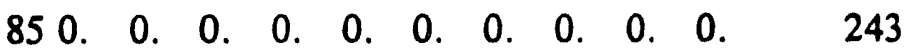

850.0 .120 .0 .0 .0 .010 .0 .0 .0 .0 .244

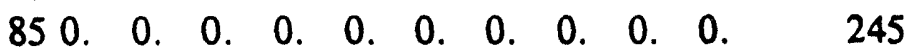

850 . 0.0 .0 .0 .0 .0 .0 .0 .0 .0 .246 


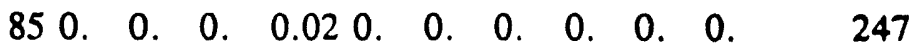

$\begin{array}{llllllllllll}85 & 0.10 & 0.07 & 0.06 & 0.04 & 0 . & 0.11 & 0.04 & 0 . & 0.03 & 0.16\end{array}$

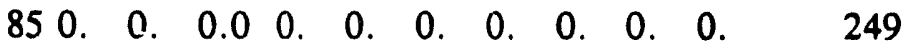

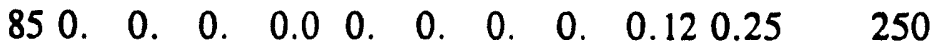

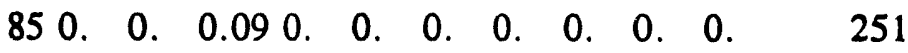

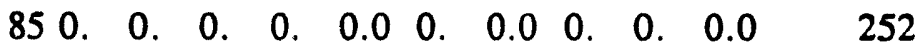

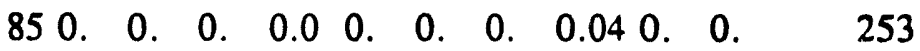

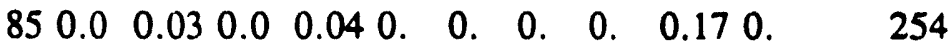

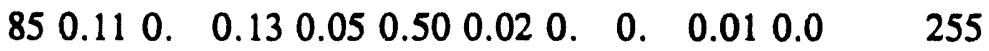

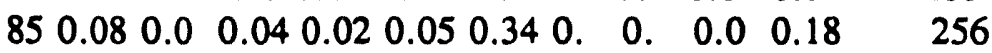

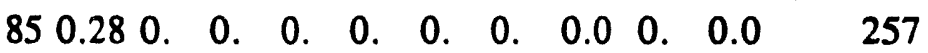

$\begin{array}{llllllllllll}85 & 0.0 & 0 . & 0.0 & 0.0 & 0.0 & 0.0 & 0.0 & 0.01 & 0.0 & 0.0 & 258\end{array}$

$\begin{array}{llllllllllll}85 & 0.0 & 0.0 & 0.0 & 0.0 & 0.0 & 0 . & 0 . & 0 . & 0 . & 0 . & 259\end{array}$

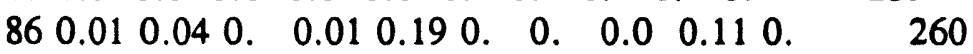

860 . $0 . \quad 0 . \quad 0 . \quad 0.060 .200 .100 .060$. $0 . \quad 261$

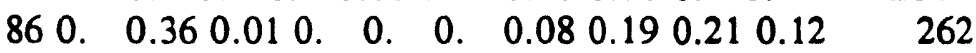

860.010 .020 .050 .010 .210 .00 . 0 . 0.0 .0 .263

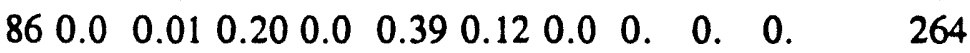

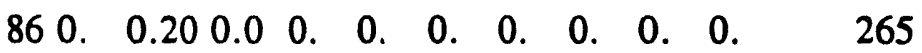

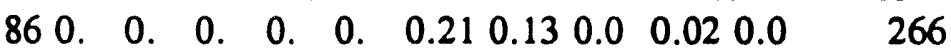

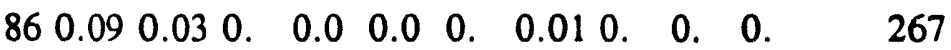

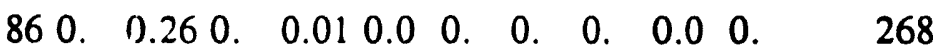

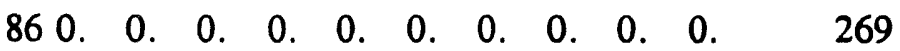

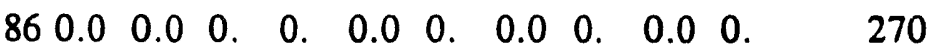

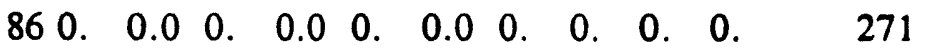

$\begin{array}{lllllllllllll}86 & 0.0 & 0.01 & 0.01 & 0 . & 0.01 & 0.20 & 0 . & 0 . & 0 . & 0.0 & 272\end{array}$

$\begin{array}{llllllllllll}86 & 0 . & 0 . & 0 . & 0 . & 0 . & 0 . & 0.0 & 0.0 & 0.0 & 0 . & 273\end{array}$

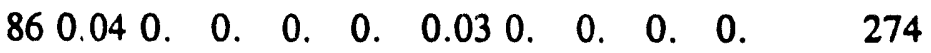

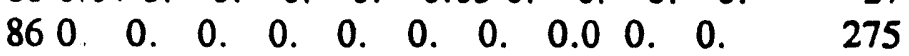

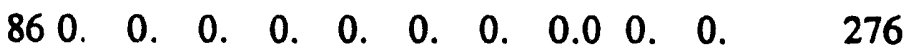

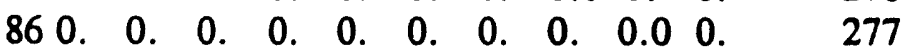

860 . $0 . \quad 0.070 .030 .100$. $0 . \quad 0 . \quad 0.010 . \quad 278$

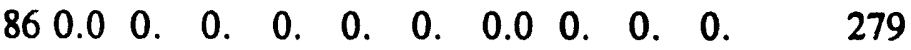

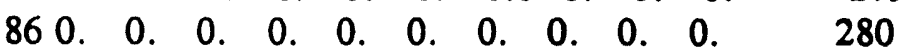

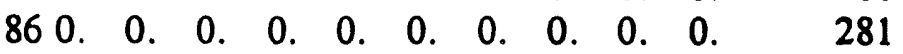

860 . 0.0 .0 .0 .0 .0 .0 .0 .0 .0 .282

860 . 0.0 .0 .0 .0 .0 .0 .0 .0 .0 .283

860.02 0. $0.0 .0 .0 . \quad 0.0 .0 .0 . \quad 0.284$

$\begin{array}{lllllllllllll}86 & 0 . & 0 . & 0.0 & 0 . & 0 . & 0.03 & 0 . & 0.54 & 0.0 & 0.06 & 285\end{array}$

860 . $0.040 .0 .0 .0 .210 .0 .00 .0 .01 \quad 286$

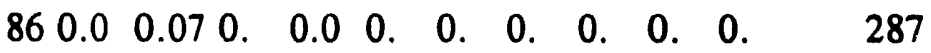

860 . $0 . \begin{array}{llllllllll} & 0 . & 0 . & 0 . & 0 . & 0 . & 0 . & 0 . & 288\end{array}$

860 . $0 . \quad 0.0 .0 .0 . \quad 0.0 .030 .080 . \quad 289$

860.0 .180 .00 .0 .0 .0 .0 .0 .0 .020 .290

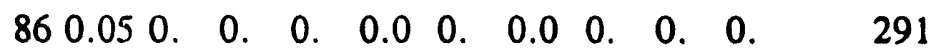

$\begin{array}{llllllllllll}86 & 0 . & 0 . & 0 . & 0.0 & 0 . & 0.0 & 0.0 & 0.17 & 0 . & 0.11 & 292\end{array}$

$860.110 .190 . \quad 0.0 .0 .0 .0 .0 .110 .190 .0 \quad 293$

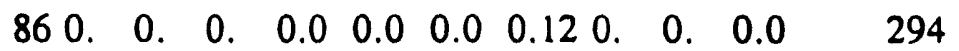

$\begin{array}{llllllllllll}86 & 0.01 & 0.08 & 0.04 & 0 . & 0.0 & 0.03 & 0 . & 0.03 & 0.08 & 0.04 & 295\end{array}$

$860.010 .030 .00 . \quad 0.00 . \quad 0.0 . \quad 0 . \quad 0 . \quad 296$ 
$870.200 .0 \quad 0.0 \quad 0.0 . \quad 0 . \quad 0.0 . \quad 0 . \quad 0 . \quad 297$

$870 . \quad 0 . \quad 0.120 .020 .0 .0 .00 .00 .0 .0 \quad 298$

$870 . \quad 0.00 .010 .060 .160 .080 .020 .0 . \quad 0 . \quad 299$

$870.130 .0 .00 .0 . \quad 0.0 . \quad 0.0 .0 . \quad 300$

$870 . \quad 0.030 .010 .110 .0 \quad 0.0 \quad 0.0 \quad 0 . \quad 0.0 . \quad 301$

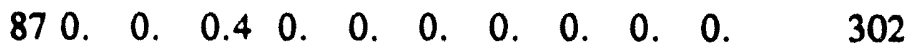

$\begin{array}{llllllllllll}87 & 0.0 & 0.08 & 0.0 & 0.02 & 0.02 & 0 . & 0.04 & 0.0 & 0.01 & 0.05 & 303\end{array}$

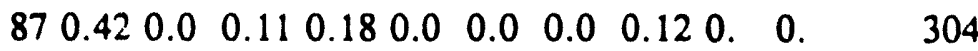

87 0. $0 . \begin{array}{llllllllll} & 0 . & 0 . & 0 . & 0 . & 0 . & 0 . & 0 . & 0 . & 305\end{array}$

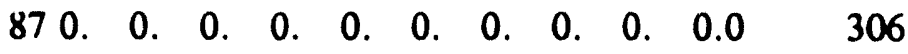

870.0 0. $0.0 .0 .0 . \quad 0.0 .120 .0 .0 . \quad 0.307$

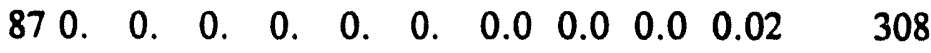

87 0. $0 . \begin{array}{llllllllll} & 0 . & 0 . & 0 . & 0 . & 0 . & 0 . & 0 . & 0 . & 309\end{array}$

$870.0 .0 \quad 0.220 .0 .0 .0 .0 .0 .0 .0 .03 \quad 310$

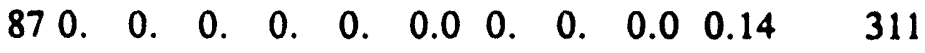

870.0 0. 0.0 .0 .0 .0 .0 .0 .0 .010 .312

$870 . \quad 0 . \quad 0 . \quad 0 . \quad 0.010 .030 .0 .0 . \quad 0 . \quad 313$

870.030 .0 .0 .0 .0 .0 .0 .0 .0 .314

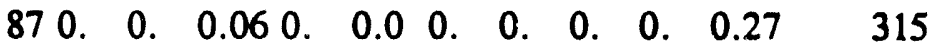

87 0. $0.0 . \quad 0.0 .0 .0 .0 .050 .120 . \quad 316$

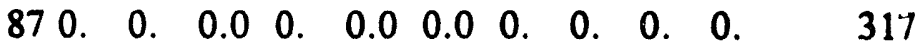

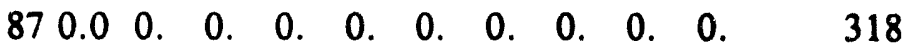

$870 . \quad 0 . \quad 0 . \quad 0 . \quad 0.040 .010 .0 .0 . \quad 0 . \quad 319$

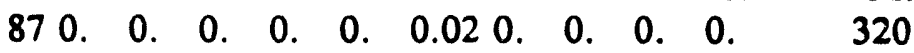

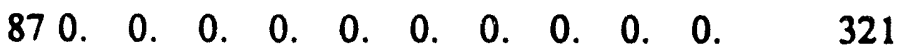

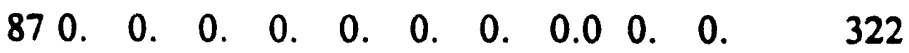

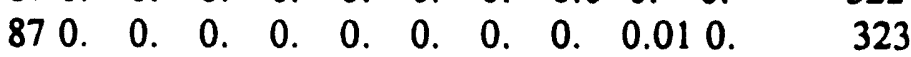

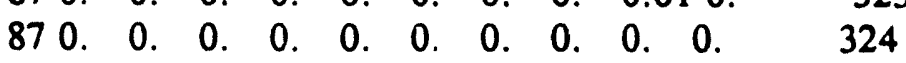

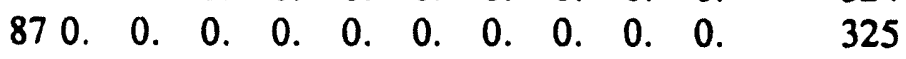

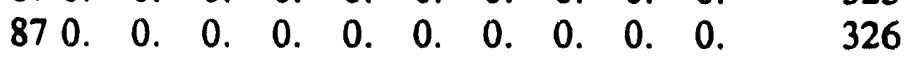

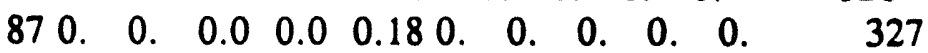

$870.0 . \quad 0.00 . \quad 0.020 .020 .100 .0 . \quad 0 . \quad 328$

87 0. 0 . $\begin{array}{lllllllllll} & 0 . & 0 . & 0.0 & 0 . & 0.0 & 0 . & 0 . & 329\end{array}$

$870 . \quad 0 . \quad 0 . \quad 0.080 .110 .260 .120 .010 .070 .15 \quad 330$

$870 . \quad 0.0 \quad 0.550 .0 . \quad 0.0 .0 .00 .090 .19 \quad 331$

$\begin{array}{lllllllllllll}87 & 0 . & 0 . & 0.0 & 0.0 & 0 . & 0.0 & 0 . & 0 . & 0.0 & 0 . & & 332\end{array}$

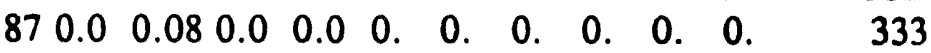

$\begin{array}{lllllllllllll}88 & 0 . & 0.0 & 0.0 & 0.02 & 0.0 & 0 . & 0.02 & 0.13 & 0.07 & 0.16 & 334\end{array}$

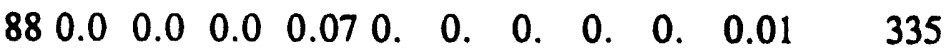

88 . $\begin{array}{llllllllll}8 . & 0 . & 0 . & 0 . & 0 . & 0.0 & 0.0 & 0 . & 0.0 & 336\end{array}$

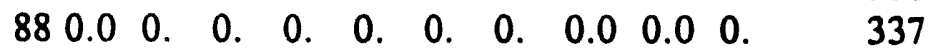

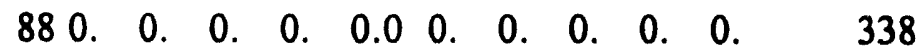

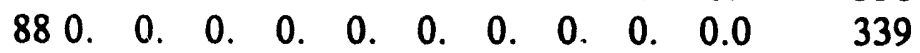

$\begin{array}{llllllllllllll}88 & 0 . & 0.0 & 0 & 0.06 & 0.0 & 0.01 & 0.21 & 0.19 & 0 . & 0 . & 340\end{array}$

88 0. $0 . \quad 0.0 . \quad 0.0 .0 .0 . \quad 0.0 . \quad 341$

$\begin{array}{llllllllllll}88 & 0 . & 0.03 & 0 . & 0 . & 0 . & 0.0 & 0 . & 0.09 & 0.01 & 0 . & 342\end{array}$

$\begin{array}{llllllllllll}88 & 0 . & 0.0 & 0.01 & 0.02 & 0 . & 0.0 & 0.0 & 0 . & 0 . & 0 . & 343\end{array}$

88 o. $\begin{array}{llllllllll}8 . & 0 . & 0 . & 0 . & 0 . & 0 . & 0.36 & 0.0 & 0.03 & 344\end{array}$

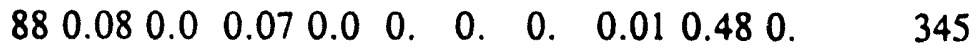

880.060 .0 .010 .0 0. $0.0 . \quad 0.0 .0 .010 .346$ 
$\begin{array}{llllllllllll}88 & 0 . & 0 . & 0.0 & 0 . & 0 . & 0 . & 0.0 & 0 . & 0.02 & 0 . & 347\end{array}$

880 . 0 . $\begin{array}{llllllllll}8 . & 0 . & 0 . & 0 . & 0 . & 0.01 & 0.28 & 0 . & 348\end{array}$

$\begin{array}{llllllllllll}88 & 0 . & 0 . & 0.02 & 0.01 & 0.0 & 0.01 & 0.07 & 0 . & 0.0 & 0.0 & 349\end{array}$

$88 \begin{array}{lllllllllll}88 & 0 . & 0 . & 0 . & 0 . & 0 . & 0 . & 0 . & 0 . & 0 . & 350\end{array}$

88 0. $\begin{array}{llllllllll}8 . & 0 . & 0 . & 0 . & 0 . & 0 . & 0 . & 0 . & 0 . & 351\end{array}$

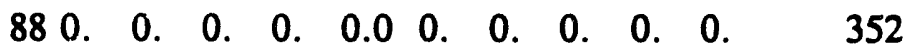

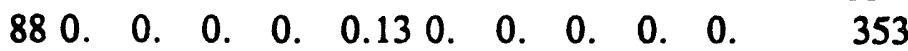

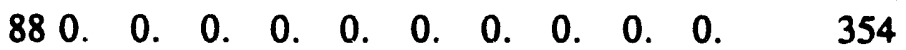

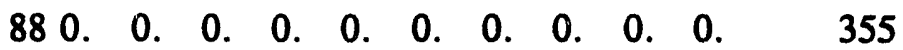

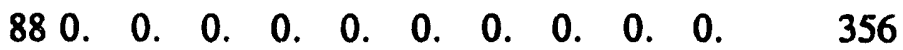

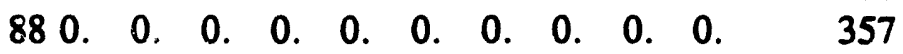

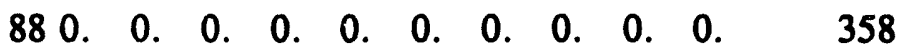

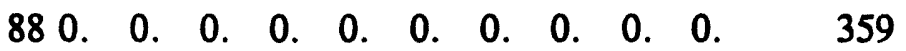

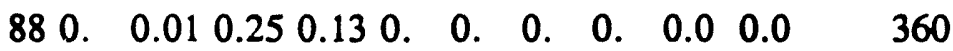

88 0. $0 . \quad 0 . \quad 0 . \quad 0 . \quad 0 . \quad 0 . \quad 0 . \quad 0 . \quad 0 . \quad 361$

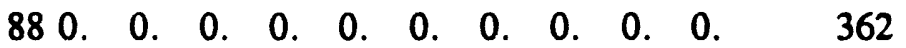

880.0 .010 .0 .0 .0 .0 .0 .0 .0 .0 .363

$\begin{array}{llllllllllll}88 & 0 . & 0 . & 0.0 & 0 . & 0 . & 0 . & 0.10 & 0 . & 0.02 & 0.09 & 364\end{array}$

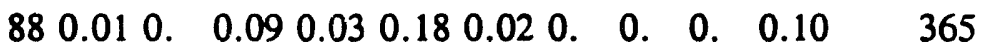

$\begin{array}{llllllllllll}88 & 0.01 & 0.02 .0 & 0 . & 0.0 & 0 . & 0.01 & 0.10 & 0 . & 0.040 . & 366\end{array}$

$\begin{array}{lllllllllllll}88 & 0 . & 0.0 & 0 . & 0 . & 0 . & 0 . & 0 . & 0.0 & 0.0 & 0.02 & 367\end{array}$

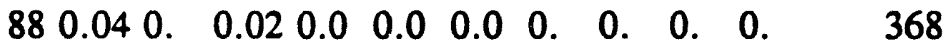

88 0. 0 . $\quad 0.050 .010 .130 .070 .060 .0 \quad 0.0 \quad 0 . \quad 369$

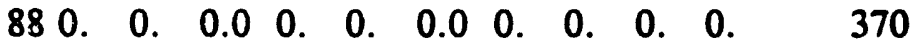


DOE/RL-93-99, Rev. 0

Attachment B-8. HELP Model Data File: DATA7 - Temperature Data for Hanford, Washington.

$\begin{array}{llllllllllll}79 & 29.7 & 26.5 & 25.7 & 21.6 & 26.5 & 34.6 & 28.1 & 28.7 & 30.6 & 22.9 & 1\end{array}$

$\begin{array}{llllllllllll}79 & 26.7 & 22.7 & 23.2 & 18.7 & 15.2 & 19.6 & 25.7 & 28.2 & 39.7 & 44.3 & 2\end{array}$

$\begin{array}{llllllllllll}79 & 48.9 & 40.6 & 44.6 & 45.3 & 40.4 & 36.0 & 36.1 & 35.8 & 34.2 & 37.6 & 3\end{array}$

$\begin{array}{llllllllllll}79 & 37.2 & 34.8 & 32.8 & 37.9 & 29.9 & 30.2 & 34.3 & 44.2 & 45.1 & 42.9 & 4\end{array}$

$\begin{array}{llllllllllll}79 & 49.4 & 44.3 & 44.8 & 51.0 & 46.6 & 45.8 & 42.0 & 44.8 & 44.7 & 39.5 & 5\end{array}$

$\begin{array}{llllllllllll}79 & 42.5 & 39.3 & 36.5 & 33.8 & 38.9 & j 2.7 & 36.6 & 42.2 & 43.4 & 39.1 & 6\end{array}$

$\begin{array}{llllllllllll}79 & 29.3 & 23.0 & 35.6 & 39.7 & 32.2 & 31.6 & 43.2 & 33.1 & 36.0 & 31.9 & 7\end{array}$

$\begin{array}{llllllllllll}79 & 30.1 & 28.0 & 33.8 & 39.4 & 46.8 & 42.0 & 36.4 & 46.3 & 57.4 & 47.2 & 8\end{array}$

$\begin{array}{llllllllllll}79 & 44.9 & 42.4 & 42.7 & 52.1 & 55.0 & 54.6 & 48.4 & 50.9 & 55.8 & 56.4 & 9\end{array}$

$\begin{array}{llllllllllll}79 & 47.0 & 56.7 & 55.6 & 41.6 & 40.4 & 33.6 & 34.8 & 37.8 & 30.0 & 50.7 & 10\end{array}$

$\begin{array}{llllllllllll}79 & 37.8 & 37.6 & 45.0 & 51.9 & 46.7 & 50.5 & 58.8 & 64.0 & 68.9 & 66.3 & 11\end{array}$

$\begin{array}{llllllllllll}79 & 68.0 & 54.0 & 50.9 & 47.8 & 50.9 & 48.7 & 53.3 & 46.0 & 46.3 & 50.5 & 12\end{array}$

$\begin{array}{llllllllllll}79 & 47.3 & 52.6 & 52.6 & 58.2 & 57.0 & 62.1 & 57.6 & 55.2 & 61.4 & 51.7 & 13\end{array}$

$\begin{array}{llllllllllll}79 & 55.0 & 59.8 & 60.1 & 55.3 & 64.0 & 58.3 & 54.6 & 57.0 & 58.9 & 56.0 & 14\end{array}$

$\begin{array}{llllllllllll}79 & 48.7 & 57.7 & 58.3 & 47.0 & 53.1 & 48.8 & 58.2 & 61.6 & 60.7 & 69.2 & 15\end{array}$

$\begin{array}{llllllllllll}79 & 66.8 & 67.3 & 79.2 & 68.7 & 59.8 & 62.9 & 70.1 & 70.0 & 69.2 & 68.7 & 16\end{array}$

$\begin{array}{llllllllllll}79 & 68.5 & 71.5 & 72.1 & 61.2 & 56.8 & 57.7 & 62.0 & 71.3 & 76.8 & 64.7 & 17\end{array}$

$\begin{array}{llllllllllll}79 & 68.9 & 70.3 & 71.4 & 69.2 & 70.8 & 70.8 & 73.7 & 68.2 & 66.2 & 69.6 & 18\end{array}$

$\begin{array}{llllllllllll}79 & 69.7 & 66.9 & 66.7 & 65.6 & 66.7 & 72.6 & 73.5 & 74.3 & 75.5 & 78.6 & 19\end{array}$

$\begin{array}{llllllllllll}79 & 74.0 & 71.9 & 72.6 & 79.9 & 82.7 & 84.1 & 81.1 & 77.7 & 79.9 & 77.5 & 20\end{array}$

$\begin{array}{llllllllllll}79 & 81.3 & 79.9 & 81.8 & 80.8 & 74.4 & 72.1 & 72.2 & 68.3 & 62.8 & 61.6 & 21\end{array}$

$\begin{array}{llllllllllll}79 & 58.8 & 62.2 & 63.7 & 64.5 & 60.5 & 58.6 & 58.8 & 64.0 & 69.7 & 72.3 & 22\end{array}$

$\begin{array}{llllllllllll}79 & 75.2 & 79.9 & 74.0 & 76.5 & 64.1 & 57.6 & 58.9 & 53.0 & 57.9 & 68.4 & 23\end{array}$

$\begin{array}{llllllllllll}79 & 61.4 & 54.6 & 66.3 & 67.9 & 69.1 & 69.1 & 68.7 & 65.1 & 64.3 & 61.3 & 24\end{array}$

$\begin{array}{llllllllllll}79 & 55.9 & 55.7 & 55.3 & 51.2 & 53.7 & 55.3 & 64.0 & 50.7 & 50.7 & 49.7 & 25\end{array}$

$\begin{array}{llllllllllll}79 & 50.6 & 50.6 & 51.7 & 53.5 & 55.1 & 44.5 & 48.4 & 54.5 & 51.4 & 64.2 & 26\end{array}$

$\begin{array}{llllllllllll}79 & 61.6 & 62.0 & 60.6 & 61.3 & 59.7 & 57.8 & 62.5 & 60.0 & 54.6 & 64.2 & 27\end{array}$

$\begin{array}{llllllllllll}79 & 61.9 & 66.7 & 60.4 & 58.8 & 55.5 & 54.9 & 64.4 & 54.3 & 61.8 & 65.9 & 28\end{array}$

$\begin{array}{llllllllllll}79 & 60.3 & 65.3 & 65.3 & 63.8 & 63.9 & 53.8 & 49.8 & 52.9 & 55.0 & 46.5 & 29\end{array}$

$\begin{array}{llllllllllll}79 & 48.4 & 46.1 & 42.6 & 52.2 & 42.9 & 40.6 & 38.5 & 40.2 & 52.1 & 51.8 & 30\end{array}$

$\begin{array}{llllllllllll}79 & 49.7 & 51.1 & 48.1 & 53.2 & 53.5 & 44.9 & 48.3 & 51.0 & 47.4 & 50.6 & 31\end{array}$

$\begin{array}{llllllllllll}79 & 49.1 & 51.8 & 53.9 & 56.5 & 57.5 & 55.0 & 51.5 & 46.6 & 55.4 & 51.7 & 32\end{array}$

$\begin{array}{llllllllllll}79 & 48.7 & 38.4 & 45.4 & 44.9 & 34.7 & 32.6 & 29.6 & 30.0 & 38.3 & 41.5 & 33\end{array}$

$\begin{array}{llllllllllll}79 & 33.9 & 34.0 & 45.0 & 34.4 & 39.6 & 32.6 & 36.1 & 30.9 & 30.5 & 39.3 & 34\end{array}$

$\begin{array}{llllllllllll}79 & 34.4 & 35.9 & 39.9 & 30.5 & 23.0 & 19.9 & 14.0 & 12.4 & 24.7 & 37.0 & 35\end{array}$

$\begin{array}{llllllllllll}79 & 39.4 & 29.0 & 26.2 & 15.5 & 17.0 & 29.2 & 35.9 & 42.1 & 40.7 & 41.0 & 36\end{array}$

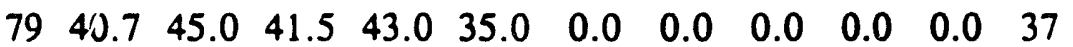

$\begin{array}{llllllllllll}80 & 34.8 & 30.9 & 29.6 & 26.1 & 32.4 & 36.5 & 35.1 & 27.7 & 18.6 & 20.3 & 38\end{array}$

$\begin{array}{llllllllllll}80 & 11.9 & 19.4 & 10.7 & 11.5 & 15.6 & 18.8 & 25.2 & 28.8 & 31.3 & 27.4 & 39\end{array}$

$\begin{array}{llllllllllll}80 & 31.3 & 25.7 & 28.3 & 22.4 & 22.3 & 17.2 & 27.0 & 29.7 & 23.9 & 21.1 & 40\end{array}$

$\begin{array}{llllllllllll}80 & 25.6 & 34.3 & 29.7 & 29.2 & 34.0 & 31.1 & 30.9 & 37.2 & 39.1 & 46.3 & 41\end{array}$

$\begin{array}{llllllllllll}80 & 43.2 & 40.6 & 42.0 & 30.8 & 24.5 & 31.7 & 36.3 & 26.3 & 27.2 & 32.6 & 42\end{array}$

$\begin{array}{llllllllllll}80 & 34.2 & 35.8 & 30.4 & 34.7 & 36.7 & 31.1 & 30.6 & 36.2 & 31.0 & 30.5 & 43\end{array}$

$\begin{array}{llllllllllll}80 & 31.6 & 26.0 & 26.4 & 24.4 & 35.6 & 47.4 & 46.7 & 45.4 & 41.3 & 37.0 & 44\end{array}$

$\begin{array}{llllllllllll}80 & 45.9 & 50.6 & 50.4 & 40.7 & 46.1 & 51.4 & 44.2 & 35.5 & 32.5 & 30.4 & 45\end{array}$

$\begin{array}{llllllllllll}80 & 38.6 & 39.6 & 53.0 & 59.0 & 57.2 & 59.1 & 48.6 & 52.0 & 48.7 & 54.9 & 46\end{array}$

$\begin{array}{llllllllllll}80 & 51.4 & 50.1 & 53.6 & 50.5 & 40.9 & 41.5 & 41.7 & 46.9 & 49.3 & 43.2 & 47\end{array}$ 
$\begin{array}{llllllllllll}80 & 53.4 & 66.2 & 60.6 & 64.3 & 55.1 & 49.3 & 42.0 & 50.1 & 53.6 & 41.7 & 48\end{array}$

$\begin{array}{llllllllllll}80 & 51.8 & 57.0 & 62.8 & 68.2 & 60.6 & 49.5 & 49.0 & 41.7 & 54.7 & 55.6 & 49\end{array}$

$\begin{array}{llllllllllll}80 & 53.2 & 57.7 & 45.9 & 57.1 & 64.1 & 52.4 & 53.8 & 60.2 & 61.0 & 56.0 & 50\end{array}$

$\begin{array}{llllllllllll}80 & 57.0 & 56.8 & 50.9 & 45.1 & 39.3 & 37.4 & 40.4 & 45.6 & 46.6 & 56.5 & 51\end{array}$

$\begin{array}{llllllllllll}80 & 56.8 & 61.8 & 59.4 & 56.0 & 56.1 & 55.9 & 56.0 & 57.9 & 47.4 & 54.9 & 52\end{array}$

$\begin{array}{llllllllllll}80 & 58.6 & 58.2 & 53.7 & 49.4 & 48.5 & 62.9 & 64.2 & 66.3 & 66.7 & 73.3 & 53\end{array}$

$\begin{array}{llllllllllll}80 & 71.0 & 69.0 & 69.3 & 61.7 & 59.5 & 57.5 & 56.1 & 51.8 & 53.1 & 61.1 & 54\end{array}$

$\begin{array}{llllllllllll}80 & 65.0 & 65.9 & 73.0 & 67.4 & 72.0 & 65.5 & 59.6 & 60.9 & 66.8 & 72.2 & 55\end{array}$

$\begin{array}{llllllllllll}80 & 78.4 & 69.4 & 75.7 & 73.0 & 72.9 & 76.6 & 76.1 & 71.3 & 76.5 & 79.5 & 56\end{array}$

$\begin{array}{llllllllllll}80 & 80.4 & 85.1 & 77.8 & 80.1 & 70.8 & 70.5 & 69.5 & 67.8 & 73.2 & 70.2 & 57\end{array}$

$\begin{array}{llllllllllll}80 & 67.6 & 69.2 & 70.8 & 76.2 & 74.4 & 78.1 & 75.6 & 75.4 & 69.1 & 75.7 & 58\end{array}$

$\begin{array}{llllllllllll}80 & 74.6 & 70.7 & 72.5 & 68.7 & 70.4 & 72.6 & 70.5 & 67.5 & 64.7 & 70.8 & 59\end{array}$

$\begin{array}{llllllllllll}80 & 77.3 & 78.8 & 68.3 & 71.6 & 68.0 & 73.1 & 64.9 & 67.0 & 62.4 & 69.2 & 60\end{array}$

$\begin{array}{llllllllllll}80 & 67.2 & 68.5 & 61.8 & 67.7 & 72.8 & 69.4 & 65.0 & 63.0 & 63.0 & 67.0 & 61\end{array}$

$\begin{array}{llllllllllll}80 & 63.9 & 61.5 & 69.7 & 74.3 & 74.5 & 74.1 & 71.9 & 69.8 & 68.9 & 65.6 & 62\end{array}$

$\begin{array}{llllllllllll}80 & 61.9 & 63.7 & 65.6 & 64.2 & 72.0 & 77.2 & 66.0 & 55.3 & 56.5 & 60.0 & 63\end{array}$

$\begin{array}{llllllllllll}80 & 56.6 & 55.8 & 55.8 & 56.7 & 51.5 & 60.3 & 62.3 & 62.4 & 52.1 & 56.6 & 64\end{array}$

$\begin{array}{llllllllllll}80 & 56.1 & 51.8 & 50.7 & 46.3 & 45.4 & 53.9 & 45.7 & 49.3 & 47.7 & 51.1 & 65\end{array}$

$\begin{array}{llllllllllll}80 & 51.4 & 49.7 & 49.2 & 44.5 & 48.6 & 53.1 & 59.7 & 66.2 & 61.7 & 62.8 & 66\end{array}$

$\begin{array}{llllllllllll}80 & 59.2 & 62.5 & 60.3 & 58.7 & 53.5 & 45.6 & 42.8 & 42.4 & 47.3 & 51.1 & 67\end{array}$

$\begin{array}{llllllllllll}80 & 46.9 & 40.5 & 38.8 & 41.0 & 43.3 & 35.2 & 39.1 & 45.6 & 46.6 & 46.8 & 68\end{array}$

$\begin{array}{llllllllllll}80 & 41.6 & 45.1 & 31.4 & 42.5 & 44.3 & 39.8 & 30.9 & 37.2 & 40.2 & 45.3 & 69\end{array}$

$\begin{array}{llllllllllll}80 & 39.6 & 39.1 & 43.5 & 42.4 & 41.4 & 40.8 & 30.7 & 24.1 & 38.3 & 34.3 & 70\end{array}$

$\begin{array}{llllllllllll}80 & 41.7 & 45.2 & 49.1 & 42.2 & 46.5 & 48.2 & 52.0 & 38.9 & 31.1 & 37.9 & 71\end{array}$

$\begin{array}{llllllllllll}80 & 37.2 & 26.2 & 19.0 & 15.6 & 21.0 & 16.3 & 17.3 & 23.6 & 19.1 & 23.2 & 72\end{array}$

$\begin{array}{llllllllllll}80 & 32.1 & 24.6 & 18.0 & 23.7 & 23.8 & 29.2 & 34.6 & 32.2 & 27.2 & 22.0 & 73\end{array}$

$\begin{array}{llllllllllll}80 & 18.4 & 13.4 & 21.7 & 31.9 & 34.3 & 33.9 & 0.0 & 0.0 & 0.0 & 0.0 & 74\end{array}$

$\begin{array}{llllllllllll}81 & 37.3 & 34.6 & 35.5 & 29.6 & 32.6 & 32.0 & 23.6 & 17.0 & 23.3 & 32.7 & 75\end{array}$

$\begin{array}{llllllllllll}81 & 32.7 & 30.4 & 34.9 & 32.8 & 34.7 & 33.6 & 29.4 & 29.6 & 34.9 & 33.5 & 76\end{array}$

$\begin{array}{llllllllllll}81 & 31.9 & 28.0 & 34.3 & 26.9 & 23.5 & 21.1 & 28.0 & 24.1 & 34.7 & 41.7 & 77\end{array}$

$\begin{array}{llllllllllll}81 & 41.4 & 44.0 & 36.7 & 37.8 & 35.9 & 43.6 & 37.7 & 40.7 & 33.5 & 42.5 & 78\end{array}$

$\begin{array}{llllllllllll}81 & 39.7 & 44.1 & 48.8 & 37.9 & 44.5 & 33.1 & 32.6 & 37.3 & 30.1 & 30.2 & 79\end{array}$

$\begin{array}{llllllllllll}81 & 34.1 & 40.3 & 34.7 & 31.6 & 30.6 & 39.0 & 40.1 & 43.9 & 40.3 & 35.0 & 80\end{array}$

$\begin{array}{llllllllllll}81 & 29.3 & 43.5 & 35.8 & 32.7 & 42.1 & 39.1 & 38.5 & 48.6 & 39.0 & 31.1 & 81\end{array}$

$\begin{array}{llllllllllll}81 & 20.7 & 35.2 & 31.6 & 37.2 & 31.7 & 38.0 & 40.5 & 38.3 & 42.4 & 37.0 & 82\end{array}$

$\begin{array}{llllllllllll}81 & 43.1 & 39.2 & 47.5 & 43.0 & 37.9 & 36.8 & 31.1 & 43.6 & 41.6 & 43.7 & 83\end{array}$

$\begin{array}{llllllllllll}81 & 42.8 & 41.5 & 41.1 & 41.7 & 37.0 & 42.8 & 37.5 & 44.0 & 46.5 & 52.2 & 84\end{array}$

$\begin{array}{llllllllllll}81 & 47.6 & 43.8 & 50.5 & 48.0 & 50.2 & 52.2 & 59.4 & 54.2 & 58.2 & 57.6 & 85\end{array}$

$\begin{array}{llllllllllll}81 & 60.0 & 54.9 & 61.1 & 58.5 & 66.4 & 59.0 & 65.2 & 60.1 & 55.9 & 57.3 & 86\end{array}$

$\begin{array}{llllllllllll}81 & 48.2 & 50.5 & 48.2 & 44.4 & 57.4 & 55.6 & 53.4 & 54.1 & 55.2 & 60.1 & 87\end{array}$

$\begin{array}{llllllllllll}81 & 50.1 & 52.9 & 54.1 & 53.9 & 56.4 & 52.3 & 53.9 & 49.2 & 45.5 & 49.4 & 88\end{array}$

$\begin{array}{llllllllllll}81 & 57.4 & 59.5 & 59.8 & 59.3 & 54.6 & 58.8 & 58.2 & 63.0 & 62.3 & 66.8 & 89\end{array}$

$\begin{array}{llllllllllll}81 & 72.0 & 71.4 & 69.5 & 71.7 & 75.1 & 70.3 & 67.5 & 59.7 & 54.9 & 56.8 & 90\end{array}$

$\begin{array}{llllllllllll}81 & 51.9 & 51.4 & 50.4 & 52.1 & 52.6 & 63.4 & 60.4 & 57.9 & 60.6 & 61.9 & 91\end{array}$

$\begin{array}{llllllllllll}81 & 62.0 & 67.6 & 67.7 & 63.0 & 61.1 & 71.3 & 70.4 & 60.5 & 59.3 & 60.1 & 92\end{array}$

$\begin{array}{llllllllllll}81 & 58.2 & 66.0 & 59.3 & 59.8 & 64.1 & 69.9 & 70.0 & 67.4 & 78.1 & 77.8 & 93\end{array}$

$\begin{array}{llllllllllll}81 & 66.5 & 61.8 & 65.5 & 68.2 & 73.7 & 72.5 & 75.9 & 71.7 & 77.1 & 81.6 & 94\end{array}$

$\begin{array}{llllllllllll}81 & 80.3 & 78.1 & 77.3 & 68.5 & 71.6 & 68.4 & 69.1 & 66.8 & 69.5 & 71.5 & 95\end{array}$

$\begin{array}{llllllllllll}81 & 73.1 & 67.5 & 66.8 & 64.0 & 71.6 & 69.3 & 70.1 & 66.9 & 70.4 & 68.1 & 96\end{array}$

$\begin{array}{llllllllllll}81 & 61.7 & 62.2 & 61.7 & 63.7 & 63.6 & 66.8 & 65.2 & 60.6 & 62.8 & 64.9 & 97\end{array}$ 
$\begin{array}{llllllllllll}81 & 71.3 & 59.7 & 63.4 & 68.7 & 65.2 & 65.4 & 53.9 & 55.2 & 58.9 & 57.1 & 98\end{array}$ $\begin{array}{llllllllllll}81 & 50.7 & 56.8 & 51.7 & 54.6 & 53.7 & 53.4 & 58.3 & 68.8 & 68.5 & 63.6 & 99\end{array}$

$\begin{array}{llllllllllll}81 & 54.6 & 57.1 & 58.8 & 56.7 & 54.2 & 60.1 & 55.5 & 50.4 & 53.4 & 52.4 & 100\end{array}$

$\begin{array}{llllllllllll}81 & 56.6 & 52.8 & 53.6 & 51.2 & 54.9 & 49.6 & 46.2 & 45.5 & 52.1 & 49.2 & 101\end{array}$

$\begin{array}{llllllllllll}81 & 53.2 & 50.5 & 56.6 & 54.2 & 54.4 & 56.0 & 62.1 & 61.4 & 49.4 & 60.6 & 102\end{array}$

$\begin{array}{llllllllllll}81 & 54.5 & 56.2 & 61.3 & 64.3 & 56.8 & 60.2 & 64.7 & 48.7 & 53.9 & 59.7 & 103\end{array}$

$\begin{array}{llllllllllll}81 & 43.3 & 34.1 & 31.9 & 24.8 & 21.3 & 30.7 & 39.2 & 44.2 & 44.8 & 45.2 & 104\end{array}$

$\begin{array}{llllllllllll}81 & 45.3 & 41.7 & 46.2 & 51.7 & 44.6 & 43.9 & 36.3 & 45.9 & 50.4 & 61.4 & 105\end{array}$

$\begin{array}{llllllllllll}81 & 44.9 & 33.8 & 33.6 & 36.8 & 41.8 & 47.2 & 35.3 & 40.2 & 42.1 & 50.4 & 106\end{array}$

$\begin{array}{llllllllllll}81 & 43.2 & 42.0 & 41.1 & 39.5 & 27.8 & 34.5 & 29.8 & 38.0 & 43.6 & 42.0 & 107\end{array}$

$\begin{array}{llllllllllll}81 & 29.7 & 17.7 & 29.3 & 28.9 & 33.3 & 33.0 & 28.3 & 24.3 & 11.7 & 11.1 & 108\end{array}$

$\begin{array}{llllllllllll}81 & 17.2 & 16.3 & 24.9 & 31.3 & 34.1 & 27.5 & 29.5 & 27.0 & 31.2 & 25.7 & 109\end{array}$

$\begin{array}{llllllllllll}81 & 23.7 & 21.0 & 23.6 & 30.5 & 30.7 & 33.1 & 36.5 & 35.5 & 39.7 & 20.4 & 110\end{array}$

$\begin{array}{llllllllllll}81 & 21.7 & 19.1 & 21.6 & 21.2 & 28.0 & 33.9 & 0.0 & 0.0 & 0.0 & 0.0 & 111\end{array}$

$\begin{array}{llllllllllll}82 & 26.8 & 20.4 & 29.6 & 24.7 & 36.1 & 33.9 & 38.7 & 30.8 & 33.7 & 29.8 & 112\end{array}$

$\begin{array}{llllllllllll}82 & 23.4 & 20.1 & 26.2 & 23.1 & 17.2 & 13.4 & 10.8 & 18.8 & 20.9 & 21.8 & 113\end{array}$

$\begin{array}{llllllllllll}82 & 16.2 & 19.3 & 22.2 & 32.5 & 34.5 & 39.6 & 33.9 & 37.4 & 46.4 & 36.7 & 114\end{array}$

$\begin{array}{llllllllllll}82 & 36.3 & 38.3 & 39.7 & 36.0 & 37.8 & 30.7 & 33.9 & 22.1 & 26.9 & 24.8 & 115\end{array}$

$\begin{array}{llllllllllll}82 & 39.0 & 42.9 & 46.3 & 48.3 & 37.9 & 37.9 & 44.4 & 38.4 & 41.4 & 39.8 & 116\end{array}$

$\begin{array}{llllllllllll}82 & 42.1 & 50.6 & 44.2 & 39.6 & 42.1 & 40.3 & 38.4 & 39.6 & 35.4 & 32.8 & 117\end{array}$

$\begin{array}{llllllllllll}82 & 28.7 & 26.8 & 25.2 & 32.1 & 38.6 & 34.8 & 34.6 & 43.0 & 32.8 & 35.6 & 118\end{array}$

$\begin{array}{llllllllllll}82 & 39.6 & 34.3 & 37.0 & 27.7 & 32.7 & 28.7 & 41.1 & 45.5 & 44.7 & 48.2 & 119\end{array}$

$\begin{array}{llllllllllll}82 & 35.8 & 48.3 & 38.6 & 34.3 & 29.4 & 40.7 & 43.4 & 47.2 & 47.2 & 38.0 & 120\end{array}$

$\begin{array}{llllllllllll}82 & 30.3 & 35.5 & 43.5 & 37.2 & 48.5 & 47.3 & 49.1 & 51.0 & 51.8 & 48.3 & 121\end{array}$

$\begin{array}{llllllllllll}82 & 43.8 & 46.6 & 45.0 & 41.4 & 36.1 & 36.8 & 45.1 & 44.0 & 55.9 & 64.5 & 122\end{array}$

$\begin{array}{llllllllllll}82 & 55.1 & 49.3 & 49.2 & 57.9 & 59.2 & 53.2 & 51.1 & 47.8 & 52.7 & 54.2 & 123\end{array}$

$\begin{array}{llllllllllll}82 & 55.1 & 62.3 & 68.4 & 66.3 & 57.5 & 57.3 & 56.1 & 58.8 & 64.4 & 64.6 & 124\end{array}$

$\begin{array}{llllllllllll}82 & 70.8 & 71.0 & 63.0 & 58.2 & 68.9 & 65.9 & 60.4 & 55.9 & 53.0 & 52.8 & 125\end{array}$

$\begin{array}{llllllllllll}82 & 55.9 & 61.9 & 64.2 & 56.7 & 53.9 & 45.6 & 40.3 & 45.9 & 46.7 & 52.7 & 126\end{array}$

$\begin{array}{llllllllllll}82 & 55.0 & 51.5 & 54.6 & 62.6 & 64.5 & 65.1 & 62.2 & 58.2 & 60.3 & 58.5 & 127\end{array}$

$\begin{array}{llllllllllll}82 & 56.5 & 61.0 & 62.4 & 61.7 & 66.1 & 64.2 & 65.0 & 67.2 & 65.6 & 68.1 & 128\end{array}$

$\begin{array}{llllllllllll}82 & 66.9 & 57.7 & 66.9 & 71.4 & 66.2 & 67.2 & 68.8 & 66.6 & 65.4 & 66.9 & 129\end{array}$

$\begin{array}{llllllllllll}82 & 74.5 & 76.6 & 76.6 & 75.4 & 69.9 & 73.0 & 69.1 & 66.1 & 67.4 & 72.7 & 130\end{array}$

$\begin{array}{llllllllllll}82 & 73.5 & 75.8 & 75.2 & 80.5 & 78.9 & 75.5 & 76.0 & 72.0 & 76.5 & 69.2 & 131\end{array}$

$\begin{array}{llllllllllll}82 & 70.2 & 66.3 & 75.8 & 72.5 & 71.1 & 71.2 & 68.6 & 68.1 & 74.2 & 73.0 & 132\end{array}$

$\begin{array}{llllllllllll}82 & 68.2 & 68.2 & 69.3 & 64.0 & 71.8 & 72.0 & 76.8 & 76.2 & 75.8 & 63.4 & 133\end{array}$

$\begin{array}{llllllllllll}82 & 59.6 & 67.6 & 66.9 & 64.8 & 66.0 & 74.5 & 70.7 & 65.7 & 64.6 & 65.5 & 134\end{array}$

$\begin{array}{llllllllllll}82 & 64.8 & 58.9 & 65.0 & 63.3 & 62.1 & 75.1 & 72.6 & 73.9 & 67.9 & 62.3 & 135\end{array}$

$\begin{array}{llllllllllll}82 & 59.8 & 62.6 & 71.5 & 69.8 & 69.8 & 64.4 & 63.7 & 52.8 & 59.5 & 62.6 & 136\end{array}$

$\begin{array}{llllllllllll}82 & 50.2 & 42.4 & 44.9 & 47.4 & 49.9 & 54.3 & 60.6 & 60.4 & 66.7 & 64.4 & 137\end{array}$

$\begin{array}{llllllllllll}82 & 71.0 & 64.2 & 71.0 & 63.9 & 64.4 & 65.8 & 67.5 & 62.5 & 65.8 & 58.8 & 138\end{array}$

$\begin{array}{llllllllllll}82 & 60.7 & 69.8 & 75.8 & 59.5 & 58.3 & 61.5 & 58.5 & 54.3 & 42.5 & 43.9 & 139\end{array}$

$\begin{array}{llllllllllll}82 & 49.3 & 56.5 & 57.3 & 59.8 & 55.8 & 53.5 & 59.1 & 64.3 & 60.3 & 56.4 & 140\end{array}$

$\begin{array}{lllllllllllll}82 & 54.2 & 45.3 & 37.2 & 42.8 & 50.5 & 53.7 & 48.4 & 35.7 & 36.8 & 44.7 & 141\end{array}$

$\begin{array}{llllllllllll}82 & 38.1 & 44.4 & 37.9 & 34.6 & 33.4 & 39.1 & 52.9 & 46.2 & 52.6 & 47.4 & 142\end{array}$

$\begin{array}{llllllllllll}82 & 52.2 & 56.0 & 60.1 & 51.7 & 51.1 & 54.7 & 51.6 & 42.0 & 36.7 & 28.6 & 143\end{array}$

$\begin{array}{llllllllllll}82 & 24.6 & 32.1 & 33.4 & 35.8 & 45.1 & 39.3 & 37.5 & 29.9 & 39.7 & 40.6 & 144\end{array}$

$\begin{array}{llllllllllll}82 & 36.1 & 27.0 & 26.1 & 35.5 & 30.8 & 30.2 & 35.4 & 27.1 & 31.5 & 27.8 & 145\end{array}$

$\begin{array}{llllllllllll}82 & 30.8 & 25.9 & 22.9 & 21.8 & 26.7 & 31.2 & 28.2 & 31.5 & 24.8 & 19.5 & 146\end{array}$ $\begin{array}{llllllllllll}82 & 22.1 & 22.7 & 17.6 & 19.5 & 27.2 & 43.4 & 43.6 & 42.2 & 41.0 & 34.5 & 147\end{array}$ 
$\begin{array}{llllllllllll}82 & 39.3 & 32.8 & 32.3 & 26.4 & 28.6 & 33.9 & 0.0 & 0.0 & 0.0 & 0.0 & 148\end{array}$

$\begin{array}{llllllllllll}83 & 32.1 & 34.3 & 30.5 & 22.5 & 18.9 & 26.8 & 35.2 & 39.4 & 40.3 & 25.9 & 149\end{array}$

$\begin{array}{llllllllllll}83 & 32.1 & 21.7 & 18.9 & 26.6 & 21.9 & 11.3 & 18.7 & 17.5 & 15.4 & 12.8 & 150\end{array}$

$\begin{array}{llllllllllll}83 & 15.3 & 20.1 & 30.4 & 27.7 & 29.2 & 34.1 & 40.7 & 41.6 & 36.6 & 39.3 & 151\end{array}$

$\begin{array}{llllllllllll}83 & 39.7 & 46.3 & 46.8 & 43.3 & 35.0 & 32.2 & 28.9 & 31.1 & 32.0 & 19.8 & 152\end{array}$

$\begin{array}{llllllllllll}83 & 21.4 & 22.5 & 24.3 & 24.0 & 23.7 & 24.3 & 24.6 & 32.3 & 37.2 & 38.9 & 153\end{array}$

$\begin{array}{llllllllllll}83 & 46.4 & 38.6 & 44.1 & 42.6 & 48.8 & 35.6 & 39.0 & 39.3 & 37.0 & 32.6 & 154\end{array}$

$\begin{array}{llllllllllll}83 & 32.4 & 38.9 & 35.5 & 39.5 & 27.1 & 35.1 & 38.7 & 53.8 & 56.5 & 63.1 & 155\end{array}$

$\begin{array}{llllllllllll}83 & 55.1 & 46.7 & 50.9 & 53.3 & 58.8 & 64.9 & 49.8 & 50.1 & 48.8 & 45.7 & 156\end{array}$

$\begin{array}{llllllllllll}83 & 42.0 & 37.1 & 37.6 & 37.9 & 41.7 & 38.8 & 46.3 & 38.2 & 40.5 & 41.5 & 157\end{array}$

$\begin{array}{llllllllllll}83 & 36.4 & 32.0 & 30.7 & 43.3 & 37.2 & 34.0 & 37.6 & 40.4 & 35.6 & 40.8 & 158\end{array}$

$\begin{array}{llllllllllll}83 & 33.5 & 31.4 & 44.4 & 37.0 & 37.0 & 40.5 & 40.2 & 42.3 & 42.8 & 50.6 & 159\end{array}$

$\begin{array}{llllllllllll}83 & 51.7 & 56.3 & 57.7 & 59.4 & 45.4 & 45.2 & 52.6 & 51.1 & 55.9 & 56.3 & 160\end{array}$

$\begin{array}{llllllllllll}83 & 65.3 & 49.7 & 39.5 & 49.6 & 47.5 & 51.7 & 55.8 & 54.6 & 62.3 & 55.0 & 161\end{array}$

$\begin{array}{llllllllllll}83 & 47.9 & 48.7 & 56.7 & 60.1 & 59.8 & 67.2 & 67.0 & 58.5 & 49.4 & 56.6 & 162\end{array}$

$\begin{array}{llllllllllll}83 & 60.8 & 58.2 & 60.8 & 62.8 & 68.6 & 69.1 & 59.9 & 67.2 & 63.5 & 67.1 & 163\end{array}$

$\begin{array}{llllllllllll}83 & 61.5 & 55.3 & 56.8 & 61.8 & 58.7 & 55.5 & 58.3 & 58.7 & 61.5 & 64.1 & 164\end{array}$

$\begin{array}{llllllllllll}83 & 71.9 & 73.0 & 77.3 & 68.4 & 58.2 & 63.3 & 65.0 & 62.5 & 65.1 & 59.1 & 165\end{array}$

$\begin{array}{llllllllllll}83 & 60.9 & 59.3 & 59.1 & 63.4 & 64.4 & 60.5 & 55.9 & 57.4 & 64.8 & 65.7 & 166\end{array}$

$\begin{array}{llllllllllll}83 & 69.2 & 60.9 & 64.0 & 64.5 & 62.4 & 67.7 & 70.4 & 74.3 & 75.7 & 68.4 & 167\end{array}$

$\begin{array}{llllllllllll}83 & 72.6 & 64.2 & 67.7 & 75.0 & 75.5 & 74.9 & 75.3 & 75.3 & 77.8 & 81.4 & 168\end{array}$

$\begin{array}{llllllllllll}83 & 69.5 & 70.4 & 68.2 & 70.3 & 71.9 & 73.2 & 79.8 & 76.0 & 69.8 & 70.7 & 169\end{array}$

$\begin{array}{llllllllllll}83 & 72.0 & 72.3 & 80.1 & 82.2 & 71.6 & 68.8 & 71.2 & 66.8 & 63.6 & 70.7 & 170\end{array}$

$\begin{array}{llllllllllll}83 & 68.0 & 67.8 & 68.6 & 67.6 & 68.5 & 74.4 & 79.4 & 73.4 & 78.0 & 71.5 & 171\end{array}$

$\begin{array}{llllllllllll}83 & 70.5 & 72.7 & 72.0 & 66.7 & 63.9 & 59.9 & 54.2 & 51.9 & 53.4 & 51.8 & 172\end{array}$

$\begin{array}{llllllllllll}83 & 58.7 & 58.3 & 59.7 & 66.8 & 71.9 & 67.5 & 59.7 & 52.3 & 47.2 & 45.2 & 173\end{array}$

$\begin{array}{llllllllllll}83 & 52.2 & 60.4 & 66.4 & 59.9 & 60.9 & 50.8 & 52.0 & 46.9 & 55.7 & 65.2 & 174\end{array}$

$\begin{array}{llllllllllll}83 & 63.1 & 60.6 & 58.3 & 54.1 & 52.1 & 45.2 & 46.4 & 55.9 & 51.6 & 47.6 & 175\end{array}$

$\begin{array}{llllllllllll}83 & 54.1 & 57.0 & 57.2 & 61.0 & 72.4 & 73.3 & 63.9 & 67.5 & 70.8 & 56.7 & 176\end{array}$

$\begin{array}{llllllllllll}83 & 52.2 & 61.2 & 52.0 & 48.7 & 52.6 & 57.6 & 55.8 & 57.9 & 48.4 & 46.9 & 177\end{array}$

$\begin{array}{llllllllllll}83 & 43.8 & 34.5 & 39.4 & 41.2 & 28.1 & 33.7 & 35.7 & 36.5 & 44.6 & 38.7 & 178\end{array}$

$\begin{array}{llllllllllll}83 & 43.5 & 41.1 & 38.6 & 44.6 & 43.1 & 44.4 & 50.1 & 52.2 & 46.1 & 33.8 & 179\end{array}$

$\begin{array}{llllllllllll}83 & 35.3 & 34.8 & 34.9 & 35.5 & 35.2 & 34.2 & 37.3 & 42.4 & 41.6 & 42.1 & 180\end{array}$

$\begin{array}{llllllllllll}83 & 45.2 & 53.3 & 44.8 & 53.8 & 48.8 & 44.2 & 41.7 & 46.2 & 49.3 & 49.0 & 181\end{array}$

$\begin{array}{llllllllllll}83 & 49.1 & 45.3 & 58.5 & 54.1 & 38.2 & 31.4 & 31.8 & 25.6 & 35.7 & 35.5 & 182\end{array}$

$\begin{array}{llllllllllll}83 & 39.7 & 33.6 & 35.0 & 35.3 & 42.4 & 31.7 & 43.7 & 47.8 & 44.8 & 31.8 & 183\end{array}$

$\begin{array}{llllllllllll}83 & 30.6 & 37.3 & 30.2 & 28.6 & 29.4 & 20.8 & 24.8 & 25.0 & 24.5 & 31.4 & 184\end{array}$

$\begin{array}{llllllllllll}83 & 24.4 & 29.6 & 36.9 & 31.7 & 36.6 & 33.9 & 0.0 & 0.0 & 0.0 & 0.0 & 185\end{array}$

$\begin{array}{llllllllllll}84 & 34.4 & 27.9 & 32.3 & 27.6 & 17.8 & 20.0 & 15.9 & 27.2 & 25.0 & 23.6 & 186\end{array}$

$\begin{array}{llllllllllll}84 & 31.4 & 28.6 & 31.1 & 33.2 & 23.8 & 23.9 & 23.9 & 22.7 & 16.7 & 13.3 & 187\end{array}$

$\begin{array}{llllllllllll}84 & 24.1 & 25.5 & 26.4 & 20.4 & 21.0 & 16.7 & 19.4 & 19.3 & 30.4 & 34.8 & 188\end{array}$

$\begin{array}{llllllllllll}84 & 34.7 & 40.6 & 37.8 & 36.0 & 28.7 & 24.3 & 34.8 & 45.8 & 36.2 & 36.8 & 189\end{array}$

$\begin{array}{llllllllllll}84 & 40.0 & 39.0 & 31.7 & 35.2 & 35.2 & 36.3 & 38.9 & 31.4 & 38.5 & 37.7 & 190\end{array}$

$\begin{array}{llllllllllll}84 & 35.6 & 35.0 & 42.5 & 46.3 & 44.7 & 41.6 & 48.9 & 42.6 & 47.3 & 40.6 & 191\end{array}$

$\begin{array}{llllllllllll}84 & 41.7 & 40.2 & 31.2 & 43.2 & 38.6 & 32.9 & 35.2 & 28.1 & 27.8 & 38.1 & 192\end{array}$

$\begin{array}{llllllllllll}84 & 47.7 & 44.3 & 37.5 & 44.5 & 44.1 & 37.6 & 40.3 & 39.4 & 46.7 & 46.1 & 193\end{array}$

$\begin{array}{llllllllllll}84 & 40.7 & 54.5 & 51.1 & 48.5 & 52.4 & 52.6 & 48.8 & 44.5 & 43.9 & 45.4 & 194\end{array}$

$\begin{array}{llllllllllll}84 & 38.6 & 37.8 & 43.4 & 50.9 & 61.2 & 64.3 & 59.8 & 55.4 & 53.0 & 49.5 & 195\end{array}$

$\begin{array}{llllllllllll}84 & 63.5 & 57.8 & 51.4 & 45.7 & 51.1 & 51.9 & 45.6 & 52.0 & 54.7 & 48.3 & 196\end{array}$

$\begin{array}{llllllllllll}84 & 56.1 & 55.4 & 44.3 & 39.8 & 42.1 & 39.6 & 42.6 & 49.5 & 48.1 & 52.2 & 197\end{array}$ 
$\begin{array}{llllllllllll}84 & 49.1 & 48.4 & 60.1 & 57.8 & 53.9 & 61.8 & 54.1 & 52.3 & 54.8 & 52.0 & 198\end{array}$ $\begin{array}{llllllllllll}84 & 43.1 & 53.1 & 64.4 & 65.1 & 64.8 & 67.0 & 59.2 & 63.9 & 64.6 & 68.8 & 199\end{array}$ $\begin{array}{llllllllllll}84 & 69.4 & 60.6 & 54.9 & 58.7 & 64.2 & 58.4 & 62.0 & 60.7 & 68.3 & 64.4 & 200\end{array}$ $\begin{array}{llllllllllll}84 & 65.0 & 69.2 & 68.5 & 64.4 & 58.3 & 54.9 & 53.8 & 60.9 & 65.3 & 65.7 & 201\end{array}$ $\begin{array}{llllllllllll}84 & 62.7 & 62.0 & 55.6 & 57.0 & 59.2 & 62.7 & 64.8 & 65.3 & 63.1 & 63.5 & 202\end{array}$ $\begin{array}{llllllllllll}84 & 70.8 & 61.9 & 64.2 & 62.3 & 67.8 & 66.2 & 67.9 & 68.2 & 67.3 & 69.7 & 203\end{array}$ $\begin{array}{llllllllllll}84 & 66.4 & 67.3 & 65.1 & 63.8 & 68.3 & 73.5 & 78.1 & 76.5 & 75.9 & 74.4 & 204\end{array}$ $\begin{array}{llllllllllll}84 & 67.2 & 68.9 & 68.5 & 68.7 & 68.9 & 71.4 & 72.0 & 64.5 & 64.4 & 61.1 & 205\end{array}$ $\begin{array}{llllllllllll}84 & 68.4 & 75.7 & 74.1 & 72.3 & 77.2 & 75.0 & 77.4 & 79.4 & 80.8 & 71.1 & 206\end{array}$ $\begin{array}{llllllllllll}84 & 71.6 & 74.1 & 72.4 & 76.2 & 71.9 & 79.2 & 68.2 & 70.1 & 76.1 & 76.2 & 207\end{array}$ $\begin{array}{llllllllllll}84 & 70.4 & 65.9 & 72.5 & 59.4 & 64.4 & 66.3 & 68.5 & 67.5 & 70.2 & 70.4 & 208\end{array}$ $\begin{array}{llllllllllll}84 & 67.3 & 67.4 & 63.0 & 65.0 & 65.8 & 58.7 & 66.5 & 68.2 & 69.5 & 69.0 & 209\end{array}$ $\begin{array}{llllllllllll}84 & 64.1 & 67.9 & 70.7 & 69.4 & 66.7 & 69.4 & 59.5 & 56.1 & 57.9 & 54.3 & 210\end{array}$ $\begin{array}{llllllllllll}84 & 60.1 & 61.6 & 68.6 & 56.4 & 65.4 & 59.4 & 57.8 & 57.1 & 60.5 & 61.6 & 211\end{array}$ $\begin{array}{llllllllllll}84 & 64.0 & 72.3 & 62.8 & 69.2 & 62.5 & 58.7 & 50.9 & 56.7 & 49.1 & 44.3 & 212\end{array}$ $\begin{array}{llllllllllll}84 & 49.8 & 57.6 & 57.3 & 52.7 & 60.3 & 49.3 & 44.4 & 49.1 & 51.1 & 45.6 & 213\end{array}$ $\begin{array}{llllllllllll}84 & 55.6 & 49.4 & 45.5 & 53.7 & 49.1 & 52.1 & 51.7 & 45.5 & 46.2 & 46.2 & 214\end{array}$ $\begin{array}{llllllllllll}84 & 43.9 & 40.6 & 33.2 & 38.8 & 39.4 & 44.8 & 48.4 & 50.4 & 44.2 & 33.6 & 215\end{array}$ $\begin{array}{llllllllllll}84 & 33.7 & 34.0 & 42.1 & 34.6 & 41.9 & 42.6 & 45.5 & 42.8 & 47.3 & 55.4 & 216\end{array}$ $\begin{array}{llllllllllll}84 & 49.5 & 50.6 & 51.6 & 45.4 & 42.5 & 38.5 & 37.9 & 42.8 & 47.7 & 42.4 & 217\end{array}$ $\begin{array}{llllllllllll}84 & 53.2 & 43.6 & 42.0 & 41.3 & 36.9 & 39.5 & 29.3 & 30.1 & 22.3 & 29.2 & 218\end{array}$ $\begin{array}{llllllllllll}84 & 27.7 & 28.5 & 31.8 & 34.4 & 33.4 & 36.3 & 35.4 & 35.8 & 32.8 & 32.9 & 219\end{array}$ $\begin{array}{llllllllllll}84 & 34.1 & 31.7 & 27.7 & 35.3 & 37.2 & 26.2 & 29.2 & 28.3 & 30.6 & 28.4 & 220\end{array}$ $\begin{array}{llllllllllll}84 & 29.0 & 24.3 & 28.7 & 23.7 & 31.2 & 26.1 & 24.9 & 21.7 & 23.3 & 31.7 & 221\end{array}$ $\begin{array}{llllllllllll}84 & 32.0 & 30.2 & 33.6 & 30.7 & 27.6 & 33.7 & 0.0 & 0.0 & 0.0 & 0.0 & 222\end{array}$

$\begin{array}{llllllllllll}85 & 32.2 & 38.8 & 33.8 & 38.4 & 38.8 & 34.4 & 30.8 & 22.9 & 25.2 & 22.4 & 223\end{array}$ $\begin{array}{llllllllllll}85 & 22.2 & 25.2 & 22.1 & 27.2 & 16.9 & 17.7 & 24.9 & 32.1 & 32.4 & 33.8 & 224\end{array}$ $\begin{array}{llllllllllll}85 & 32.2 & 37.6 & 44.6 & 29.5 & 28.4 & 20.9 & 26.6 & 28.7 & 27.4 & 24.3 & 225\end{array}$ $\begin{array}{llllllllllll}85 & 17.8 & 32.7 & 30.5 & 37.8 & 35.9 & 43.8 & 49.9 & 44.3 & 36.6 & 33.4 & 226\end{array}$ $\begin{array}{llllllllllll}85 & 31.6 & 30.9 & 25.0 & 29.7 & 38.7 & 34.7 & 27.3 & 26.0 & 25.4 & 23.2 & 227\end{array}$ $\begin{array}{llllllllllll}85 & 26.6 & 27.0 & 30.9 & 35.3 & 43.0 & 45.8 & 51.6 & 51.3 & 56.6 & 56.0 & 228\end{array}$ $\begin{array}{llllllllllll}85 & 46.0 & 51.6 & 48.8 & 49.6 & 49.9 & 44.4 & 48.3 & 45.2 & 45.3 & 46.2 & 229\end{array}$ $\begin{array}{llllllllllll}85 & 54.6 & 43.7 & 48.4 & 34.3 & 43.9 & 39.0 & 25.6 & 36.7 & 30.8 & 32.8 & 230\end{array}$ $\begin{array}{llllllllllll}85 & 38.4 & 35.8 & 46.0 & 42.6 & 36.7 & 36.3 & 41.6 & 35.2 & 29.8 & 47.8 & 231\end{array}$ $\begin{array}{llllllllllll}85 & 51.7 & 46.2 & 49.2 & 50.6 & 50.7 & 41.8 & 37.2 & 36.0 & 44.0 & 41.1 & 232\end{array}$ $\begin{array}{llllllllllll}85 & 44.1 & 37.5 & 47.9 & 57.3 & 61.3 & 72.1 & 57.1 & 50.9 & 49.4 & 46.0 & 233\end{array}$ $\begin{array}{llllllllllll}85 & 54.5 & 47.3 & 41.9 & 49.9 & 49.7 & 56.2 & 61.3 & 57.1 & 52.7 & 57.8 & 234\end{array}$ $\begin{array}{llllllllllll}85 & 51.5 & 56.8 & 56.5 & 51.8 & 49.4 & 55.3 & 56.9 & 52.0 & 50.6 & 54.8 & 235\end{array}$ $\begin{array}{llllllllllll}85 & 57.2 & 55.6 & 52.2 & 44.6 & 52.1 & 46.9 & 54.4 & 60.3 & 63.8 & 57.6 & 236\end{array}$ $\begin{array}{llllllllllll}85 & 59.7 & 56.3 & 55.6 & 49.2 & 46.2 & 52.3 & 53.4 & 64.6 & 71.3 & 71.8 & 237\end{array}$ $\begin{array}{llllllllllll}85 & 71.2 & 64.9 & 62.8 & 59.9 & 56.3 & 56.1 & 58.6 & 66.8 & 70.2 & 65.8 & 238\end{array}$ $\begin{array}{llllllllllll}85 & 69.7 & 64.2 & 63.4 & 58.3 & 61.0 & 59.6 & 64.3 & 68.6 & 67.0 & 67.2 & 239\end{array}$ $\begin{array}{llllllllllll}85 & 66.8 & 65.4 & 67.0 & 66.1 & 69.0 & 74.1 & 68.8 & 70.1 & 75.9 & 68.3 & 240\end{array}$ $\begin{array}{llllllllllll}85 & 70.6 & 71.4 & 70.2 & 68.8 & 68.4 & 68.3 & 68.4 & 70.3 & 68.8 & 76.5 & 241\end{array}$ $\begin{array}{llllllllllll}85 & 77.0 & 75.5 & 78.7 & 79.6 & 74.9 & 70.9 & 65.9 & 64.6 & 71.3 & 70.6 & 242\end{array}$ $\begin{array}{llllllllllll}85 & 64.7 & 70.2 & 70.8 & 74.0 & 69.5 & 66.1 & 68.8 & 64.6 & 65.4 & 68.0 & 243\end{array}$ $\begin{array}{llllllllllll}85 & 75.2 & 76.0 & 70.7 & 73.7 & 67.6 & 70.1 & 73.0 & 72.9 & 73.7 & 65.0 & 244\end{array}$ $\begin{array}{llllllllllll}85 & 67.6 & 67.6 & 74.8 & 65.6 & 65.3 & 66.4 & 64.6 & 67.9 & 67.9 & 73.1 & 245\end{array}$ $\begin{array}{llllllllllll}85 & 75.6 & 70.6 & 76.6 & 70.9 & 69.6 & 66.5 & 71.0 & 69.9 & 75.4 & 79.2 & 246\end{array}$ $\begin{array}{llllllllllll}85 & 75.5 & 69.1 & 69.5 & 68.2 & 67.0 & 61.1 & 63.6 & 62.9 & 60.3 & 59.7 & 247\end{array}$ 
$\begin{array}{llllllllllll}85 & 65.4 & 59.9 & 57.1 & 59.3 & 57.7 & 55.5 & 53.2 & 63.1 & 58.9 & 64.3 & 248\end{array}$

$\begin{array}{llllllllllll}85 & 59.9 & 62.4 & 58.1 & 56.9 & 68.9 & 63.5 & 58.2 & 54.8 & 51.6 & 52.2 & 249\end{array}$

$\begin{array}{llllllllllll}85 & 56.7 & 51.5 & 53.3 & 54.4 & 56.8 & 55.6 & 56.2 & 54.5 & 54.0 & 51.2 & 250\end{array}$

$\begin{array}{llllllllllll}85 & 56.5 & 53.6 & 52.8 & 47.2 & 60.0 & 45.0 & 42.9 & 43.9 & 43.0 & 42.7 & 251\end{array}$

$\begin{array}{llllllllllll}85 & 56.0 & 51.9 & 51.7 & 51.4 & 35.1 & 47.0 & 53.6 & 44.0 & 37.2 & 30.4 & 252\end{array}$

$\begin{array}{llllllllllll}85 & 26.5 & 29.7 & 28.8 & 32.3 & 31.2 & 33.3 & 36.2 & 31.9 & 36.4 & 30.7 & 253\end{array}$

$\begin{array}{llllllllllll}85 & 37.7 & 33.2 & 36.7 & 29.9 & 38.1 & 49.0 & 45.3 & 48.5 & 42.6 & 36.7 & 254\end{array}$

$\begin{array}{llllllllllll}85 & 31.3 & 38.3 & 36.4 & 41.5 & 39.2 & 36.5 & 49.5 & 44.5 & 44.9 & 40.2 & 255\end{array}$

$\begin{array}{llllllllllll}85 & 33.1 & 38.4 & 43.6 & 48.0 & 46.1 & 47.0 & 43.4 & 32.9 & 28.2 & 23.0 & 256\end{array}$

$\begin{array}{llllllllllll}85 & 27.6 & 27.7 & 20.9 & 22.5 & 23.8 & 31.8 & 29.2 & 36.4 & 36.7 & 30.5 & 257\end{array}$

$\begin{array}{llllllllllll}85 & 32.6 & 37.7 & 44.1 & 33.6 & 33.7 & 33.4 & 34.4 & 34.9 & 39.9 & 38.6 & 258\end{array}$

$\begin{array}{llllllllllll}85 & 28.7 & 25.0 & 23.9 & 34.5 & 33.9 & 33.7 & 0.0 & 0.0 & 0.0 & 0.0 & 259\end{array}$

$\begin{array}{llllllllllll}86 & 25.9 & 33.0 & 36.0 & 32.7 & 35.0 & 38.9 & 42.1 & 42.7 & 34.5 & 29.6 & 260\end{array}$

$\begin{array}{llllllllllll}86 & 31.1 & 38.1 & 37.8 & 37.6 & 31.8 & 25.4 & 19.5 & 23.1 & 29.3 & 31.4 & 261\end{array}$

$\begin{array}{llllllllllll}86 & 38.0 & 34.4 & 32.6 & 29.8 & 29.0 & 33.4 & 34.0 & 39.4 & 38.1 & 47.8 & 262\end{array}$

$\begin{array}{llllllllllll}86 & 35.1 & 39.4 & 32.5 & 29.5 & 38.1 & 40.2 & 23.1 & 35.3 & 38.2 & 36.2 & 263\end{array}$

$\begin{array}{llllllllllll}86 & 32.5 & 22.2 & 28.5 & 37.9 & 43.2 & 41.2 & 44.7 & 46.9 & 49.1 & 41.5 & 264\end{array}$

$\begin{array}{llllllllllll}86 & 43.0 & 42.3 & 40.3 & 39.0 & 44.2 & 48.3 & 42.3 & 49.7 & 43.3 & 37.1 & 265\end{array}$

$\begin{array}{llllllllllll}86 & 40.3 & 40.8 & 40.2 & 34.0 & 34.3 & 34.8 & 43.2 & 36.5 & 35.1 & 41.9 & 266\end{array}$

$\begin{array}{llllllllllll}86 & 49.9 & 39.9 & 34.4 & 27.6 & 41.7 & 46.4 & 48.5 & 54.8 & 51.7 & 55.2 & 267\end{array}$

$\begin{array}{llllllllllll}86 & 52.6 & 42.5 & 34.8 & 36.1 & 34.9 & 34.7 & 40.2 & 48.9 & 49.3 & 51.2 & 268\end{array}$

$\begin{array}{llllllllllll}86 & 47.0 & 49.3 & 33.0 & 40.9 & 34.9 & 43.7 & 51.5 & 40.8 & 44.0 & 48.5 & 269\end{array}$

$\begin{array}{llllllllllll}86 & 47.6 & 49.5 & 60.2 & 59.9 & 55.8 & 57.5 & 48.4 & 52.4 & 58.0 & 61.3 & 270\end{array}$

$\begin{array}{llllllllllll}86 & 55.6 & 58.4 & 46.3 & 50.7 & 47.1 & 50.8 & 52.7 & 59.0 & 64.5 & 59.2 & 271\end{array}$

$\begin{array}{llllllllllll}86 & 56.0 & 53.4 & 53.8 & 52.1 & 59.6 & 60.8 & 66.3 & 70.4 & 62.7 & 68.1 & 272\end{array}$

$\begin{array}{llllllllllll}86 & 68.7 & 58.6 & 48.1 & 47.2 & 53.8 & 56.1 & 66.2 & 64.7 & 57.2 & 53.2 & 273\end{array}$

$\begin{array}{llllllllllll}86 & 42.2 & 43.9 & 50.3 & 50.3 & 51.7 & 55.6 & 49.2 & 46.1 & 57.9 & 61.7 & 274\end{array}$

$\begin{array}{llllllllllll}86 & 62.6 & 61.0 & 64.2 & 59.3 & 63.8 & 62.7 & 67.2 & 70.1 & 71.5 & 64.4 & 275\end{array}$

$\begin{array}{llllllllllll}86 & 62.5 & 57.9 & 61.7 & 54.5 & 55.1 & 58.8 & 68.7 & 75.0 & 75.7 & 72.1 & 276\end{array}$

$\begin{array}{llllllllllll}86 & 69.4 & 70.6 & 68.3 & 76.6 & 73.6 & 71.0 & 70.4 & 70.9 & 65.0 & 62.1 & 277\end{array}$

$\begin{array}{llllllllllll}86 & 65.7 & 71.7 & 67.6 & 65.8 & 68.4 & 78.3 & 72.6 & 72.9 & 70.9 & 75.0 & 278\end{array}$

$\begin{array}{llllllllllll}86 & 75.4 & 71.7 & 71.0 & 66.5 & 66.9 & 67.1 & 63.6 & 67.5 & 72.1 & 75.1 & 279\end{array}$

$\begin{array}{llllllllllll}86 & 72.9 & 67.1 & 65.2 & 72.1 & 70.6 & 69.8 & 68.8 & 72.6 & 72.3 & 72.9 & 280\end{array}$

$\begin{array}{llllllllllll}86 & 74.5 & 74.5 & 72.1 & 75.3 & 71.3 & 66.6 & 62.6 & 66.1 & 68.0 & 68.6 & 281\end{array}$

$\begin{array}{llllllllllll}86 & 63.6 & 63.8 & 63.5 & 60.4 & 64.3 & 63.9 & 67.5 & 71.4 & 67.4 & 74.0 & 282\end{array}$

$\begin{array}{llllllllllll}86 & 78.5 & 79.2 & 81.7 & 75.9 & 74.7 & 71.3 & 71.9 & 69.4 & 66.1 & 61.4 & 283\end{array}$

$\begin{array}{llllllllllll}86 & 60.1 & 58.5 & 60.1 & 62.6 & 56.8 & 60.8 & 64.0 & 59.7 & 59.4 & 62.3 & 284\end{array}$

$\begin{array}{llllllllllll}86 & 65.7 & 70.9 & 64.9 & 68.7 & 63.1 & 49.3 & 53.9 & 56.1 & 54.4 & 50.3 & 285\end{array}$

$\begin{array}{llllllllllll}86 & 53.1 & 52.4 & 52.0 & 55.6 & 60.6 & 54.8 & 53.8 & 50.6 & 54.5 & 53.2 & 286\end{array}$

$\begin{array}{llllllllllll}86 & 53.7 & 44.4 & 40.5 & 37.7 & 44.4 & 50.8 & 48.0 & 46.8 & 49.8 & 65.7 & 287\end{array}$

$\begin{array}{llllllllllll}86 & 61.4 & 58.2 & 55.0 & 54.8 & 55.5 & 56.2 & 54.2 & 58.1 & 61.7 & 61.4 & 288\end{array}$

$\begin{array}{llllllllllll}86 & 63.4 & 75.5 & 71.5 & 70.8 & 72.9 & 58.5 & 50.8 & 53.6 & 39.7 & 37.4 & 289\end{array}$

$\begin{array}{llllllllllll}86 & 40.9 & 28.3 & 38.7 & 40.4 & 40.4 & 33.4 & 24.4 & 39.9 & 34.1 & 41.9 & 290\end{array}$

$\begin{array}{llllllllllll}86 & 47.1 & 41.4 & 37.6 & 48.5 & 39.5 & 43.3 & 45.6 & 50.3 & 50.1 & 41.7 & 291\end{array}$

$\begin{array}{llllllllllll}86 & 32.2 & 32.9 & 37.6 & 36.3 & 44.0 & 47.9 & 42.3 & 35.9 & 42.1 & 36.9 & 292\end{array}$

$\begin{array}{llllllllllll}86 & 29.3 & 32.1 & 35.0 & 34.8 & 22.7 & 19.3 & 30.2 & 26.3 & 30.6 & 36.0 & 293\end{array}$

$\begin{array}{llllllllllll}86 & 40.5 & 38.5 & 31.5 & 25.3 & 23.9 & 31.3 & 21.1 & 26.4 & 31.2 & 19.4 & 294\end{array}$

$\begin{array}{llllllllllll}86 & 14.5 & 14.5 & 7.1 & 12.1 & 28.4 & 20.1 & 23.3 & 21.1 & 21.4 & 26.4 & 295\end{array}$

$\begin{array}{llllllllllll}86 & 31.5 & 31.3 & 33.2 & 35.8 & 36.1 & 33.7 & 0.0 & 0.0 & 0.0 & 0.0 & 296\end{array}$

$\begin{array}{llllllllllll}87 & 37.7 & 34.8 & 27.5 & 39.1 & 28.9 & 29.0 & 33.0 & 35.2 & 30.9 & 34.7 & 297\end{array}$ 
DOE/RL-93-99, Rev. 0

$\begin{array}{llllllllllll}87 & 22.7 & 21.5 & 25.3 & 22.6 & 25.7 & 26.3 & 26.8 & 25.2 & 29.8 & 29.2 & 298\end{array}$

$\begin{array}{lllllllllllll}87 & 34.0 & 32.7 & 32.1 & 31.3 & 37.0 & 33.5 & 32.8 & 28.5 & 24.6 & 24.5 & 299\end{array}$

$\begin{array}{llllllllllll}87 & 20.9 & 23.1 & 26.9 & 31.9 & 32.4 & 32.0 & 39.7 & 38.7 & 34.5 & 34.0 & 300\end{array}$

$\begin{array}{llllllllllll}87 & 31.4 & 31.2 & 37.9 & 35.5 & 32.7 & 36.2 & 44.4 & 35.6 & 30.9 & 24.6 & 301\end{array}$

$\begin{array}{llllllllllll}87 & 32.5 & 35.3 & 40.0 & 40.0 & 40.0 & 31.1 & 27.2 & 23.4 & 26.5 & 17.4 & 302\end{array}$

$\begin{array}{llllllllllll}87 & 22.9 & 34.3 & 34.6 & 28.8 & 27.0 & 33.4 & 32.1 & 41.7 & 40.0 & 36.9 & 303\end{array}$

$\begin{array}{llllllllllll}87 & 35.6 & 32.3 & 41.3 & 42.2 & 40.0 & 42.9 & 43.9 & 42.3 & 43.9 & 51.3 & 304\end{array}$

$\begin{array}{llllllllllll}87 & 49.1 & 39.6 & 40.2 & 50.5 & 49.8 & 49.7 & 46.8 & 53.7 & 48.0 & 53.1 & 305\end{array}$

$\begin{array}{llllllllllll}87 & 44.0 & 34.7 & 37.5 & 48.4 & 46.2 & 48.7 & 49.8 & 42.9 & 46.2 & 54.9 & 306\end{array}$

$\begin{array}{llllllllllll}87 & 60.9 & 65.3 & 56.7 & 58.1 & 51.3 & 59.6 & 51.5 & 51.1 & 54.7 & 55.2 & 307\end{array}$

$\begin{array}{llllllllllll}87 & 57.6 & 50.7 & 51.7 & 44.0 & 45.2 & 49.9 & 63.1 & 54.5 & 50.3 & 49.4 & 308\end{array}$

$\begin{array}{llllllllllll}87 & 51.3 & 51.2 & 48.9 & 54.0 & 57.6 & 58.9 & 52.2 & 54.1 & 58.0 & 52.2 & 309\end{array}$

$\begin{array}{llllllllllll}87 & 57.9 & 48.1 & 45.7 & 53.4 & 53.5 & 56.4 & 54.8 & 57.0 & 55.3 & 49.0 & 310\end{array}$

$\begin{array}{llllllllllll}87 & 55.0 & 56.5 & 63.8 & 63.0 & 63.9 & 55.8 & 61.4 & 59.0 & 60.1 & 60.9 & 311\end{array}$

$\begin{array}{llllllllllll}87 & 69.3 & 68.1 & 76.4 & 73.1 & 75.2 & 71.1 & 71.8 & 77.2 & 64.5 & 69.5 & 312\end{array}$

$\begin{array}{llllllllllll}87 & 64.6 & 56.1 & 50.6 & 58.9 & 69.1 & 68.5 & 71.3 & 63.7 & 72.0 & 72.8 & 313\end{array}$

$\begin{array}{llllllllllll}87 & 63.0 & 59.3 & 62.2 & 61.6 & 65.0 & 61.1 & 60.5 & 67.1 & 65.5 & 64.0 & 314\end{array}$

$\begin{array}{llllllllllll}87 & 69.4 & 79.9 & 78.5 & 83.8 & 75.6 & 78.9 & 73.2 & 74.4 & 70.1 & 71.1 & 315\end{array}$

$\begin{array}{llllllllllll}87 & 71.2 & 65.7 & 65.1 & 68.7 & 79.9 & 76.4 & 73.6 & 68.1 & 68.5 & 70.4 & 316\end{array}$

$\begin{array}{llllllllllll}87 & 62.5 & 67.3 & 74.2 & 74.3 & 70.6 & 73.2 & 74.2 & 67.3 & 69.5 & 72.7 & 317\end{array}$

$\begin{array}{llllllllllll}87 & 70.3 & 75.1 & 76.7 & 74.9 & 73.0 & 74.0 & 72.1 & 66.8 & 60.3 & 59.8 & 318\end{array}$

$\begin{array}{llllllllllll}87 & 65.2 & 64.2 & 63.1 & 65.9 & 60.6 & 61.2 & 63.8 & 61.3 & 61.4 & 58.3 & 319\end{array}$

$\begin{array}{llllllllllll}87 & 67.8 & 68.1 & 76.4 & 80.7 & 70.7 & 70.9 & 69.2 & 68.9 & 75.1 & 63.4 & 320\end{array}$

$\begin{array}{llllllllllll}87 & 62.2 & 68.5 & 69.1 & 70.3 & 80.7 & 80.5 & 76.6 & 75.0 & 69.3 & 63.7 & 321\end{array}$

$\begin{array}{llllllllllll}87 & 65.0 & 57.0 & 56.7 & 58.4 & 63.7 & 56.8 & 57.2 & 71.8 & 67.4 & 62.8 & 322\end{array}$

$\begin{array}{llllllllllll}87 & 64.3 & 55.5 & 49.5 & 50.3 & 58.6 & 64.1 & 57.3 & 51.8 & 50.2 & 52.9 & 323\end{array}$

$\begin{array}{llllllllllll}87 & 55.7 & 62.2 & 54.2 & 57.4 & 47.8 & 46.4 & 57.8 & 46.0 & 40.1 & 40.4 & 324\end{array}$

$\begin{array}{llllllllllll}87 & 42.1 & 51.5 & 60.2 & 58.2 & 55.8 & 50.9 & 51.5 & 61.1 & 58.0 & 60.9 & 325\end{array}$

$\begin{array}{llllllllllll}87 & 52.9 & 53.3 & 57.2 & 52.2 & 49.7 & 54.7 & 49.9 & 54.1 & 49.5 & 54.0 & 326\end{array}$

$\begin{array}{llllllllllll}87 & 44.5 & 49.4 & 51.8 & 55.7 & 53.1 & 40.4 & 42.0 & 41.5 & 33.4 & 30.6 & 327\end{array}$

$\begin{array}{llllllllllll}87 & 37.2 & 43.7 & 42.3 & 37.2 & 34.2 & 28.8 & 34.1 & 35.1 & 38.1 & 49.4 & 328\end{array}$

$\begin{array}{llllllllllll}87 & 41.6 & 40.4 & 39.3 & 35.8 & 41.8 & 43.1 & 39.2 & 44.2 & 54.5 & 45.3 & 329\end{array}$

$\begin{array}{llllllllllll}87 & 37.9 & 29.1 & 24.0 & 23.4 & 35.8 & 29.3 & 24.0 & 28.5 & 25.5 & 30.0 & 330\end{array}$

$\begin{array}{llllllllllll}87 & 25.7 & 26.5 & 23.3 & 29.3 & 26.7 & 32.8 & 41.1 & 30.4 & 27.5 & 24.2 & 331\end{array}$

$\begin{array}{llllllllllll}87 & 34.7 & 29.7 & 26.2 & 31.7 & 40.1 & 32.9 & 31.7 & 28.2 & 18.8 & 18.3 & 332\end{array}$

$\begin{array}{llllllllllll}87 & 11.3 & 10.6 & 12.1 & 18.8 & 28.6 & 33.7 & 0.0 & 0.0 & 0.0 & 0.0 & 333\end{array}$

$\begin{array}{llllllllllll}88 & 29.8 & 23.9 & 20.3 & 21.3 & 19.1 & 24.7 & 30.2 & 39.9 & 33.1 & 33.2 & 334\end{array}$

$\begin{array}{llllllllllll}88 & 45.4 & 37.6 & 35.4 & 22.3 & 23.0 & 27.6 & 35.1 & 37.7 & 26.4 & 11.3 & 335\end{array}$

$\begin{array}{llllllllllll}88 & 25.0 & 26.8 & 31.4 & 28.6 & 28.9 & 39.5 & 39.7 & 49.2 & 40.7 & 36.2 & 336\end{array}$

$\begin{array}{llllllllllll}88 & 32.3 & 40.7 & 48.0 & 41.4 & 33.5 & 35.3 & 45.0 & 33.5 & 32.0 & 28.0 & 337\end{array}$

$\begin{array}{llllllllllll}88 & 35.8 & 27.9 & 32.7 & 36.5 & 33.1 & 29.5 & 32.3 & 37.0 & 44.3 & 39.1 & 338\end{array}$

$\begin{array}{llllllllllll}88 & 32.9 & 29.4 & 33.5 & 30.2 & 41.7 & 44.4 & 51.2 & 54.5 & 41.4 & 39.5 & 339\end{array}$

$\begin{array}{llllllllllll}88 & 36.6 & 38.7 & 32.0 & 38.6 & 42.4 & 45.7 & 43.6 & 41.2 & 44.2 & 43.5 & 340\end{array}$

$\begin{array}{llllllllllll}88 & 45.1 & 49.8 & 48.9 & 54.3 & 49.8 & 46.1 & 56.8 & 47.9 & 55.0 & 53.0 & 341\end{array}$

$\begin{array}{llllllllllll}88 & 47.2 & 46.6 & 53.9 & 42.3 & 42.5 & 47.8 & 45.5 & 39.0 & 33.9 & 44.3 & 342\end{array}$

$\begin{array}{llllllllllll}88 & 51.1 & 38.1 & 37.9 & 34.0 & 36.8 & 35.7 & 41.3 & 45.7 & 48.5 & 41.8 & 343\end{array}$

$\begin{array}{llllllllllll}88 & 38.2 & 46.2 & 51.3 & 45.8 & 51.1 & 55.0 & 53.1 & 52.7 & 56.2 & 56.5 & 344\end{array}$

$\begin{array}{llllllllllll}88 & 57.7 & 61.5 & 62.5 & 61.2 & 53.3 & 49.4 & 49.3 & 40.3 & 44.6 & 52.4 & 345\end{array}$

$\begin{array}{llllllllllll}88 & 49.5 & 55.3 & 49.6 & 51.6 & 57.0 & 53.0 & 58.0 & 64.9 & 53.3 & 54.4 & 346\end{array}$

$\begin{array}{llllllllllll}88 & 58.8 & 55.4 & 55.0 & 60.5 & 52.8 & 54.9 & 58.9 & 61.9 & 59.6 & 63.9 & 347\end{array}$ 


\begin{abstract}
$\begin{array}{llllllllllll}88 & 56.1 & 50.1 & 54.0 & 62.7 & 57.7 & 61.4 & 61.2 & 53.9 & 58.9 & 63.9 & 348\end{array}$
$\begin{array}{llllllllllll}88 & 60.9 & 61.5 & 54.2 & 61.4 & 63.3 & 66.3 & 65.5 & 65.2 & 67.2 & 69.6 & 349\end{array}$

$\begin{array}{llllllllllll}88 & 73.3 & 69.3 & 68.2 & 70.9 & 68.1 & 73.7 & 69.8 & 73.6 & 76.8 & 73.7 & 350\end{array}$

$\begin{array}{llllllllllll}88 & 75.7 & 74.1 & 76.9 & 77.0 & 65.3 & 69.8 & 72.6 & 73.8 & 70.6 & 67.0 & 351\end{array}$

$\begin{array}{llllllllllll}88 & 66.6 & 68.9 & 73.6 & 69.0 & 57.8 & 70.4 & 65.7 & 68.6 & 65.0 & 62.7 & 352\end{array}$

$\begin{array}{llllllllllll}88 & 64.7 & 65.0 & 67.0 & 69.0 & 68.8 & 65.2 & 69.0 & 66.0 & 65.8 & 65.9 & 353\end{array}$

$\begin{array}{llllllllllll}88 & 64.1 & 65.3 & 67.8 & 71.1 & 67.2 & 64.4 & 68.1 & 67.8 & 64.4 & 72.1 & 354\end{array}$

$\begin{array}{llllllllllll}88 & 75.3 & 74.9 & 74.1 & 77.5 & 69.1 & 65.0 & 73.2 & 64.5 & 64.6 & 64.3 & 355\end{array}$

$\begin{array}{llllllllllll}88 & 60.0 & 64.2 & 60.4 & 64.1 & 67.6 & 66.6 & 66.2 & 65.0 & 63.9 & 67.3 & 356\end{array}$

$\begin{array}{llllllllllll}88 & 68.4 & 73.1 & 73.6 & 64.8 & 67.7 & 76.4 & 79.1 & 78.1 & 69.9 & 68.2 & 357\end{array}$

$\begin{array}{llllllllllll}88 & 72.5 & 71.7 & 66.4 & 71.5 & 69.3 & 60.9 & 56.7 & 55.2 & 54.6 & 58.6 & 358\end{array}$

$\begin{array}{llllllllllll}88 & 57.1 & 64.1 & 66.3 & 69.3 & 72.9 & 69.3 & 63.8 & 75.3 & 69.5 & 65.9 & 359\end{array}$

$\begin{array}{llllllllllll}88 & 68.3 & 63.4 & 58.9 & 54.5 & 64.6 & 55.4 & 53.6 & 52.0 & 54.1 & 69.0 & 360\end{array}$

$\begin{array}{llllllllllll}88 & 69.9 & 59.3 & 43.5 & 45.5 & 49.1 & 58.6 & 63.4 & 63.8 & 58.5 & 59.9 & 361\end{array}$

$\begin{array}{llllllllllll}88 & 60.4 & 49.0 & 49.7 & 51.7 & 45.3 & 50.0 & 54.9 & 52.6 & 63.9 & 63.8 & 362\end{array}$

$\begin{array}{llllllllllll}88 & 53.9 & 40.7 & 45.8 & 45.9 & 40.9 & 37.5 & 45.5 & 50.1 & 47.2 & 36.6 & 363\end{array}$

$\begin{array}{llllllllllll}88 & 30.5 & 35.8 & 41.6 & 43.6 & 45.8 & 38.6 & 34.0 & 40.3 & 45.4 & 44.0 & 364\end{array}$

$\begin{array}{llllllllllll}88 & 45.6 & 39.5 & 29.8 & 27.1 & 35.0 & 31.8 & 29.0 & 23.2 & 29.9 & 29.5 & 365\end{array}$

$\begin{array}{llllllllllll}88 & 40.6 & 33.6 & 29.8 & 36.4 & 34.8 & 33.9 & 37.6 & 47.6 & 44.1 & 28.9 & 366\end{array}$

$\begin{array}{llllllllllll}88 & 30.5 & 35.3 & 38.8 & 40.3 & 35.0 & 34.6 & 34.1 & 26.3 & 24.8 & 32.0 & 367\end{array}$

$\begin{array}{llllllllllll}88 & 28.8 & 27.5 & 25.5 & 26.5 & 32.1 & 19.2 & 27.2 & 32.9 & 36.9 & 29.0 & 368\end{array}$

$\begin{array}{llllllllllll}88 & 33.6 & 30.9 & 26.1 & 29.3 & 25.3 & 20.1 & 22.1 & 25.9 & 20.1 & 22.3 & 369\end{array}$

$\begin{array}{llllllllllll}88 & 17.4 & 23.1 & 23.7 & 31.7 & 36.9 & 26.6 & 0.0 & 0.0 & 0.0 & 0.0 & 370\end{array}$
\end{abstract}


Attachment B-9. HELP Model Data File: DATA10 - Soils Data for Hanford Barrier.

SAIC/ERDF EIS/RC/FS/ WA. 923-E412

CASE 4 - HANFORD BARRIER

3/10/94 YEARS 100-110 CAS4JV11.OUT

$8 \quad 1.000000 \quad 77.000000 \quad 4$

$\begin{array}{lllllll}19.37 & 59.37 & 5.91 & 11.81 & 59.00 & 11.80 & 5\end{array}$

$\begin{array}{lllllll}5.91 & 3.95 & 000.00 & 0.00 & 0.00 & 0.00 & 6\end{array}$

$\begin{array}{lllllll}0.4603 & 0.3702 & 0.3509 & 0.3178 & 0.4170 & 0.4170 & 7\end{array}$

$\begin{array}{llllllll}0.0220 & 0.4170 & 0.0000 & 0.0000 & 0.0000 & 0.0000 & 8\end{array}$

$\begin{array}{lllllll}0.2272 & 0.2109 & 0.0705 & 0.0391 & 0.0210 & 0.0454 & 9\end{array}$

$\begin{array}{lllllll}0.0210 & 0.0450 & 0.0000 & 0.0000 & 0.0000 & 0.0000 & 10\end{array}$

$\begin{array}{lllllll}0.0632 & 0.0500 & 0.0326 & 0.0200 & 0.0200 & 0.0200 & 11\end{array}$

$\begin{array}{lllllll}0.0200 & 0.0200 & 0.0000 & 0.0000 & 0.0000 & 0.0000 & 12\end{array}$

$\begin{array}{lll}0.000992999994 & 0.000001600000 & 0.000154999987\end{array}$

$\begin{array}{lll}0.100000001490 & 1.000000000000 & 0.000000010000\end{array}$

0.00050000002413

$\begin{array}{llll}0.000000000000 & 0.000000000000 & 0.000000000000\end{array}$

0.01000000002414

$\begin{array}{lllllll}0.0954 & 0.0556 & 0.0714 & 0.0367 & 0.0697 & 0.0454 & 16\end{array}$

$\begin{array}{lllllll}0.0210 & 0.0261 & 0.0000 & 0.0000 & 0.0000 & 0.0000 & 17\end{array}$ 43560. 18

0.00000000000015

$\begin{array}{lllllllllllll}1 & 1 & 1 & 1 & 1 & 2 & 3 & 1 & 0 & 0 & 0 & 0 & 19\end{array}$

$\begin{array}{lllllll}0.00 & 0.00 & 0.00 & 0.00 & 0.00 & 2.00 & 20\end{array}$

$\begin{array}{lllllll}0.00 & 0.00 & 0.00 & 0.00 & 0.00 & 0.00 & 21\end{array}$

$\begin{array}{lllllll}0.0 & 0.0 & 0.0 & 0.0 & 0.0 & 760.0 & 22\end{array}$

$\begin{array}{lllllll}0.0 & 0.0 & 0.0 & 0.0 & 0.0 & 0.0 & 23\end{array}$

$\begin{array}{llllllll}1.00000000 & 1.00000000 & 1.00000000 & 1.00000000 & 1.00000000 & 1.00000000 & 24\end{array}$

$\begin{array}{llllllll}1.00000000 & 1.00000000 & 1.00000000 & 1.00000000 & 1.00000000 & 1.00000000 & 25\end{array}$ 0.000026

800 
DOE/RL-93-99, Rev. 0

Attachment B-10. HELP Model Data File: DATA11 - Climate Data for Hanford, Washington.

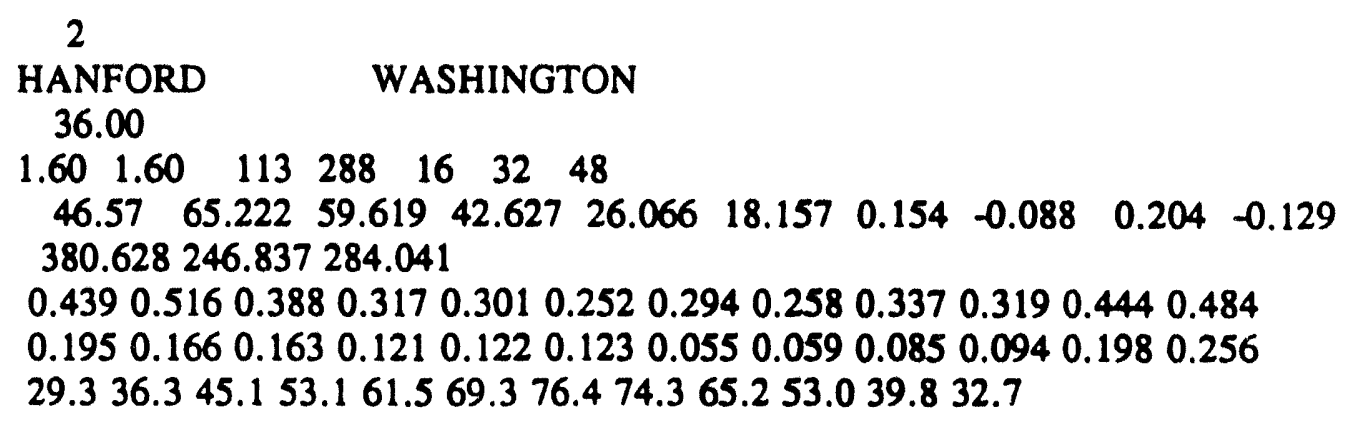


DOE/RL-93-99, Rev. 0

Attachment B-11. HELP Model Data File: DATA11 - Climate Data for Spokane, Washington.

\author{
3 \\ SPOKANE WASHINGTON \\ 36.00

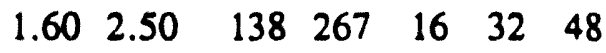 \\ $\begin{array}{llllllllll}46.50 & 58.00 & 53.00 & 37.00 & 26.60 & 16.50 & 0.166 & -0.090 & 0.270 & -0.180\end{array}$ \\ 396.00258 .00297 .00 \\ $\begin{array}{llllllllllll}0.648 & 0.600 & 0.542 & 0.409 & 0.469 & 0.400 & 0.240 & 0.388 & 0.395 & 0.479 & 0.584 & 0.621\end{array}$ \\ $\begin{array}{llllllllllllll}0.361 & 0.269 & 0.239 & 0.225 & 0.202 & 0.200 & 0.099 & 0.121 & 0.154 & 0.184 & 0.278 & 0.386\end{array}$ \\ 25.732 .437 .645 .854 .361 .769 .768 .159 .447 .634 .929 .0
}


Attachment B-12. HELP Model Data File: DATA13 - Solar Radiation Data for Hanford, Washington.

$\begin{array}{lllllllllllll}79 & 102.7 & 107.4 & 148.8 & 63.3 & 91.1 & 89.1 & 114.1 & 103.0 & 124.1 & 40.1 & 1\end{array}$ $\begin{array}{llllllllllll}79 & 40.5 & 99.1 & 45.8 & 41.7 & 124.7 & 93.5 & 65.3 & 80.9 & 102.3 & 153.2 & 2\end{array}$ $\begin{array}{lllllllllllll}79 & 145.6 & 110.1 & 46.3 & 46.9 & 166.2 & 165.8 & 204.7 & 214.5 & 187.1 & 50.7 & 3\end{array}$

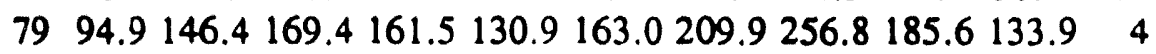

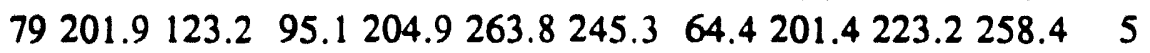

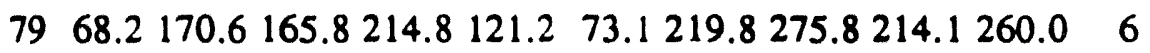

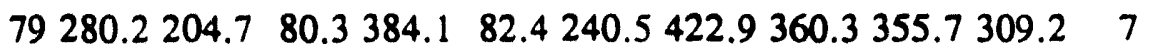

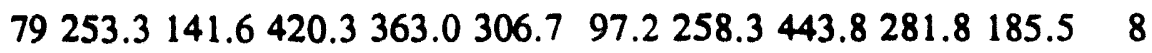

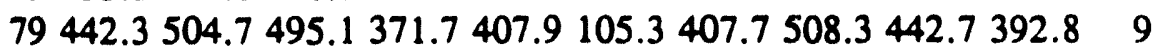
$79318.0165 .3412 .7492 .6522 .7285 .5366 .4117 .9376 .3461 .0 \quad 10$ $79442.9275 .2545 .8364 .7380 .4323 .4449 .2373 .0496 .4602 .1 \quad 11$ $\begin{array}{ll}79602.3524 .1 \quad 470.1531 .7471 .6667 .6 & 643.3635 .6686 .3213 .1 \quad 12\end{array}$

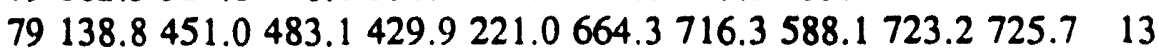

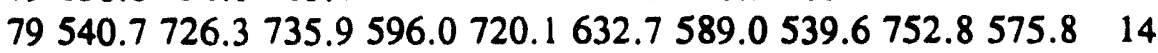
$\begin{array}{ll}79663.0760 .2762 .5655 .0719 .4536 .3639 .5 & 552.0632 .2776 .5 \quad 15\end{array}$ $79610.2725 .7708 .7657 .6582 .0525 .6590 .6425 .5682 .6596 .1 \quad 16$ $79476.4486 .1646 .7792 .2688 .6773 .4629 .4681 .4599 .4613 .8 \quad 17$ $79539.9793 .7793 .5694 .0792 .8773 .2775 .1785 .5790 .5620 .3 \quad 18$ $\begin{array}{ll}79788.9787 .9765 .5612 .2671 .5540 .5731 .7687 .0342 .1638 .2 & 19\end{array}$ 79582.3712 .4772 .1751 .9759 .5712 .9763 .9707 .9456 .5587 .320 $79650.7509 .5697 .4608 .4630 .7741 .0665 .6489 .7555 .4709 .3 \quad 21$ $79599.2722 .4719 .1649 .6656 .9617 .8553 .2458 .9529 .4540 .2 \quad 22$ $\begin{array}{ll}79451.8426 .0424 .7456 .5210 .9220 .2636 .8574 .5657 .0652 .6 & 23\end{array}$ $79473.4262 .4473 .5521 .6630 .0525 .4392 .5615 .8585 .9439 .4 \quad 24$ $79502.0552 .3549 .8329 .1434 .7391 .1559 .1558 .2516 .2493 .3 \quad 25$ $79360.4408 .8462 .3410 .4435 .4487 .8326 .4513 .5420 .1226 .8 \quad 26$

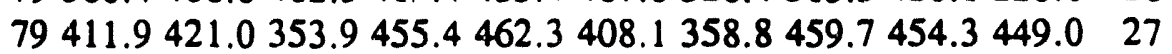

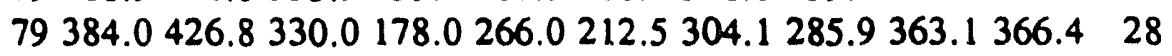

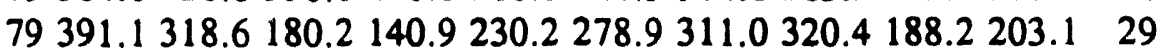

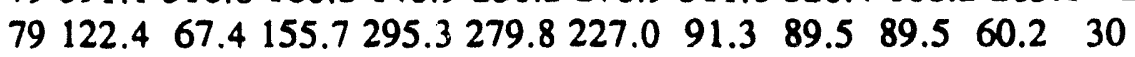

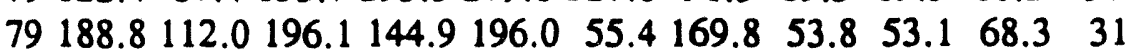

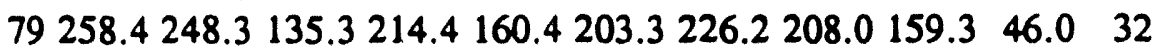
$\begin{array}{llllllllllll}79 & 109.2 & 164.0 & 44.3 & 139.7 & 103.6 & 42.9 & 185.1 & 42.0 & 57.0 & 41.1 & 33\end{array}$

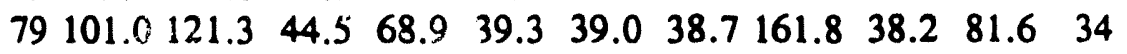
$\begin{array}{lll:llllllllll}79 & 75.2 & 67.6 & 148.7 & 139.2 & 122.6 & 117.7 & 100.2 & 80.5 & 36.5 & 112.5 & 35\end{array}$ $\begin{array}{llllllllllll}79 & 36.3 & 36.3 & 109.5 & 128.4 & 141.3 & 96.2 & 36.3 & 36.4 & 36.5 & 146.4 & 36\end{array}$ $\begin{array}{llllllllllll}79 & 112.4 & 36.8 & 37.0 & 37.1 & 37.3 & 0.0 & 0.0 & 0.0 & 0.0 & 0.0 & 37\end{array}$ $\begin{array}{llllllllllll}80 & 37.6 & 77.7 & 79.4 & 38.3 & 69.8 & 53.6 & 39.1 & 39.5 & 39.8 & 168.0 & 38\end{array}$

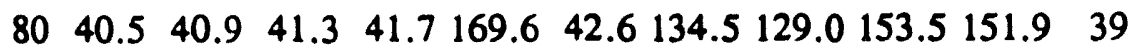

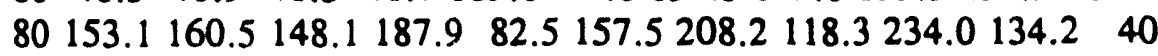

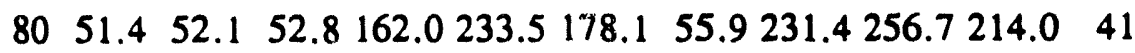
$\begin{array}{llllllllllll}80 & 129.3 & 78.1 & 168.8 & 111.7 & 62.6 & 85.7 & 114.4 & 129.9 & 72.9 & 92.6 & 42\end{array}$

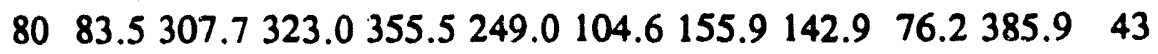
$80270.4204 .9307 .4300 .7150 .4378 .0256 .1238 .7172 .0257 .5 \quad 44$

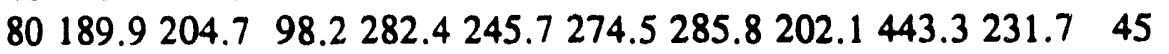
$80495.0307 .5198 .5312 .1417 .2465 .1416 .4331 .9179 .7447 .1 \quad 46$ $80290.4505 .4563 .8569 .1385 .5487 .7 \quad 181.3333 .9511 .3448 .6 \quad 47$ 
$80346.6609 .8562 .6453 .3544 .9629 .2471 .5421 .8537 .6472 .6 \quad 48$ $80468.0656 .7540 .7539 .1357 .8597 .0591 .0682 .3323 .8524 .6 \quad 49$ $80564.7528 .9701 .9484 .3581 .3604 .2454 .6719 .8546 .3 \quad 370.2 \quad 50$ $80426.8515 .8524 .3621 .2148 .4386 .6668 .0708 .3752 .8735 .5 \quad 51$ $80705.8529 .9334 .7672 .8683 .0605 .1573 .5566 .4669 .3608 .5 \quad 52$ $80495.5632 .3655 .5681 .1755 .9765 .2777 .3656 .5690 .5789 .4 \quad 53$ $80743.9592 .4738 .8575 .7339 .3793 .0713 .7287 .9678 .1694 .0 \quad 54$ $80645.8403 .1640 .3711 .9561 .7364 .8242 .8207 .4669 .5789 .8 \quad 55$ $80570.7622 .7786 .9785 .8776 .1783 .3782 .0412 .6582 .0648 .1 \quad 56$ $80652.6773 .9582 .9652 .6569 .6627 .5638 .4761 .6655 .9704 .5 \quad 57$ $80698.5751 .9749 .3746 .6666 .2663 .4626 .7735 .1681 .0640 .3 \quad 58$ $80683.0555 .9641 .4715 .7633 .2637 .1705 .1701 .4567 .1693 .9 \quad 59$ $80605.5568 .6438 .9451 .9407 .4659 .8627 .5605 .4624 .5354 .5 \quad 60$ $80239.9426 .9541 .3575 .7511 .5625 .3585 .2615 .8518 .8606 .2 \quad 61$ $80434.6580 .7591 .4586 .4398 .6466 .3571 .2566 .1560 .9359 .8 \quad 62$ $80526.4482 .5315 .1451 .0488 .3425 .4465 .2 \quad 140.8309 .7280 .3 \quad 63$ $80421.9422 .1446 .1293 .7393 .0364 .9465 .1402 .1334 .3343 .3 \quad 64$ $80305.0438 .3429 .9135 .0228 .7177 .5374 .6406 .6382 .8333 .1 \quad 65$ $80206.8305 .8251 .9302 .1354 .4145 .7175 .7 \quad 193.5113 .0258 .4 \quad 66$

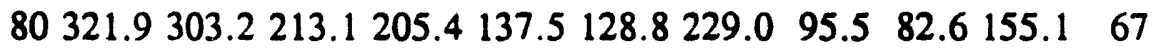

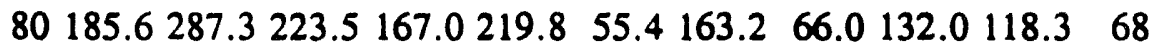

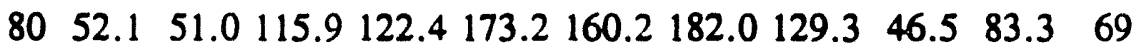

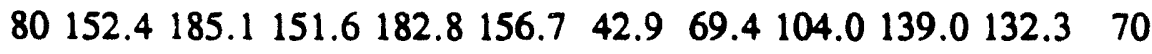
$\begin{array}{llllllllllll}80 & 126.0 & 40.3 & 120.5 & 39.6 & 60.3 & 39.4 & 38.7 & 38.4 & 38.2 & 81.0 & 71\end{array}$ $\begin{array}{llllllllllll}80 & 37.7 & 144.8 & 103.4 & 39.6 & 84.8 & 142.5 & 140.7 & 74.2 & 79.7 & 63.9 & 72\end{array}$ $\begin{array}{llllllllllll}80 & 61.9 & 102.2 & 113.8 & 87.3 & 36.3 & 36.3 & 117.7 & 90.6 & 36.5 & 36.6 & 73\end{array}$

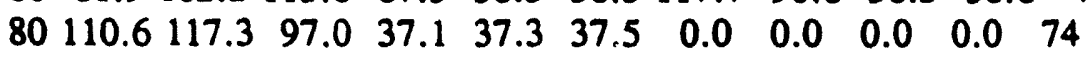
$\begin{array}{lllllllllllll}81 & 37.6 & 95.5 & 121.2 & 81.0 & 115.1 & 151.4 & 94.2 & 46.0 & 119.2 & 109.5 & 75\end{array}$ $\begin{array}{llllllllllll}81 & 96.9 & 53.2 & 88.9 & 83.2 & 107.9 & 95.4 & 43.1 & 151.1 & 44.1 & 101.1 & 76\end{array}$ $\begin{array}{llllllllllll}81 & 45.2 & 45.7 & 228.2 & 137.6 & 150.6 & 48.1 & 48.7 & 49.4 & 50.0 & 151.8 & 77\end{array}$

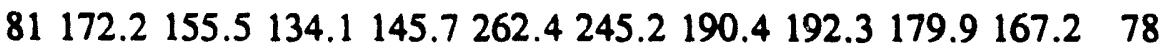

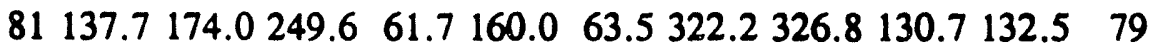

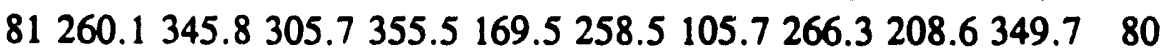
$81302.2320 .2308 .3396 .7382 .8417 .5289 .6240 .1 \quad 178.2311 .0 \quad 81$ $81335.8298 .0394 .9440 .6214 .5274 .9338 .0329 .9386 .5425 .7 \quad 82$ $81356.6483 .1326 .3276 .7340 .3526 .4403 .4327 .9317 .8321 .2 \quad 83$ $81317.9403 .9465 .7480 .4426 .6521 .5490 .8456 .1496 .9503 .3 \quad 84$ $81570.4453 .1524 .7376 .1558 .8487 .8575 .5528 .6599 .1647 .7 \quad 85$ $81560.8252 .7633 .2665 .5455 .0674 .0610 .2682 .3535 .8690 .3 \quad 86$ $81694.2675 .8623 .3673 .5564 .4658 .8682 .0571 .6717 .4603 .4 \quad 87$ $81526.8435 .9531 .7445 .0741 .9678 .9712 .6584 .7697 .6669 .7 \quad 88$ $81757.8660 .7762 .5758 .6766 .9701 .1623 .6772 .9631 .6773 .6 \quad 89$ $81701.6779 .7746 .3782 .6766 .5554 .7786 .4552 .4375 .5704 .5 \quad 90$ $81684.0697 .6697 .9792 .2736 .3678 .1616 .9793 .6701 .7709 .8 \quad 91$ $81641.9775 .5741 .6676 .0601 .5792 .4680 .1572 .0640 .8515 .5 \quad 92$ $81615.7451 .7673 .6706 .5674 .3429 .4685 .6676 .8596 .6710 .5 \quad 93$ $81753.3773 .9772 .1770 .1768 .1751 .1763 .9761 .6759 .3737 .7 \quad 94$ $81667.7751 .9660 .7731 .1708 .9741 .0622 .7735 .1540 .5443 .0 \quad 95$ $81585.7722 .4616 .8667 .7594 .7474 .3625 .6643 .1697 .7548 .8 \quad 96$ $81570.7668 .8682 .1575 .6534 .1519 .4395 .2577 .6555 .6626 .4 \quad 97$ 
$81563.5522 .7639 .2570 .9630 .0625 .3501 .8346 .7611 .0589 .9 \quad 98$ $81454.1591 .6523 .9373 .6334 .5493 .8445 .0467 .5560 .9555 .7 \quad 99$ $81255.5353 .4540 .0421 .1429 .2499 .6462 .3407 .7243 .5439 .7 \quad 100$ $81398.8421 .7411 .4235 .3421 .4467 .3 \quad 379.7 \quad 345.0269 .9324 .0 \quad 101$ $81342.1209 .1311 .4427 .6387 .4417 .1345 .7382 .6161 .5348 .7 \quad 102$

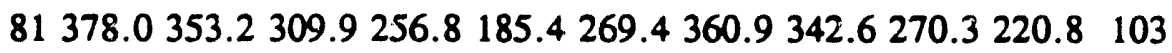
8i $16^{n} .4 \quad 155.7332 .3 \quad 310.8306 .0216 .0222 .6208 .1305 .4 \quad 151.8 \quad 104$

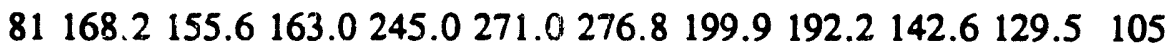
$\begin{array}{lllllllllllll}81 & 134.7 & 190.0 & 179.3 & 190.8 & 49.0 & 191.3 & 47.7 & 47.1 & 46.5 & 46.0 & 106\end{array}$ $\begin{array}{lllllllllllll}81 & 45.4 & 163.3 & 147.9 & 165.3 & 43.3 & 172.1 & 147.7 & 120.8 & 161.4 & 124.9 & 107\end{array}$ $\begin{array}{llllllllllll}81 & 107.8 & 127.2 & 95.8 & 79.6 & 129.0 & 104.4 & 133.0 & 162.6 & 38.2 & 37.9 & 108\end{array}$

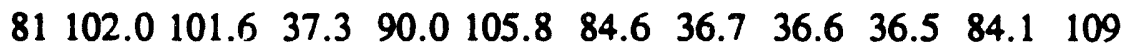
$\begin{array}{llllllllllll}81 & 147.3 & 36.3 & 36.3 & 68.1 & 66.9 & 91.4 & 119.7 & 36.4 & 115.9 & 36.6 & 110\end{array}$

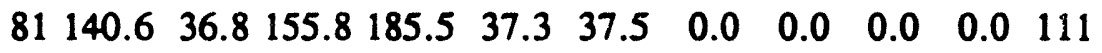
$\begin{array}{lllllllllllll}82 & 37.6 & 37.8 & 97.0 & 38.3 & 110.1 & 134.5 & 105.2 & 148.3 & 160.8 & 92.1 & 112\end{array}$ $\begin{array}{lllllllllllll}82 & 151.6 & 158.0 & 88.5 & 107.6 & 165.1 & 42.6 & 124.0 & 139.4 & 122.1 & 216.7 & 113\end{array}$

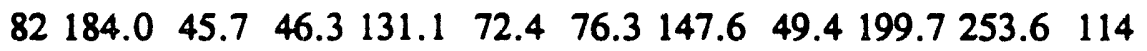
$82203.3190 .6179 .7 \quad 188.7 \quad 79.8241 .4279 .5283 .5271 .7214 .7 \quad 115$

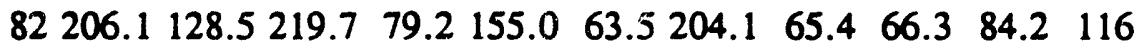

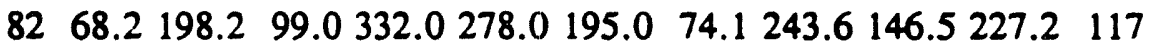
$82312.6396 .3340 .3230 .5270 .5290 .1304 .6310 .9162 .0439 .1 \quad 118$ $82357.1370 .1392 .4353 .6361 .4459 .4344 .0257 .6286 .5493 .7 \quad 119$ $82450.5342 .6323 .1369 .9354 .5428 .9280 .6285 .0 \quad 108.5109 .6 \quad 120$ $82186.5150 .0530 .7327 .3271 .5115 .9250 .1484 .9591 .5538 .6 \quad 121$ $82367.6609 .8614 .7619 .6471 .3474 .6388 .2574 .4532 .5534 .0 \quad 122$ $82607.6552 .6582 .4533 .5454 .0483 .0678 .2682 .3686 .3474 .0 \quad 123$ $82694.2698 .1701 .9705 .6611 .2552 .9644 .4719 .8607 .3619 .9 \quad 124$ $82688.6682 .6735 .9738 .9685 .5597 .2543 .7750 .2752 .8612 .9 \quad 125$ $82666.0695 .0762 .5737 .7766 .9769 .0443 .3523 .8722 .6723 .1 \quad 126$ $82686.2524 .5762 .7524 .8712 .1710 .6720 .8787 .5587 .1425 .3 \quad 127$ $82668.8746 .9729 .6553 .1673 .2662 .9765 .1784 .8713 .0775 .6 \quad 128$ $82609.7793 .7659 .1733 .2590 .6584 .4613 .0264 .0534 .5789 .8 \quad 129$ $82723.6670 .4639 .8759 .0784 .6754 .6673 .7680 .7779 .0658 .7 \quad 130$ $82775.7719 .5513 .2619 .8688 .1589 .0735 .1698 .1618 .3585 .1 \quad 131$ $82689.5751 .9715 .8588 .8589 .3741 .0651 .9735 .1675 .1611 .9 \quad 132$ $82695.6718 .3719 .1665 .5544 .9507 .4681 .3621 .0546 .9602 .2 \quad 133$ $82327.8634 .3682 .1678 .1594 .3609 .8665 .6661 .3 \quad 558.2 \quad 470.4 \quad 134$ $82648.2606 .6516 .6475 .7365 .1498 .7569 .7615 .8570 .6551 .3 \quad 135$ $82199.9315 .7429 .6504 .9569 .8115 .3 \quad 390.2438 .1456 .0493 .7 \quad 136$ $82488.3473 .9382 .5298 .0529 .4472 .4471 .3494 .6346 .5502 .7 \quad 137$ $82410.0163 .0228 .1246 .7342 .4248 .0231 .6 \quad 91.9422 .8325 .3 \quad 138$

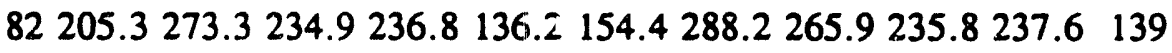
$82193.1264 .2336 .4354 .4363 .6 \quad 365.9360 .9356 .0219 .7329 .8 \quad 140$

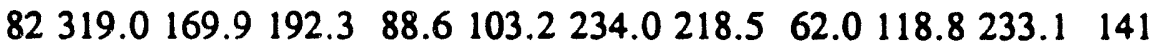

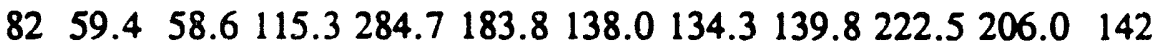
$\begin{array}{llllllllllll}82 & 180.5 & 173.8 & 123.8 & 81.1 & 210.0 & 177.1 & 191.0 & 200.7 & 46.5 & 46.0 & 143\end{array}$

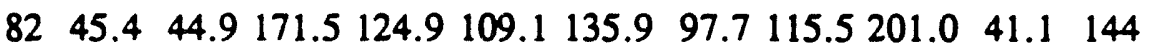

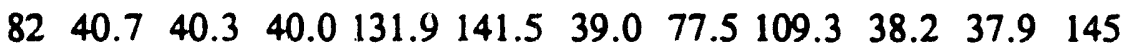

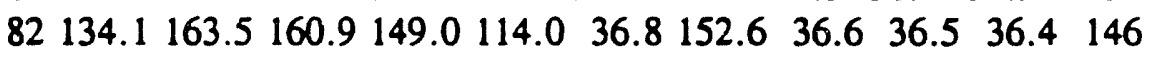
$\begin{array}{lllllllllllll}82 & 107.5 & 79.4 & 36.3 & 36.3 & 36.3 & 115.2 & 128.7 & 131.7 & 76.7 & 61.3 & 147\end{array}$ 
$\begin{array}{llllllllllll}82 & 61.5 & 109.3 & 134.1 & 65.3 & 116.3 & 37.5 & 0.0 & 0.0 & 0.0 & 0.0 & 148\end{array}$

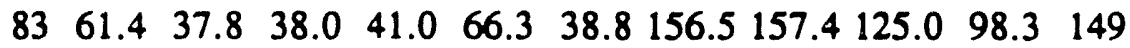

$\begin{array}{llllllllllll}83 & 97.1 & 112.8 & 150.4 & 126.6 & 170.9 & 42.6 & 129.8 & 43.6 & 44.1 & 88.5 & 150\end{array}$

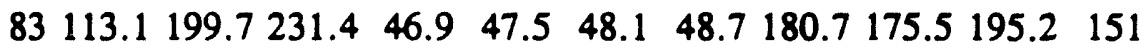

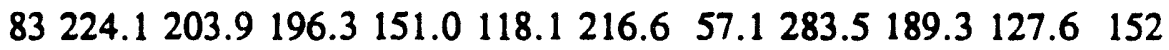

$\begin{array}{llllllllllll}83 & 59.2 & 120.9 & 121.4 & 131.9 & 69.3 & 89.6 & 306.1 & 132.8 & 114.0 & 183.9 & 153\end{array}$

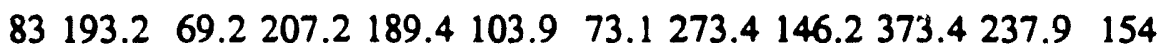

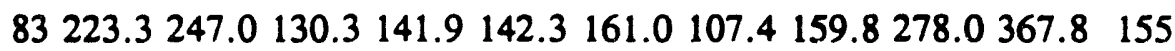

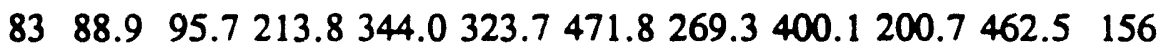

$83334.4378 .9270 .8271 .2313 .7 \quad 105.3424 .8116 .3542 .6444 .3 \quad 157$

$83449.4292 .7457 .3480 .7427 .8482 .1456 .6536 .5470 .1599 .8 \quad 158$

$83437.2495 .1379 .1582 .8624 .4629 .2 \quad 478.7439 .2415 .6 \quad 620.3 \quad 159$

$83480.4563 .2269 .6559 .9496 .6590 .4586 .0483 .8686 .3 \quad 360.3 \quad 160$

$83599.7456 .1620 .5376 .0154 .3523 .3 \quad 317.9662 .3723 .2669 .3 \quad 161$

$83520.3642 .2674 .3738 .9660 .1579 .3564 .2516 .4500 .6602 .4 \quad 162$

$83629.5545 .1547 .8654 .3766 .9557 .8568 .6590 .4654 .1509 .5 \quad 163$

$83748.0477 .5781 .2757 .7765 .3634 .0615 .5668 .2768 .3789 .4 \quad 164$

$83342.6446 .4655 .8761 .9420 .2714 .3663 .3681 .1519 .4793 .8 \quad 165$

$83656.9641 .6793 .5643 .6570 .2482 .9672 .7791 .2790 .5581 .8 \quad 166$

$83682.0787 .9685 .3526 .0661 .4699 .8772 .5566 .7597 .9575 .1 \quad 167$

$83775.7773 .9634 .2753 .0620 .1764 .7763 .9761 .6759 .3756 .9 \quad 168$

$83724.2631 .5749 .3568 .3417 .3628 .7738 .1572 .4677 .1578 .3 \quad 169$

$83648.5722 .4587 .0490 .1504 .3673 .6628 .6609 .8565 .6693 .9 \quad 170$

$83431.3464 .6461 .4523 .0404 .7669 .8634 .5661 .3496 .5623 .3 \quad 171$

$83469.8638 .3620 .9434 .9482 .6605 .1442 .1 \quad 360.7541 .3 \quad 366.5 \quad 172$

$83429.3550 .0481 .0545 .5521 .2474 .8433 .4463 .0449 .7352 .6 \quad 173$

$83370.2375 .9394 .3352 .9446 .1524 .1418 .5416 .1353 .6395 .9 \quad 174$

$83 \quad 122.4253 .0349 .2323 .0475 .8339 .4436 .3459 .7454 .3449 .0 \quad 175$

$83430.2438 .3433 .0374 .6422 .4363 .4342 .6292 .6306 .4307 .7 \quad 176$

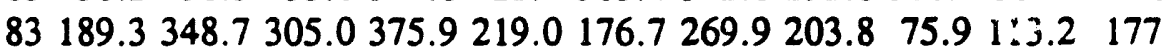

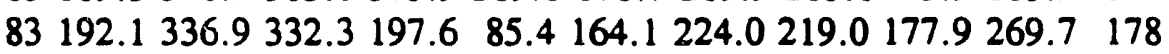

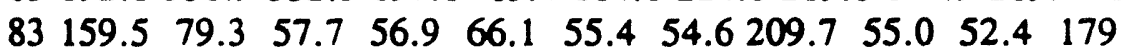

$\begin{array}{llllllllllll}83 & 103.2 & 174.3 & 59.1 & 49.6 & 72.2 & 48.4 & 47.7 & 47.1 & 46.5 & 46.0 & 180\end{array}$

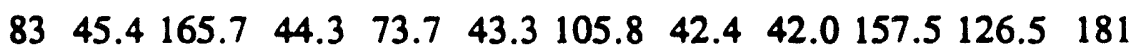

$\begin{array}{llllllllllll}83 & 115.3 & 40.3 & 70.6 & 56.5 & 93.6 & 39.0 & 93.8 & 38.4 & 38.2 & 116.0 & 182\end{array}$

$\begin{array}{llllllllllll}83 & 37.7 & 60.0 & 37.3 & 37.1 & 100.1 & 36.8 & 80.0 & 36.6 & 117.0 & 36.4 & 183\end{array}$

$\begin{array}{llllllllllll}83 & 111.0 & 36.3 & 36.3 & 112.7 & 80.0 & 71.8 & 66.4 & 36.4 & 36.5 & 113.4 & 184\end{array}$

$\begin{array}{llllllllllll}83 & 36.7 & 96.6 & 37.0 & 37.1 & 66.4 & 37.5 & 0.0 & 0.0 & 0.0 & 0.0 & 185\end{array}$

$\begin{array}{llllllllllll}84 & 103.2 & 37.8 & 38.0 & 124.2 & 86.9 & 115.9 & 66.9 & 168.8 & 116.3 & 40.1 & 186\end{array}$

$\begin{array}{llllllllllll}84 & 125.4 & 104.7 & 104.8 & 92.1 & 126.3 & 42.6 & 110.9 & 83.7 & 102.0 & 146.0 & 187\end{array}$

$\begin{array}{llllllllllll}84 & 45.2 & 135.1 & 231.4 & 225.5 & 237.4 & 111.7 & 198.3 & 238.8 & 156.5 & 217.1 & 188\end{array}$

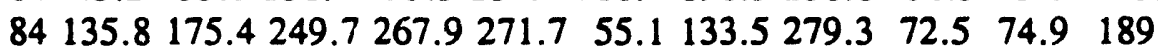

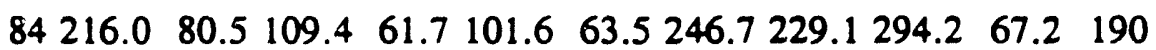

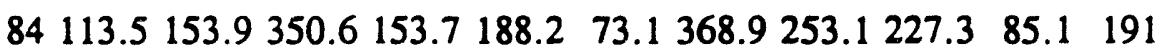
$84121.6396 .3 \quad 335.7270 .7412 .2 \quad 356.7347 .4342 .3 \quad 367.5319 .5 \quad 192$ $84376.8386 .9241 .7315 .493 .3208 .1269 .7335 .1381 .1270 .0 \quad 193$ $84204.7441 .2262 .7370 .1257 .5184 .0482 .0377 .8423 .4453 .0 \quad 194$ $84442.1327 .0493 .4476 .6192 .5573 .8584 .6390 .1379 .2572 .2 \quad 195$ $84543.5533 .2 \quad 122.9420 .6557 .1629 .2575 .0602 .8567 .2575 .4 \quad 196$ $84422.4542 .2545 .0581 .1669 .8674 .0678 .2682 .3686 .3581 .6 \quad 197$ 
$84493.6652 .9588 .3638 .2528 .3712 .8689 .8719 .8723 .2714 .5 \quad 198$ $84675.4650 .9735 .9383 .6678 .2744 .7709 .5601 .0731 .8368 .1 \quad 199$ 84626.3446 .4750 .7653 .4668 .3676 .3771 .0662 .3754 .6716 .3200 $84625.9588 .4781 .2680 .4661 .8435 .0479 .5723 .6387 .3707 .8 \quad 201$ 84665.4742 .3652 .1228 .1704 .8653 .7627 .3648 .5549 .4793 .8202 $84793.8635 .8596 .8430 .0538 .7464 .8791 .9749 .8790 .5789 .8 \quad 203$ 84495.4651 .7549 .0772 .5784 .6655 .3728 .4687 .0552 .1694 .1204 84775.7596 .1772 .1745 .7766 .5571 .0707 .3409 .0586 .2756 .9205 $84667.4636 .2536 .3516 .6546 .5703 .0666 .8593 .4531 .0304 .8 \quad 206$ 84534.0575 .6568 .6715 .7605 .5708 .7602 .5673 .0685 .1673 .0207 84564.5517 .9620 .8610 .2674 .0619 .4648 .9594 .6615 .0531 .7208 $84448.9643 .7354 .9455 .5524 .1502 .0620 .6533 .4354 .9606 .2 \quad 209$ 84586.3596 .4513 .0586 .4581 .4551 .6544 .7400 .7159 .6248 .1210 $84534.4375 .1364 .8534 .7529 .4417 .1422 .5365 .1330 .1415 .2 \quad 211$ $84468.3275 .2343 .8256 .9407 .4291 .2 \quad 93.0293 .6444 .6318 .4212$ $84353.4438 .3344 .7394 .2142 .4258 .6152 .7293 .5199 .5328 .1 \quad 213$ $84211.6359 .6188 .6328 .1317 .4142 .7274 .8277 .9308 .3252 .7 \quad 214$ $84334.1336 .9227 .8215 .7 \quad 162.4218 .5 \quad 95.4175 .4118 .9123 .0 \quad 215$

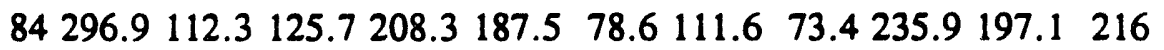

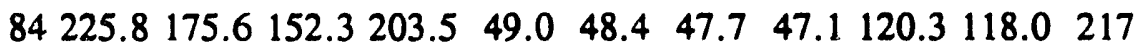
$\begin{array}{llllllllllll}84 & 162.8 & 44.9 & 44.3 & 43.8 & 43.3 & 198.8 & 186.2 & 42.0 & 41.5 & 121.8 & 218\end{array}$ $\begin{array}{llllllllllll}84 & 152.6 & 40.3 & 40.0 & 39.6 & 132.9 & 171.6 & 170.5 & 111.8 & 86.5 & 108.6 & 219\end{array}$ $\begin{array}{llllllllllll}84 & 37.7 & 37.5 & 48.1 & 37.1 & 86.4 & 36.8 & 36.7 & 78.2 & 79.6 & 113.5 & 220\end{array}$ $\begin{array}{lllllllllllll}84 & 78.3 & 36.3 & 140.5 & 102.4 & 36.3 & 107.8 & 105.8 & 83.1 & 129.2 & 121.5 & 221\end{array}$

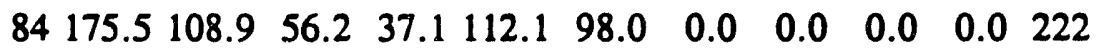
$\begin{array}{llllllllllllll}85 & 37.6 & 115.9 & 90.7 & 100.1 & 121.8 & 138.1 & 62.8 & 137.4 & 179.1 & 139.0 & 223\end{array}$

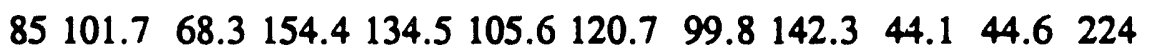
$\begin{array}{llllllllllll}85 & 178.2 & 45.7 & 183.4 & 191.3 & 193.4 & 216.7 & 209.3 & 207.6 & 114.0 & 100.3 & 225\end{array}$

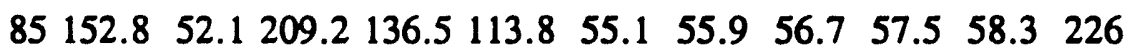

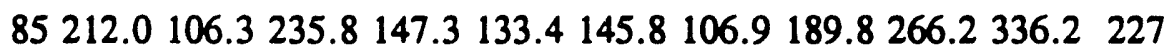
$\begin{array}{llllllll}85213.6 & 251.0350 .6327 .2 & 332.4308 .4271 .1 & 182.1 & 183.0 & 270.1 & 228\end{array}$

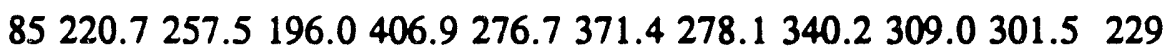
85336.9380 .1410 .2305 .9355 .6471 .8477 .3445 .7480 .5493 .7230 $85499.2416 .0341 .7248 .4344 .6393 .1531 .8107 .4108 .5351 .6 \quad 231$ $85346.0265 .4383 .8355 .6540 .8539 .4572 .9477 .6407 .9424 .0 \quad 232$ $85425.7586 .9411 .5567 .1518 .1608 .3615 .8413 .9421 .5337 .8 \quad 233$ $85554.5234 .6439 .6665 .5592 .8538 .9661 .3620 .8565 .7529 .3 \quad 234$ 85683.0643 .1617 .5705 .6613 .0712 .8716 .3693 .9636 .1726 .5235 $85729.7626 .7147 .2535 .9551 .6744 .7549 .5666 .3740 .4713 .2 \quad 236$ $85663.8760 .2660 .1764 .8616 .7769 .0656 .2629 .4611 .8646 .8 \quad 237$ $85661.3691 .9621 .4782 .6708 .9785 .2289 .6752 .4512 .4757 .7 \quad 238$ $85544.6567 .7791 .6554 .4573 .8620 .9793 .4774 .8724 .0623 .3 \quad 239$ $85677.6483 .2763 .1604 .0558 .8666 .1791 .9671 .2645 .2679 .8 \quad 240$ 85754.6718 .0770 .1692 .1617 .5642 .2718 .9641 .7549 .0687 .1241 85718.1565 .6606 .7677 .0768 .1766 .1763 .9610 .5630 .3584 .9242 85520.2751 .9706 .4426 .2640 .7583 .8738 .1527 .4694 .6728 .9243 85602.3610 .6719 .1715 .7551 .3473 .7648 .6557 .2697 .7520 .3244 $85319.4351 .1565 .3407 .7411 .8669 .8665 .6657 .1657 .0547 .8 \quad 245$ 85627.4643 .7602 .1511 .9420 .4621 .3568 .0462 .8524 .4606 .2246 $85601.3491 .1552 .5122 .3 \quad 324.4283 .3 \quad 379.7410 .3495 .7555 .7 \quad 247$ 


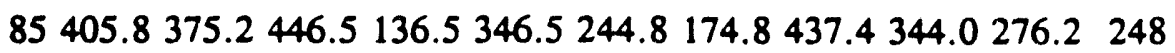

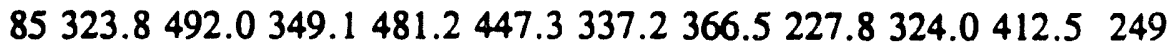
$85364.9287 .2433 .0194 .3 \quad 354.0377 .2 \quad 316.4372 .4216 .9183 .2 \quad 250$ $85288.9386 .0266 .6252 .6265 .8197 .9253 .0259 .0193 .4219 .1 \quad 251$ 85314.1216 .1289 .3264 .2187 .6261 .0214 .4176 .6214 .7301 .1252

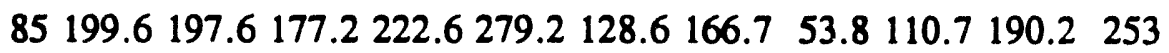

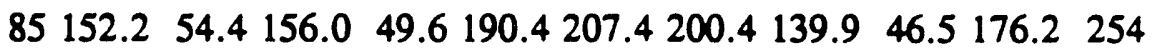
$\begin{array}{llllllllllll}85 & 45.4 & 97.0 & 44.3 & 43.8 & 43.3 & 42.9 & 148.8 & 91.0 & 41.5 & 151.0 & 255\end{array}$ $\begin{array}{llllllllllll}85 & 40.7 & 126.8 & 40.0 & 39.6 & 39.3 & 39.0 & 111.3 & 136.8 & 113.6 & 37.9 & 256\end{array}$ $\begin{array}{llllllllllll}85 & 37.7 & 125.7 & 148.0 & 118.7 & 157.8 & 122.2 & 84.6 & 84.4 & 96.1 & 117.6 & 257\end{array}$

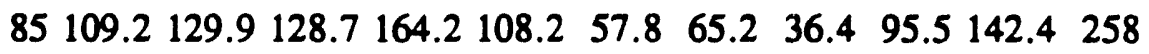

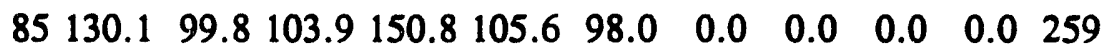
$\begin{array}{lllllllllllll}86 & 37.6 & 37.8 & 91.5 & 38.3 & 38.5 & 82.1 & 106.8 & 102.1 & 39.8 & 91.4 & 260\end{array}$ $\begin{array}{llllllllllll}86 & 102.9 & 92.7 & 85.4 & 150.4 & 42.2 & 42.6 & 43.1 & 43.6 & 131.5 & 155.1 & 261\end{array}$ $\begin{array}{llllllllllll}86 & 55.9 & 45.7 & 46.3 & 95.0 & 133.2 & 101.6 & 48.7 & 49.4 & 50.0 & 50.7 & 262\end{array}$

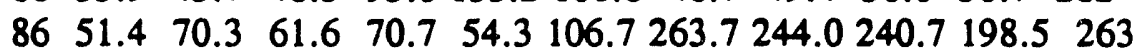

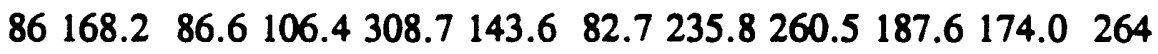
$86303.1101 .6235 .0185 .5212 .5287 .5329 .4352 .5368 .3259 .6 \quad 265$ $86142.9174 .2320 .0379 .6390 .9148 .0187 .0265 .2 \quad 261.4348 .6 \quad 266$ $86158.9183 .6338 .5305 .1394 .7273 .5217 .8419 .2 \quad 365.2 \quad 482.1 \quad 267$

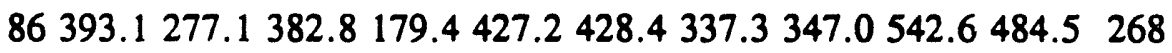
$86523.8540 .5363 .4472 .5574 .3528 .9470 .3 \quad 391.0382 .2 \quad 310.0 \quad 269$ $86509.3609 .8508 .3467 .1380 .4524 .9586 .7638 .6573 .4535 .1 \quad 270$ $86423.3656 .7351 .8609 .8669 .8674 .0484 .8682 .3 \quad 578.0688 .7 \quad 271$

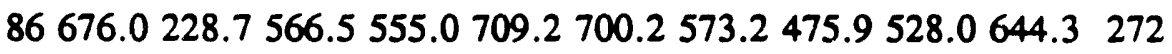
$86601.4355 .5418 .0505 .8660 .7633 .6678 .2699 .8646 .6439 .0 \quad 273$ $86429.7760 .2740 .9687 .5736 .9387 .3637 .5693 .1751 .2776 .5 \quad 274$ 86626.0719 .9723 .6635 .7602 .6781 .0786 .4787 .5788 .4789 .4275 86790.2790 .9787 .6718 .4593 .3560 .7576 .1630 .4686 .7493 .7276 $86616.8585 .5680 .4768 .3792 .8707 .5622 .9791 .2606 .8687 .8 \quad 277$ 86713.4511 .3218 .4403 .6476 .4637 .6782 .0700 .9486 .2777 .4278 86658.1722 .6751 .3736 .5671 .6706 .7763 .9761 .6759 .3756 .9279 $86415.7503 .9438 .7575 .7505 .1580 .2738 .1735 .1695 .6670 .0 \quad 280$ 86725.7613 .1703 .6715 .7712 .2386 .5584 .5664 .7542 .6492 .3281 $86513.5686 .1662 .1678 .1674 .0615 .9521 .3576 .3 \quad 324.4355 .3 \quad 282$ $86349.7488 .2527 .0423 .3497 .4566 .2620 .6534 .0496 .0606 .2 \quad 283$ $86601.3596 .4557 .9404 .2581 .4488 .1540 .9370 .7369 .2521 .7 \quad 284$ $86440.5545 .3540 .0491 .7529 .4376 .4518 .8418 .0508 .1438 .2 \quad 285$

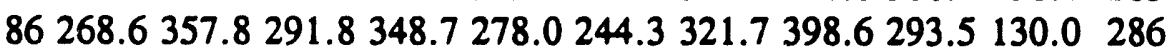
$86329.6259 .5412 .1338 .2261 .5240 .0244 .6293 .5301 .4293 .7 \quad 287$

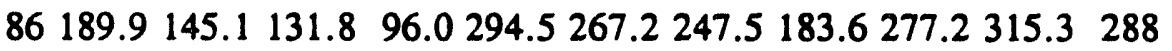

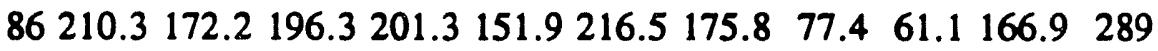

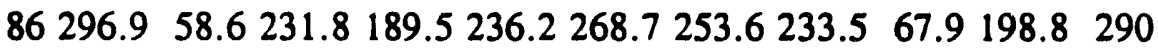

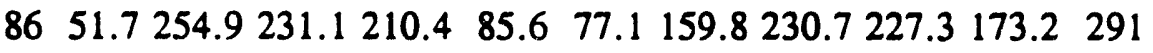

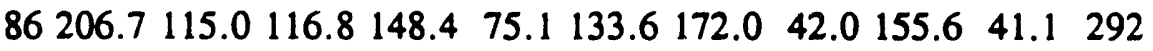
$\begin{array}{llllllllllll}86 & 40.7 & 40.3 & 108.6 & 102.3 & 192.7 & 96.1 & 153.9 & 38.4 & 38.2 & 88.9 & 293\end{array}$

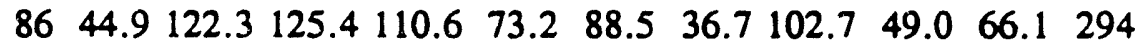

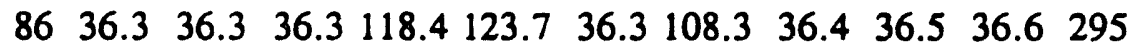

$\begin{array}{llllllllllll}86 & 36.7 & 36.8 & 92.7 & 110.2 & 133.8 & 98.0 & 0.0 & 0.0 & 0.0 & 0.0 & 296\end{array}$

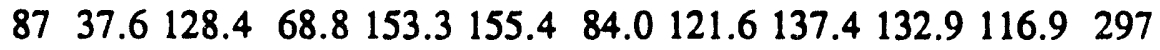




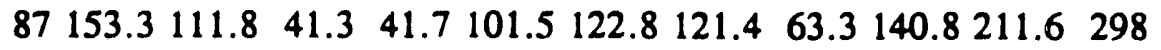

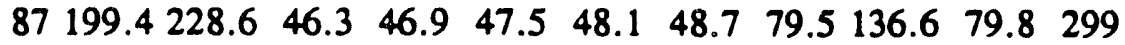
8751.4260 .6165 .3180 .3247 .5261 .5173 .8262 .0193 .9208 .5300 $87270.1122 .1125 .0171 .7226 .4317 .7224 .3217 .7331 .5299 .0 \quad 301$ 87341.0240 .8139 .3219 .6331 .7274 .4335 .0375 .6281 .2235 .6302 $87321.0213 .1345 .8240 .4315 .6200 .6225 .4428 .2181 .8 \quad 87.8 \quad 303$ $87204.2196 .2217 .5208 .1214 .8276 .4373 .7283 .5488 .3493 .7 \quad 304$ $87499.2385 .7510 .1416 .6346 .1526 .4402 .8537 .2417 .7408 .9 \quad 305$ $87458.5405 .4532 .9396 .0563 .4420 .5411 .9439 .9574 .3522 .7 \quad 306$ $87604.8569 .4529 .8601 .3589 .0519 .5235 .3528 .1643 .2647 .7 \quad 307$ 87598.6521 .3327 .9568 .5623 .1537 .0387 .9658 .6454 .7151 .0308 $87596.9597 .4574 .2705 .6612 .5584 .6445 .5693 .5504 .7706 .0 \quad 309$ $87680.5732 .8411 .7642 .0741 .9744 .7711 .3713 .3752 .8641 .2 \quad 310$ $87597.0498 .5499 .1664 .3766 .9688 .2720 .8680 .2645 .6225 .1 \quad 311$ $87647.3574 .0753 .0644 .9597 .6660 .8577 .5582 .5788 .4686 .3 \quad 312$ 87605.9635 .4612 .6743 .6727 .9312 .6476 .1650 .2569 .3735 .6313 $87504.4793 .7763 .9495 .4792 .8535 .9617 .6784 .2674 .0676 .0 \quad 314$ $87543.2765 .9786 .9537 .5497 .5580 .5782 .0650 .2421 .9777 .4 \quad 315$ 87727.7685 .6726 .3723 .5567 .1658 .7649 .3235 .7513 .1557 .4316 $87451.0463 .7497 .9711 .9669 .2668 .7545 .2652 .6550 .8601 .5 \quad 317$ 87374.0674 .0719 .1637 .6459 .6586 .1598 .1701 .4697 .7622 .8318 $87378.2639 .4682 .1678 .1666 .0470 .6665 .6661 .3624 .2366 .3 \quad 319$ 87432.2545 .3561 .6613 .4406 .6487 .7568 .7469 .6325 .9393 .0320 87391.7568 .2520 .5486 .8471 .7568 .6434 .7436 .5560 .9555 .7321 87550.5421 .3359 .0521 .8348 .2411 .0492 .7423 .2404 .5402 .9322 87249.4166 .7343 .6351 .2475 .8404 .8465 .1459 .7232 .1388 .4323 87409.5412 .8433 .0427 .6378 .4417 .1411 .8289 .6401 .4391 .6324 $87239.7237 .9303 .9370 .0328 .6290 .5327 .4294 .0249 .0226 .0 \quad 325$ 87341.6223 .2332 .3327 .7303 .8207 .2278 .5309 .8288 .9208 .4326

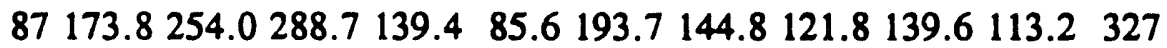

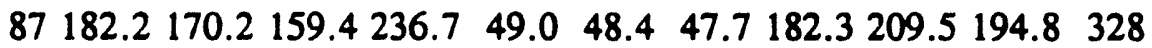

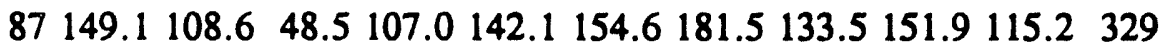

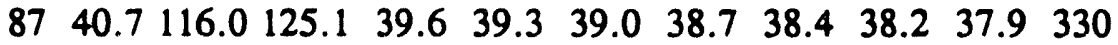
$\begin{array}{llllllllllll}87 & 71.6 & 125.4 & 37.3 & 87.8 & 87.4 & 59.8 & 92.3 & 73.8 & 36.5 & 36.4 & 331\end{array}$ $\begin{array}{lllllllllllll}87 & 102.6 & 73.5 & 123.4 & 167.6 & 142.1 & 96.2 & 114.0 & 123.0 & 79.2 & 145.5 & 332\end{array}$ $\begin{array}{llllllllllll}87 & 121.8 & 36.8 & 65.3 & 99.9 & 98.7 & 98.0 & 0.0 & 0.0 & 0.0 & 0.0 & 333\end{array}$ $\begin{array}{llllllllllll}88 & 82.4 & 99.8 & 120.8 & 38.3 & 67.8 & 116.1 & 39.1 & 39.5 & 39.8 & 40.1 & 334\end{array}$ $\begin{array}{llllllllllll}88 & 146.4 & 72.8 & 125.5 & 41.7 & 103.2 & 148.9 & 146.1 & 144.5 & 84.9 & 44.6 & 335\end{array}$ $88 \quad 179.2 \quad 205.5 \quad 194.7222 .2180 .5130 .2234 .6225 .6 \quad 161.7 \quad 167.7 \quad 336$

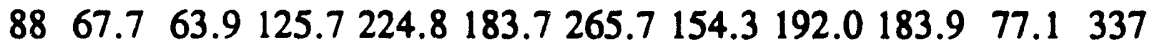
$88247.4192 .4228 .6308 .7313 .2317 .7 \quad 198.1227 .0299 .3257 .7 \quad 338$

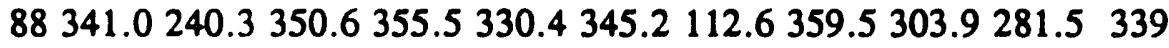

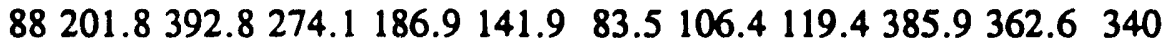
$88415.8216 .4192 .5280 .3294 .3399 .8392 .0351 .3386 .0370 .5 \quad 341$ $88499.2456 .8434 .3405 .0383 .5466 .5423 .5329 .0253 .7434 .4 \quad 342$ 88497.8465 .5440 .9402 .0528 .3346 .5335 .8493 .6594 .8523 .6343 $88604.8563 .4614 .7619 .6450 .3445 .0423 .2127 .7523 .6387 .2 \quad 344$ $88484.9587 .4364 .3523 .3469 .7601 .6639 .8370 .3 \quad 355.0537 .2 \quad 345$ 88694.2590 .9303 .8590 .9489 .9483 .1446 .7617 .5319 .3518 .4346 $88670.0532 .2622 .5499 .0741 .9744 .7747 .5713 .7379 .2755 .4 \quad 347$ 
88511.4550 .0762 .5764 .8676 .9737 .8727 .6651 .5470 .9649 .1348 $88676.7682 .7307 .2536 .7687 .1510 .0721 .5642 .7751 .6753 .7 \quad 349$ $88738.0666 .0791 .6732 .8581 .1668 .6667 .0661 .2765 .4779 .6 \quad 350$ $88613.3565 .5793 .5793 .2792 .8685 .9761 .8791 .2776 .9789 .8 \quad 351$ 88542.4725 .8479 .2747 .9784 .6710 .0612 .7780 .5779 .0618 .5352 $88710.1593 .9571 .4619 .3298 .4766 .1687 .7761 .6759 .3740 .5 \quad 353$ 88655.5693 .8706 .0545 .8638 .8648 .4696 .8657 .6397 .8616 .6354 88658.1695 .0652 .9715 .7711 .2708 .7559 .6526 .0625 .7448 .4355 88547.7394 .0618 .6517 .8653 .8652 .2665 .6573 .8520 .7537 .1356 $88608.3563 .5639 .2603 .3490 .1475 .4475 .4534 .4474 .7441 .3 \quad 357$ $88601.3376 .9380 .1378 .4523 .6305 .3301 .4413 .1380 .4380 .7 \quad 358$ $88345.3539 .6514 .3512 .2483 .1365 .4355 .2513 .5387 .3502 .7 \quad 359$

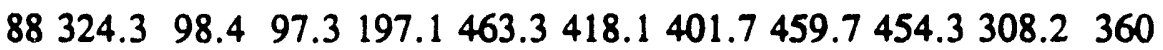
$88368.0304 .0342 .3420 .8339 .6371 .4219 .2379 .0401 .4355 .0 \quad 361$

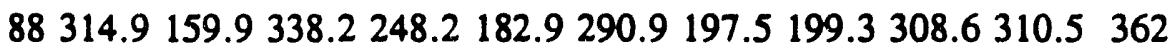

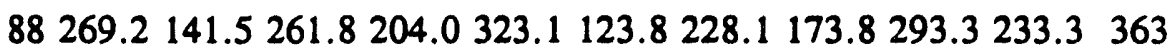

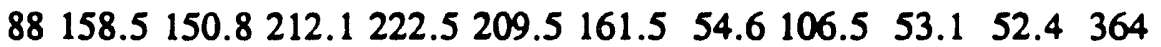

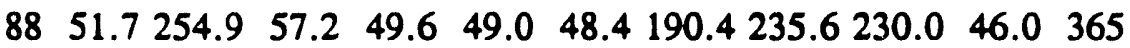

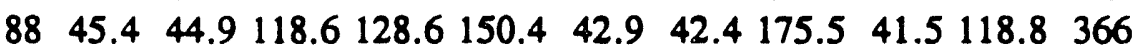
$\begin{array}{lllllllllllll}88 & 80.1 & 153.5 & 122.5 & 143.1 & 77.7 & 110.0 & 175.3 & 144.1 & 118.3 & 37.9 & 367\end{array}$

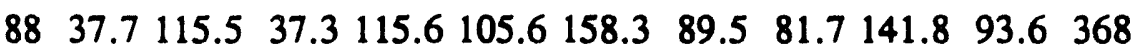
$\begin{array}{llllllllllll}88 & 92.0 & 62.1 & 36.3 & 36.3 & 36.3 & 36.3 & 36.3 & 91.9 & 103.9 & 136.1 & 369\end{array}$

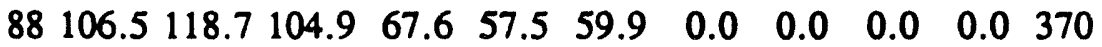


DOE/RL-93-99, Rev. 0

\section{APPENDIX C \\ ACCEPTABLE SOIL AND LEACHATE CONCENTRATION LIMITS}

\section{REFERENCE}

DOE-RL, 1993, Hanford Site Baseline Risk Assessment Methodology, DOE/RL 91-45, Rev. 2, U.S. Department of Energy, Richland Operations Office, Richland, Washington.

DOE-RL, 1992, Hanford Site Groundwater Background, DOE/RL-92-23, U.S. Department of Energy, Richland Operations Office, Richland, Washington. 
DOE/RL-93-99, Rev. ú

\section{CONTENTS}

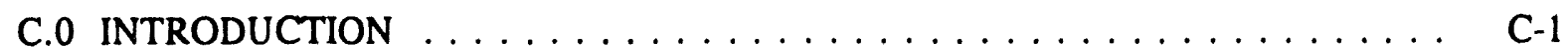

C.1 SOIL CONCENTRATION LIMITS $\ldots \ldots \ldots \ldots \ldots \ldots \ldots$ C-1

C.2 LEACHATE CONCENTRATION LIMITS $\ldots \ldots \ldots \ldots \ldots \ldots$ C-2 


\section{C.0 INTRODUCTION}

This appendix provides soil and leachate concentration limits for waste accepted at the ERDF. These limits may be used to ensure that predicted human and ecological risks associated with the ERDF design alternatives will be acceptable. The soil concentration limits ensure that inadvertent intrusion into the waste will not result in unacceptable risks to humans or ecological receptors. The leachate limits ensure that groundwater contaminant concentrations below the ERDF do not exceed acceptable concentrations and are used in Appendix A and Chapter 9 to evaluate impacts to groundwater for the different alternatives. These soil and leachate limits may be used to assist development of waste acceptance criteria for the ERDF. The development of risk-based soil concentration limits is presented in Section C.1 and the development of acceptable leachate concentration limits is presented in Section C.2.

\section{C.1 SOIL CONCENTRATION LIMITS}

Acceptable soil limits are calculated assuming that active controls prevent intrusion for 100 years, passive controls prevent intrusion for 500 years, and a barrier thickness of at least 15 feet prevents intrusion due to excavation for at least 10,000 years. Therefore, the acceptable soil concentrations are based on the drilling scenario in 500 years (described in Section 6.3). The drilling scenario assumes that waste is brought to the surface in the form of drill cuttings and eventually spread over an area of $100 \mathrm{~m}(328 \mathrm{ft})$ by $50 \mathrm{~m}(164 \mathrm{ft})$ to a depth of $15 \mathrm{~cm}(5.9$ in.) for a total volume of $750 \mathrm{~m}^{3}\left(26,000 \mathrm{ft}^{3}\right)$. Assuming a drill bit diameter of $20 \mathrm{~cm}(7.9 \mathrm{in}$.)

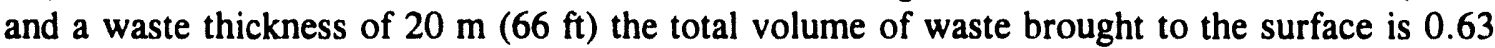
$\mathrm{m}^{3}\left(22 \mathrm{ft}^{3}\right)$. Dividing the volume of surface soil by the amount of waste results in a dilution factor of 1,190 , which is rounded down to 1,000 .

The parameters, pathways, and equations used to calculate acceptable soil exposure concentration limits in surface soils are described in Chapter 6. Exposure limits for human health are provided for all the contaminants detected in waste that might be received at the ERDF (Tables 3-8, 3-9, and 3-10) and are based on an ICR of $1 \times 10^{-5}$ and a HQ of 1 . Exposure limits for ecological protection are only provided for the potential contaminants of concern in soils (Table 5-8) and are based on NOAELs for the pocket mouse (see Chapter 6). The exposure concentration limits are summarized in Table C-1. The limiting exposure concentration for each contaminant is highlighted. In most cases, protection of human health is the driving factor.

Acceptable soil concentration limits for ERDF waste are calculated from the limiting acceptable exposure concentration assuming 500 years of decay and a 1,000-fold dilution and are provided in Table C-1. The decay coefficients for the constituents are provided in Chapter 4. Comparison with the maximum detected concentrations in the 100,200, and 300 Area wastes are also provided for reference. For all constituents except copper, the maximum detected concentration is less than the acceptable soil concentration. The acceptable soil concentration for copper $(8,200 \mathrm{mg} / \mathrm{kg})$ is approximately one order of magnitude less than the maximum detected concentration. 


\section{C.2 LEACHATE CONCENTRATION LIMITS}

Leachate concentration limits were calculated assuming the base-conditions groundwater exposure scenario described in Section 6.1 and the fate and transport parameters presented in Chapter 4. This scenario assumed no liner and an infiltration rate of $0.5 \mathrm{~cm} / \mathrm{yr}(0.2 \mathrm{in} . / \mathrm{yr})$. To begin with, any constituent with a travel time greater than 10,000 years or a half-life less than 12 years would not present a risk to groundwater and was assumed to have an unlimited leachate concentration limit. (Assuming a vadose zone travel time of at least 520 years, any constituent with a half-life less than 12 years would decay to less than $1 \times 10^{-13}$ of its original concentration before it reached groundwater). This screening step eliminated all the organics, the short-lived radionuclides, and the moderately to strongly sorbing metals and radionuclides.

Risk-Based and ARAR-Based Groundwater Standards. Risk-based and ARAR-based target groundwater concentrations were determined for the constituents that were not eliminated in the screening step. The risk-based standards were determined using a target ICR of $1 \times 10^{-5}$ and a HQ of 1 , and were calculated for the groundwater ingestion and volatile inhalation pathways, assuming HSBRAM (DOE-RL 1993) residential exposure parameters. The ARAR-based standards are the minimum ARAR from Table 7-5.

Risk-based groundwater concentrations for non-radioactive constituents are presented in Table C-2. Minimum ARAR groundwater concentrations for non-radioactive constituents are presented in Table C-3. Risk-based and minimum ARAR groundwater concentrations for radionuclides are presented in Table $\mathrm{C}-4$.

Acceptable Leachate Limits. Many contaminant concentrations will decrease during transport through the vadose zone due to radiological decay, biological or chemical degradation, or volatilization. In addition, contaminant concentrations are diluted when the contaminant reaches the groundwater. These processes were accounted for using a modified version of the fate and transport model presented in Appendix A. Whereas the original spreadsheet model calculates leachate and groundwater concentrations based on bulk soil concentrations in waste, the modified spreadsheet model performs the reverse calculation; that is, it calculates leachate concentrations based on target groundwater concentrations. Soil concentration limits for the waste that result in protection of groundwater were not calculated because of the large uncertainties in waste release calculations.

The results are presented in Table C-5. In addition to presenting risk-based and ARAR-based acceptable leachate concentrations, the table also indicates whether the constituent travel time is greater than 10,000 years, whether the constituent decays in the vadose zone, and the Hanford Site groundwater background value. An unlimited acceptable leachate concentration indicates that no matter how high the initial leachate concentration, it would not result in an unacceptable impact on groundwater. The acceptable leachate concentration may be identified as unlimited because its vadose zone travel time is greater than 10,000 years and/or the constituent decays in the vadose zone. As discussed above, any constituent with a half-life less than 12 years would decay in the vadose zone and was identified in the screening step as having an unlimited acceptable leachate concentration. In addition, if the calculated leachate concentration exceeds $1 \times 10^{6} \mathrm{mg} / \mathrm{L}$, the acceptable leachate concentration was presented as unlimited. This is because a pure substance has a density equal to its specific gravity times $1 \times 10^{6} \mathrm{mg} / \mathrm{L}$ (the density of water), and it is theoretically impossible for the concentration of a substance to exceed its density. Although some contaminants have densities greater than 
$1 \times 10^{6} \mathrm{mg} / \mathrm{L}$, it is unlikely that they would be mobile in their pure form. In reality, leachate concentrations cannot exceed solubilities, which are generally less than $1 \times 10^{3} \mathrm{mg} / \mathrm{L}$.

Most of the organic compounds in Table C-5 decay completely in the vadose zone because of their relatively short half-lives. The remaining contaminants have travel times that are greater 10,000 years. Thus, acceptable leachate concentrations are unlimited for all organic compounds. This analysis assumed that organics would only migrate in the dissolved state; migration of free product was not addressed.

As shown in Table C-5, the non-radionuclide inorganic constituents do not decay in the vadose zone. However, several have travel times greater than 10,000 years. Acceptable leachate limits were also compared to Hanford Site groundwater background for the inorganic constituents. If the calculated limit is less than the background concentration, then the acceptable leachate limit was set equal to the background concentration. Arsenic was the only constituent with a calculated acceptable leachate limit that was less than the Hanford Site groundwater background value.

As shown in Table C-5, most of the radionuclides decay completely in the vadose zone. Generally, only those radionuclides with long half-lives reach groundwater at significant concentrations. These include carbon-14, neptunium-237, potassium-40, technetium-99, and all the uranium isotopes. However, the travel times for neptunium-237 and potassium-40 are greater than 10,000 years and the acceptable leachate concentrations for these radionuclides are therefore unlimited. 
Table C-1. Acceptable Soil Concentration. (Sheet 1 of 7)

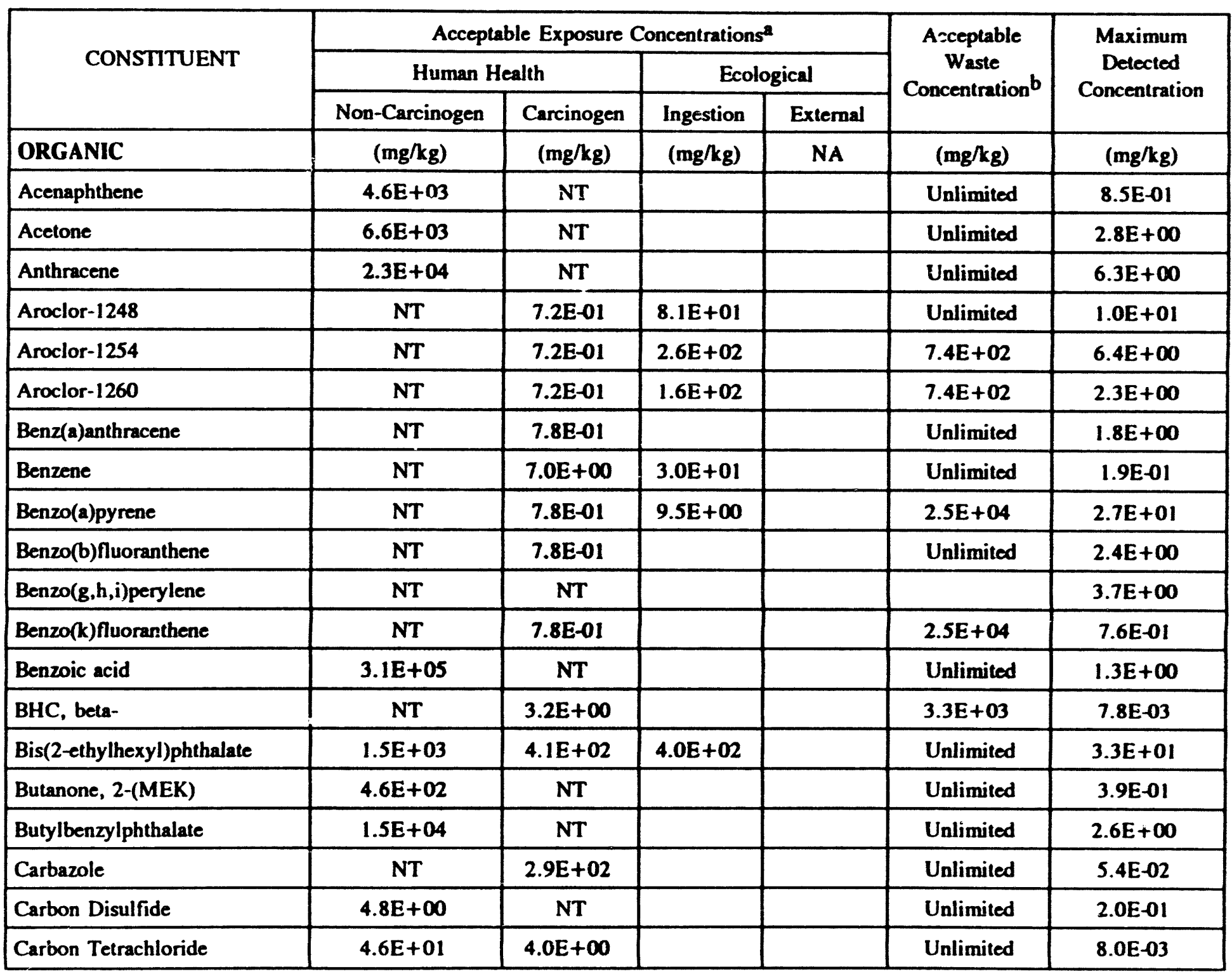


Table C-1. Acceptable Soil Concentration. (Sheet 2 of 7)

\begin{tabular}{|c|c|c|c|c|c|c|}
\hline \multirow{3}{*}{ CONSTITUENT } & \multicolumn{4}{|c|}{ Acceptable Exposure Concentrations ${ }^{a}$} & \multirow{3}{*}{$\begin{array}{c}\text { Acceptable } \\
\text { Waste } \\
\text { Concentration } b\end{array}$} & \multirow{3}{*}{$\begin{array}{c}\text { Maximum } \\
\text { Detected } \\
\text { Concentration }\end{array}$} \\
\hline & \multicolumn{2}{|c|}{ Human Health } & \multicolumn{2}{|c|}{ Ecological } & & \\
\hline & Non-Carcinogen & Carcinogen & Ingestion & External & & \\
\hline Chlordane (gamma) & $4.6 \mathrm{E}+00$ & $4.4 \mathrm{E}+00$ & & & Unlimited & $1.8 \mathrm{E}-02$ \\
\hline Chloro-3-methyphenol, 4- & NT & NT & & & Unlimited & $3.8 \mathrm{E}-02$ \\
\hline Chloroaniline, 4- & $3.1 \mathrm{E}+02$ & NT & & & Unlimited & $6.3 E+\infty 0$ \\
\hline Chloroform & $6.6 \mathrm{E}+02$ & $1.0 \mathrm{E}+00$ & $8.8 E+01$ & & Unlimited & 8.0E-02 \\
\hline Chrysene & NT & $7.8 \mathrm{E}-01$ & & & Unlimited & $4.3 E+01$ \\
\hline DDD, 4,4- & NT & $2.4 \mathrm{E}+01$ & & & $7.6 \mathrm{E}+05$ & $1.1 \mathrm{E}-01$ \\
\hline DDE, 4,4'- & NT & $1.7 \mathrm{E}+01$ & & & $5.4 \mathrm{E}+05$ & $1.7 \mathrm{E}-01$ \\
\hline Di-n-butylphthalate & $7.7 E+03$ & NT & & & Unlimited & $5.5 E+00$ \\
\hline Dibenz(a,h)anthracene & NT & $7.8 \mathrm{E}-01$ & & & Unlimited & $1.7 \mathrm{E}+00$ \\
\hline Dibenzofuran & NT & NT & & & & $5.0 \mathrm{E}-01$ \\
\hline Dichlorobenzene, 1,3- & NT & NT & & & & $4.8 \mathrm{E}-02$ \\
\hline Dichlorobenzene, 1,4- & $9.7 \mathrm{E}+06$ & $2.4 E+02$ & & & Unlimited & $5.1 \mathrm{E}-02$ \\
\hline Dichloroethene, 1,2-(total) & $6.0 \mathrm{E}+02$ & NT & & & Unlimited & $1.0 E+00$ \\
\hline Dieldrin & $3.9 \mathrm{E}+00$ & $3.6 \mathrm{E}-01$ & $1.4 \mathrm{E}-01$ & & Unlimited & 2.1E-02 \\
\hline Diethylphthalate & $6.2 E+04$ & NT & & & Unlimited & $1.0 \mathrm{E}+\infty 0$ \\
\hline Ethylbenzene & $2.3 E+03$ & NT & & & Unlimited & $3.3 \mathrm{E}-01$ \\
\hline Fluoranthene & $3.1 \mathrm{E}+03$ & NT & & & Unlimited & $2.9 \mathrm{E}+00$ \\
\hline Fluorene & $3.1 \mathrm{E}+03$ & NT & & & Unlimited & $1.7 \mathrm{E}+00$ \\
\hline Hexanone, 2- & $4.6 E+02$ & NT & & & Unlimited & $9.0 \mathrm{E}-03$ \\
\hline Indeno(1,2,3-cd)pyrene & NT & $7.8 \mathrm{E}-01$ & & & Unlimited & $1.6 \mathrm{E}+00$ \\
\hline Methoxychlor & $3.9 \mathrm{E}+02$ & NT & & & Unlimited & 8.3E-02 \\
\hline
\end{tabular}


Table C-1. Acceptable Soil Concentration. (Sheet 3 of 7)

\begin{tabular}{|c|c|c|c|c|c|c|}
\hline \multirow{3}{*}{ CONSTITUENT } & \multicolumn{4}{|c|}{ Acceptable Exposure Concentrations } & \multirow{3}{*}{$\begin{array}{c}\text { Acceptable } \\
\text { Waste } \\
\text { Concentration b }\end{array}$} & \multirow{3}{*}{$\begin{array}{l}\text { Maximum } \\
\text { Detected } \\
\text { Concentration }\end{array}$} \\
\hline & \multicolumn{2}{|c|}{ Human Health } & \multicolumn{2}{|c|}{ Ecological } & & \\
\hline & Non-Carcinogen & Carcinogen & Ingestion & External & & \\
\hline Methyl-2-pentanone, 4- & $3.2 \mathrm{E}+01$ & NT & & & Unlimited & $1.1 \mathrm{E}-02$ \\
\hline Methylene Chloride & $1.1 E+03$ & $4.6 \mathrm{E}+01$ & $2.2 \mathrm{E}+01$ & & Unlimited & $4.5 \mathrm{E}+00$ \\
\hline Methylnaphthalene, 2- & $3.1 \mathrm{E}+02$ & NT & & & Unlimited & $1.3 \mathrm{E}+01$ \\
\hline Methylphenol, 4- & NT & NT & & & Unlimited & $1.0 \mathrm{E}+\infty 0$ \\
\hline Naphthalene & $3.1 \mathrm{E}+02$ & NT & & & Unlimited & $4.1 E+\infty 0$ \\
\hline Nitrosodiphenylamine, $n-$ & NT & $1.2 \mathrm{E}+03$ & & & Unlimited & $1.8 \mathrm{E}+00$ \\
\hline Pentachlorophenol & $2.3 \mathrm{E}+03$ & $4.8 \mathrm{E}+01$ & $1.8 \mathrm{E}+03$ & & Unlimited & $1.5 E+00$ \\
\hline Phenanthrene & $2.3 \mathrm{E}+03$ & NT & & & Unlimited & $3.9 \mathrm{E}+00$ \\
\hline Phenol & $4.6 \mathrm{E}+04$ & NT & & & Unlimited & 2.4E-01 \\
\hline Pyrene & $2.3 E+03$ & NT & & & Unlimited & $1.2 \mathrm{E}+01$ \\
\hline Tetrachloroethane, 1,1,2,2- & NT & $4.0 E-01$ & & & Unlimited & $3.0 \mathrm{E}-03$ \\
\hline Tetrachloroethene & 7.7E+02 & $6.7 \mathrm{E}+01$ & & & Unlimited & $1.1 E+\infty$ \\
\hline Toluene & $3.4 E+02$ & NT & & & Unlimited & $1.5 \mathrm{E}-01$ \\
\hline Trichloroethane, 1,1,1- & $4.8 \mathrm{E}+02$ & NT & & & Unlimited & $6.0 \mathrm{E}-03$ \\
\hline Trichloroethene & $4.0 \mathrm{E}+02$ & $1.6 \mathrm{E}+01$ & $1.1 \mathrm{E}+03$ & & Unlimited & $3.9 \mathrm{E}-01$ \\
\hline Vinyl Chloride & NT & $1.5 \mathrm{E}-01$ & & & Unlimited & 2.4E-02 \\
\hline Xylenes (total) & $1.3 E+05$ & NT & & & Unlimited & $1.1 E+\infty$ \\
\hline INORGANIC & $(\mathrm{mg} / \mathrm{kg})$ & $(\mathrm{mg} / \mathrm{kg})$ & $(\mathrm{mg} / \mathrm{kg})$ & NA & & \\
\hline Aluminum & $4.7 \mathrm{E}+04$ & NT & $1.8 \mathrm{E}+03$ & & Unlimited & $7.8 \mathrm{E}+04$ \\
\hline Ammonia & $4.6 E+01$ & NT & & & $4.6 \mathrm{E}+04$ & $1.4 E+02$ \\
\hline Antimony & $1.9 \mathrm{E}+01$ & NT & $3.2 \mathrm{E}+01$ & & $1.9 E+04$ & $1.9 \mathrm{E}+01$ \\
\hline
\end{tabular}


Table C-1. Acceptable Soil Concentration. (Sheet 4 of 7)

\begin{tabular}{|c|c|c|c|c|c|c|}
\hline \multirow{3}{*}{ CONSTITUENT } & \multicolumn{4}{|c|}{ Acceptable Exposure Concentrations ${ }^{\mathbf{a}}$} & \multirow{3}{*}{$\begin{array}{c}\text { Acceptable } \\
\text { Waste } \\
\text { Concentration } b\end{array}$} & \multirow{3}{*}{$\begin{array}{c}\text { Maximum } \\
\text { Detected } \\
\text { Concentration }\end{array}$} \\
\hline & \multicolumn{2}{|c|}{ Human Health } & \multicolumn{2}{|c|}{ Ecological } & & \\
\hline & Non-Carcinogen & Carcinogen & Ingestion & External & & \\
\hline Arsenic & $2.4 \mathrm{E}+01$ & $3.0 \mathrm{E}+\infty 0$ & $2.0 \mathrm{E}+02$ & & $3.0 \mathrm{E}+03$ & $6.2 \mathrm{E}+01$ \\
\hline Barium & $2.5 \mathrm{E}+03$ & NT & $9.4 \mathrm{E}+02$ & & $9.4 \mathrm{E}+05$ & $4.3 \mathrm{E}+03$ \\
\hline Beryllium & $1.7 \mathrm{E}+02$ & $2.6 \mathrm{E}-01$ & $9.9 \mathrm{E}+03$ & & $2.6 \mathrm{E}+02$ & $4.7 \mathrm{E}+00$ \\
\hline Cadmium & $7.0 \mathrm{E}+01$ & $3.9 \mathrm{E}+02$ & $3.9 E+01$ & & $3.9 \mathrm{E}+04$ & $2.9 E+01$ \\
\hline Calcium & NT & NT & & & & $9.5 \mathrm{E}+04$ \\
\hline Chloride & NT & NT & & & & $1.9 \mathrm{E}+02$ \\
\hline Chromium (VI) & $3.7 \mathrm{E}+02$ & $5.9 \mathrm{E}+01$ & $1.5 \mathrm{E}+04$ & & $5.9 \mathrm{E}+04$ & $2.5 \mathrm{E}+03$ \\
\hline Cobalt & $4.2 \mathrm{E}+03$ & NT & & & Unlimited & $9.0 \mathrm{E}+01$ \\
\hline Copper & $3.2 \mathrm{E}+03$ & NT & $8.2 \mathrm{E}+00$ & & $8.2 \mathrm{E}+03$ & $9.5 \mathrm{E}+04$ \\
\hline Fluoride & $4.8 \mathrm{E}+03$ & NT & & & Unlimited & $4.0 \mathrm{E}+01$ \\
\hline Iron & NT & NT & & & & $1.8 \mathrm{E}+05$ \\
\hline Lead & NT & NT & $2.4 E+03$ & & & $7.5 E+02$ \\
\hline Magnesium & NT & NT & & & & $5.0 \mathrm{E}+04$ \\
\hline Manganese & $1.1 \mathrm{E}+04$ & NT & $4.4 \mathrm{E}+02$ & & $4.4 \mathrm{E}+05$ & $3.1 \mathrm{E}+03$ \\
\hline Mercury & $1.8 \mathrm{E}+01$ & NT & $3.3 E+00$ & & $3.3 E+03$ & 3.7E+01 \\
\hline Nickel & $1.4 \mathrm{E}+03$ & NT & $1.1 \mathrm{E}+03$ & & Unlimited & $1.8 \mathrm{E}+03$ \\
\hline Nitrate & $7.9 E+03$ & NT & & & Unlimited & $1.3 \mathrm{E}+02$ \\
\hline Nitrite (NO2 as N) & $7.9 \mathrm{E}+03$ & NT & & & Unlimited & $2.9 \mathrm{E}+00$ \\
\hline Potassium & NT & NT & & & & $1.3 E+04$ \\
\hline Selenium & $4.0 \mathrm{E}+02$ & NT & & & $4.0 \mathrm{E}+05$ & $1.1 \mathrm{E}+01$ \\
\hline Silver & $3.5 \mathrm{E}+02$ & NT & $2.4 \mathrm{E}+03$ & & $3.5 \mathrm{E}+05$ & $3.6 \mathrm{E}+02$ \\
\hline
\end{tabular}


Table C-1. Acceptable Soil Concentration. (Sheet 5 of 7)

\begin{tabular}{|c|c|c|c|c|c|c|}
\hline \multirow{3}{*}{ CONSTITUENT } & \multicolumn{4}{|c|}{ Acceptable Exposure Concentrations ${ }^{\mathrm{a}}$} & \multirow{3}{*}{$\begin{array}{c}\text { Acceptable } \\
\text { Waste } \\
\text { Concentration b }\end{array}$} & \multirow{3}{*}{$\begin{array}{c}\text { Maximum } \\
\text { Detected } \\
\text { Concentration }\end{array}$} \\
\hline & \multicolumn{2}{|c|}{ Human Health } & \multicolumn{2}{|c|}{ Ecological } & & \\
\hline & Non-Carcinogen & Carcinogen & Ingestion & External & & \\
\hline Sodium & NT & NT & & & & $2.6 \mathrm{E}+03$ \\
\hline Strontium & 4.7E+04 & NT & & & Unlimited & $3.1 \mathrm{E}+01$ \\
\hline Sulfate & NT & NT & & & & $7.1 E+03$ \\
\hline Thallium & $5.6 \mathrm{E}+00$ & NT & & & $5.6 \mathrm{E}+03$ & $5.4 E+00$ \\
\hline Vanadium & $3.3 \mathrm{E}+02$ & NT & $1.6 \mathrm{E}+03$ & & $3.3 \mathrm{E}+05$ & $3.9 E+02$ \\
\hline Zinc & $2.4 \mathrm{E}+04$ & NT & $3.0 \mathrm{E}+02$ & & $3.0 \mathrm{E}+05$ & $6.2 \mathrm{E}+03$ \\
\hline RADIONUCLIDES & NA & $(\mathrm{pCi} / \mathrm{g})$ & $(\mathrm{pCi} / \mathrm{g})$ & $(\mathrm{pCi} / \mathrm{g})$ & $(\mathrm{pCi} / \mathrm{g})$ & (pCi/g) \\
\hline Americium-241 & & $1.5 \mathrm{E}+01$ & $3.4 \mathrm{E}+08$ & $1.3 E+08$ & $3.4 \mathrm{E}+04$ & $3.4 \mathrm{E}+01$ \\
\hline Barium-140 & & 7.7E-01 & $2.3 \mathrm{E}+07$ & $5.9 \mathrm{E}+06$ & Unlimited & $4.0 \mathrm{E}+02$ \\
\hline Beryllium-7 & & $2.8 \mathrm{E}+\infty 0$ & $7.9 E+10$ & 2.1E+07 & Unlimited & $9.0 \mathrm{E}+01$ \\
\hline Carbon-14 & & $8.5 E+03$ & $4.3 E+04$ & $4.4 \mathrm{E}+11$ & $9.0 \mathrm{E}+06$ & $6.4 E+02$ \\
\hline Cerium-141 & & $3.2 \mathrm{E}+00$ & $1.9 E+10$ & $1.9 \mathrm{E}+07$ & Unlimited & $3.0 \mathrm{E}+00$ \\
\hline Cerium-144 & & $1.6 \mathrm{E}+01$ & $5.4 \mathrm{E}+08$ & $8.3 E+07$ & Unlimited & $5.0 \mathrm{E}-01$ \\
\hline Cesium-134 & & $8.0 \mathrm{E}-02$ & $1.7 \mathrm{E}+05$ & $6.4 \mathrm{E}+05$ & Unlimited & $5.6 \mathrm{E}+01$ \\
\hline Cesium-137 & & $2.1 \mathrm{E}-01$ & $1.5 \mathrm{E}+05$ & $1.7 \mathrm{E}+06$ & $2.0 \mathrm{E}+07$ & $1.1 E+05$ \\
\hline Chromium-51 & & $4.5 \mathrm{E}+00$ & $3.6 \mathrm{E}+09$ & $3.5 \mathrm{E}+07$ & Unlimited & $3.5 \mathrm{E}+00$ \\
\hline Cobalt-58 & & $1.3 \mathrm{E}-01$ & $7.5 \mathrm{E}+07$ & $1.0 \mathrm{E}+06$ & Unlimited & $1.4 \mathrm{E}+01$ \\
\hline Cobalt-60 & & $4.8 \mathrm{E}-02$ & $2.5 E+07$ & $3.8 \mathrm{E}+05$ & Unlimited & $1.1 E+04$ \\
\hline Europium-152 & & $1.2 \mathrm{E}-01$ & $1.2 \mathrm{E}+09$ & 8.7E+05 & $1.3 \mathrm{E}+13$ & $2.9 E+04$ \\
\hline Europium-154 & & $1.0 \mathrm{E}-01$ & 4.7E+08 & $7.9 E+05$ & Unlimited & $9.2 \mathrm{E}+03$ \\
\hline Europium-155 & & $7.1 E+\infty 0$ & $2.4 E+09$ & $3.3 E+07$ & Unlimited & $9.6 \mathrm{E}+03$ \\
\hline
\end{tabular}


Table C-1. Acceptable Soil Concentration. (Sheet 6 of 7)

\begin{tabular}{|c|c|c|c|c|c|c|}
\hline \multirow{3}{*}{ CONSTITUENT } & \multicolumn{4}{|c|}{ Acceptable Exposure Concentrations ${ }^{a}$} & \multirow{3}{*}{$\begin{array}{c}\text { Acceptable } \\
\text { Waste } \\
\text { Concentration b }\end{array}$} & \multirow{3}{*}{$\begin{array}{c}\text { Maximum } \\
\text { Detected } \\
\text { Concentration }\end{array}$} \\
\hline & \multicolumn{2}{|c|}{ Human Health } & \multicolumn{2}{|c|}{ Ecological } & & \\
\hline & Non-Carcinogen & Carcinogen & Ingestion & External & & \\
\hline Hydrogen-3 & & $1.4 E+05$ & $4.3 E+05$ & NT & Unlimited & $2.9 \mathrm{E}+04$ \\
\hline Iron-59 & & $1.0 \mathrm{E}-01$ & $1.5 \mathrm{E}+08$ & $8.0 \mathrm{E}+05$ & Unlimited & $1.0 \mathrm{E}+00$ \\
\hline Manganese-54 & & $1.4 \mathrm{E}-01$ & $2.9 \mathrm{E}+07$ & $1.2 \mathrm{E}+06$ & Unlimited & 7.0E-02 \\
\hline Neptunium-237 & & $9.2 \mathrm{E}-01$ & & & $9.2 \mathrm{E}+02$ & $6.9 \mathrm{E}-03$ \\
\hline Nickel-63 & & $3.1 \mathrm{E}+04$ & $1.1 \mathrm{E}+07$ & NT & $9.7 \mathrm{E}+08$ & $6.2 \mathrm{E}+04$ \\
\hline Plutonium-238 & & $1.8 \mathrm{E}+01$ & $1.9 \mathrm{E}+07$ & $3.8 E+10$ & $9.1 \mathrm{E}+05$ & $1.4 \mathrm{E}+02$ \\
\hline Plutonium-239/240 & & 1.7E+01 & $2.0 \mathrm{E}+07$ & $3.9 E+10$ & $1.8 \mathrm{E}+04$ & $2.8 \mathrm{E}+03$ \\
\hline Potassium-40 & & 7.7E-01 & & & $7.7 \mathrm{E}+02$ & $3.3 \mathrm{E}+01$ \\
\hline Radium-226+D & & $6.9 \mathrm{E}-02$ & $1.4 \mathrm{E}+05$ & $5.4 \mathrm{E}+05$ & $8.6 \mathrm{E}+01$ & 4.3E+01 \\
\hline Radium-228 & & $1.4 \mathrm{E}-01$ & & & $1.4 \mathrm{E}+02$ & \\
\hline Ruthenium-103 & & $2.8 \mathrm{E}-01$ & $1.5 \mathrm{E}+08$ & $2.2 \mathrm{E}+06$ & Unlimited & $1.0 \mathrm{E}+00$ \\
\hline Ruthenium-106 & & $2.3 \mathrm{E}+03$ & $1.5 \mathrm{E}+08$ & $2.2 \mathrm{E}+06$ & Unlimited & $8.0 \mathrm{E}-01$ \\
\hline Sodium-22 & & $5.8 \mathrm{E}-02$ & $6.1 E+05$ & $4.5 E+05$ & Unlimited & $9.9 E+\infty 0$ \\
\hline Strontium-90+D & & $2.1 \mathrm{E}+02$ & $5.7 \mathrm{E}+03$ & $2.5 E+08$ & $3.8 \mathrm{E}+10$ & $2.0 \mathrm{E}+03$ \\
\hline Technetium-99 & & $5.6 \mathrm{E}+03$ & & & $5.6 \mathrm{E}+06$ & $1.1 E+00$ \\
\hline Thorium-228+D & & $7.4 \mathrm{E}-02$ & $5.9 E+07$ & $6.0 \mathrm{E}+05$ & $7.4 \mathrm{E}+01$ & $1.7 \mathrm{E}+01$ \\
\hline Thorium-232 & & $4.6 E+01$ & $6.8 \mathrm{E}+07$ & $1.1 \mathrm{E}+10$ & $4.6 \mathrm{E}+04$ & $3.6 \mathrm{E}+00$ \\
\hline Thorium-234 & & $1.1 \mathrm{E}+02$ & & & Unlimited & $1.0 \mathrm{E}+00$ \\
\hline Uranium-233/234 & & $4.6 \mathrm{E}+00$ & & & $4.6 \mathrm{E}+04$ & 2. $1 E+03$ \\
\hline Uranium-235 & & $1.7 \mathrm{E}+00$ & & & $1.7 E+03$ & $6.4 \mathrm{E}+02$ \\
\hline Uranium-238 + D (total) & & $7.8 \mathrm{E}+00$ & $1.5 \mathrm{E}+06$ & $5.3 E+05$ & $7.8 \mathrm{E}+03$ & $9.1 \mathrm{E}+00$ \\
\hline
\end{tabular}


Table C-1. Acceptable Soil Concentration. (Sheet 7 of 7)

\begin{tabular}{|c|c|c|c|c|c|c|}
\hline \multirow{3}{*}{ CONSTITUENT } & \multicolumn{4}{|c|}{ Acceptable Exposure Concentrations ${ }^{a}$} & \multirow{3}{*}{$\begin{array}{c}\text { Acceptable } \\
\text { Waste } \\
\text { Concentration b }\end{array}$} & \multirow{3}{*}{$\begin{array}{c}\text { Maximum } \\
\text { Detected } \\
\text { Concentration }\end{array}$} \\
\hline & \multicolumn{2}{|c|}{ Human Health } & \multicolumn{2}{|c|}{ Ecological } & & \\
\hline & Non-Carcinogen & Carcinogen & Ingestion & External & & \\
\hline Zinc-65 & & $2.1 \mathrm{E}-01$ & $4.8 E+04$ & $1.7 \mathrm{E}+06$ & Unlimited & $3.0 \mathrm{E}-01$ \\
\hline Zirconium-95 & & $1.7 E-01$ & $8.4 \mathrm{E}+09$ & $1.4 E+06$ & Unlimited & $5.6 \mathrm{E}-01$ \\
\hline \multicolumn{7}{|c|}{$\begin{array}{l}\text { Acceptable exposure concentrations do not account for decay or dilution. } \\
\text { b Acceptable waste concentrations are derived from the smallest acceptable exposure concentration, and account for a } 1,000 \text {-fold } \\
\text { dilution and } 500 \text {-year decay. "Unlimited" means that, for organic or inorganic wastes, the acceptable waste concentration } \\
\text { exceeds } 1 \mathrm{E}+06 \mathrm{mg} / \mathrm{kg} \text {. For radioactive wastes, "Unlimited" means that the acceptable waste concentration exceeds the } \\
\text { specific activity for the associated radionuclide. } \\
\text { NT }=\text { No toxicity information. } \\
\text { NA }=\text { Not applicable. }\end{array}$} \\
\hline
\end{tabular}


Table C-2. Risk-Based Groundwater Concentrations for Inorganic Constituents

\begin{tabular}{|c|c|c|c|c|c|c|c|c|c|c|}
\hline \multirow[t]{2}{*}{ Constituent } & \multirow{2}{*}{\begin{tabular}{|c|} 
Limiting \\
Groundwater \\
Concentration \\
$(\mathrm{mg} / \mathrm{L})$ \\
\end{tabular}} & \multicolumn{4}{|c|}{ Groundwater Ingestion } & \multicolumn{5}{|c|}{ Groundwater Inhalation (volatiles) } \\
\hline & & $\begin{array}{l}\text { Oral RfD } \\
(\mathrm{mg} / \mathrm{kg}-\mathrm{d}) \\
\end{array}$ & $\begin{array}{c}\mathrm{RBC} \\
(\mathrm{mg} / \mathrm{L}) \\
\end{array}$ & \begin{tabular}{|c|} 
Oral SF \\
$(\mathrm{mg} / \mathrm{kg}-\mathrm{d})-1$ \\
\end{tabular} & $\begin{array}{c}\mathrm{RBC} \\
(\mathrm{mg} / \mathrm{L}) \\
\end{array}$ & volatile? & \begin{tabular}{|l|}
$\begin{array}{l}\text { Inhal. RfD } \\
(\mathrm{mg} / \mathrm{kg}-\mathrm{d})\end{array}$ \\
\end{tabular} & $\begin{array}{c}\text { RBC } \\
(\mathrm{mg} / \mathrm{L})\end{array}$ & $\begin{array}{c}\text { Inhal. SF } \\
(\mathrm{mg} / \mathrm{kg}-\mathrm{d})-1\end{array}$ & $\begin{array}{c}\mathrm{RBC} \\
(\mathrm{mg} / \mathrm{L})\end{array}$ \\
\hline antimony & \begin{tabular}{|l|l|}
$6.4 \mathrm{E}-03$ \\
\end{tabular} & $4.0 \mathrm{E}-04$ & $6.4 \mathrm{E}-03$ & no tox & no tox & no & not vol & not vol & \begin{tabular}{|l|} 
not vol \\
\end{tabular} & not vol \\
\hline arsenic & $4.1 \mathrm{E}-04$ & $3.0 \mathrm{E}-04$ & $4.8 \mathrm{E}-03$ & $2.0 \mathrm{E}+00$ & 4.1E-04 & no & not vol & not vol & not vol & not vol \\
\hline chromium (VI) & $8.0 \mathrm{E}-02$ & $5.0 \mathrm{E}-03$ & $8.0 \mathrm{E}-02$ & no tox & no tox & no & not vol & not vol & not vol & not vol \\
\hline fluoride & $9.6 \mathrm{E}-01$ & $6.0 \mathrm{E}-02$ & $9.6 \mathrm{E}-01$ & no tox & no tox & no & not vol & not vol & not vol & not vol \\
\hline nitrate (as N) & $2.6 \mathrm{E}+01$ & $1.6 \mathrm{E}+00$ & $2.6 \mathrm{E}+01$ & no tox & no tox & no & not vol & not vol & not vol & not vol \\
\hline nitrite (as N) & $1.6 \mathrm{E}+00$ & $1.0 \mathrm{E}-01$ & $1.6 \mathrm{E}+00$ & no tox & no tox & no & not vol & not vol & not vol & not vol \\
\hline selenium & $8.0 \mathrm{E}-02$ & $5.0 \mathrm{E}-03$ & 8.0E-02 & no tox & no tox & no & not vol & not vol & not vol & not vol \\
\hline \multicolumn{11}{|c|}{$\begin{array}{l}\text { NOTES: } \\
\text { Target ICR = 1E-05; Target } \mathrm{HQ}=0.1 \\
\text { no tox = no toxicity factor available for this contaminant pathway. } \\
\text { not vol = not a volatile compound. } \\
\mathrm{RBC}=\text { risk-based concentration } \\
\mathrm{RFD}=\text { reference dose } \\
\mathrm{SF}=\text { slope factor }\end{array}$} \\
\hline
\end{tabular}


DOE/RL-93-99, Rev. 0

Table C-3. Minimum Groundwater ARARs for Inorganic Constituents

\begin{tabular}{|l|c|}
\hline \multicolumn{1}{|c|}{ Constituent } & \multicolumn{1}{|c|}{$\begin{array}{c}\text { Minimum } \\
\text { ARAR (a) } \\
(\mathrm{mg} / \mathrm{L})\end{array}$} \\
\hline antimony & $6.0 \mathrm{E}-03$ \\
\hline arsenic & $5.2 \mathrm{E}-05$ \\
\hline chromium (V) & $1.8 \mathrm{E}-02$ \\
\hline fluoride & $9.6 \mathrm{E}-01$ \\
\hline nitrate (as N) & $1.0 \mathrm{E}+01$ \\
\hline nitrite (as N) & $1.0 \mathrm{E}+00$ \\
\hline selenium & $5.0 \mathrm{E}-02$ \\
\hline & \\
NOTES: & \\
(a) Based on Table 7-5. & \\
\hline
\end{tabular}


DOE/RL-93-99, Rev. 0

Table C-4. Risk-Based and Minimum ARAR Groundwater Concentrations for Radionuclides

\begin{tabular}{|l|c|c|}
\hline RADIONUCLIDES & $\begin{array}{c}\text { Risk Based } \\
\text { Conc. (a) } \\
(\mathrm{pC} / \mathrm{L})\end{array}$ & $\begin{array}{c}\text { Minimum } \\
\text { ARAR (b) } \\
\text { (pCi/L) }\end{array}$ \\
\hline carbon-14 & $5.1 \mathrm{E}+02$ & $2.0 \mathrm{E}+03$ \\
\hline technetium-99 & $3.5 \mathrm{E}+02$ & $9.0 \mathrm{E}+02$ \\
\hline tritium & $8.5 \mathrm{E}+03$ & $2.0 \mathrm{E}+04$ \\
\hline uranium-233/234 & $2.9 \mathrm{E}+01$ & $3.0 \mathrm{E}+02$ \\
\hline uranium-235 + D & $2.9 \mathrm{E}+01$ & $3.0 \mathrm{E}+02$ \\
\hline uranium-238 & $1.6 \mathrm{E}+01$ & $3.0 \mathrm{E}+02$ \\
\hline \multicolumn{3}{|l|}{} \\
NOTES: \\
$\begin{array}{l}\text { (a) Target ICR }=1 \mathrm{E}-05 . \\
\text { (b) From Table 7-5. } \\
\text { Only the groundwater ingestion pathway is evaluated. The inhalation } \\
\text { pathway is not considered for radionuclides since they are not volatile. } \\
\text { Only carcinogenic risk is considered. }\end{array}$
\end{tabular}


Table C-5. Acceptable Leachate Concentration Limits

\begin{tabular}{|c|c|c|c|c|c|}
\hline CONSTITUENT & $\begin{array}{c}\text { Risk-Based } \\
\text { Leachate } \\
\text { Concentration } \\
(\mathrm{mg} / \mathrm{L})\end{array}$ & $\begin{array}{c}\text { ARAR-Based } \\
\text { Leachate } \\
\text { Concentration } \\
(\mathrm{mg} / \mathrm{L})\end{array}$ & $\begin{array}{c}\text { Travel Time } \\
>10,000 \\
\text { yrs? }\end{array}$ & $\begin{array}{c}\text { Decays } \\
\text { in Vadose } \\
\text { Zone? }\end{array}$ & $\begin{array}{c}\text { Hanford Site } \\
\text { Groundwater } \\
\text { Background } \\
(\mathrm{mg} / \mathrm{L})\end{array}$ \\
\hline \multicolumn{6}{|l|}{ ORGANIC } \\
\hline Acenaphthene & unlimited & unlimited & yes & yes & - \\
\hline Acetone & unlimited & unlimited & no & yes & - \\
\hline Anthracene & unlimited & unlimited & yes & yes & - \\
\hline Aroclor- 1248 & unlimited & unlimited & yes & yes & - \\
\hline Aroclor-1254 & unlimited & unlimited & yes & yes & - \\
\hline Aroclor- 1260 & unlimited & unlimited & yes & yes & - \\
\hline Benz(a)anthracene & unlimited & unlimited & yes & yes & - \\
\hline Benzene & unlimited & unlimited & no & yes & - \\
\hline Benzo(a)pyrene & unlimited & unlimited & yes & yes & - \\
\hline Benzo(b)fluoranthene & unlimited & unlimited & yes & yes & - \\
\hline Benzo $(g, h, i)$ perylene & unlimited & unlimited & yes & yes & - \\
\hline Benzo(k)fluoranthene & unlimited & unlimited & yes & yes & - \\
\hline Benzoic acid & unlimited & unlimited & no & yes & - \\
\hline BHC, beta- & unlimited & unlimited & yes & no & - \\
\hline Bis(2-ethylhexyl)phthalate & unlimited & unlimited & yes & yes & - \\
\hline Butanone, 2- (MEK) & unlimited & unlimited & no & yes & - \\
\hline Butylbenzylphthalate & unlimited & unlimited & no & yes & - \\
\hline Carbazole & unlimited & unlimited & yes & yes & - \\
\hline Carbon disulfide & unlimited & unlimited & no & yes & - \\
\hline Carbon Tetrachloride & unlimited & unlimited & .70 & yes & - \\
\hline Chlordane (gamma) & unlimited & unlimited & yes & yes & - \\
\hline Chloro-3-methyphenol, 4- & unlimited & unlimited & no & yes & - \\
\hline Chloroaniline, 4- & unlimited & unlimited & yes & yes & - \\
\hline Chloroform & unlimited & unlimited & no & yes & - \\
\hline Chrysene & unlimited & unlimited & yes & yes & - \\
\hline $\mathrm{DDD}, 4,4-$ & unlimited & unlimited & yes & yes & - \\
\hline DDE, $4,4^{\prime}-$ & unlimited & unlimited & yes & yes & - \\
\hline Di-n-butylphthalate & unlimited & unlimited & yes & yes & - \\
\hline Dibenz $(a, h)$ anthracene & unlimited & unlimited & yes & yes & - \\
\hline Dibenzofuran & unlimited & unlimited & yes & yes & - \\
\hline Dichlorobenzene, $1,3-$ & unlimited & unlimited & no & yes & - \\
\hline Dichlorobenzene, 1,4- & unlimited & unlimited & no & yes & - \\
\hline Dichloroethene, 1,2-(total) & unlimited & unlimited & no & yes & - \\
\hline \begin{tabular}{|l|} 
Dieldrin \\
\end{tabular} & unlimited & unlimited & yes & yes & - \\
\hline Diethylphthalate & unlimited & unlimited & no & yes & - \\
\hline Ethylbenzene & unlimited & unlimited & no & yes & - \\
\hline Fluoranthene & unlimited & unlimited & yes & yes & - \\
\hline Fluorene & unlimited & unlimited & yes & yes & - \\
\hline Hexanone, 2- & unlimited & unlimited & no & yes & - \\
\hline Indeno(1,2,3-cd)pyrene & unlimited & unlimited & yes & yes & - \\
\hline
\end{tabular}


Table C-5. Acceptable Leachate Concentration Limits

\begin{tabular}{|c|c|c|c|c|c|}
\hline CONSTITUENT & \begin{tabular}{|c|}
$\begin{array}{c}\text { Risk-Based } \\
\text { Leachate } \\
\text { Concentration } \\
(\mathrm{mg} / \mathrm{L})\end{array}$ \\
\end{tabular} & $\begin{array}{c}\text { ARAR-Based } \\
\text { Leachate } \\
\text { Concentration } \\
(\mathrm{mg} / \mathrm{L})\end{array}$ & $\begin{array}{c}\text { Travel Time } \\
>10,000 \\
\text { yrs? }\end{array}$ & $\begin{array}{c}\text { Decays } \\
\text { in Vadose } \\
\text { Zone? }\end{array}$ & $\begin{array}{c}\text { Hanford Site } \\
\text { Groundwater } \\
\text { Background } \\
(\mathrm{mg} / \mathrm{L})\end{array}$ \\
\hline Methoxychlor & unlimited & unlimited & yes & yes & - \\
\hline Methyl-2-pentanone, 4- & unlimited & unlimited & no & yes & - \\
\hline Methylene Chloride & unlimited & unlimited & no & yes & - \\
\hline Methylnaphthalene, 2- & unlimited & unlimited & yes & yes & - \\
\hline Methylphenol, 4- & unlimited & unlimited & no & yes & - \\
\hline Naphthalene & unlimited & unlimited & yes & yes & - \\
\hline Nitrosodiphenylamine, $n-$ & unlimited & unlimited & yes & yes & - \\
\hline Pentachlorophenol & unlimited & unlimited & yes & yes & - \\
\hline Phenanthrene & unlimited & unlimited & yes & yes & - \\
\hline Phenol & unlimited & unlimited & no & yes & - \\
\hline Pyrene & unlimited & unlimited & yes & yes & - \\
\hline Tetrachloroethane, $1,1,2,2-$ & unlimited & unlimited & no & yes & - \\
\hline Tetrachloroethene & unlimited & unlimited & no & yes & - \\
\hline Toluene & unlimited & unlimited & no & yes & - \\
\hline Trichloroethane, $1,1,1$ - & unlimited & unlimited & no & yes & - \\
\hline Trichloroethene & unlimited & unlimited & no & yes & - \\
\hline Vinyl Chloride & unlimited & unlimited & no & yes & - \\
\hline Xylenes (total) & unlimited & unlimited & no & yes & - \\
\hline \multicolumn{6}{|l|}{ INORGANIC } \\
\hline Aluminum & unlimited & unlimited & yes & no & ND \\
\hline Ammonia & unlimited & unlimited & yes & no & $1.20 \mathrm{E}-01$ \\
\hline Antimony & $1.1 \mathrm{E}-01$ & $1.0 \mathrm{E}-01$ & no & no & - \\
\hline Arsenic & $1.0 \mathrm{E}-02(\mathrm{a})$ & $1.0 \mathrm{E}-02(\mathrm{a})$ & no & no & $1.00 \mathrm{E}-02$ \\
\hline Barium & unlimited & unlimited & yes & no & $6.85 \mathrm{E}-02$ \\
\hline Beryllium & unlimited & unlimited & yes & no & ND \\
\hline Cadmium & unlimited & unlimited & yes & no & ND \\
\hline Calcium & unlimited & unlimited & yes & no & $6.36 \mathrm{E}+01$ \\
\hline Chromium (VI) & $1.3 E+00$ & $3.0 \mathrm{E}-01$ & no & no & ND \\
\hline Cobalt & unlimited & unlimited & yes & no & - \\
\hline Copper & unlimited & unlimited & yes & no & ND \\
\hline Fluoride & $1.6 \mathrm{E}+01$ & $1.6 \mathrm{E}+01$ & no & no & 7.75E-01 \\
\hline Iron & unlimited & unlimited & yes & no & 8.60E-02 \\
\hline Lead & unlimited & unlimited & yes & no & ND \\
\hline Magnesium & unlimited & unlimited & yes & no & $1.65 \mathrm{E}+01$ \\
\hline Manganese & unlimited & unlimited & yes & no & $2.45 \mathrm{E}-02$ \\
\hline Mercury & unlimited & unlimited & yes & no & ND \\
\hline Nickel & unlimited & unlimited & yes & no & ND \\
\hline Nitrate & $4.3 \mathrm{E}+02$ & $1.7 \mathrm{E}+02$ & no & no & $1.24 \mathrm{E}+01$ \\
\hline Nitrite (NO2 as N) & $2.7 \mathrm{E}+01$ & $1.7 E+01$ & no & no & - \\
\hline Potassium & unlimited & unlimited & yes & no & $7.98 \mathrm{E}+00$ \\
\hline Selenium & $1.3 E+00$ & 8.4E-01 & no & no & ND \\
\hline
\end{tabular}


Table C-5. Acceptable Leachate Concentration Limits

\begin{tabular}{|c|c|c|c|c|c|}
\hline CONSTITUENT & $\begin{array}{c}\text { Risk-Based } \\
\text { Leachate } \\
\text { Concentration } \\
(m g / L)\end{array}$ & $\begin{array}{c}\text { ARAR-Based } \\
\text { Leachate } \\
\text { Concentration } \\
(m g / L)\end{array}$ & $\begin{array}{c}\text { Travel Time } \\
>10,000 \\
\text { yrs? }\end{array}$ & $\begin{array}{c}\text { Decays } \\
\text { in Vadose } \\
\text { Zone? }\end{array}$ & $\begin{array}{c}\text { Hanford Site } \\
\text { Groundwater } \\
\text { Background } \\
\text { (mg/L) }\end{array}$ \\
\hline Silver & unlimited & unlimited & yes & no & ND \\
\hline Sodium & unlimited & unlimited & yes & no & $3.35 E+01$ \\
\hline Strontium & unlimited & unlimited & yes & no & $2.64 \mathrm{E}-01$ \\
\hline Thallium & unlimited & unlimited & yes & no & - \\
\hline Vanadium & unlimited & unlimited & yes & no & $1.50 \mathrm{E}-02$ \\
\hline Zinc & unlimited & unlimited & yes & no & ND \\
\hline RADIONUCLIDES & $(\mathrm{pCi} / \mathrm{L})$ & & & & \\
\hline Americium-2A1 & unlimited & unlimited & yes & yes & - \\
\hline Barium-140 & unlimited & unlimited & yes & yes & - \\
\hline Beryllium-7 & unlimited & unlimited & yes & yes & - \\
\hline Carbon-14 & $9.1 \mathrm{E}+03$ & $3.6 \mathrm{E}+04$ & no & no & - \\
\hline Cerium-141 & unlimited & unlimited & yes & yes & $\dot{-}$ \\
\hline Cerium-144 & unlimited & unlimited & yes & yes & - \\
\hline Cesium-134 & unlimited & unlimited & yes & yes & - \\
\hline Cesium-137 & unlimited & unlimited & yes & yes & - \\
\hline Chromium-51 & unlimited & unlimited & no & yes & - \\
\hline Cobalt-58 & unlimited & unlimited & yes & yes & - \\
\hline Cobalt -60 & unlimited & unlimited & yes & yes & - \\
\hline Europium-152 & unlimited & unlimited & yes & yes & - \\
\hline Europium-154 & unlimited & unlimited & yes & yes & - \\
\hline Europium-155 & unlimited & unlimited & yes & yes & - \\
\hline Iron-59 & unlimited & unlimited & yes & yes & - \\
\hline Manganese-54 & unlimited & unlimited & yes & yes & - \\
\hline Neptunium-237 & unlimited & unlimited & yes & no & \\
\hline Nickel-63 & unlimited & unlimited & yes & yes & - \\
\hline Plutonium-238 & unlimited & unlimited & yes & yes & - \\
\hline Plutonium-239/240 & unlimited & unlimited & yes & yes & - \\
\hline Potassium -40 & unlimited & unlimited & yes & no & - \\
\hline Radium-226 & unlimited & unlimited & yes & yes & - \\
\hline Ruthenium-103 & unlimited & unlimited & yes & yes & - \\
\hline Ruthenium-106 & unlimited & unlimited & yes & yes & - \\
\hline Sodium-22 & unlimited & unlimited & yes & yes & - \\
\hline Strontium-90 & unlimited & unlimited & yes & yes & - \\
\hline Technetium-99 & $6.0 \mathrm{E}+03$ & $1.5 \mathrm{E}+04$ & no & no & - \\
\hline Thorium-228 & unlimited & unlimited & yes & yes & - \\
\hline Thorium-232 & unlimited & unlimited & yes & yes & - \\
\hline Thorium-234 & unlimited & unlimited & yes & yes & - \\
\hline Tritium & unlimited & unlimited & no & yes & - \\
\hline Uranium-233/234 & $4.8 \mathrm{E}+02$ & $5.1 E+03$ & no & no & - \\
\hline Uranium-235 & $4.8 E+02$ & $5.0 \mathrm{E}+03$ & no & no & - \\
\hline Uranium-238 & $2.8 E+02$ & $5.0 \mathrm{E}+03$ & no & no & - \\
\hline
\end{tabular}


DOE/RL-93-99, Rev. 0

Table C-5. Acceptable Leachate Concentration Limits

\begin{tabular}{|c|c|c|c|c|c|}
\hline CONSTITUENT & $\begin{array}{c}\text { Risk-Based } \\
\text { Leachate } \\
\text { Concentration } \\
(\mathrm{mg} / \mathrm{L})\end{array}$ & $\begin{array}{c}\text { ARAR-Based } \\
\text { Leachate } \\
\text { Concentration } \\
\text { (mg } / \text { ) }\end{array}$ & $\begin{array}{c}\text { Travel Time } \\
>10,000 \\
\text { yrs? }\end{array}$ & $\begin{array}{c}\text { Decays } \\
\text { in Vadose } \\
\text { Zone? }\end{array}$ & $\begin{array}{l}\text { Hanford Site } \\
\text { Groundwater } \\
\text { Background } \\
\text { (mg } / \text { ) }\end{array}$ \\
\hline Zinc-65 & unlimited & unlimited & yes & yes & - \\
\hline Zirconium-95 & unlimited & unlimited & yes & yes & - \\
\hline
\end{tabular}


DOE/RL-93-99, Rev. 0

APPENDIX D

LEACHATE GENERATION MEMO 
TO: Kevin Kelly, MW Richland

December 15, 1993

Larry Bennett, MW Boise

Project File

FR: Frank Shuri, GAI Redmond 75

RE: ERDF LEACHATE VOLUME ESTIMATES, Job No. 923-A024

Two estimates of leachate production at the ERDF have been performed for different purposes. This memo will discuss those estimates, including background, assumptions, results, and applications.

\section{LEACHATE PRODUCTION AFTER INTERIM CLOSURE}

This study was performed as part of the Trench Operations Sequence Engineering Study WHC-SD-W296-ES-01, 1993 (TOS Study). The objective of the analysis was to determine whether a low-permeability layer would be required in addition to the 2 -foot-thick interim soil cover that will be placed over the waste once a particular portion of the ERDF trench has been filled. The purpose of this interim cover is to provide containment against dispersion of contaminated soil due to wind, traffic, animals, etc. prior to construction of the Hanford Barrier. This cover will consist of soils excavated from the ERDF trench, probably silty fine sands, and consequently is not expected to have a low permeability. As a result, some precipitation could infiltrate the waste and form leachate which would be collected by the liner system and removed by pumping. There is no regulatory requirement for RCRA Subtitle $C$ facilities to have a low-permeability interim cover prior to installation of the final closure cover (the Hanford Barrier). However, it may be desirable to install such a cover to limit the amount of leachate that must be treated and thus reduce ERDF operational costs. Hence, the analysis for the TOS Study consisted of a comparative analysis of the costs of installing a low-permeability liner vs. treating leachate. The cost fo: treating leachate is of course strongly dependant on the volume of leachate.

To estimate the average annual volume of leachate, the Hydrologic Evaluation of Landfill Performance (HELP) model Version 2.05 was used. The HELP model is accepted by EPA and is probably the most widely-used tool for determining the performance of landfill covers. It is intended primarily as a screening tool for comparing the performance of several potential cover designs, and the authors of the model caution against using it as an absolute predictive tool. Nevertheless, it incorporates many of the physical processes that govem water balance in landfill covers, and it has been verified against field data. Consequently it is considered useful for conceptual level estimates such as the TOS Study.

For the modelling done as part of the TOS Study, the following assumptions were used:

1. The interim soil cover is 2 feet thick.

2. The interim soil cover was modelled with permeabilities of $10^{-3}, 10^{-4}$, and $10^{-5}$ $\mathrm{cm} / \mathrm{sec}$. This is considered to represent the range of permeabilities that can be 
expected from the fine-grained ERDF soils. For comparison purposes, a permeability of $10^{-3} \mathrm{~cm} / \mathrm{sec}$ is characteristic of a fairly clean silt, which is finer grained than any material identified to date at the ERDF site. A value of $10^{-3}$ $\mathrm{cm} / \mathrm{sec}$ represents a clean sand. To place this value in perspective, the Minimum Technology Requirement for the drainage layer in a RCRA Subtitle $C$ landfill is $10^{-2} \mathrm{~cm} / \mathrm{sec}$, only 1 order of magnitude higher.

3. Porosity, field capacity, and wilting point for the interim cover were HELP default values for sand.

4. The waste layer is 70 feet thick.

5. The waste has a permeability of $1.6 \times 10^{-1} \mathrm{~cm} / \mathrm{sec}$. This material is modelled as a gravelly sand; the permeability value was determined by Westinghouse Hanford Company in The Results of Laboratory Tests to Determine the Physical Properties of Various Barrier Construction Materials, WHC-SD-ER-DP-006, Rev. 0, 1993. This value was also used by the U.S. Army Corps of Engineers (USACE) for HELP modelling of long-term leachate generation as described in the Engineering Study for the Trench and Engineered Barrier Configuration for the Environmental Restoration Storage and Disposal Facility DOE/RL/12074-13 Rev. 0,1993 (TEB Study). This relatively high permeability value allows any water that passes through the interim cover to reach the liner system relatively rapidly, and is thus considered conservative.

6. Porosity, field capacity, and wilting point for the waste were HELP default values for gravelly sand.

7. The initial moisture content of the waste was set equal to the field capacity of 0.045 . In other words, it is assumed that the waste contains the maximum amount of water that it can hold and has no additional capacity to store infiltration. This is considered a conservative assumption.

8. The initial water content of the interim cover was determined by the HELP model at $81 \%$ of the field capacity.

9. An SCS runoff number of 77 was assigned to the interim cover. This corresponds to bare soil, and is the most conservative condition.

10. The maximum leaf area index was assumed to be zero, ie., no vegetation. This is a lower bound condition that does not allow for moisture removal by plant transpiration. If grasses were planted on the interim cover, this assumption would be very conservative.

11. The evaporative zone was assumed to be 18 inches deep, based on previous HELP modelling for the Hanford site (DOE/RL 88-20 Low-Level Burial Grounds Dangerous Waste Permit Application 1989).

12. Daily temperature and precipitation data for the Hanford site for the years 1979 through 1988 were used in the modelling. The average annual precipitation during this time was 7.08 inches, compared with the long-term average of 6.25 
inches Permanent Isolation Surface Barrier: Functional Performance, WHC-EP0650, 1993). Hence, the modelling represents a realistic to slightly conservative moisture input.

13. Solar radiation data for Yakima, Washington, were used. These values were provided by the HELP program.

The results of the modelling showed that annual leachate production at the bottom of the waste layer ranged from 1.1 inches for the $10^{-3} \mathrm{~cm} / \mathrm{sec}$ interim cover down to 0.7 inches for the $10^{\mathrm{s}} \mathrm{cm} / \mathrm{sec}$ interim cover. These results are equivalent to 30,000 gallons/acre/year and 19,000 $\mathrm{g} / \mathrm{ac} / \mathrm{yr}$, respectively.

Another approach for estimating leachate is actual experience at commercial hazardous waste sites. As described in the TOS Study, leachate volumes at the Arlington, Oregon, facility from a landfill comparable to the proposed ERDF have ranged from about $3,000 \mathrm{~g} / \mathrm{ac} / \mathrm{yr}$ to 5,000 $\mathrm{g} / \mathrm{ac} / \mathrm{yr}$. It should be noted that the Arlington site receives an annual rainfall of about 10.6 inches, $70 \%$ higher than Hanford. The difference between the Arlington results and the HELP modelling results is attributed to the many conservative assumptions used in the HELP modelling, particularly with respect to storage capacity of the waste. Assuming the upper limit of the Arlington data $(5,000 \mathrm{~g} / \mathrm{ac} / \mathrm{yr})$ and a lined trench area of 88 acres at the end of Project W296, the maximum annual leachate production is estimated to be 440,000 gallons.

Comparative cost analyses indicated that even the least expensive low-permeability layer in the interim cover (a geomembrane) was economically justified only if both leachate volumes and leachate treatment costs were at the high end of reasonably expected ranges. Based on engineering judgement and the Arlington data, it is possible that actual leachate volumes will be much lower than those predicted by the HELP modelling. This will depend to a large extent on the grain-size and moisture content of the waste placed in the ERDF, which is not well defined at the present time. Because a geomembrane can be installed after the interim cover is in place with no significant economic penalty, there is no requirement to install it at the same time as the interim cover. Hence, a "wait and see" approach was recommended, where actual leachate volumes would be monitored during the first few years of ERDF operation and a decision on a low-permeability interim cover would be made at that time.

\section{LEACHATE PRODUCTION DURING ACTIVE LANDFILL OPERATIONS}

Leachate production during the active phase of landfill operations, i.e., prior to placement of the upper interim cover, was also estimated. This estimate was required for sizing the storage and treatment facilities that would be required at the ERDF site. In contrast to the approach used above where long-term average values for leachate generation are important, the operational phase estimate considered the 25 -year, 24 -hour storm as a maximum design event that would dictate storage and treatment capacity. A single large storm event is expested to produce the most severe requirements for timely removal of leachate from the landfill (see $60 \%$ ERDF CDR, Conceptual Design Report for the Environmental Restoration Disposal Facility, 60\% Draft, DOE/RL/12074-28 Rev. 0, 1993). This approach is consistent with RCRA Subtitle C requirements which specify use of this storm for design of runon and runoff facilities. This approach has also been used - and accepted - for the one existing RCRA Subtitle $C$ landfill on the Hanford site, the Project W-025 landfill (see Design Report, Project W-025, Radioactive Mixed Waste (RMW) Land Disposal Facility, Non-Drag-Off, WHC-SD-W025-FDR-001, Rev. 1, 1992). 
The 25-year, 24-hour storm depth at the Hanford site is 1.56 inches (see W-025 Design Report). Water from any area that collects this rainfall event must be treated if it comes in contact with waste. For sizing the ERDF leachate storage and treatment system, it was assumed that precipitation falling on interim cover did not form leachate, but was entirely removed through evapotranspiration. It was also assumed that any precipitation falling on uncovered waste or on the liner system was converted entirely into leachate. It is recognized that both of these assumptions are simplifications of the actual processes, but such an approach is considered adequate at this stage of design.

As described in the $60 \%$ CDR, the ERDF landfill will be developed as a number of hydraulically isolated cells to limit the amount of leachate that is produced. The amount of leachate therefore depends on the number of cells which are open and contain waste at any given time. A proposed filling sequence is presented in the TOS study. Based on this approach, a reasonable "worst-case" scenario for leachate generation is to have two comer cells and one side cell approximately half full of waste, as shown on the attached Figure 3-6. Earlier in the operation, fewer cells will be developed, and later in the operation, more interim cover will be in place. The calculated volume of leachate from the design storm falling on this configuration is approximately 800,000 gallons, as shown on the attached calculation sheet.

As described in the CDR, leachate will be stored in two tanks (plus a third backup tank) with 400,000 gallons capacity each. For illustrative purposes, each tank would be 150 feet in diameter and 3 feet deep. This is not considered a particularly large or costly tank, and consequently additional tanks could be added at a later date with little impact to the project if the need arises. The system is designed so that the full contents of both tanks can be pumped to the leachate treatment facility in 120 days at 6 hours per day. This provides substantial excess capacity.

\section{SUMMARY}

Two types of leachate production estimates for the ERDF have been performed to date. Each has a different purpose. Long-term average leachate generation rates were evaluated using the HELP model. This study indicated that a low-permeability interim cover was not economically justified unless both the volume and unit cost of leachate treatment were relatively high.

Leachate generation rates during active landfill operations were estimated in order to size the leachate storage and treatment system. For this purpose, a single large storm event, rather than average long-term rates, will control facility requirements. This approach is consistent with regulatory requirements and previous work at the Hanford site. The design in the $60 \%$ CDR is based on this approach.

It is recognized that a number of uncertainties exist that can significantly influence leachate generation estimates. However, many of these uncertainties will not be resolved until waste is actually received at the ERDF, well beyond the end of the design process. To allow design to proceed, reasonably conservative values have been used as leachate estimates. However, it is considered desirable to avoid incurring excessive capital costs in the initial phases of the project by constructing facilities large enough to accommodate all conceivable contingencies. Consequently, there is some risk that additional leachate system capacity may need to be added in the future. Such capacity would consist of additional storage tanks, 
treatment units, or other facilities that could be added with little impact to the existing plant. The net consequences of such future additions are considered relatively minor.

The analyses described here are simple approaches suitable for conceptual-level scoping calculations. Issues related to the leachate storage and treatment system will be reviewed in a greater level of detail during the Definitive Design phase of the ERDF. More comprehensive modelling is planned to better define expected leachate volumes and required treatment plant capacity.

leachate.w51 

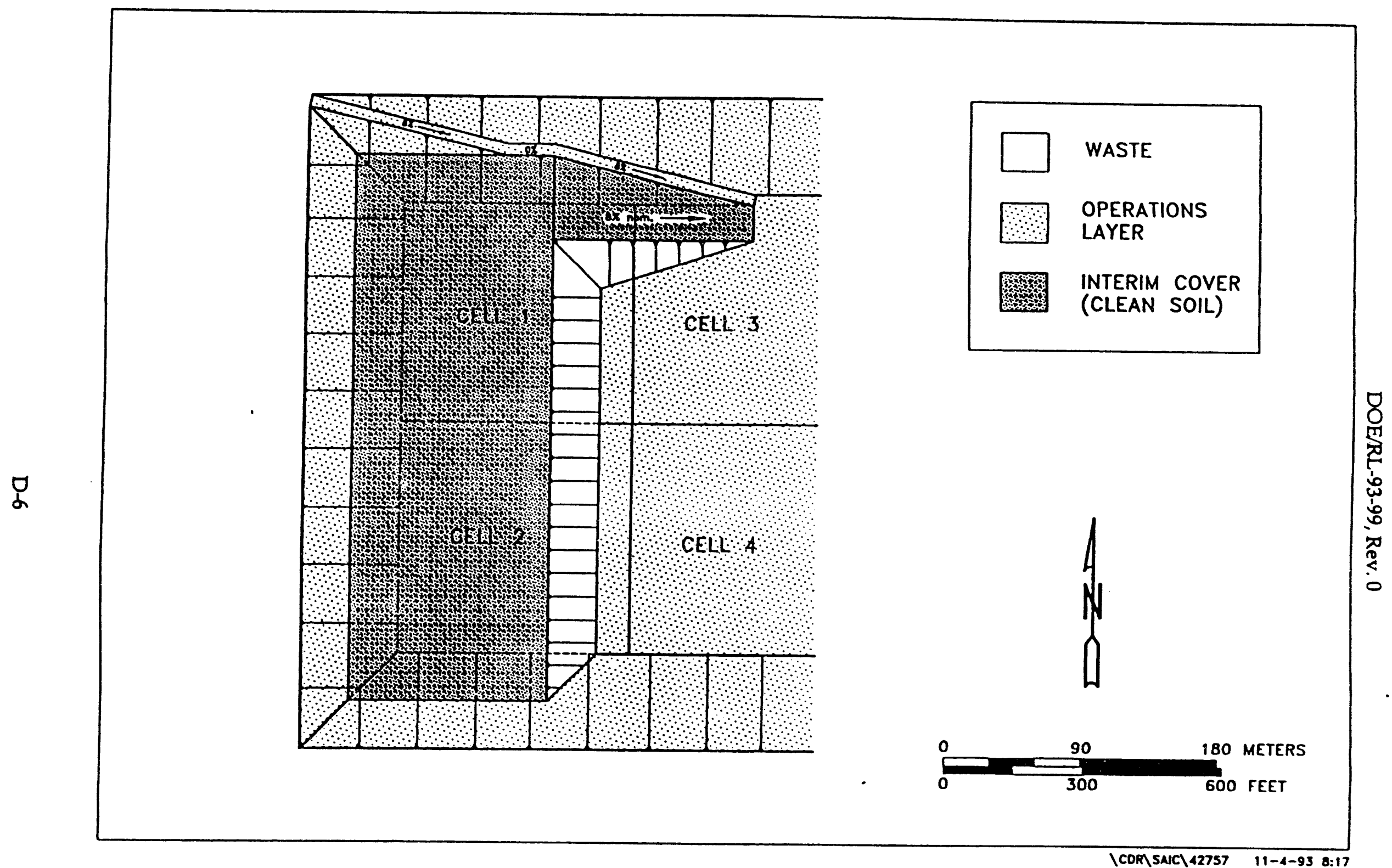

Figure 3-6. Trench Filling Sequence, Stage 5 


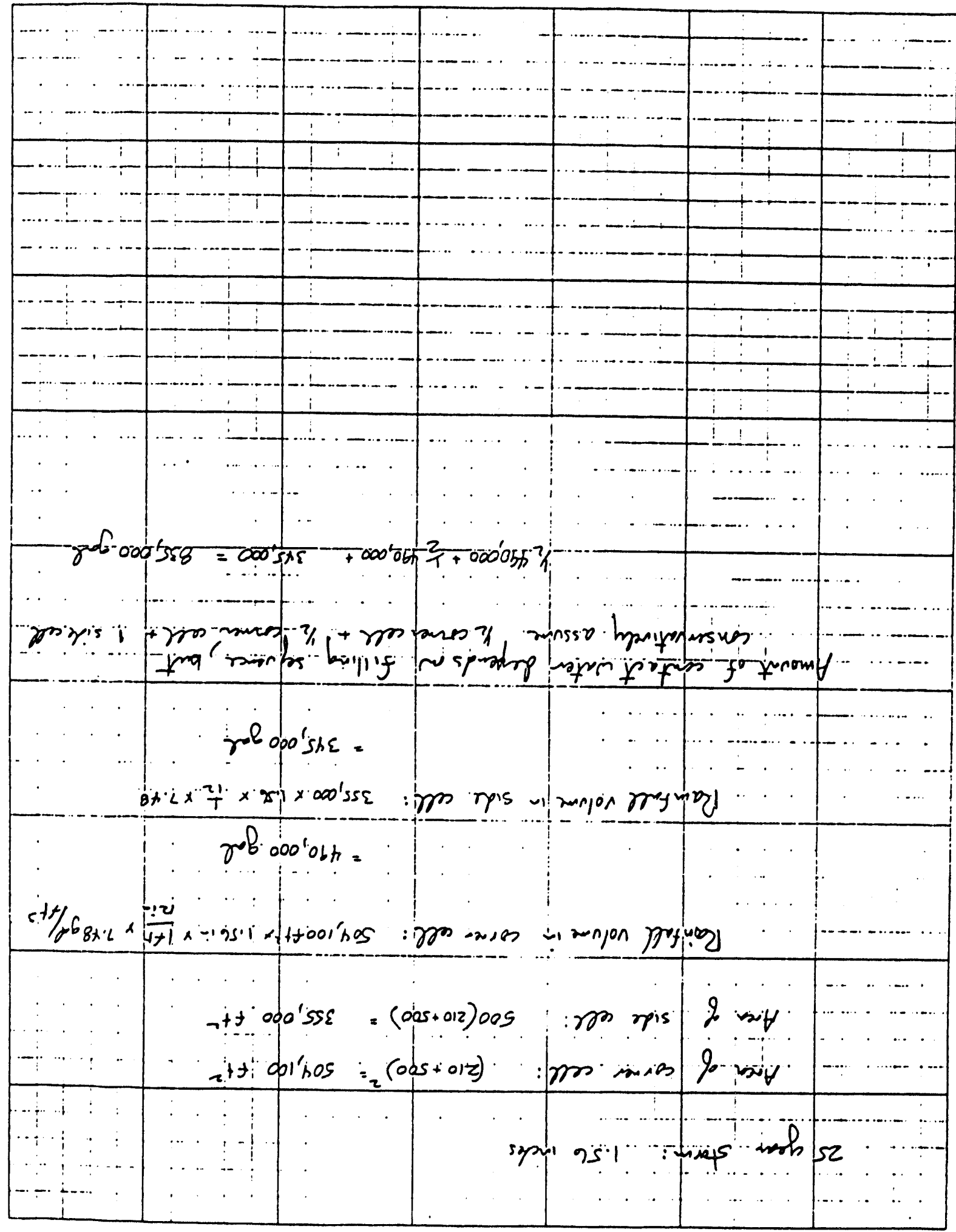

\begin{tabular}{|c|c|c|c|c|c|}
\hline $\begin{array}{ccc}1 & 10 & 1 \\
{[-b} & -2 \mid & -11 \\
\end{array}$ & $\begin{array}{r}10045 \\
\text { 9180 } \\
\end{array}$ & ss & 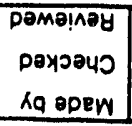 & & 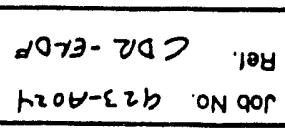 \\
\hline \multicolumn{2}{|c|}{ sany } & 39 7015 $=$ & ชमว3у & $=n$ & yniz.lS IOJrans \\
\hline
\end{tabular}

\section{səje!joss גOPIOS}


DOE/RL-93, 99 Rev. 0

DISTRIBUTION

\section{Number of Copies}

Onsite

43

1

30
U.S. Department of Energy. Richland Operations Office

K. M. Thompson (42)

A5-19

Public Reading Room

A $1-65$

Pacific Northwest Laboratory

Hanford Technical Library

P8-55

Westinghouse Hanford Company

L. D. Arnold

B2-35

V. R. Dronen

P. J. Mackey

F. V. Roeck (61)

EPIC (7)

ERC (G. Fitzgibbon)

ERE (L. Hermann) (2)

ERE Project File

ER Program office (2)

IRA (3)

Resource Center
A5 -56

B3-06

H6-26

H6-08

H6-07

H6-01

H6-03

H6-27

$\mathrm{H} 4-17$

N3-05 

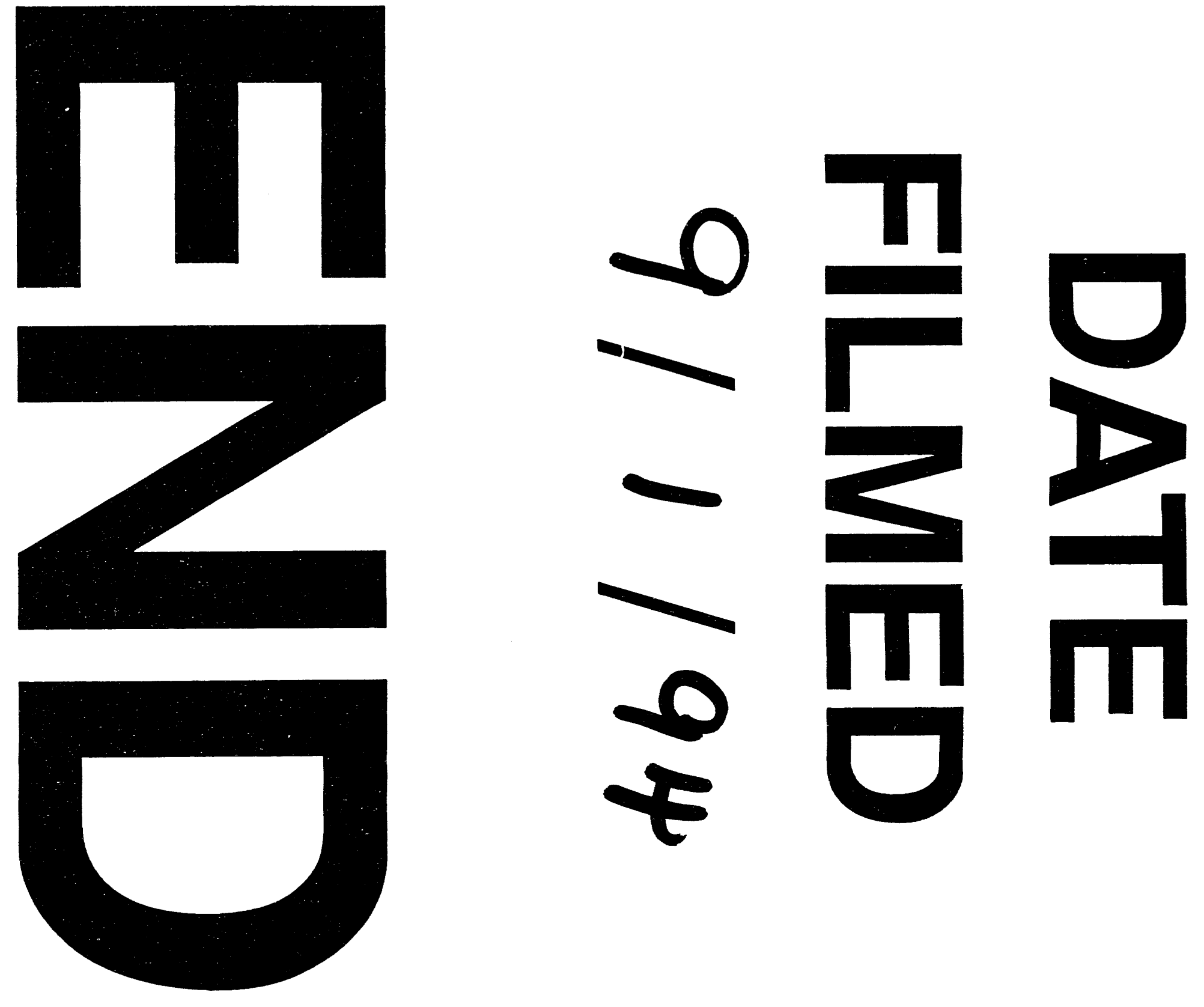


(1)

